1996

\title{
A Comprehensive Annotated Book of Mormon Bibliography
}

Donald W. Parry

Jeanette W. Miller

Sandra A. Thorne

Follow this and additional works at: https://scholarsarchive.byu.edu/mi

Part of the Religious Education Commons

\section{Recommended Citation}

Parry, Donald W.; Miller, Jeanette W.; and Thorne, Sandra A., "A Comprehensive Annotated Book of Mormon Bibliography" (1996). Maxwell Institute Publications. 1.

https://scholarsarchive.byu.edu/mi/1

This Book is brought to you for free and open access by BYU ScholarsArchive. It has been accepted for inclusion in Maxwell Institute Publications by an authorized administrator of BYU ScholarsArchive. For more information, please contact scholarsarchive@byu.edu, ellen_amatangelo@byu.edu. 
A.

A.001 "Aaron Teaches Lamoni's Father." Friend 23 (March 1993): 32-33. Scenes from Aaron's conversion of King Lamoni's father illustrated in color for children. [S.H.]

A.002 Abbott, John S. C. The History of the State of Ohio. Detroit: Northwestern, 1875. Briefly discusses Mormonism and the Book of Mormon. The author accepts the Spaulding theory for the origin of the Book of Mormon. He also discusses the 1834 Anthon denial regarding the "sealed book" incident. [M.R.]

A.003 Abdo, Michael J. "There's Room in My Chart Bag." Ensign 19 (September 1989): 67-68. While flying in an airplane from Brazil to Africa, the author tells of the joy of sharing a most priceless possession (the Book of Mormon) with someone who gave him aid. [J.W.M.]

A.004 "Abinadi and King Noah." Friend 12 (March 1982): 27-29. Cartoon for children presenting the story of Abinadi. [J.W.M.]

A.005 "About the Book of Mormon." Deseret Weekly 54 (12 June 1897): 826. The connection of the Book of Mormon with Solomon Spaulding's Manuscript Story was invented by E. D. Howe in his book, Mormonism Unveiled. Howe's "book was a lie from beginning to end, and it is now pretty certain that Howe knew that it was a lie when he published it." [D.M.]

A.006 About the Book of Mormon. Leatherhead, Surrey, England: West European Mission, 1965. A tract that describes the contents of the Book of Mormon, presents comments on the eleven witnesses, and introduces some archaeological proposals about metal plates. [D.M.]

A.007 About the Book of Mormon: You Can Be Happier. N.p.: West European Mission, n.d. A pamphlet that encourages Book of Mormon reading by providing interesting facts and an overview of its contents and the testimonies of the eleven witnesses. [J.W.M.]

A.008 Adair, James. The History of the American Indians: Particularly Those Nations Adjoining to the Mississippi East and West Florida, Georgia, South and North Carolina, and Virginia. London: Edward and Charles Dilly, 1775. An evangelical essay attempting to demonstrate that the American Indians are descendants of the lost ten tribes by comparing certain features of American Indian life and customs with Old Testament practices. Deals with Indians' division into tribes, worship of Jehovah, nations of theocracy, belief in the ministration of angels, prophets and high priests, celebration of festivals, fasts, religious rites, daily sacrifices, ablutions, anointings, traditions concerning laws of uncleanliness, social relations, manner of curing the sick, burial of the dead,and raising up seed to a deceased brother. Some critics have suggested that Joseph Smith may have drawn upon this source in writing the Book of Mormon. [M.R.]

A.009 Adams, George J. Joseph Smith Jr.'s Rare Reprints. Burlington, WI: n.p., 1991. A copy of a "Lecture on the authenticity and scriptural character of the Book of Mormon," written by George J. Adams in 1844. Confirms that the Book of Mormon is not the only scripture accepted by the Church, the Mormons also believe the Bible "as far as it has been translated correctly." [L.D.] 
A.010 Adams, George J. A Lecture on the Authenticity and Scriptural Character of the Book of Mormon. Boston: J. E. Farwell, 1844. An early tract defending the Book of Mormon. Notes that the Book of Mormon does not replace the Bible. Cites prooftexts from Isaiah 28:29, Ezekiel 37, Psalm 35, and Genesis 48-49. Refers to the Urim and Thummim, the Anthon encounter, and archaeological finds. [D.M.]

A.011 Adams, George J. Letter to John Tyler. New York: Calhoun, 1844. Letter of George J. Adams addressed to John Tyler, President of the United States, describing a revolution that is to take place in the United States. Adams utilizes Book of Mormon scriptures and other references within the letter. [L.D.]

A.012 Adams, John Q. "Origin of the Maoris." IE 25 (April 1922): 507-8. A reference to an experience of a Captain Barclay, recorded in the Australian Review of Reviews, where Barclay saw sacred stone figures on an island in New Zealand. Subsequently he saw similar figures in the Easter Islands and in Peru. This is seen by Adams as evidence that the Polynesians came from the Americas. [D.M.]

A.013 Adams, John Quincy. The Birth of Mormonism. Boston: Gorham, 1916. A polemical work against Mormonism. The author discusses issues relating to the translation of the Book of Mormon, dismisses the testimonies of the Book of Mormon witnesses as unreliable. The Anthon denials are discussed, and the author alleges that the Book of Mormon has little value beyond what it plagiarizes from the Bible. [M.R.]

A.014 Adams, L. LaMar. "I have a Question: Many non-LDS scholars claim that the second half of the book of Isaiah was written after the time Lehi left Jerusalem. Yet the Book of Mormon contains material from both halves. How do we explain this?" Ensign 14 (October 1984): 29. Disputes the claims of multiple and late authorship of the book of Isaiah and cites a literary style analysis claiming that "there is a unique authorship style throughout the various sections of Isaiah." [S.P.S.]

A.015 Adams, William James. "Some Ways in Which the 'Plain and Precious Parts' Became Lost." SEHA 159 (July 1985): 1-6. Finds that ancient scribes, both non-biblical and biblical, took many liberties in their translations. Suggests that up to 30 percent of the original text of the Old Testament may have been deleted as the angel told Nephi would occur (1 Nephi 13:23). [J.W.M.]

A.016 Adams, William James Jr., and Ray T. Matheny. "Archaeological and Cryptological Analyses of the Manti Inscriptions." Utah Historical Quarterly 44 (Spring 1976): 133-40. The Manti Sanpete County, Utah, inscriptions include eight limestone tablets discovered in 1963, four additional tablets found in 1970, and small lead plates situated in a lead box discovered in 1977. The authors conclude that all three finds were "fraudulently manufactured." [D.W.P.]

A.017 "The Advent of the Prince of Peace." Relief Society Magazine 5 (December 1918): 709-12. 3 Nephi 8 records the great calamity and destruction that occurred at the coming of Christ to America. Similar destructive occurrences will occur before Christ's Second Coming to the world. Drawing parallels between the two comings of Jesus assists those of the latter-days to prepare for his coming. [J.W.M.]

A.018 "An Advertiser and the Book of Mormon." SH 49 (11 June 1902): 572. A plea is made to all saints to await the great judgment of God, when the enemies of the Book of Mormon will be judged and the saints vindicated. There are righteous causes that cannot be tried in the tribunals of men. [J.W.M.]

A.019 Affleck, Gordon Burt. "Testimonial Trustworthiness (Witnesses to the Book of Mormon)." Instructor 101 (December 1966): 490-92. In a credibility test for witnesses, the following standards must be met: honesty, ability, 
number and consistency, conformity of testimony with experience, and coincidence of their testimony with collateral circumstances. The Three and Eight Witnesses fulfill all of these requirements. [A.C.W.]

A.020 Agignier, Pierre. "Linguistic Evidence for the Presence of Israelites in Mexico." SEHA 112 (February 1969): 4-5. Demonstrates that the Oaxacan languages are similar to the Semitic languages by comparing Hebrew words with words belonging to the Sawi-zaa languages. [J.W.M.]

A.021 "Agriculture and Stock Raising Among Book of Mormon Peoples." Relief Society Magazine 5 (May 1918): 291-94. Pioneers and New World peoples often place an emphasis on agriculture when settling a new land. Such was the case with the Book of Mormon peoples who brought fruits and grains to America. [J.W.M.]

A.022 Ahlstrom, Sydney E. A Religious History of the American People. London: Yale University Press, 1972. Dedicates about ten pages to Mormonism. Author rejects the Spaulding theory, but believes that the Book of Mormon was the result of Joseph Smith's "responsiveness to the provincial opinions of his time." This work is reviewed in B.016. [B.D.]

A.023 Ahmanson, John. "The Book of Mormon." In Ahmanson's Secret History: A Translation of Vor Tids Muhamed, translated by Gleason L. Archer, 75-102. Chicago, IL: Moody Press, 1984. A polemic against the Book of Mormon. Gives a description of the plates and recalls the story of the translation of the Book of Mormon. Investigates the Kinderhook plates and the Spaulding theory. Argues against the veracity of the Three Witnesses. Contents of the Book of Mormon prove that it is a fraudulent work. This work is reviewed in B.231. [J.W.M.]

A.024 Alexander, Thomas G. "New Testament, Christianity and the Book of Mormon." Sunstone 12 (July 1988): 67. Argues that assisting people through "governmental measures" or "charity" is consistent with basic principles of Christianity, the Constitution, and free agency. [L.D.]

A.025 Alexander, Thomas G. "The Reconstruction of Mormon Doctrine." In Line Upon Line, edited by Gary James Bergera, 53-66. Salt Lake City: Signature Books, 1989. Explores doctrinal development in the LDS church in the period between 1830 and 1835. The doctrine of the early church resembles closely Trinitarian doctrine of the Methodist Arminianism. There is little evidence that the early church believed in a differentiation between God and Christ. Through following periods the doctrines changed and ideas in the Book of Mormon were rejected. [J.W.M.]

A.026 Alexander, Thomas G. Review of Mormonism: The Story of a New Religious Tradition, by Jan Shipps. Dialogue 18 (Winter 1985): 185. Book review.

A.027 Alexander, Thomas G. Review of "Studies of the Book of Mormon" by B. H. Roberts, from B. H. Roberts and the Book of Mormon. Dialogue 19 (Winter 1986): 190-93. Book review.

A.028 Allen, Annie E. "The Book of Mormon in Literature." SH 54 (23 October 1907): 969-71. In rebuttal to Rudyard Kipling's criticism that the Book of Mormon lacks literary style, Allen provides reasons why the Book of Mormon does not evidence greater variety of style. However, the author does cite evidence of multiple authorship for the Book of Mormon. [J.W.M.]

A.029 Allen, J. Michael. Review of Doctrinal Commentary on the Book of Mormon, Vol. 3, Alma through Helaman by Joseph Fielding McConkie and Robert L. Millet. Review of Books on the Book of Mormon 4 (1992): 147-53. Book review. 
A.030 Allen, James X. "Mound Builders and American Antiquities." IE 8 (April 1905): 436-40. Provides circumstantial evidence that the architectural styles of ancient America are similar to ancient Babylonian architecture, due to the Jaredites who left Babylonia approximately three hundred years before the time of Abraham. [J.W.M]

A.031 Allen, James B., and Glen M. Leonard. The Story of the Latter-day Saints. Salt Lake City: Deseret Book, 1976. Authors present (on pages 31-46) an "introductory overview" of Moroni's visit to Joseph Smith, and the subsequent translation and publication of the Book of Mormon. [D.W.P.]

A.032 Allen, Joseph L. "A Comparative Study of Quetzalcoatl, the Feathered-Serpent God of Meso-America, with Jesus Christ, the God of the Nephites." M.A. thesis, Brigham Young University, 1970. A dissertation that draws on Spanish historical accounts, archaeological evidence, and the Book of Mormon scriptures. Draws parallels between Quetzalcoatl and Jesus Christ, suggesting that they may have been the same divine individual. Discusses the problems and possibilities of making the comparison. [J.W.M.]

A.033 Allen, Joseph L. Exploring the Lands of the Book of Mormon. Orem, UT: BYU Print Services, 1989. Describes the languages, history, geography, and culture of some of the peoples described within the Book of Mormon, and presents a number of possible sites where this ancient civilization actually lived. This work is reviewed in P.037 and in P.398. [L.D.]

A.034 Allred, J. R. "President Benson Addresses Cache Regional Conference." Ensign 17 (May 1987): 98. The Book of Mormon testifies of Christ; it was written for our day. It exposes the enemies of Christ and fortifies the humble followers of Christ. It contains the fulness of the gospel. [J.W.M.]

A.035 "Alma Teaches About Faith." Friend 23 (November 1993): 15. Color illustrations for children of scenes from Alma's sermon on faith. [S.H.]

A.036 Almira, Sister. "The Book of Mormon." SH 48 (23 October 1901): 868-69. Provides personal reflections and thoughts after having read the Book of Mormon for the fourth time. [J.W.M.]

A.037 Alward, Benjamin. Know the Latter-day Scriptures. Salt Lake City: Deseret Book, 1958. The work presents a scriptural anthology of thirty-eight basic gospel subjects. Topic number thirty-eight (pp. 509-35) features a presentation of the Book of Mormon and the manner in which it is a companion with the Bible. Also identifies the individual books of the Book of Mormon, discusses some archaeological information, and comments about the eleven witnesses. [J.W.M.]

A.038 "American Antiquities." TS 3 (15 July 1842): 858-60. Presents a comparison of many of the metals, animals, and plants mentioned in the Book of Mormon with similar things found in the United States. [L.D.]

A.039 "American Antiquities: Corroborative of the Book of Mormon." MS 21-22 (1 January 1859-2 June 1860): 12-14, 28-30, 48-50, 64-66 161-63, 177-78, 193-94, 209-210, 226-27, 240-42, 258, 273-74, 306-7, 321-23, 370-71, 401-3, 433-34, 449-51, 467, 513-14, 546, 577-79, 593-95, 625-26, 657-58, 689-91, 706, 737-38, 78687, 818-19, 835-36, 13-14, 30, 61-63, 77-78, 93-94, 124-27, 173-75, 158-59, 188-90, 206-7, 220-23, 237-39, 285-86, 300-301, 316-18, 349-50. Provides evidence to confirm the authenticity of the Book of Mormon. Describes the contents of the Book of Mormon and archaeological findings and discoveries, such as ancient cities, temples, altars, tools, and wells. [J.W.M.] 
A.040 "American Antiquities-More Proofs of the Book of Mormon." TS 2 (15 June 1841): 440-42. A report of two lectures on Central America by Mr. Catherwood who reports his findings at the sites of Copan, Santa Cruz del Quiche, Gueque Tenago, Ocosingo, Palenque, and Uamal. Sees proof that a nation skilled in the arts and sciences once resided in America. [B.D.]

A.041 American Heritage News. Sampson Co., NC: Piney Green Press, 1976. A whimsical newspaper-like publication that describes Book of Mormon events as if they were happening today. Cartoon drawings are included. [D.M.]

A.042 American Indian Restoration Enterprises (AIRE). The Meaning of Indian Restoration Bulletin \#3. Alexandria, VA: American Indian Restoration Enterprises, March 1962. The American Indians have lost more than buffalo and animals of the forest. Their greatest loss was in their knowledge of the Great Spirit. There is a sacred book of their history that will restore that knowledge-the Book of Mormon. [J.W.M.]

A.043 "American Warfare." MS 36 (7 July 1874): 417-20. Compares the attitudes of the people during the Civil War with people who fought in Book of Mormon wars. During the Civil War, Americans fought to the bitter end rather than surrendering when they saw that they would suffer defeat. Similar attitudes prevailed in the Book of Mormon when the Lamanites destroyed all the Nephites (Mormon 6) and the Jaredites slaughtered one another (Ether 15). [B.D.]

A.044 America's Ancients Speak From the Dust. Los Angeles: California Mission, 1950?. A missionary tract covering the origin of the Book of Mormon, the Book of Mormon witnesses, archaeological facts, and several biblical proof texts. [D.M]

A.045 "Ammon Meets King Lamoni's Father." Friend 23 (January 1993): 40-41. Scenes from Ammon's encounter with King Lamoni's father illustrated in color for children. [S.H.]

A.046 "Amulek: Receives Call." CN 38 (5 October 1968): 16. Recounts the story of Amulek, a missionary companion to Alma in the city of Ammonihah whose call came from God through an angel. [J.W.M.]

A.047 "Anachronisms and the Book of Mormon." IE 52 (October 1949): 644, 659-60. Discusses anachronisms or errors of time that would have occurred in the Book of Mormon had it been an uninspired book and shows that the Book of Mormon is the word of God because it lacks anachronisms. [L.D.]

A.048 "An Ancient American Civilization." SH 71 (2 January 1924): 3. According to some archaeologists' interpretation of an ancient Mayan calendar, the earliest known date in America was August 6, 613 B.C. This date helps to support the Book of Mormon. [J.W.M.]

A.049 "Ancient Andean Cities Unearthed." SH 88 (15 March 1941): 332. The discovery of ancient American cities, temples, and other archaeological items will bring about a universal acceptance of the Book of Mormon. It may then fulfill its purpose to convince the Lamanite, the Jew, and the Gentile that Jesus is the Christ. [J.W.M.]

A.050 "Ancient Cities of Arizona." MS 36 (18 August 1874): 516-18. Considers a chain of ancient cities located about a mile apart in Arizona and New Mexico and the artifacts found there. Looks at their sophisticated tools, reservoirs, place of worship, and other items. [J.W.M.] 
A.051 "Ancient Records." TS 4 (May 1843): 185-87. An account of the discovery of the Kinderhook plates-six brass plates held together by a ring. R. Wiley discovered them in a mound and hoped that Joseph Smith would be able to decipher them and that they would prove the authenticity of the Book of Mormon. [B.D.]

A.052 "Ancient Ruins." TS 5 (1 January 1844): 390-91, 744-48. Reprinted in slightly revised version in "Ancient Ruins in Texas." TS (15 August 1844): 622-23. Supports the case that archaeology proves the truthfulness of the Book of Mormon. Cites as an example the ruins of ancient cities, castles, and temples lying near Santa Fe, Texas. [L.D.]

A.053 Anderson, D. Brent, and Diane E. Wirth. "Book of Mormon Authorship." In Encyclopedia of Mormonism, edited by Daniel H. Ludlow, 166-67. New York: Macmillan, 1992. Critics claim that the Book of Mormon was an invention of Joseph Smith written from his own experiences. This claim has been proven false because of the book's complexity, harmony with ancient customs and languages, ancient poetic forms, and wordprinting [stylometry] studies. The time of composition of less than ninety days confirms translation as the only reasonable means to write the book. [N.K.Y.]

A.054 Anderson, Edward Henry. "The Book of Mormon Revealed to Joseph the Prophet." IE 26 (September 1923): 1053-56. Recounts the events of the night of September 21, 1823, when the angel Moroni visited with the Prophet Joseph Smith and first revealed the hiding place of the divine records. [J.W.M.]

A.055 Anderson, Edward Henry. A Brief History of The Church of Jesus Christ of Latter-day Saints: From the Birth of the Prophet Joseph Smith to the Present Time. Salt Lake City: Geo. Q. Cannon \& Sons, 1893. Gives an account of the coming forth of the Book of Mormon. Joseph Smith's mission was to translate the Book of Mormon and to reestablish the Lord's church upon the earth. Moroni's visits prepared the young prophet and, in time, the work of translation began, culminating in the organization of the Church. [J.W.M.]

A.056 Anderson, Edward Henry. "Editors Table: How About It?” IE 30 (September 1927): 1050-51. Encourages Church members to read the Book of Mormon within the next sixty days and testifies that peaceful feelings will accompany the reading of it. [B.D.]

A.057 Anderson, Edward Henry. "Hagoth's Lost Ships and Hawaii." IE 27 (March 1924): 482-83. The episode about Hagoth and his sea-venturing ships is quoted from Alma 63 and the theory advanced that the Polynesians descended from Book of Mormon peoples who sailed to Hawaii. Compares rituals and customs of the ancient Hawaiians with the Israelites. [D.M.]

A.058 Anderson, Edward Henry. "How Are the American Indians Related to the Jews." IE 23 (March 1920): 45354. The Book of Mormon points out that through marriage the Nephites united with the Mulekites who were of Jewish descent. Hence the tribe of Joseph (Nephites) mixed with the tribe of Judah (Mulekites) in a union that is presently found among the American Indians. [J.W.M.]

A.059 Anderson, Einar. History and Beliefs of Mormonism. Grand Rapids, MI: Kregel Publications, 1981. Presents a brief discussion regarding the translation of the Book of Mormon in chapter seven. Although LDS church authorities argue for the correctness of the translation, Anderson points out 25 changes made in the Book of Mormon text since its original publication in 1830. [J.W.M.]

A.060 Anderson, Einar. Inside Story of Mormonism. Grand Rapids, MI: Kregel, 1973. A polemical book on Mormonism, wherein the author claims that Joseph Smith used the Spaulding manuscript as a primary source for 
the Book of Mormon. [M.R.]

A.061 Anderson, Ernel Leroy. Four Oil Paintings Illustrating Book of Mormon Events. M.A. Thesis, Brigham Young University, 1962. A Masters of Arts thesis that presents the process of producing the paintings of "Coriantumr resting upon his sword before slaying Shiz" (Ether 15:30), "An angel of the Lord appearing before Laman and Lemuel" (1 Nephi 3:28), "The Vision of Alma the Younger and the sons of Mosiah" (Mosiah 27:11), and "Christ calling Nephi from among the multitude" (3 Nephi 11:18). [J.W.M.]

A.062 Anderson, George Kumler. The Legend of the Wandering Jew. Providence: Brown University Press, 1965. While examining the legends concerning the wandering Jew, the author considers tales surrounding the Three Nephites. He provides a brief history of the Book of Mormon and then explains some of the general characteristics of the reported sightings of the Three Nephites. [A.T.]

A.063 Andersen, H. Verlan. "Bring Up Your Children In Light and Truth." Ensign 21 (October 1991): 80-81. The Book of Mormon instructs parents to teach their children the gospel before the age when they can be tempted. They have a great ability to understand profound spiritual things. [J.W.M.]

A.064 Andersen, H. Verlan. The Great and Abominable Church of the Devil. Orem, UT: H. Verlan Andersen, 1972. Nephi and John the Revelator saw "the Great and Abominable Church of the Devil" that is operated by Satan, will eventually control every nation, and will make war on the Lord's church in the last days. A division will occur between the devil's church and the Lord's church that will cuminate in war. [J.W.M.]

A.065 Andersen, H. Verlan. Many Are Called But Few Are Chosen. Orem, UT: H. Verlan Andersen, 1967. The Book of Mormon foretells the rise of the United States of America and its divinely inspired constitution. In order for Latter-day Saints to exercise their freedom of religion the God-inspired government must be maintained. The Book of Mormon provides the pattern for maintaining the constitution and the freedom of governing oneself. [J.W.M.]

A.066 Anderson, Henry. The First Americans: A Pictorial Version of the Book of Mormon. Independence, MO: Herald House, 1947. A cartoon-style story of the Book of Mormon for children. [J.W.M.]

A.067 Anderson, Jack Northman. "Take It from a Famous Explorer." IE 47 (February 1944): 82, 118-20. Presents archaeological evidence of the Book of Mormon. Introduces the similarities between the religion of the Incas and Christianity, and a possible connection between the ancient Sumerians and the inhabitants of ancient America. [J.W.M.]

A.068 Anderson, James H. "America in Scripture over 4000 Years," in Anderson's The Present Time and Prophecy, 160-69. Salt Lake City: Deseret News Press, 1933. American history began as the Jaredites fled the situation at the Tower of Babel and arrived in the New World. [J.W.M.]

A.069 Anderson, James H. Book of Mormon A Record of the Stick of Ephraim. Salt Lake City: n.p., July 1929. In this 10-page typescript treatise, Anderson argues that the sticks of Judah and Ephraim mentioned in Ezekiel 37:16-17 do not refer to the uniting of the Bible and the Book of Mormon. [B.D.]

A.070 Anderson, James H. "Book of Mormon Promises and Promises," in Anderson's God's Covenant Race-A Selection of Addresses, 161-87. Salt Lake City: Deseret News, 1946. Teaches that the truthfulness of the Book of 
Mormon is proven through scientific, historical, doctrinal, and prophetic means. The Book of Mormon prophesies of the destiny of the United States. [J.W.M.]

A.071 Anderson, James H. "The Book of III Nephi." IE 27 (January 1924): 193-99. The teachings in the New Testament Gospels and 3 Nephi are harmonious, and events recorded in the New Testament have found some historical parallels with events listed in the Book of Mormon. Further, the great earthquakes and other upheavals of recent decades are comparable to the three days of darkness in America during the time of Jesus' crucifixion. [D.M.]

A.072 Anderson, James H. "The Book of III Nephi." Young Woman's Journal 35 (January 1924): 11-16. Discusses highlights in 3 Nephi regarding the birth of Jesus and his appearance to the Nephites. Shows historical instances outside of 3 Nephi that deal with thick darkness. [D.M.]

A.073 Anderson, James H. "The Church of Jesus Christ of Latter-day Saints: (The Mormons)." In Religious Systems of the World: A Contribution to the Study of Comparative Religion, 657-60. 2nd edition. London: Swan Sonnenschein and Co., 1892. Both the Bible and the Book of Mormon are the word of God and are consistent one with the other. The Bible refers to the Book of Mormon. Author includes a brief history of how the Book of Mormon came forth, a synopsis of the contents of the book, and the testimonies of the eleven witnesses. [J.W.M.]

A.074 Anderson, James H. "Explanation For the Scriptural Word 'Stick.' " DN (20 February 1932): 6. The use of the term "stick" in Ezekiel 37 does not refer to books as some have suggested, but it has reference to nations, i.e., the stick of Judah is the Jewish nation and the stick of Ephraim is the Ephraimite nation. [A.T.]

A.075 Anderson, James H. "Fulfillment of Book of Mormon Prophecies." MS 91 (5 September 1929): 561-67. The Book of Mormon accepts the Bible to be a true record. Christ's teachings are similar in both because he visited America. Among the future events named in the Book of Mormon are the gathering of Israel, the awakening of Mexican Indians, and the removal of the "scales of Darkness" from the eyes of the Indians. [J.W.M.]

A.076 Anderson, James H. "Sariah, Mother of the American Remnant of Joseph." In Anderson's, The Present Time and Prophecy, 592-603. Salt Lake City: Deseret News, 1933. Sariah was the wife of Lehi, a member of a covenant family, the mother of the American Indians, and one of two "goodly parents" (1 Nephi 1:1). She played a vital role in the family's exodus from Jerusalem. [J.W.M.]

A.077 Anderson, Kenneth W. "What Parents Should Teach Their Children from the Book of Mosiah." In The Book of Mormon: Mosiah, Salvation Only through Christ, edited by Monte S. Nyman and Charles D. Tate Jr., 23-36. Provo, UT: Brigham Young University Religious Studies Center, 1991. Presents five simple, scriptural lessons from the book of Mosiah that parents can teach their children. [B.D.]

A.078 Andersen, Kent R. The Glowing Stones. Independence, MO: Herald House, 1977. An illustrated children's book describing the experiences of the brother of Jared. [D.W.P.]

A.079 Anderson, Lavina Fielding. Review of An Ancient American Setting for the Book of Mormon, by John L. Sorenson. Dialogue 21 (Spring 1988): 174-76. Book review.

A.080 Anderson, Lavina Fielding. "From a Book of Mormon Notebook." Ensign 8 (August 1978): 16-20. A useful way to study the Book of Mormon is to keep a notebook of one's thoughts while reading it. This article contains the reflections of the author contained in a notebook. [J.W.M.] 
A.081 Anderson, Lawrence O. "Joseph Smith: A Student of American Antiquities." UASN (30 January 1963): 1-7. Joseph Smith had a deep interest in archaeological discoveries and antiquities of ancient America as can be seen from his writings, sermons, and personal conversations. He seemed to show particular interest in the discoveries in Central America as proof of Nephite and Lamanite existence. The ruined city of Quirigua he believed was the same as the city of Zarahemla. [J.W.M.]

A.082 Anderson, Lynn Matthews. "Delighting in Plainness: Issues Surrounding a Simple Modern English Book of Mormon." Sunstone 16 (March 1993): 20-29. Discussion by the author of his motives and methods in preparing an "Easy to Read" version of the Book of Mormon. Includes examples of verses paraphrased in simple, modern English "meant to bridge the gap between children's materials and the authorized version" for functionally illiterate adults and children. [S.H.]

A.083 Anderson, Richard. The Bible and Mormonism. Grand Rapids, MI: Faith, Prayer \& Tract League, n.d. An evangelical pamphlet opposing Mormon beliefs in respect to the Bible. The Bible is changeless, inerrant, and sufficient. God would not allow it to be corrupted as Mormons believe. Ezekiel 37:15-20 refers to the gathering of Israel, not the Book of Mormon. The Three Witnesses denied their testimonies and cannot be trusted. [M.R.]

A.084 Anderson, Richard Lloyd. "The Alvin Smith Story: Fact and Fiction." Ensign 17 (August 1987): 58-72. In an attempt to put to rest rumors created by Mark Hofmann's fraudulent Salamander Letter, Anderson uncovers myths about Alvin. It is not true that Alvin had a major role in bringing forth the Book of Mormon. [J.W.M.]

A.085 Anderson, Richard Lloyd. "Book of Mormon Witnesses." In Encyclopedia of Mormonism, edited by Daniel H. Ludlow, 214-16. New York: Macmillan, 1992. There were three primary witnesses to the Book of MormonOliver Cowdery, David Whitmer, and Martin Harris-all of whom describe an angel showing them the records and a voice from heaven affirming the translation. The Three Witnesses were later excommunicated from the Church with two eventually rejoining, but none ever denied their testimony. Eight other witnesses testify that Joseph Smith showed them the gold plates. [N.K.Y.]

A.086 Anderson, Richard Lloyd. "By the Gift and Power of God." Ensign 7 (September 1977): 79-85. The translation of the Book of Mormon required the work of Joseph Smith in conjunction with the inspiration of the Holy Ghost. It was a work consisting of "considerable spiritual, intellectual, and physical labor." Those who desire to receive the benefits of the Book of Mormon must also set forth "considerable spiritual, intellectual, and physical labor." [J.W.M.]

A.087 Anderson, Richard Lloyd. "The Certainty of the Skeptical Witnesses." IE 72 (March 1969): 62-67. Martin Harris, a witness of the validity of the existence of the gold plates, stood firm in his testimony of the Book of Mormon and gave his report to all who would listen. [J.W.M.]

A.088 Anderson, Richard Lloyd. "Confirming Records of Moroni's Coming." IE 73 (September 1970): 4-8. Presents an analysis of the five published accounts of Moroni's visits with Joseph Smith on the night of September 21-22, 1823. These accounts were dictated to secretaries with known record-keeping skills. The article carefully examines eight elements of the vision to create a composite description. [J.W.M.]

A.089 Anderson, Richard Lloyd. "Cowdery, Oliver." In Encyclopedia of Mormonism, edited by Daniel H. Ludlow, 1:335-40. 5 vols. New York: Macmillan, 1992. Oliver Cowdery was second witness to many important events of the restoration, one of the Three Witnesses of the Book of Mormon, as well as scribe during the book's translation. [J.W.M.] 
A.090 Anderson, Richard Lloyd. "The Credibility of the Book of Mormon Translators." In Book of Mormon Authorship: New Light on Ancient Origins, edited by Noel B. Reynolds, 213-37. Provo, UT: Brigham Young University Religious Studies Center, 1982. An examination of the historical evidence that gives credibility to Joseph Smith and Oliver Cowdery as they translated the Book of Mormon. Anderson argues through documentation that Joseph's and Oliver's private lives and activities were perfectly consistent with public statements they made. [L.D.]

A.091 Anderson, Richard Lloyd. "David Whitmer, The Independent Missouri Businessman." IE 72 (April 1969): 7476, 78-81. Fifty years of the non-Mormon life of David Whitmer, one of the witnesses of the Book of Mormon, is discussed and his character explored. [J.W.M.]

A.092 Anderson, Richard Lloyd. "Did Oliver Cowdery, One of the Three Special Witnesses of the Book of Mormon, Express Doubt about His Testimony?" In A Sure Foundation: Answers To Difficult Gospel Questions, 39-45. Salt Lake City: Deseret Book, 1988. Oliver Cowdery's "strong testimony of the Book of Mormon is well documented throughout his life." Both his wife Elizabeth Ann Whitmer and brother-in-law, David Whitmer, were witnesses of this fact. [J.W.M.]

A.093 Anderson, Richard Lloyd. "Five Who Handled the Plates." IE 72 (July 1969): 38-47. A review of five of the Eight Witnesses who handled the golden plates - the four Whitmer brothers and Hiram Page. The testimony of the five witnesses never failed. "In fellowship or alienation, youth or age, persecution, poverty or affluence, four Whitmer brothers and Hiram Page never altered their plain testimony that they handled the original metal record of the Book of Mormon." [B.W.J.]

A.094 Anderson, Richard Lloyd. "Gold Plates and Printer's Ink." Ensign 6 (September 1976): 71-76. Details the procedures and personalities behind the emergence of the Book of Mormon in New York and Pennsylvania, from the catalyst leading to the Moroni's vision to the time the book came off the press. [D.M.]

A.095 Anderson, Richard Lloyd. "I Have a Question: Did Oliver Cowdery, one of the three special Book of Mormon witnesses, express doubt about his testimony?” Ensign 17 (April 1987): 23-25. It is well documented that Oliver Cowdery's testimony as a Book of Mormon witness remained strong throughout his life. Some documents exist that purport to be records of Cowdery's denial of his testimony, but the author argues that these were fabricated after his death. [S.P.S.]

A.096 Anderson, Richard Lloyd. "Imitation Gospels and Christ's Book of Mormon Ministry." In Apocryphal Writings and the Latter-day Saints, edited by C. Wilfred Griggs, 53-107. Provo, UT: Brigham Young University Religious Study Center, 1986. Compares and contrasts apocryphal writings, Dead Sea Scrolls, Nag Hammadi library, and others with "Christ's Book of Mormon ministry." Discusses the resurrection, and the message and personality of Christ. [A.T.]

A.097 Anderson, Richard Lloyd. Investigating the Book of Mormon Witnesses. Salt Lake City: Deseret Book, 1980. An investigative historical summary of each of the Three Witnesses, Oliver Cowdery, David Whitmer, Martin Harris, and the Eight Witnesses. Provides a rebuttal to various arguments against the personal character of the witnesses. This work is reviewed in L.131, R.496, and in S.142. [A.T.]

A.098 Anderson, Richard Lloyd. "Martin Harris, The Honorable New York Farmer." IE 72 (February 1969): 18-21. The character of Martin Harris, one of the Three Witnesses of the Book of Mormon, is examined. The author examines accounts of the associates of Martin Harris in the three decades he lived in Palmyra, New York. [J.W.M.] 
A.099 Anderson, Richard Lloyd. "The Mature Joseph Smith and Treasure Searching." BYU Studies 24 (Fall 1984): 489-546. Studies the later years of Joseph Smith's life and disproves the theory that the Prophet continued searching for treasure after 1827. Several primary documents are examined, including the letter from Joseph Smith to Josiah Stowell in 1825 and Martin Harris's letter in 1830 to William W. Phelps. [L.D.]

A.100 Anderson, Richard Lloyd. "Most Interviewed Witness." IE 72 (May 1969): 76-83. David Whitmer represents "the last surviving witness" of the Book of Mormon plates. This article presents a number of interviews with Whitmer by various figures who interrogated him at times throughout his life. [B.W.J.]

A.101 Anderson, Richard Lloyd. "Oliver Cowdery's Non-Mormon Reputation." IE 71 (August 1968): 18-26. Review of Oliver Cowdery's life and accomplishments in the years following his excommunication until his death. Deals specifically with his reputation among associates. [B.W.J.]

A.102 Anderson, Richard Lloyd. "Oliver Cowdery's Testimony." Ensign 17 (April 1987): 23-25. Anderson evaluates two documents-"A Confession of Oliver Overstreet" and "Defence in a Rehearsal of my Grounds for Separating Myself from the Latter Day Saints"-which claim to discredit Oliver Cowdery's testimony of the Book of Mormon, and argues that the documents were fabricated after the death of Cowdery. [D.L.L.]

A.103 Anderson, Richard Lloyd. "The Religious Dimension of Emma's Letters to Joseph." In Joseph Smith: The Prophet, The Man, edited by Susan Easton Black and Charles D. Tate Jr., 117-25. Provo, UT: Brigham Young University Religious Studies Center, 1993. Emma Smith shares many religious items in her letters to her husband Joseph Smith, including the fact that she touched the plates of the Book of Mormon as they lay wrapped in a linen cloth. Emma never doubted the divinity of the Book of Mormon. [J.W.M.]

A.104 Anderson, Richard Lloyd. "Religious Validity: The Sacramental Covenant in Third Nephi." In By Study and Also by Faith, edited by John M. Lundquist and Stephen D. Ricks, 2:1-51. Salt Lake City: Deseret Book and FARMS, 1990. Compares and contrasts the baptismal and sacramental covenants as presented in 3 Nephi to sacramental observances and beliefs as viewed by early and current Christians, from the New Testament setting to contemporary times. Similarities in New Testament and Book of Mormon teachings are shown, and differences in these views from current Christian practices are presented. Changes in the ordinances through history are documented. The personal nature of the sacramental covenant is discussed and the related principles of remembering the Savior and keeping his commandments are emphasized in relation to receiving his Spirit. [A.A.]

A.105 Anderson, Richard Lloyd. "Reuben Miller: Recorder of Oliver Cowdery's Reaffirmations." BYU Studies 8 (Spring 1968): 277-93. When Oliver Cowdery rejoined the LDS Saints, he gave a speech in 1848 at Council Bluffs, in which he discounted the Spaulding theory and testified that he transcribed the Book of Mormon as Joseph Smith dictated it and that an angel showed to him the plates and the interpreters. Reuben Miller recorded and published Cowdery's speech. Anderson looks at the background and integrity of Miller and determines that the recording of Cowdery's speech by Miller was accurate and correct. [L.D.]

A.106 Anderson, Richard Lloyd. Review of "A Rhetorical Approach to the Book of Mormon: Rediscovering Nephite Sacramental Language," by Mark D. Thomas, from New Approaches to the Book of Mormon, edited by Brent Lee Metcalfe, 53-80. Review of Books on the Book of Mormon 6/1 (1994): 379-417. Book review.

A.107 Anderson, Richard Lloyd. "The Scribe as a Witness." IE 72 (January 1969): 53-59. An in-depth review of sources regarding Oliver Cowdery's testimony of the Book of Mormon. Gives details of the translation of the Book of Mormon and the disaffection and rebaptism of Cowdery. [B.W.J.] 
A.108 Anderson, Richard Lloyd. "The Second Witness of Priesthood Restoration." IE 71 (September 1968): 15, 16, 18, 20-22, 24. In addition to Oliver Cowdery's testimony of the Book of Mormon, his testimony of the restoration of the two priesthoods is of great value. As newly-appointed editor of the Church newspaper he wrote an account in installments of the translation of the Book of Mormon. As a part of this series he told of John the Baptist's visit to restore the Aaronic priesthood. [J.W.M.]

A.109 Anderson, Richard Lloyd. "Smiths Who Handled the Plates." IE 72 (August 1969): 28-32. Many of the Smiths were witnesses of the gold plates, including Emma Smith, Lucy Mack Smith, William Smith, Joseph Smith, Sr., Hyrum Smith, and Samuel Harrison Smith. [J.W.M.]

A.110 Anderson, Richard Lloyd. "The Whitmers: A Family That Nourished the Church." Ensign 9 (August 1979): 35-40. A historical discussion of the intense activity of the Whitmer family in connection with the establishment of the Church of Jesus Christ of Latter-day Saints. Author presents evidence that the Whitmer family did much to nourish the Church in the early stages of its development. [D.M.]

A.111 Anderson, Rodger I. Joseph Smith's New York Reputation Reexamined. Salt Lake City: Signature Books, 1990. In an effort to discount the Book of Mormon, Philastus Hurlbut collected over eighty signatures of those who knew the bad character of Joseph Smith and his family (affidavits contained in the appendix). Author examines Hugh Nibley's Myth Makers and finds misrepresentations and failure to consider vital sources. Considers Richard L. Anderson's "Joseph Smith's New York Reputation Reappraised," finding it also to fall short. This author finds that the allegations against Joseph Smith are true since the testimonies of many New York citizens have not been discredited. This work is reviewed in L.087. [J.W.M.]

A.112 Anderson, Ronald D. "Leitworter in Helaman and 3 Nephi." In The Book of Mormon: Helaman through 3 Nephi 8, According to Thy Word, edited by Monte S. Nyman and Charles D. Tate Jr., 241-49. Provo, UT: Brigham Young University Religious Studies Center, 1992. As in the Bible, a common literary device in the Book of Mormon is the repetition of a single word or brief phrase that acts as guiding theme words (Leitworter). Some words used in this way are: remember, pondering, O Lord, Saith the Lord, a curse, riches, and your destruction is made sure. [J.W.M.]

A.113 Anderson, Scott. Mormonism: By An Ex-Mormon Elder. Liverpool: Author, 1885. A polemical tract on Mormonism, written by a former Mormon who claims that the Book of Mormon is full of mistakes and modernisms, and that it plagiarizes the Bible. [M.R.]

A.114 Anderson, William F. The Book of Mormon, What Is It? Independence, MO: Church of Christ, 1954. A tract providing an overview of the contents of the Book of Mormon. Discusses biblical verses that make reference to the Book of Mormon. [D.W.P.]

A.115 Andreasen, Juel. "Descendant of Viking Now 91 Demonstrates Feasibility of Story Told in Book of Mormon." DN Church Section (6 February 1932): 3. A seaman creates a model of a Jaredite barge and explains its different parts. [D.W.P.]

A.116 Andrews, J. C. A Vision and Dream. Provo, UT: n.p., n.d. A tract that compares a dream experienced by Joseph Smith, Sr., with Lehi's vision of the tree of life. [A.T.]

A.117 Andrus, Hyrum L. "The Call of a Modern Prophet-New Witness For Christ and Founding the New Dispensation." In Andrus's God, Man, and the Universe, 33-93. Salt Lake City: Bookcraft, 1968. Provides history of the early life and call of Joseph Smith, Moroni's visit, the Book of Mormon's fulfillment of biblical prophecy, its 
coming forth, translation and publication, the Anthon transcript and loss of the 116 pages, and the restoration of the priesthood. [J.W.M.]

A.118 Andrus, Hyrum L. "Education and Early Experiences," and "Joseph Smith and the Ministry of Angels." In Andrus's Joseph Smith, the Man and the Seer, 52-99. Salt Lake City: Deseret Book, 1960. Joseph Smith had limited educational opportunities, but had an intense thirst for knowledge and was keen of intellect. Private tutoring by angels and the Holy God enhanced his natural quick ability to learn. He came to know the culture of the Nephites well during this time of intense instruction by Moroni, Nephi, and others. [J.W.M.]

A.119 Andrus, Hyrum L. God, Man, and the Universe. Salt Lake City: Bookcraft, 1968. Chapters two through four relate the history of the coming forth of the Book of Mormon. Contains excerpts from Joseph Smith's History of the Church, History of Wayne County, Lucy Mack Smith and various other historical sources. [J.W.M.]

A.120 Andrus, Hyrum L. "Ministry of Joseph Smith." In Andrus's God, Man, and the Universe,466-69. Salt Lake City: Bookcraft, 1970. Numerous heavenly visitors-Moroni, Nephi, Alma, and Mormon-came to Joseph Smith and instructed and prepared him to translate the Book of Mormon and to establish the Kingdom of God on the earth. [J.W.M.]

A.121 Andrus, Hyrum L. "Prelude to the Kingdom." In Andrus's God, Man, and the Universe,61-87. Salt Lake City: Bookcraft, 1970. The Book of Mormon was the instrument that opened the work among the gentiles. The Book of Mormon prophesies of the rise of America, teaches of the Spirit's part in its establishment, and links prosperity with the blessings of God. [J.W.M.]

A.122 The Angel Moroni: Fact or Fiction. Hemet, CA: Christian Tract Society, n.d. A pamphlet that warns Mormons against believing in the Book of Mormon and the Angel Moroni, for the Book of Mormon is not even good fiction. [J.W.M.]

A.123 "The Angel's Visits." CN 43 (22 September 1973): 16. Celebrates the angel Moroni's first visit to Joseph Smith and his delivering the plates to Joseph Smith. [M.D.P.]

A.124 "Another Evidence for the Book of Mormon." MS 95 (12 January 12 1933): 24-25. Announces The Great Migration, by J. Fitzgerald Lee, which is a scholarly book with the hypothesis that the Hebrew race originated in America and migrated there from Asia. Concludes that this "unwittingly testifies to the truth of the Book of Mormon." [M.D.P.]

A.125 "Another Testament." CN 58 (23 January 1988): 16. Explains why the phrase "Another Testament of Jesus Christ" is an appropriate subtitle to the Book of Mormon. [D.M.]

A.126 "Another Version of the Book of Mormon." SH 48 (28 August 1901): 695. Reprint of an article that appeared 18 August 1901 in the Denver Times. Tells of the claim of Mrs. Diadama Whitney Chittenden that Joseph Smith was working for a millwright named Spafford in Salem, Ohio, when Joseph stole the unpublished manuscripts that Spafford had composed. Joseph Smith then published the Book of Mormon using Spafford's manuscript as the greater part of the Book of Mormon. [J.W.M.]

A.127 "Another Witness." MS 100 (24 February 1938): 120-21. Stresses that the Book of Mormon, which has come through the house of Joseph, stands as a second witness of Jesus Christ. [R.H.B.] 
A.128 "Another Witness for the Book of Mormon." TS 6 (May 1845): 906-7. Suggests that the ruins of a wall of earth discovered in Michigan is evidence that an extinct race built the wall. [B.D.]

A.129 Anstadt, P. "Mormonism, Its History, Doctrines, Strength, Methods and Aims." Lutheran Quarterly 30 (April 1900): 228-43. Presents a brief history of Mormonism. Accepts the Spaulding theory for the origin of the Book of Mormon. [B.D.]

A.130 "Answers to Interesting Questions." IE 2 (April 1899): 467-72. Discusses why parts of Moroni 7 and 10 are similar to sections of I Corinthians 12 and 13. Also answers why the Book of Mormon is called the stick of Ephraim, given the fact that Lehi was a descendant of Manasseh. [D.M.]

A.131 Anthony, R. J. "Book of Mormon." SH 31 (28 June 1884): 416-18. Explains why the Book of Mormon is necessary in the latter days and gives biblical evidence of its divinity. Discusses the return of the Jews to Israel and specifically refutes the Spaulding theory, saying that "if [Joseph Smith and Sidney Rigdon] were thieves, I claim God was in the conspiracy." [A.C.W.]

A.132 "Antiquarian Evidences of the Truth of the Book of Mormon." True LDS Herald 9 (1 June 1866): 163-65. The author presents extracts from a work called An Enquiry into the Origin of the Antiquities of America, by John Delafield Jr., which shows similarities between ancient Americans, Egyptians, and Hindostans. These evidences are used to support various claims of the Book of Mormon concerning its Egyptian influence. [B.D.]

A.133 Anway, Joseph H., and Carol Anway. Adventures in a New Land: An Overview of the Book of Mormon. Independence, MO: Herald House, 1987. A Book of Mormon study guide consisting of thirty-four lessons. Also includes author's interpretations of the Book of Mormon. [L.D.]

A.134 "Apostasy and Treason." Juvenile Instructor 6 (4 February 1871, 18 February 1871, 4 March 1871, 18 March 1871, 1 April 1871): 23, 26-27, 38-39, 42-43, 54-55. Lengthy retelling of the conflict of Amalickiah and Ammoron against Moroni, Teancum, and Lehi. [D.M.]

A.135 "An Apostate-But a Friend to the Book of Mormon." Ensign 16 (February 1986): 76-77. Discusses a letter written by Mormon apostate William E. McLellin in 1880 verifying his testimony of the Book of Mormon by stating that the Book of Mormon is "one of the truest, purest books on earth." [L.D.]

A.136 "Applying Ancient Writ in Latter Days." CN 56 (2 November 1986): 7. Excerpts from the 1986 Book of Mormon Symposium. The liahona was more than a compass, it provided spiritual guidance. The wilderness represents the fight between good and evil. Mormon protected and abridged the Book of Mormon through much of his life to bless future generations. God will fulfill his covenants with Israel. The Book of Mormon is the true testament of Christ. [M.R.]

A.137 "Appreciation for Book of Mormon Deepens with Re-reading, Stake Finds." CN 57 (27 February 1987): 4. The Kamus Stake in Utah was challenged to read the Book of Mormon. Many people accepted the challenge and their understanding and love for the book increased. [M.R.]

A.138 Arbaugh, George Bartholomew. Gods, Sex, and Saints: The Mormon Story. Rock Island, IL: Augustana Press, 1957. A polemical tract dealing with the doctrines of Mormonism. Claims that the Book of Mormon borrows much of its material from the Bible, lists anachronistic parallels between New Testament and Book of Mormon, claims 
the Book of Mormon incorrectly uses Isaiah quotes from the King James version of the Bible. Argues that Mormon scriptures and teachings frequently contradict each other. [M.R.]

A.139 Arbaugh, George B. "Revelation in Mormonism: Its Character and Changing Forms." Ph.D. diss., University of Chicago, 1932. A critical work that argues that the Book of Mormon was a product of Joseph Smith and his environment. According to the author, Solomon Spaulding was responsible for the historical parts of the Book of Mormon, Sidney Rigdon provided religious material, and Joseph Smith filled in the blanks. To support this thesis, a list of comparisons between the Spaulding manuscript and the Book of Mormon are provided. [M.R.]

A.140 Archaeological Research Committee. "Archaeology Alert." Witness 67 (Winter 1989): 15. Reports a Maya codex that was discovered in a typical home, suggesting that common people were literate. This reportedly confirms the Book of Mormon indication that many people could read. Also reported is the discovery of Ponta de Chimino, "one of the most heavily fortified sites in the ancient Maya world." This and other sites "call to mind a way of defense designed by Chief Captain Moroni." [B.D.]

A.141 Archaeological Research Committee. "La Mojarra: A Voice from the Past." Witness 64 (February 1989): 4-6. The La Mojarra stela, a monument found November 1986 in the Acula River southeast of Veracruz, Mexico, is said to exhibit characteristics of Egyptian art and the "Hebrew literary device," chiasmus. [B.D.]

A.142 "Archaeological Support of Book of Mormon Dates." SH 78 (11 March 1931): 239. Reprinted from the Kansas City Star, 24 February 1931, wherein Alberto R. Escalona, Mexican archaeologist, is quoted as saying "the Mayas arrived in Yucatan about 275 B.C." The date provided by Escalona coincides approximately with proposed Book of Mormon dates. [B.D.]

A.143 "Archaeological Testimony of the Book of Mormon." Relief Society Magazine 7 (November 1920): 665-71. Draws parallels between Book of Mormon peoples and ancient civilizations in Central and South America. Twelve reasons are given why Catlin, in the work entitled North American Indians, thought that the American Indians were descendants of the Hebrews. [J.W.M.]

A.144 Archaeology and the Book of Mormon. Provo, UT: Department of Seminaries and Institutes of Religion, LDS Church, 1966. The Book of Mormon explains ancient civilizations of the New World. It is a history of three early migrations from the Old World to the New. Testing the Book of Mormon on archaeological and historical terms corroborates the Book of Mormon and elucidates archaeological and historical finds. [J.W.M.]

A.145 Archaeology Proves the Book of Mormon. Concord, CA: Pacific, 1982. Charging that Book of Mormon archaeologists and LDS church members do not possess adequate or credible qualifications, the author finds there is no archaeological evidence to prove that the Book of Mormon is the record of ancient American inhabitants. Known artifacts do not bear Nephite inscriptions and Book of Mormon cities have not be located as have biblical cities and texts. [J.W.M.]

A.146 "Archaeology Says Spaulding Manuscript Claim Was Fake." California Intermountain News(21 December 1978): 8. Reports the conclusions of Samuel E. Shepley, who points out that Spaulding's manuscript pretended to be an imaginative novel concerning a boatload of Roman Christians sailing to the Americas. Its premise has no archaeological support as does the Book of Mormon. It lacks Hebrew idioms such as "it came to pass," but it includes modern phrases like "bite the dust." [D.M.] 
A.147 Archambault, Hubert J. America or the Precious Things of Heaven. Pamphlet. Rock Island, IL: n.p., n.d. The author encourages people to accept the Book of Mormon yet reject the LDS church because the devil has used the uninspired Pearl of Great Price and Doctrine and Covenants to dilute the message of the Book of Mormon. [A.T.]

A.148 Archambault, Hubert J. The Book of Mormon and the Bible, Discourses Series VI. Rock Island, IL: n.p., 1970. A tract claiming that the edition changes of the Book of Mormon have not damaged its message. Similarly, the biblical text experienced a number of changes. [A.T.]

A.149 Archambault, Hubert J. The Devil a Fallen Angel from Heaven. Rock Island, IL: Archambault, n.d. A 31-page doctrinal tract arguing that Satan fell from heaven and that Satan "hates the Book of Mormon." Author claims that Joseph Smith was a false prophet and that the LDS church is false. [A.T.]

A.150 Archambault, Hubert J. The Great Value of the Book of Mormon, Discourses Series V. Rock Island, IL: n.p., n.d. A 27-page tract arguing for the truthfulness of the Book of Mormon but against the Mormon church, polygamy, and baptism for the dead. Claims Satan inspired the term "Mormon church" to link the LDS church with the Book of Mormon. [A.T.]

A.151 Archambault, Hubert J. The Truth About the Book of Mormon. Rock Island, IL: n.p., 1970?. A pamphlet outlining positive aspects of the Book of Mormon, directed to individuals who do not believe its teachings. [D.W.P.]

A.152 Archambault, Hubert J. The Unrecognized and the Rejected Truth. Rock Island, IL: n.p., n.d. An 8-page tract that claims that the Mormon Church is false because it does not follow the teachings of the Book of Mormon. Encourages readers to pray and find out the truthfulness of the Book of Mormon for themselves. [A.T.]

A.153 "Are Mormon Scriptures Based on Fraud?" Current Opinion 54 (February 1913): 134-35. Bishop F. S. Spalding of the Protestant Episcopal Church in Utah hopes to prove Joseph Smith a charlatan and his Book of Mormon a fraud by pointing out flaws in the facsimiles of the Pearl of Great Price. [J.W.M.]

A.154 Arnold, Marilyn. "Book of Enos." In Encyclopedia of Mormonism, edited by Daniel H. Ludlow, 1:148. 5 vols. New York: Macmillan, 1992. Enos, the son of Jacob, grandson of Lehi, recorded his own touching testimony and the promises that the Lord made to him concerning the Nephite records and his Nephite and Lamanite brothers. His mighty efforts to pray brought him a remission of his own sins. [J.W.M.]

A.155 Arnold, Marilyn. "Book of Jarom." In Encyclopedia of Mormonism, edited by Daniel H. Ludlow, 1:148. 5 vols. New York: Macmillan, 1992. The Book of Jarom was written by Jarom, son of Enos, who excuses his brevity by calling attention to limited space and lack of new doctrine. [J.W.M.]

A.156 Arnold, Marilyn. "Book of Omni." In Encyclopedia of Mormonism, edited by Daniel H. Ludlow, 1:148. 5 vols. New York: Macmillan, 1992. The Book of Omni records the brief writings of several authors, Omni, Amaron, Chemish, Abinadom, and Amaleki, who were not spiritual leaders, but were descendants of Jacob. [J.W.M.]

A.157 Arnold, Marilyn. "The Nephi We Tend to Forget." Ensign 8 (January 1978): 69-71. Nephi, the grandson of Helaman, led the church at the time of Christ's birth and appearance to the Nephites (3 Nephi 1:2). Mormon's abridgment of Nephi's record reveals that Nephi was a man of great faith, an overpowering preacher, and a courageous, effective leader of the church at a climactic time in the earth's history. [D.H.M.] 
A.158 Arnoldson, A. J. Book of Mormon Guide: With References Given so Plainly That a Child Could Understand Them. Salt Lake City: n.p., 1931?. Presents an anthology of scriptural references from the Book of Mormon that pertain to the various doctrines, including the plan of redemption, baptism, law of Moses, and the coming of Christ. [D.W.P.]

A.159 Arnoldson, A. J. Book of Mormon Guide: With Surprising Latter-day Events and the Unread Word of God Brought to Light. Centerfield, UT: author, 1940. Consists of 42 poems concerning latter-day events that are prophesied of in the Book of Mormon. Subjects of the poetry include: opposition in all things, the Church is organized, and the Lamanites are to be a blessed people. [J.W.M.]

A.160 Arnoldson, Larry M. "Making the Book of Mormon Study Irresistible." In A Symposium on the Book of Mormon, 24-25. Salt Lake City: Church of Jesus Christ of Latter-day Saints, 1979. Proposes a method to involve and interest students in Book of Mormon study that includes problem solving and finding answers to questions in the book. [N.K.Y.]

A.161 Arrington, Leonard. Review of The Farm Boy and the Angel, by Carl Carmer. Dialogue 5 (Summer 1970): 97. Book review.

A.162 Arrington, Leonard J., and Davis Bitton. "Appeals of Mormonism" In The Mormon Experience: A History of the Latter-day Saints, 20-43. New York: Vintage Books, 1980. The Mormon appeal rests on a new view of God and heavenly messengers who restored the primitive Church of Christ. The publication of the Book of Mormon set the movement apart from other restoration movements of 1830. It was a concrete piece of evidence that provided a sweeping history of America. The book's complex story clarified problematical biblical passages and controversial religious issues. [J.W.M.]

A.163 Arrington, Leonard J., and Davis Bitton. "The Beginning." In The Mormon Experience: A History of the Latterday Saints, 3-19. New York: Vintage Books, 1980. Presents a brief history of Joseph Smith and his family, the first vision, Moroni's visit to Joseph Smith, Martin Harris's role in the translation and publication of the Book of Mormon, and attempts to discredit the Book of Mormon. [J.W.M.]

A.164 Arrington, Leonard J., and Joann Jolley. "The Faithful Young Family." Ensign 10 (August 1980): 52-57. After purchasing a Book of Mormon from Samuel Smith, brother of Joseph Smith, Phinehas Young thought it his duty to prove the book a fraud. He thought Joseph must have been deceived and read the book to discover the errors and save the people from the deception. He was soon convinced otherwise and recommended the book to his devoutly religious family, including Brigham Young, who joined the Church. [J.W.M.]

A.165 "Article." M\&A 1 (February 1835): 77. Praises Orson Pratt's skills in explaining and defending the Book of Mormon. [D.M.]

A.166 "As I View the Thing, Mormonism and the Book of Mormon in the American Schoolroom." IE44 (September 1941): 539, 65. Discusses and quotes at length Sam Tucker, a columnist of the Decative Herald in Illinois, who suggests that the Book of Mormon and Mormonism be taught in courses of religious instruction in the public schools. Tucker argues that (1) the Book of Mormon is the American Bible, and (2) the stories of the Book of Mormon and Mormon history are very exciting. [L.D.]

A.167 Asay, Carlos E. "Memory." NE 16 (July 1986): 46-50. Speaks out on the relationships between "memory and mood, memory and testimony, memory and models, memory and thoughts, and memory and you." Asay quotes 
many scriptures from the Book of Mormon to support his ideas, including Alma 36, Moroni 10, Alma 18, and Helaman 5. [L.D.]

A.168 Asay, Carlos E. "Opposition to the Work of God." Ensign 11 (November 1981): 67-69. Three accounts of anti-Christs recorded in the Book of Mormon suggest ways to prevent individuals from being drawn in by Satan and his servants. The accounts instruct individuals to keep the commandments, avoid those who tear down faith, follow the living prophets, refrain from contending over doctrine, search the scriptures, stay true to the mission of the Church, pray for one's enemies, practice pure religion, and remember that some things must be taken on faith. Opposition to the Church has a refining influence, indicates that the work is divine, and is bound to fail because the cause of the Church is just. [J.W.M.]

A.169 Asay, Carlos E. "Words of Christ: A Liahona." CR (October 1978): 77-81. The words of Christ that are revealed in the scriptures must become, for each individual, a personal compass or liahona, giving light and guidance to the path of eternal life. Similarly, each individual must heed the words of the living prophet, for his words are the words of Christ. [R.C.D.]

A.170 Ashe, Geoffrey, et. al. "The Book of Mormon and the American Indians." In The Quest for America, 8-9. New York: Praeger Publishers, 1971. Notes that the Book of Mormon is an American religious source that identifies the Israelite lineage of the American Indians. Claims that the book's assertions are unverifiable. [D.M.]

A.171 Ashley, F. B. Mormonism: An Exposure of the Impositions. London: John Hatchard, 1851. Joseph Smith is one of the false prophets referred to in Matthew 24:4, 5, 11. He pretended to have visions of angels that brought gold plates. An affidavit prepared by Peter Ingersol states that Joseph Smith confided his evil plan to him. The Book of Mormon weaves the Spaulding manuscript with biblical scriptures. [J.W.M.]

A.172 Ashment, Edward H. "The Book of Mormon and the Anthon Transcript: An Interim Report." Sunstone 5 (May-June 1980): 29-31. Points out that the reformed Egyptian language in which the Book of Mormon was written was not new but was following a tradition. The Egyptian language of the brass plates was changed according to the manner of speech prevalent in the days of Nephi. Contains a comparison between the Anthon transcript and Micmac Indian script. [J.W.M.]

A.173 Ashment, Edward H. "The Book of Mormon-A Literal Translation?" Sunstone 5 (March-April 1980): 10-14. Examines the method of the translation of the Book of Mormon and provides second-hand statements made after the book's publication describing the method by which Joseph Smith accomplished the translation. Concludes that the translation was conceptual, not literal word for word. [J.W.M.]

A.174 Ashment, Edward H. " 'A Record in the Language of My Father': Evidence of Ancient Egyptian and Hebrew in the Book of Mormon." In New Approaches to the Book of Mormon: Explorations in Critical Methodology, edited by Brent Lee Metcalfe, 329-93. Salt Lake City: Signature, 1993. "Examines evidence of ancient Egyptian or Hebrew in the Book of Mormon, discussing first the claims made in the book itself, then those made by Joseph Smith and his associates, and finally those made by modern apologists." The paper also examines the claim of individual authorship in the Book of Mormon, or wordprint studies. Author concludes that "there is no direct evidence to support the historical claims of the Book of Mormon-nothing archaeological, nothing philological," and there is "no direct, linguistic evidence for the gold plates being written in either Egyptian or Hebrew." [A.T.]

A.175 Ashton, Marvin J. "Murmur Not." In BYUSY (9 December 1969). Provo, UT: BYU Press. The destructive influence of murmuring is explored. One principal difference between Laman and Lemuel and their brother Nephi 
was that the two older brothers possessed the habit of murmuring and finding fault. [J.W.M.]

A.176 Ashton, Marvin J." 'Neither Boast of Faith Nor of Mighty Works.' "Ensign 20 (May 1990): 65-67. Also CR

A.177 Ashton, Wendell J." 'That Which I Have Written Is True.'” MS 97 (8 August 1935): 506-8. Ambrose R. Winch, through reading and manually copying a borrowed copy of the Book of Mormon, was converted to the Church. [R.H.B.]

A.178 Ashworth, Brent. "Martin Harris' 1873 Letter to Walter Conrad." BYU Studies 23 (Winter 1983): 112-19. Tells about a recently discovered letter in which Martin Harris wrote his testimony as one of the Three Witnesses. A photograph of the letter and a typed transcription are supplied. (Editor's note: this document has since been proven a forgery.) [D.M.]

A.179 Aston, Warren P., and Michaela J. Aston. "And We Called the Place Bountiful." Provo, UT: FARMS, 1991. Through an employment of historical and scriptural evidences, "this study concludes that an objective and precise identification of [the Book of Mormon] Bountiful with a present-day location is now feasible and introduces data on physical traces revealing very early human involvement at the site." [A.T.]

A.180 Aston, Warren P., and Michaela J. Aston. "The Place Which Was Called Nahom." Provo, UT: FARMS, 1991. A place in Yemen called Nehem, called such from the pre-Islamic era, may be the location of Nahom mentioned in the Book of Mormon. [A.T.]

A.181 Aston, Warren P., and Michaela J. Aston. "The Search for Nahom and the End of Lehi's Trail in Southern Arabia." Provo, UT: FARMS, 1989. “Examines historical, geographical, and archaeological evidence that helps specify the location of Nahom and thus also of Bountiful." Determines that Nahom was most likely close to the Wadi Jauf in the present day Yemen Arab Republic. Argues against the Hilton's proposal of Salalah as Bountiful and suggests that Bountiful may be found further west along the Dhofar coast of Oman, or the Hadramaut coast of Yemen. [Description formerly read as follows: "Argues against Dhofar as the location of Bountiful, as has been proposed by the Hiltons. The probable location for Bountiful is along the Hadramaut coast." - BH, Online Ed.] [A.T.]

A.182 Aston, Warren P., Michaela Aston, Stephen D. Ricks, and John W. Welch. "Lehi's Trail and Nahom Revisited." In Reexploring the Book of Mormon, edited by John W. Welch, 47-52. Salt Lake City: Deseret Book and FARMS, 1992. Speculates on different possible sites for Nahom in Lehi's route to the Americas. [D.M.]

A.183 "At The Young Age of 6 He's Read Book of Mormon." CN 38 (23 November 1968): 15. Andrew James Everson began reading at age four with help from his father. Six months after turning six he has read the Book of Mormon. His younger brother Marc, 5, has begun reading it also. [J.W.M.]

A.184 Atkinson, Mabel Sanford. The Land Shadowing with Wings. Independence, MO: Herald House, 1952. A fictional narrative based upon the Book of Mormon. The author uses the events and names as recorded in the Bible and the Book of Mormon as she puts the narrative in story form quoting extensively from the actual text as the characters speak. [J.W.M.]

A.185 "Author Finishes Commentary on Book of Mormon." CN 31 (23 December 1961): 6. Describes the set of seven volumes, Commentary on the Book of Mormon, prepared by Philip Reynolds, and celebrates the completion of the last volume. [M.D.P.] 
A.186 Avant, Gerry. "Ammon Received Spirit of Prophecy, Revelation after Much Study, Faith." CN 58 (14 May 1988): 14. Relates Ammon's fourteen years of unselfish missionary service. [J.W.M.]

A.187 Avant, Gerry. "Amulek Becomes Fellow Laborer on Alma's Mission." CN 58 (7 May 1988): 14. Alma and Amulek share common experiences before and during their missionary experiences. [J.W.M.]

A.188 Avant, Gerry. " 'Anti-Christs' Are Still Present, Active." CN 58 (6 August 1988): 12. Lists nine ways to guard against the influences of anti-Christs in modern days. [J.W.M.]

A.189 Avant, Gerry. "Apostasy Led to Schism among Nephi, Brothers." CN 58 (30 January 1988): 14. Nephi's brothers came to the point of apostasy because "they knew not the dealings of that God who created them" (1 Nephi 2:12). [J.W.M.]

A.190 Avant, Gerry. "Apostates Sway Lamanites from Gospel Truths." CN 58 (28 May 1988): 14. The apostate Amalekites and Amulonties influenced the Lamanites to practice wickedness. [J.W.M.]

A.191 Avant, Gerry. "Baptism Was Savior's Primary Emphasis." CN 58 (17 September 1988): 14. To bring individuals into unity with God through baptism was the message of the Savior to the Nephites at the time of his visit. [J.W.M.]

A.192 Avant, Gerry. "Better Than a Mystery." CN 58 (27 August 1988): 16. After a wife hides her husband's novels and mysteries, he has no alternative but to read the Book of Mormon, which leads to conversion. [J.W.M.]

A.193 Avant, Gerry. "Book of Mormon Fathers Taught by Precept, Word, Deed." CN 58 (16 January 1988): 14. Quotes and paraphrases President Benson's talk from the priesthood session of October 1985 that Book of Mormon fathers are perfect examples for fathers of this era to teach their children. [J.W.M.]

A.194 Avant, Gerry. "Book of Mormon is Book of Doctrine, Not Simply a History or Geography." CN 58 (30 April 1988): 10. The complexity of the Book of Mormon makes it more than a geographical or historical sketch of an ancient American civilization. Its doctrine is its most important contribution. [J.W.M.]

A.195 Avant, Gerry. "The Book of Mosiah Clearly Is Not a Daily Journal or Chronology." CN58 (2 April 1988): 14. The book of Mosiah covers a vast amount of history and is carefully structured to give an interpretive and analytical perspective. [J.W.M.]

A.196 Avant, Gerry. "Collector Finds Rare Book, Autographed Statement by Prophet." CN 55 (23 June 1985): 10. A first edition of the Book of Mormon that contains Joseph Smith's signature as well as an original statement in the prophet's handwriting have been acquired by Brent Ashworth. (Editor's note: the signature and statement have been proven to be forgeries.) [J.W.M.]

A.197 Avant, Gerry. "Contention in the Land." CN 58 (16 July 1988): 14. Helaman 2 identifies Pahoran as a righteous man who sat upon the judgment seat and had to deal with great contention both within and without the government. [J.W.M.]

A.198 Avant, Gerry. "Doctrines of Salvation Taught with Plainness." CN 58 (20 February 1988): 14. The doctrines of the Book of Mormon are more plain and systematic than those of the Bible. Nephi's account of Christ's baptism, for example, is set forth with plainness. [K.M.] 
A.199 Avant, Gerry. "Enos: A Zealous Servant Who Had the Strength of Purity." CN 54 (26 February 1984): 12. Describes the historical setting of the Nephites and Lamanites during the time of Enos, provides a brief summary of the book of Enos, and then focuses upon Enos, a man of great faith. [A.T.]

A.200 Avant, Gerry. "Enos Hungered After Blessings of Spirit." CN 58 (5 March 1988): 14. Enos presents a positive model of how prayer is to be conducted. [J.W.M.]

A.201 Avant, Gerry. "Great Faith and Obedience are Marks of Nephi." CN 54 (1 January 1984): 5. The outstanding spiritual qualities of Nephi are noted, including his resolve to keep the commandments, and his great faith in the Lord. Nephi was a leader, statesman, and teacher. [A.T.]

A.202 Avant, Gerry. "Habit Formed to Read Book of Mormon." CN 57 (17 October 1987): 8-10. Youth form a daily habit of Book of Mormon scripture study. [A.C.W.]

A.203 Avant, Gerry. "Icelandic Members Have Testimonies, Faith in the Gospel." CN 50 (27 September 1980): 8-9. Missionary work in Iceland and Icelandic members are described, mentioning that they are anxious to receive the Icelandic translation of the Book of Mormon. [M.D.P.]

A.204 Avant, Gerry. "Jacob: A Man of Great Faith, A Mighty Prophet." CN 54 (29 January 1984): 11. Jacob had great faith, saw a vision of the Messiah, presented powerful exhortations, and succeeded Nephi as leader of his people. [A.T.]

A.205 Avant, Gerry. "King Mosiah Began His Reign During Era of 'Profound Peace.' " CN 58 (26 March 1988): 14. King Mosiah, son of Benjamin, began his reign during a period of peace, reigning over a people who were righteous. [K.M.]

A.206 Avant, Gerry. "Korean Is Like a 'Living Treasure' Among Members." CN 56 (2 February 1986): 6. The life story of Han In Sang who translated the Book of Mormon into Korean. [M.D.P.]

A.207 Avant, Gerry. "Lamoni Becomes a Benevolent King." CN 58 (21 May 1988): 14. Before his conversion Lamoni was a severe, harsh ruler, but after his conversion he was a peaceful, wise ruler and counselor. [K.M.]

A.208 Avant, Gerry. "Land of Promise Awaited Righteous." CN 58 (26 November 1988): 14. Relates Moroni’s teaching that the promised land is for the righteous, and that the wicked would be swept off the same land. [K.M.]

A.209 Avant, Gerry. "Last Three Nephite Kings were Men of Faith and Courage." CN 54 (1 April 1984): 11. A brief note describing the lives and contributions of the final three Nephite kings, Mosiah, Benjamin and Mosiah II. [A.T.]

A.210 Avant, Gerry. "Leaders Continue Legacy." CN 58 (30 July 1988): 14. Nephites follow common cultural trend in naming their sons after noble ancestors or leaders. [K.M.]

A.211 Avant, Gerry. " 'Listen to Warning Voices.' " CN 58 (20 August 1988): 10. Inhabitants of the world need to listen to the Lord's counsel or be doomed to follow the mistakes of past peoples and nations. [K.M.]

A.212 Avant, Gerry. "The Lord Directs Jaredites on Journey to a New Land." CN 58 (19 November 1988): 14. Upon the request of the brother of Jared, the Lord did not confound the Jaredite language and he directed them in their journey to a new land. [K.M.] 
A.213 Avant, Gerry. "The Lord Sends Accredited Witnesses." CN 59 (28 January 1989): 14. The Lord has always used two or three witnesses to establish his word, including when he chose the Three Witnesses of the Book of Mormon. [K.M.]

A.214 Avant, Gerry. "Many Lamanites Become Righteous." CN 58 (4 June 1988): 14. Due to the preaching of the sons of Mosiah, many Lamanites converted to the Gospel of Jesus Christ and became righteous. [K.M.]

A.215 Avant, Gerry. "Moroni Preserved Message of His Father to Church Members." CN 58 (3 December 1988): 14. Moroni preserves a sermon from his father Mormon (Moroni 7), who counsels readers to "enter the rest of the Lord." [K.M.]

A.216 Avant, Gerry. "Mosiah Was Appointed King over People of Zarahemla." CN 58 (12 March 1988): 14. King Mosiah and his people migrated and eventually united with the people of Zarahemla. King Mosiah became the ruler of both peoples. [K.M.]

A.217 Avant, Gerry. "Nephi Delighted in Words of Isaiah." CN 58 (6 February 1988): 14. Mentions the usage of the writings of Isaiah in the Book of Mormon and explains why Latter-day Saints should study Isaiah. [K.M.]

A.218 Avant, Gerry. "Nephi Grew Up in Jerusalem in Time of Solomon's Temple." CN 58 (23 January 1988): 14. Nephi was raised in Jerusalem and the temple of Solomon would have had a great deal of religious significance is his life. [K.M.]

A.219 Avant, Gerry. "Nephites Were 'Wanderers in a Strange Land.' " CN 58 (9 July 1988): 14. From the time of Lehi's departure from Jerusalem until their demise, the Nephites were continually migrating, perhaps traveling thousands of miles. Perhaps they considered themselves strangers in a land far from their original home. [K.M.]

A.220 Avant, Gerry. "Parliament of World's Religions: Event is 'Greatest Gathering of Religious Leaders in History." CN 63 (11 September 1993): 3-4. Five hundred copies of the Book of Mormon in fifteen languages were distributed from the LDS church's booth at the 1993 Parliament of the World's Religions. [S.H.]

A.221 Avant, Gerry. "President Benson Visits Puerto Rico." CN 57 (18 April 1987): 3, 5. President Benson speaks to a large group of Puerto Ricans, counseling them to use the Book of Mormon as the basis for their teaching and missionary work. [K.M.]

A.222 Avant, Gerry. "A Priest of Noah, Alma Was Abinadi's 'Golden Convert.' " CN 58 (16 April 1988): 14. The conversion of Alma, which came due to the preaching of Abinadi, led to great spiritual ramifications that lasted for hundreds of years among the Nephites. [K.M.]

A.223 Avant, Gerry. "Prophet Retraces Paths of Church History." CN 56 (10 August 1986): 7-9. President Benson visits key Church history sites that are connected to the coming forth of the Book of Mormon and bears testimony of its truthfulness. [K.M.]

A.224 Avant, Gerry. "Prophet Walks Historic Paths During Ohio Visit." CN 56 (30 March 1986): 3-4. President Benson visits historic Church sites in Kirtland, Ohio, and reminds the Latter-day Saints to use the Book of Mormon in family and home life because it was written for the people of this present era. [K.M.] 
A.225 Avant, Gerry. "Prophet Warns Against Sins of Last Days." CN 58 (13 February 1988): 14. President Benson uses the Book of Mormon to warn people that the plaguing sin of this generation is sexual immorality, and that pride is the universal sin. Both sins, however, can be combated. [K.M.]

A.226 Avant, Gerry. "Signs Foretell Christ's Birth, Death." CN 58 (3 September 1988): 14. In the New World, definite signs were given of Christ's birth and death. [K.M.]

A.227 Avant, Gerry." 'Two-Continent Story' Tells of Jesus Christ." CN 58 (10 September 1988): 14. The Book of Mormon supports New Testament teachings about Christ and the resurrection. [K. M.]

A.228 Avant, Gerry. "Two Powerful, Persuasive Prophets." CN 54 (6 May 1984): 11. The lives and conversion of Alma the Elder and Alma the Younger are recounted. Both were powerful men that turned to righteousness from wickedness and never regressed. [A.T.]

A.229 Avant, Gerry. "Two Sets of Plates Contain Writings From 11 Engravers." CN 58 (9 January 1988): 14. The Book of Mormon was written by 11 engravers, nine of whom worked on the small plates of Nephi, and the other two worked with Mormon's plates. [K.M.]

A.230 Avant, Gerry. "Wicked Nephites Reject Message." CN 58 (13 August 1988): 14. For a period of time the Lamanites were more righteous than the Nephites, and the wicked Nephites rejected the Lamanite message of righteousness. [K.M.]

A.231 Avant, Gerry. "Wickedness Is Not Happiness." CN 58 (11 June 1988): 14. Contrary to popular belief, when you are being wicked and having fun you are not creating happiness. [M.R.]

A.232 Avant, Gerry. "Young Women of Zarahemla." CN 58 (20 August 1988): 8-9, 12. For five days a group of young women from 10 LDS stakes met in a Tennessee camp, studied the Book of Mormon, and dramatized Book of Mormon stories. [K.M.]

A.233 Avant, Gerry. "Younger Alma was Foe to the Church. After Repentance, He Became a Leader." CN 58 (23 April 1988): 14. Alma the Younger, onetime foe to the Church, was converted to the Gospel and became a leader and faithful member of the same Church. [K.M.]

A.234 Avant, Gerry, and Michael C. Cannon. "Valiant 'Sons' of Helaman." CN 58 (2 July 1988): 14. Retells the story of the 2,000 stripling warriors. The Lord helped with military strategy. Helaman was a leader during times of war and peace. President Benson counsels the young men of the Aaronic Priesthood to liken themselves spiritually to the Sons of Helaman. [A.C.W.]

A.235 Avery, W. B. E. "A Letter on the Book of Mormon." MS 98 (17 September 1936): 605. A letter by a nonmember of the Church who was impressed by the Book of Mormon and after reading it understood more fully what Mormons believe. [M.D.P.]

A.236 Axelgard, Frederick W. "1 and 2 Nephi: An Inspiring Whole." BYU Studies 26 (Fall 1986): 53-65. With so much emphasis on studying single words, phrases, verses, and short scriptural pericopes by scriptural commentators and scholars, "the holistic approach to the study of scriptural texts" is often ignored. Doctrinal/historical/literary themes are brought forward with greater force and are better understood when whole chapters or entire sections of scripture are considered by the student of the scriptures. To prove the point 
of his thesis, the author proposes that 1 and 2 Nephi should be seen as "an inspiring whole" by examining the recurring themes, evident correlations, and obvious connections, which unify all the segments and parts that make up these two books. [D.W.P.] 
B.

B.001 B. H. Roberts' Manuscripts Revealed: A Photographic Reproduction of Mormon Historian B. H. Roberts' Secret Studies on the Book of Mormon. Salt Lake City: Modern Microfilm, 1980. Reproduction of parts of B. H. Roberts's 1922 typescript work "A Book of Mormon Study." It is heavily edited to focus on Roberts's questions and concerns about the Book of Mormon, not his answers nor his testimony. [J.W.M.]

B.002 B., S. A. "Interesting Facts About the Book of Mormon." SH 70 (11 April 1923): 337-38. The title page of the Book of Mormon that declares that Joseph Smith was the author of the book stands in compliance with the copyright laws of the day. [J.W.M.]

B.003 B., S. A. "On Solomon Spaulding Story." SH 65 (28 August 1918): 834. Suggests that after thirty-two years no further evidence has come to light to prove the theory that the Spaulding manuscript was the basis for the Book of Mormon. [J.W.M.]

B.004 B., S. A. Untitled. SH 70 (11 April 1923): 337-38. Discusses the instructions issued by the copyright division of the U.S. Patent Office for the title page of the Book of Mormon. The words "author and proprietor" that appear on the title page were required to fulfill the requirements of the copyright. [J.W.M.]

B.005 B., W. W. "The Book of Doctrine and Covenants, and the Book of Mormon Do Harmonize." SH 23 (1 June 1876): 336-37. Deals specifically with the way in which the terms "eternal torment" and "endless punishment" are used in the Book of Mormon and in the Doctrine and Covenants. [A.T.]

B.006 Bacheler, Origen. Mormonism Exposed Internally and Externally. New York: 162 Nassau Street, 1838. One of the first major exposes of the Book of Mormon. The author considers the book "trash," "vulgar," and utterly devoid of merit. He provides a plethora of examples of what he considers bad English, modern phraseology and language, anachronistic statements, contradictions with the Bible, and absurdities. Provides a fairly good summary of common objections to the Book of Mormon. [M.R.]

B.007 Bachman, Danel W. "Anthon Transcript." In Encyclopedia of Mormonism, edited by Daniel H. Ludlow, 1:43-44. 5 vols. New York: Macmillan, 1992. The Anthon Transcript was a piece of paper that Martin Harris took to Professor Charles Anthon, professor of classical languages at Columbia College in 1828. It contained a sample of characters transcribed from the gold plates by Joseph Smith; it also contained a translation thereof. Martin Harris desired a scholarly opinion before investing time and money in the translation of the plates. [J.W.M.]

B.008 Bachman, Danel W. "A Look at the Newly Discovered Joseph Smith Manuscript." Ensign 10 (July 1980): 6973. Describes the discovery of an original copy of a document upon which Joseph Smith copied several characters from the gold plates, supposedly representing the document that Martin Harris presented to Professor Charles Anthon in February of 1828. (Editor's note: this document has since been shown to be a forgery.) [D.M.]

B.009 Bachman, Danel W. "Sealed in a Book: Preliminary Observations on the Newly Found 'Anthon Transcript.'" BYU Studies 20 (Summer 1980): 321-45. Various descriptions and reproductions of the "Anthon Transcript" are examined. Bachman concludes that the document found by Mark Hofmann in a Smith family Bible is probably the original. Reproductions of the "Whitmer Text," "the 1844 placard stick of Joseph," and "The Hofmann document" also appear in the article. (Editor's note: the "Hofmann document" has since been proven a forgery.) [J.W.M.] 
B.010 Bachman, Danel W., et al. Review of The Prophet Joseph Smith: Essays on the Life and Mission of Joseph Smith, edited by Larry C. Porter and Susan Easton Black. BYU Studies 28/4 (1988): 103. Book review.

B.011 Backman, Milton V., Jr. Eyewitness Accounts of the Restoration. Orem, UT: Grandin Book, 1983. A narrative of the first vision, the coming forth of the Book of Mormon, visits of Moroni and other heavenly messengers assigned to instruct Joseph during the period 1823-1827 are presented using Joseph Smith's four written histories in conjunction with other accounts written by Lucy Smith, Orson Pratt, Oliver Cowdery, and others. Also provides observations and recollections concerning Joseph Smith during the period of the translation and publication of the Book of Mormon. This work is reviewed in P.301. [J.W.M.]

B.012 Backman, Milton V. Jr. "Joseph Smith and the Restitution of All Things." In Joseph Smith: The Prophet, The Man, edited by Susan Easton Black and Charles D. Tate Jr., 89-99. Provo, UT: Brigham Young University Religious Studies Center, 1993. The Book of Mormon was a great tool in restoring a religion that welded Old and New Testament doctrines, bringing about a restitution of all things. It contained the practices, doctrine, power, and authority of the primitive church. [J.W.M.]

B.013 Backman, Milton V., Jr. Joseph Smith's First Vision. Salt Lake City: Bookcraft, 1971, [R]1980. Provides the accounts of Joseph Smith's first vision. Also, contains a description of the religious and economical environment of Palmyra as a background for the first vision. Uses the Book of Mormon as a witness of Joseph Smith's divine calling. A separate chapter gives a brief account of the Three Witnesses and the Eight Witnesses. [A.T.]

B.014 Backman, Milton V., Jr. "The Mormon Movement in Its American Setting: Judaeo-Christian Roots." In Religion and Philosophy in the United States of America edited by Peter Freese, 1:31-45. Essen: Verlag Die Blaue Eule, 1987. Deals with the religious atmosphere in America during the period of the organization of the LDS church and how the Church fit into this religious culture. The Book of Mormon played a role in the coming forth of the Church. [A.T.]

B.015 Backman, Milton V., Jr. Review of Christian Deviations: the Challenge of the New Spiritual Movements, by Horton Davies. Dialogue 1 (Summer 1966): 107. Book review.

B.016 Backman, Milton V., Jr. Review of A Religious History of the American People, by Sydney E. Ahlstrom. Dialogue 8 (Spring 1973): 106. Book review.

B.017 Badger, Ralph A. "The Moving Finger Writes." IE 53 (March 1950): 195, 239. Describes several crudely drawn petroglyphs chiseled on rocks and walls of the Hava Supoi Canyon (Indian Reservation on the South Rim of the Grand Canyon), then concludes that "man and prehistoric animals must have lived at the same time, for man could not make a picture of an elephant or a mastodon if he had not seen one." [R.C.D.]

B.018 Badger, Wanda West. "A Book Worth Giving." CN 58 (3 September 1988): 3-4. Many people give a copy of the Book of Mormon and their testimony to non-members, of whom many are converted by reading these gifts of the Book of Mormon. [M.R.]

B.019 Badlam, A. "A Cunning Device Detected." TS 1 (January 1840): 47. Contains an interview with Solomon Spaulding's widow, Matilda Davidson, and daughter, Mrs. McKinistry, concerning the Spaulding manuscript's connection with the Book of Mormon. The wife and daughter saw little resemblance between the two documents, thinking there may have been a similarity in some names. [D.M.] 
B.020 Baer, James L. "The Third Nephi Disaster: A Geological View." Dialogue 19 (Spring 1986): 127-32. A scientific, geological answer to the question, "Could the disastrous events described in 3 Nephi 8 have really taken place?" The author concludes that the entire scene could indeed be explained by "a gigantic earthquake with attendant storms and volcanic activity" that would accompany such a catastrophic event in nature. [J.W.M.]

B.021 Baggerly, Earl W. The Record of the Nephites. Kansas City, MO: Baggerly, 1955. A 16-page tract inviting readers to accept the Palmyra edition of the Book of Mormon. Current editions of the Book of Mormon contain, alleges the author, corruptions made "by carnal man to match the traditions of man." [A.T.]

B.022 Bagley, C. Stuart. "A New Approach to the Geography of the Book of Mormon." In 14th Symposium on Archaeology of the Scriptures, 70-86. Provo, UT: Brigham Young University, 1963. Book of Mormon lands are located in Mesoamerica. Many Book of Mormon sites are discussed, one of which, the city of Nephi, is located in the peninsula of Yucatan. A map is also provided. [B.D.]

B.023 Bagley, Pat. I Spy a Nephite. Salt Lake City: Deseret Book, 1991. A children's picture book in which the reader looks for a fictitious Nephite character, Norman, in several different scenes that deal with the Book of Mormon or Latter-day Saints. A Mormon's version of Where's Waldo. [M.D.P.]

B.024 Bagley, Pat. If You Were a Boy in the Time of the Nephites. Salt Lake City: Deseret Book, 1989. An imaginative children's activity book designed for boys, suggesting possible Nephite culture from a modern American point of view. [D.M.]

B.025 Bagley, Pat. If You Were a Girl in the Time of the Nephites. Salt Lake City: Deseret Book, 1989. An entertaining children's activity book geared to LDS girls, showing what life may have been like for their Nephite counterparts. Contains mazes, word games, and various puzzles. [D.M.]

B.026 Bagley, Pat. A Nephite in the Works. Salt Lake City: Deseret Book, 1992. A Book of Mormon cartoon book for children based upon popular work entitled Where's Waldo. [B.D.]

B.027 Bahlinger, Heidi. "A German Girl's Prayer Answered." NE 5 (April 1975): 10-12. A story of a German girl who was converted to the Gospel by the Book of Mormon after praying to find out if it was true. [M.D.P.]

B.028 Bahner, Ann. "The Book of Mormon By?" Christian Contemporary 3 (1977): 4-5. A brief, newsy-type piece, raising the question of the Spaulding manuscript and the authorship of the Book of Mormon. [D.W.P.]

B.029 Bailey, George H. "What the Book of Mormon Means to Me." MS 90 (3 May 1928): 286-88. A testimonial of the truthfulness of the Book of Mormon. Provides a very brief account of the contents of the Book of Mormon and shares the lessons learned and the spiritual strength received by the author from the Book of Mormon. [A.T.]

B.030 Bailey, H. Deloyd, comp. The Standard Works Digest (Index to General Authority comments on scriptural verses). U.S.A.: H. D. Bailey, 1986. A collection of scriptural references from more than 225 books, magazines, and commentaries that reviews how the General Authorities of the Church of Jesus Christ of Latter-day Saints have used given scriptures. Includes references to scriptures in the Book of Mormon. [B.D.]

B.031 Bailey, J. W. A. "Supplementary Notes On the Urim and Thummim." SH 80 (15 March 1933): 338-39. The Urim and Thummim were instruments used in translating the Book of Mormon, were utilized by the brother of Jared, and were prepared by God to bring to light all the works of darkness and secret organizations. [J.W.M.] 
B.032 Bailey, J. W. A. "Where Hill Cumorah is Located." SH 79 (18 May 1932): 478. Provides a list of references from the Book of Mormon concerning the location of the Hill Cumorah. [J.W.M.]

B.033 Bailey, Wilfrid C. Review of "A Possible Focus of Asiatic Influences in the Late Classic Cultures of Mesoamerica," by Gordon F. Ekholm, from Asia and North America: Transpacific Contacts, edited by Marian Smith. U.A.S.N. 14 (10 August 1953): 14.1. Book review.

B.034 Bailey, Wilfrid C. Review of Asia and North America: Transpacific Contacts, edited by Marian Smith. U.A.S.N. 14 (10 August, 1953): 14.1. Book review.

B.035 Bailey, Wilfrid C. Review of Indian Corn in Old America, by Paul Weatherwax. U.A.S.N. 48 (19 March, 1958): 48.2. Book review.

B.036 Baird, J. Edwin. Selected Scriptural References Concerning Lamanites from the Book of Mormon. Salt Lake City: Department of Education Church of Jesus Christ of Latter-day Saints, 1959. A sequential list of scriptures that deal with the Lamanites. [J.W.M.]

B.037 Baker, Christine Purves. "Helaman3." In Encyclopedia of Mormonism, edited by Daniel H. Ludlow, 2:585. 5 vols. New York: Macmillan, 1992. Helaman, the son of Helaman, was the chief judge and keeper of the Nephite records for fourteen years. The book of Helaman takes its name from him; he received the records from Shiblon and left them to his son Nephi2. [J.W.M.]

B.038 Baker, Christine Purves. "Ishmael." In Encyclopedia of Mormonism, edited by Daniel H. Ludlow, 2:704-5. 5 vols. New York: Macmillan, 1992. Ishmael was of the house of Ephraim and was summoned by Nephi to leave Jerusalem to join Lehi in the wilderness with his two sons and five daughters about 600 B.C. Zoram and the children of Lehi married Ishmael's children. [J.W.M.]

B.039 Baker, DeVere. The Raft Lehi IV: 69 Days Adrift on the Pacific Ocean. Long Beach: Whitehorn, 1959. Provides day-by-day descriptions of a voyage conducted by the author and three others from San Pedro harbor, California, to Hawaii. The voyage comprised a 69-day trip on an $18 \times 24$ foot raft. The purpose for the excursion was to demonstrate that Lehi's transoceanic crossing was possible. [A.T.]

B.040 Baker, George R. "Heeded Moroni." CN 63 (1 May 1993): 16. Story of author's conversion. He joined the Church after reading the Book of Mormon and praying about it according to Moroni's challenge. [S.H.]

B.041 Baker, H. E. "Ancient Arizona and the Book of Mormon." Contributor 15 (1893-94): 41-49, 91-97, 214-19, 313-23. Describes the culture of the Zuni tribe located in the four corners region of the United States and concludes that because of their civilized lifestyle they must have been of Nephite descent. [A.T.]

B.042 Baker, Lewis Henry. Highlights of the Book of Mormon. Los Angeles: author, 1934. Features 86 brief chapters, each containing a number of verses from the Book of Mormon. Some chapters are introduced with a note from the author. [D.W.P.]

B.043 Baldwin, E. E. "A Bit of Original Evidence." Lucifer's Lantern (May 1900): 181-83. Believes that the story about the Book of Mormon was intended to be a practical joke and that Joseph Smith realized there was money in perpetrating this hoax. [D.M.] 
B.044 Bales, James D. The Book of Mormon? Rosemead, CA: Old Paths Book Club, 1958. This book is evangelical and polemical in nature. The author discounts various propositions set by the Church and the Book of Mormon, such as the corruption of the Bible, the testimonies of Book of Mormon witnesses, and the idea that Joseph Smith was an inspired translator. The author provides evidence in favor of the Spaulding origin of the Book of Mormon, including seventy-five parallels between both books. Discusses possible source material that may have been available to Joseph Smith before the publication of the Book of Mormon. Anachronisms are identified and criticized. [M.R.]

B.045 Bales, James D. "The Book of Mormon and Spaulding Manuscripts." Christian Soldier 4/9 (14 August 1942): 5. Discusses 49 similarities between the Book of Mormon and the Spaulding manuscripts, and concludes that the manuscripts were the basis for the Book of Mormon. [D.W.P.]

B.046 Bales, James D. The Testimony of the Holy Ghost to the Book of Mormon. N.p., n.d. A pamphlet that holds that the claim of Moroni 10:4-5 regarding how to gain a testimony of the Book of Mormon is a denominationalistic approach and is not a conclusive method. [D.W.P.]

B.047 Ball, Isaac B. "Additional Internal Evidence for the Authenticity of the Book of Mormon." IE 34 (May-June 1931): 387-89, 428-29, 457-59, 494-95. Defends the reality of the natural catastrophes described in 3 Nephi 810. Quotes descriptions of more recent hurricanes and earthquakes to show how similar the details are and how accurate the Book of Mormon account is. The account in 3 Nephi 8-10 is so accurate that neither Joseph Smith nor Oliver Cowdery could have had sufficient knowledge of the facts of natural disasters to have invented this description. [B.D.]

B.048 Ball, Russell H. "An Hypothesis Concerning the Three Days of Darkness Among the Nephites." Journal of Book of Mormon Studies 2 (Spring 1993): 107-23. Provides a list of the "mechanisms of destruction described in 3 Nephi 8 and 9," and notes that throughout the destructions, no rain was mentioned and yet the inhabitants of the land were unable to kindle a fire. Concludes that a tremendous earthquake with a local cloud of volcanic ash was the cause of the effects listed in 3 Nephi 8 and 9, including the three days of darkness. Also examines the phrase "whole earth" as it relates to the destructions. [A.T.]

B.049 Ball, Terry B. "Second Book of Nephi." In Encyclopedia of Mormonism, edited by Victor Ludlow, 1:146-47. New York, NY: Macmillan, 1992. Provides a summary description of 2 Nephi in sections: Lehi's admonitions and testament to his posterity before his death (1:1-4:11); Lehi pronounces blessings on all his children and Nephi writes a small historical segment (4:12-5:34); a sermon by Jacob (chapters 6-10), and a lengthy written discourse from Nephi (chapters 11-33) in which he quotes large portions of Isaiah. [B.D.]

B.050 Ballard, M. Russell. "Steadfast In Christ." Ensign 23 (December 1993): 50-53. Just as a well-placed anchor can hold a giant ship in turbulent seas, each person who takes Jesus Christ as an anchor will stand fast in these turbulent social times. It is necessary to know if Joseph Smith was a prophet and if the Book of Mormon is in fact the work of God. We must know for ourselves. Every great prophet, whether in the Bible or Book of Mormon, has had to go through the same process to come to a sure knowledge of Christ. [J.W.M.]

B.051 Ballard, M. Russell. "You-The Leaders in 1988." Ensign 9 (March 1979): 69-73. To be a leader in the Church takes total commitment to the Lord, an understanding that Joseph Smith was a prophet and that he translated the Book of Mormon by the gift and power of God, and a willingness to withstand the difficulties and winds of temptation. Leaders must be prepared, and preparation consists of reading, praying about, and pondering the Book of Mormon. [J.W.M.] 
B.052 Ballard, Melvin J. "Ancient Ruins of South America: Some External Evidences Supporting the Story of the Book of Mormon." IE 30 (September 1927): 960-73. This piece is largely an account (accompanied by photographs) of a trip by the author to ancient ruins in the Andes Plateau. Monoliths and the ruins of temples in the sites of three ancient cities are described. The workmanship of the ruins is marvelous, states the author, and comparable to ancient Egyptian buildings. [D.M.]

B.053 Ballard, Melvin J. "Book of Mormon Evidences." DN 2 (30 April 1932); 5, 7, 8. Describes several external evidences of the Book of Mormon: an Egyptian Prince declared that he could understand a pure Egyptian dialect spoken in Mesoamerica; compares Egyptian and Mayan alphabet characters and says one borrowed from the other; discusses the theory of Atlantis as a possible land bridge; relates the discovery of the "earliest American date, 6 August 613 B.C."; sets forth the existence of the horse, elephant, steel, gold, and cement in ancient America. The worship of Pizarro and Cortez by the Indians as gods indicates that Christ visited America anciently. [B.D.]

B.054 Ballard, Melvin J. "Book of Mormon Evidences." In Sermons and Missionary Services of Melvin Joseph Ballard, edited by Bryant S. Hinkley, 191-203. Salt Lake City: Deseret Book, 1949. Also found in Crusader for Righteousness, edited by Melvin J. Ballard, 163-73. Salt Lake City: Bookcraft, 1966. Offers "tangible evidence" of the authenticity of the Book of Mormon, including archaeological ruins in Mexico, the Egyptian influence on ancient Book of Mormon culture, the temples built after the manner of Solomon's temple, the ancient Mayan calendar stone, traditions of the Great White God who visited ancient inhabitants, and others. [J.W.M.]

B.055 Ballard, Melvin J. "Book of Mormon Evidences." MS 94 (16 June 1932): 369-75, 378-80. The discovery of pyramids and other archaeological ruins, the usage of steel among the ancient peoples of America, the connections between Egyptian and Mayan alphabets, and the traditions of Quetzalcoatl are evidences for the Book of Mormon. [A.C.W.]

B.056 Ballard, Melvin J. "The Divine Purpose in the Bringing Forth of the Book of Mormon." Liahona 21 (29 January 1924): 297-300. The Book of Mormon came forth to bring redemption to the Lamanites, to benefit the world, to bring men to repentance, and to provide a sign of the nearness of the Second Coming. Exhorts members of the Church to be obedient to the teachings contained in the Book of Mormon. [A.T.]

B.057 Ballard, Melvin J. "Jesus Christ Visits America." DN Church Section (29 December 1934): 2, 7. Recounts Christ's visit to the Nephites in the Americas. Refers to external evidences, such as the Mexican calendar stone and Joseph Smith's witnesses, that help support the truth and divinity of the Book of Mormon. [M.D.P.]

B.058 Ballard, Melvin J. "The Mission of the Book of Mormon." IE 37 (March 1934): 160-61. Declares that the mission of the Book of Mormon, which is to show the great things that the Lord has done to the remnant of the House of Israel (including the Lamanites) and to convince them that Jesus is the Christ, has not been fulfilled. [B.D.]

B.059 Ballard, Melvin J. "New Witness for Christ." IE 39 (December 1936): 746-47. Also in Handbook of the Restoration, 487-91. Independence, MO: Zions Printing and Publishing, 1944. The sacred mission of the Church and the Book of Mormon is to bring all nations to Christ. The book gives an account of Jesus' visit on the American continent and provides a new witness for him. [J.W.M.]

B.060 Ballard, Melvin J. "Our Duty as Custodians of the Book of Mormon." IE 31 (December 1927): 103-8. Members of the Church are expected to obtain a spiritual testimony of the Book of Mormon and then help move it 
toward its divine destiny. The mission of the book is described on the title page. The book is to be taken to the descendants of Lehi and the time will come when substantial numbers of them will respond. [D.M.]

B.061 Ballard, Melvin J. Untitled talk. CR (October 1923): 28-33. The purpose of the Book of Mormon is to bring to pass the redemption of the Lamanites and to bring salvation to the people of the world. The elders of the Church need to work with God to bring about this end. [B.D.]

B.062 Bancroft, Hubert Howe. The Works of Hubert Howe Bancroft: The Native Races of the Pacific States. 5 vols. San Francisco, CA: A. L. Bancroft, 1883. In a chapter entitled, "On the Origins of the Americans" (5:96-102), the author reviews the LDS (Book of Mormon) view regarding the inhabiting of the ancient Americas by the Jaredites, Nephites, and Mulekites. [D.W.P.]

B.063 Bankhead, Reid E. "America's Decision About Christ." In Sidney B. Sperry Symposium: The Book of Mormon, edited by A. Gary Anderson, 1-10. Provo, UT: Brigham Young University Religious Studies Center, 1981. Those who reject the Book of Mormon will be brought into captivity, spiritually and temporally. The early Latter-day Saints left the inhabited areas of America because of the rejection of the Book of Mormon and of Christ by the American people. [J.W.M.]

B.064 Bankhead, Reid E. The Bible and the Book of Mormon. Salt Lake City: Church of Jesus Christ of Latter-day Saints, 1955. Reasons that if God is indeed no respecter of persons, then it is logical that Christ would make himself known to nations other than the Jews. The descendants of Joseph in America were in every way qualified to have Christ minister to them. The Bible and the Book of Mormon are both witnesses of the same God. [A.L. \& P.H.]

B.065 Bankhead, Reid E. Concluding Messages of the Book of Mormon. Provo, UT: Brigham Young University, 1956. A transcript of a series of talks, wherein the author teaches various messages of the Book of Mormon including the Atonement, sacrament, continuing revelation, Christian creeds, and Nephite destructions. His purpose is to encourage listeners to study the Book of Mormon as a means to becoming more effective teachers. [A.T.]

B.066 Bankhead, Reid E., and Glenn L. Pearson. A Doctrinal Approach to the Book of Mormon. Salt Lake City: Bookcraft, 1962. A study aid intended to demonstrate the many rich doctrinal topics contained in the Book of Mormon. One doctrinal topic discussed, for instance, is the divine birth of Jesus. Aids the reader with cross referencing and scripture marking. [A.T.]

B.067 Bankhead, Reid E., and Glenn L. Pearson. Missionary Work with the Book of Mormon. Palmyra, NY: Cumorah Mission, 1967. Compiles approaches in using the Book of Mormon in connection with missionary work. [J.W.M.]

B.068 Bankhead, Reid E., and Glenn L. Pearson. The Word and the Witness: The Unique Mission of the Book of Mormon. Salt Lake City: Bookcraft, 1970. Instructional aid to assist LDS missionaries in using the Book of Mormon. The majority of the work contains sample dialogues between a missionary and investigator. [A.T.]

B.069 Bantista, M. "A Faith-Promoting Experience." IE 23 (September 1920): 978-84. A testimonial from Old Mexico, wherein the author explains the role of the Book of Mormon in his conversion to the Church of Jesus Christ of Latter-day Saints. [J.W.M.]

B.070 Barber, F. C. "Mormonism in the United States." De Bow's Review: A Monthly Journal of Commerce, Agriculture, Manufactures, Internal Improvements, Statistics, etc., etc. 16 (April 1854): 368-82. Describes the surprising rise of 
Mormonism. Praises the Book of Mormon as having great literary value, but discounts its divine origin. [B.D.]

B.071 Barber, Ian. What Mormonism Isn't: A Response to the Research of Jerald and Sandra Tanner. Aukland, New Zealand: Pioneer, 1981. A response to Jerald and Sandra Tanner, who oppose the teachings of the Book of Mormon. Pages 4-11 discuss issues relating to the translation of the Book of Mormon and describe how it relates to the language of the text. [M.R.]

B.072 Barber, John. "Oriental Enigma." Biblical Archaeology Review 16 (1990): 83-95. There is strong evidence in support of transpacific crossings 1000 years before Columbus. Diverse evidences come from the study of metallurgy, agriculture, and parasitology. The Mayan calendar shows connections between the Mayan and the Hebrew and Greek alphabets. [J.W.M.]

B.073 Barefoot, J. L. "Stories About Utah: The Deseret Museum." Juvenile Instructor 10 (18 September 1875): 224. Fossil bones of an elephant, found near Payson, Utah, in 1870, were sold to the Deseret Museum. Elephants were present during Book of Mormon times. [D.M.]

B.074 Barker, Clarence. "Husband and Wife Musician Team Finds Truth in Gospel." CN (25 May 1974): 14. Musicians Marvin and Nadina Bryan were converted to the gospel of Jesus Christ through the example of a young LDS member who read the Book of Mormon while his fellow workers played poker, and by reading the Book of Mormon themselves. [M.R.]

B.075 Barker, James L. "The Language of the Book of Mormon." IE 63 (June 1960): 388-89, 444, 446, 450-54. English, the language of translation employed by Joseph Smith, retains the original thought, personal writing styles, distinctive patterns, and unique phraseology belonging to each of the ancient writers and prophets of the Book of Mormon. Barker also discusses the language of the gold plates, which has been described as being a combination of the "learning of the Jews and the language of the Egyptians" (1 Nephi 12), and as "reformed Egyptian" (Mormon 9:32). Too little is known about the characters of reformed Egyptian, which had been "altered" by the Nephites (Mormon 9:32). [D.W.P.]

B.076 Barlow, Philip L. "Before Mormonism: Joseph Smith's Use of the Bible, 1820-1829." Journal of the American Academy of Religion 57 (Winter 1989): 739-71. A defense that "Mormons are Bible-believing Christians" that explores Joseph Smith's background, the influence of the Bible in his culture, and his production of additional scripture to reinforce the Bible. Through the use of Book of Mormon passages, it is shown that biblical language and passages are woven into new interpretations and expansions of traditional biblical thought unknown in Joseph's day. [J.W.M.]

B.077 Barlow, Philip L. Mormons and the Bible: The Place of the Latter-day Saints in American Religion. New York: Oxford University Press, 1991. Deals with the use of the Bible in the LDS church. Compares the Book of Mormon with the Bible, showing similarities and differences. This work is reviewed in F.092. [A.C.W.]

B.078 Barnes, C. Douglas. "Lehi's Route to America." IE 42 (January 1939): 26-28, 49. Traces Lehi's possible migration route following ocean currents from the Arabian Peninsula across the Pacific Ocean to Central America. Includes a discussion of the theory surrounding the origin of the Polynesian people. [J.W.M.]

B.079 Barnett, Henry W. "The Aborigines of America." MS 22 (April 1860): 258-60. Old Testament and Book of Mormon prophecies provide answers to questions concerning the origins of the American Indians who are of the House of Israel. The record called the stick of Joseph came forth as the Book of Mormon. [J.W.M.] 
B.080 Barrett, Ivan J. Joseph Smith and the Restoration: A History of the Church of Jesus Christ of Latter-day Saints to 1846. 2d ed. Provo, UT: Brigham Young University Press, 1973. Chapter 4, "Glad Tidings from Cumorah," tells of Moroni's visit and Joseph Smith's first visit to the Hill Cumorah. Chapter 5, "Delivery and Translation of the Ancient Record" and Chapter 6, "Publication of the Book of Mormon," deal specifically with the Book of Mormon. This work is reviewed in D.144. [A.T.]

B.081 Barrett, Ivan J. "A Nation Aroused: Alma 46." Instructor 104 (June 1969): 198-99. Reviews the story of Captain Moroni (Alma 46) as an example of a righteous leader, student of the scriptures, man of faith, and a "champion of human liberty." [A.T.]

B.082 Bartlett, Daniel H. The Mormons or Latter-Day Saints, Whence Came They? London: Nisbet, 1911. A polemical work against Mormonism. The author, who favors the Spaulding theory for the origin of the Book of Mormon, asserts that the book anachronistically quotes Shakespeare, mentions steel and various domesticated animals. [M.R.]

B.083 Barrett, Robert T. "The Jaredites Leave Babel." Friend 20 (April 1990): 20-21. An illustrated story for children that tells of the Jaredites leaving Babel in order to find the promised land. [M.D.P.]

B.084 Barrett, Robert T. "The Lord Leads the Jaredites to a Promised Land." Friend 20 (May 1990): 19-22. An illustrated story for children that tells of the Jaredites traveling to the promised land through the Lord's guidance. [M.D.P.]

B.085 Bartley, Peter. Mormonism: The Prophet, the Book and the Cult. Dublin: Veritas, 1989. Booklet that opposes Joseph Smith and his work. Discusses the Book of Mormon witnesses, the Anthon interview, and the Book of Mormon plates. Emphasizes archaeological arguments and internal evidence. Claims that the Book of Mormon plagiarizes the Bible and borrows extensively from the King James Version. Notes changes in the text of Book of Mormon editions. This work is reviewed in P.208. [D.M.]

B.086 Barton, Marie Musig. Our Promised Land: Book of Mormon Stories for Boys and Girls. Salt Lake City: Salt Lake Times, 1949. Consists of moral lessons from the Book of Mormon written for children. Emphasizes that the ancient Book of Mormon peoples were taught that they must serve God or perish. [J.W.M.]

B.087 "Basketball Tournament Turned into Missionary Tool by Ward." CN 56 (21 December 1986): 6. A story of how a young man organized a basketball tournament and delivered copies of the Book of Mormon to a number of participants, thus effectively doing missionary work. [M.D.P.]

B.088 Bassett, Arthur R. "Alma the Elder." Ensign 7 (February 1977): 5-10. Alma the Elder became the father of nine generations of prophets. His faith was so great that it brought him to repentance, sustained him for over twenty years in the wilderness, brought him to his knees over a rebellious son, and gave him compassion as a chief judge. [J.W.M.]

B.089 Bassett, Arthur R. "Floods, Winds and The Gates of Hell." Ensign 21 (June 1991): 6-11. Christ's visit to America was concluded when he taught four principles designed to protect individuals against "spiritual erosion": avoid unrighteous judgment, negative

B.090 Bassett, Arthur R. "It Begins with a Family: Some Major Teachings in the First Half of the Book of Mormon." Ensign 6 (September 1976): 13-18. One may gain more from reading the Book of Mormon by placing one's self in 
the situation of some person in the book. For example, fathers might personally relate to the patriarch Lehi by reading the history of his life as presented in the Book of Mormon. Mothers may gain much by demonstrating empathy with mother Sariah, and righteous sons can identify with Nephi. In this manner one might better understand some of the principles illustrated by the various stories in the Book of Mormon. [B.T.]

B.091 Bassett, Arthur R. "Jesus' Sermon to the Nephites." Ensign 8 (February 1978): 58-62. Discusses the five major segments in Jesus' first sermon to the Nephites contained in 3 Nephi 11-14. The Savior invites all to come to him and focuses on how to gain the spiritual strength to become his true disciple. [D.H.M.]

B.092 Bassett, Arthur R. "Now Abideth These Three: Faith, Hope and Charity." Ensign 7 (September 1977): 7-11. A discussion of faith, hope, and charity as found in the last half of the Book of Mormon. [J.W.M.]

B.093 Bassett, Arthur R. "The Shepherd and His Other Sheep." Ensign 8 (February 1978): 53-57. Using the text of the Jesus Christ's visit to the American continent, as recorded in 3 Nephi 11-30, the author emphasizes the need to know the Savior, which knowledge leads to eternal life. Knowing the Savior leads one to become like him. [J.W.M.]

B.094 Bassett, K. Douglas. "Four Faces of Pride in the Book of Mormon." In Doctrines of the Book of Mormon, 1991 Sperry Symposium, edited by Bruce A. Van Orden and Brent L. Top, 16-28. Salt Lake City: Deseret Book, 1992. The four faces of pride are the wearing of costly apparel (which may have reference to conspicuous consumption in our day), class distinctions, contention, and anti-enemy attitudes. Those who possess an anti-enemy posture may have no time for the pro-kingdom of God. Pride can be overcome by humility. [B.D.]

B.095 Bassett, K. Douglas. "Nephi's Freedom Thesis and the Sons of Helaman." In The Book of Mormon: Alma, The Testimony of the Word, edited by Monte S. Nyman and Charles D. Tate Jr., 191-304. Provo, UT: Brigham Young University Religious Studies Center, 1992. Christ preserves freedom for the inhabitants of the land of America who live righteously. The account of Helaman's stripling warriors is representative of this theme. If the stripling warriors did not doubt the Lord's promise of protection and freedom, God would deliver them. Their obedience to leadership under trying circumstances has a message for Church membership today. [N.K.Y.]

B.096 Bates, Ernest Sutherland. American Faith. New York: Norton, 1940. A polemical work that discusses Mormonism on pages 341-58. The author considers the Book of Mormon "an unsuccessful imitation of the style of the King James Version" of the Bible. After a brief review of the Book of Mormon's contents the author notes alleged anachronisms such as biblical plagiarism, quotations from Shakespeare, and others. Reference is also made to the incident of Anthon's 1834 denial of the "sealed book." [M.R.]

B.097 Bates, Kathryn Ricks. "Scripture Sketches." Ensign 21 (June 1991): 67. Sunday evenings in the Bates family home are spent drawing pictures of Book of Mormon characters and stories in compliance with President Benson's challenge to display Book of Mormon pictures in the home. [J.W.M.]

B.098 Bayne, Elbert. "A Time Appointed." In Recent Book of Mormon Developments; Articles From the Zarahemla Record, 2:185-86. Independence, MO: Zarahemla Research Foundation, 1992. Argues using Alma 19:33-34 (RLDS versification), that there is an appointed time for the establishment of Zion that is not dependent upon the righteousness of Christ's followers. [B.D.]

B.099 Bays, Davis H. The Doctrines and Dogmas of Mormonism Examined and Refuted. St. Louis, MO: Christian, 1897. An ex-Mormon examines Mormon doctrines. Chapters 18-32 deal with the Book of Mormon. The Book of 
Mormon is full of faults and errors, does not fulfill biblical prophecy, nor does it fit the criteria found within the book itself. [J.W.M.]

B.100 Beadle, J. H. "The 'Golden Bible': Sidney Rigdon's Grandson Says Their Family Understood it to be a Fraud." New York Tribune (17 April 1888): n.p. Walter Sidney Rigdon, grandson of Sidney Rigdon, reports that he had talked with the older Rigdon "hundreds of times." He was a "religious crank" who became "cracked." The whole family rejected his story. The whole thing about "the Golden Bible" is a fraud. [J.W.M.]

B.101 Beadle, James Hanson. Life In Utah or the Mysteries and Crimes of Mormonism. Philadelphia: National Publishing Company, 1870. An exposé of Mormonism. Pages 21-35 discuss the Book of Mormon. Presents a somewhat garbled description of the Book of Mormon narrative; the testimony of the book of Mormon witnesses is discounted on the grounds that they were disreputable. The author accepts the Spaulding theory of Book of Mormon origins. [M.R.]

B.102 Bean, Orestes U. Corianton: An Aztec Romance. Salt Lake City: n.p., 1902?. A romantic drama (written in four acts) based upon the trial of Korihor, the Anti-Christ. [J.W.M.]

B.103 Bean, W. W. "Ancient Battlefields Puzzle U.S. Historians: Ruins Found in New York Tell of Carnage." DN Church Section (16 August 1941): 4, 5. Book of Mormon accounts of the final battles of the Nephites are compared with historical reports of DeWitt Clinton and O. Turner who tell of formidable fortresses with deep trenches, double walls, mass graves, and rusted tools in the state of New York. [J.W.M.]

B.104 Bean, Willard. A.B.C. History of Palmyra and the Beginning of "Mormonism." Palmyra, N.Y.: Palmyra Courier Co., 1938. Writes concerning the early history of Palmyra, the arrival and history of the Smith family, Joseph Smith's interest in the religious revival, the details of the First Vision, and the coming forth of the Book of Mormon. [J.W.M.]

B.105 Bean, Willard. "Cumorah Land." DN Church Section (23 February 1935): 6. Describes the Hill Cumorah and country surrounding it. Also gives evidence of ancient American Indians. [M.D.P.]

B.106 Bean, Willard. "The Indians of Cumorah Land." DN Church Section (2 March 1924): 6, 8. Discusses different traditions and beliefs of the American Indians that correspond to those of the Nephites and the Lamanites. For example, he shows that the American Indians believe in a Great Spirit, an Indian Redeemer, and of once having a "white man's book" among them that they had used. [M.D.P.]

B.107 Beardall, C. Douglas, and Jewel N. Beardall. About the Three Nephites. Provo, UT: LDS Book Publications, 1992. A discussion of the Three Nephites (3 Nephi 28:1-9). Presents a collection of some sixty different Three Nephites stories. [B.D.]

B.108 Beardsley, Harry Markle. Joseph Smith and His Mormon Empire. Boston: Houghton Mifflin and Riverside, 1931. A historical polemical work against Mormonism. Chapter 8 discusses various alleged anachronisms and absurdities in the Book of Mormon. The author rejects the Spaulding Theory in favor of the psychological environmentalist explanation proposed by Woodbridge Riley for the origin of the Book of Mormon. [M.R.]

B.109 Beardsley, Harry Markle. "The Mormons in Illinois." Illinois State Historical Society 40 (1933): 45-54. Presenting a brief history of the Mormons in Illinois, the author offers a psychological interpretation of Joseph Smith, considering the Book of Mormon to be "the product of an adolescent mind, and a mind obviously suffering 
from the characteristic mental disease of adolescence-dementia praecox. The Mormon faith is the result of the reaction of an adolescent nation to that book." [M.R.]

B.110 Bechler, C. F. J. "The Book of Mormon and I." IE 26 (March 1923): 405-8. A first person narrative testimonial of a man in Germany who found a friend in the Book of Mormon on a cold, lonely, and hopeless night. Following World War I, the man first found himself in despair, then found that the Book of Mormon offered him hope and comfort. [J.W.M.]

B.111 Beckert, Charles B. "What I Have Learned about Family Relations from the Book of Mormon." In The Sixth Annual Church Educational System Religious Educators' Symposium on the Book of Mormon, 1-4. Salt Lake City: Church of Jesus Christ of Latter-day Saints, CES, 1982. Draws upon the writings of Nephi, Jacob, Benjamin, as well as the story of Lamoni and his wife to learn about family relationships. The points emphasized include: all behavior has consequences, family unity is an important goal, worship is a family affair, and one can gain tremendous strength from a spouse. [A.T.]

B.112 Beecher, Maureen Ursenbach. "The 'Golden Bible.' " Friend 5 (December 1975): 11-13. Conversion story of Mary Elizabeth Rollins Lightner, taken from her autobiography and adapted for children. As a child she read the Book of Mormon and knew it was true. [A.C.W.]

B.113 Beers, R. W. The Mormon Puzzle and How to Solve It. Chicago: Funk \& Wagnalls, 1887. A polemical attack on Mormonism. The Book of Mormon contains plagiarized passages from the Bible. [M.R.]

B.114 Bell, James. "John W. Welch: Taking the Stand." This People 8-9 (February 1987): 48-50, 61, 63. Features the Foundation for Ancient Research and Mormon Studies (FARMS) and its founder, John W. Welch. One goal of FARMS is to better understand the ancient foundations and cultural background of the Book of Mormon, which will then strengthen an individual's testimony of the book. [J.W.M.]

B.115 Benard, David R., John W. Welch, and Daniel C. Peterson. "Secret Combinations." In Reexploring The Book of Mormon, edited by John W. Welch, 227-29. Salt Lake City: Deseret Book and FARMS, 1992. Alexander Campbell was the first to suggest that the references to secret combinations in the Book of Mormon were merely Joseph Smith's anti-Masonic sentiments. Sometime later, even Campbell later dropped this flawed argument. The authors show several contemporaneous uses of the phrase "secret combinations" and demonstrate that the term was widely used and referred to by many organizations that sought to illegally get gain. [B.D.]

B.116 Benbow, Dennis Everett. "Current Book of Mormon Evidence." SH 72 (16 December 1925): 1335-38. Some archaeologists find similarities between ancient American and Egyptian ruins. Both the horse and the camel are believed to have originated in America, fossils of huge elephant-like animals have been found, and white Indians have been located in remote areas of South America. [J.W.M.]

B.117 Bennett, Archibald F. "Dawning Day for the Children of Lehi: No Longer a Vanishing Race." DN Church Section (25 March, 1 April 1935): 6, 8. A two-part article that states that there were approximately 1,150,000 descendants of Lehi in Mexico when the Europeans arrived. Intermarriages took place between the two groups and as a result many Americans now have Lamanite blood. Argues that thousands of Church members are descendants of Lehi, showing that Lehi's promises are being fulfilled. [J.W.M.]

B.118 Bennett, Archibald F. "For a Wise Purpose." MS 100 (31 March 1938): 194-96, 203. Stresses that keeping genealogical records by all branches of the House of Israel is of great import. Outlines the sequence of prophets 
who prepared the sacred record that we have as the Book of Mormon. [R.H.B.]

B.119 Bennett, Archibald F. "Nine Generations of Spiritual Leaders." IE 48 (March-June 1945): 144, 160, 200, 284, 286, 352. Also in A Book of Mormon Treasury, 99-113. Salt Lake City: Bookcraft, 1959, [R]1976. Identifies a number of well-known Book of Mormon spiritual leaders, many of whom consisted of fathers and their sons (i.e., Alma/Alma the Younger, Mormon/Moroni). [A.T.]

B.120 Bennett, John Cook. "The Book of Mormon. Its Origin, and the Evidence of Its Truth." In Bennett's The History of the Saints; Or, An Exposé of Joe Smith and Mormonism, 103-24. Boston: Leland and Whiting, 1842. Discounts the testimonies of the eleven witnesses and others concerning the Book of Mormon. Believes that Joseph Smith had a poor character and the Book of Mormon came about through a fraudulent manner. [J.W.M.]

B.121 Bennett, John Cook. "The Claims and Absurdities of the Book of Mormon." In Bennett's The History of the Saints: Or; An ExposŽ of Joe Smith and Mormonism, 124-28. Boston: Leland and Whiting, 1842. Several authors are quoted who believe that the Book of Mormon does away with all that existed previously in religion because of its new covenant. The fact that the Book of Mormon claims that it contains the fullness of the gospel and that it has preeminence over the Bible angers authors William Harris, E. D. Howe, and J. N. T. Tucker. [J.W.M.]

B.122 Bennett, Joshua M. The Gospel of the Great Spirit. Salt Lake City: Morning Star, 1990. The sacred stories of the Indians from North, Central, and South America have many affinities and parallels with the stories featured in the Bible and Book of Mormon. [D.M.]

B.123 Bennett, Michael J. "The Book of Mormon and a World of Changing Beliefs." MS 112 (April 1950): 108-9. In an unbelieving world it is easier to prove a man to be a fraud than a prophet. The proof of a prophet lies in the witness of the Holy Ghost. The witness of the Spirit is more important than external evidences. The enlightened nature of the Book of Mormon startled the Christian world of the nineteenth century by answering numerous concerns. During the century that followed, religions modified their perspectives because of the Book of Mormon. [J.W.M.]

B.124 Bennett, William A. "Some Traditions of the American Indians." MS 68 (August 1906): 510-11. Compares Apache Indian traditions to the Three Nephites of the Book of Mormon (3 Nephi 28). Apache Indians celebrate a rite that appears to recall the power and ministerial actions of the Three Nephites. Further, Apache Indians do not eat pork, a practice that may have been handed down to them from Lehi who carried the law of Moses to the American continent. [B.D.]

B.125 Bennett, William S. "My Struggle With the Book of Mormon." Restoration Witness (May 1973): 4-6. Recalls accepting the Book of Mormon in six stages - he first ignored the book, then opposed it, then tolerated it, followed by convicting it, and finally accepting it and using it as a "sword of the spirit." Bears testimony of the spiritual nature of the book. [J.W.M.]

B.126 Bennion, Adam S. "An Appreciation of the Book of Mormon." In Gleaner Manual: Course of Study and Activities, 71-140. Salt Lake City: General Board of The Young Ladies Mutual Improvement Association, 1932. A manual for instructors of the Mutual Improvement Association program topically arranged according to different facets of the Book of Mormon. Suggestions for teaching included. [S.H.]

B.127 Bennion, Adam S. "We May Find Joy in Master's Service." CN 31 (18 February 1961): 16. The Book of Mormon shows that we need to "center our thinking in the joys of living the gospel," of service, and of living in the 
world. [M.D.P.]

B.128 Bennion, Francine. "Encounter in Ammonihah." Ensign 7 (April 1977): 24-29. Using the text of Alma 8-15 (the Ammonihah pericope), the author examines the motives and immoral tactics of those who seek for gain by twisting the laws of the land. [J.W.M.]

B.129 Bennion, Francine. "Women and the Book of Mormon." In Women of Wisdom and Knowledge, Talks Selected from the BYU Women's Conferences, edited by Marie Cornwall and Susan Howe, 169-78. Salt Lake City: Deseret Book, 1990. Why were women of the Book of Mormon seemingly placed in subsidiary roles, often not presented in the record by name, and not portrayed as significant individuals? Author concludes that the Book of Mormon speaks concerning the importance of both men and women. [A.T.]

B.130 Bennion, Heber. Gospel Problems. Dugway, UT: Pioneer, 1920. Sets forth several questions regarding doctrines of the LDS faith. Pages 8-22 pertain to the Book of Mormon. Questions the correctness of the translation of the Book of Mormon and the validity of some of the prophecies in the Book of Mormon and then invites Church members to study and pray to find the answers to the questions proposed. [A.T.]

B.131 Bennion, John W. "Book of Mormon Perspectives on Prosperity." IE 73 (May 1970): 14-17. Points out that "prosperity can become a curse and lead to moral and spiritual decay." Several scriptures are quoted and discussed to help teach the correct use of material wealth. "Prosperity in and of itself does not improve a man's character." [B.W.J.]

B.132 Bennion, Kenneth S. "What Plates Came from Cumorah?" Instructor 89 (January 1954): 64-65. Provides a description of the various sets of plates from which the Book of Mormon was translated and includes a serviceable diagram of the plates. [R.H.B]

B.133 Bennion, Lowell L. The Book of Mormon: A Guide to Christian Living. Salt Lake City: Deseret Book, 1985. Encourages students of the Book of Mormon to earnestly "look for religious ideas and feelings" in the Book of Mormon. Author's book is divided into three parts-"Wisdom in Everyday Living," "Principles and Ordinances of the Gospel," and "Some Universal Concepts." [A.T.]

B.134 Bennion, Lowell L. "The Book of Mormon-A Guide to Religious Living" (Series). Instructor 83 (January 1948 -December 1948): 16, 54, 112, 165, 219, 273, 318, 357, 406, 461, 507, 567. The Book of Mormon teaches practical works and doctrinal truths: government by law brings blessings; all are precious in God's sight; faith, baptism, repentance bring mercy and satisfy justice, etc. [R.H.B.]

B.135 Bennion, Lowell L. The Church of Jesus Christ. Salt Lake City: Deseret Sunday School Union, 1941. A series of Sunday School lessons that presents a history of the Church of Jesus Christ and recalls the story of the coming forth of the Book of Mormon. The Book of Mormon is a new revelation and the events that brought about the Book of Mormon were foretold in the book itself. [J.W.M.]

B.136 Bennion, Lowell L. Understanding The Scriptures. Salt Lake City: Deseret Book, 1981. Gives keys on how to study and understand the scriptures. Claims that the Book of Mormon is not a book of great literary acclaim, nor is it a historical record, a geographical or archaeological guidebook. The Book of Mormon, however, is a "profoundly religious record." that is "enriched, like much of the Bible, by its authors' deep religious convictions." The Book of Mormon teaches us concerning the attributes of God and clearly adds to our "understanding of the gospel and church of Jesus Christ." [J.W.M.] 
B.137 Bennion, Milton Lynn, and J. A. Washburn. Our Standard Works. Salt Lake City: Deseret Sunday School Union, 1946. Chapters 15-28 deal with the Book of Mormon. Explains why the Book of Mormon is needed, describes the history of its peoples, relates its coming forth and translation, and discusses its message of the divinity of Christ. [B.D.]

B.138 Bennion, Samuel O. Untitled talk. DN (6 April 1918): 42-45. Testifies of the promise to receive a testimony of the Book of Mormon by praying as Moroni 10:2-5 exhorts and encourages the Latter-day Saints to read the Book of Mormon regularly. [B.D.]

B.139 Benson, Alvin K. "Some Key Ingredients for Finding and Understanding the Truth in Science and Religion." In The Book of Mormon: Second Nephi, The Doctrinal Structure, edited by Monte S. Nyman and Charles D. Tate Jr., 34154. Provo, UT: Brigham Young University Religious Studies Center, 1989. Citing 2 Nephi 9:31-32 and other sources, the author demonstrates God's prescribed way to find the truth of all things in both science and religion. [B.D.]

B.140 Benson, Ezra Taft. "America: Land of the Blessed." IE 51 (May 1948): 283, 342-43. Book of Mormon prophets proclaimed the Lord's intent to protect the blessed land of America. The brother of Jared, Nephi, Joseph Smith, and others spoke concerning America's great destiny. Man-made governments often threaten the foundation of liberty. Though the Constitution will "hang by a thread," the promise guarantees that the thread will not break. [J.W.M.]

B.141 Benson, Ezra Taft. "Beware of Pride." Ensign 19 (May 1989): 4-6. Also in CR (April 1989): 3-7. The main message of the Book of Mormon, as defined in the Doctrine and Covenants, is directed to our day, "Beware of pride, lest ye become as the Nephites of old" (D\&C 38:39). President Benson defines pride as enmity with God and our fellow men. It is basically competitive, rebellious, and selfish. [J.W.M.]

B.142 Benson, Ezra Taft. "The Book of Mormon and the Doctrine and Covenants." Ensign 17 (May 1987): $83-85$. Also in CR (April 1987): 104-8. Speaks of the mission of the Book of Mormon and the Doctrine and Covenants. The Book of Mormon is the keystone and the Doctrine and Covenants is the capstone of the LDS religion. Each book testifies of the other, and the Doctrine and Covenants serves as the greatest external witness of the Book of Mormon, excluding the Three Witnesses. "The Book of Mormon brings men to Christ. The Doctrine and Covenants brings men to Christ's kingdom." [S.P.S.]

B.143 Benson, Ezra Taft. "Book of Mormon is a 'Standard for the Church' President Benson tells Priesthood Leaders." Ensign 16 (May 1986): 105. Reports of President Benson's address to Church leaders, April 4, 1986. The prophet explains the great mission of the Book of Mormon. [J.W.M.]

B.144 Benson, Ezra Taft. "The Book of Mormon Is the Word of God." Ensign 5 (May 1975): 63-65. Also in CR (April 1975): 93-97. Forcefully declares the Book of Mormon to be the word of God. God inspired the writing, compilation, and translation of the Book of Mormon. Bears personal testimony of the Book of Mormon and provides examples of how it should be used in everyday life. [B.T.]

B.145 Benson, Ezra Taft. "The Book of Mormon Is the Word of God." Ensign 18 (January 1988): 2-5. A slightly edited version of President Benson's General Conference address of April 1975. See Ensign 5 (May 1975): 63-65, and CR (April 1975): 93-97. 
B.146 Benson, Ezra Taft. "The Book of Mormon-Keystone of Our Religion." Ensign 16 (November 1986): 4-7. Also in CR (4-5 October 1986): 3-7. Also in Studies In Scripture: 1 Nephi-Alma 29, edited by Kent P. Jackson, 7:1-9. Salt Lake City: Deseret Book, 1987. Outlines the careful preparation that went into the introduction of the Book of Mormon to the world at the proper time. The sequence of events that followed bear witness that this book is the keystone of the Church of Jesus Christ of Latter-day Saints. There are three ways that it is the keystone: It is a witness of Christ, it was meant for this day, and it helps people draw nearer to God. [J.W.M.]

B.147 Benson, Ezra Taft. "The Book of Mormon: Our Heritage of Freedom." CR (October 1961): 69-75. Warns of the threat of communism, likening it to a continuation of the war in heaven and the Gadianton robbers of Book of Mormon times. The warning is clear in the Book of Mormon, the threat comes from within in the form of socialism. Lists several steps to ensure freedom. [J.W.M.]

B.148 Benson, Ezra Taft. "Book of Mormon Outlines Our Duty to America." CR (April 1962): 103-6. Ancient Book of Mormon prophets foresaw the entire history and destiny of America and predicted continual freedom on the basis of righteousness. However, those same prophets warned of dire judgments and captivity if America fails to maintain its "spiritual integrity." [R.C.D.]

B.149 Benson, Ezra Taft. "The Book of Mormon Overcomes Deception." CR (October 1963): 15-19. Suggests three tests to assist individuals in avoiding deception: (1) Know what the scriptures say, especially the Book of Mormon, about a particular circumstance; (2) know what the Latter-day prophets say; and (3) have the Holy Ghost. [J.W.M.]

B.150 Benson, Ezra Taft. "The Book of Mormon Warns America." In BYUSY (21 May 1968). Provo, UT: BYU Press. Testifies of the value of the Book of Mormon as a warning voice to America. Determines that communism is a great threat to society and is a secret combination. Warns concerning civil war in the United States. Raises the plea for people to listen to the warning voice of the Book of Mormon. [J.W.M.]

B.151 Benson, Ezra Taft. "Born of God." Ensign 15 (November 1985): 5-7. Also in CR (October 1985): 46-49. Commentary on Mosiah 1:7-"the Lord works from the inside out." Those who sincerely seek the Lord will experience an indescribable feeling of change, a transformation, fundamental and permanent. Those changed by Christ will be swallowed up in his will (John 5:30), they will desire to please the Lord. They are witnesses of Christ, losing themselves in him but finding eternal life. [J.W.M.]

B.152 Benson, Ezra Taft. "Civic Standards for the Faithful Saints. Four Guidelines to Help Saints Carry Out Their Civic Responsibilities." Ensign 2 (July 1972): 59-61. Also in CR (April 1972): 48-53. Benson calls the Book of Mormon the "greatest handbook for freedom in this fight against evil." Tells of the godless secret conspiracies that caused the downfall of two American civilizations and offers a warning against upholding the evils of the adversary. [J.W.M.]

B.153 Benson, Ezra Taft. "Cleansing the Inner Vessel." CR (5-6 April 1986): 3-6. Also in Ensign 16 (May 1986): 4-7. Unless members of the Church read and give heed to the teachings of the Book of Mormon, the whole Church will be under condemnation. Church members need not speak more of the Book of Mormon, but now is the time that they must "do more with it" by placing it in "the center of our personal study, family teaching, preaching, and missionary work." [J.W.M.]

B.154 Benson, Ezra Taft. "Come unto Christ." Ensign 17 (Nov. 1987): 63-65. Also in CR (October 1987): 101-4. Honest seekers of truth can gain a testimony of Jesus Christ through the prayerful study of the Book of Mormon. 
Individuals are invited to "come unto Christ" by learning the precepts taught in the Book of Mormon. [S.P.S.]

B.155 Benson, Ezra Taft. "Doctrine and Covenants is 'Capstone.' " CN 59 (7 January 1989): 3. The Book of Mormon and Doctrine and Covenants are bound together. One testifies of the other. In this way the Doctrine and Covenants is the capstone and the Book of Mormon is the keystone. [M.R.]

B.156 Benson, Ezra Taft. "Flooding the Earth with the Book of Mormon." Ensign 18 (November 1988): 4-6. Also in CR (1-2 October 1989): 3-5. The earth must be flooded with the Book of Mormon. Author presents many ways that he envisions the book being used, so that the condemnation that is upon the Church will be lifted. Saints are to use the book when teaching the gospel and are encouraged to participate in the family-to-family Book of Mormon program. The power of the Book of Mormon is beyond the understanding of man. [J.W.M.]

B.157 Benson, Ezra Taft. "Flooding the Earth with the Book of Mormon." Friend 19 (August 1989): inside front cover. A message to the children of the Church. Commends faithful members who read the Book of Mormon and take its message into all the world. [J.W.M.]

B.158 Benson, Ezra Taft. "Founding of America: Its Decline." CR (October 1944): 128-34. Quoting Ether 2:10, 12 , President Benson admonishes America to beware of its growing spiritual decay. [R.C.D.]

B.159 Benson, Ezra Taft. "The Gift of Modern Revelation." Ensign 16 (November 1986): 78-80. Also in CR (October 1986): 100-3. The purpose of the Book of Mormon and the Doctrine and Covenants is to bless lives and help mankind to resist the powers of Satan. The Book of Mormon does not detract from the value of the Bible, but supports and sustains its truthfulness. The Book of Mormon is the keystone of the Church and has the power to reveal false doctrines, help people overcome temptations, and bring individuals closer to God than any other book. [J.W.M.]

B.160 Benson, Ezra Taft. "Godly Characteristics of the Master." Ensign 16 (November 1986): 45-48. Also in CR (October 1986): 59-64. Using the Savior's challenge in the Book of Mormon, "What manner of men ought ye to be? Verily I say unto you, even as I am" (3 Nephi 27-27), encouragement is given to the priesthood holders of the Church to obtain the divine attributes of the Savior. Each man can develop Christlike faith, virtue, knowledge, temperance, patience, brotherly kindness, and charity. [A.C.W.]

B.161 Benson, Ezra Taft. "The Greatest Book in the World." CN 58 (2 January 1988): 3, 5. The Book of Mormon is the greatest book in the world, it therefore must be re-enthroned and honored. The Prophet Joseph Smith described it as the keystone of the LDS religion. [R.H.B.]

B.162 Benson, Ezra Taft. "In His Steps." Ensign 18 (September 1988): 2-6. By carefully reading the Book of Mormon and following Moroni's promise (Moroni 10:3-5), one will gain knowledge that the Church of Jesus Christ of Latter-day Saints is the Lord's Church. This knowledge will strengthen the individuals that they may become like Jesus Christ. [J.W.M.]

B.163 Benson, Ezra Taft. "Jesus Christ-Gifts and Expectations." Ensign 18 (December 1988): 2-6. Christ both lived and died for mankind. He has provided many great gifts, among which include the Book of Mormon. It was written for those of the present era and will help to dispel the false theories and philosophies of men of the present age. [J.W.M.] 
B.164 Benson, Ezra Taft. "Joy in Christ." Ensign 16 (March 1986): 3-5. Also in Ensign 23 (December 1993): 2-5. The chief mission of the Book of Mormon is to convince the world that Jesus is the Christ. Using Book of Mormon scriptures, the author outlines the role and character of Jesus Christ-he is the creator, he is distinguished by his excellent character, he does not change, he cannot lie, he is no respecter of persons, he is a God of love, he is the Redeemer and Savior. [J.W.M.]

B.165 Benson, Ezra Taft. "Keys to Successful Member-Missionary Work." Ensign 20 (September 1990): 2-7. The four keys for successful missionary work are (1): obtain the Spirit, pray sincerely, and search the scriptures, especially the Book of Mormon; (2) acquire humility; (3) demonstrate love for people; and (4) work diligently. [J.W.M.]

B.166 Benson, Ezra Taft. “The Keystone of Our Religion.” Ensign 22 (January 1992): 2-7. Reprint from Benson's A Witness and a Warning. Salt Lake City: Deseret Book, 1988. The Book of Mormon is a greater gift than any modern invention. Its great worth was testified of by God himself. It is the keystone, stands as witness of Christ, it was written for our day, and it is the most correct book and will bring one closer to God than any other book. [J.W.M.]

B.167 Benson, Ezra Taft. "Last Days and Book of Mormon Promises." In Proceedings of the Mexico Area Conference, 127-32. Salt Lake City: Church of Jesus Christ of Latter-day Saints, August 1972. Book of Mormon prophets saw our day and provided a message for the world of this era. The great promises of the Book of Mormon give comfort and assurance to the faithful. The American hemisphere shall be protected so long as its inhabitants serve God. [J.W.M.]

B.168 Benson, Ezra Taft. "The Lord's Base of Operations." IE 65 (June 1962): 454-57. The Book of Mormon testifies of the great mission of America. America is a beacon of liberty to all the world. It is the Lord's base of operations. Church members must protect it from its greatest threat-moral decay from within-and we "must return to a love and respect for the basic spiritual concepts upon which this nation has been established." [J.W.M.]

B.169 Benson, Ezra Taft. "A Mighty Change of Heart." Ensign 19 (October 1989): 2-5. To truly come to repentance individuals must: (1) realize that the gospel plan is the plan of happiness; (2) understand that repentance must be preceded by faith in Jesus Christ; (3) have a change of heart as well as of actions; (4) have a "godly sorrow;" (5) know that the Lord is anxious to see a change of heart; and (6) not lose hope. The author uses Book of Mormon to support these six principles. [J.W.M.]

B.170 Benson, Ezra Taft. "Moroni and the Communist Threat to America." CR

B.171 Benson, Ezra Taft. "A New Witness for Christ." Ensign 14 (November 1984): 6-8. The Church is under condemnation because its members are not "using the Book of Mormon as God intends." The Book of Mormon is of great value in drawing men closer to God. Its purpose is to "bring men to Christ and to be reconciled to him, and then to join his Church-in that order." The people of the world are on trial as to what they will do with the Book of Mormon. [S.P.S.]

B.172 Benson, Ezra Taft. "Of the Most Worth." NE 19 (June 1989): 4-7. Declares the Book of Mormon to be a missionary tool of greatest value. Coupled with the Spirit, the Book of Mormon will do more to bring the souls of men to the Lord than anything else. It is the great standard of the Church. [J.W.M.]

B.173 Benson, Ezra Taft. "The Power of the World." Ensign 16 (May 1986): 79. Daily scripture study, with special attention paid to the Book of Mormon, will produce more spiritual rewards than any of the important Church 
programs to increase the level of church activity. Testimonies will increase, families will be stronger, commitment greater, and personal revelation will flow as a result of meaningful study of the scriptures. [J.W.M.]

B.174 Benson, Ezra Taft. "Pray Always." Ensign 20 (February 1990): 2-5. Provides commentary on Alma 34:26 which gives the exhortation to "pray always." There are five ways to improve communication with Heavenly Father: pray frequently, find an appropriate place to meditate and pray, prepare for prayer, make prayer meaningful and pertinent, and take the responsibility to assist in making the request be granted. The Lord is always mindful and ready to respond. [J.W.M.]

B.175 Benson, Ezra Taft. "A Sacred Responsibility." CR (5-6 April 1986): 98-100. Also in Ensign 16 (May 1986): 7778. In relating the three-fold mission of the Church, President Benson stated that the second mission of the Church is to strengthen the membership of the Church. The most valuable way to do this is to learn the will of the Lord and then do it. There is a need to study the Book of Mormon as individuals and as families. Studying the Book of Mormon one-half hour daily was his recommendation. [J.W.M.]

B.176 Benson, Ezra Taft. "The Savior's Visit to America." Ensign 17 (May 1987): 4-7. Also in CR (4-5 April 1987): 37. Recounts the events leading up to and including the visit of Jesus Christ to the Nephites (3 Nephi), President Benson shows "parallels to our own day as we anticipate the Savior's second coming," and calls the book of 3 Nephi a "testimony of the resurrected Christ in America." [S.P.S.]

B.177 Benson, Ezra Taft. "The Scriptures Have the Answers: Make Book of Mormon Study Life Long Pursuit." CN 56 (13 April 1986): 5, 23. Excerpts from address given by President Benson emphasizing need to study the Book of Mormon throughout one's life. The Book of Mormon brings men to Christ and confounds/exposes the enemies of Christ. The only issue to be resolved in gaining a testimony is whether or not the Book of Mormon is true, since all else hinges on that knowledge. [A.C.W.]

B.178 Benson, Ezra Taft. "To the Children of the Church." Ensign 19 (May 1989): 81-83. Also in CR (1-2 April 1989): 102-5. President Benson congratulates young people who were learning about the Book of Mormon, who have read it, and have sung songs about it. He calls the Book of Mormon "Heavenly Father's special gift." [J.W.M.]

B.179 Benson, Ezra Taft. "To the Young Women of the Church." Ensign 16 (November 1986): 81-85. Counsels young women to stay close to family members, to read the Book of Mormon, to ponder and apply its teachings. He gives a promise that the young woman who knows and loves the Book of Mormon will stand against evil and will be a tool in the hands of the Lord. [J.W.M.]

B.180 Benson, Ezra Taft. "To the 'Youth of the Noble Birthright.' "CR 56 (5-6 April 1986): 55-60. Also in Ensign 16 (May 1986): 43-46. Calling attention to the Book of Helaman and the relationship of the stripling warriors to their mothers, President Benson counsels young men to draw close to their mothers and other family members, to read again and again the Book of Mormon, and to prepare for missionary service by being chaste and clean. [J.W.M.]

B.181 Benson, Ezra Taft. "Trust Not the Arm of Flesh." IE 70 (December 1967): 55-58. The precepts of men are in conflict with the principles of God. Those who choose to follow the revelations of God are not deceived (2 Nephi 4:34; 28:14). The Lord does not give reasons for every commandment, some things need to be taken on faith. Only by loving God first can we best love and serve our fellowmen. [J.W.M.]

B.182 Benson, Ezra Taft. Untitled talk. CR (5-6 October 1985): 4-7. President Benson discusses the importance of the Book of Mormon and addresses the fact that the Church is under condemnation for neglecting this keystone 
of the Church. [A.L.]

B.183 Benson, Ezra Taft. "Using the Book of Mormon." CR (October 1984): 4-7. Raises five critical questions about the Book of Mormon and then provides answers to his questions. The questions posed are: Is the Book of Mormon the Word of God? For whom was it written? How important it is? What is its major purpose? And how are we to use it? [R.C.D.]

B.184 Benson, Ezra Taft. A Witness and a Warning: A Modern-day Prophet Testifies of the Book of Mormon. Salt Lake City: Deseret Book, 1988. Defines the many purposes of the Book of Mormon and the method by which one may come closer to Christ. This book represents the testimony and attitude of the Prophet and President of the Church of Jesus Christ of Latter-day Saints, concerning the value of the Book of Mormon to men and women living in modern times. The book contains both a warning and a divine promise dependant upon the use of the Book of Mormon. This work is reviewed in W.152. [J.W.M.]

B.185 Benson, Ezra Taft, Gordon B. Hinckley, Thomas S. Monson, Howard W. Hunter, Boyd K. Packer, Marvin J. Ashton, L. Tom Perry, David B. Haight, James Faust, Neal A. Maxwell, Russell M. Nelson, Dallin H. Oaks, M. Russell Ballard, Joseph B. Wirthlin, and Richard G. Scott. "We Add Our Witness: Living Prophets Share Their Feelings About the Book of Mormon." Ensign 19 (March 1989): 5-9. The First Presidency and Quorum of the Twelve share their personal testimonies and experiences concerning the Book of Mormon. This in answer to the request of President Benson to "flood the earth with the Book of Mormon." This article is filled with heart-warming experiences, strong testimonies, and wonderful insights as prophets of God reveal inner thoughts about the Book of Mormon. [J.W.M.]

B.186 Benson, Ezra Taft. "Worthy Fathers, Worthy Sons." Ensign 15 (November 1985): 35-7. Provides examples of close relationships between fathers and sons in the Book of Mormon and shows that they are appropriate models for families today. [D.M.]

B.187 Benson, Reed A. "Sword of Laban." In Encyclopedia of Mormonism, edited by Daniel H. Ludlow, 3:1427-28. 5 vols. New York: Macmillan, 1992. The sword of Laban was taken from Laban's dead body by Nephi, following the Lord's command to kill him in order to obtain the brass plates. This sword was used as a model for weapons of war and was part of those items found with the gold plates by Joseph Smith. The witnesses were allowed to view this sword. [J.W.M.]

B.188 Benton, A.W. "Mormonites." Evangelical Magazine And Gospel Advocate. 1831:120. A letter dated March 1831 from S. Bainbridge to the Magazine and Advocate in an effort to stop the progress of the Mormon religion, provides a history of Joseph Smith declaring that he is a deceitful impostor of no good character. His great deception lies in his claim to have received new revelation in the Book of Mormon. [J.W.M.]

B.189 Benyola, Joseph. Pocket Reference Book of the Bible and the Book of Mormon. Monongahela City, PA: Church of Jesus Christ, 1956. A topical reference work containing a list of the books from the Book of Mormon and the Bible with their corresponding contents by chapter and verse. Topics include falling away, Restoration, baptism, and laying on of hands. [J.W.M.]

B.190 Bergin, Allen E. "Nephi: A Universal Man." Ensign 6 (September 1976): 65-70. Nephi possessed a multitude of talents and positive characteristics. He was a "prophet, teacher, ruler, colonizer, builder, craftsman, intellect, writer, poet, military leader, father of nations, son, husband and physical powerhouse." Certainly "he belongs ... in the company of the greatest men of every age." [B.T.] 
B.191 Berrett, LaMar C. Review of The Making of a Prophet, by Lindsay R. Curtis. Dialogue 3 (Summer 1968): 147. Book review.

B.192 Berrett, LaMar C. "The So-Called Lehi Cave." Provo, UT: FARMS, 1982. Describes the cave found on the side of Khirbet Beit Lei (southwest of Jerusalem) and attempts to determine if it was the cave used by Nephi and his brothers when fleeing Laban. Concludes that this was not the cave used by Nephi. [A.T.]

B.193 Berrett, Lyman C. "What I Like to Teach About the Book of Mormon." IE 67 (February 1964): 92-93, 116. Nephi warned future readers that the Book of Mormon was not a history (2 Nephi 5:32-33). Rather, the book is an instrument to bring people to Christ. Nephi, Lehi, Abinadi, Jacob, Alma, and other prophets knew the mission of Christ and taught it. [J.W.M.]

B.194 Berrett, William Edwin. "Great Teachings from the Book of Mormon." In Know Your Religion Series, 1:1-60. Provo, UT: Brigham Young University, 1953. Five lectures on the Book of Mormon (presented October 21November 18, 1953) discussing such topics as the purpose of the Book of Mormon, the nature of man and God, the manner in which the Book of Mormon contributes to an understanding of the Bible, the relationship of spirituality to political and economic life, and a warning to the nations. [L.D.]

B.195 Berrett, William Edwin. "How to Teach the Book of Mormon." IE 63 (November 1960): 804-5, 856. Teachers of the Book of Mormon may teach the historical, geographical, literary, or archaeological aspects of the book, but they should emphasize the doctrines and teachings of Jesus Christ and demonstrate in what manner the book assists individuals in our present day world conditions. [R.C.D.]

B.196 Berrett, William Edwin. The Latter-day Saints: A Contemporary History of the Church of Jesus Christ. Salt Lake City: Deseret Book, 1985. Pages 35-76 contain Joseph Smith's account of the coming forth of the Book of Mormon, visitations of heavenly beings, obtaining the gold plates, the mode of translation of the plates, and related historical items. [J.W.M.]

B.197 Berrett, William Edwin. "The Origin and General History of Mormonism." In Berrett's Doctrines of the Restored Church, 21-28. Salt Lake City: Deseret Book, 1941. Includes Joseph Smith's testimony concerning the nature of the Book of Mormon, the problems encountered during the translation, and examines items related to the mode of translation. States that the message of the Book of Mormon is to convince both Jews and the Gentiles that Jesus is the Christ. [J.W.M]

B.198 Berrett, William Edwin. "The Relationship of Spirituality to National Prosperity." IE 55 (March 1952): 16061, 176-78. Also published as "The Book of Mormon and National Prosperity." In A Book of Mormon Treasury, 25159. Salt Lake City: Bookcraft, 1959, [R]1976. The Book of Mormon makes it clear that the economic welfare of any nation is inevitably linked with the level of spirituality among the people. Nations become prosperous when their spiritual level remains high or they sink into social decay with continual disregard for the word of God. [R.C.D.]

B.199 Berrett, William Edwin. The Restored Church. Salt Lake City: Deseret Book, 1974. Chapters 5-8 deal with the coming forth of the Book of Mormon, the Urim and Thummim, the facsimile taken to Professor Anthon, Grandin's Press, the publication and distribution of the Book, and the witnesses of the Book of Mormon. Analyzes the effect of the book since its publication and the world's opposition to it. [J.W.M.]

B.200 Berrett, William Edwin. "The Scriptures and Literature of the Church." In Berrett's Doctrines of the Restored Church, 324-32. Salt Lake City: Deseret Book, 1941. Moroni confirmed the Bible as an important book of scripture 
when he announced the coming forth of the Book of Mormon. Joseph was made aware of errors contained in the Bible and the need for further revelation to support the Bible and to rectify its errors. Those who abridged the Book of Mormon chose specific theological ideas to make the it the foundation of the new Church, thus creating a difference between the Restored Gospel and other Christian religious systems. [J.W.M.]

B.201 Berrett, William Edwin. "Spirituality and Armed Conflict." IE 55 (April 1952): 242-44, 271-73. Also published as "The Book of Mormon Speaks on War." In A Book of Mormon Treasury, 275-84. Salt Lake City: Bookcraft, 1959, [R]1976. The position of the Church concerning war and armed conflicts is dictated by the teachings in the Book of Mormon. War is condemned by God and peace is always valiantly sought. However, at times wars must be fought by the righteous in order to safeguard liberty. Although God aids the righteous in war, the righteous may suffer or be slain. [R.C.D.]

B.202 Berrett, William Edwin. "Spirituality and Political Reform." IE 55 (February 1952): 86-88. Also published as "The Book of Mormon and World Government." In A Book of Mormon Treasury, 260-67. Salt Lake City: Bookcraft, 1959, [R]1976. On the subject of national political reform, the Book of Mormon speaks out with unwavering conciseness. It states that no form of government will succeed unless the people maintain a high spiritual level; national ills cannot be cured by any amount of legislation if the spirituality of the people remains neglected. [R.C.D.]

B.203 Berrett, William Edwin. Teachings of the Book of Mormon. Salt Lake City: Deseret Sunday School Union Board, 1950, [R]1952. Sunday School manual comprising forty-four lessons designed for beginning students of the Book of Mormon. Topics include faith, repentance, baptism, and the nature of God. [L.D.]

B.204 Berrett, William E., and Alma P. Burton. "The Coming Forth of the Book of Mormon." In Berrett and Burton's Readings in LDS Church History: From Original Manuscripts, 1:19-41. Salt Lake City: Deseret Book, 1953. A compilation of early church historical accounts and commentaries that tell the story of the coming forth of the Book of Mormon, including accounts written by Oliver Cowdery, Joseph Smith, Brigham Young, Edward Stevenson, and Lucy Mack Smith. They tell of Moroni's visits, describe the Hill Cumorah, and write concerning the stone box, the gold plates, the breastplate, and Urim and Thummim. [J.W.M.]

B.205 Berrett, William E., and Alma P. Burton. "The Translation and Publication of the Book of Mormon." In Berrett and Burton's Readings in LDS Church History: From Original Manuscripts, 1:43-56. Salt Lake City: Deseret Book, 1953. Uses early church historical accounts and commentaries that tell the story of the translation and publication of the Book of Mormon, including the role of Joseph Smith, Martin Harris, Anthon, and those involved with the printing of the book. [J.W.M.]

B.206 Berrett, William E., and Alma P. Burton. "Witnesses to the Book of Mormon." In Berrett and Burton's Readings in LDS Church History: From Original Manuscripts, 1:57-63. Salt Lake City: Deseret Book, 1953. Includes Joseph Smith's written account of the events that occurred when the Three Witnesses, Oliver Cowdery, Martin Harris, and David Whitmer viewed the gold plates. Subsequent testimonies from the Three Witnesses affirm the fact that they saw the plates, the angel, and heard the voice of God. [J.W.M.]

B.207 Berrett, William Edwin, Milton R. Hunter, Roy A. Welker, and H. Alvah Fitzgerald. A Guide to the Study of the Book of Mormon. Salt Lake City: Church of Jesus Christ of Latter-day Saints, Department of Education, 1938. An introduction to the Book of Mormon, featuring external evidences, teachings about God and Christ, immortality, and ethical and social teachings of the Book of Mormon. [D.W.P.] 
B.208 Berry, John. Plain Facts Against the Latter Day Saints. Cheshire, England: Altrincham, 1841. A lecture demonstrating that the Book of Mormon contradicts the Bible. Sees problem with Lehi's teaching that without the Fall there would have been no posterity. Argues that water baptism by immersion is not necessary for salvation. [D.M.]

B.209 Beskow, Per. "The Angel with the Golden Plates." In Beskow's Strange Tales About Jesus, 31-41. Philadelphia: Fortress Press, 1983. Writes of Joseph Smith, the golden plates, and the angel Moroni from a polemical angle, believing the story to be false and imaginative. [L.D.]

B.210 Best, Brian. "Nephi, Lehi and Samuel the Lamanite." Ensign 7 (December 1977): 44-51. An intimate look into the lives and human characteristics of the prophets in the Book of Helaman-Nephi, Lehi, and Samuel. At a time when their nation was ripe in iniquity shortly before the coming of the Savior to the Nephites, these great men stood firm in defending the truth. [J.W.M.]

B.211 Beth. "The Deluge." Juvenile Instructor 13 (1 March 1878): 55. Relates the Book of Mormon and Indian legends to the flood at the time of Noah. Also speaks of stone and wood tablets found in lowa, Illinois, and Ohio, some of which possess Egyptian-like characters. [D.M.]

B.212 Bethel, May. "Purpose of the Book of Mormon." SH 122 (February 1975): 89. Testimony and conversion experience based on the Book of Mormon. [A.C.W.]

B.213 Beverley, Jim. Mormon's View of God: True or False? St. Louis, MO: Personal Freedom Outreach, 1982. An polemical tract designed to encourage Mormons to question their belief in the Book of Mormon. [D.W.P.]

B.214 Bickerstaff, George. Book of Mormon Stories for Children. Salt Lake City: Bookcraft, 1971. Book of Mormon stories told on a child's level of understanding. The stories tell of Joseph Smith, the brother of Jared and the shining stones, Lehi's vision, and Nephi and the brass plates. [L.D.]

B.215 Bickerstaff, George. The Church Story: From Sacred Grove to Land of Zion. Salt Lake City: Bookcraft, 1974. An illustrated book for children that retells church history concerning the coming forth of the Book of Mormon from the angel Moroni's visit to its publication. [J.W.M.]

B.216 Bickerstaff, George. "Great Teachers in the Book of Mormon." Instructor 96 (May 1961): 179-81. Lehi, Jacob, King Benjamin, mothers, and other characters are honored as being great Book of Mormon teachers. [B.W.J.]

B.217 Bickerstaff, George. "The Nephite Wars." Instructor 102 (July 1967): 295-97. A discussion of war in the Book of Mormon. Reasons for Nephite successes and failures in war are cited. [B.W.J.]

B.218 Biederwolf, William Edward. Mormonism under the Searchlight. Chicago: Glad Tidings, 1914. A polemical work against Mormonism and Mormon scripture. The author asserts that the Book of Mormon contains anachronisms, grammatical errors, and plagiarizes the Bible. There are no archaeological evidences that support the book. Author ridicules what he esteems to be numerous absurd and fantastic elements in the narrative, which include the Jaredite barges, Nephi's temple, battle accounts, alleged contradictions with the Bible, and others. [M.R.] 
B.219 Bigelow, Sabina H., and Sabina Susan Bytheway. Book of Mormon Companion: Dictionary and More. Sandy, UT: Bright Impressions, 1988. A reading guide for children. Contains a Book of Mormon chronology, drawings, games, and a dictionary. This work is reviewed in R.242. [D.M.]

B.220 "Biggest Year for Translations: Book of Mormon in 66 Languages." CN 54 (12 February 1984): 3. Twelve selections and one full text of the Book of Mormon were translated during the year 1983. These include Mayan, Siuhala, Kekchi, Mam, Armenian, Turkish, Efik, China-P, Kisii, Demotiki, Hmong, Persian, and Haitian Creole. Contains a chart to show growth. [J.W.M.]

B.221 Bilderback, John C. "Masonry and Mormonism: Nauvoo, Illinois 1841-1847." M.A. thesis, University of lowa, 1937. A historical treatment of Mormonism and its possible connection with Free-masonry. The author suggests that the Book of Mormon's Gadiaton Robbers reflect nineteenth century influences of anti-Masonic hysteria in New York during the late 1820s. [M.R.]

B.222 Bingman, Margaret. Encyclopedia of the Book of Mormon. Independence, MO: Reorganized Church of Jesus Christ of Latter Day Saints, 1978. An encyclopedic work attending to a number of Book of Mormon topics. Entries deal with biography, history, and doctrine. [L.D.]

B.223 Bird, Randall C. "How to Make the Book of Mormon Exciting in the Lives of Students." In Sixth Annual Church Education System Religious Educator's Symposium on the Book of Mormon, edited by the Church Education System, 58. Salt Lake City: LDS Church 1982. Introduces a new principle for teaching called the me-here-now principle: the ability to inspire each individual to liken the scriptures to themselves in their own circumstances as a son or daughter of God. Urges teachers to use the principle in teaching the Book of Mormon. [B.D.]

B.224 Birrell, Verla L. The Book of Mormon Guidebook. Salt Lake City: Stevens and Wallis, 1948. A guidebook that treats such Book of Mormon topics as prophecy, ancient records, topography, major and minor migrations of the people, government, political and social customs, military, language and writing, science, animal and plant life, archaeology, and a number of religious traditions and doctrines. [L.D.]

B.225 "Birthday Present is Gift for Others." CN 58 (1 October 1988): 6, 12. Sister Ella Adkins has donated 99 cases of the Book of Mormon to different missions in the world. Within each copy she placed her picture and a copy of her testimony. [M.R.]

B.226 Bishop, Francis G. A Proclamation from the Lord to His People Scattered throughout All the Earth. Kirtland, $\mathrm{OH}$ : n.p., 1851. A proclamation written to the inhabitants of the world regarding the coming forth of the Book of Mormon and the restoration of the gospel. Provides a description of the golden plates, the Urim and Thummim, the breast plate, and the sword of Laban. [D.W.P.]

B.227 Bishop, Gary Lyman. "The Tradition of Isaiah in the Book of Mormon." M.A. thesis, Brigham Young University, 1974. "A textual and grammatical analysis of 52 passages of Isaiah as they are found in cave IV of the Dead Sea Scrolls, the Masoretic Text, the Septuagint, the King James Version, and the Book of Mormon. The objective was to determine the relationship, if any, of those verses in the Book of Mormon with the other textual traditions. Based on the differences between the Book of Mormon text and the King James Version, and upon the confirmation of those Book of Mormon differences by the other traditions, it was concluded that the Book of Mormon follows its own tradition." [A.T.] 
B.228 Bishop, Lynn L., and Steven L. Bishop. "Book of Mormon Examples of Priesthood-Kingdom-Church Relationship." In The Keys of the Priesthood Illustrated, written and compiled by Lynn L. Bishop and Steven L. Bishop, 79-83. Draper, UT: Review and Preview Publishers, 1971. The books of Omni and Mosiah suggest that Nephite kings, Mosiah I, Benjamin, and Mosiah II, held roles of priesthood leadership over the people. Later when Alma became the head of the Church, he ultimately answered to Mosiah II who held a greater role of spiritual leadership. [J.W.M.]

B.229 Bitton, Davis. Review of Joseph Smith: The First Mormon, by Donna Hill. BYU Studies 17 (1977): 376. Book review.

B.230 Bitton, Davis. Review of New Approaches to the Book of Mormon, by Brent Lee Metcalfe. Review of Books on the Book of Mormon 6/1 (1994): 1-7. Book review.

B.231 Bitton, Davis. Review of Secret History: A Translation of VOR TIDS MUHAMED JOHN AHMANSON, by Gleason L. Archer. Sunstone 10/7 (1985):44. Book review.

B.232 Black, Don J. "Could I Touch This Holy Book?" Ensign 7 (September 1977): 76-77. The power of the Book of Mormon to change lives is evident in the stories of conversion set forth in this article. In presenting the Book of Mormon to investigators, the author was impressed by the humility of the young husband who, awestruck by the holiness of the book, asked in meekness if he could touch it. [J.W.M.]

B.233 Black, Golden H., and Louis H. Petersen. "The Largest Mound in America." IE 29 (April 1926): 547-48. A large mound located at Moundville, West Virginia, is believed to have existed for some three thousand years. Three human skeletons were discovered within the mound's two vaults. A stone located at the mound and now held at the Smithsonian Institute contains an inscription that has never been deciphered. These things are considered to be archaeological evidences of the Book of Mormon. [L.D.]

B.234 Black, James. New Forms of the Old Faith. London: Nelson, 1948. In some twenty pages (pages 240-61) of this polemical work the author discounts the Spaulding Theory on the grounds that the Manuscript Found has little resemblance to the Book of Mormon. Unable to accept Joseph Smith's own claims, the author favors Woodbridge Riley's environmental-psychological hypothesis as the best explanation for the Book of Mormon. He notes alleged modernisms and anachronisms in the book such as the use of New Testament and King James language, Westminster Confession of faith, Shakespeare, pre-Columbian domesticated animals, and the proposition of new and continual revelation. [M.R.]

B.235 Black, Susan Easton. "Behold, I Have Dreamed a Dream." In The Book of Mormon: First Nephi, The Doctrinal Foundation, edited by Monte S. Nyman and Charles D. Tate Jr., 113-24. Provo, UT: Brigham Young University Religious Studies Center, 1988. The significance and setting of Lehi's tree of life dream is set forth. Demonstrates the manner in which the family of Lehi was affected by the dreams of Lehi. [A.T.]

B.236 Black, Susan Easton. The Book of Mormon: A Witness of Christ. N.p.: the author, 197?. An earlier manuscript draft of the author's published work entitled Finding Christ through the Book of Mormon. [D.W.P.]

B.237 Black, Susan Easton. "The Book of Mormon Bears Witness of the Father Through the Son." In A Symposium on the Book of Mormon, 20-23. Salt Lake City: Church of Jesus Christ of Latter-day Saints, 1982. The Book of Mormon teaches that God the Father has a body, parts, and passions and that he is literally the Father of us, his 
mortal children. Statistical evidence is given for references to the nature of God in the Book of Mormon and names for Jesus Christ found in the Book of Mormon. [B.D.]

B.238 Black, Susan Easton. Finding Christ through the Book of Mormon. Salt Lake City: Deseret Book, 1987. Jesus Christ is the central figure in the Book of Mormon. He is referred to about every 1.7 verses and is called by 101 different names. The Book of Mormon explains how to know about Christ and be like him and how to be an example of him. Author includes helpful charts listing the names of Christ and the average number of references to Christ per book in the Book of Mormon. This work is reviewed in W.341. [B.D.]

B.239 Black, Susan Easton. "I Am Not Any Longer to Be Alone." Ensign 19 (January 1989): 50-56. Many individuals became fellow witnesses with Joseph Smith as they suffered persecution with him, received divine manifestations, and testified of the divine origin of the Book of Mormon. [J.W.M.]

B.240 Black, Susan Easton. "King Benjamin: In the Service of Your God." In The Book of Mormon: Mosiah, Salvation Only through Christ, edited by Monte S. Nyman and Charles D. Tate Jr., 37-48. Provo, UT: Brigham Young University Religious Studies Center, 1991. King Benjamin emphasized the importance of service and knowing the mysteries of God, two concepts that are interrelated. [B.D.]

B.241 Black, Susan Easton. "Lest Ye Become As the Nephites of Old." In The Book of Mormon: The Keystone Scripture, edited by Paul R. Cheesman, S. Kent Brown, and Charles D. Tate Jr., 256-68. Provo, UT: Brigham Young University Religious Studies Center, 1988. Discusses the righteous reasons to want to have the blessings of prosperity and the pitfalls associated with wealth, such as pride. [B.D.]

B.242 Black, Susan Easton. "Names of Christ in the Book of Mormon." Ensign 8 (July 1978): 60-1. The main purpose of the Book of Mormon is to testify of Christ. There exists in the book one hundred different names and titles of Jesus, appearing an average of once every 1.7 verses in the Book of Mormon. Author includes a chart showing the average number of references to Christ per book in the Book of Mormon, and a second chart listing the one hundred different names and titles of Jesus in the book. [B.D.]

B.243 Black, Susan Easton. Stories from the Early Saints: Converted by the Book of Mormon. Salt Lake City: Bookcraft, 1992. Presents a collection of conversion stories of early saints who relate in their own words how they received testimonies of Christ and his gospel through reading the Book of Mormon. Conversion stories are provided by Lucy Mack Smith, Wilford Woodruff, Orson Hyde, and others. This work is reviewed in P.209. [B.D.]

B.244 Blackman, Emily C. History of Susquehanna County, Pennsylvania. Baltimore, MD: Regional, 1873, [R]1970, [R]1980. Pages 577-82 deal with the Book of Mormon. Author discredits the Book of Mormon story by providing statements by J. B. Buck, Isaac Hale, and others concerning Mormons and the Book of Mormon, and considers Joseph Smith to be a "madman." [A.T.]

B.245 Blair, William W. "Harmony of the Bible, Book of Mormon, and Doctrine and Covenants." True LDS Herald 10 (1 September 1866): 69-73. The use of the terms "endless," "forever," and "everlasting" is consistent in the Book of Mormon, the Bible, and the Doctrine and Covenants. [B.D.]

B.246 Blair, William W. Joseph the Seer: His Prophetic Mission Vindicated. Plano, IL: Reorganized Church of Jesus Christ of Latter Day Saints, 1877. An apologetic work written in reply to an attack made by Rev. William Sheldon against Joseph Smith and the Book of Mormon. [L.D.] 
B.247 Blake, Vira H." 'Book of Mormon to Go' Is House Specialty." CN 59 (6 May 1989): 7. Restaurant owners resolve to "flood the earth with the Book of Mormon" and do so by distributing thirty to fifty copies of the Book of Mormon a week to patrons of their restaurant. [J.W.M.]

B.248 Blake, Vira H. "The Missionary Fires Continue to Burn for Faithful Ninety-Year-Old." CN 57 (21 November 1987): 5. A story of a 90-year-old woman who sends copies of the Book of Mormon, along with her testimony, to her non-member relatives and friends. [M.D.P.]

B.249 Blake, Vira H. "A Mother's Dream." Ensign 16 (March 1986): 52-54. Having lost two children previously, faithful parents struggle to save the life of their fifth child. The mother dreams of the tree of life and two young men who were sent from God to save her child. LDS missionaries came a week later and were inspired to underline the passages concerning Lehi's dream in the Book of Mormon, which led to events that saved the child's life. [J.W.M.]

B.250 Blanch, Mae. "Challenges to the Reign of the Judges." In Studies in Scripture: 1 Nephi-Alma 29, edited by Kent P. Jackson, 7:283-93. Salt Lake City: Deseret Book, 1987. The type of government existing under the reign of the judges was established by Mosiah as inspired law, given by covenant, and founded upon the law of Moses. This rule of law was ultimately undermined by class distinction, pride, and unrighteousness. [J.W.M.]

B.251 Blanch, Mae. "Samuel the Lamanite (Helaman 13-16)." In Studies in Scripture: Alma 30-Moroni, edited by Kent P. Jackson, 8:116-24. Salt Lake City: Deseret Book, 1987. Expounds upon Samuel and the example of righteous Lamanites to the proud, iniquitous Nephites. Samuel's prophecies of Christ and his powerful sermon brought a number of Nephites to repentance, but most rejected his warning. Samuel's words were verified shortly thereafter, proving that he was a true prophet. [A.C.W.]

B.252 Blanke, Gustav H. "Early Theories About the Nature and Origin of the Indians, and the Advent of Mormonism." Amerikastudien 25 (1980): 243-68. Reviews various theories held between the 16th and 19th centuries regarding the descent of the American Indian from biblical peoples, including theories regarding Cain, Ham, Magog, the Hebrews, and others. Believes that the idea of a Hebrew origin for the American Indian was readily accessible to Joseph Smith, and thus favors an environmentalist explanation for the Book of Mormon's origin. [M.R.]

B.253 Blankmeyer, Helen Van Cleave. David Whitmer. N.p.: by the author, 1955. A history of David Whitmer written for his descendants, but also includes a history of Joseph Smith, the coming forth of the Book of Mormon, and the apostasy of the "Mormon Church." Also provides a historical sketch of Solomon Spaulding, calling attention to the fact that David Whitmer never denied his testimony of the Book of Mormon. [J.W.M.]

B.254 "Blasphemy." Cincinnati Advertiser and Ohio Phoenix 8 (2 June 1830): 1. Early, hysterical announcement of the publication of the Book of Mormon. [D.M.]

B.255 Bloss, G. M. D. "Who Wrote the Book of Mormon?" In Historic and Literary Miscellany, edited by G. M. D. Bloss, 440-42. Cincinnati: Robert Clarke, 1875. A polemic against the Book of Mormon, claiming Joseph Smith wrote the book. [D.W.P.]

B.256 Blossom, Rose B. The Four Standard Works of the Church of Jesus Christ of Latter-day Saints. Los Angeles: Triple S., 1939. Provides a chart reviewing the different editions of the Book of Mormon and their dates, an outline of the Book of Mormon, and a parallel outline of the Book of Mormon and the Bible, presenting a "bird's eye view." [B.D.] 
B.257 Blumell, Bruce D. "Was the Book of Mormon Based on the Spaulding Manuscript or Ethan Smith's View of the Hebrews?" In A Sure Foundation: Answers to Difficult Gospel Questions, 54-60. Salt Lake City: Deseret Book, 1988. Also found in Ensign 6 (September 1976): 84-87. Provides a brief history of both the Spaulding Manuscript and Smith's View of the Hebrews and concludes that neither work bears relationship to the Book of Mormon in style or content. [J.W.M]

B.258 Blumenschien, Marian. "America's Legacy from Sumer." SH 123 (August 1976): 476-79. Compares the studies of Samuel N. Kramer on the Sumerian culture at the time of the tower of Babel with the Jaredite culture as explained in the Book of Mormon. [B.D.]

B.259 Blumenthal, Walter Hart. Heaven and Hades: Two Excursions for Bookmen. Worcester, MA: Achille J. St. Onge, 1965. Identifies books that are "diabolical" and others that are God-inspired (hence the title). Believes that the Book of Mormon was God-inspired. Presents a brief history of the acquisition and translation of the Book of Mormon. [B.D.]

B.260 Blumenthal, Walter Hart. "Heaven's Library: Archives and Annals of the Gods of Old." American Book Collector 11 (February 1961): 10-20. Gives a brief history of numerous accounts of divinely inspired or protected books as well as heaven-sent books, including the Book of Mormon. [B.D.]

B.261 Bluth, J. V. "More Book of Mormon Evidence." MS 56 (8 October 1894): 648-50. While archaeologists search for the secrets to the origin of the early inhabitants of America, members of the Church believe the keys to understanding such things are contained in the Book of Mormon. [J.W.M.]

B.262 Boewe, Charles. "A Note on Rafinesque, the Walam Olum, the Book of Mormon, and the Mayan Glyphs." Numen 32 (July 1985): 101-13. "The Walam Olum is a long narrative poem beginning with the Creation and recording the wanderings of the Delaware Indians through many generations; its text was preserved by C. S. Rafinesque." The Walam Olum was not published in English until 1836 and there is no indication that Joseph Smith was familiar with the Walam Olum before the publication of the Book of Mormon. [A.T.]

B.263 Bogard, Ben M. An Exposure of Mormonism. Little Rock, AR: Missionary Baptist Seminary, 1965. A polemical work against Mormonism. The writer favors the Spaulding Theory for the origin of the Book of Mormon, believes that the Book of Mormon plagiarizes the King James Version of the New Testament, and gives a brief discussion of the Anthon episode. Much of the work is devoted to exposing alleged errors in the Book of Mormon. Mormon interpretations of the prophecy in Isaiah 29 used to support the Book of Mormon are criticized. [M.R.]

B.264 Bolitho, A. D., response by Elder B. H. Roberts. "Book of Mormon Controversy." MS 50 (20 February 1888): 113-17. An interchange of correspondences between Bolitho, who endeavors to prove the Book of Mormon false through a discussion of the dates of Christ's birth and death, and Roberts who explains the possible differences between the Nephite and Jewish calendrical systems. [A.C.W.]

B.265 Bond, Myron H. "The Book of Mormon." SH 29 (15 February 1882): 49-51. A testimonial to the truth of the Book of Mormon. The author briefly tells the story of the Jaredites, finds the Book of Mormon to be a fulfillment of the prophesy in Genesis 48:13-26, Psalm 85, and Ezekiel 37, and relates the story of the coming forth of the Book of Mormon. [A.T.]

B.266 Bond, Myron H. "The Lord's Prayer in the Book of Mormon." SH 68 (30 August 1921): 822-23. Proposes reasons why the Lord's prayer that is recorded in the Book of Mormon does not match perfectly the Lord's prayer 
of the Joseph Smith's Translation of the Bible-errors may belong to the publisher, which in 1820 was not only possible but probable; there may have been scribal errors or other human errors. [J.W.M.]

B.267 Bond, William. The Early History of Mormonism, and the True Source Where the Aborigines of the Continent Came from. Portland: Schwab Brothers, 1890. A polemical article against Joseph Smith and the Book of Mormon. The author discusses Joseph's use of the seerstone, Book of Mormon witnesses, Shakespeare and the Book of Mormon, the condemnation of polygamy in the Book of Mormon, Spaulding theory, and other related items. [M.R.]

B.268 "Book Available in Three More Languages." CN 58 (15 October 1988): 5. An announcement of portions of the Book of Mormon being available in three more languages - Lingala, Shona, and Urdu (languages spoken in Africa). [M.D.P.]

B.269 "Book Notice of Complete Concordance to the Book of Mormon." IE 7 (December 1904): 151-52. Announces the completion of George Reynolds's Book of Mormon concordance and advertises its sale. [A.C.W.]

B.270 "The Book of Ether." Evening and Morning Star 1 (August 1832): n.p. Brief outline of the contents of the book of Ether. [M.D.P.]

B.271 "The Book of Jacob." Evening and Morning Star 1 (September 1832): n.p. Summarizes the book of Jacob. [M.D.P.]

B.272 "The Book of Mormon." Book-Lore 18 (May 1886): 162-65. A pejorative evaluation of the Book of Mormon, considering it to be "tiresome and uninteresting." Accepts the Spaulding story for the book's origin. Informs the reader about the Three Witnesses, especially David Whitmer, regarding him as "an honest fanatic." [D.M.]

B.273 "The Book of Mormon." The Church of England Magazine (July 1854): 29-31. Recites the history of the coming forth of the Book of Mormon and summarizes its contents. Discredits the Three Witnesses and holds that the Book of Mormon was a take off of the Spaulding manuscript. [D.W.P.]

B.274 "The Book of Mormon." Consolation 26 (11 April 1945): 23-27. A supercilious discussion on the Book of Mormon, where an unnamed author believes that its contents were derived largely from "writings by Spaulding, Isaiah, and others, with copious additions by Smith." Lists 49 similarities between the Book of Mormon and Spaulding's manuscript. Emphasizes similarities between the Book of Mormon and the King James Bible. Associates the name "Nephi" with the Hebrew "Nephilim," or fallen angels at the time of Noah. [D.M.]

B.275 "The Book of Mormon." DN 27 (9 October 1878): 569. Reprint of an article from the Richmond (Missouri) Conservater. Concerns David Whitmer and his tenacious testimony of the Book of Mormon. Whitmer claimed to be in possession of the original manuscript. [D.M.]

B.276 "The Book of Mormon." Deseret Weekly 45 (10 December 1892): 779-80. Quotes excerpts from an article entitled "Criticism of the Old Testament" published in the Edinburgh Review. The same objections and methods applied to the Book of Mormon may be applied to the Bible. Both must stand or fall together. The LDS realize that the Book of Mormon "invite[s] investigation and maintain that if this record must be rejected, the Bible must be rejected, too, since every objection that can be raised against the Book of Mormon finds its true counterpart among the objections raised against the Bible." [J.W.M. \& D.M.] 
B.277 "The Book of Mormon." Evening and Morning Star 1 (June 1832): 8. A one-paragraph article encouraging all to read Genesis 49 and Ezekiel 37 and ponder if the stick of Joseph does not refer to the Book of Mormon. If not, then to what does it refer? In addition to biblical proof there are remains of cities of ancient peoples in America support the claims of the Book of Mormon. [J.W.M.]

B.278 "The Book of Mormon." Evening and Morning Star 1 (January 1833): n.p. Tells of the Apostasy and of the Restoration. It also shows how the Bible prophesied of the coming forth of the Book of Mormon in the last days and its importance. [M.D.P.]

B.279 "The Book of Mormon." Evening and Morning Star 2 (June and July 1833): n.p. The first chapter of Nephi and an announcement that the Book of Mormon would be printed chapter by chapter in the Evening and Morning Star. In July they announced the discontinuance of this due to the second publication of the Book of Mormon that allowed people easy access to the Book of Mormon. [M.D.P.]

B.280 "Book of Mormon." In The Home University Encyclopedia, 12 vols., edited by C. Ralph Taylor and Carl Van Doren, 3314. NY: Books, 1944. A brief encyclopedic entry describing the Book of Mormon as "an alleged translation" by Joseph Smith. [D.W.P.]

B.281 "The Book of Mormon." IE 26 (December 1922): 155-56. Consists of a compilation of quotes about the Book of Mormon from the Journal of Discourses. All quotes are from former leaders of the Church of Jesus Christ of Latter-day Saints. [L.D.]

B.282 "The Book of Mormon." IE 32 (September 1929): 879. Moroni visited Joseph Smith in his room on September 21, 1823, and, among other things, showed Joseph where the plates were hidden. After four years, Joseph received the plates and translated them. [B.D.]

B.283 "The Book of Mormon." IE 64 (March 1961): 189, 199. The Book of Mormon was important in the restoration of the priesthood and the Church. It has survived a century and a quarter of anti-Mormon criticism. [M.D.P.]

B.284 Book of Mormon. Independence, MO: Board of Publication of the RLDS Church, 1953. Authorized edition of the Book of Mormon of the RLDS Church. Translated by Joseph Smith Jr. Compared with the original manuscript and the Kirtland edition of 1837. [J.W.M.]

B.285 "The Book of Mormon." MS 48 (22 November 1886): 739-41. Testifies of Book of Mormon's truthfulness, exhorting all to read for "joy and solace." The Book of Mormon restores plain and precious things removed from Bible and does not depend on external evidences for its proof of divine origin. [A.C.W.]

B.286 "Book of Mormon." MS 83 (3 February 1921): 72-74. Announces a new edition of the Book of Mormon. [M.D.P.]

B.287 "Book of Mormon." In Nelson New Loose Leaf Encyclopedia, edited by William M. Schuyler, 287. London: Thomas Nelson, 1932. An objective encyclopedic entry that explains the coming forth of the Book of Mormon. [D.W.P.]

B.288 "Book of Mormon." In The New Encyclopaedia Britannica, edited by Robert McHenry, 8:329. 29 vols. Chicago: Encyclopaedia Britannica, 1993. A brief encyclopedic article outlining the general contents of the Book of 
Mormon. [D.W.P.]

B.289 "The Book of Mormon." The Reflector 2 (14 February 1831): 102. Tells about Oliver Cowdery's mission to Painesville and his meeting with the "notorious Sidney Rigdon." Rigdon took the Book of Mormon under advisement and shortly declared it of "heavenly origin." Rigdon then testified that the world would come to an end in two or three years. [J.W.M.]

B.290 "The Book of Mormon." Relief Society Magazine 29-30 (December 1942; January 1943): 871-73; 57-60. A two-part series prepared for Relief Society theology lessons. Part 1 reviews the historical accounts of the coming forth of the Book of Mormon; part 2 considers the authenticity of the book by listing five reasons why the Book of Mormon is true. [J.W.M.]

B.291 The Book of Mormon. Salt Lake City: Church of Jesus Christ of Latter-day Saints, 1976. A pamphlet designed to introduce non-LDS to the Book of Mormon. Tells of the coming forth of the Book of Mormon and of Jesus' visit to the Nephites. [D.W.P.]

B.292 "The Book of Mormon." TS 2 (March 1841): 354-55. Presents the title page of the Book of Mormon and the testimonies of the Three and Eight Witnesses. [D.W.P.]

B.293 "The Book of Mormon: A New Claim Of Authorship." Pittsburg Telegraph (6 February 1879): 1. Research by W.W. Sharp of Amity, PA, has uncovered new evidence to prove the authorship of the Book of Mormon. The reporter interviewed Joseph Miller, who knew Spaulding well, and who recognized the similarities to Spaulding's romance in the Book of Mormon. Miller declared that Spaulding left his manuscript in Mr. Patterson's printing office, and the manuscript was stolen by Sidney Rigdon who rewrote it, and used it as the basis of the Book of Mormon. [J.W.M.]

B.294 "Book of Mormon: A Rare Possession." CN 57 (14 November 1987): 6-7. Update on progress of LDS film "How Rare a Possession," which features the effect of the Book of Mormon upon individual lives. Elder Hugh Pinnock explains the necessity of gaining a testimony and rediscovering the Book of Mormon personally. [A.C.W.]

B.295 "Book of Mormon Activity." Friend 16 (February 1986): 37. An activity for children. Cut out the pieces and make a replica of the Book of Mormon. [J.W.M.]

B.296 "The Book of Mormon Again Sustained." DN 31 (22 February 1882): 70-71. It has been claimed that the breastplate that Joseph Smith said accompanied the gold plates was unhistorical, but a recent book has reported a skeleton found wearing a breastplate of brass. Also found was a stone covered with hieroglyphs, which the author compares to the engraven stone interpreted by Mosiah. [D.M.]

B.297 The Book of Mormon: An Account Written by the Hand of Mormon, upon Plates Taken from the Plates of Nephi. Scottsdale, AZ: Stakes West, 1981. A pamphlet consisting of selected reproductions from the "Independence edition" of the Book of Mormon, with the intention of demonstrating changes and deletions in footnotes in a later edition, though no comparisons are shown. [D.M.]

B.298 "The Book of Mormon an Inspirer of Art." Relief Society Magazine 14 (September 1927): 436-37. Sculpture, painting, stained glass windows, hymns, drama, pageants, and poems are forms of art that the Book of Mormon has inspired. [J.W.M.] 
B.299 "The Book of Mormon and the Bible." Awake 34 (22 January 1953): 20-23. A polemical article written against the Book of Mormon. Challenges the LDS view that "many plain and precious things" were excised from the biblical writings. Rejects Mormon proof texts from Ezekiel 37:16, 17; Revelation 14:6; John 10:16; Revelation 7:9, 10; and Psalms 85:11. [M.R.]

B.300 "The Book of Mormon and the Mormonites." Athenaeum, Museum of Foreign Literature, Science, and Art 42 (July 1841): 370-74. Writes against the Book of Mormon. Quotes part of Nephi's vision and identifies the "great and abominable Church with the 'Church of Rome.' "Sees Nephi's compass as an anachronism. The Greek Christ is a title, not a proper name. Greek culture was not mixed with the Semitic that early. Has problems with the name "Jesus" and "Alpha and Omega." Accepts the Spaulding theory. [D.M.]

B.301 "The Book of Mormon and the Stranger." IE 67 (April 1964): 308. The Book of Mormon is a witness of Jesus Christ and a valuable tool in teaching the gospel. Discusses a program of placing copies of the Book of Mormon in hotel rooms. [L.D.]

B.302 The Book of Mormon and You. Salt Lake City: Church of Jesus Christ of Latter-day Saints, n.d. Pamphlet that explains that Jesus Christ is the central message of the Book of Mormon. Doctrinal topics such as the resurrection, infant baptism, and others are discussed in the Book of Mormon. [B.D.]

B.303 "Book of Mormon Appeals to Avid Readers." CN 43 (17 November 1973): 10. A conversion story of a man who believed the Book of Mormon was true after he read it in two days. [M.D.P.]

B.304 "The Book of Mormon as a Best Seller." Relief Society Magazine 10 (September 1923): 432. The Book of Mormon may become a best seller, and "the last few years has probably witnessed the sale of a quarter of a million copies." [J.W.M.]

B.305 "The Book of Mormon as a Literary Product." Relief Society Magazine 10 (September 1923): 432-35. The Book of Mormon is a standard work of American literature and its essentials are in harmony with the Bible. [J.W.M.]

B.306 "Book of Mormon Authenticity Hit." Moody 78 (September 1977): 17. Claims that Solomon Spaulding wrote some of the Book of Mormon. [D.W.P.]

B.307 "The Book of Mormon Bears Witness That Jesus Is the Christ." CN 58 (2 January 1988): 4. The Book of Mormon's subtitle, "Another Testament of Jesus Christ," is inspired. Testifying of Christ is a major purpose of the Book of Mormon. [A.C.W.]

B.308 Book of Mormon Believers. Independence, MO: Church of Christ, Nondenominational Bible Assembly, 197 ? An essay claiming that the expansion of Isaiah 29 in the Book of Mormon and in the Inspired Version of the Bible has historical problems related to the "learned" and "unlearned" who would try to read the book. [D.M.]

B.309 “The Book of Mormon ... Can It Add to Your Life?” Readers Digest (May 1981): 83-86. An advertisement insert in a popular magazine intended as a missionary vehicle. Explains what the Book of Mormon has done in a positive way for some people, and what it can do for the reader. [D.M.]

B.310 "Book of Mormon Christmas Project." IE 68 (July 1965): 635. A Christmas project, for all members of the Church to give a special edition of the Book of Mormon to non-members as Christmas cards. [M.D.P.] 
B.311 "Book of Mormon Chronicles Ancient American Peoples." CN 58 (2 January 1988): 10. Lists chronologically the major groups identified in the Book of Mormon. Includes a graph of the four major groups. [R.H.B.]

B.312 "Book of Mormon Chronology Chart." Ensign 6 (September 1976): 55-57. Provides three color pages listing Book of Mormon events according to their chronological order with a chart showing their order and scriptural passages where they are discussed. [J.W.M.]

B.313 "A Book of Mormon Claim Substantiated." MS 91 (24 January 1929): 61. Helaman 3:7-11 speaks of the use of cement. A recent article in Bulletin No. 145, Bureau of Plant Industry (Washington, D.C.), 1909 confirms that pyramids and ruins found in Mexico, Central, and South America contained cement. [J.W.M.]

B.314 "Book of Mormon Comes Alive for Idaho Children." CN 58 (27 August 1988): 7. Tells of Primary children in the Idaho Falls, Idaho, Ammon Stake, that participated in their own Book of Mormon pageant. [M.D.P]

B.315 "Book of Mormon Committee Report-Comparison of Differences in the Text of the Manuscript and the Palmyra Edition of the Book of Mormon." SH 31 (23 August 1884): 545-48. Report on the comparison made between the Palmyra or First Edition of the Book of Mormon, the current edition, and the manuscript that David Whitmer, Sr., had in his possession. While numerous changes exist they "do not affect the doctrine taught." Provides an extensive list of the changes. [J.W.M.]

B.316 "The Book of Mormon Compared with the Bible." The Watch Tower (15 May 1962): 313-18. Presents a comparison of the Book of Mormon with the Bible and finds many contradictions. The Old Testament makes no mention of Jesus as the Christ, yet the Book of Mormon does. [J.W.M.]

B.317 "The Book of Mormon Confirmed." MS 60 (13 January 1898-10 February 1898): 24-28, 33-39, 56-63, 7277, 81-87. Five-part series sets forth external evidences of the Book of Mormon, including the archaeological findings that "point to successive periods of occupation" in ancient America, evidence of Hebrew origin/descent for the American Indians, and the idea that there was an advanced civilization in ancient America. Also discusses metal plates and provides geological proof of the great destruction recorded in 3 Nephi 8. [A.C.W.]

B.318 "Book of Mormon Contains Teachings Necessary for Fullness of Blessings." CN 58 (15 October 1988): 10. The Book of Mormon contains the principles of salvation by which individuals may attain heaven. [R.H.B.]

B.319 "The Book of Mormon Converts." CN 35 (12 June 1965): 20. The Book of Mormon, through the Spirit, converts thousands of people and will continue to do so. Children should read the Book of Mormon with their family. Individuals need to read it often. [M.D.P.]

B.320 "Book of Mormon Copies Flood Midwestern Fair." CN 60 (20 January 1990): 7. When copies of the Book of Mormon were not available at a county fair in Albert Lea, MN, 100 copies were sent and helped interest inactive members and investigators. [M.R.]

B.321 Book of Mormon Course of Study: Inservice Insert Sheets for Released Time Seminary Teacher. N.p., 1974-75. Helpful teaching aids for teachers of the Book of Mormon. Includes a list of course objectives, course outline, methods of teaching the students, scripture chase items, and other teaching tools. [D.W.P.]

B.322 "A Book of Mormon Christmas." NE 23 (December 1993): 20-23. A list of verses from the Book of Mormon prophesying of the birth of Christ. [S.H.] 
B.323 "Book of Mormon Distribution." CN 31 (5 August 1961): 2. Presents statistics of the number of Books of Mormon that were distributed through placements (i.e. hotels, motels, stores, etc.). [M.D.P.]

B.324 The Book of Mormon for Our Day: An Advanced Course. Independence, MO: Herald House, 1951-52. A quarterly series, presented in a manual format with discussion questions. Addresses witnesses, Rigdon-Spaulding theory, metal plates. [A.C.W.]

B.325 The Book of Mormon Foundation. The Book of Mormon as the Basis for Some Vital Conclusions. N.p.: The Book of Mormon Foundation, n.d. Quotes Mosheim to show that apostasy made it necessary for a restoration; for this reason the Book of Mormon was brought forth. David Whitmer tells of the translation of the book by means of a seer-stone in a hat. Points out the failure of the Latter-day Saints to follow the Lord's commandments and their neglect of the Book of Mormon. [J.W.M.]

B.326 "Book of Mormon Goes to Antarctic." IE 43 (March 1940): 157-58. A copy of the Book of Mormon is presented to the crew of the "North Star" which was on its way to the Antarctic. [J.W.M.]

B.327 "The Book of Mormon in Japanese." IE 13 (December 1909): 178-80. Announces the completion of the Japanese translation of the Book of Mormon and lauds the beautiful work done and the effort spent in the project. [D.M.]

B.328 "Book of Mormon in Scandinavian." SH 50 (10 June 1903): 522. Announces the recent publication of the Scandinavian edition of the Book of Mormon. [J.W.M.]

B.329 "Book of Mormon Is 'A Standard for the Church,' President Benson Tells Priesthood Leaders." Ensign 16 (May 1986): 105. Quoting a recent talk by President Benson, this article states that the mission of the Book of Mormon is to bring men to Christ and expose falsehoods and the enemies of Christ. It fortifies the humble followers of Christ. [J.W.M.]

B.330 “Book of Mormon 'Is Expression of God's Love.." CN 58 (31 December 1988): 7. Leaders of the Montgomery Alabama Stake tell members that reading the Book of Mormon is a top priority. [M.D.P.]

B.331 "The Book of Mormon: Is Its Modern Claim to Divine Inspiration Justified?" Awake! 34 (22 January 1953): 16-20. A polemical article written against the Book of Mormon. The writer notes what he feels are certain anachronisms, absurdities, and contradictions with the Bible. [M.R.]

B.332 "Book of Mormon is Now in 71 Languages." CN 57 (4 April 1987): 4. Update on the current number of translations available of the Book of Mormon. The newest translations are the Greek, Arabic, and Aymara editions of the Book of Mormon. [A.C.W.]

B.333 "Book of Mormon is Presented to South African Zulu Leader." CN 58 (30 January 1988): 3. Shortly after the Book of Mormon was translated into Zulu it was presented to the Zulu chief, Dr. Margosuthu G. Buthelezi, who said he hoped it would bring Christ into the lives of his people. [M.R.]

B.334 "Book of Mormon is Special Witness." IE 68 (July 1965): 634. Members bearing testimony of the Book of Mormon as inspired by the Holy Ghost are able to touch the hearts of those who listen. More witnesses to the Book of Mormon are needed. [J.W.M.] 
B.335 "Book of Mormon is the Pivotal Point of Gospel." CN 58 (2 January 1988): 3, 12. Reports an interview with Elder Robert L. Simpson concerning the Book of Mormon as the gospel doctrine course of study for the upcoming year. Simpson urges members to read the Book of Mormon and come to class prepared since the Book of Mormon is "the key to carrying out the mission of the Church." [A.C.W.]

B.336 "Book of Mormon Is True Record." CN 44 (6 April 1974): 5. John H. Vandenberg proclaimed that the Book of Mormon is to bring all to Christ. The name Mormon as defined by Joseph Smith means "more good." The Bible is good and the Book of Mormon is an extension of the good of the Bible. [J.W.M.]

B.337 The Book of Mormon: It Begins with a Family. Salt Lake City: Deseret Book, 1983. Contains twenty-three reprints of articles previously published in the Ensign. See under individual entries throughout this bibliography. [J.W.M.]

B.338 "Book of Mormon Lesson: A People of Promise, the Jews." Relief Society Magazine 5 (August 1918): 471-74. The achievements of Judah and Ephraim have begun "to show forth in mighty power" (p. 471). Jewish people have accomplished much in the world of finance, medicine, arts, journalism, statesmanship, and philosophy. In 3 Nephi 20 the Savior proclaimed the great worth of the people of Israel. Among the Latter-day Saints there are also a great many talented and valuable people. [J.W.M.]

B.339 "Book of Mormon Light On a Profound Christian Truth." Instructor 85 (March 1950): 68, 79. Discusses the manner in which Jesus Christ is the Savior of mankind. [R.H.B.]

B.340 "Book of Mormon 'Lives.' " CN 43 (7 April 1973): 14. Elder Loren C. Dunn said that the Book of Mormon is the "second evidence" of Christ's resurrection (the Bible being the first). [M.D.P.]

B.341 "Book of Mormon Manuscript." IE 50 (February 1947): 94. Reports that fragments of an original Book of Mormon manuscript are given to the Church by Charles C. Richards. [J.W.M.]

B.342 "Book of Mormon Manuscript Fragments Examined." Ensign 22 (April 1992): 74-75. Reports of a project led by Royal Skousen to study original Book of Mormon manuscript fragments. Ultraviolet photographs have allowed Skousen to identify fragments from six different passages in the Book of Mormon. [A.C.W.]

B.343 "A Book of Mormon Manuscript in Russian." IE 40 (June 1937): 339. Tells of the work conducted by Andre K. Anastasiou on a Russian translation of the Book of Mormon. [J.W.M.]

B.344 "Book of Mormon Manuscript Pages Acquired." Ensign 13 (October 1983): 77. Brent Ashworth has recently acquired two pages of the Book of Mormon original manuscript that appear to be part of Joseph Smith's copy that was sealed in the cornerstone of the Nauvoo House in 1841. (Editor's note: these have since been shown to be forgeries.) [J.W.M.]

B.345 "Book of Mormon Misunderstood?" Utah Christian Tract Society 13 (November-December 1982): 2. Expresses disdain that LDS church leaders added the subtitle "Another Testament of Jesus Christ" to the Book of Mormon. Contends that the Book of Mormon contradicts LDS doctrines. [D.M.]

B.346 The Book of Mormon: My Personal Study Guide. Provo, UT: BYU, 1966. Provides a checklist that may be marked as study of certain Book of Mormon passages is completed. Claims that the Book of Mormon itself is the best study guide. [J.W.M.] 
B.347 "Book of Mormon Names." MS 63 (21 March 1901): 177-80. Refutes a polemical claim that Book of Mormon proper names are not translatable, only transferable from one language to another. The fact that no Book of Mormon names appear in Central America does not prove the Book of Mormon to be false. Cites Book of Mormon names that have Hebrew origins and shows Mayan similarities to Book of Mormon names. [A.C.W.]

B.348 "Book of Mormon Near Four Million Mark." CN 30 (1 October 1960): 10. In the 130th year of its publication, nearly four million copies of the Book of Mormon had been sold, and it had been published in 23 languages. [A.C.W.]

B.349 The Book of Mormon: 1 Nephi-Alma 29. Historical and Doctrinal Exam Questions. Provo, UT: Brigham Young University, 1973. A study aid that covers the first one-half of the Book of Mormon. Comprises approximately 206 historical questions, with scriptural references and approximately 167 doctrinal questions, also with scriptural references. [D.W.P.]

B.350 Book of Mormon New World 1991: How to Get to Heaven. Texas: New World Press, 1991. Cites a number of Book of Mormon scriptures dealing with selected topics including prayer, fasting, false prophets, baptism, and ancient America. Concludes that the Book of Mormon teaches humanity the way to heaven. [J.W.M.]

B.351 "Book of Mormon Now in 80 Languages." Ensign 18 (March 1988): 75. In 1987 the Book of Mormon was translated into 6 new languages, bringing the total of Book of Mormon translations to 80. [L.D.]

B.352 "Book of Mormon Now in Seventy Languages." Ensign 16 (March 1986): 86. The latest translation of the Book of Mormon is in Bislama, the language of the island chain of Vanuatu. Work began in 1980. The new edition contains selections for areas where membership is small. [J.W.M.]

B.353 "Book of Mormon Personalities." In Encyclopedia of Mormonism, edited by Daniel H. Ludlow, 1:195. 5 vols. New York: Macmillan, 1992. Briefly identifies the primary personalities of the Book of Mormon, including the chief leaders, kings, statesmen, prophets, and historians. Jesus Christ is the most important personality of the Book of Mormon. [N.K.Y.]

B.354 The Book of Mormon Picture Packet. Salt Lake City: Bookcraft, 1976. A set of twelve Book of Mormon pictures by artist Arnold Friberg printed in color. The reverse side of each picture contains a description of the picture. [D.W.P.]

B.355 "Book of Mormon Pictures." DN Church Section (11 November, 9 December 1939): 5, 3. Series displaying J. Leo Fairbank's paintings depicting Book of Mormon scenes, accompanied by appropriate Book of Mormon text. [E.G.]

B.356 "Book of Mormon-Place In Time." CN 53 (27 November, 4 December 1983): 8-9, 8-9. Two chronologies of the Book of Mormon that synchronize secular and biblical events with events from the Book of Mormon. [M.D.P.]

B.357 "Book of Mormon Plates." SH 64 (26 September 1917): 915. Likens the Nephite plates of gold to the tablets of stone that bore the Ten Commandments. Both possessed great spiritual value and both were generally hidden from the eyes of humanity. Seeing the plates is not going to solve the questions of their origin or their spiritual value. It rests upon the individual to find their spiritual worth through faith and to receive revelation concerning their divine origin. [J.W.M.] 
B.358 The Book of Mormon Portfolio of Paintings. Salt Lake City: Deseret Book, 1961. Paintings by Arnold Friberg of ten Book of Mormon events. Contains scriptural text to accompany the prints. [J.W.M.]

B.359 "Book of Mormon Printed First in Palmyra, New York." CN 23 (25 July 1953): 1, 12. Identifies the bulding where the first edition of the Book of Mormon was printed. Gives historical items about the printing of the Book of Mormon. [D.M.]

B.360 "Book of Mormon Printed in Chinese." IE 69 (March 1966): 170. Reports that the printing of the Book of Mormon in Chinese culminates a long and laborious task of translation by two men who were called to the assignment. [J.W.M.]

B.361 "Book of Mormon Printed in Indonesian." CN 47 (16 April 1977): 6. After seven and a half years of work the Book of Mormon was translated into the official dialect of Indonesia and 5,000 copies were made. [M.R.]

B.362 "Book of Mormon Prophecies." Young Woman's Journal 32 (January 1921): 38-49. A series of lessons dealing with America as a promised land and the scattering and gathering of Israel. [D.M.]

B.363 "Book of Mormon Republished in Braille." Ensign 20 (June 1990): 77. An announcement concerning the republication of the Braille edition of the Book of Mormon, including the corrections of the 1981 English edition. [J.W.M.]

B.364 "Book of Mormon Settles 'Great Question.' " CN 56 (19 October 1986): 11. Report on a Book of Mormon Symposium address by Neal A. Maxwell. Bears testimony that the Book of Mormon sets forth that there truly is a redeeming Christ. [A.C.W.]

B.365 "Book of Mormon Strengthens and Converts." CN 58 (31 December 1988): 8-10. Contains eight brief conversion stories from around the world, wherein individuals were converted to the gospel of Jesus Christ through the Book of Mormon. [D.M.]

B.366 "Book of Mormon Studies." MS 90 (12, 19, 26 January; 2, 16, 23, February; 22, 29 March; 19, 26 April; 24, 30 May; 21, 28 June; 19, 26 July; 23, 30 August; 20, 27 September; 25 October; 1, 22, 29 November 1928): 2223, 46-47, 62-64, 77-80, 109-11, 123-25, 181-83, 204-6, 251-54, 267-68, 332-33, 350-52, 396-98, 413-16, 459-62, 477-78, 542-43, 558-59, 606, 623, 683-84, 702-3, 750-51, 764-65. Series of articles intended for Relief Society course study. Discusses importance of the Book of Mormon, its coming forth (i.e., the translation, the witnesses, the publication, Joseph Smith), brief overview of its contents, and explains the text from 1 Nephi 1 through Alma 58. Each article features several questions that are helpful in synthesizing and applying the Book of Mormon to daily life. [A.C.W.]

B.367 "Book of Mormon Studies." MS 91 (January-November 1929): 14, 41-42, 102, 179-80, 244, 325-26, 387 88, 453-54, 517-18, 581-82, 660-61, 740-41. A series of articles that takes a story, message, or verses out of the Book of Mormon and relates it to everyday life. [M.D.P.]

B.368 "Book of Mormon Study." Christian Century 96 (24 October 1979): 1031. A brief article describing the work of Wayne A. Larson and Alvin C. Rencher on Book of Mormon wordprints. [M.R.]

B.369 "Book of Mormon Study Has Been 'Great Blessing.' " CN 58 (31 December 1988): 7. The Sunday School study of the Book of Mormon has strengthened members' testimonies. [A.C.W.] 
B.370 Book of Mormon Supplement. USA: Deseret Sunday School Union, 1970. Lesson manual for teaching youth. Gives objectives, ideas to be taught, and learning activities to be used. [J.W.M.]

B.371 The Book of Mormon. Te Buka A Mormona. Salt Lake City: Church of Jesus Christ of Latter-day Saints, 1983. Gospel Doctrine Sunday School manual published in Tahitian. Contains 46 lessons. Lessons begin with 1 Nephi and continue through Moroni. [D.W.P.]

B.372 "Book of Mormon Testimony." MS 59 (29 April 1897): 266-68. One purpose of the Book of Mormon is to bear testimony of the truthfulness of the Bible. The corroborating witness of the Book of Mormon should encourage Christians to approach the Bible as a sacred text rather than human work. [A.C.W.]

B.373 Book of Mormon Texts. N.p., 1960. Contains a topical index to the Book of Mormon, showing 220 topicsfrom "act" to "Zion"-keyed according to the RLDS authorized version (1908) of the Book of Mormon. Some commentary accompanies the topical index. [D.W.P.]

B.374 "The Book of Mormon the Key." Deseret Weekly 51 (1895): 105. Announces the discovery of an ancient copper mine in Montana and uses the Book of Mormon to explain its significance. Believes that the Book of Mormon "is undoubtedly the key to American archaeology." [D.M.]

B.375 "The Book of Mormon: The Story of the Man Who First Printed It." American Bookseller 4 (15 December 1877): 617-18. Tells the story of J. H. Gilbert who was the printer and proprietor of the Wayne (Palmyra) Sentinel, and who first set up the type for the Book of Mormon. The title page that lists Joseph Smith as "Author and Proprietor" has been changed to "Translator" to facilitate the claim that the book is supernatural. Gives descriptive facts about the printer's manuscript, the seerstones, and the book's translation. Favors the Spaulding theory. [J.W.M.]

B.376 "Book of Mormon Theology Lesson." Relief Society Magazine 4 (December 1917): 709-12. Presents a discussion about the various metal plates connected with the Book of Mormon, including the Jaredite plates and the plates of Nephi that Mormon abridged. Provides a list of the historians and the dates that their records were made. [J.W.M.]

B.377 "Book of Mormon Translated into Aymara." CN 46 (6 March 1976): 4. The story of the Book of Mormon's translation into Aymara, the language spoken by Indians in Bolivia and Peru, and of the missionary work that has occurred in Bolivia and Peru. [M.D.P.]

B.378 "Book of Mormon Translations." Ensign 10 (April 1980): 19. Lists the languages and the years of publication for translations of the Book of Mormon. [J.W.M.]

B.379 "The Book of Mormon: Ward Teaching Supplement." IE 64 (March 1961): 189, 99. The Lord coincided the restoration of the Book of Mormon with the restoration of the Church and the priesthood purposefully, for the Book of Mormon is the word of God. [J.W.M.]

B.380 "A Book of Mormon Year." Instructor 72 (December 1937): 526-27. Encourages Church members to read the Book of Mormon, and tells faith promoting stories of those who have read the book and have experienced a "spiritual revival" in their lives. [J.W.M.] 
B.381 "The Book of Moroni." Evening and Morning Star 1 (October 1832): n.p. Briefly summarizes the book of Moroni. [M.D.P.]

B.382 "The Book of Pukei." The Reflector 1 (12 June, 7 July 1830): 36-37, 60-61. A series of articles, printed in scripture-style verse-a spin-off of the Book of Mormon for the purpose of derision. [J.W.M.]

B.383 The Book of Third Nephi: A Course for Junior Classes. Salt Lake City: Church of Jesus Christ of Latter-day Saints, 1925. A study guide for reading 3 Nephi with suggested teaching and discussion topics for teachers. [J.W.M.]

B.384 "Books." TS 3 (1 September 1842): 908-9. Speaks of the methods in which ancient books were bound. Books consisting of tablets, plates, metal, or wood were made of leaves bound with rings at the back. Flexible materials were sewn in long sheets and rolled around a stick, like a scroll. That the Book of Mormon was similarly bound is evidence of its authenticity. [J.W.M.]

B.385 “Books!!!” TS 1 (July 1840): 139-40. Announces that copies of the Book of Mormon are available after a long shortage and big demand for them. [J.W.M.]

B.386 Booth, A. L. "A Divine Record." MS 57 (August 1895): 488-90. A brief summary of David Whitmer's life and testimony of the Book of Mormon. [B.D.]

B.387 Booth, A. L. "An Objection Answered." MS 57 (14 March 1895): 168-69. Defends criticisms that the Book of Mormon contains bad grammar by stating that any errors of the book are the errors of man. Mentions the errors of the Bible. [B.D.]

B.388 Booth, Thornton Y. "The Book of Mormon." MS 100 (8 September 1938): 565-66. Identifies the Book of Mormon as an additional scriptural witness of Christ and as the stick of Judah. [R.H.B.]

B.389 Boucher, Theophiel. Mormonism ... Faith or Fallacey. New York: Pageant, 1959. A polemical work against Mormonism wherein the author presents a skeptical account of the events surrounding the coming forth of the Book of Mormon. [M.R.]

B.390 Boudinot, Elias. A Star in the West or A Humble Attempt to Discover the Long Lost Ten Tribes of Israel, Preparatory to Their Return to Their Beloved City Jerusalem. Freeport, NY: Books for Libraries Press, 1970. This is a reprint of Boudinot's work, originally published in 1816. The work itself is an evangelical essay attempting to demonstrate that the American Indians are descendants of the lost ten tribes of Israel. The author examines elements of native American language, customs, habits, known religious rites and ceremonies of worship, and moral code and compares them with similar Hebrew elements described in the Old Testament and the law of Moses. Some Book of Mormon critics have suggested that this work was a source drawn upon by Joseph Smith while writing the Book of Mormon. Ethan Smith's work View of the Hebrews quotes frequently from the earlier work of Boudinot. [M.R.]

B.391 Bouquet, A. C. Sacred Books of the World. London, England: Penguin, 1962. Briefly discusses the Book of Mormon and its history in a chapter entitled "Post-biblical Sacred Books in America." The author doubts the authenticity of the Book of Mormon and charges that "there is not the slightest shred of [anthropological] evidence" to support the Book of Mormon. [B.D.] 
B.392 Bousquet, George H. "Another Scholar Speaks! The Rigdon-Spaulding Theory Re-examined." MS 96 (October 1934): 626-30. A non-Mormon scholar states that the Spaulding theory is false and that Joseph Smith is not a fraud, arguing that the Book of Mormon witnesses who left the Church would have exposed the Book of Mormon story if it truly were fraudulent. [B.D.]

B.393 Bousquet, George H. "The Rigdon-Spaulding Theory Reexamined." DN Church News (25 August 1934): 1, 8. The author, not a member of the Church, examines the Rigdon-Spaulding theory of the origin of the Book of Mormon. He gives several reasons why the Rigdon-Spaulding theory is false and states that the Book of Mormon was not influenced by the writings of Solomon Spaulding. [M.D.P.]

B.394 Bowen, Donna Lee, and Camille S. Williams. "Women in the Book of Mormon." In Encyclopedia of Mormonism, edited by Daniel H. Ludlow, 4:1577-80. 5 vols. New York: Macmillan, 1992. There is little information about women in the Book of Mormon, but some general conclusions may be reached. Men had the prominent roles in political, military, and religious institutions. As in the Near East, marriage and childbearing carried religious significance and great honor. Monogamy was expected unless otherwise commanded of the Lord. Husbands and wives were expected to be loyal and faithful to one another. Only six women are named in the book. [J.W.M.]

B.395 Bowers, J. Alden. "The Book of Mormon in Portuguese." IE 43 (July 1940): 398. The first printing of the Book of Mormon in Portuguese rolled from the press March 15, 1940, after two and one-half years of effort. [J.W.M.]

B.396 Bowes, John. Mormonism Exposed. London: Manchester, Fletcher \& Tubbs, 1850. A polemical tract against Mormonism. The writer suggests that Joseph Smith fabricated a false set of plates for the Book of Mormon witnesses and mentions Anthon's 1834 denial, the Spaulding theory, alleged plagiarisms of the Bible, the manner in which the Book of Mormon contradicts the Bible, and the use of the compass before Christ. [M.R.]

B.397 Bown, M. D. "One Hundred Similarities between the Book of Mormon and the Spaulding Manuscript." N.p.: n.p., 1937?. Unpublished manuscript with direct quotations from the Book of Mormon and the Spaulding manuscript as supporting evidence for Bown's claim that one hundred parallels exist between the two works. [A.C.W.]

B.398 Boyce, Robert D. "Realism of Truth and the Anti-Christ." In A Symposium on the Book of Mormon, 1-4. Salt Lake City: Church of Jesus Christ of Latter-day Saints, CES, August 1986. The scientific method is too limited for the understanding of spiritual truth, as is shown in the case of two Anti-Christs, Sherem and Korihor, in the Book of Mormon. Alma and Jacob are examples of people who used man's reasoning supplemented with spiritual revelation to know truth. [B.D.]

B.399 Boyd, George. "The Traditional Mormon Doctrine of Man." In Line Upon Line: Essays on Mormon Doctrine, edited by Gary James Bergera, 145-57. Salt Lake City: Signature Books, 1989. The concept of the nature of man in Mormon theology is influenced greatly by the optimistic view of the Book of Mormon. It teaches that men are to have joy, that the Fall was a part of God's plan, that this earth was created for man, and that human beings are capable of perfection. [J.W.M.]

B.400 Boyd, Theo E. Poetic Reflections from the Dust. Independence, MO: Herald House, 1979. Reprints selected Book of Mormon passages in a form that makes them appear more poetic, including 1 Nephi 1:1-2, 1 Nephi 3:2737, 2 Nephi 1:25-39, and Jacob 2:34-43. (Verses are numbered according to RLDS.) [A.T.] 
B.401 Boyle, Wm. "Statement of David Whitmer." The Utah Evangelist 1 (May 1884): no pages given. Provides a letter from E. C. Brand calling attention to David Whitmer's testimony of the truthfulness of the Book of Mormon. Includes Whitmer's condemnation of Joseph Smith's activities following 1830. [J.W.M.]

B.402 Braden, Charles Samuel. The Scriptures of Mankind. New York: Macmillan, 1952. On pages 477-83 of this work the author provides a brief history of the Book of Mormon and discusses Joseph Smith's translation methods. He mentions the lack of credibility of the Eight Witnesses and the possible influence of the Spaulding Manuscript. [B.D.]

B.403 Bradford, William R. "How Do You Know?" Ensign 13 (November 1983): 68-69. The Book of Mormon is the record of a fallen people, and contains the solution to overcoming the fallen nature of mankind. It "outlines ... what has been done for us and what we must do ourselves to overcome our fallen condition and return to the presence of God." [S.P.S.]

B.404 Bradley, Ruth Olive. Great Themes from the Book of Mormon for Family Activities. Independence, MO: Herald House, 1974. The goal of this work is "to increase family interest and skill in using the Book of Mormon" with the hope that all will better understand "the influence of Jesus Christ upon all people." Includes a series of activities designed to open the way to better communication within family groups. Activities include planting a Book of Mormon garden, planning a family reunion, and making a family autograph book. [A.T.]

B.405 Brady, Rodney H. Book of Mormon Outline. Tucson, AZ: Brady, 1961. An outline that intends to aid students of the Book of Mormon to understand how each part of the Book of Mormon relates to the whole. Author identifies various Book of Mormon writers according to book name and chapter, chronology and locale, and general and specific events surrounding the individual. [J.W.M.]

B.406 Bramwell, E. Craig. "Hebrew Idioms in the Small Plates of Nephi." M.A. thesis, Brigham Young University, 1960. An examination is made of the influence of biblical English literature prevalent in Joseph Smith's day upon the translation of the Book of Mormon. Also a scholarly inquiry into the verbal and syntactical structure in the small plates compared with Hebrew grammatical structures. [J.W.M.]

B.407 Bramwell, E. Craig. "Hebrew Idioms in the Small Plates of Nephi." IE 64 (July 1961): 496-97, 517. Inasmuch as the Book of Mormon is a literal translation from a Hebrew record, one would expect to find the frequent use of Hebraic idiomatic expressions in it. Bramwell provides examples of a number of Hebraisms, such as compound subjects, frequent usage of the conjunction "and," a limited number of vocabulary words, and the repetitive use of possessive pronouns. [R.C.D.]

B.408 Brand, E. C. "The Book of Mormon: Elder Brand's Objections to Mr. Royle's Article." The Utah Evangelist 1 (April 1884): n.p. Response to Royle, J. C. "Faith and Credulity." Earnest Worker 1 (December 1883): n.p. Asserts that the original translation of the Book of Mormon is in the hands of one of the witnesses. It is perfect and complete. There is no evidence to prove that it was taken from the Spaulding Manuscript. [J.W.M.]

B.409 Brandt, Edward J. "I Have a Question: Why are the words adieu, bible, and baptize in the Book of Mormon? These words weren't known in Book of Mormon times." Ensign 15 (October 1985): 17-18. Also in A Sure Foundation: Answers to Difficult Gospel Questions, 16-18. Salt Lake City: Deseret Book, 1988. Answers allegations that the words "adieu," "bible," and "baptize" in the Book of Mormon are anachronisms. [D.M.] 
B.410 Brandt, Edward J. "The Law of Moses and the Law of Christ." In A Witness of Jesus Christ, edited by Richard P. Draper, 18-36. Salt Lake City: Deseret Book, 1990. Refers frequently to the Book of Mormon (and other sources) to explain the role of the law of Moses and the law of Christ in salvific history. [D.M.]

B.411 Brandt, Edward J. "The Name 'Jesus Christ' Revealed to the Nephites." In The Book of Mormon: Second Nephi, The Doctrinal Structure, edited by Monte S. Nyman and Charles D. Tate Jr., 201-6. Provo, UT: Brigham Young University Religious Studies Center, 1989. The name "Jesus Christ" is of Greek derivation. It appears, however, in the Book of Mormon because Book of Mormon prophets received revelation telling them the name by which Jesus would be known in the future. [B.D.]

B.412 Brannan, Samuel. "Another Evidence of the Book of Mormon." The Prophet Vol. "L" (8 March 1845): 1. Compares the story of the brother of Jared and his family with a Scythian/ Phoenician historical account that possesses similar elements, i.e., building a tower, the confusion of tongues, and a family whose language was preserved. [J.W.M.]

B.413 Brannan, Samuel. "The Journey of Lehi and His Family from Jerusalem to the Continent of America" in Five Parts. In The Prophet Vol. "L" (1, 8, 15, 22, 29 March 1845): 1 (note: each of the five parts begins on page 1 and is one page long). Part 1 contains an Aztec map preserved among the Mexican natives, depicting the journey of their forefathers to America that recalls the Nephites journey to America; part 2 presents an old facsimile depicting four persons traveling toward a tree with a rod leading toward it, recalling the tree of life story of the Book of Mormon; parts 3 and 4 relate the Zion's Camp march and a report of finding a burial mound with stone altars, which resulted in the discovery of Zelph, who had fallen in the final battle among the Lamanites; part 5 does not deal directly with the Book of Mormon. [J.W.M.]

B.414 "The Brass Plates." Friend 19 (July 1989): 16-20. Cartoon depiction for children of the story of the brass plates. [J.W.M.]

B.415 Bravo, P. Ernesto. "Los Mormones." In Las Sectas en America Latina, edited by Antonio Quarracino, 39-78. Buenos Aires: Editorial Claretiana, 1988. Discusses Joseph Smith, the gold plates, the Three Witnesses, and the Spaulding Manuscript. [D.M.]

B.416 Brewerton, Denton. "His Languages Aid Spread of the Gospel." CN 41 (12 June 1971): 11. Tells the story of how Ermel J. Morton, who has a knowledge of several languages, translated the Book of Mormon into the Tongan language. [M.D.P.]

B.417 Bricherstaff, George. The Church Story: Book 1 .. From Sacred Grove to Land of Zion. Salt Lake City: Bookcraft, 1974. A storybook for young readers contains full-page colored illustrations. Chapters 2-6 relate the story of the coming forth of the Book of Mormon. [J.W.M.]

B.418 A Brief Account of the Discovery of the Brass Plates Recently Taken from a Mound Near Kinderhook, Pike County, Illinois. Nauvoo, III: Taylor and Woodruff, 1843. A photograph and brief account of the Kinderhook plates. [J.W.M.]

B.419 A Brief Examination of the Book of Mormon and the Doctrine and Covenants. Santa Ana, CA: Christian Apologetics: Research and Information Service, n.d. Compares several editions of the Doctrine and Covenants and the Book of Mormon with the intent of showing that several additions, deletions, and changes in these texts make them the works of man and therefore invalid. [J.W.M.] 
B.420 Briggs, E. C. "Letter to Bro. Joseph Smith" SH 31 (21 June 1884): 396-97. A letter describing a conversation between E. C. Briggs and David Whitmer. David Whitmer spoke of the vision of the angel and the gold plates, the process of translation, and of an attempt by Orson Pratt to purchase the final manuscript for printing. [B.R.M.]

B.421 Briggs, Irene M. "The Tree of Life Symbol: Its Significance in Ancient American Religion." M.A. thesis, Brigham Young University, 1950. Focuses upon the cross as a religious symbol in ancient Mesoamerica. The crossshaped tree found in Mesoamerica has conventionally become known as the "Tree of Life." [L.D.]

B.422 Briggs, Kay, comp. Most Quoted Scriptures of the Standard Works of the Church of Jesus Christ of Latter-day Saints. Orem, UT: Randall Publishers, 1980. Lists scriptural passages from the Book of Mormon and other standard works under a comprehensive list of gospel topics. [J.W.M.]

B.423 Brigham, Janet. "Original Copy of Gold Plate Characters Discovered." Ensign 10 (June 1980): 74-76. Tells of the purported discovery of a handwritten copy of characters from the Book of Mormon's gold plates. (Editor's note: this document has since been shown to be a forgery.) [D.H.M.]

B.424 Brigham, Johnson. "The Original Manuscript of the Book of Mormon." World Today 9 (October 1905): 11016. Recounts what happened to both the original manuscript of the Book of Mormon and a second manuscript deposited in the cornerstone of the Nauvoo House. Inserts a detailed account of the coming forth of the Book of Mormon, using Joseph Smith's own account as the main source. [D.M.]

B.425 Brigham Young University College of Religious Instruction. A Catalogue of Theses and Dissertations Concerning the Church of Jesus Christ of Latter-day Saints, Mormonism and Utah. Provo, UT: Brigham Young University, 1971. The theses and dissertations are listed according to authors and titles. Subjects such as "Lamanites and Polynesians," "Book of Mormon History," and "Book of Mormon" can be found in the subject index. [B.D.]

B.426 Brimhall, Carla. "Faith and Actions Mark True Belief in Book of Mormon." CN 55 (6 October 1985): 7. News report of the First Annual Symposium on the Book of Mormon held Sept. 27-28, 1985. The keynote speaker was Daniel H. Ludlow who bore testimony that the Book of Mormon is the word of God. [J.W.M.]

B.427 Brimhall, Carla. "Members Admonished to 'Refurbish' Their Lives." CN 56 (28 September 1986): 3, 7. President Benson lists six ways for members to increase their faith, one of which is to read and ponder the Book of Mormon. President Monson relates a story of a family that was converted by the Book of Mormon. Elder Dunn said that the spiritual side of man is built by reading the scriptures, especially the Book of Mormon. Elder Oswald showed a list of members who had committed to read the Book of Mormon. [M.D.P.]

B.428 Brimhall, Dennis C. "The Eight-Year Book of Mormon." Ensign 19 (February 1989): 32-33. A family received many rewards from reading the Book of Mormon together every day until they finished it eight years later. [B.D.]

B.429 Brimhall, George H. "The Book of Mormon an Evidence in Itself of Its Divinity." IE 26 (September 1923): 981-82. The author notes that the Book of Mormon can be considered a classic work, since interest in it endures. Some people vouch for the valuable principles contained in it, but cannot accept the miraculousness of it. Its harmony with the Bible makes it a genuine new witness for the life, teachings, and divinity of Jesus Christ. [D.M.]

B.430 Brimhall, George H. "Men and Monuments Speak of Joseph Smith." IE 6 (July 1903): 652-54. Includes a clipping from a newspaper that talks of the ancient ruins of Central America and the magnificence of the race that 
occupied these ruins. Author writes that such ruins are evidence that the peoples of the Book of Mormon did indeed exist. [M.D.P.]

B.431 Brimhall, George H. MIA Lessons for the Advanced Senior Class. Bountiful, UT: Children of Alsina Elizabeth Brimhall Holbrook, 1988. Pages 323-29 feature MIA lessons about prophecy and the Book of Mormon. The lesson outlines were previously published in the Young Women's Journal 36 (January-April 1925). [D.W.P.]

B.432 Brinley, Douglas E. "The First Families of the Book of Mormon." In Doctrines of the Book of Mormon, 1991 Sperry Symposium, edited by Bruce A. Van Orden and Brent L. Top, 29-41. Salt Lake City: Deseret Book, 1992. The Book of Mormon provides excellent guidance regarding family relationships. For instance, Lehi showed how to avoid family arguments, Sariah demonstrated qualities of motherhood, and a number of positive and negative familial attitudes appeared in the brothers of Nephi, Laman, and Lemuel. [B.D.]

B.433 Brinley, Douglas E. "The Promised Land and Its Covenant Peoples." In The Book of Mormon: Helaman through 3 Nephi 8, According to Thy Word, edited by Monte S. Nyman and Charles D. Tate Jr., 39-63. Provo, UT: Brigham Young University Religious Studies Center, 1992. Shows the covenantal relationship between God and the ancient inhabitants of the Americas - the antediluvian patriarchs, the Jaredites, the Lehites, and Mulekites. Includes a discussion of the gentiles. Enumerates ten stages that exist between righteousness and wickedness. [D.M.]

B.434 Brinley, Geri. "The Book of Mormon as a Guide for Parents." Ensign 18 (July 1988): 38-41. Finding solutions to parenting problems while studying the Book of Mormon was an answer to fervent prayer. This article contains a full-page chart of principles, scriptural references, and application to daily life. [J.W.M.]

B.435 Broadbank, Thomas W. "The Book of Mormon Plates." MS 68 (9 August 1906, 16 August 1906): 499-502, 524-27. An exhibition of the gold plates would not convert nonbelievers to the truthfulness of the Book of Mormon. Few people would have access to, or would be able to read the plates. The testimonies of the witnesses were never revoked. [A.C.W.]

B.436 Broadfoot, Raymond. "Indians of the Americas: A Racial Puzzle, Part I." SH 125 (February 1978): 80-82. Discusses the similarities and differences between native Americans and "mediterranean type people." Concludes that "for the person with an open mind there exists evidence which shows that mediterranean type people lived in the New World in the past and that their physical characteristics have been transmitted to today's Indians" (p. 82). [B.D.]

B.437 Broadfoot, Raymond R. "Indians of the Americas: A Racial Puzzle, Part II." SH 125 (March 1978): $152-53$. Writes that the Jaredites may have had mongoloid type peoples among them. Remnants of the Jaredite culture with mongoloid characteristics may have intermarried with the Lamanites and this would explain how the Lamanites became dark skinned. [B.D.]

B.438 Broadfoot, Raymond R. "Time Scales and the Book of Mormon." SH 106 (24 August 1959): 797-801. Gives an overview of pre-Columbian history (Maya, Aztec, Inca) in ancient America to show that many different groups of people inhabited the land of America. The Nephites and Jaredites were among these groups, but not all archaeological evidence can be matched up with the groups of the Book of Mormon. [A.C.W.]

B.439 Broadhurst, Dale R. A New Basis for the Spaulding Theory. Delaware, Ohio: Methodist Theological School in Ohio, March 1981. A significant collection of data on the Spaulding manuscript. Asserts that there are many 
resemblances between the Spaulding manuscript and the Book of Mormon. Gives a history of the Spaulding manuscript itself, and a useful bibliography of sources dealing with this theory of Book of Mormon origins. [M.R.]

B.440 Broadhurst, Dale R. The Secular and the Sacred: An Examination of Selected Parallels in the Writings of Solomon Spaulding and the Book of Mormon. Delaware, OH: Methodist Theological School in Ohio, 1982. Compares the Book of Mormon ocean crossing narratives with the Spaulding manuscript and finds twenty-four significant similarities. The author believes that Solomon Spaulding remains the leading candidate for Book of Mormon authorship. [A.T.]

B.441 Broadhurst, Dale R. Spaulding Research Project Working Papers 1-10. Delaware, OH: Methodist Theological School in Ohio, 1980. A significant collection of research papers on the Spaulding manuscript. 188 similarities between the Book of Mormon and the Spaulding Manuscript are noted in detail. Also contains a transcript of the Spaulding manuscript and a collection of statements about the manuscript made by some of Spaulding's neighbors. [M.R.]

B.442 Brockbank, Bernard P. "Book of Mormon on Prayer." CR (October 1979): 83-86. Book of Mormon teachings on prayer instruct individuals that repentance coupled with prayer purifies and leads to greater perfection, meaningful prayer leads to salvation, and sincere prayer brings answers and blessings. [J.W.M.]

B.443 Brockbank, Bernard P. "Seek and Ye Shall Find." IE 71 (December 1968): 61-63. The Book of Mormon is a missionary tool that teaches the true character of Jesus Christ. The proper approach to obtaining a testimony of the Book of Mormon is outlined. [B.W.J.]

B.444 Brockway, Edith. The Golden Land. Independence, MO: Herald House, 1968. A "fictional account of the Jaredite migration" written for youth. [D.W.P.]

B.445 Brodie, Fawn M. No Man Knows My History: The Life of Joseph Smith the Mormon Prophet. New York: Knopf, 1945; 2nd edition revised and enlarged 1973. A biography of Joseph Smith with some discussion of the Book of Mormon. Chapter 3, "Red Sons of Israel," discusses environmental influences that Brodie feels Joseph Smith used in fabricating the Book of Mormon. Among these are speculations regarding Indian origins that are discussed in such books as View of the Hebrews, Moonbuilder Civilizations, and other works. Chapter 4, "A Marvelous Work and a Wonder," discusses the Anthon episode, translation of the Book of Mormon, and Joseph Smith, Sr.'s, dream of the tree of life; In Chapter 5, "Witnesses for God," the author rejects the Spaulding theory in favor of an environmental explanation. She also notes various alleged anachronisms and problems in the Book of Mormon. These include the description of Jaredite boats, domesticated animals in America, Old World crops in America before Columbus, and others. This work is reviewed in H.259. [M.R.]

B.446 Bronson, H. C. "The Book of Mormon is the Stick of Ephraim." SH 30 (1 September 1883): 565-66. Argues that the tribe of Ephraim exists upon the Americas and that the Book of Mormon is referred to in Ezekiel 37:16 as the stick of Ephraim. [A.T.]

B.447 Brook, Zadoc. Introduction to the Book of Mormon. Monongahela, PA: Gilkey and Underwood Printers, 1923. Publication of the Church of Jesus Christ (Bickertonite Group). A general introduction of the Book of Mormon, with some discussion dealing with discoveries in Central America and Peru that the author believes to be "evidence to the divinity of the Book." [L.D.] 
B.448 Brookbank, T. W. "A Book of Mormon Consistency." IE 13 (September 1910): 997-98. The author notes that Jesus did not mention the Scribes and Pharisees in his 3 Nephi discourses, even in the parallel passages from the Sermon on the Mount. [D.M.]

B.449 Brookbank, T. W. "The Book of Mormon Needed." MS 72 (March 17, 24, 1910): 161-66, 177-80. The moral and religious principles contained in the Book of Mormon are akin to those in the Bible. The Book of Mormon does, however, contain new teachings. It specifies the proper mode of baptism, rejects infant baptism, rejects the doctrine of predestination, is a second witness of the Savior, stresses the terrible consequences of disobedience to gospel laws, and demonstrates the principle of modern revelation. [R.H.B.]

B.450 Brookbank, T. W. "The Book of Mormon Originally Written in Hieroglyphics." IE 14 (March 1911-September 1911): 395-99; 500-505; 703-10; 983-88. Offers some evidence from worldwide sources to corroborate Mormon's statement in the Book of Mormon that the text was written in reformed Egyptian characters. [L.D]

B.451 Brookbank, T. W. "Concerning the Book of Mormon." MS 76 (February 1914): 88-92. Argues that the idea that Joseph Smith actually wrote the Book of Mormon is ridiculous and such an accomplishment would be similar to someone writing a 10-year historical work in a few weeks. [B.D.]

B.452 Brookbank, T. W. "Concerning the Book of Mormon Plates." MS 75 (July 1913): 424-28, 440-45. Argues that it would be useless to show the Book of Mormon plates to the public, for a display of the gold plates would not build faith in Jesus Christ. The Lord has already sent a multitude of witnesses to testify of the Book of Mormon. [B.D.]

B.453 Brookbank, T. W. Concerning the Brass Plates. Liverpool: MS Office, 1924. This short apologetic work argues from biblical evidence that the brass plates represented the master copy of the Israelite scriptures in Palestine until Lehi took them to the Americas. Also claims that the brass plates were written in Egyptian hieroglyphics. [A.L. $\&$ P.H.]

B.454 Brookbank, T. W. “Concerning the Brass Plates." MS 83 (July-August 1921): 433-36, 449-53, 465-68, 48184, 497-501. In response to the objection that Israelites could not have engraved a record on brass plates, Brookbank shows examples in the Old Testament that indicate that they did in fact use brass in creating records (Isaiah 8:1-2 and Habakkuk 2:2). The brass plates used by Isaiah and Habakkuk are what became the brass plates that Lehi took to the America. [B.D.]

B.455 Brookbank, T. W. "Concerning the Charge of Copying." MS 76 (3 September 1914): 568-73. Answers the charge that Joseph Smith copied passages from the Bible into the Book of Mormon by arguing that often the Lord does not repeat laws and prophecies to men verbatim. This is clearly seen in the Hebrew Bible where it is observed that men who lived in the same land and in corresponding time periods recorded events differently as a comparison between passages of the Bible shows. [J.W.M.]

B.456 Brookbank, T. W. "Concerning the Urim and Thummim." MS 76 (August 1914): 552-7. Argues that the Urim and Thummim used by Joseph Smith was the same employed by the Israelites as mentioned in the Bible. The Mulekites brought it to the American continent and it was handed down through the generations and finally buried with the plates that Moroni gave to Joseph Smith. [B.D.]

B.457 Brookbank, T. W. "A Defence [sic] of the Book of Mormon." MS 86 (17 January 1924): 36-39, 52-55, 59-60. Presents evidences of the Book of Mormon, including: the Book of Mormon omits the letters 9 , x, or w from proper 
names, does not use contractions, indicative of a Hebrew language; omits from the book of Ether references to the priesthood, the law of Moses, stories of Abraham, Isaac, Jacob, Joseph, Moses, and other references that are Israelite, except for commentary inserted by Moroni. Also argues that Joseph Smith did not use the published writings of Del Rio, who visited ruins in America in 1767, as he translated the Book of Mormon. [J.W.M.]

B.458 Brookbank, T. W. "Easily Caught." MS 75 (July 1913): 488-93. Responds to the objection that the Book of Mormon was originally inscribed on metal plates. Numerous examples in the Old Testament demonstrate the working of metal from early ages, including Tubal-Cain's work with brass and iron (Genesis 4:22), the brass gates of Babylon (Isaiah 45:1-2), the use of steel in Job's day (Job 20:24), the golden calf made in the wilderness, and all the gold of Moses' tabernacle (Exodus 25:17-36). [B.D.]

B.459 Brookbank, T. W. "Hebrew Idioms and Analogies in the Book of Mormon" (series). IE 13 (December 1909, January 1910, February 1910, March 1910, April 1910): 117-21, 234-39, 336-42, 418-20, 538-43. Vol. 17, 18 (January 1914, February 1914, March 1914, May 1914, July 1914, August 1914, September 1914, October 1914, December 1915): 189-92, 366-70, 471-75, 623-27, 881-84, 972-75, 1061-63, 1147-51, 136-43. A series that produces evidence that the Book of Mormon is an ancient Hebrew work, containing Hebraisms. Emphasizes: (1) The Book of Mormon contains peculiar grammatical structures that are similarly found in the Bible, (2) many of the proper names in the Book of Mormon possess a notable Jewish character, and (3) many of the Jaredite proper names contain Hebraic similarities that date back to the period predating the Tower of Babel. [D.M.]

B.460 Brookbank, TW. “Nephite-Christian Experience." MS 72 (10 February 1910): 81-85. There is no greater Christian experience than that of Nephi as recorded in 2 Nephi 4. Nephi traverses from the agony of spiritual battle with the hosts of darkness through various levels of assurance, obtaining relief, gratitude, then victory. Nephi's conflict provides an example to missionaries who must look to God. [J.W.M.]

B.461 Brookbank, TW. "Parentage of Ancient American Art and Religion." MS 72 (2 September-24 November 1910): 609-14, 628-31, 644-47, 661-63, 684-86, 692-95, 708-11, 730-33, 740-43, 747. A series that discusses the Babylonian and Israelite people who established Book of Mormon civilizations. Suggests that the Jaredites were Semites. The ancient ruins left in America have distinct Babylonian and Assyrian influence. The NephiteIsraelite people of the Book of Mormon have also left their mark upon civilization. [J.W.M.]

B.462 Brookbank, TW. "Pitfalls Avoided by the Translator of the Book of Mormon." MS 71 (6 May 1909): 273-79, 289-93. Describes many mistakes that Joseph Smith could have made if he were a fraud who wrote the Book of Mormon. For instance, Joseph Smith did not incorporate modern geographical names, punctuation, chapter and verse markings, modern terms for clothing, alcoholic beverages, military terms, days of the week, names of months, nor titles such as mister or doctor. [B.D.]

B.463 Brookbank, T. W. "Reply to a Recent Critic." MS 75 (9, 16 July 1914): 440-45, 456-61. Defends the Book of Mormon against the charge that it cannot be God-inspired since its literary merits are so poor. Believes that its poor literary style supports its claim even more since good style cannot be had from translating Egyptian hieroglyphics. [B.D.]

B.464 Brookbank, TW. "A Study in American Hebraic Names." IE 20-21 (December 1916; January, February, June 1917): 166-70; 224-36, 328-35, 669-76. Cites many words and names found in the Americas that coincide and correspond with Hebrew names and words. [L.D.] 
B.465 Brookbank, TW. A Study in Hebrew and Indian Languages. Salt Lake City: Salt Lake Efficiency, 1926.

Compares the similarities and correspondences between the ancient Hebrew language and Indian language. [L.D.]

B.466 Brookbank, TW. "Were the Brass Plates Written in Egyptian?” Young Woman's Journal32 (April, May, June 1921): 204-8, 292-95, 368-70. Looking at a variety of cultural and linguistic aspects to support his point of view, the author defends the Mormon belief that the brass plates were written in Egyptian. [L.D.]

B.467 Brooks, Melvin R. "Book of Mormon." In Brooks's LDS Reference Encyclopedia, 51-54. Salt Lake City: Bookcraft, 1960. A brief narration of the coming forth and publication of the Book of Mormon precedes a list and discussion of 28 "Peculiarities of the Book of Mormon," including: the Book of Mormon does not use surnames, nor names for modern fabric or articles of clothing. Typical of the Hebrew language, contractions are not used nor are the letters q, x, or w used in proper names. [J.W.M.]

B.468 Brooks, Melvin R. "Parables of the Book of Mormon." In Brooks's Parables of the Kingdom, 155-57. Salt Lake City: Deseret Book, 1965. A brief historical account of the Book of Mormon is given recognizing that the teachings of the Lord existed in the Book of Mormon before the Savior's ministry. However, the parables were absent. During his visit, he taught parables in America paralleling those in the Bible. [J.W.M.]

B.469 Brooks, Van Wyck. Sketches in Criticism. New York: Dutton, 1932. The author considers the Book of Mormon to be a "solemn parody of the Bible" (p. 253) and a product of a nineteenth-century New England environment. [M.R.]

B.470 "The Brother of Jared." Friend 18 (January 1988): 16-17. A short summary of the story of the brother of Jared designed for children. [M. D. P.]

B.471 "The Brother of Jared." SH 74 (30 March 1927): 377-79. Recounting the story of the brother of Jared brings greater understanding of the personality of God and his creation of man. [J.W.M.]

B.472 Brotherton, Edward. Mormonism: Its Rise and Progress. Manchester: L. and S. Smith, 1845. A tract against Mormonism. Pages 20-36 deal specifically with the Book of Mormon, arguing against the witnesses, the use of modern phrases and King James style English, contradictions with the Bible, and various anachronisms and absurdities. Criticizes the Mormon use of biblical prophecy to support the Book of Mormon and provides alternative interpretations for such prophecies. [M.R.]

B.473 Brotherton, Helen. "The Story Behind the Book of Mormon in Chinese." ZR 12 (Spring 1981): 4-5, 7-8. See also Witness 70 (Fall 1990): 9. Tells of Wang Chun Chang's conversion to the RLDS church and his efforts to translate the Book of Mormon into Chinese. [A.T.]

B.474 Brough, Janet N. Book of Mormon Activity Book. Salt Lake City: Acorn, 1983. Contains crossword puzzles, matching games, and other activities for children. [D.W.P.]

B.475 Brown, Amanda J. "A Design Study in Costume for Projected Dramatic Productions Prescribing a Book of Mormon Setting Identified Herein as Late Preclassic Mesoamerican Culture." M.A. thesis, Brigham Young University, 1968. Creates drawings of costumes that attempt to be historically accurate to the Late Preclassic period (500 B.C.>- A.D. 200) of Mesoamerica and are dramatically effective. [B.D.] 
B.476 Brown, Bruce L. "The Stick of Joseph and the Stick of Judah." In BYU 1985-1986 Devotional and Fireside Speeches, edited by Karen Seely, 172-179. Provo, UT: BYU Press, 1986. When studied in conjunction with each other, the Hebrew Bible and the Book of Mormon provide the reader with greater insights into scriptural studies. Author shares personal learning experiences. [J.W.M.]

B.477 Brown, Cheryl. "Book of Alma." In Encyclopedia of Mormonism, edited by Daniel H. Ludlow, 1:150-52. 5 vols. New York: Macmillan, 1992. An overall view of the longest book in the Book of Mormon, the book of Alma, which covers thirty-nine years of Nephite history (91-52 B.C.). The theme of the entire book is that the pure testimony of Christ is mightier than politics or the sword in establishing peace and goodness. [J.W.M.]

B.478 Brown, Cheryl. " 'I Speak Somewhat Concerning That Which I Have Written.' I I The Book of Mormon: Jacob through Words of Mormon, To Learn with Joy, edited by Monte S. Nyman and Charles D. Tate, 55-72. Provo, UT: Brigham Young University Religious Studies Center, 1990. Gives reasons why the Book of Mormon writers excluded some materials from the Book of Mormon and yet included other items. Knowing what was included and why permits members of the Church to know what the Lord wants them to learn from the Book of Mormon and how he wants them to approach the book. [B.D.]

B.479 Brown, Gayle O. "Book of Mormon Teaches Members How to Love." CN 55 (27 October 1985): 12. Those who need to learn more about love may study the Book of Mormon. There are many examples found there. [J.W.M.]

B.480 Brown, Gayle O. "Love in the Book of Mormon." In The Book of Mormon: The Keystone Scripture, edited by Paul R. Cheesman, S. Kent Brown, and Charles D. Tate Jr., 151-63. Provo, UT: Brigham Young University Religious Studies Center, 1988. There are many ways that the Book of Mormon teaches about love. It instructs readers what to love and what not to love. It also demonstrates how individuals can increase their ability to love. [B.D.]

B.481 Brown, Hugh B. "Are Mormons Christians?" In Brown's The Abundant Life, 23-34. Salt Lake City: Bookcraft, 1965. Bears testimony concerning the Book of Mormon. Claims that no teaching in it contradicts the Bible. Avers that criticisms, to be valid, should be accurate: "I am under no obligation to defend what you say I believe if I don't in fact believe it. Let me say what I believe and then you can attack my beliefs but don't set up something that you say I believe and then ask me to defend it." [D.M.]

B.482 Brown, Hugh B. "The Book of Mormon ... A Divine Record." In Brown's Continuing the Quest, 281-86. Salt Lake City: Deseret Book, 1961. The 9th Article of Faith confirms the Church's official recognition of all revelation. Acknowledging the Book of Mormon as the revealed word of God in no way diminishes the value or faith placed in the Old and New Testaments. To the contrary, it supports and sustains the miraculous nature of the Bible. Its divine message shows the application of the Savior's Atonement and resurrection in the lives of hundreds of people. [J.W.M.]

B.483 Brown, Hugh B. "Book of Mormon Testimony." In Brown's Continuing the Quest, 95-111. Salt Lake City: Deseret Book, 1961. Tells what the Book of Mormon says about Christ. [D.M.]

B.484 Brown, Hugh B. "A Book You Should Read-And Why." In Eternal Quest, edited by Charles Manley Brown, 140-43. Salt Lake City: Bookcraft, 1956. Presents an overview of the Book of Mormon and its message. Bears his testimony and exhorts his readers to test Moroni's promise. [J.W.M.] /p> 
B.485 Brown, Hugh B. "President Brown Talks on Mormonism at Pittsburgh College." CN 32 (3 March 1962): 7 , 12-15. Address delivered at Presbyterian Theological Seminary, giving history of LDS church and basic doctrinal beliefs. Discusses the translation, story line, compatibility with the Bible, and powerful effect of the Book of Mormon. Concludes with testimony of the truthfulness of the gospel. [A.C.W.]

B.486 Brown, Hugh B. "We Affirm Our Faith." IE 61 (December 1958): 944-45. After one hundred thirty years the influence of the Book of Mormon continues to steadily increase. It is the word of God, a sacred record of ancient inhabitants of America, translated by the power of God. Though many have tried to discredit it, the Book of Mormon is probably the most influential and most widely discussed book in America. It is a witness of Christ. [J.W.M.]

B.487 Brown, Richard A. Studies in Jacob. Independence, MO: Herald House, 1988. A study guide booklet presenting lessons from the book of Jacob. [D.W.P.]

B.488 Brown, Richard A. Studies in II Nephi. Independence, MO: Herald House, 1990. A study guide booklet with a devotionalist approach, containing lessons of Nephi's psalm and farewell, the Atonement, choosing joy, and others. [D.W.P.]

B.489 Brown, Robert L., and Rosemary Brown. They Lie in Wait to Deceive. Vol. 2. Mesa, AZ: Brownsworth, 1984. A rebuttal and refutation of the claims made by the authors of Who Really Wrote the Book of Mormon? Shows that the authors apparently falsified statements made by handwriting analysts. Also shows why most today reject the Spaulding origin for the Book of Mormon. [M.R.]

B.490 Brown, S. Kent. "Alma's Conversion: Reminiscences in His Sermons." In The Book of Mormon: Alma, The Testimony of the Word, edited by Monte S. Nyman and Charles D. Tate Jr., 141-56. Provo, UT: Brigham Young University Religious Studies Center, 1992. Recalls Alma's conversion and the profound change it made upon the Nephite church. Allusions to his experience are given in most of Alma's recorded sermons (see Alma 5, 7, 9-13, 29, 30, 32, 33, 36, and 38-42). Alma saw himself racked with eternal torment for three days and finally received indescribable joy knowing of the Atonement of Jesus, and was born again. [N.K.Y.]

B.491 Brown, S. Kent “The Exodus: Seeing It As a Test, a Testimony, and a Type." Ensign 20 (February 1990): 54-57. The Israelite exodus of the Old Testament parallels certain Book of Mormon passages and demonstrates that God can and will deliver his people from bondage. Several Book of Mormon characters recalled the Israelite exodusNephi, to provide encouragement for his brothers; Helaman, to members of the Gadianton robbers; Alma the Elder, when he fled from King Noah; and the people of King Limhi used it as a pattern. [J.W.M.]

B.492 Brown, S. Kent. "The Exodus Pattern in the Book of Mormon." BYU Studies 30 (Summer 1991): 111-26. An expansion of an article written for the Ensign, February 1990. Similarities between the exodus of the children of Israel and Lehi's departure are listed. The exodus motif is used throughout the Book of Mormon. [J.W.M.]

B.493 Brown, S. Kent. "Lehi's Personal Record: Quest for a Missing Source." BYU Studies 24 (1984): 19-42. An argument that the brothers Nephi and Jacob employed the personal record of Lehi their father as a primary source in writing their records. In developing their scriptural records, Nephi and Jacob would have had access to their father's writings or may have recalled his teachings and exhortations. This can be demonstrated by the fact that in many instances the brothers quoted their father directly and at other times they paraphrased what was said or written by him. Through detailed study of the writings of Nephi and Jacob much can be learned about the 
record of Lehi. In fact, "three easily discernible categories" pertaining to the nature and content of the record of Lehi come to view. These are his "prophecies, visions, and teachings." [D.W.P.]

B.494 Brown, S. Kent. "Nephi's Use Of Lehi's Record." In Rediscovering The Book of Mormon, edited by John L. Sorenson and Melvin J. Thorne, 3-14. Salt Lake City: Deseret Book and FARMS, 1991. Explores the references to Lehi's record as found in $1 \& 2$ Nephi and Jacob, and discusses Nephi's use of that record. Lehi's dreams and prophecies hold instructions on a variety of subjects including the marriage relationship, Adam and Eve, the Fall, choices, the role of the Savior, and the house of Israel. [J.W.M.]

B.495 Brown, S. Kent. "The Prophetic Laments of Samuel the Lamanite." Provo, UT: FARMS, 1992. Explains how the laments of the prophet Samuel are part of the literary genre known as lament literature. The first lament, apparently an individual lament, is recorded in Helaman 13:32b-33a; the second lament, characterized as a communal lament, is found in Helaman 13:33b-37. [B.D.]

B.496 Brown, S. Kent. "The Prophetic Laments of Samuel the Lamanite." Journal of Book of Mormon Studies 1 (Fall 1992): 163-80. The sermon of Samuel the Lamanite comprises poetic forms that bear similarities to laments found in the Bible and the Dead Sea Scroll Thanksgiving Hymns. The prophetic laments of Samuel exhibit a set of prophecies that find fulfillment in later periods, including during the days of Mormon, the compiler and editor of the Book of Mormon. [R.H.B.]

B.497 Brown, S. Kent, John A. Tvedtnes, and John W. Welch. "When did Jesus Appear to the Nephites in Bountiful?" Provo, UT: FARMS, 1989. Brown concludes that "the cumulative evidence weighs in the direction of the Savior's having come to the Nephites only after a substantial period of time. That period must have assuredly extended into the latter half of the year-presumably between October and April-if we trust Mormon's chronological notions concerning the timing of both the destruction (3 Nephi 8:5) and the manifestation of the Savior (3 Nephi 10:18)." See also under John Tvedtnes. [B.D.]

B.498 Brown, S. Kent, and Terrance L. Szink. "Lehi." In Encyclopedia of Mormonism, edited by Daniel H. Ludlow, 2:827-28. 5 vols. New York: Macmillan, 1992. Lehi, the patriarch of the Book of Mormon people, led his family from Jerusalem about 600 B.C. His descendants split into two groups following his death. He was a prophet whose words are partially retained in the Book of Mormon. Many of his prophecies are yet to be fulfilled. [J.W.M.]

B.499 Brown, Wade. The God-Inspired Language of the Book of Mormon: Structuring and Commentary. Clackamas, OR: Rainbow, 1988. Arranges the entire text of the Book of Mormon according to parallelistic patterns. Presents explanations on the different forms of parallelisms and poetic patterns and shows how they relate to the interpretation of the text. This work is reviewed in P.070 and in W.441. [B.D.]

B.500 Bryant, Verda Evelyn Bilger. Between the Covers of the Book of Mormon. Independence, MO: Herald House, 1945. A re-creation of Book of Mormon stories, with a concern for telling them rather than analyzing or criticizing them. [L.D.]

B.501 Bryant, Verda E. “The Book of Mormon ... Those 'Queer Names.'” SH 91 (19 February 1944): 227, 231. About one-third of the Book of Mormon names have biblical roots and many other names may have had their beginning in the biblical text because of their similarity. [J.W.M.]

B.502 Bryson, Conrey. "Cabeza de Vaca... Among the Lamanites." IE 45 (August 1942): 504-5. Cabeza de Vaca, an European who traversed across what is now Texas in the fall of 1537, mingled among the Indians and found their 
traditions and beliefs closely related to Christianity. [J.W.M.]

B.503 Bucci, Timothy D. Jew and the American Indian. 3rd edition. Monongahela, PA: Church of Jesus Christ (Bickertonites), 1968. Gives a brief history of the Jewish people and biblical references concerning their future, then lists Book of Mormon prophecies relating to the future of the American Indian. [A.T.]

B.504 Buchanan, Golden R. America's Scripture. Salt Lake City: Church of Jesus Christ of Latter-day Saints, n.d. A tract written to non-LDS presenting an overview of the coming forth and the contents of the Book of Mormon. [D.W.P.]

B.505 Buchanan, Golden R. "Indian Traditions." IE 58 (April 1955): 240-41, 285-87. A number of ancient religious Indian traditions are rehearsed, including accounts of the creation, the great deluge, a large tower, the scattering of nations, ancient writings, sacred stones, transoceanic crossings, good brothers against evil brothers, darkness and destruction on the American continent, and the visit of a "great white spirit." The author suggests that a "core of truth" is preserved within these traditions. [R.C.D.]

B.506 Buchmiller, Golden A. "Copyrights Halt Illegal Publication of the Book of Mormon." CN 50 (1 March 1980): 10. Celebrates the 150th anniversary of the first printing of the Book of Mormon. Also tells how Joseph Smith stopped a local newspaper from printing parts of the Book of Mormon by using his copyrights that he had secured. [M.D.P.]

B.507 Buchmiller, Golden A. "Four-Section Chart Teaches World and Religious History in Unusual Way." CN 51 (7 November 1981): 13. A chart based on world and religio-historical events. Includes events and prophets from the Book of Mormon and the Pearl of Great Price. [M.D.P.]

B.508 Buchmiller, Golden A. "Grandin Building Opens to Visitors in Palmyra." CN 52 (30 October 1982): 3. Egbert Bratt Grandin, with whom Joseph Smith contracted to publish the Book of Mormon, was the owner of the Grandin Printing Building. A brief description of the present condition and history of the Grandin Building is given along with a history of the printing and publication of the 5,000 copies of the first edition of the Book of Mormon. [A.T.]

B.509 Buchmiller, Golden A. "An Original Book of Mormon Found." CN 52 (1 May 1982): 7. A story of how a missionary found and bought a first edition of the Book of Mormon. [M.D.P.]

B.510 Budge, W. "Appreciate the Book of Mormon." MS 42 (January 1880): 41-44. Describes the contents of the Book of Mormon and its translation and publication. [B.D.]

B.511 Budge, W. "A Marvelous Work." MS 41 (20 January 1879): 40-43. The promises and prophecies of the Book of Mormon made to the descendants of the ancient American inhabitants are being fulfilled. The descendants have accepted and rejoiced in the Book of Mormon, as was foretold in the book. The gathering of Israel is based upon faith, repentance, baptism, and the reception of the Holy Ghost. [J.W.M.]

B.512 Budvarson, Arthur. The Book of Mormon Examined. La Mesa, CA: Utah Christian Tract Society, 1959. A polemical work against the Book of Mormon. The Book of Mormon contradicts the Bible, and the testimonies of the Three Witnesses cannot be trusted. The Book of Mormon claims to have "the everlasting gospel" and yet many important Mormon doctrines are not found in the book. The Book of Mormon also contradicts many of Joseph Smith's own teachings and is completely unsupported by archaeological evidence. The Anthon incident is discussed. [M.R.] 
B.513 Budvarson, Arthur. The Book of Mormon-True or False? Grand Rapids, MI: Zondervan Publishing, 1961; Concord, CA: Pacific, 1967. A polemical work against the Book of Mormon. The testimonies of Book of Mormon witnesses cannot be trusted. Many changes have been made in the Book of Mormon since its first edition. The Book of Mormon contradicts the Bible and Joseph Smith's own teachings. [M.R.]

B.514 Budvarson, Arthur. A Rebuttal to 'The Problems of the Book of Mormon.' La Mesa, CA: Utah Christian Tract Society, 1966. A polemical work, Budvarson writes in response to Sidney B. Sperry's book The Problems of the Book of Mormon, in which Sperry criticizes Budvarson's booklet The Book of Mormon-True or False. This work is basically an extension of Budvarson's arguments set forth in his earlier work, The Book of Mormon-True of False? [B.D.]

B.515 Budvarson, Arthur. True Archaeological Data Versus Book of Mormon. La Mesa, CA: Utah Christian Tract Society, n.d. Polemically oriented tract dealing with Book of Mormon archaeology. Features correspondence between the Smithsonian Institute and an individual who is opposed to the Book of Mormon. [D.M.]

B.516 Buerger, David John. "Salvation in the Theology of Joseph Smith." In Line Upon Line: Essays on Mormon Doctrine, edited by Gary James Bergera, 159-69. Salt Lake City: Signature Books, 1989. The earliest Book of Mormon teachings did not reflect Calvinistic theology. At Sidney Rigdon's request Joseph Smith inquired of the Lord concerning high priests and learned that Nephi, son of Helaman, was granted power to seal in heaven as well an in earth. From this emerged the Calvinistic teaching of eternal salvation in conjunction with priesthood ritual and ordinances. [J.W.M.]

B.517 "Building a Ship." Friend 11 (March 1981): 20-21. A two-page full-color cartoon depiction that recalls Nephi building the ship to carry the family to the promised land (1 Nephi 17-18). [J.W.M.]

B.518 "Building the Ship." Friend 17 (October 1989): 40-41. Children's illustrated story about Nephi building the ship. [M.R.]

B.519 Bullock, Alonzo Mansfield. Mormonism and the Mormons: An Epitome. Menasha, WI: Breeze, 1898. A polemical tract against Mormonism. The author accepts the Spaulding theory of the Book of Mormon origins. [M.R.]

B.520 Bulseco, Albert C." 'Blue Book' Quenched Thirst for Truth." CN 58 (23 July 1988): 5. Author testifies of the great influence of the Book of Mormon on his personal life by claiming "no other literature made me weep as this book has. Neither has there been any influence that has touched my soul and marked a marvelous change in me." [R.H.B.]

B.521 Bunker, William E. "Promises of Old-Yet New." IE 47 (December 1944): 741. A collection of Book of Mormon scriptures that reiterate the promises of the Lord concerning the coming forth of the Book of Mormon. [J.W.M.]

B.522 Bunker, William E. "Some Facts Concerning America's Witness for Christ." IE 48 (September 1945): 500. A list of the fifteen books of the Book of Mormon and a chronological order of the Book of Mormon scribes, from Nephi to Moroni. [J.W.M.]

B.523 Burgess, Allan K. Living the Book of Mormon. Salt Lake City: Bookcraft, 1991. Sixty-one brief chapters discuss various sections of the Book of Mormon. Gospel application is the goal of the author. The author states, "When we immerse ourselves in the scriptures with the desire to apply what we learn, we receive a much deeper 
understanding and witness of the eternal truths found there than when we merely read to learn facts" (preface). This work is reviewed in S.432. [D.W.P.]

B.524 Burgess, Allan K., and Max H. Molgard. Fun For Family Night: Book of Mormon Edition. Salt Lake City: Bookcraft, 1990. Lessons and activities geared to the needs of children for family home evening. There are twenty lessons on Book of Mormon subjects and people. This work is reviewed in R.243. [J.W.M.]

B.525 Burgess, Allan, Max Jean, and Bette Molgard. A Child's Book of Mormon Activity Book. 3 vols. Salt Lake City: Bookcraft, 1987. A clever activity book for children in three volumes. A Book of Mormon story is retold, then games and puzzles follow to reinforce the story. [J.W.M.]

B.526 Burgess, J. M. The Book of Mormon Contradictory to Common Sense, Reason, and Revelation; or, The Mormon Hierarchy Founded Upon a Fiction. Liverpool: J. Blevin, 1850. A polemical work against the Book of Mormon. Deals with alleged internal inconsistencies within the Book of Mormon, contradictions with the Bible, absurdities of Nephite destruction of Christ's death, Jaredite barges, Christian teachings before Christ. [M.R.]

B.527 Burgess, S. A. "The Book of Mormon: A Brief Notation on Editions." SH 77 (26 March 1930): 369-71. Burgess discusses the different editions of the Book of Mormon, including items about when and where they were printed. [B.D.]

B.528 Burgess, S. A. "The Book of Mormon and Archaeology." SH 74 (27 July 1927): 862-63. Presents a list of works written on the subject of the Book of Mormon and archaeology. Much has been unearthed to prove Book of Mormon statements that were once in question. [J.W.M.]

B.529 Burgess, S. A. "The Book of Mormon and Archaeology." SH 74 (10 August 1927): 925-26. The Book of Mormon introduced many new ideas into the world, including its own language from which it was translated, the liahona or compass, and the existence of Christianity in America long before archaeology proved it to exist in America. [J.W.M.]

B.530 Burgess, S. A. "Book of Mormon and the Bible." SH 74 (6 July 1927): 775-77. The Book of Mormon fulfills prophecies found in Genesis, Isaiah, Hosea, Ezekiel, and Nahum. [J.W.M.]

B.531 Burgess, S. A. "The Book of Mormon and the Bible." SH (13 July 1927): 797-98. The Book of Mormon is a manifestation that God loves all people and an "added witness of the goodness of God" and his concern for all humanity. It was never intended that the Book of Mormon replace the Bible, as some contend. [J.W.M.]

B.532 Burgess, S. A. "Book of Mormon Archaeology." SH 86 (4 February 1939): 136, 142. Reports that there exist more than seventy-five editions of the Book of Mormon and several archaeological books that prove the authenticity of the book. [J.W.M.]

B.533 Burgess, S. A. "Book of Mormon Bibliography." SH 77 (2 April 1930): 397-98. A brief bibliography of books and tracts on the Book of Mormon. [B.D.]

B.534 Burgess, S. A. "The Book of Mormon Manuscripts." SH 81 (30 January 1934): 137-39, 146. Discusses various concepts regarding the two manuscripts of the Book of Mormon, including ownership, history, and significance. [J.W.M.] 
B.535 Burgess, S. A. "The Book of Mormon Plates." SH 74 (20 July 1927): 830-31. Discusses the ancient plates and records from which came the present Book of Mormon. These are (1) The brass plates of Laban, (2) the large plates of Nephi, (3) the small plates of Nephi, 4) the record of Zeniff, (5) the twenty-four gold plates or record of the Jaredites, (6) and the gold plates of the Book of Mormon. [J.W.M.]

B.536 Burgess, S. A. "The Book of Mormon: Summary." SH 74 (31 August 1927): 1012-13. The Lord has given many schoolmasters to bring people to Christ, including: the Old Testament, Confucius, Mohammed, and the Book of Mormon. The Book of Mormon fosters greater spiritual and mental growth. [J.W.M.]

B.537 Burgess, S. A. "The Coming Forth of the Book of Mormon." SH 74 (8 June 1927): 654-55. Presents a brief outline of Joseph Smith's life, an overview of the coming forth of the Book of Mormon, and Joseph's account of Moroni's visits in 1823. [J.W.M.]

B.538 Burgess, S. A. "Emma Smith and the New York Sun." SH 80 (12 September 1933): 1163-64. The authenticity of a letter purported to have been written by Emma Smith is called into question. Emma Smith denies the truthfulness of the letter and bears witness that at no time did she ever question Joseph Smith's divine calling or the divinity of the Book of Mormon that he translated. [J.W.M.]

B.539 Burgess, S. A. "Family of the Brother of Jared." Journal of History 18 (1925): 255-56. Argues that the LDS reading of the word "families" in Ether 1:16 is incorrect. The word "families" should be corrected, according to the original manuscript of the Book of Mormon, to read "family." The RLDS version of the Book of Mormon presents the correct reading. [B.D.]

B.540 Burgess, S. A. "The Plates of the Book of Mormon." SH 74 (15 June 1927): 691-92. Reviews the historical events dealing with the reception and translation of the gold plates by Joseph Smith. Joseph Smith was given great assistance from God to perform his prophetic work. [J.W.M.]

B.541 Burgess, S. A. "Various Editions of the Book of Mormon." SH 74 (22 June 1927): 719-21. The editions of the Book of Mormon include the original manuscript, the first edition, the Liverpool editions, the editions of the Reorganized Church, the Salt Lake editions, the Chicago and Independence editions, and translations into Welsh, French, German, Dutch, Danish, Swedish, Spanish, Italian, Hawaiian, Tahitian, and Japanese. [J.W.M.]

B.542 Burgess, S. A. "Where the Plates Were Found." SH 74 (3 August 1927): 893-94. Oliver Cowdery provides a description of the Hill Cumorah area where the gold plates were found and the sacred events that took place there. [J.W.M.]

B.543 Burgess, S. A. “Where Was the Book of Mormon Translated?” SH 88 (19 April 1941): 491-92. Sets forth the places where the Book of Mormon was translated, beginning in Harmony, Pennsylvania, to its completion in the home of Peter Whitmer, Sr. The role of Martin Harris and the lost 116 manuscript pages are also discussed. [J.W.M.]

B.544 Burgon, Glade L. "An Analysis of Style Variations in the Book of Mormon." M.A. thesis, Brigham Young University, 1958. Reviews the style, vocabulary, and unique characteristics of the various books within the Book of Mormon. Concludes that the books were authored by a number of writers rather than a single writer, Joseph Smith. [J.W.M.] 
B.545 Burgon, Glade L. "The Book of Mormon and the Charge: 'The Product of One Man of Mediocre Ability.' "IE 65 (January-February 1962): 44-48 108-9, 134-35. An apologetic work responding to claims that the Book of Mormon is the product of one man of mediocre ability. The author reports the finds of an analysis comparing the styles of different Book of Mormon writers and concludes that the different writers each have different styles. This supports Joseph Smith's claim that he translated the work. [B.D.]

B.546 Burgon, Glade L. The Tree of Life As a World Symbol of Divine Origin. Provo, UT: n.p., August 1959. Writes concerning the symbolical nature of the tree of life in Old and New World cultures. The Book of Mormon treatment of the tree of life (1 Nephi 11-15) clarifies and adds greater significance to the subject than does the Bible. [J.W.M.]

B.547 Burgon, Heber J. "Internal Evidences of the Book of Mormon." MS 67 (11 May 1905): 292-93. Cites the promise made in Moroni 10:4 that honest seekers may receive a spiritual witness of the truthfulness of the Book of Mormon. The testimonies of many thousands of converts bears witness to this truth. [R.H.B.]

B.548 Burnham, Leon. "The Book of Mormon and the Federal Soil Conservation Program." DN (27 February 1937): 3, 8. Compares the American Indian's agriculture, soil conservation, and the use of natural resources to that of modern days. [M.D.P.]

B.549 Burns, Dawson. Mormonism Explained and Exposed. London: Houlston and Stoneman, 1853. A polemical tract against Mormonism. The Book of Mormon abounds in anachronisms, such as the use of the compass in 600 B.C. The Book of Mormon witnesses only claimed to see the plates with their "spiritual eyes," therefore their testimony is of questionable value. The author asserts that the Spaulding theory best accounts for the origin of the Book of Mormon. [M.R.]

B.550 Burr, Brenda Hulse. "Home Evening Scripture Parties." Ensign 20 (April 1990): 73. One enjoyable way to approach Book of Mormon scripture reading with the family is given. [B.D.]

B.551 Burrell, Maurice C. "The Mormon Scriptures." In Burrel's Wide of the Truth: A Critical Assessment of the History, Doctrines and Practices of the Mormon Religion, 16-40. London: Marshall, Morgan, \& Scott, 1972. Pages 1640 of this polemical work deal with Mormon scripture, including the Book of Mormon. The author claims that the Book of Mormon has undergone numerous changes since its publication in 1830 and the testimony of Book of Mormon witnesses is of no value. Traditional Mormon usages of biblical prophecies to prove the need for the Book of Mormon are dismissed. While archaeologists have found abundant evidence for the Bible, there exists no archaeological evidence for the Book of Mormon. The book betrays a dependence upon View of the Hebrews and the Bible and plagiarizes much of the New Testament. It also attributes King James English to people living thousands of years ago. Theories regarding its origin are briefly reviewed. [M.R.]

B.552 Burrell, Maurice C. Mormonism. London: Church Book Room Press, 1961. A polemical work that sets forth claims against Mormonism and its doctrines. The account of the angel and his gold plates is of questionable authenticity since the plates themselves are not available for inspection. Charles Anthon denied the Mormon version of the Martin Harris incident, and Harris must have lied or exaggerated greatly. There is no archaeological evidence for the Book of Mormon. It attributes King James English to people who lived thousands of years ago, and moreover it attributes Christian ideas and phrases to people who lived long before Christ's coming in the flesh. The testimony of the Book of Mormon witnesses is also dismissed as worthless. [M.R.] 
B.553 Burton, Alma P. "Book of Mormon." In Burton's Doctrines From The Prophets: Choice Selections from Latter-day Leaders, 56-62. Salt Lake City: n.p., 1970. A compilation of quotes that shares the testimonies of Joseph Smith, Brigham Young, Heber J. Grant, and George Q. Cannon concerning the coming forth of the Book of Mormon, its purpose and power, its contents, and the heritage of America. Also contains Joseph Smith's own testimony concerning the literal translation of the title page. [J.W.M.]

B.554 Burton, Alma P. “The Natural Man ... An Enemy to God?” IE 68 (December 1965): 1094-95, 1182-83. King Benjamin stated that "the natural man is an enemy to God, and has been since the fall of Adam" (Mosiah 3:19). Brigham Young declared mankind God's noblest work, but when Adam and Eve fell from the presence of God they were brought into an unnatural state, in contact with influences of an evil nature. The "natural man" spoken of by King Benjamin is equivalent to President Young's "unnatural man." Both refer to mankind that has been estranged from God. [J.W.M.]

B.555 Burton, Robert H., and Vernon Proctor. "The Family-to-Family Book of Mormon Program." Ensign 17 (May 1987): 101-2. Participation in the family-to-family Book of Mormon program is an excellent way to help the missionary effort. [J.W.M.]

B.556 Burton, Theodore M. Untitled talk. CR 155 (October 1985): 80-83. Uses Alma 41:9-10 and 3 Nephi 18 to exhort the Saints to love and help a person who has transgressed come back into the Church. [B.D.]

B.557 Burton, Theodore M. "Wisdom and Learning of the World." CR (April 1961): 126-29. Describes the pitfalls of scholarship without righteousness and obedience. Utilizes the Book of Mormon teaching, "to be learned is good if they hearken unto the counsels of God." [R.C.D.]

B.558 Bush, Edna K. "And It Came to Pass." Dialogue 10 (Autumn 1977): 139-42. Analyzes the modern English edition of the Book of Mormon called the "reader's edition," published in 1966 by the RLDS church. [B.D.]

B.559 Bush, Edna K. "The Book of Mormon and My Conversion." Ensign 2 (June 1972): 28-31. A personal conversion account. Through the reading of the Book of Mormon, the author tells of the Spirit testifying of the truth of the book. [B.T.]

B.560 Bush, Edna K. Dissecting the Book of Mormon: A Fresh Approach to the Book of Mormon. St. Petersburg, FL: Edna K. Bush, 1968. A Book of Mormon classroom or Family Home Evening study aid, designed to help students reach a better understanding of the contents of the Book of Mormon. [L.D.]

B.561 Bush, Edna K. "Magnificent Messages." Instructor 102 (November 1967): 460. Gives references for several "choice passages" in the Book of Mormon, which include sermons, father-to-son talks, letters, missionary experiences, and visits of Jesus Christ. Accompanying chart details compilation of records that made up the plates given to Joseph Smith. [A.C.W.]

B.562 Bush, Edna K. Review of The Book of Mormon (RLDS). Dialogue 10 (Fall 1977): 139. Book review.

B.563 Bush, Lester E., Jr. "The Spaulding Theory Then and Now." Dialogue 10 (Autumn 1977): 40-69. A scholarly review of the Spaulding theory and its importance today. The author concludes that due to imprecise evidence, the Spaulding theory is not conclusive. Included are extensive notes and references on the subject. [B.D.] 
B.564 Bushman, Claudia. Review of The Book of Mormon Story, by Mary Pratt Parrish. Dialogue 2 (Spring 1967): 113. Book review.

B.565 Bushman, Richard L. "The Book of Mormon and the American Revolution." BYU Studies16 (Autumn 1976): 3-20. Also in Book of Mormon Authorship: New Light on Ancient Origins, edited by Noel B. Reynolds, 189-212. Provo, UT: Brigham Young University Religious Studies Center, 1982. Analyzes the statement that "the Book of Mormon can best be explained by [Joseph Smith's] responsiveness to the [political] provincial opinions of [his] time." Bushman looks at the political milieu of Joseph Smith's New York, the attitude of heroic resistance or divine deliverance, enlightenment and popular opposition to monarchy, the reign of the judges and American constitutional government. Bushman concludes that Book of Mormon politics are biblical and American politics are not; the Book of Mormon does not reflect American political attitudes of Joseph Smith's time. [B.D.]

B.566 Bushman, Richard L. "The Book of Mormon in Early Mormon History." In New Views of Mormon History: A Collection of Essays in Honor of Leonard J. Arrington, edited by Davis Bitton and Maureen Ursenbach Beecher, 3-18. Salt Lake City: University of Utah Press, 1987. Many scholars have concluded that magic "lay at the heart of nineteenth-century Mormonism," but they overlook the role that the Book of Mormon played in the attitudes of the early Church. Bushman proposes to analyze broad themes in the Book of Mormon and consider how they affected the early Church. Also explains how prominent the theme of record keeping is in the Book of Mormon, and the manner in which whole societies lived, perished, and were restored based on record keeping. The importance of records and their translation greatly affected the Church, especially Joseph Smith who was constantly occupied with translating records. [B.D.]

B.567 Bushman, Richard L. "Faithful History." In Faithful History: Essays on Writing Mormon History, edited by George D. Smith, 1-17. Salt Lake City: Signature Books, 1992. Written histories change as historical methods and new evidence is uncovered; Mormon history is consistent with this. Mormon historians may obtain insights into the nature of history from the Book of Mormon. It offers clues of what are appropriate concerns for Mormon historians - the tension between humanity and God, the Church and the world, and economic forces. The eyes of those who love God see the effects of revelation, providential direction, and inspiration on history. [J.W.M.]

B.568 Bushman, Richard L. Joseph Smith and the Beginnings of Mormonism. Chicago, IL: University of Illinois Press, 1984. Explains the history of Joseph Smith's family, the first vision, and the translation of the Book of Mormon. Provides details about the restoration of the gospel and early Mormon teachings relating to revivalist churches, such as the Cambellites. This work is reviewed in J.100 and in W.014. [L.D.]

B.569 Bushman, Richard L. "Joseph Smith in the Current Age." In Joseph Smith: The Prophet, The Man, edited by Susan Easton Black and Charles D. Tate Jr., 33-48. Provo, UT: Brigham Young University Religious Studies Center, 1993. The writings of the Book of Mormon prophets were concerned deeply with the rise and fall of nations as well as public and private morality. Such ideas from the book and subsequent revelations aided Joseph Smith in outlining a new organizational pattern that ultimately led to the desire to build Zion. It is the vision of Moroni, the concept of a miraculous translation of the Book of Mormon, and continuing revelation that makes it so hard for rational, educated people of our day to accept the gospel. [J.W.M.]

B.570 Bushman, Richard L. "The Lamanite View of Book of Mormon History." In By Study and Also by Faith, edited by John M. Lundquist and Stephen D. Ricks, 2:52-72. Salt Lake City: Deseret Book and FARMS, 1990. Considers the Book of Mormon story from the standpoint of the Lamanites and other people who dissented from the Nephites. The continual Lamanite complaints, beginning with Laman and Lemuel, were that the government 
power and rule belonged to them. The angry Lamanites and Nephite dissenters were consistently at war with the Nephites to subject them, to enslave them, to force them away from their belief in Christ and his gospel, and to destroy them. This militant, complaining, and forceful manner that led to deprivation is contrasted with the submissive, righteous, and faithful response of the Nephites that led them to prosperity and happiness. [A.A.]

B.571 Butler, Jon. "Toward the Antebellum Spiritual Hothouse." In Awash in a Sea of Faith: Christianizing the American People, 225-56. Cambridge, MA: Harvard University Press, 1990. Devotes part of the chapter to Joseph Smith and the Book of Mormon. Believes that the Book of Mormon reflects American religious tradition, and singles out New England evangelicalism yet perceives some uniqueness: 'The Book of Mormon offered American readers a wholly fresh, wholly novel, and-most important-wholly innocent new scripture. In it there were no theological schools and no theological wrangling. A new Mormon revelation made possible the recovery of ancient spiritual truth that had been hobbled by the corruptions of time and imperfect Christian practice." [D.M.]

B.572 Butler, Margot J. "Women in the Book of Mormon." In The Sixth Annual Church Educational System Religious Educators' Symposium on the Book of Mormon, 9-12. Salt Lake City: Church of Jesus Christ of Latter-day Saints, CES, 1982. Lists every woman mentioned in the Book of Mormon and provides a thought or note that might assist instructors when teaching about each woman. [A.T.]

B.573 Butterworth, F. E. How to Mark the Book of Mormon, a Packet of Missionary Insert Materials with Instructions. Independence, MO: Herald House, 1973. Presents a method of marking the Book of Mormon by linking certain subjects together. Includes missionary inserts to be glued to the pages of the Book of Mormon where the subject is marked. [B.D.]

B.574 Butterworth, F. E. "Jaredite arges." Witness 21 (Spring 1992): 3. Reprinted from Butterworth's Pilgrims of the Pacific. Independence, MO: Herald House, 1974. Two photographs and a diagram offer explanations of a possible design for Jaredite barges. [A.C.W.]

B.575 Butterworth, F. E. "Marking the 'Book of Mormon' for Missionary Use." In Guide-Lines to Leadership. N.p., n.d. A method to mark the Book of Mormon for missionaries, designed to be glued into Book of Mormon pages. [J.W.M.]

B.576 Butterworth, F. E. Pilgrims of the Pacific. Independence, MO: Herald House, 1974. Discusses relations between the Jaredites and Polynesians, the story of Hagoth, and the route of Lehi out of Jerusalem. [B.D.]

B.577 Butterworth, F. E. The Sword of Laban. 4 vols. Independence, MO: Herald House, 1969, [R]1972. A fictional narrative written especially for youth. The story of the exodus of Lehi and his company from Jerusalem is told to Moroni by his father, Mormon, during the final battle between the Nephites and Lamanites. [J.W.M.] 
C.001 C., J. E. "Dr. Duncan and the Book of Mormon." MS 52 (1 September 1890): 552-56. A defense of the Book of Mormon against the criticism of Dr. Duncan in the Islington Gazette of August 18th. Dr. Duncan, evidently a literary critic, concluded that the Book of Mormon was either a clumsy or barefaced forgery or a pious fraud. The author writes that the Book of Mormon makes clear many doctrines that are difficult to understand in the Bible. Also, the history and gospel taught by the Bible and the Book of Mormon are similar because both were inspired of God. [B. D.]

C.002 C., M. J. "Mormonism." Plainsville Telegraph (March 3, 1831): 4. Tells of the conversion of Sidney Rigdon who read the Book of Mormon and "partly condemned it" but after two days accepted it as truthful. He asked for a sign though he knew it was wrong and saw the devil appearing as an angel of light. The author of this article warns against the Book of Mormon and against the deception of the Mormons. [J.W.M.]

C.003 Cadman, Sadie B., and Sara Cadman Vancik. A Concordance of the Book of Mormon. Monongahela, PA: Church of Jesus Christ, 1986. A complete but not exhaustive concordance, listing words al phabetically. Contains also a historical chronology of the events in the Book of Mormon. [D.W.P.]

C.004 Caine, Frederick Augustus. Morumon Kei To Wa Nanzo Ya? Tokyo: Church of Jesus Christ of Latter-day Saints, 1909. A two-page tract. English title is "What is the Book of Mormon?" [D.W.P.]

C.005 Cake, Lu B. Peepstone Joe and the Peck Manuscript. New York: L. B. Cake, 1899. A polemical work against Mormonism. The author enumerates various criticisms of the Book of Mormon related to domesticated animals, the Spaulding theory, contradictions with the Bible, King James English, the Hebrew/Egyptian background, and the testimony of Book of Mormon witness. [M.R.]

C.006 Calder, Graydon K. A Brief Preview of the Book of Mormon. Australian Mission: Reorganized Church of Jesus Christ of Latter Day Saints, n.d. A summary of the contents of the Book of Mormon, with some explanatory notes. The work explains the structure and historical background of the Book of Mormon to the unfamiliar reader. [B.D.]

C.007 Caldwell, C. Max. "A Mighty Change." In The Book of Mormon: Alma, The Testimony of the Word, edited by Monte S. Nyman and Charles D. Tate Jr., 27-46. Provo, UT: Brigham Young University Religious Studies Center, 1992. Alma reminds the people of Zarahemla of their recent physical and spiritual captivity and reviews how the devil is able to forge the chains of hell and make them captive. Truth, which brings freedom and a "mighty change" in the hearts of individuals, is available through scripture, living prophets, and the Holy Ghost. [N.K.Y.]

C.008 Caldwell, C. Max. "What Think Ye of Christ?" Ensign 14 (February 1984): 18-22. How one perceives Christ will determine one's attitude toward God's commandments, Church leaders, and life's obstacles. Trials and tribulations may become "stepping-stones or stumbling blocks," depending on how the Atonement of Jesus is received by an individual. [S.P.S.]

C.009 Calhoon, W. R. "The Book of Mormon." SH 31 (13 December 1884): 801-2. Personal testimony of the importance of the Book of Mormon. Includes a 12-stanza poem by Sr. Randall concerning "the precious boon" of the Book of Mormon. Exhorts RLDS people to "repent and remember the new covenant, even the Book of Mormon." [A.C.W.] 
C.010 Call, Gail. "Antenantiosis in the Book of Mormon." In Reexploring the Book of Mormon, edited by John W. Welch, 96-97. Salt Lake City: Deseret Book and FARMS, 1992. Antenantiosis states a proposition in terms of its opposite. The figure of speech is used in Jacob 4:8 as "despise not the revelations of God," and Mormon 9:29, "if ye do this and endure to the end, ye will in nowise be cast out," and in several other places. The technique, used also in the Old Testament, is an effective teaching tool. [N.K.Y.]

C.011 Call, Lamoni. Anti-Mormon Queries. Bountiful, UT: n.p., 1900. A four-page polemical tract asking questions about the Urim and Thummim, the translation processes, and the changes in the Book of Mormon. [D.M.]

C.012 Call, Lamoni. 2000 Changes in the Book of Mormon. Bountiful: Lamoni Call (reprint by Modern Microfilm: Salt Lake City), 1898. A polemical work against the Book of Mormon. The author assumes a letter perfect and grammar perfect translation of the Book of Mormon through the Urim and Thummim. He therefore presents over 2000 changes in the text of the Book of Mormon since the 1830 edition and concludes that Joseph Smith was therefore uninspired. [M.R.]

C.013 Callis, Charles A. "Book of Mormon Prophecies Fulfilled." DN (28 August 1943): 7-8. Text of radio address that details the numerous prophecies from the Book of Mormon that have since been fulfilled, including Nephi's prophecies about the Gentiles and the gospel, the existence of latter-day believers who will receive the Holy Ghost and endure martyrdom, and the birth of Jesus Christ. "Confirmed by completion," these prophecies are evidence of the truthfulness of the Book of Mormon. [A.C.W.]

C.014 Callis, Charles A. "The Coming Forth of the Book of Mormon." DN Church Section (25 September 1943): 11, 12. On September 21, 1823, an angel of God announced that records of an ancient American people taught by the Savior were to come forth. The inspired records would bring the fulness of the gospel to the house of Israel and to the Gentiles and add a second witness to the Bible. [J.W.M.]

C.015 Callis, Charles A. Fundamentals of Religion: A Series of Radio Addresses. Independence, MO: Zion's Printing and Publishing, 1945. Includes two addresses about the Book of Mormon: "Book of Mormon Prophecies Fulfilled," pages 102-13, sets forth many prophecies of the Book of Mormon that have been fulfilled; and "The Coming Forth of the Book of Mormon," pages 155-70, shows that the Book of Mormon came forth at a time of spiritual unrest and higher criticism of the Bible. Includes a short narrative of the angel Moroni's visit, the delivering of the gold plates to Joseph Smith, and provides six purposes for which the Book of Mormon was written. [J.W.M.]

C.016 Callis, Charles A. "Power of the Book of Mormon." DN Church Section (24 June 1939): 2, 7. In keeping with the Lord's promises in the Book of Mormon that the land of America should be free from monarchical forms of government and slavery, the U.S. government has adopted many policies to protect America and fulfill the prophecy that it would be a "choice land above all others" (1 Nephi 13:30). Two inspired measures that assist in the preservation of America are the Constitution and the Monroe Doctrine. [J.W.M.]

C.017 Callis, Charles A. "Testimony from the Book of Mormon." IE 49 (November 1946): 700, 717. Presents his testimony of the truthfulness of the Book of Mormon. [L.D.]

C.018 Callis, Charles A. Untitled talk. CR (October 1911): 87-89. The Book of Mormon came forth to establish the truthfulness of the Bible and to declare the divinity of Jesus Christ. Joseph Smith brought forth the Book of Mormon and subsequently suffered persecution similar to the manner in which Wycliffe and Tyndall were persecuted as they made the Bible available. [J.W.M.] 
C.019 Callis, Charles A. Untitled talk. CR (October 1916): 93-96. Burial mounds in the Southern United States prompt questions concerning the identity of the people who are buried there. The Book of Mormon may shed light on such questions. The warning issued by the Lord to the ancients and to those of the present day are to follow Jesus, experience a spiritual rebirth, and practice faith, repentance, and humility as recorded in Alma 32. [J.W.M.]

C.020 Callis, Charles A. Untitled talk. CR (October 1937): 120-23. The richest hills on earth have not brought forth gold and silver in great amounts, but have brought forth the greatest spiritual wealth. They are Calvary in Jerusalem where the Savior wrought the Atonement and the Hill Cumorah that brought forth the truth of the Savior's marvelous ministry to his people in America. Like the Bible, the Book of Mormon testifies of Christ and reveals the great destiny of America. [J.W.M.]

C.021 Callis, Charles A. "Vest Pocket Notes on the Book of Mormon." DN Church Section (24 April, 1, 8, 22 May 1937): 3, 2, 2, 2. Announces the number of languages into which the Book of Mormon has been translated, summarizes the book's contents, and discusses its prophecies concerning the United States. [M.D.P.]

C.022 Campbell, Alexander. "Delusions: An Analysis of the Book of Mormon." Millennial Harbinger 2 (7 February 1831): 85-96. Reprinted as Delusions: An Analysis of the Book of Mormon. Pamphlet. Boston: Green, 1832. An early attempt to identify specific problems with the Book of Mormon. Various anachronisms, absurdities and contradictions with the Bible are identified. The Book of Mormon shows evidence of being a mere product of its environment. [M.R.]

C.023 Campbell, Alexander. "The Mormon Bible." The Millennial Harbinger 3 (June 1839): 265-68. Rejects the Book of Mormon as an inspired book claiming that it was a "superstition so gross as that which must have characterized the founders of this pretended religious sect." Accepts the Spaulding theory. [M.R.]

C.024 Campbell, Alexander. Mormonism Weighed in the Balances and Found Wanting: Being an Analysis of the Internal and External Evidences of the Book of Mormon. London: Arthur Hall, Virtue, 1849. Associates Joseph Smith with false Jewish messiahs and Christian impostors. Gives an overview of the Book of Mormon, claiming the presence of several anachronisms. Calls the Book of Mormon a "romance." Says the Nephites believed in the doctrines of the Calvinists and Methodists. Makes negative comments about Lehi and Mormon. Argues that if the Bible was of God, the Book of Mormon could not have had the same author. Takes issue with the testimony of the Three Witnesses. [D.M.]

C.025 Campbell, Lester E. Scripture Index of FARMS Reprints and Preliminary Reports. Provo, UT: FARMS, 1987. "This index lists scriptures used in FARMS papers up to early 1987. It is organized according to the subject categories in the FARMS catalog" as follows: (1) The Book of Mormon and the Ancient Near East, (2) The Book of Mormon and Ancient Mesoamerica, (3) The Book of Mormon-commentary, (4) other scriptural studies and materials. [B.D.]

C.026 "Can the Book of Mormon Be Trusted?" Utah Christian Tract Society 13 (May-June 1982): 2. Inasmuch as the 1981 edition of the Book of Mormon changes the phrase "white and delightsome" (2 Nephi 30:6) to read "pure and delightsome" (having reference to the Lamanites), the Book of Mormon is not to be trusted. [D.M.]

C.027 Canney, Maurice E. "The Book of Mormon." In An Encyclopedia of Religions, edited by Maurice E. Canney, 248. London: George Routledge, 1921. An encyclopedic entry states that the Mormons believe that the Book of Mormon is sacred and divinely inspired, and that it was translated by Joseph Smith by the use of the Urim and Thummim. [J.W.M.] 
C.028 Cannon, Abraham H. Book of Mormon Catechism: Questions and Answers on the Book of Mormon. Salt Lake City: Juvenile Instructor Office, 1886. The work was created to "induce the young people of Zion to search with greater diligence for the valuable truths contained in the revelation so ancient and modern times." Contains 62 pages of basic questions and answers about the Book of Mormon. [A.T.]

C.029 Cannon, Elizabeth Rachel. The Cities of the Sun: Stories of Ancient America Founded on Historical Incidents in the Book of Mormon. Salt Lake City: Deseret News, 1911. Fictionalized accounts designed for youth based on historical incidents in the Book of Mormon. Stories deal with the Gadiantons, General Moroni, Ammon's mission to the Lamanites, and the ships of Hagoth. [B.D.]

C.030 Cannon, Elizabeth Rachel. "The Gadiantons." IE 14 (August 1911): 862-72. A fictional account of the Gadianton robbers based on the story in the Book of Mormon. Author uses actual characters such as Cezoram, Hagoth, and Seantum. [L.D.]

C.031 Cannon, George Q. "The Abundant Testimonies to the Work of God." JD 22:252-59. Liverpool, England: Church of Jesus Christ of Latter-day Saints, 18 September, 1881. God has sent a number of witnesses who have testified concerning the truthfulness of the Book of Mormon, including the Three Witnesses, the Eight Witnesses, and Joseph Smith. The convincibility of the book also lies in its prophecies. For instance, the Book of Mormon prophesies concerning the persecution of the saints and others and also prophesies that the Indians will "become an enlightened people and be redeemed from their present condition." [B.D.]

C.032 Cannon, George Q. "Book of Mormon Geography." Instructor 73 (April 1938): 159-60. Voices strong objection to the introduction and circulation of maps that attempt to depict the geography of the Book of Mormon. Cannon raises doubts as to the authenticity of a piece entitled the "Route Traveled by Lehi and His Company" that places the landing site of Lehi's party in Chili. [R.H.B.]

C.033 Cannon, George Q. "The Book of Mormon Geography." Juvenile Instructor 25 (1 January 1890): 18-19. Contention over Book of Mormon geography is detrimental to the cause of truth. The reason for this contention is due to the fact that the Book of Mormon is not a geographical primer meant to teach geographical truths. The drawing of Book of Mormon maps is discouraged. [J.W.M.]

C.034 Cannon, George Q. "Book of Mormon Prophecies Fulfilled." JD 25:119-29. Liverpool, England: Church of Jesus Christ of Latter-day Saints, 6 April 1884. Analyzes Book of Mormon prophecies found in 2 Nephi 29, 30, and 3 Nephi 16 that had been fulfilled and emphasizes the divine origin of the book, the purity of its translation, and the great effect it would have on many nations and peoples. Also teaches that the gospel would be carried to the remnant of Lehi and that the Bible and the Book of Mormon would be united to confound false doctrine. [J.W.M.]

C.035 Cannon, George Q. Book of Mormon Stories, Adapted to the Capacity of Young Children and Designed for Use in Sabbath Schools, Primary Association, and for Home Readings. Salt Lake City: George Q. Cannon and Sons Co., 189299. "Written for the purpose of presenting the Book of Mormon narrative in language that can be understood by small children." Contains illustrations. [B.D.]

C.036 Cannon, George Q. "The Book of Mormon Witnesses-Answers to Questions." Juvenile Instructor 26 (1 September 1891): 534. Offers an explanation why eight of the eleven witnesses were members of two families. [J.W.M.] 
C.037 Cannon, George Q. "Discourse by President George Q. Cannon." JD 25:119-29. Liverpool, England: Church of Jesus Christ of Latter-day Saints, 16 April 1884. Discusses the predictions of the Book of Mormon, some evidences of its divinity, and points out the plainness of its teachings. [L.D.]

C.038 Cannon, George Q. "Editorial Thoughts." Juvenile Instructor 3 (1 January 1868): 4. A didactic editorial lauding Nephi's obedience and recommending imitation by the youth of the Church. [D.M.]

C.039 Cannon, George Q. "Editorial Thoughts." Juvenile Instructor 3 (1 June 1868): 84. Asserts that the inhabitants discovered by the Europeans in America are descendants of Laman and Lemuel. The Book of Mormon peoples lived principally in Central and South America. LDS church members should recognize the important role of the Indians among the Gentiles. [D.M.]

C.040 Cannon, George Q. "Editorial Thoughts." Juvenile Instructor 7 (23 November 1872): 188. Describes a disease called epizootic, which killed many horses in the Eastern states. The Book of Mormon (3 Nephi 21:14) "foretells a time when, if the people would not repent, the Lord would destroy their horses." Author the asks "who can say that the epizootic has no connection with that threat of divine displeasure?" [B.D.]

C.041 Cannon, George Q. "Editorial Thoughts." Juvenile Instructor 10 (11 December 1875): 294-95. Discusses Korihor and refutes his anti-Christ methods and doctrines. Relates and compares anti-Christ teachings to American popular opinion, concluding that Satan has not changed his tactics through the centuries. [A.C.W.]

C.042 Cannon, George Q. "Editorial Thoughts." Juvenile Instructor 11 (1 February 1876): 30. Didactic essay, showing how the Ammonite striplings or sons of Helaman are examples of childhood training that might well be exemplified in LDS homes. [D.M.]

C.043 Cannon, George Q. "Editorial Thoughts." Juvenile Instructor 11 (1 March 1876): 54-55. Editorial reflections on the Book of Mormon concepts of America as the choicest of lands and the necessity for righteousness for its inhabitants. Discusses secret combinations. [D.M.]

C.044 Cannon, George Q. "Editorial Thoughts." Juvenile Instructor 11 (15 August 1876): 186. The hostile attitude of the Americans towards the Indians is a remarkable fulfillment of Book of Mormon prophecy. LDS chruch members should consider the glorious future of the Lamanites. [D.M.]

C.045 Cannon, George Q. "Editorial Thoughts." Juvenile Instructor 13 (1 July 1878): 150. Refers to the dangerous and unstable secret societies that are located throughout Europe and America and relates them to the secret combinations spoken of by Moroni. [D.M.]

C.046 Cannon, George Q. "Editorial Thoughts." Juvenile Instructor 14 (October 1879): 222. Cannon reports that a German scholar, Professor Rudolph, noted striking resemblances between the leading Semitic languages (Arabic and Hebrew) and the Aymara language, belonging to the Incas in Peru. Cannon suggests that a reading of the Book of Mormon would enlighten the professor. [D.M.]

C.047 Cannon, George Q. "Editorial Thoughts." Juvenile Instructor 16 (1 May 1881): 102. Civilized manners were not taught to the Lamanaites by Laman and Lemuel, and the Lamanites existed in a degenerate condition. On the other hand, due to the instructions of Nephi, the Nephites existed in a more civilized condition. [D.M.] 
C.048 Cannon, George Q. "Editorial Thoughts." Juvenile Instructor 17 (1 April 1882): 104. All churches except the Church of Jesus Christ of Latter-day Saints are part of the great and abominable church that was prophesied by Nephi. They will fight against the true church and will fall into the pit that they prepared for the people of the Lord. [B.D.]

C.049 Cannon, George Q. "Editorial Thoughts." Juvenile Instructor 18 (1 February 1883): 40. When the Book of Mormon was published it was assumed that the American Indians were headed for extinction, but the Book of Mormon predicted that they would become a mighty people. This prophecy will yet be fulfilled. [D.M.]

C.050 Cannon, George Q. "The Future Fate of the Red Man." In Cannon's Writings From The "Western Standard," 269-73. Liverpool: George Q. Cannon, 1864. While most of the original inhabitants of America were destroyed in warfare, the Book of Mormon contains promises made to them that will be fulfilled with their descendants, the American Indians. The Indians will not always be treated as an inferior people nor will God allow them to be exterminated. It would be of benefit for nations today to embrace the American Indians and care for their needs. [J.W.M.]

C.051 Cannon, George Q. "The Indians: Death of Lehi." Juvenile Instructor 1 (1 June 1866): 43. Recounts sundry aspects of the Book of Mormon, including an evaluation of the disposition of the Lamanites as opposed to the Nephites. [D.M.]

C.052 Cannon, George Q. Life of Joseph Smith, the Prophet. Salt Lake City: Juvenile Instructor Office, 1888, [R] Deseret Book, 1907, 1964, 1972, 1986, 1989. A book written for youth that presents faith promoting historical events. Gives the events that led from Moroni's first visit to the publication of the Book of Mormon. [B.D.]

C.053 Cannon, George Q. The Life of Nephi, Son of Lehi, Who Emigrated from Jerusalem, in Judea to the Land Which is Now Known as South America, about Six Centuries before the Coming of the Savior. Salt Lake City: Juvenile Instructor Office, 1883. A biography of Nephi, in which the author narrates Nephi's story by adding personal insights and scholarly insights. [A.T.]

C.054 Cannon, George Quayle. "A Marvelous Work." In Cannon's Writings From The "Western Standard." Liverpool: George Q. Cannon, 1864, 117-119. The Book of Mormon is a great and marvelous work that was brought forth by an angel and translated by Joseph Smith. Left without excuse, this generation will know that the Book of Mormon is an inspired record. [J.W.M.]

C.055 Cannon, George Q. "Nephi's Character." Contributor 13 (April 1892): 289-90. The character of Nephi is exemplified by his many accomplishments, skills, and relationships. He was a leader, son, and brother who possessed great love and inspired others. He was a craftsman and hunter who showed ingenuity, industry, and good sense. [J.W.M.]

C.056 Cannon, George Q. "Prophecies and Truth of the Book of Mormon." Juvenile Instructor10 (23 January 1875): 16-17. Points out that plain and precious truths lost from the Bible are included in the Book of Mormon, specifically truths concerning the mortal ministry of Jesus Christ. Quotes the teachings of Nephi and King Benjamin regarding the Messiah's earthly advent. [A.C.W.]

C.057 Cannon, George Q. "A Remarkable Coincidence." MS 52 (13 October 1890): 641-42. Lehi, in his final farewell to his family, stated that he "must soon lay down in the cold and silent grave, from whence no traveler can return" (2 Nephi 1:14). Inasmuch as similar words appear in the writings of William Shakespeare, Church critics 
believe that Joseph Smith borrowed the Book of Mormon statement from Shakespeare. However, in the ruins of Mexico similar words have been found to have been used in an ancient funeral speech. [J.W.M.]

C.058 Cannon, George Q. "Secret Combinations." In Collected Discourses Delivered by President Wilford Woodruff, His Two Counselors, the Twelve Apostles, and Others (1894-1896), edited by Brian H. Stuy, 4:18-25. Burbank, CA: B. H. S. Publishing, 1991. The Book of Mormon warns against secret combinations (Ether 8:19-26). Such a warning is relevant in an era of communism, nihilism, and anarchism. Therefore, Church members are advised to avoid all secret societies. [J.W.M.]

C.059 Cannon, George Q. "The Standard Works. Our Scriptures." In Gospel Truth: Discourses and Writings of President George Q. Cannon, vol. 2, edited by Jerald L. Newquist, 246-62. Salt Lake City: Deseret Book, 1974. The Book of Mormon contains much internal evidence coupled with the power and Spirit of God so that readers may know of its divine authenticity. Those who reject the book will find that neither external evidences nor the testimonies of witnesses will satisfy them. [J.W.M.]

C.060 Cannon, George Q. "Topics of the Times." Juvenile Instructor 19 (1 April 1884): 106-8. Speaks concerning Martin Harris's visit with Professor Anthon and David Whitmer as one of the witnesses of the gold plates. [A.C.W.]

C.061 Cannon, George Q. "Visit to the Land and Hill of Cumorah." Juvenile Instructor 8 (5 July 1873): 108-9. After making a visit to the Hill Cumorah, located near Palmyra, the author presents a description of the hill, and considers the destruction of two Book of Mormon peoples at the site. [D.M.]

C.062 Cannon, George Q. "Who Are the Indians?" Juvenile Instructor 1 (1, 15 January, 1, 15 February, 1 April, 1 June 1866): 1, 2, 12, 15, 28, 43. Believes that "all the Indians in North and South America, and the inhabitants of some of the islands in the Pacific Ocean, are descendants of [the Lehite] family, who came away from Jerusalem about 2,400 years" ago. [D.M.]

C.063 Cannon, Lucy Grant. "You, Too, Have Freedom of Choice." Instructor 98 (June 1963): 225. President Heber J. Grant, hoping to help his wayward brother Brigham, prayed, then opened the Book of Mormon hoping for the answer to his brother's plight. The book fell open to Alma 36, a chapter of hope. When Brigham read the words of consolation and faith, his life was changed. [J.W.M.]

C.064 Cannon, M. Hamlin. "Contemporary Views of Mormon Origins: (1830)." Mississippi Valley Historical Review 31 (September 1944): 261-66. Discusses a number of early views of the Mormon religion. E. D. Howe's Mormonism Unveiled (1834) was not the first piece of literary criticism against the Mormons as generally assumed. Editor Obadiah Dogberry, of the freethinking newspaper the Reflector, wrote on the Mormons before and after the official establishment of the Church (April 6, 1830) and the publication of the Book of Mormon (March, 1830). [B.D.]

C.065 Caras, Clark H. "Naive to deny pre-Columbian navigators." CN 55 (6 October 1985): 7. Points out that there were major contacts between the American continent and Asia, European, and Mediterranean peoples before Columbus. [J.W.M.]

C.066 Card, Orson Scott. "The Book of Mormon-Artifact or Artifice?" In Card's A Storyteller in Zion, 13-48. Bookcraft: Salt Lake City, 1993. The translator's influence is apparent in a text because of his/her choice of words. The Book of Mormon is no different. Compares Joseph Smith to fiction writer James Macpherson who fraudulently claimed to have translated ancient Celtic poetry. The fraudulent author will inadvertently give himself 
away by his cultural perspectives that cannot be viewed out of context. Joseph Smith was not the author of the book but merely the translator. [J.W.M.]

C.067 Card, Orson Scott. "Dissent and Treason." Ensign 7 (September 1977): 53-58. Examines nine accounts of dissent in the Book of Mormon and determines why they failed. He shows that unrighteous, selfish desires for gain were the chief motivating factors among the dissenters. The unselfish desire to protect freedom and God was always successful in defending against the dissenters. [B.D.]

C.068 Card, Orson Scott. Folk of the Fringe. West Bloomfield, MI: Phantasia, 1989. Takes Book of Mormon prophecies and weaves a science fiction story of their fulfillment. [E.G.]

C.069 Card, Orson Scott. Tales of Alvin Maker. 3 vols. New York: TOR, 1987-89. A science fiction story that tells of the rise of a prophet with all the characteristics of Joseph Smith. [E.G.]

C.070 Card, Orson Scott. "Three Kings and a Captain: Nephite Leaders in the Land of Nephi." Ensign 7 (January 1977): 76-82. The land of Nephi produced many notable leaders including Alma, Abinadi, Zeniff, Noah, Limhi, and Gideon as recorded in the books of Omni and Mosiah. Righteous Zeniff stood in antithesis to the evil king Noah. Gideon was a righteous defender of the faith throughout his life, finally dying by the sword in defending the gospel against Nehor. [B.D.]

C.071 Cardall, Duane V. The Day of the Lamanite. Salt Lake City: University of Utah Institute of Religion, 1 April 1977. Shows how Book of Mormon prophecies concerning the Lamanites are beginning to be fulfilled. [D.M.]

C.072 Cardon, Joseph E., and Samuel O. Bennion, comps. Testimonies of the Divinity of the Church of Jesus Christ of Latter-day Saints by Its Leaders. Independence, MO: Zion's Printing and Publishing, 1930. Contains testimonies of leaders of the LDS church concerning the Book of Mormon as well as other topics. Included are Joseph Smith and his family members and close associates, the witnesses to the Book of Mormon, and those involved in the translation and publication of the Book of Mormon. [J.W.M.]

C.073 Carlisle, J. E. "Corroborating the Book of Mormon." MS 52 (17 May 1890): 312-14. Argues that archaeological evidences that predate Columbus indicate that two distinct races once inhabited the Americas. This and other findings corroborate the truthfulness of the Book of Mormon. [J.W.M.]

C.074 Carlisle, J. E. "A Modern Miracle." MS 52 (September 1890): 584-85. Author believes that it is as foolish to try to disprove the Book of Mormon as it is the Bible, for both works are built upon revelation. There are, however, many who refuse to accept the teachings of both scriptures. [J.W.M.]

C.075 Carlsen, Earl W. Christ's Answer to the Atheist, to the Jew: Who Wrote It? Amherst, WI: Palmer, 1987. The Bible and its followers do not provide adequate proof that God exists or that Christ is his Son. The Book of Mormon does provides that proof and testifies of the divinity of Christ. The author presents 52 evidences that support the authenticity of the Book of Mormon, including the use of chiasmus, engraved metal plates, cultural similarities between the ancient Near East and ancient Mesoamerican culture, and word-print analyses. This work is reviewed in H.352. [B.D.]

C.076 Carlson, A. Edward, Jr. "Isn't the Bible Enough?" Ensign 16 (March 1986): 54-55. Recounts the conversion story of an individual who believed that the Bible was the only scripture needed by mankind. He read and prayed 
about the Book of Mormon, and after reading 2 Nephi 29:6-8, he was convinced that the Book of Mormon represented an additional scripture that came from God. [J.W.M.]

C.077 Carmack, John K. The Book of Mormon Witnesses. Salt Lake City: University of Utah Institute of Religion, 24 October 1986. Chronicles the experiences of the Book of Mormon witnesses and reviews their tenacious testimonies. [D.M.]

C.078 Carmer, Carl. The Farm Boy and the Angel. Garden City, NY: Doubleday, 1970. Chapters 1-7 of this work deal with the Book of Mormon. Discusses the coming forth of the Book of Mormon and points out the secretive nature under which the book came forth. Believes that Joseph Smith was ill-prepared for such a work and was given to grandiose imaginations. This work is reviewed in A.161. [J.W.M.]

C.079 Carmichael, Max. "The Book of Mormon in Our Church Program." SH 67 (9 February 1921): 129-30. Criticisms against the Book of Mormon's style and lack of unity does not mean that the book does not contain spiritual material. Its plainness and doctrinal content excels the Bible and should have an equal place with the Bible on the pulpit. Its most important purpose is to be a missionary tool. [J.W.M.]

C.080 Carpenter, Claude I. "The Faith and Belief of the Gospel." In Message of the Book of Mormon/Gospel Quarterly, edited by Charles B. Woodstock, 1-64. Independence, MO: Herald House, 1932. Thirteen Sunday School lessons for members of the RLDS church dealing with philosophical and theological issues of the Book of Mormon. Discusses the plan of salvation, the fall of man, the trinity, and the gathering of Israel. [B.D.]

C.081 Carpenter, Claude I. An Outline of the Book of Mormon. Independence, MO: Reorganized Church of Jesus Christ of Latter Day Saints, 1903, 1981. In outline form, this work discusses a number of aspects dealing with the Book of Mormon, including its purpose, coming forth, publication, story, characters, and message. Includes corresponding references to the Book of Mormon and Church history. [J.W.M.]

C.082 Carpenter, Claude I. "The Principles of the Gospel." In The Message of the Book of Mormon/Gospel Quarterly, edited by Charles B. Woodstock, 1-64. Independence, MO: Herald House, 1932. Thirteen Sunday School lessons of the RLDS church. Discusses the practical aspects of the Gospel as presented in the Book of Mormon including repentance, baptism, the laying on of hands, and the sacrament. [B.D.]

C.083 Carr, John E. "Q \& A: Do people still speak in tongues today?" NE 5 (March 1975): 48-49. One evidence that people today speak in tongues is the translation of the Book of Mormon into the many languages of the world. Also presents other evidences. [J.W.M.]

C.084 Carr, John Edward. "For in that Day...": A History of Translation and Distribution, 1965-1980. Salt Lake City: author, 1985. Chapter eight details the history of the translation of the Book of Mormon into various languages. Translation languages of the Book of Mormon include Afrikaans, Vietnamese, Braille, and dozens of others. [D.W.P.]

C.085 Carrieres, Joseph T. Mormon Controversies: A Balanced Approach. Phoenix, AZ: Sideris Press, 1988. Contains the tandem views of a non-vitriolic non-Mormon and a fundamentalist Mormon. Discusses the Three Witnesses, the process of translation, and the feasibility of the Egyptian language for the Book of Mormon. [D.M.]

C.086 Carruth, William Herbert. "Mormonism and Its Founder." The Dial 34 (1 January 1903): 1618. A brief review of William Linn's work, The Story of the Mormons and Riley's, The Founder of Mormonism. Carruth favors 
Riley's psychological thesis over the Spaulding theory for the origin of the Book of Mormon. [M.R.

C.087 Carter, Charles W. Organization of the Church of Jesus Christ of Latter-day Saints and Their Belief. Also the Life and History of Their Prophet, Seer and Revelator, Joseph Smith, During His Brief Life of 38 1/2 Years. Salt Lake City: Utah Lithography, n.d. Chapters 2 through 7 pertain to the Book of Mormon. Sets forth the coming forth of the Book of Mormon, including angel Moroni's visit, its translation and publication. Contains a description of the gold plates and testimonies of Church leaders. Rejects the Spaulding story. Writes concerning the room inside of the Hill Cumorah that was filled with plates and writings. [J.W.M.]

C.088 Carter, George F. "Before Columbus." In The Book of Mormon: The Keystone Scripture, edited by Paul R. Cheesman, S. Kent Brown, and Charles D. Tate Jr., 164-86. Provo, UT: Brigham Young University Religious Studies Center, 1988. The origins of New World plants and chickens prove the diffusionist theory of pre-Columbian transoceanic contacts. [B.D.]

C.089 Carter, Kate B., ed. Mormondom's First Woman Missionary Louisa Barnes Pratt: Life Story and Travels Told in Her Own Words. Vol. 8 Salt Lake City: Daughters of the Utah Pioneers, 1974. The Book of Mormon was introduced to Louisa Barnes Pratt and her husband by Louisa's sister. Both were eventually converted, and Louisa became the first woman missionary in the Church. [J.W.M.]

C.090 Case, Oscar. "A Voice of Warning." In Case's My Book of Acts: Missionary Experiences and Short Sermons, 3538. Independence, MO: Lambert Moon, 1956. The angel Moroni visited a young man telling him that he would soon be receiving the stick of Joseph, or the Book of Mormon, from the Lord. [J.W.M.]

C.091 Caswell, Henry. The Prophet of the Nineteenth Century: or the Rise, Progress, and Present State of the Mormons, or Latter-day Saints. London: J.G.F. \& J. Rivington, 1843. Desires to reveal the fraudulent nature of the Mormon religion. Chapter 2 discusses Solomon Spaulding and the Spaulding Manuscript. Chapter 3 is an account of the publication of the Book of Mormon. The appendix features a summary of the contents of the Book of Mormon with interjections by the author. [A.T.]

C.092 "A Catacomb of Mummies Found in Kentucky". TS 3 (2 May 1842): 781-82. The discovery of mummies in Kentucky recalls the Hebrew practice of embalming. Author suggests that this practice was brought to ancient America by the Hebrews because, according to the Book of Mormon, the native Americans are descendants of Hebrews. [L.D.]

C.093 "Catalan Dialect is Book of Mormon Translation \#32." CN 51 (6 June 1981): 14. Catalan, a Spanish dialect of Northeastern Spain, is the thirty-second complete translation of the Book of Mormon. [J.W.M.]

C.094 Caywood, Charles Sr. I was a Protestant Minister. Independence, MO: Herald Publishing House, n.d. Caywood, a Baptist minister, was offered a Book of Mormon to read while visiting the home of his brother. Doubt was replaced with intense interest and conversion came through reading the book. [J.W.M.]

C.095 Cazier, Donald A. "I Have A Question: We Learn in Mosiah 25:6 that the account of Alma's group covered the time they left Zarahemla until they 'returned again.' Since Alma and his followers were presumably born in the land of Nephi and had never been to Zarahemla, how is this matter reconciled?" Ensign 22 (August 1992): 60-1. Cazier gives a brief summary of Nephite history, and then suggests two possible explanations to the question posed in the title. (1) "Alma and his brethren" includes ancestors involved in the original colonization effort. (2) Perhaps a different time frame is involved and it is possible that Alma came from Zarahemla to colonize. [A.C.W.] 
C.096 Cazier, Donald A. "Mormon's Message to Modern Militants-Or, Why Is There So Much about War in the Book of Mormon?" In A Symposium on the Book of Mormon, 5-11. Salt Lake City: Church of Jesus Christ of Latterday Saints, CES, August 1986. Explores possible reasons for Mormon's inclusion of so much material relating to war and analyzes the teachings of Book of Mormon concerning the following four questions: (1) When is war justified? (2) What rules govern the righteous conduct of war? (3) What must a nation do in order to win a war? (4) What effects, good or bad, can a righteous people expect from war?" [A.T.]

C.097 Cazier, Donald A. "Nephite and Israelite Governmental Institutions and Policies." In A Symposium on the Book of Mormon, 26-32. Salt Lake City: Church of Jesus Christ of Latter-day Saints, 1979. Reviews the patriarchal origins of Nephite government, the theocratic ideal government, and how it was developed by biblical and Nephite civilizations. Other topics discussed include government by popular consent, protection of personal liberty from government, crime and punishment, morality and public welfare, and the resolution of disputes with other nations. [N.K.Y.]

C.098 Cazier, Donald A. A Study of Nephite, Lamanite, and Jaredite Governmental Institutions and Policies as Portrayed in the Book of Mormon. M.A. thesis, Brigham Young University, 1972. Analyzes the Book of Mormon governmental institutions. Considers: "1. The governmental structure under which [the Nephite, Lamanite, and Jaredite] nations lived at different times in their history and the theoretical powers and duties of their officers. 2. The laws that were enacted and domestic policies which were pursued. 3. The rights enjoyed by the citizens. 4. The 'foreign policy' of these nations, where applicable, including military policy. 5. The teachings of Book of Mormon prophets and secular leaders of the various types of government ... and the lessons which can be drawn from the political experiences of the Book of Mormon peoples." [A.T.]

C.099 Central States Mission. The Book of Mormon and You. Independence, MO: Central States Mission of the Church of Jesus Christ of Latter-day Saints, n.d. A pamphlet that presents a brief overview of the Book of Mormon story and a discussion of the value of the Book of Mormon in individual lives. [J.W.M.]

C.100 Central States Mission of the Church of Jesus Christ of Latter Day Saints. From Whence Came the American Indian: America's Ancients Speak from the Dust. Independence, MO: LDS Church, 1958?. A flyer with a collection of Book of Mormon claims and facts. It is a compilation of archaeologists findings, testimonies of the witnesses, the origin of the Book of Mormon, and the Book of Mormon fulfills Bible prophecy. [J.W.M.]

C.101 Central States Mission of the LDS Church. Historic Origin of the American Indian. Independence, MO: Central States Mission, n.d. An illustrated brochure claiming that the American Indians are a chosen people. Depicts Book of Mormon history and the beginnings of missionary work among the Indian people. [J.W.M.]

C.102 Ceram, C. W. The First American: A Story of North American Archaeology. New York: Harcourt Brace Jovanovich, 1971. Explains (pp. 204-5) that the Book of Mormon does not consider the ancient inhabitants of America to be from the lost ten tribes, but rather from the period of the Tower of Babel, and Israelites from 600 B.C. [D.M.]

C.103 Chadwick, Bruce A., and Thomas Garrow. "Native Americans." In Encyclopedia of Mormonism, edited by Daniel H. Ludlow, 3:981-85. 5 vols. New York: Macmillan, 1992. Presents an overview of the Book of Mormon story. Latter-day Saints believe that the Book of Mormon is a record of the ancestors of the native inhabitants of the Western Hemisphere. The message of the book is specifically for them. [J.W.M.] 
C.104 Chadwick, Clinton. "Down the Dark Path: Sherem, Nehor, and Korihor as Archetypal Anti-heroes." Insight 8 (Fall 1992): 1-4. Looks at Book of Mormon anti-Christs within a model set up by Joseph Campbell showing some degree of reversal of the mythic hero type. They are depicted as counterfeits, and experience a tragic "ironic twist of the sacrificial archetype epitomized by Christ." [D.M.]

C.105 "Challenge Met with Imagination." CN 59 (28 January 1989): 4. Members of a local congregation accept their leader's challenge to read the Book of Mormon. [M.R.]

C.106 Chamberlain, Jonathan M. "I Have a Question: What is the meaning of Luke 16:18 and 3 Nephi 12:32?" Ensign 23 (January 1993): 59-60. A discussion about the permissibility of divorce on grounds other than adultery in the law of Moses as compared to the higher law Jesus offered. [S.H.]

C.107 Chambers, Robert. History of the Mormons. N.p., 1853. A polemical work against Mormonism. The testimony of the Book of Mormon witnesses may be discredited due to the fact that most of them were members of the Smith and Whitmer families. The 1834 Anthon denial is cited. The Spaulding theory is accepted by the author as the most likely source behind the Book of Mormon, which he finds full of errors of grammar and anachronisms. [M.R.]

C.108 Chandler, Neal. "Book of Mormon Stories That My Teacher Kept from Me." Dialogue 24 (Winter 1991): 1330. In the mood of whimsy the author discusses various aspects of story telling in and about the Book of Mormon. Refers to a current school in textual criticism that claims that the main subject of a book is what it does not say. For the Book of Mormon the subject of sex is the missing ingredient. [D.M.]

C.109 Chandler, Rick D. "O Remember and Perish Not: A Scriptural Study of the Process of Memory as a Vehicle to Exaltation." In The Second Annual Church Educational System Religious Educators' Symposium: A Symposium on the Book of Mormon, edited by The Church Educational System, 33-37. Salt Lake City: Corporation of the President of the Church of Jesus Christ of Latter-day Saints, 1979. A treatment, in outline form, of the term "remember" in its various forms and its antonyms that occur in the Book of Mormon and the Doctrine and Covenants. The author lists dictionary definitions of remember, memory, and remembrance, lists citations from passages that are relevant to his study, and occasionally gives brief commentary to elicit the meaning of remembering or forgetting. [B.D.]

C.110 Charles, Melodie Moench. "Book of Mormon Christology." In New Approaches to the Book of Mormon: Explorations in Critical Methodology, edited by Brent Lee Metcalfe, 81-114. Salt Lake City: Signature, 1993. Author is unable to resolve the differences between Abinadi's teachings concerning Christ (Mosiah 15:1-4) and current Mormon theology. Compares Book of Mormon teachings about Christ to Jewish messianic expectations at Jesus' time, to early Christian beliefs about Christ, and to current Mormon beliefs and concludes that the Book of Mormon teaches that God the Father and Jesus Christ are not distinct individuals. This work is reviewed in M.339. [A.T.]

C.111 Charles, Melodie Moench. "The Mormon Christianizing of the Old Testament." In The Word of God: Essays On Mormon Scripture, edited by Dan Vogel, 131-42. Salt Lake City: Signature, 1990. Mormon scripture incorrectly imposes Christian ideas and doctrines upon the Old Testament. Book of Mormon teachings regarding the law of Moses, the coming of a Messiah, and views of an afterlife are not in accord with what is known about Old Testament peoples. [M.R.]

C.112 Charles, Melodie Moench. "Scriptural Precedents for Priesthood." Dialogue 18 (Fall 1985): 14-20. Lists and discusses the qualifications for holding the priesthood as given in the Book of Mormon. [B.D.] 
C.113 Charlesworth, James H. "Messianism in the Pseudepigrapha and the Book of Mormon." In Reflections on Mormonism, edited by Truman G. Madsen, 99-137. Salt Lake City: Bookcraft, 1978. Reviews five pseudepigrapha with Jewish origins and four pseudepigrapha with Christian origins that contain references to the Messiah, the anointed one, and the Christ. These references are then compared with the citations to the same titles in the Book of Mormon. [B.D.]

C.114 Chase, Daryl. Sidney Rigdon-Early Mormon. Ph.D. dissertation, University of Chicago, 1931. A historical examination of the life of Sidney Rigdon that discusses the theories concerning the origin of the Book of Mormon. Concludes that Sidney Rigdon had no contact with Joseph Smith nor the Spaulding Manuscript prior to 1830. [J.W.M.]

C.115 Chase, Lance D. "Spaulding Manuscript." In Encyclopedia of Mormonism, edited by Daniel H. Ludlow, 3:14023. 5 vols. New York: Macmillan, 1992. Also known as the Manuscript Found. The Spaulding manuscript was written by Solomon Spaulding, and consists of 175 handwritten pages. The work was first published in 1885. It is a fictional story about a group of Romans who were lost in a storm and settled in America about the fourth century A.D. Enemies of the LDS church claimed it was the basis for the Book of Mormon. This theory was propagated by Philastus Hurlbut and E. D. Howe in the early days of the Church when the manuscript was lost. The manuscript was found after forty-five years and that theory was proved invalid. [J.W.M.]

C.116 Chatburn, Mrs. T. W., and William Pooler. "Two Living Witnesses Who Saw David Whitmer." The Iron Rod 1 (May 1924): 19-20. Two individuals report that David Whitmer possessed a strong, personal testimony of the Book of Mormon gold plates. [J.W.M.]

C.117 Checketts, Darby, and Sharon Checketts. Scripture Focus for Everyday Living. Provo, UT: Cornerstone ProDev Press, 1992. A scripture study program. Contains fifty-two post-on-the-wall scriptural thoughts (one for each week of the year) designed to inspire, teach, and motivate students of the Book of Mormon. [D.W.P]

C.118 Cheesman, Millie Foster. Book of Mormon Pioneers. Provo, UT: Promised Land Publications, 1975. Consists of poetry, each poem dedicated to one of the prophets or heroes in the Book of Mormon. [L.D.]

C.119 Cheesman, Paul R. An Analysis of the Kinderhook Plates. N.p., n.d. A thorough analysis of the history and authenticity of the Kinderhook plates is presented. The author concludes that the evidence is inconclusive as to whether or not they are authentic. Includes extensive appendix of known data on the problem. [B.D.]

C.120 Cheesman, Paul R. "Ancient Writing in the Americas." BYU Studies 13 (Autumn 1972): 80-90. Subsequent to Joseph Smith's statement that descendants of Hebrews in ancient America inscribed metal plates, many examples of ancient American writings on metal have been discovered. Examples include the Kinderhook plates, the Arizona tablets, the Metcalf stone, Newspaper Rock, a Peruvian gold plate, and a copper plate from Equador. [B.D.]

C.121 Cheesman, Paul R. "Ancient Writing on Metal Plates." Ensign 9 (October 1979): 42-47. A photographic essay of ancient writing on metal plates. The author notes that while many examples of ancient metal inscriptions exist in the Old World, examples of metal plates in the New World are just beginning to surface. This is in part due to the lack of archaeological study in the New World. [D.M.]

C.122 Cheesman, Paul R. Ancient Writing on Metal Plates: Archaeological Findings Support Mormon Claims. Bountiful, UT: Horizon, 1985. The Book of Mormon was translated from gold plates. Correspondingly, many examples of 
writings on metal plates and other pre-Columbian writings have been discovered since the time of Joseph Smith. Such items lend credence to the gold plates of the Book of Mormon. [B.D.]

C.123 Cheesman, Paul R. "Answers to Questions Regarding Archaeological Evidences of the Book of Mormon." NE 5 (March 1975): 49-50. Gives evidences of a high civilization in Meso and South America, including towers seen by Cortez, highways up to 9,000 miles in length that cross South America, and metallurgy including gold, silver, and copper all of which lend support to the Book of Mormon. [L.D.]

C.124 Cheesman, Paul R. "Archaeology and the Book of Mormon." Instructor 103 (November 1968): 428-32. The author reviews archaeological evidences of the Book of Mormon and other finds that clarify understanding of the Book of Mormon. The subjects reviewed include: ancestry of the American Indian, the calendar, iron, elephants, and horses. [B.D.]

C.125 Cheesman, Paul R. "Book of Helaman." In Encyclopedia of Mormonism, edited by Daniel H. Ludlow, 1:152-53. 5 vols. New York: Macmillan, 1992. The book of Helaman records the period preceding the birth of the Savior. It was written by Helaman and was abridged by Mormon who inserts his own commentary. The most prominent person in the book is $\mathrm{Nephi}_{2}$. Also included are prophecies and teachings of Samuel the Lamanite and the rise of the Gadianton robbers. [J.W.M.]

C.126 Cheesman, Paul R. Book of Mormon Lands: A Photographic Essay. Salt Lake City: Blaine Hudson Printing, 1978. A photographic essay of Book of Mormon lands. "With a little effort the reader will become immersed in the beauty of the ancient citadels and landscapes and sense their relationship to the spirit of the scriptures [the Book of Mormon]." This work is reviewed in U.014. [B.D.]

C.127 Cheesman, Paul R. The Book of Mormon: The Keystone Scripture. Provo, UT: Brigham Young University Religious Studies Center, 1988. Collection of papers presented on the campus of Brigham Young University at the First Annual Book of Mormon Symposium. Individual selections appear in this bibliography under the names of the respective authors. [J.W.M.]

C.128 Cheesman, Paul R. "A Cultural Analysis of the Nephite-Lamanite-Mulekite Civilizations from the Book of Mormon." Project for Ph.D., Brigham Young University, 1967. "The purpose of this project is to analyze the cultural aspects of the ancient American people, part of whose history is presented in the text of the Book of Mormon. It is presented in such a manner that, hopefully, this analysis could serve as the basis of a reconstruction of the Book of Mormon civilizations that would be helpful in the production of motion pictures." [A.T.]

C.129 Cheesman, Paul R. "Cultural Parallels between the Old World and the New World." In The Book of Mormon: The Keystone Scripture, edited by Paul R. Cheesman, S. Kent Brown, and Charles D. Tate Jr., 206-17. Provo, UT: Brigham Young University Religious Studies Center, 1988. Argues for the theory of diffusion between the Old and the New World. Cites evidence of pre-Columbian transoceanic voyages, modern voyages by means of primitive craft, and cultural similarities. [B.D.]

C.130 Cheesman, Paul R. Early America and the Book of Mormon: A Photographic Essay of Ancient America. Salt Lake City: Deseret Book, 1972. A photographic essay of Mesoamerica and the narrow coastal region and highlands of the Middle Andes, which includes Peru, Ecuador, and Bolivia. [B.D.]

C.131 Cheesman, Paul R. "External Evidences of the Book of Mormon." In By Study and Also by Faith, edited by John M. Lundquist and Stephen D. Ricks, 2:73-90. Salt Lake City: Deseret Book and FARMS, 1990. Mentions practices, 
legends, ceremonies and beliefs of the Olmecs, Mayans, and Aztecs that support the stories contained in the Book of Mormon. Examples include Quetzalcoatl, the Bearded White God, the architecture of buildings, the existence of stone boxes and writings on metal, the religious beliefs of an afterlife and a heavenly kingdom, the evidences of Christian-like practices and rites, the legends of a dark and a light people, the existence of fortifications and weapons suggesting warfare, and the discovery of stelas and other carvings that make reference to the tree of life and other Book of Mormon themes. [A.A.]

C.132 Cheesman, Paul R. Great Leaders of the Book of Mormon. Salt Lake City: Promised Land Publications, 1970. Every major leader and character of the Book of Mormon is spotlighted with a short history, a poem, and a portrait. [B.D.]

C.133 Cheesman, Paul R. "Helaman2." In Encyclopedia of Mormonism, edited by Daniel H. Ludlow, 2:584. 5 vols. New York: Macmillan, 1992. The second Helaman mentioned in the Book of Mormon was the eldest son of Alma the Younger. He became a High Priest, military commander, Nephite record keeper, and prophet. He is noted for preaching repentance. [J.W.M.]

C.134 Cheesman, Paul R. The Keystone of Mormonism: Little Known Facts About the Book of Mormon. Salt Lake City: Deseret Book, 1973. A review of the "primary and secondary accounts which pertain to the coming forth of the Book of Mormon." The author's goal is for readers to discover the divine literature of the Book of Mormon and to consider its historical and theological aspects. [R.M.]

C.135 Cheesman, Paul R. The Keystone of Mormonism: Early Visions of the Prophet Joseph Smith. Provo, UT: Eagle Systems International, 1988. Examines the details of the accounts of the early visions of Joseph Smith. Skeptics have a problem with the time that elapsed before the accounts were written. It is suggested that the sacred nature of the visions required a time of secrecy. Some of the accounts were written by intimate associates of the prophet who may have received details in the oral account given them that Joseph's own written account did not include, or these authors may have put in their own embellishments. There are some discrepancies, but the basic elements are consistent. Discusses the part played by the Urim and Thummin in the translation of the Book of Mormon. This work is reviewed in P.302. [J.W.M.]

C.136 Cheesman, Paul R. "Lehi's Journeys." In The Book of Mormon: First Nephi, The Doctrinal Foundation, edited by Monte S. Nyman and Charles D. Tate Jr., 241-50. Provo, UT: Brigham Young University Religious Studies Center, 1988. Examines the journey of the Lehite colony in the wilderness and attempts to determine the route taken and specific locations dealing with the journey. [A.T.]

C.137 Cheesman, Paul R. "Monuments of Vanished Peoples." Ensign 2 (September 1972): 43-45. A brief description of eight major Mesoamerican archaeological sites—Copan, Teotihuacłn, Monte Alban, La Venta, Palenque, Tikal, Cuicuilco, and Dzibilchaltun-is provided. [B.T.]

C.138 Cheesman, Paul R. "Origin of the American Indian and Why the Earth was Divided." In A Symposium on the Book of Mormon, 14-17. Salt Lake City: Church of Jesus Christ of Latter-day Saints, 1979. Writes concerning the origin of American Indians. Theorizes that the continents were divided because God desired a separated land for the proposed habitation by groups of righteous people. Such groups could leave their witness of Christ for subsequent generations. [N.K.Y.] 
C.139 Cheesman, Paul R. "The Power to Repent." Instructor 104 (December 1969): 436-37. Writes concerning the doctrine of repentance. Helaman 13-15 (see especially Helaman 13:38) indicates that as individuals choose evil, their power to choose is taken away until destruction is made sure. As individuals choose righteousness, their power to choose increases. The concepts of freedom and free agency are directly related. [B.D.]

C.140 Cheesman, Paul R. "Q \& A: Is there anything that has been found among the archaeological evidences that would sustain or support the Book of Mormon?" NE 5 (March 1975): 49-50. Proof of the Book of Mormon lies in the spiritual realm. However, there is evidence that supports it: architecture, cement, highways, weapons of war, metallurgy, medicine, and highly organized priesthood. There are many native legends that tell of a Christ-like god whose teachings resemble Christ's. [J.W.M.]

C.141 Cheesman, Paul R. "The Ruins of Monte Alban." Instructor 105 (July 1970): center insert. The ruins of Monte Alban ("sacred mountain") date back to 500 B.C. and a composite of peoples occupied it for two thousand years. Such peoples may be connected with those of the Book of Mormon. [J.W.M.]

C.142 Cheesman, Paul R. "The Stone Box." IE 69 (October 1966): 875-78, 900. Prior to Joseph Smith's encounter with the stone box that contained the gold plates no record existed that described the stone boxes of antiquity. The author includes descriptions of various stone boxes that have subsequently been found in Central and South America. [J.W.M.]

C.143 Cheesman, Paul R. These Early Americans: External Evidences of the Book of Mormon. Salt Lake City: Deseret Book, 1974. Presents numerous archaeological, anthropological and ethnological data to support ideas found in the Book of Mormon. Discusses such topics as Quetzalcoatl, the wheel, stone boxes, language, and ancient writing. This work is reviewed in S.517. [B.D.]

C.144 Cheesman, Paul R. "Transatlantic Crossings: A New Look." Ensign 5 (January 1975): 50-51. A report of the findings of the 1973 Pre-Columbian Transatlantic Crossings Symposia held in Lumpkin, Georgia. Three important conclusions were drawn by the presenters: (1) Ancient Americans were literate and kept records. (2) PreColumbian Americans had the technology necessary for the production of iron. (3) Ancient Americans actually came from the Old World via the Atlantic as well as the Pacific. [D.H.M.]

C.145 Cheesman, Paul R. View of the Hebrews. N.p., n.d. Examines the claim that Joseph Smith used Ethan Smith's book View of the Hebrews to write the Book of Mormon. After comparing the two books the author concludes that "for any person to suggest that the Book of Mormon thesis was adopted from ideas found in the View of the Hebrews suggests that a proper comparison was not attempted." [B.D.]

C.146 Cheesman, Paul R. "The Wheel in Ancient America." BYU Studies 9 (Winter 1969): 185-97. Discusses ancient highways that have been uncovered, and the early uses of the wheel, wheeled toys, and other wheel-like objects found in Central America and Mexico. [L.D.]

C.147 Cheesman, Paul R. The World of the Book of Mormon. Salt Lake City: Deseret Book, 1978. Discusses many subjects concerning external evidences of the Book of Mormon, including the relevance of the bearded white God to Jesus Christ, geography of the Book of Mormon, ancient ruins from Central and South America, ancient writing, stone boxes, the wheel, horses, and medicine. This work is reviewed in I.005. [B.D.]

C.148 Cheesman, Paul R., and Barbara Hutchins. Pathways to the Past: A Guide to the Ruins of Mesoamerica. Bountiful, UT: Horizon, 1984. A tour guide intended for the novice LDS audience. Maps, photographs, and 
directions are provided. Also included are the author's interpretations of how certain Mesoamerican sites and ruins correspond to the Book of Mormon. [B.D.]

C.149 Cheesman, Paul R., and Millie F. Cheesman. Ancient American Indians: Their Origins, Civilizations and Old World Connections. Bountiful, UT: Horizon, 1991. The goals of the authors are to show "(1) the origins of the American Indians, (2) cultural parallels between the Old and the New World, and (3) temples, mounds, and ruins in prehistoric North America." Includes photographs and illustrations. This work is reviewed in R.007. [D.W.P.]

C.150 Cheesman, Paul R., and Millie Foster Cheesman. Early America and the Polynesians. Provo, UT: Promised Lands Publications, 1975. Through the employment of quotes from authorities of the Church, scientific data, and photographic presentations of Polynesia, the author discusses the possibilities that the Polynesians were descendants of Lehi. [B.D.]

C.151 Cheesman, Paul R., moderator, Noel B. Reynolds, John L. Sorenson, and Arthur Wallace. "External Evidences of Scripture: A Panel." In Scriptures for the Modern World, edited by Paul R. Cheesman and Wilfred C. Griggs, 121-35. Provo, UT: Brigham Young University Religious Studies Center, 1984. The panel fields several issues dealing with Book of Mormon external evidences, e.g., the persuasiveness of evidences to nonbelievers, the value of evidences to members with testimonies, the possibility that some alleged evidences are invalid, and whether or not non-Mormon scholars agree with Book of Mormon archaeology. [B.D.]

C.152 Cheesman, Paul R., S. Kent Brown, and Charles D. Tate Jr., eds. The Book of Mormon: The Keystone Scripture. Provo, UT: Brigham Young University Religious Studies Center, 1988. Contains fifteen papers from the First Annual Book of Mormon Symposium. Each of the articles are dealt with elsewhere in this bibliography. The volume deals with such Book of Mormon topics as Jesus Christ, fasting, faith, hope, charity, and Old and New World similarities. [B.D.]

C.153 Cheesman, Paul R., and Wilfred C. Griggs, eds. Scriptures for the Modern World. Provo, UT: Brigham Young University Religious Studies Center, 1984. Three Book of Mormon articles treated in this volume deal with Moroni, the allegory of the Olive Tree, and external evidences of scriptures. The three articles are dealt with elsewhere in this bibliography. [B.D.]

C.154 Cheney, Silas L., Roy A. Welker, J. Karl Wood. "A New Sacred Scripture Revealed." In The Church: Its History and Mission, edited by Cheney, Welker, and Wood, 83-147. Salt Lake City: LDS Department of Education, 1952. Details the coming forth of the Book of Mormon and provides many purposes for the book as identified by its prophets. [J.W.M.]

C.155 Cherry, Alexander. Article on 'Book of Mormon and Latter Day Work' begun by Brother Alexander Cherry and continued by Brother Charles Ashton. Monongahela, PA: Gilkey and Underwood, 1936. Discusses the present whereabouts of the posterity of Judah, Joseph, Manassah, and Ephraim. The land of America is the "land blessed of the Lord" above all lands. Believes that the American Indian will be used in the latter days in revealing the mysteries of the Lord. [L.D.]

C.156 Cheville, Roy A. Book of Mormon Speaks for Itself. Independence, MO: Herald House, 1971. Explores twelve separate aspects of the Book of Mormon, investigating such topics as how "the book speaks of God in history, the book centers on the universal Christ, and the book predicts the ministry of the Holy Spirit." [L.D.] 
C.157 Cheville, Roy A. "How the Book of Mormon Helps Us in Everyday Living." In Lessons from the Book of Mormon/Gospel Quarterly, 1-64. Independence, MO: Herald House, 1943. A series of thirteen lessons for young students featuring such Book of Mormon topics as money, idleness, family life, war, drink, Zion, and government. [B.D.]

C.158 Cheville, Roy A. "A Journey into Ancient America." In Finding God through Ancient Peoples/Gospel Quarterly, 163. Independence, MO: Herald House, 1953. A collection of 13 Book of Mormon lessons for young children. The lessons discuss major historical events in the Book of Mormon, including Joseph Smith's acquisition and translation of the plates, the Nephite journey to America, the Lamanite rebellion and separation, the rule of the judges, Christ's visit to America, and the final destruction of the Nephites. [B.D.]

C.159 Cheville, Roy A. "A Journey into Ancient Times." In Lessons from the Book of Mormon/Gospel Quarterly, 1-60. Independence, MO: Herald House, 1942. A series of thirteen lessons for young Book of Mormon students, covering the history of the peoples in the Book of Mormon and its translation. [B.D.]

C.160 Cheville, Roy A. Meet Them in the Scriptures. Independence, MO: Herald House, 1960. Examines the personalities of important persons in the scriptures, including characters of the Book of Mormon. [B.D.]

C.161 Cheville, Roy A. "Overviews of the Book of Mormon." Gospel Quarterly Review 52 (January-March 1950): 370. A lesson manual for young Book of Mormon students, consisting of thirteen lessons on the Book of Mormon and a variety of maps at the end. Lessons address the nature of the Book of Mormon, its coming forth, religion and government of the Nephites, and other topics. [L.D.]

C.162 Cheville, Roy A. "People Who Lived in Book of Mormon Times." In Lessons from the Book of Mormon/Gospel Quarterly, 1-64. Independence, MO: Herald House, 1943. A series of thirteen lessons for young students covering the major characters of the Book of Mormon. [B.D.]

C.163 Cheville, Roy A. "People Who Lived in the Book of Mormon." In Finding God through Ancient Peoples/Gospel Quarterly, edited by Chris B. Hartshorn, 1-48. Independence, MO: Herald House, 1954. A series of thirteen lessons for the young students, acquainting them with the major characters of the Book of Mormon. [B.D.]

C.164 Cheville, Roy A. Scriptures From Ancient America. Independence, MO: Herald Publishing House, 1964. Establishes the criteria for religious writings that would be placed in a world Library of Sacred Writings-they must have survival quality, an applicable conception of man, usability in ceremonies, devotions, and memorial occasions, quotability, elasticity and expandability (symbolic and figurative language), and a functional conception of divinity. The Book of Mormon meets the criteria to belong in such a library. It is a Hebrew collection of scriptures that supplements and supports the Bible and contributes much to the modern world. The history and story of the Book of Mormon is included. [J.W.M.]

C.165 Cheville, Roy A. They Made a Difference. Independence, MO: Herald Publishing House, 1970. Contains history and testimonies of early members of the Church of Jesus Christ of Latter-day Saints who had a significant impact on the restoration movement. Includes Joseph Smith, the witnesses of the Book of Mormon, those who were converted to the Church by the Book of Mormon, used it as a missionary tool, and supported and helped in its translation and publication. [J.W.M.]

C.166 Cheville, Roy A. "Torchbearers of the Book of Mormon." Gospel Quarterly Series 54 (April-June 1946): 9-79. A series of thirteen lessons dealing with the Book of Mormon that are directed towards the Sunday Schools of the 
RLDS church. Also includes a Book of Mormon chronology chart. [L.D.]

C.167 Chidester, C. Richard. "The Natural Man and Spiritual Rebirth." In A Symposium on the Book of Mormon, 1217. Salt Lake City: Church of Jesus Christ of Latter-day Saints, Church Educational System, August 1986. Shows how a correct understanding of the doctrines of the Fall, natural man, Atonement, and spiritual rebirth can bring about a spiritual change that leads individuals to God. [A.T.]

C.168 Child, A. Lon. "Plates of the Book of Mormon." Juvenile Instructor 85 (August 1950): 256-57. Features a chart and explanation of the different sets of plates identified in the Book of Mormon, including the brass plates, the twenty-four gold plates, the small and large plates of Nephi, Mormon's abridgment of Nephi's large plates, and Moroni's abridgment of Jaredite record. [A.C.W.]

C.169 "Children Challenge Adults on Scriptures." CN 59 (4 February 1989): 5. Children of an LDS congregation challenged the adults to a scripture chase and won consistently. [M.R.]

C.170 "Children's Section-Testimonies Regarding the Book of Mormon." Juvenile Instructor 52 (September 1917): 484-86. Students of Calvin S. Smith's theology class in the Latter-day Saints University bear testimony of the Book of Mormon. [J.W.M.]

C.171 Childress, Harvey. "Did Smith Translate Egyptian?" Christian Soldier 4/9 (14 August 1942): 1-3. Believes that Joseph Smith was not an Egyptologist and could not/did not translate the Book of Mormon that was written in the Egyptian language. [D.W.P.]

C.172 Childs, Larry G. "Epanalepsis in the Book of Mormon." Provo, UT: FARMS, 1986. Also published in an abbreviated form in Childs, Larry G. "Epanalepsis in the Book of Mormon." In Reexploring the Book of Mormon, edited by John W. Welch, 165-66. Salt Lake City: Deseret Book and FARMS, 1992. Epanalepsis is a literary device utilized by at least fifteen Book of Mormon writers. Called "resumptive repetition," epanalepsis contains two identical or near identical phrases within a longer sentence. Between the two phrases is interjected a parenthetical expression that adds additional information to the principal statement being expressed. An example of epanalepsis is found in Alma 3:1. Narrative, rather than poetry, lends itself to this figure. An appendix containing a complete listing of references of epanalepsis in the Book of Mormon is appended to the article. [D.W.P.]

C.173 Choate, Jane McBride. "The Brother of Jared Saw the Finger of God." Friend 18 (November 1988): 48-49. The great faith of the brother of Jared permitted him to see the finger of God (Ether 1-6). [J.W.M.]

C.174 Choate, Jane McBride. "Teancum: Fighter for Freedom." Friend 18 (May 1988): 48-49. Teancum, Nephite military leader, fights and voluntarily gives his life for the liberty of his people. [J.W.M.]

C.175 Christ for the Cults. Book of Mormon Vs. the Bible (or common sense). San Juan Capistrano, CA: Christian Research Institute, 1970?. A polemical pamphlet that compares the Book of Mormon with the Bible in order to show the falsity of LDS religion. [J.W.M.]

C.176 Christensen, A. H. Little Known Facts, Volume 2. Denver, CO: n.p., 1955. Provides brief facts and statements regarding Book of Mormon geography. Deals with the location of the last battle, the location of the Hill Cumorah, the Nephite wilderness, and other geographical items. [D.W.P.] 
C.177 Christensen, A. H. "The Present Status." SH 71 (16 July 1924): 677-78. The Book of Mormon discusses both the seer and priestcraft. Mosiah 5:79-80 presents the definition of a seer. Priestcraft is confounded by both the written word and by the living prophet, seer, and revelator who holds powers from God. [J.W.M.]

C.178 Christensen, Ann Nicodemus. "Where Are the Prophets?" Ensign 19 (September 1989): 69. A conversion story of a young woman who studies the Book of Mormon and determines that there exist living prophets of God. [J.W.M.]

C.179 Christensen, Bart L. Challenged. Nuneaton, England: Nuneaton Newspapers, 1920s or 1930s. A tract defending Mormonism and the Book of Mormon. Refers to archaeological evidence. [D.M.]

C.180 Christensen, Harold. "Speculations on Polynesian Origins." IE 38 (November 1935): 672-74, 711. Believes that the Polynesians are of the blood of Israel and that they journeyed from the American continent at the time Hagoth built his ships. [B.D.]

C.181 Christensen, James. "The Land of Promise" (photo essay). NE 5 (January 1975): 20-29. The aim of this photo essay is to help readers visualize Book of Mormon scenery. There are thirteen photographs with accompanying scriptures. The work is "not meant to suggest any real locations in the Book of Mormon." [A.T.]

C.182 Christensen, Joe J. "Everyman's Vital Questions." Instructor 103 (March 1968): 126-28. The Book of Mormon is "doctrinally relevant" in today's world as it provides answers to vital questions concerning Christ's divinity, mission, resurrection, the essential nature of baptism, the power of the Holy Ghost, God as a God of miracles, and the reality of a final day of judgment. [A.C.W.]

C.183 Christensen, Joe J." 'In Conclusion.' "In A Symposium on the Book of Mormon, 111-12. Salt Lake City: Church of Jesus Christ of Latter-day Saints, 1979. Summarizes the proceedings of a Book of Mormon symposium. The purpose of the symposium was to stimulate scholarship, improve teaching, and provide fellowship among teachers. [N.K.Y.]

C.184 Christensen, Kevin. "The Big Picture." Sunstone 15 (April 1991): 3-4. Argues with John Kunich over the article "Multiply Exceedingly: Book of Mormon Population Sizes" (Sunstone 14 [June 1990]: 27-44). Suggests that Kunich fails to define the problem of population size, to control appropriately the statistics, and to understand Lamanite lifestyles. [J.W.M.]

C.185 Christensen, Kevin." 'Nigh Unto Death': NDE Research and the Book of Mormon." Journal of Book of Mormon Studies 2 (Spring 1993): 1-20. "This article suggests that contemporary near-death research casts light on several episodes in the Book of Mormon." The conversions of Alma, Limhi, and Limhi's father all demonstrate elements of near death experiences. In addition, the dreams of Lehi and Nephi show elements of both ancient and modern "other world journey literature." Author concludes that "the Book of Mormon matches the revelatory literature of the great traditions." [A.T.]

C.186 Christensen, Leon N. The Little Book: Why I Am a Mormon. Boston: Branden Press, 1976. The Book of Mormon played a great role in the conversion of the great leaders in the early Church. Its philosophical content established a way of life for peaceful, God-fearing people. Its doctrines, including baptism, sacrament prayers, mode of conducting meetings, and the precise way of bestowing the Holy Ghost, restores correct truths that had been lost to the world. [J.W.M.] 
C.187 Christensen, Robert J. "How the Book of Mormon Can Help Teachers Deal Kindly with Wayward students." In The Sixth Annual Church Educational System Religious Educators' Symposium on the Book of Mormon, 13-16. Salt Lake City: Church of Jesus Christ of Latter-day Saints, Church Educational System, 1982. Uses the lives of Laman, Lemuel, Alma the Younger, the four sons of Mosiah, and Alma as examples of how to deal with wayward students. [A.T.]

C.188 Christensen, Ross T. "Ancient Diffusion from Mesoamerica to the 'Mound Area' of Eastern United States; an Annotated Bibliography." Bulletin of UASN 1 (May 1950): 13-19. Provides an annotated bibliography on mounds found in the United States. [D.M.]

C.189 Christensen, Ross T. "Cement in Ancient America." UASN 51 (16 July 1958): 3. The cement found in the more advanced Mesoamerican civilizations of ancient America is "approximately equivalent to modern lime cements." It appears that cement was the principal building material of the era. [J.W.M.]

C.190 Christensen, Ross T. "Did Book of Mormon Peoples Reach Peru?" UASN 67 (7 July 1960): 1-7. Theorizes that the Central Andes of Peru may have been home to much of the Book of Mormon civilization. Also, the "narrow neck of land" may have been the Isthmus of Tehuantepec. Many "large-scale migrations" are recorded in the Book of Mormon. [J.W.M.]

C.191 Christensen, Ross T. "Geography in Book of Mormon Archaeology." SEHA 147 (December 1981): 1-4. The stricture of George Q. Cannon in 1890 against concern for Book of Mormon geography studies was appropriate because comparative secular knowledge was not then available. Now it is. If archaeology is to be considered at all in connection with the Book of Mormon then both geography and chronology of the scriptures must be specified then compared systematically with external information. Argues briefly that "the Tehuantepec correlation" of geography has come to be widely accepted among LDS students of the subject, as against "the Panama correlation." The SEHA should lead out in such geography study. [J.L.S.]

C.192 Christensen, Ross T. "The Horse in Ancient America." UASN 47 (29 January 1958): 4. Evidence that horses existed at a very early date before agricultural civilizations sprung up has been found, but only a small amount of evidence exists to prove that they were contemporary with pre-Colombian civilizations. [J.W.M.]

C.193 Christensen, Ross T. "Lehi's Landing Place." UASN 46 (17 December 1957): 4-5. No "official LDS view" of the place of Lehi's landing in ancient America exists. All views of Book of Mormon geography are personal, private interpretations, but the most popular contemporary view requires a landing for the Lehite company in Southern Central America. [J.W.M.]

C.194 Christensen, Ross T. "Mormon Archaeology." New World Antiquity 4 (July 1957): 105-6. Basic explanation of LDS beliefs and Book of Mormon migrations. Book of Mormon archaeologists need to correlate textual descriptions with New World archaeological sites and land configurations. [A.C.W.]

C.195 Christensen, Ross T. "On the Study of Archaeology by Latter-day Saints." UASN 64 (January 1960): 1-6. Latter-day Saints should be trained and active because we have "with archaeology and the Book of Mormon the one instance in the history of the world ... in which it is possible to put a decisive scientific test to the key foundation stone of a major religious system." Archaeologists ought, moreover, to be interested in the Book of Mormon for what it potentially can tell them. [J.L.S.] 
C.196 Christensen, Ross T. "Other Explanations of the Izapa Tree-of-Life Sculpture." UASN 50 (4 June 1958): 5. Defends Wells Jakeman's interpretation that the Stela 5 sculpture found at the ruins of Izapa represents the tree of life. [J.W.M.]

C.197 Christensen, Ross T. "The Phoenician Theory of New World Origins Re-examined." SEHA 111 (13 January 1969): 1-11. Suggests that Mulek escaped with the aid of Phoenician mariners. "Sidon was the principal metropolis of the Phoenician homeland, the Mulekites and Nephites were unable to understand each others' language, and Phoenician inscriptions have been found in America." Responds to questions and gives topics for further investigation relating to his theory. [A.C.W.]

C.198 Christensen, Ross T. "The Place Called Nahom." Ensign 8 (August 1978): 73. A spot in Yemen on a 1763 map is called "Nehhm." It qualifies as the place "Nahom" mentioned by Nephi as Ishmael's burial place, alternative to the locus proposed by the Hiltons. Semiticists, and ultimately archaeologists, should examine this possibility carefully. [J.L.S.]

C.199 Christensen, Ross T. "Possible Routes Suggested for Mulek's Voyage." Ensign 3 (September 1973): 76-77. One route for Mulek's journey from Jerusalem to the New World may have been through the Mediterranean Sea and westward across the Atlantic Ocean. An alternative route may have been around Africa and the Cape of Good Hope, then northwest towards the Gulf of Mexico. The existence of strong ocean currents supports the plausibility of either of the two routes. [D.M.]

C.200 Christensen, Ross T. "Present Status of Book of Mormon Archaeology." MS, Part I, 114 (September 1952): 206-11, 218; Part II, 114 (October 1952): 234-37, 244; Part III, 114 (November 1952): 246-47, 263; Part IV, 114 (December 1952): 293-97, 304. Defines Book of Mormon archaeology as "that branch of general archaeology which studies the discoveries ... [for] every fact which throws light upon the Book of Mormon." It can be expected both to elucidate the scripture and to confirm it. Using the study of the Bible through archaeology as a model, he lays out a logic and methods for doing so, notably by establishing "major" and "minor" correspondences. Major correspondences consist of geographical and chronological frameworks in the real (New) world that compare adequately with what the Book of Mormon says. Minor correspondences consider specific cultural elements such as the use of iron, the wheel, the horse, etc. Ultimately it should be possible to test "the historical claims" of the Book of Mormon by archaeology. The status thus far is reviewed and the interim conclusion is reached that "in large part the Book of Mormon is vindicated by archaeological science; but many points still remain ... to challenge us." [J.L.S.]

C.201 Christensen, Ross T. Progress in Archaeology (an Anthology). Provo, UT: Brigham Young University, 1963. Selections from 1951-1963 issues of the University Archaeology Society Newsletter that are scripture-related. Many deal with Book of Mormon subjects: transoceanic influences, Book of Mormon geography and chronology, the horse in ancient America, use of cement, Mayan writing. [A.C.W.]

C.202 Christensen, Ross T. "Renewed Latter-day Saint Interest in the Phoenicians." IE 73 (October 1970): 12-15. New evidence reveals Phoenician contact with the New World between 1000 to 500 B.C. Phoenician inscriptions record in remarkable detail the voyages of mariners, pinpointing both departure and arrival dates and places. Christensen hypothesizes that the guardian(s) of Mulek may have asked Phoenician friends to aid in their escape from the Babylonians. [J.W.M.]

C.203 Christensen, Ross T. "The River of Nephi: An Archaeological Commentary on an Old Diary Entry." SEHA 158 (December 1984): 1-8. An 1881 diary entry made by Charles Lowell Walker states that the Prophet Joseph Smith 
identified a key location to Book of Mormon geography. He spoke of a great temple that was located in Central America. The River Copan was anciently called the River of Nephi. A second account by Mosiah Lyman Hancock substantiates Walker's entry. Maps are included. [J.W.M.]

C.204 Christensen, Ross T. "The Seven Lineages of Lehi." NE 5 (May 1975): 40-41. Discusses the different "ites" of the Book of Mormon. The Nephites were divided into Nephites, Jacobites, Josephites, and Zoramites, and the Lamanites were divided into Lamanites, Lemuelites, and Ishmaelites. Defines several terms, including five different definitions of the term "Lamanite." [A.T.]

C.205 Christensen, Ross T. "Stela 5, Izapa: A Review of Its Study As the 'Lehi Tree of Life Stone.' " SEHA 156 (March 1984): 1-6. Gives a precis of scholarly work dealing with Stela 5 and Lehi's tree of life dream. [D.M.]

C.206 Christensen, Ross T. "The Symbol of the Tree of Life in Ancient America, and the New Tree-of-Life Carving Discovered at Izapa, Chiapas, Mexico." U.S.A.N. 59.22 (1 July 1959): 4. Also in Christensen, Ross T. Progress in Archaeology: An Anthology, 120-24. Sculptors of the tree of life carving found in Mexico must have been acquainted with Lehi's/Nephi's account. Draws information from Irene Briggs Woodford's thesis. The carving in Mexico is recognized as Stela 5. [J.W.M.]

C.207 Christensen, Ross T. "A Tour and Brief Description of Some of the Ancient Ruined Cities of Central and Southern Mexico or 'Land Northward' of the Book of Mormon." U.S.A.N. 28 (10 August 1955): 3-5. Also in Christensen, Ross T. Progress in Archaeology: An Anthology, 149-152. Reports on a tour taken by several members of the BYU archaeological department. The archaeologists speculate on the possible connection between Book of Mormon cities and those visited-Teotihuac'an, Copilco, Cuicuilco, Cholula, Mitla, and Monte Alban. Many significant parallels were observed. [J.W.M.]

C.208 Christensen, Ross T. "Tree-of-Life Discovery in Peru." UASN 92 (15 December 1964): 1-3. On the peninsula of Paracus overlooking the Pacific Ocean carved into the mountainside is a representation of the tree of life. Six hundred feet in height, this colossal carving is thought to have been created by an ancient pre-Inca civilization. A comparison is made between the carving and the Israelite menorah-both are stylized trees, have seven branches, balls at the ends of the branches, and a base structure. [J.W.M.]

C.209 Christensen, Ross T. The Tree of Life in Ancient America. Provo, UT: Brigham Young University, 1968. Makes a comparison of the Stela 5, Izapa, stone with the tree of life described in the dream of Lehi. Provides a detailed description and analysis of Stela 5, Izapa, and concludes that the stone is a religious carving representing the events depicted in the Book of Mormon tree of life scene. Includes photographs of the stone. [J.W.M.]

C.210 Christensen, Ross T. "The Value and Development of Book-of-Mormon Archaeology as a Field of Study." U.S.A.N. 6.1 and 44.00 (27 September 1957): 1-2. Also in Christensen, Ross T. Progress in Archaeology: An Anthology, 144-147. Authentication and elucidation of the Book of Mormon is the purpose for Book of Mormon archaeology. It is as important as biblical archaeology or archaeology in the Aegean that sheds light on Homer's lliad and Odyssey as important historical documents. [J.W.M.]

C.211 Christensen, Ross T., ed. Papers of the Fifteenth Annual Symposium of the Archaeology of the Book of Mormon. Salt Lake City: Church of Jesus Christ of Latter-day Saints, 1964. A collection of papers relating archaeology to the scriptures, many of which are relevant to Book of Mormon subjects: Joseph Smith's knowledge of archaeology, Mulek's migration, pyramid architecture, metals in the New World, etc. [A.C.W.] 
C.212 Christensen, Ross T., ed. Transoceanic Crossings to Ancient America. Provo, UT: Brigham Young University Press, 1970. Contains selected articles from the Newsletter and Proceedings of the Society for Early Historic Archaeology (SEHA) that pertain to transoceanic crossings prior to Columbus. Determines that the ancient inhabitants of the New World consisted of multi-races. Sees a Phoenician influence in the Americas.

Archaeologists have found artifacts of many cultures including those of Mediterranean descent who knew Christianity. [J.W.M.]

C.213 Christensen, Ross T., and Ruth R. Christensen. "Archaeology Reveals Old Testament History: Digging for the Truth." Ensign 4 (February 1974): 60-66. Discusses many historical events of the Old Testament that archaeologists have been able to sustain. At Tel Arad broken pottery was discovered that exhibits a combination of the Hebrew alphabet with Egyptian hieratic and suggests that this is an example of reformed Egyptian. [J.W.M.]

C.214 Christensen, Ross T., and Ruth R. Christensen. "Georgia Symposium Considers Transatlantic Contacts." SEHA 135 (August 1974): 1-9. Petroglyphs in Georgia, the Metcalf stone, the Bahaman ruins, coins from the Mediterranean scattered throughout the eastern U.S., the Batcreek stone, Roman artifacts in Arizona, and runes in Oklahoma all indicate the existence of pre-Colombian transoceanic contact between the Old and New World. [A.C.W.]

C.215 Christensen, Ross T., and Ruth R. Christensen. "Perspectives on the Route of Mulek's Colony." SEHA 131 (September 1972): 1-6. Proposes two possible routes for the transoceanic Mulekite journey: (1) The Mediterranean/North Atlantic route, or (2) the African/South Atlantic route. The first choice is seen as the more likely. [D.M.]

C.216 Christenson, Allen J. "Chiasmus in Mayan Texts." Ensign 18 (October 1988): 28-31. Christenson investigates the possibility of the use of chiasmus in Mayan writings. Of the thirty-seven Mayan documents examined, chiastic patterns are found in sixteen. [D.L.L.]

C.217 Christenson, Allen J. "Chiasmus in Mesoamerican Texts." In Reexploring the Book of Mormon, edited by John W. Welch, 233-35. Salt Lake City: Deseret Book and FARMS, 1992. Examines thirty-seven Mayan texts and discovers numerous simple and complex chiastic forms. [N.K.Y.]

C.218 Christenson, Allen J. "Maya Harvest Festivals and The Book of Mormon." In Review of Books On The Book of Mormon, edited by Daniel C. Peterson, 1-31. Provo, Utah: FARMS, 1991. Examines the harvest festival celebrated in Guatemala on November 11 that resembles Mayan traditions more than Christian ones. This is not only a harvest festival, but is also a New Year's celebration and a time of renewal of kingship. Many elements of the tradition parallel King Benjamin's address in the Book of Mormon. Discusses the tree of life motif and its association with the cross. [J.W.M.]

C.219 Christenson, Allen J. "Nephite Trade Networks and the Dangers of a Class Society." In The Book of Mormon: Helaman through 3 Nephi 8, According to Thy Word, edited by Monte S. Nyman and Charles D. Tate Jr., 223-40. Provo, UT: Brigham Young University Religious Studies Center, 1992. Proposes that one of the reasons for the deterioration of Nephite society described in Helaman and 3 Nephi 1-7 "was the establishment of elaborate trade networks with the express purpose of accumulating wealth and power. This in turn stimulated the rise of a class society and the desire among those of noble lineages to reinstitute kingship to control international trade." [D.M.]

C.220 Christenson, Allen J. "The Use of Chiasmus by the Ancient Quiché-Maya." Provo, UT: FARMS, 1989. Points out the use of chiasmus in several Quiché-Maya texts that were written in the Quiché-Mayan language using Latin 
letters. Also compares those texts that contain chiasms with those that do not. [B.D.]

C.221 Christenson, Allen J. "The Use of Chiasmus in Ancient Mesoamerica." Provo, UT: FARMS, 1988. A working paper from which Christenson derived "The Use of Chiasmus by the Ancient Quiché-Maya." [B.D.]

C.222 "Christianity Known to Ancient Indians." CN 23 (21 February 1953): 12. The American Indians possessed "a well-developed concept of Christianity which had degenerated when the white man arrived" on the scene. [D.M.]

C.223 Christianson, James R. "The Bering Strait and American Indian Origins." In The Book of Mormon: The Keystone Scripture, edited by Paul R. Cheesman, S. Kent Brown, and Charles D. Tate Jr., 218-36. Provo, UT: Brigham Young University Religious Studies Center, 1988. Examines the archaeological and ethnological evidence that supports the theory that the Americas were peopled via the Bering Strait. The author determines that the evidence that supports this theory is extremely lacking, and offers the Book of Mormon solution of transoceanic crossings of various peoples at differing times. [B.D.]

C.224 Christianson, James R. "Crawfish Tails, Possum, and Other Missionary Delights." Ensign 19 (April 1989): 4851. Historic tidbits of Wilford Watts Jordan, who through prayer and reading the Book of Mormon received a testimony of it. [B.D.]

C.225 "Christopher Columbus." Juvenile Instructor 1 (15 April 1866): 29. Praises Christopher Columbus and shows how he fulfilled a prophecy by Nephi. [D.M.]

C.226 Church Educational System. Teaching the Scripture Readers: A Beginning Course Teacher Manual. Salt Lake City: Church of Jesus Christ of Latter-day Saints, 1984. A lesson guide for teachers of students who are nonreaders or beginning readers. There are various games and activities that are Book of Mormon related. [D.M.]

C.227 "Church Filming Most Ambitious Movie Ever." CN 57 (18 July 1987): 8-9. Description of LDS film "How Rare a Possession." The film's purpose is to motivate individuals to "read, study, and live the principles of the Book of Mormon." [A.C.W.]

C.228 Church of Christ (Lukites). Do the Latter Day Saints Teachings Agree with the Book of Mormon? Independence, $\mathrm{MO}$ : Church of Christ, n.d. An evangelical pamphlet that asserts that the teachings of the Church of Jesus Christ of Latter-day Saints are contradictory to the Book of Mormon. [M.R.]

C.229 Church of Christ (Lukites). Do You Know What the Book of Mormon Teaches? Independence, MO: Church of Christ, n.d. An evangelical pamphlet outlining several points of doctrine taught in the Book of Mormon. [M.R.]

C.230 Church of Christ (Temple Lot). Plain and Precious Things: A Study Guide to the Establishment of the Stick of Judah and the Stick of Joseph in One. Independence, MO: Church of Christ, April 1956. A Sunday School manual for the Church of Christ. Provides a historical sketch of the book's coming forth and some of its teachings on faith, repentance, baptism, laying on of hands, resurrections, eternal judgment, and priesthood authority. [J.W.M.]

C.231 Church of Christ (Temple Lot). This Is What We Believe and Teach. Independence, MO: Board of Publication, Church of Christ, 1970. A pamphlet that states that the above church believes that the Bible contains the word of God and the Book of Mormon is an added witness. Evidences and scriptures such as Ezekiel 37:19 and Genesis 49:22-26 are cited to support the Book of Mormon. [B.D.] 
C.232 Church of Christ (Temple Lot). Whence Came the Book of Mormon? Independence, MO: Church of Christ, n.d. Booklet seeking to prove that the Book of Mormon is true but the LDS church is false. Discusses the translation and witnesses of the Book of Mormon and the ways in which the Book of Mormon confirms the Bible. The Book of Mormon teaches doctrines different from those taught in the LDS church concerning God, the afterlife, and the Atonement. [A.C.W.]

C.233 Church of Jesus Christ of Latter-day Saints. Book of Mormon, 1 Nephi through Alma 29, Gospel Doctrine Teacher's Supplement. Salt Lake City: Church of Jesus Christ of Latter-day Saints, 1975. A manual containing fortytwo lessons for teachers of adult Sunday School classes. Each lesson consists of: "(1) the object or purpose for which the lesson is taught, (2) lesson sections, each with a heading that indicates its content, and (3) suggested methods for presenting these sections." The manual contains charts and commentaries on selected passages. [A.T.]

C.234 Church of Jesus Christ of Latter-day Saints. Book of Mormon, Alma 30 through Moroni 10, Gospel Doctrine Teacher's Supplement. Salt Lake City: Church of Jesus Christ of Latter-day Saints, 1977. A teacher's manual for the adult Sunday School class written to enable the student "to become more familiar with the people, places, and events of the scriptures, [and] to feel more secure in using the scriptures to answer life's questions." [B.D.]

C.235 Church of Jesus Christ of Latter-day Saints. The Book of Mormon and You. Salt Lake City: Church of Jesus Christ of Latter-day Saints, n.d. A pamphlet designed for the non-Mormon audience. Provides interesting facts about the Book of Mormon and a brief description of its contents. [L.D.]

C.236 Church of Jesus Christ of Latter-day Saints. Book of Mormon Daily Student Manual. Salt Lake City: Church of Jesus Christ of Latter-day Saints, 1978. Written to assist youthful readers of the Book of Mormon in gaining a greater understanding of the Book of Mormon. Contains charts, stories, games, puzzles, maps, and biographies of Book of Mormon characters. [A.T.]

C.237 Church of Jesus Christ of Latter-day Saints. The Book of Mormon: Gospel Doctrine Teacher's Manual. Salt Lake City: Church of Jesus Christ of Latter-day Saints, 1991. A teacher's manual intended as a resource for Sunday School teachers of adult classes. Each lesson has two parts-"scriptural highlights which summarize the reading assignment, and a discussion and applications section." [A.T.]

C.238 Church of Jesus Christ of Latter-day Saints. The Book of Mormon: Gospel Doctrine Teacher's Supplement. Salt Lake City: Church of Jesus Christ of Latter-day Saints, 1987. A lesson manual containing forty-six chapters designed to assist Sunday School teachers with the Book of Mormon. Each chapter contains the lesson objective, preparation suggestions, main ideas, suggested methods for preparing the lesson, summary and application, class assignment, and resource material. [A.T.]

C.239 Church of Jesus Christ of Latter-day Saints. Book of Mormon Lesson Units. Salt Lake City: Church of Jesus Christ of Latter-day Saints, 1968. A collection of thirty-nine lessons on the Book of Mormon that are to be taught in nine months. [B.D.]

C.240 Church of Jesus Christ of Latter-day Saints. Book of Mormon Manuscript. Salt Lake City: Church of Jesus Christ of Latter-day Saints, 198?. A photograph of a page of the original manuscript translation of the Book of Mormon showing 1 Nephi 2:2 to 1 Nephi 3:18. [A.T.]

C.241 Church of Jesus Christ of Latter-day Saints. The Book of Mormon Marking Project. Salt Lake City: Church of Jesus Christ of Latter-day Saints, 1964. A six-page pamphlet giving instruction for marking copies of the Book of 
Mormon for placement in hotels and other locations. The purpose of the marking is to highlight that the Book of Mormon is a second witness for Christ, to describe faith, and to point out other aspects of the book. [A.T.]

C.242 Church of Jesus Christ of Latter-day Saints. The Book of Mormon Pavilion, 'Ancient America Speaks': An Exhibit by the Church of Jesus Christ of Latter-day Saints. Spokane: Church of Jesus Christ of Latter-day Saints, 1974. A pamphlet presented to visitors of the Book of Mormon pavilion that summarizes the contents of the Book of Mormon and beliefs of the Church. [M.D.P.]

C.243 Church of Jesus Christ of Latter-day Saints. Book of Mormon Pretest, Postest. Salt Lake City: Church of Jesus Christ of Latter-day Saints, 1982. A booklet containing ninety-four multiple choice questions about the Book of Mormon. The booklet does not provide the answers. Designed for high school students. [A.T.]

C.244 Church of Jesus Christ of Latter-day Saints. A Book of Mormon Reader for Youth. Salt Lake City: Church of Jesus Christ of Latter-day Saints, 1973. Comprises sixteen different Book of Mormon stories, each illustrated with black and white drawings, captions, and an outline of each story. [A.T.]

C.245 Church of Jesus Christ of Latter-day Saints. Book of Mormon Stories for Beginning Readers. Salt Lake City: Church of Jesus Christ of Latter-day Saints, 1978. Contains colored drawings of scenes from the Book of Mormon with a short caption located below each picture. [A.T.]

C.246 Church of Jesus Christ of Latter-day Saints. Book of Mormon Sunday School Lessons. Salt Lake City: Church of Jesus Christ of Latter-day Saints, 19281940. Sunday School lessons published as weekly leaflets through 1931, as a quarterly through 1937, and for the full year in 1938 and 1940. Book of Mormon lessons are interspersed throughout and include history of the book, testimonies, doctrine, and other items. [B.D.]

C.247 Church of Jesus Christ of Latter-day Saints. Book of Mormon Supplement. Salt Lake City: Church of Jesus Christ of Latter-day Saints, 1972. A teacher's manual containing forty-two lessons to assist in teaching the Book of Mormon, providing "raw materials and suggested procedures out of which lessons may be built." Each lesson contains a main idea, supporting ideas, objectives, preassessment, ideas to be taught, learning activities, references, and teaching tools. [A.T.]

C.248 Church of Jesus Christ of Latter-day Saints. The Book of Mormon (Teachers' Supplement). Salt Lake City: Church of Jesus Christ of Latter-day Saints, 1983. Outlines for adult Sunday school lessons on the Book of Mormon. Includes quotations and statements of doctrine from Church leaders, thought provoking questions, and discussion suggestions. [J.W.M.]

C.249 Church of Jesus Christ of Latter-day Saints. Gold Plates Used Anciently. Salt Lake City: Deseret News Press, 1963. A pamphlet describing a number of ancient metal plates containing writings on them. These findings support claims that the Book of Mormon was written on metal plates. [B.D.]

C.250 Church of Jesus Christ of Latter-day Saints. History and Teachings of the Book of Mormon: Supplement for Religion 421 and 422. Provo, UT: Brigham Young University, 1967, [R]1968. This supplement is designed for university students of religion. It presents students with background information, doctrinal approaches, and bibliographical sources related to the Book of Mormon. [B.D.]

C.251 Church of Jesus Christ of Latter-day Saints. Jesus Christ Lives Today! Salt Lake City: Church of Jesus Christ of Latter-day Saints, 1970?. Pamphlet that explains that the Bible and the Book of Mormon bear witness of the 
divinity of Jesus Christ. [J.W.M.]

C.252 Church of Jesus Christ of Latter-day Saints. Jesus Christ, Savior and Mediator of Mankind. Salt Lake City: Church of Jesus Christ of Latter-day Saints, 1970. A pamphlet that declares that the Book of Mormon and the Bible bear witness of Christ's mission in two hemispheres. A brief history of how the Book of Mormon came forth is given. [J.W.M.]

C.253 Church of Jesus Christ of Latter-day Saints. Lamanites and the Book of Mormon. Salt Lake City: Church of Jesus Christ of Latter-day Saints, 1976. A pamphlet addressed to native American Indians, explaining that their ancestors are the people of the Book of Mormon. Ezekiel 37:16-17 and John 10:16 are quoted as support for the Book of Mormon. [B.D.]

C.254 Church of Jesus Christ of Latter-day Saints. The Life of Jesus Christ. Salt Lake City: Church of Jesus Christ of Latter-day Saints, 1976. A pamphlet depicting scenes from the life and teachings of Christ. [J.W.M.]

C.255 Church of Jesus Christ of Latter-day Saints. Living Truths from the Book of Mormon: Teacher's Supplement. Salt Lake City: Church of Jesus Christ of Latter-day Saints, 1972. A teacher's Sunday School manual containing fortythree lessons. The goal of the manual is to direct the attention of adult Church members to spiritual things. Each lesson contains a lesson plan and scriptural quotations relating to the topics being covered. [A.T.]

C.256 Church of Jesus Christ of Latter-day Saints. Merrie Miss B, Blazer B, Sunday School Course 11. Salt Lake City: Church of Jesus Christ of Latter-day Saints, 1981. Lessons for young people in Sunday School, based on Book of Mormon characters, events, and doctrine. [J.W.M.]

C.257 Church of Jesus Christ of Latter-day Saints. Message of the Book of Mormon: Indian Seminary Course of Study: Teacher Manual Course 9. Provo, UT: Department of Seminaries and Institutes of Religion, 1970. A manual for Seminary teachers who teach American Indians. Seventeen lessons cover a variety of topics including, transmission of the Book of Mormon, faith, courage, obedience, and the destiny of the Indian. [B.D.]

C.258 Church of Jesus Christ of Latter-day Saints. "Metal Plates, Stone Boxes." CN 39 (8 November 1969): 16. Attempts to demonstrate that contemporaries of Lehi used stone boxes and metal plates. [A.T.]

C.259 Church of Jesus Christ of Latter-day Saints. "More Gold Plates Found." CN 36 (25 June 1966): 16. Report of three 8 in. $x 5$ in. gold sheets found near Rome. Two were inscribed with ancient Etruscan, the other Phoenician. [A.T.]

C.260 Church of Jesus Christ of Latter-day Saints. Moroni: Prophet, Soldier, Scribe. Salt Lake City: Church of Jesus Christ of Latter-day Saints, 1974. A pamphlet that describes Moroni as a prophet, soldier, and scribe. [B.D.]

C.261 Church of Jesus Christ of Latter-day Saints. A New Volume of Scripture: The Revelations of God to the Ancient Americans. Liverpool: Millennial Star Office, 1885. A three-page advertisement announcing the availability of the Book of Mormon. Describes briefly the contents of the Book of Mormon. [B.D.]

C.262 Church of Jesus Christ of Latter-day Saints. An Overview: The Book of Mormon Course of Study. N.p., n.d. Three pamphlets provide helpful study aids for the Book of Mormon teacher. Includes an overview of the lessons and suggestions for audiovisual presentations. [B.D.] 
C.263 Church of Jesus Christ of Latter-day Saints. Read the Book of Mormon: It Can Change Your Life. Salt Lake City: Church of Jesus Christ of Latter-day Saints, 1975. A missionary tract encouraging people to read the Book of Mormon. The tract briefly explains a number of doctrines including belief in God, the Fall of Adam, and the Atonement of Christ. [A.T.]

C.264 Church of Jesus Christ of Latter-day Saints. Scriptures Stories. Salt Lake City: Church of Jesus Christ of Latter-day Saints, 1980. Designed for youth, comprises many illustrated stories from the Bible and the Book of Mormon, including escape of Limhi's people, and the stories of Ammon and Nephi. [L.D.]

C.265 Church of Jesus Christ of Latter-day Saints: Southern California District Seminaries. Resource Units for Book of Mormon Course Study. Salt Lake City: Church of Jesus Christ of Latter-day Saints, 1954-1955, [R] 1956. Resource material for part-time seminary teachers in the southern California district seminaries designed to aid the teachers in selecting the most significant events and facts from Book of Mormon history and how they can best be taught. [B.D.]

C.266 Church of Jesus Christ of Latter-day Saints. A Sure Foundation: Answers to Difficult Gospel Questions. Salt Lake City: Deseret Book, 1988. A selection of questions/answers dealing with Mormon belief. Representative Book of Mormon questions include: Why does the Book of Mormon use the terms "adieu," "Bible," and "baptize?" Why was Jesus was born at Jerusalem? Why have changes been made in editions of the Book of Mormon subsequent to the first edition? How is the Book of Mormon related to the writings of Spaulding and Ethan Smith? [B.D.]

C.267 Church of Jesus Christ of Latter-day Saints. Third Nephi, the Book of Nephi: Christ's Ministry in America, from the Book of Mormon. Salt Lake City: Mutual Improvement Association of the LDS Church, 1946. A pocket-sized work containing the book of 3 Nephi, selections from the Joseph Smith History describing Moroni's visit and the translation of the gold plates, the testimony of the Three and Eight Witnesses, and a number of Book of Mormon references. [A.T.]

C.268 Church of Jesus Christ of Latter-day Saints. 23 Questions Answered by the Book of Mormon. Salt Lake City: Church of Jesus Christ of Latter-day Saints, 1977. A one page list of twenty-three questions concerning doctrine of the Church and God's dealings with humanity followed by references from the Book of Mormon that provide the answers. [J.W.M.]

C.269 Church of Jesus Christ of Latter-day Saints. What is the Book of Mormon? Salt Lake City: Church of Jesus Christ of Latter-day Saints, 1982. A missionary tract explaining the coming forth and background of the Book of Mormon. Contains photographs of ancient ruins in Central and South America as evidence for the Book of Mormon. [A.T.]

C.270 Church of Jesus Christ of Latter-day Saints. Witnesses to the Book of Mormon. Salt Lake City: Church of Jesus Christ of Latter-day Saints, 1973. A missionary tract containing the testimonies of Oliver Cowdery, Martin Harris, David Whitmer, Emma Smith, and Lucy Mack Smith as they concern the Book of Mormon. [A.T.]

C.271 Church of Jesus Christ of Latter-day Saints, Board of Education. Introduction to a Study of the Book of Mormon Prepared Especially for Use in the Schools of the Church. Salt Lake City: Church of Jesus Christ of Latter-day Saints, 1917. A Book of Mormon lesson manual designed for seminary students. Discusses the First Vision, the origin of the book of Mormon, the witnesses to the gold plates, and other related items. [J.W.M.] 
C.272 Church of Jesus Christ of Latter-day Saints, Board of Education. Introduction to a Study of the Book of Mormon. Salt Lake City: Church of Jesus Christ of Latter-day Saints, 1914. A Book of Mormon manual for seminary students that includes a narration of the First Vision, the origin of the Book of Mormon, and a discussion of the witnesses to the gold plates. [J.W.M.]

C.273 Church of Jesus Christ of Latter-day Saints, Board of Education. Selected References Concerning Lamanites from the Journal of Discourses and Extracts from the Comprehensive History of the Church. Salt Lake City: Church of Jesus Christ of Latter-day Saints, 1960. A compilation of references dealing with the Lamanites taken from the Journal of Discourses and from the Comprehensive History of the Church. The references include prophecies about the Lamanites, a description of their Book of Mormon background, and the blessings that await them. [M.D.P.]

C.274 Church of Jesus Christ of Latter-day Saints, CES. The Book of Mormon Course of Study. Salt Lake City: Church of Jesus Christ of Latter-day Saints, 1970. A kit containing two manuals and 36 folders for seminary teachers of the Book of Mormon. The manuals contain general instructions and ideas for teaching and the folders contain lesson outlines, devotional suggestions, topical resources, and creative ways to present the lesson. [M.D.P.]

C.275 Church of Jesus Christ of Latter-day Saints, CES. Book of Mormon Student Manual, Religion 121 \& 122. Salt Lake City: Church of Jesus Christ of Latter-day Saints, 1989. A manual for college students of the Book of Mormon, covering all chapters of the Book of Mormon. [B.D.]

C.276 Church of Jesus Christ of Latter-day Saints, CES. Home-Study Seminary Teacher Outline. Salt Lake City: Church of Jesus Christ of Latter-day Saints, 1986, 1989. A manual comprising thirty-two lessons for the homestudy seminary teacher. The manual contains teacher's aids, charts, drawings, and scriptural commentary. [A.T.]

C.277 Church of Jesus Christ of Latter-day Saints, CES. Message of the Book of Mormon. Provo, UT: Department of Seminaries and Institutes of Religion, 1964. A seminary teacher's manual designed for Indian students. Includes lesson outlines, lesson objectives, ideas for devotional materials, creative ways to present the lesson, and lesson preparation aids. [M.D.P.]

C.278 Church of Jesus Christ of Latter-day Saints, CES. Seminary Student Manual Answers: Book of Mormon. Salt Lake City: Church of Jesus Christ of Latter-day Saints, 1986, 1989. Contains the answers for the questions located in a companion volume entitled Seminary Student Manual: Book of Mormon. [A.T.]

C.279 Church of Jesus Christ of Latter-day Saints, CES. Seminary Student Manual: Book of Mormon. Salt Lake City: Church of Jesus Christ of Latter-day Saints, 1986, 1989. Manual for youth enrolled in the seminary program of the Church. Contains charts, maps, instructions for marking the Book of Mormon, commentary on Book of Mormon passages, testing exercises, reading assignments, and personal application sections. [A.T.]

C.280 Church of Jesus Christ of Latter-day Saints, Church Schools. To Show What Great Things the Lord Hath Done for Our Fathers: A Book of Mormon. Pacific Islands: Church of Jesus Christ of Latter-day Saints, n.d. A "Book of Mormon reader for youth," dealing with the history and events of the Book of Mormon. The work has illustrations and a vocabulary of difficult words. [B.D.]

C.281 Church of Jesus Christ of Latter-day Saints, Finnish Missions. The Challenge the "Book of Mormon" Makes to the World. Finland: Church of Jesus Christ of Latter-day Saints, n.d. A missionary tract that challenges nonbelievers to duplicate the text of the Book of Mormon. There are 30 specific challenges: one challenge reads, for 
instance, "over 80,000 competent salesmen must be so sold on your book that they gladly give up two or more years of their lives to take it to all parts of the world." [D.W.P.]

C.282 Church of Jesus Christ of Latter-day Saints, Youth and Young Adult Correlation Committee of the LDS Church. Student Manual, Book of Mormon. 2 vols. Salt Lake City: Church of Jesus Christ of Latter-day Saints, 1973. A manual for the use of college students. [B.D.]

C.283 "Church-Produced Tapes of Book of Mormon Available." CN 58 (12 November 1988): 7. An announcement that a new set of audiocassette tapes of the Book of Mormon, produced by the Church, are now available. [M.D.P.]

C.284 "Church Scholars Speak." IE 63 (December 1960): 956-58. A number of excerpts from previously published articles by LDS authors cover such Book of Mormon related topics as the "fifth gospel," the stick of Joseph, language, the significance of scientific discoveries, and the manner in which Alma speaks to our day. [J.W.M.]

C.285 Claiborne, David J. The Story of a Mormon Convert: How he was lured into Mormonism and how he found the light again. Cleveland, OH: Utah Gospel Mission, 1904. A pamphlet published to reveal the evil designs of the Mormon Church. The Book of Mormon is a deceptive book, which contains 2,000 changes. [J.W.M.]

C.286 Clapp, J. C. "Probation After Death." SH 52 (29 March 1905): 321-24. The Book of Mormon sheds great light on the subject of life and the judgments of God that will occur after death. [J.W.M.]

C.287 Clark, Curtis W. "The Mound Builders and the Indians." SH 64 (14, 21 November 1917): 1085-89, 1109-14. A two-part series. The Book of Mormon presents the history and civilization of three distinct peoples who settled in the Americas. Clark identifies these peoples with the Mound Builders found in North and South America, who were well acquainted with Egyptian language and culture. Also compares the destruction of the Cliff Dwellers or Pueblo Indians with the people destroyed at the time of Christ's appearance on the American continent. These Indians used iron and steel and possessed animals that had their origin in Asia and Egypt. [J.W.M.]

C.288 Clark, Curtis W. "A Testimony of the Book of Mormon." SH (15 December 1945): 14-15. Describes a dream concerning the author's work with the Book of Mormon and its external evidences, and the eventual fulfillment of a dream described in the article "The Mound Builders and the Indians." [D.M.]

C.289 Clark, David L. "Lehi and El Niño: A Method of Navigation." BYU Studies 30 (Summer 1990): 57-65. Also, Provo, UT: FARMS, 1991. Natural means might have been used to transport Lehi's group to the promised land. Under ordinary circumstances it would be difficult to traverse eastward from Indonesia to America as the ocean currents flow westerly. But a natural occurrence that happens every two to ten years changes the flow of currents to an easterly direction-it is called El Niño. Had Lehi traveled from the Arabian Peninsula in August at the height of the monsoonal cycle and reached the Pacific in time to catch the El Niño he would have landed on the west coast of Central America. [J.W.M.]

C.290 Clark, E. Douglas. The Grand Design: America from Columbus to Zion. Salt Lake City: Deseret Book, 1992. Asserts that history is often so obscure that God's help is needed to understand it. The Book of Mormon is the providential means to understand the history and future of America. It contains prophecies about Columbus, the discovery and establishment of America, and future events connected with America, including the establishment of Zion. [B.D.] 
C.291 Clark, E. Douglas, and Robert S. Clark. Fathers and Sons in the Book of Mormon. Salt Lake City: Deseret Book, 1991. Describes the relationships between fathers and sons in the Book of Mormon. For instance, righteous fathers taught their sons and righteous sons followed the example of their fathers. The greatest father and son are represented to be God and Jesus Christ. The book reinforces and describes the most important role of a manfatherhood. This work is reviewed in J.114 and M.240. [B.D.]

C.292 Clark, George Edward. Why I Believe: 54 Evidences of the Divine Mission of the Prophet Joseph Smith. Salt Lake City: Bookcraft, 1952. The 54 evidences are divided into three sections: general evidences, doctrinal evidences, and Book of Mormon evidences. Book of Mormon evidences involve external evidence including the Savior in America, steel, horses and elephants, Hebrew language, literary style, and many others. [J.W.M.]

C.293 Clark, J. Reuben, Jr. " 'All Roads Lead to Rome.'” IE 63 (June 1960): 398-99. Discusses Lehi's vision, Christ's sermon at the temple to the Nephites, and emphasizes the correctness of the Book of Mormon translation. The Book of Mormon, when used in concert with the Bible, will guide individuals to the one and only road to heaven. [A.C.W.]

C.294 Clark, J. Reuben, Jr. "Eighth Period: The Benediction upon Our Lord's Ministry-His Visit to the Western Hemisphere." In Clark's Our Lord of the Gospels, 463-517. Salt Lake City: Deseret News Press, 1954. Uses scriptural references from 3 Nephi interspersed with commentary to tell about the Savior's visit to the American Continent. [J.W.M.]

C.295 Clark, J. Reuben Jr. "A Heavenly Being Brings Good Tidings." In Clark's On the Way to Immortality and Eternal Life, 127-35. Salt Lake City: Deseret Book, 1949. Describes the visit of angel Moroni to Joseph Smith and reception of the Book of Mormon. The best explanation of the Book of Mormon is the one delivered by Joseph Smith. The eleven witnesses have confirmed his testimony with their testimonies. [J.W.M.]

C.296 Clark, John A. Gleanings By the Way. Philadelphia: Simon \& Carter, 1842. A polemical attack on Mormonism. The 1841 Anthon denial is recounted. The author espouses the Spaulding theory for the origin of the Book of Mormon. Enumerates various anachronisms in the Book of Mormon, such as the idea of a church before the time of Christ, modern teachings among the Nephites, the term "Christians," and the New Testament language in the Book of Mormon. [M.R.]

C.297 Clark, John E. "Book of Mormon Geography." In Encyclopedia of Mormonism, edited by Daniel H. Ludlow, 176-79. 5 vols. New York: Macmillan, 1992. Geographic features of the Book of Mormon, including the narrow neck of land, the east and the west seas, the hill Cumorah that figured in the final battles of two major civilizations, and the time of travel between areas by journeying groups and individuals permit some evaluation of Book of Mormon geography. Studies indicate the most dense population activity was west of the Yucatan Peninsula. No Church sanction has been given to any proposals regarding Book of Mormon geography. [N.K.Y.]

C.298 Clark, John, William Hamblin, and Mark V. Withers. Review of Deciphering the Geography of the Book of Mormon by F. Richard Hauck. Review of Books on the Book of Mormon 1 (1989): 20-70, 71-77, 78-79. Book review.

C.299 Clavey, Bruce W. "Biblical Messianism and the Book of Mormon." In Restoration Studies III, edited by Maurice L. Draper, 232-43. Independence, MO: Herald House, 1986. The Book of Mormon concept of kingship and messianism came from the world of the Bible, from which the Book of Mormon peoples originated. The early Book of Mormon prophets selected Old Testament passages to identify Jesus Christ as the Messiah who would suffer the atoning sacrifice for the sins of mankind. [J.W.M.] 
C.300 Clawson, Rudger. Untitled talk. CR (April 1904): 42-45. A talk on prayer that emphasizes the fact that the coming forth of the Book of Mormon was greatly influenced by prayer. Doctrine and Covenants 10 clearly shows that the records of the Book of Mormon were preserved in answer to prayers offered by Nephite prophets up to 1400 years ago. [J.W.M.]

C.301 Clawson, Rudger. Untitled talk. CR (April 1926): 139-42. Affirming the Christian status of the Church of Jesus Christ of Latter-day Saints, the author declares that the standard works of the Church include the Bible, the Book of Mormon, the Doctrine and Covenants, and the Pearl of Great Price and then describes why each work is considered scripture by the Church. [J.W.M.]

C.302 Clawson, Rudger. Untitled talk. CR (April 1929): 25-29. There are four scriptural works that stand as witnesses to the Gospel of Christ-the Bible, Book of Mormon, Doctrine and Covenants, and Pearl of Great Price. The Book of Mormon is a sacred history of the ancient inhabitants of America. The Three Witnesses, Eight Witnesses, and Joseph Smith all bear individual testimonies concerning the truth of the Book of Mormon. [J.W.M.]

C.303 Clay, Edmund. The Book of Mormon: Its History and an Analysis of its Contents. London: Wertheim and Macintosh, 1850. A polemical tract against the Book of Mormon, wherein the book is viewed as a shallow fraud. Discussed are various anachronisms, contradictions with the Bible, use of the compass, Christian doctrines, alleged plagiarisms from the Bible, Jaredite barges, and other items. [M.R.]

C.304 Clay, Edmund. The Book of Mormon Proved to Be a Blasphemous and Impudent Forgery. London: Wertheim and Macintosh, 1850. A polemical tract against the Book of Mormon. Various anachronisms are enumerated by the writer. Criticisms of Book of Mormon witnesses, the Spaulding theory, and contradictions with the Bible are briefly discussed. [M.R.]

C.305 Clay, Edmund. The Doctrines and Practices of the 'Mormons' and the Immoral Character of Their Prophet Joseph Smith. London: Wertheim and Macintosh, 1853. Alleges that Joseph Smith possessed an immoral character and that the Book of Mormon is no more inspired of God than was the evil man who published it. [J.W.M.]

C.306 Clayton, Corliss. "Mormon and the Book of Mormon." Friend 18 (October 1988): 48-49. A rebus (a story puzzle with pictures representing part of the words) of the story of Mormon. [J.W.M.]

C.307 Clement, Russell T. "Polynesian Origins: More Word on the Mormon Perspective." Dialogue 13 (Winter 1980): 88-98. Reviews the claims of the scientists and Mormon leaders regarding the origin of the Polynesians. The debate continues among scientists, some favoring American origins, while most tend to Asian origins. Mormon leaders have consistently held that the Polynesians came from the American continent. [B.D.]

C.308 Clemmer, Janice White. "A Testimony." In Sidney B. Sperry Symposium: The Book of Mormon, edited by A. Gary Anderson, 11-17. Provo, UT: Brigham Young University Religious Studies Center, 1981. A testimonial wherein the author states that knowledge of the Old and New Testaments prepared her for the Book of Mormon. The Book of Mormon explained her American Indian heritage and gave her dignity. [J.W.M.]

C.309 Clift, Frederic. "Book of Mormon Language: Hebrew and Egyptian." IE 8 (January 1905): 168-76. A stance defending the proposition that the Book of Mormon was written in Egyptian. Hints that neighboring alphabets, such as Hebrew, Arabic, Chaldean, and Assyriac are also found in the Book of Mormon. Charles Anthon's comments to Martin Harris regarding the Book of Mormon characters are also mentioned. [D.M.] 
C.310 Cloward, Robert A. The Joseph Smith Translation: The Restoration of Plain and Precious Things, 163-200. Provo, UT: Brigham Young University Religious Studies Center, 1985. Also in "The Sermon on the Mount in the Joseph Smith Translation of the Bible and the Book of Mormon." Provo, UT: FARMS, 1985. Demonstrates how the Joseph Smith Translation of the Bible and the Book of Mormon enlarge one's understanding of the Sermon on the Mount. Examines such topics as: audience and setting, disciples and beatitudes, salt and light, and the old and the new law. The author highlights differences in the three versions and provides a short commentary. [A.T.]

C.311 Cloward, Robert A., and Kathleen P. Cloward. "Teaching the Divine Attribute of Mercy with the Book of Mormon." In A Symposium on the Book of Mormon, 18-23. Salt Lake City: Church of Jesus Christ of Latter-day Saints, CES, August 1986. Sets forth one approach that teachers of the Book of Mormon may utilize to teach mercy to their students. [A.T.]

C.312 Cluny, Russell F. "The Book of Mormon, The Testimony of the Witnesses." In Cluny's Positive Evidence of the Restored Church, 26-30. Salt Lake City: Russell F. Cluny, 1953. Declares that both the Bible and the Book of Mormon are spiritual guides for the Church. The Book of Mormon is in harmony with the Bible and contains the everlasting gospel as preached to the Savior's "other sheep" in America. The Book of Mormon is an abridgment of several metal plates and the Three Witnesses testify of its truthfulness. [J.W.M.]

C.313 Coe, Michael. "Mormons and Archaeology-An Outside View." Dialogue 8 (Winter 1973): 40-48. Discusses the history of and demonstrates the fallacies of LDS attempts to establish the truth of the Book of Mormon through archaeological evidences. Cites the improbability of there existing horses, chariots, wheat, and metallurgy in ancient America, as the Book of Mormon claims. [A.C.W.]

C.314 Cohen, Irving H. The Jews in Relation to the Book of Mormon, Jews of Torah. Scotia, NY: Cumorah, 1967. Shows how the Torah was revealed. Argues that the Bible is incomplete and that the Book of Mormon should be esteemed as highly as the Bible. Uses Ezekiel 37:16-17, 2 Nephi 29, and Moroni 10 in his discussion of the importance of the Book of Mormon. [B.D.]

C.315 Cole, Clarissa Katherine. "Promised Land, Concept of a." In Encyclopedia of Mormonism, edited by Daniel H. Ludlow, 3:1160. 5 vols. New York: Macmillan, 1992. The Book of Mormon gives special meaning to the land of promise. It is a land of inheritance belonging to the Lord, a place of freedom and refuge for those who serve the Savior. [J.W.M.]

C.316 Cole, William A., and Elwin W. Jensen. Israel in the Pacific. Salt Lake City: Genealogical Society, 1961. A textbook for the Polynesian people that deals with their origin, genealogy, traditions, responsibilities, and blessings as a chosen people of God. Includes charts, photographs and illustrations. [J.W.M.]

C.317 Coleman, Clifford E. "The Book on My Closet Shelf." Ensign 19 (June 1989): 54-55. After searching for the answer to, "Which church is true?" the author remembered the book on the shelf. He found the answer to his question in the Book of Mormon and bears witness to its truthfulness. [J.W.M.]

C.318 Collier, Fred C. "The Enigma of Book of Mormon Theology and the Fullness of the Gospel which It Contains." Restoration 4 (July 1985): 1, 10-14, 19-23. The Book of Mormon contains the fulness of the gospel of Christ. Many critics have pointed out that Joseph Smith's later Nauvoo period teachings are not contained in the Book of Mormon. Joseph Smith's later teachings pertain to the higher order of the Church of the Firstborn, the gospel of the Father, the doctrine of exaltation, which supersedes and is built on the gospel of Jesus Christ, the 
doctrine of salvation. The Book of Mormon hints at such teachings but does not reveal them (3 Nephi 27:10, 23, 3 Nephi 26:6-11, 16, 18). [B.D.]

C.319 Collier, Fred C. The Nauvoo Doctrine in Light of Book of Mormon Prophecy. Salt Lake City: Collier's Publishing, 1986. The Doctrine of Salvation (the Doctrine of Christ) is found clearly in the Book of Mormon and the Doctrine of Exaltation (the Nauvoo Doctrine or Doctrine of the Father), which deals with temple ordinances, is present in the Book of Mormon. The Book of Mormon does reveal and illuminate the "covenant which God the Father made to the Patriarchs Abraham, Isaac, and Jacob ... the 'work of the Father' (1 Nephi 14:17)." [J.W.M.]

C.320 Collins, William P. "The Baha'i Faith and Mormonism: Further Reflections." World Order 17 (Spring 1983): 25-33. Members of the Baha'i faith do not believe that Joseph Smith was a prophet nor do they consider the Book of Mormon divinely inspired scripture. In spite of the book's inadequacies, it is acknowledged as a book filled with "powerful, eternal, spiritual meaning that is capable of changing and guiding the lives of men." [J.W.M.]

C.321 Collins, William P. "Thoughts on the Mormon Scriptures: An Outsider's View of the Inspiration of Joseph Smith." Dialogue 15 (Autumn 1982): 49-59. A sympathetic appraisal of Mormon inspiration and scripture, written by a non-Mormon and member of the Baha'i faith. [M.R.]

C.322 Colom, P. Antonio J. "Teologia? Mormona (Exposicion y Refutacion).” Doctrina Politica Argentina (196?): 4257. Polemical article about Joseph Smith and the Book of Mormon that questions its authenticity and claims that certain passages imitate parts of the Methodist Book of Discipline. Discusses Book of Mormon teaching of Adam's $\sin$ [D.M.]

C.323 Combs, George Hamilton. Some Latter-Day Religions. Chicago: Revell, 1899. A polemical work highlighting the alleged problems and foibles of various "modern" religious groups. Pages 205-22 discuss Mormonism and the Book of Mormon. The author alleges that the Three Witnesses to the Book of Mormon denied the testimony of the book. The author advances the Spaulding theory to account for the book's origin. [M.R.]

C.324 "The Coming Forth of the Book of Mormon." Ensign 13 (December 1983): 31-51. A pictorial collection of documents, artifacts, and old photographs related to the coming forth of the Book of Mormon, accompanied by written accounts of the circumstances surrounding this event. [S.P.S.]

C.325 "Coming Forth of the Book of Mormon." Relief Society Magazine 20 (January 1933): 52-53. Reviews the obtaining and the translation of the gold plates by Joseph Smith, the Anthon incident and the publication of the Book of Mormon. [J.W.M.]

C.326 "Coming Forth of Book of Mormon Is a Sign Israel Is Being Gathered." CN 58 (15 October 1988): 10. The coming forth of the Book of Mormon is a sign that the Lord has commenced to gather Israel and to fulfill his covenants with them. [R.H.B.]

C.327 "Comparative Languages." CN 27 (30 November 1957): 7. Reprint of the Anthon transcript and the Meriotic script taken from the Stela of Prince Akininzaz. Points out that the "Meroites, Lehi's contemporaries, became isolated in [Central] Africa and developed a 'reformed Egyptian' style of writing." [A.C.W.]

C.328 Compier, Hendrik. "Inner Evidence." Restoration Witness 7 (May 1969): 4-5, 15. Author's testimony is not based on archaeology or history, but on the "plainness, honesty, simplicity, directness, boldness, and unapologizing 
approach" of the Book of Mormon. The Book of Mormon is a commentary on the Bible and clarifies its meaning. [J.W.M.]

C.329 Compilation of the Book of Mormon. Provo, UT: Department of Audio-Visual Communication BYU, n.d. Color diagram of the records that became the Book of Mormon, beginning with the brass plates to the finished product. [J.W.M.]

C.330 Compton, Giles Roy, Jr. True Origin of the Indian. Jacksonville, Alabama: Jacksonville State College, 1958. A pamphlet that enumerates several features of American Indian history that coincide with items found in the Book of Mormon. Discusses Quetzalcoatl, idols, and bees. [D.M.]

C.331 Compton, Todd. Review of Rediscovering the Book of Mormon: Insights You May Have Missed Before,by John L. Sorenson and Melvin J. Thorne. Sunstone 16 (August 1992): 60-61. Book review.

C.332 Compton, Todd M. "The Spirituality of the Outcast in the Book of Mormon." Journal of Book of Mormon Studies 2 (Spring 1993): 13960. The outcast of the Book of Mormon-the Lamanite, the poor, or others-often lean toward becoming spiritual, while the rich classes sometimes become wicked. Author compares the "outcast" of the Book of Mormon to John Wesley and the beginnings of Methodism, the Dionysiac religion, the poor Christians of India, and other groups. [A.T.]

C.333 Concerning the Record of the Nephites. Independence, MO: Church of Christ with the Elijah Message, 197 ? An introduction to the Book of Mormon, its people and records. 2 Nephi 28-30 presents what the Book of Mormon says concerning conditions today. [D.M.]

C.334 Condie, Spencer J. "A Mighty Change of Heart." Ensign 23 (November 1993): 15-17. Nephi, Mormon, King Benjamin, and others teach that the Holy Ghost actively participates in an individual's life by enticing, persuading, and influencing one to do good. We are admonished to cease contending with him because of pride and discouragement, which are strategies of Satan. Through the Spirit one may put the evils of pride and discouragement aside and experience the "mighty change of heart" (Mosiah 5:2) leading one toward perfection. [J.W.M.]

C.335 Condie, Spencer J. "Righteous Oaths, Reproofs, and Reconciliation (Alma 52-63)." In Studies in Scripture: Alma 30 to Moroni, edited by Kent P. Jackson, 8:80-91. Salt Lake City: Deseret Book, 1988. Discusses Captain Moroni, the Anti-Nephi-Lehies, the two thousand mothers and their stripling sons, Moroni's epistle to Pahoran, and Hagoth (Alma 52-63). Points out the importance of oaths, the proper exercise of authority, and how strength comes from unity. [J.W.M.]

C.336 Cong Ton Nu, Tuong-Vy. "Out of the Tiger's Den." Ensign 19 (June 1989): 44-47. The story and testimony of the courageous woman who translated the Book of Mormon into Vietnamese. [J.W.M.]

C.337 Conkling, Chris. "The Gentle Power of Jacob." Ensign 22 (February 1992): 7-10. Jacob's unique style as a poet-prophet demonstrates his "empathy for suffering" and "sensitivity to the challenges that women face." With sorrow and afflictions in his youth and his observance of sin in his own family, Jacob stresses the need for humility, denounces sin, and focuses on Israel's destiny. Jacob's writings show his "deep, personal witness of the suffering and sacrifice of the Savior" and of the Atonement. [A.C.W.] 
C.338 Connell, Maurice W. "The Prophet Said Silk." IE 65 (May 1962): 324-26, 338-40, 342, 344-45. The inclusion of the word "silk" in the Book of Mormon has been met with controversy. Evidence that there might have been silk production prior to the Spanish conquest is substantiated by excerpts from Thomas Gage's autobiography published in 1758. [J.W.M.]

C.339 Constance, Marguerite. "Shall I Read the Book of Mormon ... Again?" SH 117 (June 1970): 11, 36. It is necessity to reread the Book of Mormon and gain a mature understanding of it. [A.C.W.]

C.340 "Conversions through the Book of Mormon." IE 63 (November 1960): 814-15, 836. The article reprints three earlier published recollections of the profound converting effects of the Book of Mormon in the lives of three prominent early LDS personalities-Wilford Woodruff, Willard Richards, and Parley P. Pratt. Wilford Woodruff received his testimony in a missionary meeting held in a village schoolhouse. Willard Richards was touched by the Lord after reading the entire Book of Mormon twice in just ten days. Parley Pratt read the Book of Mormon straight through, non-stop, day and night, and the Spirit of the Lord came upon him and he knew it was true. [R.C.D.]

C.341 "A Convincing Analysis of the Fraudulent 'Book of Mormon." Sound Words (June 1946): 1-3. An essay consisting largely of polemical arguments of Clark Braden against the Book of Mormon. Argues that the Book of Mormon contains anachronisms, Elizabethan mediated Hebraisms, and Americanisms. Places credit for the Book of Mormon on Sidney Rigdon, a revivalist preacher. [D.M.]

C.342 Conybeare, W. J. "Mormonism." The Edinburgh Review 202 (April 1854): 320-84. A polemical article discussing the history of Mormonism. Aside from accepting the Spaulding theory, the author asserts that the Book of Mormon plagiarizes the Bible, is full of ungrammatical expressions, and condemns the practice of polygamy. He also recounts information regarding Joseph Smith's alleged money digging practices, the Anthon episode, the Book of Mormon witnesses, as well as other information relative to the Latter-day Saint movement. [M.R.]

C.343 Cook, Gene R. "Trust in the Lord." Ensign 16 (March 1986): 78-81. Challenges individuals to strive to reach their divine potential by trusting in Christ and following the Spirit's promptings. Provides an example of a young man who spoke regarding the controversial topic of the Book of Mormon for a school speech class and, trusting in the Lord, was able to bear testimony of the book and consequently touch lives. [J.W.M.]

C.344 Cook, Lyndon W., ed. David Whitmer Interviews. Orem, UT: Grandin Book, 1991. Presents a short biography and a collection of David Whitmer interviews and letters that date from March 1858 to January 1888. Many of the materials deal with his testimony of the truthfulness of the Book of Mormon. This work is reviewed in P.206. [J.W.M.]

C.345 Cook, William. The "Fowler's Snare," As Craftily Laid to Catch Unwary Souls. London: Joseph Masters, 1858. An exposé of Mormonism. The Book of Mormon plagiarizes the Bible. Its dull style makes it, for the author, a fitting sleep medicine. [M.R.]

C.346 Cook, William. A Friendly Warning to the Latter-day Saints. London: Wertheim, Macintosh \& Hunt, 1860. A polemical work against Mormonism. The author makes much of the Book of Mormon's condemnation of polygamy. [M.R.]

C.347 Coons, Lela Bartlett. "Bright Scripture." Ensign 23 (February 1993): 54. A testimony of the warmth and bright feeling reading the Book of Mormon has given to the author since childhood. [S.H.] 
C.348 Cooper, R. T. "Lamanite Traditions." SH 60 (31 December 1913): 1264-65. A synopsis of a lecture given by Patrick Miguel, chief of the Yuma California Tribe, who discusses Indian traditions concerning the cross of Jesus and Christ's visit to the Indians during ancient times. Miguel also discusses the role of the Book of Mormon in his conversion to Christ. [A.T.]

C.349 Corbett, Don C. Prophecies Contained in Book of Mormon. N.p, n.d. A mimeographed sheet containing a collection of prophecies delivered throughout the Book of Mormon. [D.M.]

C.350 Corrill, John. A Brief History of the Church of Jesus Christ of Latter-day Saints, (Commonly called Mormons); Including an Account of Their Doctrine and Discipline; with the Reasons of the Author for Leaving the Church. St. Louis, MO: John Corrill, 1839. Corrill presents a short history of the Church, including his thorough investigation of the Book of Mormon, his ultimate acceptance of it, his conversion to the Church, and the reasons he left the Church. [J.W.M.]

C.351 "Corroborative Evidence." MS 62 (6 December 1900): 783-84. The historical and religious portions of the Book of Mormon cannot be separated. External evidence verifies the historical portions. New York World reports a mound where a tablet inscribed with the Ten Commandments, "sarcophagi," pottery and pictures that resemble that flood story, and characters resembling Egyptian and Assyrian writing were found. [J.W.M.]

C.352 Cottam, William. "I Have a Question: If both the Lamanites and the Nephites became wicked in the end, why was one group destroyed while the Lord allowed the other to remain?" Ensign 20 (June 1990): 15. The wickedness of the Nephites exceeded that of the Lamanites. The Nephites were cursed if they turned from the Lord. The Lamanites, wicked because of the traditions of their fathers, would be blessed with the gospel in the latter-days. [J.W.M.]

C.353 Couch, Edward T. "The Restitution." In Couch's The Sabbath And The Restitution, March 1891, 22-28. Bay Spring, MI: n.p., March 1891. Biblical writers were aware that an apostasy would take place. Isaiah prophesied of a sealed book that would come forth. Joseph Smith translated the sealed book; witnesses bear testimony that the plates were sealed. Martin Harris's visit to professor Anthon fulfilled Isaiah's prophecy. [J.W.M.]

C.354 Cowan, Marvin W. Mormon Claims Answered. Salt Lake City: n.p., 1975. Translated in Spanish as Los Mormones: Sus Doctrinas Refutadas A La Luz de la Biblia. El Paso, Texas: Casa Bautista de Publicaciones, 1977. A polemical work against Mormonism, debunking Mormon doctrines and scripture. Pages 28-51 are concerned with the Book of Mormon. Among the numerous points discussed are: Mormon "proof texts" from Bible prophecy, the Anthon denial, thirty-two internal anachronisms, changes in the Book of Mormon, translation problems, dependence upon View of the Hebrews, problems with the Book of Mormon witnesses, and lack of scientific and archaeological evidence. [M.R.]

C.355 Cowan, Richard O. "American History Foreseen by Nephi." Instructor 101 (September 1966): 328-29. The remarkable vision of Nephi in 1 Nephi 13 speaks concerning the Savior's visit to America, Columbus' crossing the ocean, and the "plain and precious" truths of the gospel in the Book of Mormon that would come forth. [J.W.M.]

C.356 Cowan, Richard O. "Aztec History and the Book of Mormon." Instructor 102 (March 1967): 131-33. External evidences of the Book of Mormon provide an additional witness for the truth of the Book of Mormon. For instance, Aztec history has several parallels in the Book of Mormon. [B.W.J.] 
C.357 Cowan, Richard O. "Historians of the Book of Mormon." Instructor 97 (December 1962): 444-45. A synopsis of the prominent record keepers of the Book of Mormon. A serviceable chart notes the authors, the time span they covered, and the amount of pages their writings occupy. [J.W.M.]

C.358 Cowan, Richard O. "In the Mouth of Two or Three Witnesses." Instructor 99 (August 1964): 328-29. The Book of Mormon is a witness of Christ. In accordance with the ancient biblical law of witnesses, the Book of Mormon complements the Old and New Testaments with its teachings and truths. [J.W.M.]

C.359 Cowan, Richard O. "The Lamanites-A More Accurate Image." In The Book of Mormon: Helaman through 3 Nephi 8, According to Thy Word, edited by Monte S. Nyman and Charles D. Tate Jr., 251-64. Provo, UT: Brigham Young University Religious Studies Center, 1992. Discusses Laman and Lemuel and the Lamanites of today. Points out that the Lamanites often superseded the Nephites in righteousness and that the Lamanites yet anticipate a glorious destiny. [D.M.]

C.360 Cowan, Richard O. "The Lehi Stone." Instructor 103 (March 1968): 132-33. A monument in Chiapas, Mexico (the Lehi Stone) has several correlations with the Book of Mormon tree of life pericope (1 Nephi 8, 11). Author provides a drawing and brief explanation of the monument. [B.W.J.]

C.361 Cowan, Richard O. "A New Meaning of 'Restoration': The Book of Mormon on Life after Death." In The Book of Mormon: Alma, The Testimony of the Word, edited by Monte S. Nyman and Charles D. Tate Jr., 195-210. Provo, UT: Brigham Young University Religious Studies Center, 1992. The Book of Mormon and modern prophets teach many things regarding life after death - there exists a probationary time after death before the resurrection; righteous spirits are separated from the wicked; the body will be restored to the spirit at the resurrection; physical defects present at death will eventually be removed. Further, at the day of judgment all will have a bright recollection of their earthly doings. [N.K.Y.]

C.362 Cowan, Richard O. "The Tame and Wild Olive Tree." Instructor 99 (October 1964): 415-16. The prophet Zenos outlined the history of Israel in the allegory of the olive tree in Jacob 5. Author includes a graph depicting the scattering and gathering of Israel. [J.W.M.]

C.363 Cowan, Richard O." 'We Did Magnify Our Office unto the Lord.' In The Book of Mormon: Jacob through Words of Mormon, To Learn with Joy, edited by Monte S. Nyman and Charles D. Tate Jr., 73-86. Provo, UT: Brigham Young University Religious Studies Center, 1990. The Doctrine and Covenants is not the only source of information on the Church's mission and organization. The Book of Mormon also contains valuable information on the organization of the Nephite church and it also "sets forth worthy examples we should follow in order to 'magnify our office unto the Lord' (Jacob 1:19)." [B.D.]

C.364 Cowan, Richard O. "When Jesus Visited Some 'Other Sheep.' "Instructor 96 (December 1961): 444-45. The "American Gospel" (3 Nephi), as recorded in the Book of Mormon, clarifies, and supports the teachings of the Bible and testifies of its authenticity. When Jesus Christ visited the American continent he blessed his people, organized his Church, and taught the gospel. [J.W.M.]

C.365 Cowan, Richard O. "Who Are the Lamanites?" Instructor 103 (May 1968): 211. The history of the term Lamanite is traced through the scriptures. "The 'Lamanite' nation, which was preserved, included descendants not only of Laman and Lemuel, but also of Nephi and his righteous brethren." A helpful chart shows the intermingling of family lines. [B.W.J.] 
C.366 Cowan, Richard O., and Gerry Avant, comps. "Book's Purpose: 'Convince All That Jesus is the Christ.' " CN 58 (27 August 1988): 12. The stated mission of the Book of Mormon is to convince both Jew and Gentile that Jesus is the Christ. [R.H.B.]

C.367 Cowan, Richard O., Gerry Avant, and R. Scott Lloyd. "Three Nephite Disciples Have a Special Mission to Perform." CN 58 (15 October 1988): 10. Three of the Savior's Nephite disciples remain on the earth until his second coming. The Prophet Joseph Smith testified of their terrestrial state and that their translated bodies were designed for important future missions. Jesus gave them a promise of a still greater change to occur when he comes in his glory. [J.W.M.]

C.368 Cowdery, Oliver. "The Coming Forth of the Book of Mormon." In Studies in Scripture: 1 Nephi to Alma 29, edited by Kent P. Jackson, 7:10-16. Salt Lake: Deseret Book, 1987. A reprint of selected statements drawn from articles published in the Messenger and Advocate wherein Oliver Cowdery describes the events dealing with the coming forth of the Book of Mormon. [J.W.M.]

C.369 Cowdery, Oliver [sic]. Defense in a Rehearsal of My Grounds for Separating Myselffrom the Latter-day Saints. Norton, Ohio: Pressley's Job Office, 1839. A purported denial of Mormonism, allegedly made by Oliver Cowdery in 1839. Likely a spurious account that denies Mormonism, and questions the truth of the Book of Mormon and the translation process. See Anderson, Richard Lloyd. "Oliver Cowdery's Testimony." Ensign 17 (April 1987): 23-25. [M.R.]

C.370 Cowdery, Oliver. "Delusion." M\&A 1 (March 1835): 90-93. Title is taken from a pamphlet written by Alexander Campbell. Challenges Campbell's arguments and discusses the Aaronic versus the Nephite priesthood, the offering of sacrifice, a land of promise outside of Canaan, and the central role of the temple in Jerusalem. [D.M.]

C.371 Cowdery, Oliver. "Early Scenes and Incidents in the Church." IE 2 (July 1899): 652-58. Speaks of Joseph Smith's visions of Moroni, the last battles of the Jaredites, and of the Nephites on the hill Cumorah. [B.D.]

C.372 Cowdery, Oliver. "Letter." M\&A 1 (October 1834): 13-16. Tells about meeting Joseph Smith for the first time and beginning his (Oliver Cowdery's) task as the scribe in the translation process of the Book of Mormon. Bears testimony to the genuine nature of the book. [D.M.]

C.373 Cowdery, Oliver. "Letter IV." M\&A 1 (February 1835): 77-80. A recital of the events leading to the coming forth of the Book of Mormon, emphasizing Joseph Smith's encounter with the angel. [D.M.]

C.374 Cowdery, Oliver. "Letter VII." M\&A 1 (July 1835): 155-59. Describes the Hill Cumorah, and identifies it with the final scenes of destruction for the Nephites and Jaredites. [D.M.]

C.375 Cowdery, Oliver. "Letter VIII." M\&A 2 (October 1835): 195-202. Gives an account of when Joseph Smith Jr. went to find the plates in the Hill Cumorah. The box that contained the plates is described. [B.D.]

C.376 Cowdery, Oliver. Letters of Oliver Cowdery to W. W. Phelps on the Origin of the Book of Mormon, and the Rise of the Church of Jesus Christ of Latter-day Saints. Liverpool, England: n.p., 1844. Also in Joseph Smith Jr.'s Rare Reprints, \#23. Independence, MO: n.p., 1990; and in Letters of Oliver Cowdery: Showing the Rise and Progress of the LDS Church. Lamoni, IA: RLDS Church, 189?. Seven letters (ca. 1839) containing testimony concerning Cowdery's scribal work for Joseph Smith during the translation of the Book of Mormon and other items of historical interest. 
Joseph's own narrative includes an account of the place and manner in which the records were deposited, the box that held the plates, his attempts to take the plates without authorization from the angel, and the angel's warning. [J.W.M.]

C.377 Cowdery, Oliver. "O. Cowdery's First Letter to W. W. Phelps." MS 3 (January 1843): 152-54. Letter also found in M\&A 1 (October 1834): 13-16. A letter written to W. W. Phelps from Norton, Medina County, Ohio, Sabbath evening, September 7, 1834. Cowdery writes of his first meeting with the prophet and his immediate work began as scribe for Joseph Smith for the translation of the Book of Mormon. Then he writes of the manifestation of the angel to give the Aaronic Priesthood. [B.D.]

C.378 Cowdery, Oliver. "O. Cowdery's Letters to W. W. Phelps Letter \#1." The Gospel Reflector 1 (15 March 1841): 137-40. Recalls his cherished relationship with the prophet Joseph Smith and tells of his gratitude to have been a part of the translation of the Book of Mormon. [J.W.M.]

C.379 Cowdery, Oliver. "Record of the Nephites; an Account of Joseph Smith's Receiving of the Gold Plates." M\&A 2 (October 1835): 203-4. An account of the coming forth of the Book of Mormon and the receiving of the gold plates by Joseph Smith. [B.D.]

C.380 Cowdery, Oliver. "Rise of the Church: Letter VIII." TS 2 (May 1841): 391-97. Oliver Cowdery, in a letter to W.W. Phelps, describes how the plates were buried and how Joseph received them. [B.D.]

C.381 Cowdery, Oliver. "Trouble in the West." M\&A 1 (April 1835): 104-7. Responds to attacks against the Book of Mormon dealing with the Spaulding Manuscript, the birth of Jesus at Jerusalem, the ascription of Mary as the "mother of God," and the appearance of Jesus to the Lehites. [D.M.]

C.382 Cowles, A. W. "The Mormons: Pen and Pencil Sketches Illustrating their Early History." Rural New Yorker (1869): n.p. Tells of the coming forth of the Book of Mormon (includes a sketch of the Hill Cumorah), and continues with a history of the rise of the Church. The article dwells on Joseph Smith's use of the "peep stone" and a "hazel wand" and his poor reputation and low moral standards. [J.W.M.]

C.383 Cowley, Matthew. "Testimony through Reading the Book of Mormon." Relief Society Magazine 40 (January 1953): 6-12. Also published in Matthew Cowley Speaks, compiled and edited by Marba C. Josephson, 107-17. Salt Lake City: Deseret Book, 1954. A testimony of the Book of Mormon can be gained while reading the book. By reading the standard works, individuals can come to know God. [J.W.M.]

C.384 Cowley, M. F. "The Book of Mormon." In Cowley's Talks on Doctrine, 257-73. Chicago, IL: Northern States Mission, Church of Jesus Christ of Latter-day Saints, n.d. The Book of Mormon gives an account of God's dealings with many people. The prophecies of the book are being fulfilled such as no slavery or kings upon the land of America. Old theories that undermine the book's authenticity are exposed for the deceit that they contain, such as the Spaulding theory. Rejecting the book on its literary merits has no validity. [J.W.M]

C.385 Cowley, Matthias F. "The Book of Mormon." In Cowley and Whitney on Doctrine, compiled by Forace Green, 178-86. Salt Lake City: Bookcraft, 1963. Originally published as "Talks on Doctrine-the Book of Mormon." MS 100 (25 August 1938): 535. Tells of the origins of the Book of Mormon peoples. Discusses biblical passages that refer to the Book of Mormon (Matthew 13, Ezekiel 37, Isaiah 29 and Psalms 85). External evidences provide insight into the divinity of the book. The book's literary defects are explained. The divine nature of the Book of Mormon is affirmed by the witnesses. [J.W.M.] 
C.386 Cowley, Matthias F. "Were All the Unsealed Records of the Book of Mormon Translated?" IE 5 (March 1902): 393-95. Gives a description of the gold plates, discusses the Urim and Thummim that were used by Joseph Smith to translate the Book of Mormon, and believes that the entire unsealed portion of the gold plates was translated. [L.D.]

C.387 Coyner, J. M. "Extract from Address before National Teacher's Convention, Madison, Wisconsin." The Utah Evangelist 2/2 (August 1884): n.p. The first mark of Mormonism is deception. It was founded upon the Spaulding Manuscript, palmed off as golden plates. [J.W.M.]

C.388 Cracroft, R. Paul. A Certain Testimony: A Mormon Epic in Twelve Books. Salt Lake City: Epic West, 1979. Presents an epic poem based upon the Book of Mormon story. The preface points out that America would not be what it is without the Book of Mormon nor could Mormonism be what it is without America. [J.W.M.]

C.389 Cracroft, R. Paul. "A Clear Poetic Voice." Ensign 14 (January 1984): 28-31. The author examines the traces of Hebrew literary forms found in the Book of Mormon-particularly the forms of parallelism and chiasmus. [S.P.S.]

C.390 Cracroft, Richard H. "The Gentle Blasphemer: Mark Twain, Holy Scripture, and the Book of Mormon." BYU Studies 11 (Winter 1971): 119-40. Examines Mark Twain's treatment of sacred writings and religious institutions in order to put into context his treatment of the Book of Mormon and Mormon practices. Twain is known for his exaggeration and misrepresentation of facts in order to give a humorous treatment of the subject. [B.D.]

C.391 Cracroft, Richard H., and Neal E. Lambert. "Voices from Cumorah: The Personal Experience of the Book of Mormon." NE 4 (November 1974): 16-21. Fictional account of the feelings and thoughts of Joseph Smith on the Book of Mormon. [A.C.W.]

C.392 Craig, Alison. "The Saints in Indonesia." Ensign 7 (January 1977): 86-90. Tells of the translation of the Book of Mormon into Indonesian by a committee of American and Indonesian Latter-day Saints. The group searched for simple language that would convey the beauty of the book. [J.W.M.]

C.393 Craig, G. Scott. "Keystone or Stumbling Block: Shifting RLDS Perspectives on the Book of Mormon." Student Review 7 (21 October 1992): 6. Discusses current tensions among the RLDS regarding the proper place of the Book of Mormon within its confessional sphere: some accept the traditional Latter-day Saint view that the book is actual history, while others consider it inspired but fictional religious literature. The difference in outlook has caused dissension. The RLDS hierarchy deals with the situation by resorting to "strategic caution" and "discreet silence." [D.M.]

C.394 Craig, Marshall R. "Father Lehi: Prophet and Patriarch." Ensign 6 (September 1976): 58-63. There are important teachings in the Book of Mormon regarding the role of Lehi as a prophet and a patriarch. He sees visions, cares for the welfare of his family, guides them physically and spiritually, and he blesses them. [B.D.]

C.395 Craig, Robert H. The Book of Mormon at-a-Glance. Sonora, CA: Yankee Hill Book, 1988. Gives a point-bypoint precis of the Book of Mormon contents, from 1 Nephi to Moroni. [D.M.]

C.396 Craig, Robert H. The Book of Revelation and the Vision of Nephi: (Compared Side-by-Side). Sonora, CA: Yankee Hill Book, 1988. Explains the relationship between Nephi's vision and the New Testament book of Revelation. Presents common themes by placing verses in parallel columns. [D.M.] 
C.397 Cramer, Lew W. "Abinadi." In Encyclopedia of Mormonism, edited by Daniel H. Ludlow, 1:5-7. 5 vols. New York: Macmillan, 1992. Abinadi, the best-known martyr of the Book of Mormon, has his story recorded in the Book of Mosiah. He may have come from Zarahemla; he taught repentance to the royal court of King Limhi during his mock trials. His only recorded convert was Alma the Elder. His teachings, for which he was burned to death, included the Ten Commandments, interpretations of Isaiah, and prophecies of Christ. [J.W.M.]

C.398 Crane, Charles. The Bible and Mormon Scriptures Compared: Or the Educational Process of Winning Mormons. Joplin, MO: College Press, 1976, 1983. A polemical, evangelical booklet exposing the errors of Mormon scriptures and doctrine. Pages 15-35 deal specifically with the Book of Mormon. While archaeology has proven the accuracy of the Bible, no such evidence exists for the Book of Mormon. It mentions the use of steel and coins long before they were ever in use. Various other anachronisms are discussed. The proper names found in the book are taken from the Bible or are "the product of the writers own fertile imagination." The author favors the Spaulding theory of Book of Mormon origins. [M.R.]

C.399 Crawford, Robert P. "An Index, or Reference to the Second and Third Editions of the Book of Mormon, Alphabetically Arranged." In Crawford's Book of Mormon, 5-21. Philadelphia: Brown, Bicking, and Guilbert, 1842. An index to the second and third editions of the Book of Mormon that was located in the back of the third edition. Gives the page numbers of different events in the Book of Mormon as they appear in the second and third editions. [L.D.]

C.400 Crawley, D. S. "The Sealed Book." SH 50 (2 September 1903): 817-18. Author believes that the sealed book identified in the book of Revelation and Isaiah 29:9 has reference to the Book of Mormon. Joseph Smith was the "unlearned" man to whom the book was delivered by the power of God. [J.W.M.]

C.401 Creigh, Alfred. "Mormonism." In History of Washington County from Its First Settlement to the Present Time, 8993. Harrisburg, PA: B. Singerly, 1871. Accepts the Spaulding theory for the origin for the Book of Mormon. [D.M.]

C.402 Crespo, Jose A. Andrade. Preguntas y Respuestas. Lincoln, NE: Biblioteca de Bolsillo "La Biblia Dice," 1972. The Book of Mormon contains anachronisms, lacks the spirit of the Bible, and contains language from the "Westminster Confession" and the Methodist "Discipline." [D.M.]

C.403 Critchlow, William J., Jr. "A Divine Key to Knowledge." IE 63 (June 1960): 405-6. Skeptics and critics of the Book of Mormon who must see to believe may not find the answer in seeing. The true testimony comes from reading its sacred pages. [J.W.M.]

C.404 Critchlow, William J., Jr. "Read the Book of Mormon." IE 68 (June 1965): 519-20. The Book of Mormon must be read slowly, personally, and purposefully. Reading the Book of Mormon will reveal the gospel of Jesus Christ. [J.W.M.]

C.405 Critchlow, William J., Jr. Untitled talk. CR (April 1965): 73-75. Sermonettes on keeping the Sabbath day holy, and the Book of Mormon testifies of Christ. [J.W.M.]

C.406 Critchlow, William J., III. "Manuscript, Lost 116 Pages." In Encyclopedia of Mormonism, edited by Daniel H. Ludlow, 2:854-55. 5 vols. New York: Macmillan, 1992. The 116 pages of the original manuscript known as the "lost manuscript" were transcribed primarily by Martin Harris. They were translated by Joseph Smith from the record of Lehi abridged by Mormon. They were lost by Harris causing much grief for both translator and scribe. [J.W.M.] 
C.407 "Criticisms on the Book of Mormon." SH 50 (1 July 1903): 594. Encourages people to be faithful to the teachings of the Book of Mormon. Many critics fail to read the book before expressing their opinions, and then their opinions vary widely. [J.W.M.]

C.408 Croft, D. James. "Book of Mormon 'Wordprints' Reexamined." Sunstone 6 (March-April 1981): 15-21. An examination of Larsen, Rencher, and Layton's article "Who wrote the Book of Mormon? An Analysis of Wordprints." Croft states that the "conclusions of its authors may be premature and that several areas of the study seem vulnerable to criticism." Immediately following Croft's article is a response by Larsen and Rencher. [B.D.]

C.409 Cross, Whitney R. The Burned-over District. Ithaca: Cornell University Press, 1950. Outlines the social and intellectual history of religions in Western New York in the early nineteenth century. Chapter 8 deals with Joseph Smith and the Book of Mormon. The author sees Joseph Smith's teachings and the Book of Mormon as products of his enthusiastically religious environment. This can be seen from modern elements in the Book of Mormon such as proper names, modern Christian doctrines, and others. [M.R.]

C.410 "Crossing the Sea." Friend 19 (November 1989): 28-29. Cartoon depiction of Lehi's family crossing the sea designed for children. [J.W.M.]

C.411 Crouch, Brodie. The Myth of Mormon Inspiration. Shreveport, LA: Lambert's Book House, 1968. A polemical work against Mormonism. The author sets up certain criteria by which he feels the Bible has been proven reliable and then attempts to show that the Book of Mormon fails to do so. He cites lack of archaeological evidence, no coins found in America, and similar items. [M.R.]

C.412 Crowe, W. L. Mormon Waterloo; Being a Condensed and Classified Array of Testimony. St. Paul, Nebraska: by the author, 1902. A polemical work against Mormonism. The author dismisses the testimonies of the Book of Mormon witnesses by asserting their poor character and credulous nature. The Book of Mormon contains numerous anachronisms such as the account of the Jaredite barges, discusses pre-Columbian domesticated animals, Old World crops in the New World before Columbus, alleged absence of archaeological evidence, anthropological difficulties, Lehi's desert journey, the mongoloid origin of the Indians, contradictions with the Bible, and others. [M.R.]

C.413 Crowell, Angela. "Adieu: The Right Word After All." In Recent Book of Mormon Developments: Articles from the Zarahemla Record, 2:40. Independence, MO: Zarahemla Research Foundation, 1992. Explains that "adieu" in Jacob 5:48 (RLDS versification) is a proper translation of the Hebrew barak. "Adieu," according to the 1828 dictionary, is a common English loan word from French that means the same as the English farewell, or the Hebrew barak. [B.D.]

C.414 Crowell, Angela. A Comparative Study of Biblical Hebrew Sentence Structure in the Old Testament and in the Book of Mormon. M. A. thesis, Central Baptist Theological Seminary, August 1988. Describes some 50 forms of biblical Hebrew sentence structures, giving examples of its usage in the Bible and compares them to similar forms in the Book of Mormon (1908 RLDS edition). [B.D.]

C.415 Crowell, Angela. "Hebraisms in the Book of Mormon." In Recent Book of Mormon Developments, 55-62. Independence, MO: Zarahemla Research Foundation, 1982, pub. 1984. Also published in ZR 17 and 18 (Summer and Fall 1982), 1-7, 16. Introduces the reader to a broad coverage of Hebraisms in the Book of Mormon, such as numerals, the compound subject, compound prepositions, and the prophetic perfect. [D.W.P.] 
C.416 Crowell, Angela. "Hebrew Poetry in the Book of Mormon: Part I and II." ZR 32-33 (1986): 2-9; 7-12. An introduction to Hebrew poetry in the Book of Mormon. The author introduces several poetic types, including synonymous, synthetic, staircase, alternate, chiastic, and antithetical parallelisms. Other poetic and literary patterns are also investigated. In most instances Crowell gives only one example of each poetic type from the Bible, followed by one from the Book of Mormon. [D.W.P.]

C.417 Crowell, Angela. "Lead Us Not into Temptation: A Hebrew Idiom." ZR 17 (Summer/Fall 1982): 13 Quotes several biblical scholars in support of Joseph Smith's translation of the Lord's prayer (3 Nephi 13:12), which differs slightly from Matthew's account (Matthew 6:14). [J.W.M.]

C.418 Crowell, Angela. "The Learning of the Jews." ZR 41 (February 1989): 2. Explains the use of adieu at the end of Jacob. Although a French word, its use is justified by its definition and as a fitting ending for the chiasmus in the last verse of Jacob. [A.T.]

C.419 Crowell, Angela. "The Learning of the Jews." ZR 47 (February 1990): 2. Examines the difference between the Joseph Smith Translation and the Book of Mormon version of the Lord's Prayer (3 Nephi 5:10-15). The author explains that Hebrew idiomatic usage resolves the differences. [A.T.]

C.420 Crowell, Angela. "Midrash: Ancient Jewish Interpretation and Commentary." In Recent Book of Mormon Developments; Articles from the Zarahemla Record, 2:27-30. Independence, MO: Zarahemla Research Foundation, 1992. Crowell identifies two forms of Midrash in the Book of Mormon that are common to the Bible. The two forms are Homiletic Midrash, including proem and yelammedenu homilies, and Narrative Midrash.[B.D.]

C.421 Crowell, Angela M. "New Findings From Scrolls: Scholars Gathered to Share Research." ZR 66 (March/April 1993): 1-3. After attending a conference on the Dead Sea Scrolls the author suggests that the Dead Sea Scrolls are some of the other books mentioned in 1 Nephi 13:38-41. [A.T.]

C.422 Crowley, Ariel L. About the Book of Mormon. Idaho City, ID: Deseret News, 1961. A compilation of the author's previous works on the Book of Mormon, covering such topics as the Anthon transcript, Lehi's travel, the name Laman, Jesus in the Book of Mormon, Ethan Smith's View of the Hebrews, steel, olive tree, the Urim and Thummim, and Mulek's escape. [B.D.]

C.423 Crowley, Ariel L. "The Anthon Transcript." IE 45 (January-March 1942): 14-15, 58-60, 76-80, 124-125, 150-151, 182-183. Also in A Book of Mormon Treasury, 67-76. Salt Lake City: Bookcraft, 1959, 2nd printing 1976. Tells of Joseph Smith's desire to have someone examine characters copied from the gold plates. Reprints a portion of Joseph Smith's history dealing with the visit of Martin Harris to Charles Anthon. Also contains a letter sent to John A. Widtsoe by Frederick M. Smith of the Reorganized Church stating that the original copy of the Egyptian characters made by Joseph Smith is in the hands of the Reorganized Church. Tells of several different copies of the Egyptian characters in existence and gives examples of people verifying the genuineness of the characters as Egyptian. [A.T.]

C.424 Crowley, Ariel L. "The Anthon Transcript." IE 47 (September 1944): 542, 576-83. Presents a character-bycharacter analysis and interpretation of the Anthon transcript and concludes that a translation is still confronted with "formidable obstacles," but that it is clearly Egyptian and "most closely akin to demotic." [B.D.]

C.425 Crowley, Ariel L. "The Anthon Transcript and the Maya Glyphs." In A Book of Mormon Treasury, 77-80. Salt Lake City: Bookcraft, 1959, [R]1976. Also in IE 55 (September 1952): 644-45. A. Hiatt Verrill's work, Old 
Civilizations of the New World, reproduces an "inscription found at Sahhuayacu, Peru" that closely approximates "the script of the Anthon Transcript." Argues that the Mayan people did not progress from pictographs to a linear script, but possessed a linear, semicursive script from its early history. [A.T.]

C.426 Crowley, Ariel L. Aurichalcum: A Brochure Upon the Brass Plates of Israel. Boise, ID: n.p., 6 December 1934. Presents evidence to support the claim that the record of the Jews was written on plates of brass in the language of the Egyptians. [B.D.]

C.427 Crowley, Ariel L. "The Escape of Mulek." IE 58 (May 1955): 324-26. An attempt to reconcile the biblical account of Zedekiah's capture and the implied extermination of all his male royal line, with the Book of Mormon account of an escape by one son, referred to as Mulek. Using logic the author makes a reconciliation between the two accounts. [R.C.D.]

C.428 Crowley, Ariel L. "Laman Found." IE 54 (February-March 1951): 80-82, 156-57, 205-6. Citing early Spanish writers and historians, the author demonstrates that the name "Laman" existed among the Indians at least as early as the time of Columbus' discovery of America. [R.C.D.]C.429 Crowley, Ariel L. "Lehi's River Laman." IE 47 (January 1944): 14-15, 56-57, 59-61. Deals with Lehi's migration from Jerusalem and discusses the river Laman (1 Nephi 2:6). Quoting from the W. M. Flinders Petrie journal that recalls an expedition in Sinai, Crowley presents possible locations for the river Laman and the valley of Lemuel. A map of the region is included. [J.W.M.]

C.430 Crowley, Ariel L. "Metal Record Plates in Ancient Times." In Crowley's Statement of Beliefs of the Church of Jesus Christ of Latter-day Saints, 122-45. Idaho City, ID: Deseret News Press, 1961. Presents examples of written records on metal from the Romans, Greeks, Hittites, Egyptians, Babylonians, Chinese and Jews and demonstrates that the Jews were familiar with inscribing records on metal before the time of Moses. Such evidence of metal record plates suggests that the Book of Mormon may have been written on golden plates, according to the claim of Joseph Smith and others. [B.D.]

C.431 Crowley, Ariel L. Metal Record Plates in Ancient Times. N.p., 1947. Produces many evidences that ancient Israelites engraved their records upon metal plates. [B.D.]

C.432 Crowley, Elmer S. "An Angel from on High." IE 51 (September 1948): 556-57, 590. Discusses the life and mission of the angel Moroni, his visits with Joseph Smith, and his role in the translation of the Book of Mormon. [J.W.M.]

C.433 Crownover, A. Orlin. You Should Read the Book of Mormon. Independence, MO: Reorganized Church of Jesus Christ of Latter Day Saints, n.d. A brochure that summarizes the contents of the Book of Mormon. [B.D.]

C.434 Crowther, Duane S. "Biblical Proof of the Book of Mormon." In Crowther's Doctrinal Dimensions: New Perspectives on Gospel Principles, 48-71. Bountiful, UT: Horizon Publishers, 1986. Talks on cassette tape (19801986). The Book of Mormon stands as a witness of Christ parallel with the Bible and is of equal significance. The Book of Mormon explains biblical references to "the other sheep," Jacob's prophecy in Genesis 49 of a "fruitful bough by a well," Ezekiel 37 concerning "the stick of Joseph," the psalmist's prophecy that "truth shall spring out of the earth," and Isaiah's prophecies of the Book of Mormon, i.e., the Anthon transcript, the destruction of the Nephite nation (Isaiah 29), and the great apostasy. [J.W.M.]

C.435 Crowther, Duane S. Inspired Prophetic Warnings. Bountiful, UT: Horizon, 1987. Prophetic warnings of the Book of Mormon directed to the inhabitants of the earth are discussed. The author enumerates the instruments of 
God's judgments and outlines the ways that individuals can prepare for survival. [J.W.M.]

C.436 Crowther, Duane S. The Plan of Salvation and the Future in Prophecy. Bountiful, Utah: Horizon Publishers, 1971. Combines Book of Mormon passages with others from the standard works of the Church to outline the plan of salvation. Many Book of Mormon passages foretell future conditions. [J.W.M.]

C.437 Crowther, Duane S. The Prophecies of Joseph Smith. Bountiful, UT: Horizon Publishers, 1983. An in-depth study of Joseph Smith's prophecies and their fulfillment, many of which apply to the Book of Mormon. Includes a history of Joseph Smith from Moroni's visit to the completion of the book's translation and publication. [J.W.M.]

C.438 Crowther, Duane S. Prophetic Warnings to Modern America. Bountiful, UT: Horizon, 1977. Refers to passages from the Book of Mormon that warn of perilous circumstances that will come to America, including the intrusion of secret combinations. [D.M.]

C.439 Crowther, Duane S. Reading Guide to the Book of Mormon. Bountiful, UT: Horizon, 1975. By dividing the reading of the Book of Mormon into twelve one-week periods, that book can be completely read in three months. Each major portion of the Book of Mormon is outlined, providing a preview for the reader. Also contains a doctrinal guide that references major doctrinal themes. [B.D.]

C.440 Crowther, Jean D. Book of Mormon Puzzles and Pictures of Young Latter-day Saints. Bountiful, UT: Horizon 1977. A book full of Book of Mormon games, puzzles and coloring pictures for children. [L.D.]

C.441 Cullimore, James A. "The Book of Mormon." Ensign 6 (May 1976): 84-86. The purpose of the Book of Mormon is outlined and those who take the book too lightly are condemned. Contains testimonies of the power of the book to change individual lives, nations, and the world. [J.W.M.]

C.442 Cummings, Horace H. "Eternal Evidences of the Book of Mormon." Juvenile Instructor 59 (September 1924): 466-67. External evidences of the Book of Mormon include the testimony of eleven witnesses, the fulfillment of many prophecies, and modern archaeological discoveries. The greatest evidence, however, comes from reading, praying, and pondering the message of the book. [J.W.M.]

C.443 Cummins, Lawrence. "Ammon the Valiant." Friend 15 (May 1985): 48-49. Deals with the story of Ammon, the son of Mosiah, who served King Lamoni, and the subsequent conversion of the king, his family, and the people (Alma 17-19). [J.W.M.]

C.444 Cummins, Lawrence. "Benjamin the Prophet King." Friend 18 (June 1988): 48-49. A narrative about King Benjamin and his address at the temple (Mosiah 1-6). [J.W.M.]

C.445 Cummins, Lawrence. "Nephi's Courage." Friend 16 (June 1986): 48-49. A narrative of Nephi's return with his brothers to obtain the brass plates from Laban (1 Nephi 2-4). [J.W.M.]

C.446 Cundick, Robert Milton. "The Song of Nephi, a Cantata for Tenor, Chorus and Orchestra." Ph.D. diss., University of Utah, 1955. "The text of the 'Song of Nephi' was adapted from the Book of Mormon, 2 Nephi 4:1635 inclusive." [B.D.]

C.447 Curtis, Bardella Shipp. Sacred Scriptures and Religious Philosophy: A Comparative Study. Caldwell, ID: Caxton Printer, 1942. Explains sacred scripture found in various cultures with regard to the Book of Mormon. The Book of 
Mormon can be divided into four divisions: the plates of Nephi, Mormon, Ether, and the brass plates of Laban. Archaeological research supports the Book of Mormon. [J.W.M.]

C.448 Curtis, Delbert W. Christ in North America. Tigard, OR: Resource Communications, July 1993. Suggests that Book of Mormon lands are in the United States of America, particularly in the area of New York State. The narrow neck of land mentioned in the book lies between Lake Erie and Lake Ontario. The Spirit bears witness to the truthfulness of the Book of Mormon and a knowledge of the geography is not necessary. [J.W.M.]

C.449 Curtis, Delbert W. The Land of the Nephites. American Fork, UT: Delbert W. Curtis, 1988. Claims that the Book of Mormon lands were located near the Hill Cumorah in New York and the Great Lakes. This work is reviewed in P.038. [B.D.]

C.450 Curtis, Lindsay R. "Equal Time." NE 17 (April 1987): 8-10. Individuals can build their testimony through attendance at church meetings and scripture study, especially study of the Book of Mormon. [J.W.M.]

C.451 Curtis, Lindsay R. The Making of a Prophet. Salt Lake City: Deseret Book, 1967. An illustrated history of Joseph Smith for young readers. Presents a narrative of the coming forth of the Book of Mormon from the first visits of Moroni to the testimonies of the witnesses. This work is reviewed in B.191. [J.W.M.]

C.452 Curtis, Susan. "Early Nineteenth Century America and the Book of Mormon." In The Word of God: Essays on Mormon Scripture, edited by Dan Vogel, 81-96. Salt Lake City: Signature, 1990. The author explains that the Book of Mormon is a product of the early 19th-century American culture, and that the Book of Mormon "gives modernday readers a glimpse at one aspect of the socio-intellectual context of the United States in the 1820s and 1830s." [B.D.]

C.453 Curtis, Susan. Palmyra Revisited: A Look at Early 19th Century American Thought. Emerson, IA: by the author, 1977. Treats the Book of Mormon as a piece of literature written by Joseph Smith. Gives a summary of works supposed to be the basis of Joseph's writings-View of the Hebrews, The Star in the West, and other publications reflecting thought that was prevalent in the 1820-1830 period regarding the origins of the American Indians. [J.W.M.]

C.454 Curtis, Theodore E. "A Nation Speaks Out From the Dust." IE 30 (September 1927): 939. A poem that speaks about the coming forth of the Book of Mormon in the last day. [L.D.]

C.455 Cuthers, John. "The Book of Mormon Aspect of Preparedness." IE 19 (April 1916): 516-17. Quoting the book of Alma pericope regarding the refusal of the newly converted Anti-Nephi-Lehies to take up arms against their antagonists, the author pleads for peace during the World War. [D.M.]

C.456 Cutler, Ed. "Glad Tidings from Cumorah." In The Restored Gospel and Applied Christianity: Student Essays in Honor of President David O. McKay, 1992, 91-97. Provo, UT: Brigham Young University, Center of the Study of Christian Values in Literature and the Religious Studies Center, 1992. It is significant that the Restoration began in the spring, a period of rebirth. Moroni's message is a message of hope in Jesus Christ amid the despair of death (Moroni 10:27). The Book of Mormon is a call for all to come to Christ. [J.W.M.] 
D.001 Dahl, Curtis. "Mound-Builders, Mormons, and William Cullen Bryant." New England Quarterly 34 (June 1961): 178-90. Dahl reviews many of the major works of numerous authors who between 1800 and 1840 were using archaeology and conjecture to explain the origins of the mound-builders. He compares these works to Bryant's poems "The Prairies" and "Thanatopsies." Concerning the Book of Mormon, Dahl writes that it is "certainly the most influential of all Mound-Builder literature," and that "whether one wishes to accept it as divinely inspired or as the work of Joseph Smith, it fits exactly into the tradition." [B.D.]

D.002 Dahl, Larry E. "The Concept of Hell in the Book of Mormon." In Doctrines of the Book of Mormon, 1991 Sperry Symposium, edited by Bruce A. Van Orden and Brent L. Top, 42-56. Salt Lake City: Deseret Book, 1992. The concept of hell plays a prominent role in the Book of Mormon. The term "hell" is attested sixty-two times in the Book of Mormon. Addresses the following questions regarding hell: Is hell temporary or permanent? What does it mean to die in our sins? Can one repent in hell? Can one receive the gospel and improve his/her condition between death and the resurrection? [N.K.Y.]

D.003 Dahl, Larry E. "The Doctrine of Christ: 2 Nephi 31-32." In The Book of Mormon: Second Nephi, The Doctrinal Structure, edited by Monte S. Nyman and Charles D. Tate Jr., 355-75. Provo, UT: Brigham Young University Religious Studies Center, 1989. Discusses the meaning of the doctrine of Christ as contained in 2 Nephi 31-32. The doctrine of Christ consists of having a full purpose of heart, being brought into the light, repentance, baptism, the gift of the Holy Ghost, pressing forward with steadfastness, enduring to the end, and having one's calling and election made sure. [B.D.]

D.004 Dahl, Larry E. "Faith, Hope, Charity." In The Book of Mormon: The Keystone Scripture, edited by Paul R. Cheesman, S. Kent Brown, and Charles D. Tate Jr., 137-50. Provo, UT: Brigham Young University Religious Studies Center, 1988. The Book of Mormon teaches that faith, hope, and charity are three distinct attitudes required for salvation and instructs individuals how to acquire these three attributes. [B.D.]

D.005 Dahl, Larry E. "The Plan of Redemption-Taught and Rejected." In Studies in Scripture: 1 Nephi to Alma 29, edited by Kent P. Jackson, 307-20. Salt Lake City: Deseret Book, 1987. The teachings of Alma and Amulek in Ammonihah are featured in Alma 9-16. Those who accepted the message of Alma and Amulek were cast out and their families burned. Repentance was the message rejected by those entrenched in priestcraft and false doctrine. Includes a list of questions that aid the reading of these chapters. [J.W.M.]

D.006 Daines, Robert H. "Cotton and the Book of Mormon." IE 65 (October 1962): 722-24, 751-53. Evidence indicates that cotton seeds from the Old World were transported across the ocean and interbred with wild cotton plants to produce a superior New World plant that was then cultivated. [B.D.]

D.007 Daines, Robert H. "The Globe-Trotting Sweet Potato." Ensign 5 (March 1975): 67. The South American sweet potato is cited as one possible proof "of the influence of Lehi's descendants on the Polynesian culture." Various theories are listed concerning how the potato arrived on the South Pacific Islands. [B.T.]

D.008 Daniken, Erich von. "Sagenhafte Zeiten." In Daniken's Die Strategie der Gotter: das achte Weltwunder, 7-48. Dusseldorf: Econ Verlag, 1982. "Uses biblical and Book of Mormon passages to evidence the visits of 
extraterrestrials to the earth. Specifically, singles out Chavin de Huanter in the Andes as the Jerusalem of South America." [D.W.P.]

D.009 Danish Missions of the Church of Jesus Christ of Latter-day Saints. Hvis de blev bedt om at skrive en bog. Denmark: Church of Jesus Christ of Latter-day Saints, 1967. The English title of this missionary tract is The Challenge the Book of Mormon Makes to the World. [D.W.P.]

D.010 Darling, Joseph W. "The Book Will Prove Itself." MS 111 (September 1949): 282-83. Discusses attempts to discredit the Book of Mormon and Joseph Smith. Refers to Alexander Campbell, the Spaulding theory, and the Woodbridge Riley Theory. The best evidences of the divinity of the Book of Mormon are found within its own pages. [J.W.M.]

D.011 Darter, Francis M. The Gathering of Israel: ... From a Scriptural Standpoint. Long Beach, CA: n.p., 1915. The Book of Mormon came by way of the Gentiles because of the destruction of the Nephites and rejection by the House of Israel. The book is to be used to gather Israel. [J.W.M.]

D.012 "David Whitmer and the Book of Mormon." MS 43 (December 1881): 785-89. An article reprinted from the Chicago Times, written after a reporter interviewed David Whitmer. David Whitmer confirms his testimony of the Book of Mormon and says that the Spaulding Theory is false. Sidney Rigdon did not know of the Book of Mormon until after it was published. Whitmer also showed the reporter the printer's manuscript of the Book of Mormon. [B.D.]

D.013 "David Whitmer Interview." Chicago Times (7 August 1875): n.p. Denouncing the Latter-day Saints of Utah, Whitmer reaffirms his testimony concerning the Book of Mormon, which is a supplement to the Bible. [J.W.M.]

D.014 "David Whitmer's Last Hours and Testimony." MS 50 (27 February 1888): 139-40. Reprint of an article in the Deseret News that reprints portions from the Richmond Democrat of January 26. David Whitmer, the last of the Three Witnesses, told how he saw the plates and other objects. The article also reprints his last testimony of the Book of Mormon, recorded shortly before his death. [B.D.]

D.015 Davidson, Gustav. A Dictionary of Angels, Including the Fallen Angels. New York: Free Press, 1967. A dictionary dealing with angels. Includes an entry on Moroni, describing him as "the Mormon angel of God, son of Mormon, the last great leader of the Nephites." Notes the statue of Moroni on the Hill Cumorah. [D.M.]

D.016 Davidson, Matilda Spaulding. "The Mormon Bible." Millennial Harbinger 3 (1839): 265-68. Also published as Folly and Falsehood of the Book of Mormon. Hexham: E. Pruddah, 1839; "The Mormon Bible." The Family Magazine 6 (1839): 429-30; "The Mormon Bible." The Family Magazine 7 (1840): 38-39. The wife of Solomon Spaulding, Matilda Spaulding Davidson, provides reasons why Spaulding wrote Manuscript Found. She believes that the Book of Mormon is built on Manuscript Found and that Sidney Rigdon had access to the manuscript left by Spaulding at the printing office of Mr. Patterson sometime between the years 1812 and 1816. [B.D.]

D.017 Davies, Charles A. "A Testimony of the Book of Mormon." SH 110 (1 March 1963): 152-54. A presentation of Davies's testimony of the divinity and truthfulness of the Book of Mormon. [A.C.W.]

D.018 Davies, Charles A. "View of the Hebrews and the Book of Mormon." SH 109 (1 August 1962): 9-11. Fawn Brodie's statement in her book No Man Knows My History that "it may in fact have been [Ethan Smith's] View of the 
Hebrews that gave Joseph Smith the idea of the Book of Mormon" is not based upon sound reasoning nor is it a historical fact. [B.D.]

D.019 Davies, Horton. Christian Deviations: Essays in Defense of the Christian Faith. London: SCM Press, 1954. A polemical attack on various religious groups that the author considers heretical. Chapter seven is devoted to Mormonism. He finds repugnant the LDS "doctrine of progressive revelations" and considers the Book of Mormon to be a forgery that plagiarizes the Bible, Shakespeare and the Westminster Confession of Faith. This work is reviewed in B.015. [M.R.]

D.020 Davies, Legrande. "Isaiah: Texts in the Book of Mormon." In Encyclopedia of Mormonism, edited by Daniel H. Ludlow, 2:700-701. 5 vols. New York: Macmillan, 1992. Contains a chart listing Isaiah citations in the Book of Mormon and compares the Book of Mormon Isaiah to the Isaiah of the Masoretic Text, Septuagint, and Vulgate. The author argues that the Isaiah portions in the Book of Mormon show the error in the multiple authorship theories for the book of Isaiah. [A.T.]

D.021 Davies, Richard. Mormonism Unmasked: Being a Statement of Facts Relating to the Self-Styled "Latter-day Saints" and the Book of Mormon. Burnley: J. Clegg, 1841. In this tract the author sets about to prove that Mormonism is false and that the Book of Mormon is "a silly fabrication of falsehood and wickedness." States that the Book of Mormon story is fictitious and believes that it represents a plagiarism of Solomon Spaulding's Manuscript Found. [B.D.]

D.022 Davies, W. D. "Reflections on the Mormon 'Canon.' " Harvard Theological Review 79 (January, April, July 1986): 44-66. Mormon scriptures are unusual, unique from any other. They claim the Book of Mormon to be the word of God, the translation of which was done through the Urim and Thummim. The book purports to be the records of pre-Columbian Americans. In reality, it is a fraud or forgery. Mormons have a large amount of written material in their canon that has become as important as the biblical writings. [J.W.M.]

D.023 Davis, George E. "The United States in Prophecy." SH 48 (31 July 1901): 616. The Book of Mormon records many of the prophecies of Isaiah, which teach that Zion will stand and not the United States of America. [J.W.M.]

D.024 Davis, H. N. "Where Is the Land of Cumorah." SH 49 (22 October 1902): 1030-33. Attempts to locate the Hill Cumorah in the Northeastern United States, arguing that such a location more fully fits the criteria of the Book of Mormon than other areas of the continent. [J.W.M.]

D.025 Davis, Howard A., D. R. Scales, W. L. Cowdery, and G. Passantino. Who Really Wrote the Book of Mormon? Santa Ana: Vision House, 1977. A detailed polemic against the Book of Mormon that claims that the Spaulding manuscript was the primary source of the Book of Mormon. Includes background historical material, a brief bibliography, and eight appendices. Attempts to demonstrate a connection between Sidney Rigdon and Solomon Spaulding. [D.W.P.]

D.026 Davis, Inez Smith. "Chapters IV-XI." In Davis's The Story of the Church, 26-98. Independence, MO: Herald House, 1943. This history uses journal entries, letters, histories written by the Prophet Joseph and others, and articles from the Times and Seasons and Saints' Herald. It tells of the Prophet Joseph, Martin Harris, Oliver Cowdery, the Whitmer family, Emma, Joseph Smith Sr.'s family, Sidney Rigdon, the publication of the Book of Mormon, and how the Spaulding theory got started. [J.W.M.] 
D.027 Davis, Inez Smith. "The Men and Their Message." In The Message of the Book of Mormon, edited by Charles B. Woodstock, 1-72. Independence, MO: Herald House, 1931-32. Thirteen Sunday School lessons for members of the RLDS church, covering the biographies of prominent men of the Book of Mormon. [B.D.]

D.028 Davis, Joseph H. "The Book of Mormon." MS 73 (21 December 1911): 804-6. Biblical prophets foretold the coming forth of the Book of Mormon. Includes a brief synopsis of the Book of Mormon story line. Mentions Martin Harris's visit to Professor Anthon. Joseph Smith had divine aid in translating. [A.C.W.]

D.029 Davis, Mark, and Brent Israelson. International Relations and Treaties in the Book of Mormon. Provo, UT: FARMS, 1982. A description of the civic and military characteristics of the Nephites and Lamanites. Shows ways in which political circumstances conform to observed customs in the Middle East. [D.M.]

D.030 Davis, Nora A. "Moroni the Faithful." Relief Society Magazine 18 (May 1931): 279-80. Moroni was a man who was faithful in life, in death, and as a resurrected being. Under the most difficult circumstances during and after the Nephite civil war, he lived as an outcast rather than deny his testimony. [J.W.M.]

D.031 Davis, Nora A. "Moroni the Faithful." MS 96 (7 June 1934): 358-59, 365. Gives biographical sketch of Moroni based on the account in the Book of Mormon. Praises his spirituality in time of turmoil and loneliness. Discusses his role in the restoration of the gospel. [A.C.W.]

D.032 Davis, S. J. S. Origin of the Book of Mormon, together with an Account of the Rise and Progress of the Mormon Church. Louisville, KY: Pentecostal, 1899. A polemical work against the Book of Mormon. The author notes the common interest of many nineteenth-century Americans regarding the origins of the American Indians. He views Joseph Smith as having borrowed from the Spaulding romance and the common theories regarding Indian origins in formulating the Book of Mormon. [M.R.]

D.033 Davis, Tal. "The Book of Mormon: Is It 'Another Testament of Jesus Christ'?" The Evangel 39 (April, May-June 1992): 8-9, 8-9. Brief summary of LDS beliefs, history, and the Book of Mormon story line. Points out lack of corroborating archaeological evidence for the Book of Mormon. Concludes that Joseph Smith authored the book, that it does not agree with current LDS doctrines, and that therefore it cannot be recognized as "another testament of Jesus Christ." [A.C.W.]

D.034 Day, Afton J. "Then I Could Touch People's Hearts." Ensign 7 (September 1977): 72-73. As a tour guide at the Washington D.C. Temple, Linda Turman realized she needed to deepen her testimony of the Book of Mormon. She began reading and felt the Book of Mormon prophets teaching her. She was then able to bear testimony that touched the lives of others. [J.W.M.]

D.035 De Fuentes, Carmen Rodriguez. "A Lamp unto My Feet." Ensign 23 (October 1993): 68-69. The Book of Mormon assists individuals in every facet of life-when the teachings of the world contradict gospel teachings, in moments of discouragement, when faith needs strengthening, in marriage, and in times of fear and suffering. It is a good parental guide. [J.W.M.]

D.036 De Hoyos, Arturo. The Old and the Modern Lamanite. Provo, UT: Institute of the American Indian Services and Research, 1970. The term Lamanite applies to the native inhabitants (the Indians) of the American continent, the Eskimos, the Samoans of the Pacific Islanders, and other groups. [B.D.] 
D.037 de Jagar, Jacob. Untitled talk. In Official Report of the First Area General Conference for Germany, Austria, Holland, Italy, Switzerland, France, Belgium, and Spain, August 1973, 102-5. Salt Lake City: Church of Jesus Christ of Latter-day Saints, 1973. Bears testimony of the truthfulness of the Book of Mormon and states that an angel taught and visited with Joseph Smith, and that the book that he brought forth contains the fullness of the gospel as it was taught to the inhabitants of ancient America. It is a missionary tool to convert both Jew and Gentile to Jesus' gospel. [J.W.M.]

D.038 De La Mare, Phillip. A Brief Account of the Life of Phillip De La Mare. Salt Lake City: Phillip De La Mare, 1852. An historical sketch of the life of the man who translated the Book of Mormon into French under the direction of John Taylor and with the assistance of L. A. Bertran, C. C. Bolton, and John Peck. [J.W.M.]

D.039 Decker, J. Edward. The Massive Mormon Scripture Mess. Issaquah, WA: Saints Alive, n.d. A polemical attack on Mormon scriptures, including the Book of Mormon. There is no archaeological evidence for the Book of Mormon. Various anachronisms found in the Book of Mormon, such as the use of steel and Nephi's temple in America, are discussed. [M.R.]

D.040 Decker, J. Edward. To Moroni with Love. Seattle: Life Messengers, 1980. An anti-Mormon pamphlet designed to encourage members of the LDS church to leave their religion. The Book of Mormon adds to God's word in the Bible. [M.R.]

D.041 Decker, J. Edward. Those Plain and Precious Things. Issaquah, WA: Saints Alive, 1982. A slender polemical tract. Notes that several "plain and precious things" taught in the LDS church are not found in the Book of Mormon, and that both the Bible and the Book of Mormon oppose doctrines taught in the Church. [D.M.]

D.042 Decker, J. Edward, and Dave Hunt. The God Makers: A Shocking Exposé of What the Mormon Church Really Believes. Eugene, OR: Harvest, 1984. A sensationalistic exposé of Mormonism. Pages 99-115 discuss the Book of Mormon. Among the numerous "problems" discussed by the authors are the Kinderhook plates, the credulity of the Book of Mormon witnesses, possible Satanic connections, textual changes, Bible plagiarism, King James English, and possible dependence upon the View of the Hebrews. [M.R.]

D.043 Dee, Genet Bingham. "The Book of Mormon, A Sacred History of Ancient America." IE 42 (December 1939): 750. Comments regarding A Voice from the Dust, an edition of the Book of Mormon that the author edited and rearranged. [B.D.]

D.044 Dee, Genet Bingham, ed. A Voice from the Dust, A Sacred History of Ancient America. Salt Lake City: Deseret News Press, 1939. A recreation of the entire text of the Book of Mormon. Contains commentary and pictures of sites in Mexico that may correspond with Book of Mormon lands. [L.D.]

D.045 "Defense of Abinadi the Prophet." Young Woman's Journal 5 (November 1893): 82-87. A dramatic rendition of Abinadi's prophetic message to King Noah. [D.M.]

D.046 Dellenbach, Robert K. "Hour of Conversion." Ensign 20 (November 1990): 23-24. A testimonial and exhortation in which the author relates his experience of finding out that the Book of Mormon contains the word of God. In order for an individual to receive a testimony of the Book of Mormon, he/she must have a desire, set forth good works, pray unto God, and trust in the Lord. [B.D.] 
D.047 DeLong, Richard A. Chiasmus, Internal Evidence of Book of Mormon Authorship. Independence, MO: Foundation for Research on Ancient America, 1984. RLDS professor at Graceland College defends the authenticity of the Book of Mormon by showing examples of chiasmus. [D.M.]

D.048 DeLong, Richard A. "Maya Glyphs May Identify Hill Cumorah." The Witness 67 (Winter 1989): 4-5, 14. The temple of inscriptions at Palenque in Mexico has a glyph that "can be interpreted as meaning Hill Ramah or Hill Cumorah." Delong believes that Cerro Rabon is a prime candidate for the Hill Cumorah in Mesoamerica. [B.D.]

D.049 DePillis, Mario S. "The Quest for Religious Authority and the Rise of Mormonism." Dialogue 1 (Spring 1966): 68-88. An attempt to understand how Mormonism's idea of "religious authority" appealed to early converts. Refers to the Book of Mormon to describe Mormonism's idea of religious authority. Discusses the role of the book in the formulation of Joseph Smith's philosophy and doctrine. [M.R.]

D.050 DePillis, Mario S. "The Social Sources of Mormonism." Church History 37 (March 1968): 52-79. An attempt to understand Mormonism and its nineteenth-century context. The idea of "religious authority" may have had great appeal for early converts to Mormonism. [M.R.]

D.051 Derbidge, Gertrude. "The Women of the Book of Mormon." Young Woman's Journal 8 (November 1896): 8082. Celebrates the noble women in the Book of Mormon, notably Sariah and the mothers of the stripling soldiers who fought under Helaman. [D.M.]

D.052 Derry, George. "Importance and Necessity of Book of Mormon." SH 47 (4 July 1900): 435-37. Quotes relevant passages from the Doctrine and Covenants showing the importance of the Book of Mormon. Ends with a charge to study the Book of Mormon, and a testimony of its truthfulness. [A.T.]

D.053 Derry, George. "Twelve Nephite Apostles." SH 55 (11 November 1908): 1095-97. Summarizes the main events of Christ's visit to the Americas and determines that the Nephite twelve apostles were on the same level as the twelve in Jerusalem. [A.T.]

D.054 Deseret Sunday School Union. Living Truths from the Book of Mormon. Salt Lake City: Church of Jesus Christ of Latter-day Saints, 1970. [R] 1972. Contains forty-three Sunday School lessons designed for the student. Each lesson contains a commentary on several topics assigned from the reading for that section. Topics include the testimony of the witnesses, the plan of redemption, the allegory of the olive tree, and the abridgment and correlation of sacred records. [A.T.]

D.055 Deseret Sunday School Union. Messages for Exaltation: Eternal Insights from the Book of Mormon. Salt Lake City: Church of Jesus Christ of Latter-day Saints, 1967. A Sunday School instructor's manual containing forty-five Book of Mormon lessons. The lessons feature lesson objectives, commentary, selected related scriptural references, and an assignment for the next class. [A.T.]

D.056 Deseret Sunday School Union. Sunday School Outlines, First and Second Years. Salt Lake City: Church of Jesus Christ of Latter-day Saints, 1903, 1905, 1907. Outlines of lessons for Sunday School classes that cover many subjects relating to Mormonism, including the Book of Mormon. [B.D.]

D.057 Deseret Sunday School Union Leaflets. Salt Lake City: Deseret Sunday School Union, 1901. The Third Division of this book contains a collection of Book of Mormon leaflets that present Book of Mormon lessons to be presented to the Sunday School adult classes for the years 1889, 1896, 1898. Also includes in the Fourth Division 
lessons on the life of Joseph Smith and the coming forth of the Book of Mormon. These are dated 1889, 1890, and 1896. [J.W.M.]

D.058 Desmons, Frederic. Essai Historique et Critique du Mormonisme. Strasbourg: leuve Berger-Levrault, 1856. A polemical work divided in two parts, one dedicated to the history of the Church and the second to the Book of Mormon. The Book of Mormon contains anachronisms, mistakenly uses Greek words, and presents supernatural and miraculous events that are not to be believed. Joseph Smith's claim that the Book of Mormon was written in reformed Egyptian does not hold up, and the Book of Mormon introduces new doctrine. [B.D.]

D.059 Despain, Goldie B. "The Tapestry of the Ages." Instructor 103 (November 1968): 458. Traces the succession of those who kept the records of the Book of Mormon until Moroni gave them to Joseph Smith. [B.D.]

D.060 "The Destruction of the Jaredites." Friend 20 (June 1990): 18-20. Children's illustrated story of Ether and the Jaredites. [M.R.]

D.061 Dewey, L. Valess. “Regarding Joseph Smith's Mission." IE 29 (October 1926): 1164-67. The prophet Joseph Smith was the instrument through which the Book of Mormon was produced. The gospel of Jesus Christ was revealed through the mind of Joseph in modern scripture-the Book of Mormon, the Pearl of Great Price, and the Doctrine and Covenants. These scriptures are new witnesses for God. [J.W.M.]

D.062 Dexter, W. R. "The Book of Mormon as a Translation." SH 60 (11, 18 June 1913): 577-80, 598-601. The translation of the Book of Mormon was conducted under the inspiration and direction from God. The eleven witnesses bore testimony of the truthfulness of the Book of Mormon, never retracting their testimonies even though some became disaffected with the Church. [J.W.M.]

D.063 "Diabolical." The Reflector New Series 8 (27 February 1830): 66. Declares that Joseph Smith himself was the scribe of the Book of Mormon, and that he was unlearned in letters, spelling, and punctuation. Believes that the book was inspired by the devil. [J.W.M.]

D.064 "Dialogue on Mormonism." MS 2 (September/October 1841): 69-71, 81-83. Fictitious dialogue about the beliefs of the LDS church. During the dialogue an Elder of the Church explains the contents of the Book of Mormon. [D.W.P.]

D.065 "Dialogue on Mormonism: Book of Mormon." TS 2 (15 July 1841): 472-74. Imaginary dialogue between an "Elder Pierce," "Mr. Matthews" and "Mr. Roberts" on Book of Mormon topics, including the visit of Jesus in 3 Nephi. Examines why the Indians apparently had no traditions confirming the Book of Mormon. [D.M.]

D.066 Dias, Laurence C. Jesus Says "It Is Written": An Address to All Believers in the Bible and the Book of Mormon. Erie, PA: Laurence C. Dias of the Church of Christ, n.d. Using a compilation of biblical passages supported by Book of Mormon passages, this booklet presents a narrative concerning Christ's role and doctrine, interspersed with commentary by the compiler. [J.W.M.]

D.067 Dias, Laurence C. The One True God Revealed: An Address to All Believers in the Bible and the Book of Mormon. Erie, PA: Church of Jesus Christ, 1956. Maintains that the Book of Mormon is true but that some who believe in it have drifted from its teachings. Presents a compilation of biblical passages in conjunction with Book of Mormon passages to show that God and the Lord are one and the same God-Jesus Christ, there is no other. [J.W.M.] 
D.068 Dias, Lawrence C. To the Restored Gospel People: An Address to all Believers in the Bible and the Book of Mormon. Erie, PA: Church of Jesus Christ, n.d. A compilation of scriptural passages from the Bible with supporting Book of Mormon passages and commentary to help believers of the Book of Mormon see they have been led to believe in false doctrine. Subjects include: the gathering of Israel, Adam and Eve, the doctrine of Christ, apostasy from the primitive Church of Christ, a book to come forth, and others. Maintains that God is a spirit and that Joseph Smith and others misinterpreted their experiences. Plurality of wives is forbidden of God and the Book of Mormon. Dislikes baptism for the dead. [J.W.M.]

D.069 Dibb, Dianne. "Ether Woke Us Up." Ensign 8 (July 1978): 58-59. Family readings of the Book of Mormon helped to arouse the children's interest in the book of Ether. After reading a chapter the family would draw the chapter's main idea on a large posterboard, an activity that served to help the children remember the important points of the book of Ether. [B.D.]

D.070 Dibble, Charles E. "Mexican and Mayan Codices." IE 43 (August 1940): 464-65, 504-6; "Ancient America in the Light of Recent Findings." IE 44 (January 1941): 1; "Some Facts Concerning Costa Rica and Its Inhabitants." IE 44 (February 1941): 68; "Metal Craft in Ancient America." IE 44 (April 1941): 218; "Compilation of the Indian Language of America." IE 44 (August 1941): 456; "Toltec Problems." IE 44 (September 1941): 538; "Chiapas Ruins." IE 44 (October 1941): 599; "The Olmec Influence in Ancient America." IE 45 (January 1942): 6; "Aztec Facts." IE 45 (February 1942): 69; "The Cuicuilco Excavation." IE 45 (March 1942): 135; "The Mayan Days ... and Their Meaning." IE 45 (April 1942): 198; "Reconstructing Ruins." IE 45 (May 1942): 268; "Excavations in Mexico City." IE 45 (June 1942): 360; "Mexican Money-Axes." IE 45 (July 1942): 442; "Facts on Teotihuacán." IE 45 (August 1942): 483;0 "Priest's Dwellings in Teotihuacán." IE 45 (September 1942): 549, 593; "Copilco-Ancient Burying Ground." IE 45 (October 1942): 613; "Quetzalcoatl." IE 46 (January 1943): 6; "Aztec Recording-1518." IE 46 (February 1943): 71; "The Five Suns in Aztec Mythology." IE 46 (March 1943): 133; "La Venta Culture." IE 46 (April 1943): 197; "Pre-Colombian Irrigation." IE 46 (May 1943): 264; "Central American Migration Legend." IE 46 (June 1943): 330, 355; "The Arch and the Wheel in Ancient America." IE 46 (July 1943): 387; "Super Imposition in Central American Architecture." IE 46 (August 1943): 453; "Anthropological Conference." IE 46 (September 1943): 522; "Our Word Debt to the Aztecs." IE 46 (October 1943): 582; "Human Sacrifice Among the Indians." IE 46 (November 1943): 682; "The Religion of the Mayan Common Folk." IE 47 (July 1944): 391; "The Ten Commandments in Aztec." IE 49 (July 1946): 420; "Aztec Method of Recording History." IE 49 (October 1946): 613, 649. A series of brief comments in which the author presents archaeological findings, architectural notes, and myths and legends that deal indirectly with the Book of Mormon. Dibble discusses the wheel, ancient irrigation methods, metals, Mexican and Mayan codices, Quetzalcoatl, ancient buildings, and numerous other related items. [J.W.M.]

D.071 Dibble, Charles E. "Religious Beliefs of the Aztecs." MS 110 (October 1948): 296-97. The Aztecs of Mexico were religious fanatics who eventually were led to human sacrifice. The myths and legends of the Aztec people are perversions from the true gospel of Jesus Christ that was had in the first and second centuries A.D. [J.W.M.]

D.072 Dickens, Charles. "In the Name of the Prophet Smith." Household Words: A Weekly Journal 69 (19 July 1851): 385-89. The writer finds Mormon claims to revelation and visions "in the age of railways" somewhat absurd. He notes the similarity in language between the Book of Mormon and the Old Testament and appears to accept the Spaulding theory of its origin. [M.R.]

D.073 Dickinson, Ellen E. "The Book of Mormon." Scribner's Monthly 20 (August 1880): 614-16. Dickinson, the great-niece of Solomon Spaulding, reports an interview she conducted with Matilda Spaulding McKinstry, 
daughter of Solomon Spaulding. Gives basic facts about Spaulding's Manuscript Found. Spaulding was the first to discover the Ohio mound-builder's Israelite descent. His manuscript contained the names Mormon, Maroni, Lamenite, and Nephi and was taken to Patterson, a publisher in Pittsburg, with whom Sidney Rigdon spent time. In 1834 a man named Hurlburt asked for the manuscript for the purpose of making a comparison and the manuscript was lost. [J.W.M.]

D.074 Dickinson, Ellen E. "Communications: The Book of Mormon." Scribner's Monthly 22 (October 1881): 946-48. This letter to the editor states that Hurlburt had searched out Mrs. Davidson, widow of Rev. Spaulding. The Manuscript Found was reported to be the basis of the Book of Mormon, but upon examination was found to be "nothing of the kind." Includes several affidavits by friends and neighbors of Rev. Spaulding that assure that the Book of Mormon is similar to the Spaulding manuscript. [J.W.M.]

D.075 Dickinson, Ellen E. New Light on Mormonism. New York: Funk and Wagnalls, 1885. A polemical work on Mormonism. Pages 237-67 contain numerous affidavits relative to the Spaulding hypothesis. [M.R.]

D.076 DiFrancesca, Vincenzo. "Burn the Book." IE 70 (May 1968): 4-7. Autobiographical sketch of DiFrancesca's life-long search for the Church after finding a damaged Book of Mormon in an ash barrel. [B.W.J.]

D.077 DiFrancesca, Vincenzo. “I Will Not Burn the Book!” Ensign 18 (January 1988): 18-21. An inspiring true story of a New York Italian Protestant minister in the early 1900s who finds a copy of the Book of Mormon that lacks the title page, and cannot be identified as the Book of Mormon. The minister gains a testimony of the Book of Mormon and spends the next twenty years looking for the Church "to which the book belonged." [D.L.L.]

D.078 Dille, D. B., and Oliver Cowdery. "Testimonies of Oliver Cowdery and Martin Harris." MS 21 (July 1859): 544-46. A reprint from the Deseret News, this article contains a report of a special conference held at Council Bluffs concerning Oliver Cowdery's return to the Church. Quotes Cowdery's testimony of the Book of Mormon from that conference. Includes a report by D. B. Dille who visited Martin Harris and tells of that visit. [J.W.M.]

D.079 Dillon, Bill. A Debate with Mormons. Hazel, KY: Bill Dillon, 1981. A correspondence between a Mormon and a Baptist regarding Mormon beliefs. Common criticisms against the Book of Mormon are raised and discussed, such as the Book of Mormon's condemnation of polygamy, alleged contradictions with the Bible, lack of archaeological evidence, witnesses to the Book of Mormon, and others. [M.R.]

D.080 Di Marco, Angelico Salvatore. Review of Chiasmus in Antiquity: Structures, Analyses, Exegesis, edited by John W. Welch. Revista Biblica 31 (1983): 146-48. Book review.

D.081 "Discoveries In Yucatan." MS 57 (15 August 1895): 524-26. This reprint from the Deseret News tells of an archaeologist, Dr. Augustus le Plongeon, who deciphered several inscriptions found in Central America. He found that the hieratic (sacred) alphabet of the Mayas was almost identical to that of the Egyptians, as well as similar grammar and characters with identical meanings. Two cities in the peninsula of Yucatan were "visited by learned men from all parts of the world." Creation stories were found recorded that resemble Old World legends. Dr. Plongeon directly links Egyptian identity with the Mayan people. [J.W.M.]

D.082 "Discovery of an American Mastodon." MS 28 (8 December 1866): 775-76. Reports the discovery of bones of a mastodon 83 feet below the surface, about 100 feet from the Mohawk river at a village of Cohoes, near Troy, New York. The Book of Mormon is not mentioned but this and the article following it, "The Mastodon of the Book of Ether" are used to support the Book of Mormon. [B.D.] 
D.083 "Discovery of Ancient Ruins in Central America." Evening and Morning Star 1 (February 1833): n.p. Tells of the discovery of ancient ruins built by highly civilized peoples such as those spoken of in the Book of Mormon. [M.D.P.]

D.084 "Discovery of Historical Records in an Indian Mound." DN 27 (25 December 1878): 738. Article reprinted from Levenworth Times that reported an archaeological finding of several mounds wherein a record or a book of bark leaves was discovered that was said to be the language used in Mexico at the time of Montezuma. [D.M.]

D.085 "Divine Protection for America." CN 31 (4 November 1961): 16. The Book of Mormon relates that America is a promised land and the Lord will protect it through the covenant that he made with his people. [M.D.P.]

D.086 Divine Truths in the Book of Mormon. St. Louis, MO: Personal Freedom Outreach, 1982?. A polemical tract that avers that "Mormon theology is not contained in, but rather contradicted by the Book of Mormon." Lists several points in the Book of Mormon perceived to be harmonious with orthodox Christianity, such as the oneness of God, two possible destinations after death, and salvation by the Atonement. Names six areas wherein the Book of Mormon is out of harmony with the Bible. The Book of Mormon is a fictitious work. [D.M.]

D.087 Dixon, Derek. "A Man Who Knew." IE 70 (March 1967): 16. Edward King or Viscount Kingsborough, author of a nine-volume work The Antiquities of Mexico, believed that the ancient Americans were members of the house of Israel and at some time in their history they had been visited by Jesus Christ. [B.D.]

D.088 Dixon, Riley Lake. Just One Cumorah. Salt Lake City: Bookcraft, 1958. Argues that the Hill Cumorah, where the Nephites and Lamanites fought their last battle, was the Hill Cumorah in New York state. The author also believes that the Nephites landed in Chile thirty degrees south latitude, according to a statement attributed to Joseph Smith. This work is reviewed in K.117. [B.D.]

D.089 " 'Do It' Is a Prophet's Plea at Conference." CN 48 (24 June 1978): 3, 7. President Kimball emphasizes that knowing what is right is not enough, you have to do right. Reading the Book of Mormon is the best way to avoid adopting the evils that plague the world. [M.R.]

D.090 “Do You Know?" Friend 18 (February 1988): 33. An activity for children concerning Lehi's son Nephi. [J.W.M.]

D.091 Dobson, J. Laverd, and J. D. Dobson. Omni. Salt Lake City: Dobson Family, 1980. An extensive discussion of the book of Omni. Examines the personalities, geography, and plates of Omni, and presents charts and illustrations. [D.M.]

D.092 Doddridge, David W. "Fertility, Right?" Sunstone 15 (October 1991): 9. Takes issue with John Kunich's theory that a 2 percent per year population growth in the Book of Mormon is "unheard of." According to newly issued population reports of May 1991, the Mideast is expanding at 2.8 percent, South Asia at 2.3 and Africa and 3 percent. It is possible that this type of population growth can occur. [J.W.M.]

D.093 Dogberry, Obediah. "From the Book of Mormon." The Reflector New Series 2, 3, Extra (2 January, 13 January, 22 January 1830): 9, 17, 27. A series: extracts from the pages of the Book of Mormon prior to publication of the book. [J.W.M.] 
D.094 "Domestic Life Among the Nephites." Relief Society Magazine 5 (February 1918): 107-11. Nephite women were descendants of Hebrew women, who had to adapt to a semi-tropical climate. The architecture of their homes was perhaps related to the Hebrew custom of hollow squares, flat roofs, and a courtyard in the center. While home life was simple and pleasant, the women were industrious. [J.W.M.]

D.095 Domonoske, Gladys E. "The Land Shadowing with Wings." N.p., 1981. Theorizes that the land northward in the Book of Mormon is the Ontario Peninsula and the land southward is New York State. Presents the results of her research with maps, scriptures from the Old Testament, and exploration of the Book of Mormon text. Identifies the River Sidon as the Niagara River. Uses archaeologists' observations. [J.W.M.]

D.096 Donaldson, Lee L. "Benjamin and Noah: The Principle of Dominion." In The Book of Mormon: Mosiah, Salvation Only through Christ, edited by Monte S. Nyman and Charles D. Tate Jr., 49-58. Provo, UT: Brigham Young University Religious Studies Center, 1991. The book of Mosiah offers a penetrating look at the differences between King Benjamin and King Noah, the former epitomizing righteousness and the latter wickedness. The two kings are contrasted in seven areas: their use of temples, conflicts with the Lamanites, plans for succession, sermons, physical labor and service, and their attitude toward scripture and the living prophet. [B.D.]

D.097 Done, Otto. "U.A.S. Members Complete Archaeological Tour of Book of Mormon Lands." U.A.S.N. 26 (31 March 1955): 1-3. Also in Christensen, Ross T. Progress in Archaeology: An Anthology, 162-65. Tells of viewing the Izapa tree-of-life stone and other places of interest that are identified as the "land Southward" in the Book of Mormon. [J.W.M.]

D.098 Doty, Donald B. "The Book of Mormon: 'The Most Correct Book.' " Ensign 18 (August 1988): 28-29. Rehearses two popular reasons why the Book of Mormon is called "the most correct book." Presents a list of doctrinal contributions of the Book of Mormon. [D.L.L.]

D.099 Douglas, Josiah. "He [Lehi] May Have Gone Another Way." CN 58 (2 January 1988): 11, 13. Lehi and his family may not have traveled the Frankincense Trails but may have traveled down to the horn of Africa where the Nogul Valley could have possibly been Bountiful. [M.R.]

D.100 Douglas, Norman. "The Sons of Lehi and the Seed of Cain: Racial Myths in Mormon Scripture and Their Relevance to the Pacific Islands." Journal of Religious History 8 (June 1974): 90-104. Discusses Mormon racial beliefs regarding polynesians and blacks and their relationship to the Book of Mormon and the book of Abraham. [M.R.]

D.101 Dowding, Goff. "Word Portraits from Third Nephi." IE 51-52 (September-January 1948-49): 550, 614, 678, 782, 6. A series presenting narrative taken from 3 Nephi 1-28 with accompanying illustrations. Illustrations depict the events surrounding Christ's birth, death, and visit on the American continent.[B.D.]

D.102 Downs, Robert Bingham. "Joseph Smith's, 'The Book of Mormon.' " In Books That Changed America, 26-35. New York: Macmillan, 1970. Discusses twenty-five books that succeeded in shaping American thought. Chapter 4 is dedicated to the Book of Mormon. The author concludes that "the possession of their own scriptures ... has proved to be the Mormons' greatest missionary tract, giving permanence and stability to their religion and providing them with a faith by which to live." [B.D.]

D.103 Doxey, Roy W. "I Have a Question: Some passages in the Book of Mormon seem to indicate that there is only one God and that he is a spirit only. How can we explain this?" Ensign 15 (August 1985): 11-13. Also in A Sure 
Foundation: Answers to Difficult Gospel Questions, 5-11. Salt Lake City: Deseret Book, 1988. Doxey explains, citing many scriptures, how the Book of Mormon "does indeed teach that God the Father, his Son Jesus Christ, and the Holy Ghost are three separate beings and that the Father and the Son are not personages of spirit." [B.D.]

D.104 Doxey, Roy W. "I Have a Question: What was the approximate weight of the gold plates from which the Book of Mormon was translated?" Ensign 16 (December 1986): 65. Also in A Sure Foundation: Answers to Difficult Gospel Questions, 50-52. Salt Lake City: Deseret Book, 1988. Citing Joseph Smith's own description of the physical appearance of the plates as well as several contemporary accounts of persons who were permitted to lift them, the author provides an approximate weight of the gold plates. [S.P.S.]

D.105 Doxey, Roy W. "Modern Fulfillment of a Book of Mormon Prophecy." IE 53 (November 1950): 879-80, 924. A prophecy made by Nephi (2 Nephi 30:3) states that many gentiles of the last days will believe the words of the Book of Mormon. The great numbers of persons who read and accept the Book of Mormon in this era demonstrate eloquent fulfillment of this prophecy. [R.C.D.]

D.106 Doxey, Roy W. "One of Joseph Smith's Contributions-Translation of the Book of Mormon." Relief Society Magazine 56 (November 1969): 857-62. The Book of Mormon is a witness to the Bible's truthfulness, proclaims the reality of Christ's resurrection, imparts and clarifies gospel truths, and is an instrument for salvation. Having faith in the Book of Mormon increases faith in Christ. [A.C.W.]

D.107 Doxey, Roy W. "Satan's Opposition to the Coming Forth of the Book of Mormon." Relief Society Magazine 44 (November 1957): 760-64. In opposition to the Lord's great work of saving the souls of mankind, Satan has sought to destroy the same. Joseph Smith was cautioned that temptations would arise concerning the gold plates. The loss of the manuscript was not a frustration to God's work, it was an important lesson. [J.W.M.]

D.108 Doxey, Roy W. "The Three Special Book of Mormon Witnesses." Relief Society Magazine 45 (January 1958): 49-55. The testimonies of the Three Witnesses were strengthened by their spiritual experiences with Joseph Smith and the Book of Mormon. Oliver Cowdery, Martin Harris, and David Whitmer never denied their testimonies. [J.W.M.]

D.109 Doxey, Roy W. Untitled talk. CR (October 1948): 104-6. The author tells the story of a man who visited his office who had served as an evangelist. He read the Book of Mormon, was touched by the spirit of God, and desired to obtain more copies to distribute. He felt greater faith could be had through the Book of Mormon than could be obtained through the Bible. [J.W.M.]

D.110 Draper, Maurice L. "Evidences of the Divine Authenticity of the Book of Mormon." SH 99 (11, 18 August 1952): 749, 776-77. Defends the Book of Mormon against the charge that Joseph Smith fabricated it; lists Egyptian and Hebraic influences found in the Book of Mormon; discusses the methods of translating the work and its literary style. [A.T.]

D.111 Draper, Maurice L. The Founding Prophet: An Administrative Biography of Joseph Smith Jr. Independence, MO: Herald House, 1991. Deals with the coming forth of the Book of Mormon, including angel Moroni's visit to Joseph Smith, the obtaining of the gold plates, the book's translation and publication, and the witnesses to the book and their testimonies. [J.W.M.]

D.112 Draper, Maurice L. "Some Questions and Answers about the Book of Mormon." SH 98 (12 February 1951): 155-57. Writes concerning the translation of the Book of Mormon, its multiple references to Christ, and peculiar 
phrases found in the Book of Mormon. Discusses the use of King James language and phrases in the book, Joseph Smith's ability as a translator, and the clarity of Book of Mormon prophecies. [A.C.W.]

D.113 Draper, Melvin S. Our Cousins the American Indian. Santa Maria, CA: n.p., 1962. Draws upon cultural and anthropological relationships between ancient American peoples and the civilizations in the Book of Mormon. Discusses Ixtilixochitl, Quetzalcoatl, and the "Fair God" of Mesoamerica. [D.M.]

D.114 Draper, Richard D. "The Book of Mormon Teachings on the Gathering of Israel." In A Symposium on the Book of Mormon, 38-41. Salt Lake City: Church of Jesus Christ of Latter-day Saints, 1979. The Book of Mormon provides a host of materials regarding the gathering of Israel in the last days and God's promises to restore Israel to their ancient lands. [N.K.Y.]

D.115 Draper, Richard D. "The Mortal Ministry of the Savior Understood by the Book of Mormon Prophets." Journal of Book of Mormon Studies 2 (Spring 1993): 80-92. Examines Book of Mormon passages that concern Christ's mortal ministry, concluding that the revelations of Book of Mormon prophets contain the essential elements of Christ's ministry and character, providing the necessary information for Book of Mormon peoples to have faith in Christ. The paper focuses on Christ's uniqueness, "showing why he was neither human nor man, and the importance of His distinction from other mortals." [A.T.]

D.116 Driggs, H. Wayne. America's Witness for Christ: a pageant from the stick of Joseph, known to the world as the Book of Mormon. N.p.: n.p., n.d. This collection includes a script for a pageant entitled The Book of Mormon. It explains the meaning and purpose of the Book of Mormon. [J.W.M.]

D.117 Driggs, Howard R. "Gospel Messages from the Book of Mormon." Relief Society Magazine 35 (September 1948): 640-47. Treasures of wisdom comparable to the biblical book of Proverbs may be found scattered throughout the Book of Mormon. The author presents many Book of Mormon examples of proverbial sayings. [J.W.M.]

D.118 Driggs, Howard R. "The Spaulding Manuscript." Juvenile Instructor 50 (October 1915): 631-34. Provides a history and selections of the Spaulding manuscript with the goal of showing that it was not the source of the Book of Mormon. [D.W.P.]

D.119 Driggs, Jean R. The Palestine of America. Salt Lake City: n.p., 16 March 1928. Argues that the Book of Mormon lands were located in Honduras and Guatemala, extending "no further northward than southern parts of Mexico." Three maps are included. [B.D.]

D.120 Driggs, William King. 'The Liahona'; a Dramatic Cantata for Mixed Voices. Los Angeles: The Liahona Choral Society, 1952. A cantata paraphrased from 1 and 2 Nephi. [B.D.]

D.121 Drummond, Peggy Ann. "One Good Conversion Deserves Another." NE 5 (March 1975): 43. A story of a girl who was converted by the Book of Mormon and she in turn helped convert ten other people. [M.D.P.]

D.122 Duckwitz, Norbert H. O. "Amulek." In Encyclopedia of Mormonism, edited by Daniel H. Ludlow, 1:38-39. 5 vols. New York: Macmillan, 1992. Amulek was a prominent and wealthy Nephite of the wicked city Ammonihah. Once rebellious toward God, he was called by an angel to assist Alma the Younger and became his missionary companion. His powerful and articulate testimony confounded lawyers and called many to repentance. [J.W.M.] 
D.123 Dudley, Alex. The Purpose of Book of Mormon and Bible. Lansing, MI: private, 1957. A 19-page, typewritten manuscript addressed to the leaders of the RLDS church, calling them to repentance because they practice priestcraft and deny Christ by not believing that he is Christ the Son and God the Father in one person. The purpose of the Book of Mormon and the Bible is to convince individuals that Christ and God the father are one person. [B.D.]

D.124 Duerden, Noel. "Cuban Couple Writes of Ancient Cultures." CN 36 (15 January 1966): 11. Research proves that the "ancient Indians of the Americas possessed a rich theatrical culture," an evidence that supports the Book of Mormon. [M.D.P.]

D.125 Duff, Sean G. "The Four Quadrants." ZR 45 (November 1989): 3-4. Proposes a location for the river Sidon and a quadrant system location of the land northward, southward, and eastward. The quadrant system is based on the idea that "the river Sidon divided the east from the west" and "the border between the Nephites and the Lamanites divided the north from the south." [A.T.]

D.126 Duke, K. E. "Meliton Gonzalez Trejo: Translator of the Book of Mormon into Spanish." IE 59 (October 1956): 714-15, 753. An historical account of the life, sacrifices, and accomplishments of Meliton Gonzalez Trejo, who, being guided by a dream, left his homeland Spain and moved to Salt Lake City, Utah, where he joined the LDS church. Trejo translated the Book of Mormon into Spanish. [R.C.D.]

D.127 Duncan, Betty L. "The Invitation." The Restoration Witness 231 (March 1982): 6-10. Relates the events of her conversion through reading the Book of Mormon, and shares a personal experience and testimony regarding the coming of Christ to the Americas as recorded in 3 Nephi. [J.W.M.]

D.128 Dundas, Gregory. Review of By Study and Also by Faith, vol. 2, edited by John M. Lundquist and Stephen D. Ricks. Review of Books on the Book of Mormon 4 (1992): 127-38. Book review.

D.129 Dunford, C. Kent. "The Book of Mormon As a Record for the Future." In A Symposium on the Book of Mormon, 24-28. Salt Lake City: Church of Jesus Christ of Latter-day Saints, CES, August 1986. The Book of Mormon prophesies latter-day moral decay; it is a voice that warns against secret combinations and the denial of Christ; it solves religious confusion by supporting the Bible; it clarifies biblical doctrine and reveals plain and precious parts that have been taken out of the Bible; it is an additional witness of Jesus Christ. [B.D.]

D.130 Dunford, C. Kent. A Testament for Our Times. Salt Lake City: Bookcraft, 1993. The Book of Mormon was written for our day. The doctrines in the Book of Mormon are relevant to the twentieth century. It corrects a world in religious decline, gives counsel on war and politics, and guides against demonic influences, teaches of God and his dealings with the nations, clarifies the Atonement, true conversion, the Christian way of life, the resurrection, judgment, and the afterlife. [B.D.]

D.131 Dunford, C. Kent, et. al. Problems in Archaeology and Religion. Provo, UT: LDS Institute, Brigham Young University, 1966. Poses many problems pertaining to scriptural archaeology and provides a number of tentative or positive solutions. [D.M.]

D.132 Dunn, Charles W. The Master's Other Sheep: An Epic of Ancient America. Logan: J. P. Smith, 1929. Contains a poetic account of "the people and events depicted ... by the Book of Mormon." [B.D.] 
D.133 Dunn, Loren C. "Gaining a Testimony through the Book of Mormon." CR (October 1972): 95-97. Also found in Ensign 3 (January 1973): 84-85. Dunn presents two main points regarding a testimony of the Book of Mormon: (1) "The real strength of this Church is to be measured by the individual testimonies to be found in the total membership of the Church." (2) The Lord brought forth the Book of Mormon primarily to give individuals who study, ponder, and pray about it a testimony of its truthfulness. [R.C.D.]

D.134 Dunn, Loren C. "Read, Ponder, Pray." In BYUSY (7 March 1972). Provo, UT: BYU Press. The key to conversion and gaining a testimony of the mission and glory of Jesus Christ and the restoration of his gospel is found in the Book of Mormon. [J.W.M.]

D.135 Dunn, Loren C. "A Second Witness for Christ." Ensign 3 (July 1973): 44-46. Also found in CR (April 1973): 65-69. The Book of Mormon stands as a second witness of the nature, mission, and resurrection of Christ. [B.T.]

D.136 Dunn, Paul H. "Have Ye Inquired of the Lord?" In BYUSY (8 April 1969). Provo, UT: BYU Press. During a personal crisis of any kind individuals should remember the words of 1 Nephi 15:8, "Have ye inquired of the Lord?" Author cites several stories as examples. [R.J.L.]

D.137 Dunn, Paul H. A Look at the Book of Mormon. N.p.: n.p., 197?. Provides a series of tables and outlines identifying Book of Mormon time frames and events; includes Book of Mormon references to many archaeological and doctrinal passages. [D.M.]

D.138 Dunn, Scott C. "Spirit Writing: Another Look at the Book of Mormon." Sunstone 10 (June 1985): 16-26. An effort to explain the speed with which the Book of Mormon was translated. The writer reviews numerous cases of the phenomena of "spirit writing" and suggests that a similar phenomena could have occurred in the translation of the Book of Mormon. [M.R.]

D.139 Durham, A. Richards. "Antiquity, Scholarship, and the Prophet Joseph Smith." In Papers of the Fifteenth Annual Symposium on the Archaeology of the Scriptures, edited by Ross T. Christensen, 8-17. Provo, UT: Brigham Young University, 1964. When determining the competency of the prophet Joseph Smith, whether from a spiritual or a scholarly viewpoint, the same conclusion must be drawn: the Book of Mormon and the Book of Abraham are without question "genuine document[s] out of antiquity." [J.W.M.]

D.140 Durham, G. Homer. "The Christ of the Book of Mormon." In Brigham Young University 1978 Devotional and Fireside Speeches, 41-45. Provo, UT: Brigham Young University. The Book of Mormon answers questions that plague humanity in the latter days. It provides key information concerning the divine role of Jesus Christ. [J.W.M.]

D.141 Durham, G. Homer. Joseph Smith-Prophet-Statesman. Salt Lake City: Bookcraft, 1944. The first section of this work focuses on "the political theory of the Book of Mormon." Several political aspects are treated, including the founding of the Nephite republic (Mosiah 29:10-29), the welfare of the state (Alma 4:11-12, 15-20), and the ideal Christian society (4 Nephi 1-3, 16-17). [R.J.L.]

D.142 Durham, Lowell M. Review of Book of Mormon Oratorio, by Leroy Robertson. Dialogue 2 (Autumn 1967): 149. Book review.

D.143 Durham, Reed C. A History of Joseph Smith's Revision of the Bible. Ph.D. diss., Brigham Young University, 1965. Compares verses of the King James Version that are quoted in the Book of Mormon that are significantly 
different from the same verses in Joseph Smith's Revision of the Bible. The lack of harmony between the two works is "strong evidence that the revision was incomplete." [B.D.]

D.144 Durham, Reed C. Review of Joseph Smith and the Restoration, by Ivan J. Barrett. BYU Studies 8/3 (1968): 342. Book review.

D.145 Durham, Reed C., Jr. Some Recent Historical and Archaeological Evidences for the Book of Mormon. R. C. Durham, 1980. An outline listing a number of Book of Mormon archaeological evidences, with an accompanying bibliography. Evidences include: Beit Lehi inscriptions, chaismus, transoceanic influences, Mayan and Egyptian calendar parallels, Zuggurats, horses. [D.M.]

D.146 Durham, W. Cole, Jr. "Moroni." Ensign 8 (June 1978): 56-61. As a witness to the destruction of the entire Nephite civilization, Moroni's writings on the gold plates add special insights to today's society. [D.M.]

D.147 Dutton, Jasper O. "The Book of Mormon." SH 87 (18 May 1940): 621-23. Many principles and ordinances of the gospel of Jesus Christ are taught in the Book of Mormon, including faith, repentance, the merciful kindness of God, charity, baptism, the laying on of hands, and prayer. [J.W.M.]

D.148 Dyer, Alvin R. "The Precepts of Men." IE 72 (June 1969): 39-42. Nephi once taught of the unfortunate condition of mankind when they cease to trust in God and to rely on "the precepts of men and denieth the power of God, and the gift of the Holy Ghost" (2 Nephi 28:26). One of the evil doctrines of our education system is sex education in our schools. The "new morality" fails to make the distinction between right and wrong. Personal agency is in jeopardy. [J.W.M.] 
E.

E.001 E., A. "The Anthon Account." MS 113 (September 1951): 206-7, 224. Isaiah saw the great work of the Book of Mormon and prophesied concerning Martin Harris's visit with Professor Anthon (Isaiah 29:11-12). The article contains Martin Harris's account of this visit. Edward Stevenson wrote that Martin Harris saw his visit as a fulfillment to Isaiah's prophecy. Metallic sheets discovered in Iran buried in the palace of Darius verify the statements made by Joseph Smith and the Book of Mormon about metal records. [J.W.M.]

E.002 E., F. Joseph Smith in His Own Defense. Lamoni, lowa: Herald Publishing House, n.d. Written at least fifteen years after the death of Joseph Smith, but in the first person to express Joseph Smith's views as understood by the author. Quotes Jacob 2 to condemn polygamy and repudiates the idea of celestial marriage. [E.G.]

E.003 E., F. Joseph Smith: The Martyr, In His Own Defense. Australia: Australian Tract Club, 1908. Published first in the Salt Lake Tribune, July 26, 1908, written as if Joseph Smith had authored this pamphlet. The Book of Mormon condemns polygamy as an abomination. Charges that none of Joseph's words can be used to vindicate this practice. The Lord does not allow polygamy in his church. [J.W.M.]

E.004 E., R. L. "Book of Mormon Studies" (Series). MS 90-91 (12 January 1928; 29 November 1928; 17 January 1929; 21 November 1929): 22-23, 46-47, 62-64, 77-80, 109-11, 123-25, 181-83, 204-6, 251-54, 267-68, 33233, 350-52, 396-98, 413-16, 459-62, 477-78, 542-43, 558-59, 606, 623, 683-84, 702-3, 750-51, 764-65, 41, 102, 179-80, 244, 325-26, 387-88, 453-54, 517-18, 581-82, 660-61, 740-41. Series of brief articles intended for Relief Society course study. Discusses the importance of the Book of Mormon, its coming forth (i.e., the translation, the witnesses, the publication, Joseph Smith), and features a brief overview of its contents. Covers 1 Nephi through Moroni. [A.C.W. \& R.H.B.]

E.005 E., R. L. "The Standard Works." MS 89 (1 September 1927): 554-56. The LDS church accepts four separate works as the standard works - the Bible, the Book of Mormon, the Doctrine and Covenants, and the Pearl of Great Price. These works are authoritative and set forth revelations of God. [D.W.P.]

E.006 Eames, Rulon D. "Book of Mormon: First Book of Nephi." In Encyclopedia of Mormonism, edited by Daniel H. Ludlow, 1:144-45. 5 vols. New York: Macmillan, 1992. Summarizes the book of 1 Nephi and provides a map of the Arabian Peninsula that traces the possible route of Lehi. [A.T.]

E.007 Earl, Mary Hasler. "Bach, Beethoven, and the Book of Mormon." NE 13 (August 1983): 10-11. Offering a simple analogy to motivate individuals to read the Book of Mormon, the author compares piano practice to scripture study. "Just as I have to learn new piano techniques, I must review the Book of Mormon and learn eternal techniques." [R.J.L.]

E.008 "The Early History, Rise and Progress of Mormonism." Frank Leslie's New Family Magazine 2 (February 1858): 112-21. Includes the LDS account of the coming forth of the Book of Mormon but accepts the Solomon Spaulding theory for its origin. Also speaks concerning the attempts by mobs to steal the gold plates, the mode of translation, and Joseph Smith's literary aptitude. [D.M.]

E.009 Easter, Edna. "The Book of Mormon Plates: An Estimate of the Probable Size from Which Joseph Smith Made His Translation." SH 84 (31 July 1937): 973. Estimates that the weight of the gold plates from which Joseph 
Smith translated the Book of Mormon was sixty pounds. [J.W.M.]

E.010 Eastwood, Laura Teichert, and Robert O. Davis. Rich in Story, Great in Faith: The Art of Minerva Kohlhepp Teichert. Salt Lake City: Church of Jesus Christ of Latter-day Saints, 1988. A booklet containing a photographic essay on the life and paintings of Minerva Teichert. Created to accompany an exhibition at the Museum of Church History and Art, the work contains representations of several of Teichert's Book of Mormon paintings. [D.W.P.]

E.011 Eaton, Mrs. Horace. "The Origin of Mormonism." In Handbook on Mormonism, 1-4. Salt Lake City: Handbook Publishing, 1882. A polemical discussion on the origins of Mormonism, with mention of the Spaulding theory. [M.R.]

E.012 Ebeling, F. J. "Book of Mormon Its Own Vindicator." SH 51 (12 October 1904): 952-59. Opponents of the Book of Mormon claim that the book stands or falls on the character of Joseph Smith, but Ebeling argues that the book stands upon its own strength. Had the book been written by Solomon Spaulding, it may have taught the prevalent doctrines of his day, i.e., a sprinkling baptism rather than immersion, a denial of miracles and revelation, and that the remission of sins comes through faith and prayer. [J.W.M.]

E.013 Edholm, J. R. W. The Bible and the Book of Mormon Fully Harmonize. Salt Lake City: J. R. W. Edholm, 1938?. A pamphlet comparing 1 Corinthians 15:25-32 with 2 Nephi 9:24, and Mosiah 15:8, 16:8 and 1 Nephi 11:26-27. Those who believe in genealogical temple work for the dead do not understand the scriptures. [J.W.M.]

E.014 Edvalson, Carl I. "Martin Harris and the Book of Mormon." 13 September 1947. Transcription of a talk given at the graveside of Martin Harris, eulogizing his part in the restoration. Views the Book of Mormon as the answer to materialism, atheism, and higher criticism. Typescript held at the LDS Church Office Building Historical Library. [D.M.]

E.015 Edwards, F. Henry. "The Book of Mormon Offers Opportunities for Church Writers to Serve." SH(22 July 1957): 681-83, 696. Sees a "vast field for exploration" in writing about the Book of Mormon, saying that the main task is to present the Book of Mormon to the world while keeping in touch with the book itself. Sets literary standards and outlines areas of urgent need, including foreign language translations, study aids, apologetics, and creative studies. [A.C.W.]

E.016 Edwards, F. Henry. The Missionary Message of the Book of Mormon. Independence, MO: Herald House, 1929. Contains thirteen lessons for adults on instructions and teachings within the Book of Mormon on missionary work. [B.D.]

E.017 Edwards, Kay P. "The Kingdom of God and the Kingdoms of Men." In Studies in Scripture: 1 Nephi to Alma 29, edited by Kent P. Jackson, 7:270-82. Salt Lake City: Deseret Book, 1987. Examining Mosiah 25-29 provides insights into Alma's first address to the combined congregation of reunited Nephites and the people of Zarahemla. Alma taught the first principles and ordinances of the gospel and the process of spiritual rebirth. Discusses various forms of government, including government by the voice of the people and finds that government is important and is sanctioned by God, who does not necessarily endorse any particular system of government. [J.W.M.]

E.018 Edwards, Kay P. "What the Doctrine and Covenants Says about the Book of Mormon." Ensign 19 (January 1989): 34-37. In the Doctrine and Covenants the Lord testifies of the truthfulness of the Book of Mormon. The Doctrine and Covenants teaches that the Book of Mormon came forth under the direction of the Lord, that it should be studied by mankind, that woe will come to those who neglect it, that blessings of knowledge and eternal 
life are promised to those who receive it, that it will bring Lamanites and Jews to the Lord, and that it will bring to light the true points of Christ's doctrine. [A.A.]

E.019 Eggenberger, Oswald. "Die Bibel und das Buch Mormon-Das Buch Mormon-eine Hilfe zum Verstpndnis der Bibel?" Bibel Report (1977): 6-7. A polemic written against the Book of Mormon and the idea that Jesus visited ancient America. [D.W.P.]

E.020 Eggington, William. "Our Weakness in Writing": Oral and Literate Culture in the Book of Mormon. Provo, UT: FARMS, 1992. "Investigates aspects of the socio-cultural structure of the Nephite, Lamanite, and Mulekite people of the Book of Mormon from the point of view of those who study the nature of oral and literate societies." Lehi and his descendants functioned in an "Oral residual culture," a culture that writes to accomplish some very narrow functions, but acts, to a large extent, like an oral culture. "If we somehow can begin to understand the discourse and socio-cultural structures of the Book of Mormon authors, and the natures of their text production constraints and our text perception constraints, we may more clearly comprehend the text and its vital messages." [B.D.]

E.021 Eidmann, Karl. Brief Studies of the Life and Times of Lehi. St. Paul, MN: Liahona, 1947. A sketch of Lehi's life that draws heavily on Jewish sources and terminology. [D.M.]

E.022 "The Eight Witnesses" Historical Record 6 (1888): 195-219 Oliver Cowdery, David Whitmer, and Martin Harris desired the privilege and responsibility of being the Three Witnesses to the Book of Mormon. This article contains Joseph Smith's words concerning this event, the testimony of the Three Witnesses and a lengthy history of each. [J.W.M.]

E.023 "1873 Martin Harris Letter Reaffirms Book of Mormon Testimony." Ensign 12 (November 1982): 97-99. A news account of the discovery of a letter by Martin Harris confirming his testimony as one of the Three Witnesses to the Book of Mormon. (Editor's note: this document has since been shown to be a forgery.) [S.P.S.]

E.024 "1829, A Momentous Year." CN 49 (29 December 1979): 3. In 1829 the Book of Mormon was translated, the priesthood was restored, and Joseph Smith received fourteen revelations. [M.R.]

E.025 “1829 Lucy Mack Smith Letter Displayed." Ensign 12 (October 1982): 70-73. News of the discovery of a "previously unknown 1829 letter by Lucy Mack Smith to her sister-in-law in which [she] discusses her son's work." (Editor's note: the letter has since been identified as a Hofmann forgery.) [S.P.S.]

E.026 Einige Interessante Hinweiseim Buch Mormon. n.p., 19?. A missionary tract that provides a brief overview of the contents of the Book of Mormon. [D.W.P.]

E.027 "Elder Hunter Describes Trip to Ruins in Bolivia and Peru." CN 27 (17 August 1957): 4. A description of Milton R. Hunter's trip to South America. Archaeological support for the Book of Mormon includes: gold artifacts, fine cloth, stone work, a horse carving, and what appears to be an ancient baptismal font. [A.C.W.]

E.028 Eldred, Phil. "Records Yet to Come Forth." Witness 79 (Winter 1992): 8-9. 14. Scriptural passages in the Book of Mormon refer to "other records" that have been lost or withheld that will be given at a later time. It is pointed out that the Book of Mormon must be received, embraced, and cherished before the promised records will be given. [J.W.M.] 
E.029 Elefson, Vern. "Speculations on Book of Mormon Populations." ZR 15 (1981-82): 4-8. The author claims that "the Book of Mormon record is in agreement with population theory." Selected passages from the Book of Mormon are used to show its relationship to a population growth model. Charts and graphs are included. [R.J.L.]

E.030 "Eleven Original Manuscript Pages Now Laminated." CN 38 (26 October 1968): 5, 14. Eleven of the seventy-five pages that the Church owns of the original manuscript of the Book of Mormon have been successfully laminated in plastic in Richmond, VA. The process of restoration and preservation of the pages is described. [J.W.M.]

E.031 "The 'Eleven Witnesses' to the Book of Mormon." Utah Christian Tract Society 11 (January-February 1977): 2. Argues against the reliability of the witnesses of the Book of Mormon and expresses concern over textual changes in the book. [D.M.]

E.032 Eliott, Jennie Z. "A Nephite and the Risen Christ: An Easter Fantasy." SH 101 (12 April 1954): 348. A fictional story about a young Nephite who followed the star that led to the Christ child. [J.W.M.]

E.033 el-Kaveh, Badeh F. "Book of Mormon is Wonderful." DN (21 July 1934): 7. A non-member read and studied the Book of Mormon for six months and was very impressed by it. [M.D.P.]

E.034 Elledge, Helen. Book of Mormon Stories for Children. Independence, MO: Herald House, 1962. Simplified Book of Mormon stories are given for children, with illustrations. [B.D.]

E.035 Elliott, David C. "America: God's Promised Land for the Gathering and Redemption of Israel." ZR 29, 30,31 (1985-86): 14-17, 22. Through Bible and Book of Mormon references, Elliott claims that "the history of America and the history of the Israelite peoples have been inseparably entwined together." Both the land of Israel and the land of America are lands of promise, both have a city called Jerusalem, and both are gathering places for the House of Israel. America will play a major role in the redemption of the world. [R.J.L.]

E.036 Elliott, Dorice Williams. "Cultural Dogmas Vs. Universal Truths." Sunstone 12 (May 1988): 31-32. A reflection on the relationship between cultural dogmas and timeless truths, and their relevance to a study of the Book of Mormon, with emphasis on the problems of racism and sexism. The curse of the Lamanites is brought out as a case in point. [D.M.]

E.037 Elliott, Max B. "Hand in Hand: Indian Traditions and the Book of Mormon." Instructor 104 (January 1969): 30. LDS missionaries taught the Book of Mormon story to a Navajo spiritual leader and his family. The spiritual leader acknowledged that their story is true and already known in Navajo tradition. 3 Nephi 30:5-6 is applied to this event. [R.J.L.]

E.038 Elliott, Peter. Reasons for Disbelief: A Survey of the Historical and Theological Beliefs of the Reorganized Church of Jesus Christ of Latter Day Saints. Australia: Elliott, 1980. Cites reasons why one should not accept Mormonism; reprints the Smithsonian statement regarding the Book of Mormon, compares Quetzalcoatl or Viracocha and Jesus Christ, and concludes that they are different characters; sees Ethan Smith's View of the Hebrews as the source of the Book of Mormon. [B.D.]

E.039 Ellis, Alvin R. The Divinity of the Book of Mormon. Grand Rapids: Evans, n.d. Lists many prophecies given in the Book of Mormon and gives historical and statistical facts to show how these prophecies have been realized. [B.D.] 
E.040 Ells, Josiah. Prophetic Truth Confirmed in the Appearing of the Book of Mormon. Pittsburgh: n.p., 1881. A dialogue between one who believes and one who does not believe in the Book of Mormon. The author quotes biblical prophecies dealing with the Book of Mormon, and discusses the Kinderhook plates and the Anthon transcript. [B.D.]

E.041 Ells, Josiah. "Stick of Ephraim." SH 30 (22 December 1883): 817-18. A rebuttal to an earlier article written by E. H. Gurley, Josiah Ells defends the claims that Ezekiel 39 and Hosea 8:12 refer to the Book of Mormon. He mentions the gathering of the lost ten tribes and the grammatical structure of those prophesies. [A.T.]

E.042 Ellsworth, German E. Untitled talk. CR (April 1912): 89-93. Discusses the Apostasy, the Restoration, and the Book of Mormon. Though many reject its divinity, none have been able to disprove it. In the world there are many honest and good people who must be sought out and given the truths of the gospel. [J.W.M.]

E.043 Ellsworth, German E. Untitled talk. CR (April 1916): 79-83. Never has there been a book that has come forth with more evidences and testimonies of its truthfulness. Mentioned are the angel Moroni's visit, the testimony of the Three and Eight Witnesses, and the Book of Mormon prophets. [J.W.M.]

E.044 Ellsworth, John Orval. "A Land of Many Waters." IE 30 (December 1926): 180-81. Claims that certain geographical references in the Book of Mormon describe the land and lakes in central and northern New York. [R.J.L.]

E.045 Ellsworth, Richard G. "Growing toward the Good." NE 16 (May 1986): 8-13. A testimonial by an individual in the navy who studied the Book of Mormon and felt a great spiritual power accompany the book. The promise in Moroni 10 had a long lasting effect upon him. [B.D.]

E.046 Ellsworth, Richard G. "Witness Comes with Calm Assurance." CN 55 (August 4, 1985): 12. Evil is shocking and much easier to perceive than good. Good is often overlooked. Ultimately good testifies of Christ. Ellsworth tells of his first experience with reading the Book of Mormon-his prayer of faith in response to Moroni's promise, and the quiet power that permeated his soul in answer. [J.W.M.]

E.047 Emmons, S. B. The Spirit Land. Philadelphia: Potter, 1857. A polemical work on various religions. Pages 96102 contain a discussion of Mormonism and the Book of Mormon. The author considers the Book of Mormon "a bungling attempt to imitate the style of the sacred scriptures." He accepts the Spaulding theory regarding the Book of Mormon's origin. [M.R.]

E.048 Enciso, N. Paul. "When a Lamanite Reads the Book of Mormon." In The Sixth Annual Church Educational System Religious Educators' Symposium on the Book of Mormon, 24-26. Salt Lake City: Church of Jesus Christ of Latter-day Saints, 1982. A testimonial by a Native American who gained a knowledge of the truthfulness of the Book of Mormon. Recalls statements by his grandparents concerning the migration of their ancestors to the American continents and the visit of the "Creator" to their ancestors. [A.T.]

E.049 England, Eugene. "Benjamin, the Great King." Ensign 6 (December 1976): 26-31. The life of King Benjamin is recounted. King Benjamin may be the greatest king who ever lived because he brought his people to both temporal and spiritual redemption. [B.D.]

E.050 England, Eugene. Converted to Christ through the Book of Mormon. Salt Lake City: Deseret Book, 1989. A compilation of various individuals' experiences with the Book of Mormon. The work is divided into three main 
sections: (1) the Book of Mormon family-to-family program in which families provide gift copies of the Book of Mormon to others; (2) stories of persons being converted to the Book of Mormon; and (3) reconversion stories of lifetime members of the Church. [B.D.]

E.051 England, Eugene. "Eugene England Replies." Sunstone 15 (April 1991): 8-9. Nephi set the racist attitude of the Book of Mormon, one similar to biblical record keepers. The mark placed on those who sinned was propagated by themselves by either marking their own bodies or by intermarriage with those who had been genetically marked with a dark skin. Latter-day Saint people need to put away racial attitudes and see that God recognizes all men as equal. [J.W.M.]

E.052 England, Eugene. " 'Means Unto Repentance': Unique Book of Mormon Insights Into Christ's At-One-Ment." In Rediscovering The Book of Mormon, edited by John L. Sorenson and Melvin J. Thorne, 153-67. Salt Lake City: Deseret Book and FARMS, 1991. Explores the popular Christian theories about the Atonement, the "satisfaction" and "moral influence" theories. Discusses the LDS view and finds that the Fall of Adam was an essential part of the at-one-ment. The Book of Mormon makes this clear. [J.W.M.]

E.053 England, Eugene. "Moroni and His Captains: Men of Peace in a Time of War." Ensign 7 (September 1977): 29-36. While abridging ancient records, Mormon recorded many items dealing with wars in Alma 42-63. It was his desire to identify the righteous attributes of military captains Moroni, Helaman, Lehi, and Teancum. [B.D.]

E.054 England, Eugene. The Quality of Mercy: Personal Essays on Mormon Experience. Salt Lake City: Bookcraft, 1992. Several pages of this work are devoted to showing how the Book of Mormon teaches the principle of mercy in relationship to the Atonement and the condition of the Lamanites. [D.M.]

E.055 England, Eugene. Review of Since Cumorah, by Hugh W. Nibley, vol. 7 of The Collected Works of Hugh Nibley. BYU Studies 30/4 (1990): 104. Book review.

E.056 England, Eugene. Review of The Folk of the Fringe; The Tales of Alvin Maker: Seventh Son; The Red Prophet; Prentice Alvin, by Orson Scott Card. Review of Books on the Book of Mormon 2 (1990): 56-62. Book review.

E.057 England, Eugene. Review of "Warfare and the Book of Mormon," from Warfare in the Book of Mormon, by Hugh W. Nibley, 127-45. BYU Studies 30/4 (1990): 104. Book review.

E.058 England, Eugene. "A Second Witness for the Logos: The Book of Mormon and Contemporary Literary Criticism." In By Study and Also by Faith, edited by John M. Lundquist and Stephen D. Ricks, 2:91-125. Salt Lake City: Deseret and FARMS, 1990. Presents internal consistency of the Book of Mormon with respect to biblical patterns, metaphorical language, topological structures, Christ-centered content and eschatological meaning. These techniques, as used by the literary critics Frye and Girard on the Bible, show the presence and divinity of the Logos or redeeming Word of God in the Book of Mormon as well. Man's dark pilgrimage through life toward the ultimate tree of life, made possible by God's love and Christ's Atonement, is considered in light of patterns in the Book of Mormon. Nephi's killing of Laban and God's use of violence is discussed. [A.A.]

E.059 England, Eugene. "Through the Arabian Desert to a Bountiful Land: Could Joseph Smith Have Known the Way?" In Book of Mormon Authorship: New Light on Ancient Origins, edited by Noel B. Reynolds, 143-56. Provo, UT: Brigham Young University Religious Studies Center, 1982. Compares the details of Lehi's journey across the Arabian desert to knowledge of the Arabian desert during Joseph Smith's time, showing that Joseph did not use worldly knowledge to translate the Book of Mormon. [B.D.] 
E.060 England, Eugene. "Why Nephi Killed Laban: Reflections on the Truth of the Book of Mormon." Dialogue 22 (Fall 1989): 32-51. Violence and non-violence in the Book of Mormon is examined, including the killing of Laban (1 Nephi 4), the story of the Anti-Nephi-Lehies (Alma 24) and King Benjamin's address (Mosiah 4). [B.D.]

E.061 "Enos." Friend 11 (October 1981): 20-21. Cartoon pages for children telling the story of how Enos went into the wilderness to pray. [J.W.M.]

E.062 “Enos." Friend 20 (March 1990): 28-29. An illustrated story for children about Enos. [M.D.P.]

E.063 "Enos's Prayer." Friend 13 (July 1983): 48-49. A children's version of Enos and his prayer. [J.W.M.]

E.064 Ensign, Kathy. "One Thing I Remember from the Book of Mormon." NE 7 (May 1977): 41. A young woman was touched by Alma 34:28 as she read it to a group of deaf visitors to Temple Square who had requested that she read it. It speaks of those who turn away the needy and warns that their prayers are in vain. [M.D.P.]

E.065 Epperson, Steven. "Jewish Identity and Destiny in the Book of Mormon." In Epperson's Mormons and Jews: Early Mormon Theologies of Israel, 19-41. Salt Lake City: Signature, 1992. Joseph Smith's interest in the Jewish people was ever enduring and figured prominently in the Book of Mormon, which contains a worldview different than any other. The Book of Mormon holds future Israel and Judaism in high esteem as they preserve the biblical records, embrace the Messiah in the gathering to his place of refuge, reconcile to Christ and recognize his love and mercy. [J.W.M.]

E.066 Epstein, Jeremiah F. "Pre-Columbian Old World Coins in America." Current Anthropology 21 (February 1980): 1-12, 17-20. Evaluates forty reports of Greco-Roman and Hebrew coins found on the American Continent, and then concludes that no single report of a classical-period coin in America can be used as evidence of preColumbian transatlantic contact. [B.D.]

E.067 Erickson, Einar C. "New Dates for the Reign of Zedekiah." In Papers of the Fifteenth Annual Symposium on the Archaeology of the Scriptures, edited by Ross T. Christensen, 39-46. Provo, UT: Brigham Young University, 1964. Nephi records that his family left Jerusalem during the first year of the reign of Zedekiah. The discovery of new archaeological evidence, the Babylonian Chronicle, makes possible the exact dating of Zedekiah's reign, the Babylonian conquest of Jerusalem, and therefore Lehi's and Mulek's migrations to America. [J.W.M.]

E.068 Ernst, Justus. "Translation Aids." In Conference on the Language of the Mormons, 95-138. Provo, UT: BYU Language Research Center, 8 April 1974. Provides aids for translators of the Book of Mormon, including a "scripture comparison list" that shows textual parallels to the Book of Mormon and the King James Version of the Bible and a "Book of Mormon translation guide" to give translators the best choices for Book of Mormon terminology. [B.D.]

E.069 Escobar, Victor. "A Book of Mormon Triptych Painting." M.F.A. thesis, Brigham Young University, 1969. Presents a triptych painting (a three-panel composition) depicting (1) Christ with the Nephites feeling his wounds; (2) Christ blessing Nephite children; (3) a harvest scene symbolizing that prosperity is the result of following Christ's teachings. [B.D.]

E.070 Essig, Fred, and Daniel Fuller. Nephi's Slaying of Laban: A Legal Perspective. Provo, UT: FARMS, 1982. A detailed examination of the legal ramifications of Nephi's execution of Laban. [D.M.] 
E.071 Ettinger, Cecil. "A Testimony of the Book of Mormon." Restoration Witness 8 (April 1970): 6-7. Bears a testimony that is not based on archaeological evidences connected to the Book of Mormon, but on the contents of the book. [J.W.M.]

E.072 Etzenhouser, Rudolph. "About Cumorah." SH 50 (18 March 1903): 246-51. Believes that even though the major events of the Book of Mormon took place in South America, it would have been possible for the gold plates to have been brought to New York. Author argues, therefore, that the Hill Cumorah is in New York. [J.W.M.]

E.073 Etzenhouser, Rudolf. The Book of Mormon and Its Translator. Independence, MO: Ensign House, 1899. The Book of Mormon, like the Bible, is necessary for humanity. Joseph Smith translated the Book of Mormon from inscribed plates. Presents archaeological evidence of ancient cities, elephants, and horses. [B.D.]

E.074 Etzenhouser, Rudolf. The Book Unsealed; An Exposition of Prophecy and American Antiquities. Independence, MO: Ensign Print, 1892, [R]1895. Cites biblical prophecies and archaeological and other scientific studies to provide external evidence for many claims of the Book of Mormon concerning ancient American culture: evidence of highly civilized peoples, Hebrew customs, ancient writings, textiles, horses and elephants, metals, Egyptian influence, and the fulfillment of Psalms 85 and Isaiah 29. [B.D.]

E.075 Etzenhouser, Rudolf. Engravings of Prehistoric Specimens from Michigan, U.S.A. Detroit, Michigan: John Borman and Son, 1910. Contains depictions of stone, copper, and clay tablets, boxes and other objects upon which are found ancient engravings. [B.D.]

E.076 Etzenhouser, Rudolf. From Palmyra, New York, 1830 to Independence, Missouri 1894. Independence, MO: Ensign House, 1894. The book is divided into three parts, two of which contain a discussion of the Book of Mormon. Features a revised and enlarged edition of the author's Book Unsealed (1892) reviews eleven works written against Mormonism, and examines six United States school histories and four encyclopedias that deal with Mormonism. [B.D.]

E.077 Etzenhouser Rudolph. "The Straight Road: The Book of Mormon; What Is It?" SH 54 (20 November 1907): 1068. The Book of Mormon records the history of the early inhabitants of America and God's dealings with them. [J.W.M.]

E.078 Evans, J. Fred. "Calendar Stone Gives Exact Date of Geologic Cataclysm." DN Church Section(2 November 1935): 1. Shows that the Mexican Calendar Stone gives an account and the exact date of the "great cataclysm," and that it is the same date and account that is given in the Book of Mormon. The "great cataclysm" is the destruction that happened to the land during and after the crucifixion of Jesus Christ. [M.D.P.]

E.079 Evans, John Frederick. Remarkable Discoveries by Our Scientists of Book of Mormon Names on the Stone Ruins of Mexico, Central America and South America. Salt Lake City: Vanity, 1940?. Relates names from New World inscriptions to names or titles in the Book of Mormon. Names of calendar months and other titles were associated with Book of Mormon words such as Laman, Mulek, Enos, Laban, Benjamin, Nephi, and so forth. [D.M.]

E.080 Evans, John Henry. "Bishop Spalding's Jumps in the Logical Process." IE 16 (February 1913): 343-46. Bishop Spalding makes three unwarranted inferences in his pamphlet "Joseph Smith, Jr., As a Translator"-that the Book of Abraham is translated incorrectly, that the Book of Mormon cannot be authentic if the Book of Abraham is poorly translated, that all Mormon belief should be discarded since the Book of Mormon is the basis of the religion. [J.W.M.] 
E.081 Evans, John Henry. “The Book of Mormon." In Evans's Joseph Smith: An American Prophet, 33-50. New York: Macmillan, 1940. Young Joseph Smith one day disappeared from the village of his youth. It was rumored that he was writing a book about the early inhabitants of America. Three years later he returned with a young bride and a bulky manuscript and set the town in an uproar. The author recounts the story of the coming forth of the Book of Mormon, a volume to answer the many questions prevalent in Joseph's day and the most effective missionary tool the Church had. The article contains conversion stories. [J.W.M.]

E.082 Evans, John Henry. "The Book of Mormon," in Evans's The Heart of Mormonism. Salt Lake City: Deseret News Press, 1931. Writes concerning the coming forth of the Book of Mormon. While engaged in the translation of the book Joseph Smith encountered many questions and experienced many things that helped to re-establish the Church of Christ on the earth. [J.W.M.]

E.083 Evans, John Henry. "The Book of Mormon as a Motivating Force in 'Mormonism. " DN (19 November 1932): 5, 7. Text of an address showing the power that the Book of Mormon exerts on human hearts. Gives conversion stories of early Church leaders, and relates the Book of Mormon teachings to the principles of personal knowledge, righteousness, and service that are the heart of the New Testament. [A.C.W.]

E.084 Evans, John Henry. "Book of Mormon Women and Their Work." Relief Society Magazine 15 (March 1928): 121-26. Women in the Book of Mormon were probably similar to women of all eras, the inspiration behind good men. Book of Mormon women that are referred to by name include Sariah, the wife of Lehi, and Abish, a Lamanite servant to King Lamoni. Women were held in high esteem, possessed great talents, and their work was important. [J.W.M.]

E.085 Evans, John Henry. "The Book with Golden Leaves," "Through Urim and Thummim," and "The Red Man's Bible." In Evans's Our Church and People, 67-86. Salt Lake City: Deseret Book, 1924. The author gives a very personal side of Joseph Smith's experience concerning the coming forth of the Book of Mormon. Observes that the translation of the Book of Mormon was a great period of training for the young prophet of God. There were two other purposes - to teach the gospel to the native inhabitants of America and to reinforce the teachings of the New Testament and make them easy to understand. [J.W.M.]

E.086 Evans, John Henry. "The Christ of the Book of Mormon." Relief Society Magazine 15 (April 1928): 179-90. The Book of Mormon presents a clearer understanding of Jesus Christ than does the Bible. It teaches regarding his pre-earth life, his Godhood, his godly attributes, and his appearance to the Nephites. [J.W.M.]

E.087 Evans, John Henry. "Conversions through the Book of Mormon" (Series). Instructor 78-79 (November 1943 -December 1944): 565, 624, 25, 56, 120, 156, 211, 322, 374, 413, 469, 579. A series of accounts and stories of individuals who were converted through the Book of Mormon. Relates the stories of a hardened criminal, Thomas B. Marsh, George Ottinger, John Wells, Lester F. Bardin, Alvina Covert Turner, Robert Thomas Hill, Josephine and Otto Gaeth, A. William Lund, Heber J. Grant, and a Shoshone Indian, all of whom were converted by reading the Book of Mormon. [R.H.B.]

E.088 Evans, John Henry. "Form and Structure." Relief Society Magazine 19 (February 1932): 97-101. On the basis of its involved structure, the author argues that the Book of Mormon is a translation of an ancient document and not a modern composition. [S.H.]

E.089 Evans, John Henry. "The Gold Plates and the Book of Mormon." In Evans's A Short History of the Church of Jesus Christ of Latter-day Saints, 15-27. Salt Lake City: Church of Jesus Christ of Latter-day Saints, 1946. Evans 
briefly describes major points in the history of the coming forth of the Book of Mormon. He mentions various hiding places for the plates, the help of Martin Harris and Oliver Cowdery, the changing of residences, and the contract to publish with E. B. Grandin. Gives a synopsis of Nephite record keeping. Also mentions the testimonies of the Three and Eight Witnesses and finally mentions the fact that there are external as well as internal evidences. [B.D.]

E.090 Evans, John Henry. Joseph Smith: An American Prophet. Salt Lake City: Deseret Book, 1989. Chapter three deals specifically with the Book of Mormon, its coming forth and contents, and the positive effect it has had upon people. [J.W.M.]

E.091 Evans, John Henry. Message and Characters of the Book of Mormon. Salt Lake City: n.p., 1929. Written for young people. Details the historical background of the coming forth of the Book of Mormon, its translation, and then presents selected messages and characters from the Book of Mormon. [J.W.M.]

E.092 Evans, John Henry. "Nephite Philosophy of Life." IE 30 (September 1927): 955-59. Nephite leaders and teachers possessed a distinct philosophy regarding life. For instance, God demonstrates an impartiality towards the human race, the Holy Ghost is available to direct one's life, the principle of freedom is attached to obedience to divine law, an eternal view of things is advanced as opposed to the limited temporal view that mankind is prone to take. [D.M.]

E.093 Evans, John Henry. "Opening of the New Dispensation." In Evans's One Hundred Years of Mormonism, 1-120. Salt Lake City: n.p., 1905?. Recounts events taking place in America and Europe from 1815 to 1820, and sets forth the Smith family history relevant to the Prophet Joseph. The errors that had crept into the Bible and the arguments over doctrine are examined. Gives vivid accounts of the miracles surrounding the period of translation and provides many details concerning the coming forth of the Book of Mormon, the witnesses' testimonies, and accusations concerning the book's authenticity, contents, and the calling of Joseph Smith. [J.W.M.]

E.094 Evans, John Henry. "Side Lights on the Book of Mormon" (series). Relief Society Magazine 18 (October, November 1931; January, April, June 1932): 546-48, 606-10, 97-101, 218-22. June 1932 article is also in MS 94 (4 August 1932): 490-95. Between 1820 and 1830 Joseph Smith received a great spiritual education through contact with heavenly beings and learning of God's dealings with men in the Book of Mormon. The literary structure of the Book of Mormon is complex, filled exposition of doctrine and many details regarding people, events, and things. The Book of Mormon clears up many disputed doctrines of the Bible, such as baptism, the Godhood of Christ, pre-earth life, the nature of man, the purpose of life, and others. Hebrew culture, customs, ideas, and mode of thought is at the very root of the book. Early converts to the Church-Thomas Marsh, Parley P. Pratt, Willard Richards, and others-received their testimony from reading the Book of Mormon. [J.W.M.]

E.095 Evans, R. C. Forty Years in the Mormon Church: Why I Left It! Toronto, Canada: by author, 1920. An exmember and apostle in the RLDS church gives his own history. As he matured it became increasingly difficult to believe in the Book of Mormon, since he found that Joseph Smith was a deceit and a fraud. Favors the Spaulding theory as the origin of the Book of Mormon. [J.W.M.]

E.096 Evans, Richard C. The Book of Mormon: Evidences of Its Divinity. Independence, MO: Ensign House, 1898. The purpose of the Book of Mormon is to convince the Jew and the gentile of the divinity of Jesus Christ. Evans cites many biblical passages to show that the Book of Mormon contains the truth and that it fulfills its purpose. [B.D.] 
E.097 Evans, Richard C. Joseph Smith: Was He a Prophet of God? Independence, MO: Ensign Publishing House, April 1902. Many bear witness of Joseph Smith's divine mission and the Book of Mormon's authenticity. They never denied their testimonies. Many reformers testified of the apostasy of the Church and looked forward to a restoration. During the first vision Joseph was told to join no church. An angel delivered the Book of Mormon plates restoring the primitive gospel of Christ. [J.W.M.]

E.098 Evans, Richard C. "A Voice from the Dust." MS 89 (June 9, 1927): 361-2. Recent archaeological excavations help authenticate the Book of Mormon. Discussion includes such topics as iron, monuments, and temples. [D.W.P.]

E.099 Evans, Richard L. "Communication." IE 66 (December 1963): 1074-76. The Book of Mormon is not a substitute but a supplement for the Bible, and a sacred record preserved by prophets of ancient America. [J.W.M.]

E.100 Evans, Richard L. "This You Can Count On." IE 72 (December 1969): 73-74, 76. "The eternal purposes of the Lord shall roll on, until all his promises shall be fulfilled" (Mormon 8:22). In making choices do not be deceived. Trust in the laws of God upon which you can rely. [J.W.M.]

E.101 Evans, Richard P. "Another Evidence." MS 100 (27 October 1938): 674-75. Having spent most of his life in Shiprock, New Mexico, the author explains the history of the American Indian through his knowledge of the Book of Mormon. He cites a knowledge of the cross symbol among pre-Columbian Indians. [R.H.B.]

E.102 Evans, Richard P. “Mormonism for the Red Man." MS 99 (October 1937): 693-95, 700-701. Evans rejoices in the fact that missionaries are now being sent to preach to the Navaho Indians. The Navahos have many legends that are similar to biblical myths such as the flood, and Jonah in the great fish. Many have tried to determine the origin of the Native Americans. The Book of Mormon gives the answer that they descend from Lehi, a Jew from Jerusalem. [B.D.]

E.103 Evans, William. "The Origin of the American Indian." MS 100 (4 August 1938): 482-85. Studies the habits and customs of the Xlavajo Indians for forty years and concludes that the Book of Mormon represents the true explanation of their origin. [R.H.B.]

E.104 Everton, George B., and Ellen N. Everton. Truths and Testimonies Touching the Book of Mormon. Nibley, UT: Everton, 1986. A pamphlet containing standards by which the Book of Mormon may be judged if someone were to duplicate the effort. [J.W.M.]

E.105 "The Evidence Mounts." CN 44 (14 September 1974): 16. Joseph Mahan of the Columbus (Ga.) Museum of Arts and Crafts sees evidence that people from the eastern Mediterranean have migrated to America since 2,000 B.C. A clay tablet containing Sumerian cuneiform has been discovered. This is further evidence that people should read the Book of Mormon. [J.W.M.]

E.106 "Evidences of the Truth of the Book of Mormon." CN 37 (24 June 1967): 16. Excerpts from an address of LeGrand Richards. There are many evidences of the truthfulness of the Book of Mormon-the witnesses who saw the book, many have put Moroni's promise to the test, it makes biblical passages easier to understand. [J.W.M.]

E.107 "Evidences of the Truth of the Book of Mormon." SH 4 (September-November 1863): 81-85, 97-101, $152-$ 57, 168-70. Four part series: No 1. "The Vision of All," focuses on Isaiah 29, the "marvelous work and a wonder," Martin Harris's visit to Professor Anthon, and related items. No. 2. "The Woe on the Enemies of the Marvelous Work," having reference to Isaiah's prophecy of a "woe" that would come upon the enemies of the "marvelous 
work," or the Book of Mormon. Discusses other prophecies of Isaiah 29 related to the Book of Mormon, e.g., the deaf would hear the words of the book, the joy of the meek would increase. No. 3. "The Stick of Joseph," presenting a discussion of Ezekiel 37 and the sticks representing the Bible and the Book of Mormon that would confound the false doctrines of the world. The Book of Mormon is the record of Joseph's descendants in the land of promise, or America. No. 4. "Joseph's Blessing," connected with the Abrahamic covenant of a promised land. The family of Joseph inherited the promised land of America. [J.W.M.]

E.108 Ewing, William C. "The Golden Bible and Mormonism." Current Literature (May 1905): 428-32. The Church of Jesus Christ of Latter-day Saints, which has become a significant economic and political factor, rests primarily on the Book of Mormon, an addition to the Bible. Claims that no disciple of Joseph Smith saw the plates. [J.W.M.]

E.109 "An Excellent Book." Deseret Weekly 38 (19 January 1889): 112. Claims that archaeological evidences in the Americas substantiate the Book of Mormon. The book, The American Indian, by Elijah M. Haines, unwittingly supports the Book of Mormon. [D.M.]

E.110 "Expert's Report Quells Attack on Authenticity of the Book of Mormon." CN 47 (15 October 1977): 14. The claim by three researchers that Soloman Spaulding wrote part of the Book of Mormon was refuted by a handwriting expert. [M.R.]

E.111 "Extensive Advertisers." SH 64 (22 August 1917): 798. Condemning the "Utah Mormons," this author claims they are confusing the public by large newspaper ads about the Book of Mormon that have appeared in many metropolitan dailies. The religious beliefs of Utah Mormons are inconsistent with the teachings of the Book of Mormon, e.g., their belief in polygamy. [J.W.M.]

E.112 "External Evidences of Scripture: A Panel ... With Noel Reynolds, John L. Sorenson, Arthur Wallace, and Paul R. Cheesman, moderator." In Scriptures For The Modern World, edited by Paul R. Cheesman and C. Wilfred Griggs, 121-35. Provo, UT: Brigham Young University Religious Studies Center, 1984. Conversion depends upon the reception of the witness of the Holy Ghost, however, testimonies may be stimulated and strengthened by external evidence. Discusses the distinction between internal and external evidence of the Book of Mormon, who wrote the book, what is its purpose, what influence do external evidences have on nonbelievers, do external evidences prove anything about the existence of God, can Mormonism be proved experimentally, and many others. [J.W.M.]

E.113 "Extract." TS 3 (January 1842): 657-59. A proclamation to the inhabitants of America that Jesus Christ has appeared to the forefathers of the Indians, that God inspired Columbus to discover America, and that America became a free land "to prepare the way for the coming of the Book of Mormon." A warning for the same inhabitants to repent and believe in the words of Jesus Christ as presented in the Book of Mormon. [D.W.P.]

E.114 "Extract From The Book of Mormon." TS 1 (March 1840): 66-68. An extract from the Book of Mormon concerning the dispersion and gathering of Israel (1 Nephi 22). [J.W.M.]

E.115 Eyre, Floyd G. "A Formula for Spiritual Knowledge." MS 98 (8 July 1937): 434-36, 444-45. Believes that the formula for understanding spiritual truth is found in Moroni 10:4-5, "by the power of the Holy Ghost ye may know the truth of all things." Some of the best tools to find spiritual truth are desire, sincerity, faith, pure living, and communication with God. [J.W.M.] 
E.116 Eyring, Carl F. "The Book of Mormon Speaks: A Radio Address." May 19, 1940. "The worth of souls is great in the sight of God" (D\&C 93:29). Amulek taught Zeezrom that Christ and his Atonement provide everyone the opportunity for immortality and eternal life, and all, even the wicked, are precious to God. Seeing ones own worth as God sees it can be our greatest strength. [J.W.M.]

E.117 Eyring, Carl F. "The Book of Mormon Speaks: 'Living Scripture.'” DN Church Section (11 May 1940): 8. The Book of Mormon could not have been translated from a language unknown by an unlearned young man such as Joseph Smith. Either the book was a miracle or a fraud to be explained away by natural means. Those who believed were permitted to view the plates (Martin Harris, Oliver Cowdery, David Whitmer), or were convinced of its truthfulness (Phinehas and Brigham Young and Parley P. Pratt). It is a living book that offers a rebirth for all who read it. [J.W.M.]

E.118 Eyring, Carl F. "The Book of Mormon Speaks: Personal Freedom." DN (1 June 1940): 8. The Book of Mormon teaches us that for true freedom to exist, there must be a law (2 Nephi 2:10-16). [B.D.]

E.119 Eyring, Carl F. The Book of Mormon Speaks: Service to Neighbor Is Service to God. Salt Lake City: Church of Jesus Christ of Latter-day Saints, 1940. A transcript of the author's radio address on KSL Radio, May 5, 1940, wherein the author testifies that the Book of Mormon contains the word of God and is a true work, and recounts briefly how the book affected the lives of early Saints like Parley P. Pratt and Brigham Young. [B.D.]

E.120 Eyring, Henry B. "The Brother of Jared." Ensign 8 (July 1978): 62-65. Mahonri Moriancumer, or the brother of Jared (Ether 2), was humble, persistent, willing to work hard, and had great faith in the Lord. [B.D.] 
F.

F.001 F., J. B. "American Antiquities." Juvenile Instructor 19 (15 July 1884, 1 August 1884, 15 August 1884): 222, 235, 250-51. Correct answers concerning the origins of past civilizations in the Americas were not found until the Book of Mormon was published. Discusses mounds in North and South America. Notes distinct historical periods in Mexico, Central America, and Peru. [D.M.]

F.002 FARMS Staff. Book of Mormon Critical Text: A Tool for Scholarly Reference, edited by Robert F. Smith. 3 vols. Provo, UT: FARMS, 1984-1987, Second ed. 1986-1987. Good for an overall view of the textual development of the Book of Mormon, but cannot be fully relied upon in specific instances. Its text is derived from a computerized 1830 edition, with changes based on visual examination of hard-to-read microfilms of the original and printer's manuscripts. The apparatus lists a good many textual variants (but not all), again based on a visual examination of most of the significant editions of the Book of Mormon. The apparatus also contains biblical and other ancient parallels and commentary. The appendices provide a number of valuable but preliminary lists of archaisms, names, textual errors, and page headings, as well as a manuscript register and a chronology. [R.S.]

F.003 FARMS Staff. "Lands of the Book of Mormon-Footnoted and Annotated Script." Provo, UT: FARMS, 1983. Tells of a media production to be used as an educational tool available as $35 \mathrm{~mm}$ slides with an audio cassette or as a video cassette. Conveys an assurance that the Book of Mormon is a historical document within a true cultural setting. Shows that scholars have achieved a consensus that the New World setting of the Book of Mormon lies in Mesoamerica. [J.W.M.]

F.004 FARMS Staff. "Martin Harris' Visit with Charles Anthon: Collected Documents on Short-Hand Egyptian." Provo, UT: FARMS, 1985. Using available historical information, this article serves to document the meeting between Harris and Anthon and to "illustrate the kind of information about Egyptian available to Anthon by 1828." Appendices contain reproductions of many relevant documents. [A.T.]

F.005 FARMS Staff. "Weights and Measures in the Time of Mosiah II." Provo, UT: FARMS, 1983. Examines the possible Akkadian and Sumerian origin of the terms sheum and limnah and uses the results of this study as one possible basis for deciphering weights and measurements in the Book of Mormon. [A.T.]

F.006 "Facsimile of First Edition of Book of Mormon Is Published." CN 50 (5 April 1980): 9. A replication of the first edition of the Book of Mormon was presented on March 26, 1980 to the First Presidency, exactly 150 years after it was first produced. The reproduction is as close to the original as is possible with today's equipment. [M.R.]

F.007 Facsimile of the Plates Discovered in Pike Co., Illinois. New York: The Prophet, 1845. Sets forth the story of the discovery of the six bell-shaped plates of brass containing inscriptions, now known as the Kinderhook plates. Also shows facsimiles of the plates. [D.W.P.]

F.008 "Facts Are Stubborn Things." TS 3 (15 September 1842): 921-22. Comments on and quotes from Stephen's Incidents of Travel in Central America. It is claimed that the Toltecs were of the house of Israel, a concept that is seen as corroborating the existence of Nephites and Lamanites. [D.M.]

F.009 Fairbanks, Delamar R. For Students of the Book of Mormon Only. N.p., n.d. Maintains that it is possible to identify geographical locations of the Book of Mormon. Asserts that the "Land of Nephi was... in the southern half 
of Costa Rica, between the 9th and 10th north degree parallel, south of the great wilderness. Bountiful ... was very close to [the] $11^{\circ}$ north parallel." [B.D.]

F.010 Fairchild, James Harris. "Manuscript of Solomon Spaulding and the Book of Mormon." Magazine of Western History 4 (1886): 30-39. A theory proposed by E. D. Howe (Mormonism Unveiled) purports that Sidney Rigdon stole Spaulding's manuscript and rewrote it for Joseph Smith to publish. It was research into the history of the manuscript that led to the conclusion that the Book of Mormon and Spaulding manuscript are not related. An excerpt from the manuscript is reprinted and Spaulding's religious beliefs are explored. Rigdon's denial is included. [J.W.M.]

F.011 Fairchild, James Harris. "Manuscript of Solomon Spaulding and the Book of Mormon." SH 65 (21 August 1918): 818-23. This is a reprint from Western Reserve Historical Society 3:185-200, and is also found in Tract \#77, March 23, 1886, RLDS Church. The author concludes that Spaulding's Manuscript Lost and the Book of Mormon are not related, contrary to the theory suggested by Howe's Mormonism Unvailed. An excerpt from Manuscript Lost is reprinted as well as Spaulding's feelings about the Christian religion and the Bible. Rigdon's denial that he wrote the book is included. [J.W.M.]

F.012 Fairchild, James Harris. "Mormonism and the Spaulding Manuscript." Bibliotheca Sacra 43 (January 1886): 167-74. Draws comparisons between the Book of Mormon and the Spaulding manuscript and concludes that there is no resemblance between the two. [D.W.P.]

F.013 Fairchild, James Harris. "Solomon Spaulding and the Book of Mormon." Bibliotheca Sacra 42 (January 1885):173-74. Fairchild gives his opinion, after comparing the Book of Mormon with the Spaulding manuscript, that there is "no resemblance between the two." [D.W.P.]

F.014 "Falsehoods and Misrepresentations by the 'Gospel Messenger No. 3.' "SH 52 (25 January 1905): 73-76. Allegations were published in the Gospel Messenger by Charles M. Yearout that members of the Church claim that Joseph Smith thought he was Elijah, that the Book of Mormon conflicts with the Bible, that Joseph Smith used criminal acts to prove the Book of Mormon, that the book he wrote was the famine spoken of in Amos, as well as other claims. In response to these accusations, it is countered that the allegations concerning Joseph Smith are not true, and that the Book of Mormon does teach of Christ and agrees with the New Testament. [J.W.M.]

F.015 "A Family Project to Build Faith." CN 31 (28 October 1961): 16. Sets forth a few ideas on how to make reading the Book of Mormon more interesting to children. [M.D.P.]

F.016 "The Family-to-Family Book of Mormon Program." Ensign 17 (May 1987): 101-2. Discusses the "Family to Family Book of Mormon Plan" developed by Robert H. Burton and Vernon Proctor. [L.D.]

F.017 Farley, J. Robert. “Discovering God's Will in My Life." In Recent Book of Mormon Developments; Articles from the Zarahemla Record, 2:153-56. Independence, MO: Zarahemla Research Foundation, 1992. Farley explains the promptings of the Spirit that brought him to paint oil paintings. Five of his paintings are described here. He explains the inspiration he received in order to accurately depict his subject, especially the painting of Lehi discovering the Liahona. [B.D.]

F.018 Farley, J. Robert. An Overview of the Book of Mormon. Independence, MO: Zarahemla Research Foundation, 1980. A general overview of the main characters and events in the Book of Mormon, illustrated in color and probably intended for youth. [B.D.] 
F.019 Farley, S. Brent. "The Appearance of Christ to the People of Nephi." In Studies in Scripture: Alma 30 to Moroni, edited by Kent P. Jackson, 8:149-60. Salt Lake City: Deseret Book, 1988. Christ's visit to the Nephites is "the apex of the Book of Mormon." Christ emphasized authority and ordinances, especially baptism, taught the people the Beatitudes and the Lord's Prayer, and showed them how to live the higher plane of the gospel. By building upon the rock of Christ, one can gain eternal rewards. [A.C.W.]

F.020 Farley, S. Brent. "Come Unto Christ (Moroni 9-10)." In Studies in Scripture: Alma 30 to Moroni, edited by Kent P. Jackson, 8:304-12. Salt Lake City: Deseret Book, 1988. Explains how a testimony may be gained from testing Moroni's promise (Moroni 10:3-5). Discusses the gifts given by the Spirit and the supreme challenge and goal offered by Moroni to "come unto Christ and be perfected in Him" (Moroni 10:32-33). [A.C.W.]

F.021 Farley, S. Brent. "Nephi, Isaiah, and the Latter-day Restoration." In The Book of Mormon: Second Nephi, The Doctrinal Structure, edited by Monte S. Nyman and Charles D. Tate Jr., 227-39. Provo, UT: Brigham Young University Religious Studies Center, 1989. Both Nephi and Isaiah prophesy of the restoration of the fullness of the gospel through the Book of Mormon, of the gold plates that will be delivered to Joseph Smith, of Charles Anthon, and of the Three and Eight Witnesses. [B.D.]

F.022 Farnsworth, Dewey. Buried Empires of South America. Salt Lake City: Deseret Book, 1953. Contains pictures and explanations of ancient American cities, statues, and water systems. The author shows how the ancient American ruins are closely related to the remnants found in Old World civilizations such as those of the Egyptians, Saxons, Hebrews, and others. [G.A.]

F.023 Farnsworth, Dewey. Grandeur of Ancient America. El Paso, TX: Dewey Farnsworth, 1939. Large booklet with black and white photographs depicting ruins in Latin America. One of the great discoveries that has been made is an exact date of the arrival of the Mayas. This date was deciphered from Mayan hieroglyphics and scientists claim it to be August 6, 613 B.C. [M.D.P.]

F.024 Farnsworth, Dewey, and Edith Wood. The Americas Before Columbus. El Paso, TX: Farnsworth Publishing, 1947. A presentation of photographs, notes, and comments dealing with ancient South and Central America. Discusses Hebrew and Egyptian parallels in the New World, four brothers as founders of the early South American culture, Christianity before Columbus, cement roads, and the use of metal. This work is reviewed in S.515. [B.D.]

F.025 Farnsworth, Dewey, and Edith Wood, comps. Book of Mormon Evidences in Ancient America. Salt Lake City: Deseret Book, 1953. Presents archaeological findings from ancient America that provide support for the Book of Mormon. This work is reviewed in S.512. [B. D.]

F.026 Farnsworth, Dewey, and William Farnsworth. "Looking Back at Ancient America." IE 43-44 (December 1940-October 1941): 708, 22, 77, 134, 200, 279, 340, 408, 473, 537, 600. A presentation of photographs of ancient American ruins, accompanied by brief descriptions and comments. [B.D.]

F.027 Farnsworth, William J. Defensive Walls of Peru. N.p., n.d. An aerial photograph of a defensive wall in Peru that "extends roughly due east from the Pacific Ocean at the mouth of the Santa River." It is compared with Alma 50:911. [B.D.]

F.028 Farr, Beth Richards. Jesus Christ Visits the Americas: A Book of Mormon Story for Children. Salt Lake City: Little One's Books, 1977. Large drawings designed for children illustrate the text of 3 Nephi, wherein Jesus visited the 
Nephites and blessed the children. [B.D.]

F.029 Farrell, Ralph W. "Book of Mormon Geography." SH 66 (12 March 1919): 249. Looks at geographical and historical aspects of Central America and Mexico, seeking external evidence in support of the Book of Mormon. [J.W.M.]

F.030 Farrell, Ralph W. "Thurlow Weed Speaks on the Book of Mormon." SH 67 (24 March 1920): 270. An excerpt from the Autobiography of Thurlow Weed explains that Joseph Smith had approached Mr. Weed, a publisher, to print the Book of Mormon. Mr. Weed refused to print the work. [J.W.M.]

F.031 Farthing, R. J. "Isaiah-One Prophet or Three." SH 107 (14 March 1960): 259, 262. The Book of Mormon presents evidence that a single prophet wrote the book of Isaiah, not three, as biblical scholars have maintained. [B.D.]

F.032 Faulconer, James E. "The Olive Tree and the Work of God: Jacob 5 and Romans 11." In The Allegory of the Olive Tree: The Olive, The Bible, and Jacob 5, edited by Stephen D. Ricks and John W. Welch, 347-66. Salt Lake City: Deseret Book and FARMS, 1994. Compares the use of olive symbolism in Romans 11 and Jacob 5. The focus in both is on grafting. There is a great deal of similarity, possibly indicating a common text underlying both Jacob 5 and Romans 11. These two passages are responses to different situations. Jacob 5 is a call to repentance, while Paul uses the occasion to warn the Gentiles not to think themselves superior to the Jews. [J.W.M.]

F.033 Faulring, Barbara, and Scott Faulring. "Revisions in the LDS Triple." Seventh East Press 2 (24 August 1982): B1-B8. Reviews the changes made in the 1981 edition of the triple combination. Book of Mormon changes are provided on pages B-1 and B-2. [B.D.]

F.034 Faunce, Edward. "Is the Book of Mormon Written in an Ancient Hebraic Poetic Style?" ZR 27-28 (1985): 1-4. Reproduces 1 Nephi 1:1, 1 Nephi 6:8-9; 2 Nephi 3:24-66 (RLDS versification) to demonstrate the elements of Hebrew poetry found in each passage. Briefly discusses poetic parallelism. [A.T.]

F.035 Faust, James E. "The Keystone of Our Religion." Ensign 13 (November 1983): 9-11. Also in CR (October 1983): 9-12. The Book of Mormon is the keystone of the Church of Jesus Christ of Latter-day Saints because it "establishes and ties together eternal precepts, rounding out the basic doctrines of salvation." Also claims that the book is not primarily a history nor a geographical primer, but a confirming evidence of the life and work of Christ and the restoration of the gospel. The Book of Mormon brings individuals to Christ. [S.P.S.]

F.036 Faves, Louis. Joseph Smith et les Mormons. Lausanne: Delafontaine et Comp., 1854. Discusses the establishment of the LDS church, the coming forth of the Book of Mormon, the Spaulding manuscript, and points out the biblical passages extant in the Book of Mormon. [D.W.P.]

F.037 Featherstone, Vaughn J. "Moroni Example: Patriotism and Freedom in a Choice Land." CR (October 1975): 8-12. Speaking of America, Elder Featherstone encourages all citizens to greater loyalty to country and to stronger patriotism to the United States. If we all followed general Moroni's example (and his "title of liberty") we would all show by words and action how grateful we are for our freedom and our country here in this choice land. [R.C.D.]

F.038 Felt, Marie F. "A Chosen Servant: Mormon." Instructor 99 (April 1964): 149-51. For a juvenile audience, an account of Mormon's role in compiling the records of the Book of Mormon. [A.C.W.] 
F.039 Felt, Marie F. "A Father's Love Rewarded." Instructor 96 (March 1961): 91-2. Children's flannel board story of Alma and the people he baptized at the waters of Mormon, and Alma the Younger's conversion. [A.C.W.]

F.040 Felt, Marie F. "How We Got the Book of Mormon." Instructor 103 (May 1968): 193-95, 197. Children's flannel board story concerning the coming forth of the Book of Mormon and its translation by Joseph Smith. [A.C.W.]

F.041 Felt, Marie F. "Our Heavenly Father Listens." Instructor 97 (June 1962): 199-200. Children's flannel board story about the Jaredites. [A.C.W.]

F.042 Felt, Paul E. The Book of Mormon, the Lamanite, and His Prophetic Destiny. Provo, UT: Brigham Young University Press, 1964. Contains four lectures given by the author at a conference at BYU on the Indian program of the Church. Lecture one explains the curse on the Lamanites and explains how curses come through disobedience. Lecture two deals with the promised restoration of the Lamanites and their role in building the New Jerusalem. Lecture three discusses statements by church authorities on the Lamanite's role in the building of the New Jerusalem and missionary work among the Lamanites. Lecture four speaks concerning the era when the Lamanites will blossom as a rose (D\&C 49:24). [B.D.]

F.043 Felt, Paul E. "Lamanite Israel Today-BYU'S Unique Challenge." In Understanding American Israel, edited by Glen L. Pearson, Mildred Hardy, Claude B. Duerden, Paul E. Felt, 45-63. Provo, UT: Brigham Young University Extension Office, 1967. Discusses the importance of bringing the gospel to the Lamanites and explains several Indian programs, including the Indian Education Program of Brigham Young University. [B.D.]

F.044 Felt, Paul E. "Remnants of Israel Who? When Gathered? In Sidney B. Sperry Symposium: The Book of Mormon, edited by A. Gary Anderson, 83-95. Provo, UT: Brigham Young University Center, 24 January 1981. The Book of Mormon identifies the remnants of Israel and clarifies their destiny. [J.W.M.]

F.045 Fenn, Grace J. As I See It: My Geography of the Book of Mormon, as Gleaned from Its Reading. n.p., 1962. Selects numerous Book of Mormon geographical sites and locates the places on a map. Various notes and opinions on the Book of Mormon are included. [B.D.]

F.046 Fenn, Lucius. Letter to Birdseye Bronson. Seneca Co., New York: n.p., 1830. Tells of the mysterious stories concerning three men who had reported that an angel had appeared telling of a "gold log" in the area that had been hidden for fourteen hundred years in a stone chest. [J.W.M.]

F.047 Ferguson, George C. "Book of Mormon and Napoleon III." MS 42 (4 October 1880): 636-39. John Taylor, Curtis E. Bolton, and John Pack present a French edition of the Book of Mormon to Emperor Napoleon, who suffered great losses by ignoring the sacred record. [J.W.M.]

F.048 Ferguson, Larry S. "The Most Powerful Book." Dialogue 23 (Fall 1990): 9-10. A reaffirmation by Larry S. Ferguson on behalf of his father Thomas Stuart Ferguson that he (Thomas Stuart Ferguson) believed the Book of Mormon to be the word of God until the day that he died. [M.R.]

F.049 Ferguson, Thomas S. Cumorah-Where? Independence, MO: Zion's, 1947. Ferguson looks at the conflicting theories that the original Hill Cumorah was in New York or in Mesoamerica and concludes that it was in Mesoamerica. [B.D.] 
F.050 Ferguson, Thomas S. "Gold Plates and the Book of Mormon." IE 65 (April 1962): 233-34, 270-71. Ferguson reports on the discovery of two Persian gold plates. One was engraved in the 4th century B.C. in the days of Darius II and the other dates to the 5th century B.C. [B.D.]

F.051 Ferguson, Thomas S. Great Message of Peace and Happiness. Orinda, CA: author, n.d. A book containing text and pictures that illustrate archaeological claims about the Book of Mormon. [D.M.]

F.052 Ferguson, Thomas S. "Joseph Smith and American Archaeology." Bulletin of the UASN 4 (March 1953): 19-25. Shows "striking agreements between the Book of Mormon history and the independent findings of modern archaeological-historical research." [D.M.]

F.053 Ferguson, Thomas S. One Fold and One Shepherd. San Francisco: Book of California, 1958. Comparisons are made between the stories and claims of the Book of Mormon and ancient American myths, legends, and archaeological finds. Includes a discussion of Quetzalcoatl. [G.A.]

F.054 Ferguson, Thomas S. "Some Important Book of Mormon Questions." IE 44 (September 1941): 528, 569-71. Advances several questions and answers about the Book of Mormon, including: Are all the Indians Lamanites? No. Did any white people survive the battle of Cumorah? Yes. Did the Book of Mormon people occupy the greater part of the western hemisphere? No. Is it true that the Nephites and Lamanites spent most of their time at warfare? No. Do archaeologists accept the Book of Mormon and use it as a guide in discovering ruined cities? No. [B.D.]

F.055 Ferguson, Thomas S. "The Wheel in Ancient America." IE 49 (December 1946): 785, 818-19. Argues against those that believe that the ancient Americans had no knowledge of the wheel by presenting five reproductions of wheeled toys and several scholarly views on the existence of such in Mesoamerica. [B.D.]

F.056 Ferguson, Thomas S. The World's Strangest Book-The Book of Mormon. n.p., 195?. A thirteen-page paper defending the Book of Mormon from an archaeological viewpoint. [D.M.]

F.057 Ferguson, Thomas S., and Milton R. Hunter. Ancient America and the Book of Mormon. Oakland, CA: Kolob, 1950. The Spanish conquest of Mexico resulted in the deliberate destruction of almost all written native records. Fortunately there were some who remembered the contents of the destroyed records. One of those was Ixtililxochit who wrote as best he could a history of ancient America. This book uses parallel quotations from the Works of Ixtililxochitl and the Book of Mormon. Striking similarities confirm to a remarkable degree the story of the Book of Mormon. [R.H.B.]

F.058 Fernhagel, D. T. “Das Buch Mormon." In Fernhagel's Die Wahrheit ueber das Mormonenthum. Blaetter aus Utah, 20-43. Zurich: Verlags-Magazine, 1889. Deals with the Three and Eight Witnesses, the coming forth of the Book of Mormon, and presents a brief overview of its contents. [D.W.P.]

F.059 Ferris, Benjamin G. Utah and the Mormons. New York: Harper \& Brothers, 1856. A polemical work against Mormonism. Argues that Solomon Spaulding is responsible for most of the text of the Book of Mormon, through the agency of Sidney Rigdon; the 1834 Anthon denial is cited; the testimonies of the Book of Mormon witnesses are discredited on the grounds that they had disreputable characters; and the author claims that Mormons have departed from the doctrines of the Book of Mormon. [M.R.]

F.060 A Few Plain Words About Mormonism Showing That Latter-Day Saints Are No Saints at All, Proved By Extracts from Their Writings. London: John Wright Steam Press, Bristol, 184?. Finds that the Bible is the word of God. The 
Book of Mormon is found lacking, indeed an imposture. Provides some relevant statistics about the book, its claims, and its story using extracts from its text. Compares these extracts with biblical ones to show that the Book of Mormon is absurd and ridiculous, pointing out atrocities from the book. [J.W.M.]

F.061 "A Few Reasons Why You Should Study the Book of Mormon." The Rod of Iron 1 (July, August, September 1924): 25. The Book of Mormon deals with many important topics, including baptism for the dead, deathbed repentance, secret societies, and the organization of Christ's church. [J.W.M.]

F.062 "Fifty-two Quotes." IE 64 (January 1961): 28-30. A challenge to readers of the Book of Mormon to memorize scriptural quotes as they read the work. [J.W.M.]

F.063 "Film Aids Scripture Story." CN 42 (16 September 1972): 12. A film released by Brigham Young University shows the background, history, and content of the Book of Mormon. [M.R.]

F.064 "Films Urge Youths-Stay 'Free to Choose.' " CN 56 (7 September 1986): 8-9, 13. A series of Church films for young adults portrays modern parallels to Book of Mormon stories. [M.D.P.]

F.065 Firmage, Edwin Brown. "Violence and the Gospel: The Teachings of the Old Testament, the New Testament, and the Book of Mormon." BYU Studies 25 (Winter 1985): 31-53. The use and misuse of war and bloodshed as seen from a study of the Bible and the Book of Mormon is treated. The study considers issues of force, war, repentance, the "Just War" theory, nonviolence, and pacifism. [D.L.L.]

F.066 Firmage, Edwin, Jr. "Historical Criticism and the Book of Mormon: A Personal Encounter." Sunstone 16 (July 1993): 58-64. The author rearranges the order in which Joseph Smith "composed" the Book of Mormon in order to explain textual problems. 1 Nephi through Words of Mormon are placed last according to handwriting analysis and subjects covered. [S.H.]

F.067 First Presidency of the Church of Jesus Christ of Latter-day Saints. "Book of Mormon." In Principles of the Gospel, 92-115. Salt Lake City: Church of Jesus Christ of Latter-day Saints, 1943. Explains the content and history of the Book of Mormon, and provides evidences of the book's divine authenticity. The Bible does not conflict with the Book of Mormon's historical, prophetic, and doctrinal passages. [J.W.M.]

F.068 First Presidency of the Church of Jesus Christ of Latter-day Saints. "Modern Language Editions of the Book of Mormon Discouraged." Ensign 23 (April 1993): 74. An announcement of the number of copies sold in 1992 of the Book of Mormon followed by a discouragement of the publication of modern language editions of the Book of Mormon because they risk the introduction of doctrinal errors. [S.H.]

F.069 First Presidency of the Church of Jesus Christ of Latter-day Saints. "New Spanish Book of Mormon Has Study Helps." CN 63 (13 March 1993): 4. Announcement of a new Spanish-language Book of Mormon that includes study helps, chapter headings, footnotes, and an index. [S.H.]

F.070 First Presidency of the Church of Jesus Christ of Latter-day Saints. "Official Policies and Announcements." CN 55 (17 November 1985): 2. Members of the Church help to distribute the Book of Mormon by giving the book as gifts to non-members, through the family-to-family program, by placing them in libraries and at fairs, exhibits, visitor centers, and by putting them in hotels, professional offices, etc., by permission. [J.W.M.] 
F.071 First Presidency of the Church of Jesus Christ of Latter-day Saints. "Rewriting Book into Modern English Not Authorized." CN 63 (20 February 1993): 3. Announcement of the number of Books of Mormon sold during 1992 coupled with a statement that modern English translations of the book were not authorized by the Church authorities. [S.H.]

F.072 Fischer, Wilford A. "A Book of Mormon Guide: A Simple Way to Teach a Friend." N.p., 1988. A study guide intended to aid those unfamiliar with the Book of Mormon. Shows that the stick of Joseph of Ezekiel 37:15-20 refers to the Book of Mormon and that the Book of Mormon is another testament of Jesus Christ. This work is reviewed in G.056. [B.D.]

F.073 Fisher, David G. "Mormon." Moody Monthly 78 (November 1977): 4, 6. An article in the September issue of Moody Monthly reported that analyses of the manuscript of the Book of Mormon and the Spaulding manuscript confirm that they were written by the same person. In this letter to the editor, Fisher exhorts the publishers to report the evidence on both sides of the issue. He mentions that Henry Silver, one of three handwriting analysts, withdrew from involvement after stating that he had been misrepresented in published statements. In response the editor refers to an extensive article on the subject in the November issue. [B.D.]

F.074 Fisher, V.H. The Godhead: A Discussion of the Godhead as Revealed in the Bible, Book of Mormon, and Doctrine and Covenants. N.p.: by the author, 1953. This pamphlet was written to dispel the false doctrine that Jesus Christ is the Supreme deity. Doctrines found in the scriptures agree with the beliefs of the Restoration that God the Father and Jesus Christ are distinct and separate persons in the Godhead, one in purpose but not in person. [J.W.M.]

F.075 Fisk, Samuel. Answering the Book of Mormon's Challenge. La Mesa, CA: Utah Christian Tract Society, 1978. A tract that argues against Moroni's admonition to read the Book of Mormon (Moroni 10:4-5) and warns people against reading the book. The Book of Mormon is not doctrinally correct and its teachings do not accord with the Bible. [D.W.P.]

F.076 Fitzgerald, Heber Alvah. "Progressive Opinion of the Origin and Antiquity of the American Indian." M.A. thesis, Brigham Young University, 1930. Comprehensive study on the theories that have been held concerning the provenance of the American Indians from the time of Columbus to 1929. [D.M.]

F.077 "Five Accept Pres. Benson's Invitation to Receive Copies of Book of Mormon." CN 56 (25 May 1986): 10. President Benson gave five personalized Books of Mormon away. [M.D.P.]

F.078 Flake, Chad J., ed. A Mormon Bibliography 1830-1930; Books, Pamphlets, Periodicals, and Broadsides Relating to the First Century of Mormonism. Salt Lake City: University of Utah Press, 1978. An indexed bibliography of works dealing with the LDS church. References concerning the Book of Mormon are included. This work is reviewed in M.386. [B.D.]

F.079 Flammer, Philip M. "A Land of Promise, Choice above All Other Lands." In The Book of Mormon: First Nephi, The Doctrinal Foundation, edited by Monte S. Nyman and Charles D. Tate Jr., 217-29. Provo, UT: Brigham Young University Religious Studies Center, 1988. Discusses the "promised land" covenant in the Book of Mormon and the divine intervention in the instances of Columbus, the Pilgrims, and the Revolutionary War. Concludes that the vision of the promised land must have been a sustaining force to Nephi and Lehi during their struggles in the wilderness. [A.T.] 
F.080 Flanders, W. C. A Chronological Data of the Book of Mormon. N.p., n.d. The whole title of the pamphlet is as follows: "A Chronological Data of the Book of Mormon Based on the Cycles, Eclipses, Earthquakes, and Comets, Including the Principal Events, Together with the Kings of the Old World, and the Whereabouts of the Lost Tribes and Their Tribes and Their Kings Who Reigned Contemporaneously." [B.D.]

F.081 Flanigan, J. H. Mormonism Triumphant! Truth Vindicated, Lies Refuted, the Devil Mad, and Priestcraft in Danger!! Being a Reply to Palmer's Internal Evidences against the Book of Mormon. Liverpool: R. James, 1849. A systematic response to William Palmer's polemical tract. Contains documentary evidence from Sidney Rigdon that he had nothing to do with the Spaulding manuscript. Examines the language of the Book of Mormon, allegations of internal contradictions, and Book of Mormon inconsistencies with the Bible. [D.M.]

F.082 Fletcher, Lyle L. "Pronouns of address in the Book of Mormon." M.A. thesis, Brigham Young University, 1988. This thesis explores the second person pronominal usage of the English language in the Book of Mormon to discover the method of translation and the influence of God within the pages of the book. Fletcher finds "that the Book of Mormon is the word of God translated into the English of Joseph Smith" under the inspiration of God. [J.W.M.]

F.083 Fletcher, Rupert J. A Land Which Is Choice above All Lands. Independence, MO: n.p., 1971. Finds that there is "ample proof in the Book of Mormon to identify the location" of the choice land. Both the Nephites and the Jaredites lived in the area of the United States of America. [D.M.]

F.084 Fletcher, Rupert J. The Way of Deliverance. Independence, MO: Author, 1969. Writes concerning the coming forth of the Book of Mormon, the testimony of the Three and Eight Witnesses, the evils of the present world as presented in the scriptures, and the future establishment of the New Jerusalem. [D.W.P.]

F.085 Fleugel, James H. Review of Lehi's Isle of Promise: A Scriptural Account with Word Definitions and a Commentary, by Arthur J. Kocherhans. Review of Books on the Book of Mormon 3 (1991): 96-100. Book review.

F.086 Flint, B. C. The Book of Mormon. Independence, MO: Church of Christ (Temple Lot), 1972. An evangelical tract explaining the purpose and teachings of the Book of Mormon, written by an apostle of the Church of Christ. [M.R.]

F.087 Flint, Bert C. An Outline History of the Church of Christ. Independence, MO: The Board of Publication for the Church of Christ, 1953. Retells the story of the coming forth of the Book of Mormon. Quotes from Joseph Smith as well as S. M. Smucker, Josiah Quincey, Oliver Cowdery, James H. Fairchild. Contains the testimonies of the eleven witnesses and evidences from archaeology and Indian legends that vindicate the book. [J.W.M.]

F.088 "'Flooding' Project is Answer to Prophet's Call." CN 59 (25 March 1989): 11. When the prophet gave instructions to "flood the earth" with copies of the Book of Mormon, many LDS congregations complied with fliers advertising the Book of Mormon. When missionaries went to schools to help in religious studies, 94 students requested copies of the Book of Mormon. [M.R.]

F.089 Flory, Joseph. "A Good Reply by Joseph Flory." SH 52 (4 January 1905): 5-7. An apologetic reply to allegations that the Book of Mormon is not a work inspired by God wherein the author defends the Book of Mormon as having been written by an inspired prophet of God, Mormon, and translated by Joseph Smith who was called by God to perform the work. [J.W.M.] 
F.090 Folk, Edgar E. The Mormon Monster or the Story of Mormonism. Chicago: Revell, 1900. An alleged exposé of Mormonism and its beliefs wherein the Book of Mormon is considered to be "heavy" and "verbose" in style. The author asserts that most of the proper names of the Book of Mormon could have been formed from biblical, Latin, or modern names. Various anachronisms are noted, such as the assertion in the Book of Mormon regarding the presence of pre-Columbian domesticated animals, passages from Shakespeare, modern phraseology, and ungrammatical expressions. Numerous Book of Mormon phrases are listed that the author views as being peculiar to nineteenth-century revival language. [M.R.]

F.091 "Follow Guidelines When 'Sending the Book of Mormon on a Mission.' " CN 58 (15 October 1988): 14. Follow guidelines when sending testimonies and pictures to missionaries. Send money instead of books and try to get your testimony translated into another language. [M.R.]

F.092 Folsom, Marvin. Review of Mormons and the Bible: The Place of the Latter-day Saints in American Religion, by Philip L. Barlow. Review of Books on the Book of Mormon 4 (1992): 1-4. Book review.

F.093 Folsom, Marvin H., and Alan F. Keele. Learn German through the Book of Mormon. Provo, UT: Brigham Young University Press, 1978. Contains nine lessons for learning German using the German translation of the Book of Mormon as the text. Each lesson contains different rules of grammar plus exercises. [L.D.]

F.094 "Foreign Languages Taught By Using Book of Mormon." CN 49 (3 February 1979): 14. A learning system developed by two BYU professors teaches language using the Book of Mormon. This system stresses similarities in languages and uses familiar context to teach foreign languages such as German, French, and Spanish. [M.R.]

F.095 Foremaster, Philip. "Chastened, but Not Forgotten." IE 26 (September 1923): 995-97. The Mexican people are a chosen race of people. According to Isaiah 29:4 they have been brought down in the dust. However, they are descendants of Joseph, through Lehi (1 Nephi 5:14) and they will be redeemed (2 Nephi 30:5-6). [B.D.]

F.096 Forster, F. P. Mormonismens Laere. Kjobenhaven, Denmark: author, 1854. Tells in Danish about the Book of Mormon, Joseph Smith, Mormon doctrine, and Mormons in Denmark. [J.W.M.]

F.097 Forster, John. "Book of Mormon: Worldwide Impact Felt for 150 Years." CN 47 (24 September 1977): 4. Bears testimony as to the importance and the impact of the Book of Mormon in modern history and the LDS church. [A.C.W.]

F.098 Foster, Ralph Leonard. The Book of Mormon on Trial. Klamath Falls, OR: Ralph Leonard Foster, 1963. A polemical booklet wherein the author hopes to "help stop the spread of Mormonism" and to encourage people to disbelieve the contents of the Book of Mormon. Contains ten photographed letters representing correspondences with Mormon authorities and others on questions pertaining to the Book of Mormon. [D.W.P.]

F.099 Fowler, Barbara. "Double Negatives in the Book of Mormon? Yes! Yes!" ZR 58 (December 1991): 2-4. Reprinted in Recent Book of Mormon Developments; Articles From the Zarahemla Record, 2:57-59. The restoration of the original text of the Book of Mormon has uncovered double negatives that offend the speaker of modern English. Previous to 1762, when Robert Lowth of Oxford created rules applying the mathematical rule of double negatives equaling a positive, double negatives were used in English. The double negatives in the original text are further evidence of Hebraisms in the Book of Mormon. Several examples are given. [J.W.M.] 
F.100 Fowler, Melvin L. "The Origin of Corn with Relation to the Book of Mormon." SH 98 (30 July 1951): 732-34. Questions the appearance of crops in the Book of Mormon, then discusses the "golden crop of America," maize. Gives botanical evidence that an Asian ancestor of maize probably existed, and hybrid crossing with Old and New World crops would produce corn as found in America. Therefore, the Book of Mormon record is "possible in light of the best scientific knowledge on the subject." [A.C.W.]

F.101 Fowles, John L. "The Decline of the Nephites: Rejection of the Covenant and Word of God." In The Book of Mormon: Helaman through 3 Nephi 8, According to Thy Word, edited by Monte S. Nyman and Charles D. Tate Jr., 8192. Provo, UT: Brigham Young University Religious Studies Center, 1992. Proposes that the downfall of the Nephites in the book of Helaman was caused by flouting their covenants. Emphasizes the debilitating nature of pride. Suggests some warnings appropriate to the latter days. [D.M.]

F.102 Fowles, John L. "Zenos' Prophetic Allegory of Israel." In A Symposium on the Book of Mormon, 29-36. Salt Lake City: Church of Jesus Christ of Latter-day Saints, CES, August 1986. Sets forth the reason individuals should study Jacob 5 and provides the keys to interpreting the allegory of the olive tree and a verse-by-verse commentary. [A.T.]

F.103 Fox, Robert B. Behold, I Am Moroni. Salt Lake City: Granite, 1976. A fictionalized work about Moroni, the Nephite scholar and prophet who on several occasions met with Joseph Smith. [B.D.]

F.104 Fox, Robert Barlow. The Sons of Helaman. Bountiful: Robert Barlow Fox, 1980. A fictional book about the sons of Helaman based upon the Book of Mormon (Alma 24, 53, 56, 57, 62, and 63). [L.D.]

F.105 Francisco, Donna. "Book of Mormon Slide Production Labor of Love For Project's Creator." CN 60 (22 September 1990): 7. Hazel Staley produced a slide show, using her Sunday School class, that depicted part of the Book of Mormon. This project eventually involved the whole congregation and took over 1 1/2 hours to show. [M.R.]

F.106 Frandsen, Russell M. "Antichrists." In Encyclopedia of Mormonism, edited by Daniel H. Ludlow, 1:44-45. 5 vols. New York: Macmillan, 1992. The title antichrist applies to those who deny essential parts of the gospel and the divinity of Jesus Christ. They actively oppose and/or seek to destroy the faith of the Savior's followers. The term is defined in the Book of Mormon and exemplified by Sherem, Nehor, and Korihor. [J.W.M.]

F.107 Fraser, Gordon H. Are the Navajos Lamanites? La Mesa, CA: Utah Christian Tract Society, 1978. A polemical tract against the Book of Mormon. The author asserts that the Navajo Indians are "pure mongoloid" and therefore not of Hebrew origin. [M.R.]

F.108 Fraser, Gordon H. Is Mormonism Christian? Chicago: Moody, 1957. Pages 124-50 of this polemical work against Mormonism criticize the Book of Mormon from a number of directions. The Book of Mormon witnesses were somewhat credulous. In fabricating the Book of Mormon, Joseph Smith drew upon speculation that the American Indians were descendants of the lost ten tribes, borrowing ideas found in the View of the Hebrews and other works. The author identifies a number of alleged anachronisms, such as the description of Lehi's desert journey, mention of weapons, animals, the wheel, and lack of archaeological evidence. Issues regarding the Sermon on the Mount in 3 Nephi and the Smithsonian statement regarding the Book of Mormon are also raised. [M.R.]

F.109 Fraser, Gordon H. Joseph and the Golden Plates: A Close Look at the Book of Mormon. Eugene, OR: Industrial Litho, 1978. A revised version of Fraser's 1964 work, What Does the Book of Mormon Teach? [M.R.] 
F.110 Fraser, Gordon H. A Manual For Christian Workers: A Workshop Outline For the Study of Mormonism. Hubbard, OR: Fraser, 1978. The author asserts the gold plates of the Book of Mormon never existed because gold was not used in America until the eleventh century. The Indians are of mongoloid origin and not Hebrew. Joseph Smith plagiarized the Bible, Book of Mormon witnesses did not really see the plates, and there is no archaeological evidence for the Book of Mormon. [M.R.]

F.111 Fraser, Gordon H. What Does the Book of Mormon Teach? An Examination of the Historical and Scientific Statements of the Book of Mormon. Chicago: Moody, 1964. Presents a detailed polemic against the Book of Mormon. The Book of Mormon is full of blunders and anachronisms. Discusses fine-twined linen, reformed Egyptian, the migrations to America, the concept of a dark and loathsome people, warfare, the so called biblical prophecies of the Book of Mormon, and other items. There are many contradictory accounts as to who wrote the Book of Mormon. [D.W.P.]

F.112 Frater, Alan S. Joseph Smith Prophet of God; A Reply to Dr. Rumble. Rozelle, Australia: Reorganized Church of Jesus Christ of Latter-Day Saints, n.d. An apologetic work replying to Dr. Rumble's criticisms of Mormonism in The Mormons or Latter-Day Saints. [M.R.]

F.113 Frater, Nettie. "First Impressions of the Book of Mormon." SH 99 (30 June 1952): 612-13. While reading the Book of Mormon for the first time, the author was disappointed because it did not meet her expectations. She found it to lack "the grandeur of the Old Testament language," personal stories, and too little mention of women. [A.T.]

F.114 Frazier, Herb. "Helps in Teaching the Book of Mormon to Lamanites." In A Symposium on the Book of Mormon, 42-44. Salt Lake City: Church of Jesus Christ of Latter-day Saints, 1979. The promises of God to the Lamanites are great. The curse given to the Lamanites long ago has at times been lifted and will be removed as they become righteous. [N.K.Y.]

F.115 Free, Jack. Mormonism and Inspiration. Concord, CA: Pacific, 1962. A polemical work against Mormonism and Mormon scripture. The author attacks the interpretations of biblical prophecy supporting the Book of Mormon, previously advanced by Orson Pratt, B. H. Roberts, and other Mormon writers. The testimonies of Book of Mormon witnesses are also discussed and dismissed. The writer further alleges the complete lack of historical, scriptural, or archaeological evidence supporting the Book of Mormon. The Book of Mormon, he asserts, contradicts pagan practices of certain native American peoples and asserts that they bear no relation to descriptions in the Book of Mormon. He asserts a mongoloid rather than a Hebrew origin for these peoples. [M.R.]

F.116 "French Members Fulfill Challenge to Read Scriptures." CN 57 (17 January 1987): 14. A challenge was issued in Paris, France, for members to read the Book of Mormon and then send their testimonies to James D. Fife. Over 100 people accepted the challenge. [M.R.]

F.117 Frere, John. A Short History of the Mormonites; or Latter Day Saints. London: Joseph Masters, 1850. This pamphlet presents a strong condemnation of Joseph Smith and hence of Mormonism. It presents a critical "history" of the key events of the "restoration." It includes a statement by Mrs. Matilda Davison, identified as a former wife of Solomon Spaulding, stating that Spaulding's fictitious story is plagiarized in the Book of Mormon. The document concludes with "Profanity of Mormon Doctrines" that enumerates and ridicules key Mormon doctrines. [R.H.B.] 
F.118 "From Lehi to Moroni." Friend 10 (February 1980): 20-21. An illustrated children's story of the Book of Mormon; includes one picture per book. [M.R.]

F.119 “From Stephens' Incidents of Travel in Central America." TS 3 (15 September 1842, 1 October 1842): 911-15, 927-28. Using extracts from the writings of Stephens, these articles suggest that the archaeological and historical observations of Stephens in Central America provide evidence that the Book of Mormon contains the truth. [J.W.M.]

F.120 Fronk, Camille. "Prophecy in the Book of Mormon." In Encyclopedia of Mormonism, edited by Daniel H. Ludlow, 3:1163-64. 5 vols. New York: Macmillan, 1992. Discusses various types of prophecy in the Book of Mormon including Messianic prophecy, prophecy of future Book of Mormon events, latter-day prophecy, and false prophecy. [A.T.]

F.121 Fronk, Camille. "Show Forth Good Examples in Me." In Studies in Scripture: 1 Nephi to Alma 29, edited by Kent P. Jackson, 7:321-34. Salt Lake City: Deseret Book, 1987. All things typify Christ-the ordinances, the law of Moses, the prophets, and all God's creations. Every creation of God assists in understanding the Atonement and Christ's mission. This typology is replete in Alma 17-23. The sons of Mosiah exemplified Christ-like behavior following the mighty change of their hearts. Service, humility, unselfish sacrifice, and obedience were some of the Christ-like qualities Ammon typified. [J.W.M.]

F.122 Frost, S. E., Jr. The Sacred Writings of the World's Great Religions. New York: New York Home Library, 1943. One chapter of this work is dedicated to the sacred writings of Mormonism. Provides a brief history of the discovery and translation of the Book of Mormon, followed by a brief synopsis of each individual book. Reprints scriptural passages from the Book of Mormon. [B.D.]

F.123 Fry, Charles. "Benefits to Young Studying the Book of Mormon." SH 61 (9 December 1914): 1165-66. Encourages young people to study the Book of Mormon because it "helps in understanding Bible, solves problems of America's past, helps understanding of conditions of times, and gives better appreciation for country." [A.T.]

F.124 Fry, Charles. "From Bishop Charles Fry at Cumorah." SH 74 (3 August 1927): 892, 918. An admonishment to read the Book of Mormon "in recognition of the centennial," or one hundred years since the plates were received by Joseph Smith. An intense study of the scriptures will refine, strengthen, and purify all those who will participate. [J.W.M.]

F.125 Fry, Charles. "A Glimpse at the Urim and Thummim." SH 85 (9 July 1938): 873-77, 883. Examines the origin, description, names, and purposes of the Urim and Thummim and the revelations received through them. Details the names of individuals who have used them. [J.W.M.]

F.126 Fry, Charles. "The Message Which the Book of Mormon Bears to the American Nation." SH 74 (21 September 1927): 1098-1100. The Book of Mormon states that America is a choice land that is reserved for a righteous people. It declares that Jesus Christ is the God who calls to every person all over the world and to the inhabitants of America to repent. Failure to heed this message will culminate in the failure of the nation. [J.W.M.]

F.127 Fry, Charles. "Twelve Reasons Why I Believe the Book of Mormon." SH 60 (5, 12 March 1913): 232-37, 25257. Fry's reasons for believing the Book of Mormon include, it presents Christ as the Redeemer of the world; its doctrines are in full harmony with the doctrines of the Bible; its history is in harmony with the history of the Bible; 
every part is in perfect harmony with the whole; it is supported by competent witnesses; many of its prophecies have been fulfilled; it proves the fatherhood of God over the whole world; the Holy Spirit confirms its divinity. [A.T.]

F.128 Fry, Evan A. "The Book of Mormon and the Crucifixion." SH 92 (31 March 1945): 294-96. Great destruction, followed by thick darkness and a heavy vapor occurred at the time of the crucifixion of Christ. Such an atmosphere may have been the result of an eruption of a volcano similar to the eruption of Mt. Vesuvius. [J.W.M.]

F.129 Fry, Evan A. "Book of Mormon Characters: Alma." SH 92 (12 May 1945): 440-44. Alma was a great statesman, judge, theologian, and missionary. His message of salvation and prophecies of Jesus had a great impact on the people of many cities. [J.W.M.]

F.130 Fry, Evan A. "Book of Mormon Characters: Ammon ... A Great Missionary." SH 92 (7 July 1945): 634-36. Ammon, his brothers, and Alma2, once persecutors of the church, were called to repentance by an angel of the Lord. Ammon later spent fourteen years in missionary service to the Lamanites, thousands of whom were converted to the gospel. [J.W.M.]

F.131 Fry, Evan A. "Book of Mormon Characters: Jacob." SH 92 (14 April 1945): 346-48. Jacob, younger brother of Nephi, became the second scribe of the gold plates, delivered a powerful temple sermon, called the people to repentance, taught the allegory of the Olive Tree, and defeated the anti-Christ Sherem. [J.W.M.]

F.132 Fry, Evan A. "Book of Mormon Characters: Lehi." SH 92 (10 March 1945): 13-15. Lehi was a great father, faithful prophet of God, spiritual leader, and a man of great vision. [J.W.M.]

F.133 Fry, Evan A. "Book of Mormon Characters: Mormon ... the Boy General." SH (23 June 1945): 587-88, 591. Mormon was a record keeper, author, prophet, general, and editor. He recorded the tragic events that he had witnessed and tried to save a sinful and dying nation with his personal testimony of Jesus Christ. [J.W.M.]

F.134 Fry, Evan A. "Book of Mormon Characters: Moroni." SH 92 (2 June 1945): 506-7. Moroni, one of the Book of Mormon's great military generals and the creator of the title of liberty, was a man of integrity and honor. He did much to preserve the liberty of his people by defeating his government's enemies. [J.W.M.]

F.135 Fry, Evan A. "Book of Mormon Characters: Moroni, son of Mormon." SH 92 (3 June 1945): 602-3. Moroni was the last surviving historian/writer of the Book of Mormon, a witness of the demise of his nation, an abridger of the Jaredite record, and prophet of God. [J.W.M.]

F.136 Fry, Evan A. "Book of Mormon Characters: Mosiah." SH 92 (21 April 1945): 364-66. It was during Mosiah's reign that Zeniff's group returned to the land of Nephi. Upon the return of both the people of Zeniff and Alma, the great statesmanship and wisdom of King Mosiah was most apparent. He stressed the responsibility of each man in a democratic society to bear his share in the decisions, cost, and labor of government. [J.W.M.]

F.137 Fry, Evan A. "Book of Mormon Characters: Nephi." SH 92 (24 March 1945): 268-70. The character of Nephi, son of Lehi, is best exemplified in the story of his return to obtain the plates of Laban. Nephi was obedient, courageous, and resourceful. He was a teacher, spiritual leader, and wrote for the purpose of bringing all to Christ. [J.W.M.]

F.138 Fry, Evan A. "Book of Mormon Characters: Nephi, Son of Helaman." SH 92 (9 June 1945): 534-36. Living in a time of great wickedness while the Gadianton robbers flourished, Nephi, son of Helaman, preached by the spirit of 
prophecy, taught of Christ, and supported the ministry of Samuel the Lamanite. [J.W.M.]

F.139 Fry, Evan A. "Book of Mormon Characters: Nephi, Son of Nephi." SH 92 (16 June 1945): 553-54. Nephi, son of Nephi, began his ministry in the very troubled era immediately prior to the crucifixion of Christ. He lived to become one of the Nephite twelve disciples and to preside during part of the golden age of Nephite history. [J.W.M.]

F.140 Fry, Evan A. "The Book of Mormon In Prophecy." SH 87 (2, 16 November 1940): 1391, 1455. This two-part series deals with biblical prophecies that dealt with the Book of Mormon. Part I mentions Genesis 17 and 49, Deuteronomy 33, Genesis 11, and Ezekiel 17 in connection with the Book of Mormon; part II discusses Ezekiel 37, or the sticks of Joseph and Judah, and Isaiah 29, or the prophecy concerning the "marvelous work and a wonder," that was to come forth in the last days. [J.W.M.]

F.141 Fry, Evan A. "Book of Mormon Talks." SH 91-92 (15 July 1944-24 February 1945): 903-904, 907, 943-44, 950, 976-77, 981, 1003-1004, 1011, 1042-44, 1068-70, 1084-86, 1094-95, 1099, 1114-15, 1133-35, 1151, 1165-66, 1180-81, 1211-12, 1226-27, 1277-78, 1332-33, 1254-56, 1375-76, 1419-20, 1297-99, 29-30, 80-81, $105-07,121-22,135,171-73$. A series of reprints consisting of 26 radio talks. The topics vary from teachings of the Book of Mormon concerning government and war to prayer and the Atonement. Other topics are concerned with material evidences that the Book of Mormon is true, rebuttal to Book of Mormon critics, the testimony of the eleven witnesses, archaeology, comparison between the doctrine of the Bible and the Book of Mormon, and many others. [J.W.M.]

F.142 Fry, Evan A. "Christ's Visit to America." SH 92 (7 April 1945): 316-17. The Savior's ministry among the ancient inhabitants of America represents "the only explanation of many facts of American archaeology and native tradition." It also clarifies why the Spanish conquistadors were welcomed by people who already possessed Christian traditions. [J.W.M.]

F.143 Fry, Evan A. "The First Christmas in America." SH (23 December 1944): 1463-64. A second story of the first Christmas, contemporaneous with that recorded in Luke, is recorded in the Book of Mormon. The people in America were Christ's "other sheep." They were given signs of his birth. [J.W.M.]

F.144 Fry, Evan A. Hear Our Story. Independence, MO: Herald House, n.d. Relates the story of the coming forth of the Book of the Mormon as part of an introduction to the RLDS church. [J.W.M.]

F.145 Fry, Evan A. "How Did We Get the Book of Mormon?" SH 92 (8 September 1945): 850-51, 854. An overview regarding Moroni's guardianship over the gold plates and the coming forth of the Book of Mormon, including the method of translation, the dictation to scribes, and the publication of the work. [J.W.M.]

F.146 Fry, Evan A. "The Teachings of the Book of Mormon." SH 87 (23 November 1940): 1487-89. The teachings of the Book of Mormon tend to clarify controversial theological subjects such as baptism, repentance, the purity of little children, spiritual gifts, riches of the world, and marriage. [J.W.M.]

F.147 Fry, Evan A. "Where Are the Book of Mormon Plates?" SH 92 (15 September 1945): 874-75. Provides three reasons why the gold plates were returned to the angel Moroni: the gold from which the plates were made was of great value and could not have been protected in a "backwoods pioneering community"; the violent persecution would have been reason enough to have returned the plates to safety; the sealed portion that must wait for 
translation would have been too great of a temptation. We need not see the original to believe in the book. [J.W.M.]

F.148 Fry, Evan A. "Who Wrote the Book of Mormon?" SH 91 (2 September 1944): 6-7, 11. Reasons that Joseph Smith could not have utilized the Spaulding manuscript to create the Book of Mormon, but that he translated the book by the gift of God. [D.W.P.]

F.149 Fry, Evan A. "Why Do We Need the Book of Mormon?" SH 92 (21 July; 11-25 August 1945): 682-84, 707709, 749-51, 777-78, 794-96. A five-part series: the Book of Mormon is a witness for Christ and in accordance with Old Testament laws of evidence there must be two or three witnesses; it is to be the means of bringing the house of Israel to Christ; it prophecies of America and warns of kings and wickedness; it clarifies doctrine about baptism, the Atonement, God's love, moral agency, sin, the condition of souls after death, and the restoration; it explains American origins. [J.W.M.]

F.150 Fry, Roger. "Ancient American Art." In Fry's Vision and Design, 104-13. New York: New American Library, 1974. Discusses Mayan, Incan, and Aztec archaeology, culture, and art in ancient America. Scholars disagree as to the origin of these cultures; some favor the lost ten tribes theory and others are in favor of Eastern Asiatic influence. Mormons in Utah found bronze plates with inscriptions of what looks like an extremely bad copy of Chinese art objects. [J.W.M.]

F.151 Frye, Frank E. "The Principle of First Mention." In Recent Book of Mormon Developments; Articles From the Zarahemla Record, 2:201-203. Independence, MO: Zarahemla Research Foundation, 1992. The "principle of first mention" (Henry M. Morris, Many Infallible Proofs) is the idea that the first time an important word or concept is mentioned in the Bible provides the foundation for understanding its full development in later parts. Frye explains this principle and uses it to analyze the meaning of several Book of Mormon passages. [B.D.]

F.152 Frye, Frank Evan. "Who Are the Lamanites?” The Witness 79 (Winter 1992): 5-9, 14. Presents a concise summary of the origins and migrations of the three Book of Mormon peoples (Jaredites, Nephites, Mulekites). Describes the religious and political divisions of the Nephites that gave rise to the Lamanites. [R.H.B.]

F.153 "Full Text of Lucy Mack Smith's Letter." CN 52 (28 August 1982): 3. Brent F. Ashworth claimed that he had acquired a letter written by Lucy Mack Smith to her sister-in-law, Mary Pierce. It is claimed to be the earliest known document concerning the Book of Mormon. (Editor's note: this letter has been proven to be a forgery.) [J.W.M.]

F.154 Fuller, Barney R. Stick of Joseph. Pasadena, CA: Tri-Tech, 1969. Reviews Book of Mormon passages that deal with the earthly mission of Christ, his visit to the Americas, the restoration of the Church in this era, and the prophecies concerning the descendants of the Nephites and Lamanites in the last days. [A.T.]

F.155 Furse, Nani Lii S. "Portrait of Mosiah 18." Ensign 22 (July 1992): 48. A poem about those who listened to Alma's teachings at the Waters of Mormon. [J.W.M.]

F.156 "Future Edition of Standard Works." Ensign 9 (October 1979): 17. An announcement that new editions of the scriptures including the Book of Mormon are scheduled tentatively for 1981. There will be new crossreferencing material and newly written chapter headings. [J.W.M.] 
F.157 Fyans, J. Thomas. "The Book of Mormon's Witness of Jesus Christ." Ensign 17 (May 1987): 28-29. Compares the body's need for oxygen to the soul's need for a sure knowledge of God and Jesus Christ. Author asserts that the best source for such knowledge is the Book of Mormon, and the witness of the book's truthfulness comes by the power of the Holy Ghost. [S.P.S.]

F.158 Fyans, J. Thomas. "The Lamanites Must Rise in Majesty and Power." Ensign 6 (May 1976): 12-13. Also in CR (April 1976): 16-18. The rapid growth of the Church in Mexico and Central America fulfills Book of Mormon prophecy. The Lamanites will again reach the spiritual heights their ancestors once attained. [B.D.]

F.159 Fyans, J. Thomas. "The Pattern." NE 18 (August 1988): 4-5. Mankind cannot follow what uninspired men teach because their perception of truth always changes, but the gospel truths, as outlined in the Book of Mormon, remain the same. [B.D.]

F.160 Fyans, J. Thomas. Untitled talk. In Proceedings of the Stockholm Area Conference, 36-40. Salt Lake City: Church of Jesus Christ of Latter-day Saints, 1974. The Book of Mormon is an important part of sharing the gospel and flooding the earth with the word of God. Its purpose is to bring all to Christ. The Lord told Joseph Smith that it would be as fruitless for man to try to stop the mighty Mississippi as to try to stop the heavens from pouring down knowledge. A great part of that knowledge comes through the Book of Mormon. [J.W.M.] 
G.

G.001 G. "Old Bottles and Elephants." Juvenile Instructor 16 (1 April 1881): 82. Discusses earthenware manufacture in antiquity. Points out that some bottles and pottery vessels dug up on the American continent resemble elephants. Also mentions that the discovery of elephant bones in the United States tend to prove the truth of the Jaredite record. [A.C.W.]

G.002 G., L. A. "Prehistoric People." SH 51 (16 November 1904): 106-7. Quoting a clipping from the Denver Post written by Doctor Baum who had conducted expeditions in the southwestern United States, the author wonders why the archaeologists do not read the Book of Mormon to find answers to their questions about ancient inhabitants of America. [J.W.M.]

G.003 Gabbott, Mabel Jones. "Abinadi." Children's Friend 61 (September 1962): 44-45. A children's story of Abinadi preaching to King Noah. [M.D.P.]

G.004 Gabbott, Mabel Jones. "Alma." Children's Friend 61 (October 1962): 12-13. A children's story of how Alma believed Abinadi and then organized the Church of Christ after preaching in secret to the people. [M.D.P.]

G.005 Gabbott, Mabel Jones. "Alma, the Younger." Children's Friend 61 (December 1962): 18-19. A children's story of the angel that appeared to Alma the Younger and the four sons of Mosiah and how they were converted by this experience. [M.D.P.]

G.006 Gabbott, Mabel Jones. "Ammon." Children's Friend 62 (February 1963): 18-19. A children's story of Ammon teaching among the Lamanites. [M.D.P.]

G.007 Gabbott, Mabel Jones. "Amulek." Children's Friend 62 (January 1963): 18-19. A children's story of Amulek. [M.D.P.]

G.008 Gabbott, Mabel Jones. "Circle of Fire." Children's Friend 62 (August 1963): 16-17. A children's story of Nephi and Lehi and the miracles that took place inside the Lamanite prison. [M.D.P.]

G.009 Gabbott, Mabel Jones. "Circle of Fire." Friend 7 (January 1977): 28-29. A children's story of Nephi and Lehi who were protected by a circle of fire in a Lamanite prison and converted all the Lamanites who were present. [M.D.P.]

G.010 Gabbott, Mabel Jones. "Famine in the Land." Children's Friend 62 (October 1963): 6-7. A children's story of how Nephi asked God to smite the earth with a famine instead of having the people destroyed by the sword so that the people might repent. [M.D.P.]

G.011 Gabbott, Mabel Jones. "Gideon." Children's Friend 61 (November 1962): 12-13. A story for children about Gideon who came up with a plan for King Limhi and his people to escape from the bondage of the Lamanites. [M.D.P.]

G.012 Gabbott, Mabel Jones. "Helaman and the Two Thousand." Children's Friend 62 (July 1963): 16-17. A children's story of Helaman and the two thousand stripling warriors. [M.D.P.] 
G.013 Gabbott, Mabel Jones. Heroes of the Book of Mormon. Salt Lake City: Deseret Book, 1975. The author rewrites, on a child's level, topics such as Lehi's vision and journey into the wilderness, Nephi and the brass plates, Nephi building a ship, the faith of Jacob, Abinadi, Alma, Amulek, Ammon, the Anti-Nephi-Lehies, Helaman, Samuel the Lamanite, the brother of Jared, and Moroni hiding the brass plates. [B.D.]

G.014 Gabbott, Mabel Jones. "Jacob." Children's Friend 61 (August 1962): 34-35. A children's story of Jacob from the time he was born in the wilderness to his meeting with Sherem, the anti-Christ. [M.D.P.]

G.015 Gabbott, Mabel Jones. "Lehi." Children's Friend 61 (April 1962): 10-11. A story for children of Lehi leaving Jerusalem for the promised land. [M.D.P.]

G.016 Gabbott, Mabel Jones. "Mormon." Children's Friend 61 (January 1962): 32-34. A children's story of Mormon up to the time he received the plates. [M.D.P.]

G.017 Gabbott, Mabel Jones. "Moroni." Children's Friend 61 (February 1962): 16-17. A story for children about Moroni. [M.D.P.]

G.018 Gabbott, Mabel Jones. "The Murder of the Chief Judge." Children's Friend 62 (September 1963): 20-21. A children's story of Nephi prophesying of the murder of the chief judge. Many people thought Nephi was guilty, but Nephi shows that the chief judge's brother, Seantum, actually did it. [M.D.P.]

G.019 Gabbott, Mabel Jones. "Nephi and the Bow." Children's Friend 61 (June 1962): 14-16. A children's story of Nephi making a new bow to feed his family while they were in the wilderness. [M.D.P.]

G.020 Gabbott, Mabel Jones. "Nephi Builds a Ship." Children's Friend 61 (July 1962): 44-45. A children's story of Nephi building a ship to travel to the promised land. [M.D.P.]

G.021 Gabbott, Mabel Jones. "Nephi, Son of Nephi." Children's Friend 63 (December 1963): 22-23. A story for children. Nephi mourned for his people because of their wickedness and the Lord comforted him. Nephi saw the signs and wonders of Christ being born in Jerusalem. [M.D.P.]

G.022 Gabbott, Mabel Jones. "Nephi-The Plates of Brass." Children's Friend 61 (May 1962): 34-36. A children's story of Nephi getting the plates of brass from Laban. [M.D.P.]

G.023 Gabbott, Mabel Jones. "The Nephite Maiden." Children's Friend 62 (May 1963): 22-23. A children's story of a maid servant of Morianton who warned Moroni of Morianton's plans, which in turn allowed Moroni to stop the people of Morianton. [M.D.P.]

G.024 Gabbott, Mabel Jones. "One Thousand and Five." Children's Friend 62 (March 1963): 16-17. A story for children about the Anti-Nephi-Lehies and the 1005 that were killed by the Lamanites after they had taken an oath not to take up weapons against their brethren. [M.D.P.]

G.025 Gabbott, Mabel Jones. "Samuel, the Lamanite." Children's Friend 62 (November 1963): 10-11. A children's story of Samuel the Lamanite. [M.D.P.]

G.026 Gabbott, Mabel Jones. "The Three Generals." Children's Friend 62 (June 1963): 10-11. A story for children about three Nephite generals-Moroni, Teancum, and Lehi-during a war with the Lamanites. [M.D.P.] 
G.027 Gabbott, Mabel Jones. "The Un-named Soldier." Children's Friend 62 (April 1963): 16-17. A story for children. One of Moroni's soldiers, during a war with the Lamanites, smote and raised Zerahemnah's scalp up with his sword, which led to a covenant of peace. [M.D.P.]

G.028 Gaer, Joseph. The Legend of the Wandering Jew. New York: Mentor, 1961. Chapter 12 discusses the tradition of "the wandering Jew among the Mormons," wherein the author cites examples of Mormons seeing one of the Three Nephites or the wandering Jew. [A.T.]

G.029 Galbraith, Madelyn. There is a Book. Independence, MO: Herald House, 1971. A novel about an Indian's search for his identity and his encounter with the Book of Mormon. [D.M.]

G.030 Galbraith, Madelyn. Village in the Sun. Independence, MO: Herald House, 1975. A novel set in Mexico, detailing the main character's discovery of the Book of Mormon. [D.M.]

G.031 Gallenkamp, Charles. Review of The Complex 'Tree-of-Life' Carving on Izapa Stella 5: A Reanalysis and Partial Interpretation, by M. Wells Jakeman. U.A.S.N. 70 (24 February 1961): 73.2. Book review.

G.032 Gardner, Marvin K. "The Book Seemed to Cry Out to Her." Ensign 18 (December 1988): 20-21. The Book of Mormon was the motivating factor in the conversion of Marilu Ramirez to the LDS faith. She found and purchased it from a magazine rack when she was eight years old, believed it was true and later became a member of the Church. [B.D.]

G.033 Gardner, Owen I. "2 Sets of Plates Make up the Book of Mormon." CN 58 (25 June 1988): 10. Instructional aid: chart and explanation of the Book of Mormon's compilation. Shows who wrote on which plates and how and by whom those plates were subsequently abridged. Gives approximate dates and span of years for each book, and how many chapters and pages they comprise in the current edition of the Book of Mormon. [A.C.W.]

G.034 Garmendia, Guillermo. Untitled talk. In The Official Report of the First Mexico and Central America Area General Conference of the Church of Jesus Christ of Latter-day Saints, August 1972, 38-41. Salt Lake City: Church of Jesus Christ of Latter-day Saints, 1972. Members of the Church with Lamanite heritage recall the origin and lineage of their progenitors. Inhabitants of the Huasteca area, which now constitutes the recently organized Tampico stake, were descendants of the OImecas and the Maya-Quiches Indians. Great promises have been made to the Lamanite people (1 Nephi 2:18-20; Ether 1:38-43; Enos 1, 3-5, 15-18; 2 Nephi 1:6, 9, 10, 20). [J.W.M.]

G.035 Garn, Stacy D., as told to Dorothy O. Rea. "Sacred Book Saved: Faithful Indian Convert Bears Humble Testimony." CN 30 (4 June 1960): 16. When an Indian's house burned down and only the Book of Mormon was spared, she bears testimony of the Book of Mormon. "This book has gone through fire for me.... Now I am willing to go through fire for it." [A.C.W.]

G.036 Garner, Kent R. "Insights into the Old Testament from the Small Plates of Nephi." In A Symposium on the Book of Mormon, 37-46. Salt Lake City: Church of Jesus Christ of Latter-day Saints, CES, August 1986. The Book of Mormon "contributes considerably to [the] understanding of various things pertaining to the Old Testament," including the following areas - the book of Isaiah, Eden and the Fall of Adam and Eve, prophecies of and references to Christ, the role of opposition and suffering, revelation and the ongoing process of scripture, and the scattering, gathering and apostasy of the house of Israel. [B.D.] 
G.037 Garr, Arnold K. "Columbus: Fulfillment of Book of Mormon Prophecy." In Garr's Christopher Columbus: A Latter-day Saint Perspective, 1-5. Provo, UT: Brigham Young University Religious Studies Center, 1992. Columbus testified that he was guided to the New World by a divine hand. Orson Hyde testified that part of Moroni's ministry was to preside over the destiny of America and was with Columbus and protected his journey. Many Church authorities add their witness of the divine mission of Columbus and the Lord's intervention in his behalf. [J.W.M.]

G.038 Garrard, LaMar E. "Creation, Fall and Atonement." In Studies in Scripture: 1 Nephi to Alma 29, edited by Kent P. Jackson, 7:86-102. Salt Lake City: Deseret Book, 1987. A study of 2 Nephi 2, dealing with the concepts of creation, the Fall, law and justice, and the Atonement. [D.M.]

G.039 Garrard, LaMar E. "The Fall of Man." In Principles of the Gospel in Practice, 1985 Sperry Symposium, edited by Robert J. Matthews, 39-70. Salt Lake City: Randall, 1985. Discusses the manifold consequences of the Fall, concluding that it was not a "negative or catastrophic event," but a necessary part of the Lord's program for mankind. Quotes liberally from the Book of Mormon. [D.M.]

G.040 Garrard, LaMar E. "Korihor the Anti-Christ." In Studies in Scripture: Alma 30 to Moroni,edited by Kent P. Jackson, 8:1-15. Salt Lake City: Deseret Book, 1988. Discusses different aspects of Korihor's philosophy using modern terms including: epistemology, the nature of the universe, and the nature of humanity. Refers to the viewpoint of Bertrand Russell. Finds absolute confidence in naturalism to be limited. [D.M.]

G.041 Garrett, H. Dean. "The Book of Mormon on War." In A Symposium on the Book of Mormon, 47-52. Salt Lake City: Church of Jesus Christ of Latter-day Saints, CES, August 1986. Author questions why so much of the Book of Mormon is dedicated to wars and warfare. The lessons to be learned from Book of Mormon warfare include: (1) It is important to always follow God's prophet; (2) God will reveal to the righteous when war is necessary; (3) An individual going to war for the correct reasons can live a righteous life. [A.T.]

G.042 Garrett, H. Dean. "Inspired By a Better Cause." In Studies in Scripture: Alma 30 to Moroni, edited by Kent P. Jackson, 8:69-79. Salt Lake City: Deseret Book, 1988. An essay justifying why so much space in the Book of Mormon is devoted to war and warfare, and explaining when war is justified and when it is not. [D.M.]

G.043 Garrett, H. Dean. "Nephi's Farewell." In The Book of Mormon: Second Nephi, The Doctrinal Structure, edited by Monte S. Nyman and Charles D. Tate Jr., 377-90. Provo, UT: Brigham Young University Religious Studies Center, 1989. By reading Nephi's farewell address one can learn about his commitment to God, his love for his people, and his faith in the promises of God. [B.D.]

G.044 Garrett, H. Dean. "Peace Within.” Ensign 18 (September 1988): 20-25. Many pages of Book of Mormon are devoted to warfare. Garrett discusses war in connection with the role of government, individual responsibility, and how war affects humanity today. [D.L.L.]

G.045 Garrett, H. Dean. "The Three Most Abominable Sins." In The Book of Mormon: Alma, The Testimony of the Word, edited by Monte S. Nyman and Charles D. Tate Jr., 157-72. Provo, UT: Brigham Young University Religious Studies Center, 1992. Discusses the three greatest sins against God as outlined by Alma. They are (1) the sin against the Holy Ghost, (2) the shedding of innocent blood, and (3) sexual sin. [N.K.Y.]

G.046 Garth, Norman V. "I Have a Question: What is the current status of research concerning the 'tree of life' carving from Chiapas, Mexico?" Ensign 15 (June 1985): 54-55. The Izapa Stela 5 seems to depict the tree of life 
discussed in 1 Nephi 8. A total of eighty-nine stone monuments similar to the Stela have been found. Theories as to their meaning include: there is an anthropomorphic god whose symbol is the sun, he is god of the tree of life, the tree relates to life after death, physical resurrection is implied, worship involves a divine atonement, and the spirit of a child originates in heaven. [J.W.M.]

G.047 Gates, Susa Young. "Dialogue from the Book of Mormon." Young Woman's Journal 3 (April 1892): 289-94. A script for a dramatic presentation depicting the conversion of King Lamoni, written to encourage greater interest in the Book of Mormon among the young women of the Church. [D.M.]

G.048 Gates, Thomas J. "Succession of Book of Mormon Authors." IE 37 (March 1934): 162. Lists chronologically the succession of the authors of the Book of Mormon with dates. [L.D.]

G.049 Gatewood, Otis. Gatewood/Farnsworth Debate on 'Mormonism' Held in Salt Lake City, in Beautiful Liberty Park on August 17-21, 1942. Salt Lake City: n.p., 1942. A debate between a Mormon apologist and Mormon critic dealing primarily with the Bible and the Book of Mormon. A variety of Book of Mormon issues are discussed, including the Anthon episode, the testimonies of the Book of Mormon witnesses, Bible prophecies and the Book of Mormon, and the use of Egyptian by Book of Mormon writers. [M.R.]

G.050 Gatrost, Michael. "An Adventure with the Book of Mormon at Graceland College." The Witness 76 (Spring 1992): 4-5. Reports upon a Book of Mormon Conference that was held at Graceland College for young men and women of the RLDS church. The Book of Mormon is a valuable treasure to be shared. [J.W.M.]

G.051 Gaunt, LaRene. "The Book Changed My Life: Members Share Their Testimonies of the Book of Mormon." Ensign 12 (February 1991): 18-21. Members of the LDS church bear witness of the influence that the Book of Mormon had in their lives. It strengthened testimonies, brought personal witness of Christ, assisted in conversion, and helped to reactivate members. [J.W.M.]

G.052 Gaunt, LaRene. "Does the Book of Mormon Count? For these families, the answer is an emphatic yes!" Ensign 21 (June 1991): 20-23. Church members share experiences they had following the council of President Benson to read the Book of Mormon with their families. Small children understood and loved the stories of the book, a husband was reactivated, etc. [J.W.M.]

G.053 Gaunt, LaRene. "Painting the Word." Ensign 22 (January 1992): 32-35. Depicts a selection of paintings and original artwork with Book of Mormon themes, the result of international art competition. [A.C.W.]

G.054 Gee, John. "Limhi in the Library." Journal of Book of Mormon Studies 1 (Fall 1992): 54-66. It was an ancient Near Eastern practice for kings to employ scribes to record all of their official statements, and it appears that all of the direct quotations of King Limhi were recorded by an official scribe. Limhi's quotations of documents precede the cited documents themselves and all quotations are from material chronologically preceding Limhi, and to which he could have had access. [R.H.B.]

G.055 Gee, John. "A Note on the Name 'Nephi.'” Journal of Book of Mormon Studies 1 (Fall 1992): 189-91. The name Nephi is a Syro-Palestinian Semitic form of an Egyptian man's name dating from the Late Period in Egypt. [R.H.B.]

G.056 Gee, John. Review of A Book of Mormon Guide: A Simple Way to Teach a Friend, by Wilford A. and Norma J. Fischer. Review of Books on the Book of Mormon 2 (1990): 77-85. Book review. 
G.057 Gee, John. Review of By Grace Are We Saved, by Robert L. Millet. Review of Books on the Book of Mormon 2 (1990): 100-106. Book review.

G.058 Gee, John. Review of New Approaches to the Book of Mormon, by Brent Lee Metcalfe. Review of Books on the Book of Mormon 6/1 (1994): 51-120. Book review.

G.059 Gee John, and Daniel C. Peterson. "Graft and Corruption: On Olives and Olive in the Pre-Modern Mediterranean." In The Allegory of the Olive Tree: The Olive, The Bible and Jacob 5, edited by Stephen D. Ricks and John W. Welch, 186-247. Salt Lake City: Deseret Book and FARMS, 1994. Philological evidence indicates that the olive originated in the area of Syro-Palestine. It was considered first among trees and its oil was an equivalent of money. The article explores methods of planting, grafting, pruning, digging, nourishing, dunging, and harvesting of the olive tree, and the pressing and storage of the oil, all in relation to Zenos's parable of Jacob 5. [J.W.M.]

G.060 Gee, John, John L. Sorenson, and Michael D. Rhodes. Review of By His Own Hand upon Papyrus: A New Look at the Joseph Smith Papyri, by Charles M. Larson. Review of Books on the Book of Mormon 4 (1992): 93-119, 120-26. Book review.

G.061 "Genealogical Records Relationship." IE 23 (September 1920): 962-66. Book of Mormon accounts of Hagoth agree fully with Maori and Hawaiian traditions, legends, and genealogical records. [J.W.M]

G.062 General Church Board of Education. Outlines in Theology: The Nephite Dispensation. Salt Lake City: Board of Education, 1916. A teacher's guide to teaching about the Nephites to high school age children. [L.D.]

G.063 Gentry, Leland H. "Early Reactions to the Book of Mormon." In Mormon History Association 15th Annual Meeting. Palmyra, N.Y.: n.p., May 1980. Explores events between September 22, 1827, and March 25, 1830, which shaped the course of Mormon history: the way the local populace responded to reports of the existence of the plates, the difficulties in obtaining a publisher, the fall of Martin Harris and the Whitmers, and the response of the media to the publication of the Book of Mormon. [J.W.M.]

G.064 Gentry, Leland H. "God Will Fulfill His Covenants with the House of Israel." In The Book of Mormon: Second Nephi, The Doctrinal Structure, edited by Monte S. Nyman and Charles D. Tate Jr., 159-76. Provo, UT: Brigham Young University Religious Studies Center, 1989. "One reason Latter-day Saints understand Isaiah better than other students is the excellent commentary provided by Nephite prophets." The Book of Mormon explains Isaiah's prophecies and shows how they will be fulfilled. [B.D.]

G.065 Gentry, Leland H. "Vengeance is Mine, Saith the Lord." In A Symposium on the Book of Mormon, 54-56. Salt Lake City: Church of Jesus Christ of Latter-day Saints, CES, August 1986. The Book of Mormon teaches members of the LDS church how to deal with anti-Mormon works and workers. Members are to be humble, forgiving, and not to avenge their wrongs. [A.T.]

G.066 Gentry, Leland H. "Why So Much Isaiah in the Book of Mormon." In A Symposium on the Book of Mormon, 4547. Salt Lake City: Church of Jesus Christ of Latter-day Saints, 1979. The Book of Mormon contains twenty-one chapters from the book of Isaiah. The prophet Isaiah had much to say about the history, scattering, and gathering of Israel. The Book of Mormon convinces the children of Israel that they are not forgotten and they will be gathered. [N.K.Y.] 
G.067 "Geography Problems." CN 48 (29 July 1978): 16. It is difficult to find various landmarks of the Book of Mormon because there is not enough information. If the Lord wanted people to know where they were he would inspire prophets to tell them. Why not keep hidden what the Lord wanted hidden? [M.R.]

G.068 Ghormley, Pearl. This Book. St. George, UT: Rupegy, 1978. While attempting to determine the truthfulness of the Book of Mormon the author asked many questions, including, "Is the Bible incomplete?" "Was the book of Revelation to be the final word?" "Did the biblical prophets prophesy of the Book of Mormon?" "Are the testimonies of the Three Witnesses true?" Ghormley answers these and other questions. [A.T.]

G.069 Giacalone, Joseph. "Growing into the Church." Ensign 14 (June 1984): 64-65. A loving wife and children and other members of the Church brought this man closer to Church membership, but it was in discovering the beauty of the Book of Mormon that he gained his testimony. [J.W.M.]

G.070 Gibbs, Josiah F. "The Book of Mormon-Historical Synopsis," in Gibbs, Lights and Shadows of Mormonism. Salt Lake City: Salt Lake Tribune, 1909. A polemical work against Mormonism. Presents an overview of the Book of Mormon and concludes that Joseph Smith was merely a child of nature and that the Book of Mormon was a product of his environment. "The book is the offspring of Joseph Smith's fertile and highly imaginative brain." [M.R.]

G.071 Gibson, George Rutledge. "The Origin of a Great Delusion." The New Princeton Review2 (September 1886): 203-22. The author considers Mormon theology "stupid and retrogressive" and the Book of Mormon to be "dull and prolix in the extreme." After a brief review of the Book of Mormon narrative the author notes the allegedly anachronistic use of King James English and New Testament ideas. The Spaulding theory is evaluated based upon the recent discovery of the manuscript by James Harris Fairchild. The author notes the dissimilarities between the two documents and concludes that Spaulding played no part in the origin of the Book of Mormon. [M.R.]

G.072 Gibson, William. "Remarks on the Book of Mormon." MS 12 (15 July; 1 August; 1, 15 September; 1, 15 October 1850): 209-12, 225-28, 261-65, 283-86, 289-92, 313-15. Defends the Book of Mormon against current calumny. Cites reasons why God's communications are not limited to the Bible. Explains why the plates should not be available for inspection. Shows the harmony between the Book of Mormon and the Bible, using many prooftexts, including Zechariah 10:7-11, Hosea 11:9ff, and Isaiah 28. Discusses archaeological confirmations. [D.M.]

G.073 Gigena, Marcelo A. "My Surprising Senior Year." NE 22 (June 1992): 8-10. A conversion story of a young man who became interested in the Church through his friends' examples and received his testimony after reading the Book of Mormon. [M.D.P.]

G.074 Gilberts, Helen. “Mulek's Ship.” SH 125 (November 1978): 696-97. A fictional story for a popular audience. The young Mulek learns about boat building from the prophet Jeremiah. He must learn this to someday build a fleet to sail to the American continent. [B.D.]

G.075 Gilberts, Helen. Sariah. Independence, MO: Herald House, 1970. A fictional book based upon the exodus of Lehi's family from Jerusalem and their journey to the promised land, written from the perspective of Lehi's wife, Sariah. [J.W.M.]

G.076 Gilchrist, Donald B. "The Fullness of the Gospel As Found in the Book of Mormon and Other Written Sources." In A Symposium on the Book of Mormon, 48-54. Salt Lake City: Church of Jesus Christ of Latter-day Saints, 
1979. The Book of Mormon contains the fullness of the gospel. The author discusses this idea and provides possible meanings. [N.K.Y.]

G.077 Gileadi, Avraham. The Book of Isaiah: A New Translation with Interpretive Keys from the Book of Mormon. Salt Lake City: Deseret Book, 1988. A poetic translation of Isaiah, utilizing four interpretive keys from Nephi and Jesus. The keys are the "spirit of prophecy," or revelation by the Holy Ghost, the "letter of prophecy" or the "manner" of the Jews, searching Isaiah diligently, and seeing Isaiah's teachings as "types" within salvific history. This work is reviewed in K.124, P.290, S.216 and in P.069. [D.M.]

G.078 Gileadi, Avraham. "Isaiah-Key to the Book of Mormon." In Rediscovering the Book of Mormon, edited by John L. Sorenson and Melvin J. Thorne, 197-206. Salt Lake City: Deseret Book and FARMS, 1991. The Book of Mormon teaches four concepts that assist in understanding the Book of Isaiah: the spirit of prophecy, the manner of the Jews, search Isaiah's words, and types (events in the past that foreshadow events in Israel's future). A knowledge of Isaiah's influence in the Book of Mormon assists in its understanding as well. [J.W.M.]

G.079 Gileadi, Avraham. The Last Days: Types and Shadows from the Bible and the Book of Mormon. Salt Lake City: Deseret Book, 1991. Finds that Book of Mormon writers followed the manner of Jewish writers who built information into the structure of their writings, thus conveying messages through literary techniques. A prominent feature is the viewing of future events in the light of the past through typology. The "Great and Marvelous work of the Lord" is associated with the "Great and terrible day of the Lord" when two opposing forces meet in a "kind of showdown" as described in the Book of Mormon. Discusses the allegory of the olive tree in Jacob 5. The last days will be filled with more destruction than any other time in the history of the earth. To prepare for this time we keep God's commands and honor him. [J.W.M.]

G.080 Giles, Christie. "Taking It Personally." NE 23 (March 1993): 26-29. Description of a three-day conference where youth acted out the Book of Mormon in order to better understand and gain testimonies of it. [S.H.]

G.081 Giles, Henry E. The Truth Has Spoken from the Dust. Salt Lake City: n.p., 1927. Sheet music written in commemoration of the centennial of the year Moroni entrusted the plates to Joseph Smith. [D.M.]

G.082 Giles, John D. "Father Lehi's Children." IE 49 (September 1946): 556-59, 601-2. Describes President George Albert Smith's visit to Mexico city. Several prophecies concerning the Lamanites are quoted to show the importance of the Lamanites in the last days. [B.D.]

G.083 Gillmor, B. F. "Joseph Smith, the Mormon Prophet: A Study of a Religious Psychopath." Medical Herald 33 (April 1914): 151-56, 206-10, 237-38, 259-61, 338-42. Pejorative psychological explanation of Joseph Smith. Claims that Joseph Smith "breathed an air saturated with the superstitions of debased forms of Christianity, pervaded with beliefs in signs, wonders and heavenly testimonials and peopled with spirits, angels and devils." Sees the Book of Mormon in this setting. Avers that while Joseph Smith worked on the Book of Mormon, he "appears to have assumed a multiplicity of personalities." [D.M.]

G.084 Gillum, Gary P. Book of Mormon Books in Print, April 1984, with Published Book Reviews. Provo, UT: FARMS, 1988. Lists two-and-a-half pages of citations of books on the Book of Mormon published before April 1984. Also includes reprints of published book reviews of many of the listed books. [B.D.]

G.085 Gillum, Gary P. “Book of Mormon Reviews through 1987." Provo, UT: FARMS, 1988. A collection of photocopies of book reviews from several sources such as BYU Studies, U.A.S. Newsletter, Improvement Era, Dialogue, 
and others.

G.086 Gillum, Gary P. Hugh Nibley Quotes: Of the Book of Mormon. Provo, UT: FARMS, 1982. A reprint of a number of quotes by Hugh Nibley on the Book of Mormon from Gillum's Of All Things: A Nibley Quote Book. Salt Lake City: Signature Books, 1981. [B.D.]

G.087 Gillum, Gary P. "Repentance Also Means Rethinking." In By Study and Also by Faith, edited by John M. Lundquist and Stephen D. Ricks, 2:406-37. Salt Lake City: Deseret Book and FARMS, 1990. Repentance involves a new way of thinking, a change of perspective to the way the Lord thinks. This change of perspective comes by way of the Holy Ghost, and with it comes a boost of self-confidence. The Book of Mormon emphasizes three concepts: all people must repent, there must be enough time for all to repent, and faith must be present. Repentance brings about a change of heart. [J.W.M.]

G.088 Gillum, Gary P. Review of A Sure Foundation: Answers to Difficult Gospel Questions. Review of Books on the Book of Mormon 2 (1990): 26-30. Book review.

G.089 Gillum, Gary P. Review of Mormon Answer to Skepticism: Why Joseph Smith Wrote the Book of Mormon, by Robert N. Hullinger. Dialogue 13 (Fall 1980): 136. Book review.

G.090 Gillum, Gary P. "Romans 11:17-24: A Bibliography of Commentaries." In The Allegory of the Olive Tree: The Olive, The Bible, and Jacob 5, edited by Stephen D. Ricks and John W. Welch, 367-72. Salt Lake City: Deseret Book and FARMS, 1994. An alphabetical list of biblical scholars and articles or books that have been written about the passage in Romans 11 that deals with the olive tree. [J.W.M.]

G.091 Gillum, Gary P. Scripture Index to Hugh Nibley's Works: Book of Mormon: Preliminary Report. Provo, UT: FARMS, 1984. Gives a list of Book of Mormon scriptures and their location as quoted and used in the writings of Hugh Nibley. [J.W.M.]

G.092 Gillum, Gary P., and John W. Welch. Comprehensive Bibliography of the Book of Mormon: Preliminary Report. Provo, UT: FARMS, 1982. The preliminary work for this annotated bibliography. [J.W.M.]

G.093 Ginat, Joseph. "The Cave of Khirbet Beit Lei." SEHA 129 (April 1972): 1-5. A cave found in Israel contains ancient inscriptions in Old Hebrew and drawings of human figures and sailing vessels. It contains the name Lei that is an equivalent of Lehi. [J.W.M.]

G.094 Glick, Leonard B. "A Message to Judah." Midstream 29 (June-July 1983): 30-34. Mormons "reject antiSemitism as an intrinsically distasteful ideology." This is based on the Mormon interpretation of Ezekiel 37:16-17, which explains that the Book of Mormon is the stick of Joseph and the Bible is the stick of Judah. The Book of Mormon teaches that the "New Jerusalem" will be established on the American continent by Israelites. Descendants of Judah will reestablish Old Jerusalem. The LDS church, according to the Book of Mormon, will concern itself with building the "New Jerusalem" on the American continent. [B.D.]

G.095 Goates, Claudia T. "Converted After Years of Membership." Ensign 7 (September 1977): 49-51. After reading Mosiah 3:19 in the Book of Mormon and attending the temple, the author's prayers were answered and she felt truly converted to the gospel. [B.D.] 
G.096 "God Does Forgive." CN 43 (17 February 1973): 16. A scripture reference to Moroni 7:8 that shows that God forgives us if we have repented and sought forgiveness with real intent. [M.D.P.]

G.097 Godbey, W. C. "The Book of Mormon." The Home Monthly 7-8 (November 1869-March 1870): 226-30, 27279, 12-18, 72-75, 129-34. Five-part series offers a brief sketch of the coming forth of the Book of Mormon. Claims that the Lord himself visited Joseph Smith on September 21, 1823, and told Joseph that the American Indians were a remnant of Israel and that the record on precious plates was made of brass. Martin Harris was never allowed to see the plates, even though his name appears as one of the Three Witnesses. Parts of the Book of Mormon story resemble the Koran, Paradise Lost, and Spaulding's manuscript. [J.W.M.]

G.098 Godfrey, Dale. "Can Forgiven Sins Be Returned?” The Witness 77 (Summer 1992): 11-12. Scriptural passages in the Book of Mormon, Bible, and Doctrine and Covenants suggest that forgiven sins may not always remain so. In order to bring safety to the soul one must forgive others and "endure to the end" (1 Nephi 7:69). [J.W.M.]

G.099 Godfrey, Kenneth H. Review of Joseph Smith and the Origins of the Book of Mormon, by David Persuitte. Dialogue 19 (1986): 139-44. Book review.

G.100 Godfrey, Kenneth H. Review of Trouble Enough: Joseph Smith and the Book of Mormon, by Ernest H. Taves. Dialogue 19 (Fall 1986): 13944. Book review.

G.101 Godfrey, Kenneth W. "By the Gift and Power of God: The Remarkable Story of the Coming Forth of the Book of Mormon." In A Symposium on the Book of Mormon, 57-65. Salt Lake City: Church of Jesus Christ of Latterday Saints, CES, August 1986. A history of the coming forth of the Book of Mormon beginning with Moroni's visit to Joseph Smith followed by four years of preparation, the acquisition of the gold plates, the divine protection of Joseph and the plates, the translation, and finally the publication of the Book of Mormon by E. B. Grandin. [B.D.]

G.102 Godfrey, Kenneth W. "A New Prophet and a New Scripture: The Coming Forth of the Book of Mormon." Ensign 18 (January 1988): 6-13. Retells the coming forth of the Book of Mormon from its inception (on September 21,1823 ) to its first printing (advertised for sale on March 26, 1830). [D.L.L.]

G.103 Godfrey, Kenneth W. "Using the Book of Mormon to Better Prepare Missionaries." In A Symposium on the Book of Mormon, 55-57. Salt Lake City: Church of Jesus Christ of Latter-day Saints, 1979. The great missionary sections in the Book of Mormon detail how missionaries can be better prepared. Detailed study of the Book of Mormon and application to one's own condition can improve attitudes and knowledge and help make effective missionaries. [N.K.Y.]

G.104 Godfrey, Kenneth W. "The Zelph Story." BYU Studies 29 (Spring 1989): 31-56. This article presents all written accounts relating to the Zelph story. A detailed cross comparison of all features of the accounts are presented in tabular form. While Joseph Smith kept no record of the march of Zion's Camp, Willard Richards wrote an account in the first person, as though written by the prophet himself. Some facts are certain but "those who try to support a particular historical or geographical point of view about the Book of Mormon by citing the Zelph story are on inconclusive grounds." [R.H.B.] [B.D.]

G.105 Goff, Alan. "Boats, Beginnings, and Repetitions." Journal of Book of Mormon Studies 1 (Fall 1992): 67-84. Ancient writers relished repetition over originality. They cherished stories that were repeated in succeeding generations. The Bible is full of repeated or allusive stories, and the Book of Mormon often reinscribes this biblical 
emphasis on repetition. One such biblical reverberation in the Book of Mormon is Nephi's ocean voyage, which evokes biblical stories of origination: creation, deluge, and exodus. These three stories of beginnings are carefully alluded to in Nephi's own foundational story, exactly as would be expected in an ancient Hebraic text. [R.H.B.]

G.106 Goff, Alan. "Book of Mormon." In Encyclopedia of Mormonism, edited by Daniel H. Ludlow, 1:149-50. 5 vols. New York: Macmillan, 1992. This article is a overview of the Book of Mormon. The author identifies the theme of deliverance, the main groups that figure prominently in the text, and underlying textual sources. The book is divided into four sections: Benjamin's speech, Zeniff's record, Alma's record, and the annals of Mosiah. [A.T.]

G.107 Goff, Alan. "Book of Mosiah." In Encyclopedia of Mormonism, edited by Daniel H. Ludlow, 1:149. 5 vols. New York: Macmillan, 1992. The Book of Mosiah records events from 200 B.C. to 91 B.C. and is chronologically complex. It is filled with rich religious symbolism and significant political events. The text includes King Benjamin's address, the records of Zeniff, Alma the Elder, and Mosiah, and the first reference to the Jaredites. Its underlying theme emphasizes deliverance from physical and/or spiritual bondage. [J.W.M.]

G.108 Goff, Alan. "A Hermeneutic of Sacred Texts: Historicism, Revisionism, Positivism, and the Bible and Book of Mormon." M.A. thesis, Brigham Young University, 1989. Biblical studies take two approaches-historical and literary. The latter focuses on the narrative. This study focuses on the narrative of the Book of Mormon, which is a collection of complex, interwoven texts, a canonical work and an ancient document. The author looks at the methods of those who want to see the Book of Mormon as a nineteenth-century document. This work is reviewed in M.239. [J.W.M.]

G.109 Goff, Alan. "Mourning, Consolation, And Repentance At Nahom." In Rediscovering The Book of Mormon, edited by John L. Sorenson and Melvin J. Thorne, 92-99. Salt Lake City: Deseret Book and FARMS, 1991. The account of the death and burial of Ishmael contains suggestions of much deeper meaning than is apparent on the surface. The word Nahom carries the ideas of mourning, consolation, and repentance that link it with earlier biblical traditions. [J.W.M.]

G.110 Goff, Alan. "The Stealing of the Daughters of the Lamanites." In Rediscovering The Book of Mormon, edited by John L. Sorenson and Melvin J. Thorne, 67-74. Salt Lake City: Deseret Book and FARMS, 1991. Explores the connections between the Old World, Old Testament, and the Book of Mormon by means of the story found in Mosiah 20:1-5, the story of the wicked priests who kidnapped young Lamanite women for their wives. Finds a parallel in the book of Judges concerning the tribe of Benjamin. [J.W.M.]

G.111 Goff, Alan, and John W. Welch. "Nephi's Bows and Arrows." In Reexploring the Book of Mormon, edited by John W. Welch, 41-43. Salt Lake City: Deseret Book and FARMS, 1992. The bow is symbolic of political power. When Nephi fashioned a new one, his brothers accused him of having political ambition. [J.W.M.]

G.112 "Gold Bible." The Reflector New Series 2 (2 January 1830): 13. States that it is too early to discuss the merits or demerits of the Book of Mormon, but finds nothing treasonable that would have a tendency to subvert liberties. The religious nature cannot be determined-it must stand or fall on its own merits. [J.W.M.]

G.113 "Gold Bible." The Reflector New Series 3 (11 January 1830): 20. Calls the Book of Mormon a "wonderful work." In an effort to correct misunderstanding of the book, this article clarifies that it is unbelievers who call the Book of Mormon the "Gold Bible." States that the book as well as the "sacred volume" (the Bible) has its revilers. Says that the Book of Mormon is comprised of a number of books by different authors. It is a compilation by Mormon in "ancient Hieroglyphics" upon plates of gold. [J.W.M.] 
G.114 Gold Bible numbers 1-4. The Reflector 2 (6, 18 January; 1, 14, 28 February; 19 March 1831): 76, 84, 92-93, $101,109,126$. Series discusses the origin, rise, and progress of the Book of Mormon. States that the plates were made from "baser metals ... transmuted into gold ... of Mahomet." They contain "notices and sketches of the superstitions of the ancients." Outlines the Smith family's "stupidity and ignorance." Likens the angel Moroni's visit to the experiences of Joanna Southcote who published a book in 1804 in London telling about her meeting with a spirit. Claims that the testimonies of the Three Witnesses "differ entirely." The editor of The Reflector at this time was Obediah Dogberry. [J.W.M.]

G.115 "The Gold Plate Story." CN 28 (27 September 1958): 16. Archaeological proof given for the use of gold/metal plates in history. Examples include the records of Darius, Sargon's Annals, and the Dead Sea Scrolls. [A.C.W.]

G.116 Gold Plates Used Anciently. Salt Lake City: Deseret News Press, 1963. Citing instances when gold plates were used anciently to record sacred and historical writings, this pamphlet includes photographs and lists findings of such plates. [J.W.M.]

G.117 "The Golden Plates of Hill of Cumorah-The Book of Mormon." In History of the Mormons: Or Latter-day Saints, With Memoirs of the Life and Death of Joseph Smith, "The American Mahomet," 22-50. Auburn and Buffalo: Miller, Oremton, and Mulligan, 1854. Discusses the coming forth of the Book of Mormon, the testimonies of the Witnesses, the Harris-Anthon affair, and the Spaulding theory. [J.W.M.]

G.118 "The Golden Tables: On Which Were Inscribed the Records of the Tribe of Nephi." The Chicago Times (11 August 1875): 12-14. Contains testimonies about the coming forth of the Book of Mormon. Joseph Smith translated the plates by placing a stone in a hat. Gives the testimony of the Three Witnesses. David Whitmer reaffirms his testimony of the Book of Mormon but denounces the Utah Mormons. [J.W.M.]

G.119 Gonzales, Franklin S. The Book of Mormon and Semitic Languages. Salt Lake City: by the author, 1986. A presentation of observations by Dr. Zaki Abdel-Malek and Dr. Sami R. Hanna, who were asked to translate the Book of Mormon into Arabic, on the Book of Mormon as a translation of a semitic language. They found that the book is compatible with the Bible, that Book of Mormon events and culture are compatible with Near Eastern customs, and that the syntax in the Book of Mormon is clearly indicative of Semitic languages and not English. [B.D.]

G.120 Gonzales, Franklin S. "Teaching Helps and Insights for Alma 43-62." In A Symposium on the Book of Mormon, 58-60. Salt Lake City: Church of Jesus Christ of Latter-day Saints, 1979. Individuals can benefit from the Book of Mormon war chapters (Alma 43-62) by making an outline similar to the one Gonzales creates for the article. One can learn about heroes, results of internal dissension, the number killed in battle, the value of liberty, how drinking wine lost wars, religion and revelation helpful while going to war, and other topics of interest. [N.K.Y.]

G.121 "Good Proof." The Evening and the Morning Star 2 (June 1833): 99. Submits archaeological finds in North Carolina and Ohio as evidence that the ancient inhabitants of America, as portrayed in the Book of Mormon, were skilled in the arts and sciences. [D.M.]

G.122 Goodfellow, Mildred. "Book of Mormon." SH 77 (23 July 1930): 815. A poem describing the conflict between the Lamanites and Nephites and the final translation of the plates. [B.D.] 
G.123 Goodkind, Howard W. "Lord Kingsborough Lost His Fortune Trying to Prove the Maya Were Descendants of the Ten Lost Tribes." Biblical Archaeology Review 11 (September-October 1985): 54-65. Mentions the Book of Mormon and the Mormon belief of Hebrew origins of Native Americans. The writer is not very sympathetic to the Book of Mormon's claim in this regard, noting that few non-Mormon archaeologists espoused the theory. Alleged anachronisms are also noted, such as the pre-Columbian horse, metallurgy, and nineteenth-century ideas that have since, according to the writer, proved inaccurate. [M.R.]

G.124 Goodson, J. "Letter." M\&A 3 (October 1836): 397-99. Answers objections to the Book of Mormon concerning writing styles, quotations from the Bible contained in the Book of Mormon, non-Egyptian words such as "Jesus" and "Christ," Ezra's overlooking of Lehi's writings, and Jesus not acknowledging the fulfillment of Lehi's prophecies in his own life. [D.M.]

G.125 Goodwin, Samuel H. Additional Studies in Mormonism and Masonry. Salt Lake City: n.p., 1932. An historical look at the anti-Masonic and historical factors present in up-state New York in the late 1820s following the murder of William Morgan. The author asserts that the Book of Mormon incorporates these factors into its discussion of the Gadianton robbers. A summary of the arguments for the "Gadianton-Mason" in the Book of Mormon. [M.R.]

G.126 Goodwin, Samuel H. "Mormonism and Masonry, Anti-Masonry in the Book of Mormon." The Builder10 (November 1924): 323-48, 363-67. An attempt to explain the Gadianton robbers in the Book of Mormon on the basis of events in the late 1820 s related to the Freemasons and the murder of William Morgan. Language used in the Book of Mormon to describe the Gadianton robbers is used elsewhere to describe Freemasons. [M.R.]

G.127 Gordon, Cyrus H. "America and the Ecumene of the Old Testament." SEHA 125 (July 1971): 1-10. Shows many similarities between aspects of life in the Mediterranean world and ancient America, including linguistic similarities. [D.M.]

G.128 Gordon, Cyrus H. "A Hebrew Inscription Authenticated." In By Study and Also by Faith: Essays in Honor of Hugh Nibley, edited by John M. Lundquist and Stephen D. Ricks, 1:67-80. 2 vols. Salt Lake City: Deseret Book and FARMS, 1990. Discusses the pre-Columbian Old World contacts with the New World. Finds that the Bat Creek Inscription is early Hebrew dating back to before 686 B.C. Cites evidence of transatlantic ocean crossing by Phoenicians and others. Notes that seafaring peoples have had great skill in the ancient world. [J.W.M.]

G.129 Gordon, Cyrus H. "Pre-Columbian Discoveries Link Old and New Worlds." Ensign 1 (October 1971): 56-63. Adaptation of SEHA 125 (July 1971): 1-10. The greatest growth of civilization in the New World after its discovery took place in Central America because the New World civilization there is an extension of the civilization of the Near East. Religiously and linguistically the two civilizations are closely connected. An examination of Genesis 10 discloses world-wide settlement. Ancient historians as well as archaeological evidences bear record of transoceanic crossings. [J.W.M.]

G.130 Gordon, Steven H., and Thomas H. Patterson. Study Maps of the Book of Mormon. Provo, UT: FARMS, 1985. A collection of maps of proposed Book of Mormon geographical sites in Mesoamerica and archaeological sites in relation to contemporary locations. [J.W.M.]

G.131 Gorton, H. Clay. "If There Be Faults." Latter-day Digest 2 (March 1993): 30-38. Moroni's concern over scriptural faults or errors was due to the fact that the Book of Mormon plates were written in reformed Egyptian rather than modified Hebrew. Mistakes in the Book of Mormon were corrected using the corrective form of the 
appositive or followed by the corrective phrase. This appears 69 times in the Book of Mormon but only once in the Doctrine and Covenants and only once in the Bible. [J.W.M.]

G.132 Gottfredson, Shawna Struthers. "Our Book of Mormon Party." Ensign 23 (March 1993): 62-63. A description of a Family Home Evening party where family members portrayed characters from the Book of Mormon. [S.H.]

G.133 Graham, Daniel W. Review of A Reading Guide to the Book of Mormon, by David H. Mulholland Review of Books on the Book of Mormon 2 (1990): 118. Book review.

G.134 Graham, Pat. "Follow Righteous Leaders." Friend 18 (July 1988): 36-37. Children's story of Captain Moroni and Amalickiah, based on Alma 46. [A.C.W.]

G.135 Graham, Pat. "Fun With Favorites." Friend 18 (October 1988): 46-47. Children's game based upon the Book of Mormon Liahona. [A.C.W.]

G.136 Graham, Pat. "Helaman and the Two Thousand Young Men of Faith." Friend 16 (May 1986): 37. A brief summary for children of the story of Helaman and the two thousand stripling warriors. [M.D.P.]

G.137 Graham, Pat. "Search the Scriptures." Friend 18 (March 1988): 42-43. Children's activity to enhance knowledge of Book of Mormon by arranging the books in the correct order. [A.C.W.]

G.138 Graham, Pat, and Elise Niven Black. "Study the Book of Mormon." Friend 18 (September 1988): 40-41. Children's pictures of noted Book of Mormon figures that may be cut out and placed in chronological order. [A.C.W.]

G.139 Graham, Pat, and Laurie K. Hutchinson. "Hold to the Rod." Friend 18 (June 1988): 24-25. Children's game based on Lehi's vision (1 Nephi 8). [A.C.W.]

G.140 Graham, Winifred. The Mormons: A Popular History from Earliest Times to the Present Day. London: Hurst \& Blackett, 1913. A polemical work against Mormonism wherein the author favors the Spaulding hypothesis in explanation of its origin. [M.R.]

G.141 Grant, Carter E. "An Angel Visited This Home." IE 66 (March 1963): 168-72, 190-91. A photographic essay regarding the Joseph Smith Jr. home, where the angel Moroni visited. Includes details of activities outside the home as well as a discussion of the translation of the gold plates. [B.W.J.]

G.142 Grant, Carter E. "I Saw Another Angel Fly." In Grant's I Saw Another Angel Fly, 26-65. Salt Lake City: Deseret Book, 1959. Briefly describes the major events of the coming forth of the Book of Mormon: yearly visits to the Hill Cumorah, the final acquisition of the plates, the tricks used to hide them on different occasions, Martin Harris as scribe, the Anthon incident, the lost manuscript, the Aaronic priesthood and baptism, the return of the plates to Moroni, the Three and Eight witnesses, and the publishing of the Book of Mormon. [B.D.]

G.143 Grant, Carter E. The Kingdom of God Restored. Salt Lake City: Deseret Book, 1955. Presents a history of the events that led to the coming forth of the Book of Mormon using Joseph Smith's own words and historical accounts of Oliver Cowdery, Lucy Mack Smith, and others. There are facts about the Hill Cumorah and the monument placed there in honor of Moroni, and the translation of the Book of Mormon. [J.W.M.] 
G.144 Grant, Heber J. "Discourse by Elder Heber J. Grant." MS 60 (9 June 1898): 353-58. Grant testifies at the Salt Lake Stake Conference, March 13, 1898, that one can know gospel truths and later apostatize through disobedience. Grant reads Oliver Cowdery's testimony of the Book of Mormon and quotes him as saying that the reason he left the Church was because he had sinned and he hoped to rejoin the Latter-day Saints. [B.D.]

G.145 Grant, Heber J. "Nephi: Exemplar of Faith." Liahona 14 (15 August 1916): 112. Nephi's life and character was a guiding star in Grant's personal life. Nephi's example demonstrates the Lord's power and his fulfillment of promises. [A.C.W.]

G.146 Grant, Heber J. "The Treaty of Peace-Restoration of the Gospel." IE 23 (December 1919): 107-24. Relates Joseph Smith's vision of the angel Moroni, his revelation of where the golden plates were hidden and Joseph's yearly visits to the Hill Cumorah for instruction. [B.D.]

G.147 Grant, Heber J. Untitled talk. CR (April 1908): 55-59. Following a short discourse on the Word of Wisdom and education, Grant bears testimony of the spirit of the Book of Mormon and its impact on missionary work. Those who read it prayerfully will obtain a testimony of its divinity. Two marks of that divinity are found in Alma 36 and 29. [J.W.M.]

G.148 Grant, Heber J. Untitled talk. CR (April 1915): 81-84. Teaching of the divine mission of the Savior and his prophet Joseph Smith when doing missionary work brings a great outpouring of the spirit. The Three Witnesses of the Book of Mormon as well as many of the Eight Witnesses fell away from the Church, but never denied their testimonies of the Book of Mormon. [J.W.M.]

G.149 Grant, Heber J. Untitled talk. CR (April 1924): 152-60. Grant's recent reading of the Book of Mormon as an adult had a great impact upon his understanding of the Savior and his divine mission, and has increased his testimony of the book. He expressed gratitude for his boyhood readings and his assurance of its truthfulness. Nephi's obedience to the Lord, his confidence in the Lord, and his uncomplaining nature has been an example to Brother Grant. [J.W.M.]

G.150 Grant, Heber J. Untitled talk. CR (April 1929): 128-31. A testimony of the Book of Mormon. In a court of law the testimony of the Three Witnesses and the Eight Witnesses would make the case. A man ridiculed the Book of Mormon because it says the ancients used cement and the voice of the Lord could be heard over the whole land. Archaeologists have dug up cement that the ancients used and if the radio can carry man's voice over the whole land, surely the Lord could do it. [B.D.]

G.151 Grant, Heber J. Untitled talk. CR (October 1935): 2-12. As a youth, Heber J. Grant was ridiculed by a man for his belief in the Book of Mormon because the Book of Mormon said that there was cement in ancient Mexico and that the Lord's voice was heard throughout the land. Grant proclaimed his faith in the divinity of the book and said that time would prove its validity. Cement has now been found in Mexico, and through radio and telephones voices have been heard throughout the land. [B.D.]

G.152 Grant, Heber J. Untitled talk. CR (October 1937): 97-99. External evidences are being uncovered more and more each year to confirm the divinity of the Book of Mormon. Grant states that this book is the greatest preacher of the gospel of Jesus Christ that exists and that it brings an everlasting testimony that remains beyond the grave. [J.W.M.] 
G.153 Grant, Heber J., Anthon H. Lund, and Charles W. Penrose. "New Issue of the Book of Mormon." Relief Society Magazine 8 (February 1921): 96-97. Also published in IE 24 (February 1921): 252-53. An official announcement regarding a new edition of the Book of Mormon, having a new print type, two columns, chapter headings, book and chapter designations, footnote reference revisions, a synopsis of the chapters, a pronouncing vocabulary, and an index. [J.W.M.]

G.154 Grant, Heber J., and Melvin J. Ballard. "Editorial." IE 37 (March 1934): 160-61. Heber J. Grant writes about reading the Book of Mormon as a boy. Melvin J. Ballard speaks about the book's purpose of being carried to "all nations, kindreds, tongues, and peoples." [L.D.]

G.155 Grant, Heber J., and Melvin J. Ballard. "The Mission of the Book of Mormon." IE 37 (March 1934): 160-61. Includes testimonies of Melvin J. Ballard and Heber J. Grant and features photographs of the building in which the Book of Mormon was published, the first edition of the book, the home of Isaac Hale where the translation began, and the Hill Cumorah where the plates were deposited. [J.W.M.]

G.156 Gray, A. F. Menace of Mormonism. Anderson, IN: Gospel Trumpet, 1926. Chapter 3 of this polemical work against Mormonism is devoted exclusively to the Book of Mormon. The author attempts to discredit Mormon interpretations of Bible prophecy that support the Book of Mormon. He discusses the Anthon episode, problems in the issue of translation, Bible plagiarism and anachronistic usage of biblical material such as the Sermon on the Mount, linguistic problems, the term Bible used 600 years before Christ, New Testament phraseology, Isaiah, lack of scientific evidence, and more. He concludes that the Book of Mormon is not a true history, but a fraud. [M.R.]

G.157 Gray, Helen Hale. Dear Elizabeth and Annabel: In Answer to Your Letter "Plain and Precious Truths." Salt Lake City: Graywhale, 1991. A Temple Square guide responds to a letter written by visitors. Reaffirms that "the Book of Mormon, along with the Bible contain the fullness of the Gospel of Jesus Christ." The author uses stories from both the Book of Mormon and the Bible to rehearse the Plan of Salvation in order to assist understanding of the Book of Mormon. [J.W.M.]

G.158 Gray, J. H. Principles and Practices of the Mormons Tested in Two Lectures. Douglas, London: Blackwell, Howell, Nibbet, Wertheim, and Macintosh, 1853. A polemical/evangelical work against Mormonism. The Bible is allsufficient as a guide to salvation and there is no need for the Book of Mormon. The story of the Jaredite barges is ridiculed. The testimony of Book of Mormon witnesses is rejected. The author questions the use of King James translation language in the Book of Mormon. This is seen as evidence of plagiarism. The author accepts the Spaulding theory for the book's origin. [M.R.]

G.159 Gray, Wallace F. "One Thousand Eight Hundred Non-LDS at Symposiums in California." CN52 (31 July 1982): 3. At several different symposiums on the Book of Mormon, General Authorities stressed the purpose of the Book of Mormon as a co-witness with the Bible. The Book of Mormon is the "Church's greatest missionary tool." [M.D.P.]

G.160" 'The Greatest Book in the World.' CN 58 (2 January 1988): 3, 5. Ezra Taft Benson reemphasized the need to read the Book of Mormon daily. It contains the answer to nearly every problem faced in the world. [A.C.W.]

G.161 "The Greatest of All American Books." Relief Society Magazine 14 (September 1927): 437. This article claims that the Book of Mormon is the most important of all American books. [J.W.M.] 
G.162 "Greek, Arabic Volumes Added to LDS Scripture." Ensign 16 (May 1986): 109. A short report of the translation and publishing of the scriptures in Greek and Arabic. [J.W.M.]

G.163 Green, Dee F. "Ancient Trans-Pacific Migration.” UASN 70 (25 November 1960): 1-6. Also in Christensen, Ross T. Progress in Archaeology: An Anthology, 71-80. Provo, UT: Brigham Young University, 1963. Recent finds have renewed consideration of the possibility of transoceanic crossings and Old World influence in the New World in pre-Columbian times. A new theory is emerging that looks at three possibilities: the influence of the Old World via the Bering Strait, independent origins, and transoceanic crossings. [J.W.M.]

G.164 Green, Dee F. "Book of Mormon Archaeology: The Myths and the Alternatives." Dialogue4 (Summer 1969): 71-80. Explores archaeological trends in Book of Mormon research and finds that past efforts have been naive and have often caused more harm than good. Sets forth a number of myths related to archaeology that need to be dispelled. Holds that the Book of Mormon cannot be proven through scientific means. [J.W.M.]

G.165 Green, Dee F. "Mormon Archaeology in the 1970's: A New Decade, A New Approach." Dialogue 8/2 (1973): 49-55. Reviews movements that have characterized LDS archaeological studies since the 1950s. During the 1970s, archaeological studies emphasized elementary historical questions less and anthropological issues more. [D.M.]

G.166 Green, Dee F. "Mormonism and Anthropology." Instructor 96 (September 1961): 298-99. Discusses the intent of archaeology, anthropology, and biology in providing evidences to the truthfulness of the Book of Mormon. [L.D.]

G.167 Green, Dee F. "Newsletter Goes to the Devil." UASN 60 (29 July 1959): 3. Answers the question, to what extent may Quetzalcoatl be identified as a figure of Satan? Satan corresponds to Tezcatlipoca, a twin brother of Quetzalcoatl. [D.M.]

G.168 Green, Dee F., ed. Book of Mormon Institute. Provo, UT: Extension Publications, 1959. A collection of speeches on the Book of Mormon given at a conference at Brigham Young University. Contributors include Sidney Sperry, Ross T. Christensen, Daniel Ludlow, John L. Sorenson, Eldin Ricks, and M. Wells Jakeman. The published presentations are listed under individual authors. [D.M.]

G.169 Green, Doyle L. "Jesus Visits His 'Other Sheep.' "In Green's He That Liveth: The Story of Jesus Christ the Son of God, 204-13. Salt Lake City: Deseret Book, 1958. Written by a layman for laymen this book is a "rework" of articles published in the Improvement Era as a companion series to Talmage's Jesus The Christ. This article is an account of Christ's visit to the American continent found in 3 Nephi. [J.W.M.]

G.170 Green, Doyle L., and Marba C. Josephson. A Book of Mormon Treasury. Salt Lake City: Bookcraft, 1959. A compilation of selected articles from the Improvement Era dealing with Book of Mormon topics. Topics include: "Where is the original manuscript of the Book of Mormon?," "I cannot read a sealed book," and "The Anthon transcript." [L.D.]

G.171 Green, John P. "From The Elders Abroad." TS 1 (December 1839): 28-29. A letter from John Green reporting the activities of the mission in New Jersey. The elders had borne testimony concerning the coming forth of the Book of Mormon. [J.W.M.] 
G.172 Green, Lynn M. "Political and Economic Practices of the Nephites and Lamanites." In A Symposium on the Book of Mormon, 61-63. Salt Lake City: Church of Jesus Christ of Latter-day Saints, 1979. Reviews the types of government of both the Jaredites and Nephites, the manner in which anarchy destroyed the Nephite government just before Christ came, and the final annihilation of both civilizations. Also views the united order of the Nephites. [N.K.Y.]

G.173 Green, Lynn M. "Seership in the Book of Mormon." In The Sixth Annual Church Educational System Religious Educators' Symposium on the Book of Mormon, 30-32. Salt Lake City: Church of Jesus Christ of Latter-day Saints, 1982. The responsibilities and powers of a seer include calling people to repentance, possessing revelatory powers and the power to translate, preparing a "righteous people to enter into the rest of the Lord," establishing the Church of Christ, and recording the history of people for future generations. [A.T.]

G.174 Green, Vaughn, and Carl H. Jacob. "The Gospel Goes to the Lamanites." IE 41 (January 1938): 26-27, 44, 54. Shows examples of how the missionaries are carrying the gospel to the Indian, Mexican, and Spanish-American people. The Book of Mormon is a great converter because it tells of their ancestry and the beginning of their race. [M.D.P.]

G.175 Greene, John T. "Evidences of the Divinity of the Book of Mormon." MS 73 (9-16 February 1911): 85-87, 100-103. The coming forth of the Book of Mormon fulfills a prophecy made by David that the truth would spring forth from the earth. It is the record of the "other sheep" spoken of by the Savior. The book fulfills other scriptural prophecies in Ezekiel, Genesis, and Isaiah. There are eleven witnesses as well as Joseph Smith and thousands of others bear testimony of its truthfulness. [J.W.M.]

G.176 Greenhalgh, Joseph H. "Book of Mormon Recorders." DN Church Section (2 March 1940): 1, 4. Contains details about the 25 writers of the Book of Mormon, including who they were, where and when they lived, what they wrote, and their relationship to each other. Includes photographs of the first edition of the Book of Mormon and an artist's conception of Nephi obtaining the plates from Zoram. [J.W.M.]

G.177 Greenman, Mrs. C. N. A Revelation Published for the Enlightenment of a Deluded People. Westerly, RI: n.p., 1914. Warns that the Book of Mormon was authored by Satan. Nephi, who wrote the Book of Mormon, was Satan himself and the book is his own life record. Quotes Book of Mormon passages to show the evil designs contained in the text. [J.W.M.]

G.178 Greenman, Mrs. C. N. Solomon Spaulding's 'Manuscript Found' 1805 to 1830 A.D. Now Unsealed in 1914. Westerly, RI: n.p., 1914. Unravels the mystery surrounding the Spaulding manuscript. After Spaulding claimed to have found the manuscript, translated it, and tried to publish it, it disappeared. After several years it was found and presented to Oberlin College. Greenman claims that Satan wrote the book under the name Fabius. [J.W.M]

G.179 Gregg, Thomas. Prophet of Palmyra. New York: Alden, 1890. A polemical history of Mormonism. Chapters 110 and 41-45 deal with the Book of Mormon and advances the Spaulding theory for the Book of Mormon's origin, looks at the Anthon denials, and examines external and internal evidences against the Book of Mormon's authenticity. [M.R.]

G.180 Gregson, Louise Clark. Gregson's Book of Mormon Story and Color Book. Independence, MO: Gregson's Storybooks, 1972. A children's book that summarizes the story of the Jaredites from the Tower of Babylon to their destruction. Includes pictures that can be colored. [M.D.P.] 
G.181 Gregson, Louise Clark. Gregson's Stories of the Scriptures of Ancient America for Young and Old, a Continuous Narrative of the Book of Mormon. 5 Vols. Independence, MO: Gregson's Storybooks, 1972-1976. A series of five volumes that retell several hundred Book of Mormon stories in a brief, readable format especially suited for teaching children. The five titles are as follows: Jaredite Period, Migration, Reign of Kings, Reign of Judges, and Christ in America. [M.D.P.] [R.H.B.]

G.182 Grey Owl and Little Pigeon. Cry of the Ancients. Independence, MO: Herald House, 1974. In this collection of articles Grey Owl, an Indian, tells that he holds sacred the message of hope given in the Book of Mormon to his people. It is their history, it may be read as you would read the wampum or listen to the traditions. [J.W.M.]

G.183 Grey, Robert Avery Jr. "The Daring Book Report.” NE 19 (September 1989): 12-14. A teenager in Germany discusses the Book of Mormon in his high school class with positive results. [D.M.]

G.184 Griffin, Edith. "The Two Books." MS 77 (March 4, 1915): 134-35. Two books of scripture used by members of the Church are the Bible and the Book of Mormon. Both present God's dealings with the human family and both testify of Jesus Christ. [D.W.P.]

G.185 Griffith, Michael T. The Book of Mormon as Ancient History: A Response to the Tanners, Larry Jonas, and Other Critics. United States: Vanity, 1981. LDS Scholars respond to a number of objections to the Book of Mormon, i.e., Jesus was born "at Jerusalem," Book of Mormon parallels with the work entitled View of the Hebrews, the alleged Shakespearean quotation in the Book of Mormon, and the allegation that there are no external evidences in favor of the Book of Mormon. Also compares the Itzas and the Nephites. [D.M.]

G.186 Griffith, Michael T. "The Lehi Tree of Life Story in the Book of Mormon Still Supported by Izapa Stela 5." SEHA 151 (December 1982): 1-13. A detailed defense of Wells Jakeman's interpretation of the Stela 5 carving as it relates to Lehi's vision of the tree of life. [D.M.]

G.187 Griffith, Michael T. Tannerism-Shadow or Reality? Private, 1980. Challenges the competence of the Tanner's views on general Book of Mormon issues. [D.M.]

G.188 Griffith, Michael T. The Value of Book of Mormon Studies: A Response to Jerald and Sandra Tanner's Criticisms of Book of Mormon Archaeology As Contained in Chapter Six of Mormonism-Shadow or Reality? Private, 1980. Takes issue with the Tanners' approaches against the Book of Mormon in such areas as the Smithsonian statement, the Anthon transcript, the Kinderhook plates, the "Bat Creek" stone, the Stela 5, and other archaeological interests. [D.M.]

G.189 Griggs, C. Wilfred. "The Book of Mormon as an Ancient Book: Gold Plates and the Tree of Life from the Ancient Mediterranean." BYU Studies 22 (Summer 1982): 259-78. Also in Book of Mormon Authorship: New Light on Ancient Origins, edited by Noel B. Reynolds, 75-102. Provo, UT: Brigham Young University Religious Studies Center, 1982. Challenges the theories of the so-called "environmentalists" who declare that the Book of Mormon was a product of Joseph Smith's nineteenth-century environment. The Book of Mormon cannot accurately be compared to contemporary writings or incidents for it is an ancient text. "The challenge of the Book of Mormon lies elsewhere. It claims to be an ancient book, and it must be examined and criticized in terms of this claim." If the book is indeed an ancient book with Near Eastern origins, it will contain an adequate portrayal of Near Eastern society, law, religion, literary forms, and so on. In light of this Griggs speaks of gold plates and the tree of life. [D.W.P.] 
G.190 Griggs, C. Wilfred. "The Tree of Life in Ancient Cultures." Ensign 18 (June 1988): 26-31. The tree of life as a religious symbol is found in all ancient Near Eastern societies. Its symbols and religious significance are explained in many of the ancient religious writings of Mesopotamia, Egypt, Greece, and in the writings of the early Christian Fathers. Further, ancient texts and writings from Central America contain pictorial depictions or expositions concerning the tree of life. However, references found in the Bible and the Book of Mormon represent the truest and purest explanations of the sacred tree, with the most complete commentary being found in the Book of Mormon. Griggs's goal of demonstrating that the Book of Mormon tree of life is an ancient work by comparing its symbols with other religious writings of the period is achieved. [D.W.P.]

G.191 Groberg, John H. "The Beauty and Importance of the Sacrament." Ensign 19 (May 1989): 38-40; Also in CR (1-2 April 1989): 49-52. We can come near to the Lord through the sacrament. 3 Nephi 18 warns against partaking of the emblems unworthily. The Spirit instructs individuals as to their worthiness. [J.W.M.]

G.192 "A Group of Six Prophecies." Young Woman's Journal 32 (February 1921): 101-13. Discusses prophecies found in the Book of Mormon including: the Lamanites would be a scourge to the Nephites; the Lamanites would not be utterly destroyed; there would be an apostasy from the truth; the Jaredites would be destroyed; readers of the Book of Mormon will receive a testimony of its truthfulness if they follow the proper steps. The Book of Mormon was preserved for the benefit of those of the latter days. [D.M.]

G.193 Grover, Roscoe A. "Moroni Lives Again." IE 38 (September 1935): 542-45. Provides "an account of the dedication of the Angel Moroni Monument at Hill Cumorah, near Palmyra, New York," and discusses the significance of this dedication to the Church. [L.D.]

G.194 "Growth Highlights President Kimball's Administration." CN 55 (24 March 1985): 10. Presents a graph of Book of Mormon translations showing the phenomenal growth in the years between 1974 and 1984, years of President Kimball's administration. It matches his statement to "lengthen our stride," which typifies his life. [J.W.M.]

G.195 Gruss, Edmond C. What Every Mormon Should Know. Denver: Accent, 1976. An evangelical booklet that claims that the Book of Mormon contradicts the Bible and contains false prophesies. [M.R.]

G.196 Guernsey, Alfred H. "Solomon Spaulding and Joseph Smith." The Library Magazine 6 (July-December 1885): 444-47. In this polemical article against the Book of Mormon the author claims that the Spaulding manuscript provided the primary source for the Book of Mormon. Also notes the rediscovery of the unpublished Spaulding manuscript. [M.R.]

G.197 "Guide to Applying Book of Mormon Scriptures in Your Life." NE 23 (January 1993): 34. A list of scriptures organized by topic to help in applying the Book of Mormon to everyday life. [S.H.]

G.198 Gull, Wanda L. "An Old Acquaintance." CN 57 (3 October 1987): 16. Juanita East felt compelled to keep the Book of Mormon she purchased with a box of books at an auction. Years later she was prompted to read it and was converted. [M.R.]

G.199 Gunell, Grant, and Alice Gunell. "Little Did She Realize." CN 60 (20 October 1990): 16. While serving a mission in Nigeria, the Gunells received a referral to the chief of a local tribe. When they went to teach him the discussions they found that he had received a copy of the Book of Mormon from Alice Gunell's sister, who had also wanted to go on a mission. [M.R.] 
G.200 Gunn, Jon. "Ezekiel, Dr. Sperry and the Stick of Ephraim." Dialogue 2/4 (1968): 137-41. The author criticizes Dr. Sidney Sperry's research on the two sticks mentioned in Ezekiel 37:15-23, represented to signify the Bible and the Book of Mormon. The author analyzes these assertions and concludes that Dr. Sperry's arguments are seriously flawed. [A.L. \& P.H.]

G.201 Gunn, Rodger S. "The Comparison," in Gunn's Mormonism: Challenge and Defense. Part III. Salt Lake City: Hawkes, 1973. Responds to a polemical tract written by Don W. Oelze. Topics of discussion include alleged contradictions within LDS scripture, variations between editions of the Book of Mormon, the Anthon episode, and the idea of Christians existing before Jesus Christ. [J.T.]

G.202 Gunn, Stanley R. Oliver Cowdery, Second Elder and Scribe. Salt Lake City: Bookcraft, 1962. Provides "an unbiased history of the life and times of Oliver Cowdery." Chapter 3 discusses Cowdery as a scribe during the translation of the Book of Mormon and chapter 5 relates his experience of viewing the gold plates. [A.T.]

G.203 Gunn, Stanley R. "Oliver Cowdery, Second Elder of the Church of Jesus Christ of Latter-day Saints." M.S. thesis, Brigham Young University, 1942. A biographical treatise on the life of Oliver Cowdery. Presents a discussion of Cowdery during the formative years of the LDS church and his involvement as scribe during the translation process of the Book of Mormon. [J.T.]

G.204 Gunnell, Frank H. "Ancient Americans." IE 35 (October 1932): 732. Human bones found in caves along the Sac River near Osceola, Missouri, date to "pre-Indian" times, which Gunnell suggests may be of interest to readers of the Book of Mormon. [J.T.]

G.205 Gunnell, Wayne C. "Martin Harris-Witness and Benefactor to the Book of Mormon." M.A thesis, Brigham Young University, 1955. A biographical treatise on the life of Martin Harris that discusses his personal involvement in the coming forth of the Book of Mormon. [J.T.]

G.206 Gunnison, J. W. The Mormons or Latter-day Saints in the Valley of the Great Salt Lake. Philadelphia: Lippincott, 1856. A polemical work against Mormonism. The author espouses the Spaulding theory to explain the origin of the Book of Mormon and shows that at the time of the publication of the Book of Mormon many theories were afloat regarding the origin of the American Indian. [M.R.]

G.207 Gunsolley, J. F. "A Great City on the Narrow Neck." SH 75 (24 October 1928): 1229. The discovery of the ruins of a great city about 60 miles from Isthmus of Panama found to be the oldest known on the American continent may be a Jaredite city that is recorded in the Book of Mormon as having been built by the narrow neck of land. An idol found there resembles Assyrian sculpture hence manifesting a possible Semitic background. [J.W.M.]

G.208 Gunsolley, J. F. "The Location of Cumorah and Ramah." SH 64 (7 March 1917): 225. It is the contention of the author that the Hill Cumorah (Nephite) and the hill Ramah (Jaredite) are one and the same, though the location of the hill remains doubtful. The battle that took place at the hill would have been in the Nephite homeland and the hill Ramah was not in New York. [J.W.M.]

G.209 Gunsolley, J. F. "More Comment on Book of Mormon Geography." SH 69 (15 November 1922): 1074-76. Believes that North America is the "land north" of the Book of Mormon and South America is the "land south." The principle argument advanced is the great length of time (approx. 600 to 200 B.C.) that passed without the large 
populations of Nephites, Zarahemlaites (Mulekites), and Jaredites discovering one another, suggesting a large territory. [J.T.]

G.210 Gunsolley, Jeremiah A. "Holy Spirit Bears Testimony to the Book of Mormon." SH 89 (5 September 1942): 1135-37. This testimony of the truthfulness of the Book of Mormon states that the spirit of God led the reader to a greater understanding of the original inhabitants of the American continent. This knowledge clarified many discrepancies in Christian theology. [J.W.M.]

G.211 Gunsolley, Jeremiah A. "Nephi's Prayer." SH 76 (23 October 1929): 1277-78. 1 Nephi 3:37-44 explains how Nephi desired to see the things his father saw. The angel asked if he believed that what his father saw was true. When Nephi replied positively the angel praised him for his faith in the Son of God. Faith and a desire to know the truth of what we hear produces answers to prayers. [B.D.]

G.212 Gunsolley, Jeremiah A., ed. The Religio Quarterly: Senior Grade 15, no. 4. Lamoni, IA: Herald House, 1917. Lesson outlines and commentary on the Book of Mormon are provided. Information from the Bible, Doctrine and Covenants, archaeology, and science is used to formulate the commentary. [J.T.]

G.213 Gunsolley, Jeremiah A., ed. A Study of the Book of Mormon, Supported by Collateral Proof and Information from Other Reliable Sources, Such as the Bible, Doctrine and Covenants, Archaeology, Science, etc. Lamoni, IA: Zion's ReligioLiterary Society, 1916. Thirteen lessons for adult study of the Book of Mormon. Each lesson discusses a portion of the Book of Mormon, giving commentary, questions, evidence that substantiates the text, and the central message. [J.W.M.]

G.214 Gurley, Zenas H. (Reported by S. F. Walker). "Synopsis of a Discourse Delivered at Lamoni, Iowa." SH 26 (15 December 1879): 369-71. Examines Isaiah 29:1-6, Deuteronomy 18:22, Revelation 14:6-7, and finds these passages are related. They speak of a sealed book that the speaker believes to be the Book of Mormon. [J.W.M.]

G.215 Gustavson, Mark S. "Scriptural Horror and the Divine Will." Dialogue 21 (Spring 1988): 70-83.

Contemporary Mormon interpretive literature emphasizes atrocities found in scripture, with little attention as to whether they are morally defensible (e.g., the near sacrifice of Isaac, the execution by fire of Alma and Amulek's converts, and the conquest of Caanan). Notes a strain in Mormonism that argues for a God who, in order to strengthen humanity, arranges events that inflict great pain and suffering, especially on the faithful. He then outlines a set of core ethical paradigms. [R.H.B.] 
H.001 H., J. M. "New Records." CN 45 (4 January 1975): 15. "Hallowed Journey" is a dramatic recreation of Lehi's journey to the promised land. [M.R.]

H.002 H., M. W. "Some New Books: The Mormons." The Sun ([month unidentifiable] 7, 1844?): no pages given. Gives a short account of Joseph Smith: his family history, the first vision, and the coming forth of the Book of Mormon. Claims that the Book of Mormon's origin lies in the Spaulding manuscript. [J.W.M.]

H.003 Haag, Eldon C. "By the Gift and Power of God." Instructor 105 (March 1970): 82-83. The Lord did not need an educated man to translate the Nephite records, but one like Joseph Smith who would capture the spirit and message of the original document through divine aid. [A.C.W.]

H.004 El Habla De Mi Tierra. Montivideo: Uraguayan Mission, 1965. A tract inviting people to read about the "other sheep" spoken of by Jesus in John 10:16, having reference to the Nephites of the Book of Mormon. [D.M.]

H.005 Hadley, Thomas M. "A Thousand Copies of the Book." Ensign 19 (September 1989): 68-69. Converted through reading the Book of Mormon, Mr. Morgensen of Denmark purchased one thousand copies of the Book of Mormon to share with others, even before he received his baptism. [J.W.M.]

H.006 Hagedorn, Hermann. "My Mormon." The Outlook 137 (2 July 1924): 358-59. A member of the RLDS church discusses Church doctrine, practices, history, and the coming forth of the Book of Mormon. [J.T.]

H.007 "Hagoth." "The Book of Mormon Land." Juvenile Instructor 23 (1 October 1888-1 December 1888): 290, $307,323,338$, 354-55. A series of articles containing commentary on important Book of Mormon issues, such as the language of Nephi, Reformed Egyptian, the journey from Jerusalem to the promised land, Lehi's landing on the coast of Chili, and the possible route of Nephi's flight from his brothers. The geographies of Chili, Columbia, and other South American locations are examined in light of the Book of Mormon. [J.W.M.]

H.008 "Hagoth." "The Mounds and Their Builders." Juvenile Instructor 18 (1 November 1883): 331. Sees mounds near St. Louis, Missouri, as evidence for the Book of Mormon and speculates that the mounds are the remains of the cement houses spoken of in Helaman 3. [D.M.]

H.009 Haight, David B. "Joseph Smith the Prophet." Ensign 9 (November 1979): 22-24. The Prophet Joseph Smith was divinely commissioned to restore the Lord's Church after a profound apostasy left mankind in darkness. He worked to bring forth the Book of Mormon in order to dispel the darkness. [J.W.M.]

H.010 Haight, David B. "Remembering the Savior's Atonement." Ensign 18 (April 1988): 6-13. From the Book of Mormon and the New Testament significant truths are learned about the sacrament and the Atonement of JesusJesus gave himself for the sins of the world and the sacrament was given to remind individuals of that Atonement. [J.W.M.]

H.011 Haining, Samuel. Mormonism Weighed In the Balances of the Sanctuary and Found Wanting. Douglass, England: For the Author by Robert Fargher, 1840. Claims that the Bible is sufficient, inerrant, and infallible. The Book of Mormon adds to God's word, when this is strictly forbidden by scripture. For the author, it is "the Bible, the whole 
Bible, and nothing but the Bible." The Book of Mormon also contradicts many statements found in the Bible and is full of many ridiculous anachronisms. [M.R.]

H.012 Hainsworth, Jerome Child. "The Book of Mormon as an Instrument in Teaching the Historicity of Old Testament Events and Characters." M.R.E. thesis, Brigham Young University, 1964. Analysis of Book of Mormon passages dealing with Old Testament characters and events is made to establish the historical validity of the Bible. Several historical characters and events are mentioned, such as Adam, Eve, Moses, and the parting of the Red Sea. [J.T.]

H.013 Hale, Isaac. "Statements of Mr. Hale." New York Baptist Register XI (June 13, 1834): 68. Mr. Hale handled the box that contained the gold plates but was not allowed to look. Tells how Martin Harris came to assist in the translation, how the 116 pages were lost, and concerning Oliver Cowdery as scribe. Finds that the whole affair was a "silly fabrication of falsehood and wickedness." [J.W.M.]

H.014 Hale, Lynette Burke. "Real Testimony." Friend 23 (August 1993): 43-45. A story for children about gaining a real testimony of the Book of Mormon by reading it. [S.H.]

H.015 Hale, Van. "Defining Contemporary Mormon Concept of God." In Line Upon Line: Essays on Mormon Doctrine, edited by Gary James Bergera, 7-15. Salt Lake City: Signature, 1989. Using Book of Mormon scriptures the author attempts to understand what the concept of Deity is in the LDS church, discussing many definitions that are applied to other creeds. [J.W.M.]

H.016 Hales, Robert Lee. "A Book of Mormon Course of Study for Indian Students in Released-Time Seminaries." M.R.E. thesis, Brigham Young University, 1963. Presents Book of Mormon lesson outlines and commentary to American Indian students with a limited vocabulary or insufficient reading skills. [J.T.]

H.017 Hales, Robert E., and Sandra L. Hales. A Standard unto My People: How to Hiss Forth with the Book of Mormon. 2 vols. Orange, CA: Seven Up Publishing, 1990-91. A guide for parents on how to teach their children about the doctrinal concepts in the Book of Mormon. Book of Mormon concepts are supported with scriptural references from the standard works of the LDS church. This work is reviewed in P.068. [J.W.M.]

H.018 Hall, Brent. Review of Gadiantons and the Silver Sword: A Novel, by Chris Heimerdinger. Review of Books on the Book of Mormon 4 (1992): 77. Book review.

H.019 Hall, Enos T. The Mormon Bible: A Fabrication and a Stupendous Fraud, Its Condemnation of Polygamy. Columbus: Heer, 1899. Among the anachronistic elements discussed are Book of Mormon statements regarding animals, the Lamanite curse, condemnation of polygamy, large numbers of war casualties, and the great destructions at the time of Christ's visit to the American continent. The author advocates a Spaulding origin for the Book of Mormon. [M.R.]

H.020 Hall, Glade A. "The Book of Mormon As a Second Witness for What Jesus Christ Taught in the New Testament." In A Symposium on the Book of Mormon, 66-71. Salt Lake City: Church of Jesus Christ of Latter-day Saints, CES, August 1986. In an era that lacks faith in the divinity of Christ, the witness of the Book of Mormon is especially needed. The Book of Mormon confirms the teachings of the New Testament and sheds additional light on the first principles of the gospel and the nature of Christ. [A.L. \& P.H.] 
H.021 Hall, John Franklin. "The Olive in Greco-Roman Religion." In The Allegory of the Olive Tree: The Olive, The Bible, and Jacob 5, edited by Stephen D. Ricks and John W. Welch, 248-61. Salt Lake City: Deseret Book and FARMS, 1994. Explores the use of the olive and olive oil in Greek and Roman religions in comparison with Eastern religions. Athena was first considered as the rocky mound of the Acropolis and later as the olive tree upon the mound. In time the olive was considered only as a tree sacred to her and her gift to the Athenians. [J.W.M.]

H.022 Hall, Manly Palmer. Joseph Smith and the Book of Mormon-A Survey and an Appraisal. Long Beach, CA: n.p., 1953. Compares Joseph Smith to Mohammed. Notes that the anthropological data in the Book of Mormon does not likely reflect Jacksonian America. Discusses the characters from the plates and Joseph Smith's supposed authorship. "I think the fact remains that the Book of Mormon is more or less difficult to explain because it has remarkable internal homogeneity." [D.M.]

H.023 Hallowell, A. Irving. "The Backwash of the Frontier: The Impact of the Indian on American Culture." In The Frontier in Perspective, edited by Walker D. Wyman and Clifton B. Kroeber, 244-45. Madison: University of Wisconsin Press, 1957. Discusses the Book of Mormon within the context of American perceptions of the Indian in frontier America. The author garbles part of the story, as exemplified by this statement: "in America, the great Nephrite prophecy has been fulfilled-the Second Coming of Christ." He sees the interest in the American Indian as transcending in importance the speculations of contemporary America-it "was incorporated as a dogma of a religious sect." [D.M.]

H.024 Halter, Doris M. "Mormon Literature of the Nineteenth Century." M.A. thesis, New York University, September 1946. A perfunctory discussion on the unique LDS scriptures. Devotes a chapter to the Spaulding manuscript, concluding that proper names and writing style in that romance have affinities with the Book of Mormon. [D.M.]

H.025 Halverson, Sandy. Book of Mormon Activity Book. Bountiful, UT: Horizon, 1982. Book of Mormon oriented exercises designed for children. Includes mazes, scrambled words, and fill in the blanks. [D.M.]

H.026 Ham, Wayne. "Problems in Interpreting the Book of Mormon as History." Courage 1 (September 1970): $15-$ 22. In this environmentalist approach to the Book of Mormon the author believes that it is difficult to treat the Book of Mormon as an ancient historical document. Alleged problems extant in the Book of Mormon listed by the author include: the explicit mention of the name of Jesus Christ before Jesus' ministry in Palestine, similarities with the Bible, the Deutero-Isaiah problem, anachronistic mention of synagogues, Greek names, pre-Christian baptism, domesticated animals, Old World crops in America, and textual changes. The writer therefore espouses a "nonliteral view of the Book of Mormon." [M.R.]

H.027 Ham, Wayne. "A Textual Comparison of the Isaiah Passages in the Book of Mormon with the Same Passages in the St. Mark's Isaiah Scroll of the Dead Sea Community." M.A. thesis, Brigham Young University, 1961. A textual comparison between the Isaiah texts in the Dead Sea Scrolls and the Book of Mormon. [M.R.]

H.028 Hamblin, William J. "Armor in the Book of Mormon." In Warfare in the Book of Mormon, edited by Stephen D. Ricks and William J. Hamblin, 400-425. Salt Lake City: Deseret Book and FARMS, 1990. Discussed the history of body armor and its usage in the Book of Mormon. Mesoamerican documents confirm that such armor existed in antiquity and Book of Mormon descriptions are technically correct. [N.K.Y.]

H.029 Hamblin, William J. "Basic Methodological Problems with the Anti-Mormon Approach to the Geography and Archaeology of the Book of Mormon." Journal of Book of Mormon Studies 2 (Spring 1993): 161-200. Analyzes 
issues of the difficulties of reconstructing ancient geographies, problems with the discontinuity of Mesoamerican toponyms, the historical development of the idea of a limited geography model, and difficulties of textual and artifactual interpretation when trying to relate the Book of Mormon to archaeological remains. [A.T.]

H.030 Hamblin, William J. "Book of Mormon, History of Warfare In." In Encyclopedia of Mormonism, edited by Daniel H. Ludlow, 1:162-66. 5 vols. New York: Macmillan, 1992. Sacral warfare was extensive among the Nephites who frequently consulted prophets before going into war. At least eighty-five armed conflicts are mentioned in the Book of Mormon. No animals are mentioned in connection with Nephite warfare. The major compiler of the Book of Mormon was a general and included warfare in the record to show how it changed societies and fulfilled prophecies and how important it was to have faith in God in order to win. [N.K.Y.]

H.031 Hamblin, William J. "The Bow and Arrow in the Book of Mormon." In Warfare in the Book of Mormon, edited by Stephen D. Ricks and William J. Hamblin, 365-99. Salt Lake City: Deseret Book and FARMS, 1990. Provides a history of the development and use of the bow and arrow in the Book of Mormon. The weapon is depicted in ancient Assyrian documents, and the atlatls, much used in Mesoamerica, is another form of the bow and arrow. Hamblin also provides reasons why Nephi needed a new arrow for his wood bow. [N.K.Y.]

H.032 Hamblin, William J. "Directions in Hebrew, Egyptian, and Nephite Language." In Reexploring the Book of Mormon, edited by John W. Welch, 183-86. Salt Lake City: Deseret Book and FARMS, 1992. Cardinal directions were not expressed by ancient Egyptian and Israelite peoples as they are today. The Israelite and Egyptian directional systems differed and it is not clear which system was used by the Nephites since they were familiar with both. Hence caution is needed when one makes directional assumptions. [N.K.Y.]

H.033 Hamblin, William J. "The Importance of Warfare in Book of Mormon Studies." In Warfare in the Book of Mormon, edited by Stephen D. Ricks and William J. Hamblin, 481-500. Salt Lake City: Deseret Book and FARMS, 1990. Looks at Book of Mormon warfare and such topics as the influence of ecology; military technology; the social and economic foundations of ancient warfare; military operations; the political, cultural, and legal norms of warfare; the influence of religion; and Book of Mormon parallels to ancient warfare patterns. [N.K.Y.]

H.034 Hamblin, William J. Review of An Approach to the Book of Mormon, by Hugh W. Nibley. Review of Books on the Book of Mormon 2 (1990): 119-27. Book review.

H.035 Hamblin, William J. Review of "Apologetic and Critical Assumptions about Book of Mormon Historicity," by Brent L. Metcalfe, from Dialogue 26 (Fall 1993): 154-84. Review of Books on the Book of Mormon 6/1 (1994): 434523. Book review.

H.036 Hamblin, William J. Review of Pre-Columbian Contact with the Americas across the Oceans: An Annotated Bibliography, by John L. Sorenson and Martin H. Raish. Review of Books on the Book of Mormon 3 (1991): 154-57. Book review.

H.037 Hamblin, William J. "Sharper Than a Two-Edged Sword." Sunstone 15 (December 1991): 54-55. A response to Mark Thomas's book review of Warfare in the Book of Mormon. It is impossible to prove whether the Book of Mormon is an ancient document or not. The book Warfare was written with the premise that the Book of Mormon is an ancient record, and comparisons of Book of Mormon warfare and Near Eastern military practices are sound. No comparison with warfare in Napoleon's day or Spaulding's manuscript is necessary. [J.W.M.] 
H.038 Hamblin, William J. "Warfare in the Book of Mormon." In Rediscovering the Book of Mormon, edited by John L. Sorenson and Melvin J. Thorne, 241-48. Salt Lake City: Deseret Book and FARMS, 1991. The features of warfare in Joseph Smith's day differed from ancient warfare due to the development of gunpowder. Book of Mormon warfare resembles that of the ancient Near East and Mesoamerica. [J.W.M.]

H.039 Hamblin, William J., and A. Brent Merrill. "Notes on the Cimeter (Scimitar) in the Book of Mormon." In Warfare in the Book of Mormon, edited by Stephen D. Ricks and William J. Hamblin, 360-64. Salt Lake City: Deseret Book and FARMS, 1990. Cimeters described in the Book of Mormon could have been similar to those depicted in Mayan pictures with flint blades. They may also have reference to the jaguar claws mounted on a club thought to be used in ceremonies. [N.K.Y.]

H.040 Hamblin, William J., and A. Brent Merrill. "Swords in the Book of Mormon." In Warfare in the Book of Mormon, edited by Stephen D. Ricks and William J. Hamblin, 329-51. Salt Lake City: Deseret Book and FARMS, 1990. Examines swords in the Book of Mormon and reviews ancient Near East pictures and descriptions of swords. Jaredite references to swords and the making of copies of Laban's sword by Nephi add to our knowledge of Book of Mormon swords. [N.K.Y.]

H.041 Hamby, Wayne D. Donny Osmond Listens to Voices from the Dust, Part 1. Orem, UT: Osmond, 1977. A presentation of archaeological finds from North, Central, and South America. Artifacts presented include many from the Padre Carlo Cresa collection, the Metcalf Stone, the Bat Creek Stone, and the Tree of Life Stone. [B.D.]

H.042 Hamilton, Milton W. "Our Own Affairs." In Milton's The Country Printer: New York State, 1785-1830, 1964, 78-79. Port Washington, NY: Ira J. Friedman Inc., 1964. Two outstanding publishing events took place in western New York: William Morgan's revelation of Masonry in 1826 and Joseph Smith's publication of the Book of Mormon. Thurlow Weed, publisher in Rochester, was offered the printing of both books. Grandin ultimately published the Book of Mormon. [J.W.M.]

H.043 Hammer, G. Stephen. "The Mormons' Mammoth Pageant." Ford Times 60 (July 1967): 58-62. The Hill Cumorah Pageant, a dramatic reenactment of the events in the Book of Mormon, is reviewed. Details are given concerning the size, location, and quality of the pageant. [J.T.]

H.044 Hammond, Fletcher B. Geography of the Book of Mormon. Salt Lake City: Utah Printing Company, 1959, $[R]$ 1964. Presents information to support the idea that the Book of Mormon lands are located in Central America or Mexico. Suggests that a Hill Cumorah was located both in Palmyra New York and in Central America. A number of maps and diagrams are presented. [L.D.]

H.045 Hampton, Brad. "A Traveler in Mesoamerica." The Witness 77 (Summer 1992): 5-6. Many believe Guatemala to be the Land of Nephi. This author felt the spirit of this holy ground. His testimony of Jesus Christ was strengthened as his testimony of the Book of Mormon increased when seeing the ruins of Mesoamerica and the idolatrous worship of the people. The Book of Mormon will bring them to Christ. [J.W.M.]

H.046 Hamson, Robert L. The Signature of God: A Positive Identification of Christ and His Prophets by Computer Wordprints. Solana Beach, CA: Sandpiper Press, 1982. Computer analysis of the personal words of Jesus Christ as found in the New Testament and in the revelations of Joseph Smith shows them to be similar, suggesting that Jesus Christ is the author of both of the works mentioned. Hamson also points out that the wordstyles of Christ are different than the writings of Matthew, Mark, Luke, John, and Joseph Smith (who have their own unique writing styles), allowing a positive identification of authorship in a given text. The Book of Mormon is examined and 
the results showed multiple authorship and that the Book of Mormon wordprints were nowhere near that of Joseph Smith or his contemporaries. [J.T.]

H.047 Hancock, G. B. Mormonism Exposed; Joseph Smith an Imposter and the Book of Mormon a Fraud. Marionville, MO: Doggett, 1902. A polemical work against Mormonism and the Book of Mormon. Author believes that the Book of Mormon contradicts the Bible, both doctrinally and scripturally; there is no archaeological evidence for the Book of Mormon, the Anthon account is discredited, and no proper names in the Book of Mormon can be found in Central America. [M.R.]

H.048 Hancock, Pauline. The Book of Mormon: What Is It? Do We Need It? Independence, MO: Hancock, n.d. A polemical defense of the Book of Mormon by a member of the Church of Christ. [M.R.]

H.049 Hancock, Pauline. Do You Know What the Book of Mormon Teaches? Independence, MO: Hancock, n.d. An informative tract that presents doctrines taught in the Book of Mormon, written by a member of the Church of Christ. [M.R.]

H.050 Hancock, Pauline. Whence Came the Book of Mormon. Independence, MO: 1958. The Book of Mormon is from God and its teachings are harmonious with the Bible. The grammatical and editorial changes in the Book of Mormon deny the power of God and corrupt the Book of Mormon. [B.D.]

H.051 Hancock, Ralph C. "The Summary of '42, or Alma's Reply to Ivan." Tangents 4 (Spring 1976): 87-90. In Alma 42, Alma is explaining God's just treatment of sinners. His explanation can be applied to modern questions regarding God's justice, as in Alber Camus's book The Rebel, wherein Dostoievski's Ivan Karamazov thinks God is unjust not to save everyone and he (Ivan) refuses to be saved without the damned. [B.D.]

H.052 Hand, Wayland Debs. "The Three Nephites in Popular Tradition." Southern Folklore Quarterly 2 (September 1938): 123-29. Recounts legendary stories concerning the three Book of Mormon Nephite apostles who were given power over death until the return of Jesus Christ in the last days. [J.T.]

H.053 Hanks, Marion D. "Alone in the Moonlight." IE 64 (April 1961): 238-39, 262. Experiencing soul satisfying circumstances is better when one is not alone. Sharing such experiences with loved ones increases the satisfaction, as is exemplified in the Book of Mormon. Examples of such phenomena include Lehi, who tastes of the fruit of the tree of life and desires to share; Enos, who prays for his brethren; and the sons of Mosiah and Alma, who shared their experiences as missionaries following their conversion. [J.W.M.]

H.054 Hanks, Marion D. Book of Mormon Lessons, First Half. Private, 197?. Provides an outline for studying the Book of Mormon from 1 Nephi through the Book of Alma. Gives a summary of each section and a list of "vital lessons" that may be learned, i.e., the mysteries of God, purpose of the Book of Mormon, tree of life, etc. [J.W.M.]

H.055 Hanks, Marion D. "Fathers to Teach Sons." CR (October 1975): 35-38. The Book of Mormon teaches that fathers have the sacred responsibility to teach their children. For instance, Alma taught, counseled, reprimanded, and bore testimony to his sons. [R.C.D.]

H.056 Hanks, Marion D. "Forgiveness." CR (April 1979): 102-5. The gospel is a plan of mercy, a plan of happiness. In spite all our sins God yet loves us. And with true repentance we can receive forgiveness. Examples of these teachings are listed in the writings of Alma and Nephi. [R.C.D.] 
H.057 Hanks, Marion D. "Hard to Be Understood." IE 64 (August 1961): 586-87. The only way to clearly understand the great teachings and doctrines of the Book of Mormon is through the Holy Spirit. Science, study, and pure human intellectual pursuits, without God's spirit, will not adequately relay the full message of the Book of Mormon. [R.C.D.]

H.058 Hanks, Marion D. "I, Johnny, Parent-to-be.' " IE 64 (February 1961): 97, 113. Although being born of "goodly parents" (1 Nephi 1:1) is an ideal situation, not all children have this opportunity and privilege. However, everyone may become "goodly parents" to their own children in ways that the Book of Mormon teaches. [J.W.M.]

H.059 Hanks, Marion D. "Lessons for Living." IE 64 (January 1961): 26-27. There are many rewarding approaches to the Book of Mormon. One can approach the Book of Mormon historically, through the external evidence, through its marvelous theological teachings, and through its application to life. [J.W.M.]

H.060 Hanks, Marion D. "Mormon, Compiler of the Book of Mormon, Author, Soldier, Man of God." IE 71 (April 1968): 13-14. A biographical sketch of Mormon, who served as prophet, editor, soldier, and author. [B.W.J.]

H.061 Hanks, Marion D. "Steps to Learning." In BYUSY (4 May 1960). Provo, UT: BYU Press. Quoting an Episcopalian prayer book, the author gives "five steps to wisdom"-read, hear, mark, learn, and digest. Application of the five steps should be made to the Book of Mormon, so that one's love of the book will grow. [J.W.M.]

H.062 Hanks, Marion D. "Travels between Nephi and Zarahemla." Instructor 102 (September 1967): 372-73, 376. In this response to the criticism that Joseph Smith authored the Book of Mormon, Hanks claims that the Book is so intricate, with numerous migrations, expeditions, flashbacks, interpolations, and other plot complexities, that it would have been amazing for an untutored boy to have written it. He includes a chart of travels between Zarahemla and the land of Nephi. [C.C.]

H.063 Hanks, Marion D. Understanding and Explaining the Book of Mormon. N.p.: n.p., 197?. A one-page handout that discusses different approaches to studying the Book of Mormon-relate the Book of Mormon to the Bible, study external evidences, consider the theology, and find the "life lessons" in the book. [J.W.M.]

H.064 Hanks, Marion D. "Why Are They Not Chosen?" IE 65 (April 1962): 260-61. Alma 31:16-18 contains the prayer offered by the apostate Zoramites. They declare themselves the chosen and elect of God. 1 Nephi 1:20 tells us that the chosen are such because of their faith. Alma adds repentance and good works to faith (Alma 13:1, 3-4, 10). "The Lord chooses those who in faith choose him!" [J.W.M.]

H.065 Hanks, Marion D., and Elaine Cannon. "Era of Youth." IE 68 (November 1965): 1041-52. This article tells youth that they can find answers in the scriptures and uses stories and quotes from the Book of Mormon and the Bible to show this. [M.D.P.]

H.066 Hansen, Eric. "I Asked, He Answered." NE 22 (September 1992): 23. A story of a young man who took Moroni's challenge (Moroni 10:3-5). After he prayed, the Spirit manifested the truth of the Book of Mormon to him. [M.D.P.]

H.067 Hansen, Gerald, Jr. "The Book of Alma as a Prototype for Teaching the Word of God." In The Book of Mormon: Alma, The Testimony of the Word, edited by Monte S. Nyman and Charles D. Tate Jr., 263-80. Provo, UT: Brigham Young University Religious Studies Center, 1992. The Book of Alma emphasizes the power of preaching the word of God to accomplish much good. In Alma, the word of God is used for church reformation, conversion of 
people by missionary work, dealing with anti-Christs, teaching members of Alma's family, and bringing peace to a war-torn nation. [N.K.Y.]

H.068 Hansen, Gerald, Jr. "The Terrifying Book of Helaman." In The Book of Mormon: Helaman through 3 Nephi 8 , According to Thy Word, edited by Monte S. Nyman and Charles D. Tate Jr., 163-76. Provo, UT: Brigham Young University Religious Studies Center, 1992. An exposition on the grim message in the Book of Helaman, wherein the prophets warn against the sins of pride, aspirations for riches, crime, pseudopatrotism, and injustice. [D.M.]

H.069 Hansen, Gorge H., and Alvah Fitzgerald. A History of American Indian Origin Theories. N.p: n.p., n.d. Reprint from Utah Academy of Science 8 (July 1, 1931): 1-32. Discusses theories of the origin of the American Indian: the Atlantis Theory and the Israelitish or Lost Ten Tribe and Hebrew Theory. The most challenging is the Book of Mormon theory. [J.W.M.]

H.070 Hansen, Hans H. What the Book of Mormon Means to Me. Hammond, IN: Church of Christ, 1970. A tract in which the author bears testimony about the value of the Book of Mormon and provides comments about secret oaths and priesthood. [D.M.]

H.071 Hansen, Harold I. America's Witness for Christ: Based on the Book of Mormon. N.p., 1958. Contains the script to the Hill Cumorah pageant. [D.M.]

H.072 Hansen, L. Taylor. He Walked the Americas. Amherst: Amherst Press, 1963. This is a collection of more than fifty Indian legends concerning the Healer, the Mighty, and the Prophet. The sequence of these legends, particularly vivid among the wild tribes, form a curious pattern matching the stories told in the Book of Mormon. They tell of a saintly white teacher who performed miracles of healing. His symbols are woven into blankets, carved on canyon walls, and burned in pottery. [R.H.B.]

H.073 Hansen, Lorin K. "Chiasmus Caution." NE 1 (January 1973): 3. A letter to the editor points out that chiasmus was indeed known by English and German scholars before Joseph Smith's time, but it is probable that Joseph Smith did not know of the form during his day. [C.C.]

H.074 Hanson, Alma B. "From What Plates was the Book of Mormon Translated?" SH 47 (18 July 1900): 468-69. Argues that Nephi made two sets of plates and that Mormon made references to both sets while compiling the Book of Mormon. [A.T.]

H.075 Hanson, Paul M. "Among Ancient American Cities No. 1-11." SH 76 (13 February-29 May 1929): 184-87, 213-15, 244, 269-70, 301-302, 328-30, 517-20, 553-55, 561, 588-91, 619-21, 640, 645-48. Reprints of letters that describe the ruins of Central America: Teotihuac $¥ n$, Tula, Copan, Quirigua, Palenque, Uxmal, and others. Includes photographs. He relates Central American Culture and religion with Near Eastern Culture and religion, quoting such authors as Bancroft, Humboldt, and Lord Kingsborough, among others, to back his claims. Equates Quetzalcoatl with Jesus Christ whose visit to America is recorded in 3 Nephi 11 in the Book of Mormon. [B.D.]

H.076 Hanson, Paul M. "Ancient Christian Influence among the Mayas." SH 85 (15 January 1938): 71-74. Friar Diego de Landa's book, Yucatan Before and After the Conquest, recently published, reveals that most of the writings of the Mayas were destroyed by de Landa because he considered them workings of the devil that stood in the way of the native's conversion to Christianity. The information that was preserved tells of communal living, reckoning of time, festivals, sacraments, worship of one supreme God, baptism, immortality of the soul, and creation of the world. This new publication verifies the truthfulness of the Book of Mormon. [J.W.M.] 
H.077 Hanson, Paul M. "Book of Mormon Geography." In Recent Book of Mormon Developments,77-80.

Independence, MO: Zarahemla Research Foundation, 1984. Also in ZR 10 (Fall 1980): 4-8. Reports a shift in RLDS church attitudes toward Book of Mormon geography, comparing an 1894 map to a 1980 map of proposed Book of Mormon lands. Argues for the Isthmus of Tehuantepec as the "narrow neck" of land. Also addresses Book of Mormon population shifts and believes that that placing Book of Mormon events in Central America makes things too crowded. [A.T.]

H.078 Hanson, Paul M. "Book of Mormon Geography." SH 98 (8 January 1951): 29-31. Uses scriptures, archaeological evidence, and geography to explain that the Book of Mormon lands do not encompass as large an area as previously supposed. Suggests that the RLDS church maps placing Lehi's landing on the coast of Chile should be revised. Finds the Isthmus of Tehuantepec much more probable contender for "narrow neck of land" than the Isthmus of Panama. [A.C.W.]

H.079 Hanson, Paul M. "The Feathered Serpent in Mexico and Central America." SH 97 (4 December 1950): 116567. The origin of the "feathered serpent" in the American native culture can best be explained by the Book of Mormon scripture that tells of Moses' placing the fiery serpent upon the stick. This author sees the feathered serpent as a symbol of Christ, whose visit is recorded in Third Nephi. [J.W.M.]

H.080 Hanson, Paul M. In the Land of the Feathered Serpent. Independence, MO: Herald House, 1949. Argues that Quetzalcoatl, a major deity of pre-Columbian Mexico and Central America, may have been Christ. Presents a pictorial tour of archaeological sites-including the Toltec ruins at Tlaxcala, the ruins at Mitla, and the Temple of Quetzalcoatl at Tula, in which this deity, also known as the Feathered Serpent, is represented. [C.C.]

H.081 Hanson, Paul M. Jesus Christ among the Ancient Americans. Independence, MO: Herald House, 1945, [R]1947 \& 1959. Submits archaeological, anthropological, and historical evidence to validate the Book of Mormon. Topics include Israelite origin of Native Americans, native American myths, Quetzalcoatl-the tall white god who may have been Jesus Christ-and linguistic similarities between Hebrew words and words from Mayan, Incan, and Mexican languages. [C.C.]

H.082 Hanson, Paul M. "Quetzalcoatl." SH 72 (13 May 1925): 531-32. Considers the idea that the white god of America, Quetzalcoatl, was Jesus Christ of the Book of Mormon. [J.W.M.]

H.083 Hanson, Paul M. "The Transcript from the Plates of the Book of Mormon." SH 103 (12 November 1956): 1097-99. Says that the Book of Mormon fulfills prophecies of Isaiah and was witnessed by eleven honorable men. Egyptologists find little or no resemblance between the facsimile of characters that Martin Harris took to Charles Anthon and Egyptian writing. Hanson explains that this is because the Nephites altered the language. [A.C.W.]

H.084 Hanson, R.A. "The Rod of Iron." MS 77 (8 April 1915): 223-24. Recalls Lehi's dream of the rod of iron that leads to the tree of life. Likens those who occupied the great and spacious building and mocked those who partook of the tree of life to people of the present age who scoff at the existence of the Book of Mormon. [D.W.P.]

H.085 Harder, Erika. "An Answer Like a Splash of Fire." Ensign 13 (December 1983): 22-23. The author's conversion to the restored gospel through the Book of Mormon is told. Recounts specifically how she wanted to receive a sign but learned through a passage in Alma 32 regarding the importance of faith. [S.P.S.]

H.086 Harding, Robert George. The Gadianton Robbers. Salt Lake City: Promised Land Publications, 1969. Traces the rise and growth of organized crime in Nephite-Lamanite culture. The author discusses how, through 
conspiracy and murder, the Gadianton Robbers gained seats in the government and became the ruling force. Claims they originated with Cain. Shows how the Jaredites, 2300 B.C.-A.D. 200, were destroyed by a similar group. Draws parallels with present-day society and warns that history repeats itself and that liberty requires vigilance. [C.C.]

H.087 Hardy, Allison. The Mormon Pioneers or the Great Salt Lake Trail. Girard, KS: Haldeman-Julius, 1944. An historical discussion of Mormonism. The Anthon denials are discussed. Author considers the Book of Mormon to be "a strange jumble of pseudo-historical narrative and religious precept" and dismisses the book on the grounds that it is full of "outlandish errors in spelling, syntax and grammar." He also notes what he terms "countless anachronisms that exposed the author's ignorance of geography, chronology, physical science and Bible history." He decries the book's use of King James English and alleged pilfering of biblical material. He seems to accept the Spaulding Theory regarding its origin. [M.R.]

H.088 Hardy, Bud G. "A Study to Identify and Isolate the Principles and Lessons of the Book of Mormon Record as Inserted by the Writers and Abridgers." M.A. thesis, Brigham Young University, 1975. Maintains that the Book of Mormon contains key phrases, like "it came to pass" and "thus we see," that point out the messages of the various Book of Mormon authors and abridgers. These phrases can be historical in nature, explaining events, or polemic, explaining teachings, or they can be direct statements to the reader. The author includes tables and summaries that list the phrases. [C.C.]

H.089 Hardy, Grant. "Columbus: By Faith or Reason." In Reexploring the Book of Mormon, edited by John W. Welch, 32-36. Salt Lake City: Deseret Book and FARMS, 1992. Recent research has overturned the idea that Columbus was led by science, reason, restlessness, and conquest to discover America. Columbus was "deeply influenced by prophecy and revelation." The Book of Mormon's claim that Columbus was inspired by the Spirit of God was in opposition to the intellectual trend of 1830. Columbus wrote, but never completed, a book that set forth his views of himself as a "fulfiller of biblical prophecies" recorded in Isaiah. [J.W.M]

H.090 Hardy, Grant. "Gold Plates." In Encyclopedia of Mormonism, edited by Daniel H. Ludlow, 2:555. 5 vols. New York: Macmillan, 1992. Presents a description of the gold plates on which the Book of Mormon was written. It includes an estimate of the size of the plates. [A.T.]

H.091 Hardy, Grant. "Mormon's Agenda." In Reexploring the Book of Mormon, edited by John W. Welch, 245-47. Salt Lake City: Deseret Book and FARMS, 1992. As an editor of the Book of Mormon, Mormon devoted much of the record to warfare and to the spiritual interpretation of political events. His work shows an effort to draw uplifting lessons from mean and ugly events. His effort at simplification of complex events is remarkable where sizable groups of people are involved. [N.K.Y.]

H.092 Hardy, Grant R. "Mormon As Editor." In Rediscovering The Book of Mormon, edited by John L. Sorenson and Melvin J. Thorne, 15-28 Salt Lake City: Deseret Book and FARMS, 1991. Compares editing that was done by Mormon in the Book of Mormon with that done by biblical editors. Tries to determine Mormon's biases and purposes as he made selections from massive amounts of material. Mormon makes spiritual meanings out of historical events by the use of flashbacks, simplification, narrative, deletions, and commentary to make his messages clear. [J.W.M.]

H.093 Hardy, Grant R., and Robert E. Parsons. "Book of Mormon Plates and Records." In Encyclopedia of Mormonism, edited by Daniel H. Ludlow, 1:195-201. 5 vols. New York: Macmillan, 1992. The complicated history of the Book of Mormon is taken from many records: the twenty-four Jaredite plates, Nephi's small and large 
plates, and the brass plates of Laban. A description of the contents of each is given. Quotations from the brass plates are almost the same as quotes from biblical records but have significant textual differences and mention many prophets not found in the Bible. [N.K.Y.]

H.094 Hardy, Rufus K. Untitled talk. CR (9 April 1939): 131-32. A testimony that fifteen hundred years ago the Book of Mormon was penned by the hand of a prophet and contains the words of the Lord and Savior Jesus Christ. Joseph Smith translated it correctly, according to the will of God. Quoting Moroni's discourse on faith, hope, and charity, the author calls to the meek and lowly in heart to read the Book of Mormon. [J.W.M.]

H.095 Harkness, Georgia. "Saints and Strategists." Christian Century 52 (31 July 1935): 986-88. An attempt to explain Joseph Smith and the Three Witnesses on the basis of current pop psychology. Links Smith's reputed early practices to the coming forth of the Book of Mormon. "The Book of Mormon reads like a mixture of Old Testament, Arabian Nights and Gulliver's Travels, with a literary quality decidedly inferior to any of these." Suggests that the Three Witnesses suffered a hallucination. [D.M.]

H.096 Harmer, Earl W. Our Destiny. Salt Lake City: Deseret News, 1942. The Book of Mormon is an important part of the Restoration. It is the sacred history of the American natives and clarifies the location of the lost tribes who are "lost only as to their identity and not their location." [J.W.M.]

H.097 Harper, Bruce T. "The Church Publishes a New Triple Combination." Ensign 11 (October 1981): 8-19. An announcement and discussion concerning the publication of the new triple combination (Book of Mormon, Doctrine and Covenants, and Pearl of Great Price) in 1981. Various new features in the Triple Combination are designed to assist the student in understanding the scriptures. [D.M.]

H.098 Harris, Franklin S. "Agricultural Conditions in Book of Mormon Times." IE 17 (December 1913): 97-100. Book of Mormon references and archaeological evidences (i.e. complex irrigation systems and terraces) from early agricultural sites demonstrate advanced knowledge and practice in tilling the land among the Nephite peoples. [D.M.]

H.099 Harris, Franklin S. "Ancient Records on Metal Plates." In 13th Annual Symposium on Archaeology of the Scriptures, edited by Dee F. Green, 41-51. Provo, UT: Brigham Young University, Department of Extention Publications, 1962. Joseph Smith described the metal plates from which came the Book of Mormon as having the appearance of gold. The use of metals appeared early in world history. A recent excavation at a cemetery in Ur (approx. 2500 B.C. or earlier) uncovered sheets made of gold that could be bent and folded like paper. Similar finds are also reported in various parts of the world, including ancient America, where metallurgy was highly sophisticated. [J.W.M.]

H.100 Harris, Franklin S. "Biological Conditions in Book of Mormon Lands." IE 13 (March 1910): 385-90. Harris claims that the references in the Book of Mormon, with regard to both the Jaredite and Lehite peoples, concerning the use of timber and cement are corroborated by studies published in a bulletin from the U.S.D.A. Similar claims are made of the fauna and flora in America. [D.M.]

H.101 Harris, Franklin S. "The Book of Mormon As a Missionary." DN Church Section (19 October 1946): 10, 12. The real value of the Book of Mormon is that it is a witness of Christ and it is able to convince people of his message to the point where they will try to live his teachings and commandments. The author gives examples of how some of the first Latter-day Saints were converted by the Book of Mormon. [M.D.P.] 
H.102 Harris, Franklin S. A Book of Mormon Bibliography. N.p., n.d. A typewritten, unpublished, initial research for Seven Claims of the Book of Mormon. This bibliography deals with the origin of the Book of Mormon, harmony with biblical prophecies, witnesses, Joseph's lack of training, and other topics. [J.W.M.]

H.103 Harris, Franklin S. "Gold Plates in Persia." IE 43 (December 1940): 714-15. Provides photos and notes of a stone box containing silver and gold plates of Darius I and stone memorial tablets of Xerxes. [R.H.B.]

H.104 Harris, Franklin S. "More Book of Mormon Evidence." Young Woman's Journal 36 (January 1925): 16-17. The inhabitants of ancient America had Christian traditions in pre-Columbian times and their ancestors crossed the Pacific Ocean in boats, landing somewhere on the coast of present day Mexico. [J.W.M.]

H.105 Harris, Franklin S. "They Collected Legends." Ensign 7 (February 1977): 80-82. Legends and stories were gathered by early Spanish settlers several centuries ago, many of which correspond to Book of Mormon history. [D.M.]

H.106 Harris, Franklin S., Jr. "The Book of Mormon and Joseph Smith." DN (26 October 1946): 10. A radio address Sunday, October 20, 1946, over KSL. Critics of the Book of Mormon have three theories to explain the Book of Mormon: Joseph got the ideas from other books and ingeniously authored the Book of Mormon through Sidney Rigdon; Joseph used the Spaulding manuscript; or Joseph suffered from psychological delusions that account for his supposed inspiration. None of these theories have been convincing. [B.D.]

H.107 Harris, Franklin S., Jr. The Book of Mormon Messages and Evidences. Salt Lake City: Deseret News Press, 1953, [R]1961. An argument for the authenticity of the Book of Mormon. The author asserts that the biblical passages of the Book of Mormon represent a translation of an ancient text and that the language of the Book of Mormon indicates multiple authorship. Also discusses discoveries of metal records, the origin of the Native Americans, and Christ's visit to America. [C.C.]

H.108 Harris, Franklin S., Jr. "Confirmatory Evidences of 'Mormonism': Baptism Early in America." MS 96 (4 January 1934): 9-11. Catholic missionaries who arrived in America found the natives practicing baptism and were horrified. Some cultures sprinkled while others immersed the infant, but always it was meant to lead the individual toward a better life and salvation in the kingdom of God. These practices are explain by the Book of Mormon text that informs the reader that baptism was introduced early in America's history. [J.W. M.]

H.109 Harris, Fanklin S., Jr. "Confirmatory Evidences of 'Mormonism': The Book of Mormon." MS 96 (8 February 1934): 91-93. Joseph Smith described the gold plates as having "the appearance of gold." The word "appearance" is significant as plates of pure gold would have been in danger of easy destruction. Most likely it was a gold and copper alloy. The Book of Mormon could have been written in Hebrew on just 21 pages or plates; in Phoenician characters about 45 plates would have been necessary, even taking into account the loss of the 116 pages. [J.W.M.]

H.110 Harris, Franklin S., Jr. "Confirmatory Evidences of 'Mormonism': The Calendar in America." MS 96 (11 January 1934): 25-27. The calendar developed by the Maya Indians began somewhere between 613 and 580 B.C., though it dates back to 3373 B.C., and was arranged by the deity Quetzalcoatl. The Book of Mormon people reckoned their time from the Savior's birth. The date when Mayan history began and the correlation with the sign of the birth of deity are evidence of the authenticity of the Book of Mormon. [J.W.M.] 
H.111 Harris, Franklin S., Jr. "Confirmatory Evidences of 'Mormonism': Eastern Culture in America." MS 95 (7 December 1933): 793-95. Growing amount of evidence shows that Columbus was late in his discovery of America. Ancient manuscripts indicate that the first inhabitants of America came from the East and that they had elephants as reported in the Sheffield Weekly Telegraph, November 4. [J.W.M.]

H.112 Harris, Franklin S., Jr. "Confirmatory Evidences of 'Mormonism': Traditions of the Virgin Birth in America." MS 95 (December 1933): 826-27. Lord Kingbrough (1830-1848), H. H. Bancroft, D. G. Brinton, Torquemanda, and Angus W. McKay found traditions of the virgin birth in the traditions of Mexico, the Otomies, and Navajo Indians. Other ancient peoples such as the Aztecs and the Indians of Paraguay believed in the virgin birth of their gods. This same belief was taught to ancient Americans in the Book of Mormon. [J.W.M.]

H.113 Harris, Franklin S., Jr. "Confirmatory Evidences of 'Mormonism': Transliteration-Hebrew in 'Reformed Egyptian." " MS 96 (8 March 1934): 154-56. Harris cites many examples of one language being written with another alphabet-transliteration. This he does to support the claim of the Book of Mormon that Hebrew was written with Reformed Egyptian characters (Mormon 9:32-33; 1 Nephi 1:2). Mentions the discovery by Sir Flinders Petrie of some writings in the Peninsula of Sinai that were in the Hebrew language but written "in Egyptian hieratic characters somewhat changed." [B.D.]

H.114 Harris, Franklin S., Jr. "Confirmatory Evidences of 'Mormonism': Writing on Metal Plates in the Old World." MS 96 (25 January 1934): 57-59. The Book of Mormon records that Lehi's colony took brass plates upon which were recorded the record of the Jews and the genealogy of their forefathers. The British Museum has metal plates that are engraved with records of several different cultures. [J.W.M.]

H.115 Harris, Franklin S., Jr. "Confirmatory Evidences of 'Mormonism': Writing on Metal Plates in the New World." MS 96 (1 February 1934): 74-76. Metal plates prepared by the ancients have been found in several locations in America. There are many historical accounts of metal plates that no longer exist as they were melted down to be used in other ways. Melvin J. Ballard describes plates seen in a museum in Lima, Peru, that were gold sheets, the size of the Book of Mormon plates (DN April 30, 1932). [J.W.M.]

H.116 Harris, Franklin S., Jr. "Confirmatory Evidences of 'Mormonism': The Urim and Thummim." MS 96 (1 March 1934): 134-35, 139-41. Harris cites evidence that many ancient American cultures used "seer stones" and breastplates that suggest a corrupt form of the Urim and Thummim used with the breastplate. He shows how many Indians from North America to Peru in South America used clear stones or crystals for divination. [B.D.]

H.117 Harris, Franklin S., Jr. "Exploring the Universe." IE 40 (March 1937): 159. Refers to evidence about the existence of elephants in ancient New Mexico. [D.M.]

H.118 Harris, Franklin S., Jr. "Inscribed Metal Plates." SEHA 108 (17 September 1968): 5-8. Reports the discoveries of metal plates from pre-Roman Italy and supplies a description and illustrations. The Book of Mormon, too, came from metal plates. [D.M.]

H.119 Harris, Franklin S., Jr. "Iron in Ancient America." UASN 4 (20 January 1952): 4-5. Refers to evidences of iron found in ancient America. [D.M.]

H.120 Harris, Franklin S., Jr. "A Modern Message." DN (20 July 1946): 6. World peace can only come if there is tolerance and freedom. The Book of Mormon teaches these attributes. It also teaches there should be no law against belief and no single race is superior to another. [B.D.] 
H.121 Harris, Franklin S., Jr. "Modern Problems." DN (13 July 1946): 6, 8. Discusses what the Book of Mormon says about war. God has forbidden the shedding of blood (Ether 8:9). However, he does not command men to subject themselves to bondage, but rather to protect their freedom (Alma 6:9-14). [B.D.]

H.122 Harris, Franklin S., Jr. "Origin of the American Indians." DN (17 August 1946): 10, 12. Discusses the many books that attempt to prove the origin of the American Indian. He writes that the dominant view is that the Indian crossed the Bering Strait. Other contact by boat was also later made. [B.D.]

H.123 Harris, Franklin S., Jr. "Others Left Records on Metal Plates, Too." Instructor 92 (October 1957): 318-21. Book of Mormon peoples kept records on metal plates. Early critics claimed that this was impossible since ancient metallurgy was not sufficiently advanced, but many other metal records have been discovered since the days of Joseph Smith. Includes a table of plates found and a map of sites. [C.C.]

H.124 Harris, James R. "The 'I Am' Passages in the Gospels and in 3 Nephi." In The New Testament and the Latter-day Saints, Sperry Symposium, 1987, edited by H. Dean Garrett, et. al., 89-114. Salt Lake City: Randall, 1987. Lists passages in the Four Gospels and in 3 Nephi where Jesus uses the expression "I am." Such pronouncements of selfidentification underscore Jesus' divinity, in contrast to the views of Nicodemus and his modern counterparts, who see Jesus only as a great man. [D.M.]

H.125 Harris, James R. Patterns of Conversion in the Book of Mormon. Provo, UT: Brigham Young University, 1968. Conversion is the key to salvation. Conversion can be gained, in part, by reading the Book of Mormon and reliving its many conversion experiences. Harris identifies six patterns in these conversion experiences and suggests ways to implement them in daily life. Includes a chart of typical conversion events and a graph of steps in sanctification. [C.C.]

H.126 Harris, James R. Southwestern American Indian Rock Art and the Book of Mormon. Orem, UT: Harris House, 1991. Links inscriptions on rocks in the American Southwest with Book of Mormon themes. This work is reviewed in T.176. [D.M.]

H.127 Harris, Llewellyn. "Apache Indians." Juvenile Instructor 16 (15 September 1881): 209. In the traditions of the Apache all the Indian tribes long ago combined against a white group and exterminated almost all of them. Due to this great sin the Great Spirit allowed the Spaniards to drive them from their homes. A good book once held by their ancestors was lost long ago. [D.M.]

H.128 Harris, Llewellyn. "Miraculous Healing among the Zunis." Juvenile Instructor 14 (15 July 1879): 160-61. Some Zuni Indians consider themselves to be descendants of Montezuma. A tradition says that more than 300 years before the Spanish arrived, white men landed in Mexico and became the ancestors of the great kings, including Montezuma. They intermarried and lost their distinction. Story told of an elder who administered to 406 Indians afflicted with small pox. [D.M.]

H.129 Harris, Martin. "Complete Text of Martin Harris Letter." CN 52 (9 October 1982): 23. News article about a recently-discovered letter, written to a Walter Conrad and dated January 13, 1873, in which Martin Harris testifies that as he was praying to see the "ancient record" an angel appeared behind a table on which were the spectacles called the Urim and Thummim and the engraved plates. (Editor's note: this has since been shown to be a forgery by Mark Hofmann.) [C.C.] 
H.130 Harris, Martin. "The Testimony of Martin Harris." MS (1 January 1877): 4-5. Two letters of Martin Harris written to a Mr. Emerson, with an editorial introduction. Harris testifies that an angel showed him the plates containing the Book of Mormon and that the translation copied from them was approved by Professor Anthon. Harris states that Joseph Smith could not have translated the plates by himself. He denies that he preached against the Book of Mormon in England. [C.C.]

H.131 Harris, Russell C. "A Converter of Souls." Instructor 97 (July 1962): 232-33. On many occasions the Book of Mormon has converted practicing Christians to the LDS faith. Moroni's promise (Moroni 10:3-5) applies to all. [A.C.W.]

H.132 Harris, William. Mormonism Portrayed: Its Absurdities and Errors Exposed. Warsaw, IL: Sharp \& Gamble, 1841. Tract exposing the absurdities of Mormonism. Pages 4-14 discuss various anachronisms in the Book of Mormon. [M.R.]

H.133 Harrison, Elias L.T. "The 'Spaulding Story' Refuted from Itself." MS 19 (24 January 1857): 49-56. Harrison argues that it is impossible that the Book of Mormon be even remotely related to the Manuscript Found by Solomon Spaulding. The Manuscript Found is a fictitious account of the lost ten tribes and the Book of Mormon is an account of one family of the tribe of Joseph. [B.D.]

H.134 Harrison, G. T. Mormonism: Now and Then. N.p.: Harrison, 1961. A polemical work on Mormonism. Fifty-nine parallels between View of the Hebrews and the Book of Mormon are listed. [M.R.]

H.135 Harrison, G. T. Mormons Are Peculiar People. New York: Vantage, 1954. A polemical work critical of the Book of Mormon. Joseph Smith probably used Ethan Smith's book View of the Hebrews in creating the Book of Mormon. The Book of Mormon shows evidence that it was influenced by modern environmental factors such as freemasonry. Various anachronisms are discussed. On pages 95-167 the author lists over fifty-eight examples of what he terms false prophecies made in the Book of Mormon or by Joseph Smith. [M.R.]

H.136 Harrison, G. T. That Mormon Book: Mormonism's Keystone Exposed or The Hoax Book. N.p.: n.p., 1981. A polemical work against the Book of Mormon, declaring that the Book of Mormon is a wicked book that has deceived millions. Raises many issues, including inconsistencies of the Book of Mormon, the killing of Laban by Nephi, and "Book of Mormon fairy tales" and compares the lives of Paul and Alma. [A.T.]

H.137 Harrison, Grant Von. The Conversion Power of the Book of Mormon. Orem, UT: Accor, 1988. A handbook for missionary-minded people who want to use the Book of Mormon as a tool of conversion. [D.M.]

H.138 Harrison, Grant Von. Converting with the Book of Mormon: A Guide for Missionaries. Woods Cross, UT: Publishers Book Sales, 1981. A twenty-one page booklet designed to assist the missionary in becoming skilled in "using the Book of Mormon in every aspect of his proselytizing activities." Missionaries are told of the importance of reading the Book of Mormon with investigators and committing investigators to read the Book of Mormon. [A.T.]

H.139 Hart, Charles H. "Joseph the Prophet." IE 23 (April 1920): 491-95. It is more difficult to think Joseph Smith could invent the Book of Mormon, given his youth, limited experience, and opportunities, than to believe he was inspired. Joseph would have needed extensive research to have learned, for example, that Native Americans used stone boxes for the burial of valuables, a fact virtually unknown in his day. Not until 1906 were such boxes discovered in the areas of Toronto, Tennessee, Illinois, and New Mexico. [C.C.] 
H.140 Hart, Charles H. "Steadfast Testimony of the Three Witnesses." MS 89 (1 September 1927): 545-51. Refutes the claim made in the 1911 edition of the Catholic Encyclopedia that the Three Witnesses denied their testimonies of the Book of Mormon plates. As evidence, he cites an 1883 interview of David Whitmer, the dying declaration of Martin Harris, and an affidavit testifying that, in a Michigan murder trial, Oliver Cowdery defended the Book of Mormon. [C.C.]

H.141 Hart, Charles H. Untitled talk. CR (April 1907): 96-99. As a guide in the Kirtland temple, Martin Harris bore his testimony of the Book of Mormon. He proclaimed that he had seen the plates, handled them with his hands, seen the angel, and heard his voice. He bore this same testimony at the time of his death. [J.W.M.]

H.142 Hart, Charles H. Untitled talk. CR (October 1910): 14-19. James H. Hart of Bloomington, Idaho, met with David Whitmer in August 1883 and wrote Whitmer's words. The portion that deals with Whitmer's testimony of the Book of Mormon is quoted. [B.D.]

H.143 Hart, Charles H. Untitled talk. CR (April 1923): 150-52. The author calls for a reliance on the Book of Mormon and points out its value in understanding the "Hebrew scriptures" (the Bible). [J.W.M.]

H.144 Hart, Charles H. Untitled talk. CR (April 1924): 53-57. Two great sources of testimony are "the divine witness" and "human witnesses." The divine witness is the Holy Ghost. The Lord called human witnesses to the Book of Mormon-the Three Witnesses, Joseph Smith, and others. [J.W.M.]

H.145 Hart, Charles H. Untitled talk. CR (April 1928): 100-1. The Book of Mormon, which came from the Hill Cumorah, supports the doctrine of life after death especially as it tells of the visit of Christ to the American Continent. [J.W.M.]

H.146 Hart, John H. "The Last Witness." IE 12 (October 1909): 955-59. Poem describing David Whitmer's witness and testimony of the Book of Mormon. Approved by David Whitmer as a factual account of his experiences. [A.C.W.]

H.147 Hart, John L. "5,000 Gather to Welcome Prophet." CN 57 (4 July 1987): 3, 7. President Benson tells the saints that they need to make the Book of Mormon a lifelong study and to continue using it as a missionary tool. He also warned that "grave consequences hang on our response to the Book of Mormon. We have not been using the Book of Mormon as we should." [M.D.P.]

H.148 Hart, John L. "Book of Mormon Has Gentle, But Lasting Impact in Many Lives." CN 59 (29 July 1989): 6, 13. President Benson's counsel to read the Book of Mormon helps people by giving them peace in their souls and strengthening their testimonies. [M.R.]

H.149 Hart, John L. "Book of Mormon Is Converter." CN 50 (5 January 1980): 7. A student minister read the Book of Mormon to denounce it, but after reading it he took the lessons from missionaries and was baptized. Another man read it when he had nothing else to do and is now a full-time missionary. Even with the missionaries and discussions, the Book of Mormon is still the greatest converter. [M.R.]

H.150 Hart, John L. "Book of Mormon Printed in Pidgin for 'Bali Hai': 'Voice from the dust' speaks in 70th tongue." CN 55 (29 December 1985): 3, 10. The Book of Mormon translation into Bislama is now available to those natives who live in the chain of islands of Vanuatu. This responds to the Lord's command that the Book of Mormon should be available to all. [J.W.M.] 
H.151 Hart, John L. "Book of Mormon Translated into Four More Languages." CN 52 (6 March 1982): 3. A news update concerning the Book of Mormon's translation into Polish, Hebrew, Kuna, and Bolivia Quecha. [J.T.]

H.152 Hart, John L. "Combat Trends of World, Urges Pres. Benson." CN 56 (21 December 1986): 3, 7. Combat the world's trends by reading and studying the Book of Mormon. The Book of Mormon prepares and persuades people to go on missions. [M.D.P.]

H.153 Hart, John L. "First Convert in Thailand." CN 49 (20 October 1979): 13. Srilaksang Gottsche, the first convert in Thailand, helped translate the Book of Mormon into Thai. [M.R.]

H.154 Hart, John L. "Gospel Moving to All 'Tongues.' " CN 51 (28 November 1981): 3. Since 1979 the Book of Mormon has been translated into several new languages. They include Croatian, Greek, Hungarian, Bulgarian, Navajo, Arabic, Czech, Vietnamese, Fijian, Catalan, Russian, Icelandic, Niuean, and four Central and South American Indian languages. [J.W.M.]

H.155 Hart, John L. "Impact of Book Is Dynamic, Lasting." CN 58 (31 December 1988): 6-7. Although the Book of Mormon had a humble beginning, there have now been printed over 35 million copies in 80 languages. President Benson's admonition to read the Book of Mormon over and over has increased people's testimonies. [J.W.M.]

H.156 Hart, John L. "Members Key to Growth, Pres. Benson Tells Leaders." CN 56 (6 July 1986): 3. In a talk to mission presidents, President Benson stresses that the Book of Mormon is the "great converter." Missionaries need to build their own faith and a way to do that is to read the Book of Mormon. [M.D.P.]

H.157 Hart, John L. "Millionth Copy Given This Year." CN 51 (17 January 1981): 4. One million copies of the Book of Mormon have been donated to the personalized family-to-family Book of Mormon project since the project began in 1966. [J.W.M.]

H.158 Hart, John L. "More Missionaries Are Needed, Urges President Benson." CN 56 (9 March 1986): 3, 6. President Benson teaches that more missionaries are needed. He encourages families to read and study the Book of Mormon. "The Book of Mormon is one of the greatest means for preparing missionaries." [M.D.P.]

H.159 Hart, John L. "Opportunity Ahead: 'Raise Sights High.' " CN 54 (24 June 1984): 6. President Ezra Taft Benson urged mission presidents and missionaries at the Missionary Training Center to more effectively use the Book of Mormon. [J.W.M.]

H.160 Hart, John L. "Pres. Benson Emphasizes the 'Miracle of Conversion.' " CN 57 (27 June 1987): 3, 6. President Benson outlined basic gospel principles essential to the success of the mission presidents. One of the principles was that they should take time daily to read and study the Book of Mormon. Elder Perry told missionaries to use the Book of Mormon more to bring converts into the Church. [M.D.P.]

H.161 Hart, John L. "Prophet Donates 'Book for Our Day.' " CN 56 (26 January 1986): 10. President Benson and his family personalize dozens of copies of the Book of Mormon a month. Article describes the influence personalized Books of Mormon have and tells about the Family-to-Family Book of Mormon program. [M.D.P.]

H.162 Hart, John L. "Prophet's Visit Is 'Of Lasting Impact.' " CN 58 (25 June 1988): 3, 14. Following the counsel that President Benson gave, members will spend more time reading the scriptures, particularly the Book of Mormon, and then will share the truths they learned. [J.W.M.] 
H.163 Hart, John L. "Prophet's Words Are 'Sure Guide' for All." CN 60 (17 March 1990): 3. Elder Ashton gave encouragement to read the Book of Mormon in President Benson's behalf. [M.R.]

H.164 Hart, John L. "Small Branch Established as Converts Return to India." CN 51 (3 January 1981): 13. Edwin and Elsie Dharmaraju presented President Spencer W. Kimball a 700-page manuscript containing the translation of the Book of Mormon into Telugu. It was translated by the 82-year-old father of Elsie Dharmaraju. [J.W.M.]

H.165 Hart, John L. "Strengthening Lives." CN 57 (28 November 1987): 14. The goal of a seminar on the Book of Mormon was "to make the teachings of the Book of Mormon a part of the lives of the participants." [M.D.P.]

H.166 Hart, John L. "Subtitle Testifies of Jesus Christ." CN 52 (16 October 1982): 3. A report on the addition of the subtitle to the Book of Mormon-"Another Testament of Jesus Christ." Discusses several aspects of the LDS church's ten-year scripture project, including the creation of a topical guide and cross-references. [J.T.]

H.167 Hart, John L. " 'Super Project' Grows Up." CN 54 (4 March 1984): 3, 11. The Salt Lake Cottonwood Stake initiated a 'Super' Book of Mormon Family-to-Family program, and 27,274 personalized books have been donated. [J.W.M.]

H.168 Hart, John L. " 'When I Pray about It, I Feel All Warm Inside.' " CN 58 (30 July 1988): 5. When children send their testimonies in copies of the Book of Mormon, people respond more positively to the book and the door is opened for conversion. [M.R.]

H.169 Hartley, William G. "Close Friends as Witnesses: Joseph Smith and the Joseph Knight Families." In Joseph Smith: The Prophet, The Man, edited by Susan Easton Black and Charles D. Tate Jr., 271-83. Provo, UT: Brigham Young University Religious Studies Center, 1993. Though the family of Joseph Knight Sr. were never allowed to view the gold plates, they were of great assistance in bringing forth the Book of Mormon. Father Knight gave Joseph provisions to help until the translation was complete and donated paper needed for the translation. It was Father Knight's wagon that was used to retrieve the plates on September 23, 1827. Brother Knight observed that Joseph's excitement over the Urim and Thummim seemed to supersede his excitement over the plates. [J.W.M.]

H.170 Hartley, William G. "Every Member Was a Missionary." Ensign 8 (September 1978): 21-24. Early members of the Church were armed with strong testimonies, biblical understanding, firsthand relationships with Joseph Smith, and copies of the Book of Mormon. Before publication of the book, informal missionary work began using hand-copied teachings from the manuscript. Many were converted by its words. [J.W.M.]

H.171 Hartman, Adrienne. "Nephi's Ship." Friend 7 (September 1977): 23. A story for children about Nephi building a ship to cross the seas to the promised land. Illustrations included. [M.D.P.]

H.172 Hartshorn, Chris B. Commentary on the Book of Mormon. Independence, MO: Herald House, 1966. A verseby-verse doctrinal commentary on the Book of Mormon. The commentator's sources include histories, archaeological findings, personal religious beliefs, and other sources. [J.T.]

H.173 Hartshorn Chris B. External Evidences of the Book of Mormon. Independence, MO: Herald House, 1948. An RLDS teaching manual that addresses the topics of Book of Mormon authorship (including the Spaulding-Rigdon theory), language, metal plates, witnesses, animals, metals, and the problems of dating. [D.M.] 
H.174 Hassard, John Rose Greene. "The Two Prophets of Mormonism." The Catholic World 26 (November 1877): 227-49. Outlines the beginning of Mormonism under the leadership of Joseph Smith and Brigham Young. Believes that the Book of Mormon was created from the Solomon Spaulding manuscript, Protestant revivalism, and other events and items contemporary with Joseph Smith. [J.T.]

H.175 Hatch, Spencer F. "New Witness for Christ." n.p., 8 November 1959. A two-page article that argues that the great White God of legendary renown was Jesus Christ. [D.M.]

H.176 Hauck, F. Richard. Deciphering the Geography of the Book of Mormon. Salt Lake City: Deseret Book, 1988. A geographical and historical approach to the Book of Mormon that attempts to "document the settlement and route networks of the Book of Mormon." The author "examines the interaction and relationships between settlements, transportation routes, and cultural technology and environment for any given people, time, and place" and then creates "an actual, physical correlation of the places in the Book of Mormon.... The model fit into the portion of Ancient America that is known as southern Mesoamerica comprising portions of the modern nations of Mexico, Belize, and Guatemala." Presents numerous maps and charts. This work is reviewed in C.298 and in W.060. [A.T.]

H.177 Hauck, Forrest R., ed. Papers of the Fourteenth Annual Symposium on the Archaeology of the Scriptures. Provo, UT: Department of Extension Publications, Brigham Young University, 1963. Transcriptions of papers presented at a symposium April 13, 1963. Book of Mormon topics include Egyptian and Mayan calendars, geography, the tree of life symbols, and the Anthon transcript. [J.W.M.]

H.178 Hauglid, Brian M. Review of The Most Correct Book: Why the Book of Mormon Is the Keystone Scripture, by Monte S. Nyman. Review of Books on the Book of Mormon 4 (1992): 155-59. Book review.

H.179 Haven, John. "A Cunning Device Detected." TS 1 (January 1840): 47. Describes similarities between the Spaulding manuscript and the Book of Mormon. [A.C.W.]

H.180 Hawes, Allison M. "Performing the Book of Mormon." Ensign 23 (September 1993): 78-79. A description of the success of "Stories from the Book of Mormon" as a missionary tool. [S.H.]

H.181 Hawkes, John D. Book of Mormon Digest and 1600 Study Questions with Answers. Salt Lake City: Hawkes, 1966. An abridgment of the Book of Mormon for quick reading and reference. Reviews the story regarding the coming forth of the Book of Mormon and presents 1600 study questions with answers, explanations of Isaiah, and a system for memorizing. [J.T.]

H.182 Hawkes, John D. Book of Mormon Digest and 1700 Questions with Answers. Salt Lake City: Hawkes, 1968. A new revised edition of the author's Book of Mormon Digest and 1600 Study Questions with Answers, with additional questions and answers. [J.T.]

H.183 Hawkes, John D. Book of Mormon Talking Coloring Books. 4 vols. Salt Lake City: Hawkes, 1981. Each of the four volumes features a cassette tape and a coloring book based upon Book of Mormon stories. Vol. 1, Lehi leaves Jerusalem; Vol. 2, Lehi with the Liahona; Vol. 3, Alma Baptizes at Waters of Mormon; Vol. 4, The Savior blesses the children. [D.W.P.]

H.184 Hawkes, John D. Four-hour Book of Mormon Digest Teaching and Study Text. Salt Lake City: Hawkes, 1970. Contains 1700 study questions with answers, thirty charts, maps, and illustrations, and a summary of the contents 
of the Book of Mormon. [A.T.]

H.185 Hawkes, John D. Story-Talks for Primary. Salt Lake City: Hawkes Publishing, 1985. A collection of forty-seven illustrated Book of Mormon stories for Primary children. [R.H.B.]

H.186 Hawkins, Lisa Bolin, and Gordon Thomasson. I Only Am Escaped Alone to Tell Thee: Survivor Witnesses in the Book of Mormon. Provo, UT: FARMS, 1984. Compares survivor witnesses in the Book of Mormon with other survivor witnesses that are described in Des Pres, "Survivors and the Will to Bear Witness." Social Research 40 (1973): 668-69. [B.D.]

H.187 Hawkins, William. "Precious Pearls: Gathered from the Depths of the Book of Mormon." SH 48 (6 February -25 December 1901): 108, 311-12, 518-21, 560-63, 601-602, 775-77, 800-802, 820-22, 829-41, 859-61, 94041, 1040-42. Twelve essays based on Book of Mormon teachings that establish the concepts and principles of the Bible. Jesus Christ is the mediator; the pure in heart will come unto Christ; it is required that we forgive one another because of Christ's Atonement; Alma speaks of the Fall of Adam, the birth of Christ, and the law of Moses; Samuel the Lamanite testifies of Christ; Christ teaches in the land Bountiful; Mormon reveals the God of miracles; Ether teaches of faith; Moroni teaches the way to judge good and evil and exhorts all to come unto Christ. [J.W.M.]

H.188 Haworth, Walter J. The Book of Mormon on Trial. Wallsend, Australia: Hutton, 1900. An apologetic work that answers numerous charges against the Book of Mormon. He reviews Emma Smith's testimony that while translating the Book of Mormon, Joseph Smith "had neither manuscript nor book to read from." An attempted refutation of Bay's work, Doctrines and Dogmas of Mormonism. [M.R.]

H.189 Haws, Virgil. "The American Indian and the Blood Groups." UASN Misc. Papers 18 (December 1956). A report on blood type analyses used to determine the origins of the American Indians. A lack of B-type blood, which is outstanding in Asiatic areas, indicates that most American Indians are probably not of Mongoloid descent. Transoceanic crossings, espoused in the Book of Mormon, are discussed as a possible source for American Indian origins. [J.T.]

H.190 Hawthornthwaite, Samuel. Adventures among the Mormons. Manchester: By the author, 1857. A polemical work against Mormonism, written by a former Mormon. The Book of Mormon condemns polygamy. The book contains various anachronisms, including the mention of the Mariner's compass and the use of scimitars hundreds of years before they were ever in use. The character of the Book of Mormon witnesses is discredited. Modern terms such as "priestcraft," "lawyers," and"machinery" found in the Book of Mormon are considered to be proof of forgery. The Jaredite barges are ridiculed by the author as well. [M.R.]

H.191 Hayes, John. "The Spaulding Manuscript and the Book of Mormon." MS 50 (27 August 1888): 548-50. Hayes compares the contents of the Spaulding manuscript with the Book of Mormon. The Spaulding manuscript is a story of a Roman named Fabius who was blown off course traveling from Britain to America in the 4th century A.D. Hayes writes that nothing is similar in the Book of Mormon to what is contained in the Spaulding Manuscript. [B.D.]

H.192 Haynes, John. The Book of Mormon Examined; and Its Claims to Be a Revelation from God, Proved to Be False. Brighton: Seeley, 1853. A polemical tract attempting to expose the errors of the Book of Mormon. Advocates a Spaulding origin for the book. The Book of Mormon contradicts the Bible and mentions Christian ideas and phrases hundreds of years before the time of Christ. The author pities the poor "deluded souls" who believe in the book. [M.R.] 
H.193 Haynes, John. A Refutation of the Mormon Doctrines. Brighton and London: Edward Verrall and Seeley, 1853. A tract refuting Mormon doctrines. The Book of Mormon is "another gospel" that contradicts the Bible. It therefore should be rejected as "a foul mass of ignorance, knavery and blasphemy." [M.R.]

H.194 "He Started Marking the Book Before He Was Taught by Elders." CN 58 (31 December 1988): 10. A conversion story of a young man who read and marked the Book of Mormon before he received missionary discussions. [M.D.P.]

H.195 Heady, Gordon. "Time and the Calendar in the Book of Mormon." Witness 71-72 (Winter, Spring 1990): $9-$ 10, 10-14. Investigates textual clues to determine what type of calendrical system was used by the Nephites and the Jaredites and when these systems commenced and fell into disuse. [A.C.W.]

H.196 Heater, Dennis. "More 'No Erasers' in the Book of Mormon." ZR 39-40 (1988): 9-13. Examines Book of Mormon passages wherein the original author or editor added additional words for clarification. Since the custodians of the gold plates did not possess erasers, they used terms or phrases such as "or," "rather," and "or in other words" when adding clarifying remarks to the text. Includes a list of all the verses where this is noted. [A.T.]

H.197 Heater, Shirley R. "The 1830 Edition's History and Manuscript Comparison." In Recent Book of Mormon Developments; Articles from the Zarahemla Record, 2:89-98. Independence, MO: Zarahemla Research Foundation, 1992. A comparison of the 1830 edition with the printer's manuscript and the original manuscript showing editorial changes and variants. Heater explains the history of the 1830 edition up to the donation of the original "form proofs" by the Wilford Wood family to the LDS church in 1991. [B.D.]

H.198 Heater, Shirley R. "The 1837 Edition Introduced Significant Editorial Changes." In Recent Book of Mormon Developments; Articles from the Zarahemla Record, 2:99-105. Independence, MO: Zarahemla Research Foundation, 1992. An analysis of the significant editorial changes introduced in the 1837 edition of the Book of Mormon. Heater explains the history of the publication of the 1837 edition then describes several changes that were introduced. The different changes include "Englishized" grammar, modernization of archaic words and word changes, omissions, and additions. [B.D.]

H.199 Heater, Shirley R. "Beyond the Stone Anchor Mystery." ZR 24-26 (Spring, Summer, Fall, 1984): 18-20. A follow-up to "Chinese Stone Anchors in the New World" (ZR 15 [Winter 1981-1982]: 1-3) by the same author. Writes concerning the origin of stone anchors discovered off the coast of California. Discusses the implications that this discovery has on the Book of Mormon. [J.T.]

H.200 Heater, Shirley R. "Chiasmus Brings New Understanding of Geography." ZR 46 (December 1989): 3. Examines the chiastic structure of Alma 13:68-14:1 (RLDS versification) to better understand the geographical information contained in the passage. [A.T.]

H.201 Heater, Shirley R. The Chinese Jaredite Connection. Independence, MO: Foundation for Research on Ancient America, 1984. A pamphlet that points out that pre-Christian Chinese ships recall the form of the Jaredite barges. Also, the recent "discovery of ancient stone anchors from Asia on the shores of the New World" suggests an early contact that may point to Jaredite migration. [D.W.P.]

H.202 Heater, Shirley R. "Chinese Stone Anchors in the New World." ZR 15 (Winter 1981-82): 1-3. A report and discussion of ancient stone anchors (approx. 2000-3000 years old) discovered off the California coastline and 
their possible connection to China. Argues for a Jaredite cultural influence in China and pre-Columbian oceanic crossings. [J.T.]

H.203 Heater, Shirley R. "Christopher Columbus: Man of Vision and Faith." ZR 63 (September/October 1992): 1-4. A brief biographical sketch of Christopher Columbus, showing how he fulfills the prophecies in the Book of Mormon (1 Nephi 3:147, RLDS versification). The article also discusses the timing of Columbus's voyage and why the Americas had been kept hidden (2 Nephi 1:16-21, RLDS versification). [A.T.]

H.204 Heater, Shirley R. "Christopher Columbus: Man of Vision and Faith Part II." ZR 64 (November/December 1992): 2-4. This article explores themes in Columbus's writings. Columbus saw himself to be, in part, a fulfillment of Isaiah 11:10-12. He also expected to find the "other sheep" spoken of in John 10:16. The article also shows the accuracy of Nephi's vision regarding Columbus. [A.T.]

H.205 Heater, Shirley R. "An Experiment with Desire." In Recent Book of Mormon Developments; Articles from the Zarahemla Record, 2:166-67. Independence, MO: Zarahemla Research Foundation, 1992. The author describes how she applied the words of Alma 16 (Alma 32 in LDS versification) to her life and the new spiritual heights she reached. [B.D.]

H.206 Heater, Shirley R. "Gold Plates, Foolscap, and Printer's Ink." ZR 35-38 (1987): 3-15. Contains a history and description of the original and printer's manuscripts of the Book of Mormon. The author uses photographs to show the differences between the two manuscripts, including changes, omissions, and punctuation additions. Also presents a "study of five editions of the Book of Mormon-the 1830, 1837 and 1840 edition and the 1874 and 1908 editions, which were published during the reorganization period." Includes a number of charts and tables. [A.T.]

H.207 Heater, Shirley R. "Hebrew Poetry Brings a New Understanding of Joy." ZR 34 (1986): 14-15. Poetic analysis of Alma's words in the Book of Mormon provides insight into the meaning of word "joy." [J.T.]

H.208 Heater, Shirley R. "History of the Manuscripts of the Book of Mormon." In Recent Book of Mormon Developments; Articles from the Zarahemla Record, 2:66-79. Independence, MO: Zarahemla Research Foundation, 1992. A detailed history of the original manuscript and the printer's manuscript. Sets forth many of their differences. [B.D.]

H.209 Heater, Shirley R. "I Had a Dream." In Recent Book of Mormon Developments; Articles from the Zarahemla Record, 109-11. Independence, MO: Zarahemla Research Foundation, 1984. Author tells of the Lord's appearance to her when she was seven years old, her desire to be an archaeologist at age 15, her career conflicts, and the help the Lord gave her to finally study Book of Mormon archaeology. [B.D.]

H.210 Heater, Shirley R. "Lehi's Blessing to His Son Joseph." ZR 44 (August 1989): 2-3, 7. Lehi's blessing of Joseph in 2 Nephi follows a chiastic structure that emphasizes the importance of coming to a knowledge of the covenants of the fathers. [A.T.]

H.211 Heater, Shirley R. "Manuscripts and Editions." ZR 48 (April 1990): 2-3. Details of the history of Book of Mormon manuscripts and RLDS editions are summarized in a chart. Concludes with the suggestion that a corrected text is needed. [A.C.W.] 
H.212 Heater, Shirley R. "Moroni's Title Page." ZR 43 (June 1989): 3-4. Moroni wrote the title page of the Book of Mormon. The poetic structure of the title page emphasizes that its purpose is for the Lamanites, Jews, and Gentiles to "know the covenants of the Lord." [A.T.]

H.213 Heater, Shirley R. "The 1908 Edition Introduced Distinct Textual Variances." ZR 55 (June 1991): 2-4. Provides tables and references of word changes, omissions, and additions in the RLDS 1908 authorized edition of the Book of Mormon as compared to the 1837 printer's manuscript and discusses the significance of these textual alterations. [A.C.W.]

H.214 Heater, Shirley R. "The Power of the Word." ZR 62 (July/August 1992): 1, 4. Notes that the phrase "state of awful woundedness" (1 Nephi 13:32) in the original and printer's manuscripts was replaced in the 1837 edition of the Book of Mormon with the phrase "state of awful blindness." Then Heater references Alma 32 and writes concerning the power of the word. [D.M.]

H.215 Heater, Shirley R. "A Preview of Textual Corrections in the New Corrected Edition of the Book of Mormon: Variances Between the Printer's Manuscript and the 1830 Edition." ZR 51-52 (December, October 1990): 2-4, 24. Results of the author's textual comparison research detailing differences between the printer's manuscript and the 1830 edition of the Book of Mormon. [A.C.W.]

H.216 Heater, Shirley R. "Report on Book of Mormon Research." ZR 27-28 (Winter-Spring 1985): 5-7, 16. A detailed summary of John L. Sorenson's two-part article "Digging into the Book of Mormon," Ensign (September 1984): 26-37 and (October 1984): 12-23. Studies in the areas of geography, archaeology, war, demographics, metallurgy, and writing are discussed. [J.T.]

H.217 Heater, Shirley R. "Rio Azul: Archaeological Research Sheds Light on Book of Mormon Subject." ZR 32-33 (1986): 10-13. Discusses excavations at Rio Azul (Mayan city, 250 B.C.-A.D. 400 to 500) and possible Book of Mormon connections. Five archaeological firsts are also reported in detail: (1) locking lid jars, (2) directional hieroglyphs, (3) the hieroglyph of the verb "bury," (4) ancient Maya fabric "1000 years older than any ... previously found," and (5) carving on the jaw of a wild pig. [J.T.]

H.218 Heater, Shirley R. "Unique Differences in the 1840, 1874 and 1892 Editions." In Recent Book of Mormon Developments; Articles from the Zarahemla Record, 2:106-10. Independence, MO: Zarahemla Research Foundation, 1992. Discusses the historical situations surrounding the 1840, 1874, and 1892 editions of the Book of Mormon and some of their differences. The 1840 edition was based on the original manuscript only; the 1874 edition and the 1892 edition are RLDS editions based on the 1840 edition with some changes. [B.D.]

H.219 Heater, Shirley R. "Variances between the Original and Printer's Manuscripts." In Recent Book of Mormon Developments; Articles from the Zarahemla Record, 2:80-88. Independence, MO: Zarahemla Research Foundation, 1992. Briefly summarizes variants between the original manuscript and the printer's manuscript of the Book of Mormon. Two tables show words on the original manuscript that were omitted from the printer's manuscript and words copied incorrectly on the printer's manuscript. [B.D.]

H.220 Heater, Shirley R. "Variances in the 1908 Edition." In Recent Book of Mormon Developments; Articles from the Zarahemla Record, 2:111-15. Independence, MO: Zarahemla Research Foundation, 1992. Explains the history and background of the publication of the RLDS 1908 edition of the Book of Mormon. Heater shows that the "1908 corrections didn't go far enough" and then explains the word changes that were made. [B.D.] 
H.221 Heater, Shirley R., and Mary Lee Treat. "A Literal Manuscript Version of the Book of Mormon." In Recent Book of Mormon Developments; Articles From the Zarahemla Record, 2:65. Independence, MO: Zarahemla Research Foundation, 1992. An update of the Zarahemla Research Foundation's work on producing a text of the Book of Mormon that is "restored to read as the manuscripts read" and that is organized in "poetry-like style." [B.D.]

H.222 Heater, Shirley R., and Mary Lee Treat. "A New Edition of the Book of Mormon: A Compared, Corrected Text in Poetry-Like Format." ZR 50 (August 1990): 1. Reports on the progress of publishing a new edition of the Book of Mormon and asks for financial assistance from the reader. [A.C.W.]

H.223 Heaton, Harold Grant. Book of Mormon = Mo Men Ching. Hong Kong: Church of Jesus Christ of Latter-day Saints, 1957. A lesson outline for missionaries serving in the Southern Far East Mission. The Book of Mormon as a record of the biblical Joseph's descendants is emphasized. [J.T.]

H.224 Hedengren, Paul. "Nephite Coins." In Hedengren, In Defense of Faith: Assessing Arguments against Latter-day Saint Belief, 109-30. Provo, UT: Bradford \& Wilson, 1985. An apologetic work dealing with common criticisms of Mormon beliefs. Pages 109-30, for instance, discuss the problem of Nephite weights and measures. [M.R.]

H.225 Heidenreich, John F. "It Taught Me the Bible." Ensign 6 (September 1976): 22-23. After reading the Book of Mormon five times in seven months in a comparative study with the Bible, this divinity student of another faith found the Book of Mormon to be a great help in understanding the Bible. The divinity of Jesus Christ became more apparent through the Spirit of the Lord, which permeates the book. [J.W.M.]

H.226 Heimerdinger, Chris. Gadiantons and the Silversword. Salt Lake City: Covenant, 1991. Sequel to Tennis Shoes among the Nephites. Fiction. [J.W.M.]

H.227 Heimerdinger, Chris. Tennis Shoes among the Nephites. Salt Lake City: Covenant, 1989. A fictional account of boys of the twentieth century finding themselves traveling back in time to Book of Mormon days and places. [J.W.M.]

H.228 Heinerman, Jacob. Stories of Conversion through the Reading of the Book of Mormon. Manti, UT: Mountain Valley, 1974. A collection of journal extracts and writings that report the influence of the Book of Mormon in the lives of various individuals in the nineteenth and twentieth centuries and their conversion to the LDS faith. Includes the conversion stories of Brigham Young and Parley P. Pratt. [J.T.]

H.229 Heinrichs, Carl. "The Story of the Book of Mormon Illustrated." SH 86-87 (14 October 1939): 1286. A series of Book of Mormon illustrations accompanied by Book of Mormon scriptures in story sequence. [J.W.M.]

H.230 "Helaman and the Two Thousand Young Men of Faith." Friend 16 (May 1986): 37. Retelling of the stripling warrior story for children, with pictures and brief commentary. [A.C.W.]

H.231 Helland, Dean M. Meeting the Book of Mormon Challenge in Chile. Ann Arbor, MI: UMI Dissertation Information Service, 1992. Polemical work from a fundamentalist Protestant point of view. Contains a study guide to help Chilean Protestants learn how to "witness" to the Mormons. Includes photostat copy of the article "Book of Mormon Problems" written by the author and published by Saints Alive Journal. [D.M.]

H.232 Helmick, Daniel M. Claims of the Book of Mormon Critically Examined from Evidence Found in the Book Itself. Salt Lake City: n.p., 1906. A polemical work against the Book of Mormon. The Book of Mormon contradicts itself 
and has poor grammar showing it to be the work of an illiterate man. It is full of errors, absurdities, and gross anachronisms. [M.R.]

H.233 Hemingway, Donald W. Christianity in America before Columbus? Salt Lake City: Hawkes, 1988. Treats the symbols, practices, and beliefs of ancient America that appear to be related to Christianity that were prevalent before Columbus discovered America. Includes the cross; the use of keys, stones, and mountains in their temples; baptism; sacrament; fasting; prayer; life after death; the creation; the flood; the tower of Babel; the ten lost tribes; and many others. This work is reviewed in W.059. [J.W.M.]

H.234 Hemingway, Donald W. An Introduction to Mormon: A Native American Prophet. Salt Lake City: Publishers Press, 1978. A biographical treatise on the prophet Mormon (b. approx. A.D. 311). Includes details surrounding his compilation of the gold plates from which the Book of Mormon was translated, his personal teachings and sermons, and other historical events surrounding his life. [J.T.]

H.235 Hepburn, Andrew B. An Exposition of the Blasphemous Doctrines and Delusions of the So Called Latter-day Saints or Mormons. Sheffield: Mary Thomas \& Son, 1852. An exposé of Mormonism written by a former Mormon. The author complains that he had never heard of the Book of Mormon until after his baptism. The Book of Mormon cannot be believed since the Three Witnesses left the Church, it mentions things that would occur in the New Testament hundreds of years before they happened, and it contradicts the Bible. The author alleges that there is a chronological discrepancy in the Book of Mormon when it says that Lehi left Jerusalem 600 years before the birth of Jesus. He accepts the Spaulding theory regarding its origin. [M.R.]

H.236 Hepburn, Andrew B. Mormonism Exploded. London: Simpkin, Marshal, 1855. An exposé of Mormonism, written by a former Mormon. Spaulding was responsible for the origin of the Book of Mormon. The testimony of the witnesses of the Book of Mormon is rejected. Numerous contradictions with the Bible are listed. The Anthon denial is cited. Phrases and style in the Book of Mormon that are similar to those in the Bible are denounced as plagiarisms. [M.R.]

H.237 Hepworth, Joseph Thomas. "Watermelons, Alma 32, and the Experimental Method." BYU Studies 23 (Fall 1983): 497-511. Likening the planting of watermelon seeds in his garden to Alma's analogy of planting a seed of the word of God in one's heart (Alma 32), the author finds that some spiritual seeds fail to grow while others are successful. The procedures for experimentation are contained within the scriptures and the results can be replicated. [J.W.M.]

H.238 "Heritage of Book of Mormon Told Youth by Bishop Brown." CN 42 (2 September 1972): 13. Bishop Victor L. Brown told the youth at the Mexico Area Conference that they should be proud of their heritage and that they should honor their priesthood. [M.D.P.]

H.239 Heslop, J. M. "Book of Mormon for Thais." CN 41 (27 February 1971): 4. Srilaksana Gottsche was commissioned to help translate the Book of Mormon into Thai. [M.R.]

H.240 Heslop, J. M. "He Found the Truth after Years of Study." CN 44 (2 March 1974): 4. Wilhelm Warlenier of Bonn, Germany was converted after years of pondering the Book of Mormon. [M.R.]

H.241 Heslop, J. M., Dell Van Orden, Warren Noyce. "Book of Mormon-Place in Time." CN 53 (4 December 1983): 8-9. A chart that synchronizes historical events (from A.D. 1 to A.D. 421) of the Book of Mormon with contemporary events of the biblical and secular world. [A.T.] 
H.242 Hess, Wilford M. "Botanical Comparisons in the Allegory of the Olive Tree." In The Book of Mormon: Jacob through Words of Mormon, To Learn with Joy, edited by Monte S. Nyman and Charles D. Tate Jr., 87-102. Provo, UT: Brigham Young University Religious Studies Center, 1990. Provides a detailed examination of Zenos's allegory of the olive tree in light of present-day knowledge of horticulture and determines that from the standpoint of science the allegory is accurate. Also presents an interpretation of the allegory in relation to the house of Israel. [D.M.]

H.243 Hess, Wilford M., Daniel J. Fairbanks, John W. Welch, and Jonathan K. Driggs. "Botanical Aspects of Olive Culture Relevant to Jacob 5." In The Allegory of the Olive Tree: The Olive, The Bible, and Jacob 5, edited by Stephen D. Ricks and John W. Welch, 484-562. Salt Lake City, Deseret Book and FARMS, 1994. Examines olive culture in agricultural Palestine and the rest of the Near East, analyzing the botanical and horticultural aspects that are inherent in Jacob 5. Includes domestication, planting, seasonal attributes, flowering, grafting, root systems, and pruning procedures. The ancients had an excellent knowledge of olive culture and the Book of Mormon closely follows those patterns. [J.W.M.]

H.244 Hexham, Irving, and Karla Poewe. Understanding Cults and New Religions. Grand Rapids, MI: William B. Eerdmans Publishing, 1986. Demeaning description of newer religious movements. Joseph Smith rose from a background of change and confusion, claiming to have discovered records that clarified theological arguments of his day and the origin of the American Indian. The authors rely on the opinions of Fawn Brodie and Thomas O'Dea. [D.M.]

H.245 Hickman, Josiah E. Romance of the Book of Mormon. Salt Lake City: Deseret Book, 1937. An anthropological/archaeological approach to the Book of Mormon with emphasis on cultural parallels between Book of Mormon people and American Indians. Hebrew origins of early American aborigines and possible evidence of Christ's visit to the Americas are also discussed. [J.T.]

H.246 Hickman, Josiah E. Science, Tradition, and the Book of Mormon. Salt Lake City: General Boards of MIA, Church of Jesus Christ of Latter-day Saints, 1937. A lesson manual. Cultural/religious parallels between the Book of Mormon people and the American Indians are discussed. Cites evidence linking American aborigines to Hebrew origins. [J.T.]

H.247 Hield, Charles R. "The Horse in Ancient America." SH 116 (October 1969): 38. Report from the Society for Archaeological Research that cites nine scholarly books and articles that show evidence of horses in ancient America. Uses this to support the 14 occurrences of the word "horses" in the Book of Mormon. [A.C.W.]

H.248 Hield, Charles R. We Believe in Jesus Christ. Independence, MO: Herald Publishing, n.d. The three standard books of the RLDS church give a complete account of the life and accomplishments of Jesus Christ. Those who accept Christ and are valiant will receive greater glory than those who do not. [J.W.M.]

H.249 Higginson, Mollie. "How We Obtained the Book of Mormon." MS 78 (6 July 1916): 417-22. A six-page synopsis of the Book of Mormon. Encourages researchers of the origin of the American Indians to read the Book of Mormon and end their research there. Through prayer all can know the truth of the Book of Mormon. [B.D.]

H.250 Hight, Dan. "Gustav and the Golden Plates." The Witness 77 (Summer 1992): 14. Gustav Koehn seriously questioned the Book of Mormon. He had a dream in which an angel showed him the plates of gold, leafed through them, and declared the book to be true. He was baptized into the RLDS church and continued to testify of the Book of Mormon. [J.W.M.] 
H.251 "The Hill Cumorah and Ancient Records." In Stories from Mormon History, edited by Alma P. Burton and Clea M. Burton, 87-116. Salt Lake City: Deseret Book, 1960. An anthology of texts concerning the Hill Cumorah, the gold plates, the stone box, Urim and Thummim, and other ancient records. These accounts are recorded by early leaders of the Church, such as Brigham Young, Heber C. Kimball, Oliver Cowdery, Orson Pratt, George Q. Cannon, Lucy Mack Smith, Martin Harris, and Edward Stevenson. [J.W.M.]

H.252 Hill, Donna. "Part Two: New York." In Hill's Joseph Smith: The First Mormon, 41-125. Garden City, NY: Doubleday, 1977. Provides an historical account of the coming forth of the Book of Mormon. Shortly after his marriage he received the plates and translation began, first with Emma as scribe then Martin Harris, Oliver Cowdery, and others. It seemed at first the book would be poorly received, but that proved untrue and the Church was established. This work is reviewed in B.229. [J.W.M.]

H.253 Hill, George W. "Message from an Indian Prophet." Juvenile Instructor 14 (15 April 1879): 91-92. Report of a prophecy concerning the coming of Johnston's army and of U.S. soldiers in Utah Territory, delivered by a messenger considered to be one of the Three Nephites. [D.M.]

H.254 Hill, Keith K. "Sorrow and Joy: What We Can Learn from Lehi." Ensign 18 (January 1988): 30-33. The problems of adversity in the lives of active believing Church members are recounted. Compares the problems of parenthood in today's world to Lehi's experience in the wilderness. [D.L.L.]

H.255 Hill, Marvin S. "Afterword." BYU Studies 30 (Fall 1990): 117-24. Rebuttal to Gary Novak (BYU Studies 30 [Summer 1990]: 23-40). Hill contends that though some in the Church doubt that the Book of Mormon is an ancient document, this does not destroy their faith in the divine nature of the book. [J.W.M.]

H.256 Hill, Marvin S. "The Historiography of Mormonism." Church History 28 (December 1959): 418-26. Surveys the most important writers, both those who are critics and those who are not, who have written on the Book of Mormon, Joseph Smith, and other themes related to the Church. Offers brief critiques of their positions. [D.M.]

H.257 Hill, Marvin S. "Money-Digging Folklore and the Beginnings of Mormonism: An Interpretive Suggestion." BYU Studies 24 (Fall 1984): 473-88. Argues that while money digging stories should not be dismissed, they are not central in explaining the coming forth of the Book of Mormon. Divining rods and the like were perceived as a tangible link with the invisible world and reflect bewilderment with the confusing options incidental to religious pluralism. [D.M]

H.258 Hill, Marvin S. Review of An Approach to the Book of Mormon, by Hugh W. Nibley Church History 28 (December 1959): 41826. Book review.

H.259 Hill, Marvin S. Review of No Man Knows My History: The Life of Joseph Smith, the Mormon Prophet, by Fawn M. Brodie. Dialogue 7 (Winter 1972): 72. Book review.

H.260 Hill, Marvin S. Review of Studies of the Book of Mormon, by B. H. Roberts. Church History 55 (December 1986): 546-48. Book review.

H.261 Hill, Marvin S. Review of The Voice of One Crying in the Wilderness: Sidney Rigdon, Religious Reformer, by F. Mark McKiernan. Dialogue 7 (Summer 1972): 54. Book review. 
H.262 Hill, Theresa Snow. Stories from the Book of Mormon. Salt Lake City: Deseret Book, 1948. Presents the Book of Mormon in a narrative style, written primarily for juvenile audiences. [J.T.]

H.263 Hill, W. B., and W. E. Peak. As We View It. N.p., 1898. Report of debates between the two authors. Subject matter concerns the cognizance of the mind beyond the grave. References are made to Alma and his experiences. Pejorative comments are made about the character of Joseph Smith and the Three Witnesses. [D.M.]

H.264 Hillam, Ray C. "The Gadianton Robbers and Protracted War." BYU Studies 15 (Winter 1975): 215-24. A history of the formation, leaders, and depredations of the Gadianton robbers. Discusses the relevancy to modern rebellions, assassinations, and insurgencies. [R.H.B.]

H.265 Hillam, Ray C. "Secret Combinations." In Encyclopedia of Mormonism, edited by Daniel H. Ludlow, 3:1290-91. 5 vols. New York: Macmillan, 1992. Describes the basic elements of a secret combination and how they were manifest in the Bible, the Book of Mormon, and in the contemporary world. [A.T.]

H.266 Hills, Louis Edward. Geography of Mexico and Central America from 2234 B.C. to 421 A.D. Independence, MO: n.p., 1917. A booklet attempting to identify the geography named in the Book of Mormon with sites in Mexico and Central America. Places the Hill Cumorah in Mexico. Refers to Indian legends and Quetzalcoatl. Several maps are included. [D.M.]

H.267 Hills, Louis Edward. Historical Data from Ancient Records and Ruins of Mexico and Central America. Independence, MO: n.p., 1919. Quotes many sources, including the Quiche legends and the Popol Vuh, demonstrating anthropological and archaeological connections and correspondences with the Book of Mormon. [D.M.]

H.268 Hills, Louis Edward. New Light on American Archaeology. Independence, MO: Lambert Moon, 1924. Discusses the origin of the early inhabitants of America, Jaredite movements, the Mulekite migration, archaeological evidences that support the Book of Mormon, Jesus Christ among the ancient Americas, stories of Quetzalcoatl, and possible Book of Mormon lands and sites. [D.W.P.]

H.269 Hills, Louis Edward. A Short Work on the Popol Vuh and the Traditional History of the Ancient Americans by Ixtxochitl. Independence, MO: n.p., 1918. Describes the contents of the Popol Vuh and relates the four mythological founders of Mesoamerica to the four sons of Lehi. Draws on several anthropologists and archaeologists for various proposed evidences of the Book of Mormon. [D.M.]

H.270 Hilton, Hope A., and Lynn M. "The Lihyanites." Sunstone 9 (January-February 1984): 4-8. Discusses Lehi's eight year journey in Saudi Arabia and the possibility that he preached to and converted a group of people who later named themselves the "Lihyanites." [D.L.L.]

H.271 Hilton, John L. "On Verifying Wordprint Studies: Book of Mormon Authorship." BYU Studies 30 (Summer 1990): 89-108. Based on research conducted in Berkeley, California, by scholars who were attempting to authenticate the validity of wordprinting, this paper explores their conclusions. The results of Book of Mormon wordprints demonstrates that it is "statistically indefensible to propose Joseph Smith or Oliver Cowdery or Solomon Spaulding as the author of the ... Book of Mormon." "The Book of Mormon measures multiauthored, with authorship consistent to its own internal claims." [A.T.]

H.272 Hilton, John L. Review of Trouble Enough: Joseph Smith and the Book of Mormon, by Ernest H. Taves. "Review of Ernest Taves', Book of Mormon Stylometry." Provo, UT: FARMS, 1986. Book review. 
H.273 Hilton, John L. "Some Book of Mormon 'Wordprint' Measurements using 'Wraparound' Block Counting." Provo, UT: FARMS, 1988. A report of wordprint studies and Book of Mormon authorship. The personal writings of Joseph Smith, Oliver Cowdery, and Solomon Spaulding were included with samples of the writings of Nephi and Alma. The study concludes that the "proposition that Joseph Smith, or Oliver Cowdery, or Solomon Spaulding was the author of the Book of Mormon ... is statistically indefensible." [A.T.]

H.274 Hilton, John L. "Wordprints and the Book of Mormon." In Reexploring the Book of Mormon, edited by John W. Welch, 221-26. Salt Lake City: Deseret Book and FARMS, 1992. Wordprint studies confirm the Book of Mormon claim of multiauthorship. Usage of the terms "and," "the," "of," and "that" statistically confirm writing styles in 325 test runs of known authors. Texts by individual authors are significantly different from others. Joseph Smith, Oliver Cowdery, Solomon Spaulding, and others have no wordprints in common with the writings of the Book of Mormon. [N.K.Y.]

H.275 Hilton, John L., and Janet F. Hilton. "A Correlation of the Sidon River and the Lands of Manti and Zarahemla with the Southern End of the Rio Grijalva (San Miguel)." Journal of Book of Mormon Studies 1 (Fall 1992): 142-62. The authors construct a detailed geographical model of the Nephite homeland areas of Manti, Zarahemla, and the river Sidon using the Book of Mormon text of around 80 B.C. They nominate the southern end of the Grijalva river basin, located across the southern part of the Mexico-Guatemala border, as a possible candidate for the ancient Nephite homeland because it corresponds to the text's topography from the most general to the most detailed parts of the description. [R.H.B.]

H.276 Hilton, John L., and Ken Jenkins. "All Book of Mormon References by Author and Literary Form." Provo, UT: FARMS, 1983. A preliminary study that details the five primary literary forms found in the Book of Mormon: chapter headings, didactic sermons, first and third persons narratives, and dialogues. The study lists, for each of the five literary forms, the scriptural book, chapter, verse, author, literary form, and the number of words found therein. No mention is made of poetic forms found in the Book of Mormon text. [D.W.P.]

H.277 Hilton, Lynn M., and Hope A. "In Search of Lehi's Trail." Ensign 6 (September-October 1976): 32-54, 34-63. Attempts to identify specific sites and routes followed by Lehi's party as they traveled from Jerusalem to the coast of the Indian Ocean of the Arabian Peninsula. They believe that modern Salalah, Oman, is the Book of Mormon Bountiful. [D.M.]

H.278 Hilton, Lynn M., and Hope A. In Search of Lehi's Trail. Salt Lake City: Deseret Book, 1976. An endeavor to discover Lehi's trail in the Middle East. The authors attempt to identify such places as the Frankincense Trail, Lehi's route from Jerusalem, the Valley of Lemuel, the place of the broken bow, and the land Bountiful. [L.D.]

H.279 Hilton, Matthew. Preliminary Summary of Nephite Armed Conflict in the Book of Mormon. Provo, UT: FARMS, 1987. Outlines a "rough summary of the basic information about Nephite wars and warfare in the Book of Mormon." Includes scriptural quotations that touch upon the subject of war and gives the corresponding date. [B.D.]

H.280 Hilton, Matthew, and Neil J. Flinders. "The Impact of Shifting Cultural Assumptions on the Military Policies Directing Armed Conflict Reported in the Book of Alma." In Warfare in the Book of Mormon, edited by Stephen D. Ricks and William J. Hamblin, 237-65. Salt Lake City: Deseret Book and FARMS, 1990. Family conflicts and conflicting ideological issues evolve into war. Accepting the theistic principles taught by the Nephites or accepting agnostic principles espoused by followers of Nehor led to repeated conflicts. We should be aware of this conflict potential in our day. [N.K.Y.] 
H.281 Himes, Joshua Vaughn. Mormon Delusions and Monstrosities. A Review of the Book of Mormon and an Illustration of Mormon Principles and Practices. Boston: Joshua V. Himes, 1842. A polemical work attempting to discredit Mormonism and in particular the Book of Mormon. The first section reproduces Alexander Campbell's 1831 work, Delusions. The writer favors the Spaulding origin of the Book of Mormon. [M.R.]

H.282 Hinckley, Gordon B. "An Angel from on High, the Long, Long Silence Broke." Ensign9 (November 1979): 7-8. Summarizes the conversion of Parley Pratt by reading the Book of Mormon. The Book of Mormon is the scripture of the New World, as the Bible is of the Old. No other book so clearly illustrates that righteous nations prosper and that disregard for God's word leads to impotence and death. [R.H.B.]

H.283 Hinckley, Gordon B. "As One Who Loves the Prophet." In Joseph Smith: The Prophet, The Man, edited by Susan Easton Black and Charles D. Tate Jr. Provo, UT: Brigham Young University Religious Studies Center, 1993. Author expresses gratitude for the Prophet Joseph Smith who was instrumental in bringing forth the Book of Mormon. Mentions that the Bible was recently rated the most influential book in America, and the Book of Mormon was rated eighth most influential. The author states his belief that the Book of Mormon will be rated number two in time. [J.W.M.]

H.284 Hinckley, Gordon B. "Book of Mormon Message and Challenge." CR (October 1979): 8-11. The coming forth of the Book of Mormon was remarkable and miraculous; one of its major teachings is that it predicts tragic consequences to all societies who become wicked. The book stands (with the Bible) as a witness of the mission and Atonement of Jesus Christ. [R.C.D.]

H.285 Hinckley, Gordon B. "The Cornerstones of Our Faith." Ensign 14 (November 1984): 50-53. Also in CR (October 1984): 65-70. The cornerstones of the Church are: (1) Jesus Christ (the chief cornerstone), (2) the vision of the Father and the Son to the Prophet Joseph Smith, (3) the Book of Mormon, and (4) the Priesthood. Each cornerstone relates to the others and all are "tied to the chief cornerstone, Jesus Christ." [S.P.S.]

H.286 Hinckley, Gordon B. "Metal Plates in the British Museum." IE 39 (March 1936): 154. Research has shown that the Egyptians, Hebrews, and Greeks used tablets of metal to record important documents. The Inca-ruled natives of Peru and the Aztecs of Mexico engraved records on metal sheets. Engraved records are also found among relics of North American Indians. The British Museum possesses a set of twenty-five silver plates containing Buddha's first sermon and a gold tablet containing the dedication of the temple to Osiris by Ptolemy Eureregetes, 242-222 B.C. [R.H.B.]

H.287 Hinckley, Gordon B. “Mormon Should Mean 'More Good.' Ensign 20 (November 1990): 51-54. The name Mormon is an honorable name, borne by one who was a great prophet on the American continent. Joseph Smith said that the name meant "more good" (TJS, pp. 299-300). The book that Mormon prepared bears his name-the Book of Mormon. It has touched the lives of thousands for good, for it witnesses of the Savior and Redeemer of the world, Jesus Christ. [J.W.M.]

H.288 Hinckley, Gordon B. "My Testimony." Ensign 23 (November 1993): 51-53. Reiterates testimony that Joseph Smith is a prophet, that he conversed with God the Father and Jesus Christ, his Son, and that the Book of Mormon was written by ancient prophets and not by a young farm boy from New York. The complex and harmonious nature of the Book of Mormon does not resemble the Spaulding manuscript or the View of the Hebrews from which opponents of the Church say it is taken. [J.W.M.] 
H.289 Hinckley, Gordon B. "The Power of the Book of Mormon." Ensign 18 (June 1988): 2-6. The conversion of Parley P. Pratt and others to the restored gospel through the Book of Mormon is recited. The article also discusses the role of the Book of Mormon as a witness to the Bible. [D.L.L.]

H.290 Hinckley, Gordon B. "Praise to the Man." Ensign 13 (August 1983): 2-6. Briefly recounts the legacy of the Prophet Joseph Smith and the early Church. Confirms that the Book of Mormon stands as a witness to the divinity of the Prophet's mission and that it should be read with earnest inquiry. Reminds readers that the book has outlasted its critics for over 150 years. [S.P.S.]

H.291 Hinckley, Gordon B. "Praise to the Man." In Brigham Young University 1979 Devotional and Fireside Speeches, 202-7. Provo, UT: BYU Press. In dealing with the critics of Joseph Smith, three questions must be asked: What do you do with the Book of Mormon? How do you explain Joseph Smith's power to influence strong men to follow him, even to death? How do you rationalize the fulfillment of his prophecies? The author answers these questions. [J.W.M.]

H.292 Hinckley, Gordon B. "The Stick of Joseph." IE 62 (December 1959): 958-60. The Book of Mormon converts people to the gospel of Jesus Christ and since its first printing a number of great individuals have been converted by its message. Once the Book of Mormon is accepted as true, other truths become evident. These are that God lives, the Church is true, Joseph was a prophet, and the Bible contains the word of God. [J.W.M.]

H.293 Hinckley, Gordon B. Truth Restored. Salt Lake City: LDS Church and Deseret Book, 1979. A history of the LDS church that includes the story of the coming forth of the Book of Mormon. Photographs of historical events and places are included. [J.W.M.]

H.294 Hinckley, Gordon B. "A Unique and Wonderful University." In Brigham Young University 1988 Devotional and Fireside Speeches, edited by Karen Seely, 47-52. Provo, UT: BYU Press. Members of the Church have the responsibility to take the message of the Book of Mormon to a spiritually troubled world. Presents a testimony of a young missionary who found a copy of the Book of Mormon and was converted. The author makes a plea for those belonging to Brigham Young University to "learn to love the Book of Mormon and to love to learn from it." [J.W.M.]

H.295 Hinckley, Helen (Jones). Columbus: Explorer for Christ. Independence, MO: Herald House, 1977. A short biography on Christopher Columbus in light of the prophecy written about him by Nephi. [D.M.]

H.296 Hinton, Gary D. "This I Believe." IE 68 (August 1965): 714-15. A young man gave a Book of Mormon to his history teacher and told him that the American Indians were descendants of the people in the Book of Mormon. [M.D.P.]

H.297 "Historians of the Nephites." Contributor 1 (March 1880): 137-38. Also MS 82 (24 June 1920): 405-7. A listing and analysis of the historians in the Book of Mormon and where they stood relative to Nephite history. [D.M.]

H.298 "Historic Print Shop Site Is Purchased by Church." CN 48 (18 November 1978): 7. The Church has purchased a building in Palmyra, New York, where the first edition of the Book of Mormon was printed on March 26, 1830. [M.R.] 
H.299 History of America B.C. 2200-420 A.D. Book of Mormon: An authentic account of the origin of the American Indian. Translated from the original by Joseph Smith, Jr." Independence, MO: Missions of the Church of Jesus Christ of Latter-day Saints, 1912? Presents a brief overview of the Book of Mormon story and declares that it is in complete harmony with all other known truths including religious, historical, or scientific. Writes concerning charity, service, baptism, and other topics. [J.W.M.]

H.300 "History of Mormonism." Christian Reformer 9 (October 1842): 627-33. A reprint from The Southern Quarterly Review, April 1842, declaring Mormonism a religious fraud and folly. "One Joe Smith," while digging for something else, dug up gold plates that were a record of the "lost chronicles of several kings of Israel." This inflammatory article alleges that Joseph Smith spread falsehoods. The growth of the new religion is alarming and poses a threat to the uneducated religious community. [J.W.M.]

H.301 Hlavaty, Lauri. "The Religion of Moses and the Book of Mormon." In The Book of Mormon: Jacob through Words of Mormon, To Learn with Joy, edited by Monte S. Nyman and Charles D. Tate, 103-24. Provo, UT: Brigham Young University Religious Studies Center, 1990. Discusses Book of Mormon instruction on the religion of Moses and its emphasis on the Savior and his Atonement. The insights in the Book of Mormon are crucial to understanding the religion Moses taught. Nephi taught that all things typify Jesus Christ. The purpose of the law of Moses was to bring the children of Israel to Christ. [J.W.M.]

H.302 Hobbs, A. G. Did the Book of Mormon Come from God? Fort Worth, TX: Hobbs, 1954. A polemical tract that asserts that the use of King James English in the Book of Mormon is anachronistic. Further, the Book of Mormon contains absurdities and contradicts the Bible. [M.R.]

H.303 Hobby, June M. "Jaredite-Nephite Armor and Weaponry: Reflections upon the Work of Christopher Reinhold." Zarahemla Quarterly 2/3 (1988): 30-31. The Zapotec Indians are identified as the Western Jaredites and the Maya, the Eastern Jaredites. Artifacts have been found that depict men wearing helmets. [J.W.M]

H.304 Hobby, Michael M. "The Mulekite Connection." Zarahemla Quarterly 2/1 (1988): 34-46. There was a fourcentury cohabitation of Mulekite and Jaredite societies before the latter was destroyed. This geographical study concludes that the Mulekites landed north of the narrow neck of land, encountered the Jaredites later and adopted their religion and culture, but fled when the final battle began and established the city where the Nephites found them. [J.W.M.]

H.305 Hobby, Michael M., and Troy J. Smith. "The Narrow Necks of Panama." Zarahemla Quarterly 2/3 (1988): 421. Hydrogeologist and geoarchaeologist Michael Hobby and geoarchaeologist Troy Smith recount experiences as they investigate the Panama region for possible evidence for the narrowest point in pre-Columbian times. This report includes maps and photographs. [J.W.M]

H.306 Hoekema, Anthony A. The Bible and the Book of Mormon. Grand Rapids, MI: Back to God Tract Committee, 1967. A polemical tract wherein the author writes concerning salvation by grace, the Bible as a closed canon of scripture, and the changes that have occurred in the Book of Mormon. [D.M.]

H.307 Hoekema, Anthony A. Mormonism. Grand Rapids, MI: William B. Eerdmans Publishing, 1963. Examines the Book of Mormon language, the materials upon which the text was written, the translation of the book, and the problems of the Book of Ether. The author finds that the Book of Mormon is "one of the most cunning and wicked impositions ever palmed upon the world." [J.W.M.] 
H.308 Hoekema, Anthony A. "Mormonism." In Hoekema's The Four Major Cults: Christian Science, Jehovah's Witnesses, Mormonism, Seventh-Day Adventism, 9-87. Grand Rapids, MI: William B. Eerdman Publishing, 1963. A chief purpose of the work is "to expose the many pernicious anti-Christian teachings which the cults are disseminating throughout the world today." Discusses rudimentary information on the Book of Mormon plates and the witnesses. Includes an appendix on the language of the Book of Mormon. [D.M.]

H.309 Hoekema, Anthony A. "Mormonism." In The New International Dictionary of the Christian Church, edited by J. D. Douglas, 678-79. Grand Rapids, MI: Zondervan, 1974. A concise statement of Mormon beliefs against the backdrop of the Orthodox Christian tradition. "An examination of the doctrines taught by the Mormon Church will reveal that they deny most of the cardinal teachings of the Christian faith." Quotes, as an example, the Book of Mormon aphorism by Lehi "Adam fell that men might be; and men are, that they might have joy" (2 Nephi 2:25). [D.M.]

H.310 Hoekema, Anthony A. "Ten Questions to Ask the Mormons." Christianity Today 12 (19 January 1968): 10-12, 14. An polemical piece wherein the author provides questions that may be asked of Mormons. The first question asks if "the Bible [is] the final source of authority for Mormonism." In answer the author refers to the Book of Mormon statement that many "plain and precious" things have been deleted from the Bible "since it was first written." [D.M.]

H.311 Hogan, Mervin B. Freemasonry and the Book of Mormon. Salt Lake City: Research Lodge of Utah F. and A.M., 1976. Explains the Book of Mormon from several angles. Quotes liberally from Robert B. Downs who wrote Books That Changed America. Downs says: "Throughout the history of Mormonism, the Church's most powerful and effective weapon has been the Book of Mormon... The possession of their own scriptures ... has proved to be the Mormons' greatest missionary tract." Hogan presents an outline summary of the narrative of the Book of Mormon and a summary of its theological teachings, and he concludes by discussing the importance of being creative in interpreting symbolism in ancient scripture. [B.D.] [D.M.]

H.312 Hogan, Mervin B. " 'A Parallel': A Matter of Choice Versus Coincidence." The Rocky Mountain Mason 4 (January 1956): 17-31. Notes that the Book of Mormon was not the first document published in America that proposed the Jewish connection with the American Indians. Supplies several of B. H. Roberts's parallel column comparisons of the Book of Mormon with Ethan Smith's View of the Hebrews. [D.M.]

H.313 Holbrook, Barbara. "Heyerdahl Seeks More Evidence Polynesians Came from South America." CN 23 (24 January 1953): 15. Tells about Heyerdahl's attempt to find evidence that the Polynesians came from South America. Notes that one of the Galapagos Islands grows a species of cotton known to have been cultivated in preColumbian northern Peru. Statement about Hagoth (Alma 63) accompanies the article. [D.M.]

H.314 Holbrook, Brett L. "The Sword of Laban as a Symbol of Divine Authority and Kingship." Journal of Book of Mormon Studies 2 (Spring 1993): 39-72. This article explains the importance of the sword of Laban in the Book of Mormon and the restoration. The sword is a "symbol of divine authority and kingship." The sword of Laban was used by rulers in the Book of Mormon and for Joseph Smith was a "witness of his authority and of the divine sanction for his work." [A.T.]

H.315 Holdaway, Annie W. "Redemption of the Lamanites." IE 27 (March 1924): 418-23. A brief article explaining some of the persecutions as well as progress that the Indians have experienced. When Melvin J. Ballard visited Ft. Peck and Blackfoot reservations the Indians knew him and were waiting for the "Book" because they had seen him 
in dreams. Ballard, Holdaway writes, believed the Three Nephites had labored among those Indians for years. [B.D.]

H.316 Holland, Jeffrey R. "Alma, Son of Alma." Ensign 7 (March 1977): 79-84. Similar to the New Testament Paul, Alma, the son of Alma, was converted from an opponent of Christ to a disciple of Christ. Much of the Book of Mormon is devoted to his life story, which includes messages of the anguish of a parent over a wayward child, the reality of repentance and its accompanying suffering, and the power of Christ. [R.H.B.]

H.317 Holland, Jeffrey R. "An Analysis of Selected Changes in Major Editions of the Book of Mormon: 18301920." M.A. thesis, Brigham Young University, 1966. Compares the changes of a number of LDS editions of the Book of Mormon, including the first three editions (1830, 1837, and 1840) published under the direction of Joseph Smith, the third British edition (1852) edited by Franklin D. Richards, Orson Pratt's 1879 revision that introduced a new chapter and verse system, and James E. Talmage's 1920 version. The author displays 156 textual differences between these editions. Only a sampling of differences is provided with no intent to be systematic or complete. [R.S.]

H.318 Holland, Jeffrey R. "Conclusions and Charge." In The Book of Mormon: First Nephi, the Doctrinal Structure, edited by Monte S. Nyman and Charles D. Tate Jr., 315-23. Provo, UT: Brigham Young University Religious Studies Center, 1988. Mentions the loss of the 116 pages as a vehicle for bringing about 1 Nephi. Draws doctrinal conclusions from the first twenty verses of the Book of Mormon, and charges believers to cling to the rod of iron. [A.T.]

H.319 Holland, Jeffrey R. "Daddy, Donna, and Nephi." Ensign 6 (September 1976): 7-11. The Book of Mormon needs to be read with a questioning mind and each verse needs to be examined critically for its meaning. Every chapter is charged with meaning, often with many meanings. From the first, the book forces the serious reader to recognize divine direction from God. [R.H.B.]

H.320 Holland, Jeffrey R. "I Have a Question: 'How can I explain Nephi's killing Laban to my nonmember friends? Some really reject it as scriptural.' " Ensign 6 (September 1976): 83-84. These seven things help us understand: Nephi gives a detailed account so he would not be misunderstood; he had no desire to take Laban's life; Old Testament prophets were likewise commanded; Laban was guilty of atrocities toward Nephi's family; modern revelation condones taking the life of a wicked man; Nephi was commanded by the Lawgiver; obedience was the focal point of the story. [J.W.M.]

H.321 Holland, Jeffrey R. "Mormon: The Man and the Book." Ensign 8 (March-April 1978): 15-18, 57-59. Mormon, the prophet/historian, was uniquely qualified for the task of editing the gold plates. Under the direction of the Spirit, Mormon carefully included only those items that would be of the greatest value to our generation in his abridgment of the Nephite records. [D.M.]

H.322 Holland, Jeffrey R., and Patricia T. " 'BYU's Greatness Measured By Strength of Devotion to Values.' " CN 56 (5 October 1986): 10. Emphasizes reading the Book of Mormon along with the importance of exercising the highest personal integrity, honesty, and self-control. [M.D.P.]

H.323 Holley, Vernal. Book of Mormon Authorship: A Closer Look. Ogden: Zenos, 1983. Parallels the Spaulding manuscript with the Book of Mormon and concludes that there is a direct connection between the two. Provides a look at Book of Mormon geography. This work is reviewed in N.144. [A.T.] 
H.324 Holley, Vernal. A Report on the Book of Mormon Spaulding Theory. Ogden: Zenos, 1982. A polemical attempt to link the unpublished Spaulding manuscript with the Book of Mormon. The author presents similarities between the two documents and concludes that the Book of Mormon is largely dependent upon Spaulding. [M.R.]

H.325 Holmes, Reed M." 'The Book of Mormon and Its Message': 'Come Unto Christ and Be Perfected in Him.' " SH 91 (24 June 1944): 811-16. Historical, legendary, and archaeological evidences support the Book of Mormon. Many scholarly works of the day are cited: Velt, Travels, Gann, Maya Cities, Kingsburough, Bancroft and Ripley, and many others. The Book of Mormon is an invitation to come to Christ. [J.W.M.]

H.326 Holmes, Reed M. "Christ and Our Day." In Holmes's Seek This Christ, 1954, 29-44. Independence, MO: Herald Publishing House, 1954. Jesus is the Christ, the Son of God. He can be traced through the testimony of the Book of Mormon. The Book of Mormon is not a substitute for the Bible but is a supplement to it. This chapter investigates the passages of the Book of Mormon that relate to the Savior's ministry. [J.W.M.]

H.327 Holmes, Reed M. "Latter Day Saints? Oh Yes-l've Heard about You." Independence MO: Herald House, n.d. Sets forth the beliefs of the RLDS church, including belief in the Book of Mormon. It is not an evil book, but a book to bring Jews and Gentiles to Christ. The Book of Mormon condemns polygamy. [J.W.M.]

H.328 Holmes, Reed M. The Social and Moral Message of the Book of Mormon. Gospel Quarterly Series, \#3. Independence, MO: Herald House, 1951. When nations or individuals are peaceful, the indication is that they have a committed, loving relationship with Deity. The opposite is also true. Evidence of this is abundant in the Book of Mormon. [J.W.M.]

H.329 Holmes, Samuel L. "The Christ Story in the Book of Mormon." MS 101 (5 October 1939): 630-31, 638-39. The Nephite people knew of Christ, his birth, mission, and death. When Mexico was conquered in 1520, Cortez found a fallen Christian Church, but the descendants of Lehi had not entirely forgotten their great white god and his wondrous miracles and teachings, which had become the worship of Quetzalcoatl. Thinking he had returned, the people welcomed the Spaniards. [J.W.M.]

H.330 Holt, Russell D. The Making of "How Rare a Possession-The Book of Mormon." Salt Lake City: University of Utah Institute of Religion, 1988. Discusses the creation of a high quality Book of Mormon film. [D.M.]

H.331 Homer, William H., Jr. "The Passing of Martin Harris." IE 29 (March 1926): 468-72. Martin Harris, one of the Three Witnesses to the Book of Mormon, was persuaded to move from Kirtland, Ohio, to Utah in 1870. A prominent part of the article is devoted to Harris's tenacious adherence to his testimony of the Book of Mormon. [D.M.]

H.332 Homer, William H., Jr. "Publish It Upon the Mountains." IE 58 (March-May 1955): 144-45, 310-11, 344. Reviews Martin Harris's role in bringing forth the Book of Mormon, and discusses Harris's testimony of the Book of Mormon. [R.C.D.]

H.333 Honey, David B. Review of Lehi in the Desert; The World of the Jaredites; There Were Jaredites, by Hugh W. Nibley. Review of Books on the Book of Mormon 2 (1990): 128-42. Book review.

H.334 Honey, David B. Review of Warfare in the Book of Mormon, edited by Stephen D. Ricks and William J. Hamblin. Review of Books on the Book of Mormon 3 (1991): 118-40. Book review. 
H.335 Honore, Pierre. In Quest of the White God. New York: G. P. Putnam, 1963. Outlines numerous native American myths associated with the visit of a "white God" and his impact on societies of the New World. [M.R.]

H.336 Hopfenbeck, G. Martin. "The Book of Mormon Manuscripts." MS 85 (27 December 1923): 820-23. The history of Book of Mormon manuscripts is set forth. Includes mention of various scribes, the loss of 116 manuscript pages, publication of the Book of Mormon, and nineteen manuscript pages found in the Nauvoo House cornerstone. [A. C.]

H.337 Hopkin, Fred W. "Conversion in Honduras." Friend 18 (October 1988): 32-33. A picture story illustrating the conversion of a Central American girl through the Book of Mormon. [D.M.]

H.338 Hopkins, N. Gaylon. "The Condescension of the Father and the Son." In Sidney B. Sperry Symposium: The Book of Mormon, edited by A. Gary Anderson, 48-59. Provo, UT: Brigham Young University Religious Studies Center, 1981. The Book of Mormon reveals the paternity of Jesus Christ, his divinity as Creator, and his condescension, or his subjection into the hands of mortal men. The book also reveals the temptations that the Savior had to endure. [J.W.M.]

H.339 Hoppe, Edward W. "What We Learned from Our Book of Mormon Project." Ensign 3 (March 1973): 47. Report of successes and failures in a Brigham Young University project to send copies of the Book of Mormon to foreign missions. [A.C.W.]

H.340 Horatio. "Corianton." Contributor 10 (1889): 171-76, 206-10, 245-48, 286-90, 324-30. A fictional story about Corianton and his dealings with Korihor, the people of Ammon, Shiblon, and Isabel. [A.T.]

H.341 Horatio. "A Story of Zarahemla." Contributor 10 (January 1889): 94-101. A fictional story about Nephi (son of Helaman), his son Nephi, their dealings with the Gadianton robbers, and the drama surrounding the signs given of Christ's birth. [A.T.]

H.342 "The Horse in Ancient America." MS 90 (26 April 1928): 268-69. Through historical, scientific, and scholarly evidence, this article shows that there were indeed horses in ancient America, well before Spaniards. Nephi stated in the Book of Mormon that horses were found upon their arrival in the promised land. [M.D.P.]

H.343 "Horses, Horses, Horses." CN 42 (25 March 1972): 16. Through the years people have insisted the Book of Mormon is wrong because of its reference to horses, claiming that horses were not on the continent until the Spanish arrived. This article presents evidence that there were horses on the continent as the Book of Mormon claims there were. [M.D.P.]

H.344 Horton, George A., Jr. "Book of Mormon-Transmission from Translator to Printed Text." In The Book of Mormon: The Keystone Scripture, edited by Paul R. Cheesman, S. Kent Brown, and Charles D. Tate, Jr., 237-55. Provo, UT: Brigham Young University Religious Studies Center, 1988. Reviews the history of the English text of the Book of Mormon by discussing textual changes made or authorized by Joseph Smith and transmissional problems such as orthography, haplography, dittography, homoeoteleuton, and homoeoarchton. Concludes that "the basic meaning of the text has not been changed [and] the changes and corrections are not only correct but appropriate." [B.D.]

H.345 Horton, George A., Jr. "Changes in the Book of Mormon and How to Handle Them." In The Sixth Annual Church Educational System Religious Educators' Symposium on the Book of Mormon, 36-39. Salt Lake City: Church of 
Jesus Christ of Latter-day Saints, 1982. Examines reasons for the errors and changes in different Book of Mormon editions, such as the fact that standardized spelling in America was still in its formative stages, oral transmissional problems between Oliver Cowdery and Joseph Smith, punctuation errors, copying and typography errors, contextual errors, and intentional eliminations, additions, and improvements. Examples of each type of change are given. [A.T.]

H.346 Horton, George A., Jr. "Understanding the Textual Changes in the Book of Mormon." Ensign13 (December 1983): 24-28. Gives a history of the many textual changes made in various editions of the Book of Mormon (spelling, grammatical, punctuation, and clarification). Discusses the circumstances that made the changes necessary and how these changes should be viewed in light of Joseph Smith's statement that the Book of Mormon is the most correct book. [S.P.S.]

H.347 Hoskisson, Paul Y. "The Allegory of the Olive Tree in Jacob." In The Allegory Of The Olive Tree: The Olive, The Bible, and Jacob 5, edited by Stephen D. Ricks and John W. Welch, 70-104. Slat Lake City: Deseret Book and FARMS, 1994. Examines four aspects of the allegory of the olive tree: what are the symbols, why Jacob used the allegory in his writings, what historical events does it allude to, and what does it say to latter-day people? Concludes that the allegory refers to actual events in the history of the house of Israel. The message of the allegory is that Father in Heaven is a caring God. Jacob included this allegory to show that reconciliation with God comes through Jesus Christ. [J.W.M.]

H.348 Hoskisson, Paul Y. "The Ancient Near Eastern Background of the Language of the Book of Mormon." In The Sixth Annual Church Educational System Religious Educators' Symposium on the Book of Mormon, 40-42. Salt Lake City: Church of Jesus Christ of Latter-day Saints, 1982. Finds "indications of an ancient Near Eastern influence on the received text of the Book of Mormon [in the form of] lexemes, style, and onomastics." 1 Nephi 2:9 is an example of a lexeme. Lehi's statement that the river "emptied into the fountain of the Red Sea" does not make sense until one realizes that the "ancients of the Near East saw the oceans and subterranean waters to be the source of rivers and steams." [A.T.]

H.349 Hoskisson, Paul Y. "Book of Mormon Names." In Encyclopedia of Mormonism, edited by Daniel H. Ludlow, 1:186-87. 5 vols. New York: Macmillan, 1992. "The Book of Mormon contains 337 proper names and 21 gentilics (or analogous forms) based on proper names." Of the 337 proper names, "188 are unique to the Book of Mormon." Some semantic names have translated meanings that would be more meaningful if linguistic origins were available. [N.K.Y.]

H.350 Hoskisson, Paul Y. "Explicating the Mystery of the Rejected Foundation Stone: The Allegory of the Olive Tree." BYU Studies 30 (Summer 1990): 77-87. Relates the allegory of the olive tree (Jacob 5) to biblical eras and dispensations and demonstrates that "many of the historical metaphors" can represent actual time periods in the history of the house of Israel. However, there is a far greater purpose for the allegory than to assign time frames to its sequence of events. The deeper meaning is that it is possible for the Jewish people to build upon the foundation stone of Christ after having once rejected him. [J.W.M.]

H.351 Hoskisson, Paul Y. "An Introduction to the Relevance of and a Methodology for a Study of the Proper Names of the Book of Mormon." In By Study and Also by Faith, edited by John M. Lundquist and Stephen D. Ricks, 2:126-35. Salt Lake City: Deseret and FARMS, 1990. This well-footnoted article discusses the significance of proper names in the Book of Mormon and presents a methodology for the study of such names. Proper names can convey meaning, lead to the identity of the language of origin, preserve sounds of a mother tongue, give clues to 
the nature of peoples or events of the past, and help to identify times at which writings took place. Example etymologies of a few names are suggested and a caution raised regarding multiple languages of origin, commingling of languages, unknown languages of origin, Jaredite names, and multiple spellings of names in early Book of Mormon manuscripts. [A.A.]

H.352 Hoskisson, Paul Y. Review of Christ's Answer to the Atheist, to the Jew: Who Wrote It? by Earl W. Carlsen. Review of Books on the Book of Mormon 2 (1990): 63-64. Book review.

H.353 Hoskisson, Paul Y. Review of Little Known Evidences of the Book of Mormon, by Brenton G. Yorgason. Review of Books on the Book of Mormon 2 (1990): 258-59. Book review.

H.354 Hoskisson, Paul Y. "Scimitars, Cimeters! We Have Scimitars! Do We Need Another Cimeter?" In Warfare in the Book of Mormon, edited by Stephen D. Ricks and William J. Hamblin, 352-59. Salt Lake City: Deseret and FARMS, 1990. The term "cimeter" (now spelled scimitar) is mentioned eleven times in the Book of Mormon. The Book of Mormon cimeter is discussed and compared with those used in Near Eastern areas, and its usage and description is not improper. [N.K.Y.]

H.355 Hoskisson, Paul Y. "Textual Evidences for the Book of Mormon." In The Book of Mormon: First Nephi, the Doctrinal Foundation, edited by Monte S. Nyman and Charles D. Tate, Jr., 283-95. Provo, UT: Brigham Young University Religious Studies Center, 1988. Uses textual material from the Book of Mormon to demonstrate its ancient Near Eastern background and style. Compares Book of Mormon phrases to Ugaritic, Akkadian, and Hebrew texts, and notes that this was information not available to Joseph Smith. [A.T.]

H.356 Hoskisson, Paul Y. "Urim and Thummim." In Encyclopedia of Mormonism, edited by Daniel H. Ludlow, 4:1499-1500. 5 vols. New York: Macmillan, 1992. Lists different prophets that have been in possession of the Urim and Thummim, Joseph Smith's description of them, the meaning of the words Urim and Thummim, and future uses of the Urim and Thummim. [A.T.]

H.357 Hougey, Harold H. Archaeology and the Book of Mormon. Concord, CA: Pacific, 1976. There is, according to the author, no archaeological support for the Book of Mormon. Hougey refers to negative comments made by some Mormon scholars regarding the lack of archaeological finds relating to the Book of Mormon. He also points out the difference of opinion between various Mormon scholars regarding various points of Book of Mormon geography. [M.R.]

H.358 Hougey, Harold H. The Mystery of Joseph Smith and the Golden Plates. Concord, CA: Pacific, 1980. Provides personal accounts of the Prophet Joseph Smith from several sources (Pearl of Great Price, Times and Seasons, and History of the Church) concerning the plates and the coming forth of the Book of Mormon. Questions the validity of the unsupported story. [J.W.M.]

H.359 Hougey, Harold H. Oliver Cowdery and the Book of Mormon. Concord, CA: Pacific, 1963. An attempt to discredit the testimony of Oliver Cowdery, one of the Three Witnesses to the Book of Mormon. [M.R.]

H.360 Hougey, Harold H. 'A Parallel'-the Basis of the Book of Mormon. Concord, CA: Pacific, 1963. Ethan Smith's book View of the Hebrews provided Joseph Smith with the basic format for the Book of Mormon. Hougey lists forty-one parallels between the Book of Mormon and the View of the Hebrews. [M.R.] 
H.361 Hougey, Harold H. "Paul and Moroni." Christianity Today 5 (22 May 1961): 15. Notes that a declaration by Thomas Stuart Ferguson that the discovery of Central American cities helps to prove the truthfulness of the Book of Mormon contradicts statements and opinions of other LDS archaeologists. [D.M.]

H.362 Hougey, Harold H. The Truth about the 'Lehi Tree of Life Stone'. Concord, CA: Pacific, 1963. Mormons have frequently used Izapa Stela 5 as evidence for the Book of Mormon story of Lehi's dream of the tree of life. The author, who rejects the divine authenticity of the Book of Mormon, presents reasons why he believes that Izapa Stela 5 has nothing to do with the Book of Mormon. [M.R.]

H.363 "How about It?" IE 30 (September 1927): 1051-52. A challenge to read the Book of Mormon to commemorate the one-hundredth anniversary of the delivery of the plates to Joseph Smith, and a warning against neglecting the scriptures. The Book of Mormon is the word of God, a spiritual guide, and it confirms the truths in the Bible. Testimonies of Parley P. Pratt and B. H. Roberts are included. [J.W.M.]

H.364 "How Are the American Indians Related to the Jews?" IE 23 (March 1920): 453-55. Discusses the idea that the American Indians are descendants of Lehi, Ishmael, and Mulek, the former two being of the house of Joseph and the latter, the house of Judah. [J.W.M.]

H.365 "How the Book of Mormon Was Translated: How God Uses Human Agencies to Give His Word to Mankind." MS 68 (March 1906): 205-6. The authors know of no record from the prophet himself on exactly how he translated the Book of Mormon. They suggest that Joseph Smith's mind was quickened by the Urim and Thummim and that after getting the idea of the message, he wrote it in his own words. Thus the grammatical errors are his own. [B.D.]

H.366 "How to Better Use Book of Mormon to Enrich, Improve One's Family Life." CN 56 (28 December 1986): 15. A collection of statements made by selected readers of the Church News on how they use the Book of Mormon to inspire their families. [D.M.]

H.367 "How to Distribute the Book of Mormon." CN 57 (7 March 1987): 15. Contains nine reports from people who explain how they make the Book of Mormon available to nonmembers. The Book of Mormon is a missionary tool. [D.M.]

H.368 "How to Encourage Children to Read the Book of Mormon." CN 60 (31 March 1990): 15. Fourteen brief recommendations on how to interest children in reading the Book of Mormon. [D.M.]

H.369 "How to Give a Book of Mormon to a Friend." CN 60 (14 July 1990): 15. Suggestions for member missionaries by nine contributors on ways to share the Book of Mormon with those who are not members of the Church. [D.M.]

H.370 "How to Make Time for Book of Mormon." CN 56 (22 June 1986): 15. Brief comments on how different individuals or families find ways to read the Book of Mormon regularly. [D.M.]

H.371 "How to Study the Book of Mormon." CN 58 (2 January 1988): 15. A checklist on how to study the Book of Mormon: seek spiritual guidance, set aside a regular time for study, search for information on specific subjects, and share what you learn. [R.H.B.] 
H.372 "How We Got the Book of Mormon." Friend 10 (April 1980): 30-32. An illustrated children's story of Joseph Smith receiving the golden plates. [M.R.]

H.373 How Well Do You Know the Book of Mormon? Provo, UT: Dept. of Seminaries and Institutes, n.d. A multiple choice exam on the Book of Mormon for seminary students. [D.M.]

H.374 Howard, F. Burton. "Come Back to the Lord." Ensign 16 (November 1986): 76-78. Also in CR (4-5 October 1986): 97-100. Stresses the importance of repentance. Mentions the stories of Alma the Younger and Aminidab, showing how they repented and returned to the Lord. [A.C.W.]

H.375 Howard, Richard P. "Beating Solomon Spaulding's Poor, Dead Horse One More Time." SH124 (September 1977): 37. Writes concerning three California researchers who claim to have discovered new evidence that Joseph Smith used the Spaulding manuscript to write the Book of Mormon. Presents "three compelling evidences [that] negate" their theory. [D.W.P.]

H.376 Howard, Richard P. "Latter-day Saint Scriptures and the Doctrine of Propositional Revelation." In The Word of God: Essays on Mormon Scripture, edited by Dan Vogel, 1-18. Salt Lake City: Signature, 1990. Also published in Courage: A Journal of History, Thought and Action 1 (June 1971): 209-26. Proposes that revelation is nonpropositional and does not reveal objective truths or doctrines. [M.R.]

H.377 Howard, Richard P. "Martin Harris' March 1830 Commitment to Book of Mormon Publication." SH 127 (1 March 1980): 28. Recounts the circumstances leading to Martin Harris's willingness to finance the publication of the Book of Mormon. [D.M.]

H.378 Howard, Richard P. Restoration Scriptures: A Study of Their Textual Development. Independence, MO: Herald House, 1969. Discusses the development of the Book of Mormon, the "Inspired Version" of the Bible, and the Doctrine \& Covenants. With regard to the Book of Mormon, the author attempts to "establish the relationship between the two (original) manuscripts produced prior to publication in 1830," to "demonstrate the continuing concern of Joseph Smith, Jr. for the refinement of the Book of Mormon text," and to discuss the textual developments of various editions of the Book of Mormon. Includes in parallel columns portions of Book of Mormon texts from different editions to show changes. [A.C.W.]

H.379 Howard, Richard P. "The Two 'Original' Manuscripts to the Book of Mormon." SH 115 (1 February 1965): 83-86. Gives a brief translation and publication of the history of the Book of Mormon and explains the relationships between the two "original" manuscripts and the early editions of the book. Makes a textual comparison of the verbal dictation manuscript, the publisher's manuscript, and the 1830 edition of Book of Mormon for a section composed of 1 Nephi 2:10-28. Concludes that the RLDS manuscript (the publisher's) is the better of the two. [A.C.W.]

H.380 Howe, Eber D. History of Mormonism. Painesville: Howe, 1840. A reprint of Howe's 1834 Mormonism Unvailed. [M.R.]

H.381 Howe, Eber D. Mormonism Unvailed. Painesville: Howe, 1834. An early major exposé of the Book of Mormon. Also the first writer to suggest that the Book of Mormon owes its origin to Solomon Spaulding. The author reviews the Book of Mormon book by book and discusses alleged contradictions with the Bible, anachronisms and absurdities, as well as the 1834 Anthon denial regarding the Martin Harris incident. [M.R.] 
H.382 Howells, Rulon S. "The Book of Mormon Story." In Howells's The Mormon Story: A Pictoral Account of Mormonism, 17-25. Salt Lake City: Bookcraft, 1957. Tells Joseph Smith's story using his own words, with pictures, maps, and photographs to emphasize the historical account of the coming forth of the Book of Mormon. [J.W.M.]

H.383 Howells, Rulon S. Compilation of the Book of Mormon. Salt Lake City: Bookcraft, 1961. A large fold-out chart depicting the way in which the Book of Mormon was compiled and abridged. Includes a facsimile of the characters on the plates, the translation of the records, and an account of the method of translation. [J.W.M.]

H.384 Howells, Rulon S. The Way to Happiness. Salt Lake City: Bookcraft, 1967. This full-color illustrated booklet begins with the organization of the primitive church by Christ, and moves through the Apostasy to the Restoration of the Latter-day Church. It presents the Joseph Smith story in Smith's own words. Includes doctrines taught in the Book of Mormon on baptism, divine authority, the sacrament, and temple marriage. [J.W.M.]

H.385 Howells, Rulon S. Where the Book of Mormon Story Took Place. Salt Lake City: Bookcraft, 1961. A fold-out map of the Americas marked with Book of Mormon story events and dates showing the location where Book of Mormon peoples landed in South and Central America. To be used as a teaching aid. [J.W.M.]

H.386 Hoyt, Moroni. "Backgrounds of Mormon History, Church of Christ (Lukeite) Asks Some Interesting Questions: Attention Book of Mormon Believers." Martin Miscellaneous 1 (April/May 1976): 11, 13. A statement from the Tiffany Monthly says that the gold plates were found using a "stone" dug from the well of Mason Chase. Another report states that none of the witnesses ever saw the plates. David Whitmer denied having seen an angel and the plates. Joseph never revealed the method of translation, but D\&C 9 gives the real story, when all believed it was appearing word for word on the stone in the hat. [J.W.M.]

H.387 Hrdlicka, Ales. "Skeletal Remains Suggesting or Attributed to Early Man in North America." Smithsonian Institution Bureau of American Ethnology Bulletin 33 (1907): 9-113. Technical reports about the Mound Builders, who were early inhabitants of America, and their skeletal remains and burial practices. [J.W.M.]

H.388 Hubble, M. J. "Interview with David Whitmer." BYU Studies 14 (Summer 1947): 483-86. Transcript and copy of a hand-written document, reporting information David Whitmer gave regarding the translation of the Book of Mormon. [D.M.]

H.389 Huber, Jay H. "Lehi's 600 Year Prophecy and the Birth of Christ." Provo, UT: FARMS, 1982. Using historical data to date the time that Lehi left Jerusalem and the time of Christ's birth and death, the author concludes that the Nephites used a 360-day year and Christ was born on or near 11 April, 4 B.C., or September/October of 5 B.C. "The 360-day hypothesis agrees with all historical data dealing with Zedekiah and Herod, is consistent with the Book of Mormon account, and allows us a plausible explanation for the heavenly signs inferred from the Nephite account." [A.T.]

H.390 Hughes, Dean. The Mormon Church: A Basic History. Salt Lake City: Deseret Book, 1986. A basic history of the LDS church that includes the Smith family history, the First Vision story, and the coming forth of the Book of Mormon. [J.W.M.]

H.391 Hughes, Merritt Y. "A Neglected Document in American History." University of California Chronicle (April 1925): 153-65. Examines the Book of Mormon as a literary document in the context of the early nineteenth century and views it as a reflection of those naturalistic influences. [M.R.] 
H.392 Hullinger, Robert N. "An Apologist for Jesus Christ: The Purpose and Function of Joseph Smith's Theology." M.A. thesis, Pacific Lutheran Theological Institute, 1969. The author proposes that Joseph Smith fabricated the Book of Mormon in an attempt to combat the works of Thomas Paine and others. He enumerates various environmental influences that he feels were incorporated into the text of the Book of Mormon, such as antiMasonry, Hebrew origin of the Indians, Ethan Smith's View of the Hebrews, and others. The Book of Mormon is seen as false, but a well intentioned attempt to stimulate greater faith among early nineteenth-century Americans. [M.R.]

H.393 Hullinger, Robert N. The Harris-Anthon Consultation and Mormon Critics. Cincinnati, OH: author, 1968. After Martin Harris visited Professor Anthon and Dr. Mitchell of New York City he was persuaded to finance the publication of the Book of Mormon. The account of the visit evolved over a ten-year period. The data shows that Martin Harris took only a transcript of the characters from the plates that did not include Smith's translation nor did the scholars succeed in translating the characters. Harris's story in the official declaration varies from these findings. Smith arranged for the interview to fulfill the biblical prophecy in Isaiah 29. [J.W.M.]

H.394 Hullinger, Robert N. "Joseph Smith, Defender of the Faith." Concordia Theological Monthly 42 (February 1971): 72-87. Rejecting the Spaulding and psychological explanations for the origin of the Book of Mormon, the author believes that Joseph Smith wrote the Book of Mormon in an attempt to defend belief in God "against the sectarianism and popular skepticism of the day." He provides several interesting examples from the Book of Mormon to show how they fit within the environmentalist framework of such a thesis. [M.R.]

H.395 Hullinger, Robert N. Joseph Smith's Response to Skepticism. Salt Lake City: Signature Books, 1992. Explains Joseph Smith and the Book of Mormon on the basis of the contemporary environment. Deals with the purpose of the Book of Mormon and Joseph Smith as its translator or author. Includes chapters on the "lost book" of the Indians, the "sticks" in Ezekiel 37, the prophecies in Isaiah, and the role of masonry. [D.M.]

H.396 Hullinger, Robert N. "The Lost Tribes of Israel and the Book of Mormon." The Lutheran Quarterly 22 (August 1970): 319-29. Tells about Ethan Smith and his interest in writing the View of the Hebrews. "Joseph Smith adapted the Indian-Israelite theory for his American scripture. He made the Indian descendants of only one Israelite tribeJoseph." Joseph Smith produced the Book of Mormon to prove the existence of God and other theological propositions against popular skepticism. [D.M.]

H.397 Hullinger, Robert N. Mormon Answer to Skepticism: Why Joseph Smith Wrote the Book of Mormon. St. Louis, $\mathrm{MO}$ : Clayton, 1980. A critical work on the Book of Mormon that attempts to determine various environmental factors that may have influenced Joseph Smith to write the book. Among these are free-masonry, Ethan Smith's book View of the Hebrews, and the deistic views of Thomas Paine. The Book of Mormon is seen as a sincere attempt to combat naturalistic views of Joseph Smith's time and an attempt to win souls back to God. This work is reviewed in G.089. [M.R.]

H.398 Hunker, E. Y. "Just a Book on the Table." SH 87 (18 May 1940): 618. The author read a copy of the Book of Mormon that he found sitting on a table and it helped him to overcome his prejudice and caused him to feel a spiritual warmth, and he received a witness of its validity. [J.W.M.]

H.399 Hunt, C. J. "An Acknowledgment to John Whitmer: One of the Eight Witnesses of the Book of Mormon." SH 97 (6 February 1950): 131. John Whitmer saw and handled the plates in 1829 and assisted Joseph Smith and Oliver Cowdery in the final preparation of the Book of Mormon manuscript. In his later years, he affirmed his testimony many times. [J.W.M.] 
H.400 Hunt, C. J. The Book of Mormon. Lamoni, IA: Herald House, 1900. A pamphlet that briefly explains the nature of the Book of Mormon. The writer rejects the Spaulding Theory on the basis that Sidney Rigdon never heard of the Book of Mormon until after its publication and that the Book of Mormon bears no resemblance to the unpublished manuscript rediscovered in 1884. [M.R.]

H.401 Hunt, C. J. "The Book of Mormon Is Not Another Gospel." SH 53 (23 May 1906): 485. Considering it wrong to call the Book of Mormon another gospel, the author offers an explanation to prove that the book contains another account of the same gospel as that which is found in the New Testament. [J.W.M.]

H.402 Hunt, C. J. "The Book of Mormon Manuscript." SH 50 (3 June 1903): 510. David Whitmer treasured the Book of Mormon manuscript and would not sell it in his lifetime, but after his death it was presented to the Reorganized Church. [J.W.M.]

H.403 Hunt, C. J. "The Book of Mormon Manuscript: An Interview." SH 85 (8 October 1938): 1293. Reprint of an article from the Missouri Conservator, September 13, 1878. Elders Orson Pratt and Joseph Fielding Smith visited with David Whitmer and were shown the original manuscript. Elder Pratt recognized the handwriting of Oliver Cowdery and requested David Whitmer to surrender the copy to the "Utah Church," but was refused. Whitmer's testimony concerning the truthfulness of the Book of Mormon is included. [J.W.M.]

H.404 Hunt, C. J. "Columbus and the Three Nephites." SH 76 (19 June 1929): 739-40. Hunt reprints a story from Life and Voyages of Columbus. New York: The University Society Publishers. 1:270-72. One of Columbus's men was alone in the forest of Cuba and reported seeing three men "of as fair complexions as Europeans" in long white dresses or tunics reaching to their knees. Hunt identifies the three men as the Three Nephites. [B.D.]

H.405 Hunt, C. J. "The Eleven Witnesses to the Book of Mormon Plates and their Baptisms." SH88 (23 August 1941): 1076. Lists the birthdates of the eleven witnesses and mentions the fact that none of the witnesses denied their testimonies and all were baptized as a result of viewing the plates. [J.W.M.]

H.406 Hunt, C. J. "Is the Book of Doctrine and Covenants Foretold in the Book of Mormon?" SH 76 (17 April 1929): 454-57. Explains that 2 Nephi $12: 70$ and Jacob 3:140-47 prophesy of the coming forth of the Doctrine and Covenants. [B.D.]

H.407 Hunt, C. J. "Nephi-A Prophet, Leader, President, and Writer." SH 76 (11 December 1929): 1503-4. 3 Nephi 5, 9, and 10 describe how Nephi was chosen as the leader of the twelve disciples after Christ's coming on the American Continent. [B.D.]

H.408 Hunt, C. J. The Opinions of Sixty-five Leading Ministers and Bible Commentators on Isaiah 29:11-24 and Ezekiel 37:15-20. Lamoni, IA: RLDS, 1900. Many LDS authors hold that Isaiah 29:11-24 and Ezekiel 37:15-20 have reference to the Book of Mormon. Non-LDS biblical commentators have a different view of these verses. [J.W.M.]

H.409 Hunt, C. J. "The Opinions of Sixty Prominent Ministers, Journalists, and Historians on Prehistoric Civilization in America-The Book of Mormon Needed." SH 52 (30 August 1905): 830-33. Prominent men were questioned concerning a book that tells of ancient American history. Their answers ranged from "I know of no such book" to archaeological referrals. The author concludes that a prayerful reading of the Book of Mormon will give "knowledge and wisdom on historical, doctrinal, and inspirational matters that cannot be obtained elsewhere." [J.W.M.] 
H.410 Hunt, C. J. "Sacred Records-Balance of Book of Mormon Plates." SH 76 (6 March 1929): 271-74. The Reorganized Church will receive the remainder of the golden plates, and the "Utah Church" will not. When the Reorganized Church begins to receive these records, members in the "Utah Church" will start joining the Reorganized Church. [B.D.]

H.411 Hunt, C. J. Sacred Scriptures, and Urim and Thummim Evaluated. Independence, MO: by the author, 1979. Calls the Book of Mormon "the Stick of Joseph" and the Bible "the Stick of Judah." Examines Ezekiel 37 and Isaiah 29, finding that the Book of Mormon fits the descriptions found therein. The Urim and Thummim were a necessary part of the translation process due to the complex nature of the written text and the ignorance of the translator. [J.W.M.]

H.412 Hunt, C. J. "The Three Nephites-Angels of God." SH 76 (4 December 1929): 1471-72. Cites two stories that the author presents as pertaining to the Three Nephites. The pilgrims in 1675 were rallied by an unknown white man with a beard and frightened the Indians away. The German army was pressing the allied army at Mons in 1915 when, in a strange light that grew brighter, three personages could be seen on the British side. At that moment the German army was checked. [B.D.]

H.413 Hunt, C. J., and John A. Robinson. "Two Records and the Prophets of the Restoration." SH (23 March 1940): 370-72. It was the intention of the Prophet to make the Inspired Version of the New Testament and the Book of Mormon available to all the world. This work was accomplished in 1895 by the RLDS church in fulfillment of the prophecy in Isaiah 29. [J.W.M.]

H.414 Hunt, James Henry. Mormonism; Embracing the Origin, Rise and Progress of the Sect, With an Examination of the Book of Mormon. St. Louis: Ustick and Davies, 1844. Early polemical work written against Mormonism and the Book of Mormon. Discusses each of the Three Witnesses. Claims that names like "Nephi," "Lehi," and "Maroni" (sic) end in the Latin "I." Assumes primal authorship belonged to Solomon Spaulding. Includes a chapter on the credibility of the Book of Mormon. [D.M.]

H.415 Hunt, Mildred T. Book of Mormon and Other Poems. Sacramento: Print King, 1981. Narrative poems about Book of Mormon characters and situations. Topics include Lehi, Sam, Jacob, the tree of life vision, the waters of Mormon, and King Noah. The poet empathizes, for example, with Sam confessing his love for the family home in Jerusalem. Yet when the vision came, he never looked back. [C.C.]

H.416 Hunter, Howard W. "The Book of Mormon Testifies of Christ." CR (April 1983): 17-20. The greatest message of all is the gospel-the good news, which is Jesus Christ. It is the message of the Bible. It is also the message of the Book of Mormon. The Book of Mormon is a second witness for Christ. Reading it "will have a profound effect on your life." [R.C.D.]

H.417 Hunter, Howard W. "Evidences of the Resurrection." Ensign 13 (May 1983): 15-16. The Book of Mormon is the record of Christ's "other sheep" (John 10:14-16). It provides evidence of the resurrected Lord through its record of Christ's appearance in America following his crucifixion and resurrection. It is a confirming and harmonious testimony of the biblical record. [J.W.M.]

H.418 Hunter, Howard W." 'No Less Serviceable.' "Ensign (April 1992): 64-67. Helaman and his brethren are "no less serviceable unto the people" (Alma 48:19) than Moroni (Alma 48:17). Elder Hunter talks about other scriptural individuals that did not hold the limelight of attention. These include: Sam, Ishmael, Ishmael's daughters, Mother Sariah, Abish, Mosiah, Limhi, Amulek, Pahoran, and Shiblon. [A.T.] 
H.419 Hunter, Milton R. "Archaeology and the Book of Mormon." In Book of Mormon Talks by General Authorities, 32-45. Provo, UT: FARMS, 1990. Also published in BYUSY (19 July 1966). Provo, UT: BYU Press. This is an address given at BYU, July 19, 1966. The author gives archaeological evidences supporting the Book of Mormon. Discusses ancient civilizations, gold and silver, clothing and jewelry, Stela 5 (Izapa, Mexico), which depicts Lehi's dream, and the story of the White God visiting America. [B.D.]

H.420 Hunter, Milton R. Archaeology and the Book of Mormon. Salt Lake City: Deseret Book, 1956. Printed as a series in IE 58-59 (April-October 1955, January-May 1956): 229, 280, 282, 316-19, 338, 340-43, 496-98, 52023, 561, 576, 578, 580, 582-86, 638-39, 654, 656, 658, 724-40, 26-27, 42, 44-47, 82-84, 98, 100, 102, 168-70, 172-74, 176, 178-79, 239-41, 282, 324-26, 328, 330, 332, 334. A comprehensive compilation of archaeological artifacts in Mesoamerica that relate to Book of Mormon places and peoples. Copiously illustrated with photographs of buildings, pottery, statues, and carvings. Includes evidences of Christ's appearance to the Americas. Reviews ancient Mayan writings, including Title of the Lords of Totonicapan, the Popol Vuh, the annals of the Cakehiquels, and the words of Ixtlilxochitl. Discusses white and dark people in ancient America. [R.H.B.]

H.421 Hunter, Milton R. "Book of Mormon Evidences." IE 57 (December 1954): 912-14, 916, 918. Vast amounts of marvelous evidences for the Book of Mormon have accumulated. Archaeological evidences include the many discoveries in the Americas - La Venta, Izapa stone, Quetzalcoatl, bearded-men statues, Egyptian type burials, arts, metals, and textiles. The writings of sixteenth-century Indian historians, such as the Totonicapan, Popol Vuh, Annals of the Cakchiquels, and the Works of Ixtlilxochitl, and the writings of the sixteenth-century Catholic priests Bernardino de Sahagun, Bishop Bartholome de Las Casas, Diego de Landa, and Juan de Torquemad present correlations and correspondences to the Book of Mormon. [R.C.D.]

H.422 Hunter, Milton R. "Book of Mormon Evidences." In BYUSY (21 January 1958). Provo, UT: BYU Press. The Book of Mormon is unique, for it is the only book written completely in accordance to divine command. No other book was written by a succession of prophets. It was written for a divine purpose, preserved by a Divine Being, and stands the test of time. No other book has had more testators. Archaeology bears witness of its truthfulness. [J.W.M.]

H.423 Hunter, Milton R. Christ in Ancient America. Salt Lake City: Deseret Book, 1959. Chapters deal with Quetzalcoatl-the white bearded God-Christ the good shepherd, Teotihuac $¥ n$, and the plumed serpent. These topics are carefully related to Jesus' visit to the ancient Americas. Copiously illustrated. [R.H.B.]

H.424 Hunter, Milton R. "Gospel Dispensations in Ancient America." In The Gospel through the Ages, 82-89. Salt Lake City: Stevens and Wallis, 1945. There are two gospel dispensations identified in the Book of Mormon-the Jaredite and the Nephite. The Nephites lived the law of Moses in concert with the gospel of Christ under the direction of both the Aaronic and Melchizedek Priesthoods for 600 years before Christ's visit. [J.W.M.]

H.425 Hunter, Milton R. "A Great and Marvelous Work." IE 72 (June 1969): 87-88. The Book of Mormon is unique because Jesus Christ initiated and supervised its production. It was written under divine guidance by prophets specifically for the last days. The gold plates were in the custody of an angel. The translation was conducted by an unlearned man and completed in approximately sixty days. The Lord proclaimed its divinity and truthfulness. [J.W.M.]

H.426 Hunter, Milton R. Great Civilizations and the Book of Mormon. Salt Lake City: Bookcraft, 1970. Deals with the Olmec civilization, Indian culture, the Maya civilization, Tikal, Copan, Uxmal, Kabah, Chichen Itza, Teotihuacłn, and the origin of American Indians. [R.H.B.] 
H.427 Hunter, Milton R. "The Greatest Event in Ancient America." IE 64 (June 1961): 408-9. Various Indian traditions and practices suggest that Jesus Christ visited the American continent, as the Book of Mormon indicates. Author points out archaeological and historical similarities between Jesus and Itzamna, the god of the Mayas, and Quetzalcoatl, the "Fair God" of ancient America. [J.W.M.]

H.428 Hunter, Milton R. "Indian Traditions of the Book of Mormon." IE 58 (June 1955): 430-32. Compares oral traditions of Indian tribes that correspond to Book of Mormon stories. Two ancient Mayan writings, the Works of Ixtlilxochitl and the Popol Vuh, possess remarkable parallels with the Book of Mormon. [R.C.D.]

H.429 Hunter, Milton R. "Marriage Customs of the QuichŽ Maya." IE 59 (June 1956): 413-15. A careful study of the religious beliefs and practices of the Quiché Maya indicate that their roots may be found in the Book of Mormon narrative. Discusses marriage customs of the Quiché Maya. [J.W.M.]

H.430 Hunter, Milton R. "A Marvelous Work and a Wonder." IE 61 (December 1953): 930-33. The Book of Mormon fulfills prophecies of Isaiah. The phrase "marvelous work and a wonder" (used by both Isaiah and Nephi) has a three-fold meaning: the true gospel of Jesus Christ would be restored, the covenants the Lord made with the children of Israel would be fulfilled, and the records of the ancient American people would be given to all of the world. [J.W.M.]

H.431 Hunter, Milton R. "The Modern Scriptures-Our Greatest Aids." IE 58 (December 1955): 940-41. Joseph Smith's contributions to the scriptural canon include the Book of Mormon and the Doctrine and Covenants. Both are added witnesses of Jesus Christ and clarify the teachings and doctrines of Jesus Christ, including the conditions for eternal life or exaltation. [R.H.B.]

H.432 Hunter, Milton R. "Prophecies and Blessings to the Lamanites." IE 62 (December 1959): 928-31. God is beginning to fulfill his promises as recorded in the Book of Mormon that the gospel will be opened unto the Lamanites. [R.C.D.]

H.433 Hunter, Milton R. "Touring Book of Mormon Lands." In BYUSY (8 February 1955). Provo, UT: BYU Press. Relates his travels in Central America and gives his testimony of the Book of Mormon. He talks of Kaminaljuvu, the city of cement, of Bonampak's wallpaintings of light and dark Indians (Nephites and Lamanites), of a tower of preaching in Palenque, of an Egyptian-type burial, and of "Lehi's tree of life" carving in Izapa. [C.C.]

H.434 Hunter, Milton R. "Touring Book of Mormon Lands." CN 25 (15 January 1955): 6-7, 11. A group of tourists visits sites in Mexico that may be associated with the Book of Mormon; they see depictions of the bearded white God. [D.M.]

H.435 Hunter, Milton R. Untitled talk. CR (October 1958): 26-30. A testimony that the Book of Mormon fulfills prophecy found in both Isaiah 29 and 1 Nephi 13. In reference to Isaiah 2:3, Hunter writes that the word of the Lord came from Jerusalem in the Holy Bible and the law came from Zion in the Book of Mormon, the Doctrine and Covenants, and the Pearl of Great Price. [B.D.]

H.436 Hunter, Milton R. Untitled talk. CR (April 1969): 82-84. A testimony of the Book of Mormon. In D\&C 17:6 the Lord himself testified of the Book of Mormon. In D\&C 17:1 the Lord granted that Oliver Cowdery, David Whitmer, and Martin Harris would be the chosen Three Witnesses of the gold plates. Only through the Holy Ghost can anyone receive a testimony of the truth (1 Corinthians 2, Moroni 10:2-5). [B.D.] 
H.437 Hunter, Milton R. "Witnesses to the Book of Mormon." IE 73 (June 1970): 100-101. Also found in CR (April 1970): 136-38. Histories produced by American Indians during the colonial period of America contain accounts similar to those in the Book of Mormon. The Works of Ixtlilxochitl appears to be a Lamanite history. Four other books that may correspond with the Book of Mormon are The Annals of the Cakchiquels, Title of the Lords of Totonicapan, the Popul Vuh, and Anales do los Xahil. [B.D.]

H.438 Hunter, Milton R., and Thomas Stuart Ferguson. Ancient America and the Book of Mormon. Oakland, CA: Kolob Book, 1950. A comparison between the Book of Mormon and Spanish, Mexican, and Guatemalan sources, such as Works of Ixtlilxochitl, Popul Vuh, and Totonicapan. Joseph Smith translated the Book of Mormon independently, with no help from historical sources, as most lay unpublished in archives or had not reached the United States. [J.W.M.]

H.439 Hurd, Jerrie W. Our Sisters in the Latter-Day Scriptures. Salt Lake City: Deseret Book, 1987. Though few women are named in the Book of Mormon, they have had great power and influence. Specifically named are Sariah and Abish; many other women-sisters, mothers, queens-are unnamed. [J.W.M.]

H.440 Hutchins, Barbara, and Paul R. Cheesman. Pathways to the Past. Bountiful: Horizon, 1984. A travel guidebook to Middle America that links several Book of Mormon sites with present day locations. [C.C.]

H.441 Hutchinson, Anthony A. "The Word of God Is Enough: The Book of Mormon as Nineteenth Century Scripture." In New Approaches to the Book of Mormon, edited by Brent Lee Metcalfe, 1-19. Salt Lake City: Signature, 1993. The author lists five things that seem to undermine the consistency of the Book of Mormon and its basic Christian values. Members of the Church should abandon their old beliefs because understanding the book "as a fictional work of the nineteenth century scripture offers real advantages." This work is reviewed in M.308. [J.W.M.]

H.442 Hutchinson, Anthony H. "Prophetic Foreknowledge: Hope and Fulfillment in an Inspired Community." In The Word of God: Essays on Mormon Scripture, edited by Dan Vogel. Salt Lake City: Signature, 1990. Also in Sunstone 11 (July 1987): 13-20. An objection to the idea of "prophetic television" i.e., the concept that prophets can see details of the future exactly as they will happen. Prophecy, according to the writer, does not reveal objective knowledge about the future. He sees no evidence to the contrary in the Restoration today or in the past. He alleges that the Book of Mormon only contains "backdated prophecies" on events that had already occurred before the Book of Mormon was translated. He also notes that the Book of Mormon contains anachronistic elements such as using King James phraseology. [M.R.]

H.443 Huttinger, Beverly. "Asking in Faith." Ensign 17 (December 1987): 34-35. An account of an individual who gained a testimony of the Book of Mormon and converted to the LDS faith. [A.C.W.]

H.444 Hyde, John Hyde, Jr. "Analysis of the Book of Mormon, Internal and External also the Real Origin of The Book." In Hyde's Mormonism: Its Leaders And Designs, 1857, 210-283. New York: W.P. Fetridge \& Co., 1857. A former member of the LDS church attempts to show the evil designs of the Church. The Book of Mormon is beneath the dignity of God as he would not send it through a man of disrepute. Gives examples of how the Book of Mormon contradicts itself. Favors the Spaulding theory. [J.W.M.]

H.445 Hyde, W. A. "The Spirit and Influence of the Book of Mormon." IE 30 (September 1927): 988-92. The Book of Mormon is full of the Spirit of Truth. This Spirit carries the book's message to the hearts of its readers. [D.M.] 
H.446 Hyland, Richard. "The Gospel in the South Seas." MS 99 (25 November 1937): 758-59, 766. Believes that the Hawaiians, Samoans, Maoris, and other south sea peoples originated on the American Continent. The three native foods of Polynesia-the coconut, sweet potato, and taro root-are of American origin. The genealogical name lines of such widely separated peoples as New Zealand Maoris and Hawaiians unite 65 generations back to Hema who led a migration to New Zealand. Prior to Hema, the names in both Hawaiian and Maori legends are similar. [R.H.B.]

H.447 "Hyrum Smith's Book of Mormon." IE 37 (June 1934): 329. A picture of copies of the Book of Mormon. A very short paragraph on a page of a Book of Mormon owned by Hyrum and Joseph Smith with signatures to their testimony. [L.D.] 
I.001 "I Had No Idea What a Missionary Was." CN 58 (3 December 1988): 5. A conversion story of a young woman who was given a Book of Mormon and after reading it was converted to the Church. [M.D.P.]

I.002 "I Have a Question: Questions Relating to the Book of Mormon." Provo, UT: FARMS, 1991. A collection of questions and answers that relate to the Book of Mormon reprinted from issues of the Ensign 1985-91. Subjects include the tree of life, the Godhead, the "fulness of the gospel," eternal hell, and Hebraisms. [J.W.M.]

I.003 "'I Love This Work with All My Heart.' " CN 58 (25 June 1988): 4. President Benson taught that missionaries should daily read the Book of Mormon to increase their own faith and spirituality and "should use the Book of Mormon as the heart of their proselyting work and as the great converter." [M.D.P.]

I.004 Iba, Stephen K. "Elements of Effective Teaching: King Benjamin's Address." In The Sixth Annual Church Educational System Religious Educators' Symposium on the Book of Mormon, 43-44. Salt Lake City: Church of Jesus Christ of Latter-day Saints, 1982. Examines chapters of King Benjamin's speech for "elements of effective teaching." The elements include preparation, setting, use of rapport and examples, analogies, personal experiences, testimony, and challenges. [A.T.]

I.005 Ibarguen, J. Henry. Review of "The World of the Book of Mormon," by Paul R. Cheesman. Dialogue 11 (Autumn 1978): 92-94 Book review.

I.006 "Idaho Youths Grow Closer by Meeting Challenge to Read Book of Mormon." CN 57 (10 January 1987): 12. As an increasing number of youth were not reading the Book of Mormon, the leader of the congregation challenged them to read it. Forty youth completed the book. [M.R.]

I.007 "Illustrated Edition of Book of Mormon Published by Deseret Book." CN 32 (15 September 1962): 13-14. Report on Deseret Book's illustrated edition of the Book of Mormon, with a brief review of the book's publishing history. New edition includes Arnold Friberg paintings and other pictures of archaeological findings related to the Book of Mormon. [A.C.W.]

I.008 "Illustrated Stories of the Scriptures and Church History" (Series). Friend 14-21 (1984-1991). The editions that pertain to the Book of Mormon are: 1984, Vol. 14: January, June, August. 1989, Vol. 19: May, June, July, August, September, October, November. 1990, Vol. 20: January, February, March, April, May, June, August, October. 1991, Vol. 21: January, March, May, July, September, November. This series includes full-page, full-color cartoon stories from the scriptures and Church history for children. [J.W.M.]

I.009 "Impact of Book Is Dynamic, Lasting." CN 58 (31 December 1988): 6-7. Shows how the Book of Mormon has fared from its first printing to the present, in spite of intense opposition. [D.M.]

I.010 "In the Mouths of Witnesses." CN 34 (5 September 1964): 16. The Lord has always used witnesses in the establishment of his word. In the latter days he raised Joseph Smith, Oliver Cowdery, and Sidney Rigdon to testify of him. In addition to these witnesses he sent the Book of Mormon to testify of him. [J.W.M.]

I.011 "In This Time of Tumult, Iron Rod of Gospel Needed." CN 41 (10 April 1971): 8. Harold B. Lee compares the present time to Lehi's dream. "If there is any one thing we need in this time of tumult and frustration, it is the 'iron 
rod' of the gospel." [M.D.P.]

I.012 "Incan Descendant Finds Book Opens 'His' History." CN 58 (31 December 1988): 10. An expert in Mesoamerican art relates his conversion to the teachings of the Book of Mormon. "The Book of Mormon opened up our past to me just like it was a movie." [R.H.B.]

I.013 The Indian Bible. Book No. 1: The Book of Nephi. Alexandria, VA: American Indian Restoration Enterprises, 1962. A typewritten paraphrase of 1 and 2 Nephi geared especially for the American Indian. Divided into 300 verses. Emphasizes Indians as the audience to whom the messages are addressed. Refers to God and Christ as "the Great Spirit." [D.M.]

I.014 "Indian Mounds and Traditions." Juvenile Instructor 14 (15 May 1879): 110. Refers to a rare work by Reverend William O'Brien, entitled A Narrative of Travels in the United States of America, in which he describes ruins and Indian mounds in Ohio and quotes a "civilized Indian" who claims that biblical beliefs were once understood by his ancestors. [D.M.]

I.015 "Indian Relics." Juvenile Instructor 6 (8 July 1871): 110. Claims that archaeological finds of a Dr. Van Patten verify the Book of Mormon. [D.M.]

I.016 "Interesting Admissions by 'Deseret News.'” SH 52 (9 August 1905): 769-70. RLDS author wishes that the "Utah Mormons" would admit that the Book of Mormon strictly forbids plural marriage. [J.W.M.]

I.017 "Interesting Clipping." CN 35 (11 September 1965): 6. Reprint of article from 5 July 1965 El Paso Times entitled "Chiapas Find of Relevance to Document." Discusses archaeological evidence for the Book of Mormon, specifically a carving of six people in "near east clothing" discussing the tree of life: the three name glyphs have been translated as "Lehi," "Soriah," and "Nephi." [A.C.W.]

I.018 "An Interesting Volume." Contributor 4 (May 1883): 314-16. A specific copy of the first edition of the Book of Mormon was used in the conversion process of prominent men such as Brigham Young, Heber C. Kimball, and John P. Green. Describes the format of the first edition and reprints the preface and first page. [B.D.]

I.019 International Truth Distributors. Latest Light on Joseph Smith's Golden Plates. Los Angeles, CA: International Truth Distributors, 1928. Argues against Joseph Smith and the Book of Mormon, stating that the witnesses of the Book of Mormon plates did not testify that the plates contain truth, just that they saw them. [J.W.M.]

I.020 "An Interview with Last Book of Mormon Witness." DN Church Section (11 July 1931): 3, 8. Reprinted from the Kansas City Journal, June 5, 1881. A reporter interviews David Whitmer regarding his role as a witness, the gold plates, and his testimony of the Book of Mormon. [D.W.P.]

I.021 Introduction to the First Book of Nephi. Independence, MO: Zarahemla Research Foundation, 1986. Gives a brief overview of the setting and author of 1 Nephi up to the period of Lehi's examination of the plates of brass. Includes notes and comments on the first several verses of 1 Nephi, including a discussion of Hebrew terms. [D.M.]

I.022 "An Invitation." IE 26 (August 1923): 951. An invitation to read the Book of Mormon. Presents an overview of the coming forth of and contents of the Book of Mormon. [L.D.] 
I.023 An Invitation to Read the Book of Mormon. Independence, MO: n.p., 1970?. A four-page tract recommending three methods of studying the Book of Mormon: (1) Read it from cover to cover; (2) read the chronological highlights; and (3) read selected doctrinal passages. [D.M.]

I.024 Ireland, H. "The Book of Mormon." MS 74 (11 July 1912): 440-42. A testimony of the Book of Mormon. The Book of Mormon is not superior or inferior to the Bible-it contains the will of the same God. Many truths lost from the Bible are restored in the Book of Mormon. Through prayer a sincere person can know if it is true. [B.D.]

I.025 Ireland, H. "Good Roads in Book of Mormon Times." Liahona 24 (7 September 1926): 132-33. Draws a parallel between archaeological finds and 3 Nephi. Evidence indicates that the Mayan civilization flourished near the beginning of the Christian era. For instance, Mayan road building rivaled that of Rome in the same period. This period coincides with 3 Nephi 6:8, A. D. 29-30, which describes the advanced state of civilization and large scale road building. [C.C.]

I.026 "Iron Sword from the Time of Jeremiah Discovered near Jericho." Ensign 17 (June 1987): 57. Reports an archaeological find of an iron (or primitive steel) sword, perhaps dating to the time of King Josiah. Demonstrates that such workmanship as the sword of Laban existed at the time. [D.M.]

I.027 Irvine, Arnold. "This Week in Church History: Joseph Receives Plates." CN 35 (25 September 1965): 16. Retells the story of Joseph Smith receiving the gold plates on September 22, 1827. [A.C.W.]

I.028 Irving, Gordon. "The New Translation." CN 50 (6 December 1980): 16. The story of the translation of the Book of Mormon into Spanish. [M.D.P.]

I.029 Irwin, W. G. "The Home of an Unknown Race." MS 62 (March 1900): 198-99. A reprint from Scientific American. It is a description of an old fort found in the Ohio valley that belonged to a highly civilized ancient people. [J.W.M.]

I.030 "Is the Mormon Figure Lehi Connected with Prophetic Inscription near Jerusalem?" (containing a letter from Donna Cochran and a response from the editor). Biblical Archaeology Review 14 (November-December 1988): 19. Frank Cross of Harvard disassociates Beit Lei (erroneously known by some as "Beit Lehi") with the Book of Mormon Lehi. [D.M.]

I.031 "Is This What Mormons Base Their Faith upon? Joseph Smith Jr. as a Translator." Christ Church News 19 (May 1963): 3. Considers the verdict of the Egyptologists against the Book of Abraham in 1912 to be a sufficient control to repudiate the Book of Mormon. [D.M.]

I.032 "Israel Cave, Mexican Plates Discussed at Meet." CN 41 (23 October 1971): 6. Professors meet to discuss the Khirbet Beit Lei (Lehi) Cave, which has "ancient inscriptions in the old Hebrew script" along with drawings of human figures and sailing vessels. Small gold plates were found in Mexico. Such archaeological discoveries support the Book of Mormon. [M.D.P.]

I.033 "It Is Verily True." CN 44 (21 September 1974): 16. It took a series of miracles to restore the Book of Mormon. Knowledge of the Book of Mormon has spread around the world. [M.R.]

I.034 "Items about the Book of Mormon." Relief Society Magazine 10 (September 1923): 431. Lists the languages into which the Book of Mormon had been translated up to 1923. Dates and places of publication are included. 
[J.W.M.]

I.035 "Items of Interest Concerning the Book of Mormon." Relief Society Magazine 14 (September 1927): 430-32. An excerpt taken from a letter from Professor Hall of Cornell University to George H. Brimhall states that the Book of Mormon was one of the most famous, most widely discussed books ever published in America. [J.W.M.]

I.036 Iverson, Heber C. "Testimony of the Three Witnesses." DN (25 May 1935): 4, 7, 8. The Aaronic Priesthood was restored May 15, 1829, as a result of the translation of the book of Mormon. Includes testimonies of Oliver Cowdery, David Whitmer, and Martin Harris. [J.W.M.]

I.037 Iverson, Heber C. "The Three Witnesses." MS 97 (June 1935): 386-87, 394-96. Includes a reprint of the testimony of the Three Witnesses from the Book of Mormon, a report of Oliver Cowdery's testimony given at the conference at Council Bluffs, his testimony at the time of his death in David Whitmer's home, David Whitmer's rebuttal to John Murphy, William Harrison Homer's interview with Martin Harris, and Harris's testimony given in Salt Lake City and in Clarkston, Utah, just prior to his death. [J.W.M.]

I.038 Ivimy, John. "A Modern Parallel." In Ivimy’s The Sphinx and the Megaliths, 1975, 183-190. New York: Harper and Row, 1975. Compares the Mormons and their Book of Mormon to Egyptians who sent out colonists with their deceptions over large land masses. Finds that the Book of Mormon is a grand fraud written by Joseph Smith. [J.W.M.]

I.039 Ivins, Anthony W. "Are the Jaredites an Extinct People?" IE 6 (November 1902): 43-44. Argument for Book of Mormon authenticity. The Mayan and Egyptian hieratic alphabets are similar. The Chiapas claim descent from the "Lord of the Hollow Wood" who was at the tower of Babel. Jared was at the tower and crossed the ocean in "hollow wood" that was tight like a dish. [C.C.]

I.040 Ivins, Anthony W. "The Book of Mormon." Relief Society Magazine 14 (August 1927): 384-88. Retells the story of the angel Moroni showing the gold plates to Joseph Smith. The recent discovery of gold plates and steel represent external evidences of the truthfulness of the book. [J.W.M.]

I.041 Ivins, Anthony W. "The Book of Mormon Bears Witness of Christ." MS 89 (29 September, 6 October 1927): 609-14, 625-31. Church members are exhorted to live righteously and to know doctrine and Church history well enough to defend their faith. Testifies that the Redeemer appeared on this continent. [B.D.][C.C.]

I.042 Ivins, Anthony W. "The Book of Mormon Divine." MS 91 (30 May 1929): 337-43, 345-47. Addresses criticisms of the Book of Mormon, especially by John Fisk, who wrote that the Book of Mormon in "blissful ignorance, introduces oxen and sheep, as well as the knowledge of smelting iron, into pre-Columbian America." Ivins quotes A. Hyatt Verril who found "a steel or hardened iron implement" on the Isthmus of Panama, cites evidence of oxen and horses discovered in the asphalt pits of Los Angeles, and gives evidence of the use of pearls and the use of engraven metal plates not only by ancient Americans but by many peoples throughout the world. [B.D.]

I.043 Ivins, Anthony W. "Cumorah: A Mute Witness of Epochal Events." MS 90 (May 1928): 289-95. In connection with the 1928 Church acquisition of the Hill Cumorah, Ivins speaks concerning the records that make up the Book of Mormon, including the brass plates, consisting of the Pentateuch, Isaiah, and Jeremiah; the large and small plates of Nephi; and the twenty-four gold plates of the Jaredites. [C.C.] 
I.044 Ivins, Anthony W. "The Hill Cumorah." IE 31 (June 1928): 675-811. A report reviewing historical events dealing with the Hill Cumorah. The author recounts the history of the Nephite plates from the time Nephi began inscribing on them to when Ammaron turned them over to Mormon, followed by Moroni's acquisition of the plates and their placement in Hill Cumorah. Reference is also made to the sealed plates yet to be translated. [D.M.]

I.045 Ivins, Anthony W. "Multiplicity of Evidences Prove Divine Authenticity of the Book of Mormon." Liahona 14 (October 1916): 241-47. Response to criticism that Joseph Smith fabricated the Book of Mormon from his own milieu. It is unlikely that Joseph Smith could have realized the following points: the American Indians possess a number of legends that suggest an Israelite origin, including stories regarding the creation of the earth, the temptation of the first man and woman by a serpent, and Cain and Abel. Cement, mentioned in the Book of Mormon (Helaman 3:7, 9), was the primary building material of an ancient community that existed 40 miles north of present day Mexico City. [C.C.]

I.046 Ivins, Anthony W. The Relationship of "Mormonism" and Freemasonry. Salt Lake City: Deseret News, 1934. The LDS church is founded upon the principles of the Book of Mormon. The Book of Mormon is not a "Golden Bible" nor does it take the place of the Bible. It is not associated with secret societies, but condemns the same. [J.W.M.]

I.047 Ivins, Anthony W. Untitled talk. CR (April 1909): 57-62. A refutation of an attack on Mormonism and a testimony that the Book of Mormon is true. Hubert Howe Bancroft saw a tablet of stone with the ten commandments inscribed on it in Hebrew, which was found in a mound in Ohio. The pyramids of ancient America resemble the pyramids of the Egyptians and the Maya language resembles the Egyptian language according to professor Leplongeon. [B.D.]

I.048 Ivins, Anthony W. Untitled talk. CR (October 1920): 46-53. Teaches concerning the doctrine of mercy, repentance, and forgiveness, using Corianton, the son of Alma, as an example. [D.W.P.]

I.049 Ivins, Anthony W. Untitled talk. CR (April 1921): 18-21. Announces changes to the 1921 edition of the Book of Mormon. It has double columns, which reduced the size by one hundred pages, brief synopses of the books' contents, a list of the names and order of the books, revised footnotes, a pronouncing vocabulary, and an improved index. [J.W.M.]

I.050 Ivins, Anthony W. Untitled talk. CR (October 1923): 139-47. Refutes the charge of Mormon critics that Mormons do not teach Christ. Cites the title page and several passages of the Book of Mormon to indicate that the basic purpose of the book is to stand with the Bible as a second witness of Jesus Christ. [R.C.D.]

I.051 Ivins, Anthony W. Untitled talk. CR (April 1929): 8-16. Defends the Book of Mormon by answering major objections raised by critics. Cautiously he presents evidences of precolumbian usage of steel, domesticated animals (sheep, ox, horse), beautiful pearls, goldsmithing, and writings on plates of gold (with metal rings). Book of Mormon geography is also considered. [R.C.D.]

I.052 Ivins, Antoine R. "The Gospel and the Lamanites." Relief Society Magazine 25 (July 1938): 433-35. The Church has long been interested in the American Indians because they are descendants of Book of Mormon people. [K.M.]

I.053 Ivins, Antoine R. "The Lamanites." Relief Society Magazine 37 (August 1950): 507-14. The Book of Mormon devotes a major part of its account to discussing the Lamanite nation. It is a mistaken idea that all the indigenous groups of people who were found in America following the landing of Christopher Columbus were Lamanites. A testimony is not based on the external but internal evidences of the Book of Mormon. [J.W.M.] 
I.054 Ivins, Antoine, R. Untitled talk. CR (9 April 1939): 128-31. The greatest knowledge one receives concerning Christ comes from the New Testament and the Book of Mormon, which is "a new witness for God." The sure way to know of the Book of Mormon's veracity is through Moroni's promise. [J.W.M.] 
J.001 J., W. "Stray Thoughts." Juvenile Instructor 18 (15 June 1883): 182-83. Notes the ill treatment and antagonistic attitude of the white people toward the Indians. According to the Book of Mormon the Indians have a glorious destiny and the LDS are urged to treat them with consideration. [D.M.]

J.002 Jackson, Kent P. "The Beginnings of Christianity in the Book of Mormon." In The Book of Mormon: The Keystone Scripture, edited by Paul R. Cheesman, S. Kent Brown, and Charles D. Tate Jr., 91-99. Provo, UT: Brigham Young University Religious Studies Center, 1988. Gives scriptural reasons why the Book of Mormon prophets who lived before Jesus' birth possessed and taught Christian teachings. Christological understanding was new to Lehi and Nephi and their knowledge unfolded at intervals. The sermons and reflections about Christ by Lehi, Nephi, and Jacob influenced subsequent Lehite prophets. [D.M.]

J.003 Jackson, Kent P. "Christ and the Jaredites." In Studies in Scripture: Alma 30 to Moroni, edited by Kent P. Jackson, 245-58. Salt Lake City: Deseret Book, 1988. Comments on how the Nephites and Mulekites became aware of the Jaredites. Focuses on Ether 1-4 and the supreme role played by the brother of Jared (Mahonri Moriancumer). Discusses Ether 3:15, the appearance of Jesus to the brother of Jared. [D.M.]

J.004 Jackson, Kent P. "The Lamanite Converts Firm in the Faith of Christ." In Studies in Scripture Vol. 7: 1 Nephi to Alma 29, edited by Kent P. Jackson, 335-45. Salt Lake City: Deseret Book, 1987. A chronicle of events found in Alma 24-29, which contrasts the behavior of the Amalekites and Amulonites with the converted Lamanites. Many spiritual lessons are to be learned in these chapters. [D.M.]

J.005 Jackson, Kent P. "Latter-day Saints: A Dynamic Scriptural Process." In The Holy Book in Comparative Perspective, edited by F. Denny and R. Taylor, 63-83. Columbia, SC: University of South Carolina Press, 1985. An essay dealing with the Latter-day Saint concept of scripture. Contains a section on the Book of Mormon, describing its origin, contents, and intention. Emphasizes its truthfulness and equality with the Bible in the LDS canon. [D.M.]

J.006 Jackson, Kent P. "Nephi and Isaiah." In Studies in Scripture: 1 Nephi to Alma 29, edited by Kent P. Jackson, 13145. Salt Lake City: Deseret Book, 1987. Discusses the idea of likening scripture to one's own situation. Lists Isaiah's three major themes and explains why modern people have difficulty understanding the prophet. Outlines the Isaiah passages quoted in the Book of Mormon by topic. [D.M.]

J.007 Jackson, Kent P. "Neum." In Encyclopedia of Mormonism, edited by Daniel H. Ludlow, 3:1006. 5 vols. New York: Macmillan, 1992. Neum, mentioned once in the Book of Mormon, was an Israelite prophet that prophesied of different aspects of Christ's mortal mission. [A.T.]

J.008 Jackson, Kent P." 'Never Have I Shown Myself unto Man.' A Suggestion for Understanding Ether 3:15a." BYU Studies 30 (Summer 1990): 71-76. A presentation of several interpretations of Ether 3:15, which discusses the appearance of Jesus to the brother of Jared. Jackson holds that while Christ had previously appeared to several pre-Jaredite prophets as Jehovah, the Father, he appeared for the first time in his role as Jesus Christ, the Son, and this was because of the exceeding faith of the brother of Jared. [J.W.M.] 
J.009 Jackson, Kent P. "Nourished by the Good Word of God." In Studies in Scripture: 1 Nephi to Alma 29, edited by Kent P. Jackson, 185-95. Salt Lake City: Deseret Book, 1987. Refers to the prophet Zenos and discusses the importance of the scattering and gathering of Israel in salvation history, and then gives a brief step by step interpretation of the allegory of the olive tree in Jacob 5. [D.M.]

J.010 Jackson, Kent P. "Teaching from the Words of the Prophets." In Studies in Scripture: Alma 30 to Moroni, edited by Kent P. Jackson, 196-207. Salt Lake City: Deseret Book, 1988. Deals with Jesus' quotations of Malachi in 3 Nephi 24-25. Several themes are emphasized, including the purification of the sons of Levi, and the significance of the sealing keys restored by Elijah. [D.M.]

J.011 Jackson, Kent P. "The Tree of Life and the Ministry of Christ." In Studies in Scripture: 1 Nephi to Alma 29, edited by Kent P. Jackson, 34-43. Salt Lake City: Deseret Book, 1987. Features an overview of the images in Lehi's vision of the tree of life and presents specific concepts about Jesus and his mission in the same vision. Discusses the condescension of both the Father and the Son. [D.M.]

J.012 Jackson, Kent P. "Zenock." In Encyclopedia of Mormonism, edited by Daniel H. Ludlow, 4:1623. 5 vols. New York: Macmillan, 1992. Nephi, when teaching his family from the words of previous Israelite prophets, mentions Zenock as prophesying about the earthly mission of Jesus Christ. [A.T.]

J.013 Jackson, Kent P., ed. Studies in Scripture Vol. 7: 1 Nephi to Alma 29. Salt Lake City: Deseret Book, 1987. An collection of essays on themes from the first half of the Book of Mormon. This work is reviewed in R.258. [D.M.]

J.014 Jackson, Kent P., ed. Studies in Scripture Vol. 8: Alma 30 to Moroni. Salt Lake City: Deseret Book, 1988. A collection of essays on themes found in the second half of the Book of Mormon. [D.M.]

J.015 Jackson, Kent P., and Darrell L. Matthews. "Built upon Christ's Gospel." In Studies in Scripture: Alma 30 to Moroni, edited by Kent P. Jackson, 208-17. Salt Lake City: Deseret Book, 1988. Deals with the final four chapters of 3 Nephi, specifically analyzing the name of the Church, a definition of the gospel, the translated Three Nephites, and Mormon's counsel to modern readers not to reject revelation and miracles. [D.M.]

J.016 Jackson, Kent P., and Darrell L. Matthews. "The Lamanite Converts Firm in the Faith of Christ." In Studies in Scripture: 1 Nephi to Alma 29, edited by Kent P. Jackson, 335-45. Salt Lake City: Deseret Book, 1988. A chronicle of events found in Alma 24-29, which includes the contrasting behavior of the Amalekites and Amulonites with the converted Lamanites. Many lessons can be learned from these chapters by the modern day reader. [D.M.]

J.017 Jackson, Kent P., and Morgan W. Tanner. "Zeniff and Noah." In Studies in Scripture: 1 Nephi to Alma 29, edited by Kent P. Jackson, 230-39. Salt Lake City: Deseret Book, 1987. Contrasts the righteous ways of Zeniff with the evil doings of King Noah, and then discusses the consequences of righteousness and evil. Provides comments on the character and message of Abinadi. [D.M.]

J.018 Jackson, Valton E., and W. Russell Palfreyman. "Biblical Knowledge in Early America." MS 112 (May 1950): 136-37. Quotes exclusively from Dewey Farnsworth's The Americas before Columbus and the scriptures (Genesis 49:22-26, John 10:16) to show that American Indians are descended form the House of Israel and were acquainted with biblical stories (e.g., House of Noah, Abraham, Jacob) prior to contact with Europeans. [A.C.W.]

J.019 "Jacob and Sherem." Friend 20 (February 1990): 8-10. An illustrated story for children about Jacob and Sherem. [M.D.P.] 
J.020 Jacob, Maude Beeley. Through the Book of Mormon, Pupil's Manual. Salt Lake City: LDS Department of Education, 1941. A manual for young LDS students that contains twenty-nine lessons taken from selected texts in the Book of Mormon. Contains lesson ideas, study devices, projects, poems, and illustrations. [D.M.]

J.021 Jacobs, L. R. Mormon Non-English Scriptures, Hymnals and Periodicals 1830-1986: A Descriptive Bibliography. Salt Lake City: n.p., 1991. An alphabetical listing of translations of the Book of Mormon, including editions from both the LDS and RLDS churches. Also includes an example of the script of the language and photocopies of the cover and/or title page. [J.W.M.]

J.022 Jacobs, Leone O., and Edith S. Elliot. "Visiting Teaching Messages: Book of Mormon Gems of Truth." Relief Society Magazine 38-44 (July 1951-February 1957). Monthly Book of Mormon lessons for adult women (Relief Society). Each month a verse of Book of Mormon scripture is presented with accompanying quotes from General Authorities and writers of the Church. [J.W.M.]

J.023 Jakeman, M. Wells. "American Anthropology and Book of Mormon." DN Church Section(25 June 1938): 3, 6. Analyzes American anthropology, and concludes that recent findings correspond with Book of Mormon descriptions. [M.D.P.]

J.024 Jakeman, M. Wells. "Ancient American Religious Art." UASN 4 (20 January 1952): 9. Ancient art objects in the Americas correspond to Book of Mormon symbols, i.e., the brazen serpent and the tree of life. [D.M.]

J.025 Jakeman, M. Wells. "Ancient Maya Hieroglyphic Writings and Their Decipherment and Study." UASN 44 (27 September 1957): 2-4. Also in Christensen, Ross T. Progress In Archaeology: An Anthology, 128-30. The Book of Mormon records that there are records "of every kind" written (Helaman 3:15). Ancient Maya hieroglyphs are found on stelae, codices, vases, and on walls and steps of temples. The Mayan calendar found to be more accurate than its European counterpart dates to pre-Book of Mormon times. It is difficult to correlate it with the European calendar. [J.W.M.]

J.026 Jakeman, M. Wells. "The Ancient Middle-American Calendar System: Its Origin and Development." UASN 31 (9 December 1955): 1-2. Evidence shows that in middle America the calendar was first developed in the LehiteMulekite period. Calendars duplicate the ancient Israelite system. There is evidence of a final migration from Central America into Mexico that corresponds with the final migration of the Nephites in A.D. 327. The birth of the Christ-like god took place on April 6, A.D. 2, in correspondence with Joseph Smith's revelation (D\&C 20:1). [J.W.M.]

J.027 Jakeman, M. Wells. "The Book of Mormon Civilizations in Space and Time." UASN 22 (August 1954): 1-5. An abstract of lectures given June 21-24. Before applying the "comparative archaeological test to the Book of Mormon," one must first be sure to deal with the correct area and period. The Tehuantepec area in Mesoamerica is by far the likely area. A sketch of the history of Mesoamerican archaeology establishes that only in recent years has material of the correct (Pre-Classic) era been available for analysis. Definite correspondences (not detailed) with the Book of Mormon account are evident. [J.L.S.]

J.028 Jakeman, M. Wells. "The City Bountiful Found?" UASN 22 (23 August 1954): 4-6. Defends the thesis that Bountiful was located in the "northernmost part of Central America, including the Isthmus of Tehuantepec." [D.M.]

J.029 Jakeman, M. Wells. The Complex "Tree of Life" Carving on Izapa Stela 5. Provo, UT: n.p., 1958. A booklet containing an analysis of the tree of life and other figures and depictions on Izapa Stela 5. Illustrations are 
provided. This work is reviewed in G.031. [D.M.]

J.030 Jakeman, M. Wells. Discovering the Past: Introductory Readings and Visual Studies in Archaeology. Provo, UT: University Archaeological Society, 1954. Guide for the beginning archaeology student. The Book of Mormon stands in conflict with popular explanations of the origins of the American people. Archaeology has confirmed the value of Homer's writings as well as the Bible. It has similar value for the Book of Mormon. Cultures found by archaeologists seem to fit Nephite cultures. [J.W.M.]

J.031 Jakeman, M. Wells. "An Expedition to Central America." IE 53 (February 1950): 113-14, 144-47. Describes an archaeological expedition in January and February, 1948, to the Xicalongo Gulf Coast area of a district of western Campeche. Provides descriptions of the area's flora and fauna, the hardships of the expedition, and findings of relatively new early "pre-classic" civilizations. [R.C.D.]

J.032 Jakeman, M. Wells. "Is Book of Mormon Archeology Valid? An Exchange of Letters." UASN 34-35 (30 April 1956; 8 June 1956): 4-6, 1-4. An anonymous Los Angeles physician inquires as to the historicity of the Book of Mormon. Jakeman replies that archaeological evidences of Mexico and Central America do not "disprove the Book of Mormon history" but appear "to establish it, to a high degree of probability." Jakeman admits that his findings are preliminary. [D.W.P.]

J.033 Jakeman, M. Wells. "Izapa Stela 5 and the Book of Mormon." In Book of Mormon Institute, edited by Dee F. Green, 47-53. Provo, UT: Extension Publications, 5 December 1959. Three useful areas of correspondence between the Book of Mormon and modern science are geography, chronology, and similarities in culture traits. The Stela 5 depiction of the tree of life presents an arbitrary correspondence to the images in 1 Nephi 8. [D.M.]

J.034 Jakeman, M. Wells. "Izapa Stela 5 and the Book of Mormon." Instructor 96 (December 1961): 410-11, 429. A representation of the "tree of life" was found in a carving on a large stone monument in Southern Mexico at the ruin site of Izapa. It was the fifth of carved stone slabs located in the temple courts. The art style is pre-Mayan. It appears to represent two cherubim or Near Eastern-type figures, six figures that surround the tree, and a river of water. Two name glyphs were discovered and translated into the names Lehi and Nephi. [J.W.M.]

J.035 Jakeman, M. Wells. "The Main Challenge of the Book of Mormon to Archaeology; and a Summary of Archaeological Research to Date Giving a Preliminary Test of Book of Mormon Claims." UASN 22.01 (23 August 1954): 2-4. Finding vast numbers of remains of both cultural and skeletal materials at archaeological sites is the main challenge to Book of Mormon archaeology. Further, these materials must match with Book of Mormon accounts in dating period, geographical area, and description. Excavations in Mexico and Central America have been made since 1830 that actually date according to the Book of Mormon period. [J.W.M.]

J.036 Jakeman, M. Wells. "The Mesoamerican Pantheon." UASN 16 (1 December 1953). There are eighteen different aspects of Yahweh or Jehovah that are duplicated by the Life and Rain gods, Itzamna-Chac of Mayan culture and Quetzalcoatl-Tloloc of Central Mexico. There are too many similarities for this to be an accident. There is much evidence to show that pagan practices developed among the Lamanites in a late period. Idolatrous gods were added that are identifiable with Near Eastern gods. [J.W.M.]

J.037 Jakeman, M. Wells. "Non-Mormon Archaeologists and the Book of Mormon, a Further Reply." UASN 57 (25 March 1959): 4-5. Non-Mormon archaeologists do not use the Book of Mormon as an archaeological guide, as some well-meaning Mormons have claimed. The Book of Mormon does not claim that all Indians are Lamanites. [D.M.] 
J.038 Jakeman, M. Wells. "A Possible Remnant of the Nephites in Ancient Yucatan." In Papers of the Fifteenth Annual Symposium on the Archaeology of the Scriptures, edited by Ross T. Christensen, 110-19. Provo, UT: Brigham Young University, 1964. Evidences from archaeology and early historical sources are provided that show that the "Itzas," an ethnic group in prehispanic Yucatan, show at least nineteen similarities to the Nephites of the Book of Mormon. "We are justified in concluding that there is much more than a possibility that the Itzas were a remnant of the Nephites ... who had migrated to Yucatan in the third century A.D., thereby escaping" the destruction of their fellows. [J.L.S.]

J.039 Jakeman, M. Wells. "Present Trends in Maya Research." DN Church Section (27 August, 1938): 1, 7, 8. Presents the trends, theories, and accomplishments of ancient American researchers and how their research on the American Indians compares with the Book of Mormon story. [M.D.P.]

J.040 Jakeman, M. Wells. "Progress of 1961 Excavations at Aguacatal." 13th Annual Symposium on Archaeology of the Scriptures (1 April 1961): 60-68. There are many possible sites for the Book of Mormon city Bountiful and its temple. One possible site is Aguacatal, which in many respects is similar to the descriptions of Bountiful in the Book of Mormon. [J.W.M.]

J.041 Jakeman, M. Wells. "Progress of Archaeology in Book of Mormon Lands." UASN 22 (23 August 1954): 2-4. Archaeological information about Book of Mormon lands has come to light largely since 1830. Since 1910 excavations have revealed the existence of two pre-classic periods in Mexico and Central America: "Early preclassic" or "lower archaic" and "late pre-classic" or "upper archaic." Correspondences in these sites have been found in the Book of Mormon in areas, time or period, number and order, and characteristics. [D.M.]

J.042 Jakeman, M. Wells. Review of An Approach to the Book of Mormon, by Hugh W. Nibley. UASN 40 (30 March 1957): 1-11. Book review.

J.043 Jakeman, M. Wells. "The 'Star of David' in Ancient America?" SEHA 130 (June 1972): 1-10. A star of David, a relic of the Mayan civilization during the late classic period (650-950 C. E.), has been located at Uxmal in Yucatan. While the star "is not [a] direct evidence of an Old World origin of the ancient American civilizations, it does add to the evidence of occasional transoceanic voyages to the New World before Columbus." [D.M.]

J.044 Jakeman, M. Wells. "Stela 5, Izapa, as 'The Lehi Tree of Life Stone'; A Reply to Recent Attacks." SEHA 104 (29 November 1967): 2-11. Response to a critic who attempts to discredit Jakeman's study proposing that the Stela 5 is a depiction of Lehi's vision of the tree of life. Points out that the critic is unaware of the technical intricacies of Mesoamerican archaeology. [D.M.]

J.045 Jakeman, M. Wells. Stela 5, Izapa, Chiapas, Mexico. Provo, UT: UASN, 1958. A detailed commentary on Stela 5 , beginning with some comparisons of Near Eastern depictions of the tree of life and continuing with a long section identifying points of contact with the tree of life parable in 1 Nephi. Some illustrations are included. [D.M.]

J.046 Jakeman, M. Wells. "The Time Perspective in Ancient Mexico and Central America." IE 46 (August 1943): 470-71, 504-5. In the study of ancient civilizations in Mexico and Central America two facets should be considered-important geographical locations and the chronological factor. This article is interested in the latter concern, discussing the sequential relationship of civilizations in a given area, and the "absolute chronology" as measured by the Western calendar. [D.M.] 
J.047 Jakeman, M. Wells. "An Unusual Tree-of-Life Sculpture from Ancient Central America." Bulletin of UASN 4 (March 1953): 26-49. An early description of Stela 5 from Chiapas, Mexico, which depicts a tree of life motif. Compares features on the stone that correspond to similar artistic objects in Mesopotamia. Relates Stela 5 to the tree of life vision in 1 Nephi and concludes that Stela 5 was influenced by the Book of Mormon tree of life story. [D.M.]

J.048 Jakeman, M. Wells. "Volcanoes in the Book of Mormon." UASN 8 (25 November 1952). Theorizes that the cataclysm in 3 Nephi resulted from a volcano (or several volcanoes) that are located near the central part of the narrow neck of land. [D.M.]

J.049 Jakeman, M. Wells. "Which Is the Way? A Reply to Dee F. Green's Book of Mormon Archaeology: The Myths and the Alternatives." SEHA 117 (December 1969): 1-6. A response to Green's 1969 attack (in Dialogue) on the "geographical-historical" approach to the Book of Mormon, which he attributed to Jakeman. Jakeman defends the logic and accomplishments of his approach (that he prefers to call "historic-archaeological"), taking umbrage at Green's implications of intellectual dishonesty in his labor. Ends by emphasizing his aim "for a conclusive determination of the authenticity of the Book of Mormon," which can only be done his way. [J.L.S.]

J.050 Jakeman, M. Wells. "Who Were the Mayas?" IE 43 (February 1940): 78-79, 119-20. Also in A Book of Mormon Treasury, 157-66. Salt Lake City: Bookcraft, 1959, 2nd printing 1976. Recounts some of the archaeological discoveries found in Central and South American sites that date before the advent of the Aztecs and the Mayas. Archaeological exploration and the Book of Mormon provide clues as to the origin of the Maya people. [A.T.]

J.051 Jakeman, M. Wells, and Bernhart Johnson. "Israelite-Phoenician Commercial Relations and the Voyage of Mulek to the New World." SEHA 140 (March 1977): 1-9. During the Solomonic period and after, Israel enjoyed international trade alliances with the Phoenicians. The Phoenician influence is found in the architecture of Israel as well as religious symbols. The authors conclude that Mulek, the son of King Zedekiah, fled Israel with Phoenicians to the New World. There are several artifacts in the New World of Phoenician origin. [W.D.M.]

J.052 Jaques, John. "Salvation." MS 15 (1 October 1853, 8 October 1853): 649-53, 657-61. An imaginary dialogue between two individuals. Tells the story of the coming forth of the Book of Mormon, gives a brief description of the book's contents, and names the languages into which the book has been translated. [D.M.]

J.053 James, Coleen S. A Foe Beyond Reach. Bountiful, UT: Horizon, 1983. A novel based on the 25th to 31st years of the judges. Includes a table showing where specific allusions to the Book of Mormon are found. [D.M.]

J.054 James, Rhett Stephens. "Harris, Martin." In Encyclopedia of Mormonism, edited by Daniel H. Ludlow, 2:57476. 5 vols. New York: Macmillan, 1992. Contains a brief summary of Martin Harris's life. It includes details concerning his involvement with the Book of Mormon: assistance with the translation, taking a transcription to Charles Anthon, work as scribe, his 1829 prophecy that the Book of Mormon would be preached in England, and his experiences in becoming a witness to the Book of Mormon. [A.T.]

J.055 James, Uncle. “God's Great Men: Nephi." MS 50 (27 February 1888): 132-34. Nephi was young, probably under twenty years old, when he became a "pioneer and leader of the family." He was obedient, he was courageous in confronting Laban, and he never questioned or complained. [J.W.M.] 
J.056 Jamison, George M. "Importance of the Book of Mormon." SH 65 (6 November 1918): 1082-83. The whole earth should hear the important message of the Book of Mormon. In it God warns of future events, reveals eternal truths, and promises lasting benefits to those who comply with its precepts. Its principal concepts are faith, repentance, baptism by immersion, and remission of sins through the Holy Ghost. [J.W.M.]

J.057 Janetski, Joel C. Review of The Geography of Book of Mormon Events: A Source Book, by John L. Sorenson. Review of Books on the Book of Mormon 3 (1991): 150-53. Book review.

J.058 "Jaredite Barges." The Junior Witness in The Witness 72 (Spring 1992): 3. This article on the Jaredites has a photograph of a model of the possible construction of the Jaredite boats. [J.W.M.]

J.059 "The Jaredites Leave Babel." Friend 20 (April 1990): 20-21. An illustrated story for children about the Jaredites leaving Babel and preparing to cross the sea. [M.D.P.]

J.060 Jarrard, Jack E. "Book of Mormon Message Rings True to Lamanite." CN 39 (1 March 1969): 11. Lucio Rivera of Peru tells of his conversion to Jesus through reading the Book of Mormon and prayerful consideration. The Book of Mormon contains a promise to the Lamanites that was fulfilled in the life of Lucio. [J.W.M.]

J.061 Jarrard, Jack E. "Old New World Similarities Told." CN 40 (17 October 1970): 5. Archaeologist Cyrus H. Gordon discussed the two-way traffic between the Old and New World before the Christian era. [J.W.M.]

J.062 Jarrard, Jack E. "Story of Ancients Told in Latin American Ruins." CN 25 (April 1969): 3, 8-9. Presents recent Book of Mormon research and findings of Paul R. Cheesman. Includes photographs of ancient Latin American architecture. [J.W.M.]

J.063 Jarrard, Jack E." 'Word' Rolls Out in Many Languages." CN 41 (27 February 1971): 5. The Book of Mormon has been translated and printed in 24 different languages. It has also been translated but not printed into nine others. [M.R.]

J.064 Jarvis, Wesley. A Nation Born in a Day. Provo, UT: n.p., 1976. A doctrinal treatise that attempts to show that the Japanese are descendants of the house of Israel, some of whom may be descended from Lehi, a Book of Mormon prophet. [M.R.]

J.065 Jenkinson, S. W. "Land of America; the Past, the Present, the Future." Utah Monthly Magazine 9 (October 1892, November 1892, December 1892): 34-36, 74-77, 102-4. Discusses Columbus's discovery of America, the origin of the American Indians as taught by the Book of Mormon, and the fulfillment of prophetic statements concerning America. [D.M.]

J.066 Jennings, Lillie, et. al. Stories from the Book of Mormon. Independence, MO: Herald House, 1956. Book of Mormon stories, geared to small children, are written by several authors. [D.M.]

J.067 Jensen, De Lamar. "The Popol Vuh and the Book of Mormon." UASN 16 (1 December 1953): 1-2. A discussion of the sacred Popul Vuh, or "book of the People," written in Maya-Quiché by a learned Quiché in the 16th century. The Popul Vuh deals with the history of the world and of the Quiché people. It has etiologic similarities with the Book of Mormon and points of contact with the Bible and the Pearl of Great Price. By way of example, the Quiché people trace their ethnic beginnings to four wandering brothers who were joined with two other families. [D.M.] 
J.068 Jensen, Elwin W. Captain Cook as the Fair God Lono. Bountiful, UT: author, 1974. At the time that Captain Cook landed in Hawaii the local people assumed that he was the god Lono. On other occasions and with different characters similar scenes occurred in Mexico and Peru. Such occurrences recall the story that Jesus would someday return to the peoples of the Americas. [D.M.]

J.069 Jensen, Elwin W. Polynesians Descend from Lehi: According to Statements of the Prophets. N.p., 1977. Provides numerous quotes by LDS prophets suggesting that Polynesian peoples may be descended from Lehi, a Book of Mormon prophet. [M.R.]

J.070 Jensen, Jay E. "Why We Ask People to Read the Book of Mormon." Ensign 14 (August 1984): 18-20. Claims that the doctrines of the gospel are taught more clearly in the Book of Mormon than anywhere else. The Book of Mormon has the ability to bring people closer to God and to convince them of the divinity of Jesus Christ and his mission. [S.P.S.]

J.071 Jensen, Joan Tondro. "Records of the Ancient People of the American Continents." In A Symposium on the Book of Mormon, 72-75. Salt Lake City: Church of Jesus Christ of Latter-day Saints, CES, August 1986. The Nephite leaders and prophets accumulated a large treasury of records and plates, and the Book of Mormon in its present form represents only a fraction of the corpus. [D.M.]

J.072 Jensen, Margie Calhoun. "The Voice from the Hill Cumorah." In Jensen's When Faith Writes the Story, 38-41. Salt Lake City: Bookcraft, 1973. German E. Ellsworth was instrumental in securing the purchase of the Sacred Grove and the old Smith home and was instrumental in distributing thousands of copies of the Book of Mormon. [J.W.M.]

J.073 Jensen, Margie Calhoun, comp. Stories of Insight And Inspiration. Salt Lake City: Bookcraft, 1976. A compilation of testimonies by numerous authors indexed according to gospel topics. Those under the heading of "Book of Mormon" were written by Gregory G. Vernon, Barbara Gail Mikeska, Rex D. Pinegar, an unnamed author, and Gregg Weaver. [J.W.M.]

J.074 Jensen, Nephi. "First Nephi and Archaeology." IE 22 (August 1919): 855-58. Specific archaeological findings and a number of legends that deal with the book of 1 Nephi are discussed. Neither Solomon Spaulding nor Joseph Smith could have known about the archaeological findings nor the legends. [D.M.]

J.075 Jensen, Nephi. "Isaiah 29." IE 13 (April 1910): 512-15. Jenson testifies that the Book of Mormon fulfills the prophecy in Isaiah 29. It is a record of a fallen nation, it was a marvelous work and a wonder that the boy Joseph Smith translated the book, and it has caused the meek to increase their joy in the Lord. [B.D.]

J.076 Jensen, Nephi. "Ten Outstanding Proofs of the Divinity of the Book of Mormon." Liahona21 (8 April 1924): 399-400. Lists several proofs of the divinity of the Book of Mormon. For instance, the book contains historical information not known in 1830, it gives a substantial account of Jesus' ministry among his "other sheep," prophecies in the book have been fulfilled, and twelve witnesses saw the gold plates. [D.M.]

J.077 Jensen, Therald N. "Fragments of Social and Ethical Teachings of the Book of Mormon." Week-day Religious Educator 1 (March 1937): 3-5. Although the Book of Mormon does not contain definitive statements regarding ethical and social precepts, it does contain useful teachings regarding ethics, including statements on joy, the criteria and sanction of the good, freedom of the will, and guidelines for social problems. [D.M.] 
J.078 Jenson, Andrew. "Ancient Ruins in South America Evidence of Divine Authenticity of the Book of Mormon." Liahona 21 (23 October 1923; 6 November 1923): 153-59, 182-84. Author recalls his visit to South America and suggests several possible connections between South American archaeological ruins and the Book of Mormon. [D.M.]

J.079 Jenson, Andrew. The Book of Mormon. Liverpool: Millennial Star Office, 1907. A tract that provides a general treatise on the Book of Mormon. Discusses Joseph Smith's experiences with Moroni and the gold plates, the importance of the witnesses, and compares Indian and Polynesian traditions to the Book of Mormon. [D.M.]

J.080 Jenson, Andrew. "The Book of Mormon." MS 64 (25 September 1902): 612-14. Jenson gives a brief account of what the Book of Mormon is, how Joseph Smith obtained it and translated it, and how the witnesses of the plates were chosen and who they were. Also provides a brief biography of all eleven witnesses. [B.D.]

J.081 Jenson, Andrew. "The Book of Mormon." MS 70 (10 December 1908, 17 December 1908, 24 December 1908, 31 December 1908): 785-91, 801-8, 833-39, 849-52. Discusses the Hill Cumorah, Joseph Smith's first vision, the visit of the angel Moroni, the description of the gold plates, the translation and historical importance of the Book of Mormon, the testimonies of the Three and Eight Witnesses, Indian traditions that correspond with concepts in the Book of Mormon, legends from Tongan Islanders that are similar to those of Judaism, and the prophecy of no kings in America and its fulfillment. [A.C.W.]

J.082 Jenson, Andrew. "The Book of Mormon and the Ancient Ruins." IE 31 (February 1928): 280-83. Many archaeological excavations reveal the ancient existence of brilliant civilizations that pre-date the Aztec and Inca periods. The ruins verify descriptions found in the Book of Mormon. [D.M.]

J.083 Jenson, Andrew. "The Career of the Book of Mormon." IE 26 (September 1923): 963-68. A rehearsal of primary events connected with the Book of Mormon, including Joseph Smith's work with the gold plates, the conversion of several individuals (including Thomas B. Marsh, Willard Richards, Parley P. Pratt, and Sidney Rigdon) through the power of the book, and a discussion of the various translations of the Book of Mormon into foreign languages. [D.M.]

J.084 Jenson, Andrew. "David Whitmer." The Historical Record 7 (October 1888): 622-24. An obituary of David Whitmer that emphasizes his recollections of the emergence of the Book of Mormon. [D.M.]

J.085 Jenson, Andrew. "The Eight Witnesses." The Historical Record 7 (October 1888): 609-22. A biographical sketch of each of the Eight Witnesses of the Book of Mormon (with the exception of Hyrum Smith, and Joseph Smith Sr.). Underscores the fact that the witnesses never denied their experience of handling the plates. Mary Musselman Whitmer, the mother of the five Whitmer sons who were witnesses, is also identified. [D.M.]

J.086 Jenson, Andrew. "History and Genealogy." In Collected Discourses Delivered by President Wilford Woodruff, His Two Counselors, The Twelve Apostles, and Others (1896-1898), edited by Brian H. Stuy, 5:36-46. Woodland Hills, UT: B. H. S. Publishing, 1992. The Book of Mormon records the importance of keeping records-Nephi returned for the brass plates to preserve the language and the law, men will be judged out of the records. [J.W.M.]

J.087 Jenson, Andrew. "Nephi-An Impressive Lesson." IE 30 (October 1927): 1093. Many examples from the life of Nephi impress the author to follow the example of Nephi. [J.W.M.] 
J.088 Jenson, Andrew. "The Three Witnesses." The Historical Record 6 (May 1887): 195-219. A documentary recounting the lives of the Three Witnesses of the Book of Mormon. Attention is given to the Church careers of the men, with special emphasis on their experiences and testimonies relative to the Book of Mormon. [D.M.]

J.089 Jenson, Andrew. Untitled talk. CR (October 1907): 91-96. Jenson speaks of the value of the Book of Mormon as an historical record of the American Continent. He encourages the Saints to give to the Church any historical documents they may have as there are many gaps in the Church History. He does not want the Savior to accuse them of not having important information as he did Nephi in 3 Nephi 23:7-13 concerning Samuel the Lamanite. [B.D.]

J.090 Jenson, Andrew. Untitled talk. CR (April 1920): 66-79. Jensen gives a history of the Church from Joseph Smith's birth to 1920, including the story of the Book of Mormon. [B.D.]

J.091 Jenson, Andrew. "Whence the Names of These Towns Here in 'Mormondom'?" DN Church Section (28 December 1935): 1, 6. Gives the historical background of Utah towns that were given names from the Book of Mormon. [M.D.P.]

J.092 Jenson, Frank V. God's Greatest Gifts to Man: A Treatise on the Book of Mormon and the Holy Priesthood. Logan, UT: n.p., 1937. A theological treatise on the Book of Mormon. Quotes verbatim the permit that was issued to Joseph Smith to copyright the book. The Lord observes the laws and customs of mankind. Bears witness of the Book of Mormon's authenticity as well as the power of the priesthood. [M.R.]

J.093 Jenson, Janet. Book of Mormon Contributions to the Concept of Materialism. Author, 1959. Identifies specific places in the Book of Mormon where the acquisition of riches and its consequences are treated. Offers reflections on the neutral yet potentially precarious situation that exists when one obtains an abundance of worldly wealth. Gives some suggestions for modern day application of this prominent Book of Mormon theme. [D.M.]

J.094 Jenson, Janet. "Variations between Copies of the First Edition of the Book of Mormon." BYU Studies 13 (Winter 1973): 214-22. Not only are there differences between the several editions of the Book of Mormon, but there exist variations between copies of the first edition itself. The author compares seventy copies of the first edition and finds a number of variations (as illustrated in three tables), which include misspelled words or differences in capital and lower case words. [D.M.]

J.095 Jerald and Sandra Tanner's Distorted View of Mormonism: A Response to Mormonism-Shadow or Reality? Salt Lake City: n.p., 1977. Response to many of the criticisms raised by Mormon critics Jerald and Sandra Tanner, written by an anonymous LDS historian. Pages 43-62 deals with Mormon concepts of scripture, revelation, and translation. Although the Book of Mormon frequently quotes biblical scripture, it does so in much the same way as Jesus and other New Testament writers quote from the Old Testament, the Dead Sea Scrolls, and Jewish Apocryphal writings. [M.R.]

J.096 Jesclard, Paul Richard. "A Comparison of the Nephite Monetary System with the Egyptian System of Measure." SEHA 134 (October 1973): 1-5. Argues that there is "a connection between the Nephite monetary system, as detailed in the Book of Mormon (Alma 11:3-19), and the Egyptian wedjat-eye system of measuring grain." The Nephites altered a pattern of measuring money from the Near East. [D.M.]

J.097 Jessee, Dean C. "Joseph Smith Jr. in His Own Words, Part 1." Ensign 14 (December 1984): 22-31. Reprints 6 letters and refers to twenty-nine letters or documents and parts of two diaries that were written in the prophet 
Joseph Smith's own handwriting. Tells about the publication of the Book of Mormon. [J.W.M.]

J.098 Jessee, Dean C. "New Documents and Mormon Beginnings." BYU Studies 24 (Fall 1984): 397-428. Contains an evaluation of letters purportedly written by Joseph Smith to Josiah Stowell (June 18, 1825) and by Martin Harris to William W. Phelps (October 23, 1830). The first letter offers advice on trying to find a mine and the other deals with Book of Mormon origins. [D.M.]

J.099 Jessee, Dean C. "The Original Book of Mormon Manuscript." BYU Studies 10 (Spring 1970): 259-78. Discusses the preservation and handwriting of the original Book of Mormon manuscript. Contains pictures of sections of the original manuscript and a list of the original Book of Mormon holdings in the Church Historian's office. [L.D.]

J.100 Jessee, Dean C. Review of Joseph Smith and the Beginnings of Mormonism, by Richard L. Bushman. Dialogue 18 (Winter 1985): 187. Book review.

J.101 Jessee, Dean C. "Solomon Spaulding and the Book of Mormon." In The First Annual CES Religious Symposium: LDS Church History. 57-68. Provo, UT: Brigham Young University, 1977. Reviews how Doctor Philastus Hurlbut suggested the connection between the Spaulding manuscript and the Book of Mormon. Offers reasons why the Spaulding explanation is untenable, even though it is constantly cited as the actual origin of the Book of Mormon. [D.M.]

J.102 Jesse, Dean C." 'Spalding Theory' Is Re-examined." CN 47 (20 August 1977): 3-5. The theory that Soloman Spalding wrote a novel that was the basis for the Book of Mormon was a fabrication of Philastus Hurlbut who wanted revenge due to his excommunication from the Church. [M.R.]

J.103 Jessee, Dean C., comp. The Personal Writings of Joseph Smith. Salt Lake City: Deseret Book, 1984. Contains primary source material from Joseph Smith's writings and includes references to the coming forth of the Book of Mormon, as indicated in the index. Spelling in the original documents is retained. [D.M.]

J.104 "Jesus: Dominant Figure." CN 39 (4 October 1969): 16. Shows that Jesus Christ is the most significant personality in the Book of Mormon. Notes his appearances to the Nephites. [D.M.]

J.105 "Jesus Lives and Loves Us All." Friend 7 (April 1977): 40-41. A story for children about Christ's ministry to the Nephites after his resurrection. [M.D.P.]

J.106 "Jews and Mayans." CN 43 (16 June 1973): 16. Tells of a stone carving, found in Mayan ruins, which bears resemblance to similar carvings found among Jewish ruins. This suggests that ancient America had some connections with ancient Israel. [M.D.P.]

J.107 John, David. "Prophecies of the Coming Forth of the Book of Mormon and Their Fulfillment." Young Woman's Journal 2 (April 1891): 310-13. Quotes Isaiah 29 and prophecies within the Book of Mormon concerning its eventual appearance in the latter days. Recounts events surrounding its preparation for publication, with emphasis on the experiences of the Three Witnesses. [D.M.]

J.108 Johnson, Bernhart, and M. Wells Jakeman. "Israelite-Phoenician Commercial Relations and the Voyage of Mulek to the New World." SEHA 140 (March 1977): 1-9. Summarizes "extensive evidence, both literary and archaeological, of long and close ... relations between ancient Israel and Phoenicia," resulting in a "partial 
'Phoenicianization' " of the Israelites. Thus Book of Mormon Israelites in the New World must have had many Phoenician traits in their culture. Moreover it is likely that a Phoenician ship carried Mulek and his group to America. [J.L.S.]

J.109 Johnson, Clark V. "Alma's Counsel to His Sons." In Studies in Scripture: Alma 30 to Moroni, edited by Kent P. Jackson, 41-47. Salt Lake City: Deseret Book, 1988. Brief comments regarding the advice given by Alma the Younger to his first two sons, Helaman and Shiblon (Alma 36-38). Items taught by Alma include prosperity, the liahona, and Alma's own conversion story. [D.M.]

J.110 Johnson, Clark V. "The Beatitudes: Eight Qualities That Savor the Eternal Guest." In The New Testament and the Latter-day Saints, Sperry Symposium, 1987, edited by H. Dean Garrett, et. al., 115-28. Salt Lake City: Randall, 1987. An analysis and comparison of the beatitudes found in Matthew and 3 Nephi. [D.M.]

J.111 Johnson, Clark V. "From Small Means the Lord Brings about Great Things." In The Book of Mormon: First Nephi, The Doctrinal Foundation, edited by Monte S. Nyman and Charles D. Tate Jr., 231-39. Provo, UT: Brigham Young University Religious Studies Center, 1988. Demonstrates how the colony of Lehi was taught obedience to parents and to the Lord and the importance of the scriptures. The trials faced by the Lehites in the wilderness helped them to grow stronger physically and spiritually. [A.T.]

J.112 Johnson, Clark V. "Jacob: In Harmony with God." In Studies in Scripture: 1 Nephi to Alma 29, edited by Kent P. Jackson, 175-84. Salt Lake City: Deseret Book, 1987. A retelling of the incidents and comments in Jacob 1-3, 7. The Lord commissioned Jacob with the unenviable task of reproving the Nephites for unrighteous attitudes toward wealth, the sin of pride, and the practice of unchastity. The anti-Christ Sherem challenged Jacob regarding Christ's mission and thus met an ignominious end. [D.M.]

J.113 Johnson, Clark V. "Prophetic Decree and Ancient Histories Tell the Story of America." In The Book of Mormon: Jacob through Words of Mormon, To Learn with Joy, edited by Monte S. Nyman and Charles D. Tate Jr., 125-39. Provo, UT: Brigham Young University Religious Studies Center, 1990. Compares features of cosmology and salvation history (including the existence of a righteous and an evil power figure) in the Book of Mormon with the Popol Vuh (a sacred history of the Quiche Indians that was codified by an unknown writer to preserve generations of oral tradition shortly after the Spanish conquest of Guatemala in 1524). [D.M.]

J.114 Johnson, Clark V. Review of Fathers and Sons in the Book of Mormon, by E. Douglas Clark, and Robert S. Clark. Review of Books on the Book of Mormon 4 (1992): 29-39. Book review.

J.115 Johnson, Joseph. The Great Mormon Fraud: or The Church of Latter-Day Saints. Manchester: Butterworth \& Nodal Printers, 1885. A polemical work written against Mormonism. The Book of Mormon was likely plagiarized from the Spaulding manuscript. Book of Mormon anachronisms listed by the author include the absurd description of Jaredite barges, the alleged quoting of Shakespeare, Greek names and phrases, and Christian institutions before Christ. The practice of polygamy by the Mormons contradicts Book of Mormon teachings. [M.R.]

J.116 Johnson, Ludwell H. "Men and Elephants in America." Scientific Monthly (October 1952): 215-21. Evidence exists to prove that man and elephants coexisted in America during the premodern era. [M.R.]

J.117 Johnson, Lynn Nations. Review of To Mothers \& Fathers from the Book of Mormon, by Blaine and Brenton Yorgason. Review of Books on the Book of Mormon 4 (1992): 258-62. Book review. 
J.118 Johnson, Marion Ashby. "Minverva Teichert: Scriptorian and Artist." BYU Studies 30 (Summer 1990): 66-71. Features fifty-four Book of Mormon paintings by Minverva Teichert and gives insights concerning the paintings. Also presents background information into Teichert's life. [J.W.M.]

J.119 Johnson, Marjorie G. Book of Mormon Stories for Little Children. Bountiful: Horizon, 1976. Selected stories from the Book of Mormon for young children, with illustrations. [D.M.]

J.120 Johnson, Marjorie G. The Prophets Tell About Jesus. Salt Lake City: King, 1979. A fictional story designed for children wherein Lamanite parents tell their children about Book of Mormon prophets who taught about the mission of Christ. [D.M.]

J.121 Johnson, Orville S. "Irrefutable Evidence." MS 96 (19 July 1934): 454-55, 460-62. Fictional account of a woman who joined the LDS church against her sweetheart's will. He decided to prove the Book of Mormon false by asking Oliver Cowdery to deny his testimony. Cowdery reaffirmed his knowledge of the truthfulness of the Book of Mormon; all were converted. [A.C.W.]

J.122 Johnson, Orville S. "Irrefutable Evidence." Relief Society Magazine 19 (October 1932): 577-80. A story about Oliver Cowdery, who never denied his testimony of the Book of Mormon. [J.W.M.]

J.123 Johnson, Paul. Could He Have Written It? Gladbrook, IA: Vanity, 197?. A self-published tract arguing that Joseph Smith did not write the Book of Mormon. [D.M.]

J.124 Johnson, R. Val. "Sage's Song." Ensign 19 (August 1989): 30-35. Tells the story of the badly burned Sage Volkman and her struggle for life. Sage tells of her visit with Christ while comatose. She bears testimony of the Book of Mormon. [J.W.M.]

J.125 Johnson, Roy. "Oaths in the Old Testament and Book of Mormon." Provo, UT: FARMS, 1982. The oath in ancient Israel and other ancient civilizations was important in political, religious, social, and legal life. It included two parts - a covenant and a curse-and was a binding force, irrevocable, and needed no social or civil enforcement, for God would mete out punishment on the false swearer. [J.W.M.]

J.126 Johnson, Sherrie. "Abish, Lamanite Woman of God." Friend 18 (February 1988): 48-49. A story for children depicting Ammon teaching the gospel to King Lamoni and recounting the testimony of Abish (Alma 19). [J.W.M.]

J.127 Johnson, Sherrie. "A Change of Heart." Friend 16 (January, February 1986): 48-49, 48. A story for children telling of the conversion of Alma the Younger and the sons of Mosiah (Mosiah 27, 29 and Alma 2-8) and relating the ministry of Alma the Younger in Ammonihah (Alma 13-15). [J.W.M.]

J.128 Johnson, Sherrie. "Convert to the Truth." Friend 16 (August 1986): 48-49. A children's story of Alma, Amulek, and Zeezrom (Alma 11-15, 31). [J.W.M.]

J.129 Johnson, Sherrie. "Courage to Believe." Friend 15 (October 1985): 48-49. The conversion of Alma, priest of Noah and his ministry at the waters of Mormon (Mosiah 18:23-25) is the topic of this children's story. [J.W.M.]

J.130 Johnson, Sherrie. "Cumorah Treasure." Friend 23 (February 1993): 48, ibc. A summary for children of the history of the Book of Mormon from the first vision to translation and publication. Illustrated. [S.H.] 
J.131 Johnson, Sherrie. "Enos Prays." Friend 18 (January 1988): 48-49. A story for children that recounts Enos's experiences as he went into the forest and prayed (Jacob 7:27; Enos). [J.W.M.]

J.132 Johnson, Sherrie. "Gideon." Friend 18 (July, August 1988): 48-49, 48-49. A children's story recalling the experiences of Gideon (Mosiah 19-22; Alma 1; 2:20; 6:7). [J.W.M.]

J.133 Johnson, Sherrie. "Gidgiddoni: Prophet and Commander." Friend 18 (March 1988): 48-49. A story for children describing Gidgiddoni, the Nephite military leader (3 Nephi 3-4). [J.W.M.]

J.134 Johnson, Sherrie. "Lehi: Man of Vision." Friend 17 (October, November 1987): 48-49, 48-49. A child's story describing the prophet Lehi and his visions. [J.W.M.]

J.135 Johnson, Sherrie. "Martyr for Truth." Friend 15 (July 1985): 48-49. For children, the courageous story of Abinadi as he bears witness before King Noah (Mosiah 11-17). [J.W.M.]

J.136 Johnson, Sherrie. "Nephi, Man of Faith." Friend 18 (September 1988): 48-49. A story for children recalling when Nephi's brothers bound him, the power of the Lord loosened the cords, and Nephi forgave his brothers (1 Nephi 7). [J.W.M.]

J.137 Johnson, Thomas C. "Mormonism." Presbyterian Quarterly 13 (1899): 608-36. A polemical article against Mormonism. The writer asserts that the Book of Mormon is the production of Joseph Smith who pilfered most of the narrative from the "invalid and crack-brained Presbyterian preacher, Solomon Spaulding." Various Mormon teachings are criticized. [M.R.]

J.138 Johnson, Venna Stevens. "Book of Mormon Sheds Light on Dead Sea Scrolls: A Book Review." The Witness 78 (Fall 1992): 4-7. A review of the book The Dead Sea Scrolls Deception by Michael Baigent and Richard Leigh who claim that the law as taught in the Dead Sea Scrolls, Jesus' sayings (Matthew 5:17-19), and Paul's teachings (Romans 3:21-23; Galatians 2:16-17) do not harmonize. Stevens says the Book of Mormon (Mosiah 8:3-11, 2829, 89-91; Mosiah 1:113, 116; 3 Nephi 7:4-12 [RLDS versification]) shows that Paul's teachings and Christ's are harmonious. [B.D.]

J.139 Johnston, James F. W. "Joe Smith and the Mormons." Harpers Monthly (1851): 64-66. A polemical article against Mormonism. The writer considers the Book of Mormon "as desultory and feeble imitation of the Jewish chronicles and prophetic books" and represents little more than "a succession of unconnected rhapsodies and repetitions" addressed to a very ignorant audience. After giving a brief account of the Book of Mormon narrative, the writer ridicules the account of the Jaredite barges. He concludes by asking, "Who can tell what two centuries may do in the way of giving a historical position to this rising heresy?" [M.R.]

J.140 Jolley, Katy. "A Calming Answer." NE 23 (April 1993): 49. Though her parents are divorcing, author finds peace and calm in reading the Book of Mormon. [S.H.]

J.141 Jolley, Terry V. "Church Education System: Book of Mormon Student Competencies." M.A. thesis, Brigham Young University, August, 1988. As LDS students study the Book of Mormon in seminary, the author suggests that key scriptures in a sequential reading (as opposed to a conceptual or topical approach) be identified so that the teacher can measure the student competency (i.e., understanding) in four areas: historical, doctrinal, missionary application, and personal application. [D.M.] 
J.142 Jonas, Larry S. Mormon Claims Examined. Grand Rapids, MI: Baker, 1961. A large portion of this booklet is devoted to an attempt to discredit the Book of Mormon. The author challenges LDS claims by referring to opinions of the Smithsonian Institute and shows the views of pre-Book of Mormon publications that have similarities in thought to the Book of Mormon. He also claims that the testimonies of the Three Witnesses were faulty. [D.M.]

J.143 Jones, Byron. The Origin of the Book of Mormon. N.p., 197?. A small pamphlet, highlighting chronological events related to the coming forth of the Book of Mormon. Remarks are made about the Three Witnesses and Emma Smith. [D.M.]

J.144 Jones, Carl Hugh. "The 'Anthon Transcript' and Two Mesoamerican Cylinder Seals." SEHA 122 (September 1970): 1-8. A comparison of the "characters" from the Anthon transcript with two Mesoamerican scripts. The author concludes that the characters are similar. [D.M.]

J.145 Jones, Carl Hugh. "The Archaeological Paintings of George M. Ottinger." 14th Annual Symposium on Archaeology of the Scriptures (13 April 1963): 5-11. Paintings and illustrations that include Lehi preaching in Jerusalem, the destruction of Zarahemla, Nephi's vision, building the temple at Nephi, offering sacrifice as a token of gratitude, and others. [J.W.M.]

J.146 Jones, Carl Hugh. "An LDS View of the Apparent Jomon-Valdivia Contact." SEHA 115 (8 September 1969): 4-6. Discusses possible travel routes of the Book of Mormon peoples. Points out that other groups may well have landed in the Americas. [D.M.]

J.147 Jones, Dan. Tystioliaethau Diwrthbrawf Nad O'R “Spaulding Romance” Y Gwnaed Llyfr Mormon!!!. Abertawy: Uyhoeddwyd ac argraffwyd gan D. Jones, 1854. Title in English, Irrefutable Proofs that the Book of Mormon was Not Obtained from the "Spaulding Romance." A response in Welsh to the Spaulding theory by an early Mormon missionary. [M.R.]

J.148 Jones, Helen Hinckley. "A Writer Looks at the Book of Mormon." IE 63 (November 1960): 798-801, 834-35. A testimony of the Book of Mormon from the point of view of a successful and professional writer, Helen Hinckley Jones. In order to write an excellent book, it takes tremendous research, painstaking effort to build distinct characters, a complex form, a unique style of writing, and an appropriate theme, followed by laborious retracing, redoing, and revising. Joseph Smith had neither the talent nor the time to author the Book of Mormon. Jones concludes that Joseph Smith "was reading the Book of Mormon, not writing it." [R.C.D.]

J.149 Jones, Irene. Know Your Scriptures: A Reading Program. Independence: Herald Publishing House, 1966. Provides an outline for reading Book of Mormon passages as they refer specifically to the Old and New Testaments, then continues with a chapter-by-chapter content outline, a narrative outline, and a check-up quiz. [J.W.M.]

J.150 Jones, J. H. N. "The Case of the Book of Mormon." SH 77 (18 June 1930): 680-82. Outlines the different groups who came to America as described in the Book of Mormon and shows how the Book of Mormon story agrees consistently with the Bible in history and doctrine. [B.D.]

J.151 Jones, Miles L. Untitled talk. CR (April 1930): 123-25. When asked what publication we have that is the most reliable, or rather that gives us the most reliable information regarding the origin of the American Indian, a radio 
announcer replied that the Book of Mormon was. Jones gives a brief history of the Book of Mormon and its final publication. [B.D.]

J.152 Jones, Milton Jenkins. Book of Mormon Chart Book. Salt Lake City: Visual Arts Press, 1961. Four different charts show the Book of Mormon timeline, the historical setting of the books of the Book of Mormon, the angel Moroni's visits, and the translation of the book. [J.W.M.]

J.153 Jones, Milton Jenkins. Gospel Chart Book. Salt Lake City: Deseret Book, 1955. Provides several charts of gospel subjects, including a chronological chart of the Book of Mormon events and people and another of the Book of Mormon contents. [J.W.M.]

J.154 Jones, Paul. The Bible and the Book of Mormon: Some Suggestive Points from Modern Bible Study. Logan: n.p., 1912. In this pamphlet the author argues that the Book of Mormon cannot be an ancient document because its contents do not agree with the results of modern biblical studies. The author's point of view is informed by an evolutionary approach to Israelite religion. [A.L. \& P.H.]

J.155 Jones, S. S. "Our Indian Brother." MS 35 (13 May 1873): 296-97. The author compares the rights given to the Negro with the rights given to the Native American Indian. The Negro is now made equal with his former master and has all rights of citizenship while the Indian is still pursued and persecuted by the U.S. Government. The Lamanite "is yet to go through 'to tear in pieces and none shall deliver' and yet to 'become a light and delightsome people." " [B.D.]

J.156 Jones, Wesley M. A Critical Study of Book of Mormon Sources. Detroit: Harlo, 1964. The author believes the Book of Mormon to be a product of Joseph Smith's environment. The book discusses various sources that he believes Joseph Smith could have used in creating the Book of Mormon, including the Bible, Ethan Smith's View of the Hebrews, and Elias Boudinot's A Star in the West. [M.R.]

J.157 Jones, Wesley M. Joseph Smith, Messiah of the Last Days. Oakland, California: author, 1966. The most critical mistake Joseph Smith made was to proclaim the Book of Mormon a "history" of Israel, linking it with the Old Testament. Finds that the book resembles Ethan Smith's View of the Hebrews and Elias Boudinot's Star in the West. [J.W.M.]

J.158 Jordan, David Starr. "Constantine Samuel Rafinesque." In Pioneers of Science in America, edited by William Jay Youmans, 182-95. New York: D. Appleton and Co., 1896. Reprint of an article that first appeared in the Popular Science Monthly 29, 1886, gives a sketch of Rafinesque who spent much time in the study of the languages and customs of the Indians. He concluded that the American Indians were from the lost ten tribes and had come to America by way of Siberia, the foundation upon which Mormonism was built. It was this theory that inspired Solomon Spaulding to write his book of the prophet Mormon. Latter-day Saints hold Rafinesque in great esteem. [J.W.M.]

J.159 Jordan, T. J. I Beheld a Book. Regina (Saskatchewan) Canada: n.p., 195? Defends Book of Mormon statements that some truths have been lost from the Bible through the process of translation. Affirms that the Book of Mormon was translated by the power of God. Cites Nephi's testimony concerning the Bible beginning in 1 Nephi 3. [J.W.M.]

J.160 Jorgensen, Bruce W. "The Dark Way to the Tree: Typological Unity in the Book of Mormon." In Literature of Belief: Sacred Scripture and Religious Experience, edited by Neal E. Lambert, 217-31. Provo, UT: Brigham Young 
University Religious Studies Center, 1981. A partial thematic interpretation of the Book of Mormon. The author seeks to uncover the book's "typological or figural unity" and finds this in the dream of the tree of life in 1 Nephi. Many themes emerge from the images in this dream. The themes show up in Jacob's allegory of the olive tree and in various conversion narratives. The dream symbolizes the process of moving through the wilderness and of reaching fulfillment. [D.M.]

J.161 Jorgenson, Bruce W. "Reading the Book of Mormon as Typological Narrative." In A Symposium on the Book of Mormon, 64-70. Salt Lake City: Church of Jesus Christ of Latter-day Saints, 1979. Looks at the typological unity in the Book of Mormon and suggests using the narrative approach while reading the book. Typological or figurative/symbolic treatment is given in many stories, including Lehi's vision of the tree of life, Alma's three days of coma while he undergoes the pain of repentance, the olive vineyard, and the three days of darkness when Jesus came. [N.K.Y.]

J.162 "Joseph Smith Letter of Virtue, Signed Book of Mormon Obtained." Ensign 15 (September 1985): 77-78. News report of a collector who acquired a letter written by Joseph Smith and a Book of Mormon signed by Joseph Smith. (Editor's note: the signature in the Book of Mormon was a forgery; the letter was from another source and is considered authentic.) [J.W.M.]

J.163 "Joseph Smith Versus the Book of Mormon." Utah Christian Tract Society 12 (May-June 1980): 2. Claims that Joseph Smith's teachings regarding the Godhead contradict the teachings of the Book of Mormon of one god. [D.M.]

J.164 “Joseph Smith's 234 Pound Gold Plates?” Utah Christian Tract Society 9 (September-October 1974): 2. Claims that the gold plates may have weighed 234 pounds, making them far too heavy for a single individual to carry. [D.M.]

J.165 "Josephine." "The Book of Mormon." TS 2 (1 February 1841): 305-6. Also in MS 1 (February 1841): 299-301, and "One of the Greatest Literary Curiosities of the Day." Dialogue 12 (Spring 1979): 100-101. An article that originally appeared in the New Yorker. Retells how Joseph Smith obtained the plates. Refers to the Anthon encounter. Compares the Book of Mormon to the Koran. [D.M.]

J.166 "Journey to the Tower." NE 12 (November 1982): 46-47. Reader is asked to match a scriptural reference in Mosiah with nine different hypothetical situations. An activity for youth. [A.T.]

J.167 Judd, Ella Mae. Sunday Afternoon Workbook for Study of the Book of Mormon. 3 vols. Phoenix: n.p., 1978. A Book of Mormon workbook designed for children 9-16 years of age. Contains questions, fill in the blanks, and charts. [D.M.]

J.168 Julius. "The Priesthood of the Book of Mormon." SH 76 (31 July 1921): 921-25. Argues that the Book of Mormon peoples possessed only the Aaronic Priesthood until Christ came and gave them the Melchizedek Priesthood. Before the coming of Christ they could not hold the Melchizedek Priesthood since it was taken away with Moses (D\&C 83:4 and Deuteronomy 10:2-4). [B.D.] 
K.

K.001 Kaiser, Edgar P. How to Respond to the Latter-day Saints. St. Louis: Concordia, 1977. A polemical work against Mormonism, attempting to instruct and inform Christians on how to respond to various Mormon questions. After a brief account of the Book of Mormon narrative, the writer notes what he feels are certain internal anachronisms in the book, such as Jaredite barges, use of King James English and New Testament material before Christ, and the number of people slain in battle. He feels that the book's origin can best be explained as a product of Joseph Smith's environment. [M.R.]

K.002 Kaler, John. "The Book of Mormon." SH 58 (3 May 1911): 415-20. The author, by quoting from Revelation 12, Ezekiel 4:6, and Daniel 12:4-9, shows that the Book of Mormon came forth twelve hundred and sixty years after the apostasy. He also remarks concerning the fulfillment of the prophesies in Isaiah 29:4, 11, Zechariah 10:10, and Jeremiah 22:6, and refers to archaeological discoveries in defense of the Book of Mormon. [A.T.]

K.003 Kapp, Ardeth G. "Captains of Ten." NE 13 (November 1983): 48-50. A youth oriented challenge to read the Book of Mormon. Youth relate testimonial experiences they had while reading the Book of Mormon. [A.T.]

K.004 Karamesines, Patricia Gunter. Review of Keys to Successful Scripture Study, by George A. Horton. Review of Books on the Book of Mormon 3 (1991): 86-95. Book review.

K.005 Keck, Brian E. "Ezekiel 37, Sticks, and Babylonian Writing Boards: A Critical Reappraisal." Dialogue 23 (Spring 1990): 126-38. An assertion that the traditional Mormon interpretation of the prophecy in Ezekiel 37 regarding the Book of Mormon is both naive and unsupportable in light of Near Eastern scholarship. [M.R.]

K.006 Kee-Pi-Po-Kayo (One Hundred Bears) (J. J. Galbreath). "The Book of Mormon." IE 37 (March 1934): 139. A brief testimony of the truthfulness and value of the Book of Mormon, written by a man who is part Scottish and part Blackfoot Indian. [D.M.]

K.007 Keim, Laurence H. "My Odyssey Of Faith." Ensign 21 (April 1991): 28-30. A few months after baptism this author was given "anti-Mormon material." It was then that with earnest prayer, he turned to the Book of Mormon. He was called to serve as a mission trainer in Ecuador where he gained a testimony of the antiquity of the Book of Mormon. [J.W.M.]

K.008 Keir, James F. "Archaeological Proofs of Christ in America." SH (25 January 1941): 113-14. Contains quotes from archaeological books and newspaper articles that deal with the bearded white god, Quetzalcoatl, who was born of a virgin and was associated with the cross. Christ visited in America and these beliefs are relics of this visit. [J.W.M.]

K.009 Keir, James F. "Is the Book of Mormon True? You Be the Judge." SH 87 (20 July 1940): 907-10. Either the Book of Mormon is true or a fraud, and many intelligent, honest people have found the former. Its claims are supported by the testimony of men who witnessed the plates, by biblical prophecy, by archaeological study, and by the witness of the spirit. [J.W.M.]

K.010 Keir, James F. "The 'Mistakes' of Joseph Smith." SH 87 (27 August 1940): 531-32. A defense of Joseph Smith in response to The Children of God, by Vardis Fisher. Joseph Smith made no mistake in translating the record that 
represents a people who dwelt upon the land of America 600 years B.C. who brought no records of the minor prophets who wrote between the time of Lehi's departure and A.D. 70. [J.W.M.]

K.011 Kelesus, Jeff." 'Use the Book of Mormon' President Benson Tells Michigan Area Conference." Ensign 16 (December 1986): 68. President Benson states that the two main purposes of the Book of Mormon are (1) to act as a witness for Christ and (2) to counter the criticisms made by the enemies of the Church. [J.W.M.]

K.012 Keller, Roger R. "Mormon and Moroni as Authors." In Reexploring the Book of Mormon, edited by John W. Welch, 269-71. Salt Lake City: Deseret Book and FARMS, 1992. Mormon and Moroni served as authors, compilers, and editors of the Book of Mormon. Wordprint studies and textual analyses demonstrate a distinction between their writings. For example, Mormon used an editorial expression "and thus we see" on twenty occasions, but Moroni utilized the expression once only. [N.K.Y.]

K.013 Kelley, E. L. Antiquarian Evidences Concerning the Book of Mormon. Independence, MO: Ensign, 1896. Speaks about the validity of the Bible and argues that God has spoken to the ancient western world as well as set forth in the Book of Mormon. Adduces archaeological evidence and arguments of reason to defend the Book of Mormon. [D.M.]

K.014 Kelley, E. L. "The Book of Mormon: The Story of Its Origins." SH (5 April 1884): 209-10. Defends David Whitmer's testimony of the Book of Mormon, which was misquoted in a local newspaper. Both the misquotation and Whitmer's true testimony are included. Whitmer affirms his belief in the Book of Mormon. [A.C.W.]

K.015 Kelley, E. L. "The Reply: Supplement to Saints' Herald." SH 50 (21 January 1903): 1-3, 6-8. The Book of Mormon teaches the same beliefs and doctrines as taught in the Bible and holds the same promises of salvation. [J.W.M.]

K.016 Kelley, E. L. "Unreasonable Men: Or, Fallacious Criticisms Against the Book of Mormon." SH 50 (21 October 1903): 984-86. A defense of the Book of Mormon against critics. The author finds that the book is in accord with Old Testament prophecies, it is an additional witness for Jesus Christ, and its claims are sustained by scientific discoveries. [J.W.M.]

K.017 Kelley, Edmund Levi, and Clark Braden. Public Discussion of the Issues Between Re-Organized Church of Jesus Christ of Latter Day Saints and the Church of Christ. St. Louis, MO: Christian, 1884. A record of three long debates that took place in Kirtland, Ohio, between the two authors. Items discussed include the question concerning the divine origin of the Book of Mormon and the role or non-role of the Spaulding manuscript in the coming forth of the Book of Mormon. [D.M.]

K.018 Kelley, T. C. "The Book of Mormon on Polygamy." SH 63 (26 July and 1 August 1916): 709-11, 736-38. Uses the Book of Mormon to refute claims made by LDS authorities concerning polygamy and claims that the LDS practiced polygamy in wickedness. Argues against a statement made by Brigham Young that the Nephites were too wicked to practice polygamy and argues that "raising up seed unto the Lord" is not a valid reason for practicing polygamy. [A.T.]

K.019 Kelley, William H. "Book of Mormon Committee Report." SH 31 (23 August 1884): 545-48. A report of a committee who compared the manuscript of the Book of Mormon (held by David Whitmer) with the Palmyra and Plano editions. Some differences and changes are noted. [D.M.] 
K.020 Kelley, William H. "The Hill Cumorah, and the Book of Mormon." SH 28 (1 June 1881): 161-69. A report of two brothers' visit to Palmyra and Manchester, New York. After conducting interviews with several aged residents regarding the Joseph Smith family and the Book of Mormon, new information regarding the Smiths and the original manuscript of the Book of Mormon is produced. [D.M.]

K.021 Kelley, William H. "Joseph Smith Jr., And The Church of Jesus Christ of Latter-Day Saints." In Presidency And Priesthood: The Apostasy, Reformation, And Restoration, 193-251. Lamoni, IA: Herald Publishing House, 1895.

Retells the events of the coming forth of the Book of Mormon in narrative form, taken from the Times and Seasons interspersed with commentary. Discusses Martin Harris's visit with Professor Anthon. Shows copies of the Anthon transcript, the Kinderhook plates, and another unidentified facsimile. Argues that the Book of Mormon fulfills biblical prophecy and is an important instrument to end apostasy and begin the Restoration. Concludes with the Witnesses' testimonies. [J.W.M.]

K.022 Kelley, William H. "Modern Scientific Disclosures Corroborate the Statement of Joseph Smith, Jr." In Presidency And Priesthood: The Apostasy, Reformation, And Restoration, 252-93. Lamoni, IA: Herald Publishing House, 1895. All of the Mediterranean languages had their birth in Mesopotamia and were transmitted by the descendants of Noah. Many archaeological finds substantiate that many languages derived form one common source. The Book of Mormon peoples had a very advanced civilization and show signs of borrowing from that common source. [J.W.M.]

K.023 Kelson, John H. "Ancient Fortifications: A Testimony to the Truth of the Book of Mormon." Deseret Weekly 43 (19 September 1891, 3 October 1891): 385-86, 449-50. Relates the mounds found in the United States to war sites in the Book of Mormon. Also discusses anthropological aspects of the Book of Mormon. [D.M.]

K.024 Kelson, John H. "Unwitting Witnesses." Deseret Weekly 38 (5, 12, 19, 26 January 1889; 2, 23 February 1889; 16, 23, 30 March 1889; 4 May 1889): 33-35, 66-68, 102-4, 134-35, 169-70, 198-200, 257-59, 355-57, 391-93, 421-23, 577-80. A series, comprising a defense of the Book of Mormon from an anthropological and archaeological point of view. Quotes extensively from the Book of Mormon as well as from contemporary scholarship. [D.M.]

K.025 Kelson, John H. "Wars of the Nephites and Lamanites." Deseret Weekly 43 (17, 24, 31 October 1891; 14 November 1891): 521-22, 561-62, 593-94, 657-58. Gives ethnic descriptions of Book of Mormon peoples and discusses them as inventors, explorers, and warriors. Cites archaeological findings that relate to the Book of Mormon. [D.M.]

K.026 Kennedy, James Harrison. Early Days of Mormonism. New York: Scribner's, 1888. An historical and polemical work directed against Mormonism. The author advances the Spaulding theory to account for the Book of Mormon's origin. [M.R.]

K.027 Kennedy, James Harrison. "The Three Witnesses of the Book of Mormon." Magazine of Western History 11 (March 1890): 464-78. A discussion regarding the Three Witnesses to the Book of Mormon. While the author presents several of the definite, uncompromising testimonies of the witnesses, he generally depicts them as simple-minded and arrogant. The witnesses are first exploited and then discarded by Joseph Smith. [D.M.]

K.028 Kennedy, Richard. "Book of Mormon." In Kennedy's The International Dictionary of Religion, 33. New York: Crossroad, 1984. Provides a brief mention of the existence of the Book of Mormon. [D.W.P.] 
K.029 Kenner, S. A. "The 'Golden Bible.'” IE 13 (January 1910, February 1910): 214-18, 325-29. A discussion and response to the book entitled The Golden Bible by the Rev. M. T. Lamb, where Kenner challenges Lamb's assumptions. [D.M.]

K.030 Kenner, S. A. "The Play 'Corianton.' " IE 5 (October 1902): 980-83. A youth oriented defense of the Book of Mormon and a justification for the drama referred to in the title. [D.M.]

K.031 Kerr, Todd R. "Ancient Aspects of Nephite Kingship in the Book of Mormon." Journal of Book of Mormon Studies 1 (Fall 1992): 85-118. Nephite kings were expected to fulfill the same roles that kings played in other ancient civilizations-commander of the military forces, chief judicial official, and leader of the national religion. A king's success depended not only on the extent to which he performed each role, but also on the motives behind his service. Some Nephite kings ruled selflessly (like Benjamin) and commanded the respect and praise of the people, while others (like Noah) sought for wealth and fame and roused Old World disdain. [R.H.B.]

K.032 Key, Thomas D. S. A Biologist Looks at the Book of Mormon. Issaquah, WA: Saints Alive in Jesus, 1985. Sees many scientific anachronisms in the Book of Mormon. Points out problems dealing with language, geography, botany, zoology, physiology, and anthropology. For instance, the implied reproduction rates and populations of the Book of Mormon show physiological problems. [A.T.]

K.033 Kidder, Daniel P. Mormonism and the Mormons. New York: Lane \& Tippett, 1844. A polemical attack on Mormonism. The Book of Mormon is discussed on pages 11-60, 253-330. The Spaulding theory is espoused by the author. The testimony of the Book of Mormon witnesses is discounted. The Book of Mormon shows clear evidence of being plagiarized from the Bible. The author finds the direction of desert travel by Lehi's family somewhat absurd. Anthon's 1834 denial is recounted and various other anachronisms are discussed. [M.R.]

K.034 Kidder, Daniel P. Mormonism and the Mormons: A Historical View of the Rise and Progress of the Sect Lifestyles of Latter-day Saints. New York: Carlton and Lanahan, 1942. This polemical work sets out to "unmask the deception" of the Book of Mormon upon which "the whole fabric of Mormonism" rests. It includes an attempt to show that the Book of Mormon was a "sandy foundation upon which to build a religious system" and supports the Spaulding theory. [J.W.M.]

K.035 Kienke, Asa Solomon. Fourteen Objectives for the Reading and Study of the Book of Mormon. N.p., 1920. Lists fourteen objectives with scriptural references for reading the Book of Mormon. Objective examples include: records and plates, prophecy yet to be fulfilled, and Christ's ministry among the Nephites. [D.M.]

K.036 Kimball, Spencer W. "Book of Mormon Message to the Lamanite." CR (October 1959): 57-62. Reviews the history of Israel and the Book of Mormon from the perspective of the Lamanite people. Describes the prophetic destiny of the Lamanites as a chosen people. [R.C.D.]

K.037 Kimball, Spencer W. "A Book of Vital Message." In Faith Precedes the Miracle, 329-37. Salt Lake City: Deseret Book, 1972. Also published in IE 66 (June 1963): 490-95. The contents of the Book of Mormon are multi-faceted. It contains elements pertaining to drama, archaeology, exploration, travel, anthropology, astronomy, geology, psychology, political science, scientists, military strategy, and many other subjects. The major value of the book is its religious influence upon individuals. [D.M.]

K.038 Kimball, Spencer W. "Conference Report, October 1977." In Book of Mormon Talks by General Authorities, 8485. Provo, UT: FARMS, 1987. The Liahona (1 Nephi 16) directed Lehi's family according to their faith. Every 
individual may have that kind of faith. [B.D.]

K.039 Kimball, Spencer W. "The Lamanite." In BYUSY (15 April 1953). Provo, UT: BYU Press. Quoting the Book of Mormon, the author points out the destiny of the Lamanite people and suggests that it is the responsibility of members of the Church to assist in the great work of recovering the Lamanites. Recounts the maltreatment of the Cherokee Nation and other Indian nations. [J.W.M.]

K.040 Kimball, Spencer W. "The Lamanite." IE 58 (April 1955): 226-28, 246, 250-58. An impassioned retelling of the horrible maltreatment by the white man of the Lamanites (more especially of the Cherokee, Sioux, Navajo, and Apache Indian Nations). This maltreatment was prophesied in the scriptures. President Kimball extends a poignant plea for Church members to possess an active concern for the Lamanites by giving them opportunity, understanding, and warm fellowship. [R.C.D.]

K.041 Kimball, Spencer W. "The Lamanite and the Gospel." In Faith Precedes the Miracle, 339-49. Salt Lake City: Deseret Book, 1972. The white man has exploited the American Indians and owes a debt to them. Prophecies regarding the Lamanites are recited. The condition of the Indian is improving, their numbers are improving and their standard of living is improving. [D.M.]

K.042 Kimball, Spencer W. "Lamanite Prophecies Fulfilled." Provo, UT: Brigham Young University Press, 13 April 1965. In a devotional address the speaker shares personal memories of his official ecclesiastical involvement with the American Indian. He reviews the progress they have made, both in joining the Church and in attaining a relatively high standard of living. President Kimball cites a number of scriptures and statements of Church leaders that deal with the future of the Lamanites. [D.M.]

K.043 Kimball, Spencer W. "The Lamanites: 'And They Shall Be Restored.' "IE 50 (November 1949): 717, 762-65. The Book of Mormon prophesies much concerning the Lamanites. It is the responsibility of the Church to help them to fulfill their great destiny. Many are receiving the gospel and are bearing fervent testimonies and living the gospel. A letter from a father to his son counsels the son to look for the "Mormons," who have the record of his people. The son then writes of his search for this book that would teach him the true gospel, which he found in the Book of Mormon. [J.W.M.]

K.044 Kimball, Spencer W. "The Lamanites Are Progressing." IE 56 (June 1953): 432-35. A testimony of the redemption of the Lamanites. Kimball gives examples of certain Lamanites who are progressing in the Church. [B.D.]

K.045 Kimball, Spencer W. "A Personal Liahona." CR (October 1976): 114-17. Speaking about the Book of Mormon Liahona, President Kimball describes how Lehi and Nephi "worked it" according to their "faith and diligence." The Liahona dictated to the Nephite group the direction of travel and the manner in which to act. President Kimball likens the Liahona to one's conscience, teaching that when an individual heeds the conscience, it will guide that person to righteousness. [R.C.D.]

K.046 Kimball, Spencer W. "Redemption of the Lamanites." In The Teachings of Spencer W. Kimball, edited by Edward L. Kimball, 594-620. Salt Lake City: Bookcraft, 1982. The term "Lamanite" "includes all Indians and Indian mixtures." The Lamanites have been greatly persecuted, especially in America. It is the Church's responsibility to help them. [B.D.] 
K.047 Kimball, Spencer W. Untitled talk. CR (6 April 1960): 62-68. The Book of Mormon was Spencer Kimball's traveling companion and it thrilled him with its stories. Men of many professions would find the excitement of a life's work in this book, but its greatest power is to transform the lives of individuals and to bridge eternity. [J.W.M.]

K.048 Kimball, Spencer W. Untitled talk. CR (April 1963): 62-68. Many people may have interest in the Book of Mormon: gentiles, Jews, archaeologists, navigators, students and teachers, astronomers and geologists, politicians, and military men. It is most of all a sacred book, with the record of Christ's appearance in America. It is a second witness for Christ. [J.W.M.]

K.049 Kimball, Spencer W. Untitled talk. In Proceedings of the LaPaz, Bolivia Area Conference, 4-5, 14-15. Liverpool, England: Church of Jesus Christ of Latter-day Saints, March 1977. "Jesus did come and for some days he explained to the Lamanites and the Nephites, who are the parents of the Indians, the same doctrines that he had given the people in Jerusalem." [J.W.M.]

K.050 Kimball, Spencer W. Untitled talk. In Proceedings of the New Zealand Area Conference, 2-6. Salt Lake City: Church of Jesus Christ of Latter-day Saints, February 1976. In recent history, the Maoris came from Hawaii. Before that, however, they originated from the Book of Mormon seafarer called Hagoth (Alma 63). [D.M.]

K.051 Kimball, Spencer W. Untitled talk. In Proceedings of the Tonga Area Conference, 2-4. Salt Lake City: Church of Jesus Christ of Latter-day Saints, February 1976. A brief history of the scattering and gathering of God's people is given. A dispersion with relevancy to the Book of Mormon is detailed in Alma 63, where Hagoth the seafarer led a group of people from the American continent. Groups eventually settled in Hawaii, Tonga, and other islands of the South Pacific. [D.M.]

K.052 Kimball, Spencer W. "The Work among the Lamanites Must Not Be Postponed, If We Desire to Retain the Approval of God." IE 53 (December 1950): 980-82. An exhortation to work more towards redeeming the Lamanites. Kimball encourages the saints to remember them in their prayers and do their utmost to preach to them. He includes a prophecy of Joseph Smith that the saints will go to the Rocky Mountains and there open the door for establishing the gospel among the Lamanites. Wilford Woodruff designated the Zuni, Laguna and Isletas Indians of Southwest New Mexico as Nephite people. [B.D.]

K.053 Kimball, Stanley. "Book of Mormon Promises to Indians Coming True, Says Chief." CN 24 (1 May 1954): 7. Chief Samuel Blue, a member of the Church from the Catawba tribe, North Carolina, claims that the Book of Mormon prophecies concerning the Lamanites are being fulfilled. [D.M.]

K.054 Kimball, Stanley B. "Kinderhook Plates." In Encyclopedia of Mormonism, edited by Daniel H. Ludlow, 2:78990. 5 vols. New York: Macmillan, 1992. A brief article on the Kinderhook plates. Kimball quickly dismisses the issue since, in 1980 tests at Northwestern University, one of the six plates was proven conclusively to be a nineteenthcentury forgery. The plates were shown to Joseph Smith evidently to discredit him if he pretended to translate them. [B.D.]

K.055 Kimball, Stanley B. "Kinderhook Plates Brought to Joseph Smith Appear to be Nineteenth Century Hoax." Ensign 11 (August 1981): 66-74. A discussion of the Kinderhook Plates. After conducting an electronic and chemical analysis, the author concludes that the plates represented an elaborate hoax, possibly perpetrated in an attempt to discredit Joseph Smith. [D.M.] 
K.056 Kimball, Stanley H. B. "The Anthon Transcript: Egyptian, Mesoamerican or Phoenician?” SEHA 126 (August 1971): 1-5. A look at the relationship of the characters in the Anthon transcript to ancient Egyptian, Mesoamerican, and Phoenician scripts. The author concludes that while there are similarities between the characters in the Anthon transcript and Semitic languages, little more has been done by scholars than to define the problems. Much research remains to be done. [D.M.]

K.057 Kimball, Stanley H. B. "The Anthon Transcript: People, Primary Sources, and Problems." BYU Studies 10 (Spring 1970): 323-52. Addresses a number of questions incidental to the Harris-Anthon episode, such as who encouraged Harris to consult Anthon (as well as Mitchell), what were the qualifications of the learned men, what was the value of their observations, how reliable was Harris's report, when was the transcript made, and when did the incident become public and become a missionary tool? [D.M.]

K.058 Kimball, Stanley H. B. "Charles Anthon and the Egyptian Language." IE 63 (October 1960): 708-10, 765. Knowledge concerning the Egyptian language was underdeveloped in the 1820 s when Martin Harris presented the Book of Mormon characters and translation to Dr. Charles Anthon. While Anthon was a known Egyptian scholar of the period, he nonetheless lacked sufficient knowledge to vouch for the accurate translation of the characters. [R.C.D.]

K.059 Kimball, Stanley H. B. "I Cannot Read a Sealed Book." IE 60 (1957): 80. Also in A Book of Mormon Treasury, 19-29. Salt Lake City: Bookcraft, 1959, 2nd edition 1976. Tells of Martin Harris's visit with Charles Anthon and Dr. Mitchell in New York City in February 1828. Presents a historical profile on Anthon and Mitchell. Answers why Martin Harris went to these men instead of any others and how valid their testimony was respecting the characters shown to them. [R.C.D.]

K.060 Kimball, William Clayton. "Partaking of the Fruit." Ensign 10 (July 1980): 16-19. A discussion concerning Alma's sermon (Alma 32) to the Zoramites about the seed of faith. A greater understanding of this pericope can be gained through an examination of the context, structure, and substance of the sermon. [D.M.]

K.061 "Kin Carry on Work Begun by Samuel Smith." CN 58 (24 September 1988): 3. Descendants of Samuel Smith, the first missionary, have donated enough money to buy 1,000 copies of the Book of Mormon for missionary work. [M.R.]

K.062 “King Benjamin." Friend 12 (January 1982): 28-29. King Benjamin’s address is recalled in cartoon form for children. [A.T.]

K.063 “King Benjamin." Friend 20 (August 1990): 18-21. Children's illustrated story of King Benjamin's tower. [M.R.]

K.064 "King Benjamin Was a Just, Merciful Ruler in Zarahemla." CN 58 (19 March 1988): 14. Biography of King Benjamin based on the Book of Mormon account. Discusses his teachings and how the gathering he assembled for his farewell address reflects Old World traditions. Speculates about Zarahemla and its probable population at the time of King Benjamin. [A.C.W.]

K.065 "King Limhi and His People Escape." Friend 12 (May 1982): 30-31. Eleven cartoon drawings for children depicting the escape of Limhi's people. [A.T.] 
K.066 King, Arthur Henry. "Language Themes in Jacob 5: 'The Vineyard of the Lord of Hosts Is the House of Israel' (Isaiah 5:7). "In The Allegory of the Olive Tree: The Olive, the Bible, and Jacob 5, edited by Stephen D. Ricks and John W. Welch, 140-73. Salt Lake City: Deseret Book and FARMS, 1994. An analysis of the rhetorical language of Jacob 5. The scriptures are to be read aloud to gain their full benefits. Jacob 5 is best understood when read in paragraphs as found in the 1830 edition. There are twenty-one paragraphs, each of which is introduced by ritualistic wording and shows a passage of time. [J.W.M.]

K.067 King, David S. " 'Proving' the Book of Mormon: Archaeology Vs. Faith." Dialogue 24 (Spring 1991): 143-46. Reflects on the methodology and goals of Thomas Stuart Ferguson in his aspiration to discover the archaeological proofs of the Book of Mormon. Suggests that there are already accumulated numerous evidences of the Book of Mormon and that others will surface within science's "own inflexible timetable." While external evidences may be fascinating and illuminating, "our principle effort should be not so much to seek knowledge about the Book of Mormon as to seek knowledge of the Book of Mormon." [D.M.]

K.068 King, Norm Nielson. "Students' Mix Makes Early Morning Class Worth Waking Up For." CN 58 (18 June 1988): 7. A group of adults meet in the morning to learn more about the Book of Mormon. [M.D.P.]

K.069 Kinney, Bruce. "The Sacred Books of the Mormons," in Kinney, Mormonism: The Islam of America, 45-69. New York: Revell, 1912. A polemical treatise on the dangers inherent in Mormonism. Pages 47-69 deal with the Book of Mormon. The author appeals to the Spaulding theory to account for Book of Mormon origins. The testimonies of Book of Mormon Witnesses are discredited. Alleged anachronisms and absurdities are discussed, including the Jaredite barges, the Lamanite curse, Nephite coins, animals, and others. Refers to the many changes made in the book since 1830. He sadly concludes that "the effect of the whole book is disappointing, for, outside of the passages quoted, or, rather, plagiarized from the Bible, there is absolutely nothing uplifting or inspiring." [M.R.]

K.070 Kinney, Inez. "American Archaeology: The Pre-Incas Emerge." SH 89 (12 September 1942): 1163-64, 1171. Pachacamac, a deity of the Incas, and the ancient ruins of his cities and temple remind one of the Book of Mormon. [J.W.M.]

K.071 Kinney, Inez. "Book of Mormon." SH 90 (15 May 1943): 620-23. A less than smooth exposition in which it is argued that Lehi's colony landed in South America. The author's sources include the Book of Mormon and books on American geography and Indian history. [D.M.]

K.072 Kinney, Inez. "Book of Mormon Geography: An Answer to the Central American Landing Contention." SH 90 (15 May 1943): 620-23. Analyzing historical and legendary accounts of the ancient inhabitants of America in conjunction with Book of Mormon accounts and the geographical lay of the land, the author attempts to associate the Book of Mormon locations with ancient ruins. The greatest concentration of civilization was in Central America and Mexico, but the possibility of a Peruvian landing site is not ruled out. [J.W.M.]

K.073 Kinney, Inez. "The Search: In Guatemala and Honduras." SH 85 (17 September 1938): 1196-98, 1206. The lands of Guatemala and Honduras were anciently inhabited by two peoples. Archaeological evidence substantiates the Book of Mormon. [J.W.M.]

K.074 Kinney, Inez. "Yucatan: 'The Land of the Pheasant and the Deer.' "SH 85 (29 January 1938): 137-40, 146. For twelve years a Jew living in Mexico City gathered evidence to attempt to prove the original inhabitants of America were of Jewish descent. The material that he collected provides a great deal of evidence that the people observed the Mosaic Law, believed in one supreme God, and believed in figures like Adam, Eve, and Noah. [J.W.M.] 
K.075 Kinsley, Alvin. "The Straight Road: What Is the Book of Mormon." SH 55 (20 May 1908): 486-87. Mentions the three migrations of people to the Americas as described in the Book of Mormon. Believes that the Book of Mormon is a fulfillment of the "sealed book" prophecy in Isaiah 29, the "stick of Joseph" prophecy in Ezekiel 37, and the "truth" to "spring out of the earth" prophecy of Psalm 85. [A.T.]

K.076 Kipling. "Kipling's Estimate of Mormonism." SH 50 (17 June 1903): 545. This is a reprint of Kipling's chapter on "Mormonism" found in his American Notes. He calls the Book of Mormon a "powerful Anaesthetic" and the instruments with which the Book of Mormon was translated "gig-lamps," and he observes that the book has no "style" and is "toilsome" and "vile." [J.W.M.]

K.077 Kirban, Salem. Mormonism: Doctrines of Devils, No. 2: Exposing the Cults of Our Day. Chicago: Moody, 1973. A polemical work against Mormonism. The writer asserts that the Book of Mormon blasphemously adds to God's biblical word in direct contradiction to Revelation 22:18-19. He asserts that the book is full of gross anachronisms, such as the Jaredite barges, number of war casualties, the Lamanite curse, and pre-Columbian domesticated animals. [M.R.]

K.078 Kirby, G. W. The Mormons. Rushden, Northants, England: Stanley L. Hunt, 1959. A polemical tract against Mormonism. The writer considers Joseph Smith's account of the coming forth of the Book of Mormon "fantastic" beyond belief. He feels that the Book of Mormon was a hoax, based largely upon Solomon Spaulding's published novel. He also asserts that the Book of Mormon carelessly plagiarizes the King James translation of the Bible. [M.R.]

K.079 Kirby, William. "Origin of the Book of Mormon-Spaulding Manuscript." In Kirby's Mormonism Exposed and Refuted: Or True and False Religion Contrasted. Forty Years' Experience and Observation Among the Mormons, 412-45. Nashville, TN: Gospel Advocate, 1893. Quoting D.P. Kidder's Mormonism and the Mormons, this author favors the idea that Sidney Rigdon was the impetus behind the Book of Mormon and that Solomon Spaulding's manuscript was the basis for that book. [J.W.M.]

K.080 Kirby, William. "Witnesses to the Book of Mormon Examined and Tested." In Kirby's Mormonism Exposed and Refuted: Or True and False Religion Contrasted-Forty Years' Experience and Observations Among the Mormons, 446-77. Nashville, TN: Gospel Advocate, 1893. Discredits the testimony of the Three Witnesses. Joseph Smith deceived them by preparing fraudulent plates and speaking to them as if he were an angel. Eventually the witnesses abandoned Smith. [J.W.M.]

K.081 Kirk, Thomas J. The Mormons and Missouri. Chillicothe, MO: J. H. Darlington, 1844. The early nineteenthcentury conflict between the Mormons and the Missourians is treated. Writing about the Book of Mormon, the author believes that the book is "no idle scheme, nor production of a fanciful moment but required considerable research, and no ordinary degree of sagacity." Kirk produces a brief overview of the Book of Mormon story in the appendix. [D.M.]

K.082 Kirkham, Francis W. "America's Strangest Book." DN Church Section (22 September-10 November 1934; 1 , 15, 22 December 1934; 5, 19, 26 January, 1935; 9 February 1935): 1, 8, 5, 8, 3, 4, 5, 5, 5, 5, 8, 7, 4, 5, 6, 6, 7. Fifteen-part series. Joseph Smith was unshakable in his faith that the Book of Mormon was "the most correct book." The observations of the critics of the Book of Mormon by D. H. Bays, Rev. M. T. Lamb, the Wayne Sentinel, and the Palmyra Reflector show that the book is either true or false. The Book of Mormon is evidence of divine intervention. Reprints articles from the Wayne Sentinel dated September 16, 1829-January 2, 1830, that are inflammatory and derogatory toward the Book of Mormon and Joseph Smith. Contains facts concerning the 
translation and publication process of the Book of Mormon. Includes Joseph Smith's own words concerning commencement of the translation with Oliver Cowdery as scribe, the move to Fayette, New York, and publication by E. B. Grandin. Quotes extensively from Lucy Mack Smith concerning Joseph's reception of the plates, the work of translation, the loss of the 116 pages of manuscript, and Martin Harris's donation of money for the Book of Mormon. John S. Reed, Esq., a nonmember, delivered testimony before the state convention at Nauvoo in 1844 that Joseph had received the plates. Quotes several authors to prove that it was well-known that Joseph Smith had the plates prior to the publication of the Book of Mormon. Both friend and foe declared Joseph unlearned and devoid of the ability to write the Book of Mormon. Earnest seekers of truth and the knowledge of God acknowledge the Book of Mormon as a divine witness of Jesus Christ. [J.W.M.]

K.083 Kirkham, Francis W. "Answering an Important Question: Did Joseph Smith Obtain the Information in the Book of Mormon about the Origin of the People Who Once Lived in America from Books Published before 1830?" DN Church Section (16 March 1935): 2, 6, 8. Few books on the origin of American Indians were available in 1830 (James Adair, 1765; A View of the Hebrews, Ethan Smith, 1823; The Star of the West, Elias Boudinot, 1816). There is little evidence that Joseph Smith had access to these books because any information available would have related to American Indians in the United States east of the Mississippi. Information dealing with Mexico and Central America would have still been hidden in Spanish libraries. [J.W.M.]

K.084 Kirkham, Francis W. "Attempts to Prove the Book of Mormon Man-made." IE 54 (October 1951): 726-28. Since the Book of Mormon was first published it "has withstood a century of attempts to prove it man-made." Gives examples of different attempts and shows how each has failed. [M.D.P.]

K.085 Kirkham, Francis W. "Attempts to Prove the Book of Mormon Man-Made." In BYUSY (23 February 1954). Provo, UT: BYU Press. Reviews published reports dating between the years 1829-1951 that attempt to prove that the Book of Mormon was a fraudulent work, and then points out the varied reasons people have for claiming the book to be man-made. [J.W.M.]

K.086 Kirkham, Francis W. "The Book of Mormon and How to Read It." DN Church Section (14 May 1938): 3, 7. As an individual reads the Book of Mormon, he or she should consider the spiritual nature of the book, the "culture of the people described" within its pages, and the manner in which it stands as a second witness, with the Bible, of Jesus Christ. [D.W.P.]

K.087 Kirkham, Francis W. "The Book of Mormon, Evidence that Jesus Is the Christ." Instructor 98 (February 1963): 70-71. Examines the title page of the Book of Mormon in view of other Hebrew writings. Discusses what the Book of Mormon tells of Christ. [L.D.]

K.088 Kirkham, Francis W. Book of Mormon Writings. N.p., n.d. This collection contains nine articles. Topics include: the appearance of Christ in America, revelations of Book of Mormon prophets that relate to Christ, the Book of Mormon in the early history of the Church, evidence that the Book of Mormon is divine, and the book's influence on converts. [J.W.M.]

K.089 Kirkham, Francis W. "Early Knowledge of America's Strangest Book." IE 47 (September 1944): 552. Discusses the publication and printing process of the Book of Mormon, the present location of the original manuscript of the book, and the statement of the Three Witnesses regarding the authenticity of the Book of Mormon. [L.D.] 
K.090 Kirkham, Francis W. "Historic Data Gathered on Book's Origin." DN Church Section 84 (13 May 1933): 1-2, 7. An announcement that "all source material pertaining to the introduction and translation of the Book of Mormon is to be made available to members of the Church." [A.T.]

K.091 Kirkham, Francis W. How and Why the Book of Mormon. Salt Lake City?: n.p., 1964?. An essay that claims that the Book of Mormon was meant for the current age. [D.M.]

K.092 Kirkham, Francis W. "How to Read the Book of Mormon." DN (28 March 1936): 2, 4. The Book of Mormon is a literal translation of an ancient record, not the product of Joseph Smith as Alexander Campbell claimed. Through the spirit individuals may gain testimony of its divine origin. Included are personal testimonies of the Book of Mormon converts Wilford Woodruff and Parley P. Pratt. [J.W.M.]

K.093 Kirkham, Francis W. "The Manner of Translating the Book of Mormon." IE 42 (October 1939): 596-97, 63032. Quotes Joseph Smith, Oliver Cowdery, and other contemporary accounts to show how and where Joseph obtained the plates. Also quotes Emma Smith and the Three Witnesses to explain that the Book of Mormon was translated with divine aid and with the use of the Urim and Thummim. [A.C.W.]

K.094 Kirkham, Francis W. "New Proof Martin Harris Aided Joseph Smith." DN Church Section (19 September 1936): 1, 8. Presents evidence that Martin Harris "mortgaged his farm for $\$ 3,000$ to pay for the printing of the first edition" of the Book of Mormon. [D.W.P.]

K.095 Kirkham, Francis W. A New Witness for Christ in America. 2 vols. Independence, MO: Zion's, 1951, 2nd ed, Salt Lake City: Utah Printing, 1960. Volume 1 consists of a collection of primary documents from individuals, both sympathetic and antagonistic toward the Book of Mormon who were involved in the coming forth of the book. The documents deal with the circumstances in which Joseph Smith obtained the plates and the process of translation and printing the work. Volume 2 continues the compiler's selection of primary documents relative to varied opinions about the coming forth of the Book of Mormon. Most of the views set forth assume that the Book of Mormon came about in ways other than the process claimed by Joseph Smith. Included are early newspaper notices by Obadiah Dogberry and Alexander Campbell's resentful evaluation. [D.M.]

K.096 Kirkham, Francis W. Revelations to Nephite Prophets Concerning Jesus, the Christ, the Eternal God before His Appearance in America, after His Resurrection. Unpublished, 1964. An acceptance of the Book of Mormon as a revelation from God is a prerequisite to finding the true value of the book. Passages selected from the Book of Mormon that show that Nephite prophets knew of Jesus Christ, his earthly mission, Atonement, and gospel before his birth in Jerusalem. [J.W.M.]

K.097 Kirkham, Francis W. Source Material Concerning the Origin of the Book of Mormon. Author, 1937. Rehearses the coming forth of the Book of Mormon, as told by Joseph Smith, the mother of Joseph Smith, and others. Also included are statements by those who reject the divine nature of the Book of Mormon. This slender volume is the forerunner of the author's A New Witness for Christ in America. [D.M.]

K.098 Kirkham, Francis W. Suggestions for the Reading, Study, and Prayerful Consideration of the Book of Mormon. Salt Lake City: Vanity, 1965. Three-page essay that encourages readers of the Book of Mormon to study the volume in such a way that they will receive a testimony. [D.M.]

K.099 Kirkham, Francis W. "What Is the Book of Mormon?" DN Church Section (21 October 1933): 5. The citizens of Palmyra covenanted not to buy a single Book of Mormon from Joseph Smith who claimed a divine origin of the 
book. It was denounced by Alexander Campbell in the Millennial Harbinger in February 1831. In spite of opposition the Book of Mormon has been carried to the world. Parley P. Pratt's testimony and Joseph Smith's letter to John Wentworth are included. [J.W.M.]

K.100 Kirkham, Francis W. "What Is the Book of Mormon?" DN Church Section (21 March 1936): 2, 8. The actual translation of the Book of Mormon took place in just under ninety days, though Joseph Smith had the plates from September 22, 1827, to July 1, 1829. The printing contract was made August 25, 1829. The author's research of 700 items regarding the origin of the Book of Mormon found in the New York City Library confirmed his testimony. A newspaper article is included from the Wayne Sentinel about Martin Harris mortgaging his farm and a quote from Mormonism Unvailed stating that there are affidavits from 60 persons to prove Joseph's inability to write the book. [J.W.M.]

K.101 Kirkham, Francis W. "What Is the Book of Mormon?" MS 99 (10 June 1937): 354-56, 364. Describes the origin and translation of the plates of the Book of Mormon. The book, if true, is one of the most important messages ever sent from God to man. If false, it is a cunning, wicked fraud. Kirkham mentions the eleven witnesses who saw the plates, three of whom solemnly declared that a voice from heaven declared the book had been translated by the "gift and power of God." [R.H.B.]

K.102 Kirkham, Francis W. "Why the Book of Mormon?" Instructor 99 (December 1964): 472-73. Discusses the purpose and coming forth of the Book of Mormon, presents personal testimony regarding the truthfulness of the book, and speaks about how it helps humanity in their "search for happiness." [L.D.]

K.103 Kirkham, Francis W. "Why the Book of Mormon? Revealed Reasons for the Coming Forth of the Book of Mormon." MS 111 (June 1949); 168-69, 188-89. The Book of Mormon came forth in the midst of an unbelieving world that by faith and diligent study, mankind could come to know Jesus Christ by revelation. If the book had been a fraud, mistakes would have occurred on every page because of the complexity of the book. [J.W.M.]

K.104 Kirkham, Francis W. "The World's New Scripture." MS 98 (28 October 1937): 690-92. When the Book of Mormon was published, a local newspaper called it "The greatest piece of superstition that has come to our attention." Orson Pratt observed that the book was either true or "one of the most cunning, wicked, bold, deep-laid impositions ever palmed off upon the world." By 1937, the book was translated into sixteen languages and selling 50,000 copies a year. This should be adequate evidence of the divine nature of the book. [J.W.M.]

K.105 Kirkham, Francis W. "The Writing of the Book of Mormon." IE 44 (June 1941): 341-43, 370-75. An examination of the people and dates involved in translating the Book of Mormon. Very little of the translation occurred between the time Martin Harris lost the 116 pages of the Book of Lehi and Oliver Cowdery began serving as scribe on April 7, 1829. Information is provided regarding the hand-written manuscripts of the Book of Mormon. [D.M.]

K.106 Kirkham, Francis W., and Harvey L. Taylor. "Presentation of the Copyrights to A New Witness for Christ in America to BYU." BYUSY (12 April 1961). Provo, UT: BYU Press. BYU accepts the copyrights of Kirkham's two new books, A New Witness for Christ in America. Kirkham describes his motives behind writing the books and his experience of publishing the work. He also discusses the coming forth of the Book of Mormon to the world. [L.D.]

K.107 Kirkham, Francis W., and Sanford D. Van Alstyne. Excerpt from Palmyra Reflector and Wayne Sentinel. New York: n.p., 5 March 1934. Typescript copies of two early upstate New York newspapers that provide comments about the Book of Mormon. Includes Obadiah Dogberry's well-known satire, The Book of Pukei. [D.M.] 
K.108 Kirkham, James M. Untitled talk. CR (April 1936): 89-91. The author bears testimony of the divine nature of the Book of Mormon and that it comes from God, and he exhorts members to read and teach the Book of Mormon more. [J.W.M.]

K.109 Kirkland, Harriet Rosser. "A Book Different from Any Other." Ensign 16 (July 1986): 38-39. The personal conversion story and testimonial of a Jewish girl from New Jersey who converted to Mormonism through reading the Book of Mormon. [L.D.]

K.110 Kirtland, Boyd. "The Development of the Mormon Doctrine of God." In Line upon Line: Essays on Mormon Doctrine, edited by Gary James Bergera, 35-51. Salt Lake City: Signature, 1989. Argues that Mormons have a dilemma: the evolution of doctrine within the Church concerning the names and identities of Deity finds no reconciliation between Book of Mormon theology, biblical theology, and "Joseph Smith's later plurality-of-gods theology." [J.W.M.]

K.111 Knapp, Lamont. Interesting Manuscripts. N. p., 196?. A collection of faith-promoting documents. Includes information about the Three Witnesses and a list of ingredients needed to write something as demanding as the Book of Mormon. [D.M.]

K.112 Knight, Hal. "Book of Mormon Is Woven into the Basic Threads of Restored Gospel." CN 50 (5 January 1980): 6. The Book of Mormon's publishing history from the first edition in English in 1830 to the present day is outlined, including the dates of the different language translations of the Book of Mormon. [M.D.P.]

K.113 Knisley, Alvin. Dictionary of All Proper Names in the Book of Mormon. Independence, MO: Ensign, 1909. Lists all proper Book of Mormon names, with a pronunciation guide, a historical precis, dates, and scriptural references. [D.M.]

K.114 Knisley, Alvin. Dictionary of the Book of Mormon. Independence, MO: n.p., 1909, [R]1945. A revision of the author's Dictionary of All Proper Names in the Book of Mormon. The author describes the revision as a definitive "historical, biographical, gazetteerical and chronological" work. [D.M.]

K.115 Knowles, Eleanor. "The Hill Cumorah Pageant." IE 69 (July 1966): 624-26, 643. Gives brief histories of the Book of Mormon and the Hill Cumorah pageant. Includes appraisals from Eastern newspapers of the pageant. [D.M.]

K.116 Knowlton, Clark S. "Problems in Book of Mormon Archaeology." 13th Annual Symposium on Archaeology of the Scriptures (1 April 1961): 52-54. Book of Mormon archaeology presents many problems: the location of Book of Mormon lands is unknown; many researchers are not qualified and have made serious mistakes; some use writings that support LDS theology and ignore unsupportive writings. There is a need to test theories carefully and slowly create a basis of tested and proven evidence to support the Book of Mormon. [J.W.M.]

K.117 Knowlton, Clark S. Review of Just One Cumorah, by Riley L. Dixon. U.A.S.N. 80 (15 April 1962): 80.1. Book review.

K.118 Kocherhans, Arthur J. Lehi's Isle of Promise. Fullerton, CA: Et Cetera, Et Cetera Graphics, 1989. A word study and commentary on the Book of Mormon, with maps and pictures. Defines words such as knowledge, prophecy, and understanding according to their 1828 meanings. The Nephites fulfilled the promises of God to Abraham, Isaac, Jacob, and Joseph who was sold into Egypt. This work is reviewed in F.085. [D.M.] 
K.119 Kocherhans, Gib. "The Need for a Book of Mormon History." In The Second Annual Church Educational System Religious Educators' Symposium: A Symposium on the Book of Mormon, 71-73. Salt Lake City: Church of Jesus Christ of Latter-day Saints, 1979. Proposes that the Book of Mormon is an artistic work, compared to a symphony. Suggests outlining the book to make it more meaningful-gives examples of outlines for 1 and 2 Nephi. For example, an outline of 2 Nephi would highlight the patriarchal blessings, the doctrines of the Fall and the Atonement, the testimonies of Christ, and the coming forth of the Book of Mormon. [D.M.]

K.120 "Korean Book of Mormon." IE 70 (June 1967): 15. Discusses the translation of the Book of Mormon into Korean, published in Seoul, Korea. [L.D.]

K.121 "Korihor." Friend 23 (July 1993): 20-22. An illustrated story for children of Korihor (Alma 30). There is a caption under each picture summarizing the related scriptures. [S.H.]

K.122 Kotchongva, Dan. "Where Is the White Brother of the Hopi Indian?” IE 39 (February 1936): 82-84, 116, 118-19. Discusses the Hopi Indians and their connection with the Book of Mormon. An interpreted version of the Hopi Indian story as told by their chief in Salt Lake City. [L.D.]

K.123 Kramer, Glenn G. La Biblia Versus El Libro de Mormon. San Isidro, CA: La Iglesia de Cristo, n.d. A polemical tract against the Book of Mormon. The writer attempts to portray the Book of Mormon as "another gospel" (Galations 1:8) that is opposed to the gospel of Christ. [M.R.]

K.124 Krause, Alfred E. Review of The Book of Isaiah: A New Translation, with Interpretive Keys from the Book of Mormon, by Avraham Gileadi. Sunstone 12 (September 1988): 44. Book review.

K.125 Kraut, Ogden. The Three Nephites. Salt Lake City: Kraut, 1988. A collection of stories and testimonials from individuals who have claimed to have experienced encounters with the Three Nephites. [M.R.]

K.126 Kraut, Ogden. The Three Witnesses: A Response to the Utah Evangel. Salt Lake City: O. Kraut, 1986. A response to Robert McKay's August-September 1985 Utah Evangel article that dealt with the reliability of the testimony of the Three Witnesses. Ogden asserts that, although the witnesses possessed weaknesses, their testimony yet remains effective. Certain biblical witnesses - John the Baptist, Simon Peter, and Judas Iscariotalso had weaknesses, and yet their testimonies remain accepted to the present time. [D.M.]

K.127 Kroeber, Clifton B., and Walker D. Wyman. "Frontier in Perspective." In Frontier in Perspective, 244-45. Madison: The University of Wisconsin Press, 1957. Discusses the LDS view of the origin of the American Indians. The Book of Mormon suggests that the Indians are the degenerate posterity of a small group of Jews who migrated to the New World before the Christian era. [J.W.M.]

K.128 Kruckenberg, Janet. "Rummage-Sale Book of Mormon." Ensign 20 (February 1990): 69. A conversion story of a man and his family who were baptized after a Book of Mormon was discovered at a rummage sale. [L.D.]

K.129 Krueger, John R. An Analysis of the Names of Mormonism. Bloomington: Selbstverlag Press, 1979. A study of the proper names extant in the Book of Mormon. Author notes that over 140 biblical names occur in the Book of Mormon, while over 188 Book of Mormon names are nonbiblical. After a technical analysis the writer suggests that efforts "should be directed towards linking up the non-biblical names with names found in post-biblical literature, Talmudic materials, other Semitic languages; and particularly, in materials about South American and North American proto-languages." [M.R.] 
K.130 Kselman, John W. Review of Chiasmus in Antiquity: Structures, Analyses, Exegesis, edited by John W. Welch. Dialogue 17 (Winter 1984): 146-48. Book review.

K.131 Kunich, John C. "Multiply Exceedingly: Book of Mormon Population Sizes." In New Approaches to the Book of Mormon, edited by Brent Lee Metcalfe, 231-67. Salt Lake City: Signature, 1993. There is a real problem in believing the population sizes in the Book of Mormon. Kunich presents a computed estimate of possible growth in the New World according to accepted standards. This study argues that the numbers in the Book of Mormon are greatly inflated. There must have been indigenous native groups. However, this seems unlikely since historians carefully recorded significant events and details, and such a population would not have gone unmentioned. [J.W.M.]

K.132 Kunich, John C. "Multiply Exceedingly: Book of Mormon Population Sizes." Sunstone 14 (June 1990): 27-44. Believes that the Book of Mormon exaggerates in several places the population numbers of the Lamanites and Nephites. The small numbers in the Lehi-Mulek colonies could not have reproduced nearly so many people. [D.M.] 
L.001 L., J. L. "The Book of Mormon." SH 98 (19 February 1951): 176-77. Discusses the 1830 Palmyra Edition of the Book of Mormon, its title page, preface, and the corrections of later editions. [A.C.W.]

L.002 LDS Church. The Book of Mormon Pavilion, 'Ancient America Speaks': An Exhibit by the LDS Church. N.p., n.d. A pamphlet containing photographs of Book of Mormon exhibits shown at the World's Fair and a short message stating that the Book of Mormon is "a recipe book for joy." [J.W.M.]

L.003 "La Secta de los Mormones en los Estados Unidos." El Correo de Ultramar 12/17 (1853): 267-70. Discusses the curiosities of Mormonism, including the emergence of the Book of Mormon. Claims that the book grew out of a bad novel, Spaulding's manuscript, and was originally entitled The Golden Bible. Berates Joseph Smith for claiming to translate reformed Egyptian. [D.M.]

L.004 "The Lamanites." Juvenile Instructor 13 (15 March 1878): 51. Notes that scientists recognized that the ancestors of the American Indians were highly civilized and had apparent ties to the East. The Book of Mormon is the one reliable source to explain this. [D.M.]

L.005 Lamb, Artemus. "The Fulfillment of Mormon Prophecy." World Order: the Baha'i Magazine (November 1944): 258-62. The prophecies and teachings of the Mormon Church are contained in a book published under the same name, "Mormon." Provides an account of the visit of the angel Moroni and the prophecies of the Old Testament that he quoted. These prophecies spoke of Joseph Smith's calling, and the "Last Days" when Jesus Christ will return. None have been fulfilled. In 1844 a young Persian too received a call. He was the Bab (the Gate) through whom God would be revealed. He prophesied that God would not appear for a thousand years. [J.W.M.]

L.006 Lamb, Charles W. An Exposition of Mormonism, and a Defence of Truth, Being a Refutation of the Report That the Book of Mormon Originated in Solomon Spaulding's 'Manuscript Found.' Corinnell, IA: n.p., 1878. Author refutes the Spaulding theory and offers evidence as to the Book of Mormon's divine origin. [E.G.]

L.007 Lamb, David. "Behold, He Is the Word of Truth." ZR 50 (August 1990): 2. Shows the correlation between the Book of Mormon identification of Christ as the "Word of Truth" (Alma 18:12, RLDS versification) and the Hebrew term for truth ('emeth). [A.T.]

L.008 Lamb, David. "The Four-Part Pattern in Prophecies." ZR 44 (August 1989): 1, 8. In the Old Testament there is a four-part pattern used by prophets in prophesying: "(1) identification of $\sin$, (2) need for repentance, (3) judgment of God (if people do not repent), and (4) future in Christ." The article shows how Samuel the Lamanite, Alma, Lehi, and Abinadi followed this pattern. [A.T.]

L.009 Lamb, David. "Friend: A Covenant Term." ZR 49 (June 1990): 1, 3-4. Also in Recent Book of Mormon Developments; Articles From the Zarahemla Record, 2:50-51. Independence, MO: Zarahemla Research Foundation, 1992. The term friend is often used to express a covenantal agreement between two individuals. Such was the case between Zoram and Nephi (2 Nephi 1:55, RLDS versification). Other examples include Isaiah 41:8, 2 Chronicles 20:7, and Zechariah 13:6. [A.T.] 
L.010 Lamb, David. "The Meaning Behind Moroni's Title of Liberty." ZR 45 (November 1989): 1-2. Moroni and the Title of Liberty feature a "step-by-step procedure on preparation for spiritual warfare through the upholding of Jesus Christ." These steps are: despise evil, humble ourselves, put on the armor of God, seek God's instruction through prayer, work to save the nation, and look to the Lord. [A.T.]

L.011 Lamb, David. "The Meaning of the Name 'Mormon.' "ZR 43 (June 1989): 1-2. Suggests that the Book of Mormon was not named after a man, but after a place called Mormon where the Nephites once covenanted to observe the laws of God. This important place was very suitable as a name for a book of scripture. [A.T.]

L.012 Lamb, David. "Priests and Teachers." ZR 59 (January/February 1992): 1, 4. Points out several doublets in the Bible and Book of Mormon: parents and teachers, priest and scribe (teacher), Lord and master (teacher), ruler and teacher, and teacher and king. It is characteristically Hebraic to think of a vocation or calling in connection with being a teacher, thus the emphasis on teacher is an evidence for the authenticity of the Book of Mormon. [D.M.]

L.013 Lamb, David. "The Righteous Branch." ZR 48 (April 1990): 64. Both Lehi and Jeremiah denominate Joseph of Egypt (2 Nephi 3) as the "righteous branch," an expression that generally refers to Christ. This fact suggests that Lehi possessed or had access to a copy of Jeremiah's writings or that Nephi and Jeremiah were acquaintances. [A.T.]

L.014 Lamb, David. "Search the Words of Isaiah." ZR 60 (March/April 1992): 1, 4. Suggests following the directive of Jesus to take the writings of Isaiah seriously. To accomplish this assignment one must learn the manner of the Jews. [D.M.]

L.015 Lamb, David. "A Turnabout in the Meaning of Repentance." In Recent Book of Mormon Developments; Articles From the Zarahemla Record, 2:224-25. Independence, MO: Zarahemla Research Foundation, 1992. Lamb explains the Hebrew meaning of the verb "to repent" (shub) and shows that the Book of Mormon treatment of repentance is in accordance with the Hebrew. For example, 3 Nephi 8:65 (RLDS versification) says "return and repent." Shub means to turn around or return. [B.D.]

L.016 Lamb, David. "What's in a Number?" In Recent Book of Mormon Developments; Articles From the Zarahemla Record, 2:41. Independence, MO: Zarahemla Research Foundation, 1992. Examines Mosiah 11 (RLDS versification) in light of the symbolism of numbers. Alma's people first traveled eight days (Mosiah 11:1-4). Eight symbolizes new beginnings. In Mosiah 11:72 Alma's people travel one day. One symbolizes unity. They arrived in Zarahemla 12 days later (Mosiah 11:75-76). Twelve symbolizes perfection of government. Finally their total journey of 21 days symbolizes divine completion. [B.D.]

L.017 Lamb, Martin Thomas. The Golden Bible or the Book of Mormon, Is It From God? Salt Lake City: Salt Lake Herald, 1887. A polemical work against the Book of Mormon written by a Baptist minister who views the Book of Mormon as an absurd and shallow fraud. He enumerates various absurdities and anachronisms, including, the use and modification of biblical language and names, Lehi's desert journey, Jaredite barges, modern words and ideas, lack of archaeological evidence, contradictions with the Bible, rapid population growth, lack of pre-columbian iron, steel, brass, coins, barley, wheat, domesticated animals, and Book of Mormon geography. [M.R.]

L.018 Lamb, Martin Thomas. The Mormons and Their Bible. Philadelphia: Griffith \& Rowland, 1901. A polemical work against Mormonism. Much of the book is devoted to an attack on the Book of Mormon along the same lines as the author's 1887 work, The Golden Bible. [M.R.] 
L.019 Lambert, James R. Objections to the Book of Mormon and the Book of Doctrine and Covenants Answered and Refuted. Lamoni, IA: Herald Publishing House, 1894. [R] 1898. Responds to critics of the Book of Mormon. Writes concerning metal plates, manner of translation, poor grammar, rapid population growth, dark color of Lamanites, modern words used in the translation, polygamy, place of Christ's nativity, Holy Spirit given before Christ came in the flesh, the charge of plagiarism, and the Spaulding theory. [B.D.]

L.020 Lambert, Joseph R. "Thoughts on Charity." SH 48 (13 February 1901): 125-29. An understanding of what charity is and is not is essential in gaining safety from the counterfeits of Satan. The Book of Mormon teaches us best about charity, defining it as "the pure love of Christ" (Moroni 7:47), an everlasting, unselfish love. It is not simply a feeling, but an eternal truth that leads to complete obedience, mercy, and forgiveness. [J.W.M.]

L.021 Lambert, L. Gary. "Allegory of Zenos." In Encyclopedia of Mormonism, edited by Daniel H. Ludlow, 1:31-32. New York, NY: Macmillan Publishing Company, 1992. A brief description of the allegory of Zenos from Jacob 5. The allegory reinforces Jacob's teachings about Jesus Christ and the house of Israel's anticipated unresponsiveness toward the coming Redeemer, and instructs the people about the promised future gathering of Israel. [B.D.]

L.022 Lambert, L. Gary. "Alma1." In Encyclopedia of Mormonism, edited by Daniel H. Ludlow, 1:32-33. New York, NY: Macmillan Publishing Company, 1992. A brief description of Alma the Elder's life and ministry including his genealogy, occupation, how he was converted to God through Abinadi, his leadership, and the influence he and his descendants had on the Church. [B.D.]

L.023 Lambert, R. G. "Hawaiian Mythology." Juvenile Instructor 11 (15 October 1876): 235. Sees some elements of Hawaiian myth as correlative to the Book of Mormon. Sites some particulars of Captain Cook. [D.M.]

L.024 Lambert, Richard J. "Are You Reading the Book of Mormon?" SH 74 (10 August 1927): 923-24. Challenges members of the Church to read the Book of Mormon. Reading it will increase faith in Jesus Christ, give personal knowledge of the contents of the book, establish the habit of relying upon the word of God, give spiritual vision, and create unity in the Church. [J.W.M.]

L.025 Lambert, Richard J. "As Centennial Date Nears, Book of Mormon Readers Increase." SH 74 (31 August 1927): 1010. Many have started reading the Book of Mormon in response to the challenge to read the book before the centennial celebration. [J.W.M.]

L.026 Lambert, Richard J. "The Book of Mormon Center of Interest." SH 74 (7 September 1927): 1034. Forming small groups will assist members in reading the Book of Mormon before the commemoration of the centennial. [J.W.M.]

L.027 Lambert, Richard J. "Book of Mormon in Print a Hundred Years." SH 77 (19 February 1930): 209-10. Lambert praises the one hundred-year anniversary of the Book of Mormon, discusses the rarity and value of the first edition and urges all to heed its counsel. [B.D.]

L.028 Lambert, Richard J. "Book of Mormon Pageant at Independence." SH 74 (14 September 1927): 1059. "Remembering Cumorah" is a pageant to commemorate the centennial of the Book of Mormon. [J.W.M.]

L.029 Lambert, Richard J. "Book of Mormon Readers." SH 74 (26 October 1927): 1251-52. Letters and cards flooding the Church offices tell of new interest in reading the Book of Mormon. Excerpts from letters are included. 
[J.W.M.]

L.030 Lambert, Richard J. "Book of Mormon Would Help Them." SH 74 (13 July 1927): 795. Quoting the Wisconsin Evening Telegram concerning the origin of the native inhabitants of America, the author declares the joy of knowing the truth contained within the pages of the Book of Mormon. [J.W.M.]

L.031 Lambert, Richard J. "Interest in Book of Mormon Increases." SH 74 (2 November 1927): 1274. As individuals and families value the Book of Mormon more, they are spending more time reading it with greater rewards of spirituality and faith. [J.W.M.]

L.032 Lambert, Richard J. "Of Interest to Book of Mormon Believers." SH 76 (23 January 1929): 82-83. An article appeared in the Kansas City Times asserting that according to the Book of Mormon, a race of people wandered across the "Behring's Strait and down into the Continent of North America, establishing a great civilization." "In response to requests from the Church offices a rather lengthy and corrective news story" was published to correct the error. [B.D.]

L.033 Lambert, Roy. The Weight of an Angel. Salt Lake City: Bookcraft, 1961. A biography of Moroni, based on the Book of Mormon and comments from LDS authorities. [D.M.]

L.034 Lambert, William O. G. "The Earth's Interior." Our Desert Home 2 (June-July 1883): 126-29, 152-53. Argues that the scriptures, including the Book of Mormon, refer to places inside the earth. Makes reference to the parable of the olive tree and to the habitation of the lost tribes of Israel. [D.M.]

L.035 Lamoreaux, Adam. "Book of Mormon Bibliography." In Review of Books on the Book of Mormon 2 (1990): 267 73. Provides a bibliography of books and articles that have been written about the Book of Mormon between the years 1984 and 1989. Listed by author. [J.W.M]

L.036 Lampert, J. M. Concordance to the Book of Mormon. Lamoni, IA: Herald House, 1898. A 14-page concordance to the Book of Mormon. [D.M.]

L.037 Lancaster, James E. "By the Gift and Power of God: The Method of Translating the Book of Mormon." SH 109 (15 November 1962): 798-802, 806, 817. Reviews the accounts of several witnesses (including Joseph Smith, David Whitmer, Oliver Cowdery, Martin Harris, Michael Morse, Isaac Hale, and Emma Smith) to the procedures in translating the Book of Mormon. Joseph Smith provided few details regarding translation methods because he wanted to de-emphasize mechanical devices for receiving revelation, in deference to depending directly on the Holy Spirit. [D.M.]

L.038 Lancaster, James E. "The Method of Translation of the Book of Mormon." In Restoration Studies III, edited by Maurice L. Draper, 220-31. Independence, MO: Herald House, 1986. Reprint from the John Whitmer Historical Association Journal 3 (1983): 51-61. Analyzes the method of translation by Joseph Smith of the Book of Mormon. Joseph Smith gave no specific details about the translation process, but simply stated that the book was translated by the "gift and power of God." Witnesses relate that there were two translational aids, first the Urim and Thummim and later the "seer stone." [J.W.M.]

L.039 Lancaster, James E. "The Translation of the Book of Mormon." In The Word of God: Essays on Mormon Scripture, edited by Dan Vogel, 97-112. Salt Lake City: Signature, 1990. An essay that discusses the idea of translation and the Book of Mormon. [M.R.] 
L.040 "A Land of Promise." Relief Society Magazine 5 (April 1918): 233-36. The Book of Mormon taught that America is a land of promise and the hope of the world. All other lands stretch out their hands for the material, political, and spiritual wealth that America offers. [J.W.M.]

L.041 Landon, Donald D. The Book of Mormon is Christian. Independence, MO: Herald House, 1962. A tract designed to persuade the reader that Christology in the Book of Mormon qualifies the book to be Christian scripture, consistent with the Bible. [D.M.]

L.042 Landon, Donald D. How the Book of Mormon Confirms the Message of Christ. Independence, MO: Herald House, 196?. A tract published by the Reorganized Church designed to introduce interested readers to the Book of Mormon. Teachings from the Book of Mormon are consistent with and in agreement with biblical doctrines. [D.M.]

L.043 Lane, Keith H. "Symbolic Action and Persuasion in the Book of Mormon." M.A. thesis, Brigham Young University, 1990. Takes the methodology of Kenneth Burke to plead that Mormons read some passages of the Book of Mormon as rhetorical devices and accept Christ and live by his code. The rhetoric is couched within "scenes" from the Book of Mormon. [D.M.]

L.044 Lang, W. History of Seneca County. Springfield, OH: Transcript, 1880. An historical work on the state of New York. Pages 646-55 contain a discussion of Mormonism and the Book of Mormon. The writer accepts the Spaulding theory of the Book of Mormon's origin and includes a discussion of the Anthon incident. [M.R.]

L.045 "Languages of the Book of Mormon." Ensign 22 (August 1992): 80. By the end of 1991 the Book of Mormon had been translated into ninety languages. [A.C.W.]

L.046 Lanier, Roy H. "The Book of Mormon and Eternal Progression." Christian Soldier 4 (14 August 1942): 1, 3. Argues that the Book of Mormon doctrine on eternal progression contradicts Mormon teachings on the same, and the Book of Mormon therefore cannot be based upon truth. [D.W.P.]

L.047 Lanier, Roy H. Is the Book of Mormon from God. Richland, WA: Swift and Thayer, n.d. A polemical work against the Book of Mormon, which discusses internal anachronisms in the Book of Mormon and contradictions with the Bible. [M.R.]

L.048 Lanier, Roy H. Mistakes of "Latter-day Saints." Little Rock, AK: Harper, n.d. A polemical work against Mormonism containing similar material as the author's other work, Is the Book of Mormon From God? [M.R.]

L.049 Lapham, Fayette. "The Mormons: Interview with the Father of Joseph Smith, the Mormon Prophet Forty Years Ago. His Account of the Finding of the Sacred Plates." Historical Magazine 7 (May 1870): 305-9. Presents a distorted view of the coming forth and translation of the Book of Mormon. [J.W.M.]

L.050 Lapray, Lyle E. "Book Supply Restocked." CN 60 (25 August 1990): 16. A repair man asks about paintings of the prophets on the wall. He receives a Book of Mormon from the family and is thankful. [M.R.]

L.051 Largey, Dennis L. "The Book of Mormon, an Interpretive Guide to the New Testament." In The New Testament and the Latter-day Saints, Sperry Symposium, 1987, edited by H. Dean Garrett, et. al., 129-47. Salt Lake City: Randall, 1987. Demonstrates through several examples how the Book of Mormon clarifies doctrines only tacitly dealt with 
in the New Testament. Comments on President Benson's statements that the Book of Mormon confounds false doctrine and that members of the Church should know it better than any other text. [D.M.]

L.052 Largey, Dennis L. "Built Upon the Rock." Ensign 22 (January 1992): 47-51. Study of the Book of Mormon makes a difference in testimony, gospel knowledge, and lays a firm foundation for faith in Christ. The Book of Mormon contains the "words of life" and is a "voice of warning," supports and enhances biblical teachings and was vital to the Restoration. [A.C.W.]

L.053 Largey, Dennis L. "Enduring to the End." In Doctrines of the Book of Mormon, 1991 Sperry Symposium, edited by Bruce A. Van Orden and Brent L. Top, 57-69. Salt Lake City: Deseret Book, 1992. The principle of enduring to the end is specifically taught 22 times throughout the Book of Mormon. Endurance might be considered the fifth of the first principles and ordinances. God's children are to endure afflictions and temptations, to continue in the faith, and are entitled to divine help. Enemies of endurance include Satan's inspiration, murmuring, hardness of heart, immorality, apostasy, and priestcraft. [N.K.Y.]

L.054 Largey, Dennis L. "The Enemies of Christ: 2 Nephi 28." In The Book of Mormon: Second Nephi, The Doctrinal Structure, edited by Monte S. Nyman and Charles D. Tate Jr., 287-305. Provo, UT: Brigham Young University Religious Studies Center, 1989. Discusses how 2 Nephi 28 exemplifies President Benson's proposition that the Book of Mormon reveals Christ's enemies. The following forms of enemies are treated: (1) the precepts of men or false doctrines, (2) spurious teachers, (3) pride, and (4) Satan. [D.M.]

L.055 Largey, Dennis L. " 'Enemies of Righteousness': The Book of Mormon Identifies Latter-day Forces That Oppose the Lord." Ensign 19 (December 1989): 6-11. Shows how 2 Nephi 28 exposes the enemies of Christ. They are identified as false doctrines, false teachers, priestcrafts, pride, apathy, and Satan,. [D.M.]

L.056 Largey, Dennis L. "Enos: His Mission and His Message." In The Book of Mormon: Jacob through Words of Mormon, To Learn with Joy, edited by Monte S. Nyman and Charles D. Tate Jr., 141-56. Provo, UT: Brigham Young University Religious Studies Center, 1990. Enlarges on several themes in Enos including forgiveness as a consequence of a "wrestle before God," concern for other people, revelation, confidence that the Lord honors his covenants with his disciples, and the importance of parents teaching their children. [D.M.]

L.057 Largey, Dennis L. "Lessons from the Zarahemla Churches." In The Book of Mormon: Mosiah, Salvation Only through Christ, edited by Monte S. Nyman and Charles D. Tate Jr., 59-71. Provo, UT: Brigham Young University Religious Studies Center, 1991. The materials in Mosiah 25-27 were selected for the benefit of members of the Church: the standard of truth is set forth for a darkened world; the Nephites dealt with flattery, teaching the rising generation, persecution, transgression in the Church; and the conversion of Alma the Younger and the Sons of Mosiah is a model for hope. [D.M.]

L.058 Larsen, Dean L. American Indians Today. Provo, UT: Extension Publications, 1965. A booklet containing four lectures on the Indians. Author endeavors to identify the American Indians, deals with the condition and status of the North American Indians as of 1964, discusses the LDS Indian programs, and is concerned with the ways in which the Caucasian sector of the Church can be of service to the Indians. [D.M.]

L.059 Larsen, Dean L. "Likening the Scriptures unto Us." In The Book of Mormon: Alma, The Testimony of the Word, edited by Monte S. Nyman and Charles D. Tate Jr., 1-13. Provo, UT: Brigham Young University Religious Studies Center, 1992. The Book of Mormon bears a primary role in standing as a second witness of Jesus' divinity. It also holds a great value by virtue of what we can learn from the experiences of the people in the record by finding vivid 
parallels for our own day. For instance, the people of the Book of Mormon sometimes dwindled in unbelief and apostasy, often followed periods of righteousness and prosperity. [N.K.Y.]

L.060 Larsen, Dean L. "Looking Beyond the Mark." Ensign 17 (November 1987): 11-12. Makes an analogy between the shot put of an athlete and the scripture that states that "blindness came by looking beyond the mark" (Jacob 4:14). The mark needs to be faith in Jesus Christ. Replacing faith in the Savior with other goals, including pursuing the mysteries, pride, and reading scriptural commentaries only is the downfall of mankind. [J.W.M.]

L.061 Larsen, Dean L. You and the Destiny of the Indian. Salt Lake City: Bookcraft, 1966. Largely concerned with the identity of the American Indians, their noble heritage, and their role in the events of the latter days. Several Book of Mormon passages dealing with the Lamanites are reviewed and listed. [D.M.]

L.062 Larsen, Vernon. Out of the Dust: Verse Inspired by the Book of Mormon. Provo, UT: Promised Land Publications, 1980. A collection of poems based on passages of the Book of Mormon. [D.M.]

L.063 Larsen, Wayne A., and Alvin C. Rencher. "Response to Book of Mormon 'Wordprints' Reexamined" Sunstone 6 (March-April 1981): 22-26. A reaction to an article by D. James Croft (Sunstone, March-April 1981) who challenges the methodology of an earlier article by Larsen and Rencher (BYU Studies, Spring 1980). Larsen and Rencher claim that different word styles of each Book of Mormon author can be reasonably maintained, though they recognize that their studies have limitations. [D.M.]

L.064 Larsen, Wayne A., Alvin C. Rencher, and Tim Layton. "Multiple Authorship of the Book of Mormon." NE 9 (November 1979): 10-13. Results of the author's use of statistical analysis to determine how many individuals authored the Book of Mormon. Results: "The odds against these books being the work of one author exceeded 100 billion to one!" Also compares Book of Mormon authors with Joseph Smith's contemporaries, specifically men suggested as having been authors of the Book of Mormon. Result: "None of the wordprints of the modern authors resembled the Book of Mormon wordprints at all." Also did cluster analysis, discriminant analysis, and classification analysis. A brief description is given of each with the results. [A.T.]

L.065 Larsen, Wayne A., Alvin C. Rencher, and Tim Layton. "Who Wrote the Book of Mormon? An Analysis of Wordprints." BYU Studies 20 (Spring 1980): 225-51. Also in Book of Mormon Authorship: New Light on Ancient Origins, edited by Noel B. Reynolds, 157-88. Provo, UT: Brigham Young University Religious Studies Center, 1982. Tests the claim that the Book of Mormon was written by a number of ancient authors using an analysis called "wordprint" or the science of stylometry. Discusses potential non-Book of Mormon authors, Manova, cluster analysis, and classification analysis. [L.D.]

L.066 Larson, Anthony E. Parallel Histories: The Nephites and the Americans. Orem, UT: Zedek Books, 1989. Suggests ways in which incidents and historical situations in the Book of Mormon are similar to those of the present era. Twelve parallels may be drawn between the Book of Mormon society and modern American society that may predict future events in America. Both nations had similar origins and crossed the ocean as a result of difference of religion and philosophy. Both degenerated in morality. This work is reviewed in P.289. [J.W.M.] [D.M.]

L.067 Larson, Clinton F. Corianton and Moroni. Provo, UT: Brigham Young University, 1961. Two dramatic plays using Book of Mormon material showing the "tragic potential in the parallel destructions of the peoples of Jared and Nephi." [J.W.M.] 
L.068 Larson, Clinton F., Stuart Heimdal, and Paul R. Cheesman. Illustrated Stories from the Book of Mormon. Provo, UT: Promised Land Publications, 1967. This is a sixteen-volume work for young readers. Major events are narrated and illustrated. [B.D.]

L.069 Larson, John. Mormonism Refuted. San Francisco: Protestant Publishing House, 1899. A polemical attack on Mormon beliefs. The author objects to the Mormon idea of expanding revelation, since the Bible is, as he asserts, infallible. The Book of Mormon contradicts the practice of plural marriage. [M.R.]

L.070 Larson, Kenneth Lloyd. "UFO's and Time of the End Patterns: Some Comments on the Bible and the Book of Mormon." Flying Saucers 80 (Spring 1973): 14-24. Sightings of flying saucers in specified years are tied in with the advent of the Book of Mormon, the coming judgments, and the establishment of Zion. [D.M.]

L.071 Larson, Stan. "The Historicity of the Matthean Sermon on the Mount in Third Nephi." In New Approaches to the Book of Mormon, edited by Brent Lee Metcalfe, 115-63. Salt Lake City: Signature, 1993. Using textual criticism to determine whether or not the Book of Mormon is an ancient document must include an establishment of the "original" text of Matthew. A detailed comparison is made of several passages showing the Book of Mormon was clearly revised, but retains the problematic language of the King James Version that scholars have questioned for years. It varies significantly from the "original" text generated by scholars from early documents. The author asserts that Joseph Smith wrote the Book of Mormon and that he flagrantly plagiarized the Bible. Illustrations are included in the article. [J.W.M.]

L.072 Larson, Stanley R. "Changes in Early Texts of the Book of Mormon." Ensign 6 (September 1976): 77-82. Makes comparisons between the original hand-written printer's manuscript and subsequent editions of the Book of Mormon, pointing out changes in the Book of Mormon texts. Author examines the changes made and comes to the conclusion that these corrections, when properly reviewed, become a testimony for the truthfulness of the book rather than witnessing against it. Photographs of the original manuscripts are included. [J.W.M.]

L.073 Larson, Stanley R. "Conjectural Emendation and the Text of the Book of Mormon." BYU Studies 18 (Summer 1978): 563-69. Proposes a number of plausible conjectural emendations for the text of the Book of Mormon, namely: "sun of righteousness" rather than "son of righteousness," rights for rites, raiment rather than remnant in 2 Nephi 24:19, travail versus travel, Shiblom versus Shiblon, year instead of yea (in several cases), desert versus dissent, and possible examples of accidental word loss. [R.S.]

L.074 Larson, Stanley R. "Early Book of Mormon Texts: Textual Changes to the Book of Mormon in 1837 and 1840." Sunstone 1 (Fall 1976): 44-55. Classifies and discusses the main types of textual changes in the 2nd (1837, Kirtland) and 3rd (1840, Nauvoo) editions of the Book of Mormon, including corrections of typos from the 1st (1830, Palmyra) edition, revisions by Joseph Smith for the 2 nd edition, corrections in the 3rd edition by reference to the original manuscript, and accidental errors in both editions. [R.S.]

L.075 Larson, Stanley R. "I Have a Question: Chronological dates are recorded at the bottom of the pages in the Book of Mormon. How reliable are these dates? Are there any that need to be corrected?" Ensign 7 (September 1977): 38-39. The Book of Mormon gives a fairly accurate chronological dating system. The notes are provided to assist the reader in converting that system into the dating system used in the present era. [J.W.M.]

L.076 Larson, Stanley R. "A Most Sacred Possession: The Original Manuscript of the Book of Mormon." Ensign 7 (September 1977): 89-91. Provides a brief historical outline of the original manuscript, during and after the translation, a detailed description of the appearance of the manuscript, and a synopsis of its value. He points out 
four examples of corrections that have been made. Church historian Leonard Arrington believes that this document is the most sacred possession of the Church. [J.W.M.]

L.077 Larson, Stanley R. "The Odyssey of Thomas Stuart Ferguson." Dialogue 23 (Spring 1990): 55-93. An examination of the life and work of Thomas Stuart Ferguson, a well known Book of Mormon apologist and founder of the New World Archaeological Foundation. The writer concludes that Ferguson lost faith in the Book of Mormon before he died. [M.R.]

L.078 Larson, Stanley R. "The Sermon on the Mount: What Its Textual Transformation Discloses Concerning the Historicity of the Book of Mormon." Trinity Journal 7 (1986): 23-45. Compares the version of the Sermon on the Mount that appears in 3 Nephi with what textual critics of the dominant school (from Tischendorf to the Alands) have proposed is the original text for Matthew's version of the sermon. Selects eleven variant passages that all these textual critics have agreed on and shows that in all eleven cases the Book of Mormon agrees with Erasmus's "Textus Receptus" (on which the 1611 King James Version of the New Testament was based) but against what these textual critics have proposed. Assumes that the reconstructed text of these textual critics must be the original text (despite our substantial lack of knowledge concerning the history of the New Testament text for the first several centuries) and therefore concludes that the Book of Mormon text for the Sermon on the Mount is non-historical. [R.S.]

L.079 Larson, Stanley R. "A Study of Some Textual Variations in the Book of Mormon Comparing the Original and the Printer's Manuscripts and the 1830, the 1837, and the 1840 Editions." M.A. thesis, Brigham Young University, 1974. A horizontal columnar comparison of the original manuscript, the printer's manuscript, corrections in the printer's manuscript for the 1830, 1837, and 1840 editions. Also presents a review of the bringing forth of the Book of Mormon, and six appendices. [D.M.]

L.080 Larson, Stanley R. "Textual Variants in the Book of Mormon Manuscripts." Dialogue10 (Autumn 1977): 8-30. Examines fifty textual changes found in the currently published Book of Mormon in contrast with the original hand-copied printer's manuscript. There are three categories of variations: (1) corrections within the manuscripts themselves, (2) transcription errors, and (3) differences between the manuscript version and the printed copy. [J.W.M.]

L.081 LaRue, William Earl. The Foundations of Mormonism. New York: Revell, 1919. The Book of Mormon is a fabrication that plagiarizes from the Bible. An evidence of failed prophecy is that so few Indians have accepted the book and joined the Mormon Church. According to the author, the Book of Mormon "has made no valuable contribution to the knowledge of religion. It is a cunningly devised fable that requires ignorance, credulity, and superstition in order that one may believe in it." [M.R.]

L.082 Lassetter, Courtney, J. "Lehi's Dream and Nephi's Vision: A Look at Structure and Theme in the Book of Mormon." Perspective: A Journal of Critical Inquiry (Winter 1976): 50-54. A challenge to the idea that the Book of Mormon is composed of discreet, unrelated episodes, but rather it is literarily unified. The vision of the tree of life, for example, unfolds themes that appear throughout the book. The symbolism of the tree of life as the love of God as manifested in Christ is seen dramatically through a chronological view of Jesus' role on earth-from his condescension, to the crucifixion, to his personal visit to the Lehites. [D.M.]

L.083 "Latter-day Prophets Have Emphasized Book's Worth." CN 58 (2 January 1988): 5. A listing of brief testimonies regarding the truthfulness of the Book of Mormon by Church Presidents, from Joseph Smith to Ezra Taft Benson. [R.H.B.] 
L.084 "Latter-day Scriptures in Two More Languages." Ensign 20 (March 1990): 78. Selections from the Book of Mormon are available in Chamorro, which is spoken in Guam. [J.W.M.]

L.085 Laub, Normand D. "He Knew David Whitmer." Ensign 11 (September 1981): 63. While laboring as a missionary in Jackson County, Missouri, this author met a man who as a child had known David Whitmer and was present when Whitmer bore witness of the Book of Mormon prior to his death. [J.W.M.]

L.086 Launius, Roger D. Review of Trouble Enough: Joseph Smith and the Book of Mormon, by Ernest H. Taves. Western Illinois Regional Studies 8 (Fall 1985): 76-78. Book review.

L.087 Launius, Roger D. Review of Joseph Smith's New York Reputation Reexamined, by Rodger I. Anderson. Dialogue 24 (Summer 1991): 146. Book review.

L.088 Layton, Lynn C. "An 'Ideal' Book of Mormon Geography." IE 41 (July 1938): 394-95, 439. Contains a map of the proposed geography of the Book of Mormon but does not super-impose this geography over a present-day map. The author makes an analysis of the geographical descriptions in the Book of Mormon text. [J.W.M.]

L.089 Layton, Lynn C., and H. J. Layton. Book of Mormon Lands. n.p., 194?. Speculates on Book of Mormon geography. Defends the view that Moroni hid the plates in upstate New York. [D.M.]

L.090 Layton, Melaine N. I Pray that the Eyes of Your Heart May be Enlightened. Wheeling, IL: n.p., 1975. This polemical treatise on Mormonism ventures into several issues, including the reported methods by which the Book of Mormon was translated, the changes that have been made in the book since 1830, and the King James language found in the book. The author sees a connection between the Book of Mormon and Ethan Smith's View of the Hebrews. [D.M.]

L.091 Lea, Leonard J. Compendium of the Scriptures: Including Texts of the Standard Books of the Church . Independence, MO: Herald Publishing House, 1951. Compendium of scriptural references from the Book of Mormon and other standard works of the RLDS church appear under subject headings to assist greater understanding of doctrinal topics. Topics include the divine nature of God, the Book of Mormon, divine revelation, authority and priesthood. [J.W.M.]

L.092 Lea, Leonard J. "New Information about Old American Civilization." SH 76 (28 August 1929): 1047-48. Quotes several passages from A. Hyatt Verrill, Old Civilizations of the New World wherein Verrill writes that archaeology does not reveal a primitive culture that gradually evolved to a higher state. Verrill wonders at the technological abilities of the ancient Americans and maintains that they probably used steel. Evidence of the wheel is presented and a discovery of Greek- and Phoenician-inscribed pottery near the Amazon. These evidences support the Book of Mormon. [B.D.]

L.093 Lea, Leonard J. Presenting the Book of Mormon. Independence, MO: Reorganized Church of Jesus Christ of Latter Day Saints, n.d. A four-page pamphlet inviting the reader to consider the Book of Mormon. [D.M.]

L.094 Lea, Leonard J." 'Secret Combinations.' " SH 84 (6 March 1937): 292. True secret combinations are alliances between the criminal underworld and corrupt government officials. They are designed to exploit, to plunder public treasures, and to promote vice. [J.W.M.] 
L.095 "Leaders Thanked, Books Presented." CN 57 (28 February 1990): 7. Personalized copies of the Book of Mormon were given to members of the Virginia State Legislature in a gesture to thank public servants. [M.D.P.]

L.096 "The Learning of the Peoples of the Book of Mormon." The Relief Society Magazine 5 (September 1918): 534. The Book of Mormon peoples had access to the early teachings of the Bible. They had great opportunities of learning and built complex and important civilizations. The tedious task of record keeping on plates of metal seriously hampered their ability to pass on their learning. [J.W.M.]

L.097 Leavitt, Carrick D. "Papyrus Boat Sails Ocean." CN 40 (18 July 1970): 15. Reports the Atlantic crossing by Thor Heyerdahl in his papyrus boat Ra 2. This achievement is seen as important support for Book of Mormon accounts that the Nephites, Jaredites, and Mulekites crossed the oceans on their way to the Americas. [J.W.M.]

L.098 Leavitt, Janit Perry. "Prized Possession." Friend 23 (June 1993): 15-17. A story for children teaching that the Book of Mormon is a "prized possession" that should be shared with friends. [S.H.]

L.099 LeBaron, E. Dale. "The Book of Mormon: Pattern in Preparing a People to Meet the Saviour." In Doctrines of the Book of Mormon, 1991 Sperry Symposium, edited by Bruce A. Van Orden and Brent L. Top, 70-79. Salt Lake City: Deseret Book, 1992. One of the purposes of the Book of Mormon is to provide guidance in preparing individuals and groups for the Second Coming of Jesus. The editors (Nephi, Mormon, Moroni) saw our day and selected materials that are germane to this era. The signs of the coming are becoming so common that we scarcely recognize them. [D.M.]

L.100 LeBaron, E. Dale. "The Role of the Book of Mormon in Preparing a Generation to meet the Savior." In The Sixth Annual Church Educational System Religious Educators' Symposium on the Book of Mormon, 48-51. Salt Lake City: Church of Jesus Christ of Latter-day Saints, 1982. Discusses the great experiences of Nephi, Mormon, and Moroni that qualified them to write and abridge the Book of Mormon. All three were personally visited by Jesus Christ and received a clear vision of the latter days. Therefore, their input to the Book of Mormon is geared specifically for the latter days and preparing individuals for the Second Coming. The article includes two charts illustrating Book of Mormon references regarding latter-day challenges and "Mormon's Abridging MethodsRatio of Pages to Years." [A.T.]

L.101 "Lecture Series Explores the Book of Mormon." Sunstone 13 (February 1989): 52-55. Abstracts of twelve Book of Mormon lectures presented in 1988. The topics include, "Lehi's Doctrine of Opposition in its Nineteenth and Twentieth Century Contexts," "Book of Mormon History from the Lamanite Perspective," "The Literary Aspects of the Book of Mormon Narrative," and "The Gadianton Robbers." [D.M.]

L.102 Leddy, Herbert J. "Selections from Book of Mormon Translated into Guam Language." CN60 (17 February 1990): 11. Parts of the Book of Mormon were translated into Chamorro, the language of Guam, and presented to leaders of government in Guam. [M.R.]

L.103 Lederer, Dr. Visions of Joseph Smith, the Seer; Discoveries of Ancient American Records and Relics. Lamoni, IA: Reorganized Church of Jesus Christ of Latter Day Saints, 1896. An evangelical tract written by a former Jew supporting the Book of Mormon and its claims to antiquity. The author discusses evidence that he feels supports the Book of Mormon, such as the testimony of the witnesses, the Newark Stone, and similarities between native Americans and Hebrews. [M.R.] 
L.104 Lee, George P. "Lamanite Heritage." CR (October 1975): 149-51. Proud of his Lamanite heritage, and proud to bear testimony that Lamanites are a chosen people, Lee urges all people to unite and to become one regardless of nationality or race. [R.C.D.]

L.105 Lee, Harold B. Address Delivered by Elder Harold B. Lee. Cambridge, MA: New England Mission, 21 May 1962. An address to missionaries on the angel "flying in the midst of heaven" (Moroni) and the Book of Mormon containing the fullness of the gospel. [D.M.]

L.106 Lee, Harold B. "Communion with Deity." IE 69 (December 1966): 1142-44. Aaron chided Ammon for boasting, but Ammon reminded his brother that he did not boast in his own strength, but in the strength of God. Spiritual strength is needed to serve in our earthly missions thus we must be attuned to God through repentance, faith, good works, and continual prayer. [J.W.M.]

L.107 Lee, Harold B. "The Iron Rod." Ensign 1 (June 1971): 5-10. See also CR 141 (April 1971): 89-94. Lehi's vision of the tree of life provides the best antidote for the modern malady known as aimlessness. The rod of iron or the word of God gives direction to those who are seeking. Liberals both in the Church and out are like those who scoffed in the vision. Hold fast to the iron rod and continue to learn the truths of the Savior to remain steadfast. [J.W.M.]

L.108 Lee, Hector. The Three Nephites: The Substance and Significance of the Legend in Folklore. Albuquerque, NM: University of New Mexico Press, 1949. A scholarly analysis of the legend of the Three Nephites among Latter-day Saints in Utah. Lee explains the history of the Three Nephites and shows the chronological frequency and distribution of the legends. Lee analyzes the dominant motifs of the legends and discusses their historical, sociological, and psychological impact. More than thirty legends of the Three Nephites are included in the appendix. [B.D.]

L.109 Lee, Rex E. "The Book of Mormon: Another Testament of Jesus Christ," in Lee's, What Do the Mormons Believe? 11-18. Salt Lake City: Deseret Book, 1992. Gives an overview of Book of Mormon contents in one chapter. Notes that external evidences of the Book of Mormon are interesting but not critical, for they are as yet tentative. Emphasizes the spiritual power generated in the book. [D.M.]

L.110 Lee, S. N. "Remarkable Discoveries in America." MS 71 (3 June 1909): 337-38. Reports that Mr. Kinkaid, an employee of the Smithsonian Institute, found an entrance to a very large cave while traveling in the Grand Canyon. He estimates that more than fifty-thousand highly civilized people would have been able to live in this cave system hewn out of rock. The author speculates this could have been a Jaredite colony. Such discoveries will ultimately show that Joseph Smith is a prophet and was inspired of God to bring forth the Book of Mormon. [J.W.M.]

L.111 "Legends 'Brought Back Home.' " CN 55 (26 May 1985): 11. A rare booklet, The Title of the Lords of Totonicapan, containing Mayan legends from oral histories of the Quiche Indians has been returned to its place of origin after 10 years. This book contains a similar history to that of the Book of Mormon. [J.W.M.]

L.112 Legg, Phillip R. Oliver Cowdery: The Elusive Second Elder of the Restoration. Independence, MO: Herald Publishing House, 1989. Gives an in-depth historical account of the life of Oliver Cowdery who was scribe for Joseph Smith as he translated the Book of Mormon, and a witness who never denied his testimony. He died at the age of 43, following years of difficulties, disappointment, and failing health. Contains Elizabeth Cowdery's testimony that Oliver affirmed his testimony of the divinity of the book. [J.W.M.] 
L.113 "Lehi Leaves Jerusalem." Friend 19 (June 1989): 40-41. For children, contains illustrative cartoon panels narrating Lehi and his family fleeing Jerusalem. [D.M.]

L.114 "Lehi Warns the People." Friend 19 (May 1989): 15. For children, cartoon illustrations and written narrative explains Lehi's dealings with the people of Jerusalem. [D.M.]

L.115 "Lehi's Dream." Friend 19 (September 1989): 20-22. For children, depicts cartoon drawings of Lehi's vision of the tree of life. [D.M.]

L.116 "Lehi's Warning." Friend 11 (January 1981): 20-21. Story of Lehi designed for children in cartoon form. [J.W.M.]

L.117 Leigh, Samuel F. Testimony of the Three Witnesses. Samuel F. Leigh, 191?. A brief tract recounting the testimony of the Three Witnesses to the Book of Mormon and the their subsequent adherence to that testimony until the time of their deaths. [M.R.]

L.118 Leonard, Glen M. “Documents, Press Recall Palmyra Events." CN 60 (31 March 1990): 7. Many people have preserved one of the original 5,000 copies of the Book of Mormon. These have been collected by Church members or the Church History Museum. [M.R.]

L.119 LePlongeon, Augustus. Sacred Mysteries among the Mayas and the Quiche 11,500 Years Ago. New York: Robert Macoy, 1886. The sanctuaries and religious rituals of the Mayas and Quiche are investigated. The question of where and when Freemasonry originated is examined. Religious symbols of the New World are compared with symbolic representations of old Egypt, Greece, Rome, and elsewhere in the Old World. [D.M.]

L.120 LePoidevin, Cecil George. Zion, Land of Promise: An Atlas Study of Book of Mormon Geography. N.p.: n.p., 1977. An atlas containing numerous drawings of maps in which various geographical locations in the Book of Mormon are identified. Migration patterns, battle sites, missionary routes, and the paths of explorations are mapped. Relevant Book of Mormon verses are offered with some commentary. [D.M.]

L.121 Lesh, Ralph F. Ancient Mesoamerica: A Preliminary Study of Book of Mormon Geography. Independence, MO: Zarahemla Research Foundation, 1980. Large map of Central America showing the migration routes of the Book of Mormon peoples. Uses double arrows to indicate a northward direction as well as a true north to accommodate directions used in the Book of Mormon. Identifies the "Narrow Neck" with the Isthmus of Tehuantepec. [J.W.M.]

L.122 Lesh, Ralph F. "The Book of Mormon as Indicative of the Universality." In Restoration Studies IV, edited by Marjorie B. Troeh, 208-17. Independence, MO: Herald Publishing, 1988. There was a great deal of influence from the Freemasons and the Legend of Enoch upon the way the revelation of the Book of Mormon to Joseph Smith was interpreted. There are many similarities between the legend of Enoch and Joseph Smith's testimony concerning the Gold Plates. The Book of Mormon was revealed to the prophet in answer to his questions concerning his nineteenth-century environment. [J.W.M.]

L.123 Lesh, Ralph F. "Development of the Map." In Recent Book of Mormon Developments, 81-82. Independence, MO: Zarahemla Research Foundation, 1984. Also published in ZR 10 (Fall 1980): 3, 7-8. After the publication of Ancient Mesoamerica in 1980 in which the author uses a double north arrow-one arrow labeled "northward" and the other true north-authors challenged his theory of what the Book of Mormon people considered to be north. 
Upon review of the other theories, the author continues to support his theory that the north of the Nephites was true North. [A.T.]

L.124 Lesh, Ralph F. "Is North, North?" In Recent Book of Mormon Developments, 86-89. Independence, MO: Zarahemla Research Foundation, 1984. Also published in ZR 19/20/21 (Winter/Spring/Summer 1983): 21-24. The author published Ancient Mesoamerica in 1980 in which he used a double north arrow-one labeled "northward" and the other "true north" to show that they may not have meant the same thing for the Nephites. After the publication of this book, authors challenged his theory. After a review of the other theories, the author continues to support his theory that the north of the Nephites was true north. [A.T.]

L.125 Lesh, Ralph F. "Lehi in the North Pacific: An Alternative to the Equatorial Route." ZR4 (1979): 3-4, 10. A challenge to the view taken by the Committee on American Archaeology, appointed by the RLDS conference in 1894, that Lehi's ocean route was along the equator. Author argues for a route north of the equator, the Kuroshio or Japan Current, and believes that Lehi sailed north of Hawaii. The voyagers eventually landed in Guatemala or El Salvador. [D.M.]

L.126 "Lesser Lights of the Book of Mormon." Contributor 1 (April 1880): 149-51. Focuses on the book of Enos, first describing the contrasting lifestyles of the Nephites and Lamanites of his day, then retelling the events Enos recorded about his life. [D.M.]

L.127 Lesueur, James W. "Ancient American Ruins and Their Story." Utah Genealogical and Historical Magazine (January 1920): 28-33. Some traditions of the Native Americans speak of people of the American continent who were descendants of Shem and were scattered at the time of "the confusion of tongues," of people who believed they descended from the Jews and had preserved traditions of Moses and a miraculous crossing of the Red Sea. Joseph Smith brought forth the Book of Mormon by the power of God and it explains the ruins and ends the mystery surrounding them. [J.W.M.]

L.128 Lesueur, James W. The Guatamalan (sic) Petroglyphs: The Nephite Story or From Whence Came the Aztecs. Mesa, AZ: n.p., 1946. The author reviews many Indian legends and beliefs that parallel Book of Mormon claims. Such legends include: Jesus Christ visiting the Americas, their ancestors as descendants of Hebrews and their travel across the sea, and the voyages of Hagoth. The author interprets the Boturini Codex of the Peregrinacion de Los Aztecas, using the Book of Mormon. His interpretation parallels precisely the history of the Book of Mormon peoples. [B.D.]

L.129 Lesueur, James W. Indian Legends. Independence, MO: Zion, 1928. The legends of Indians who dwelt in North, Central, or South America are compiled. The legends concern the Indians' origin, migrations, wars, cosmogonic stories, recitals of a universal flood, the building of a great tower, and visitations of a god and white prophets. Religious beliefs of the Indians are listed. One section juxtaposes selected passages in the Book of Mormon with analogous Indian legends. [D.M.]

L.130 Lesueur, James W. Untitled talk. CR (7 April 1918): 118-20. Proposes external evidences of the Book of Mormon by claiming that in the Salt River Valley, Arizona, there exist ruins of a great Nephite city, fifteen miles wide and thirty or forty miles long, and a Nephite irrigation canal that is still used. [B.D.]

L.131 LeSueur, Stephen C. Review of Investigating the Book of Mormon Witnesses, by Richard Lloyd Anderson. Sunstone Review 2/6 (1982): 25. Book review. 
L.132 Letchworth, H. I. "Concerning the Divinity of the Book of Mormon." SH 96 (10 October 1949): 970. Discusses the Tower of Babel, Nimrod, and the Jaredites and argues that the Gazelem mentioned in the book of Alma is the brother of Jared. [A.C.W.]

L.133 "Let's Talk About... Book of Mormon." CN 41 (27 February 1971): 14. Quotes on the Book of Mormon from Joseph Fielding Smith, Harold B. Lee, N. Eldon Tanner, LeGrande Richards, and Bruce R. McConkie. [M.D.P.]

L.134 "Letter." MS 3 (September 1842): 86-88. A report of George J. Adams's lectures on the Book of Mormon delivered in Boston, wherein Adams uses standard biblical proof texts in his defense of the Book of Mormon. [D.M.]

L.135 "Letter Confirms His Testimony." CN 52 (9 October 1982): 23. Brent F. Ashworth announces that he has acquired a 110-year-old letter written by Martin Harris concerning his testimony of the Book of Mormon. The complete text is contained in the article. (Editor's note: this letter has since been shown to be a forgery.) [J.W.M.]

L.136 "Letter to the Editor." The Reflector 2 (6 January 1831): 77. Writes that Joseph Smith's Book of Mormon, the "most clumsy of all impositions" has excited curiosity. [J.W.M.]

L.137 "Letters from the West." TS 2 (15 February 1841): 322-24. Reprint of an article from the Upper Mississippian that relates some aspects concerning the Book of Mormon. Says that Joseph Smith found brass plates and was instructed by the Lord to employ people to translate them. The translation contained a prophecy about the condition of the Latter-day Saints, including their persecutions in Missouri. The Times and Seasons editor notes that some of the views about the Book of Mormon in the article are off quite "widely from the mark." [D.M.]

L.138 Leuba, Philippe. “The Sonora Ruins.” Deseret Weekly 52 (8 February 1896): 231-32. Editorial comments claim increasing archaeological evidences in support of the Book of Mormon. [D.M.]

L.139 Lewis, Ben E. "The Most Correct Book." In BYUSY (18 January 1972). Provo, UT: Brigham Young University, 1971. An admonitional speech encouraging individuals to regard the Book of Mormon with resolution. The stories relating Alma's encounter with Korihor and Alma's parting words to his three sons are recalled. The Book of Mormon is vital to our spiritual condition. [D.M.]

L.140 Lewis, Carl G. Book of Mormon. Lamoni, IA: Carl G. Lewis, 191?. A tract defending the LDS understanding of the condemnation of polygamy set forth in Jacob 2. The writer notes that polygamy is only permitted when the Lord commands it. [M.R.]

L.141 Lewis, Gordon R. The Bible, The Christian, and Latter-day Saints. Philadelphia, PA: Presbyterian and Reformed, 1975. A polemical work against Mormonism, where the author alleges that Protestant doctrines are contained in the Book of Mormon, such as monotheism, the trinity, and others. Other Book of Mormon problems dealt with include anthropological and archaeological difficulties, the Smithsonian statement, the Anthon denial, textual changes, King James English, plagiarism, problems with the testimonies of Book of Mormon witnesses, environmental influence, Hebrew origin of Indians, anachronisms, absurdities, and alleged doctrinal problems. [M.R.]

L.142 Lewis, Gordon R. Confronting the Cults. Philadelphia, PA: Presbyterian and Reformed, 1966. A polemical work against Mormonism and other alleged cults. Numerous anachronisms and other problems with the Book of 
Mormon are discussed. Many of the same arguments are posed in the author's work, The Bible, the Christian, and Latter-day Saints. [M.R.]

L.143 Lewis, William, Jr. "An Adaptation of the Book of Mormon for Radio." M.A. thesis, Northwestern University, 1948. A series of dramatic scripts based on the Book of Mormon, designed as radio programs. Music, sound effects, and dialogue are features of the thesis. [D.M.]

L.144 Ley, Zenas H. "Synopsis of a Discourse Delivered at Lamoni, lowa." SH 26 (15 December 1879): 360-71. The sealed book foretold in Isaiah 11 is the Book of Mormon. To bring this book to light was the divine call of Joseph Smith. The "other sheep" of whom Jesus Christ referred were the people on the American continent. [J.W.M.]

L.145 "The Liahona." Friend 13 (November 1983): 48-49. For children. Describes the account of the liahona. [A.T.]

L.146 El Libro de Mormon: La Historia de las Americas Antes de Colon. Salt Lake City: Deseret News Press, n.d. A pamphlet describing the advent and contents of the Book of Mormon, explaining the existence of inhabitants in America before Columbus. [D.M.]

L.147 Lindgren, A. Bruce. "Sign or Scripture: Approaches to the Book of Mormon." Dialogue 19 (Spring 1986): 6975. Also in The Word of God: Essays on Mormon Scripture, edited by Dan Vogel, 55-62. Salt Lake City: Signature, 1990. Discusses the value of various approaches to Book of Mormon study. The author asserts that scriptural status does not rest upon historicity. The Book of Mormon may be unhistorical and yet retain its value as scripture, since it "has the capacity to illuminate and communicate the gospel." He considers questions of historicity to be secondary to other concerns. [M.R.]

L.148 Lindgren, A. Bruce. "Sin and Redemption in the Book of Mormon." In Restoration Studies, edited by Maurice L. Draper and A. Bruce Lindgren, 201-6. Independence, MO: RLDS Temple School, 1983. The Book of Mormon portrays humanity as being sinful and depraved. Far from depicting an optimistic view that man is capable of progressing in righteousness to great heights, the Book of Mormon outlines the cyclical model of people ultimately succumbing to pride and sin after a period of righteousness and resultant prosperity. Enduring to the end is required but difficult. The predicament graphically presented in the Book of Mormon is answered in the redemption motif of Romans 8. [D.M.]

L.149 Lindsey, Jessie M. Book of Mormon Genealogy, with Index, and Period Covered about 2200 B.C. to 421 A.D. Honolulu: n.p., 1963. A self-published work containing a brief explanation of the Book of Mormon, several Jaredite and Lehite genealogical charts, and an index identifying each person in the Book of Mormon. [D.M.]

L.150 Lindsey, Robert. A Gathering of Saints: A True Story of Money, Murder and Deceit. New York: Simon and Schuster, 1988. Tells the history of the coming forth of the Book of Mormon, the translation and loss of the 116 pages of manuscript, the story of the book, and the claim that Mormons made of the reinstitution of God's Old Testament Church. The author presents much Church history and organization to set the stage for the deceit and murder that took place in Salt Lake City in conjunction with the Mark Hofmann forgeries. [J.W.M.]

L.151 Linn, William Alexander. "New Light on Mormonism." The World Today 3 (September 1902): 1828-32. Sidney Rigdon placed a manuscript in Smith's hands to proclaim as the Book of Mormon. This conspiracy was contrived by Rigdon and the manuscript was a revised edition of Solomon Spaulding's manuscript. [J.W.M.] 
L.152 Linn, William Alexander. The Story of the Mormons: From the Date of Their Origin to the Year 1901. New York: Macmillan, 1902. A history of Mormonism written by a non-Mormon. Chapters 6-11 discuss various aspects of the Book of Mormon, such as its translation, the 1834 Anthon denial, the role of the Three Witnesses, the Kinderhook plates, alleged quotes from Shakespeare, and various anachronisms and absurdities such as the presence of common Bible passages, pre-Columbian domesticated animals, and grammatical blunders. [M.R.]

L.153 "A Link of History: Mormonism and Joe Smith... The Book of Mormon or Golden Bible." New York Herald (2 July 1858): n.p. A polemical article providing the true facts concerning the first printing of the Book of Mormon. [J.W.M.]

L.154 Lippy, C. H. "Book of Mormon." In Abingdon Dictionary of Living Religions, edited by Keith Crim, 115-16. Nashville: Abingdon, 1981. Briefly describes the origin and contents of the Book of Mormon and raises the question regarding its authorship. [D.W.P.]

L.155 Lipsit, S. J., C. W. Clark, David Winslow, James D. Wardle, Jim Christenson, and Evan A. Shute. "Shall We Improve the Book of Mormon?" SH 102 (7, 21 February, 21 March, 4, 18 April 1955): 139, 186, 273-74, 329, 37071. Editorials concerning whether or not changes should be made to the Book of Mormon. Lipsit warns against tampering with Divine will; Clark argues that the book's imperfections show that Joseph Smith was not the author; Winslow supports correction of punctuation and grammatical errors; Wardle gives a history of various Book of Mormon editions, saying that a corrected edition is needed; Christenson argues for a modern English version of the Book of Mormon; Shute, whose original proposal for another edition of the Book of Mormon aroused the controversy, urges the RLDS church to work on foreign language translations of the Book of Mormon and to set up a committee to produce a "good English" translation of the Book of Mormon. [A.C.W.]

L.156 "List Motivates Missionaries to Read the Book of Mormon." CN 58 (11 June 1988): 5. A challenge was given to the missionaries at the LDS Missionary Training Center to read the Book of Mormon. Several missionaries accepted the challenge to read it. [M.D.P.]

L.157 "Listen to the Lessons from History of Past." CN 45 (12 April 1975): 4. N. Eldon Tanner spoke on how Church members should heed the lessons of the past, especially those found in the Book of Mormon. [M.D.P.]

L.158 Litster, Allen, E. "I Have a Question: How many languages has the Book of Mormon been translated into and how many copies have been distributed in the years since it was first printed?" Ensign 7 (September 1977): 37-38. Since 1830 the Book of Mormon has been published in twenty-seven languages. Eighteen million copies have been distributed by the LDS church and one million copies by the RLDS. [J.W.M.]

L.159 Little, James A. "The Book of Mormon as History." Juvenile Instructor 13 (15 July 1878): 158-59. Briefly discusses the Book of Mormon as inspired history. [D.M.]

L.160 Little, James A. "Book of Mormon Sketches" (Series). Juvenile Instructor 14-15 (1, 15 January, 15 September 1879-15 December 1880): 8-9, 14-15, 209, 218-19, 232, 249, 256-57, 266-67, 284-85, 10-11, 20-21, 35, 3940, 57-58, 62-63, 75-76, 86-87, 98-99, 116-17, 124-25, 134-35, 152-53, 164-65, 178, 189, 201-2, 212-13, 221 , 237-38, 244-45, 262-63, 266-67, 281. Retells Book of Mormon stories: priests of Noah, Mosiah and Alma's ministries, Amlici's civil war, Alma and Amulek's mission, Ammon's mission, Korihor and the Zoramites, Zarahemnah's battle with Moroni, war with Amalickiah, Moroni's warfare tactics, Pahoran and the king-men, Teancum's exploits, Hagoth's expedition, Gadianton and Kishkumen, Nephi and Cezoram, Samuel the Lamanite's prophecies, signs of Christ's birth, war between Giddianhi and Gidgiddoni, destruction at the time of Christ's 
crucifixion, Christ's ministry among the Nephites, subsequent righteousness, ensuing wickedness, Mormon and Moroni's abridgments, and the Nephite destruction. [A.C.W.]

L.161 Little, James A. "A Family Dialogue." Juvenile Instructor 17 (15 May 1882): 155. Discusses fulfillment of prophecy given in 1 Nephi 13:14. Columbus and Indian oppression was foretold centuries ago, and prophecies yet remain to be fulfilled in the future. [A.C.W.]

L.162 Little, James A. "The Jaredite Colony to America." Juvenile Instructor 13 (15 September 1878): 208-9. Retelling of the story of the voyage of the Jaredites to America. [D.M.]

L.163 Little, James A. "Reflections on Reading the Book of Mormon." MS 39 (30 July 1877): 501-3. A testimony of the Book of Mormon. The Book of Mormon exposes false doctrine and guides men in the proper course of their lives. Consistent with God's divine justice and mercy, God had guided his peoples on both the eastern and western continents. The Book of Mormon is not a history of a people, for that would not have changed human affairs, but it is a book of doctrine. [B.D.]

L.164 Lively, Asenith. "The Name of the Church and of the People of God." SH 65 (13 November 1918): 1104-5. The Book of Mormon clearly teaches the name of Jesus' church and outlines the requirements of membership. One must be willing to take the name of Christ upon him or herself and enter into covenants with nim. [J.W.M.]

L.165 Livesy, Richard. An Exposure of Mormonism Being a Statement of Facts Relating to the Self-Styled "Latter-Day Saints," and the Origin of the Book of Mormon. Manchester, New York: William Shackleton and Son, 1840. An early polemical tract against Mormonism that accepts uncritically E. D. Howe's book Mormonism Unveiled. [M.R.]

L.166 Lloyd, D. Clyde. Is That in the Book of Mormon? Salt Lake City: Deseret Book, 1962. A book containing trivia questions about the Book of Mormon. [D.M.]

L.167 Lloyd, R. Scott. "Book of Mormon Crucial to Survival, Prophet Declares." CN 58 (21 May 1988): 4. Social, ethical, cultural or educational converts will not survive under the heat of the day unless their taproots go down to the fullness of the gospel that the Book of Mormon contains. [R.H.B.]

L.168 Lloyd, R. Scott. "Messages, Music Move Listeners." CN 57 (24 January 1987): 3. President Benson and Elder Ashton spoke at a leadership conference concerning the importance of the Book of Mormon. President Benson stressed the importance of using the Book of Mormon in missionary work and in practical religion. [A.C.W.]

L.169 Lloyd, R. Scott. "Reach Out to Others, Leaders Urge." CN 57 (30 May 1987): 6. Admonishment by President Benson at a regional conference to "read, ponder, and teach" from the Book of Mormon, especially since "it was written for us." [A.C.W.]

L.170 Lloyd, R. Scott. "Region Members Pleased, Prophet Came after All.” CN 56 (23 November 1986): 3. President Benson visited a conference and taught that "the Book of Mormon is the word of God." [M.R.]

L.171 Lloyd, T. E. Carroll-Lloyd Exposé: Elder T. E. Lloyd Replies to Rev. Carroll, Defending the Book of Mormon and Prophetic Mission of Joseph Smith. N.p., 1895. The Bible does not indicate a cessation of revelation, and was not intended to be the last and only rule of faith and practice. Joseph Smith received revelation that the Book of Mormon was a divine document. Hurlbut originated the Spaulding theory. Professor Anthon's statement is examined. Discusses the witnesses to the Book of Mormon and finds their testimonies valid. [J.W.M.] 
L.172 Logan, Cordell Eckre. "A Voice From the Ground." In Logan's Spiritual Matter, 55-64. U.S.A.: n.p., 1980. The story of the Book of Mormon begins with those who came out from Babylon in the days of the Tower of Babel and then completes the story with Lehi's and Ishmael's families who were Joseph's seed who left Jerusalem. [J.W.M.]

L.173 "The Long-Lost Records." MS 20 (October 1858): 669-71. A reprint of a letter published in the Liverpool Daily Post written by the Rev. Dr. Baylee concerning a well found in the countryside near Chicago. Though a date or period may not be assigned to this find, the long-lost records of these people have been disclosed in the Book of Mormon. An earnest plea is made to read this "long lost chronicle of the past" with an unbiased mind to learn the truth under the guidance of the Holy Ghost. [J.W.M.]

L.174 Longden, John. "A Marvelous Work." IE 63 (June 1960): 436-37. Faithful men and women all over the world bear witness of the authenticity of the Book of Mormon. The message can be spread throughout the world through Church members. Two stories, one of a Methodist minister and another of a young Baptist, reveal the value of this concept. [J.W.M.]

L.175 "The Lord Leads the Jaredites to a Promised Land." Friend 20 (May 1990): 19-22. An illustrated story for children. The brother of Jared saw the Lord and the Jaredites were led across the sea to the promised land. [M.D.P.]

L.176 Louthan, Bruce D. "Belief in Transoceanic Influence Becomes Intellectually Respectable-Again." SEHA 132 (April 1973): 1-7. Four separate books accept the theory of diffusion from the Old World in explaining the origin of the pre-Columbian inhabitants of the Americas. The first two books are anthologies, the other two books were authored by scholars Cyrus Gordon and Thor Heyerdahl. [D.M.]

L.177 Lovalvo, V. James. It Is Written: Truth Shall Spring Out of the Earth. Fresno, CA: Mid-Cal Publishers, 1980. Both the Apostasy and the Restoration are prophesied of in the Book of Mormon. The book is an important part of the Restoration. This work discusses Old World apostasy, then retells the history of the coming forth of the book, its story, the testimony of the witnesses, and a brief analysis of its teachings. [J.W.M.]

L.178 Loveland, Jerry K. "Hagoth and the Polynesian Tradition." BYU Studies 17 (Autumn 1976): 59-73. Accepts the common LDS belief that the Polynesians are descended from expeditions spearheaded by Hagoth, although there is not irrefutable evidence in Polynesian lore that links them with Hagoth. The traditions voiced by current Polynesians are not totally reliable due to changes that could enter into the legends, but there are some possible parallels arising out of Polynesian legends. [D.M.]

L.179 "A Lover of Truth." Evening and Morning Star 3 (September 1842): 86-88. The author tells of series of lectures that he attended delivered by G. J. Adams in which he testified and gave evidence of the truthfulness of the Book of Mormon. [M.D.P.]

L.180 Loving, Albert L. From the Tower of Babel to the Hill Ramah Cumorah in Mexico. Independence, MO: Author, 1976. Speaks concerning the Jaredites and the Lehites, with emphasis on the Tower of Babel and the dispersion. Claims that the Hill Cumorah is located in the state of Morelos in Mexico. [D.M.]

L.181 Lowe, Gareth W. "The Book of Mormon and Early Southwest Cultures" UASN 19 (12 April 1954): 1-3. Believing that Book of Mormon events took place in Mesoamerica, the author speculates that peoples of the southwest section of the United States had connections and correspondences with their Mesoamerican 
neighbors. Other Asiatic peoples also likely played a part in the development of North American Indian culture. [D.M.]

L.182 Lowe, Gareth W. "The Book of Mormon and the Late Southwest Archaeology." University Archaeological Newsletter 18 (25 February 1954):1-2. Discourages students of the Book of Mormon from associating all archaeological remains in the Americas with the Book of Mormon, since many of them differ in time and space. [D.M.]

L.183 Lowe, Josiah Beatson. Mormonism Exposé: Being a Lecture on the Doctrines and Practices of the Latter-Day Saints. Liverpool: Edward Howell, 1852. A polemical tract against the doctrines of Mormonism and the Book of Mormon. The testimony of the Book of Mormon witnesses is suspect since they all left the Church. The Book of Mormon shows evidence of borrowing from the language of the Bible and the King James Version. The Book of Mormon also contradicts the Bible in many places. These and other anachronisms in the book make it difficult to believe it to be the word of God. [M.R.]

L.184 Lowman, Pat. Book of Mormon Monologues. Independence, Missouri: Foundation for Research on Ancient America, 1987. Contains brief, dramatic monologues that express in informal settings various scenes in the Book of Mormon. They are useful for worship services, retreats, classes, reunions, devotionals, and campfires. [D.M.]

L.185 Lubben, Mary. "Chest Is 'Storehouse' of Mormon History." CN 43 (8 December 1973): 10. Tells of a chest that belonged to Frederick Kesler in which was his prize possession-one page of the original manuscript of the Book of Mormon. It has been donated to the LDS church. [M.D.P.]

L.186 "Lucy M. Smith Letter Discovered." CN 52 (28 August 1982): 3, 14. Tells of a newly discovered letter written by Lucy Mack Smith that contains new information about the lost 116 pages of Joseph Smith's translation of the gold plates. (Editor's note: this letter has since been shown to be a forgery.) [M.D.P]

L.187 Ludlow, Daniel H. The Book of Mormon-A Modern Scripture. N.p.: n.p., 2 February 1958. Typescript of a speech given on Temple Square. When Joseph Smith translated the Book of Mormon, scholars believed the Bible was a closed book. This is no longer so because some scholars believe there may be additional scripture. Ezekiel foretold the Book of Mormon. The Book of Mormon story tells of three groups who migrated to America. The visit of Christ to America fulfills his prophecy to his disciples found in the book of John. [J.W.M.]

L.188 Ludlow, Daniel H. "The Book of Mormon was Written for Our Day." Instructor 101 (July 1966): 265-66. Lists Book of Mormon passages that demonstrate that the book was written for our day. Also lists twelve Book of Mormon subjects that are particularly relevant for the people of the latter days. [D.M.]

L.189 Ludlow, Daniel H. "The Challenge of the Book of Mormon." In The Book of Mormon: The Keystone Scripture, edited by Paul R. Cheesman, S. Kent Brown, and Charles D. Tate Jr., 1-20. Provo, UT: Brigham Young University Religious Studies Center, 1988. Challenges both the believer and non-believer to take the Book of Mormon seriously, receive a testimony, and live in harmony with its teachings. [D.M.]

L.190 Ludlow, Daniel H. A Combination Student and Teacher Guide to the Reading of the Book of Mormon: A Course of Study of the Melchizedek Priesthood Quorums of the Church of Jesus Christ of Latter-day Saints. Salt Lake City: Deseret Book, 1961. A study guide for the Melchizedek priesthood quorums of the Church of Jesus Christ of Latter-day Saints. Lessons encourage reading the Book of Mormon. [L.D.] 
L.191 Ludlow, Daniel H. A Companion to Your Study of the Book of Mormon. Salt Lake City: Deseret Book, 1976. A Book of Mormon study guide that includes a verse-by-verse commentary, five appendices, a number of charts and maps, and several expositions discussing the history behind the Book of Mormon, the purposes of the Book of Mormon, the major plates, a historical overview of biblical history preceding the Book of Mormon period, and a secular history of the peoples in the Book of Mormon. [D.M.]

L.192 Ludlow, Daniel H. A Guide to the Reading of the Book of Mormon. Provo, UT: Brigham Young University, 1964. A study guide of thirty-five sections on the Book of Mormon. Each section contains objectives, a prospectus for the assigned reading material, and study questions. Four appendices conclude the work. [D.M.]

L.193 Ludlow, Daniel H. "I Have a Question: Shouldn't Moroni's promise in the Book of Mormon (Moroni 10:4) always work?" Ensign 16 (March 1986): 50-51. Also in A Sure Foundation: Answers to Difficult Gospel Questions 1821. Salt Lake City: Deseret Book, 1988. Ludlow analyzes Moroni's promise in Moroni 10 and includes verses 1-5 that seem to indicate that it is necessary to study more than just the Book of Mormon. Biblical study is required, then ponder and pray with sincerity and faith, which makes one capable of recognizing the truths and promptings as the Holy Ghost manifests them. [J.W.M.]

L.194 Ludlow, Daniel H. "I Have a Question: Why do we say that the Book of Mormon contains the fulness of the gospel (D\&C 20:9) when it doesn't contain some of the basic teachings of the Church? Why doesn't it include such doctrines as the three degrees of glory, marriage for eternity, premortal existence of spirits, and baptism for the dead?" Ensign 15 (September 1985): 17-19. Also in A Sure Foundation: Answers to Difficult Gospel Questions, 11-15. Salt Lake City: Deseret Book, 1988. The Book of Mormon definition of the gospel of Christ is revealed in 3 Nephi 27:13-22: the Atonement, faith in Jesus Christ, repentance, baptism, and the gift of the Holy Ghost. None of the four compilers intended to include all of the teachings and ordinances of Christ. Important doctrines are restored when the church membership is ready to accept them. [J.W.M.]

L.195 Ludlow, Daniel H. Introduction to the Book of Mormon and Its Teachings. Provo, UT: n.p., 1963. Supplementary guide for a BYU class, with comments about selected passages from the first half of the Book of Mormon and quotes from various authors. [D.M.]

L.196 Ludlow, Daniel H. "List of Suggestions to Help With Your Personal Study of the Book of Mormon." CN 58 (2 January 1988): 12. Sets forth eight "dos" and five "don'ts" in studying the Book of Mormon, taken from two audio cassettes entitled, "Getting the Most Out of the Book of Mormon." Examples are: do develop a personal marking system; do not be worried about what critics say about the Book of Mormon. [D.M.]

L.197 Ludlow, Daniel H. "The Message to the Jews with Special Emphasis on 2 Nephi 25." In The Book of Mormon: Second Nephi, The Doctrinal Structure, edited by Monte S. Nyman and Charles D. Tate Jr., 241-57. Provo, UT: Brigham Young University Religious Studies Center, 1989. Defines various meanings of "Jew." Notes that 2 Nephi 25 is a synthesis of materials Nephi had learned from the plates of brass, personal revelation, instructions from Lehi and Jacob, and his own experience. This work is reviewed in R.153. [D.M.]

L.198 Ludlow, Daniel H. "A Priceless Possession: How to Gain a Testimony of the Book of Mormon." NE 16 (October 1986): 46-50. Pointing out that "signs follow them that believe," Ludlow distinguishes some of the signs that do follow believers and shows that the Lord is not adverse to signs. Signs follow faith. An outlined method of study is given. Knowing the book is true is different than being able to live by its precepts. [J.W.M.] 
L.199 Ludlow, Daniel H. Selected Reading and Reference Materials for Scripture (Book of Mormon) 121. Provo, UT: Brigham Young University Press, 1963. A forty-six page booklet containing quotes from a variety of sources dealing with various aspects of the Book of Mormon. Designed as a supplementary resource for freshman Book of Mormon classes at Brigham Young University. [D.M.]

L.200 Ludlow, Daniel H. A Series of Discussions on the Book of Mormon. Provo, UT: Brigham Young University Extension Publications, 1964. An outline organized into three discussions: "The Book of Mormon as a Part of God's System of Witnesses," "The Teachings in the Book of Mormon of the Resurrected Jesus Christ," and "Modern Messages of the Book of Mormon." [D.M.]

L.201 Ludlow, Daniel H. A Student Guide to the Reading of the Book of Mormon. Salt Lake City: Deseret News Press, 1961. The student's manual for the Melchizedek Priesthood quorums of the Church of Jesus Christ of Latter-day Saints. The Book of Mormon is a companion book to the Bible. Presents lessons with a stated objective, a prospectus of the reading material for each lesson, and points to ponder. Includes a list of the records included in the book, chronological charts of leaders and their journeys. [J.W.M.]

L.202 Ludlow, Daniel H. A Supplement for Religion 421 and 422. Provo, UT: Brigham Young University Press, 1968. Designed as a supplement for students in Book of Mormon classes to provide essential background information, to acquaint students with the doctrinal and other great messages of the Book of Mormon, and to provide them with additional materials and bibliographical sources. Includes visual materials relating to the Book of Mormon. [A.T.]

L.203 Ludlow, Daniel H. "The Title Page." In The Book of Mormon: First Nephi, The Doctrinal Structure, edited by Monte S. Nyman and Charles D. Tate Jr., 19-33. Provo, UT: Brigham Young University Religious Studies Center, 1988. Reviews statements by Joseph Smith that the title page of the Book of Mormon was translated from the last leaf of the gold plates. Notes changes in the title page between various editions of the Book of Mormon and proposes that one portion of the title page was written by Mormon and another by Moroni. [A.T.]

L.204 Ludlow, Daniel H. "Zenos." In Encyclopedia of Mormonism, edited by Daniel H. Ludlow, 4:1623-24. 5 vols. New York: Macmillan, 1992. "Zenos is one of four Israelite prophets of Old Testament times cited in the Book of Mormon whose writings appeared on the plates of brass but who are not mentioned in the Old Testament." [A.T.]

L.205 Ludlow, Daniel H., comp. "The Holy Scriptures." In Latter-day Prophets Speak: Selections from the Sermons and Writings of the Presidents of the Church of Jesus Christ of Latter-day Saints, 343-56. Salt Lake City: Bookcraft, 1948. Quotes Latter-day prophets Brigham Young, George Albert Smith, Wilford Woodruff, Joseph Smith, Heber J. Grant, and John Taylor on a variety of topics concerning the scriptures. These include "The scriptures are the word of God," "Read the Scriptures," "The Book of Mormon ... the American Scripture," "We Believe the Book of Mormon to Be The Word of God," "The Bible and The Book of Mormon Agree," and many others. [J.W.M.]

L.206 Ludlow, Douglas Kent. "Liahona." In Encyclopedia of Mormonism, edited by Daniel H. Ludlow, 2:829-30. 5 vols. New York: Macmillan, 1992. A brief description of the Liahona, also referred to as the ball, compass or director that was shown to Joseph Smith and the Three Witnesses along with the Book of Mormon plates. [B.D.]

L.207 Ludlow, Victor L. "Book of Mormon's Framework Shaped by Ancient Roots." CN 58 (2 January 1988): 7, 12. Shows how features in the Book of Mormon reflect Semitic roots. The following areas are cited: tribal culture, stewardship of Nephite kings and judges (King Benjamin's speech echoes aspects of the biblical Samuel and Moses), authentic Semitic names, vows and oaths, and the line of prophets. [D.M.] 
L.208 Ludlow, Victor L. Isaiah: Prophet, Seer and Poet. Salt Lake City: Deseret Book, 1982. Author analyzes the book of Isaiah "in terms of historical context, literary style, scriptural context, and doctrinal application." Emphasis is placed upon Isaiah's cultural and historical surroundings and his use of parallelism. LDS perspectives are employed where possible (e.g., wide use of the Book of Mormon Isaiah passages is made), yet passages are interpreted in an open-ended fashion, with the assumption that Isaiah's pronouncements may typically refer to more than one event. Isaiah is affirmed as the sole author of the text. [A.L. \& P.H.]

L.209 Ludlow, Victor L. Jesus' “Covenant People Discourse” in 3 Nephi: With Old Testament Background and Modern Application. Provo, UT: Brigham Young University Religious Studies Center, 1988. The first purpose of the Book of Mormon as stated on the title page is to demonstrate to the remnant of the House of Israel the great things the Lord has done for their fathers, and to show that because of past covenants latter-day generations are not excluded from divine interest. [D.M.]

L.210 Ludlow, Victor L. "Jesus' Covenant Teachings in Third Nephi." In Rediscovering the Book of Mormon, edited by John L. Sorenson and Melvin J. Thorne, 177-85. Salt Lake City: Deseret Book and FARMS, 1991. At least 113 passages in the Book of Mormon contain important information about the Lord's covenants with his people. Most of these are concentrated in 3 Nephi. The Lord gives key signs and events that demonstrate that his covenants are being fulfilled in the Book of Mormon. [J.W.M.]

L.211 Ludlow, Victor L. Review of Isaiah and the Book of Mormon: A Study Guide for Understanding the Writings of Isaiah in the Book of Mormon, by Philip J. Schlesinger. Review of Books on the Book of Mormon 3 (1991): 147-49. Book review.

L.212 Ludlow, Victor L. "Scribes and Scriptures." In Studies in Scripture: 1 Nephi to Alma 29, edited by Kent P. Jackson, 196-204. Salt Lake City: Deseret Book, 1987. Addresses Enos, Jarom, Omni, and the Words of Mormon. Themes considered are prayer, the importance of records, and the procedures followed by Nephi and Mormon that later compensated for the loss of the 116 pages from the Book of Lehi. [D.M.]

L.213 Ludlow, Victor L. "Secret Covenant Teachings of Men and the Devil in Helaman through 3 Nephi 8." In The Book of Mormon: Helaman through 3 Nephi 8, According to Thy Word, edited by Monte S. Nyman and Charles D. Tate Jr., 265-82. Provo, UT: Brigham Young University Religious Studies Center, 1992. Shows the counterfeit covenants members of secret combinations entered into with Lucifer, as recorded in Helaman and 3 Nephi. Includes several tables. [D.M.]

L.214 Luff, Joseph. The Book of Mormon: Is It "The Stick of Ephraim" Referred to in the Thirty-Seventh Chapter of Ezekiel, Verses Fifteen to Nineteen. N.p., n.d. An RLDS author takes issue with the traditional LDS interpretation of the sticks of Judah and Ephraim being the Bible and the Book of Mormon. [D.M.]

L.215 Lund, A. William. "The Book of Mormon-Greatest Missionary." DN Church Section(26 March 1932): 5, 7. The "Book of Mormon is the greatest missionary in all the world." Those who prefer to believe the Spaulding theory should publish the manuscript and make a comparison. There are two tests that must be applied to any man claiming to be a prophet of God: Are the things he prophesied coming true? Are the doctrines he teaches the same as those taught by Jesus Christ? In both instances Joseph Smith passes the test. [J.W.M.]

L.216 Lund, Anthon, H. "Discourse by Elder Anthon H. Lund." MS 62 (25 January 1900): 49-53. A testimony that a prophet of God guides the Church. Similar to the dream of Lehi, mists of darkness surround individuals today. The 
rod of iron, relied on in faith, leads to the tree of life. Lund explains that he reveres the Bible, but he also believes the Book of Mormon. [B.D.]

L.217 Lund, Anthon H. Untitled talk. CR (April 1902): 87-89. The Book of Mormon has been translated into Tahitian, Samoan, Maori, Hawaiian, and Turkish. There are many external and internal evidences of its authenticity and the Holy Ghost will tell individuals that it is true. The discovery of the Spaulding manuscript destroys the Spaulding theory, though some wrongly say there was another manuscript. Sidney Rigdon did not know about the Book of Mormon until after it was published. The writing style of the Book of Mormon differs from Sidney Rigdon's. [B.D.]

L.218 Lund, Anthon H. Untitled talk. CR (October 1905): 6. Explains that the British mission is distributing pamphlets that tell about the Book of Mormon. Many saints of other nations desire the Book of Mormon printed in their own language. It is difficult to get the books into countries like Turkey and Armenia. Others, like saints in Japan, are awaiting a translation. [J.W.M.]

L.219 Lund, Anthon H. Untitled talk. CR (April 1908): 115-20. The Lord told the Prophet Joseph Smith he was to perform a marvelous work. The publication of the Book of Mormon took moral courage. It proved to be a good missionary tool and many received a testimony of the truths it contained. Brigham Young, Joseph Young, Phineas Young, Lorenzo Young, and John Young are among the first converts because of the convincing power of the book. [J.W.M.]

L.220 Lund, Anthon H. Untitled talk. CR (October 1912): 11-15. Bearing testimony that Latter-day Saints esteem the Bible as the word of God as highly as any people on earth, this author calls attention to some discrepancies in the various translations to show the possibility of errors in the text and offers the Book of Mormon as an answer to know how correctly the Bible has been preserved. The Latter-day scriptures are as important as are the ancient ones that they support and sustain. [J.W.M.]

L.221 Lund, Anthon H. Untitled talk. CR (October 1919): 35-41. In this testimony of the "vitality of 'Mormonism," Lund testifies that nothing will stop the work of the Lord. He mentions that although all the Three Witnesses fell away from the Church, they never denied their testimonies of the Book of Mormon. Oliver Cowdery rejoined the Church at Council Bluffs. [B.D.]

L.222 Lund, Anthon H. Untitled talk. CR (4 April 1920): 16-22. Lund mentions the testimonies of the Three Witnesses. Martin Harris and Oliver Cowdery rejoined the Church but David Whitmer died without returning. All three held to their testimonies all their lives. [B.D.]

L.223 Lund, Gerald N. "An Anti-Christ in the Book of Mormon-the Face May Be Strange, but the Voice Is Familiar." In The Book of Mormon: Alma, The Testimony of the Word, edited by Monte S. Nyman and Charles D. Tate Jr., 107-28. Provo, UT: Brigham Young University Religious Studies Center, 1992. An entire chapter of the Book of Mormon is dedicated to Korihor, an example of an anti-Christ. Korihor acts as a negative example of the "power of the word" in contrast to the positive side, which is illustrated and discussed in the chapters before and after Alma 30. Points out that Korihor's views in three branches of philosophy-metaphysics, axiology, and epistemology-are still taught today. [D.M.] [N.K.Y.]

L.224 Lund, Gerald N. "Countering Korihor's Philosophy." Ensign 22 (July 1992): 16-21. Relates Korihor's philosophical foundations and rationalizations to current beliefs and arguments used against the gospel. Alma's answer used revelation and true doctrine, not academic debate, and exposed Korihor's lies. [A.C.W.] 
L.225 Lund, Gerald N. "Divine Indebtedness and the Atonement." In The Book of Mormon: Mosiah, Salvation Only through Christ, edited by Monte S. Nyman and Charles D. Tate Jr., 73-89. Provo, UT: Brigham Young University Religious Studies Center, 1991. Mosiah taught that as a result of our nothingness and of constant blessings, especially that of the Atonement, we are indebted to our "heavenly King," for which we should be profoundly grateful. [D.M.]

L.226 Lund, Gerald N. "An Exploration of the Process of Faith As Taught in the Book of Mormon." In The Second Annual Church Educational System Religious Educators' Symposium: A Symposium on the Book of Mormon, 74-80. Salt Lake City: Church of Jesus Christ of Latter-day Saints, 1979. An essay on the dynamic relationship of faith with hope, knowledge, power, and perfection. Exposition is based on Alma 32, Ether 12, Moroni 7, and the Lectures on Faith. [D.M.]

L.227 Lund, Gerald N. "The Fall of Man and His Redemption." In The Book of Mormon: Second Nephi, The Doctrinal Structure, edited by Monte S. Nyman and Charles D. Tate Jr., 83-106. Provo, UT: Brigham Young University Religious Studies Center, 1989. Focus is on 2 Nephi 2. Outlines aspects that deal with the Fall and the Redemption. Illustrates with charts the role of the Messiah, the place of grace and works, and the difference between one who has a broken heart and a contrite spirit and one who does not. Discusses the importance of opposition. [D.M.]

L.228 Lund, Gerald N. " 'Knowest Thou the Condescension of God?' "In Doctrines of the Book of Mormon, 1991 Sperry Symposium, edited by Bruce A. Van Orden and Brent L. Top, 80-92. Salt Lake City: Deseret Book, 1992. Notes that the word "condescension" relative to God's relationship to the world is used three times by Nephi, twice in his dream of the tree of life, and once in his psalm (2 Nephi 4:26). Proposes that there are three applications to this word in those passages: (1) the birth of Christ, (2) his mortal ministry, and (3) his mercies. Discusses the significance of the christological hymn in Philippians 2:5-8. [D.M.] [N.K.Y.]

L.229 Lund, Gerald N. "The Mysteries of God Revealed by the Power of the Holy Ghost." In The Book of Mormon: First Nephi, The Doctrinal Foundation, edited by Monte S. Nyman and Charles D. Tate Jr., 151-59. Provo, UT: Brigham Young University Religious Studies Center, 1988. Examines 1 Nephi 9:6, 1 Nephi 10:17, and 1 Nephi 10:18-21, as prelude to Nephi's vision. The vision of Nephi is used as a basis for discussing the question, "When Nephi says the Lord knows all things, does that truly imply that he has all knowledge in the Universe?" The author then describes the vastness of the universe and discusses time and relativity in relation to Nephi's vision. [A.T.]

L.230 Lund, Gerald N. "Sanctification and Justification Are Just and True." In Sidney B. Sperry Symposium: The Book of Mormon, edited by A. Gary Anderson, 28-38. Provo, UT: BYU Religious Instruction, 24 January 1981. A vigorous doctrinal discussion on sanctification and justification, clarifying the terms by examining their Semitic and Greek roots. Explains practical application, arguing that the terms are not abstruse but easily understandable. [D.M.]

L.231 Lund, Herbert Z. "Joseph Smith and the Book of Mormon." MS 95 (26 October 1933): 689-95. Argues against statements that Joseph Smith produced the Book of Mormon by way of "visionary seizures." The testimony of the Three Witnesses is reprinted, as is a description of David Whitmer's testimony before he died. [A.T.]

L.232 Lundeen, Vernon E. "Just What is the Book of Mormon?" SH 98 (15 January 1951): 59-60. To clarify false impressions about the Book of Mormon, this article gives a brief summary of the narrative in the Book of Mormon, an account of its discovery and translation, and explains that the RLDS church is the "legal and spiritual successor" to the foundation built upon the doctrine of the Book of Mormon. [A.C.W.] 
L.233 Lundgren, Alice. " 'In the Learning of the Jews': A Testimony." ZR 27-28 (1985): 14-15. Refers to mourning rituals enacted by Jews upon the death of a loved one and demonstrates how the rituals apply directly to the pattern given in Alma 30:2, where fasting, mourning, and prayer are mentioned. [D.M.]

L.234 Lundquist, John M., and John W. Welch. "Ammon and Cutting Off the Arms of Enemies." In Reexploring the Book of Mormon, 180-81. Salt Lake City: Deseret Book and FARMS, 1992. Compares similar practices in the Near East to Ammon's cutting off the arms of enemies in Alma 17:39, explaining possible reasons for this prevalent phenomena in the ancient world. [A.C.W.]

L.235 Lundquist, John M., and John W. Welch. "Kingship and Temple in 2 Nephi 5-10." In Reexploring the Book of Mormon, edited by John W. Welch, 66-68. Salt Lake City: Deseret Book and FARMS, 1992. In antiquity kings and temples were closely related. Nephi's intent to build a temple paved the way toward his kingship. It was necessary for covenant ceremonies at the temple to establish a legitimate state. [J.W.M.]

L.236 Lundquist, John M., and Stephen D. Ricks, eds. By Study and Also by Faith. 2 vols. Salt Lake City: Deseret Book and FARMS, 1990. These two volumes contain essays written by various authors in honor of Hugh W. Nibley. Many of the articles are related to Book of Mormon topics, such as the sacramental covenants, the Lamanite view, external evidences of the Book of Mormon, Lehi's family and others. This work is reviewed in D.128. [J.W.M.]

L.237 Lundstrom, Harold. "Bravos Highlight Oratorio Concerts." CN 42 (3 June 1972): 7. An oratorio concert focused on stories from the Book of Mormon. [M.D.P.]

L.238 Lundstrom, Harold. "Gallery of Writers Furnish Imposing Choice of Books." CN 32 (29 December 1962): 16, 23. Announcements of new books, including a new edition of the Book of Mormon. [M.D.P.]

L.239 Lundstrom, Harold. "Heyerdahl Book Supports Theory Polynesians Came from 'America.' " CN23 (29 August 1953): 13. Reports on Heyerdahl's book American Indians in the Pacific-The Theory Behind the Kon-Tiki Expedition . Argues that the Polynesians originated from the pre-Inca inhabitants of South America. [D.M.]

L.240 Lundstrom, Harold. "Original Words of the Book of Mormon." IE 51 (February 1948): 84-86, 116. During the period of 1820-1830 coining words was less common than at any subsequent time in America. The fact that the Book of Mormon contains so many unfamiliar words is a testimony of its divinity. B. H. Roberts studied the names in the Book of Mormon and found that Jaredite names end with consonants and Nephite names in vowels. One hundred eighty-one new words came forth out of seventy-five working days of translation. [J.W.M.]

L.241 Lundstrom, Joseph. "Book of Mormon Manuscripts: 2 'Original' Copies Were Made." CN 38 (26 October 1968): 5, 14. There were two copies of the manuscript of the Book of Mormon-the original manuscript (written mostly by Oliver Cowdery as Joseph translated) and the printer's copy (recopied mainly by Emma Smith). The original was placed in the cornerstone of the Nauvoo House and the printer's manuscript went to Oliver Cowdery who gave it to David Whitmer just prior to his death. [J.W.M.]

L.242 Lundstrom, Joseph. Book of Mormon Personalities. Salt Lake City: Deseret Book, 1969. A collection of more than fifty profiles of Book of Mormon personalities. Each sketch originally appeared in the CN as a series. [D.M.]

L.243 Lundstrom, Joseph. " Unto Three Shall They Be Shown.' CN 11 (13 July 1968): 10. Visitors to the visitor's center on Temple Square in Salt Lake City, Utah, can hear readings of testimonies of the Book of Mormon from the 
Three Witnesses, Emma Smith, and Lucy Mack Smith. [M.D.P.]

L.244 Lyman, Albert R. A Voice Calling. Salt Lake City: Deseret News Press, 196?. A pamphlet directed to the American Indians as a missionary message. Summarizes the contents of the Book of Mormon and invites the Indians to investigate the book. [D.M.]

L.245 Lyman, Melvin A. Out of Obscurity into Light. Salt Lake City: Albany Books, 1985. Using President Kimball's definition of Lamanite, this book focuses upon the native American inhabitants as descendants of Lehi and Ishmael. The author tells of the evil treatment that these children of Lehi have received in North and Latin America. Archaeological, historical, and traditional evidence reinforce the Book of Mormon. The Book of Mormon records the Lord's promises to the Lamanites and those who are under obligation to aid in the fulfillment of these blessings. [J.W.M.]

L.246 Lyman, Richard R. "The Twenty-Second Day of September." MS 99 (16 September 1937): 600-1. An editorial commemorating Joseph Smith's receipt of the gold plates from the hand of the angel Moroni. [R.H.B.]

L.247 Lynn, Ervin. "The Book That Would Not Burn." Ensign 16 (October 1986): 61-62. A Book of Mormon had been delivered to a home in New Mexico by two missionaries. Some time later the home burned and among the ashes was found the "untouched Book of Mormon." This miracle converted and strengthened many. [J.W.M.]

L.248 Lynn, Wayne B. The Book of Mormon Our Unpaid Debt. Salt Lake City: Church of Jesus Christ of Latter-day Saints, Church Schools, Dept. of Seminaries and Institutes of Religion, 198?. Noting that the Book of Mormon came from the ancestors of the Lamanites, the author admonishes Church members to take more seriously the mandate to inform the Lamanites of their book and their great role in the latter days. [D.M.]

L.249 Lyon, Warren H. "Book of Mormon Studies." MS 66 (3 March 1904): 140-41. The Book of Mormon explains the concept of Godhead, and treats "vital questions of theology ... with startling clearness," explaining the Bible and correcting false traditions. [A.C.W.] 
M.

M.001 M., M. R. "Sacred Stones in the Vicinity of Near, Licking County, Ohio." MS 28 (1, 8 December 1866): 753-59, 769-

74. "The Two Bibles" refers to the discovery of "sacred stones of Ohio," upon which were inscribed Hebrew phrases

(MS 28/41:641-43). This article analyzes the inscriptions further, showing that the decalogue was poorly written. It suggests the tribes of Dan, Reuben, Zebulun, or Joseph could have wandered to America and deposited the stones in Ohio. [B.D.]

M.002 M., W. A. "The Book of Mormon in Prophecy." MS 69 (16 May 1907): 305-11. Old Testament prophecies of Christ are conclusive proofs of his divinity; therefore, biblical prophecies of Book of Mormon are conclusive proofs of its divinity as well. [A.C.W.]

M.003 M., W. A. “Lessons from the Life of Nephi." MS 70 (November 1908): 705-8. The account of Nephi's conduct and Laman and Lemuel's treatment of him while crossing the ocean teaches important principles of the gospel. A righteous person will prosper and the unrighteous will not. We bind ourselves by cords that hinder us by evil speaking, neglect of prayer, disobedience, and failure to pay tithing. [B.D.]

M.004 Mabey, Charles R. "Let Its Words Be Judged." MS 64 (October 1902): 641-47. Though external evidence validates the Book of Mormon, it is the internal evidence that reveals its divinity. Like the Bible, the Book of Mormon rebukes sin, explains the existence of mankind, is filled with the "pure spirit of inspiration," explains the law of opposition, and discusses the philosophy that brings one to believe in God. [J.W.M.]

M.005 Mabey, John Hicksen. "The Book of Mormon as an Instrument in Teaching the Concept of Prayer." M.A. thesis, Brigham Young University, 1963. A comprehensive report on the teachings of prayer in the Book of Mormon. A primary interest of the author is to provide teachers in the Church with a source for teaching prayer. [D.M.]

M.006 MacFarlane. "Abinadi the Martyr." Contributor 10 (July 1889): 352-53. A poem telling the story of Abinadi, his preaching to King Noah, and his martyrdom. [A.T.]

M.007 MacGregor, D. "Shackles Fettering the Book of Mormon." SH 48 (13 February 1901): 129. The size and price of the Book of Mormon often prevent its sale. It is the best missionary tool available and should go to "every nation, kindred, and people." It has a heavenly influence that penetrates the hearts of men to convict, convert, and confound. It is a lack of faith that prevents its wide distribution. [J.W.M.]

M.008 Macgregor, Maggie. "The Restoration Accomplished.” In Macgregor's Light At Evening Time: The Gospel Restored, 183-254. Independence, MO: Board of Publication of The Church of Christ, 1942?. Provides Joseph Smith's own testimony of the coming forth of the Book of Mormon. The Book of Mormon is the sign of the Restoration, and fulfills all the criteria of the biblical prophecies concerning the sign. Presents the witnesses' testimonies, archaeological evidences, internal evidences, literary and moral features of the book. [J.W.M.]

M.009 Mackay, Thomas W. "Mormon and the Destruction of Nephite Civilization." In Studies in Scripture: Alma 30 to Moroni, edited by Kent P. Jackson, 231-44. Salt Lake City: Deseret Book, 1988. Begins by reflecting on Mormon's feelings concerning Nephite heroes and scoundrels. Describes the degeneration and social disintegration of the Nephite society as 
witnessed by Mormon. Comments on Mormon's message to the present world. Concludes by discussing Moroni's role in winding up his father's record. [D.M.]

M.010 Mackay, Thomas W. “Mormon's Philosophy of History: Helaman 12 in the Perspective of Mormon's Editing Procedure." In The Book of Mormon: Helaman through 3 Nephi 8, According to Thy Word, edited by Monte S. Nyman and Charles D. Tate Jr., 129-46. Provo, UT: Brigham Young University Religious Studies Center, 1992. The concerns and cosmology of Mormon as a historian and editor coalesce in Helaman 12. History is explained providentially rather than mechanistically or apart from God's intervention as a reaction to human behavior. [D.M.]

M.011 Mackenna, Irma de. "The Book of Mormon Taught Me to Read." Ensign 5 (February 1975): 40-41. An elderly lady in Chile learned to read from the Book of Mormon through the help of the Lord. She prayed for help, and had her daughter read a few lines which she then memorized and then began to study line by line to learn to read. [J.W.M.]

M.012 Maddox, Julie Adams. "Lehi's Vision of the Tree of Life: An Anagogic Interpretation." M.A. thesis, Brigham Young University, 1986. A look at Lehi's vision from a literary-critical point of view. Emphasis is placed on symbolic aspects of the tree of life, especially as it relates to death and renewal of life. [D.M.]

M.013 Madsen, Ann N., and Susan Easton Black. “Joseph and Joseph: 'He Shall Be Like unto Me' (2 Nephi 3:15).” In The Old Testament and the Latter-day Saints; Sperry Symposium, 1986, 125-40. U.S.A.: Randall, 1986. The Book of Mormon contains information about ancient Joseph that is found in no other place. There are many similarities between Joseph Smith and the ancient prophet Joseph. Each traveled with their families, experienced time in prison, each had a divine calling, and had dreams in their youth. [J.W.M.]

M.014 Madsen, Brigham D. “B. H. Roberts' Studies of the Book of Mormon.” Dialogue 26 (Fall 1993): 77-86. Uses B. H. Roberts's "Studies of the Book of Mormon" and other of his writings as evidence that Roberts in his later years believed the Book of Mormon to be a product of Joseph Smith's "fertile imagination" and Ethan Smith's book View of the Hebrews. [S.H.]

M.015 Madsen, Brigham D., ed. Studies of the Book of Mormon. Urbana and Chicago: University of Illinois Press, 1985. A collection of letters by B. H. Roberts concerning his work on the Book of Mormon in 1921-22, together with "Book of Mormon Difficulties: A Study" (1922) and "A Book of Mormon Study" (1922), with "A Parallel" (1927). A biographical essay by Sterling M. McMurrin praises Roberts as an honest and vigorous intellectual and emphasizes his concern about Book of Mormon questions for which no satisfactory answer had yet been found. Madsen finds that B. H. Roberts seriously questioned the ancient authorship, the origin, the substance, the literary style, and the historical authenticity of the Book of Mormon. This work is reviewed in S.108, S.261, W.155, and in S.109. [J.W.M.]

M.016 Madsen, Brigham D., and Sterling M. McMurrin. Reply to John W. Welch and Truman G. Madsen. N.p.: by the authors, March 1986. John W. Welch suggested that Brigham D. Madsen, editor of Studies of the Book of Mormon, a collection of writings of B. H. Roberts, intended to attack the Book of Mormon. This typescript reply contends that there was no such desire, but argues that B. H. Roberts had serious doubts concerning the Book of Mormon that were obvious in his writings. [J.W.M.] 
M.017 Madsen, John M. "Jesus Christ, the Son of the Living God." Ensign 23 (May 1993): 26-27. The Book of Mormon is the "instrument" with which to "flood the earth" with a knowledge of the divine mission of Jesus Christ so that the inhabitants may "be of good cheer." [S.H.]

M.018 Madsen, Truman G. "B. H. Roberts after Fifty Years: Still Witnessing for the Book of Mormon." Ensign 13 (December 1983): 10-19. A brief history of the life of B. H. Roberts and his work as a defender of the Book of Mormon. Argues that Roberts never lost his testimony of the Book of Mormon as some critics have claimed. Roberts's goal was to prepare future defenders of the book by showing where critics could attack it. [S.P.S.]

M.019 Madsen, Truman G. "B. H. Roberts and the Book of Mormon." BYU Studies 19 (Summer 1979): 427-45. Also in Book of Mormon Authorship: New Light on Ancient Origins, edited by Noel B. Reynolds, 7-32. Provo, UT: Brigham Young University Religious Studies Center, 1982. Discusses B. H. Roberts's dedication in analyzing the Book of Mormon throughout his life. Discusses Roberts as a historian, analyst of translation, defender, teacher, and writer. [L.D.]

M.020 Madsen, Truman G. "B. H. Roberts: The Book of Mormon and the Atonement." In The Book of Mormon: First Nephi, The Doctrinal Structure, edited by Monte S. Nyman and Charles D. Tate Jr., 297-314. Provo, Utah: Brigham Young University Religious Studies Center, 1988. Gives a brief description of the preparation of The Truth, the Way, the Life, a sixvolume work by B. H. Roberts, then examines this work in relation to the Book of Mormon. The specific topics covered are: "The Presuppositions of the Atonement," "Four Kinds of Suffering," and "The Law of Opposites." [A.T.]

M.021 Madsen, Truman G. "Facets of Prayer." IE 69 (February 1966): 157-59. An essay for youth about prayer, using Enos as the model. [D.M.]

M.022 Madsen, Truman G. "Guest Editor's Prologue." BYU Studies 10 (Spring 1970): 252-54. Discusses the critics of the Book of Mormon and how they have virtually helped the book prove itself throughout the tests of time. [L.D.]

M.023 Madsen, Truman G. "Ye Are My Witnesses." In Christ and the Inner Life, 43-54. Salt Lake City: Bookcraft, 1978. A short story based on events surrounding the appearance of Christ in 3 Nephi. [D.M.]

M.024 Madsen, Truman G., et. al. The Bible and the Book of Mormon: A Panel Discussion. N.p., 9 December 1962. Transcript of a panel discussion presented on television in St. John, New Brunswick, in which the author, president of the New England mission, faces three Protestant ministers. Aspects discussed concern the King James language of the Book of Mormon, archaeology, the divinity of Christ, the trinity, and continuous revelation. [D.M.]

M.025 Madsen, Truman G., and John W. Welch. “Did B. H. Roberts Lose Faith in the Book of Mormon?” Provo, UT: FARMS, 1985. Although Roberts was aware of some potential objections to the Book of Mormon, and was not always prepared to answer them, his conviction regarding its truthfulness never wavered. His views were recorded in several journals of people he interacted with, especially his missionaries in the eastern states. [D.M.]

M.026 Maeser, Karl G. "Sketches from the Book of Mormon: Abinadi." MS 30 (January 1868): 6-8. A brief description of the mission of Abinadi. He was the Stephen of that dispensation, sent by God in response to the wickedness of King Noah. [B.D.] 
M.027 Maeser, Karl G. "Sketches from the Book of Mormon: Alma the Great." MS 30 (February 1868): 69-71. A brief description of the life and mission of Alma: He was of pure blood of Nephi and became one of the greatest prophets and leaders of the Nephites. [B.D.]

M.028 Maeser, Karl G. "Sketches from the Book of Mormon: The Expedition of Ammon." MS 29 (December 1867): $818-20$. A brief summary of the events recorded in the Book of Mosiah. Maeser mentions King Mosiah2, Abinadi, Limhi, Gideon, and King Noah, and the expedition of Ammon. [B.D.]

M.029 Maeser, Karl G. "Sketches from the Book of Mormon: Jacob, the Brother of Nephi." MS 29 (November 1867): 695-96. Just as Moses had appointed Joshua as the secular leader and Aaron as the spiritual leader of the people, so too had Nephi anointed a king as the secular leader and Jacob the spiritual leader. Jacob provides valuable lessons on polygamy and the outcome of the anti-Christ such as Sherem. [B.D.]

M.030 Maeser, Karl G. "Sketches from the Book of Mormon: Nephi." MS 29 (October 1867): 673-74. A short description of Nephi's character. Maeser writes that Nephi had a strong character and was an excellent servant of God because of his temperance caused by his submission to the will of God and the promptings of the Holy Spirit. [B.D.]

M.031 Maeser, Karl G. "Sketches from the Book of Mormon: The Seven Prophets of the House of Jacob." MS 29 (November 1867): 759-60. A brief discussion of the seven prophets after Jacob and before King Benjamin. Maeser also summarizes the events that these prophets recorded. [B.D.]

M.032 Maestas, John R., and Jeff Simons. The Lamanite. Provo, UT: Brigham Young University, n.d. This work contains statements by prophets from Joseph Smith to Spencer W. Kimball concerning the Lamanites. Topics treated include: "Nephites Found in New Mexico," "Lamanites a Shield to Us," "Blessings Promised to Lamanites," and "Zelph-White Lamanite." [J.W.M.]

M.033 Maestas, John R., and Jeff Simons. The Lamanites_In the Words of the Prophets. Utah: n.p., 1980. Discusses the origin and history of the American Indians (Lamanites), mistreatment of Indians, God's directing hand in their affairs, and the latter-day responsibility of the Church to take the gospel to them. [L.D.]

M.034 Magleby, Kirk A. "And the Waters Prevailed: Some Andean Indian Versions of the Flood." NE 13 (January-February 1983): 9-12. North, Central, and South American Indians all "preserved the story of the flood." Their deluge accounts share with the Bible three main themes: "(1) mankind becomes wicked and offends the Gods, (2) a worldwide flood destroys sinners and purifies the earth, and (3) one righteous family or group is spared to begin a new, improved human race." Samples of the writings of early American explorers relating to Indian traditions about the flood are given. [A.T.]

M.035 Magleby, Kirk A. "Four Peruvian Versions of the White God Legend." NE 8 (December 1978): 14-17. Chronicles recorded shortly after the Spaniards reached South America describe Peruvian legends of a great white god. Author parallels four prominent versions of the white god legend with the account of Christ's visit to the Nephites shortly after his resurrection. [D.M.] 
M.036 Magleby, Kirk A. "A Survey of Mesoamerican Bearded Figures." Provo, UT: FARMS, 1983. A detailed study of bearded men as found in artifacts and historical accounts of Mexico and Central America. Relates findings to the Book of Mormon, concluding that the groups mentioned in that book resided in Mesoamerica. [D.M.]

M.037 Mahaffey, James Ervin. Found at Last! "Positive Proof" that Mormonism is a Fraud and the Book of Mormon a Fable. Augusta, GA: Chronicle Job Office, 1902. Author dogmatically asserts that the Spaulding Manuscript was the source from whence the Book of Mormon sprang. He lists twenty-two "points of perfect identity" between the two books and dismisses the witnesses' testimonies on the grounds that they only claimed to have seen with one "eye of faith." [M.R.]

M.038 Mahoney, W. LeRoy. "A Comparison of the Egyptian and Mayan Calendars." In 14th Symposium on Archaeology of the Scriptures, edited by Forrest R. Hauck, 87-94. Provo, UT: Brigham Young University, 1963. Lehi's measurement of time was influenced by the Egyptian calendric system, a system that was ultimately handed down to the Mayans. Several points of similarity between the Egyptian and Mayan calendars are noted, such as a luni-solar year consisting of twelve months of thirty days. [D.M.]

M.039 Maley, Thomas S. Why I Believe in the Book of Mormon. Minneapolis, MN: n.p., 197?. A brief statement on how the Book of Mormon answers vital questions. [D.M.]

M.040 Mangelson, David R. "The Book of Mormon as an Instrument in Teaching the Historicity of the New Testament of Events of Christ's Life." M.A. thesis, Brigham Young University, 1968. The Book of Mormon is a corroborating witness with the New Testament concerning the events of the pre-mortal and historical Jesus. Thematically similar passages from the New Testament and Book of Mormon are juxtaposed in parallel columns, an exercise that allows readers to view the manner in which the Book of Mormon stands as another witness of Jesus Christ. [D.M.]

M.041 Mangelson, David R. "The Book of Mormon As Another Witness of Jesus Christ." In A Symposium on the Book of Mormon, 76-80. Salt Lake City: Church of Jesus Christ of Latter-day Saints, CES, August 1986. Certain Christian groups exist who do not believe in the divinity of Jesus. The Book of Mormon, with the Bible, stands as a witness that Jesus is the Christ. The Book of Mormon testifies of Jesus Christ with regard to his pre-mortal existence, divine birth, ministry, trials, suffering, death, and resurrection. [D.M.]

M.042 Manges, Robert W., and Beatrice Epstein. From Mormonism into the Restored Church of Jesus Christ. Johnstown, PA: author, n.d. Former members of the "Mormon" Church give reasons for denouncing the LDS church and joining the RLDS church. The Book of Mormon is a second witness for Christ, it states that all are the children of God regardless of race or color. The authors condemn the practice of discrimination against people of color as well as the practice of polygamy, which is also condemned by the Book of Mormon. [J.W.M.]

M.043 Mannering, Effa L. 2000 Questions and Answers from the Book of Mormon. Independence, MO: n.p., 1971. Large, homemade study guide for the benefit of RLDS members. Contains questions answered by citing the relevant verses directly. Used as a study guide. [D.M.]

M.044 Mansfield, M. W. "Jacob's Isle." IE 7 (January 1904): 264-67. Discusses the writings in the Bible and Book of Mormon that use the term "isles" and discusses what land is referred to by the prophets. [L.D.] 
M.045 “The Manuscript Found." SH 32 (15 August 1885): 528-533. Introduces Spaulding's Manuscript Found and reprints the first few pages of the manuscript for the purpose of showing RLDS readers that the manuscript bears no resemblance to the Book of Mormon. [D.W.P.]

M.046 "The Manuscript Found." SH 50 (18 February 1903): 147. Reprint of a letter from the Toledo Weekly Blade accusing 'Mormons' of printing Spaulding's Manuscript Found for the purpose of refuting the argument that the Book of Mormon is based on that manuscript. [J.W.M.]

M.047 "Manuscript of Solomon Spalding" Journal of History 17 (April 1924): 169-82. An RLDS publication, containing primary documents relative to the Spaulding manuscript, including letters from L. L. Rice and a lecture by James $H$. Fairchild of Oberlin College. Concludes that it is unlikely that Spaulding had anything to do with the Book of Mormon. [D.M.]

M.048 Maples, Evelyn. The Brass Plates Adventure. Independence, MO: Herald House, 1972. Short, illustrated storybook for children about the acquisition of the plates of brass. [D.M.]

M.049 Maples, Evelyn. Lehi, Man of God. Independence, MO: Herald House, 1972. Illustrated children's storybook about Lehi. [D.M.]

M.050 Marchant, Byron. Mormonism's Connection to the British Enlightenment. Salt Lake City: by the author, 1988. Accepts Sidney Rigdon as the real impetus behind the Book of Mormon. Sees the following chain in nascent Mormonism: from Sidney Rigdon to Alexander/Thomas Campbell and from them to John Locke. [D.M.]

M.051 Markham, Julie Cannon. "Chapter-a-Week Home Evening." Ensign 20 (February 1990): 72. Describes several successes in reading a chapter of the Book of Mormon at each family home evening. Gives specific examples. [D.M.]

M.052 Marks, David. The Life of David Marks, to the 26th Year of His Age. Limerick, ME: Office of the Morning Star, 1831. The autobiography of a young preacher's experiences in New England during the early 19th Century. Pages $340-42$ discuss his brief encounter with Mormons and the Book of Mormon and his dismissal of the book as a fraud. [M.R.]

M.053 Marks, David. "Particulars of My Travels and Labors from November, 1829 to September 1830." In Memoirs of the Life of David Marks, Minister of the Gospel, edited by Marilla Marks, 233-245. Dover, N.H.: William Burr printer, published by The Free-Will Baptist Printing Establishment, 1846. Tells about attending a meeting in the home of the Whitmers on March 29, 1830. Here he learned of the Book of Mormon and the Whitmers' testimonies that an angel had shown them the plates and their testimony of Joseph Smith. States that he did not buy the book because he could not support deception. [J.W.M.]

M.054 Marler, Ezra L. "The Book of Mormon: The Bible. Is It Enough? A New Volume of Scripture." In Marler's High Way Helps: Lights along Lifes Great Highway, 152-59. Independence, MO: Zion's Printing, 1945. Quoting 2 Nephi 28:29-29:10, the author calls attention to what would be lacking if the Bible were our only religious literature: the nature of God, the meaning and plan of life, origin and destiny of man, the mode of baptism, the destiny of righteous dead. The Book of Mormon does not detract from or contradict the Bible, it adds clarity to the Bible. [J.W.M] 
M.055 Marler, Ezra L. Christ in the Book of Mormon. Salt Lake City: Deseret Book, 1956. An anthology of scriptural quotations from the Book of Mormon. The brief work is divided into two main sections-the predictions of Christ's birth in the holy land and his visit to the Americas. No commentary is supplied by the compiler. [D.M.]

M.056 Marler, Ezra L. Gospel Teachings in the Book of Mormon. Salt Lake City: Deseret Book, 1956. A topically arranged ready reference on gospel subjects taken from the Book of Mormon. The compiler offers no commentary. [D.M.]

M.057 Marler, Ezra L. History and Stories in the Book of Mormon. Salt Lake City: Deseret Book, 1956. Historical narratives are extracted from the Book of Mormon and quoted verbatim to create a Book of Mormon history. The selections are arranged in historical order from 1 Nephi to Mormon, with the exception of the book of Ether, which is placed last. [D.M.]

M.058 Marquardt, H. Michael. Book of Mormon Cross Reference. Bountiful, UT: Restoration Research, 1983. This pamphlet cross references the LDS 1981 edition with the RLDS 1908 and 1966 editions of the Book of Mormon. [J.W.M.]

M.059 Marquardt, H. Michael. "Early Nineteenth Century Events Reflected in the Book of Mormon." Journal of Pastoral Practice 3/1 (1979): 114-36. A polemical article that attempts to enumerate numerous modern environmental factors that influenced the Book of Mormon such as anti-Masonic influences, theories regarding Indian origins, and money digging. The 1826 trial of Joseph Smith, Anthon episode, Book of Mormon witnesses, lack of archaeological evidence, and plagiarisms from the Bible are also discussed. [M.R.]

M.060 Marquardt, H. Michael. "The Use of the Bible in the Book of Mormon." Journal of Pastoral Practice 2/2 (1978): 95117. A polemical article attempting to show that the Book of Mormon uses biblical material anachronistically and that the Book of Mormon plagiarizes biblical material. Numerous examples are listed. The writer also suggests that many Book of Mormon events are patterned after events in the Bible. [M.R.]

M.061 Marquardt, H. Michael. The Use of the Bible in the Book of Mormon and Early Nineteenth Century Events Reflected in the Book of Mormon. Salt Lake City: Modern Microfilm Company, 1979. Two articles reprinted from the Journal of Pastoral Practice 2/3 (1978-1979). In the first article the author argues that Joseph Smith used the KJV to write the Book of Mormon. To show plagiarism, the author lists Book of Mormon passages opposite Bible passages. In the second article, the author argues that early nineteenth-century attitudes contributed to the Book of Mormon: secret combinations and antiMasonic feelings, the origin of the American Indians, Joseph's money digging. There is no archaeological evidence for the Book of Mormon and the exhortation to pray for truth (Moroni 10:2-5) does not work. [B.D.]

M.062 Marriott, Dean L. "I Have a Question: Is the book of Revelation the remainder of the vision Nephi recorded in 1 Nephi?" Ensign 17 (June 1987): 25-26. Both Nephi and John beheld similar visions but each wrote only a portion of what he saw. It is not entirely clear if the book of Revelation is that portion of Nephi's vision that the apostle John was commanded to write. Differences and similarities between the two records are examined. [S.P.S.]

M.063 Marsden, Carlyle. "Alma the Son of Alma, a cantata, text Book of Mormon: Book of Alma for chorus, solo voices, and organ." M.S. thesis, University of Utah, 1952. Musical selections for chorus, solo voices, and the organ. [J.W.M.] 
M.064 Marsh, Herbert J. Book of Mormon Reference. Houston, TX: Texas Mission, 10 April 1943. A small handbook of references for missionaries. The scriptural references are placed according to topic: "Where does faith come from?" "Is sincerity of belief enough?" "Who should be baptized?" and "Are revelations continuous?" [J.W.M.]

M.065 Marshall, Craig G. "Father Lehi." Ensign 6 (September 1976): 58-63. An overview of the life and personality of Lehi. Lehi was an exceptional prophet, a visionary character who prophetically foresaw events concerning his family down through the ages. [B.T.]

M.066 Marshall, Evelyn. "Title of Book Fascinates Her Searching Co-worker." CN 58 (31 December 1988): 8-9. Conversion narrative wherein a Book of Mormon was shared with a co-worker. [A.C.W.]

M.067 Marshall, Robert. "Teancum, a True Friend to Liberty." Instructor 100 (July 1965): 297. Fictional story based on account of Teancum in Alma 62. [A.C.W.]

M.068 "Martin Harris's 1873 Letter to Walter Conrad." BYU Studies 23 (Winter 1983): 112-19. Contains an explanation written by Brent Ashworth of how the Martin Harris letter was acquired, and a photocopy of the manuscript along with a transcription. (Editor's note: this letter has since been shown to be a forgery.) [L.D.]

M.069 Martin, Walter. The Kingdom of the Cults. Minneapolis, MN: Bethany Fellowship, 1965. A polemical work against several religious faiths that the author sees as heretical. He devotes a chapter to Mormonism. Items discussed pertaining to the Book of Mormon are lack of archaeological evidence, Spaulding theory, Anthon denials, Mongoloid origin of native Americans, and contradictions with the Bible. [M.R.]

M.070 Martin, Walter. The Maze of Mormonism. Santa Ana: Vision House, 1978. A polemical work against Mormonism. The author discusses numerous elements that he sees as anachronistic, including contradictions with the Bible, Christian teachings before Christ, and alleged plagiarisms from the New Testament. [M.R.]

M.071 Martin, Walter. Mormonism. Minneapolis, MN: Bethany Fellowship, 1957, revised 1976. A polemical tract against Mormonism debunking Mormon history, doctrines, and the Book of Mormon. The book of Mormon "adds" to the word of God contradicting the divine warning of Revelation 22:18. [M.R.]

M.072 Martineau, Theodore. "Voices from the Dust." IE 36 (January 1933): 146-47. Chihuahua, Mexico was once inhabited by a brilliant civilization. A visit to the ruins shows remarkable skills in masonry, textiles, and pottery, as well as a preoccupation with warfare and ingenious designs for protection. The inhabitants of this civilization may have been the Gadianton robbers. [D.M.]

\section{M.073 Martinez, Arturo R. Untitled talk. In The Official Report of the First Mexico and Central American Area General} Conference of the Church of Latter-day Saints, August 1972, 140-42. Salt Lake City: Church of Jesus Christ of Latter-day Saints, 1972. Expresses gratitude for ancestors who received the testimony of the truthfulness of the Book of Mormon. They followed the council of Moroni to pray to God in the name of Christ and after much study received a manifestation of the truth through the Holy Ghost. A great and mighty people lived at one time in Guatemala. The Book of Mormon unfolds their history. They were they of whom the Savior testified were his "other sheep." [J.W.M.] 
M.074 Marty, Martin E. "Two Integrities: An Address to the Crisis in Mormon Historiography." Faithful History: Essays on Writing Mormon History, edited by George D. Smith, 169-88. Salt Lake City: Signature, 1992. Since historians cannot prove or disprove the truth of the Book of Mormon or whether Joseph Smith was a prophet, they should adopt a middle ground and only discuss secondary issues. Thus, they simply seek to understand how the Book of Mormon influences those who believe in it without discussing whether or not it is true. [B.D.]

M.075 Masters, George F. "3 Nephi 12:1-12: The Savior's Emphasis on the Weightier Matters." In A Symposium on the Book of Mormon, 81-85. Salt Lake City: Church of Jesus Christ of Latter-day Saints, CES, August 1986. The beatitudes of the sermon at Bountiful may signify the weightier matters neglected by the Pharisees (Matthew 23:23). Each succeeding beatitude represents a step toward perfection. [D.M.]

M.076 Matheny, Deanne G. "Does the Shoe Fit? A Critique of the Limited Tehuantepec Geography." In New Approaches to the Book of Mormon, edited by Brent Lee Metcalfe, 269-328. Salt Lake City: Signature, 1993. Many Book of Mormon geographers agree that the geographical setting of the Book of Mormon must be found in a limited area. At first glance it seems that their theories fit areas of Mexico and Mesoamerica, but an intensive study uncovers many problems, the first of which is directional, since the Mayan directional systems have been deciphered. Archaeology poses another problem. Specific locations proposed by Book of Mormon archaeologists to be possible Book of Mormon sites are compared with actual archaeological sites and are found to be lacking similarity. The models proposed by Book of Mormon geographers fall short of plausibility and probability. This work is reviewed in S.513. [J.W.M.]

M.077 Matheny, Ray T. "An Analysis of the Padilla Gold Plates." BYU Studies 19 (Fall 1978): 21-40. Discusses the circumstances of the discovery of the Padilla gold plates, their physical description, means of production, and the content of the engravings on them. The article attempts to determine the plates' historical value. "If authentic [the Padilla gold plates] represent the most significant archaeological evidence of the Book of Mormon yet to appear." Author concludes that the plates are not authentic. [L.D.]

M.078 Mather, Frederic G. "The Early Days of Mormonism." Lippincott's Magazine 26 (August 1880): 196-211. A tendentious and sardonic but highly imaginative recounting of Joseph Smith's life, including the events leading to the coming forth and publishing of the Book of Mormon. Entertaining mixture of fiction with fact. [D.M.]

M.079 Matthews, Robert J. "Abinadi: Prophet and Martyr." Ensign 22 (April 1992): 25-31. Abinadi's forceful ministry "influenced the entire second half of the Nephites' history." Discusses the man and the prophet Abinadi, his trial and conviction, his death and his doctrinal teachings about the law of Moses, the Atonement, and the resurrection. [A.C.W.]

M.080 Matthews, Robert J. "Abinadi: The Prophet and Martyr." In The Book of Mormon: Mosiah, Salvation Only through Christ, edited by Monte S. Nyman and Charles D. Tate Jr., 91-111. Provo, UT: Brigham Young University Religious Studies Center, 1991. Article is divided into two parts: (1) a historical sketch of Abinadi, including the circumstances he faced before King Noah's court; (2) A consideration of Abinadi's doctrinal teachings, with emphasis on the raison d'etre of the law of Moses and clarifications on the Atonement and resurrection. [D.M.]

M.081 Matthews, Robert J. "An Appreciation for the Book of Mormon." In Sidney B. Sperry Symposium: The Book of Mormon, edited by A. Gary Anderson, 18-27. Provo, UT: BYU Religious Instruction, 24 January 1981. Speaks about themes 
covered in the Book of Mormon: the mission of Christ, the Fall and the Atonement, salvation only through Christ, the nature of God, the devil, spiritual gifts, the ministry of angels, and the philosophies of men. Includes a table listing the names of Christ in the Book of Mormon. [D.M.]

M.082 Matthews, Robert J. "The Atonement of Jesus Christ: 2 Nephi 9." In The Book of Mormon: Second Nephi, The Doctrinal Structure, edited by Monte S. Nyman and Charles D. Tate Jr., 177-99. Provo, UT: Brigham Young University Religious Studies Center, 1989. Rehearses information about the Book of Mormon prophet Jacob, but expends most of the essay on the Atonement, using 2 Nephi 9 as well as other scriptures. The Atonement paid for the original sin, and is "infinite." [D.M.]

M.083 Matthews, Robert J. A Bible! A Bible! Salt Lake City: Bookcraft, 1990. Joseph Smith taught that the Book of Mormon is a witness for the Bible. It testifies of Jesus Christ and His divinity, teaches a wide range of secular and religious topics, and identifies the enemies of Christ. The Book of Mormon is the most correct of any book on earth, the keystone of the LDS religion, and individuals will "get nearer to God by abiding by its precepts than by any other book." [J.W.M.]

M.084 Matthews, Robert J. "The Bible and Its Role in the Restoration." Ensign 9 (July 1979): 40-45. The Bible played a vital role in the Restoration of the gospel. The angel Moroni used biblical verses to instruct Joseph Smith. Many basic doctrines of the Church, including the age of accountability, three degrees of glory, and celestial marriage, were developed as a result of Joseph's efforts to translate the Bible. The literary style of the Book of Mormon was adopted from the Bible. [D.M.]

M.085 Matthews, Robert J. "The Book of Mormon a Witness for the Bible." Instructor 101 (April, May 1966): $160,205$. Compilation of quotes from scripture and Church leaders that demonstrate how the Book of Mormon is a witness for the Bible. Charts of scriptures comparing Old Testament, New Testament, and Book of Mormon show unity of doctrine. [A.C.W.]

M.086 Matthews, Robert J. Book of Mormon and Bible Study Handouts: Some Book of Mormon Parallels to the Bible. Unpublished holdings in the LDS Church Office Building, 1967. There are many parallel passages in the Book of Mormon and the Bible. [J.W.M.]

M.087 Matthews, Robert J. "The Book of Mormon as a Co-Witness with the Bible and as a Guide to Biblical Criticism." In The Sixth Annual CES Religious Educators' Symposium on the Book of Mormon, 55-58. Salt Lake City: Church of Jesus Christ of Latter-day Saints, 1982. Explains what the eighth article of faith means with regard to the Bible. The paper describes variations in biblical texts and the ways in which those variations came about. The Book of Mormon clarifies and restores the text of the Bible. [A.T.]

M.088 Matthews, Robert J. "Book of Mormon Symposium Focuses on Teaching of Jacob." CN 58 (5 November 1988 ): 7. Tells of Jacob's teachings on the Atonement. [M.D.P.]

M.089 Matthews, Robert J. "Christ's Authority, His Other Sheep, and the Redemption of Israel." In Studies in Scripture: Alma 30 to Moroni, edited by Kent P. Jackson, 161-71. Salt Lake City: Deseret Book, 1988. A discussion of 3 Nephi 15-16, with elaboration of the biblical Sermon on the Mount, dealing with the question of Christ's authority, the "other sheep" referred to in John 10:16, and the meaning of "gentile." [D.M.] 
M.090 Matthews, Robert J. "The Doctrine of the Resurrection as Taught in the Book of Mormon." BYU Studies 30 (Summer 1991): 41-56. Discusses aspects of the resurrection as taught by each prophet in the Book of Mormon, while noting that every writer on the subject emphasized peculiar features. There is no one place in the Book of Mormon where the complete teachings on the resurrection are brought together. The author lists 23 separate components of resurrection scattered throughout the Book of Mormon. [D.M.]

M.091 Matthews, Robert J. "Establishing the Truth of the Bible." In The Book of Mormon: First Nephi, The Doctrinal Foundation, edited by Monte S. Nyman, and Charles D. Tate Jr., 193-215. Provo, Utah: Brigham Young University Religious Studies Center, 1988. References Book of Mormon statements to Old and New Testament events to show how the Book of Mormon supports Biblical events and historical figures such as the creation, Noah, Babel, and Abraham. The Book of Mormon tells the history of the Bible. [A.T.]

M.092 Matthews, Robert J. Handouts for Religion Classes. Unpublished holdings at LDS Church Office Building, 196 ?. Interesting Book of Mormon facts and their scriptural references: medical practices, the Nephites and Jaredites probably never met, Mormon was probably impressed to name his son Moroni while abridging the Nephite records, occupations and callings of Book of Mormon personalities, and other items. [J.W.M.]

M.093 Matthews, Robert J. "I Have a Question: Why do the Book of Mormon selections from Isaiah parallel the King James Version and not the older-and presumably more accurate-Dead Sea Scrolls text?" Ensign 10 (March 1980): 40. For two reasons the Isaiah passages in the Book of Mormon parallel the King James Version rather than the Dead Sea Scrolls. First, the Dead Sea Scrolls have been found to differ considerably from texts of the same vintage. Second, the translation in the Book of Mormon may not reflect the "minute and highly detailed analysis of every word on the gold plates." [J.W.M.]

M.094 Matthews, Robert J. "I Have a Question: Why have changes been made in the printed editions of the Book of Mormon?" Ensign 17 (March 1987): 47-49. The changes and corrections made in various editions of the Book of Mormon were necessary to correct "typographical errors, misspellings, misplaced or dropped words, and ambiguities." These original textual errors arose from non-standardized spelling in the 1800 s, errors made by various scribes, editors and typesetters, and from the difficulty of communicating the things of God in the language of man. [S.P.S.]

M.095 Matthews, Robert J. “Jacob: Prophet, Theologian, Historian.” In The Book of Mormon: Jacob through Words of Mormon, To Learn with Joy, edited by Monte S. Nyman and Charles D. Tate Jr., 33-53. Provo, UT: Brigham Young University Religious Studies Center, 1990. Compiles the historical information available on Jacob, discusses his and his brother Joseph's calling as priest and a teacher, and summarizes his style of speaking and the content of his message. [D.M.]

M.096 Matthews, Robert J. "Joseph Smith-Translator." In Joseph Smith: The Prophet, the Man, edited by Susan Easton Black and Charles D. Tate Jr., 77-87. Provo, UT: Brigham Young University Religious Studies Center, 1993. A prophet is an instrument of God to bring forth scripture. The Prophet Joseph Smith brought forth many scriptures, many through the gift of translation: the Book of Mormon, the Doctrine and Covenants, the Joseph Smith Translation of the Bible, the Book of Abraham translated from papyri, and the scroll of Joseph of Egypt part of which was also translated from papyri. [J.W.M.] 
M.097 Matthews Robert J. "Modern Revelation: Window to the Old Testament." Ensign 3 (October 1973): 20-23. Latter-day revelation is the key to understanding the Old Testament. The Book of Mormon, Doctrine and Covenants, and the Pearl of Great Price give an expanded view of certain writings of Old Testament prophets and supplement the doctrine. [J.W.M.]

M.098 Matthews, Robert J. "The New Publications of the Standard Works-1979, 1981." BYU Studies 22 (Fall 1982): $387-$ 424. Discusses the changes in format of the Book of Mormon, Doctrine and Covenants, Pearl of Great Price, and the Bible in their new editions. There was a need for publication of an LDS edition of the Bible and that led to an update of the other standard works of the Church. Contains photographs of the printer's copy of the Book of Mormon, the original Book of Mormon manuscript, the "Kirtland Revelation Book," and Joseph Smith translations. [L.D.]

M.099 Matthews, Robert J. "Notes on Lehi's Travels." BYU Studies 12 (Spring 1972): 312-14. Sets forth the sources that declare that the course of Lehi ended up in "South America, in Chile, thirty degrees south latitude." [L.D.]

M.100 Matthews, Robert J. "Patterns of Apostasy in the Book of Helaman." In The Book of Mormon: Helaman through 3 Nephi 8, According to Thy Word, edited by Monte S. Nyman and Charles D. Tate Jr., 65-80. Provo, UT: Brigham Young University Religious Studies Center, 1992. A discussion of identifiable characteristics that led to a spiritual degeneration of large groups as recorded in the book of Helaman. Notes the uncompromising righteousness of Helaman, brothers Nephi and Lehi, and Samuel the Lamanite, and the unrighteousness of Kishkumen, Gadianton, and the Gadianton robbers. [D.M.]

\section{M.101 Matthews, Robert J. "The Probationary Nature of Mortality." In The Book of Mormon: Alma, The Testimony of the} Word, edited by Monte S. Nyman and Charles D. Tate Jr., 47-60. Provo, UT: Brigham Young University Religious Studies Center, 1992. A commentary on Alma 12. Expounds on the idea that greater truth is given to those who are prepared, the lesser truth to those who are not. Elaborates on the "chains of hell," the second death, the probationary period, and the "rest of the Lord." [D.M.]

M.102 Matthews, Robert J. "Resurrection." Ensign 21 (April 1991): 6-11. Examines the doctrine of the resurrection in the Old and New Testaments. The teachings in the Book of Mormon clarify why the death and resurrection of Jesus Christ are vital. Explores the teachings of Lehi, Jacob, Benjamin, Abinadi, Amulek, Alma, and those given at the temple when Christ appeared. Jesus atoned for man's sins and the resurrection was an important part of the plan. [J.W.M.]

M.103 Matthews, Robert J. "The Savior's Sermon to the Nephites Compared with the Sermon on the Mount." In The Sixth Annual Church Educational System Religious Educators' Symposium on the Book of Mormon, 52-54. Salt Lake City: Church of Jesus Christ of Latter-day Saints, 1982. The two sermons are compared and contrasted using the KJV, JST, and Book of Mormon. The elements examined include: the Beatitudes, the Lord's prayer, the law of Moses, and Scribes and Pharisees. The author concludes that the Nephite sermon is "fresh and independent, totally adapted to the particular situation of the Nephite people to whom it was given." [AT.]

M.104 Matthews, Robert J. "Some Comparisons of the Book of Mormon with the Old and New Testaments." In A Symposium on the Book of Mormon, 18-23. Salt Lake City: Church of Jesus Christ of Latter-day Saints, 1979. Cites the promise of 3 Nephi that the records of Judah and those of the Nephites would be combined. Compares Matthew 5 with 3 Nephi 12; Matthew 6 with 3 Nephi 13 and JST Matthew 6; JST Matthew 7 with Matthew 7. [N.K.Y.] 
M.105 Matthews, Robert J. "Some Thoughts on the Atonement." Provo, UT: FARMS, 1989. Uses the greater knowledge presented in the Book of Mormon to clarify Jesus' "points of doctrine" concerning his Atonement. The dimensions of the Atonement include elements of love, service, legality, and debt payment. A divine redeemer of mortal and immortal parentage was needed to offer the holy sacrifice. [J.W.M.]

M.106 Matthews, Robert J. "Two Ways in the World: The Warfare between God and Satan." In Studies in Scripture: 1 Nephi to Alma 29, edited by Kent P. Jackson, 146-61. Salt Lake City: Deseret Book, 1987. 2 Nephi 26-30 contrasts the ways of God and Satan. Shows the modus operandi of the two and refers to prophecies about how they would be (and are being) expressed in the latter days. [D.M.]

M.107 Matthews, Robert J. "What the Book of Mormon Tells Us about Jesus Christ." In The Book of Mormon: The Keystone Scripture, edited by Paul R. Cheesman, S. Kent Brown, and Charles D. Tate Jr., 21-43. Provo, UT: Brigham Young University Religious Studies Center, 1988. A variety of Christological roles of Jesus found in the Book of Mormon are discussed, including Jesus Christ as the universal Savior, the resurrected Lord, and as the figure who wrought the Atonement. [D.M.]

M.108 Matthews, Robert J. "What the Book of Mormon Tells Us about the Bible." In Doctrines of the Book of Mormon, 1991 Sperry Symposium, edited by Bruce A. Van Orden and Brent L. Top, 93-113. Salt Lake City: Deseret Book, 1992. The Book of Mormon declares the Bible to be a sacred and true record, but it sustained serious losses in its early stages, which has caused considerable stumbling. Many biblical scholars today reject the authenticity of many of the teachings of Jesus. The Book of Mormon confirms the truthfulness of the Bible. [D.M.]

M.109 Matthews, Robert J. Who's Who in the Book of Mormon? Salt Lake City: Deseret Book, 1964, [R]1976. A Who's Who of Book of Mormon personalities. Part 1 presents a listing of each person named; part 2 contains a listing of all people not specifically named. Appendix 1 provides a description of the Book of Mormon plates; appendix 2 presents random facts about the Book of Mormon; appendix 3 names the categories of people in the Book of Mormon. This work is reviewed in R.223. [D.M.]

M.110 Matthews, Robert J. "Why Have Changes Been Made in the Printed Editions of the Book of Mormon?" In A Sure Foundation: Answers to Difficult Gospel Questions. 33-39, Salt Lake City: Deseret Book, 1988. Translating from one language to another is difficult at best; spelling errors and dropped or misplaced words are common. The process is complex and with each edition small mistakes are corrected. Spelling had not been standardized at Joseph Smith's time. The same kind of process took place with the Bible. [J.W.M.]

M.111 Matthews, Robert J. "Why the Book of Mormon Is the Keystone of Our Religion." In A Symposium on the Book of Mormon, 86-90. Salt Lake City: Church of Jesus Christ of Latter-day Saints, CES, August 1986. While not depreciating the Bible, the author sees the Book of Mormon as being a more correct work, since its language was not at the mercy of so many generations of translations with their inevitable errors. The Book of Mormon testifies profoundly about Christ and his Atonement, and other crucial aspects of life that weigh heavily on mankind. This work is reviewed in H.178. [D.M.]

M.112 Mattson, Vernon W., Jr. The Dead Sea Scrolls and Other Important Discoveries. Brandon, FL: Buried Records, 1978. A compilation of quotations by different people on the Dead Sea Scrolls and other ancient records. The author ties the 
archaeological discoveries in both hemispheres to the Book of Mormon and retells the story of the gold plates from Joseph Smith's point of view. [D.M.]

M.113 Maughan, Merrill Owen. The Golden Treasure. Illinois: Merrill Owen Maughan. Written for investigators of the LDS church. The Book of Mormon compliments the Bible and the two make the Lord's sacred record complete. A short synopsis of the book is presented as well as historical facts concerning its coming forth. A promise is made to all who sincerely desire to know of its truthfulness. [J.W.M.]

M.114 Maxfield, M. Richard. "The Book of Mormon and the Conversion Process to the Church of Jesus Christ of Latter-day Saints: A Study of Recent Converts." Ph.D. diss., Brigham Young University, 1977. Examines the conversion stories of a number of LDS converts and attempts to determine the precise role of the Book of Mormon in the conversion process. Determines that personal prayer, the witness of the Spirit, and the spirit of the missionaries tended to be more formidable determinants in the conversion process than did the influence of the Book of Mormon. [D.M.]

M.115 Maxson, Helen F. "From Emerson to Alma: A Personal Odyssey." Dialogue 26 (Winter 1993): 143-51. The author relates her philosophical journey from transcendentalism to existentialism to Mormonism and explains how her studies of Emerson and modern poets prepared her for her conversion. [S.H.]

M.116 Maxwell, Donna K. "How to Make the Book of Mormon a Part of Daily Gospel Study." CN63 (4 September 1993 ): 15. Suggestions for effective daily study of the Book of Mormon coupled with a testimony of its benefits. [S.H.]

M.117 Maxwell, Neal A. "An Ancient Record—with Relevancy." Instructor 105 (July 1970): 240-41. Discusses the Book of Mormon as an ancient record that was predestined to come forth in this day and is a work relevant to our day. [L.D.]

M.118 Maxwell, Neal A. "The Book of Mormon: A Great Answer to 'The Great Question.' " In The Book of Mormon: First Nephi, The Doctrinal Structure, edited by Monte S. Nyman and Charles D. Tate Jr., 1-17. Provo, Utah: Brigham Young University Religious Studies Center, 1988. The Book of Mormon answers the great question, "Is there really a redeeming Christ?" The Book of Mormon restores truth lost from the Bible, is important for our time, and provides and defines a plan and purpose for our existence. Reviews Moroni's promise, the way Book of Mormon peoples observed the law of Moses and the importance of searching the scriptures. [A.T.]

M.119 Maxwell, Neal A. "The Book of Mormon is Relevant Today." Instructor 105 (July, August, September, October, November 1970): 240-41, 306-7, 316-17, 370-71, 404-5. Five-part series showing how the Book of Mormon is relevant today: all generations need to learn from the past for it teaches of the sorrowing of the damned and the danger of unchastity. Author details some of the "magnificent miscellany" contained in the Book of Mormon, such as the erosion of spiritual experience, reason vs. inspiration, and the importance of two-way communication; shows how the Book of Mormon is congruent with the Bible; details some milestones for modern Christians found in the Book of Mormon in the areas of charity, prayer, and testimony. [A.C.W.]

M.120 Maxwell, Neal A. "The Children of Christ." In The Book of Mormon: Mosiah, Salvation Only through Christ, edited by Monte S. Nyman and Charles D. Tate Jr., 1-22. Provo, UT: Brigham Young University Religious Studies Center, 1991. Explores the divine declaration of Jesus Christ as found in the book of Mosiah in the Book of Mormon and the manner in 
which mortals may become children of Christ. The author explains the value of exploring all of the rooms and corridors of the Book of Mormon that he likens to a vast mansion. The Restoration has produced a great feast of gospel messages. [J.W.M.]

M.121 Maxwell, Neal A. "The Children of Christ." BYUSY (4 February 1990):79-91. Focuses on Christology in the Book of Mosiah, using the teachings of King Benjamin, Mosiah, Abinadi, and Alma the Younger. There are significant insights into Christ's role and ministry and the process by which mortals may become his children and receive eternal life. The Atonement is relevant because it opens the way to reconciliation with Father. Book of Mormon prophets exemplify the way. [J.W.M.]

M.122 Maxwell, Neal A. "A Choice Seer." Ensign 16 (August 1986): 6-15. Also in Brigham Young University $1985-1986$ Devotional and Fireside Speeches, 113-21. Provo, UT: Brigham Young University Press, 1985. An essay about the Prophet Joseph Smith as a seer. Referring to the translation of the Book of Mormon, the author writes that "since Joseph, who knew the 'particulars' [of the translating process], chose not to describe them in detail, we cannot presently be definitive about methodology." [D.M.]

M.123 Maxwell, Neal A. "Endure It Well." Ensign 20 (May 1990): 33-35. Also in CR (March/April 1990): 42-46. Commentary on 2 Nephi 31:15 wherein it is written that "he that endureth to the end, the same shall be saved." Testing is an integral part of life; endurance is more than merely putting up with a problem. It is learning from what we experience, loving and proceeding in spite of fatigue. It enlarges the mind and the heart. [J.W.M.]

M.124 Maxwell, Neal A. "Good and Evil Spoken of among All People." Washington, DC: n.p., 7 February 1986. Address given to the BYU Management Society. Contains reflections on Joseph Smith and the Restoration. Talks about B. $\mathrm{H}$. Roberts's testimony of the Book of Mormon and various allegations against Mormonism. [D.M.]

M.125 Maxwell, Neal A. "King Benjamin's Manual of Discipleship." Ensign 22 (January 1992): 8-13. In Mosiah 2-5, King Benjamin describes how to be a true disciple of Christ. The process begins with casting away the tendencies of the natural man and intently striving to become a follower of Christ through obtaining godly characteristics, giving service to fellowmen, and rendering all that we have to God. "The qualities of a disciple haven't changed since King Benjamin spoke centuries ago." [B.D.]

M.126 Maxwell, Neal A. Looking Beyond the Mark. Salt Lake City: University of Utah Institute of Religion, 1976. A devotional address concentrating on Jacob's observation of people who "miss the point" or "look beyond the mark." [D.M.]

M.127 Maxwell, Neal A. Plain and Precious Things. Salt Lake City: Deseret Book, 1983. The purpose of the Book of Mormon is to support the Bible in bearing witness of Christ. Though it is a highly complex instructional book in its plot, structure, and symbolism, its greatest value lies in its spiritual message. The purpose of scriptures is to remove stumbling blocks, to elevate our minds, hearts, and standards, and to deepen our trust by revealing the purposes of God. [J.W.M.]

M.128 Maxwell, Neal A. "The Reality of the Living Scriptures.” In Maxwell's Things As They Really Are, 83-109. Salt Lake City: Deseret Book, 1978. Attempting to encourage greater scripture study, the author testifies that the Book of Mormon is the "most correct book," a second witness for Christ, and that there is "a seamless structure of truths" in the scriptures. The 
scriptures define reality in very profound ways. The Book of Mormon passages sustain and clarify many biblical teachings. [J.W.M.]

M.129 Maxwell, Neal A. That Ye May Believe. Salt Lake City: Bookcraft, 1992. A collection of letters written to the author's grandchildren with Book of Mormon scriptures interspersed throughout. Early members of the Church had received a firm testimony in spite of limited amounts of leisure time to study its contents. The author bears his own witness of the timeliness in which the Book of Mormon came forth. [J.W.M.]

M.130 Maxwell, Neal A. "Three Jaredites." Ensign 8 (August 1978): 6-11. A didactic essay, demonstrating positive and negative qualities of Ether, Shiz, and Coriantumr. Traits to be emulated and avoided are indicated. [D.M.]

M.131 "Mayan Stone Highways." MS 91 (31 October 1929): 701-2. Presents an extract from Science Supplement concerning discoveries of ancient Mayan cities, roads, temples and other ruins of interest to Latter-day Saints. [R.H.B.]

M.132 Mayer, Alfred G. "The Mastadon at the Brooklyn Institute Museum." SH 48 (29 May 1901): 440-41. In 1899 a skeleton of a mastodon was found in North America and scientists believe that these ancient relatives of the elephant co-existed with men. [J.W.M.]

M.133 Mayhew, Henry. The Mormons: Or Latter-day Saints. London: Office of the National Illustrated Library, 1852. An historical work on Mormonism, from a non-Mormon perspective. The author notes what he feels are several problems in the testimonies of the Book of Mormon witnesses. He recounts Anthon's 1834 letter of denial and accepts the Spaulding theory for the book's origin. He also asserts that much of the material from the Book of Mormon has been plagiarized from the Bible and that there are many anachronisms and ungrammatical expressions in the book. [M.R.]

M.134 Mazzuchelli, Samuel. "The False Prophet Joseph Smith, Golden Book of Mormon—Sect of the Latter-day Saints and Their Absurd Doctrines. In Mazzuchelli's Memoirs, Historical and Edifying of a Missionary Apostolic, 303-10. Chicago: W. F. Hall, 1915. Claiming Joseph Smith to be the "great impostor of our century," this article tells a brief history of the "prophet's claims." States that the Book of Mormon was written by Spaulding, claims "sufficient evidence proves" this theory, and continues with blasts against the doctrines of the Church. [J.W.M.]

M.135 McAllister, Duncan M. "Important Appeal to Native Hawaiians and Other Polynesians." IE 24 (June 1921): $703-12$. Discusses a number of facts and theories that indicate that the Polynesians are descendants of the American aborigines and that the ancestors of the native Americans were Israelites. [L.D.]

M.136 McAllister, Jack. "The Unlikely Daniel Webster Jones: First Spanish Translations from the Book of Mormon." Ensign 11 (August 1981): 50-52. Daniel Webster Jones went with a company of men from Missouri to fight in the war with Mexico. He was taken to Provo to recuperate from a gun accident and was introduced to the Book of Mormon. He was the first to translate portions of the book into Spanish with Mileton G. Trejo. [J.W.M.]

M.137 McBride, W. C. "The Cliff Dwellers and The Mormon Theory." Pacific Monthly (June 1907): 697-713. Written by a non-Mormon, the bulk of the article describes the terrain of the American Southwest. Last few pages deal with Book of 
Mormon origins. The author associates the migration of the Jaredites with a statement by Josephus, and he speculates on where the Book of Mormon peoples landed and settled. [D.M.]

M.138 McConkie, Bruce R. "Article 8: We believe the Bible to be the word of God as far as it is translated correctly; we also believe the Book of Mormon to be the word of God." In McConkie's A New Witness for the Articles of Faith, 389-471. Salt Lake City: Deseret Book, 1985. The Bible contains the fulness of the gospel, however, it has been perverted. Those who believe the Bible believe the Book of Mormon. The Book of Mormon is the record of Joseph, and it comes to us as a voice from the dust. The sealed portion of the Book of Mormon will be opened during the millennium. The restoration of the gospel will be effected as a result of the Book of Mormon. Moroni 10:3-5 teaches how to know the Book of Mormon is true, which knowledge is necessary because the Book of Mormon is the keystone of the Church of Jesus Christ of Latter-day Saints. [B.D.]

M.139 McConkie, Bruce R. "The Book of Mormon." IE 64 (June 1961): 402-5. The best possible missionary tool is the Book of Mormon combined with the power of the Holy Ghost. Joseph Smith said the Book of Mormon is the "most correct of any book on earth" and it is "the keystone of our religion." Author explains how anyone can find out for himself if the Book of Mormon is true. [M.D.P.]

M.140 McConkie, Bruce R. "The Book of Mormon: A Missionary Tool." CR (April 1961): 38-40. The Book of Mormon is the "most effective, compelling, and persuasive missionary tool ever given to any people in any age." It is the keystone of the LDS religion. With a testimony of it, the verity of the three greatest truths of the entire Restoration-Jesus Christ is the Son of God, Joseph Smith was a true prophet, and that the Church is true-will also be confirmed. [R.C.D.]

M.141 McConkie, Bruce R. ” 'Book of Mormon' and Others.” In McConkie's Mormon Doctrine, 92-94. Salt Lake City: Bookcraft, 1958. Discusses the purposes of the Book of Mormon and presents a number of encyclopedic entries on Book of Mormon topics, including the brass plates, gold plates, Jaredites, Lamanite curse, Moroni, Mulekites, Nephites and Lamanites, Stick of Ephraim, Three Nephites, and the witnesses of the Book of Mormon. [D.W.P.]

M.142 McConkie, Bruce R. “The Book of Mormon and the Second Coming." In McConkie's The Millennial Messiah, $146-58$. Salt Lake City: Deseret Book, 1982. The Book of Mormon was brought forth to prepare all of God's children for the Second Coming of Jesus Christ. The Book of Mormon, along with the Bible testifies to all that Jesus is the Christ. The sealed portion of the Book of Mormon will not be revealed until after the restoration of all things. [G.A.]

M.143 McConkie, Bruce R. The Book of Mormon-Its Eternal Destiny. N.p., n.d. Excerpts from an address on 18 August 1978 at BYU, and an October 1983 General Conference address. The 8th Article of Faith verifies LDS value of the Bible. Book of Mormon passages concerning the Jesus Christ's doctrine surpass their counterparts in the Bible. The Book of Mormon's destiny is to be a witness of Christ, to bring men to Christ, to aid in the gathering of Israel, and to offer salvation to people. [J.W.M.]

M.144 McConkie, Bruce R. "The Book That Prepares the Way." In McConkie's The Millennial Messiah, 169-181. Salt Lake City: Deseret Book, 1981. The Book of Mormon prepares humanity for the Second Coming of Jesus Christ. The Bible and the Book of Mormon work together in gathering the children of Israel, in both a spiritual and a temporal manner. [G.A.] 
M.145 McConkie, Bruce R. "The Book That Welcomes the Second Coming." In McConkie's The Millennial Messiah, 159-68. Salt Lake City: Deseret Book, 1982. The Book of Mormon bears witness of Jesus Christ, sustains the teachings of the Bible, gathers scattered Israel into the true fold, and prepares humanity for the Second Coming of the Lord. Further, the Book of Mormon is a threat to Satan and will diminish his power. Therefore, Satan tries to convince individuals that revelation has ceased, and that the Book of Mormon is not necessary. [G.A.]

M.146 McConkie, Bruce R. "Come: Hear the Voice of the Lord." Ensign 15 (December 1985): 54. Tells about some of the features of the 1979 edition of the Book of Mormon, including some of the changes. [D.M.]

M.147 McConkie, Bruce R. "The Keystone of Our Religion." IE 68 (June 1965): 500-1. Those who seek truth may find it in the same way Joseph Smith did. The way has been prepared through the Book of Mormon, it is the witness of the divinity of the work of Jesus Christ and his Church. [J.W.M.]

M.148 McConkie, Bruce R. "The Keystone of Our Religion." IE 71 (June 1968): 46-48. Delineates the role of the Book of Mormon as the keystone of the LDS religion. [B.W.J.]

M.149 McConkie, Bruce R. "Scattering and Gathering of Israel." In Proceedings of the Mexico and Central America Area Conference, August 1972. Salt Lake City: Church of Jesus Christ of Latter-day Saints, 1973. The Book of Mormon contains a number of teachings regarding the scattering and gathering of Israel. [G.A.]

M.150 McConkie, Bruce R. "This Generation Shall Have My Word through You." Ensign 10 (June 1980): 54-59. Joseph Smith had the responsibility of giving the Lord's word to the world. That word is found in the scriptures, the chief of which is the Book of Mormon, another witness of Christ comparable to the Bible. [J.W.M.]

M.151 McConkie, Bruce R. Untitled talk. CR (October 1949): 75-80. The Book of Mormon is a tool for carrying the message of salvation to the world in this generation through Joseph Smith. The Book of Mormon is a witness that Joseph Smith is a prophet of God. The LDS message centers on three truths: Jesus is the divine Christ, his messages have been restored through Joseph Smith, and the LDS church is the kingdom of God on earth. The Book of Mormon is the living witness to these truths. Those who read the Book of Mormon will "grow in faith and in righteousness until they become the sons of God, heirs to his eternal kingdom." [B.D.]

M.152 McConkie, Bruce R. Untitled talk. CR (April 1965): 27-29. Every person may receive answers in the same way Joseph Smith did. God is no respecter of persons, he answers prayers. The way to receive the answer is through personal faith, prayer, and reading the Book of Mormon. This message was delivered by a holy angel and contains the record of a fallen people and the fullness of the gospel of Jesus Christ. It is the keystone of the LDS religion. [J.W.M.]

M.153 McConkie, Bruce R. Untitled talk. CR (April 1968): 19-21. The Book of Mormon contains the voice, mind, and will of God concerning his dealings with a people who possessed the fullness of the gospel of Jesus Christ. Its teachings conform with those of the Bible. Salvation is not found in a book, it is only found in Christ through his atoning sacrifice - it comes by the grace of God. Many prophets assisted in bringing forth the Book of Mormon. All may verify its truthfulness by following Moroni's counsel. [J.W.M.] 
M.154 McConkie, Bruce R. Untitled talk. In Proceedings of the Santiago, Chile Area Conference. Salt Lake City: Church of Jesus Christ of Latter-day Saints, March 1977. Since all must hear the gospel, the Lord makes available his greatest missionary tool, the Book of Mormon. The message of the Church centers on three truths-Jesus is the divine Christ, his messages have been restored through Joseph Smith, and the LDS church is the kingdom of God on earth. The Book of Mormon is the living witness to these truths. [J.W.M.]

M.155 McConkie, Bruce R. "What Think Ye of the Book of Mormon?" Ensign 13 (November 1983): 72-74. In order for an individual to know for certain whether or not the Book of Mormon is true, that individual must read the book, then ponder and pray about it. Individuals should not rely solely upon the testimony of others, but receive one's own testimony regarding the Book of Mormon. Outlines two tests that the reader can apply while reading the book to know if it is true. [S.P.S.]

M.156 McConkie, Bruce R. "What Think Ye of the Book of Mormon." In Doctrines of the Restoration: Sermons and Writing of Bruce R. McConkie, edited by Mark L. McConkie, 25775. Salt Lake City: Bookcraft, 1989. Relating an experience with ministers of other faiths, the author points out the problems and importance of presenting the Book of Mormon to the world. The Book of Mormon is an essential part of the restitution of all things, and coupled with the Bible comprises that portion of the Gospel that people are willing to receive. Neither is the complete record of God. The Book of Mormon is a correction text and proves the truthfulness of the Bible. [J.W.M.]

M.157 McConkie, Joseph Fielding. "The Book of Mormon and the Doctrinal Restoration." In A Symposium on the Book of Mormon, 91-96. Salt Lake City: Church of Jesus Christ of Latter-day Saints, CES, August 1986. The Book of Mormon contains the fullness of the gospel. It teaches the plan of salvation and the necessity of gospel ordinances. One mission of the Book of Mormon was to bring about the doctrinal restoration, thus ending the apostasy. [G.A.]

M.158 McConkie, Joseph Fielding. "A Comparison of Book of Mormon and Bible Teachings on the Doctrines of Salvation." In The Book of Mormon: The Keystone Scripture, edited by Paul R. Cheesman, Kent S. Brown, and Charles D. Tate Jr., 7390. Provo, UT: Brigham Young University Religious Studies Center, 1988. The Bible delivers a detailed account of events, but does not provide reasons why the events occurred. The Book of Mormon provides detailed reasons why events occurred and explains doctrines with completeness and clarity. [G.A.]

M.159 McConkie, Joseph Fielding. "The Final Gathering to Christ." In Studies in Scripture: Alma 30 to Moroni, edited by Kent P. Jackson, 184-95. Salt Lake City: Deseret Book, 1988. A commentary on the theme of gathering as taught in 3 Nephi 20-22. Defines "gentiles," and points out their role in the last days; shows how the gathering is connected with the Abrahamic covenant; discusses the New Jerusalem and the role the Jews will have in the gathering. [D.M.]

M.160 McConkie, Joseph Fielding. "The Gathering of Israel and the Return of Christ." In The Sixth Annual Religious Educator's Symposium on the Book of Mormon, 59-62. Salt Lake City: Church of Jesus Christ of Latter-day Saints, 1982. Uses the Book of Mormon as a guide for understanding the scattering and gathering of Israel. Discusses why the scattering took place, when the gathering will occur, when the old and new Jerusalems will be built/rebuilt, the role of Christ, and other related items. [A.T.] 
M.161 McConkie, Joseph Fielding. His Name Shall Be Joseph: Ancient Prophecies of the Latter-day Seer. Salt Lake City: Hawkes, 1980. An elaboration of the prophecy of Lehi in 2 Nephi 3, which is similar to the prophecy in JST Genesis 50. A useful study on prophetic anticipations of Joseph Smith. [D.M.]

M.162 McConkie, Joseph Fielding. "The Promise of Eternal Life." In Studies in Scripture: 1 Nephi to Alma 29, edited by Kent P. Jackson, 162-74. Salt Lake City: Deseret Book, 1987. Reflections on 2 Nephi 31-33. Discusses the first principles and ordinances of the gospel and how Christ set the perfect example by being baptized. Treats the blessings derived from the Holy Ghost and the importance of prayer. Nephi's testimony is solemn and binding. [D.M.]

M.163 McConkie, Joseph Fielding. "The Testimony of Christ Through the Ages." In The Book of Mormon: Jacob through Words of Mormon, To Learn with Joy, edited by Monte S. Nyman and Charles D. Tate Jr., 157-73. Provo, UT: Brigham Young University Religious Studies Center, 1990. Jacob 4 teaches that all prophets testified of Christ; all prophets worshipped the father in the name of Christ; Abraham's offering of Isaac was a representation of Christ (as was the law of Moses); we should not look beyond the mark; and someday the Jews will recognize the Christ known to their fathers. [D.M.]

M.164 McConkie, Joseph Fielding, and Donald W. Parry. A Guide to Scriptural Symbols. Salt Lake City: Bookcraft, 1990. Discusses seven principal figures of speech that assist in understanding scriptural symbols: metaphors, similes, implication, symbols revealed in plain language, metonymy, synecdoche, and parallelism. Examples of these principles are found in the Book of Mormon as well as the other books of the standard works. [J.W.M.]

M.165 McConkie, Joseph Fielding, and Robert L. Millet. Doctrinal Commentary on the Book of Mormon: Volume 1-First and Second Nephi. Salt Lake City: Bookcraft, 1987. Verse-by-verse doctrinal comments on 1 and 2 Nephi. Introductory essays include "Why the Book of Mormon," "Doctrinal Contributions of the Book of Mormon," and "Testimony of the Book of Mormon." This work is reviewed in M.304 and in V.045. [D.M.]

M.166 McConkie, Joseph Fielding, and Robert L. Millet. Doctrinal Commentary on the Book of Mormon: Volume 2-Jacob through Mosiah. Salt Lake City: Bookcraft, 1988. Consideration of doctrines taught in the books of Jacob to Mosiah, discussed verse-by-verse or in clusters of verses. Each section includes a heading, one or more verses quoted from the Book of Mormon, and then a commentary by the authors. This work is reviewed in M.304 and in V.045. [D.M.]

M.167 McConkie, Joseph Fielding, and Robert L. Millet. Doctrinal Commentary on the Book of Mormon: Volume 3-Alma through Helaman. Salt Lake City: Bookcraft, 1991. Authors make topical comments on each verse (or cluster of verses) of Alma and Helaman. Alma chapters 43-62, which deal with war, do not contain a detailed discussion of verses, but a sixpage exposition on various subthemes. The work is doctrinally oriented. This work is reviewed in A.029. [D.M.]

M.168 McConkie, Joseph Fielding, Robert L Millet, and Brent L. Top. Doctrinal Commentary on the Book of Mormon: Volume 4-3 Nephi through Moroni. Salt Lake City: Bookcraft, 1992. The final volume of the series, consisting of commentary on verses from 3 Nephi through Moroni. A reflective essay culminates the work. [D.M.]

M.169 McConkie, Kathleen. "Defending Against Evil." Ensign 22 (January 1992): 19-21. Explains why Mormon used valuable space on the plates to record military intrigue and battle strategy. Satan's war "against truth and righteousness" occurring today requires divine guidance as found in the Book of Mormon, "the Lord's combat manual for the latter days." By 
using warfare chapters as a "type and shadow' of the eternal war between good and evil," individuals can prevail against Satan's forces. [A.C.W.]

M.170 McConkie, Oscar W. "Book of Mormon.” In McConkie's The Kingdom of God, 285-92. Salt Lake City: Church of Jesus Christ of Latter-day Saints, 1962. A priesthood manual for priests. Recounts the events and facts surrounding angel Moroni's visit in September 1823, gives a short synopsis of the Book of Mormon and of references from the Old and New Testaments that refer to the Book of Mormon: Ezekiel 37, Isaiah, and Revelation 14. The testimony of the witnesses reinforce Moroni's challenge to read the book and ask concerning the truth. [J.W.M.]

M.171 McConkie, Oscar W. "Tradition and the Book of Mormon." DN Church Section (31 March 1928): vii. Claims that the Book of Mormon is without fault both in its history and teaching. Cites Indian legends that relate to the Book of Mormon. Includes a reference to Quetzalcoatl. Discusses ancient American records. [D.M.]

M.172 McConkie, Oscar W. "The Uniting of the Holy Scriptures." DN Church Section (24 September 1938): 5, 7. See also MS 101 (29 June 1939): 406-7, 413-14. Address quoting Moroni's title page, testimony of the Three Witnesses, Ezekiel 37:15-20, 1 Nephi 29:8, Nephi's vision of the latter days, and various prophecies about the Jews. Exhorts listeners to repent and serve God. Shows how the Book of Mormon and other latter-day scriptures complement the Bible and provide the fullness of the gospel. [A.C.W.]

M.173 McConkie, Oscar W. "Witnesses Divinely Called." DN Church Section (13 January 1934): 3-5, 8. Witnesses of the truth are a very important part of God's plan. The Three Witnesses to the Book of Mormon were respected men who approached the Lord in humble prayer in daylight and open air. Eight other witnesses added their testimonies. The chief human witness was the translator, Joseph Smith. [J.W.M.]

M.174 McConkie, Oscar W. "The Witnesses to the Book of Mormon." MS 96 (15 February 1934): 97-103. The legal status of the testimony of the witnesses to the Book of Mormon is important. "Their witness stands unimpeached before the world." Despite apostasy, none ever denied his testimony; all were honorable, upstanding men. [A.C.W.]

M.175 McConley, Myron A. "The Book of Mormon." SH 75 (28 November 1928): 1359. Concentrates on the claim of the Book of Mormon that it is a record of God's dealings with the ancient inhabitants of America and that Jesus Christ is the God of the American continent. [J.W.M.]

M.176 McCormick, Marjorie A. "You Bring Them and I'll Read Them." Ensign 7 (September 1977): 75-76. A friend at work gave some LDS tracts to this author's husband. The couple purchased and read the Book of Mormon, and the Holy Ghost testified of its truthfulness in a miraculous way. [J.W.M.]

M.177 McDermott, Don J. "Joseph Smith and the Treasure of Hiram Abiff." The Cryptic Scholar (Winter/Spring 1991): 40-50. The link between Joseph Smith and the Masons is equivocal. At the time of Joseph Smith's death, it was thought that Masonry was a threat to free government and the Book of Mormon revealed Masonic secrets. The accounts of the brother of Jared, Lehi, and others contain Masonic elements. [J.W.M.] 
M.178 McDonald, A. Melvin. The Day of Defense. Denton, TX: Alpha, 1974. Places the Book of Mormon in a hypothetical trial situation with a judge (Jewish rabbi), prosecutors (members of religious denominations), and defendants (LDS missionaries). The verdict is that the Book of Mormon was truly revealed of God. [J.W.M.]

M.179 McDonald, Angus. Prophetic Numbers: Or the Rise, Progress, and Future Destiny of the Mormons by a Free Thinking Optical Professor, Who Will Deliver Lectures on the Subject, Illustrated by Stereopticon Dissolving Views, and Zodiacal Map. Salt Lake City: W. M. Egan, 1885. Shows how using the prophetic numbers may prove that the establishment of the LDS church and the coming forth of the Book of Mormon fits the prophetic timetable found in the scriptures such as those in Daniel and the book of Revelation. Advocates that the Book of Mormon substantiates plural marriage. [J.W.M.]

M.180 McDonald, Carolyn. "The Textbook Was a Revelation." Ensign 19 (March 1989): 10-11. A personal story of conversion to the Book of Mormon and the Church through attendance at religion class. [D.M.]

M.181 McDonnell, John. "Lehi's Vision and the Parable of the Sower." In Recent Book of Mormon Developments, $145-47$. Independence, MO: Zarahemla Research Foundation, 1984. Also published in ZR 11 (Winter 1981): 3, 6, 8. Divides the parable of the sower and Lehi's vision into four responses: the first is unbelief, represented by Laman and Lemuel and the seeds that fell by the wayside; second is "partial belief; no effort"; the third is "more belief; some effort"; and the fourth is "belief leads to faith with assurance." [A.T.]

M.182 McElveen, Floyd. "The Book of Mormon_Joseph Smith's or God's?" In McElveen's Will the "Saints" Go Marching In?, 41-51. Glendale, CA: Regal Books, 1977. In accepting the Book of Mormon, the "Saints" in the Mormon church deny the correctness of the Bible, ancient manuscripts, the Dead Sea Scrolls, and the writings of the Church fathers contemporary with John. The author examines the problems of the Book of Mormon, the language, the poor grammar, and the changes. The witnesses of the Book of Mormon all apostatized from the Church knowing the book's deceitful nature. [J.W.M.]

M.183 McElveen, Floyd. God's Word, Final, Infallible, and Forever. N.p.: by the author, 1985. Believes that the Bible is infallible, all sufficient, and inerrant. Therefore, there is no need for the Book of Mormon, which adds to God's word. In fact, adding to God's word is prohibited by scripture. Provides evidence for the accuracy of biblical manuscripts. [M. R.]

M.184 McElveen, Floyd. The Mormon Illusion. Ventura: Regal Books, 1977. A polemical work against Mormonism that enumerates various criticisms against the Book of Mormon, such as changes in the Book of Mormon, translation through the seer stone, use of King James English, Book of Mormon witnesses, Anthon denials, use of Egyptian, and others. [M.R.]

M.185 McGavin, E. Cecil. An Apology for the Book of Mormon. Salt Lake City: Deseret News Press, 1930. The relationship of the Book of Mormon to the Bible from the standpoint of literary accuracy is discussed. The author justifies the textual changes in the Book of Mormon by rehearsing a historical trail of changes made in the English Bible. [D.M.]

M.186 McGavin, E. Cecil "Book of Mormon and Peace.” MS 104 (19 November 1942): 738-39, 749. From the Nephites we learn the importance of self-defense to protect one's homeland, freedom, and religion, but also the necessity of finding lasting peace. Contrasts two individuals-Moroni and Zerahemnah. [A.C.W.] 
M.187 McGavin, E. Cecil. "The Book of Mormon and the Red Man." DN Church Section (9, 16 1938): 1, 6, 7, 8. Talks about the American Indians, their customs and culture, and how they are connected with the Book of Mormon. [M.D.P.]

M.188 McGavin, E. Cecil. "Book of Mormon Held to Be Introductory Volume." DN Church Section (15 August 1931): 6. The Book of Mormon represents only a "fragment of the inspired writings recorded on metallic plates by Israelitish prophets in America." There existed many additional records, which may be revealed in a future day. [D.W.P.]

M.189 McGavin, E. Cecil. "The Book of Mormon Survives." DN Church Section (18 June 1938): 1, 8. The Book of Mormon was published in an environment of intense opposition. The enemies of the book published strange stories concerning its origin. Newspapers printed numerous articles (some reprinted in this article) prejudicing the public, claiming that the "next generation" would not remember the Book of Mormon. The Book of Mormon survived the opposition and has been published in foreign languages. [J.W.M.]

M.190 McGavin, E. Cecil. Cumorah's ‘Gold Bible.' Salt Lake City: Deseret News Press, 1940. A fictional account of a mission president instructing his missionaries on how to use the Book of Mormon effectively as a proselytizing tool. This imaginary exchange takes place in the Palmyra-Manchester area in 1939. [D.M.]

M.191 McGavin, E. Cecil. How We Got the Book of Mormon. Salt Lake City: Deseret Book, 1960. Details the coming forth of the Book of Mormon by naming its authors and their records, the transferal of the gold plates from generation to generation, the nature of metal records, and Joseph Smith's role in the process. [D.M.]

M.192 McGavin, E. Cecil. "Indian Traditions of the Book of Mormon.” Instructor 66 (August 1931): 449-52. Traditions of the Indians tell of "a book" that their forefathers once possessed. It was taken from them, buried, and promised that it would come forth at a later time. Accounts from letters and journals of early missionaries of the Church as well as scholars of ancient Indians tell of these traditions. [J.W.M.]

M.193 McGavin, E. Cecil. “Joseph Smith—An Inspired Translator.” DN Church Section (14 July 1934): 6. Gives evidence and reasons that Joseph Smith did not quote from the Bible in translating the Book of Mormon as many critics suggest. [M.D.P.]

M.194 McGavin, E. Cecil. "The Lord's Promise to the Lamanites." IE 30 (October 1927): 1095-97. Contrasts the benighted condition of the Indians when the European colonists arrived in America with the glorious promises that are yet to come as prophesied in the Book of Mormon. [D.M.]

M.195 McGavin, E. Cecil. "A Man of Destiny." IE 42 (October 1939): 600, 628. The voyage of Christopher Columbus was foreseen by the Book of Mormon prophets. The spirit of the Lord "wrought upon the man." Columbus wrote to King Ferdinand of his desire to spread the word of God as foretold by the prophet Isaiah in chapters 24 and 64 . His journal excerpts show his loyalty to God and his own knowledge of his divine appointment. He recorded that an angel appeared to him and gave him keys to "bind the oceans" and to link the continents. [J.W.M.]

M.196 McGavin, E. Cecil. "Martin Harris and the Lost Manuscript.” In McGavin's The Historical Background of the Doctrine and Covenants, 23-39. Salt Lake City: Paragon, 1949. Martin Harris was changeable and fickle, while his wife was strong 
willed and aggressive. She was convinced that the new religious movement started by Joseph Smith was fraudulent. No one knows the real story of how the Book of Mormon manuscript pages were lost. The small plates of Nephi filled the gap made by the loss. So strong was the impression of this lesson on Joseph Smith's mind that from that time forward copies were made of all written material. [J.W.M.]

M.197 McGavin, E. Cecil. "A Marvelous Work and a Wonder." CN 11 (21, 28 June; 5, 12, 19, 26 July; 2, 9, 16, 23, 30 August; 6, 13, 20, 27 September; 4 October 1941): 7, 7-8, 7, 7-8, 7; 4, 6, 4, 7, 6, 6, 6-7, 7, 6, 8, 6-7, 6-7, 5-6, 8. Also in MS 103-105 (1941-1943): 773-75, 810-11, 815-16, 23, 26-27, 117-19, 154-56, 160, 218-19, 223, 282-85, 359, 362-63, 423, 236-27, 432, 502-3, 511, 535, 538, 598-99, 602-3, 646-47, 650-56, 707-9, 762-65, 806-7, 810, 816, 84-86. Deals with a wide variety of aspects of the Book of Mormon including Joseph Smith, Obadiah Dogberry, ancient fortifications, metal plates, Spaulding theory, clarifications of biblical doctrine, the abridging work of Mormon, record of the Jaredites, differences between the Bible and the Book of Mormon, witnesses of the Book of Mormon, history, literary qualities, Hebrew traits in the book, its relation to the Bible, and evidence of its antiquity. [D.M.]

M.198 McGavin, E. Cecil. A Marvelous Work and a Wonder. Salt Lake City: KSL radio, 1941. A series of radio addresses on the Book of Mormon discussing metal plates, the Spaulding manuscript, Hebrew traits and Bible quotations within it, the antiquity of the book, its current relevance, the Book of Mormon as a witness of the Bible, and the witnesses. [D.M.]

M.199 McGavin, E. Cecil. "Moroni Looks Down upon a World at War." IE 47 (January 1944): 6, 37. Moroni experienced two aspects of war-he rallied his soldiers in defense of their liberties and later witnessed the destruction of his people. Moroni later wrote concerning the destruction of his people. [D.M.]

M.200 McGavin, E. Cecil. "Quotations from St. Paul in the Book of Mormon." CN 4 (4 August 1934): 3, 8. Notes that Moroni's sermons about spiritual gifts, the sacrament, and charity resemble Paul's teachings in 1 Corinthians 13 . Suggests that Jesus was actually the originator of Paul's words, since Paul could have collected records from his contemporaries that were not included in the four gospels. Moroni would have learned from Jesus' actual words to his disciples in America, which explains the similarities in the teachings of 1 Corinthians and the Book of Mormon. [A.C.W.]

M.201 McGavin, E. Cecil. "Whitmer Hospitality." In McGavin's The Historical Background of the Doctrine and Covenants, 5560. Salt Lake City: Paragon, 1949. The final work of translation of the Book of Mormon took place in the home of Oliver Cowdery's good friends, the Peter Whitmers. The final task of translation was done in relative silence and great care was taken so as to create no contention in the home or the neighborhood. The Whitmer sons were given a special witness of the divinity of the work and later as a reward their mother was favored to see the plates at the hands of Moroni. [J.W.M.]

M.202 McGavin, E. Cecil, and A. S. Reynolds. " 'And It Came to Pass.' " DN Church Section (13 November 1938$): 2,7$. Discusses the phrase "and it came to pass" in the Book of Mormon and its importance as a token of Hebrew abridgment. [M.D.P.]

M.203 McGavin, E. Cecil, and A. S. Reynolds. "The Coming Forth of the Book of Mormon." MS 101 (17 August 1939): $517-$ 18, 523. Because of fear, the people of Palmyra tried to prevent publication of the Book of Mormon. For this reason two copies of the translation were made and only portions went to the publisher at a time. A covenant was made among people 
in the community that not a single copy would be bought. Despite this difficult beginning, the Book of Mormon has become the second best seller in the nation, published also in Braille. [J.W.M.]

M.204 McGavin, E. Cecil, and A. S. Reynolds. "The Consistency of the Book of Mormon." MS101 (21 September 1939): 602-3, 606. It would have been impossible for an uneducated farm boy to have written the text of the Book of Mormon without provincialism upon every page. Anachronisms and other errors are not part of it. Much information that has recently been uncovered by archaeologists support the book. Though Shakespeare was an accomplished writer his works contain modernized character's attire. [J.W.M.]

M.205 McGavin, E. Cecil, and A. S. Reynolds. "Literary Aspects of the Book of Mormon." MS 101 (19 October 1939): 66768. A literary study of the Bible assists in understanding its origin, purpose, and interpretation; the same is true of the Book of Mormon. Religious truths are conveyed in a distinctive way. The Book of Mormon is mainly narration of a pedantic style with a universal appeal. It was far more important to both recorder and translator that the book be understood than to be a literary masterpiece. [J.W.M.]

M.206 McGavin, E. Cecil, and Willard W. Bean. "Cumorah-Land, An Ancient Battlefield." IE44 (September 1941): 526, 57172. Discusses the authors' point of view concerning the identity of the Hill Cumorah as an ancient battlefield. Authors conclude that the scholars "need not search for (Cumorah) in Mexico or Yucatan." [L.D.]

M.207 McGavin, E. Cecil, and Willard W. Bean. The Geography of the Book of Mormon. Salt Lake City: Bookcraft, 1948. Argues that the Hill Cumorah and Hill Ramah as geographical locations in the Book of Mormon were located in upstate New York. It therefore challenges the theory that the Hill Cumorah was located somewhere in Latin America. At least some Book of Mormon history took place in southeast Canada and the northeast United States. [D.M.]

M.208 McGimsey, Harry A. The Book of Mormon Versus the Scientific Facts. San Bernardino, CA: Vanity, 1963. Small fourpage polemical brochure containing a letter by the author to the Smithsonian Institute and the Institute's response. [D.M.]

M.209 McGimsey, Harry A. Mormonism Versus the Holy Bible. Hemet, CA: Vanity, n.d. Small brochure claiming that the LDS church opposes the Bible. Notes that Joseph Smith declared the Book of Mormon to be the most correct book. [D.M.]

M.210 McGimsey, Harry A., and A. T. Schroeder. The Truth about the Origin of the Book of Mormon. San Bernardino, CA: Vanity, 1963?. Attempts to explain the Book of Mormon on the basis of Spaulding's Manuscript Found. Does not discuss the 1884 discovery of the manuscript. [D.M.]

M.211 McGraw, Robert. "Use Book of Mormon to Counter Error, President Benson Teaches." Ensign 19 (January 1989): 7576. A news report of a talk given by President Benson, wherein Benson outlines a four-step method of dealing with objections to the Church. The Book of Mormon is "the great standard" by which Church members are to show that Joseph Smith is a prophet. The mission of the Book of Mormon is to bring individuals to Christ. [J.W.M.]

M.212 McHale, Ellen E. "Witnessing for Christ: The Hill Cumorah Pageant in Palmyra, New York." Western Folklore 44 (January 1985): 34-40. A non-Mormon describes her experience as a member of the cast of the Hill Cumorah Pageant in 
Palmyra in 1983. She interprets the activities of the two weeks in an anthropological framework referring to the experience as a rite of passage for young Mormons throughout the country. She quotes testimonies of several participants. [D.M.]

M.213 McKay, David O. "Church President Presents Five Marks to Prove a Claim Authentic." CN29 (9 May 1959$)$ : $3,12,16$. Presents five guidelines to determine the authenticity of the New Testament and the Book of Mormon: (1) the claim must be a sensible fact, appealing to the physical senses, (2) there must be witnesses of the fact, (3) the witnesses must be reputable, (4) there must be a memorial/monument to the claim, (5) and the memorial/monument must date back to the claim itself. [A.C.W.]

M.214 McKay, David O. "Power of Choice: Each Age Carries Own Responsibility." CN 29 (2 May 1959): 4, 8. Address delivered at BYU: applies "proof of truth" to the Book of Mormon, which requires that (1) the event appeal to the physical senses, (2) it have witnesses, (3) their reliability be tested, (4) a memorial remain, and (5) the memorial/monument date back to the original event. Based on these prerequisites, McKay concludes with a testimony of the truthfulness of the Book of Mormon. [A.C.W.]

M.215 McKay, David O. "Three Witnesses of the Book of Mormon." IE 63 (November 1960): 790-91, 855. A review of the lives of Oliver Cowdery, David Whitmer, and Martin Harris, the Three Witnesses of the Book of Mormon. Although the Three Witnesses later left the Church, none of them ever denied their testimony of the Book of Mormon. [R.C.D.]

M.216 McKay, David O. Value of the Priesthood. Salt Lake City: Deseret Book, 1962. Discusses the Priesthood. Also explains how the Three Witnesses conform to five criteria for determining the soundness of a testimony. [D.M.]

M.217 McKay, David O. "Witnesses to the Truth." IE 54 (July 1951): 493-94, 542. There are many witnesses to the truth. The Three Witnesses saw the plates and bore witness of the validity of the Book of Mormon. The Holy Spirit also is a witness to the truth. [J.W.M.]

M.218 McKay, Robert. "Book of Mormon Translations." The Evangel 39 (October 1992): 1. Reports statistics of Book of Mormon translations and maintains that the Book of Mormon is not scripture no matter which language it is read in. [A.C.W.]

M.219 McKay, Robert. "Church Proclaims Falsehood.” The Evange/ 39 (October 1992): 1. Finds fault with LDS pageant "The Man Who Knew" by discussing Lucy Harris's negative attitude toward Joseph Smith and his work. [A.C.W.]

M.220 McKay, Robert. "Could a Man Have Written It?” The Evange/ 39 (October 1992): 12. Points out that even if the Book of Mormon was inspired, it was written by a man or men. Because it contains false doctrine and anachronisms the Book of Mormon is clearly not an inspired work. [A.C.W.]

M.221 McKay, Robert. "Distinctive Mormon Beliefs: The Book of Mormon." The Evangel 39 (March 1992): 9. Points out "absurdities and anachronisms" in the Book of Mormon that contradict LDS teachings and disagree with the Bible, therefore invalidating Mormonism. [A.C.W.]

M.222 McKay, Robert. "A Prophecy of Columbus?” The Evange/ 39 (November 1992): 6. Since the Book of Mormon contradicts itself, the Bible, and the LDS church, the statement in 1 Nephi 13:12 traditionally interpreted as a prophecy of 
Columbus's arrival in America was obviously not written before 1492, making the Book of Mormon "at best a pious fraud." [A.C.W.]

M.223 McKay, Robert. "Testimony From the Book of Mormon." The Evange/ 39 (January-February 1992): 7. Warns that accepting Mormonism due to the Book of Mormon's influence is dangerous because it contradicts the essentials of Mormonism and is out of harmony with historical and archaeological facts. [A.C.W.]

M.224 McKay, Robert A., and John L. Smith. Why Mormonism Is a Cult. Marlow, OK: Utah Missions, 1985. A polemical tract against Mormonism attempting to explain why Mormonism is a cult. Numerous textual changes in the various editions of the Book of Mormon are noted. The description in 3 Nephi of the destruction of the wicked at the time of Christ's death is incompatible with the concept of a merciful God. [M.R.]

M.225 McKeage, Sylvia, and C. B. Woodstock. The Downfall of a Righteous People. Independence, MO: Herald House, 1950. A Book of Mormon lesson manual for adults of the Reorganized Church. The manual teaches of the Jaredite nation and the Nephite nation 200 years after the appearance of Jesus in the New World. [D.M.]

M.226 McKeage, Sylvia, and C. B. Woodstock. "An Introductory Study of the Book of Mormon, Part 2." Gospel Quarterly 16 (January-March 1942): 2-72. Consists of a series of thirteen lessons prepared for the study of the Book of Mormon by adults of the RLDS church. The lesson topics include such areas of study as: the reign of King Benjamin, the church in Zarahemla, and Alma's ministry, and others. [L.D.]

M.227 McKean, Jerry. " 'Just Cut My Hair and Don't Preach!' " Ensign 20 (April 1990): 63-65. A touching and humorous conversion story, in which the Book of Mormon was the converting agent. [D.M.]

M.228 McKeever, Bill. Answering Mormon's Questions: Bible Explanations to Mormon Misinterpretations. United States: William McKeever, 1981. A polemical work against Mormonism, which responds to various questions often asked by Mormons dealing with the Bible and Mormon scripture. [M.R.]

M.229 McKeever, Bill. Answering Mormons' Questions: Simple Biblical Explanations to the Most Common Questions That Mormons Ask. Minneapolis, MN: Bethany House, 1991. Questions 20, 34, and 35 deal with the Book of Mormon: the traditional Mormon interpretation of Ezekiel 37:16-17 is erroneous and the proper interpretation refers to the nations of Israel and Judah; praying about the Book of Mormon is not necessary since the Bible warns against those who preach any other gospel than what has been preached in the Bible; the Book of Mormon is not inspired of God as John 1:18 says that "no man hath seen God at any time" and since Joseph Smith claims to have seen God, he is a false prophet. [J.W.M.]

M.230 McKeever, Bill. Joseph Smith vs. the Book of Mormon: They Both Can't Be Inspired. El Cajon, CA: Mormonism Research Ministry, 198?. A small tract that presents perceived contradictions between Joseph Smith's teachings and those found in the Book of Mormon. [D.M.]

M.231 McKeever, Bill. An Open Letter to All Members of the Church of Jesus Christ of Latter-day Saints. El Cajon, CA: Mormonism Research Ministry, 198?. A polemical letter written against LDS doctrines and teachings. The Book of Mormon 
is supposed to contain the fullness of the gospel yet does not discuss proxy baptism or celestial marriage. The Book of Mormon condemns the doctrine of a second chance, thereby vitiating the need for baptism for the dead. [D.M.]

M.232 McKeever, Bill. "We Also Believe the Book of Mormon to be the Word of God . .." El Cajon, CA: Mormonism Research Ministry, 1982. An polemical tract that discusses contradictions and errors in the Book of Mormon. The Bible is the sole word of God. [D.W.P.]

M.233 McKeever, William. " 'Book of Mormon Lands' Article Draws Harsh Criticism." Mormonism Researches (Summer 1992): 3-4. Responds to criticisms of author's earlier article "Visiting the Book of Mormon Lands?" Quotes various sources to support his viewpoint that the FARMS tour will not necessarily visit actual Book of Mormon sites. [A.C.W.]

M.234 McKeever, William. "Columbus or Mahonri Moriancumer?" Mormonism Researches (Fall 1992): 3-4, 8. Quotes from Ether and Orson Pratt to discuss the impracticalities of Jaredite barges. [A.C.W.]

M.235 McKeever, William. "Problems in 'the Land of' Jerusalem." Mormonism Researches (Winter 1992): 3-4. Uses Biblical quotations and the Amarna tablets to refute the LDS claim that Bethlehem was included in "the land of Jerusalem" as referred to in Alma 7:10. [A.C.W.]

M.236 McKeever, William. "Visiting the Book of Mormon Lands?" Mormonism Researches (Spring 1992): 4, 8. Based on a lack of agreement among LDS scholars as to the location of Book of Mormon events, McKeever argues that an upcoming FARMS tour cannot claim to visit Book of Mormon lands. [A.C.W.]

M.237 McKiernan, F. Mark. "Advent of Mormonism into the Western Reserve." In McKiernan's The Voice of One Crying in the Wilderness, 1971, 25-42. Lawrence, KS: Coronado Press, 1971. Gives an historical account of the life of Sidney Rigdon, his conversion through the Book of Mormon to the LDS church, and refutes the theory that Sidney Rigdon had any connection with the Spaulding manuscript or authorship of the Book of Mormon. Family members offer proof that Matilda Davidson and Ellen E. Dickinson had reported falsely about Rigdon's involvement. This work is reviewed in $\mathrm{H} .261$ and in R.497. [J.W.M.]

M.238 McKim, B. L. What Shall We Do with the Book of Mormon? Independence, MO: n.p., n.d. Contends that the Book of Mormon has greater authority than the living oracles of the Church. "Other things, which were added to the Church after the translation of that book may be proven not true and still the Church stand, but not so with the Book of Mormon." [D.M.]

M.239 McKinlay, Daniel B. Review of "A Hermeneutic of Sacred Texts: Historicism, Revisionism, Positivism, and the Bible and Book of Mormon," by Alan Goff. Review of Books on the Book of Mormon 2 (1990): 86-95. Book review.

M.240 McKinlay, Daniel B. Review of Fathers and Sons in the Book of Mormon, by E. Douglas and Robert S. Clark. Review of Books on the Book of Mormon 4 (1992): 24-28. Book review.

M.241 McLellin, William E. "McLellin Expresses Feelings in Letter." CN 55 (8 December 1985): 6, 10. The full text of a letter written by William E. McLellin dated August 14, 1880, to J. T. Cobb in which he reaffirms his testimony of the Book of Mormon. He denies that Sidney Rigdon helped to author the book as he had not known Joseph Smith until after publication of the Book of Mormon. [J.W.M.] 
M.242 McNeely, Brent E. "The Book of Mormon and the Heavenly Book Motif." In Reexploring the Book of Mormon, edited by John W. Welch, 26-28. Salt Lake City: Deseret Book and FARMS, 1992. Joseph Smith's reception of the gold plates from the angel Moroni fits a common pattern of the ancient Near East. Many writings, both biblical (i.e., Exodus 31:18, Ezekiel 2:9-10, Revelation 10:8), and non-biblical (i.e., the Vision of Hermas) were delivered to individuals from a heavenly being. [N.K.Y.]

M.243 McNiece, Robert G. "Mormonism." The Presbyterian Review 2 (April 1881): 331-48. A polemical article against Mormonism that appeals to the Spaulding theory for an explanation of the Book of Mormon's origin. [M.R.]

M.244 McNiece, Robert G. "Reply to Mr. Brand." The Utah Evangelist 1 (April 1884): n.p. Response to Brand, E. C. "The Book of Mormon: Elder Brand's Objections to Mr. Royle's Article." The Utah Evangelist 1 (April 1884): n.p., which is a response to Royle, J. C. "Faith and Credulity." Earnest Worker 1 (December 1883): n.p. Asserts that the witnesses of the Book of Mormon were only carrying out a "cunning trick arranged for them by Joseph Smith." [J.W.M.]

M.245 Meader, Robert F. W. "The Shakers and the Mormons." The Shaker Quarterly 2 (Fall 1962): 83-96. Gives a brief summary of Joseph Smith's first vision and the coming forth of the Book of Mormon, stating that Mormons are Trinitarians. For Mormons the Bible is supplemented by the Book of Mormon, the Doctrine and Covenants, and the Pearl of Great Price. The Book of Mormon was the sect's conversion tool with which the Mormon missionaries approached the Shakers. A narration of events is given comparing LDS historical records with Shaker records. [J.W.M.]

M.246 Meek, Shirleen. "Inosi's Golden Book." Ensign 21 (August 1991): 64-66. After almost two years of excuses and avoiding the missionaries and their "golden book," the loss of a newborn son made Inosi think about religion and God. Soon he accepted the challenge of baptism. [J.W.M.]

M.247 Mehew, Randall K. Historical Outline of the Book of Mormon. Orem, UT: Millennial Press, 1983. Contains a thumbnail sketch of several important personalities in the Book of Mormon. Provides Book of Mormon maps, tables, and materials dealing with chronology. [D.M.]

M.248 Mehew, Randall K. A Most Convincing Witness: Reasons Why the Book of Mormon Is the True Word of God. Orem, UT: Keepsake Paperbacks, 1990. Presents arguments dealing with the authenticity of the Book of Mormon, including discussions about Jesus, the Shepherd, the witnesses, revelation from God, the translation of the work, ancient discoveries, and testimonials. [R.H.B.]

M.249 "Melchizedek Priesthood: Book of Mormon Is Special Witness." IE 68 (July 1965): 634. Members should "bear their witness of the truth of the restoration of the gospel" and of the Book of Mormon. [M.D.P.]

M.250 "Melchizedek Priesthood for a Spiritual Awakening . . Read the Book of Mormon." IE 64 (October 1961): $756-57$. Tells of the assignment, given to every Melchizedek Priesthood holder, to read the Book of Mormon during the year 1961. [M.D.P.] 
M.251 Melonakos, Christine. Turn Your Little Ones into Book of Mormon Whiz Kids. Bountiful, UT: Horizon, 1990. Activities for young children designed to increase their fine and gross motor skills while teaching them about the Book of Mormon. [D.W.P.]

M.252 Melton, J. Gordon. "The Book of Mormon, of Smith, or of Whom?" Christianity Today 23 (16 February 1979): 38-40. A discussion of three polemical works written against Mormonism and the Book of Mormon: Wayne Cowdery, Who Really Wrote the Book of Mormon?; Harry Ropp, The Mormon Papers; and Floyd McElveen, Will the "Saints" Go Marching In? [M.R.]

M.253 Melville, Alton C. "Quetzalcoatl." IE 32 (December 1928): 122-26. Provides several legends and descriptions of the "feathered serpent" god called Quetzalcoatl and links Jesus Christ and his visit to the Americas (3 Nephi) with him. Quetzalcoatl was known as a light complexioned wise benefactor. After having spent some time with the ancestors of the Aztecs, he promised to return to them. [D.M.]

M.254 Melville, Alton C. "Recent Scientific Investigations: They Substantiate the Book of Mormon." IE 30 (February 1927): 311-14. A study of archaeological remains in Panama lead one archaeologist from New York to call it "the Pompeii of ancient America." Melville believes Panama finds corroboration with the Book of Mormon in such issues as location and size, commerce, industries, cloth, tools, and elephants. [D.M.]

M.255 Melville, Alton C. "The Reign of the Judges: An Outline of Nephite Government." IE 31 (January 1928): 240-41. Discusses King Mosiah's political discourse in which he introduces a democratic government and does away with the autocratic government system of kings. Democratic laws that were implemented into the Nephite judicial system at this time include the right to appeal, capital punishment, cross examination, and religious freedom. [L.D.]

M.256 “Members Responding to Prophet's Challenge." CN 57 (10 May 1987): 10. Church President Ezra Taft Benson challenges members to read the Book of Mormon and the members respond by reading the book. [M.D.P.]

M.257 "Memoir of the Mormons." The Southern Literary Messenger 14 (November 1849): 641-54. A polemical article on Mormonism. Considering the Mormon movement to be a "fanatical delusion," the author asserts that Joseph Smith used the Spaulding manuscript as the basis for the Book of Mormon narrative. [M.R.]

M.258 Menzies, James S. The Book is True. Independence, MO: Herald House, n.d. An apologetic tract wherein the author produces two conversion stories and reasons why the Book of Mormon should be made a matter of prayer. [D.M.]

M.259 Menzies, James S. A Second Witness for Jesus Christ. Independence, MO: Herald House, n.d. A tract that emphasizes that America is a choice land and that those who possess it will be free from bondage if they serve Christ; otherwise they will be swept off the land. Quotes Isaiah 29 and John 10:16 to show that the Book of Mormon fulfills biblical prophecy. [D.M.]

M.260 Menzies, James S., Merle P. Guthrie, and Richard M. Reid. Christ in America. Independence, MO: Herald House, 1965. A tract that briefly recites the account of Jesus' ministry to the Lehites. Offers archaeological and other evidences to substantiate the event. [D.M.] 
M.261 Menzies, James S., Merle P. Guthrie, and Richard M. Reid. Evidences of the Book of Mormon. Independence, MO: Herald House, 1966. Authors make reference to secular evidences related to the Book of Mormon that are offered by nonLDS scholars in such matters as medicine and astronomy. They also relate the Book of Mormon to passages in Ezekiel 37 , Jeremiah 49, Genesis 49, and Isaiah 29. [D.M.]

M.262 Mercer, Samuel A. B. “Joseph Smith as an Interpreter and Translator of Egyptian.” Utah Survey 1 (September 1913): 4-36. A defense of F. S. Spaulding's pamphlet Joseph Smith Jr., As a Translator that shows that Joseph Smith was either self-deceived or an impostor. Compares the facsimiles in Abraham and the characters of the Anthon transcript and asserts that the Book of Abraham and the Book of Mormon were written in the same Egyptian and therefore the Book of Mormon may be judged on the same basis as the Book of Abraham. The facsimiles have been proven to be falsely translated-thus the Book of Mormon also must surely be a false translation or a product of Joseph Smith. [J.W.M.]

M.263 Merkley, E. Heloise. "The Gadianton: A Story of Zarahemla." Instructor 66, 67 (December 1931—September 1932): 713-17, 11-15, 76-79, 140-43, 199-203, 257-60, 324-27, 377-80, 416-19, 434-37, 494-97, 513, 556-58, 585. A fictional story that tells of a Gadianton spy who falls in love with the daughter of Gidgiddoni and plans the extermination of his own secret band. [J.W.M.]

M.264 Merkley, Heloise Day. "The Answer." IE 31 (February 1928): 308-15. A one-act play of the first Christmas in America taken from the book of Alma. [L.D.]

M.265 Merkley, Marion G. Leaders of the Scriptures. Salt Lake City: Deseret Sunday School Union, 1947. A Sunday School manual for youth containing lessons from the Bible and Book of Mormon. [D.M.]

M.266 Mernitz, Susan Curtis. "Palmyra Revisited: A Look at Early 19th Century American Thought and the Book of Mormon." The John Whitmer Historical Association Journal 2 (1982): 30-37. The Book of Mormon is a reflection of the views and values of Puritan America that nevertheless shifted in essence from a framework that emphasized "community, hierarchy, and an agrarian economy" to an interest in "individualism, democracy, and competitive market capitalism." In effect, the Book of Mormon is a product of Jacksonian America in general and the burned-over district of Western New York in particular. [D.M.]

M.267 Merrill, A. Brent. "Nephite Captains and Armies." In Warfare in the Book of Mormon, edited by Stephen D. Ricks and William J. Hamblin, 266-95. Salt Lake City: Deseret Book and FARMS, 1990. Compares the organization of armies of the Book of Mormon to those of the ancient Near East. Discusses the Nephite captains and chief captains. Fifties, hundreds, thousands, and ten thousands were the usual army units. The Book of Mormon depicts war as being sordid, tedious, destructive, exhausting, and boring. It depicts great military leaders who deplored war and may help us see the futility of it in our day. [N.K.Y.]

M.268 Merrill, Alton D. "An Analysis of the Papers and Speeches of Those Who Have Written or Spoken about the Book of Mormon Published During the Years of 1830 to 1855 and 1915 to 1940 to Ascertain the Shift in Emphasis." M.A. thesis, Brigham Young University, 1940. Provides a bibliographic listing of articles on the Book of Mormon that were published in Church periodicals during the years named in the title of the work, also presents comparisons of themes emphasized in one period over against the other. [D.M.] 
M.269 Merrill, Amos N. Lesson Book for the Religion Classes in the Church of Jesus Christ of Latter-day Saints. Salt Lake City: Deseret Book, 1924. A lesson manual on the Book of Mormon designed for students in the seventh grade. [D.M.]

M.270 Merrill, Amos N., and Alton D. Merrill. "Changing Thought on the Book of Mormon." IE 45 (September 1942): 568. A published summary of Merrill's thesis, written in 1940 (see above), wherein the author examined publications dealing with the Book of Mormon and noted the themes emphasized during the periods 1830-1855 and 1915-1940. [L.D.]

M.271 Merrill, Byron R. "Government by the Voice of the People: A Witness and a Warning." In The Book of Mormon: Mosiah, Salvation Only through Christ, edited by Monte S. Nyman and Charles D. Tate Jr., 113-37. Provo, UT: Brigham Young University Religious Studies Center, 1991. Provides a history and definition of the Nephite system of government and shows parallels and differences with the American political system. The warnings outlined in Mosiah 29 are relevant to the present condition in America. [D.M.]

M.272 Merrill, Byron R. "Joseph Smith and the Lamanites." In Joseph Smith: The Prophet, the Man, edited by Susan Easton Black and Charles D. Tate Jr., 187-202. Provo, UT: Brigham Young University Religious Studies Center, 1993. Joseph taught that the aboriginal inhabitants of North America were literal descendants of Abraham, people of the covenant. Following the first interview with Moroni, Joseph related to his family detailed descriptions of their mode of dress, travel, animals, cities, buildings, warfare and religious worship. He left them a great legacy in the form of the translation of the record of their ancestry, which has done more for the Lamanite than any other effort made in their behalf. [J.W.M.]

M.273 Merrill, Byron R. "To Become as a Little Child: The Quest for Humility." In Doctrines of the Book of Mormon, 1991 Sperry Symposium, edited by Bruce A. Van Orden and Brent L. Top, 114-26. Salt Lake City: Deseret Book, 1992. To be humble in the scriptural sense does not mean to be obsequious but to obey God cheerfully in all things, to possess the traits of a child, i.e., submissiveness, meekness, patience, being filled with love, and to discard the negative trappings of adulthood. Pride is the opposite of humility, as exemplified by the Rameumptom. Other examples, positive and negative, are given. [D.M.]

M.274 Merrill, David. "Behind the Spaulding Controversy." Sunstone 3 (November, December 1977): 28-29. Gives a report on the attempt of Howard Davis, Warren Cowdrey, and Donald Scales to validate the Spaulding theory by soliciting the services of handwriting experts. [D.M.]

M.275 Merrill, Harrison R. "Mexico and the Book of Mormon." DN Church Section (8, 15, 22, 29 October, 19 November, 1938): 4, 5, 2, 2. Suggests that much of the Book of Mormon activity took place in Mexico, speaks concerning Book of Mormon geography, archaeology, ancient races of Mexico, and traditions of the Mexican Indians. [D.W.P.]

M.276 Merrill, Harrison R., and Sidney B. Sperry. An Interview on the Book of Mormon. N.p., n.d. A radio program made into a booklet, in which Merrill interviews Sperry about the Book of Mormon. Sperry speaks about the population problem, the horse, metals, and the Hebrew language. [D.W.P.]

M.277 Merrill, Hyde M. "Christopher Columbus and the Book of Mormon.” IE 69 (February 1966): 96-98, 135-36. Discusses Lehi's prophecy regarding "a man among the Gentiles" (Columbus) who would be "wrought upon" by the Holy Ghost and travel "forth upon many waters" (1 Nephi 13:12). Presents evidence from Columbus's journals and letters that supports the 
claim that he was an inspired man who accomplished "a thing more divine than human to have found that way never before known to go to the east where the spices grow" (Sebastian Cabot). [B.W.J.]

M.278 Merrill, Joseph F. "The Coming Forth of the Book of Mormon." DN Church Section (26 September 1931): 4. Retells Joseph Smith's account of the angel Moroni's visit, his acquisition of the plates, and the translation. Concludes with the testimony of the Three Witnesses. [J.W.M.]

M.279 Merrill, Joseph F. "Cumorah Monument Significant.” IE 38 (October 1935): 619. The new monument on the Hill Cumorah commemorates the coming forth of the Book of Mormon, a most significant book. [J.W.M.]

M.280 Merrill, Joseph F. "A Marvelous Book." DN Church Section (8 December 1945): 10, 12. A radio address delivered Sunday, December 1, 1945, over KSL. Explains how Joseph Smith received the plates from the angel, translated them and published them. Determines that the Three Witnesses were privileged to view the plates. [B.D.]

M.281 Merrill, Joseph F. "The Resurrection and the Book of Mormon—An Anthology." DN Church Section (9 January 1937):

4. The disillusioned disciples of Christ in the Old World were changed from fearful, hesitant men to bold and anxious testifiers when they learned the Savior had risen. The Book of Mormon adds credence to the resurrection both in its content and in its coming forth. As the resurrected Lord was to the ancient apostles, so is the Book of Mormon to the Latter-day Saints. It is to strengthen and make unafraid the disciples of Christ. [J.W.M.]

M.282 Merrill, Joseph F. The Truth Seeker and Mormonism. Independence, MO: Zions, 1946. Transcripts of radio messages, two of which relate to the Book of Mormon. Speaks concerning the truthfulness of the Book of Mormon; contains the testimony of the Eight Witnesses, the final statements of the Three Witnesses, and explores the possibility of collusion. [J.W.M.]

M.283 Merrill, Joseph F. Untitled talk. CR (April 1930): 147-48. The Book of Mormon is physical evidence of the divinity of the Church of Jesus Christ of Latter-day Saints. If the Book of Mormon is true then God is a personal being and has visited the earth. If the Book of Mormon is false, then Mormonism is a fraud. [B.D.]

M.284 Merrill, Joseph F. Untitled talk. CR (April 1937): 37-42. Discusses Joseph Smith's first vision, the appearance of the angel Moroni, the restoration of the Priesthood, and the Book of Mormon as the best evidence of Joseph Smith's prophetic call. The book came forth by the power of God and cannot be refuted. [J.W.M.]

M.285 Meservy, Keith H. "The Book of Mormon, Biblical Prophecies about." In Encyclopedia of Mormonism, edited by Daniel H. Ludlow, 1:159-60. New York: Macmillan, 1992. The Book of Mormon fulfills many Bible prophecies: Joseph, who was sold into Egypt, later prophesied about his numerous descendants; Jesus referred to other sheep of his fold; Isaiah predicted cities like Ariel (Jerusalem) would be destroyed but her speech would whisper as a voice out of the ground; Ezekiel prophesied about two records, one of Ephraim and another of Judah. [N.K.Y.]

M.286 Meservy, Keith H. "Discoveries at Nimrud and the 'Sticks' of Ezekiel." SEHA Newsletter 142 (November 1978): 1-10. The word for "stick" in Ezekiel 37 (Hebrew etz) is normally translated "wood." The word corresponds to the Babylonian is 
le'u, referring to a writing tablet. Etymologically and culturally, it is likely that Ezekiel wrote about joining the tablets of Judah and Joseph to form what would eventually be called the Bible and the Book of Mormon. [D.M.]

M.287 Meservy, Keith H. “Ezekiel's Sticks.” Ensign 7 (September 1977): 22-27. Discusses how Ezekiel knew that Joseph's stick (the Book of Mormon) would be joined to Judah's stick (the Bible) from Ezekiel 37:16-17. Provides scriptural and archaeological notes. [L.D.]

M.288 Meservy, Keith H. "Ezekiel's Sticks and the Gathering of Israel." Ensign 17 (February 1987): 4-13. Links a 1948 discovery - that ancient scribes kept records on wax-covered, wooden writing boards—to the sticks of Joseph and Judah spoken of in Ezekiel 37. The coming together of these two records mark the beginning of the physical gathering of Israel (gathering to lands and countries) and the spiritual gathering of Israel (return to God). [S.P.S.]

M.289 Meservy, Keith H. "Jerusalem at the Time of Lehi and Jeremiah." Ensign 18 (January 1988): 22-25. Quotes from the Old Testament book of Jeremiah and the Book of Mormon in order to summarize the history of Jerusalem during the time of Nebuchadnezzar's rule. [D.L.L.]

M.290 Meservy, Keith H. "The 'Writing Boards' of Ezekiel and What They Mean." In A Symposium on the Book of Mormon, 81-92. Salt Lake City: Church of Jesus Christ of Latter-day Saints, 1979. An exposition of Ezekiel 37. In order to bring about the Lord's program of restoration it was necessary to remedy five problem areas: (1) the scattering of Israel, Judah included; (2) Judah's nonacceptance of the Messiah; (3) the floundering of Joseph's descendants resulting from a loss of identity; (4) the need to call Israel back to the Lord; and (5) replacement of false doctrine with true doctrine. The two sticks of Joseph and Judah may be seen as writing tablets or boards. [D.M.]

M.291 Mesle, Carl. "The Fifth and Sixth Gospels." Restoration Witness 7 (April 1969): 4-5. The Book of Mormon is an account of God's dealings with his people in America and is a second witness for Christ. 3 Nephi may be considered the "Fifth Gospel" and the Doctrine and Covenants represents the "Sixth Gospel" of Christ. Together these works set forth the correct way of life. [J.W.M.]

M.292 Mesle, Robert. Review of Since Cumorah, by Hugh W. Nibley. Courage 2 (September 1971): 331-32. Book review.

M.293 The Message of the Book of Mormon Is True about Its Own Divine Authenticity. Rozelle, New South Wales: Reorganized Church of Jesus Christ of Latter Day Saints, n.d. A pamphlet that discusses the testimony of the Book of Mormon witnesses and argues that the book carries its own evidence or authenticity. [J.W.M.]

M.294 Metcalfe, Brent Lee. "Apologetic and Critical Assumptions about Book of Mormon Historicity." Dialogue 26 (Fall 1993): 153 - 84. An attack on the assumptions made by "apologetics" in asserting the historicity of the Book of Mormon. Special attention is paid to showing the inconsistencies in the apologetics methodology and hermeneutics, especially in the areas of chiasmus in the text and a Book of Mormon geography limited to Mesoamerica. The author also shows the contradictions inherent in any attempt to reconcile apologetic and critical methodologies. This work is reviewed in $\mathrm{H} .035$. [S.H.] 
M.295 Metcalfe, Brent Lee. New Approaches to the Book of Mormon. Salt Lake City: Signature Books, 1993. Contains articles by several authors: Anthony A. Hutchinson, Dan Vogel, Mark D. Thomas, Melodie Moench Charles, Stan Larson, David P. Wright, Deanne G. Matheny, Edward H. Ashment, and Brent Lee Metcalf. This is a scholarly attempt to "expand appreciation of Mormon scripture through critical analysis." This work is reviewed in G.058, T.338, W.154, B.230, and in S.215. [J.W.M.]

M.296 Metcalfe, Brent Lee. "The Priority of Mosiah: A Prelude to Book of Mormon Exegesis." In New Approaches to the Book of Mormon, edited by Brent Lee Metcalfe, 395-444. Salt Lake City: Signature, 1993. There are three theories regarding the order of dictation of the contents of the Book of Mormon: "The Priority of 1 Nephi," "The Priority of Words of Mormon," and "The Priority of Mosiah." There is much evidence (historical, holographic, and stylistic) to support the priority of Mosiah. The sequence of dictation is very important in determining that Joseph Smith was more than an "inspired marionette" or "a slavish plagiarist" in the process. This work is reviewed in R.470. [J.W.M.]

M.297 Meyer, Edward. "The Origin of Mormonism." In Meyer's The Origin and History of the Mormons. Translated from the original German by Heinz F. Rahde and Eugene Seaich, 1-44. Salt Lake City: University of Utah, 1961. Meyer discusses the history of the acquisition, translation, and publication of the Book of Mormon as an unbiased historical critic. He proposes natural explanations for many of the supernatural events. He believes that the Three Witnesses did see the plates in a vision. However, he offers the explanation that the vision was probably caused by a sort of group hypnosis or hallucination. [B.D.]

M.298 Michelsen, Rasmus. "Paleontology and the Book of Mormon." IE 36 (January 1933): 150-52. Provides information regarding a number of recent paleontological discoveries that shed light on Book of Mormon statements regarding oxen, sheep, and other animals, and the smelting of iron. [D.M.]

M.299 Michelsen, Rasmus. Perler fra Mormons Bog. Kobenhavn: Udgivet og forlagt af Holger M. Larsen, 1929. A missionary tract that recalls the coming forth of the Book of Mormon and summarily sets forth its contents. [D.W.P.]

M.300 Mickelson, Lynn A. "What Is Truth?" Ensign 20 (November 1990): 27-29. Anti-Mormon literature destroyed the faith of one individual but strengthened a second individual. When dealing with religious literature, the right questions need to be asked, hearts must be prepared, truth must be sought with the aid of the spirit. [J.W.M.]

M.301 Midgley, Louis C. "The Acids of Modernity and the Crisis in Mormon Historiography." In Faithful History: Essays on Writing Mormon History, edited by George D. Smith, 189-225. Salt Lake City: Signature Books, 1992. Discusses Martin Marty's idea that Mormon historians should not be concerned with the truth of the Book of Mormon or Joseph Smith's prophetic calling and only discuss secondary issues. (Marty, Martin E. "Two Integrities: An Address to the Crisis in Mormon Historiography." In Faithful History: Essays on Writing Mormon History, edited by George D. Smith, 169-88.) Midgley argues that the truth of the Book of Mormon is a fundamental issue when writing about its impact. The historian's belief in the Book of Mormon affects the manner in which he/she treats its influence. To adopt a middle-ground approach to the truth or falsehood of the Book of Mormon is to assume the Book of Mormon is false. [B.D.]

M.302 Midgley, Louis C. "The Challenge of Historical Consciousness: Mormon History and the Encounter with Secular Modernity." In By Study and Also by Faith, edited by John M. Lundquist and Stephen D. Ricks, 2:502-51. Salt Lake City: 
Deseret Book and FARMS, 1990. Relates the tensions that have arisen between two types of Mormon historians: those who see history naturalistically and those who perceive a divine dimension. The Book of Mormon is explained on either basis, and the implications of one's approach yields significant implications. [D.M.]

M.303 Midgley, Louis C. " 'O Man Remember, and Perish Not' Mosiah 4:30.” In Reexploring the Book of Mormon, edited by John W. Welch, 127-29. Salt Lake City: Deseret Book and FARMS, 1992. Elements of the phrase "remember" is repeated some 200 times in the Book of Mormon and emphasized on its title page and in the sacramental prayers. To remember one's covenants is an essential gospel principle that is taught both in the Book of Mormon and in the Old Testament. [N.K.Y.]

M.304 Midgley, Louis C. Review of Doctrinal Commentary on the Book of Mormon: Volume I, First and Second Nephi; Volume II, Jacob through Mosiah, by Joseph Fielding McConkie, and Robert L. Millet. Review of Books on the Book of Mormon 1 (1989): 92-113. Book review.

M.305 Midgley, Louis C. Review of On the Barricades: Religion and Free Inquiry in Conflict, by Robert Basil, Mary Beth Gehrman, and Tim Madigan. Review of Books on the Book of Mormon 4 (1992): 5-12. Book review.

M.306 Midgley, Louis C. Review of Since Cumorah, by Hugh W. Nibley. Dialogue 4 (Winter 1969): 76-85. Book review.

M.307 Midgley, Louis C. Review of The Word of God: Essays on Mormon Scripture, edited by Dan Vogel. Review of Books on the Book of Mormon 3 (1991): 261-311. Book review.

M.308 Midgley, Louis C. Review of "The Word of God Is Enough: The Book of Mormon as Nineteenth-Century Scripture," by Anthony A. Hutchinson. In New Approaches to the Book of Mormon, edited by Brent Lee Metcalfe, 1-19. Review of Books on the Book of Mormon 6/1 (1994): 200-254. Book review.

M.309 Midgley, Louis C. "Ways of Remembrance." In Rediscovering The Book of Mormon, edited by John L. Sorenson and Melvin J. Thorne, 168-76. Salt Lake City: Deseret Book and FARMS, 1991. Over two hundred times the Book of Mormon uses terms related to "remembering" and "forgetting." The word remembrance seems to carry the connotations of not only recalling past information but also involves an active participation linked with covenant keeping. [J.W.M.]

M.310 Mikeska, Barbara Gail. "The Morning After." In Stories of Insight and Inspiration, edited by Margie Calhoun Jensen, 34-37. Salt Lake City: Bookcraft, 1976. A conversion story of a woman raised in a Catholic home who, during a time of great despair, sought the Lord in prayer and was introduced to the Book of Mormon by a friend. [J.W.M.]

M.311 Miller, Anita. "If You're Having Trouble Getting Started." Ensign 2 (December 1972): 71. A story of conversion through the Book of Mormon. A teacher advised that if anyone had trouble getting started reading the Book of Mormon that they should begin with 3 Nephi. Mrs. Miller did and gave the book to her husband to do the same. Within six months he had completed the entire book and was baptized. [J.W.M.]

M.312 Miller, C., ed. "The Book of Mormon Characters." Zion's Ensign 43 (24 September 1931): 617-19. Refers to a book by Reverend D. H. Bays who collected views of eminent scholars on the authenticity of Martin Harris's "characters." Central 
American scholars Augustus LePlongeon and Ignatius Donnelly identified Mayan inscriptions with elements of Egyptian writing in them. [D.M.]

M.313 Miller, Helen M. "Now I Wake Early." Ensign 6 (September 1976): 21-22. Two young men with a Book of Mormon answered a desire of the author to know the origin of the ancient inhabitants of America. As a hungry person feasting, the author feasts upon the words of Christ in the Book of Mormon each morning. [J.W.M.]

M.314 Miller, Jeanette W. "The Tree of Life, A Personification of Christ." Journal of Book of Mormon Studies 2 (Spring 1993): 93-106. The author proposes "that the tree of life is a personification of Jesus Christ." Compares some of the basic elements of Lehi's dream and its subsequent interpretation with other passages of scripture and with symbolism of the tree of life in other cultures, and writes concerning the tree of life in connection with the temple and temple typology. [A.T.]

M.315 Miller, Ken. "The Book of Mormon.” In Miller's Mormonism: A Happy Way to Live! 97-109. Bountiful, UT: Horizon, 1977. Also published as “The Book of Mormon." In Miller's What the Mormons Believe: An Introduction to the Teachings of the LDS Church, 97-109. Bountiful, UT: Horizon Publishers, 1981. "The purpose of the Book of Mormon is to help us come to know and live the plan of our Heavenly Father, to believe in Jesus Christ, and to learn and practice his teachings." This chapter includes a synopsis of the coming forth of the Book of Mormon, declares the Book of Mormon to be a second witness for Christ, discusses the appearance of Jesus in the Americas, and exhorts the readers to study, pray about, and learn of the truthfulness of the Book of Mormon for themselves. [J.W.M.]

M.316 Miller, Kenneth Dale. An Outline from Which a Course of Study of the Book of Mormon Can Be Written for the 9th and 10th Grade Lamanite Students of the Church Schools and Seminaries of the LDS Church. M.A. thesis, Brigham Young University, 1972. Contains a proposed lesson guide for teaching the Book of Mormon to 9th and 10th grade Lamanite students. Appendix contains scripts for nine film strips and an activities manual. [D.M.]

M.317 Miller, M. Lee. "Priesthood Principles and Church Organization in the Book of Mormon." In The Sixth Annual CES Religious Educator's Symposium on the Book of Mormon, 63-65. Salt Lake City: Church of Jesus Christ of Latter-day Saints, 1982. The Church was organized and functioned with common priesthood principles in Book of Mormon times similar to the way in which the LDS church is now organized. Author provides evidence of organizational principles, priesthood functions and priesthood keys, apostolic power, and similar items. [A.T.]

M.318 Millet, Robert L. "Abinadi's Messianic Sermon (Mosiah 12-16)." In A Symposium on the Book of Mormon, 97-103. Salt Lake City: Church of Jesus Christ of Latter-day Saints, CES, August 1986. Covers several points in Mosiah 12-16: the relationship between the law of Moses and the Atonement; Abinadi's exposition on Isaiah's suffering servant (Isaiah 53); the ways in which Christ embodies the roles of Father and Son; and teachings on the resurrection. [D.M.]

M.319 Millett, Robert L. "Alma2." In Encyclopedia of Mormonism, edited by Daniel H. Ludlow, 1:3335. 5 vols. New York: Macmillan, 1992. A description of Alma, the son of Alma, and his activities for and against the Church. [B.D.]

M.320 Millet, Robert L. "Another Testament of Jesus Christ." In The Book of Mormon: First Nephi, the Doctrinal Foundation, edited by Monte S. Nyman and Charles D. Tate Jr., 161-75. Provo, Utah: Brigham Young University Religious Studies Center, 1988. Addresses the need for the Book of Mormon as an additional testament to the Bible and as another witness of 
Christ, the identity of the guide in the vision of Nephi, the condescension of God (1 Nephi 11:13-16), and the importance of the tree of life in the visions of Nephi and Lehi. [A.T.]

M.321 Millet, Robert L. "The Brass Plates: An Inspired and Expanded Version of the Old Testament." In The Old Testament and the Latter-day Saints, 415-43. Provo, UT: Randall, 1986. Discusses the influence of the brass plates in the Book of Mormon, their nature and origin, and information from the plates that is not contained in the Bible. This new information strongly resembles "in subject and specific language" the Joseph Smith Translation of the Bible. [A. L. \& P. H.]

M.322 Millet, Robert L. By Grace Are We Saved. Salt Lake City: Bookcraft, 1989. Elaborates on the Book of Mormon theme of grace as it applies to salvation. Relates it to justification, sanctification, perfection, and acknowledging God's hand in all things. This work is reviewed in G.057. [D.M.]

M.323 Millet, Robert L. "The Gathering of Israel in the Book of Mormon: A Consistent Pattern." In Rediscovering the Book of Mormon, edited by John L. Sorenson and Melvin J. Thorne, 186-96. Salt Lake City: Deseret Book and FARMS, 1991. The Book of Mormon passages concerning the gathering of Israel paint a picture consistent with biblical ones. Joseph Smith and the Book of Mormon and those who possess it play a key role in the gathering. [J.W.M.]

M.324 Millet, Robert L. "The Holy Order of God." In The Book of Mormon: Alma, The Testimony of the Word, edited by Monte S. Nyman and Charles D. Tate Jr., 61-88. Provo, UT: Brigham Young University Religious Studies Center, 1992. A study on the priesthood as found in Alma 13. The priesthood of the Nephites was patriarchal, and many leaders were foreordained. The priesthood is "from eternity to all eternity." Explains the concept of "entering into the rest of God." Defines various properties of the priesthood and then describes Melchizedek as a prototype. [D.M. \& N.K.Y.]

M.325 Millet, Robert L. "The Influence of the Brass Plates on the Teachings of Nephi." In The Book of Mormon: Second Nephi, The Doctrinal Structure, edited by Monte S. Nyman and Charles D. Tate Jr., 207-25. Provo, UT: Brigham Young University Religious Studies Center, 1989. The Nephites learned a great deal from the brass plates and incorporated teachings from them in their scriptures. [D.M.]

M.326 Millet, Robert L. "Joseph Smith among the Prophets." In Joseph Smith: The Prophet, the Man, edited by Susan Easton Black and Charles D. Tate Jr., 15-31. Provo, UT: Brigham Young University Religious Studies Center, 1993. Joseph Smith as the head of the final dispensation is a revealer of Christ. Gives evidence that Joseph Smith was ordained of God to bring forth the Book of Mormon. Joseph Smith was not just given the scriptures but was taught and tutored by the authors themselves. [J.W.M.]

M.327 Millet, Robert L. "Joseph Smith and Modern Mormonism: Orthodoxy, Neoorthodoxy, Tension, and Tradition.” BYU Studies 29 (Summer 1989): 49-68. Challenges the assertion by Mormon revisionist historians related to "Mormon neoorthodoxy" that Joseph Smith taught a trinitarian concept in the Book of Mormon, but became progressively more liberal after 1835, when he evolved a view of Godhead describing three distinct beings. Disputes the "neoorthodoxy" thesis regarding the view of the Fall, nature of man, and pathways to redemption. [D.M.]

M.328 Millet, Robert L. "Joseph Smith, the Book of Mormon, and the Nature of God." In To Be Learned Is Good If. .., edited by Robert L. Millet, 59-76. Salt Lake City: Bookcraft, 1987. Argues that the Book of Mormon is valuable in illuminating the 
Bible. Seeming New Testament doctrinal anachronisms in the Book of Mormon are brought about by the loss of "plain and precious truths" from the original Bible. Defends the Book of Mormon as an inspired record, not as an aspect of Joseph Smith's evolving theology. Discusses the doctrine of the Father and the Son in the Book of Mormon. [D.M.]

M.329 Millet, Robert L. "Justice, Mercy, and the Life Beyond." In Studies in Scripture: Alma 30 to Moroni, edited by Kent P. Jackson, 56-68. Salt Lake City: Deseret Book, 1988. Treats the subjects dealt with when Alma was instructing Corianton (Alma 40-42): restoration, resurrection, justice, and mercy. Points out that what for Paul in Galatians is the law of the harvest for is restoration Alma. If justice were destroyed, God would cease to be God. [D.M.]

M.330 Millet, Robert L. Lifting the Condemnation: The Sanctifying Power of the Book of Mormon. Provo, UT: BYU Continuing Education, 1990. A seminar presentation. The Latter-day Saints are under condemnation for not paying sufficient attention to the Book of Mormon. The Book of Mormon was written for our day and shows the manner in which individuals can sanctify their souls and draw closer to God. [D.W.P.]

M.331 Millet, Robert L. "The Love of God and of All Men: the Doctrine of Charity in the Book of Mormon." In Doctrines of the Book of Mormon, 1991 Sperry Symposium, edited by Bruce A. Van Orden and Brent L. Top, 127-44. Salt Lake City: Deseret Book, 1992. Considers various strands of charity or love. God loves us and we are to love one another. Comments on ingredients of charity mentioned in Moroni 7 and 1 Corinthians 13 . Notes that there are obstacles to charity, such as immorality and crudeness. Charity is a fruit of the spirit and a key to enduring to the end. [D.M.]

M.332 Millet, Robert L. "The Ministry of the Father and the Son." In The Book of Mormon: The Keystone Scripture, edited by Paul R. Cheesman, S. Kent Brown, and Charles D. Tate Jr., 44-72. Provo, UT: Brigham Young University Religious Studies Center, 1988. Expounds on the differences between the Father and the Son, but also emphasizes that they are united. Shows the ways in which Jesus is the Eternal God, and the various ways in which he takes on the role of Father. [D.M.]

M.333 Millet, Robert L. "The Natural Man: An Enemy to God." In The Book of Mormon: Mosiah, Salvation Only through Christ, edited by Monte S. Nyman and Charles D. Tate Jr., 139-59. Provo, UT: Brigham Young University Religious Studies Center, 1991. Bases his exposition on King Benjamin's discourse, "the natural man is an enemy to God." Provides an indepth discussion of the fall: its definition, its characteristics, and several misconceptions concerning it. Mankind is fallen and lost without the Redeemer and his Atonement. [D.M.]

M.334 Millet, Robert L. "Nephi on the Destiny of Israel." In Studies in Scripture: 1 Nephi to Alma 29, edited by Kent P. Jackson, 73-85. Salt Lake City: Deseret Book, 1987. A study of 1 Nephi 19-22. States some possible theories of the origin of Laban's plates of brass and then discusses Nephi's teachings of the future of Israel as outlined by Zenos and Isaiah. [D.M.]

M.335 Millet, Robert L. "The Only Sure Foundation: Building on the Rock of our Redeemer." In The Book of Mormon: Helaman through 3 Nephi 8, According to Thy Word, edited by Monte S. Nyman and Charles D. Tate Jr., 15-37. Provo, UT: Brigham Young University Religious Studies Center, 1992. Discusses the doctrines taught by Helaman to his sons Nephi and Lehi in Helaman 5. Comments on the significance of deliverance from sin. Expounds on the role of the Father in the process of redemption, and of the stability of recognizing Jesus as our rock. [D.M.] 
M.336 Millet, Robert L. "The Path of Repentance." In Studies in Scripture: Alma 30 to Moroni, edited by Kent P. Jackson, 4855. Salt Lake City: Deseret Book, 1988. A discussion of Corianton's sin and Alma's response to it in Alma 39. Of the three most grievous sins, only the first two are not covered by the Atonement. For all others repentance is possible. [D.M.]

M.337 Millet, Robert L. "The Plates of Brass: A Witness of Christ." Ensign 18 (January 1988): 26-29. Prophetic records, such as the brass plates, are important for the preservation of God's people. This article discusses the possible origins and the contents of the plates of brass. Gospel teachings of Israelite prophets not mentioned in the Bible (Zenos, Zenock, Neum, and Ezias), who were descendants of Joseph, show that the witness of Christ in the brass plates is more explicit than in our Old Testament. The Joseph Smith Translation of the Bible may, in fact, "contain some of the information found on the plates of brass." [A.A.]

M.338 Millett, Robert L. "Redemption through the Holy Messiah." In Studies in Scripture: 1 Nephi to Alma 29, edited by Kent P. Jackson, 115-30. Salt Lake City: Deseret Book, 1987. A consideration of 2 Nephi 6-10. The doctrine of the redemption of the dead in Israel was understood earlier than current scholars are willing to allow. The Atonement is infinite in three ways: (1) it circumvents death, (2) it extends to all of Christ's creations, (3) it was performed by an infinite being. All will be judged, but Jesus suffered to enable us to choose life. Jacob taught how to take advantage of the Atonement. [D.M.]

M.339 Millet, Robert L. Review of "Book of Mormon Christology," by Melodie Meonch Charles. In New Approaches to the Book of Mormon, edited by Brent Lee Metcalfe, 81-114. Review of Books on the Book of Mormon 6/1 (1994): 189-99. Book review.

M.340 Millet, Robert L. "Sherem the Anti-Christ." In The Book of Mormon: Jacob through Words of Mormon, To Learn with Joy, edited by Monte S. Nyman and Charles D. Tate Jr., 175-91. Provo, UT: Brigham Young University Religious Studies Center, 1990. Identifies characteristics of the anti-Christ as exhibited through Sherem: (1) denies the need for a Christ figure, (2) uses flattery, (3) accuses brethren of false teachings, (4) has a naturalistic frame of reference, (5) distorts scripture, and (6) seeks after signs. Shows how Jacob prevailed over Sherem, illustrating the tragic end of sign-seekers. The downfall of Sherem provides a warning for today. [D.M.]

M.341 Millet, Robert L. " 'So Glorious a Record.' " Ensign 22 (December 1992): 7-11. Emphasizes that the Book of Mormon was written and has relevance for our day. Mlllet pleads for the members of the Church not take it lightly. [D.M.]

M.342 Millet, Robert L., and Joseph Fielding McConkie. Our Destiny: The Call and Election of the House of Israel. Salt Lake City: Bookcraft, 1993. Traces the call and election of the house of Israel from its pre-mortal existence through its temporal history until and including the era of the millennium. Explores doctrines related to the house of Israel, including the scattering, gathering, blessings as a covenant people, concepts concerning the ten tribes, the lands of promise, the role of the priesthood, and the role of Jesus Christ. The authors demonstrate the Book of Mormon's clarity, import, and message regarding the house of Israel. [D.W.P.]

M.343 Mills, John M. Pronouncing Vocabulary. Salt Lake City: Deseret Sunday School Union, 1920. Pamphlet containing pronouncing guide for Book of Mormon names, designed to be taped into the back of the 1920 edition of the scriptures. [J.W.M.] 
M.344 Milner, Winifred M. Light from the Dust, a Historical Novel. Independence, MO: Herald House, 1971. An imaginative novel, based on historical documents, about the coming forth of the Book of Mormon. [D.M.]

M.345 Miner, Edward G. "The Book of Mormon." University of Rochester Library Bulletin 5 (Autumn 1949): 1-12. Highly fanciful retelling of Joseph Smith's early life and the coming forth of the Book of Mormon. Accepts the Spaulding story and tries to link its connection with Sidney Rigdon's "versatile genius." Claims that John H. Gilbert said that Rigdon "came to Palmyra and there cooked up the scheme with Smith." [D.M.]

M.346 Minkler, Hazel L. "The Book of Mormon as a Supplement to the Bible." SH 80 (19 December 1933): 1628-30. Believers in the Bible should look forward to further revelation from the Lord. The Book of Mormon restores ancient knowledge that has been lost, such as the plan of salvation. The doctrine of the Atonement is no better explained in all of scripture than in the Book of Mormon. The law of opposites and the concept of Satan is clarified. [J.W.M.]

M.347 Minkler, Ruth. "The Book of Mormon Confirmed by Tradition." SH 80 (19 September 1933): 1197. The traditions of the Maya are recorded in the book known as the Popol Vuh. These traditions include the creation story, the Tower of Babel, and the bearded, white God. These traditions coincide with some Book of Mormon teachings and may aid in its authentication. [J.W.M.]

M.348 Minkler, Ruth I. "Words of Mormon." SH 91 (23 December 1944): 1473. Mormon, the last historian of the Book of Mormon, inserted his commentary along with the small plates of Nephi after examining their content and finding them to be very valuable. They were put there for the special purpose of converting his people in the last days. They replaced the lost 116 pages. [J.W.M.]

M.349 Mintun, J. F. "David Whitmer and Stewardships." SH 73 (24 March 1926): 268-70. David Whitmer's testimony of having seen the plates never wavered. He was faithful in his stewardship, which included more than witnessing for the Book of Mormon. The Three Witnesses were called upon by the Prophet Joseph to select the twelve apostles. The Three Witnesses accomplished their work and in spite of their mistakes were accepted of the Lord. [J.W.M.]

M.350 "Mission Lessons: LDS Church History" (Series). Relief Society Magazine 26 (August—November 1939): 574-77, 647-50, 724-26, 799-801. Recounts the appearances of Moroni to the Prophet Joseph Smith in September 1823. Joseph received the plates in September 1927, but many difficulties arose and the actual work of translation did not commence until April 1829. It was finished in early summer 1829. Although some of the eleven witnesses left the Church, their testimonies remain unchanged. The ultimate witness of the truthfulness of the Book of Mormon is the Holy Ghost. [J.W.M.]

M.351 "Missionaries, Members Cover State with Book of Mormon." CN 59 (8 July 1989): 12. A news report that LDS missionaries and members in New Hampshire are placing copies of the Book of Mormon in every public library. [M.R.]

M.352 "Missionaries Number Thirty-Three Thousand." CN 57 (14 March 1987): 3. Tells about the rising number of LDS missionaries, a record high of 33,000, and coupled with "perhaps the most extensive missionary circulation ever of the Book of Mormon" as a missionary tool. [M.D.P.] 
M.353 "Missionary Growth Outpaces General Book of Mormon Fund." CN 63 (7 August 1993): 3, 5. A lack of copies of the Book of Mormon available for missionaries prompts a request for more donations to the Church's General Book of Mormon Fund. [S.H.]

M.354 Mitchell, J. Leslie. "The Buddha of America." The Cornhill Magazine 72 (January-June 1932): 595-604. The author of this paper accuses Moroni of not letting competent professionals view the golden plates. Mysteries concerning the ancient Mesoamericans, will forever remain unknown until Moroni descends and reveals to professionals where to find the hidden golden plates. One such mystery, for instance, pertains to whether or not Quetzalcoatl is related to the Asian Buddha. [B.D.]

M.355 Mitchell, William J. A Christian Looks at Mormonism. Mesa, AZ: William J. Mitchell, 1977. A polemical work against Mormonism. The author notes what he feels are numerous "difficulties" in accepting the claims of the Book of Mormon, such as King James English, plagiarism, domesticated animals before Columbus, contradictions with the Bible, lack of archaeological evidence, and the mongoloid nature of native Americans. [M.R.]

M.356 Mittler, Bruno J., and Judy K. Pruden. "Recent Developments in Regard to Ancient Transpacific Influence on the New World." SEHA 115 (8 September 1992): 1-4. Short essay discusses possible pre-Columbian, transoceanic contacts in two parts: (1) voyages of Japanese fishermen to Ecuador, and (2) very old pottery found in Ecuador that has affinities with ceramic products in ancient Japan. [D.M.]

M.357 "Modern Superstition-The Mormonites." Visitor of Monthly Instructor (1841): 61-64, 153-56, 237-39. Early British diatribe against Mormonism, lamenting the receptiveness of Britons to the Church. Tells about Moroni's visit, the first scene at the Hill Cumorah, the manner of translation, the loss of the 116 pages, the role of Martin Harris, and the theory of the Spaulding manuscript. Relies heavily on the Episcopal Recorder in Philadelphia. [D.M.]

M.358 "Mohawk Singer and the Book of Mormon." MS 98 (20 August 1936): 535. A famous Mohawk singer, Os-ke-non-ton, was told the story of the Book of Mormon and his ancestors and said, "Of the many anthropological explanations of the origin of the American Indian the Mormon one impresses me as the briefest and most feasible." [M.D.P.]

M.359 Moler, H. E. "The Book of Mormon." SH 50 (3 June 1903): 501-9. The Book of Mormon people were assigned to America by God. The article includes the story of the book, the testimonies of the witnesses, why it is called the Book of Mormon, when the sealed portion will be given, the fulfillment of biblical prophecies, evidence found in the relics of antiquity, and the language of the book. It was not written by Solomon Spaulding. [J.W.M.]

M.360 Moler, H. E. "The Book of Mormon and the Inspired Translation, Do They Agree?" SH 49 (8 October 1902): 980-81. A response to allegations that the Old Testament quotes in the Book of Mormon and the Inspired Translation that Joseph Smith made do not agree. The results of Moler's comprehensive study are reported. The conclusion is that, though the Book of Mormon was translated many years before the Inspired Version, the texts do agree. [J.W.M.]

M.361 "Moments in History." CN 40 (6 June 1970): 2. David Whitmer traveled to Harmony, Pennsylvania, to return with Joseph Smith and Oliver Cowdery to the Whitmer home where the translation of the Book of Mormon would be completed. Whitmer's fears were allayed by the appearance of a man who told him he was going to Cumorah and then disappeared. [J.W.M.] 
M.362 "Moments in History." CN 40 (13 June 1970): 2. Samuel Smith was the first missionary with copies of the completed Book of Mormon. He gave one copy to Rev. John P. Greene, who was converted, and he passed it on to the Young family, many of whom were also converted. It was also given to Heber C. Kimball. [J.W.M.]

M.363 "Moments in History." CN 41 (17 April 1971): 2. In April of 1889 the Book of Mormon was first printed in the Maori language in New Zealand. [M.R.]

M.364 "Moments in History." CN 41 (14 August 1971): 2. In 1942 President McKay obtained proof sheets of the first edition of the Book of Mormon from Wilford C. Wood. [M.R.]

M.365 "Moments in History." CN 42 (23 September 1972): 2. A list of important moments in Church history including a missionary giving a copy of the Book of Mormon to the King of Sweden in 1897. [M.D.P.]

M.366 Monch, Elder L. F. "The Book of Mormon, and the End of the World." MS 48 (29 March, 5, 12, 19, 26 April, 3 May 1886): 193-96, 209-13, 235-40, 243-47, 267-71, 283-88. Six-part series discussing how Mormonism fulfills biblical prophecy concerning the last days: the coming of Elijah, restoration of the gospel and correct ordinances such as baptism by immersion and the sacrament, Church organization, and continuing revelation. [A.C.W.]

M.367 Monson, Leland H. Ancient America Speaks. Salt Lake City: Deseret Book, 1958. This book wishes to motivate members of the Church to read the Book of Mormon with greater benefit. The Book of Mormon is directed to the Lamanites, Jews, and Gentiles; the author provides biographical sketches of prominent figures, expounds on character traits, and treats selected doctrinal themes. [D.M.]

M.368 Monson, Leland H. "An Appreciation of the Book of Mormon." Relief Society Magazine 39 (June 1952): 364-66. A lessening of belief in "the divine Christ" began in the seventeenth century. By Joseph Smith's day "higher criticism" of the Bible, like a snake coiled, was squeezing the life blood out of Christianity. The Book of Mormon came forth to reaffirm the divinity of Christ. In 1946, the New York Times Book Review listed the Book of Mormon thirty-eighth on the list of books that have most influenced America. [J.W.M.]

M.369 Monson, Leland H. "Book of Mormon in Brief." Instructor 87 (June 1952): 170. A brief overview of the story of the Book of Mormon. [R.H.B.]

M.370 Monson, Leland H. "Characters and Teachings of the Book of Mormon." Relief Society Magazine 38-44 (July 1952February 1957). A six-year series of theology lessons that follow a chronological order of the Book of Mormon. Lessons analyze the structure and purposes of the book, the witnesses, its divine origin, the Jaredite nation, Lehi's exodus, and prophecies concerning the Jews, Gentiles and Lamanites. "The Book of Mormon is 'A New Witness for Christ.' " [J.W.M.]

M.371 Monson, Leland H. Life in Ancient America, A Study of the Book of Mormon. Salt Lake City: Deseret Sunday School Union, 1946. A Sunday School manual that contains lesson outlines, commentaries, and study questions. Divides the Book of Mormon into the following subsections: the period between Jerusalem and Zarahemla, the reign of kings (starting with King Benjamin), the reign of the judges, the ministry of Jesus, the fall of the Nephites, and the works of Mormon and Moroni. [D.M.] 
M.372 Monson, Leland H. “Long Road of Corianton.” Instructor 94 (June 1959): 178-79. Discusses Corianton's trip to Antionum to teach the gospel of Jesus Christ to the Zoramites. [L.D.]

M.373 Monson, Leland H. "Mormon." IE 48 (September, October 1945): 512, 550-51, 576, 612-13. Also in Instructor 98 (October 1963): 344-45. Writes concerning the conditions of the people and era when Mormon grew up and the manner in which Mormon's family influenced him for good. Discusses Ammaron's influence on Mormon, and Mormon as a record keeper, teacher, and warrior. [L.D.]

M.374 Monson, Leland H. "Moroni Addresses the Future." IE 49 (March 1946): 149, 181-82. Discusses Moroni's abridgment of the gold plates, his wanderings, his address concerning the future, the war at Cumorah, and how to gain a testimony of the Book of Mormon (Moroni 10:4). [L.D.]

M.375 Monson, Leland H. "Moroni Spoke Also to Us." Instructor 103 (June 1968): 216-17. Discusses Moroni's closing words in the Book of Mormon (Moroni 10:1, 10:24). Discusses the admonitions and promises he left for those who read the Book of Mormon. [L.D.]

M.376 Monson, Leland H. "The Nephite Pattern of Personality." Instructor 97 (November 1962): 363, 365. Analyzes the physical being, the intellectual being, and the emotional being in relation to the Nephites in the Book of Mormon. Several Book of Mormon scriptures describe the character of the people, including Alma 7:10-11, 4 Nephi 1:3, and 4 Nephi 1:15. [L.D.]

M.377 Monson, Leland H. "The Structure of the Book of Mormon." IE 49 (July 1946): 436-37, 474-75. Discusses the plates of Mormon, source material, and the use made of the plates. Explains the general structure of the Book of Mormon and how to identify different writers in the Book of Mormon. [L.D.]

M.378 Monson, Thomas S. "You Make A Difference." Ensign 18 (May 1988): 41-43. Also CR (April 1988): 49-53. Follow the prophets and study the Book of Mormon. Sins are like barnacles that fasten themselves to the hull of a ship, weighing it down, slowing its progress, and decreasing its efficiency. Repentance will rid us of these. [J.W.M.]

M.379 “A Montana Editor on the Book of Mormon." SH 48 (24 July 1901): 594-95. This reprint of a newspaper article declares that the Book of Mormon is of the highest moral type and suggests that there is no internal evidence that it is a romance written by a skillful author. It is consistent with the "highest type of Christian life." [J.W.M.]

M.380 Montgomery, M. W. The Mormon Delusion: Its History, Doctrines, and the Outlook in Utah. Boston: Congregational Sunday School and Publishing Society, 1890. A polemical work against Mormonism. Accepts the Spaulding theory regarding the Book of Mormon's origin. The author lists several examples of New Testament plagiarism in the Book of Mormon. [M.R.]

M.381 Moody, William A. "Origin of the Samoans." MS 59 (September 1879): 587-88. Argues that the Samoans originate from American shores, namely from Hagoth (Alma 63:5-8). [B.D.]

M.382 Mooney, Richard E. Colony Earth. Greenwich, CN: Fawcett Crest, n.d. Lists the Book of Mormon and its group of Israelites as one explanation for the beginnings of early American civilizations. Names archaeological aspects that fit the 
Book of Mormon (the Popol Vuh, cement, and metal plates), but points out certain animals do not fit the scheme of the book. [D.M.]

M.383 Moore, C. E. "Anachronisms and the Book of Mormon." IE 52 (October 1949): 644, 659-60. This article argues that there is a marked absence of anachronisms in the Book of Mormon. One method of detecting a fraudulent historical document is to examine it for anachronisms. It is almost impossible to keep such errors from slipping into documents when one is producing the document in a time period other than that about which it is being written. [J.W.M]

M.384 Moore, June A. "Tests of the Truth of the Book of Mormon." MS 91 (8 August 1929): 507-9. The four fundamental tests that may be used to determine the truthfulness of the Book of Mormon are science, history, doctrine, and prophecy. Moore gives an example of each of these four tests. [R.H.B.]

M.385 Moore, Sidney. Stories from the Book of Mormon. Independence, MO: Herald House, 1956. A collection of 20 Book of Mormon stories for children, illustrated by Sidney Moore and written by different authors. This work contains such stories as "The Alter of Stones," "The Rod of Iron," "The Strange Ball," and “Gideon's Plan." [J.W.M]

M.386 Moorman, Donald R. Review of A Mormon Bibliography, 1830-1930: Books, Pamphlets, Periodicals, and Broadsides Relating to the First Century of Mormonism, edited by Chad Flake. Dialogue 12 (Summer 1979): 133. Book review.

M.387 "More Book of Mormon Translations. [Shona, Lingala, Urdu, and Gilbertese]." Ensign 19 (January 1989): 76. Four additional languages have been added to the list of translations of the Book of Mormon: Shona, Lingala, Urdu, and Gilbertese. There are now seventy-five besides English. [J.W.M.]

M.388 “More Gold Plates." CN 48 (6 May 1978): 16. Nineteen golden plates were discovered in South Korea in 1965. These contain the records of Buddhist scripture. Archaeologists also confirm that this is how most ancient records were kept. [M.R.]

M.389 “More Gold Plates Found." CN 36 (25 June 1966): 16. Tells of a discovery made in Italy when archaeologists found three gold plates that date back to 500 B.C. This, along with the Dead Sea Scrolls, proves that such records like the Book of Mormon were kept in ancient times. [M.D.P.]

M.390 "More Than One Way to Study the Book of Mormon." Ensign 21 (Feb. 1991): 21. Gives suggestions on methods of studying the Book of Mormon: write down important principles, listen to the Spirit and gain strength from the messages hidden between the lines, and pray over passages not understood. [J.W.M.]

M.391 Morgan, D. J. The Gospel of Christ Restored. Independence, MO: n.p., 192?. RLDS pamphlet lauding the Book of Mormon and quoting passages related to vital themes: baptism, gift of the Holy Ghost, ordination to the ministry, the sacrament, tithing, and people having all things in common. [D.M.]

M.392 Morgan, John. "The Book Of Mormon." In Opinions of the Leading Statesmen of the United States on the Edmunds Law and Refutation of the Spaulding Story Tract \#3, 1884?, 20-23. Salt Lake City: Juvenile Instructor Office, 1884?. Refutes the Spaulding theory by providing a reprint of James $\mathrm{H}$. Fairchild's letter admonishing that the theory be repealed. Believes that the Spaulding manuscript shows no similarity to the Book of Mormon. [J.W.M.] 
M.393 Morgan, M. H. "The Book of Mormon Plates and Other Records." SH 85 (15 January 1938): 79-80, 84. There were many sets of plates mentioned in the Book of Mormon. The brass plates, the large plates of Nephi that Mormon abridged, the small plates and the records of the Jaredites. All these were buried in the Hill Cumorah. [J.W.M.]

M.394 Morgan, M. H. "Central American Architecture." SH 80 (4 January 1933): 15, 19. Central American architecture is similar to ancient Near Eastern architecture as found in Babylon and Egypt. The ruins in Central America fit criteria of architecture of the Book of Mormon. [J.W.M.]

M.395 Morgan, M. H. "Of Interest to Book of Mormon Students." SH 84 (19 June 1937): 781-82. Some of the Jaredite nation possibly broke away from the main colony to journey southward to South America to become the Inca and pre-Inca civilization. Lehi's colony on the other hand did not spread out, but stayed close to their point of origin since the land was fertile. [J.W.M.]

M.396 Morgan, Stephen G. Are You Mormons 'Ignoramuses'? Salt Lake City: Nicholas G. Morgan, Sr., 1966. The bulk of this book is made up of 13 appendices, three of which deal directly with the Book of Mormon. The first is a brief historic or "panoramic view" of the book. The second is a study guide. The third is a treatise on the sticks of Judah and Joseph. [D.M.]

M.397 Morley, Ray Gerald. "A Comparative Study of the Book of Mormon Secret Combinations and the American Mafia Organization." M.R.E. thesis, Brigham Young University, 1972. Thesis consists of three parts: (1) an overview of secret combinations in the book of Moses and the Book of Mormon; (2) a history of the mafia in Sicily and America; (3) a comparison of practices of secret combinations in the Book of Mormon and America. [D.M.]

M.398 Morley, Ray Gerald. An Investigation of Anti-'Mormon' Hypotheses for the Origin of the Book of Mormon. Provo, UT: Brigham Young University, 1965. A mimeographed report on anti-Mormon explanations of the Book of Mormon: the Spaulding-Rigdon combination, Ethan Smith, David H. Bays, I. W. Riley, Walter F. Prince, Bernard DeVoto, Harry M. Beardsley-James Black, George B. Arbaugh, and Fawn M. Brodie. Contains refutations, and Albert E. Bowen's critique of Brodie. [D.M.]

M.399 “Mormon and the 'Small Plates' of Nephi." Instructor 75 (August 1940): 344. Gives an explanation of the lost 116 pages and how the small plates of Nephi were substituted for these lost pages that had been translated from the large plates of Nephi. [J.W.M.]

M.400 "The Mormon Bible." The Family Magazine (1 April 1839): 429-30. Explains the Book of Mormon's origin by an appeal to the Spaulding theory. [M.R.]

M.401 “The 'Mormon Bible.' " MS 40 (4 February 1878): 68-70. Reprint from the Deseret News. An article written in the Post and Tribune contains much false information about the Book of Mormon, including that the witnesses had denied their testimonies and the book was written by Spaulding. The Book of Mormon corroborates and supports the Bible, but does not replace it. [J.W.M.] 
M.402 "Mormon Defined by a Chicago Editor." SH 48 (28 August 1901): 694. Reprint of and rebuttal to an article that appeared in Northwestern Christian Advocate, April 17, 1901, which claims that Sidney Rigdon was a "literary genius" who adapted the Manuscript Found by Spaulding to Joseph Smith's and his own ideas. [J.W.M.]

M.403 “Mormon Group 'Explores' Latin America." CN 31 (9 September 1961): 6. Tour report by Milton R. Hunter. Archaeological evidence, in the form of carvings and artifacts viewed in Central and South America, are given as support for the veracity of the Book of Mormon. [A.C.W.]

M.404 "Mormon Migrations." Boston Evening Transcript (17 October 1890): none given. Mormons who believe that the Book of Mormon was delivered by an angel of the Lord have been troublesome wherever they have been: Kirtland, Ohio, Missouri, Illinois, and Salt Lake City, Utah. Gives the history of the rise of the anti-polygamy Mormons, the Josephite Mormons, or RLDS church. [J.W.M.]

M.405 "Mormon Mystery." Time 110 (11 July 1977): 69. A brief article describing attempts to demonstrate a connection between the handwriting of Solomon Spaulding and the unknown scribe who wrote several pages of the Book of Mormon manuscript. [M.R.]

M.406 "Mormon Pseudo-Archaeology." Utah Christian Tract Society 10 (March-April 1975): 2. Argues that the Book of Mormon is not supported by archaeological evidence. [D.M.]

M.407 "Mormon Relics." Weekly Inter Ocean (26 October 1886): 9. Article about David Whitmer's memories of his early role in the coming forth of the Book of Mormon. Also discusses the original Book of Mormon manuscript. [D.M.]

M.408 "Mormon Religion." Vermont Gazette 2 (18 September 1831): 1. A very early account of the coming forth of the Book of Mormon. Attributes the book to "the Smiths and Rangdon." [D.M.]

M.409; "Mormon 'Revelation and Inspiration.' " Utah Christian Tract Society 10 (July-August 1976): 2. Sees problems in the Martin Harris—Charles Anthon story. Asks how Anthon could be expected to identify reformed Egyptian. [D.M.]

M.410 "Mormon 'Revelation and Inspiration.' " Utah Christian Tract Society 10 (September-October 1976): 2. Urges that Joseph Smith bore false witness by claiming to be the author of the Book of Mormon. [D.M.]

M.411 "Mormona." "The Brother of Helam." Juvenile Instructor 57, 58 (August-December 1922, January-June 1923): 421 24, 477-80, 533-39, 652-56, 6-9, 63-66, 116-20, 167-70, 221-24, 279-81. A fictional account of Abinadi, Alma, and Limhi. [J.W.M.]

M.412 "Mormona." "The Lure of the Homeland." Juvenile Instructor 56, 57 (December 1921_July 1922): 631-35, 7-15, 6573, 121-29, 181-89, 239-43, 298-302, 365-69. A fictional story of Zeniff. [J.W.M.]

M.413 "Mormonism." Christian Journal 1 (28 May 1835): 1. Blustery article on the Book of Mormon and its production by "Joe Smith," Martin Harris, and Oliver Cowdery. Accepts the Spaulding story. [D.M.] 
M.414 "Mormonism." The Christian Reformer 8 (June 1841): 286. Calls the Book of Mormon "a religious romance in the style and phraseology of scripture." Believes Solomon Spaulding wrote the Book of Mormon. [D.W.P.]

M.415 "Mormonism." In The Sacred Writings of the World's Great Religions, selected and edited by S. E. Frost Jr., 367-69. New York: The New Home Library, 1943. Gives a synopsis of what the LDS church believes and tells of the origin of the Book of Mormon. Briefly tells what is in each of the 15 books that comprise the Book of Mormon with a short text from each, [J.W.M]

M.416 "Mormonism." Leisure Hour (5 January 1867): 27-31. A polemical piece on Joseph Smith and the Book of Mormon. Claims that the Bible advises people not to expect further revelation. Tries to discredit the Three Witnesses. Takes issue with prooftexts found in Ezekiel 37 and Revelation 14:6-7. [D.M.]

M.417 "Mormonism." The Reflector 2 (9 March 1831): 116-17. A correspondent relates that Joseph Smith entered Waterloo with his wife decked in a profusion of gold jewelry. They were selling stocks in the "Gold Bible." [J.W.M.]

M.418 "Mormonism: An Impartial History of a Strange People." My Daily Tribune (3 November 1889): 7-8. Gives H. H. Bancroft credit for placing side by side both Mormon and anti-Mormon literature in his book "History Of Utah." Calls the rural inhabitants who live on the "selvage of American civilization" primitive. These "primitive" people were willing to believe in revelation and supernatural manifestations. It was fertile soil for Joseph Smith who told a story of a golden Bible. The Mormons seem sincere and upright in their purposes. [J.W.M.]

M.419 "Mormonism and the Mormons." London Quarterly and Holburn Review 2 (1854): 95-127. A polemical article against Mormonism and the Book of Mormon. Discusses the testimonies of Book of Mormon witnesses and the Spaulding theory. [M.R.]

M.420 "Mormonism: Authentic Account of the Origin of this Sect from one of the Patriarchs." Harper's Weekly (11 June 1881): none given. Reprint from Kansas City Journal (5 June 1881): none given. Gives the testimony of David Whitmer, the manner of translation, and an account of the loss of the 116 pages of Book of Mormon manuscript-the Book of Lehi. Also an account of the events surrounding the Three Witnesses seeing the plates, as well as the eight who saw them later. [J.W.M]

M.421 "Mormonism Exposed and Refuted." Universalist Union (5 May 1838): 205. Denounces Mormonism and the Book of Mormon that breathes "a spirit of cruelty" that is common in every man-devised religion. Through its doctrine of endless misery Mormonism consigns to hell those who do not believe in it. [J.W.M.]

M.422 Mormonism Exposed: In Which Is Shown the Monstrous Imposture, the Blasphemy, and the Wicked Tendency of That Enormous Delusion, Advocated by a Professedly Religious Sect, Calling Themselves “Latter Day Saints.” New York: N. Y. Watchman, 1842. Made up of quotations of Mormon writings that are being kept hidden from the public. Equates Joseph Smith with Mohammed and reveals the "bloody nature" of Mormons. Joseph Smith pretended to find the Book of Mormon in earth. He wrote the Book of Mormon for the purpose of making money. This fact is attested to by Martin Harris. [J.W.M.] 
M.423 "Mormonism—Its Character, Origin, and Tendency." Christian Magazine 3 (January-June 1848): 145-50, 157-62, 169-76, 181-84, 193-96, 205-10. Pejorative series of articles on the early LDS church. Accepts the contents of E. D. Howe's Mormonism Unveiled, including Book of Mormon connections with Spaulding. Discusses the Three Witnesses, and scorns items found within the Book of Mormon, such as the Liahona as a compass and the Jaredite barges. [D.M.]

M.424 "Mormonism: Its Origin and Character." The Eclectic Review 6 (October 1853): 479-98. "The books [Joseph Smith] published are imitations of the Bible, without one proof of their being given from heaven, and abounding with proofs that they were not, and could not be." Favors a Spaulding explanation for Book of Mormon origins. [D.M.]

M.425 “Mormonism-Whence Came It?” The British Quarterly Review 23 (January 1856): 62-81. A polemical article against Mormonism. The author favors the Spaulding theory in explanation of the Book of Mormon's origin. Bible influence and Book of Mormon plagiarisms are discussed. [M.R.]

M.426 "The Mormonites." The Churchman 1 (4 February 1832):181-82. Finds that Joseph Smith, Martin Harris, and Sidney Rigdon are religious fanatics claiming to possess a Golden Bible, but in reality only possessing a wild imagination and a desire to become rich. These reprobates hold meetings to disseminate their plot-the Book of Mormon. [J.W.M.]

M.427 "The Mormonites." The English Review 13 (June 1850): 399-440. Considers "Mormonites" to be "deluded fanatics," and is surprised and worried about their growth. Accepts the Spaulding story. Also quotes several Book of Mormon passages, including those calling Joseph Smith a "choice seer." [D.M.]

M.428 "The Mormonites." The Monthly Review 159 (1842): 190-213. A polemic that states that the Book of Mormon "by no means is made up of a series of skillfully constructed pieces, nor even of individual forgeries cunningly concocted. The workmanship must appear spurious to any person who brings a small share of scholarship or of critical knowledge to test it. In short, it is a clumsy affair altogether, which can only in its present shape impose upon the ignorant, the illiterate, and the most credulous." [D.M.]

M.429 “The Mormons." The Christian Examiner 64 (May 1858): 421-40. A polemical article on Mormonism. The writer considers Joseph Smith to be an impostor. He cites the Anthon denial as evidence against the Harris account. The Book of Mormon narrative is attributed to Spaulding. He further notes a resemblance between the tendency of the Jews to interpret Old Testament prophecy literally and the literalistic interpretations made by Mormons. The writer finds this literalism unpalatable. [M.R.]

M.430 "The Mormons." The Christian Reformer 8 (March 1852): 183-85. A correspondence about the Mormons and the Book of Mormon that denies the fact that many individuals are accepting the book and its teachings. [D.W.P.]

M.431 "Mormons." Knowledge: A Weekly Magazine 1 (2 August 1890): 175-88. The author considers Joseph Smith to be on impostor and a fanatic, alleging that Joseph Smith plagiarized the manuscript of Solomon Spaulding in order to create the Book of Mormon. [M.R.]

M.432 "Mormons Add a Twist to Their Holy Book." Christianity Today 26 (12 November 1982): 91. A news item relating that leaders of the LDS church have added the subtitle "Another Testament of Jesus Christ" to the Book of Mormon. [D.W.P.] 
M.433 "The Mormons and Their Bible." The United States Magazine 3 (September 1856): 220-24. The editor decries Mormonism in general and introduces a "sketch . . prepared by a gentleman attached to the United States Army, who was stationed sometime in the Salt Lake Valley" that summarizes the contents of the Book of Mormon. He comments that the sayings of Jesus in 3 Nephi are merely altered copies of New Testament scripture, and the whole Book of Mormon is explained by Solomon Spaulding's Manuscript Found that Sidney Rigdon furnished to Joseph Smith. [B.D.]

M.434 "The Mormons and Their Book." The Treasury (1898-99): 604-11. Talks about the Three Witnesses and the manner of translation. Notes that President Fairchild of Oberlin College compared the newly discovered Spaulding manuscript to the Book of Mormon and found the two texts bore little resemblance one to another. The latter, however, "does not need the Spaulding manuscript to account for it. It is a prosy imitation of the Old Testament, showing no special genius, and no ability more than Smith may very well have had." [D.M.]

M.435 The Mormons, or, Knavery Exposed. Philadelphia, PA: E. G. Lee, 1841. Devotes several pages to the role of Martin Harris in the coming forth of the Book of Mormon. [D.M.]

M.436 "Moroni and Space." CN 39 (27 September 1969): 16. On the anniversary of Moroni's visit to Joseph Smith, the moon astronauts were noted as not being the only men of space. Moroni and others came from God through space to present their messages. If God allows men to walk in space, a miracle in and of itself, then why not angels sent from his presence? [J.W.M.]

M.437 "Moroni Did Come!" CN 53 (18 September 1983): 16. Testimony stating that the gold plate story is true and that Moroni did visit Joseph Smith. [A.T.]

M.438 "Moroni Raises the Title of Liberty." Friend 12 (July 1982): 48. The story of Captain Moroni is retold for children. [A.T.]

M.439 Morris, Bonnie. A Wounding Truth: A Message of Love for RLDS Seekers of Truth. Issaquah, WA: Saints Alive, 1982. An polemical tract designed to lead individuals away from the Book of Mormon and the Doctrine and Covenants. [D.W.P.]

M.440 Morris, George Q. "What Is the Book of Mormon." DN Church Section (7 December 1940): 8 . The Book of Mormon is not an ordinary history, it is a book with a purpose. It is a "new witness" for Jesus Christ. Its greatest purpose is to convince Jews and Gentiles that Jesus is the Christ. Out of 239 chapters only seventy-five have no relationship with the things of God. The testimony of Nephi and Jacob sustain the idea that the Book of Mormon was written to bear testimony of Jesus Christ. [J.W.M.]

M.441 Morris, George Q. What Is the Book of Mormon? Salt Lake City: Church of Jesus Christ of Latter-day Saints, 1940. A KSL radio presentation presenting an overview of the contents of the Book of Mormon. [D.W.P.]

M.442 Morris, Nephi Lowell. "Book of Mormon Prophecy I \& II." In Morris's Prophecies of Joseph Smith and Their Fulfillment, 217-58. Salt Lake City: Deseret Book, 1926. Discusses America's role as a choice and promised land and how latter-day events have confirmed Book of Mormon prophecies: God fights for America, he will fortify it, it will be free from bondage, and there will be no kings upon it. [A.C.W.] 
M.443 Morris, Nephi Lowell. The 'Book of Mormon,' the Story of Its Discovery-Its Construction-The Testimony of the Witnesses-The Internal Evidences of Its Truth. Salt Lake City: Deseret News, 1899. An LDS tract that describes Joseph Smith's encounter with Moroni, the contents of the Book of Mormon, the role of the witnesses, and presents some of the book's internal evidences. [D.M.]

M.444 Morris, Nephi Lowell. "Columbus and the Book of Mormon." DN Church Section (7 July 1928): 6. Examines Nephi's prophecy of "a man among the Gentiles" who crossed the waters in light of Columbus's life and Joseph Smith's knowledge of Columbus. Discusses Columbus's feeling of divine guidance and concludes that he is the man to whom Nephi referred. [A.C.W.]

M.445 Morris, Nephi Lowell. Prophecies of Joseph Smith and Their Fulfillment. Salt Lake City: Deseret Book, 1920. The Book of Mormon is a volume of prophecy and also a fulfillment of other prophecies. Morris cites many passages that prophesy of the greatness of America and the liberty to be enjoyed on the American continent. These passages have been fulfilled particularly noting the Monroe Doctrine and the ill success of Emperor Maximilian over Mexico and Dom Pedro of Brazil. [B.D.]

M.446 Morris, Nephi Lowell. The Story of the Discovery of the Book of Mormon. Chicago: n.p., 1910. An LDS missionary pamphlet that deals with Book of Mormon origins and comments on the Three Witnesses. [D.M.]

M.447 Morris, Nephi Lowell. "What Prophecy Asserts, History Affirms." IE 4 (October 1901): 895-900. The Monroe Doctrine states that the United States government will overthrow any type of monarchy set up on the western continent. This corresponds with the Book of Mormon in 2 Nephi 10:11-14 where it says that no king will be set upon the American continent. The south side of the pyramid of Zochicako tells of a destruction in the land that Morris relates to the destruction before Christ appeared on the American continent (3 Nephi 8-9). [B.D.]

M.448 Morrise, Mark J. "Simile Curses in the Ancient Near East, Old Testament, and Book of Mormon." Journal of Book of Mormon Studies 2 (Spring 1993): 124-38. Also published as "Simile Curses in the Ancient Near East, Old Testament and Book of Mormon." Provo, UT: FARMS, 1981. Simile curses, a combination of the literary feature called "simile" and an oath of malediction, are common elements in ancient Near Eastern texts, including the Old Testament and Book of Mormon. Simile curses occur most often in three contexts—treaties, religious covenants, and prophecies. A Book of Mormon example of a simile curses is found in Alma 44:1-4 where the simile "even as this scalp has fallen to the earth" is followed by the curse, "so shall ye fall to the earth." A ritualistic act or visual action often accompanies the curse, such as rending garments, felling a tree, or breaking a weapon, making the symbolism of the curse more effective. The attestation of simile curses in the Book of Mormon may suggest a historical connection between the new world scripture and the ancient records of the old world. [D.W.P.]

M.449 Morrish, William John. The Latter-day Saints and the Book of Mormon. A Few Words of Warning from a Minister to His Flock. Ledbury, England: J. Gibbs Jr., September 1840. As a minister concerned to protect his congregation against "all erroneous and strange doctrines, contrary to God's word," the author tells the popular Spaulding-Ridgon story as the explanation for the Book of Mormon. The Book is a deception, and its doctrines are contrary to the true Gospel. [D.M.] 
M.450 Morrish, William John. The Latter-day Saints and the Book of Mormon. A Few Words of Warning from a Minister to His Flock. Ledbury, England: J. Gibbs Jr., 15 October 1840. An argument against the LDS and the Book of Mormon, warning people against the movement. Explains the contents of the Book of Mormon. [D.M.]

M.451 Morrow, Cherry L. "My Nonmember Missionary." Ensign 19 (July 1989): 53-54. Personal conversion story based upon the Book of Mormon. The author was given a Book of Mormon by a nonmember friend. After reading and praying about the contents of the book Morrow became a member of the Church of Jesus Christ of Latter-day Saints. [A.C.W.]

M.452 Mortimer, A. E. "Slanderers Unmasked." SH 48 (24 July 1901): 597-600. Prominent leaders of non-LDS churches were enraged against the Book of Mormon and polygamy. They set forth accusations that Spaulding had written the manuscript that had become the Book of Mormon and that Joseph Smith was a fraud. The accusations were put to rest when the Spaulding manuscript was found and placed in Oberlin College by President Fairchilds in 1884-85. A debate was held in which Elder R. C. Evans defended the Book of Mormon and confounded those opposed to the book. [J.W.M.]

M.453 Mortimer, Wm. James. "The Coming Forth of the LDS Editions of Scripture." Ensign 13 (August 1983): 35-41. An account of the work that led to the publication of the LDS edition of the King James Version of the Bible, and new editions of the Book of Mormon, the Doctrine and Covenants, and the Pearl of Great Price. [S.P.S.]

M.454 Morton, F. W. "Visit To Miner's Hill: One of the Places Celebrated in the History of the Mormons." Chicago Times: n.p., n.d. Joseph Smith pretended to find gold plates and the Urim and Thummim in Miner's Hill (Hill Cumorah). In reality he took the book from Spaulding's manuscript and engaged Oliver Cowdery as an accomplice in his scheme. Martin Harris was a dupe who bore the expense of publication. Harris's intelligent wife saw through the scheme and burned the manuscript. [J.W.M.]

M.455 Morton, William A. "The Bible and the Book of Mormon." MS 83 (July 1921): 468-71. Includes a very lengthy quote of the book, God's Message to the Human Soul, by John Watson. The Bible's main theme is the fellowship of man with God. The same can be said of the Book of Mormon. To show this the author quotes 1 Nephi 6:4-6 and Moroni 10:30-32. [B.D.]

M.456 Morton, William A. "The Book of Mormon in Prophecy." MS 69 (16 May 1907): 305-11. The author's purpose is to "prove, from the holy scriptures, the divine authenticity of the Book of Mormon." The Book of Mormon peoples are a fulfillment of the prophecies in Deuteronomy 28:63-64, and Genesis 49:22, 26; Christ's visit to America is a fulfillment of John 10:16; and the coming forth of the Book of Mormon a fulfillment of Isaiah 29:4-6; 45:8, Psalm 85:11, Ezekiel 37:16-19, Isaiah 29:11-12, and Revelation 14:6, 7. [A.T.]

M.457 Morton, William A. Book of Mormon Ready References. Salt Lake City: Geo. Q. Cannon \& Sons, 1898. [R]1914. A collection of passages from the Book of Mormon that deal with subjects incidental to the restored gospel, such as the Atonement and the gathering of Israel. Includes "traditions and discoveries confirming the Book of Mormon." [D.M.]

M.458 Morton, William A. A Brief Concordance to the Book of Mormon. Independence, MO: Church of Jesus Christ of Latter Day Saints, 1919. Selected words, verse citations, and scriptural phrases are featured in this 83-page concordance to the Book of Mormon. [D.W.P.] 
M.459 Morton, William A. "Concerning the Testimony of the Three Witnesses." MS 84 (7 September 1922): 570-71. The author responds to an article that claimed that the Three Witnesses "afterwards renounced Mormonism and said that their testimony was false." The Witnesses never denied their testimony of the Book of Mormon. [M.D.P.]

M.460 Morton, William A. From Plowboy to Prophet: Being a Short History of Joseph Smith for Children. Salt Lake City: Deseret Book, 1958. An illustrated story book for children, provides a narrative of the coming forth of the Book of Mormon. [J.W.M.]

M.461 Morton, William A. 'Gems' from the Book of Mormon and Doctrine and Covenants. Salt Lake City: n.p., 1925. A quote book made up of selected passages from the Book of Mormon and the Doctrine and Covenants, useful for preparing speeches and lessons. [D.M.]

M.462 Morton, William A. "A Little More Evidence." MS 70 (13 August 1908): 513-17. Those who refuse to believe the Book of Mormon because Joseph Smith did not show the plates to more witnesses are not much different than the Jews who would not believe the resurrection because Jesus did not show himself to them. Believing the Solomon Spaulding theory is foolish. The true story about Martin Harris's visit to Professor Anthon is explained. [J.W.M.]

M.463 Morton, William A. Mother Stories from the Book of Mormon. Salt Lake City: W. A. Morton, 1911. Twenty stories from the Book of Mormon designed for children. [D.M.]

M.464 Morton, William A. "Objections to the Book of Mormon Answered." MS 83 (13 October 1921): 641-45. Morton responds to three objections to the Book of Mormon. Mr. Rought Brooks of the Burnley News maintains that the Book of Mormon is weakened because Joseph Smith used a "peek-stone" to search for money, and the Book of Mormon mentions the use of "precious steel," domesticated horses, cows and oxen, and the compass. Morton counters that the Chinese used magnetic directors in 2634 B.C., ancient iron remains have been dug up in the New World, as have remains of horses.

Buffaloes are domesticated cows and oxen gone wild. [B.D.]

M.465 Morton, William A. "Why I Believe The Book of Mormon To Be The Word Of God." MS 83 (8 September 1921): 561 66. A testimony of the Book of Mormon. The Spaulding theory is absurd. Spaulding was a Presbyterian minister who would never preach against infant baptism as is preached in Moroni 8:90-21. Joseph Smith translated the Book of Mormon by the aid of God. There are many prophecies relating to the Book of Mormon in the Bible: Genesis 49:22-26, Isaiah 29:4, 11-14, Psalms 85:11, Ezekiel 37:15-20, John 10:14-16 ,and Revelations 14:6-7. [B.D.]

M.466 Morton, William A. Why I Believe the Book of Mormon to Be the Word of God. Salt Lake City: Church of Jesus Christ of Latter-day Saints, 1918. [R]1925, 1949, 1957. Also "Why I Believe the Book of Mormon to Be the Word of God." In Handbook of the Restoration, 392-411. Independence, MO: Zions, 1944. A testimonial of the truthfulness of the Book of Mormon. Discusses the origin of the Book of Mormon and uses the Bible to prove the Book of Mormon to be of God. The Bible prophesies of the Book of Mormon, and the Lord gave eleven witnesses to verify its authenticity. The Book of Mormon assists in the solving of theological problems. [L.D.]

M.467 Morton, William A. "Why the Plates of the Book of Mormon Were Not Shown to the World." Young Woman's Journal 24 (October 1913): 613-15. The gold plates were not/are not available for inspection because acceptance of the 
Book of Mormon is a matter of faith. Those predisposed to disbelieve the Book of Mormon would not be converted to the Gospel even if they saw the plates. [D.M.]

M.468 Moss, James R. "Six Nephite Judges—a Study in Integrity." Ensign 7 (September 1977): 61-65. Evaluates and praises the integrity of several Nephite judges. Brings out four principles that they observed: (1) law, not personality, authority or force, governs society; (2) law was to be determined by the voice of the people; (3) prophets as God's agents communicate proper principles of law; (4) laws were established through a spiritual foundation. [D.M.]

M.469 Moss, Robert H. The Abridger, A Novel of Mormon. Salt Lake City: Acme, 1989. A novel based on the life and character of the prophet Mormon. [D.M.]

M.470 Moss, Robert H. I Nephi-A Novel of the Sons of Lehi. Bountiful: Horizon, 1984. A novel dealing with the life and ministry of Nephi, the first author of the Book of Mormon. [D.M.]

M.471 Moss, Robert H. That I Were an Angel, A Novel of Alma the Younger. Salt Lake City: Acme, 1987. A novel that retells the doings of Alma the Younger-his experiences with his father in Helan, his conversion, his friendship with the sons of Mosiah, and his dramatic missionary experiences. [D.M.]

M.472 Moss, Robert H. Title of Liberty, A Novel of Helaman and Moroni. Salt Lake City: Acme, 1988. A fanciful set of scenarios in novel form revolving around the lives of Helaman and Captain Moroni. [D.M.]

M.473 Moss, Robert H. Valiant Witness, A Novel of Moroni. Bountiful: Horizon, 1954, 1989. Based upon scriptural and historical sources, this fictional narrative of the life and mission of the angel Moroni links the prophet Moroni with the legends surrounding the "pale one" of Indian legend. [J.W.M.]

M.474 Moss, Robert H. The Waters of Mormon, A Novel of Alma the Elder. Bountiful, UT: Horizon, 1986. A novel based on the writings of Alma the Elder in the Book of Mormon. [L.D.]

M.475 Moss, Wayne S. "Book of Mormon Doctrine about American Nation Was Factor in Conversion." CN 58 (31 December 1988): 10. A conversion story. Upon reading the Book of Mormon, the author was intrigued by references to American history that paralleled his beliefs about the inspired constitution. [J.W.M.]

M.476 Mowbray, C. P. Ancient American Civilization: Ruins, Hieroglyphs, Writings, etc. South Africa: South African Mission, 1932. A missionary tract that describes some of the ruins of Yucatan and Guatemala. Presents an overview of the contents of the Book of Mormon. [D.W.P.]

M.477 Moyle, Henry D. "He Saw the Golden Plates." Instructor 95 (July 1960): 226-27, 229. An account of an interview between David Whitmer and the author's father, James $\mathrm{H}$. Moyle, in which Whitmer reaffirmed the validity of the plates and the angel who showed them to him. [B.D.]

M.478 Moyle, Henry D. "To the End He Held that He Saw the Golden Plates." Instructor 95 (July 1960): 226-27, 229. Contains a reproduction of the testimony of the Three Witnesses. David Whitmer, after being excommunicated from the Church, still testifies of the truthfulness and divinity of the Book of Mormon. [L.D.] 
M.479 Moyle, James H. "Authenticity of the Book of Mormon." DN Church Section (29 October 1927): 8, 10. Discusses the Israelite origin of the Indians, Ezekiel's prophecy of two records, the horse, elephant, agriculture, cement, Indian traditions, archaeological items, and other evidences for the Book of Mormon. [A.C.W.]

M.480 Moyle, James H. Untitled talk. CR (April 1929): 18-22. Moyle writes of archaeological evidence of the Book of Mormon. Doctor Spinden of the Peabody Museum of Boston proclaimed that the excellence of cloth manufacture in ancient Peru was not equaled by any other nation of that time. The Book of Mormon explains clearly the high culture to which the ancient Americans attained. [B.D.]

M.481 Moyle, James H. Untitled talk. CR (April 1930): 118-23. When returning home from the University of Michigan in 1885 Moyle spoke with David Whitmer. Whitmer affirmed his testimony of the Book of Mormon. [B.D.]

M.482 Mulder, William. "The Mormon Gathering." In Mormonism and American Culture, edited by Marvin S. Hill and James B. Allen, 87-100. New York: Harper and Row, 1972. The Book of Mormon was a "portent and symbol" of American culture. As a "narrative of ancient religious migration," it was America's migration story and prepared the way for the modern Mormon migration. The Book of Mormon contained the "gospel of the gathering." [J.W.M.]

M.483 Mulholland, David H. A Reading Guide to the Book of Mormon. Salt Lake City: Deseret Book, 1989. A reading guide and study aid that asks questions of the Book of Mormon chapter by chapter. Answers are given in the back. This work is reviewed in G.133. [D.M.]

M.484 Mullen, Robert. The Mormons. London: W. H. Allen, 1967. As part of chapter three, "Pageant in Palmyra," the author relates the story of Moroni's visit to the Prophet Joseph Smith and some of the scenes that relate to the Hill Cumorah Pageant. [J.W.M.]

M.485 Mulliner, H. L. "Internal Evidences of the Truth of the Book of Mormon." IE 9 (October 1906): 913-23. Provides several examples to show that the Book of Mormon taught against many of the popularly held views and practices of Joseph Smith's day. He, therefore, was not an impostor who desired to have his views accepted and approved. [D.M.]

M.486 Murphy, Rondo A. “The Book of Mormon.” In Murphy's Relativity of Knowledge, 72-89. New York: Carlton Press, 1976. Though the original text of the Book of Mormon has been altered in later editions to reflect Joseph Smith's views on plural marriage and multiple gods, Mosiah 15:1-9 teaches of a monotheistic God, e.g., Christ as the Eternal Father. The author analyzes how Jeremiah connects with the Jaredites and how Ezekiel connects with the Nephites. Associating the way events happen in relationship with each other is called the relativity of knowledge. [J.W.M.]

M.487 “Museum Walls Proclaim Fraud of Mormon Prophet." New York Times Magazine Section (29 December 1912): 1, 3. Article mocks Joseph Smith's claims that he translated the Book of Mormon under the inspiration of God, or that he had received gold plates. As proof that the Book of Mormon is fraudulent, Reverend F. S. Spalding of Utah's Episcopal Church contacted eight renowned Egyptologists who state that the facsimiles are poorly copied and the translation was inept. Smith's work is compared to artifacts found in the Metropolitan Museum in New York. [J.W.M.] 
M.488 Myer, Janet R. "Mexican Diary." In Recent Book of Mormon Developments; Articles From the Zarahemla Record, 1:120-21. Independence, MO: Zarahemla Research Foundation, 1984. The author describes a trip she took to Mesoamerica, reports some supernatural experiences, and writes that she desires to live in accordance with the principles of the Book of Mormon so that the Lord will reveal the sealed portion of the Book of Mormon. [B.D.]

M.489 Myer, Percy L. "The Bible Reveals the True Month and Day of the Birth of Christ." In Treasures of Knowledge, edited by Percy Livingstone Myer, 1:1-52. Caldwell, NJ: n.p., 1945. Discusses various evidences in the Bible, Book of Mormon, and writings of Josephus that pertain to the birthdate of Christ. [L.D.]

M.490 Myer, Percy L. The Three Witnesses Testify: A Doctrinal Treatise Pertaining to the One God Referred to in the Testimony of the Three Witnesses to the Book of Mormon. Caldwell, NJ: Vanity, 11 September 1958. Argues for the belief in monotheism (one God) on the basis of a statement of the Three Witnesses and selected passages from the Book of Mormon. [D.M.] 
N.

N.001 N., W. N. " 'Then Shall They Rejoice.'” MS 91 (31 January 1929): 72-73. Describes episodes in which modern-day Lamanites of Mexican descent rejoiced upon receiving the Book of Mormon. [R.H.B.]

N.002 Nackos, Louis J. "Judah in the Days of Jeremiah and Lehi." In Papers of the Fifteenth Annual Symposium on the Archaeology of the Scriptures, edited by Ross T. Christensen, 30-37. Provo, UT: Brigham Young University, 1964. Explores the events that led up to the destruction of Jerusalem and the reign of Zedekiah who was king when Lehi left Jerusalem. Lehi was one of the prophets that the Lord sent to call the people to repentance. Accounts found by archaeologists suggest that the Israelites were confident that no harm would come to them in spite of the prophets' warnings. [J.W.M.]

N.003 "Nauvoo and Deseret: Imposture and History of the Mormons." International Magazine of Literature, Art, and Science 4 (1 December 1851): 577-87. Reprinted in The National Magazine 6 (June 1854): 481-89. Claims that Joseph Smith and Sidney Rigdon entered into an early conspiracy that led to the Book of Mormon. Discusses the role of the Three Witnesses, referring especially to the "feeble and superstitious mind" of Martin Harris. [D.M.]

N.004 Neal, Harry Edward. Before Columbus: Who Discovered America? New York: Julian Messner, 1981. In a work designed for youth the author looks at several theories regarding who first discovered America. Considers Columbus, Huishen, St. Brendan, Leif Ericsson, John Cabot, Norsemen, the Nephites-but does not provide a conclusion. [D.W.P.]

N.005 Neal, H. R. The Stick of Ephraim vs. the Bible of the Western Continent, or, the Manuscript Found vs. the Book of Mormon. Cincinnati: n.p., 1899. Polemical tract stating that Joseph Smith is so closely tied to the Book of Mormon that if one were proved false, it would prove the other false. Finds that the origin of the Book of Mormon lies in the Spaulding manuscript. Provides historical accounts by Joseph Smith, Oliver Cowdery, and others concerning the first vision and the coming forth of the Book of Mormon. Demeans the idea of the three Nephite disciples who are claimed to still live. [J.W.M.]

N.006 Neal, Nellie W. A Song from the Dust: A Poetic Version of the Book of Mormon. Ogden, UT: by the author, 1970. Author rewrites in poetic version the entire Book of Mormon, employing both rhythm and rhyme. [D.W.P.]

N.007 Neal, R. B. "Book of Mormon 'Caractors' or, An Old Mormon Lie Cornered and Slaughtered." Christian Standard 44 (18 April 1908): 3-4. A polemical article against the Book of Mormon attempting to refute statements made by early Mormons regarding the Anthon episode, and also attempting to show that the 'reformed Egyptian' characters on the transcription that Martin Harris presented to Anthon were a forgery. [M.R.]

N.008 Neal, R. B. "Book of Mormon 'Caractors' vs. A Pious Forgery." Christian Standard 44 (10 October 1908): 2125. A polemical article, attempting to demonstrate that the Mormon account of Martin Harris's visit to Anthon was false and that the characters on the Anthon transcript were a forgery. [M.R.]

N.009 Neal, R. B. The Stick of Ephraim vs. The Bible of the Western Continent or the Manuscript Found vs. the Book of Mormon. Grayson, KY: R. B. Neal, 1899. A polemical work attempting to discredit the Book of Mormon. The writer wonders why Joseph Smith did not simply reproduce the lost 116 pages if they had in fact been given by inspiration. Deals also with the Spaulding manuscript. [M.R.] 
N.010 Neal, R. B. The Stick of Ephraim vs. the Bible of the Western Continent or the Manuscript Found vs. the Book of Mormon: Part II. Grayson, KY: R. B. Neal, 1899. A polemical tract against the Book of Mormon. The writer enumerates several anachronisms in the Book of Mormon and discusses the characters on the Anthon transcript, the Anthon denial, the phrase "and it came to pass," and related matters. He advocates a Spaulding origin for the Book of Mormon and attempts to discredit Mormon efforts to link biblical prophecies to the Book of Mormon. [M.R.]

N.011 Neal, R. B. The "Stone" in the "Hat". Grayson, KY: R. B. Neal, n.d. Quotes David Whitmer and John Hyde Jr. to show that Joseph Smith used a "peep stone" to receive revelation and to translate the Book of Mormon. Finds that those closest to Joseph, particularly David Whitmer, state that some revelations were of God and others were not. [J.W.M.]

N.012 Neal, R. B. The Three Nephite Apostles (No. 11 from the Sword of Laban Leaflets). Grayson, KY: American AntiMormon Association, n.d. A polemic that claims that the Doctrine and Covenants contradicts the Book of Mormon because the former says that no one on earth could translate the Book of Mormon characters, yet the Book of Mormon says that the three Nephite disciples were still alive. [D.M.]

N.013 "Nearer to God." CN 58 (31 December 1988): 16. The prophetic counsel to read the Book of Mormon daily has not been reversed. Coming nearer to God is the very reason for reading its pages. [J.W.M.]

N.014 "Needed: A Revelation about Types." ZR 59 (January/February 1992): 2-4. Types are a pattern for the future and reveal an understanding that God is in control. Every future event between the present and the millennium has been foretold through types in the scriptures. Types contained in the Book of Mormon include Lehi's journey in the wilderness, Nephites/Lamanites, warfare, and the 158 years between Mosiah as king and the coming of Christ. [J.W.M.]

N.015 Neeley, Dela Petersen. Child's Story of the Book of Mormon. 4 vols. Salt Lake City: Deseret News Press, 1949-53. Published by Deseret Book in 1987. A presentation of the Book of Mormon to young children. The stories of the Book of Mormon are dramatized and told in a simple language. [L.D.]

N.016 Negaard, Sadi. Heroes for God. 4 parts. Independence, MO: Herald House, 1961. Parts 2-3 feature Book of Mormon stories for youth, with illustrations. [D.M.]

N.017 Neill, Edward Duffield. "The Book of Mormon." Historical Magazine 6 (August 1869): 68-69. Attempts to link the Book of Mormon with the Spaulding manuscript. Joseph Miller, an acquaintance of Spaulding, recollected reading about the Amalekites marking their foreheads with red. [D.M.]

N.018 Nelson, Fred W., Jr. "The Colossal Stone Heads of the Southern Gulf Coast Region of Mexico." SEHA 103 (12 August 1967): 2-8. Analyzes the features of several stone heads discovered in Veracruz and speculates that they might belong to the Jaredite culture. A map, table, and pictures are supplied. [D.M.]

N.019 Nelson, Nels Lars. "The Dictionary of Slander." Mormon Point-of-View 1 (1 January 1904, 1 April 1904): 73100, 157-96. Catalogs several charges against the Mormons including the Spaulding connection to the Book of Mormon. Shows in detail how this explanation is untenable. Discusses Book of Mormon witnesses. [D.M.]

N.020 Nelson, Nels Lars. "The Harris-Anthon Episode." Mormon Point-of-View 1 (1 July 1904): 282-92. Weighs the probabilities of the viewpoints of Martin Harris and Charles Anthon with regard to their interview concerning the 
Book of Mormon characters. [D.M.]

N.021 Nelson, Nels Lars. "Human Side of the Book of Mormon." Mormon Point-of-View 1 (1 April 1904): 105-56. Treats the possibility of errors existing in the Book of Mormon. Points out that revelation coming through human media is bound to be imperfect, by the very nature of human weakness. Shows areas where mistakes might have been made by Mormon the compiler, and Joseph Smith the translator. Discusses anachronisms and affinities with the Bible in phraseology. Considers Joseph Smith's method of translating. Concludes that the Book of Mormon is a divine record. [D.M.]

N.022 Nelson, Reed. "That Book is True!" Ensign 13 (December 1983): 23. A story of divine coincidences in which a young man was exposed to the Book of Mormon and became a convert to the Church. [S.P.S.]

N.023 Nelson, Russell M. "Jesus Christ-Our Master and More." In The Book of Mormon: Helaman through 3 Nephi 8, According to Thy Word, edited by Monte S. Nyman and Charles D. Tate Jr., 1-14. Provo, UT: Brigham Young University Religious Studies Center, 1992. Comments on several Christological titles in the Book of Mormon and other scriptures. Jesus Christ is the creator and Jehovah of the Old Testament. He is the advocate with the Father, the Son of God. He is the promised Immanuel, the Anointed One, Savior and Redeemer. He is both judge and exemplar. He is the Millennial Messiah. [J.W.M.] [D.M.]

N.024 Nelson, Russell M. "Thanks for the Covenant." In Brigham Young University 1988-89 Devotional and Fireside Speeches, 53-61. Provo, UT: Brigham Young University Publications, 1989. A discussion of the Abrahamic covenant. Points out that the patriarch Joseph received the birthright in Israel and that the land allotted to him was not Canaan but the Americas. "America was to serve as the repository of sacred records written on metallic plates. It one day was to become the location for the restoration of the gospel. It was to host headquarters of the Lord's restored Church." [D.M.]

N.025 Nelson, Russell M. “A Treasured Testament." Ensign 23 (July 1993): 61-65. Declares the translation of the Book of Mormon by Joseph Smith a "marvelous miracle." The many different forms of Hebraisms in the book attest to its Semitic origins. The book stands as another testament of Christ. [S.H.]

N.026 Nelson, Steven G. Review of Dominions of the Gadiantons, by Robert Marcum. Review of Books on the Book of Mormon 4 (1992): 154. Book review.

N.027 Nelson, Ted, Glen Scott, Lyle Smith, Brenda Trimble, and Linda Trimble. "Archaeology Alert." The Witness 67 (Winter 1989): 15. Points out two different findings in Mexico that show how archaeology converges with the Book of Mormon. The two excavations uncovered a Maya Codex in a city close to San Salvador and a lost fort found in Guatemala. [L.D.]

N.028 Nelson, Ted, Glen Scott, Lyle Smith, Brenda Trimble, and Linda Trimble. "La Mojarra: A Voice from the Dust." The Witness 64 (February 1989): 4-6. A large engraved stone with hieroglyphics and a picture of a fully clothed man was discovered in the Acula River, southeast of Veracruz, Mexico in 1986. Many scholars believe the hieroglyphics represent an earlier version of the Maya language, probably Olmec. [L.D.]

N.029 "Nephi and the Exodus." Ensign 17 (April 1987): 64-65. Asserts that "one of the most important of all Hebrew motifs, the exodus cycle, is woven throughout 1 Nephi." "The exodus cycle is a pattern of enslavement and divine rescue used often in the Bible and other Jewish writings." Because Nephi was raised a Jew and knew Hebrew literary styles, he used this literary method in writing his own record. [S.P.S.] 
N.030 The Nephite Dispensation: Outlines in Theology for Use in the Church Schools of High School Grade. N.p.: LDS Church General Board of Education, November 1916. An outline of lessons presented on the Book of Mormon with suggested teaching procedures and emphasis. [J.W.M.]

N.031 The Nephite Records. Translated by Joseph Smith Jr. N.p.: The Church of Christ, 1899. Reprint of the Palmyra edition of the Book of Mormon, the Whiterites' Book of Mormon. [J.W.M.]

N.032 "Nephites." In Encyclopedia of Mormonism, edited by Daniel H. Ludlow, 3:1006. 5 vols. New York: Macmillan, 1992. A brief description of the term "Nephite" in the Book of Mormon. A Nephite is distinguished by his belief in the gospel of Jesus Christ. [B.D.]

N.033 Neser, Arlin P. "A Witness From the Holy Ghost." Ensign 14 (July 1984): 22-25. Explains how an investigator in Yugoslavia knew by looking at a German Book of Mormon, especially the pictures, and by praying that it was true, even though she was not able to read it. [D.M.]

N.034 "New and Interesting Discovery in South America." TS 5 (1 December 1844): 733-34. Reports the discovery of "extraordinary ruins" by Judge Neito in Peru. The proportions were immense with the remains of ancient dead within. It "must be the greatest building in the world in point of size." The workmanship is exquisite. This is archaeological evidence that the Book of Mormon is true. [J.W.M.]

N.035 "New Developments in Book of Mormon Research." Ensign 18 (February 1988): 12-17. A compilation of research reports on the Book of Mormon discussing such topics as Jesus Christ, law, biblical and Near Eastern studies, archaeology, anthropology, language, and literature. [L.D.]

N.036 "New Donations Slip Lists Fund for Book of Mormon." Ensign 21 (March 1991): 74-75. The new donation slips are designed to replace the Family-to-Family Book of Mormon program. The volume of books donated make it impossible for Church headquarters to place the pictures and testimonies in so many books. [J.W.M.]

N.037 “New General Fund Will Provide More Copies of Book of Mormon.” CN 60 (29 December 1990): 3. By having the Book of Mormon fund included with the tithing and fast offering slip, the First Presidency hopes to increase donations for the Book of Mormon fund. [M.R.]

N.038 The New Heresy!! An Exposure of Mormonism Shewing Its Origin, Absurdity and Impiety. Dunstable: Harper Twelvetrees, 1850?. This pamphlet, written as a conversation between "James Anxious" and his "cousin Henry," discusses the Book of Mormon and refutes the validity of the story by asserting that the book was written by Rev. Solomon Spaulding. Questions the Liahona, the Urim and Thummim, and the New and Everlasting Covenant. [J.W.M.]

N.039 A New Heresy Entitled "The Mormonites," and by Themselves, "The Latter-day Saints." London, Central Tract Depot.: Wertheimer and Co. This pamphlet purports that Spaulding was the original author of the Book of Mormon. [J.W.M.]

N.040 "New Home in the Promised Land." Friend 11 (July 1981): 21-22. For children, cartoon story of the animosity that Laman and Lemuel felt toward Nephi, and Nephi's need to leave and find a new home after Lehi's death. Depicts the way the records were kept by Lehi, Nephi, Jacob, and Enos. [J.W.M.] 
N.041 "A New Home in the Promised Land." Friend 20 (January 1990): 20-21. An illustrated story for children about the Nephites and Lamanites after they arrived at the promised land. [M.D.P.]

N.042 "New Issue of the Book of Mormon." IE 24 (February 1921): 352-54. Official announcement of the LDS church First Presidency (Heber J. Grant, Anthon H. Lund, and Charles W. Penrose) reporting a new printing of the Book of Mormon. The issue features new typesetting, larger printed type, two columns of text per page, chapter headings, and an updated footnotes and index. [A.C.W.]

N.043 "New Leather Case for Original Manuscript." CN 42 (27 May 1972): 5. Announcing a new leather case made to hold the original manuscript of the Book of Mormon. Includes a history of the original manuscript. [M.D.P.]

N.044 "New Light on the Shining Stones of the Jaredites." Provo, UT: FARMS, 1992. Research by Sandia National Laboratories produced radioluminescent light sources. These may provide light without electrical power supplies for as long as 20 years. Such technology shows a possible answer as to how the Lord touched Jared's 16 stones in response to his faith. [J.W.M.]

N.045 "The New Scripture." Relief Society Magazine 15 (January, February 1928): 46-48, 104-6. Three lesson outlines for Relief Society that focus on the prophecies concerning the Book of Mormon, its guardian messenger and his mission, the Urim and Thummim, and the method of translation. [J.W.M.]

N.046 A New Volume of Scripture! Revelations of God to the Ancient Americans. Liverpool, England: Millennial Star Office, 1890. Missionary tract presenting an overview of the contents of the Book of Mormon. [D.W.P.]

N.047 Newberry, S. "Ancient American Civilizations." Deseret Weekly 44 (4 June 1892): 771-72. Refers to an article in the June, 1892 issue of Popular Science Monthly by S. Newberry, whose description of ancient civilizations of Latin America harmonize with information in the Book of Mormon. [D.M.]

N.048 Newell, Linda King, and Valeen Tippetts Avery. “Emma and Joseph 1825-1827, The 'Elect Lady' 18271830." In Newell's and Avery's Mormon Enigma: Emma Hale Smith, Prophet's Wife, "Elect Lady," Polygamy's Foe, 15-30. Garden City, NY: Doubleday, 1984. Describes the family backgrounds of Joseph Smith and Emma Hale, and the relationship between the families. There is a detailed narration of the coming forth, translation, and publication of the Book of Mormon. [J.W.M.]

N.049 Newquist, Jerreld L. "The Western Standard." IE 62 (April 1959): 238-39, 274-82. George Q. Cannon, who established The Western Standard (newspaper) for the purpose of publishing items of interest to Latter-day Saints, tells of publishing the Book of Mormon in the Hawaiian language, which received a great deal of opposition from members of the Church in San Francisco. [J.W.W.]

N.050 Nibley, Hugh W. "Ancient Temples: What Do They Signify?" Ensign 2 (September 1972): 46-49. Reprinted in CWHN 8:265-73. Comments about the roles of ancient temples in general, with emphasis on Mesoamerican temples as centers of religion, culture, the arts, and world view. [J.W.W.]

N.051 Nibley, Hugh W. An Approach to the Book of Mormon. Salt Lake City: Council of the Twelve Apostles of the Church of Jesus Christ of Latter-day Saints, 1957. 2nd ed. Salt Lake City: Deseret Book, 1964. 3rd ed. vol. 6 of CWHN, edited by John W. Welch. Salt Lake City: Deseret Book and FARMS, 1988. This book was originally published as the lesson manual for the Melchizedek Priesthood quorums of the Church of Jesus Christ of Latterday Saints. Compares the Book of Mormon to the world of Lehi's day, Lehi's training and profession, travel, 
relations with Egypt, politics in Jerusalem and with Laban, sects living in the wilderness, the Dead Sea scrolls, the apocrypha, ancient warfare, the ideologies of intellectuals and the wicked, and the sobering message of the Book of Mormon regarding the downfall of civilizations. This work is reviewed in H.034, J.042, and in H.258. [J.W.W.]

N.052 Nibley, Hugh W. "Archaeology and Our Religion." Seventh East Press (18 January 1982): 4-7. Methodological musings on the inadequacies and interpretive pitfalls of archaeology against a setting of the general debate between science and religion. [J.W.W.]

N.053 Nibley, Hugh W. "The Atonement of Jesus Christ." Ensign 20 (July-October 1990): 18-23, 30-34, 22-26, 2631. A four-part series that emphasizes that the Book of Mormon teaches the correct principles of the Atonement. The power of resurrection is provided only by the Savior. Only the Book of Mormon teaches the fulness of the truth of the Atonement, why life is as it is, and how one may approach God to be at one with him. Since all fall short, the blood sacrifice of the Savior was the indispensable step. Atonement is both individual and collective and so God's people must be "of one heart and one mind." "The Atonement is one of the grand constants in nature." [J.W.M.]

N.054 Nibley, Hugh W. "Bird Island." Dialogue 10 (Autumn 1977): 120-23. Satirical lecture on some of the excesses and weaknesses of archaeology and theories of Book of Mormon geography. [J.W.W.]

N.055 Nibley, Hugh W. "The Book of Mormon and the Ruins: The Main Issues." Provo, UT: FARMS, 1980. Lecture notes regarding Mesoamerican ruins, pre-Columbian, American races, Cumorah, and the disappearance of ancient cultures. [J.W.W.]

N.056 Nibley, Hugh W. "Book of Mormon as a Mirror of the East." IE 51 (April 1948): 204-6, 249-51. Reprinted, without illustrations, in IE 73 (November 1970): 115-20, 122-25. Revised version appears in Lehi in the Desert (1952). Book of Mormon proper names are related to Egyptian etymologies. [J.W.W.]

N.057 Nibley, Hugh W. "The Book of Mormon as a Witness." In Nibley's The World and the Prophets. 189-96. Salt Lake City: Deseret Book, 1954. Radio talk on the Book of Mormon as a witness of continuing revelation and God's dealings with mankind. [J.W.W.]

N.058 Nibley, Hugh W. "The Book of Mormon: Forty Years After." A talk given at the Sunstone 1988 Book of Mormon Lecture Series, May 10, 1988. Reprinted in CWHN 8:533-69. Even after forty years of research, new insights are still to be found in the Book of Mormon. Examples come from the episode at the waters of Sebus, wordprinting, Enos and the princes of India, Isabel as a Phoenician name, the Zoramites as dissenters, and clear statements about God and man, riches, economics, and repentance. [J.W.W.]

N.059 Nibley, Hugh W. "Book of Mormon Near Eastern Background." In Encyclopedia of Mormonism, edited by Daniel H. Ludlow, 1:187-90. 5 vols. New York: Macmillan, 1992. The main Book of Mormon groups migrated at different times from the Near East and Asia to the Americas. External and circumstantial evidence exists to confirm such ties. Narratives discovered closely parallel recently discovered manuscripts, describe desert travel, customs, and terrain characteristics, duplicate intricate ancient coronation ceremonies, sustain the Near Eastern custom of writing on gold plates for special documents, and other unusual features. [N.K.Y.]

N.060 Nibley, Hugh W. “The Book of Mormon: True or False?” MS 124 (November 1962): 274-77. Reprinted in CWHN 8:219-42. Argues that if Joseph Smith was not telling the truth when he provided the world with the Book 
of Mormon, then he recklessly exposed his forgery and fraud to public discovery. The Book of Mormon is authentic history, not a forgery, and not a product of the tendencies of Joseph Smith's day. [J.W.W.]

N.061 Nibley, Hugh W. "The Boy, Nephi, in Jerusalem." Instructor 96 (March 1961): 84-85. Reprinted in CWHN 8:207-11. Historical fiction about the possible thoughts on a day in the life of the twelve-year-old Nephi in Jerusalem. [J.W.W.]

N.062 Nibley, Hugh W. "Censoring the Joseph Smith Story." Provo, UT: FARMS, 1961. Reprinted in CWHN 11:55101. Explains how Joseph Smith's critics in the 1840s and also Fawn Brodie rewrote Joseph's story to suit their perceptions of the Book of Mormon and the First Vision. [J.W.W.]

N.063 Nibley, Hugh W. "Christ Among the Ruins." Ensign 13 (July 1983): 14, 16-19. Compare CWHN 8:407-34. Subtitled, "A comparison of the Old World early Christian 'forty-day ministry' story with the New World 3 Nephi accounts." Compares Jesus' post-resurrection words to his disciples in Galilee with accounts in the Book of Mormon. [J.W.W.]

N.064 Nibley, Hugh W. "Christ Among the Ruins." In Book of Mormon Authorship, edited by Noel B. Reynolds, 12141. Provo, UT: Brigham Young University Religious Studies Center, 1982. Compares Jesus' words in 3 Nephi with Jesus' post-resurrection words to his disciples in Galilee as reported in several apocryphal sources. [J.W.W.]

N.065 Nibley, Hugh W. "Churches in the Wilderness." In Nibley on the Timely and Timeless, edited by Truman D. Madsen. Provo, UT: Brigham Young University Religious Studies Center, 1978. Reprinted in CWHN 8:289-327. Compares passages in the Enoch Scroll and the Manual of Discipline from Qumran with the Book of Moses and the Book of Mormon regarding the establishment of churches of anticipation, worship, baptism, and hymns. [J.W.W.].

N.066 Nibley, Hugh W. "Columbus and Revelation." Instructor 88 (October 1953): 319-20. Reprinted in CWHN 8:49-53. Relevant to 1 Nephi 13:11-12, this brief article gives historical evidence showing that Columbus was moved upon by the Holy Ghost. [J.W.W.]

N.067 Nibley, Hugh W. "The Comparative Method." IE 62 (October-November 1959): 744-47, 759, 848, 854, 856. Reprinted in CWHN 8:193-206. Rejects the idea that the Book of Mormon copies Ethan Smith's View of the Hebrews. [J.W.W.]

N.068 Nibley, Hugh W. "Dark Days in Jerusalem: The Lachish Letters and the Book of Mormon." In Book of Mormon Authorship, edited by Noel B. Reynolds, 103-20. Provo, UT: Brigham Young University Religious Studies Center, 1982. Makes a comparison between the Lachish Letters, discovered in 1935 and translated by Harry Torczyner, and the narrative found in 1 Nephi 1. Finds many parallels: the same time and place framework, similar classes of society confronted with same difficult circumstances, similar writing techniques, and other items. [J.W.M.]

N.069 Nibley, Hugh W. “Dear Friend of the Book of Mormon." Provo, UT: FARMS, 1983. An open letter praising the formation of the Foundation for Ancient Research and Mormon Studies as an important work, providing an opportunity for serious study of the Book of Mormon. [J.W.W.]

N.070 Nibley, Hugh W. "Eduard Meyer's Comparison of Mohammed and Joseph Smith." Provo, UT: FARMS, 1962. Rough notes on Meyer's 1912 book on the unique religious origins of Mormonism. [J.W.W.] 
N.071 Nibley, Hugh W. "Freemen and Kingmen in the Book of Mormon," in CWHN 8:328-79. Captain Moroni was a man of peace. Analyzes war, government, management, the political tactics and strategies of Amalickiah, and the constant struggle between those who follow the ways of righteousness and those who promote wicked political agendas. Includes notes about similar political problems in ancient Mesoamerican societies. [J.W.W.]

N.072 Nibley, Hugh W. "The Grab Bag." IE 61 (July 1959): 530-33, 446-48. Reprinted in CWHN 8:170-81. Shows that Book of Mormon critics have made an art of explaining a very large and complex text by focusing only on a very small part of it. [J.W.W.].

N.073 Nibley, Hugh W. "How to Write an Anti-Mormon Book." In A Seminar on the Prophet Joseph Smith, 30-41. Provo, UT: Brigham Young University, 17 February 1962. A penetrating satire on the foibles of typical antiMormon publications. [J.W.W.]

N.074 Nibley, Hugh W. "Howlers in the Book of Mormon." MS 125 (February 1963): 28-34. Reprinted in CWHN 8:243-58. Lists over twenty Book of Mormon points that may have seemed ridiculous in 1830 but that "appear very different" in light of modern scholarship, including transoceanic voyaging, gold plates, steel, elephants, coins, names, literary and ritual patterns, execution, modes of prophecy and revelation. [J.W.W.]

N.075 Nibley, Hugh W. "Just Another Book." IE 62 (May-July 1959): 345-47, 388-91, 412-13, 501-3, 530-31, 565. Reprinted in CWHN 8:148-69. Shows ways in which the Book of Mormon was out-of-sorts with the nineteenth century and thus not just another book of that time. [J.W.W.]

N.076 Nibley, Hugh W. "Kangaroo Court." IE 62 (March-April 1959): 145-48, 184-87, 224-26, 300-301. Reprinted in CWHN 8:127-47. A witty exposŽ of anti-Mormon methods of Book of Mormon criticism. [J.W.W.].

N.077 Nibley, Hugh W. "The Lachish Letters: Documents from Lehi's Day." Ensign 10 (December 1981): 48-54. Reprinted in CWHN 8:380-406. Suggests connections between the Lachish letters written at the time Jerusalem was destroyed by the Babylonians and events associated with Lehi's departure. Includes political pressures on prophets, types of proper names, and a possible identification of Mulek. [J.W.W.]

N.078 Nibley, Hugh W. "Last Call: An Apocalyptic Warning from the Book of Mormon." Sunstone 12 (January 1988): 14-25. Reprinted in CWHN 8:498-532. The Book of Mormon's message of Christ specifically is to "show" and "convince" by a bulwark of historical evidence through which the doctrine must be considered. The ascension motif-righteous man rising above the wicked world by supplicating God-is repeated over and over. It is symbolic and warns mankind to spiritually break away from his real enemy, himself, in the world of sin. [J.W.M.]

N.079 Nibley, Hugh W. "Lehi in the Desert." IE 53 (January-October 1950): 14-16, 66-72, 102-4, 155-59, 200-2, 222, 225-26, 229-30, 276-77, 486-87, 516-19, 566-67, 587-88, 640-42, 670, 706-8, 744, 804-6, 824, 826, 828, 830. Reprinted, without illustrations, as the first half of Lehi in the Desert and the World of the Jaredites. Salt Lake City: Bookcraft, 1952. Reprinted, with illustrations, in CWHN 5:1-149. A classic reflection on Lehi's world in Arabia: poetry, tree of life, family affairs, politics, imagery, travel, tents, and foods. One of the first attempts to test the Book of Mormon against known geographical and cultural details in the regions where Lehi probably traveled in the Old World. [J.W.W.]

N.080 Nibley, Hugh W. Lehi in the Desert and the World of the Jaredites. Salt Lake City: Bookcraft, 1952. Reprinted in 1980, with an index prepared by Gary P. Gillum, and again in 1987, with corrections, full indexing, and with the original illustrations restored. Also in CWHN 5:1-282. A reflection on Lehi's world in Arabia. Most of these 
materials appeared in IE 1950-1952 (original illustrations and some other materials are not included in the 1952 edition). [J.W.W.]

N.081 Nibley, Hugh W. Lehi in the Desert, The World of the Jaredites, There Were Jaredites. Vol. 5 of CWHN, edited by John W. Welch, with Darrell L. Matthews and Stephen R. Callister. Salt Lake City: FARMS and Deseret Book, 1988. Three works, previously published separately, which examine evidences of Old World connections reflected in the Book of Mormon. See separate annotations. This work is reviewed in H.333 and in R.257. [J.W.M.]

N.082 Nibley, Hugh W. "The Lesson of the Sixth Century B.C." Provo, UT: FARMS, 1956. Lehi, Solon, Thales, Buddha, Confucius, Lao Tze, Zarathustra, and Pythagoras are discussed as contemporaries living in an important and booming "axial" era, the seminal 6th century B.C. [J.W.W.]

N.083 Nibley, Hugh W. “The Liahona's Cousins." IE 64 (February 1961): 87-89, 104-6, 108-11. Reprinted in CWHN 7:251-63. Analysis of the Liahona, especially in light of Arabic divination arrows. Proposes an etymology for this name. [J.W.W.].

N.084 Nibley, Hugh W. "Literary Style Used in the Book of Mormon Insured Accurate Translation." DN Church Section (29 July 1961): 10, 15. Reprinted in CWHN 8:212-18. Discusses why the Book of Mormon uses King James English to communicate effectively with Joseph Smith's audience. [J.W.W.]

N.085 Nibley, Hugh W. "Mixed Voices: A Study in Book of Mormon Criticism." IE 62 (March-November 1959): 145-48, 184-87, 224-26, 300-1, 345-47, 388-91, 412-13, 501-3, 530-33, 546-48, 565, 590-92, 610, 612, 61415, 744-47, 759, 848, 854, 856. Reprinted in CWHN 8:127-206. A series about the Book of Mormon and its nineteenth-century American critics. David Marks, who heard the story of the book from the Whitmer family, dismissed it as deception that he could not support by purchasing the book. Alexander Campbell, Origen Bacheler, E. D. Hose, and Professor Rafinesque joined him. The critics could not believe in angelic visits, visions, and further revelation from God. They criticized the grammar and content, rebuked the translator as a fraud, a liar, and a money-digging, peep-stone looking cheat. One critic relied upon the words of another without checking to see if there was any truth. [J.W.W.]

N.086 Nibley, Hugh W. "The Mormon View of the Book of Mormon." Concilium Int'l Revue of Theology 10 (December 1967): 82-83. Also in Concilium: Theology in the Age of Renewal 30 (1968): 170-73, and in other foreignlanguage editions of this Catholic journal in French, 151-53; Portuguese, 144-47; German, 855-56. Reprinted as "The Book of Mormon: A Minimal Statement," in Nibley on the Timely and the Timeless, 149-53. Provo, UT: Brigham Young University Religious Studies Center, 1978. Reprinted in CWHN 8:259-64. A summary statement of the content and purpose of the Book of Mormon prepared for Concilium, a journal devoted to an examination of the Christian scriptures. Explains it as an ancient record, a companion to the Bible with revealed Christianity before Christ and 40-day literature from the appearance of Christ among the Nephites. [J.W.W.]

N.087 Nibley, Hugh W. "New Approaches to the Book of Mormon Study." IE 56, 57 (November 1953-July 1954): 830-31, 859-62, 919, 1003, 30-32, 41, 88-89, 125-26, 148-50, 170, 232-33, 246, 248-50, 252, 308-9, 326, 330, 389, 447-48, 450-51, 506-7, 521. Reprinted in CWHN 8:54-126. Vividly displays internal and external evidences to test whether the Book of Mormon is or is not a forgery, using the standard scholarly criteria for detecting forged writings. Very insightful comments on methodology for studying the Book of Mormon, evaluating evidence, using newly discovered documents, metal plates, literary criticism, poetry, lower criticism, and history. Also comments on animals, weights and measures, and the use of the Bible in the Book of Mormon. [J.W.W.] 
N.088 Nibley, Hugh W. "Of The Book of Mormon." In Of All Things!: Classic Quotations from Hugh Nibley, edited by Gary P. Gillum, 125-59. Salt Lake City: Deseret Book and FARMS, 1993. Using quotes from various sources, the editor brings to the reader a greater understanding of Nibley's perception of the Book of Mormon. The quotes range from humorously witty to serious appraisals of the great value of the book. Nibley's testimony of the Book of Mormon is clearly put: "It is carefully organized, specific, sober, factual, and perfectly consistent." [J.W.M.]

N.089 Nibley, Hugh W. "Old World Ritual in the New World." In Nibley's An Approach to the Book of Mormon, 24356. Salt Lake City: Deseret Book, 1957. Compares King Benjamin's speech with the ancient Year Rite festivals. [J.W.W.]

N.090 Nibley, Hugh W. "Paul and Moroni." Letter to Christianity Today 5 (22 May 1961): 727. A response to a letter by C. Sumter Logan of the Trinity Presbyterian Church in Ogden, Utah, that had appeared in Christianity Today 5 (27 March 1961): 551. Comments on Moroni 7 and Paul's praise of charity in 1 Corinthians 13. [J.W.W.]

N.091 Nibley, Hugh W. "The Prophetic Book of Mormon." Seventh East Press 1 (27 March 1982): 6-8, 16-17. Reprinted in CWHN 8:435-69. This 1981 lecture relates present-day political circumstances to the "polarizing" that caused the collapse of the Nephites and that has been a major cause in the sudden and complete downfall of many civilizations. This work is reviewed in P.212. [J.W.W.]

N.092 Nibley, Hugh W. The Prophetic Book of Mormon. Vol. 8 of CWHN, edited by John W. Welch. Salt Lake City: Deseret Book and FARMS, 1989. Explores the many ways in which the Book of Mormon is a true, prophetic, historical, and apocalyptic book. [J.W.W.]

N.093 Nibley, Hugh W. "Rediscovery of the Apocrypha." Provo, UT: FARMS, 1965. Transcript of a talk about patterns of prophecy and early Israelite traditions about the plan of salvation found in newly discovered apocryphal writings and in the Book of Mormon. [J.W.W.]

N.094 Nibley, Hugh W. "Rediscovery of the Apocrypha and the Book of Mormon." In Temple and Cosmos, edited by Don E. Norton, 212-63. Salt Lake City: Deseret Book, 1992. Nibley describes images that are important in the Apocrypha and the Book of Mormon. The imagery discussed is as follows: desert imagery, the plan, heavenly treasures, apocalyptic imagery, the right and left hand of God, the white garment, the strait way, the filthy and pure waters, looking beyond the mark, flight into the wilderness, the tree of life, Zenos/Zenez, Olive culture, Redeemer of Israel, likening the scriptures, ritual war, and kings and covenants. [B.D.]

N.095 Nibley, Hugh W. "Review essay of Bar-Kochba: The Rediscovery of the Legendary Hero of the Second Jewish Revolt against Rome, by Yigael Yadin." BYU Studies 14 (Autumn 1973): 115-26. Reprinted in CWHN 8:274-88. Points out that Yadin's discoveries seem to show, among other things, that the presumably feminine name Alma was also used by Jews as a masculine name, just as it was in the Book of Mormon. Draws a number of parallels between the Bar Kochba artifacts and the Lehi colony. Compares materials in the Book of Mormon about Lehi, Captain Moroni, and the name Alma with Palestinian warfare and practices from the first century A.D. [J.W.W.]

N.096 Nibley, Hugh W. Review of Our Book of Mormon, by Sidney B. Sperry. IE 51 (January 1948): 42. Book review.

N.097 Nibley, Hugh W. "Scriptural Perspectives on How to Survive the Calamities of the Last Days." BYU Studies 25 (Winter 1985): 7-27. Reprinted in CWHN 8:470-97. Repentance, humility, and righteousness, not weapons, are essential for surviving the last days. The Nephite response to war and to challengers is analyzed. Good guys and bad guys are identified by individual religious virtues. [J.W.W.] 
N.098 Nibley, Hugh W. Since Cumorah. Vol. 7 of CWHN, edited by John W. Welch. Salt Lake City: FARMS and Deseret Book, 1967, [R]1988. Examines the Book of Mormon in light of the discoveries at Qumran, Nag Hammadi, and throughout the ancient world, challenging many traditional scholarly assumptions and opening avenues of inquiry regarding the Book of Mormon and its present-day implications. This work is reviewed in M.292, S.634, T.339, E.055, and in M.306. [J.W.W.]

N.099 Nibley, Hugh W. "Since Cumorah: New Voices from the Dust." IE 67, 68, 69 (October 1964-December 1966): 816-21, 844-47, 924-28, 974-75, 977,78, 980-83, 1032, 35, 1126-28, 34-37, 60-64, 100-103, 146-47, 210-13, 227, 228, 230-32, 234, 308-11, 326, 328-32, 406-7, 444, 482-83, 574-76, 616-17, 916-17, 974-77, 1013, 1040, 1090-91, 1165-68, 32-34, 44-46, 118-22, 196-97, 334-36, 419-20, 422, 424, 582-83, 636-38, 71012, 794-95, 799-800, 802, 804-5, 884-85, 974-75, 1028-31, 1084-85, 1162-65. Reprinted as CWHN 7. The changing attitudes of biblical scholars toward basic questions about scripture allow room for claims made by the Book of Mormon. Discusses external evidences, the primitive church, Lehi, Zenos, the olive tree, and the Dead Sea Scrolls. [J.W.W.]

N.100 Nibley, Hugh W. "The Stick of Judah and the Stick of Joseph." IE 56 (January-May 1983): 16-17, 38-41, 9091, 123-27, 150-52, 191-95, 250, 267, 331-32, 334, 336, 338, 341, 343, 345. Reprinted in CWHN 8:1-48. Writing on tally sticks is related to Ezekiel 37 and the meaning of the prophecy that two sticks shall become one. Extensive commentary on the traditional interpretations given to Ezekiel 37. [J.W.W.]

N.101 Nibley, Hugh W. "A Strange Order of Battle." In Nibley's An Approach to the Book of Mormon, 169-80. Salt Lake City: Deseret Book, 1957. Reprinted as a FARMS paper, 1964. Compares Captain Moroni's military practices, title of liberty, and oath, with descriptions from the Near East. [J.W.W.].

N.102 Nibley, Hugh W. "Strange Ships and Shining Stones." In A Book of Mormon Treasury: Selections from the Papers of the Improvement Era, 133-51. Salt Lake City: Bookcraft, 1959. Included in Nibley's An Approach to the Book of Mormon, 2nd ed. Compares the ships of the Jaredites with boats from Mesopotamia and the Gilgamesh Epic, and the sixteen stones of the brother of Jared with shining stones reported in the pseudepigrapha, Jerusalem Talmud, and by Greek historians. [J.W.W.]

N.103 Nibley, Hugh W. "Strange Ships and Shining Stones (A Not So Fantastic Story)." IE 59 (July-September 1956): 509-11, 415, 516, 566-67, 602, 630-32, 672-75. Revised as a chapter in An Approach to the Book of Mormon, 340-58, 2nd ed., 1964. Demonstrates some striking similarities between the Jaredite account of their barges with sixteen light-giving stones and old legends about Noah's ark and epic literature from Babylonia. [J.W.W.].

N.104 Nibley, Hugh W. Teachings of the Book of Mormon: Semester 1-4. Provo, UT: FARMS, 1989-1990. Tanscripts of lectures by Hugh Nibley presented to an Honors Book of Mormon class at Brigham Young University during the years 1989-1990. Semester 1 covers 1 Nephi-Mosiah 5; semester 2 covers Mosiah 6-Alma 41; semester 3 covers Alma 45-3 Nephi 20; semester 4 covers the rest of the book. Contains historical, biblical, and traditional insights from ancient times that assist in understanding events and doctrine within the Book of Mormon. [B.D.]

N.105 Nibley, Hugh W. "There Were Jaredites." IE 59-60 (July 1956-February 1957): 509-11, 514, 516, 566-67, 602, 630-32, 672-75, 710-12, 745-53, 818-19, 857-58, 906-7, 26-27, 41, 94-95, 122-24. Reprinted in CWHN 5:283-454. This wide-ranging series discusses the "epic milieu" of the second millennium B.C. and places the Jaredites in their historical context alongside the Babylonians, Egyptians, early Greeks and others. Makes a comparison between the Book of Ether and ancient writings of Babylon, Egypt, Sumer, and others. The description 
of the Jaredite boats seem to resemble the boat of Ut-Napitshtim who was the Sumerian counter-part of Noah. Old Jewish and even older Indian sources record the use of shining stones that protect the owner beneath the water. These have been traced back to Babylonian tales of the deluge. Since the Jaredite record reports that their boats were patterned after Noah's ark, ancient myths that surely have their foundation in real events help to provide greater understanding of the book of Ether. The book of Ether meets all the criteria of epic traditions of heroic societies. The remains of heroic societies are difficult to identify. [J.W.W.]

N.106 Nibley, Hugh W. Tinkling Cymbals and Sounding Brass: The Art of Telling Tales about Joseph Smith and Brigham Young. Vol. 11 of CWHN, edited by David J. Whittaker. Salt Lake City: Deseret Book and FARMS, 1992. A collection of answers to the works of Mormon critics Fawn Brodie, J. B. Turner, John C. Bennett, Henry Caswell, Pomeroy Tucker, and many others, pointing out their inconsistencies, and unconfirmed and distorted historical claims. Their attacks are confirmed by unreliable witnesses. Joseph Smith's opponents often played by no rules of fairness and often changed the rules as they argued. [J.W.M.]

N.107 Nibley, Hugh W. "Two Shots in the Dark: i. Dark Days in Jerusalem; ii. Christ among the Ruins." In Book of Mormon Authorship: New Light on Ancient Origins, edited by Noel B. Reynolds, 103-42. Provo, UT: Brigham Young University Religious Studies Center, 1982. Reprinted in CWHN 8:380-434. Presents information about the names used and the political and the social conditions of Lehi's Jerusalem based on contemporaneous messages written on pottery found at Lachish. [J.W.W.]

N.108 Nibley, Hugh W. "Warfare and the Book of Mormon." In Warfare in the Book of Mormon, edited by Stephen D. Ricks and William J. Hamblin, 127-45. Salt Lake City: Deseret and FARMS, 1990. Compares the descriptions of warfare in the Book of Mormon with the writings and axioms of Karl von Clausewitz's military treatise, Vom Kriege, that served the military as a bible for 150 years and was published in 1833. Descriptions of Book of Mormon warfare match von Clausewitz's principles very well. Again the internal evidence of the Book of Mormon establishes its accuracy in describing technical subjects unknown to Joseph Smith. This work is reviewed in E.057. [N.K.Y.]

N.109 Nibley, Hugh W. “What Frontier, What Camp Meeting?” IE 62 (August 1959): 590-92, 610, 612, 614-15. Reprinted in CWHN 8:182-92. Responds to the assertion that the Book of Mormon is a product of the religious and political milieu of the American frontier. [J.W.W.]

N.110 Nibley, Hugh W. "The World of the Jaredites." IE 54, 55 (September 1951-July 1955): 628-30, 673-75, 704-6, 752-55, 786-87, 833-35, 862-63, 946-47, 22-24, 92-94, 98, 100, 102, 104-5, 162-65, 167-68, 236-38, 258, 260-65, 316-18, 340-42, 344, 346, 398-99, 462-64, 510, 550. Reprinted as the second half of Lehi in the Desert and the World of the Jaredites. Salt Lake City: Bookcraft, 1952. Reprinted in CWHN 5:151-282. A detailed reconstruction of the epic milieu and ancient historical setting in the third millennium B.C. in Mesopotamia and Asia relative to details about the Jaredites: their ships, shining stones, government, wars, society, and worldview. This work is reviewed in W.061. [J.W.W.]

N.111 Nibley, Preston. "The Book of Mormon Manuscripts." In BYUSY (9 April 1957). Provo, UT: BYU Press. Explores the character of Joseph Smith and the conditions of poverty under which he translated of the Book of Mormon. Gives excerpts of journals written by those who knew Joseph at the time of translation to show the great humility, prayer, and determination of the Prophet. A lengthy discussion on the fate of the original manuscripts is given. [J.W.M.] 
N.112 Nibley, Preston. "The Three Witnesses of the Book of Mormon." Relief Society Magazine 31 (August 1944): 431-34. A historical account of the vision the Three Witnesses received on the Peter Whitmer farm during the latter part of June 1829. Includes the testimonies of Oliver Cowdery, David Whitmer, and Martin Harris. [J.W.M.]

N.113 Nibley, Preston. The Witnesses of the Book of Mormon. Salt Lake City: Stevens and Wallis, 1946. 2nd and 3rd eds. Salt Lake City: Deseret Book, 1953, 1968. Features verses in the Doctrine and Covenants and Book of Mormon pertaining to the witnesses of the Book of Mormon. Discusses statements by the Prophet Joseph Smith and others concerning the witnesses of the Book of Mormon. Gives brief histories of the Three Witnesses and the Eight Witnesses. [L.D.]

N.114 Nicholes, Mary. "Book of Mormon Strengthens and Converts." CN 58 (31 December 1988): 9, 10. An Incan man, twin sisters from Finland, a seven-year-old girl, and others are converted to Christ through the Book of Mormon. The rich spirit of the Book of Mormon warms the hearts of those who read it. [J.W.M.]

N.115 Nicholes, Mary. "Donated Book Helps Lead to Baptism of Neighbor Family." CN 58 (31 December 1988): 9. Investigators received a Book of Mormon donated by a family in their area and soon after were baptized. [M.R.]

N.116 Nichols, Robert E. "Beowulf and Nephi: A Literary View of the Book of Mormon." Dialogue 4 (Autumn 1969): 40-47. The life and character of Beowulf, the great hero of the epic age, parallels that of Nephi. Both were mighty in their deeds, both enjoyed great powers of strength and endurance, and both possessed various "manly skills." The Book of Mormon is "a work laden with promise for the literary analyst." More than a century has elapsed since the Book of Mormon has come forth and "literary scholarship" has all but ignored the literary aspects of this sacred text. [D.W.P.]

N.117 Nicholson, John. "Discourse on the Book of Mormon." JD 22:17-27. Discusses the remarkable nature of the Book of Mormon. Refers to prophecies in the book, especially those relative to the conversion of the Latter-day Lamanites, and the menace of secret combinations. Notes that "in the early rise of this Church the Lord manifested his displeasure with the Saints because they did not pay sufficient attention to the revelations contained in the Book of Mormon." [D.M.]

N.118 Nicholson, John. "The Lamanites." Juvenile Instructor 9 (21 November 1874; 5, 19 December 1874): 27475, 280-81, 291-92, 303. Discusses the prophecy that the Lamanites will become a "white and delightsome people," and conjectures that the Three Nephites are ministering to them. [D.M.]

N.119 Nicholson, John. "The Lamanites." MS 37 (16, 23 February; 2, 9 March 1875): 97-99, 113-14, 131-32, 15051. Nicholson tells of two instances in which, in his opinion, the Three Nephites appeared to Indian Chiefs. Indian Chief Torbuka was visited by three men who mysteriously disappeared after giving their messages. He then arranged to have members of his tribe baptized. An Indian leader of the Uintah Reservation relates that while in Washington to speak with government officials he was visited by a personage on three different evenings who told him to trust the Mormons and told him about the Book of Mormon. [B.D.]

N.120 Nicholson, John. The Latter-day Prophet. Liverpool: William Budge, 1880. Writes concerning the need for a true prophet. The Book of Mormon was given by the power of God to clarify misunderstood passages in the Bible. Isaiah foretold of Martin Harris's visit to Professor Anthon. The Book of Mormon is the story of the ancient American inhabitants, whose descendants are receiving the truth in vast numbers. [J.W.M.] 
N.121 Nicholson, John. "The Modern Prophet." In Joseph Smith: Was He a Prophet of God? An Investigation and Testimony, edited by J. M. Sjodahl. Salt Lake City: Deseret Book, 1891. Discusses why prophets are needed, the organization of the Church, evidences that the Book of Mormon is authentic, and modern day prophecy and the fulfillment of that prophecy. [L.D.]

N.122 Nicholson, John. The Modern Prophet. Salt Lake City: Deseret News Co., 189?. A work about Joseph Smith that devotes considerable space to the Book of Mormon. Tells about Joseph Smith's encounter with Moroni and the translation of the plates. Quotes separate testimonies of the Three Witnesses. Discusses the important role of the American Indians. [D.M.]

N.123 Nicholson, John. "Thoughts on the Indian Question." MS 53 (2 March 1891): 138-42. A reprint of an article from the Young Woman's Journal. Writes concerning the Indians, their lands, and Book of Mormon prophecies. [B.D.]

N.124 Nickyforuk, Nicholas. "Children Study the Book of Mormon." CN 50 (6 September 1980): 11. A family that is studying the Book of Mormon together describes the children's reactions and the knowledge they received from reading it. [M.D.P.]

N.125 Nielsen, C. M. "Oliver Cowdery for the Defense." IE 46 (August 1943): 464, 504. Excerpted from the Deseret News, February 21, 1910. Recital of Oliver Cowdery's testimony of the Book of Mormon before a court in Michigan. [D.M.]

N.126 Nielsen, F. Kent. Book of Mormon Teachings. Provo, UT: Brigham Young University, 1960. A series of four lectures. Makes connections and correspondences between the land of promise and God, Zion, gentiles, and descendants of Joseph. Also points out differences between the LDS view of the Second Coming and those of the world in general. [D.M.]

N.127 Nielson, Harold K. Mapping the Action Found in the Book of Mormon. Orem, UT: Cedar Fort, 1987. Contains synopses of each chapter in the Book of Mormon, 32 hypothetical maps to illustrate where events took place, and listings of geographical references. This work is reviewed in S.514. [D.M.]

N.128 Ninnis, Ernest W. The Marred Servant of the Book of Mormon. Melbourne: n.p., n.d. A tract attempting to prove the truthfulness of the Book of Mormon through a discussion of the marred servant (Isaiah 52:13-15). [D.W.P.]

N.129 Njeim, George A. "Book of Mormon Prophecies." SH 98 (30 July 1951): 725-28. Examines prophecies in the Book of Mormon and relates them to historical events of the twentieth century. Prophecies are classified as follows: (1) the vision of Nephi-1 Nephi 3:210-216 (RLDS scriptures); (2) the prophecy of Nephi-2 Nephi 11:116-117; (3) the word of Christ relative to gentile disobedience-3 Nephi 9:64-71, and the return of the Jews -3 Nephi 9:85-101; (4) warning to Gentile America-Ether 1:29-35. [A.C.W.]

N.130 Njeim, George A. "The Golden Book." SH 95 (3 July 1948): 636-39. For an audience unfamiliar with the Book of Mormon, Njeim explains its contents, purpose, and effect upon the world. The Book of Mormon restores lost truths from the Bible, witnesses of Christ and eternal life, and is the authority brought by God to quell "spiritual anarchy." [A.C.W.] 
N.131 Njeim, George A. Insights into the Book of Revelation; as Illuminated by the Book of Mormon. Lawrence, KS: n.p., 1970. A commentary on the book of Revelation written by a minister of the RLDS church. In spite of the title, the Book of Mormon is scarcely utilized. [D.M.]

N.132 Njeim, George A. "The Three Witnesses to the Book of Mormon." SH 117 (September 1970): 28-30, 54. Discusses the character of the Three Witnesses, saying that their apostasy from the early Church was "a blessing in tragic guise" since it validated their testimony of the Book of Mormon that they were able to leave the Church but not deny their eyewitness experience. [A.C.W.]

N.133 "Nonmember Collector of Old Books Gives Early Edition of Book of Mormon to Church." CN 46 (14 August 1976): 12. Two Mormon missionaries were given a copy of the first edition of the Book of Mormon by Mrs. Merton Good. [M.R.]

N.134 Nordgren, Weston N. Centennial Lessons for the Relief Society in the European Missions of the Church of Jesus Christ of Latter-day Saints. Liverpool: LDS European Mission, 1930. Ten theology lessons designed to give evidences of the divine origin of the Book of Mormon. Bible passages foretold the Book of Mormon. Tells about the translation and publication of the manuscript, provides the testimonies of the witnesses, explains the objections to the Book of Mormon, Indian traditions, and similarities between the Biblical and Book of Mormon passages. [J.W.M.]

N.135 Nordgren, Weston N. "Taught by Their Mothers." MS 91 (9 May 1929): 297-98. Compares modern-day missionaries to the stripling warriors of Helaman. [R.H.B.]

N.136 Nordgren, Weston N. "'Then Shall They Rejoice.' "MS 91 (31 January 1929): 72-73. Speaks of the prophecy in the Book of Mormon that the Lamanites, or the American Indians, shall rejoice of the Book of Mormon and its message. Gives several examples of American Indians that have read the Book of Mormon and were baptized because of their faith in its truthfulness. [M.D.P.]

N.137 Norman, Keith E. Review of Old Testament and Related Studies, by Hugh W. Nibley. Sunstone (March 1987): 33-35. Book review.

N.138 Norman, V. Garth. "I Have a Question: What is the current status of research concerning the 'Tree of Life' carving from Chiapas, Mexico?" Ensign 15 (June 1985): 54-55. The author is cautious and tentative, but believes that the "stela 5 may prove to be the first deciphered artifact from the Nephite civilization." [D.M.]

N.139 Norman, V. Garth. "San Lorenzo as the Jaredite City of Lib." SEHA Newsletter 153 (June 1983): 1-9. Agrees with archaeologist Michael D. Coe that there are no direct archaeological evidences of the Book of Mormon. Proposes that the Olmec civilization corresponds to the Jaredite nation and that the present San Lorenzo is located at the site of the Jaredite city Lib. [D.M.]

N.140 Norman, V. Garth. "The Tree of Life Symbol in Ancient Israel." In Papers of the Fourteenth Annual Symposium on the Archaeology of the Scriptures, edited by Forrest R. Hauck, 37-51. Provo, UT: BYU Dept. of Extension, 1963. Compares various symbols of the tree of life found throughout the world to the Israelite representation of the tree of life. Briefly offers some insight into Lehi's dream. [B.D.]

N.141 North Western States Mission. Jesus Is the Christ. Portland, OR: Church of Jesus Christ of Latter-day Saints, 1975. Reports concerning Jesus Christ's visit to the Americas, and encourages those interested in the Bible and 
the life of Christ to study the Book of Mormon. [J.W.M.]

N.142 Northrup, Joseph A. "Book of Mormon Confirmed by Chippewa Traditions." SH 69 (31 May 1922): 511-12. A letter written by a Chippewa Indian from the RLDS church. Legends from that tribe corroborate aspects of the Book of Mormon, including references to what may be the Three Nephites. [D.M.]

N.143 Norton, Walter A. "Comparative Images: Mormonism and Contemporary Religions as Seen by Village Newspapermen in Western New York and Northeastern Ohio, 1820-1833." Ph.D dissertation, Brigham Young University, 1991. Includes quotations and references from early newspapers referring to Joseph Smith and the Book of Mormon in the formative stages in Church history. [D.M.]

N.144 Norwood, L. Ara. Review of Book of Mormon Authorship: A Closer Look, by Vernal Holley. Review of Books on the Book of Mormon 1 (1989): 80-88. Book review.

N.145 Norwood, L. Ara. Review of Covering Up the Black Hole in the Book of Mormon, by Jerald and Sandra Tanner. Review of Books on the Book of Mormon 3 (1991): 158-69. Book review.

N.146 Norwood, L. Ara. Review of Joseph Smith and the Origins of the Book of Mormon, by David Persuitte. Review of Books on the Book of Mormon 2 (1990): 187-204. Book review.

N.147 "Noted Explorer Plans Seminar To Study Mexican Expeditions." CN 34 (January 4, 1964): 12. Announces a seminar to be conducted by Jose O. Davila addressing the topics of Lehi's landing in America, ancient cities, and the brass plates. He will present slides of archaeological evidences and gold plates taken from a tomb of Oaxaca that are inscribed with Egyptian. [J.W.M.]

N.148 Novak, Gary F. "Naturalistic Assumptions and the Book of Mormon." BYU Studies 30 (Summer 1990): 23-40. This well-documented and didactic essay examines selected assumptions and consequences of naturalistically written history. "Naturalistic" explanations of the Book of Mormon are those that offer an "environmental" (instead of a theological) answer to its coming forth. Focuses on the writings of Dale Morgan and Fawn M. Brodie while also discussing the New Mormon History and one of its historians, Marvin S. Hill. [D.L.L.]

N.149 "Now From Scandinavia." CN 50 (20 September 1980): 16. Many early critics of the Book of Mormon ridiculed the story of the gold plates. Now archaeologists are saying that many ancient records were made from valuable metals. Norsemen also wrote on metal plates. [M.R.]

N.150 Noyes, J. O. The Genesee Valley of Western New York. Ovid, NY: W. E. Morrison, 1858. Reprint from The National Magazine (February, 1858). A history of western New York. The writer briefly mentions the Book of Mormon in chapter 2 and favors the Spaulding theory. [M.R.]

N.151 Noyes, J. O. "Joseph Smith and the Golden Plates." In The Genesee Valley of Western New York. N.p., 1858. Reprint from the National Magazine (February, 1858), printed by W. E. Morrison Co., Ovid, New York. Claims the Book of Mormon is a religious romance story written by an invalid clergyman (Spaulding). [J.W.M.]

N.152 Numano, Jiro. "The Japanese Translation of the Book of Mormon: A Study in the Theory and Practice of Translation." M. A. thesis, Brigham Young University, 1976. Discusses theory of translation and applies it to the Book of Mormon. Argues that the Japanese translation of the book, although it is claimed to be colloquial, is too 
literal and hard to read. Considers the translation not sufficiently aware of Hebrew idioms or of the Jewish and Egyptian cultures from which the Book of Mormon originated. [D.M.]

N.153 Nunley, E. W. "My Testimony to the Truth of the Book of Mormon." SH 52 (28 June 1905): 634. A former member of the Baptist Church bears testimony that after he borrowed and read the Book of Mormon, the Spirit testified its truthfulness. He wants his testimony to stand until Christ comes again. [J.W.M.]

N.154 Nutting, John Danforth. Contradictions in Mormon Books and Doctrine. Cleveland, OH: Utah Gospel Mission, n.d. Polemical pamphlet by a career Mormon critic, pointing out perceived contradictions between the Book of Mormon and LDS doctrines. The subjects deal largely with the nature of God. [D.M.]

N.155 Nutting, John Danforth. "Reorganized" or "Josephite" Mormonism Carefully Considered in the Light of the Bible and of Good Reason. Cleveland, OH: Utah Gospel Mission, 1899. A critic writes against Mormonism. The Reorganized Mormons are one and the same as the Utah Mormons-their origins were the same and remained so until 1848. A history of Joseph Smith and the coming forth of the Book of Mormon is presented. Provides a reprint of the Anthon transcript and compares it with Egyptian hieroglyphs to proclaim the book a "bald hoax." Joseph Smith was the author of the Book of Mormon, and Mormons, which ever sect they belong to, are not Christians. [J.W.M.]

N.156 Nutting, John Danforth. The Teachings of Mormonism and Christianity Compared With The Bible And Sound Reason. Cleveland, OH: Utah Gospel Mission, 1928. A critic finds that Joseph Smith worked with Sidney Rigdon to revise Christian religion to suit their own claims that the Bible was imperfect. For this reason they claimed to have found gold plates and "translated" them and then "translated" the Bible when neither knew a word of Hebrew or Greek. No further revelation was needed for the truth has already been revealed. [J.W.M.]

N.157 Nutting, John Danforth. The Wonderful Story of the Wonderful Book. Cleveland, OH: Utah Gospel Mission, 1908. Evangelical extolling of the Bible. Has a section entitled, "Why We Should Not Believe That Any Other Book Is from God," with some attention given to the three other Mormon standard works, which contain teachings that "are contrary to those of the real word." [D.M.]

N.158 Nyman, Monte S. "Abinadi's Commentary on Isaiah." In The Book of Mormon: Mosiah, Salvation Only through Christ, edited by Monte S. Nyman and Charles D. Tate Jr., 161-86. Provo, UT: Brigham Young University Religious Studies Center, 1991. An exegetical exercise, discussing Abinadi's prophetic message to King Noah's court, in relation to Isaiah 52:7-10 and 53. Themes include Christology and beautiful feet that bring good tidings. Tables and appendices are included. [D.M.]

N.159 Nyman, Monte S. "Ancient Message 'Book for Our Day.' " CN 58 (2 January 1988): 14. Shows how the four Book of Mormon abridgers-Nephi, Jacob, Mormon, and Moroni-saw our day and directed their writings accordingly. [D.M.]

N.160 Nyman, Monte S. "Appendix C. Isaiah in the Book of Mormon." In Nyman's Great Are the Words of Isaiah, 28387. Salt Lake City: Bookcraft, 1980. Nineteen of the sixty-six chapters of the text of Isaiah from the King James Version of the Bible are quoted in their entirety in the Book of Mormon, two others lack two verses, others are partially quoted. A list of references compares the Book of Mormon passages with their counterparts in Isaiah. [J.W.M.] 
N.161 Nyman, Monte S. "Bondage and Deliverance." In Studies in Scripture: 1 Nephi to Alma 29, edited by Kent P. Jackson, 260-69. Salt Lake City: Deseret Book, 1987. Retells the story of how Zeniff's colony of Nephites fell into bondage under the Lamanites at the end of King Noah's reign. Recalls the spiritual circumstances under which they were delivered. [D.M.]

N.162 Nyman, Monte S. "The Book of Mormon: A Blessing or a Curse?" In To the Glory of God, edited by Truman G. Madsen and Charles D. Tate Jr., 219-30. Salt Lake City: Deseret Book, 1972. Discusses the three phases of judgment that will come to all that possess the Book of Mormon. They are: the gathering of the "seed of Ephraim"; a "cleansing of the Lord's people"; and the judgments of God upon the nations that rejected the Book of Mormon. The Book of Mormon will be either a blessing or a curse depending on how individuals have received it. [A.T.]

N.163 Nyman, Monte S. "Book of Mormon Search Questions." Provo, UT: Brigham Young University, 1980. Study questions. Courses 121 and 421 address title page through Alma 29, and 122 and 422 address Alma 30 to Moroni 10 of the Book of Mormon. Designed for religion courses at Brigham Young University. [L.D.]

N.164 Nyman, Monte S. "The Book of Mormon, Why?" IE 65 (July 1962): 530-31, 538-39. Relates the important role of the Book of Mormon as a witness not only for Christ but also for the Bible. The Book of Mormon's value in helping to understand the book of Isaiah is unlimited. [J.W.M.]

N.165 Nyman, Monte S. "By the Book of Mormon We Know." In Doctrines of the Book of Mormon, 1991 Sperry Symposium, edited by Bruce A. Van Orden and Brent L. Top, 145-57. Salt Lake City: Deseret Book, 1992. Comments on the twenty doctrines enumerated in Doctrine and Covenants 20:17-36, and shows that the Book of Mormon enlightens every one. Examples include: existence of God, the commandment to love God, the creation of male and female in God's image, the Fall and the Atonement; the crucifixion, death, and resurrection, justification and grace, and the gift of the Holy Ghost. [D.M.]

N.166 Nyman, Monte S. "Come to Understanding and Learn Doctrine." In The Book of Mormon: Second Nephi, The Doctrinal Structure, edited by Monte S. Nyman and Charles D. Tate Jr., 19-31. Provo, UT: Brigham Young University Religious Studies Center, 1989. 2 Nephi is one of the most doctrinal books of the Book of Mormon. Author gives a chapter-by-chapter overview of doctrines contained in 2 Nephi. [D.M.]

N.167 Nyman, Monte S. "Confirmed to Others by the Ministering of Angels." In A Symposium on the Book of Mormon, 104-8. Salt Lake City: Church of Jesus Christ of Latter-day Saints, CES, August 1986. Presents a discussion about angels. Presents definitions and shows the role of angels in the coming forth of the Book of Mormon and the restoration of the gospel. [D.M.]

N.168 Nyman, Monte S. An Ensign to All People: The Sacred Message and Mission of the Book of Mormon. Salt Lake City: Deseret Book, 1987. Illuminates certain features of the Book of Mormon to encourage the reading of the book. The Book of Mormon is intended to be an ensign to the nations, Joseph Smith was the "choice seer" designated to bring it forth. Comments on how the Book of Mormon relates to the remnant of Ephraim, the gentiles, the Lamanites, the Jews, and the lost tribes. Includes a study of the allegory of the olive tree, and the building of two Zions, one in New Jerusalem, one in Jerusalem. [L.D. \& D.M.]

N.169 Nyman, Monte S. "Hope, Faith, and Charity." In Studies in Scripture: Alma 30 to Moroni, edited by Kent P. Jackson, 293-303. Salt Lake City: Deseret Book, 1988. A meditation on Moroni 7, a sermon by Mormon, which deals with the Christian traits faith, hope and charity. Includes a section on the spiritual status of little children. [D.M.] 
N.170 Nyman, Monte S. "I Have a Question: Why is the Book of Mormon the 'most correct book', and how does it contain the fulness of the gospel?" Ensign 6 (September 1976): 87. The Book of Mormon is the "most correct book." This is not to be understood as "perfect." The words "correct" and "perfect" are not necessarily synonymous. The book is correct in far greater ways than in grammar, spelling, punctuation, and so on. It speaks of restored doctrines of the gospel, faith, repentance, the Atonement, baptism, and the Holy Ghost. These are the saving principles and ordinances that bring one back into the presence of the Father. [J.W.M.]

N.171 Nyman, Monte S. "I Have a Question: Why were the Book of Mormon gold plates not placed in a museum so that people might know Joseph Smith had them?” Ensign 16 (December 1986): 64-65. Also in "Why Weren't the Gold Plates Placed in a Museum?" In A Sure Foundation: Answers to Difficult Gospel Questions, 52-54. Salt Lake City: Deseret Book, 1988. Asserts that the golden plates were never made available for public view for two reasons: (1) the Lord did not want the plates - with their impressive monetary value-to be used for personal or commercial gain, and (2) to test the faith of those who receive the record. [S.P.S.]

N.172 Nyman, Monte S. "Lehi and Nephi: Faith Unto Salvation." In The Book of Mormon: First Nephi, The Doctrinal Structure, edited by Monte S. Nyman and Charles D. Tate Jr., 67-77. Provo, Utah: Brigham Young University Religious Studies Center, 1988. Refers to the "Lectures on Faith" by Joseph Smith. Briefly discusses the three principles of faith and how Nephi and Lehi exemplified these attributes. The three principles are "faith as a principle of action, faith as a principle of power, and faith unto life and salvation." [A.T.]

N.173 Nyman, Monte S. "The Most Correct Book." Ensign 14 (June 1984): 20-23. As Joseph Smith stated that the Book of Mormon was the "most correct book," any errors in it are due mostly to the inadequacies of present languages. As the keystone of the LDS religion the book is important in uniting the Church, thus preventing a splintering like that of early Christianity. The Book of Mormon teaches the doctrines that will draw men and women to God. [S.P.S.]

N.174 Nyman, Monte S. The Most Correct Book: Why the Book of Mormon is the Keystone Scripture. Salt Lake City: Bookcraft, 1991. A three-pronged discussion of Joseph Smith's statement that the Book of Mormon (1) is the most correct book, (2) is the keystone of the LDS religion, and (3) enables a person to get close to God by abiding by its precepts. Subthemes deal with the translation of the book, a warning to the inhabitants of the promised land, how the book contains a fulness of the Gospel, how the book is scripture, what it has to say about the ministering of angels, how the book testifies of the Bible, and how the world is to be judged by the book. [D.M.]

N.175 Nyman, Monte S. "The Necessity of the Book of Mormon in Teaching the New Testament." In The Eleventh Annual Sidney B. Sperry Symposium: The New Testament, 73-83. Provo, UT: Church Educational System, 1983. Various aspects of the New Testament, such as the authenticity of certain books, the integrity of the Sermon on the Mount, and the reality of miracles are confirmed in the Book of Mormon, in spite of skepticism on the part of modern biblical criticism. [D.M.]

N.176 Nyman, Monte S. "Priesthood Versus Priestcraft among the Nephites." In The Sixth Annual Religious Educator's Symposium on the Book of Mormon, 66-69. Salt Lake City: Church of Jesus Christ of Latter-day Saints, 1982. Author demonstrates that Lehi held the Melchizedek priesthood. Uses the Book of Mormon to demonstrate some of the duties of an individual that holds the Melchizedek priesthood. Then the author defines priestcraft, and describes how it is different from anti-Christ. He outlines the stories of men who used priestcraft in the Book of Mormon such as Nehor and Amlici. [A.T.] 
N.177 Nyman, Monte S. "The Restoration of Plain and Precious Parts: The Book of Helaman." In The Book of Mormon: Helaman through 3 Nephi 8, According to Thy Word, edited by Monte S. Nyman and Charles D. Tate Jr., 14761. Provo, UT: Brigham Young University Religious Studies Center, 1992. Lists four areas in which the book of Helaman restores lost parts of the Bible or verifies what was not lost: (1) personages and incidents, (2) prophets, (3) prophecies and (4) New Testament precepts traced to the Old Testament. [D.M.]

N.178 Nyman, Monte S. "The Same God Yesterday, Today, and Forever." In Sidney B. Sperry Symposium: The Book of Mormon, edited by A. Gary Anderson, 117-26, Provo, UT: BYU Religious Instruction, 1981. Shows how God is the same yesterday, today, and forever through his personal appearances, the manner of his manifestations, and the fact that he is no respecter of persons. [D.M.]

N.179 Nyman, Monte S. "Source Book of Suggestions for Teaching the Book of Mormon." D.Ed. thesis, Brigham Young University, 1965. Consists of teaching suggestions for Book of Mormon classes, along with teacher responses to questionnaires. Also contains an elaborate teaching guide with statements of purpose, outlines, and questions. Includes handouts for students. [D.M.]

N.180 Nyman, Monte S. "The State of the Soul between Death and the Resurrection." In The Book of Mormon: Alma, The Testimony of the Word, edited by Monte S. Nyman and Charles D. Tate Jr., 173-94. Provo, UT: Brigham Young University Religious Studies Center, 1992. Expounds on Alma's instruction to Corianton (Alma 40:6-7, 11-14) regarding the spirit world. Sets forth where and what it is, writes concerning the wicked and righteous spirits who dwell there, and teaches concerning the work of salvation there. [D.M. \& N.K.Y.]

N.181 Nyman, Monte S. "To Learn with Joy: Sacred Preaching, Great Revelation, Prophesying." In The Book of Mormon: Jacob through Words of Mormon, To Learn with Joy, edited by Monte S. Nyman and Charles D. Tate Jr., 193208. Provo, UT: Brigham Young University Religious Studies Center, 1990. Shows how the writings of Jacob through the Words of Mormon on the small plates of Nephi followed the admonition and example set by Nephito devote the greater space to sacred things, and but little to historical events. [D.M.]

N.182 Nyman, Monte S. Two Sticks One in Thine Hand. Salt Lake City: Gen-Dex Press, 1973. "This treatise is an attempt to show how utterly false are the suppositions that the Church has its own Bible or that the Church fails to accept the Christian world's Bible. It will further endeavor to show that the Church not only accepts the Bible but is much concerned that modern Christianity maintains its faith in this sacred volume of scripture." Author uses the Book of Mormon as a basis for examining Old Testament authorship, Bible history, text, and interpretation. [A.T.]

N.183 Nyman, Monte S. "Two Sticks: One in Thine Hand." In The Third Annual Church Educational System Religious Educators' Symposium: A Symposium on the Old Testament, 243-51. Salt Lake City: Church of Jesus Christ of Latterday Saints, 1979. Argues that the Book of Mormon corrects the false views about the Bible held by Bible critics. The Book of Mormon verifies the historicity and authorships of the Bible. [D.M.]

N.184 Nyman, Monte S. "Why Study Isaiah." In The Second Annual Church Educational System Religious Educators' Symposium: A Symposium on the Book of Mormon, 93-97. Salt Lake City: Church of Jesus Christ of Latter-day Saints, 1979. Rather than being discouraged by Isaiah, Latter-day Saints should take great interest in the prophet, because the Book of Mormon expressly commands its study. Isaiah testified of the Messiah and foresaw the future of Israel. The Book of Mormon joins the New Testament and Doctrine and Covenants in helping individuals to understand Isaiah. [D.M.] 
N.185 Nyman, Monte S., and Charles D. Tate Jr. "Proving the Holy Scriptures Are True." In "To Be Learned Is Good If ...," edited by Robert L. Millet, 77-114. Salt Lake City: Bookcraft, 1987. Shows how the Book of Mormon, Doctrine and Covenants, Pearl of Great Price, and Joseph Smith Translation clarify the contents of the Bible. Includes an extensive table. [D.M.]

N.186 Nyman, Monte S., and Charles D. Tate Jr., eds. The Book of Mormon: Alma, The Testimony of the Word: Papers from the Sixth Annual Book of Mormon Symposium, 1991. Provo, Utah: Religious Studies Center, Brigham Young University, 1992. Presenters included Dean L. Larsen, Rex C. Reeve Jr., Robert J. Matthews, Robert L. Millet, and others. The topics include the "New Meaning of 'Restoration,' " anti-Christs, faith and freedom, and others, all based on the book of Alma. [J.W.M.]

N.187 Nyman, Monte S., and Charles D. Tate Jr., eds. The Book of Mormon: First Nephi, the Doctrinal Foundation. Provo, UT: Brigham Young University Religious Studies Center, 1988. A collection of lectures delivered at a Brigham Young University-sponsored symposium. Subjects include Jesus in the Book of Mormon, Christianity in the Book of Mormon, fasting, love, Columbus, Old World contacts, and more. Talks are listed under the names of the respective authors in this bibliography. This work is reviewed in P.211. [D.M.]

N.188 Nyman, Monte S., and Charles D. Tate Jr., eds. The Book of Mormon: Helaman through 3 Nephi 8, According To Thy Word: Papers from the Seventh Annual Book of Mormon Symposium, 1992. Provo, Utah: Brigham Young University Religious Studies Center, 1992. Presenters included Russell M. Nelson, Robert Millet, Robert J. Matthews, Thomas W. Mackay, Monte S. Nyman, and others. The topics include sanctification, secret covenant teachings of men, the dangers of a class society, and many others found in the books of Helaman and 3 Nephi. [J.W.M.]

N.189 Nyman, Monte S., and Charles D. Tate Jr., eds. The Book of Mormon: Jacob through Words of Mormon, To Learn with Joy. Provo, UT: Brigham Young University Religious Studies Center, 1990. A compilation of addresses delivered at a Book of Mormon Symposium at Brigham Young University. Subjects include Jacob, the allegory of the Olive Tree, the religion of Moses, Enos, Sherem, the small plates, and more. Individual talks are listed in this bibliography under the names of the contributors. This work is reviewed in W.434. [D.M.]

N.190 Nyman, Monte S., and Charles D. Tate Jr., eds. The Book of Mormon: Mosiah, Salvation Only through Christ. Provo, UT: Brigham Young University Religious Studies Center, 1991. A group of speeches given at an annual Book of Mormon symposium at Brigham Young University. Subjects include King Benjamin, Noah, the Atonement, government, the natural man, Abinadi, priesthood, church discipline in Mosiah, and more. Titles of talks are listed in this bibliography under the names of the contributors. [D.M.]

N.191 Nyman, Monte S., and Charles D. Tate Jr., eds. The Book of Mormon: Second Nephi, The Doctrinal Structure. Provo, UT: Brigham Young University Religious Studies Center, 1989. Compilation of Book of Mormon symposium addresses delivered at Brigham Young University. Subjects include free agency, the promised land, the fall of man, the Lamanite mark, God's covenants with the house of Israel, the Atonement, the brass plates, the law of witnesses, and more. Specific titles are listed in this bibliography under the name of each contributor. [D.M.]

N.192 Nyman, Monte S., and Charles D. Tate Jr., eds. The Book of Mormon: 3 Nephi 9-30, This Is My Gospel: Papers from the Eighth Annual Book of Mormon Symposium, 1993. Provo, Utah: Brigham Young University Religious Studies Center, 1993. Presenters at this symposium included Robert L. Millet, Robert J. Matthews, Monte S. Nyman, S. Kent Brown, Joseph Fielding McConkie, and numerous others. The subjects covered include prayer, the doctrine 
of translation, the gathering at the temple, service, and more. Papers are based on the book of 3 Nephi and Christ's visit to America. Specific titles are listed in this bibliography under the name of each contributor. [J.W.M.]

N.193 Nyman, Monte S., and Lisa B. Hawkins. "Book of Mormon Overview." In Encyclopedia of Mormonism, edited by Daniel H. Ludlow, 1:139-43. 5 vols. New York: Macmillan, 1992. Joseph Smith was quoted as saying the Book of Mormon was the most correct of any book on earth and that a person would get nearer to God by abiding by its precepts than by any other book. It confirms and supplements the Bible and stands as another testament of Jesus Christ. It deals primarily with the history of the Nephites and Lamanites from 600 B.C. to A.D. 400, the Jaredites from the tower of Babel until about 300 B.C., and the people of Mulek beginning at 300 B.C. and later merging with the Nephite history. [N.K.Y.] 
0.001 O., G. M. "The Mound Builders." MS 38 (February 1876): 113-15, 129-31. Discusses the culture of the mound builders whose remains stretch from New York to Central America. The mounds, thought to be works of defense, religious structures, or sepulchral monuments, are as large as 70 feet high and 1000 feet in circumference. Relics of art have been found such as implements of copper, single and double axes, pottery, and cloth. Author believes that the mound builders and the Toltecs were the same people. [B.D.]

0.002 O., G. M. "Old America: Jared." MS 37 (March 1875): 197-99, 212-13, 231. Gives a brief synopsis of Jaredite history including their sailing to the American continent from the Tower of Babel. Also cites many ancient American flood myths that relate to the biblical story of the flood at the time of Noah. [B.D.]

O.003 Oakman, Arthur A. The Central Witness of the Book of Mormon. Gospel Quarterly Series. Independence, MO: Herald House, 1950. The message of the Book of Mormon is to reveal Jesus Christ to the remnant of Lehi's children, the Jews, and the Gentiles. Several witnesses set forth the truthfulness of the book, including the Holy Ghost, the Eleven Witnesses, and the book is its own best witness. [J.W.M.]

O.004 Oakman, Arthur A. "The Doctrinal Message of the Book of Mormon." Gospel Quarterly 17 (January-March 1950): 4-64. Consists of 13 lessons directed towards adults of the RLDS church. Lesson contents include a definition of doctrine, an overview of the contents of the Book of Mormon, and discussions dealing with faith in God, the law of revelation, repentance, baptism, spiritual birth, the Holy Spirit, resurrection, justice and judgment, worship, the Trinity, and the significance of Book of Mormon doctrine. [L.D.]

O.005 Oakman, Elva T. The Book of Mormon, an Introductory Survey. Independence, MO: Herald House, 194? RLDS pamphlet that makes summary statements about three colonies-the Jaredites, Lehites, and Mulekites-and mentions the coming of Christ to ancient America Writes regarding the coming forth of the Book of Mormon. Cites archaeological evidence. [D.M.]

O.006 Oaks, Dallin H. "The Desires of Our Hearts." In Brigham Young University 1985-86 Devotional and Fireside Speeches of the Year, edited by Karen Seely, 27-31. Provo, UT: Brigham Young University, 1986. Also in Ensign 16 (June 1986): 64-67. Desires are the foundation of all actions, and thus righteous desires must be cultivated. Quotes Mormon's teachings in Moroni 7 and King Benjamin's sermon to illustrate that hearts must be right with God. [E.G.]

O.007 Oaks, Dallin H. "Free Agency and Freedom." In The Book of Mormon: Second Nephi, The Doctrinal Structure, edited by Monte S. Nyman and Charles D. Tate Jr., 1-17. Provo, UT: Brigham Young University Religious Studies Center, 1989. Distinguishes two terms: free agency is "an exercise of the will, the power to choose." Freedom is the ability and "privilege to carry out our choices." Shows both the doctrine and application of these two principles. [D.M.]

O.008 Oaks, Dallin H. "The Historicity of the Book of Mormon." Provo, UT: FARMS, 1993. Questions concerning the historicity of the Book of Mormon should be resolved with scholarship, faith, and revelation. All issues of content, vocabulary, revelation, and archaeology must be examined. [E.G.] 
O.009 Oaks, Dallin H. "The Light and Life of the World." Ensign 17 (November 1987): 63-65. Also in CR (October 1987): 75-79. Emphasizes that Jesus Christ is the Light and Life of the world, that the Church of Jesus Christ of Latter-day Saints teaches love of Christ, and that the Book of Mormon bears witness of him. [L.D.]

O.010 Oaks, Dallin H. "What Think Ye of Christ?" Ensign 18 (November 1988): 65-68. Members of the Church must turn to the Book of Mormon to protect themselves from many of the heresies that exist about Christ. Many individuals challenge the divinity of Christ and declare that man must save himself. The Book of Mormon presents the complete doctrine of the Atonement, Christ's divinity, and the fullness of the gospel he taught. Christ is the only way to salvation and life. [J.W.M.]

O.011 Oaks, Stella Harris. Martin Harris-The Third Witness. Provo, UT: Brigham Young University, August 1974. Relates Harris's connection with the coming forth of the Book of Mormon and his unfaltering testimony regarding seeing the gold plates and the angel. [D.W.P.]

O.012 "An Objection to the Book of Mormon Answered." MS 58 (27 August 1896): 557-58. Cites archaeological evidence that iron was used by ancient American inhabitants, supporting the claim made by the Book of Mormon concerning steel and iron. [A. C.]

O.013 O’Brien, T. C. "Book of Mormon." In Encyclopedic Dictionary of Religion, edited by Paul Kevin Meagher, et. al., 1:498. Washington, DC: Corpus, 1976. An encyclopedic entry that provides a brief description of the origin and contents of the Book of Mormon. [D.W.P.]

O.014 O'Dea, Thomas F. “The Book of Mormon," in O'Dea's, The Mormons, 22-40. Chicago, IL: University of Chicago Press, 1957. Chapter 2 is concerned with the environmental factors that influenced Joseph Smith in writing the Book of Mormon. The author believes the book had its origin in the 19th century, having been influenced by Ethan Smith's View of the Hebrews, various ideas regarding the Hebrew origins of the American Indian, eighteenth-century religious issues, anti-Catholic sentiment, anti-Masonry beliefs, and others. [M.R.]

0.015 "Of Good Report." Ensign 23 (June 1993): 79-80. A report of the benefits of Book of Mormon "marathons" where participants read the entire book in one sitting. [S.H.]

O.016 Ogden, D. Kelly. "Answering the Lord's Call." In Studies in Scripture: 1 Nephi to Alma 29, edited by Kent P. Jackson, 17-33. Salt Lake City: Deseret Book, 1987. Reviews the historical background of Lehi's family and their exodus from Israel. Many new insights may be gained by studying Israel's history in conjunction with 1 Nephi 1-7. Lehi's family must have been inspired as they compared their experiences to Moses and the exodus that he led from Egypt. [J.W.M.]

O.017 Ogden, D. Kelly." 'As Plain as Word Can Be.' In Doctrines of the Book of Mormon, 1991 Sperry Symposium, edited by Bruce A. Van Orden and Brent L. Top, 158-65. Salt Lake City: Deseret Book, 1992. Points out that Book of Mormon prophets made rich use of figurative language, but inasmuch as they delighted in plainness, they often explained the meaning of the figurative language that they used. Examples include the chains of hell, lake of fire and brimstone, seed (in Alma 32), and kingdom of the devil. [D.M.]

0.018 Ogden, D. Kelly. "Why Does the Book of Mormon Say that Jesus Would Be Born in Jerusalem?" In A Sure Foundation: Answers to Difficult Gospel Questions, 3-5. Salt Lake City: Deseret Book, 1988. Deals with Alma 7:10 that states that Jesus would be born at Jerusalem. Explains that Alma wrote that Jesus would be born at Jerusalem (i.e., the land of Jerusalem) and not in Jerusalem (i.e., the city of Jerusalem). [J.W.M.] 
O.019 Oldfield, David. The Book of Mormon: Divine or Deceptive? Lawton, OK: Watchman Press, 198? A tract in which the author believes the Book of Mormon is a deception and represents a plagiarism. Provides examples in which the book borrows from the Bible and other writings. [D.W.P.]

O.020 Olsen, Steven L. "Cosmic Urban Symbolism in the Book of Mormon." BYU Studies 23 (Winter 1983): 79-92. Cosmic urban symbolism is one way that complex societies dramatize their belief that the perceived order of territorial environment, in its "natural" and built-up features, reveals the structure of a sacred universe. The society personifies this belief by building reduced embodiments of the cosmos usually in the form of a capital city or a ceremonial center. In this article, the author first describes and defines cosmic urban symbolism as found in ancient civilizations, and then writes concerning the concepts of centripetality, cardinality, and inductance as found in the text of the Book of Mormon. [D.L.L.]

O.021 Olsen, Steven L. "Patterns of Prayer: Humility or Pride." Ensign 22 (August 1992): 8-11. Mormon's abridgment of the records of the Zoramite mission teach a powerful lesson on prayer. The contrast between the proud Zoramite prayers on the Rameumptum and Alma's humble supplication shows what true worship should be like. [A.C.W.]

O.022 Olson, Earl E. "Book of Mormon." In The Encyclopedia Americana, edited by Mark Cummings, 4:246. 30 vols. Danbury, CT: Grolier, 1993. Sets forth the origin and contents of the Book of Mormon in a brief, encyclopedic manner. [D.W.P.]

O.023 Olson, Eric C. "The 'Perfect Pattern': The Book of Mormon as a Model for the Writing of Sacred History." BYU Studies 31 (Spring 1991): 7-18. Takes issue with Robert Millet's proposition that Mormon historians should take the Book of Mormon as the "perfect pattern" for writing history in the sense of recognizing God's hand, while not dwelling on mortal weaknesses. The small plates are not history (Millet had cited Nephi and Jacob as model historians), and much of the large plates is instruction. The Book of Mormon should serve as a historical guide only to a limited degree. [D.M.]

O.024 Olson, Ernest. The Story of the Book of Mormon. Orem, UT: Mil-Bur, 1967. A coloring book depicting Book of Mormon life. Includes pages illustrating the role of Joseph Smith in the coming forth of the Book of Mormon. [D.M.]

O.025 Oman, Richard G. "Lehi's Vision of the Tree of Life: A Cross-Cultural Perspective in Contemporary Latterday Saint Art." BYU Studies 32 (Fall 1992): 5-34. Examines eight artists' representations of Lehi's vision of the tree of life and "shows how the differences in the artists cultural background actually enlarge our understanding of this ancient vision. In addition, an analysis of eight of these pieces can provide some insights into the current state of Latter-day Saint art." [B.D.]

O.026 O'Neill, Michael. "After the Book of Mormon, What? An Introduction to the Works of Ixtlilxochitl." California Intermountain News (23 September 1976): 4. Archaeologists have largely suppressed the writings of Ixtlilxochitl, considering them to be "baseless dreams of poetic fancy"; yet they contain records claiming Eastern origins, biblical concepts, the existence of a prior white race, and transoceanic migrations. Author implies that these writings have a bearing on the Book of Mormon. [D.M.]

O.027 O’Neill, Michael. "Ancient Mexican Myths Parallel Bible Stories." California Intermountain News (30 December 1976): 5. States that the writings of Ixtlilxochitl contain biblical stories that parallel ancient Mexican myths, e.g., concerning original sin and the flood. [D.M.] 
O.028 O’Neill, Michael. "Mexican Calendar Tells Birth Date of Quetzalcoatl." California Intermountain News (20 December 1979): 3-4. Ancient American calendars indicate that Quetzalcoatl was born on April 6, about the same year that Jesus was born. [D.M.]

O.029 O’Neill, Michael. "Mexico's Ancient Messiah: Solving the Bible’s Unsolved Messianic Scripture." California Intermountain News (25 January 1979, 8 February 1979): 3, 4-5. Relates Mexican data concerning QuetzalcoatI to the messianic concept of the Old Testament and ultimately to Jesus. [D.M.]

O.030 O’Neill, Michael. "Quetzalcoatl: Mythology Surrounds Life of "America's Ancient Messiah." California Intermountain News (24 July 1975): 10, 12. Recounts several myths about Quetzalcoatl, whom the later Mexicans identified with Jesus. [D.M.]

O.031 O’Neill, Michael. "Quetzalcoatl: Stories of Ancient American Messiah Linger as Part of Mexico's Heritage." California Intermountain News (27 March 1975): 2, 5. Reports a conversation the author had with a descendant of the Toltecs. Includes a description of and legends about Quetzalcoatl. [D.M.]

O.032 O'Neill, Michael. "Quetzalcoatl, the Resting Lord: Probing the Mystery of the Ancient Chac Mool." California Intermountain News (1 May 1980): 3-4. Relates Quetzalcoatl to the Yucatan statue of Choc Mool. [D.M.]

0.033 O’Neill, Michael. "Teo Tlogue Nahuague: 'The Universal God of All Things.' " California Intermountain News (21 October 1976): 2. Excerpts from the writings of Ixtlilxochitl are used to discuss humanity's first parents. [D.M.]

O.034" 'On the Morrow Come I Into the World'-The Book of Mormon Christmas Story." Ensign 16 (December 1986): 44-45. Discusses the account of Jesus' birth in the Book of Mormon and the events that occurred during that time in the American continent. Quotes extensively Helaman 12, 13, and 14 and 3 Nephi 1. [L.D.]

O.035 "One Work: Review of the New Manual." IE 8 (August 1905): 783-93. Stenographer's notes of B. H. Roberts's discourse on the Church's new Book of Mormon manual. Discusses the importance of the study of the Book of Mormon and includes Bible evidences of the truthfulness of the Book of Mormon and internal evidences of its truthfulness. [L.D.]

O.036 "Opening Book of Mormon Opens Heavens." CN 58 (18 June 1988): 7. President Benson's emphasis on the Book of Mormon is making a difference because people are becoming interested and getting exited about it. [R.H.B.]

O.037 Ord, Gayle Gable. "The Book of Mormon Goes to Press." Ensign 2 (December 1972): 66-70. A detailed and technical account of the printing of the Book of Mormon, including a description of the physical process used by the printers, Egbert Grandin of the Wayne Sentinel, and John H. Gilbert, the compositor. [B.T.]

O.038 "Origin and History of the Mormonites." English Review (November 1850): 400-419. This polemical article uses extracts from Joseph Smith's own writings, the Doctrine and Covenants, and the Book of Mormon combined with other sources to conclude that Joseph Smith was deluded. The Book of Mormon originated with the Spaulding manuscript, which Sidney Rigdon is purported to have stolen, altered, and embellished. [J.W.M.]

O.039 Origin of the Book of Mormon. Plano, IL: RLDS Church, 1876?. Argues that the Book of Mormon was not part of the Spaulding Manuscript. The fact that there were Three Witnesses to the gold plates presents an argument against the Spaulding theory for the origin of the Book of Mormon. [D.W.P.] 
O.040 "Origin of the Indians." MS 64 (April 1902): 213-14. The Tinneh Indians of Alaska "indisputably are of Asiatic origin," a conclusion reached through language comparisons. The writer maintains that "Mexico, Central and South America contain antiquities which are highly suggestive of Egyptian origin." These could have crossed via the ancient continent of Atlantis. [B.D.]

O.041 "The Original Manuscript." Contributor 8 (October 1887): 441, 474. A reproduction, explanation, and description of a page of the original Book of Mormon manuscript. [A.T.]

O.042 "Original Manuscript of the Book of Mormon." IE 3 (March 1900): 389-90. Gives an account about the possibility that David Whitmer or the Whitmer family possessed the original manuscripts of the Book of Mormon. [L.D.]

O.043 "Original Manuscript of Book of Mormon Traced." DN (8 August 1931): 1, 6. David Whitmer showed his copy of the Book of Mormon manuscript to Orson Pratt and Joseph F. Smith, who noticed that the signatures of the 11 witnesses were in Oliver Cowdery's handwriting. The author concludes therefore that this is the printer's manuscript, and that the original manuscript was placed into the cornerstone of the Nauvoo House. [A.T.]

O.044 Orion. Book of Mormon Talks. Lamoni, IA: Board of Publication of the Reorganized Church of Jesus Christ of Latter Day Saints, 1912. This book, for older children, is in the form of a dialogue between a father and his three children. The children ask questions about the Book of Mormon and the father answers. Some topics discussed are: where did the Book of Mormon come from, who were the peoples in it, what does it say about them, what does the Bible say about the Book of Mormon, what prophecies does the Book of Mormon contain, and which prophecies have been fulfilled? [B.D.]

$\mathbf{0 . 0 4 5}$ Orme, Gilbert Charles. L.D.S. Scriptures. Salt Lake City: Bookcraft, 1974. Teaching aid. Compilation of 1900 scriptural passages organized alphabetically under 300 subject headings. [J.W.M.]

O.046 Orr, Adrian Van Brocklin. Mormonism Dissected, or, Knavery "on Two Sticks," Exposed. Bethania, PA: Reuben Chambers, 1841. A polemical tract against Mormon interpretations of biblical prophecy supportive of the Book of Mormon. Author asserts that the Book of Mormon contradicts the Bible. [M.R.]

O.047 Osmond, Waldo L. "The Three Witnesses." MS 89 (12 May 1927): 298-300. The Three Witnesses fulfilled the function of bearing living testimonies of the truthfulness of the Book of Mormon. They became witnesses when they received a heavenly manifestation in June 1829. [D.W.P.]

0.048 Ostler, Blake T. "The Book of Mormon as a Modern Expansion of an Ancient Source." Dialogue 20 (Spring 1987): 66-123. The Book of Mormon clearly contains evidences of ancient origin and complexity, yet many elements appear to be modern. Author advances the theory of "prophetic expansion" in which certain modern elements were imposed upon the more ancient material. [M.R.]

O.049 Ostler, Blake T. "The Covenant Tradition in the Book of Mormon." In Rediscovering the Book of Mormon, edited by John L. Sorenson and Melvin J. Thorne, 230-40. Salt Lake City: Deseret Book and FARMS, 1991. Discusses the two covenant renewal festivals of the Book of Mormon-King Benjamin's address and the account of King Limhi-and finds that the ancient origins of the Book of Mormon are revealed in the similarity of the traditions of Israel and the Book of Mormon records. [J.W.M.] 
O.050 Ostler, Blake T. "The Development of the Mormon Concept of Grace." Dialogue 24 (Spring 1991): 57-84. An in-depth examination of grace, comparing the Book of Mormon concept with that of Augustine and the major instigators of the Reformation. The doctrines related to grace were largely carried through into the Nauvoo period. [D.M.]

O.051 Ostler, Blake T. "The Idea of Preexistence in Mormon Thought." In Line Upon Line: Essays on Mormon Doctrine, edited by Gary James Bergera, 127-44. Salt Lake City: Signature Books, 1989. The Book of Mormon does not clearly define the preexistence of man, but seems to foreshadow a kind of preexistence by treating the "Adamic myth as an expression of generic human experience." Joseph Smith more clearly defined the Mormon position through the Book of Moses. [J.W.M.]

O.052 Ostler, Blake T. Review of Book of Mormon Authorship: New Light on Ancient Origins, by Noel B. Reynolds. Dialogue 16 (Winter 1983): 140-44. Book review.

O.053 Ostler, Blake T. "The Throne-Theophany and Prophetic Commission in 1 Nephi: A Form-Critical Analysis." BYU Studies 26 (Fall 1986): 67-95. Compares the throne theophany of Lehi in 1 Nephi 1 with similar visions in the Old Testament pseudepigrapha. Concludes that the Book of Mormon account more closely corresponds to ancient sources than to nineteenth-century religious experiences whose reports would have been available to Joseph Smith. Contains three appendices. [D.M.]

O.054 Ostler, Shannon. "Creative Items Focus on Book of Mormon." CN 59 (11 March 1989): 6. A homemaking fair focused on the Book of Mormon. Creative ideas included a children's quiet book and a quilt depicting stories from the Book of Mormon. [M.R.]

O.055 Oswalt, M. L. Pen Pictures of Mormonism. Philadelphia: American Baptist Publication Society, 1899. A polemical work against Mormonism. Pages 30-36 discuss the Book of Mormon. Argues against the Book of Mormon's claim of multiple authorship, claims the book resembles the Spaulding manuscript, plagiarizes the Bible, and anachronistically mentions the horse and the ass. [M.R.]

O.056 Otten, Leaun G., and E. A. McKenna. Selected Statements from General Authorities Concerning Book of Mormon Passages. 3 vols. Provo, UT: BYU Press, 1971. A collection of statements made by General Authorities of the Church of Jesus Christ of Latter-day Saints concerning Book of Mormon passages. Volume one begins with statements by Church leaders concerning 1 Nephi to Words of Mormon; volume two contains statements dealing with Mosiah and Alma; volume three with the books Helaman to Moroni. [J.W.M.]

O.057 Ottinger, G. M. "Old America." Juvenile Instructor 10-11 ( 9, 23 January, 6, 20 February, 6, 20 March, 3, 17 April, 1, 15, 29 May, 12, 26 June, 10, 24 July, 7, 21 August, 4, 18 September, 2, 16, 30 October, 13, 27 November, 11, 25 December 1875, 1, 15 January, 1, 15 February, 1, 15 March, 1, 15 April, 1, 15 May, 1, 15 June 1876): 3-4, 14-15, 32-33, 40-41, 52-53, 63-64, 80-81, 87-88, 98-99, 110-111, 131-132, 142-43, 155-56, 167-78, 178-89, 182-83, 194-95, 206-7, 220-21, 230-31, 244-45, 254-55, 266-67, 287-88, 290-91, 302-3, 8-9, 15, 27-28, 4141, 51-52, 63-64, 74-75, 87-88, 98-99, 111-12, 128-29, 134-35. Series of articles dealing with archaeological, anthropological, geographical, societal, religious, and historical aspects of ancient America and their connections to the Book of Mormon, which is the key to understanding "old American" studies. [A.C.W.]

O.058 Ottinger, G. M. "Our Purpose." Juvenile Instructor 9 (7 November 1874): 266-67. The introductory essay on discoveries in American antiquities that have a bearing on the Book of Mormon. [D.M.] 
O.059 Ottinger, G. M. "Votan, the Culture-Hero of the Mayas." Juvenile Instructor 14 (1 March 1879): 57-58.

Points out "remarkable" similarities between the Book of Mormon and the Popol Vuh, relating it to the Nephites, Mulekites, Jaredites, and various geographical locations from Book of Mormon. Compares the river Sid to the Rio Usumasint and Zarahemla to the ruins of Palenque. [A.C.W.]

O.060 "Our Sacred Scripture." CN 45 (20 September 1975): 16. Nephi's vision (1 Nephi 13) shows how parts of the Bible have been removed and that "many do stumble" because of it. [M.D.P.]

O.061 "Our Work: Review of the New Manual." IE 8 (August 1905): 783-89. Review of the new (1905-06) Book of Mormon manual. Expounds on B. H. Roberts's views of the importance of the Book of Mormon. External and internal evidence supports Book of Mormon's claim to truth. The manual refutes objections to the Book of Mormon, such as the Spaulding and Rigdon theories. [A.C.W.]

O.062 Outline Illustrating the Historical Evolution of the Book of Mormon. N.p.: n.p., 1939. An illustrated outline of Book of Mormon history beginning with the exodus of the Jaredite people to Joseph Smith's visit from angel Moroni and the publication of the book. Gives a summary of the Manuscript Found by Solomon Spaulding and a reprint of the letter of President Fairchild of Oberlin College saying that the Spaulding manuscript bears no resemblance to the Book of Mormon. [J.W.M.]

O.063 Outlines in Theology For Use in the Church Schools of High School Grade: The Nephite Dispensation First Year. N.p.: The General Board of Education of LDS Church, 1916. Teacher's guide for lessons for high school students provides suggested objectives, essential messages, and topics that the students may consider. The lessons treat 1 Nephi through Moroni, ending with evidences of the authenticity of the Book of Mormon found in archaeology and ethnology taken from James E. Talmage's The Articles of Faith. [J.W.M.] 
P.001 P. "The Indians." MA 2 (January 1836): 245-48. Relates the Book of Mormon to American Indians and the gathering of Israel. [A.C.W.]

P.002 P. "Untitled." TS 3 (1 September 1842): 906-8. A transcription of part of a conversation between a clergyman and a "saint" discussing the Book of Mormon as a revelation, why the gold plates are not on display, and the propriety of angelic visitations in this enlightened age. [D.M.]

P.003 Pack, Frederick J. "The Book of Mormon." DN Church Section (13 June 1936): 5. Pack defends the veracity of the Book of Mormon and defends the Book of Mormon claim that horses existed on the American continent. [B.D.]

P.004 Pack, Frederick J. "The Book of Mormon-In the Test." DN Church Section (2 July 1932): 4. Pack defends the veracity of the Book of Mormon, dismisses the Spaulding Theory, reminds his listeners that the Three Witnesses never denied their testimonies, and reiterates Moroni's promise (Moroni 10:4) that all may know the truth of the Book of Mormon through prayer. [B.D.]

P.005 Pack, Frederick J. "The Book of Mormon-Its Purport and Message." DN Church Section (16 July 1932): 4, 8. The Book of Mormon purports to be a record of the dealings of God with certain people on the American continent. Gives a lengthy overview of the Book of Mormon story. [J.W.M.]

P.006 Pack, Frederick J. "A New Scripture." MS 98 (9 July 1936): 434-36. Gives logical evidences that support the Book of Mormon, including the short amount of time it took Joseph Smith to translate the Book of Mormon, the Three Witnesses testified of it's truth to their dying day, archaeological discoveries, and more. [M.D.P.]

P.007 Pack, Frederick J. "Revelation Ante-Dating Scientific Discovery-An Instance." IE 10 (February, June 1907): 241-47; 595-97. Investigates geological evidence that horses were present on the American Continent during the Book of Mormon period. [J.W.M.]

P.008 Pack, Frederick J. "Route Traveled by Lehi and His Company." Instructor 73 (April 1938): 160. All American editions of the Book of Mormon after 1882 contain a notation, written possibly by Frederick G. Williams, which identifies the location of the landing place of Lehi's company. It is not properly verified as to authenticity and should be avoided. [J.W.M.]

P.009 Pack, Frederick J. “The Spalding Argument." IE 16 (February 1913): 333-41. Answers F. S. Spalding's allegations that the Book of Mormon is not true and Spalding's claims that the Book of Abraham was falsely translated and therefore both documents are fraudulent. [J.W.M.]

P.010 Pack, Frederick J. "Time Involved in Translating the Book of Mormon." Instructor 70 (February 1935): 49. That the bulk of the translation was done from 7 April 1829 to June 1829 is evidence that the Book of Mormon was of divine origin. The book agrees in doctrine with the Bible and with archaeological facts that were virtually unknown in backwoods New York in 1830. [J.W.M.]

P.011 Pack, Frederick J. "Valid Testimony of the Three Witnesses." MS 90 (6 December 1928): 769-75. Discusses the men who are the Three Witnesses to the Book of Mormon, their continued testimony after leaving the Church, and the reconversion of Oliver Cowdery and Martin Harris. [L.D.] 
P.012 Pack, Melvin Deloy. "Possible Lexical Hebraisms in the Book of Mormon: the Words of Mormon to Moroni." M.A. thesis, Brigham Young University, 1967. Gives many examples of idioms used in the Book of Mormon that translate naturally back into Hebrew. Covers Words of Mormon through Moroni, continuing a similar study by E. Craig Bramwell. Includes a table of Book of Mormon verses that contain wording similar to biblical passages. [D.M.]

P.013 Packard, Dennis J. "The Beginning of Wisdom." BYU Studies 24 (Winter 1984): 53-60. One helpful method of studying the Book of Mormon is to read the scriptures aloud. The scriptures are meant to be heard like great music. [J.W.M.]

P.014 Packer, Athol B. An Open Door. Independence, MO: Herald House, 1959. A book designed for RLDS pedagogy. Two chapters discuss the contents of the Book of Mormon and claim that it supports the Bible and is sustained by archaeological evidence. [D.M.]

P.015 Packer, Boyd K. "Atonement, Agency, Accountability." Ensign 18 (May 1988): 69-72. Also in CR (2-3 April 1988): 80-84. The Book of Mormon clarifies the New Testament in regards to the Atonement, agency, the accountability of mankind, and repentance. [J.W.M.]

P.016 Packer, Boyd K. "The Book of Mormon." In Packer's, Let Not Your Heart Be Troubled, 268-85. Salt Lake City: Bookcraft, 1991. Jesus Christ is the central message of the Book of Mormon. Gives suggestions of items to tell investigators when giving them a Book of Mormon. [D.M.]

P.017 Packer, Boyd K. "Book of Mormon Military Service and War." CR (April 1968): 33-36. Those who go to war should keep the commandments and not become "conscientious objectors." The Book of Mormon justifies war when defending lives, country, and religion. Being prepared for war is not warmongery. [R.C.D.]

P.018 Packer, Boyd K. "Book of Mormon Origin: Scriptures a Blessing." CR (April 1974): 135-39. Reaffirms the divine origin of the Book of Mormon and the reality of continuing revelation. Defends textual corrections and sets forth a formula for ascertaining truth of the Book of Mormon, that of spiritual inquiry coupled with a lifetime of sincerity and humility. [E.G.]

P.019 Packer, Boyd K." 'The Law and the Light.' "In The Book of Mormon: Jacob through Words of Mormon, To Learn with Joy, edited by Monte S. Nyman and Charles D. Tate Jr., 1-27. Provo, UT: Brigham Young University Religious Studies Center, 1990. Man is unique in the animal kingdom (3 Nephi 15:9). Opposes organic evolution as the explanation for the origin of mankind. Points out intellectual and moral implications of accepting evolution. Admonishes that there are to be "no manner of -ites" (4 Nephi 1:15), but instead seekers after truth, looking to Christ as "the law and the light" (3 Nephi 15:9). [D.M.]

P.020 Packer, Boyd K. "The Library of the Lord." Ensign 20 (May 1990): 36-38. Reports on scriptural innovations: new editions of the standard works published in the early 1980s, increased numbers of translations, LDSView computer software, and the correlation of Church curriculum to the scriptures. Affirms the Book of Mormon's importance in testifying of Christ and validating the Old and New Testaments. [E.G.]

P.021 Packer, Boyd K. "Publication of LDS Edition of the Scriptures." CR (October 1982): 73-77. With the publication of the new LDS edition of the scriptures, the complete fulfillment of Ezekiel's prophecy of two sticks (records) has come to pass. The Book of Mormon will now have the title, "Another Testament of Jesus Christ," so the two sticks are now one. [R.C.D.] 
P.022 Packer, Boyd K. "Scriptures." Ensign 12 (November 1982): 51-53. Also in CR (October 1982): 73-77. Ezekiel 37 tells of the sticks of Judah and Joseph that will become one in the hands of the user. This prophecy began to come true when the Book of Mormon was published. Gives the historical setting of the printing of the book and the progressive steps toward the new edition of the scriptures. This massive undertaking draws the Bible and the Book of Mormon into one. [J.W.M.]

P.023 Packer, Boyd K. "The Things of My Soul." Ensign 16 (May 1986): 59-61. Also in CR (5-6 April 1986): 73-78. Gives an introduction to the Book of Mormon for those who have never read it. The book is not fictional, biographical, or historical, nor is it merely a novel. It has profound value as a book and possesses a sacred message and a promise. [J.W.M.]

P.024 Packer, James S. "John Lloyd Stephens and the Mayas." Ensign 2 (September 1972): 50-53. John Lloyd Stephens's discoveries of 1839 are a physical witness to the Book of Mormon. In Honduras he discovered magnificent structures that dispelled the belief that native Americans were mere savages. [J.W.M.]

P.025 Paden, William M. "The Missionary Work of the Mormons." Biblical Review 16 (October 1931): 553-73. Denigrates LDS practices and teachings. Says that missionaries circulate the Book of Mormon but not the Bible. Comments on reactions of Church leaders to an earlier article claiming that LDS teachings were changing. [D.M.]

P.026 Paden, William M. Missions among Mormons-Why? New York: Board of Home Missions of the Presbyterian Church in the United States of America, 1921. A polemical tract. Compares Mormonism with paganism, Baalism, and Islam. Paraphrases Moslem credo to be a Mormon slogan: "There are many gods, and Joseph Smith is their Prophet." Mormon scriptures have less value than the Koran. [D.M.]

P.027 Paden, William M. Questions and Answers on Mormonism. New York: Board of National Missions Presbyterian Church, USA, 1929. Spirited tract asks and answers 28 questions in a decidedly negative tone. "The Book of Mormon ... is a rather orthodox book, and that in spite of its baseless claims to authenticity and inspiration." [D.M.]

P.028 Pagan, Eduardo. "Cultural Hegemony." Sunstone 15 (December 1991): 9-11. Questions the Book of Mormon concept concerning the curse of the black skin for those who had erred in ignorance. The Book of Mormon is the history of a white culture, taken to people with a dark skin with a promise of white skin. "The cultural hegemony of white America permeates Mormonism"; thus Lamanites must give up their racial and cultural identity to gain salvation. [J.W.M.]

P.029 Pagan, Eduardo. "Innocent Racism." Sunstone 15 (April 1991): 7-8. The references in the Book of Mormon to "dark and loathsome" or "white and delightsome" are to lifestyles rather than to the color of skin. Many in the Church do not understand and thus impose a sinful heritage upon people with Jewish, African American, and Lamanite backgrounds. [J.W.M.]

P.030 Page, Gerome E. "All Secret Societies: The True Church of the Devil." n.p., n.d. A pamphlet written against "secretism," or "all lodgery, secret associations, or secret combinations" of the 19th century. Believes that the Book of Mormon prophets wrote and prophesied about such societies. [D.W.P.]

P.031 Page, John E. The Spaulding Story Concerning the Origin of the Book of Mormon, Duly Examined, and Exposed to the Righteous Contempt of a Candid Public. Pittsburgh: Author and Church of Jesus Christ of Latter-day Saints, 1843. Argues against the idea that Sidney Rigdon borrowed the Spaulding manuscript, altered the manuscript to fit his purposes, and used Joseph Smith to publish it as the Book of Mormon. [J.W.M.] 
P.032 Palfrey, Louise. The Divinity of the Book of Mormon Proven by Archaeology; a Series of Papers Formerly Published in the "Arena" Department of the Autumn Leaves. Lamoni, IA: Zion's Religio-Literary Society, 1908. A collection of papers on American archaeology connected with the Book of Mormon. It was produced as a reference handbook intended to "stimulate young people with interest in the scientific relations of the Book of Mormon." It covers preAztec, Pre-Inca, Aztec, and Inca eras as well as the ruins, religion, and origin of ancient America, the moundbuilders and cliff-dwellers. [C.W.B.]

P.033 Palfrey, Louise, ed. Lessons on the Book of Mormon and Archaeology, and Programs for Locals and Home Classes. Independence, MO: Zion's Religio-Literary Society, 1906. A four-week teaching plan on the Book of Mormon and archaeology. Includes introductions and outline, "helps" on the lesson text, thoughts and questions as well as advice for teachers. [C.W.B.]

P.034 Palmer, David A. "Cumorah." In Encyclopedia of Mormonism, edited by Daniel H. Ludlow, 1:346-47. 5 vols. New York: Macmillan, 1992. Cumorah in the Book of Mormon is the hill upon which the Nephites and Lamanites fought their last battle and also where the Jaredites were destroyed. Many ancient records were deposited in it that will someday be revealed. Moroni buried the Book of Mormon plates in an unspecified site. No specific site is identified as the Book of Mormon Hill Cumorah. [B.D.]

P.035 Palmer, David A. "Has the City of Nephi Been Found?" ZR 22-23 (1984): 6-7, 15-16. Asserts that Kaminaljuyu, ancient ruins located within the present city of Guatemala, is the city of Nephi. Archaeologists and scholars have found evidence "that meets all the criteria with respect to geography and topography which the Book of Mormon gives for the city of Nephi." [D.S.T.]

P.036 Palmer, David A. In Search of Cumorah: New Evidences for the Book of Mormon from Ancient Mexico. Bountiful, UT: Horizon Publishers, 1981. Presents evidence regarding various geographical and archaeological aspects of the Book of Mormon. Points out similarities between the culture and history of the Jaredites, Mulekites, Nephites, and the Mesoamericans. Believes that Cerro Vigia was Mormon's Hill Cumorah. This work is reviewed in R.008, and in T.336. [C.W.]

P.037 Palmer, David A. Review of Exploring the Lands of the Book of Mormon, by Joseph L. Allen. BYU Studies 30 (1990): 136. Book review.

P.038 Palmer, David A. Review of The Land of the Nephites, by Delbert W. Curtis. Review of Books on the Book of Mormon 2 (1990): 67-73. Book review.

P.039 Palmer, David A. "A Study of Mesoamerican Religious Symbolism." SEHA 103 (12 August 1967): 9-13. Palmer explores the religious symbolism that is found in the art of ancient Mesoamerica, and clarifies and explains the interrelationships of theological symbols - the tree of life, the serpent, fire, water, the snail or sea shell, and the stepped fret. Includes illustrations of the characters with the analysis. [C.W.B.]

P.040 Palmer, David A. "A Survey of Pre-1830 Historical Sources Relating to the Book of Mormon." BYU Studies 17 (Autumn 1976): 101-7. Discusses historical and religious internal reconstructions of Book of Mormon geography in Mexico and Guatemala. Discusses what authentic information on pre-A.D. 400. Mesoamerican history was available in western New York in 1829. [L.D.]

P.041 Palmer, David A. "Warfare and the Development of Nephite Culture in America." Provo, UT: FARMS, 1985. The three causes of warfare are economic, political, and religious. Book of Mormon accounts of warfare seem to 
parallel the analysis of archaeologists concerning warfare in Mesoamerica. [J.W.M.]

P.042 Palmer, David A. "The World and Times of the Jaredites." In A Symposium on the Book of Mormon, 98. Salt Lake City: Church of Jesus Christ of Latter-day Saints, 1979. Uses parallel columns to compare archaeological finds and descriptions from the Book of Ether on construction of cities, the development of cities in the narrow neck of land, mining, metal work, and civil war. [N.K.Y.]

P.043 Palmer, Spencer J., and William L. Knecht "View of the Hebrews: Substitute for Inspiration?" BYU Studies 5 (Winter 1964): 105-13. Fawn Brodie claimed that when Joseph Smith's literary creativity dissipated in 2 Nephi he simply borrowed Isaiah passages referred to in Ethan Smith's View of the Hebrews. Using statistical methods, these authors challenge Brodie's opinion and find that the correlation between the Book of Mormon and View of the Hebrews is insignificant. [D.M.]

P.044 Palmer, William. The External Evidences of the Book of Mormon Examined. London: Briscoe, 1849. Vindictive tract addresses the testimony of the witnesses to the Book of Mormon and the part played by Professor Anthon. Refers to the Book of Mormon as a "mutilated romance." Accepts the Spaulding explanation. [D.M.]

P.045 Palmer, William. Mormonism Briefly Examined. London: Briscoe, 1849?. Criticizes the Book of Mormon by writing that the Book of Mormon contradicts itself, falsifies its own prophecies, and "destroys its own theology." It contains "bad grammar, bad arrangement, bad taste, and bad material." [D.W.P.]

P.046 Palmer, William Rees. Two Pahute Indian Legends: "Why the Grand Canyon Was Made" and "The Three Days of Darkness," External Evidences of the Book of Mormon Examined. London: Bristol, 1849. The Indian legend "Why the Grand Canyon Was Made" tells of the great shaking and trembling of the earth that came after many generations and created the Grand Canyon. The account sounds very much like 3 Nephi 10:9-10. "The Three Days of Darkness" tells that at the time of the death of Shinob, younger God of the Pahute Indians, they could not light a fire. Later Shinob came back to life. This legend sounds like the account in the Book of Mormon in 3 Nephi 8:1723. This work is reviewed in P.213. [J.W.M.]

P.047 "Palmyra Edition Book of Mormon Rare." SH 50 (1 April 1903): 293. A news note regarding a rare copy of the Palmyra first edition of the Book of Mormon that was donated to the Chicago Historical Society. [J.W.M.]

P.048 The Parable of the Hidden Treasure. Oak Grove, MO: The Church of Christ, 1987?. Evangelical pamphlet containing a parable relating to the hidden treasure of eternal life. Explains that the Book of Mormon and the Bible are both maps to follow to gain this treasure. [E.G.]

P.049 Parker, Aubrey. “Mormon.” MS 84 (15 June 1922): 375. A poem about the prophet Mormon. [M.D.P.]

P.050 Parker, Aubrey J. "B: The Bible and the Book of Mormon." In Parker's ABC of Mormonism. N.p.: by the author, 1953, 17-28. The Book of Mormon is a "history of the aborigines of the Americas." It contains the fullness of the gospel and supports and corrects the errors in the Bible. [J.W.M.]

P.051 Parker, Jimmy B. "A Record of Our Kingdoms." Ensign 6 (August 1976): 22-25. 1 Nephi 9:2-3 provides a good pattern for keeping records. One's own personal record of spiritual experiences may be likened to the small plates of Nephi. [J.W.M.] 
Parkin, Max H. "Untitled Talk on Church History and the Book of Mormon." Mormon History Association Newsletter 45 (November 1980): 2-4. A brief analysis of several clues that have been used to argue possible dates that Joseph Smith received D\&C 10, which scripture deals with "instructions to replace the 116 pages of the manuscript lost by Martin Harris in 1828 with another record, which God has prepared in antiquity for that purpose." [D.S.T.]

P.053 Parkinson, David. "A Study to Compare a Programmed Approach to Reading the Book of Mormon with the Traditional Reading Method." M.A. thesis, Brigham Young University, 1969. A work involving the comparison of "a programmed approach to reading the Book of Mormon with the traditional reading method based upon student ability to relate Book of Mormon persons with Book of Mormon events." Summary of findings, conclusions, and recommendations of the study are included. [D.S.T.]

P.054 Parkinson, David P. "Engraving the Image of God upon Our Countenances." In The Sixth Annual CES Religious Educators Symposium on the Book of Mormon. 70-72. Salt Lake City: Church of Jesus Christ of Latter-day Saints, 1982. A commentary on Alma 5, especially Alma 5:19 ("the image of God engraven upon their countenances"), is studied to determine its meaning. [A.T.]

P.055 Parrish, Alan K. "Laman." In Encyclopedia of Mormonism, edited by Daniel H. Ludlow, 2:801-2. 5 vols. New York: Macmillan, 1992. Identifies Laman and describes what became of his descendants including the "noteworthy future for them in the latter days." [B.D.]

P.056 Parrish, Alan K. "Lehi and the Covenant of the Promised Land: A Modern Appraisal." In The Book of Mormon: Second Nephi, The Doctrinal Structure, edited by Monte S. Nyman and Charles D. Tate Jr., 39-59. Provo, UT: Brigham Young University Religious Studies Center, 1989. Details the covenant between Lehi and the Lord concerning the promised land and indicates the high expectations for those who now live in the land of liberty. Relates rise and fall of Book of Mormon civilizations as a warning to latter-day American society. Concludes that Americans value freedom but need increased spiritual commitment to fulfill covenantal obligations. [E.G.]

P.057 Parrish, Alan K. "Stela 5, Izapa: A Layman's Consideration of the Tree of Life Stone." In The Book of Mormon: First Nephi, the Doctrinal Foundation, edited by Monte S. Nyman and Charles D. Tate Jr., 125-50. Provo, Utah: Brigham Young University Religious Studies Center, 1988. Gives background information on the Stela 5, Izapa, the tree of life stone. Summarizes the works of V. Garth Norman, M. Wells Jakeman, and others and concludes that Stela 5, Itzapa, seems to coincide with the Book of Mormon both in dating and location. LDS church members should expect to see Book of Mormon themes in ancient American art, especially the tree of life motif because of its message, origin, and importance to Lehi and Nephi. [A.T.]

P.058 Parrish, Mary Pratt. The Book of Mormon Story. Salt Lake City: Deseret Book, 1965. A factual, adult storybook version of the Book of Mormon. It is written in the same style of language that is found in the Book of Mormon so the reader will become accustomed to its "lofty expressions and peculiar phraseology" and be able to more fully understand and enjoy the original version. This work is reviewed in B.564. [C.W.B.]

P.059 Parrott, William Saunders. The Veil Uplifted or the Religious Conspirators of the Latter-day Saints. Bristol, England: Taylor, 1865. A condemnation of Mormonism and the Book of Mormon. The Book of Mormon has many errors in grammar, which have been changed in more recent editions. The book appears to have been based upon the work of Solomon Spaulding. Mormonism is comparable with Islam. [M.R.] 
P.060 Parry, Donald W. "Antithetical Parallelism in the Book of Mormon." In Reexploring the Book of Mormon, edited by John W. Welch, 167-69. Salt Lake City: Deseret Book and FARMS, 1992. The writer of Proverbs 13:9 uses contrasting elements to emphasize an idea. The same technique is found in Alma 5:40, 9:28, and 36:21 and other Book of Mormon scriptures. Such antithetical parallelisms invoke the readers' involvement and teach them about opposite ideas in the Book of Mormon. [N.K.Y.]

P.061 Parry, Donald W. The Book of Mormon Text Reformatted according to Parallelistic Patterns. Provo, UT: FARMS, 1992. The entire text of the Book of Mormon formatted into (1) historical narrative and (2) parallelistic forms (consisting of a number of parallel and repetitious types). The narrative portions are formatted into regular blocked style. The introduction includes explanations of the forms of poetic parallelisms found in scripture. [B.D.]

P.062 Parry, Donald W. "Climactic Forms in the Book of Mormon." In Reexploring the Book of Mormon, edited by John W. Welch, 290-92. Salt Lake City: Deseret Book and FARMS, 1992. Climactic composition occurs when successive clauses, sentences, or a same word or words form the end of a text and begin another. Examples are found in Joel 1:3-4 and in Moroni 8:25-26. There are a score of other passages using this form in the Book of Mormon. Joseph Smith can be commended in his translation work for leaving the passages structurally intact. [N.K.Y.]

P.063 Parry, Donald W. "Hebrew Literary Patterns in the Book of Mormon." Ensign 19 (October 1989): 58-61. Surveys, defines, and gives specific examples of scriptural poetic forms found in the Book of Mormon, including synonymous, synthetic, antithetical, contrasting, alternate, numeric, climactic, and repeating parallelisms. These poetic literary patterns identify important passages, add emphasis to messages, define and enlarge upon main points, make certain information more memorable, and structure the text so that important material can be more easily understood and remembered. Beyond the examples given in the text, a list of several Book of Mormon scriptural references are given to illustrate the extensive use of these forms by the prophets, witnessing the divinity of the Book of Mormon. [A.A.]

P.064 Parry, Donald W. "I Have A Question: Why is the phrase 'and it came to pass' so prevalent in the Book of Mormon?" Ensign 22 (December 1992): 29. The Hebrew word wayehi is translated as "and it came to pass" numerous times in the King James Version of the Old Testament, but occurs even more frequently in the Hebrew Bible, since the King James Version translators also used alternate translations of the term. Its frequent repetition in various passages of the Book of Mormon is "further evidence [of] ties to the Hebrew language" that Joseph Smith would have been unaware of. [A.C.W.]

P.065 Parry, Donald W. "Parallelisms according to Classification." Provo, UT: FARMS, 1988. Book of Mormon scriptures are categorized according to their parallelistic structures. The categories of classification include simple alternate, anaphora, anabasis, antithetical, as well as many others. These are examples of Hebrew poetry found in the Book of Mormon. [J.W.M.]

P.066 Parry, Donald W. "Parallelisms Listed in Textual Sequence." Provo, UT: FARMS, 1988. Hebrew poetic forms found in the Book of Mormon are listed in chronological order and noted according to type of poetic structure. [J.W.M.]

P.067 Parry, Donald W. "Poetic Parallelisms in the Book of Mormon." Provo, UT: FARMS, 1988. Parallelism is often used in Hebrew poetry. There are many examples in the Bible and the Book of Mormon: synonymous, identical words or phrases, antonyms, complementaries, different inflections of the same root, gradations, and superordinates. Examples of these structures are provided. [J.W.M.] 
P.068 Parry, Donald W. Review of How to Hiss Forth with the Book of Mormon, by Robert E. and Sandra L. Hales. Review of Books on the Book of Mormon 3 (1991): 84-85. Book review.

P.069 Parry, Donald W. Review of The Book of Isaiah: A New Translation with Interpretive Keys from the Book of Mormon, by Avraham Gileadi. Review of Books on the Book of Mormon 4 (1992): 52-62. Book review.

P.070 Parry, Donald W. Review of The God-Inspired Language of the Book of Mormon, by Wade Brown. Review of Books on the Book of Mormon 1 (1989): 5-9. Book review.

P.071 Parry, Donald W. "Ritual Anointing with Olive Oil in Ancient Israelite Religion." In The Allegory of the Olive Tree: The Olive, The Bible, and Jacob 5, edited by Stephen D. Ricks and John W. Welch, 262-289. Salt Lake City: Deseret Book and FARMS, 1994. Ritual anointing was vital in temple theology, both persons and objects being anointed with olive oil. There were three groups of people who were anointed: priests, prophets, and kings. The anointing included a setting apart for divine service, and represented a "gesture of approach" before entering sacred space. Olive oil signified the Holy Ghost, and the anointed became a type of Christ. [J.W.M.]

P.072 Parry, Donald W. "Symbolic Action as Prophetic Curse." In Reexploring the Book of Mormon, edited by John W. Welch, 206-8. Salt Lake City: Deseret Book and FARMS, 1992. Isaiah and Ezekiel and other prophets of the Old Testament used symbolic actions to represent prophetic curses in the Old Testament. Similar symbolic actions are found in the Book of Mormon, including Moroni's rending of his garment, and the hanging of Zarahemnah on a tree. [N.K.Y.]

P.073 Parry, Donald W. "Teaching in Black and White: Antithetic Parallel Structure in the Book of Alma, Its Form and Function." In The Book of Mormon: Alma, The Testimony of the Word, edited by Monte S. Nyman and Charles D. Tate Jr., 281-90. Provo, UT: Brigham Young University Religious Studies Center, 1992. Book of Mormon prophets teach in black and white and never leave gray areas, a result of the objective of teaching in plainness set forth by Nephi. The technique of antithetical parallelism is an excellent way to make things black or white. It is characterized by an opposition of thoughts, or an antithesis between two or more contiguous lines. It is used in the Bible, by Alma, and other prophets of the Book of Mormon. [N.K.Y.]

P.074 Parry, Donald W." 'Thus Saith the Lord': Prophetic Language in Samuel's Speech." Journal of Book of Mormon Studies 1 (Fall 1992): 181-83. Six prophetic speech forms present in Samuel's speech-the messenger formula, the proclamation formula, the oath formula, the woe oracle, the announcement formula, and the revelation formulaare indicative of prophetic authority and prerogative. These speech forms and others dealing with the commission and divine workings of a prophet are also present in other sections of the Book of Mormon and Bible. [N.K.Y.]

P.075 Parry, E. F. "The Book of Mormon." In Scrapbook of Mormon Literature, edited by Ben E. Rich, 2:260-90. Chicago: Etten, 1917. Evidence of the authenticity of the Book of Mormon includes testimonials from Joseph Smith and the Eleven Witnesses, archaeological discoveries (coins, ancient cities), historical consistency with regard to the Bible, similarities between the Indian and Book of Mormon cultures, and others. [C.W.B.]

P.076 Parry, E. F. “The Book of Mormon Corroborated.” MS 58 (December 1896): 836-38. Quotes William Niven's description of ancient ruins at Yerba Buena in the state of Guerrero, Mexico. Niven theorizes that the city was destroyed by being suddenly submerged in water and later coming up again. Parry quotes 3 Nephi 8:5-17 that describes the violent destruction in the Nephite and Lamanite land. The Book of Mormon is supported by Niven's theory. [B.D.] 
P.077 Parry, E. F. "Objections to the Book of Mormon Considered." MS 60 (30 June 1898): 429-32. A rebuttal to Dr. Shelton, who had given several anti-Mormon lectures in one of the principal cities in England. Sheldon pointed out blemishes in the Book of Mormon and misquoted it. He ridiculed the book's ship building, grammatical construction, reference to a compass, similarity to the Bible, foreknowledge of God, and the ministry of Christ before his birth. [J.W.M.]

P.078 Parry, E. F. A Prophet of Latter Days: His Divine Mission Vindicated. Liverpool: Millennial Star Office, $1897 ?$. Joseph Smith was a true prophet, and the Book of Mormon is one of the fruits of his labors - all of which testify of his inspiration. Many external evidences are cited to demonstrate the authenticity of the Book of Mormon, including newly discovered evidence of ancient cities, and the fact that many Mesoamerican scholars support the idea that the ancient Mesoamericans' culture reflected Near Eastern relations. [B.D.]

P.079 Parry, E. F. "The Urim and Thummim." MS 59 (August 1897): 540-41. Parry argues that Joseph Smith's description of the Urim and Thummim coincide with the Bible's description. Since this and other statements of Joseph Smith coincide with the Bible, Joseph Smith was divinely inspired. [B.D.]

P.080 Parry, Keith. "Joseph Smith and the Clash of Sacred Cultures." Dialogue 18 (Winter 1985): 65-78. Deals with early Mormon missionary experiences among the American Indians. These experiences provide a great deal of insight into Mormon-Indian relationships both past and present. Shows the impact that the Book of Mormon has had upon those relationships. [J.W.M.]

P.081 Parry, Leo. "Book of Mormon Has At Least 24 Writers." CN 50 (16 February 1980): 14. Two BYU professors used a technique called word print on the Book of Mormon. It was found that the book has at least 24 authors and that none of them could be Joseph Smith, Soloman Spaulding, or any of their associates. [M.R.]

P.082 Parson, Michael K. "Sherem and Korihor: Sign Seekers Then and Now." In The Sixth Annual CES Religious Educator's Symposium on the Book of Mormon, 73-75. Salt Lake City: The Church of Jesus Christ of Latter-day Saints, 1982. Explains that signs are gifts from God and when Satan inspires individuals, such as Sherem and Korihor, to seek for signs it is a perversion of God's gift. Examines the relationship between sign seeking and faith and sign seeking and adultery. [A.T.]

P.083 Parson, Michael K. "Why Are These Things Not Recorded in Your Journal?" Ensign 19 (October 1989): 2021. The Savior's admonition to include the writings of Samuel in the sacred records of the Nephites verifies President Kimball's plea to "write it down." [J.W.M.]

P.084 Parsons, Alonzo H. Parson's Text Book. Lamoni, IA: Herald Publishing House, 1902. Herald Heritage, [R]1971. As evidence that the Book of Mormon is a true document, the author quotes early works on the antiquities of America and gives Book of Mormon references that compare with the findings of early American explorers. [J.W.M.]

P.085 Parsons, Robert E. "Becoming Perfeect in Christ". In Studies in Scripture: 1 Nephi to Alma 29, edited byA. Gary Anderson, 39|47. Provo, UT: BYU Religious Instruction, 24 January 1981. Treats the subject of perfection from several angles, the role of grace, and how individuals can become perfect in Jesus Christ. [D.M.]

P.086 Parsons, Robert E. “The Game's in the Name." Ensign 2 (December 1972): 74-78. Riddles about Book of Mormon people to be played to assist in remembering the important characters of the book. [J.W.M.] 
P.087 Parsons, Robert E. "The Great and Abominable Church." In Studies in Scripture: 1 Nephi to Alma 29, edited by Kent P. Jackson, 44-59. Salt Lake City: Deseret Book, 1987. There is a tremendous contrast between the church of Christ and Satan's kingdom. The Gentiles who crossed the sea to discover America were inspired of God. Anyone trying to identify the great and abominable church find that it cannot be identified with a specific church. [J.W.M.]

P.088 Parsons, Robert E. "Hagoth and the Polynesians." In The Book of Mormon: Alma, The Testimony of the Word, edited by Monte S. Nyman and Charles D. Tate Jr., 249-62. Provo, UT: Brigham Young University Religious Studies Center, 1992. In 55 B.C., Hagoth built a large ship, launched it into the West Sea, and sailed north with many families (Alma 63:4-9). Theories suggest that they were lost at sea or they sailed to Japan or Hawaii. It is possible that the Hawaiians or Polynesians are descended from Hagoth and his followers. [N.K.Y.]

P.089 Parsons, Robert E. "The Practices of the Church." In Studies in Scripture: Alma 30 to Moroni, edited by Kent P. Jackson, 282-92. Salt Lake City: Deseret Book, 1988. The practices of the church found in Moroni 1-6 are common to Latter-day Saints. The procedures Joseph Smith taught concerning priesthood ordinations, authority, and sacred ordinances essential for the salvation of mankind were uncommon in his day. Moroni also taught important principles like faith, proper attitude, nourishing new members, and how to conduct meetings. [J.W.M.]

P.090 Parsons, Robert E. "The Prophecies of the Prophets." In The Book of Mormon: First Nephi, The Doctrinal Foundation, edited by Monte S. Nyman and Charles D. Tate Jr., 271-81. Provo, UT: Brigham Young University Religious Studies Center, 1988. Reviews the prophecies of Zenos, Zenock, and Nehum as found in the Book of Mormon. Also questions why Nephi quoted Isaiah 48-49 in 1 Nephi 20-21 and provides assistance in understanding these two chapters. [A.T.]

P.091 Parsons, Tyler. Mormon Fanaticism Exposed. Boston: Printed for the Author, 1841. A polemical work against the Book of Mormon and Mormonism based upon a debate between the author and a Mormon named Nickerson. Contradictions with the Bible and a plethora of anachronisms and absurdities are identified. The Gadianton robbers are seen as Freemasons. The Spaulding theory is advanced as "proof" that the Book of Mormon is a fraud. Testimonies of the witnesses are discredited. [M.R.]

P.092 Partridge, E. D. "A Book of Mormon Sent on a Mission." IE 23 (February 1920): 373. Prompted by an article written by Mrs. Minnie Moore Wilson entitled, "Indians who Avoid Civilization to Save Their Souls," donations were taken from class members and a Book of Mormon was sent to Mrs. Wilson. [J.W.M.]

P.093 Partridge, Edward. "Letter." MA 1 (January 1835): 56-61. Bears testimony that the Book of Mormon proclaims the same gospel the apostles taught. [D.M.]

P.094 Patch, Robert C. "The Fifth Gospel." Instructor 103 (April 1968): 171-73. Shows more than 25 agreements between 3 Nephi and the Gospels of the New Testament. Gives reasons that 3 Nephi should be referred to as the "fifth gospel." [L.D.]

P.095 Patch, Robert G. "I Have a Question: Does the 'Pronouncing Vocabulary' in the Book of Mormon represent the way the Nephites and Lamanites actually pronounced their names?" Ensign 10 (February 1980): 68. It is thought that Joseph Smith knew the proper way to pronounce Book of Mormon names, but never recorded it. A committee suggested rules of pronunciation in 1903, and John M. Mills created a guide using those rules in 1910. [J.W.M.] 
P.096 Paterson, J. Roy H. Meeting the Mormons: A Study of the Mormon Church in Scotland and Elsewhere. Edinburgh: Constable, 1965. A polemical work against Mormonism. Alleged problems and anachronisms in the Book of Mormon are discussed such as Shakespeare, pre-Columbian domesticated animals, textual changes, King James English, plagiarism, and the Spaulding theory. [M.R.]

P.097 Patterson, Robert. "Solomon Spaulding and the Book of Mormon." In History of Washington County, Pennsylvania: With Biographical Sketches, edited by Boyd Crumrine, 425-38. Philadelphia, PA: L. H. Everts, 1882. Claims that even among Mormons it is believed that the Book of Mormon was based upon Solomon Spaulding's manuscript. Includes affidavits from family members and friends of Spaulding that claim that Sidney Rigdon stole the manuscript while working as a printer in Robert Patterson's print shop, revised the document, and produced the historical parts of the Book of Mormon in collusion with Joseph Smith. [J.W.M.]

P.098 Patterson, Robert. Who Wrote the Book of Mormon? Philadelphia: Everts, 1882. Spaulding is responsible for the authorship of the Book of Mormon as is clear from the affidavits of those who were familiar with his work and later read the Book of Mormon. The Book of Mormon must have come about through the agency of Rigdon who probably knew Spaulding. [M.R.]

P.099 Patton, Lucie Dean. Book of Mormon Course of Study. Arizona: Southwest Indian Mission, 1957. A study guide designed to be used by Lamanite children in the Southwest Indian Mission. [D.M.]

P.100 Paul, Charles Randall. "Third Nephi." In Encyclopedia of Mormonism, edited by Daniel H. Ludlow, 1:153-55. 5 vols. New York: Macmillan, 1992. A synopsis of the book of 3 Nephi in the Book of Mormon. This book is the climax in Nephite history. It focuses on three advents of Jesus: his birth, his resurrection and appearance to the Nephites, and his Second Coming. [B.D.]

P.101 Paul, George F. "The Mystery of the Pacific." IE 36 (January 1933): 148-49. A chatty travelogue of visitors to Easter Island. The underlying question is whether or not certain aspects of the island reflect cultural characteristics of the Nephite voyagers during the time of Hagoth. [D.M.]

P.102 Paul, James P. “The Ancient Mounds of Ohio." Young Woman's Journal 29 (March 1918): 133-36. Considers that the mounds in Ohio had their origins with Book of Mormon peoples. [D.M.]

P.103 Payne, David V. "Book of Mormon Defense Wins Law Class Mock Trial." CN 40 (4 April 1970): 4. Jack H. West legally defended the Book of Mormon in a court of law in 1931. The attorney gave credit to God for briefing the case, setting up the evidence, and selecting the witnesses. [J.W.M.]

P.104 "A Peaceful Heart." Friend 4 (September 1974): 7. A children's story of the translation of the Book of Mormon. [M.D.P.]

P.105 Peak, W. E. Concordance and Reference Guide to the Book of Mormon. Lamoni, IA: n.p., 1890?. Small booklet that lists and indexes topics, names, and places according to page numbers from an RLDS edition of the Book of Mormon. [J.W.M.]

P.106 Peak, W. E. "Plates or Records." SH 52 (6 September 1905): 855-57. The Book of Mormon speaks of twentytwo plates or records that are no longer available, as well as seven other records promised to come forth at a later date. [J.W.M.] 
P.107 Pearce, Virginia. "Alma and Amulek Teach the Zoramites to Pray." Friend 22 (February 1992): 12-13. Alma and Amulek preached to the Zoramites and taught them how to pray. Stresses the importance of prayer and gives the basic steps of how to offer a prayer. [M.D.P]

P.108 Pearce, Virginia. "I Feel Reverent When I Read the Scriptures." Friend 22 (April 1992): 12-13. A story of a boy who enjoyed reading the Book of Mormon with his family and how it made him a better person. [M.D.P.]

P.109 Pearce, Virginia. "Nephi Builds a Ship." Friend 22 (March 1992): 44-45. A children's story of how Nephi built a ship because he was commanded to by the Lord. It is important to obey the commandments. [M.D.P.]

P.110 Pearson, Cyril Drew. "Columbus: 'The Spirit Wrought upon the Man.' "IE 52 (October 1949): 640-42, 672, 674. Presents the events and inspirations of Christopher Columbus's life. From his birth Columbus certainly felt the call of the Lord and God's protective hand over all things. Surely it was Columbus whom Nephi foretold would cross the waters. [J.W.M.]

P.111 Pearson, George. "Service of the Book of Mormon to History." SH 54 (27 November 1907): 1092. The historical nature of the Book of Mormon corroborates, affirms, and establishes the facts that archaeologists and historians have found, and presents a complete written record of the original inhabitants of America. [J.W.M.]

P.112 Pearson, Glen L. "The Book of Mormon as a Witness of the Old Testament." Ensign 16 (June 1986): 14-18. As the world devalues the Bible more and more, the Book of Mormon becomes an even more valuable witness of the truthfulness of the Bible. Doctrines found in the Book of Mormon clarify and substantiate the Bible-the divinity of Christ, the purpose of the law of Moses, and the true authorship of the books of Moses (the Pentateuch) and Isaiah. [J.W.M.]

P.113 Pearson, Glen L. The Book of Mormon in Its Own Defense. Provo, UT: BYU Extension Division, 1954. A series of five lectures. Topics include: why we should have new revelation in addition to the Bible; mission of Jesus Christ clarified; the gathering of the house of Israel must be accomplished; one who reads the Book of Mormon must read it faithfully and know if it is true or false; the book of Mosiah is important in explaining the doctrine of the final judgment. [B.D.]

P.114 Pearson, Glen L. The Book of Mormon, Keystone to Conversion. Salt Lake City: Bookcraft, 1963. An instructional aid for the missionary offering the "single answer" system of response in confronting objections from both Christians and non-Christians. Using this system, the missionary is to show that all objections are in fact objections to revelation. In this manner the Book of Mormon is set forth as a true revelation from God that may result in conversion. [C.W.B.]

P.115 Pearson, Glen L. Significance of the Book of Mormon. Provo, UT: Brigham Young University, 1953. A series of lectures covering the following topics: "Book of Mormon Chronology," "The Mosiah Dynasty," "Abinadi," "Great Missionaries," and "Book of Mormon Theology." [D.M.]

P.116 Pearson, Glen L., and Reid E. Bankhead. Building Faith with the Book of Mormon. Salt Lake City: Bookcraft, 1986. Enlarged and revised edition of authors' Teaching with the Book of Mormon. "Our main purpose in writing this book is to help the reader to begin to fill up his 'bag' with treasures of knowledge out of the Book of Mormon that he can bring out whenever he is called upon to teach or preach." The book is divided into sections based upon such topics as faith, repentance, and baptism. [A.T.] 
P.117 Pearson, Glen L., and Reid E. Bankhead. A Doctrinal Approach to the Book of Mormon. Salt Lake City: Bookcraft, 1962. A new method of studying the Book of Mormon is proposed that includes finding some of the more important passages of the Book of Mormon and starting a structured cross-reference system. In the book a series of doctrinal topics are addressed by brief explanations, thought provoking questions, cross references, and a marking system. The goal is to help the user to be more fluent with the scriptures. [C. W.]

P.118 Pearson, Glen L., and Reid E. Bankhead. A Pin-Point Marking Guide to the Book of Mormon. Salt Lake City: Bookcraft, 1961. An early draft of the authors' two books, A Doctrinal Approach to the Book of Mormon, and Teaching with the Book of Mormon. This version is shorter and lacks the study questions. [C.W.B.]

P.119 Pearson, Glen L., and Reid E. Bankhead. Teaching with the Book of Mormon. Salt Lake City: Bookcraft, 1976. A revised edition of A Doctrinal Approach to the Book of Mormon, containing the authors' Book of Mormon study system. [C.W.]

P.120 Pearson, Glen L., and Reid E. Bankhead. The Word and the Witness: The Unique Mission of the Book of Mormon. Salt Lake City: Bookcraft, 1970. An instructional aid that provides effective missionary techniques and gives directions on how to approach different types of people and controversial issues. It also provides a series of hypothetical door approaches that result in the contact reading the Book of Mormon with the missionary. [C.W.B.]

P.121 Pearson, Howard. "Answers in Book of Mormon." CN 42 (22 April 1972): 12. The Book of Mormon provides answers concerning the origin of the early inhabitants of America. [M.D.P.]

P.122 Peck, John Mason. "Nauvoo, Illinois-The Mormons." Arthur's Home Magazine (January 1854): 38-44. An expos? of Mormonism. Among other things the author criticizes the Book of Mormon for containing King James English and containing "monstrous fictions." The Spaulding manuscript is suggested to be the original basis for the Book of Mormon. [A.T.]

P.123 Peisker, Hermann. "Book of Mormon-Doctrinal Series." SH 76 (14 August-6 November 1929): 982-84, 1015-17, 1042-44, 1071-73, 1098-1101, 1131-33, 1167-68, 1197-1200, 1227-29, 1249-52, 1282-84, 131518, 1347-48. A series of thirteen articles dealing with specific doctrinal points from the Book of Mormon. Topics include the creation, the fall of man, justice and mercy, the Atonement, salvation, repentance, conversion, baptism, probation, death, the resurrection, the judgment, the justice of God, and happiness. [B.D.]

P.124 Penman, W. "On the Book of Mormon." SH 55 (1 January 1908): 8-9. The Book of Mormon peoples had portions of the Bible. The Jesuits who came to the New World burned many books and it is possible they contained portions of the Bible handed down by Native Americans. The Book of Mormon has warnings for the United States-Ether 1:4; 3 Nephi 9:12; Ether 3:13. [A.T.]

P.125 Penrose, Charles W. The Book of Mormon. Independence, MO: Zion's, 1923. An introductory pamphlet designed for an investigator that describes the discovery and contents of the Book of Mormon. It gives both spiritual and secular examples of the divinity of the book and encourages the investigator to seek for a personal witness. [C.W.B.]

P.126 Penrose, Charles W. "Book of Mormon Teachings on Resurrection." JD 21:220-32. Compares passages from the Book of Mormon, Doctrine and Covenants, and Bible concerning the resurrection. The Church believes in the literal resurrection of the body as opposed to many other religions that reason it away by using philosophy. [J.W.M.] 
P.127 Penrose, Charles W. "The Coming Forth of the Book of Mormon." IE 26 (September 1923): 953-57. Moroni's visits to Joseph Smith in September 1823 stand second only in importance to the First Vision. It is significant that Moroni's visitations preceded the restoration of the priesthood and the organization of the Church. [D.M.]

P.128 Penrose, Charles W. "The Dead Spaulding Story Buried Out of Sight." MS 47 (20 April 1885): 248-50. James H. Fairchild of the Oberlin College library recovered the Manuscript Found written by Solomon Spaulding. Fairchild claims that after comparing the Book of Mormon and Spaulding's manuscript the theory that the two are related "will probably have to be relinquished." [B.D.]

P.129 Penrose, Charles W. "The Edict of a Century." IE 23 (April 1920): 484-87. Contains an account of the first vision received by Joseph Smith and the importance of other visions leading up to the publication of the Book of Mormon and the organization of the Church of Jesus Christ of Latter-day Saints. [L.D.]

P.130 Penrose, Charles W. "The Egyptian Hieroglyphs in Yucatan." MS 72 (2 June 1910): 344-46. It is most remarkable that "modern scientists" could overlook the Book of Mormon while so much of their research in the Americas and Egypt adds evidences to the divinity of the work. The London Magazine reports that there is a connection between the hieroglyphs of the Mayas and those of the Egyptians. Could these hieroglyphs have originated with Adam and Eve, or was it Lehi's company who brought them? [J.W.M.]

P.131 Penrose, Charles W. "The Mexican Messiah." Deseret Weekly 42 (2, 9 May 1891): 604, 620-21. Reports on an article in the May issue of Popular Science Monthly, which in turn borrowed the article from Gentleman's Magazine. Pre-Columbian Mexicans believed in a god named Quetzalcoatl, who had striking similarities to the biblical Messiah. Cortez was mistaken for this god, who was expected to return. Comments on the author's inference that Quetzalcoatl was St. Brendan, an Irish bishop. [D.M.]

P.132 Penrose, Charles W. "An Old Slander Revived and Refuted." MS 70 (4 June 1908): 360-64. Sidney Rigdon did not work for publisher Patterson who had the Spaulding manuscript nor did he know Joseph Smith until after the Book of Mormon was published. The manuscript has no significant similarities to the Book of Mormon. The testimonies of the Three Witnesses cannot be refuted as they were reaffirmed in the last years of the witnesses' lives. These final testimonies appear in this article. [J.W.M.]

P.133 Penrose, Charles W. "There are Only Two Churches." MS 70 (November 1908): 744-46. Commenting on 1 Nephi 13-14, Penrose identifies the great and abominable church as "all the institutions among mankind in all ages that are led into error ... and which lead mankind away from the true God and the true faith." [B.D.]

P.134 Penrose, Charles W. "Truth Out of the Earth." MS 100 (13 January 1938): 26-28. See also "Rays of Living Light: The Book of Mormon." In Handbook of the Restoration, 146-51. Independence, MO: Zion's Printing and Publishing, 1944. A testimony of the Book of Mormon. Truth has sprung out of the earth as Psalms 85:11 prophecies. The lost sheep of the house of Israel (Matthew 25:24) are the Nephites and Lamanites or the "voice out of the dust" (Isaiah 29:4-19). Professor Anthon fulfilled Isaiah 29:11 by saying he could not read a sealed book. The Book of Mormon is the stick of Joseph spoken of in Ezekiel 37:15-22. [B.D.]

P.135 "The People of Ammon." Friend 23 (May 1993): 89. A series of pictures for children illustrating the repentance of the people of Ammon. [S.H.] 
P.136 Perkins, Keith W. "Francis W. Kirkham: A 'New Witness' for the Book of Mormon." Ensign 14 (July 1984): 5257. Tells the story of Francis W. Kirkham and his work as a defender of the Book of Mormon. Recounts Kirkham's examination of "five explanations for the origin of the Book of Mormon, showing the strengths and weaknesses of each." [S.P.S.]

P.137 Perkins, Keith W. "I Have A Question: Some historical records indicate that Mary Musselman Whitmer was privileged to see the gold plates, in addition to Joseph Smith and the 3 and 8 Witnesses. Do we know of any other persons who may have seen or handled the plates?" Ensign 22 (July 1992): 53-5. In addition to the Three and Eight Witnesses of the Book of Mormon, Lucy Harris and Emma Smith also viewed the gold plates. [A.C.W.]

P.138 Perkins, Keith W. “Thou Art Still Chosen." Ensign 23 (January 1993): 14-19. Uses Joseph Smith's loss of the 116 pages of the Book of Mormon and his repentance process to teach repentance. [S.H.]

P.139 Perkins, Keith W. "True to the Book of Mormon: The Whitmers." Ensign 19 (February 1989): 34-41. Examines the lives, roles, contributions, testimonies, and apostasy of the five sons of Peter Whitmer, Sr.-David, Christian, Jacob, Peter Jr., and John-all of whom were special witnesses of the Book of Mormon plates. For a time, they were all very instrumental in building, defending and leading the Church. Despite their eventual estrangement from the Church, they all remained true to their testimonies regarding seeing and hefting the Book of Mormon plates and proclaiming the truthfulness of the Book of Mormon. [A.A.]

P.140 Perkins, Keith W. "Whitmer, David." In Encyclopedia of Mormonism, edited by Daniel H. Ludlow, 4:1564-66. 5 vols. New York: Macmillan, 1992. A short biography of David Whitmer, one of the Three Witnesses to the Book of Mormon. [B.D.]

P.141 Perkins, Leeman. "Joseph Smith et la Verite?." L'Etoile (October 1955): 180-86, 191-92. Discusses (in French) the history of Joseph Smith and his subsequent followers and persecutions. The testimony of Martin Harris and the experience with Charles Anthon and the Book of Mormon are credits to Joseph Smith. [A.C.W.]

P.142 Perler fra Mormons Bog. Kobenhaun: Udgivet og forlagt af Holger M. Larsen, 1929. A ready reference booklet dealing with Book of Mormon topics. [D.W.P.]

P.143 Perrie, C. Johann. What Every Christian Should Know About-The Restoration of Christ's True Gospel. Provo, UT: Author, 1990. Complete apostasy in the early Church created the need for a restoration. The events that led to the Restoration were orchestrated by the Lord. Joseph Smith's own words tell of his calling to translate and publish the Book of Mormon. Books that have been written to discredit Joseph Smith and the Book of Mormon are listed by title and author. The Book of Mormon and modern revelation identify false teachings concerning revelation, the Godhead, the eternal nature of man, priesthood authority, original sin, infant baptism, authority, mode of baptism, paid clergy, eternal marriage, heaven and hell, and Church politics. [J.W.M.]

P.144 Perry, David E. "Mormon-A Man for Our Time." In A Symposium on the Book of Mormon, 99-101. Salt Lake City: Church of Jesus Christ of Latter-day Saints, 1979. Presents an outline about the prophet Mormon, his ministries, his military efforts, and his role as editor/writer. Perry also cites eleven major purposes of the Book of Mormon. [N.K.Y.]

P.145 Perry, David E. "The Relevance and Effectiveness of Four Book of Mormon Prophets and Their Teachings." Ph.D. diss., Brigham Young University, 1974. Analyzes the prophets Lehi, Nephi, Alma, and Mormon to discover the effect that they and their teachings had upon certain peoples. Considers whether the personality of each Book 
of Mormon prophet caused him to be significantly qualified and effective in coping with the problems he faced, and whether the teachings of each Book of Mormon prophet were directly relevant to his problems, assisting him to be effective in fulfilling his assignments. [A.T.]

P.146 Perry, L. Tom. "Becoming Self-Reliant." Ensign 21 (November 1991): 64-66. Nephi was resourceful when he inquired of the Lord where to find ore to make the tools instead of asking where the tools were. The Lord "expects His children to be self-reliant to the degree they can be." [J.W.M.]

P.147 Perry, L. Tom. "The Book of Mormon, Another Testament of Jesus Christ." Salt Lake City: University of Utah Institute of Religion, 1990. Speaks of the Book of Mormon as the instrument of missionary work. Compares its translation with that of the King James Bible. Discusses its purpose, promise, and philosophy. Retells and personalizes the story of Nephi. [D.M.]

P.148 Perry, L. Tom. "Book of Mormon Messages of Decision Making." CR (October 1979): 48-52. Individuals all must learn to make the correct decisions in order to have a happy, fulfilled life. Follow the example of Nephi who chose to follow the Lord and his father Lehi. [R.C.D.]

P.149 Perry, L. Tom. "Example of Alma the Younger." CR (April 1979): 15-18. Alma the Younger lived by his own law and was in the depths of hell. Upon his conversion (meaning that he now obeyed a higher law) his joy was unfathomable. [R.C.D.]

P.150 Perry, L. Tom. "I Will Go and Do the Things Which the Lord Hath Commanded." Ensign 4 (January 1974): 5153. Lehi and his family were commanded of the Lord to return to Jerusalem for the brass plates. This difficult task was assigned to Lehi's sons. Nephi recognized it to be the inspiration of the Lord and willingly obeyed. Nephi was a lamplighter-because of his faith he brought light to an entire nation. [J.W.M.]

P.151 Perry, L. Tom. “Proclaim My Gospel from Land to Land." Ensign 19 (May 1989): 13-14. CR (1-2 April 1989): 15-17. Discusses bringing the Book of Mormon to all mankind. The Book of Mormon is a second witness to Jesus Christ. [L.D.]

P.152 Perry, L. Tom. Untitled talk. In Proceedings of the Colombia Area Conference. Salt Lake City: Church of Jesus Christ of Latter-day Saints, March 1977. Nephi considered the request to return to obtain the brass plates as an assignment from the Lord. Laman and Lemuel felt it to be a burdensome task. Lehi's family saw the immense value of the scriptures. The same is true today. We must teach the scriptures to our families. [J.W.M.]

P.153 " 'Personalized Books' Expand to Fill Added Mission Requests." CN 55 (7 July 1985): 12. Many families are joining the family-to-family program to distribute copies of the Book of Mormon containing personal testimonies. The book is the best missionary tool of the Church. [J.W.M.]

P.154 "Personalized Copy Puts You on Mission." CN 52 (21 August 1982): 14. Explains the family-to-family Book of Mormon placement program. Families attach their picture and their written testimony to a copy of the Book of Mormon and send the Book of Mormon into the mission field. The program has been very successful and has accounted for many baptisms. [G.A.]

P.155 En Personlig Studieplan for Lasning: Mormons Bok. N.p., 1965?. A tract-size study aid featuring scriptural references from the Book of Mormon and a series of questions about the Book of Mormon. [D.W.P.] 
P.156 Persons, William R. "An Analysis of Changes in the Interpretation and Utilization of Revelation in the Church of Jesus Christ of Latter-day Saints, 1830-1918." Ph.D. diss., Iliff School of Theology, 1972. Discusses changing Mormon understandings of revelation and their scripture between 1830-1918. [M.R.]

P.157 Persuitte, David. Joseph Smith and the Origins of the Book of Mormon. Jefferson, NC: McFarland, 1985. Examine the motives and means by which Joseph Smith authored the Book of Mormon. Contains an extensive comparison between Ethan Smith's View of the Hebrews and the Book of Mormon and suggests a possible connection between Ethan Smith and Solomon Spaulding. Favors an environmentalist explanation for Book of Mormon origins. This work is reviewed in G.099, W.153, and in N.146. [M.R.]

P.158 Peterfield, William. Cambridge History of American Literature. 4 vols. New York: G. P. Putnam's Sons, 1921. Volume 3:517-72 introduces the Book of Mormon as a "curiousity of literature" and a "literature of disguise" that was created by Joseph Smith. [D.W.P.]

P.159 Petersen, Emma Marr. Book of Mormon Stories for Young Latter-day Saints. Salt Lake City: Bookcraft, 1951. Contains brief stories designed for children, with illustrations. [D.M.]

P.160 Petersen, Emma Marr. The Story of Our Church for Young Latter-day Saints. Salt Lake City: Bookcraft, 1952. Retells stories for children. Book of Mormon topics include the Three Witnesses, the restoration of the Priesthood, the scribal work of Oliver Cowdery, Moroni's visits to Joseph Smith, Martin Harris's loss of the 116 pages of the Book of Mormon manuscript, and Joseph Smith's reception and translation of the gold plates and its publication. [J.W.M.]

P.161 Petersen, LaMar. Problems in Mormon Text: A brief study of certain changes in important Latter-day Saint publications including the Book of Mormon, Book of Commandments, Doctrine and Covenants, and History of the Church; with references to controversial aspects of the Restoration of the Priesthood and Mormon concepts of Deity. Concord, CA: Pacific Publishing Co., 1976. Doubts Joseph Smith's ability to remember the exact words used by the heavenly personages who visited him several years before he made a written record. The accounts of these visitations do not harmonize. Clearly controversial language has been deleted in the History of the Church and changes have been made in the Book of Mormon and other scriptures. [J.W.M.]

P.162 Petersen, Mark. "American History and Nephi's Vision." CN 3 (25 March 1933): 4, 5, 8. Compares Nephi's vision (1 Nephi 13) to the manner in which history unfolded on the American continent. Columbus was inspired, the Pilgrims came out of captivity, the gentiles fought against England, and America became a land of liberty and prosperity as Nephi prophesied. [A.C.W.]

P.163 Petersen, Mark E. Alma and Abinadi. Salt Lake City: Deseret Book, 1983. Contains narration and commentary on Book of Mormon passages about Alma and Abinadi. Chapters include: "Abinadi the Martyr," "Alma's Ministry," "Alma the Younger," "Amlici's Rebellion," and "The Zoramite Apostasy." [A.T.]

P.164 Petersen, Mark E. "America Testifies of Christ." IE 70 (June 1967): 98-101. For the general reader, testimonies of Christopher Columbus, George Washington, Abraham Lincoln, and ancient traditions from Alaska to Chile regarding the Great White God are discussed. Limited references. [B.W.J.]

P.165 Petersen, Mark E. "Ancient Records and the Book of Mormon." IE 60 (June 1957): 431-32. A testimony of the Book of Mormon comes by the Spirit (Moroni 10:4) and not from scientific research, nor from argument. And 
yet modern findings are vindications or supports to one's testimony. Such evidences are cement buildings, gold plates with ancient inscriptions, and stone boxes as depositories of metal records. [R.C.D.]

P.166 Petersen, Mark E. "Angels, Plates, Boxes and Joseph Smith." CR (October 1983): 40-44. See also Ensign 13 (November 1983): 29-31, and Book of Mormon Talks by General Authorities, (Provo, UT: FARMS, n.d.), 149-51. Moroni visited Joseph Smith on September 21, 1923, and commenced the restoration of the gospel. From this restoration came many things that shocked the world: the visitation of angels, revelation, modern day prophets, and records kept on gold plates and buried in stone boxes. The author lists examples of metal plates and stone boxes as containers for them that have been found. [B.D.]

P.167 Petersen, Mark E. Book of Mormon Addresses. Provo, UT: FARMS, 1986?. Reprints of several addresses: "The Great Prologue," BYU Speeches of the Year, September 24, 1974, and conference addresses given 6 April 1968, 4 October 1970, 1 October 1977, 2 April 1978, 1 October 1978, 1 October 1983. Individual annotations are found in this bibliography. [J.W.M.]

P.168 Petersen, Mark E. "The Book of Mormon Converts." In Petersen's Why the Religious Life, 176-78. Salt Lake City: Deseret Book, 1966. The Book of Mormon is the most effective tool in missionary work; thousands have born witness to this fact. It is God's greatest witness to the truth and everyone needs this witness. Those who earnestly and prayerfully read its message will know of its truthfulness. [J.W.M.]

P.169 Petersen, Mark E. "Book of Mormon: Origin and Background." CR (October 1977): 15-18. Joseph Smith, the Book of Mormon, and the restoration of the gospel were all envisioned and spoken of by the prophet Isaiah. Joseph Smith was the unlearned man; the Book of Mormon is the familiar spirit out of the dust; the great and marvelous work is the restoration spoken of by Isaiah. [R.C.D.]

P.170 Petersen, Mark E. Christ in America. Salt Lake City: Church of Jesus Christ of Latter-day Saints, 1983. Writes of archaeological and historical evidence of "the Great White God" of ancient America. The coming of a tall, blueeyed, bearded man from heaven was documented in several different groups of Indians and Polynesians. Petersen proposes that this great white god was Jesus. This can be documented in the Book of Mormon. [C.W.B.]

P.171 Petersen, Mark E. “Evidence of Things Not Seen." Ensign 8 (May 1978): 61-63. Also in CR (April 1978): 9498. The Bible was never considered to be all of the word of God-the Book of Mormon is necessary. The Book of Mormon and modern-day prophets add new and valuable scripture that is designed to protect the Church from false teachings. The Book of Mormon is "tangible evidence of both the seen and the unseen," and the only plausible explanation for its origin is that Moroni delivered the plates to Joseph Smith. [A.C.W.] [J.W.M.]

P.172 Petersen, Mark E. "Gold from Ancient America." In Petersen's Why the Religious Life. 73|75. Salt Lake City: 1966. The use of metal plates to record sacred and governmental writings is not unique to the Book of Mormon peoples. Archaeologists have found plates made of a variety of metals including silver and gold in various locations around the world. [J.W.M.]

P.173 Petersen, Mark E. "The Great Prologue." In Brigham Young University 1974 Devotional and Fireside Speeches, 459-72. Provo, UT: Brigham Young University, 1975. Explains the restoration of the gospel and the events that led up to it. The Book of Mormon played a prominent role in the restoration. [B.D.]

P.174 Petersen, Mark E. "The Great White God Was a Reality." IE 72 (September 1969): 6-9. A discussion of the Great White God of ancient America-he was known by various names, provided teachings that contained 
elements similar to Christian religion, and may have been Jesus Christ who visited the Nephites of Bountiful. [J.W.M.]

P.175 Petersen, Mark E. The Great White God Was a Reality. Salt Lake City: n.p., 1974. An early version of author's Christ in America. [C.W.B.]

P.176 Petersen, Mark E. "It Was a Miracle!” Ensign 7 (November 1977): 11-13. Author bears testimony concerning the prophetic office of Joseph Smith and the divine translation of the Book of Mormon and discusses the usage of metal plates and stone boxes in ancient civilizations. [J.W.M.]

P.177 Petersen, Mark E. The Jaredites. Salt Lake City: Deseret Book, 1984. Explains the story of the Jaredites; includes biblical references and charts listing the Jaredite kings. [C.W.B.]

P.178 Petersen, Mark E. "The Last Words of Moroni." Ensign 8 (November 1978): 57-59. Retells the story of the destruction of the Nephites that came about to fulfill the prophecy that those who live on the American continent "must obey God or be swept off." Author also tells of the wickedness that Moroni saw in the present era and concludes by saying that humanity should read the Book of Mormon and obey its counsels. [M.D.P.]

P.179 Petersen, Mark E. "Metal Plates, Stone Boxes." CN 39 (8 November 1969): 16. Brings attention to the recent discoveries of metal plates with inscriptions on them and stone boxes containing treasures. [D.M.]

P.180 Petersen, Mark E. "More Gold Plates Found." In Petersen's, Why The Religious Life. 147-51. Salt Lake City: Deseret Book, 1966. Archaeologists working in an Etruscan site found inscribed sheets of gold that contained tributes to a pagan goddess. The plates date to the 6th century B.C., an era that parallels Lehi's departure from Jerusalem. Modern allegations that ancient records were not kept on metal plates are no longer valid. [J.W.M.]

P.181 Petersen, Mark E. "Mormon and the Book of Mormon." Friend 14 (May 1984): 34-35. A story for children that deals with Mormon, abridger of the Nephite records. [J.W.M.]

P.182 Petersen, Mark E. "Moroni's Warning to America." CR (October 1978): 85-88. Also in Book of Mormon Talks by General Authorities, 147-48. Provo, UT: FARMS, 1990. The last words of Moroni are important for those living in America. Both Mormon and Moroni indicate that Americans must abandon pride, money, substance, and fine apparel (Mormon 8:35-36) in order to not be swept off the land as the ancient Nephites were. [B.D.]

P.183 Petersen, Mark E. "New Evidence for the Book of Mormon." IE 63 (June 1962): 456-59. Cites the studies of numerous scientists and anthropologists (especially Thor Hyerdahl) that seem to confirm the general LDS belief that Polynesians migrated from the Americas. [R.C.D.]

P.184 Petersen, Mark E. "Origin and Plight of Indians." CR (October 1970): 138-42. Also in Book of Mormon Talks by General Authorities, 140-42. Provo, UT: FARMS, 1990. All the peoples of the Americas shared a common belief in the visitation of a white God who taught them and ministered to them. The names differed-Quetzalcoatl, Votan, Gucumatz, Verachoeha, Sume, Kon-tiki, Kukulcan-but he was the same God, Jesus Christ, whose appearance is recorded in the Book of Mormon. [R.C.D.]

P.185 Petersen, Mark E. "Our Divine Destiny." In BYUSY (20 February 1968). Provo, UT: BYU Press. The promise given in 1 Nephi serves as a reminder of the importance of preserving America and its great destiny. An emphasis 
is placed on the inspiration of God in this great work and the need for his continued aid in these troubled times. [J.W.M.]

P.186 Petersen, Mark E. Polynesians Came from America! Salt Lake City: Deseret Book, 1962. The great faith of the Polynesian people indicates that they are of the blood of Israel. Evidence that they are descendants of Lehi lies in the structure of their temples, baptismal fonts, stone roadways, and the plant life with origins in North America. The first white men in these islands were greeted with great reverence because of the traditions of the people concerning their white god whose teachings resembled those of Jesus Christ. [J.W.M.]

P.187 Petersen, Mark E. Sons of Mosiah. Salt Lake City: Deseret Book, 1984. Discusses the missionary activities of the sons of Mosiah in twenty chapters. [R.H.B.]

P.188 Petersen, Mark E. "Their Greatest Tragedy." IE 68 (December 1965): 1128-30. The greatest tragedy that happened to the Jews was the rejection of their King, Jesus Christ. The people of the modern world may reject his Second Coming. Signs described in the Book of Mormon show that the Second Coming will not be unexpected. [M.D.P.]

P.189 Petersen, Mark E. Those Gold Plates! Salt Lake City: Bookcraft, 1979. Addresses the issue of the authenticity of the gold plates delivered to Joseph Smith. Author gives many examples of inscribed plates, and a list of 62 such findings. He also presents the testimonies of the Three and Eight Witnesses and their contemporaries. [C.W.B.]

P.190 Petersen, Mark E. "Three New Volumes of Scriptures Revealed." IE 67 (December 1964): 1093-95. Three new volumes of sacred literature, the Book of Mormon, the Doctrine and Covenants, and Pearl of Great Price sustain the Bible and add their own witness that divine guidance from God continues. [J.W.M.]

P.191 Petersen, Mark E. Untitled talk. In Book of Mormon Talks by General Authorities, 138-39. Provo, UT: FARMS, 1990. The United States of America is headed for ruin unless its citizens turn to God. Alma 61:13 and Ether 2:12 indicate that if Americans will turn to God they will receive again God-given freedom in America. [B.D.]

P.192 Petersen, Mark E. Untitled. In Children of Promise: The Lamanites: Yesterday and Today. Salt Lake City: Bookcraft, 1981. The Book of Mormon opens the doors for Lamanites who have been long oppressed. Though unjustly treated, scattered, and persecuted, they now have begun to fulfill their great destiny. Nephi prophesied that the mixture of his seed would be preserved and a remnant would receive the gospel. The Book of Mormon is a great instrument in gathering these children of Lehi to Jesus Christ. [J.W.M.]

P.193 Petersen, Mark E. Untitled talk. CR (April 1962): 111-15. The great faith of the Polynesian people is evidence that they are people of the blood of Israel and relatives of the American Indians. They are heirs to the promises made in the Book of Mormon. [J.W.M.]

P.194 Petersen, Mark E. Untitled talk. CR (April 1967): 111-14. Writes concerning Jesus Christ, Columbus, George Washington, native American traditions and legends that testify of the "Great White God," the Book of Mormon, and Joseph Smith who translated it. The Book of 3 Nephi records Christ's appearance in America. [J.W.M.]

P.195 Petersen, Mark E. "Who Was the Great White God?" IE 73 (December 1970): 117-20. Discusses various native traditions of the Western Hemisphere and Pacific region that refer to a "Great White God." Several sources 
are cited and their common points are discussed and compared to 3 Nephi 11. Jesus Christ was the Great White God referred to in all instances. [B.W.J.]

P.196 Petersen, Roger K. "Joseph Smith: Prophet-Poet." In The Eighth Annual Sidney B. Sperry Symposium, 265-79. Provo, UT: Religious Instruction, 26 January 1980. A literary analysis of selected writings of Joseph Smith, using the archetypal theories of Northrop Frye. A number of Book of Mormon passages are examined. [D.M.]

P.197 Petersen, Roger K. "Joseph Smith Prophet-Poet: A Literary Analysis of Writings Commonly Associated with His Name." Ph.D. diss., Brigham Young University, 1981. Shows how Joseph Smith used numerous literary patterns that are well known today but were not in his lifetime, and how this literary output reveals genius. Discusses archetypal patterns found in the Book of Mormon. [D.M.]

P.198 Peterson, Bruce Eldon. "Evaluation of the Use of Selected Book of Mormon Filmstrips in Improving the Learning of the Book of Mormon History." M.A. thesis, Brigham Young University, 1966. Evaluates the use of Book of Mormon filmstrips in youth classrooms to determine their pedagogical effectiveness. [D.M.]

P.199 Peterson, Charles D. "Mormonism and the Mormons." Graham's Magazine (May 1853): 531-40. A polemical article against Joseph Smith and the Book of Mormon. Believes that Joseph Smith was illiterate and unable to write the Book of Mormon by himself, and hence used the Spaulding manuscript to create the Book of Mormon. [M.R.]

P.200 Peterson, Clark A. Using the Book of Mormon to Combat Falsehoods in Organic Evolution. San Jose, CA: Clark A. Peterson, 1992. Cites Book of Mormon, scientific, and other sources to argue against the theories dealing with organic evolution. Believes that the Book of Mormon is opposed to organic evolution. [D.M.]

P.201 Peterson, Daniel C. "Authority in the Book of Mosiah." Provo, UT: FARMS, 1991. Priests in the Book of Mormon were consecrated, anointed, and commissioned to teach the law of Moses, the early Nephite king being the High Priest, political, and religious leader. Alma the Elder established a limited separation of church and state, where priesthood functions were severed from the political structure, and the Spirit of God, not human authority, made legitimate calls to the priesthood. [J.W.M.]

P.202 Peterson, Daniel C. "Book of Mormon Economy and Technology." In Encyclopedia of Mormonism, edited by Daniel H. Ludlow, 1:172-75. 5 vols. New York: Macmillan, 1992. The economics of Book of Mormon peoples were relatively simple. Dry measures and metal-weight units were used in a simple, efficient binary system. Trade is mentioned at times but was limited by wars. Agriculture involved livestock, horticulture, and sown crops. Horses and chariots are mentioned as are highways, cloth, silk, fine-twined linen, and steel weaponry. [N.K.Y.]

P.203 Peterson, Daniel C. "The Gadianton Robbers as Guerrilla Warriors." In Warfare in the Book of Mormon, edited by Stephen D. Ricks and William J. Hamblin, 146-73. Salt Lake City: Deseret and FARMS, 1990. Argues that the warlike behavior of the Gadianton robbers is plausible and believable. Shows chilling resemblances between their tactics of guerrilla warfare and those used by Mao Tsetung, Vo Nguyen Giap, and Ernesto "Che" Guevara. Compares secret combinations with the masons. [D.M.]

P.204 Peterson, Daniel C. "Notes on 'Gadianton Masonry." In Warfare in the Book of Mormon, edited by Stephen D. Ricks and William J. Hamblin, 174-224. Salt Lake City: Deseret and FARMS, 1990. Cites authors who assert that the secret society of Gadiantons was based on the 1820 controversy about the Freemasons being a secret society and claim this is where Joseph Smith's Book of Mormon ideas came from. The Masonic controversy may have been 
published in Palmyra, but it has not been proved that Joseph Smith even knew of it. Book of Mormon critics have grasped another feeble straw to explain how Joseph Smith wrote the Book of Mormon. [N.K.Y.]

P.205 Peterson, Daniel C. "Priesthood in Mosiah." In The Book of Mormon: Mosiah, Salvation Only through Christ, edited by Monte S. Nyman and Charles D. Tate Jr., 187-210. Provo, UT: Brigham Young University Religious Studies Center, 1991. Detailed treatment of priesthood offices, functions, and prerogatives, as carried out by Zeniff, Noah (in a negative sense), and both Alma 1 and Alma2. [D.M.]

P.206 Peterson, Daniel C. Review of David Whitmer Interviews: A Restoration Witness, edited by Lyndon W. Cook. Review of Books on the Book of Mormon 5 (1993): 113-15. Book review.

P.207 Peterson, Daniel C. Review of Everything You Ever Wanted to Know about Mormonism, by John Ankerberg and John Weldon. Review of Books on the Book of Mormon 5 (1993): 1-86. Book review.

P.208 Peterson, Daniel C. Review of Mormonism: The Prophet, the Book and the Cult, by Peter Bartley. Review of Books on the Book of Mormon 2 (1990): 31-55. Book review.

P.209 Peterson, Daniel C. Review of Stories from the Early Saints: Converted by the Book of Mormon, edited by Susan Easton Black. Review of Books on the Book of Mormon 4 (1992): 13-19. Book review.

P.210 Peterson, Daniel C. Review of The Best Kept Secrets in the Book of Mormon, by Loftes Tryk. Review of Books on the Book of Mormon 3 (1991): 31-260. Book review.

P.211 Peterson, Daniel C. Review of The Book of Mormon: First Nephi, The Doctrinal Foundation, edited by Monte S. Nyman, and Charles D. Tate Jr. Review of Books on the Book of Mormon 1 (1989): 124-28. Book review.

P.212 Peterson, Daniel C. Review of The Prophetic Book of Mormon, by Hugh W. Nibley. Review of Books on the Book of Mormon 2 (1990): 164-74. Book review.

P.213 Peterson, Daniel C. Review of Two Pahute Indian Legends: "Why the Grand Canyon Was Made" and "The Three Days of Darkness," by William Rees Palmer. Review of Books on the Book of Mormon 1 (1989): 129-31. Book review.

P.214 Peterson, Daniel C." 'Secret Combinations' Revisited." Journal of Book of Mormon Studies 1 (Fall 1992): 18488. Addresses the argument that the Gadianton robbers were merely nineteenth-century Freemasons, transparently disguised by the term "secret combinations." In 1828 Andrew Jackson used the term "secret combinations" in a vitriolic response to allegations made by Henry Clay. Jackson was a prominent Mason and would not have used the term in this fashion had it been known to refer uniquely to Freemasonry. [R.H.B.]

P.215 Peterson, Daniel C. "Text and Context." In Peterson's Review of Books on the Book of Mormon, 6:524-62. Provo, UT: FARMS, 1994. Examines the historical context out of which the book New Approaches to the Book of Mormon, edited by Brent Lee Metcalfe, developed. The authors of the book question the traditional view of the Book of Mormon held by the LDS church; their logic is tainted by prejudices and unclear motives and is based upon information that is questionable and built upon a naturalistic, irreligious world view. [J.W.M.]

P.216 Peterson, Daniel C. "Their Own Worst Enemies." In Studies in Scripture: Alma 30 to Moroni, edited by Kent P. Jackson, 92-106. Salt Lake City: Deseret Book, 1988. The narrative in Helaman 1-6 is the best example of how Mormon the editor worked. As Mormon abridged, he was surrounded by centuries of records and under the 
inspiration of the Lord chose what was important. He taught that his people were ripening for destruction and pointed out the causes and the efforts to stop it through preserving the appropriate records. [J.W.M.]

P.217 Peterson, Daniel C., ed. Review of Books on the Book of Mormon. Vol. 1. Provo, UT: FARMS, 1989. Contains reviews by various reviewers of books published on the Book of Mormon. Every type of book dealing with the Book of Mormon is reviewed including the following approaches-polemic, devotional, apologetic, evangelical, historical, and theological. Includes an introductory essay by the editor, and a bibliography of works written on the Book of Mormon. [D.M.]

P.218 Peterson, Daniel C., ed. Review of Books on the Book of Mormon. Vol. 2. Provo, UT: FARMS, 1990. See annotation for Peterson, Daniel C., ed. Review of Books on the Book of Mormon. Vol. 1. Provo, UT: FARMS, 1989.

P.219 Peterson, Daniel C., ed. Review of Books on the Book of Mormon. Vol. 3. Provo, UT: FARMS, 1991. See annotation for Peterson, Daniel C., ed. Review of Books on the Book of Mormon. Vol. 1. Provo, UT: FARMS, 1989.

P.220 Peterson, Daniel C., ed. Review of Books on the Book of Mormon. Vol. 4. Provo, UT: FARMS, 1992. See annotation for Peterson, Daniel C., ed. Review of Books on the Book of Mormon. Vol. 1. Provo, UT: FARMS, 1989.

P.221 Peterson, Daniel C., ed. Review of Books on the Book of Mormon. Vol. 5. Provo, Utah: FARMS, 1993. See annotation for Peterson, Daniel C., ed. Review of Books on the Book of Mormon. Vol. 1. Provo, UT: FARMS, 1989.

P.222 Peterson, Daniel C., ed. Review of Books on the Book of Mormon. Vol. 6. Provo, UT: FARMS, 1994. Contains reviews of the articles found in New Approaches to the Book of Mormon, edited by Brent Lee Metcalfe. [J.W.M.]

P.223 Peterson, Donald H. "Great Ministers of the Book of Mormon." Restoration Witness 8 (April 1970): 10-14. Many Book of Mormon prophets delivered a sacred message to God's people, including Lehi, Nephi, King Benjamin, Alma, and Moroni. When Christ visited the Nephites he revealed his own message and that of his Father. [J.W.M.]

P.224 Peterson, H. Donl. "Answer to Question Regarding Use of 'Lord' in Book of Mormon." Ensign 8 (October 1978): 16-17. Deals with the question of how to distinguish between the name/titles Father and Son and the word Lord in the Book of Mormon. Notes that sometimes the distinction is blurred, especially when the Son speaks on behalf of the Father in the first person. Discusses the different roles of both members of the Godhead. [D.M.]

P.225 Peterson, H. Donl. "Book of Mormon Commentaries." In Encyclopedia of Mormonism, edited by Daniel H. Ludlow, 1:171-72. 5 vols. New York: Macmillan, 1992. George Reynolds, Janne M. Sjodahl, and B. H. Roberts have produced Book of Mormon commentaries. Hugh Nibley, and Sidney B. Sperry have contributed many scholarly books on the subject. [N.K.Y.]

P.226 Peterson, H. Donl. "Church Discipline in the Book of Mosiah." In The Book of Mormon: Mosiah, Salvation Only through Christ, edited by Monte S. Nyman and Charles D. Tate Jr., 211-26. Provo, UT: Brigham Young University Religious Studies Center, 1991. Takes Mosiah 26 as the model and basis for Church discipline in its various facets, and points out that the steps described there are followed today in the LDS church. Uses quotations from scripture and General Authorities to support his argument. [D.M.]

P.227 Peterson, H. Donl. "Father Lehi." In The Book of Mormon: First Nephi, The Doctrinal Foundation, edited by Monte S. Nyman and Charles D. Tate Jr., 55-66. Provo, Utah: Brigham Young University Religious Studies Center, 
1988. Discusses the importance of Lehi as a man, prophet, record keeper, man of faith, "father of nations," seer, and explorer. Honors Lehi as a leader, man of great courage, and exemplary patriarch. [A.T.]

P.228 Peterson, H. Donl. "I Have a Question: What is the meaning of the Book of Mormon passages on eternal hell for the wicked?" Ensign 16 (April 1986): 36-38. Also in A Sure Foundation: Answers to Difficult Gospel Questions, $45-$ 50. Salt Lake City: Deseret Book, 1988. Points out that there are two hells identified in the Book of Mormon writings: one is the intermediate existence between death and the resurrection and the other is the never-ending state of the wicked. [D.M.]

P.229 Peterson, H. Donl. "The Law of Justice and the Law of Mercy." In The Book of Mormon: Alma, The Testimony of the Word, edited by Monte S. Nyman and Charles D. Tate Jr., 211-22. Provo, UT: Brigham Young University Religious Studies Center, 1992. Alma's instructions to his wayward son contain teachings on the Fall of Adam and Eve, the Atonement of Christ, and the justice and mercy of God. Justice, Alma teaches, exercises all of its demands and mercy claimeth all that is her own. God cannot bless one over another by allowing individuals to sin and not be required to fully repent. Alma summarizes his teachings on mercy and justice in Alma 42. [N.K.Y.]

P.230 Peterson, H. Donl. "Moroni2." In Encyclopedia of Mormonism, edited by Daniel H. Ludlow, 2:956-57. 5 vols. New York: Macmillan, 1992. A short description of Moroni, his role in preserving and revealing the Book of Mormon, and his depiction as an angel blowing a trumpet. [A.T.]

P.231 Peterson, H. Donl. Moroni: Ancient Prophet, Modern Messenger. Bountiful: Horizon Publishers, 1983. Uses Moroni's example to teach "(1) the resurrection is a reality, (2) the state of a celestial being is truly glorious, (3) there is opportunity for continued service in the kingdom of God beyond the veil, (4) the knowledge and intelligence one attains in mortality does rise with that person in the resurrection, and (5) this dispensation has great destiny to fulfill." [A.T.]

P.232 Peterson, H. Donl. "Moroni and the Restoration: A Closer Look." In Scriptures for the Modern World, edited by Paul R. Cheesman and C. Wilfred Griggs, 13. Provo, UT: Brigham Young University Religious Studies Center, 1984. The author outlines the character, calling, and message of Moroni and his role in training Joseph Smith for to his prophetic calling. [B.D.]

P.233 Peterson, H. Donl. "Moroni: Joseph Smith's Tutor." Ensign 22 (January 1992): 22-29. Describes Moroni's visits to Joseph Smith; discusses the finding of the plates at Cumorah, the lost manuscript, and the Three and Eight Witnesses. Moroni provided Joseph Smith with heavenly instruction and taught him line upon line on how to perform his prophetic tasks. [A.C.W.]

P.234 Peterson, H. Donl. "The Nephites and the Law of Moses." In Sidney B. Sperry Symposium, 103-16. Provo, UT: Brigham Young University, 24 January 1981. Discusses the law of Moses and the Aaronic and Melchizedek Preisthoods using both biblical and Book of Mormon references, and explains the fulfillment of the law of Moses through the crucifixion of Christ and his visit to the Nephites. [C.W.B.]

P.235 Peterson, H. Donl. "We Had a Hope of His Glory." Instructor 104 (August 1969): 300-301. The ancient Israelites, the Jaredites, and the Nephites all knew of Christ and benefited from following his gospel. Jesus is the Savior of all mankind and hope and happiness come through living his teachings. [L.M.]

P.236 Peterson, J. W. "Another Testimony." Deseret Weekly 48 (27 January 1894): 179. A newspaper article from Zion's Ensign that contains an interview with William Smith, brother of Joseph Smith. Discusses the frock covering 
the plates, Joseph Smith's character, and Reverend Lane's impetus that led to the first vision. [D.M.]

P.237 Peterson, J. W. "The Urim and Thummim." Rod of Iron 1 (February 1924): 6-7. Reports a conversation he had with William B. Smith, brother of Joseph Smith, relative to the Urim and Thummim, the breastplate, and the "two rims of a bow." Gives a fairly detailed statement about the instruments. [D.M.]

P.238 Peterson, Janet. "Clay’s Present for Jesus." Ensign 20 (March 1990): 62-63. Clay, a young man with Down's syndrome, was taught to read to his mother. In less than one year, Clay read the entire Book of Mormon from cover to cover. Clay stands as an example of the manner in which all individuals can read the book. [J.W.M.]

P.239 Peterson, Janet. "Friend to Friend." CN 20 (January 1990): 8-9. Angel Brea explains how much the Church in South America is growing and attributes this growth to the Book of Mormon. He tells about children in South America reading the Book of Mormon and the importance of doing so. [M.D.P.]

P.240 Peterson, Levi S. "The Third Nephite." Dialogue 19 (Winter 1986): 159-71. A fictional story of one of the Three Nephites placed in a modern setting. [J.W.M.]

P.241 Pew, W. Ralph. "For the Sake of Retaining a Remission of Your Sins." In The Book of Mormon: Mosiah, Salvation Only through Christ, edited by Monte S. Nyman and Charles D. Tate Jr., 227-45. Provo, UT: Brigham Young University Religious Studies Center, 1991. An exposition on the sermon by King Benjamin. Avers that Benjamin's audience already understood the principles of faith and repentance and had been baptized. Author focuses on retaining forgiveness of sins after the initial forgiveness at baptism and in feeding the hungry and clothing the naked. [D.M.]

P.242 Pew, W. Ralph. " 'Yield Your Heart to God'-the Process of Sanctification." In The Book of Mormon: Helaman through 3 Nephi 8, According to Thy Word, edited by Monte S. Nyman and Charles D. Tate Jr., 207-22. Provo, UT: Brigham Young University Religious Studies Center, 1992. An essay on the doctrine of sanctification. Includes comments on the Holy Ghost as a sanctifier and a discussion of the significance of grace. [D.M.]

P.243 Pfister, Lauren. "Is This Indian Really Jewish? An Introduction to Mormonism." Magazine of Campus Christian Living 33 (May 1973): 22-25. A polemical article that emphasizes Mormonism's deviations from conventional Christianity. Sees as problematic the Book of Mormon's reference to Christ's birth at Jerusalem, mention of steel, and the use of the word "adieu." [D.M.]

P.244 Phelps, William W. "The Book of Mormon." The Evening and the Morning Star 1 (January 1833): 57-59. An evangelical article testifying about the Book of Mormon, using such prooftexts as Psalm 85, Ezekiel 37, and John 10:16. Points out the textual purity of the book as opposed to the Bible and emphasizes the book as a new covenant to Israel. [D.M.]

P.245 Phelps, William W. "Discovery of Ancient Ruins in Central America." The Evening and the Morning Star 1 (February 1833): 71-72. Refers to ruins in Central America, extending more than twenty miles, that is seen as evidence for the Book of Mormon. [D.M.]

P.246 Phelps, William W. "The Indians." The Evening and the Morning Star 1 (December 1832): 54. The American Indians are portrayed as remnants of Joseph. Quotations about them from the Book of Mormon are supplied. [D.M.] 
P.247 Phelps, William W. "The Jews." The Evening and the Morning Star 1 (December 1832): 51-53. Addresses the prospect of the return of the Jews to Jerusalem to rebuild the holy city. Light is thrown on the subject by quoting passages from the Book of Mormon. [D.M.]

P.248 Phelps, William W. "Letter No. 10 to Oliver Cowdery Concerning the Book of Mormon with Comment." M\&A 1 (September 1835): 177-79. An appreciation and defense of the Book of Mormon by an early Church member who sees the Book of Mormon as "the foundation, or starting point of the Church of Christ." [D.M.]

P.249 Phelps, William W. "Letter No. 11 to Oliver Cowdery Concerning the American Indians." M\&A 2 (October 1835): 193-95. Exults over the spiritual promises for the American Indians and contrasts their glorious destiny with the downfall of the Nephites at the time of Mormon. Refers to Zenos's allegory of the olive tree in Jacob 5. [D.M.]

P.250 Phelps, William W. "Letter No. 12 to Oliver Cowdery Concerning Early Aspects about the Book of Mormon." M\&A 2 (November 1835): 221-23. Speaks of the Hill Cumorah, "which must become as famous among the latterday saints, as Sinai was among the former day saints." Refers to criticisms of the Book of Mormon. [D.M.]

P.251 Phelps, William W. "The Resurrection of the Just." The Evening and the Morning Star 1 (December 1832): 4951. Discusses the principle of resurrection as taught in the Bible and the Book of Mormon, a substantial part coming from Alma's instruction to Corianton. [D.M.]

P.252 Phelps, William W. "The Ten Tribes." The Evening and the Morning Star 1 (October 1833): 33-34. Discussion of the place of the ten tribes in salvific history, drawing on Jesus' allusion to "other sheep" in 3 Nephi and Jacob's allegory of the olive tree. [D.M.]

P.253 Phelps, William W. "The Tribe of Joseph." The Evening and the Morning Star 1 (November 1832): 41-43. An examination of the role of the tribe of Joseph in the latter days, quoting passages from 2 Nephi 3. Discusses the Book of Mormon relative to the stick of Joseph. [D.M.]

P.254 Phelps, William W., trans. "The Voice of Joseph." DN 2 (29 May 1852): 1. The story of Joseph Smith, the translation of the Book of Mormon, and the restoration of the Church. Originally in French in "Etoile du Deseret." [M.D.P.]

P.255 Phifer, C. L. "The Book of Mormon." Deseret Weekly 57 (18 June 1898): 7. Author praises the Book of Mormon as a sacred book and as "the greatest American novel," although he says that it "never betrays nineteenth century manner." His criticism is that "it contains no new doctrines." [D.M.]

P.256 Phillips, Arthur B. "Book of Mormon Rays on Scientific Paths" (series). SH 67 (28 April 1920-1 September 1920): 397-98, 423-24, 448-49, 473-74, 499-500, 575-76, 599-600, 648-50, 669-70, 696-98, 720-21, 746-48, 770-71, 795-96, 815-16, 839-40. Defends the Book of Mormon from the standpoint of anthropology, ethnology, chronology, archaeology, mining and metals, tools and ornaments, textile art, sciences, hierology, Egyptian writing, sociology, tradition, parallel theology with the New Testament, and changes in ortheopy and orthography. [D.M.]

P.257 Phillips, Arthur B. "The Book of Mormon Verified: Established by Forty Eminent Archaeologists and Authors." SH 49 (23 April 1902): 377-84, 397-405. Also in The Book of Mormon Verified; Established by Forty Eminent Archaeologists and Authors. Lamoni, IA: Herald House, 1912. Since the publishing of the Book of Mormon in 1830 much has came forth to promote greater understanding of the ancient inhabitants of America. Sources 
published from 1852 to 1901 are quoted to show that scientific finds have helped to establish the validity of the Book of Mormon. Topics include hieroglyphs, religion, large civilizations, governmental structure, and stone boxes. [J.W.M.]

P.258 Phillips, Arthur B. "The Undiscovered Book of Mormon." SH 74 (23 November 1927): 1365-74. Benefits derived from studying the Book of Mormon depend upon the individuals who read it. For many of its believers, it is still an undiscovered book. Advisable methods of study are to read the book from beginning to end or topical reading. [J.W.M.]

P.259 Phillips, G. F. "Skepticism and the Book of Mormon." MS 52 (10 February 1890): 104-5. Cites as evidence of the Book of Mormon a story by Montessini who visited America in the fifteenth century and discovered some Indians who "pronounced the words of Deuteronomy: Schemah Israel Adonai Elohenu Adoni Ehad (Hear O Israel, the Lord our God is one Lord)." Furthermore, he cites "Basnage's Histoire des Jeufs written in 1694," where Basnage writes that "Tis sufficiently certain that a vessel driven thither [Americas] by a tempest landed some Jews." [B.D.]

P.260 Phillips, R. Douglas. "Why Is So Much of the Book of Mormon Given Over to Military Accounts?" Ensign 8 (January 1978): 17-18. Also in Warfare in the Book of Mormon, edited by Stephen D. Ricks and William J. Hamblin, 25-28. Salt Lake City: Deseret and FARMS, 1990. Book of Mormon wars fulfill Lehi's prophecies about the terms and conditions for people to remain in the promised land. [D.M.]

P.261 Pickering, J. Frank. "Before the Days of Columbus." Liahona 14 (3 April 1917): 630. Relates Indian ruins (four photographs supplied) to the proposition that there were great civilizations in pre-Columbian America. [D.M.]

P.262 Pierce, Florence. The Golden Plates. Salt Lake City: by the author, 1946. A detailed examination of the Book of Mormon plates, their contents and the story behind them. [D.M.]

P.263 Pierce, Florence. Gospel Messages. Salt Lake City: by the author, 1951. Thorough listing of scriptural quotations addressing many themes from the standard works, including Lehi's dreams, the coming forth of the Book of Mormon, King Benjamin's speech, and Christ's ministry in America. [D.M.]

P.264 Pierce, Florence. Story of the Book of Mormon. Salt Lake City: Deseret News Press, 1947. Pierce tells chronologically the story of the Book of Mormon with added explanations and correlating archaeological evidence of the events that occurred. Photographs are included from various sites and findings in Mexico that correspond to Book of Mormon history. [C.W.B.]

P.265 Pierce, Norman C. Another Cumorah, Another Joseph. N.p., 1954. A geographical and archaelogoical look at events found in the Book of Mormon. Author argues for the existence of two Cumorahs, one in Palmyra, New York, and the other in Central America. Suggests that the existing oceanic currents aided the Nephites and Jaredites in their destinations from the Old to the New World. Sees a connection between the mound builders of Mississippi and Ohio Valleys and the mass migration of Hagoth and the other boats to the land northward.

P.266 Pierce, Norman C. "The Legend of Quetzalcoatl." IE 36 (December 1933): 858-59. A comparison of Quetzalcoatl, the Book of Mormon, and biblical passages reveals many similarities. [J.W.M.]

P.267 Pierce, Norman C. "The Legend of Quetzalcoatl." MS 96 (4 January 1934): 7, 11-13. Legends of Quetzalcoatl bear great resemblance to the account of Christ's ministry to the Nephites. [A.C.W.] 
P.268 Pierce, Norman C. "The Wheel among the Indians." DN Church Section (18 March 1933): 3. In order to support claims by the Book of Mormon, the author presents archaeological evidence that the wheel existed in ancient America. [D.W.P.]

P.269 Pierce, Perry Benjamin. "The Origin of the 'Book of Mormon.' "American Anthropologist 1 (October 1899): 675-94. A polemical article against the Book of Mormon. The author notes poor grammar in the book, reviews the Spaulding hypothesis, ridicules the idea that Joseph used a seer stone in translating the Book of Mormon, points out textual changes, and alleges that biblical plagiarism such as the Isaiah chapters and the Sermon on the Mount is present. [M R.]

P.270 Pinegar, Ed J. You, Your Family, and the Scriptures. Salt Lake City: Deseret Book, 1975. Suggested program for studying the scriptures that provides a list of scriptural passages for studying with a specific subject in mind. Subjects include prayer, fasting, the value of the Book of Mormon, searching the scriptures, and keeping records and journals. [J.W.M.]

P.271 Pinegar, Rex D. "Voices from the Book of Mormon." In Stories of Insight and Inspiration, edited by Margie Calhoun Jensen, 38. Salt Lake City: Bookcraft, 1976. A story of conversion of a young husband. Reading the Book of Mormon assisted him in his search for truth. [J.W.M.]

P.272 Plain Fact for Students of the Book of Mormon with a Map of the Promised Land. Salt Lake City: N.p., 1886. Five page booklet attempts to depict the exact geographical location of Book of Mormon lands and cities. Emphasis is placed on "Bountiful and four-sea regions." [D.W.P.]

P.273 Plan and Program for the Study of Child Culture and the Book of Mormon. N.p., 1903. Relief Society lessons. Part two outlines a course of study from the Book of Mormon. [J.W.M.]

P.274 "Plates, Metal." In Encyclopedia of Mormonism, edited by Daniel H. Ludlow, 3:1091. 5 vols. New York: Macmillan, 1992. The Book of Mormon was translated from a record kept on plates of metal. Other records were also kept on metal plates. [J.W.M.]

P.275 "Plates of the Book of Mormon." CN 58 (2 January 1988): 4. Graphic illustration of the development of the Book of Mormon in modern and ancient times. [M.R.]

P.276 "Plates of the Book of Mormon (Chart)." CN 58 (2 January 1988): 4. Chart shows relationships among the several sets of plates used by Mormon to compose the Book of Mormon. [R.H.B.]

P.277 Pledger, Arthur G. "The W and I (Book of Mormon Names)." Ensign 6 (September 1976): 24-25. It is significant that the letter $w$ is omitted in the 200 names introduced in the Book of Mormon, reflecting the Hebrew background of the text. The same is true of biblical names. [J.W.M.]

P.278 Plowman, Edward E. "Mormon Manuscript Claims: Another Look." Christianity Today 22 (21 October 1977): 38-39. A sequel to his previous article (8 July 1977), the writer describes setbacks in Davis, Cowdery, and Scales's work on the Spaulding connection. Several handwriting experts felt they had been misrepresented by the researchers. He also notes the recent criticisms of their work by Jerald and Sandra Tanner. [M R.]

P.279 Plowman, Edward E. "Who Really Wrote the Book of Mormon?" Christianity Today 21 (8 July 1977): 32-34. Contains a brief discussion of the work of Davis, Cowdery, and Scales in attempting to demonstrate a connection 
between the Spaulding manuscript and the writing of the "unknown scribe" in the Book of Mormon manuscript. The writer notes further that archaeologists have generally scoffed at the historical sections of the book, and they say there never has been such a language as "reformed Egyptian." [M.R.]

P.280 Poelman, Ronald E. "Companions from the Scriptures." In BYU 1979 Devotional and Fireside Speeches of the Year, 135-42. Provo, UT: BYU Press, 1980. Study of the scriptures is easier when one feels companionship with the people in them. Discusses the lives of Joseph of Egypt, Nephi, Paul, Moroni, and other scriptural figures. One develops a personal relationship with Jesus Christ through diligent study of the scriptures. [L.M.]

P.281 "Policies and Announcements." Ensign 16 (July 1986): 79. A letter from the First Presidency of the Church encouraging prospective missionaries to read the entire Book of Mormon. [L.D.]

P.282 "Policies and Announcements: Book of Mormon Placements." Ensign 15 (November 1985): 109. Directs members to do all they can to distribute copies of the Book of Mormon among non-members by directly giving them as gifts, through the family-to-family program, or offering them in public places. [J.W.M.]

P.283 Poll, Richard. "Liahona and Iron Rod Revisited." Dialogue 16 (Summer 1983): 69-78. Discusses Lehi's dream from the Book of Mormon, and reviews symbols and types of Liahonas and iron rods in Mormonism. [L.D.]

P.284 Pollard, Glen O. "The Book of Lehi." Ensign 7 (December 1977): 62. The book of Lehi was the source of the 116 pages of the gold plates that were translated by Joseph Smith and subsequently lost by Martin Harris. [D.H.M.]

P.285 Pollock, Gordon D. In Search of Security: The Mormons and the Kingdom of God on Earth, 1830-1844. New York and London: Garland, 1989. Analyzes the journals of Mormon converts who wrote during the early years of the Church, both those who remained faithful and those who apostatized. The author concludes that those who converted to the Church had suffered reversals and conflicts that were answered by the Book of Mormon. Even to those who rejected it, the Book of Mormon seemed to give clarification to and fulfillment of the Bible. [J.W.M.]

P.286 "Polynesian Ancestry and Traditions of the Book of Mormon." DN Church Section (6 June 1936): 2, 6. William A. Cole studied Polynesian traditions, legends, and ancestry. He found that Polynesians are direct descendants of the Nephites and gives several Polynesian legends of the migrations that took place, one of which is of the Nephite shipbuilder, Hagoth. [M.D.P.]

P.287 Pope, Jesse Curtis. "The Restoration Ideal in American Religious Thought." Ph.D. diss., Florida State University, 1990. Examines the common themes in American restoration movements. The author gives Joseph Smith's history and the history of the acquisition of the plates and their later translation. He includes opinions regarding the validity of the witnesses' testimonies and the plausibility of the Spaulding theory that he concludes cannot be proven. His estimation of the Book of Mormon is that it "reflected the common religious concerns of western New York and the frontier in 1830." [B.D.]

P.288 Pope, John Keith. Launching the Lehi. San Francisco: Academy Phototype Service, 1955. Pope foretells an expedition that will sail on a raft without food or water from Saudi Arabia to Guatemala, manned by a crew of five or six persons. The purpose of the trip is to show that a voyage such as the one that brought Lehi and his family to America is possible. [L.M.] 
P.289 Porter, Bruce D. Review of Parallel Histories: The Nephites and the Americans, by Anthony E. Larson. Review of Books on the Book of Mormon 3 (1991): 101-3. Book review.

P.290 Porter, Bruce D. Review of The Book of Isaiah: A New Translation with Interpretive Keys from the Book of Mormon, by Avraham Gileadi. Review of Books on the Book of Mormon 4 (1992): 40-51. Book review.

P.291 Porter, Elizabeth and Mary. "La Brea Tar Pits Corroborate the Book of Mormon." SH 85 (4 June 1938): 71516. The relics found in the La Brea Tar pits include deposits of prehistoric life-horses, mammoths, and other animals now extinct, proving that these animals once roamed the American continent as the Book of Mormon records. [J.W.M.]

P.292 Porter, Elizabeth Rachel Cannon. The Cities of the Sun; Stories of Ancient America Founded on Historical Incidents in the Book of Mormon. Salt Lake City: Deseret News, 1910. Fictional stories of several Book of Mormon characters and groups, including King Noah and Amulon, Alma and Abinadi, General Moroni, the Gadianton robbers, and Ammon. Pictures of artifacts and architecture are included. [J.W.M.]

P.293 Porter, L. Aldin. "Follow the Brethren." Ensign 17 (November 1987): 73-74. Also in CR (October 1987): 4952. Issues a call to follow the brethren and to develop greater love for the prophets by reading the scriptures, especially the Book of Mormon. [J.W.M.]

P.294 Porter, Larry C. "The Book of Mormon: Historical Setting for Its Translation and Publication." In Joseph Smith: The Prophet, The Man, edited by Susan Easton Black and Charles D. Tate Jr., 49-64. Provo, UT: Brigham Young University Religious Studies Center, 1993. A detailed discussion of the translation and publication of the Book of Mormon. The bulk of the work of translation was completed in a relatively short time. The process of finding a printer was difficult. Some pages of the Book of Mormon were used by missionaries prior to the book's publication. A pact was made by "Christians" in the neighborhood that none would purchase the book. Nonetheless, the 5,000 copies of the Book of Mormon were used as great missionary tools. [J.W.M.]

P.295 Porter, Larry C. "The Church in New York and Pennsylvania, 1816-1831." In The Restoration Movement: Essays in Mormon History," edited by F. Mark McKierman, 27-61. Independence, MO: Herald House, 1979. Explores the historical background of the coming forth of the Book of Mormon with excerpts from personal journals of Joseph Smith and many who knew him. Covers the early years of the prophet, the First Vision, the religious climate of Vermont and New York, Moroni's visit, Joseph's "money digging activites," and acquisition, translation, and publication of the golden plates. [J.W.M.]

P.296 Porter, Larry C. "The Colesville Branch and the Coming Forth of the Book of Mormon." BYU Studies 10 (Spring 1970): 365-85. Also published in A New Light Breaks Forth: Essays in Mormon History, edited by Lyndon W. Cook and Donald Q. Cannon, 75-96. Salt Lake City: Hawkes, 1980. The employment of Joseph Smith in the Colesville area of New York state brought him into contact with very important individuals of Church history. Josiah Stowell and Joseph Knight Jr. purposely planned to be at the Smith home when Joseph brought the plates home. There were many others who were equally important including Orson Pratt and Newell Knight as well as those who became the most prominent persecutors of the Church. [J.W.M.]

P.297 Porter, Larry C." 'The Field is White Already to Harvest': Earliest Missionary Labors and the Book of Mormon." In The Prophet Joseph: Essays on the Life and Mission of Joseph Smith, edited by Larry C. Porter and Susan Easton Black, 73-89. Salt Lake City: Deseret Book, 1988. Details how the contents of the Book of Mormon were used in proselytizing prior to its publication in March 1830. [D.M.] 
P.298 Porter, Larry C. "From a Book Coming Forth." Ensign 18 (July 1988): 42-46. Surveys letters, journals and other early Church historical writings concerning the missionary use of Book of Mormon passages from the beginning of its translation until its publication and the organization of the Church. By April, 1830, early members of the Church were instructed from and proselytized with passages from the Book of Mormon. Elements of this missionary work included written letters from Joseph Smith and Oliver Cowdery, angelic visitations and testimonies, handwritten excerpts from the translation, manuscripts and proof sheets from the printing, and finally the first edition of the Book of Mormon. [A.A.]

P.299 Porter, Larry C. "I Have A Question: Some scholars have implied that the Book of Mormon and LDS theology are products of Joseph Smith's environment. To what extent did Joseph Smith's environment influence the theological developments of the Church?" Ensign 22 (June 1992): 27-29. Rejects the so-called environment theory for the origin of the Book of Mormon. Discredits Indian, philosophical, historical, and literary influences (such as the Spaulding manuscript) upon the Book of Mormon. Contemporary religious thought appears to have been influential because the Book of Mormon answers and clarifies fundamental theological issues, but the only true source of influence upon the Book of Mormon was that of the Holy Ghost. [A.C.W.]

P.300 Porter, Larry C. "Palmyra/Manchester, New York." In Encyclopedia of Mormonism, edited by Daniel H. Ludlow, 3:1058. 5 vols. New York: Macmillan, 1992. An explanation of the importance of the Palmyra/Manchester area to LDS history. The first vision took place near there, the angel Moroni appeared there, the Hill Cumorah is only three miles southeast, and the Book of Mormon was printed there in Egbert B. Grandin's bookstore. [B.D.]

P.301 Porter, Larry C. Review of Eyewitness Accounts of the Restoration, by Milton V. Backman Jr. BYU Studies 24 (1984): 242. Book review.

P.302 Porter, Larry C. Review of The Keystone of Mormonism: Early Visions of the Prophet Joseph Smith, by Paul R. Chessman. Review of Books on the Book of Mormon 2 (1990): 65-66. Book review.

P.303 Porter, Larry C. "William E. McLellan's Testimony of the Book of Mormon." BYU Studies 10 (Summer 1970): 485-87. Contains a letter written by William E. McLellan in response to an inquiry made by James T. Cobb. Though McLellan had become a severe critic of the Church his testimony of the purity of the Book of Mormon and its divine origin remained in tact. [J.W.M.]

P.304 Porter, S. F. The Origin of the Book of Mormon. Chicago: National Christian Association, 1870. A polemical work against the Book of Mormon that advances the Spaulding theory for its origin. [M.R.]

P.305 "Possible Routes Suggested for Mulek's Voyage." Ensign 3 (September 1973): 76-77. Discusses two possible routes of the voyage of the Mulekites to the "promised land" and sets forth reasons why they think the Mulekites took one of these routes. [M.D.P.]

P.306 Poulsen, George W., Jr. Generations of the Nephites and Lamanites. Salt Lake City: n.p., 1962. A pedigree chart of the Book of Mormon families of Lehi, Ishmael, and Mulek that provides brief information with scriptural references about Book of Mormon characters and the time and location where each resided. [J.W.M.]

P.307 Powell, Lyman P. "Popular Bibles." In Cambridge History of American Literature, edited by William Peterfield Trent, et. al., 517-22. New York: Putnam, 1923. A polemical article against the Book of Mormon. The writer views the book as an inevitable product of the nineteenth century that drew upon various events and influences of the 
time such as the anti-masonic sentiment in the 1820s and common speculations regarding the Hebrew origins of the American Indian. He asserts that no true scholar takes the Book of Mormon seriously. [M.R.]

P.308 "The Power in God's Word." CN 34 (4 January 1964): 16. The message of Christ in the Book of Mormon will help to solve the ills of the world that cannot be solved by the remedies proposed by mankind. [J.W.M.]

P.309 "The Power of a Prophet." Friend 12 (October 1982): 48-49. Tells the story of Nephi 2 (prophet during the time of Christ). For children. [A.T.]

P.310 "A Powerful Convincer." CN 58 (2 January 1988): 6. States that the Book of Mormon is a powerful tool for missionaries and also "a powerful convincer" for individuals and families. Gives examples and stories of how the Book of Mormon has changed people's lives. [M.D.P.]

P.311 Pratt, David Leon. The Prehistoric Hebrews of New England. Salem, MA: Praetorian Press, 1985. Unorthodox presentation of the Book of Mormon text (1 Nephi-Jarom) as a history of the Hebrews. Says nothing about Joseph Smith or the origin of the Book of Mormon. Places the ancient Nephites in the present day New England area of the United States. Numerous footnotes provide commentary. [D.W.P.]

P.312 Pratt, Helaman. "Indian Customs and Traditions." Juvenile Instructor 15 (15 February 1880): 47. Writes about encounters with Indians in the Southwest and Mexico. The author was told that the Apaches would possess the land again, as the Book of Mormon describes. A tradition among the Pueblos listed three great events: the white race would conquer the Indians (fulfilled by Cortez), the Indians would rise up and regain their independence, and another group of white people would come with truth. [D.M.]

P.313 Pratt, John P. "Book of Mormon Chronology." In Encyclopedia of Mormonism, edited by Daniel H. Ludlow, 1:169-71. 5 vols. New York: Macmillan, 1992. Nephite history had three time references-time since they left Jerusalem, time from the commencement of the reign of the judges, and time from the birth of Christ. A table compares events in the three time references. [N.K.Y.]

P.314 Pratt, Milson R. "The Julian Calendar." N.p., 191?. A one-page statement claiming that the Book of Mormon places the birth of Christ on April 6, 4001 years after Adam and Eve. [D.M.]

P.315 Pratt, Noel B. The American Indian Bible. Alexandria, VA: Free Bible Foundation, n.d. Presents the first section of 1 Nephi as the "book of Lehi." Says nothing about the name Book of Mormon, its origins, or Joseph Smith, but entitles his series the American Indian Bible. Has no commentary or notes. [D.W.P.]

P.316 Pratt, Noel B. . .. And their Lands Remained ... Desolate." N.p., n.d. An unpublished manuscript presenting evidence that the Book of Mormon contains the history of the American Indians. Presents maps, inscriptions, and notes from scholars. [D.W.P.]

P.317 Pratt, Noel B. Prophecies of the American Indians. Independence, MO: Zion, 1966. A booklet comprising 1 Nephi of the Book of Mormon, with several headings. [D.W.P.]

P.318 Pratt, Orson. "Accounts of Book of Mormon History: Records." JD 16:47-59. Discusses the meeting of Adam with his posterity in the valley of Adam-Ondi-Ahman, the location of the valley, the covenant with Enoch, records of God's dealings with men since creation, methods of preserving ancient records, Christ among the Nephites, and the fulfillment of prophecy in the fullness of times. [L.D.] 
P.319 Pratt, Orson. "America, A Choice Land: Its Aborigines." JD 12:338-46. Discusses America as a choice and promised land and the early inhabitants of America (aborigines) or Indians who are known to members of the Church as the Nephites, Lamanites, and the Jaredites of the Book of Mormon. [L.D.]

P.320 Pratt, Orson. "The Ancient Prophecies Fulfilled." JD 2:284-98. Discusses the ancient prophecies in relation to the present generation, including prophecies about the coming forth of the Book of Mormon. [L.D.]

P.321 Pratt, Orson. "Background and Role of Book of Mormon." JD 21:128-36. Discusses the Book of Mormon and the "destiny of the kingdom of God and the Saints," the spreading of the Book of Mormon to the whole world, and presents the Book of Mormon as a divine revelation of God. [L.D.]

P.322 Pratt, Orson. "Bible Prophecy Fulfilled by Book of Mormon." JD 19:165-78. Joel's prophecy that young men will see visions and old men will dream dreams will be fulfilled only in the latter days when all men and women will be revelators. The translation of the Book of Mormon is the stick of Joseph coming forth to strengthen the Bible, the stick of Judah. [J.W.M.]

P.323 Pratt, Orson. "The Book of Mormon an Authentic Record." JD 21:168-78. Also in Masterful Discourses and Writings of Orson Pratt, compiled by N. B. Lundwall, 394-410. Salt Lake City: Lundwall, n.d. A summary of how the Book of Mormon came into Joseph Smith's hands. Pratt bears his testimony to the truthfulness of the Book of Mormon. The Three Witnesses beheld the golden plates and will condemn the world through their words. [A.L.]

P.324 Pratt, Orson. "Book of Mormon and Redemption of Zion." JD 17:289-306. Recounts many of the trials through which the Saints passed and teaches that blessings follow the trials. The redemption of Zion is one of the anticipated blessings. When the Savior spoke of his "other sheep" he spoke of the American Indian. The Saints fulfilled prophecy when they moved to the Rocky Mountains at which time the work among the other sheep commenced. [J.W.M.]

P.325 Pratt, Orson. "Book of Mormon and the Restoration." JD 14:289-99. Reports on evidences of the Book of Mormon. Mentions the works of Stevens and Catherwood on ruins of ancient cities, a mound located in Licking County in which a stone tablet was found that had a representation of Moses and the ten commandments written in ancient Hebrew. [B.D.]

P.326 Pratt, Orson. "The Book of Mormon: Autograph Letter of Orson Pratt." DN 32 (28 November 1883): 707. Letter written by Orson Pratt May 2, 1876, bearing testimony to a friendly inquirer of the gospel. Advises the correspondent that he can know that the Book of Mormon is true. [D.M.]

P.327 Pratt, Orson. "Book of Mormon. Evidences of Its Divine Authenticity." In A Compendium of The Doctrines of the Gospel, edited by Franklin D. Richards and James A. Little, 95-101. Salt Lake City: Deseret News, 1882. The Book of Mormon fulfills Enoch's prophecy that "truth would come forth from the earth and would sweep it as a flood." Old Testament scriptures bear witness of the authenticity of the Book of Mormon as do archaeological evidences. There is an agreement between biblical and Book of Mormon doctrines. [J.W.M.]

P.328 Pratt, Orson. "Divine Authenticity of the Book of Mormon." JD 18:155-68. Gives evidences concerning the divinity of the Book of Mormon. Pratt covers such topics as the history of Joseph Smith's acquisition of the plates, the use of the Urim and Thummim to translate, Charles Anthon's statement concerning the characters, the witnesses who were shown the plates by the angel and a brief lifetime history showing that they never denied their testimony, the Eight Witnesses, and Isaiah's and Ezekiel's prophecies concerning the Book of Mormon. [B.D.] 
P.329 Pratt, Orson. Divine Authenticity of the Book of Mormon. Liverpool, England: 1850. Reprinted in Orson Pratt's Works, 1-96. Orem, UT: Grandin Book, 1990. A series of missionary tracts. Defends the Book of Mormon on the grounds that new revelation is reasonable and necessary, it compares favorably with the Bible, it is confirmed by modern miracles, and it fulfills prophecies. [D.M.]

P.330 Pratt, Orson. "Divinity of the Book of Mormon." MS 28 (16 June 1866): 369-71. Also in Masterful Discourses and Writings of Orson Pratt, compiled by N. B. Lundwall, 387-90. Salt Lake City: Lundwall, n.d. The gospel writers of the New Testament fix the time of day of the Savior's crucifixion at noon and at three o'clock he was removed from the cross. The Book of Mormon records that the sign was given in the morning. The time difference is not contradictory, rather it offers proof that the Book of Mormon was not written by Joseph Smith, who could not have put such detail into the record. Three o'clock in the afternoon in Jerusalem would have been seven-thirty in the morning in America at one hundred twelve degrees west of Jerusalem. [J.W.M.]

P.331 Pratt, Orson. Editorial. MS 19 (September 1857): 600-605. A report on a visit to the Isle of Man where Pratt and others gave lectures on the divine authenticity of the Book of Mormon. They quoted from Isaiah 29 and explained how these verses apply to the Book of Mormon. [B.D.]

P.332 Pratt, Orson. "Evidences of Bible and Book of Mormon." JD 7:22-38. Author makes a scholarly comparison between the evidences supporting the Bible and the Book of Mormon. Evidences supporting the Book of Mormon include the twelve witnesses and doctrine in the Book of Mormon that is consistent with biblical doctrine. [B.D.]

P.333 Pratt, Orson. "Evidences Relating to the Divine Authority of the Bible and the Book of Mormon Compared." JD 16:209-20. The people of this world will be judged according to the doctrines in both the Bible and the Book of Mormon. The testimonies of the Three Witnesses, manifestations of the Holy Ghost, and fulfilled prophecies testify of the truth of the Book of Mormon, whereas the Bible lacks similar evidences due to mistranslations. [A.L.]

P.334 Pratt, Orson. "The Gospel Restored from Heaven." JD 17:264-77. Discusses the truthfulness of the Book of Mormon and compares the evidences of Book of Mormon witnesses, etc., to those of the Bible. They are both true with or without man's acceptance. [A.L.]

P.335 Pratt, Orson. "The Hill Cumorah." MS 28 (July 1866): 417-19. Also in Masterful Discourses and Writings of Orson Pratt, compiled by N. B. Lundwall, 390-94. Salt Lake City: Lundwall, n.d. A few notes on the Hill Cumorah. It was the site of the final battles of both Nephite and Jaredite nations, and contains a repository of plates and records. [B.D.]

P.336 Pratt, Orson. An Interesting Account of Several Remarkable Visions, and of the Late Discovery of Ancient American Records. New York: J. W. Harrison, 1841. Also published as Interesting Account of Several Remarkable Visions and of the Late Discovery Of Ancient American Records. Edinburgh: Ballyntyne and Hughes, 1840. Discusses the history of the American continent from the time of the tower of Babel to the present (1840). Also deals with the rise of the Church of Jesus Christ of Latter-day Saints and the coming forth of the Book of Mormon. [L.D.]

P.337 Pratt, Orson. "Joseph Smith: Coming Forth of Book of Mormon." JD 15:178-91. A brief synopsis of how Joseph Smith obtained the plates of gold. The stick of Joseph and the stick of Ephraim come together in the fullness of times of the gentiles for the purpose of gathering the tribes of Israel. [A.L.]

P.338 Pratt, Orson. "Joseph's Blessing: The American Indian." JD 14:7-12. Identifies the Book of Mormon as "an account of the first settlement of this country by these inhabitants [the native Indians], showing that they are not 
the ten tribes, but they are the descendants of one tribe, and they came into this country about 600 years before Christ." Included is a geographical history of the peoples of the Book of Mormon, following their movements from South America, through Central America, to North America wherein the Nephites were destroyed being "gathered together south of the great lakes in the country which we term New York." [B.D.]

P.339 Pratt, Orson. "King Limhi's Enquiry, Etc., Delivered on December 9, 1877." JD 19:204-19. Ammon's response to Limhi taught that the gift of seership is a high gift from God. By the use of the Urim and Thummim prophets translated and received revelation. The revelation the brother of Jared received cannot be revealed to mankind because of their lack of faith. The sealed portion of the Book of Mormon contains the full account of the instructions given to the brother of Jared. [J.W.M.]

P.340 Pratt, Orson. "The Knowledge of God Shall Cover the Earth As the Waters Cover the Deep." In Masterful Discourses and Writings of Orson Pratt, compiled by N. B. Lundwall, 410-24b. Salt Lake City: Lundwall, n.d. All things from past dispensations are to be revealed so that truth and the knowledge of God shall flood the earth in this dispensation of the fullness of times. Many great prophets kept records. The records that Lehi's family brought with them contain a greater account than does the Bible. Jesus also taught many things when he visited in America that have not been revealed. All these records combined with those of the Eastern continents will be revealed in due time, and the heavens and the earth will reveal their knowledge of God. [J.W.M.]

P.341 Pratt, Orson. "The Latter-day Kingdom of God." JD 13:126-35. Explains what the Book of Mormon is and offers some evidences, including the timing of Jesus' crucifixion. Notes that Book of Mormon peoples had access to the scriptures, both those from the plates of brass and contemporary preachings, due to the copying of many scribes and the spreading of the manuscripts. [D.M.]

P.342 Pratt, Orson. "A Marvelous Work, etc." JD 19:350-57. Many prophets through the ages have conversed with God. It is absurd to believe the heavens are closed to revelation. The Lord did not allow the Book of Mormon to be published until he had established the testimony of several witnesses who have never denied their testimonies. After publication of the book thousands of others testify by the Spirit of the book's truthfulness. [J.W.M.]

P.343 Pratt, Orson. Masterful Discourses and Writings of Orson Pratt, edited by N. B. Lundwall. Salt Lake City: Bookcraft, 1962. Contains many of the important works of Orson Pratt. Subjects include elephants of the Jaredite nation, darkness upon the American continent following the crucifixion, the Hill Cumorah, the Book of Mormon is consistent with the Bible, the witnesses to the Book of Mormon, and the Jaredite origins and records. [J.W.M.]

P.344 Pratt, Orson. "The Mastodon of the Book of Ether." MS 28 (8 December 1866): 776-77. Omer, a descendant of Jared, departed the Jaredite lands to a place by the seashore. His community's domesticated animals consisted of elephants and other unidentified animals that had perished by the time the Nephites arrived. Pratt muses about the disappearance of these animals and the remnants of curious animals found in New York. [J.W.M.]

P.345 Pratt, Orson. "More Evidence to Establish the Divine Authenticity of the Book of Mormon." MS 10 (15 November 1848): 341-43. Publishes an article entitled "Discoveries in America" from the Edinburgh Evening Courant 16 October 1848. Considers the discovery of Egyptian hieroglyphics in Central America and of Egyptianstyle mummies in Mexico as external evidences of the Book of Mormon. [D.M.]

P.346 Pratt, Orson. "Mormonism." JD 12:352-62. Presents a general history of the formation of "Mormonism." Only mentions Book of Mormon in reference to its place in the history of the Church. [B.D.] 
P.347 Pratt, Orson. "Nephite America-The Day of God's Power." JD 14:332-35. Contains a narrative of the Book of Mormon and descriptions of geographical locations that the author identifies as those where the events occurred. [J.W.M.]

P.348 Pratt, Orson. "Preparations for the Second Advent." The Seer 2 (August 1854): 305-20. In 1827 an angel of the Lord appeared in fulfillment of the revelations provided in Daniel and Revelation. The Book of Mormon contains the fullness of Christ's gospel, and the kingdom that was established upon the principles taught in the Book of Mormon has begun to roll forth from the tops of the mountains to establish the Lord's Zion. It is through this book that the guests are being called to the Lord's marriage feast. [J.W.M.]

P.349 Pratt, Orson. "Questions and Answers on Doctrine." The Seer 2 (February 1854): 212-15. Answers questions concerning the Book of Mormon. The Book of Mormon agrees with the Bible because they are both of divine origin and God does not disagree with himself. The Bible has been robbed of plain and simple truths. All are required to repent and accept the message of the Book of Mormon. [J.W.M.]

P.350 Pratt, Orson. "Records of Judah and Ephraim's Explanation of Term 'Stick.' " DN Church Section 82 (3 December 1932): 1, 4. An excerpt from the pamphlet "Divine Authenticity of the Book of Mormon" that claims that the stick of Judah refers to the Bible and the stick of Ephraim refers to the Book of Mormon. [A.T.]

P.351 Pratt, Orson. Remarkable Visions \#6. Liverpool: R. James, December 1818. See also Orson Pratt's Writings of an Apostle, edited by Jerry Burnett and Charles Pope, Tract \#6. Salt Lake City: Mormon Heritage, 1976. A narrative of the visions of Joseph Smith, the discovery of gold plates, their translation by the use of the Urim and Thummim, and the Book of Mormon story. Contains also the testimony of the Eleven Witnesses. [J.W.M.]

P.352 Pratt, Orson. "Reply to a Pamphlet, Printed in Glasgow, Entitled 'Remarks on Mormonism.' " MS 11 (15 March, 1 April, 1 May 1849): 85-88, 100-5, 129-33. Response to a polemical pamphlet against several aspects of Mormonism. Defends Joseph Smith's use of the Urim and Thummim, discusses the meaning of "other sheep" and "fold," and of the Book of Mormon as a covenant. [D.M.]

P.353 Pratt, Orson. "Sacred Metalic [sic] Plates." MS 28 (1, 8 December 1866): 761-64, 777-81. Refers to the discovery of "sacred stones" upon which are inscribed Hebrew characters, one of which reads "may the Lord have mercy upon me a Nephite." Scholars wonder where these people who spoke Hebrew came from, and the Book of Mormon provides the answers. The Nephites landed in Chile near the city of Valparaiso. Later Hagoth and others sailed to North America (Alma 63:4-12 and Helaman 3:3-16). The Nephites knew Hebrew and Egyptian and wrote in reformed Egyptian. [B.D.]

P.354 Pratt, Orson. "Sacred Stones in the Vicinity of Newark, Licking County, Ohio." MS 28 (December 1866): 75359, 769-74. Features a quotation from the Occident, a contemporary American paper. In it the findings of four stones are described that contain what the non-Mormon author claims are unmistakably Hebrew inscriptions. One reads, "King of the Earth, Law of the Lord, the Word of the Lord, and the Holy of Holies," and the other contains the ten commandments. [K.M.]

P.355 Pratt, Orson. Sammanlikning Emellam Bewiserna For Bibeln Och Mormons Bok. Kopenhamn: Utgifven Och Forlaggd af C. Widerborg, 1866. A translation of "Evidences of Bible and Book of Mormon." English in JD 7:22-38. [D.W.P] 
P.356 Pratt, Orson. Sammenligning Mellem Beviserne For Bibelen Og Mormons Bog. Kjobenhaun: Udgivet og Forlagt af J. Van Cott, Trykt hos F. E. Bording, 1860. The English translation of this work is found under Orson Pratt, "Evidences of Bible and Book of Mormon." English in JD 7:22-38. [D.W.P.]

P.357 Pratt, Orson. "Stick of Joseph, Etc., Delivered on January 25, 1874." JD 16:339-53. The prophecy of the two sticks in the book of Ezekiel refers to the Book of Mormon and the Bible. [J.W.M.]

P.358 Pratt, Orson. "True Christmas and New Year." JD 15:253. A reflection on the true meaning of Christmas and how the Book of Mormon shows the signs of the birth and crucifixion of Jesus Christ. [A.L.]

P.359 Pratt, Orson. "The Two Bibles." MS 28 (13 October 1866): 641-43. The two Bibles of the world are the Eastern Bible (Holy Bible) and the Western Bible (Book of Mormon). The Western Bible is the most correct book, but the Eastern Bible has been worked on by uninspired men and contains many errors. The discovery of stones inscribed with Hebrew found in ancient mounds in Ohio indicate that the ancient Indians of America had an alphabet and a written language. [B.D.]

P.360 Pratt, Orson. Untitled talk. JD 19 (October 1867): 311-21. Uses Book of Mormon references to discuss the nature of God. The brother of Jared saw Jesus Christ before his coming and thus learned that the God of the Old Testament was in the form of a man. Jacob teaches that Christ's Atonement frees everyone from temporal and spiritual bondage, and Nephi teaches that through Adam's fall all mankind are fallen. [B.D.]

P.361 Pratt, Orson. Untitled talk. JD 19 (October 1877): 111-19. The Lord instructed the Nephite twelve disciples to "be even as I am." Pratt discusses his assignment to go to England and print the Book of Mormon and the Doctrine and Covenants in a phonetic shorthand method known as Pitman's phonotype system. [B.D.]

P.362 Pratt, Orson. "Was Joseph Smith Sent of God?" MS 10 (15 August; 1, 15 September; 1 October 1848): 24751, 257-60, 273-78, 289-93. Pratt states that the Book of Mormon was revealed through Joseph Smith, that it contains the everlasting gospel and the writings of the tribe of Joseph. Explains Ezekiel 37:18-21 and Isaiah 29. Book of Mormon explains that America is the land of promise of Joseph. Thousands and tens of thousands of witnesses have accepted the Book of Mormon and witness concerning its truthfulness. [D.W.P.]

P.363 Pratt, Orson. "Yucatan." MS 10 (15 November 1848): 346-48. Takes issue with a statement from the New York Sun that "Yucatan is the grave of a great nation that has mysteriously passed away and left behind no history." Pratt claims that the Jaredites and descendants of Lehi inhabited that area and left their history in the Book of Mormon. Identifies the region of the Yucatan as the land of Desolation. Rejects the Spaulding theory. [D.M.]

P.364 Pratt, Parley P. "An Address By a Minister of the Church of Jesus Christ of L.D.S., To the People of England." In Pre-Assassination Writings of Parley P. Pratt, edited by Jerry Burnett and Charles Pope, 1-4. Salt Lake City: Mormon Heritage, 1976. Following a discourse on the basic beliefs and doctrines of the LDS church, the author declares the Book of Mormon to be a true book. The Book of Mormon contains the same doctrines and principles that were revealed to the Jews and corroborates and sustains them. [J.W.M.]

P.365 Pratt, Parley P. "Address to the Red Man and Ancient Records of the Western Hemisphere." In PreAssassination Writings of Parley P. Pratt, edited by Jerry Burnett and Charles Pope, 8-15. Salt Lake City: Mormon Heritage, 1976. Calls pagans, Jews, and all people to repent, call on the name of the Lord, and read the Book of Mormon. He tells "the Red Men of America" that they are of the house of Israel, and from the tribe of Joseph as is recorded in the Book of Mormon. [J.W.M.] 
P.366 Pratt, Parley P. "The Bible and the Book of Mormon Contrasted." The Prophet 1 (12 April 1845): 2-3. The Book of Mormon is superior to the Bible since the Book of Mormon is more simple and definite in its prophecies and doctrines. Nevertheless the Bible should be used as a companion record to the Book of Mormon despite its flaws and loss of plain truths. [A.C.W.]

P.367 Pratt, Parley P. "The Book of Mormon." IE 30 (August 1927): 938. Excerpt from JD 3:179, 308. Pratt rejoices in the Book of Mormon and says that if the world accepted its gospel all evil would cease. [A.C.W.]

P.368 Pratt, Parley P. "Book of Mormon." MS 1 (February 1841): 263-64. Announces the printing of a European edition of the Book of Mormon, a book that is worth more than "the gold and silver of Europe." [D.M.]

P.369 Pratt, Parley P. "The Book of Mormon-Origin of the American Indians, etc." In A Voice of Warning and Instruction to All People or, An Introduction to the Faith and Doctrine of the Church of Jesus Christ of LDS, 81-117. 9th edition. Salt Lake City: Deseret News Steam Printing, 1874. The Book of Mormon is the most misinterpreted and least understood book that has ever been published. The author presents a brief overview of the Book of Mormon and quotes Orson Pratt concerning its coming forth, a description of the stone box that contained the gold plates, the angel's declaration of their spiritual value and his admonition to use them properly. [J.W.M.]

P.370 Pratt, Parley P. "A Dialogue between Tradition, Reason, and Scriptus." In Pre-Assassination Writings of Parley P. Pratt, edited by Jerry Burnett and Charles Pope, 11-16. Salt Lake City: Mormon Heritage, 1976. A play in which the characters Mr. Tradition, Mr. Reason, and Mr. Scriptus discuss the need for further revelation. Mr. Reason is willing to look for further evidence from all of the scriptures, including the Book of Mormon, but Mr. Tradition says that the "canon of scripture is full." Mr. Scriptus compares evidences of the New Testament and the Book of Mormon. [J.W.M.]

P.371 Pratt, Parley P. "Discovery of an Ancient Record in America." MS 1 (June 1840): 30-37. Tells how the Book of Mormon was made known to Joseph Smith. Contains passages from Jesus' ministry in 3 Nephi. [D.M.]

P.372 Pratt, Parley P. “Editorial Remarks." MS 3 (July 1842): 44-47. Various verses from Isaiah 29 are applied to the Book of Mormon. Refers to the work as a "record of the house of Joseph." [D.M.]

P.373 Pratt, Parley P. "Interesting Discoveries." MS 1 (August 1840): 101-3. Two articles on archaeological discoveries from Athenaeum and the Manchester Guardian. Asks if it is any more astonishing that plates hidden by Moroni should be preserved than that relics in America and England should survive to be discovered centuries after they were used. [D.M.]

P.374 Pratt, Parley P. Key to the Science of Theology. Salt Lake City: Deseret Book, 1973. The western hemisphere rose, progressed, declined, and fell as is recorded by the Book of Mormon. In the latter days Joseph Smith restored the keys to the science of theology through the Book of Mormon and divine revelation. [J.W.M.]

P.375 Pratt, Parley P. "A Letter to the Queen of England (Queen Victoria)." TS 3 (15 November 1841): 593-96. See also IE 4 (October 1901): 883-94, and in Pre-Assassination Writings of Parley P. Pratt, edited by Jerry Burnett and Charles Pope, 7-14. Salt Lake City: Mormon Heritage, 1976. A missionary proclamation including an account of the origin of the Book of Mormon and its purpose. Quotes from 1 Nephi, concerning the "great and abominable Church." [D.M.] 
P.376 Pratt, Parley P. "Mormonism Unveiled!" In Pre-Assassination Writings of Parley P. Pratt, edited by Jerry Burnett and Charles Pope, 1-49. Salt Lake City: Mormon Heritage, 1976. Pratt compares the miracles recorded in the Bible and those of the Book of Mormon. When John gave the warning to not add to the book, he was not referring to the New Testament, but only to his book, the Revelation of John. That same warning is found in Deuteronomy. [J.W.M.]

P.377 Pratt, Parley P. "The Mormonites." TS 1 (January 1840): 45-46. A response to an article by Matilda Davidson. The LDS scripture is not called the "Mormon Bible" (as if to replace the well-known Bible), it is called the "Book of Mormon." The Book of Mormon corroborates the Bible. Pratt refutes Sidney Rigdon's connection with the Spaulding manuscript. [D.M.]

P.378 Pratt, Parley P. "Opposition to the Book of Mormon." MS 1 (November 1840): 185-87. Answers J. Curran's poorly reasoned objections to the Book of Mormon, published in the Manx Journal, that the New Testament forbids adding to the word of the Lord. [D.M.]

P.379 Pratt, Parley P. Plain Facts, Showing the Falsehood and Folly of the Rev. C. S. Bush (A Church Minister of the Parish of Peover): Being a Reply to His Tract against the Latter-Day Saints. Manchester: W. R. Thomas, 1840. Also published as "Plain Facts, Showing the Falsehood and Folly of the Reverend C. S. Bush." In Pre-Assassination Writings of Parley P. Pratt, edited by Jerry Burnett and Charles Pope, 1-16. Salt Lake City: Mormon Heritage, 1976. Rebuttal to Rev. Bush's publication "Plain Facts, Showing the Falsehood and Folly of The Mormonites or Latter-day Saints." Pratt confirms the Church's belief in the Bible as the word of God, but stresses that God is a God of continuous revelation. He denies that Emma Smith had signed a document stating that the Book of Mormon was false. The doctrines in the Book of Mormon are pure and holy. Whatever the medium upon which the scriptures are written or by what man of God they are recorded, their principles are the same. [J.W.M.]

P.380 Pratt, Parley P. "Present Condition and Prospects of the American Indians, Lamanites." MS 2 (July 1841): 4042. The Book of Mormon prophesies that the Lamanites will be no longer persecuted but nourished by the gentiles beginning in 1830 when the Book of Mormon was published. In fulfillment of that, the United States government has apportioned an area of gathering for all the Indians; the tribes were paid money and given provisions at the expense of the United States. [B.D.]

P.381 Pratt, Parley P. "Proclamation! To the People of the Coasts and Islands of the Pacific (Ocean), of Every Nation, Kindred, and Tongue." MS 14 (18 September 1852, 25 September 1852): 465-70, 481-85. An apostolic manifesto enunciating basic principles of the Restoration. Addresses the "red man" identifying the Book of Mormon as a record of their people. Admonishes them to respond to the gospel and promises that they will thereby feel joy. Refers to the Book of Mormon as "that book of books, that Ensign to the nations." [D.M.]

P.382 Pratt, Parley P. Proclamation!: To the People of the Coasts and Islands of the Pacific; of Every Nation, Kindred and Tongue. Sydney, Australia: C. W. Wandell, 1851. See also MS 14 (18 September 1852, 25 September 1852): 46570, 481-85. Treats the Book of Mormon as an essential element in the new dispensation of the gospel. Notifies the "red man" that the Book of Mormon is a record of their ancestors. [D.M.]

P.383 Pratt, Parley P. "Reminiscences and Testimony of Parley P. Pratt." JD 5:193-201. A testimony of the Church, Book of Mormon, and of Joseph Smith as a true prophet of God. [A.L.]

P.384 Pratt, Parley P. “A Reply to Mr. Thomas Taylor's 'Complete Failure' etc., and Mr. Richard Livesey's 'Mormonism Exposed.' In Pre-Assassination Writings of Parley P. Pratt, edited by Jerry Burnett and Charles Pope, 1- 
12. Salt Lake City: Mormon Heritage, 1976. The reply to Mr. Taylor does not pertain to the Book of Mormon, however the response to Mr. Livesey is an attempt to disprove allegations that the Book of Mormon shows no "evidence of prophecy, of miracles, of purity of doctrine." [J.W.M.]

P.385 Pratt, Parley P. "Reply to the Anthenaeum: Being An Exposition of the Ignorance and Folly of Men Who Oppose the Truth." MS 2 (May 1841): 1-5. Response to an article in the Edinburgh Intelligencer (7 April 1841), which accused the Book of Mormon of being "a pretended revelation." Pratt calls the Book of Mormon "a marvelous work and a wonder." Defends against the accusation that the Book of Mormon is a forgery of Spaulding's manuscript. [J.W.M.]

P.386 Pratt, Parley P. "Ruins in Central America." MS 2 (March 1842): 161-65. A book review of Stephen's Incidents of Travel that includes comments concerning archaeology and the Book of Mormon. [D.M.]

P.387 Pratt, Parley P. A Voice of Warning. Salt Lake City: Deseret News Press, 1874. Discusses fulfillment of prophecy and the Restoration, outlines the Book of Mormon's contents and the historical circumstances of Joseph Smith's translation. The Book of Mormon describes the origin of the American Indians. [E.G.]

P.388 Pratt, Parley P. "Wholesale Conversion of Methodists to Infidelity." MS 2 (December 1841): 114-15. Replies to several objections to the Book of Mormon listed by a minister, including that God commanded Nephi to kill Laban, that 3,000 Lamanites were killed in a battle and only seventy Nephites, that in John 17:4 Jesus says he had finished all that he was sent to do but the Book of Mormon attributed to him further duties. Pratt chides the minister for rejecting the Bible while trying to discredit the Book of Mormon. [D.M.]

P.389 Pratt, Rey L. "Book of Mormon Prophecies and the Mexican Situation." Young Woman's Journal 25 (September 1914): 529-40. Shows how the history of Mexico, beginning with the slaughters of Cortez, demonstrates the fulfillment of Book of Mormon prophecy that the Lamanites would "be scattered and smitten." [D.M.]

P.390 Pratt, Rey L. "Gospel Tidings For the Southland." MS 88 (15 April 1926): 225-30. Pratt, who has been called to conduct missionary work in "the southland," quotes 2 Nephi 1:1-11, 1 Nephi 13, 2 Nephi 30, and 3 Nephi 21 that speak of the fall, final gathering, and redemption of the Lamanites. [B.D.]

P.391 Pratt, Rey L. "The Gospel to the Lamanites." IE 16 (March, April, May, June, August 1913): 497-503, 577-85, 686-90, 796-801, 1021-25. Traces the origin, Book of Mormon prophecies regarding, subsequent conditions of, and ultimate destiny of the Lamanites. [D.M.]

P.392 Pratt, Rey L. Untitled talk. CR (October 1924): 142-45. Rejoices that the Lamanites are being brought the gospel, and says that people in Mexico and Central and South America are of the house of Israel. Those seeking to disprove the historical truth of the Book of Mormon will be unable to do so. Future archaeological excavations will strengthen its stance. [E.G.]

P.393 Pratt, Rey L. Untitled talk. CR (October 1925): 169-74. The Book of Mormon records that the Lamanites will be severely persecuted but not utterly overcome, the gentiles will bring the gospel to the Lamanites, and the time will arrive when the Lamanites will be redeemed. [B.D.]

P.394 Pratt, Rey L. Untitled talk. CR (April 1929): 70-76. Pratt speaks in conference about external evidences of the Book of Mormon. The ruins he has seen in his travels in South and Central America testify of great civilizations 
as described in the Book of Mormon. Many of the natives have legends that are similar to Christian myths. [B.D.]

P.395 Pratt, Rey L. Untitled talk. CR (October 1929): 18-22. A testimony of the Book of Mormon; Moroni 10:25 shows the way to find the truth of the Book of Mormon. [B.D.]

P.396 Pratt, Rey L., and Junius Romney. The Book of Mormon-A Divine Record Prepared by Rey L. Pratt and Junius Romney. N.p.: n.p., n.d. Many external evidences of the truthfulness of the Book of Mormon are presented-the horse, cement, paved streets, pyramids. The pamphlet seems to accompany a slide presentation presented by Rey L. Pratt. There are 47 items of archaeological evidence described. [J.W.M.]

P.397 Preece, Derek. " 'What If This Is Really True?' "Ensign 20 (September 1990): 20-21. A conversion story of a young man who received a testimony of the Book of Mormon while preparing stories to present as a home teacher. [J.W.M.]

P.398 Preece, Michael J. Review of Exploring the Lands of the Book of Mormon, by Joseph L. Allen. Review of Books on the Book of Mormon 3 (1991): 32-51. Book review.

P.399 "Presentation of the Book of Mormon to Rulers of the World." IE 43 (July 1940): 391. A list of kings, presidents, and statesmen of the world to whom a Book of Mormon has been presented, with the date and name of the presenter. [J.W.M.]

P.400 "President Benson Addresses Cache Regional Conference." Ensign 17 (May 1987): 98. Reports President Benson's address on the testament of Christ in the Book of Mormon. [L.D.]

P.401 "President Benson Addresses Members in Utah, California." Ensign 17 (September 1987): 77-78. A report on President Benson's address admonishing reading and studying the Book of Mormon throughout one's life. [L.D.]

P.402 "President Benson Counsels New Mission Presidents in Annual Seminar." Ensign 16 (September 1986): 76. President Benson advises mission presidents to use the Book of Mormon as a part of their own personal study, preaching, and missionary work. [L.D.]

P.403 "President Benson Tells of God's Gifts." CN 47 (17 December 1977): 4. President Benson lists several gifts with which the Lord has blessed mankind-one of them is the Book of Mormon. [M.D.P.]

P.404 "President Benson Visits Church Historical Sites in New York." Ensign 16 (October 1986): 73. A report of President Benson visiting historical sites in New York. He teaches that the Book of Mormon was written for today and all should read and ponder it. [L.D.]

P.405 "Presiding Bishopric's Page: Young Men Can See Further." IE 64 (October 1961): 758-59, 767. The Book of Mormon is an instrument more valuable than binoculars -it will give a clear view of the pitfalls and traps of the enemy and prepare Aaronic priesthood boys for missionary service. The life of Nephi is an excellent example of a young man of faith with clear and righteous vision. [J.W.M]

P.406 Presler, Vi. "Humility, A Gem with Many Facets." ZR 29-31 (Summer, Fall 1985, Winter 1986): 6-10, 22. The author narrates 1 Nephi 1-10, pointing out the instances where pride or humility played an important part in the narrative. [A.T.] 
P.407 Prestwich, Larry Berg. "A Visual Interpretation of Events and Personalities from the Book of Mormon." M.A. thesis, Brigham Young University, 1966. This thesis consists of drawings illustrating men and events in the Book of Mormon, with an attempt to capture emotional and spiritual expressions. Illustrations include Nephi, Enos, Omni, Mormon and Moroni. The author/artist explains in detail the techniques he used in the drawings. [D.M.]

P.408 Prettyman, C. W. "Prettyman's Reply to The Foundation of Mormonism Removed." Comstock, NE: n.p., 19?. A response to Rev. D. Collin's tract "The Foundation of Mormonism Removed." Prettyman responds on a point by point basis. [D.W.P.]

P.409 Price, John A. "The Book of Mormon vs. Anthropological Prehistory." The Indian Historian 7 (Summer 1974): 35-40. The Book of Mormon reflects common theories of the Hebrew origin of the Indian that were well known in the early nineteenth century. Many claims of the Book of Mormon are unsupported by evidence. Anachronisms are found in the Book of Mormon-the pre-Columbian presence of wheat, barley, domesticated animals, horses, and the use of the plow. View of the Hebrews may have been the source of the Book of Mormon. [M.R.]

P.410 Price, Rex Thomas Jr. "The Mormon Missionary of the Nineteenth Century." Ph.D. diss., University of Wisconsin, 1991. Tracks Mormon missionaries from 1830 to 1900, observing the place of the Book of Mormon in early LDS thought. The book shaped much of the ideological backdrop for the Church. Author explores the missionary call, finances, housing, and other items. [J.W.M.]

P.411 Priddis, Venice. The Book and the Map: New Insights into Book of Mormon Geography. Salt Lake City: Bookcraft, 1975. A geographical investigation of Book of Mormon lands. Author believes that the Book of Mormon civilization inhabited western South America spanning the countries of Columbia, Equador, Peru, and Chile. Thirty-three maps and several illustrations are included. This work is reviewed in S.516. [C.W.B.]

P.412 Priest, Josiah. "American Antiquities." MS 7 (1 March 1846): 67-71. Large pyramids and mounds discovered in the eastern United States are described. Several references are cited confirming the use of metal in antiquity. Quotes Book of Mormon descriptions of Moroni's fortifications to show how recent discoveries support the Book of Mormon. [B.D.]

P.413 Priest, Josiah. American Antiquities and Discoveries in the West. Albany, NY: Hoffman and White, 1837. Contains information about "traces of an Egyptian custom in Kentucky," "traits of the Mosaic history found" among the Indians of Mexico, and the "great stone calendar of the Mexicans." [A.T.]

P.414 Priest, Josiah, and Thomas Ward. "American Antiquities." MS 9 (1 March 1846): 67-71. Tells of ancient American Indian ruins that show remnants of several large cities. This, as well as other American antiquities, helps support the Book of Mormon. Joseph Smith did not get his idea "to write" the Book of Mormon from this evidence because it did not come out until after the Book of Mormon was published. [M.D.P.]

P.415 Prince, Walter Franklin. "A Footnote: 'Authorship of the Book of Mormon.' " American Journal of Psychology 30 (1919): 427-28. A rebuttal to an article by Theodore Shroeder. The author defends his conclusion that Joseph Smith wrote the Book of Mormon. [E.G.]

P.416 Prince, Walter Franklin. "Psychological Tests for the Authorship of the Book of Mormon." American Journal of Psychology 28 (1917): 373-89. Favors the theory that Joseph Smith was the sole author of the Book of Mormon. Claims that the book is based upon dreams experienced by the author's father and his mother's reminiscences. The highly imaginative young Joseph reveals himself in the book. He was affected by the anti-Masonic excitement 
of Western New York and the "secret combination" charges that came out of that era. Even the name "Mormon" was derived from the name Morgan, a prominent figure in the controversy. [J.W.M.]

P.417 Pritchett, Bruce. "Lehi's Theology of the Fall in Its Preexilic/Exilic Context." Provo, UT: FARMS, 1989. Explores preexilic and exilic literature that discuss the Fall of Adam to determine how Lehi received his theology on the subject of the Fall-was it solely from the brass plates or did he receive personal revelation to direct him? Concludes that the theology explained by Lehi was the same as that of the preexilic and exilic texts, and it offers the best explanation recorded. [J.W.M.]

P.418 Proctor, Martha. "The Book of Mormon: What It Is." SH 54 (6 November 1907): 1026. The Book of Mormon can defend itself. It is not a product of the Spaulding manuscript. [J.W.M.]

P.419 Proctor, Paul Dean. "American Book of Mormon Map." N.p., 1988. A color-coded, detailed map suggesting locations of cities, lands, and places recorded in the Book of Mormon text. [J.W.M.]

P.420 "A Professor's Comment on the Book of Mormon." MS 89 (27 October 1927): 682. Charles H. Hull, a nonMormon professor of American history at Cornell University, states that he believes that "the Book of Mormon to be one of the most famous and widely discussed books ever published in America." [D.W.P.]

P.421 "Projects Tell Gospel." CN 42 (29 January 1972): 10. Announcing two projects, supervised by the BYU Center for Specialized Language Study, one of which includes translating the Book of Mormon into three dialects of the Quechua language (spoken by Indians in South America). [M.D.P.]

P.422 "The Promised Land." CN 48 (7 January 1978): 16. The December 1977 issue of National Geographic told of a group of Irish monks who set out in a leather boat to find the "Promised Land of the saints" in about A.D. 600. We do not know how they knew about the Promised land. [M.R.]

P.423 "Prophecy and History." IE 28 (January-April 1925): 249-51, 362-63, 479-80, 582-83. A study guide. Several lessons address the Book of Mormon and prophecy. Deals with the Book of Mormon as fulfillment of ancient prophecy, prophecies in the Book of Mormon that have been fulfilled, are now being fulfilled, and others that have not yet been fulfilled. Also looks at prophecies dealing with the American Indian, the United States, and the Latter-day Saints. [L.D.]

P.424 "Prophecy and the Book of Mormon." Relief Society Magazine 5 (March 1918): 166-69. The prophetic teachings in 2 Nephi offer great hope and comfort as America is threatened by the crisis of World War I. Other prophecies in the Book of Mormon add to the testimony that Joseph Smith is a prophet of God. [J.W.M.]

P.425 "A Prophecy Come True." Friend 9 (December 1979): 39. A children's story: the prophecy of Samuel the Lamanite came true, for during the night it was like day and the people knew that Christ was born. [M.R.]

P.426 "Prophet Counsels Sisters to Live up to Divine Potential." CN 56 (5 October 1986): 3, 6. President Benson lists several things that the sisters of the Church should do, including the need to daily read and ponder the Book of Mormon. [M.D.P.]

P.427 "Prophets of God Bear Testimonies of the Sacred Record." IE 63 (November 1960): 794-95. The testimonies of the Book of Mormon borne by the Presidents of the Church-from the Prophet Joseph Smith through President David O. McKay-are recited. [R.C.D.] 
P.428 Pruden, Judy K., and Bruno J. Mittler. "Recent Developments in Regard to Ancient Transpacific Influence on the New." SEHA 115 (8 September 1969): 1-4. Many theories exist concerning New World origins. Transpacific currents in conjunction with archaeological excavations may solve the puzzle. Excavations in the area of Ecuador show that cultural traits were borrowed from the Old World. [J.W.M.]

P.429 Puening, Ronald L., Barbara A. Hainsworth, Karen Galley, Philip Jackson, Matt Paulson, Marilyn Stewart, Scott J. Klemm, Thomas L. Faulkner, Louis Wilkins, Peter Vokac, Richard G. Belliss, W. D. Sanders, and John W. Miller. "Queries and Comments: More on the Nephites and the Book of Mormon." Biblical Archaeology Review 14 (November-December 1988): 12, 14-18, 20. Letters responding to C. L. Sainsbury's letter (July/August issue) seeking inclusion of Nephite history on an international timeline. Contributors contend that no archaeological evidence exists for the Book of Mormon, point out the book's similarity to the Bible, and enclose the Smithsonian Institution's statement concerning the Book of Mormon. [E.G.]

P.430 Pugh, Kaye Lynne. "Things They're Saying." NE 1 (May 1971): 37. A future missionary decided the best way to learn German was to read the Book of Mormon in German. This experience helped strengthen his testimony of the book. [M.D.P.]

P.431 Putnam, Reed H. "Were the Golden Plates Made of Tumbaga?" IE 69 (September 1966): 788-89, 828-31. Also in Papers of the Fifteenth Annual Symposium of the Archaeology of the Scriptures, edited by Ross T. Christensen, 101-9. Provo, UT: Extension Publications, Division of Continuing Education, BYU, 1964. Considers the physical properties of the golden plates of Nephi, the engraving of metal plates, and the stone box that stored the plates. Suggests that the plates may have been made of tumbaga, an alloy of gold and copper. [B.W.J.]

P.432 Pycock, James. "Origin of the Book of Mormon." SH 65 (27 March 1918): 308. Refutes allegations published in the Buffalo Express that argue that the Book of Mormon was written by Solomon Spaulding or that the manuscript was adapted by Sidney Rigdon. The Book of Mormon shows no resemblance to the Spaulding manuscript. [J.W.M.] 
Q.

Q.001 "A Question About the Book of Mormon." DN 37 (9 May 1888): 262. Answers the questions, if the gospel "the power of God unto salvation" (Romans 1:16), why is the Book of Mormon necessary; is not the Bible sufficient? Points out that it is not the Bible but the gospel that is the power of God unto salvation. The Book of Mormon functions in the same way as the Bible but makes biblical doctrines clearer. [D.M.]

Q.002 "Questions and Answers." Juvenile Instructor 10 (9 January-11 December 1875): 5, 23, 34, 46, 58, 70, 8 r 99, 106, 116, 130, 137, 154, 166, 190, 214, 227, 239, 250, 262, 275, 286, 293. Series that discusses the "Reign the Judges." Based strictly on text, deals with details such as names, dates, and specific events. [A.C.W.]

Q.003 "Questions from the Field." MS 91 (11 April 1929): 237-38. Answers objections to the use of the word ste in the Book of Mormon. [R.H.B.]

Q.004 "Questions from the Field." MS 91 (25 April 1929): 271. Answers the question "Did Jesus appear to the people on the American continent before or after his ascension?" 3 Nephi 11:12 and 10:18 indicate he appearec after his final ascension in Palestine. [R.H.B.]

Q.005 Quinn, D. Michael. Early Mormonism and the Magic World View. Salt Lake City: Signature Books, 1987. Believes that the Book of Mormon came forth out of a religio-magical backdrop. The author discusses the event: of the coming forth of the Book of Mormon with commentary to help the reader look at the book in the appropriate setting, consistent with the "magical" beliefs of the 19th century. This work is reviewed in W.365, W 286, and in R.418. [J.W.M.]

Q.006 Quinn, D. Michael. "The First Months of Mormonism: A Contemporary View by Diedrich Willers." New Yo. History 54 (July 1973): 317-33. A response to an attack on the Church by Willers, a minister of the German Reformed Church. This article contains important insights into the role of the Urim and Thummim in the translation of the Book of Mormon. Ten locations are cited as places for translation besides the Whitmer home. [J.W.M.]

Q.007 Quinn, D. Michael. "The Mormon Church and the Spanish-American War: An End to Selective Pacifism." Dialogue 17 (Winter 1984): 11-30. The Book of Mormon's declarations concerning war dispense with the concepts of the war-like Jehovah of the Old Testament as well as the pacifistic Christ of the New Testament. Ear Latter-day Saints were ambivalent with respect to war until they were leaving the United States and the Mexical War developed. Although peaceful solutions were always sought, there was no opposition to the defense of liberty. A strong military stance was maintained in Utah for the sole purpose of defense. [J.W.M.]

Q.008 Quiring, John. "Mormon Christianity: A Critical Appreciation by a Christian Pluralist." Dialogue 21 (Autur 1988): 151-57. A critic gives his appraisal of Mormonism and the Book of Mormon. While he finds several examples of good moral teachings in the Book of Mormon, he finds the book's narration "flat, monotonous, imitative of the King James Version of the Bible, and lacking in vitality in contrast to the Bible itself and other scriptures of Penguin Classic stature." [M.R.]

Q.009 The Quotation Teacher. Independence, MO: Herald House, 1962?. This booklet contains fifty-two Book of Mormon quotes that may be memorized, one for each week of the year. [J.W.M.] 
R.

R.001 R. "The Interpretation of Scripture." MS 49 (31 January 1887): 72-75. Peter teaches that prophecy is not to be interpreted privately. In spite of this counsel many have done so causing discord and contention. The Book of Mormon says that many of the plain and precious truths have been taken out of the Bible. A comparison of scriptures will provide an accurate understanding of difficult passages. [J.W.M.]

R.002 R. "Lesser Lights of the Book of Mormon." Contributor 1 (May-September 1880): 177-79, 206-9, 230-33, 243-45, 269-71. A series that tells the stories of some of the lesser-known figures in the Book of Mormon: Jacob a Nephite apostate, Jarom, Zoram, Muloki, Samuel the Lamanite, Antipas, and Teancum. [A.T.]

R.003 R., C. E. "Visit to an Ancient Indian Village." Juvenile Instructor 14 (15 November 1879): 257. Report of an inspection of an archaeological site in Arizona, which may corroborate the Book of Mormon. [D.M.]

R.004 Rabe, Julie T. "I Will Read the Book of Mormon." Friend 18 (January 1988): 28. A poster for children with a reading schedule for the Book of Mormon. [M.D.P.]

R.005 Raeithel, Gert. "Nephiten and Lamaniten: Mormonen and Indianerals Vettern und Nachbarn." Merkur 38 (April 1984): 316-22. Explanation of LDS beliefs concerning Indian descent from the house of Israel as set forth in the Book of Mormon. Connects those beliefs to LDS missionary work with the Indians, the Word of Wisdom, polygamy, racial discrimination, and work with Indian reservations in Canada. [A.C.W.]

R.006 Raish, Martin. "All That Glitters: Uncovering Fool's Gold in Book of Mormon Archaeology." Sunstone 6 (January 1981): 10-15. Poor LDS scholarship has damaged Book of Mormon credibility. Raish points out several types of errors: reliance on archaeologists to lend credibility, faulty footnotes, the use of pictures not related to scriptures with which they are associated, and publishing unauthenticated artifacts that sometimes turn out to be fraudulent. [J.W.M.]

R.007 Raish, Martin. Review of Ancient American Indians: Their Origins, Civilizations and Old World Connections, by Paul R. Chessman and Millie F. Chessman. Review of Books on the Book of Mormon 4 (1992): 21-23. Book review.

R.008 Raish, Martin. Review of In Search of Cumorah, by David A. Palmer. Sunstone Review 2/2 (1982): 25. Book review.

R.009 Raish, Martin. "Tree of Life." In Encyclopedia of Mormonism, edited by Daniel H. Ludlow, 4:1486-88. 5 vols. New York: Macmillan, 1992. Describes how the tree of life is portrayed in the Book of Mormon, both in Lehi's vision (1 Nephi 8) and in Alma's allegory (Alma 32). Two mesoamerican representations of the tree of life are described: Stela 5 Izapa, Mexico, and the sarcophagus cover of King Pacal in the Mayan Temple of Inscriptions, Palenque. [B.D.]

R.010 Ralston, Russell. "Challenged to Examine." Restoration Witness 164 (August 1976): 7. An attempt to prove the Book of Mormon through external evidence led to a study of the book that opened the author's mind to concepts that had previously been blind spots: the peace of God, prayer, and man's relationship with God. [J.W.M.]

R.011 Rannie, Alma. "The Origin of the Book of Mormon." SH 96 (22 January 1949): 85-87, 91. Gives the background of Solomon Spaulding's manuscript and its similarities to the Book of Mormon. Concludes that the 
resemblances between the two works are superficial, and that those who supported the Spaulding theory were "motivated by revenge and a determination to overthrow the church." [A.C.W.]

R.012 Rannie, Edward. "Book of Mormon and Religion." SH 72 (8 April 1925): 408-9. The Book of Mormon is the most important teaching tool for youth. It portrays real characters and the results of obedience. [J.W.M.]

R.013 Rannie, Edward. "Is the Book of Mormon a Help to Solve Present-day Problems?" The Rod of Iron 1 (July/August/September 1924): 27. The Book of Mormon offers the solution to every great problem the world ever encountered with such clarity and simplicity that even children can understand the messages. [J.W.M.]

R.014 Rannie, Edward. "The Three Books." SH 74 (2 February 1927): 124-27. The Bible, the Book of Mormon, and the Doctrine and Covenants are the accepted standard scriptures of the Church following its reorganization. They determine Church government, doctrine, and practices of the Church. Together they solidify the saints into one faith. [J.W.M.]

R.015 Ransom, Ira T. Is Mormonism Based on the Book of Mormon? Sacramento, CA: United Missionary Fellowship, 1979. A polemical tract against Mormonism and the Book of Mormon, attempting to demonstrate that the Book of Mormon contradicts many Mormon teachings. [M.R.]

R.016 Rasmussen, Della Mae, and B. Keith Christensen, illustrator. The Illustrated Story of President Joseph Smith. Provo, UT: Eagle Systems, 1982. Gives an historical account of the coming forth of the Book of Mormon with color illustrations for children. [J.W.M.]

R.017 Rasmussen, Ellis T. "I Have a Question: What are the best evidences to support the authenticity of the Book of Mormon?” Ensign 17 (January 1987): 53-55. Also in A Sure Foundation: Answers to Difficult Gospel Questions. Salt Lake City: Deseret Book, 1988, 27-33. Three evidences for the Book of Mormon are available-external, internal, and spiritual. Offers "seven key concepts" for identifying various internal evidences that "carry within them a spirit of authenticity." [D.L.L.]

R.018 Rasmussen, Ellis T. "Sidney B. Sperry: Student of the Book of Mormon." Ensign 16 (July 1986): 24-27. This synopsis of Brother Sperry's life explains that he was the first Latter-day Saint to earn his doctorate in biblical languages. His life's work was the defense of the Book of Mormon. [J.W.M.]

R.019 Rasmussen, James L. "Blood Vengeance in the Old Testament and Book of Mormon." Provo, UT: FARMS, 198?. A study on capital punishment in the Old Testament and Book of Mormon. Concludes that "the concept of blood guilt is pervasive in each of the scriptures studied. Innocent blood shed cries from the ground for vengeance which will be taken ultimately by God if not by execution of the murderer." [D.M.]

R.020 Rea, Dorothy O. "BYU Library Gets Valuable Old Poster." CN 43 (21 July 1973): 4. BYU obtained an early advertisement for the Book of Mormon and is doing research on its origin. [M.D.P.]

R.021 "Read Book of Mormon in One Day." IE 31 (April 1928): 528. Clyde B. Crandall had several reasons for trying to read the Book of Mormon in one day: to understand the story in sequence, to prove that reading the Book of Mormon is not a tedious task, and to meet the challenge and accomplish it. [J.W.M.]

R.022 Read, Lenet H. "A Book about God's Love." Ensign 18 (January 1988): 40-44. Shows how the development, history, structure, and teachings of the Book of Mormon manifest the pure love of God. God's everlasting love is 
evident in the vision of Nephi, in the birth, ministry, and sacrifice of Jesus Christ (Christ's Atonement), in the redemptive experiences of Alma the younger, in the peaceful society following Christ's personal visit to the Nephites, and in the final teachings of Mormon and his son Moroni. [A.A.]

R.023 Read, Lenet H. "I Have a Question: Can you give me some keys to help me understand the parable of the tame and wild olive tree that Jacob tells?" Ensign 7 (April 1977): 30-32. The parable of the olive tree in Jacob 5 is best understood by reading 1 Nephi 15:7-20. Jacob explains the motives and emotions of the Lord and presents a clear historical and prophetic view of God's dealings with the house of Israel. [J.W.M.]

R.024 Read, Lenet H. "King Lamoni." Ensign 7 (August 1977): 60-63. This examination of King Lamoni's character presents new insights into the story of Ammon and Lamoni's conversion. [J.W.M.]

R.025 "Read the Book of Mormon." CN 31 (1 July 1961): 16. Exhortation to read "the most unusual book produced in our day," the Book of Mormon. Provides reasons to read the Book of Mormon. [A.C.W.]

R.026 "Read the Book of Mormon." Friend 18 (January 1988): 1. A collection of testimonies by prophets of God (from Moroni to Ezra Taft Benson) for children concerning the value of reading the Book of Mormon. [J.W.M.]

R.027 Read the Book of Mormon: It Can Change Your Life. Salt Lake City: Church of Jesus Christ of Latter-day Saints, 1975. A tract encouraging people to study the Book of Mormon. Gives a brief overview of the book's contents and supplies direct quotations on several different themes. [D.M.]

R.028 A Reader's Guide to the Book of Mormon. Provo, UT: BYU, 1967. A booklet that presents a book-by-book summary of the contents of the Book of Mormon from 1 Nephi-Moroni. Suggests that young people may be wise to devote their attention to the lives of Book of Mormon prophets and leave the words of Isaiah until they have more background to aid their understanding. [D.W.P.]

R.029 Reams, A. A. "Modern History and the Book of Mormon." SH 55 (26 February 1908): 203-5. Includes a report from the History of lowa stating that man and horses were in lowa, Nebraska, soon after the glaciers melted. These people built homes, made cloth, and built mounds. The author notes similarities between the History of lowa report and the account of the Jaredites. [A.T.]

R.030 Reay, Don. "The Book of Mormon." In Reay's The Gospel of Jesus Christ According to My Understanding, 62-69. New York: Exposition Press, 1969. Gives a brief account of the story of the Book of Mormon and states that the Book of Mormon is the "Stick of Joseph" referred to in Ezekiel 37. [J.W.M.]

R.031 "Recent Studies on the Book of Mormon." Ensign 19 (June, July 1989): 50-53, 62-65. Short quotes from scholars. Various topics include metal alloys in the Book of Mormon, principles found in both the Book of Mormon and the Bible, synagogues in the Book of Mormon, Mulek, Jewish festivals, King Benjamin's address, and many others. [J.W.M.]

R.032 Rector, Hartman, Jr. “The Gospel." Ensign 15 (November 1985): 74-76. Also in CR (October 1985): 95-98. The gospel of Christ ( 3 Nephi 27) centers upon Jesus Christ, his willingness to pay the price for all of the sins of humanity, to be lifted upon the cross giving his life for mankind, and to draw all men to him through repentance, baptism, and gift of the Holy Ghost. [J.W.M.] 
R.033 Rector, Hartman, Jr. "Overcoming the Natural Man." CR (6 April 1970): 139-41. King Benjamin's teachings about the natural man are illuminated by Ether 12:27 that informs the reader that the Lord gives weaknesses to individuals to teach humility. The responsibility each bears is to become teachable, then the Lord gives assistance to overcome the sins that result from the weakness. [J.W.M.]

R.034 Reed, David A., and John R. Farkas. Mormons Answered Verse by Verse. Grand Rapids, Mich.: Baker, 1992. This polemical book recounts the history of the Book of Mormon and examines selected verses from the book in an attempt to discredit it. [J.W.M.]

R.035 Reed, Karen. "Book of Mormon Musical Results in Five Baptisms." CN 59 (15 July 1989): 11. President Benson's challenge to put Book of Mormon characters to music, film and drama led Jack Jenkins to write a play in which Abinadi was the main character. Members and non-members who attended the performances were inspired. [J.W.M.]

R.036 Reed, William C. "A Model for Parenting from the Book of Mormon." In The Sixth Annual CES Religious Educators Symposium on the Book of Mormon, 55-58. Salt Lake City: Church of Jesus Christ of Latter-day Saints, 1982. Elements of the stories of Lehi, Benjamin, Alma, and the two thousand Ammonite soldiers are used to illustrate actions and characteristics of model parents. [A.T.]

R.037 Rees, Alfred D., James L. Barker, and Horace H. Cummings. "Book of Mormon: Sunday School Lessons." Instructor 67 (January-October 1932): 40, 104-5, 162-63, 225, 281-82, 342-43, 400-1, 460-61, 524-25, 58081. Sunday School lessons for youth. Gives an outline of the text covered each week. Integrates teachings of Book of Mormon prophets with examples from daily life. [J.W.M.]

R.038 Rees, Robert A. "Ammon." Ensign 7 (June 1977): 72-77. Repentance is the theme of the story of Ammon. He shows a mighty change as he was transformed from a rebellious prince into a heroic missionary. [J.W.M]

R.039 Rees, Robert A. "Melville's Alma and the Book of Mormon." Emerson Society Quarterly 2/43 (1966): 41-46. A comparison of the character of Alma in Melville's Mardi and the two Almas in the Book of Mormon. [D.M.]

R.040 Rees, Robert A. Review of the Book of Mormon Collection in the William Andrews Clark Library. Dialogue 4 (Spring 1969): 119-20. Reviews the collection of sixty-two separate editions of the Book of Mormon purchased from Charles N. Kessler and placed in the William Andrews Clark Library in Los Angeles. [J.W.M.]

R.041 Reeve, Rex C., Jr. "Book of Mormon." In Encyclopedia of Mormonism, edited by Daniel H. Ludlow, 1:156. 5 vols. New York: Macmillan, 1992. Gives a synopsis of the book of Mormon, written by the prophet Mormon, who describes the fall of the Nephites and includes his final plea to future generations. [B.D.]

R.042 Reeve, Rex C., Jr. "The Book of Mormon Plates." In The Book of Mormon: Second Nephi, the Doctrinal Structure, edited by Monte S. Nyman and Charles D. Tate Jr., 99-111. Salt Lake City: Bookcraft, 1988. The gold plates Joseph Smith received from Moroni consisted of Mormon's abridgment of the large plates of Nephi, an unabridged set of the small plates of Nephi, an abridgment of the Jaredite record made by Moroni, and a sealed portion that remained untranslated. This article contains commentary on the contents of these plates as well as the brass plates, also identified in the Book of Mormon. [J.W.M.]

R.043 Reeve, Rex C., Jr. "Brother of Jared." In Encyclopedia of Mormonism, edited by Daniel H. Ludlow, 1:235-36. 5 vols. New York: Macmillan, 1992. A description of the brother of Jared, Mahonri Moriancumer, who led the 
Jaredite people by revelation under his brother, Jared. [B.D.]

R.044 Reeve, Rex C., Jr. "Dealing With Opposition to the Church." In The Book of Mormon: Alma, The Testimony of the Word, edited by Monte S. Nyman and Charles D. Tate Jr., 15-26. Provo, UT: Brigham Young University Religious Studies Center, 1992. Alma labored 25 years in spite of internal and external opposition to the Church. Nehor taught priestcraft and after his death his followers continued his opposition. When the Church in our day experiences opposition, Church members should continue to teach the doctrines of the Church and realize that opposition has often resulted in spiritual growth for both the individual and the Church. [N.K.Y.]

R.045 Reeve, Rex C., Jr. "Fourth Nephi." In Encyclopedia of Mormonism, edited by Daniel H. Ludlow, 1:155-56. 5 vols. New York: Macmillan, 1992. 4 Nephi narrates four generations of peace, a time when there could not have been a happier people (4 Nephi 1:16). It also foreshadows the later destruction of the Nephites following their gradual rejection of the gospel. [B.D.]

R.046 Reeve, Rex C., Jr. "God's Ways or Man's: The Ultimate Choice." In Studies in Scripture: Alma 30 to Moroni, edited by Kent P. Jackson, 107-15. Salt Lake City: Deseret Book, 1988. The Book of Mormon, particularly Helaman 7-12, clearly defines the choices of agency and the corresponding consequences, whether good or evil. Nephi, who ministered shortly before the Lord's birth, was sorrowful because of the works of darkness and secret combinations among his people. Nephi, in contrast, was stable in the midst of inconsistency. He received great blessings. [J.W.M.]

R.047 Reeve, Rex C., Jr. "The Path to Eternal Life (2 Nephi 31-33)." In A Symposium on the Book of Mormon, 109-12. Salt Lake City: Church of Jesus Christ of Latter-day Saints, CES, August 1986. Uses the Book of Mormon, especially Nephi's writings to answer questions such as: "Why is the doctrine of Christ of great worth?," "What is the gate leading to the straight and narrow path?," "How essential is baptism?," and "How can you endure to the end?" Concludes that Nephi's example and teachings show what is required to gain eternal life. [A.T.]

R.048 Reeve, Rex C., Jr. "We Labor Diligently to Persuade Our Children to Believe in Christ: 2 Nephi 25:21 to 26:11." In The Book of Mormon: Second Nephi, The Doctrinal Structure, edited by Monte S. Nyman and Charles D. Tate Jr., 259-67. Salt Lake City: Bookcraft, 1989. Believers in Christ in Lehi's group had a true knowledge of Jesus Christ. This sure knowledge rested on the testimonies of at least four prophets-Lehi, Nephi, Jacob, and Isaiah, who saw Christ and possessed the sure witness of the Holy Ghost. Their faith and understanding of him was founded in the observance of the law of Moses, which points to Christ. They endeavored to bring their children to Christ and realized that some of their seed would receive the Savior and others would reject him. [J.W.M.]

R.049 References to the Book of Mormon. Kirtland: Church of Jesus Christ of Latter-day Saints, 1835. The earliest known reference guide to the Book of Mormon. Items listed are in order of pagination. The references refer to the chapters of the Book of Mormon and describe the contents of the chapter. [D.M.]

R.050 Reiser, A. Hamer. "Lets Read the Book of Mormon." Instructor 98 (September 1963): 339. Suggests a method of study for the Book of Mormon: read to learn only the story; reread marking every reference to Jesus Christ; read the third time looking for passages that expound doctrine, principles, ordinances, and ideas. [J.W.M.]

R.051 "Relief Society Lessons" (Series). Relief Society Magazine 5-6 (August 1918-May 1919): 471-74, 534-38, 592-96, 647-49, 709-13, 52-54, 114-16, 179-81, 240-43, 303-5. Series of lessons on the Book of Mormon. Subjects include: The Book of Mormon peoples had access to the teachings of the Old Testament. Methods of warfare in the Book of Mormon were elementary in the beginning, but became more sophisticated with time. 
Mosiah sought to teach his people that great iniquity and destruction characterizes the rule of monarchs. The fall of monarchies throughout the world fulfill the Book of Mormon prophecy in 2 Nephi 10:10-14. The prelude to the coming of Christ to the American continent was a time of great calamity and destruction. The Nephites lived the sacred order of heaven as recorded in 4 Nephi 1. The rearing of the temple makes living God's higher social order possible. Women and children have been ignored, but the Bible and the Book of Mormon show the importance of little children. The Book of Mormon tells of inspired individuals such as Columbus and the pilgrims. [J.W.M.]

R.052 "Relief Society Lessons" (Series). Relief Society Magazine 7-8 (September 1919; February-May, September -November 1920): 548-50, 610-14, 671-73, 721-23, 54-56, 113-15, 170-72, 239-42, 297-302, 547-51, 601-2, 603-7, 665-71. This series presents the Old Testament prophecies that are related to the Book of Mormon: Now is the day that the restoration of the Jews is to be fulfilled (1 Nephi 15)-Great Britain is planning to mandate Israel for the Jewish people. 1 Nephi 15 speaks of the redemption of Lehi's seed-in the Lord's due time, his words will reach their ears. The Book of Mormon fulfills the prophecies in the Old Testament and the blessing of Joseph who was sold into Egypt. Using the text of Jeremiah 49:30-34, the Lord warned the people in Jerusalem to flee to a land of wealth and no care-this land was America. The prophecy in Isaiah 29 seems to be fulfilled by 3 Nephi 8 and Helaman 14 and the coming forth of the Book of Mormon. The prophecies in Deuteronomy and Ezekiel are fulfilled by the Book of Mormon. [J.W.M.]

R.053 "Relief Society Theology Lessons" (Series). Relief Society Magazine 16-17 (August 1929 -April 1930): 447-50, 502-6, 557-63, 612-16, 667-70, 31-35, 88-93, 132-36, 202-6. Series of lessons on the Book of Mormon. Subjects include: A testimony of the Book of Mormon is gained by studying it and following the promise of Moroni. The Bible is a collection of sacred literature; the Book of Mormon is in reality an American Bible in that context. The scriptures that contain Jacob's teachings comprise thirty-five pages, of these twenty-one quote Isaiah. From 2 Nephi to the end of Jacob there is little narrative but rather an explanation of doctrine-the doctrine of Christ, and the need for the baptism of Christ. The account of King Benjamin's reign is a guide for rulers. Evil king Noah stands in contrast to righteous King Benjamin who knew Christ. Mosiah and the elder Alma were men of exceptional intellect and moral character with a knowledge of God. The doctrines Alma taught can be divided into three categories: the prophecy of Christ, the doctrine of faith, repentance, good works, and the resurrection. Ammon is an example of a true missionary in the service of God. [J.W.M.]

R.054 "Relief Society Theology Lessons" (Series). Relief Society Magazine 17-18 (August 1930-April 1931): 45254, 509-12, 563-68, 624-28, 687-90, 51-54, 113-16, 176-79, 230-33. Series of lessons on the Book of Mormon. Subjects include: The Book of Mormon is filled with timeless teachings on human nature. Amalickiah is the antithesis of liberty-loving Moroni and Teancum who follow the Lord's law that teaches that war should be only for self-defense with a love for liberty and righteousness. The evil spirit of war that brutalizes mankind was not present among Helaman's youthful warriors. Nephi, son of Helaman, was a man endowed with power over the elements and sealing powers in heaven and earth. The doctrine of agency is most clearly outlined in Helaman 133 Nephi 7. 3 Nephi is a fifth gospel that is longer and more insightfully outlined than the other gospels-the doctrine of Christ is clearly stated, the principle of repentance is stressed. The books of Mormon and Moroni report the fall of a nation due to the immorality and corruption of the individuals who resided therein. The structure of the Book of Mormon is evidence that Joseph Smith translated a sacred book rather than writing a book of fiction. [J.W.M.]

R.055 "Relief Society Theology Lessons" (Series). Relief Society Magazine 18-19 (August 1931-April 1932): 469 73, 529-32, 587-91, 653-57, 710-14, 50-54, 114-17, 182-86, 240-44. Series of lessons on Book of Mormon theology. Subjects include: The divine origin of the Book of Mormon is attested by Joseph Smith's testimony 
concerning Moroni's visit. The Book of Mormon's deficiency in grammar and style is a clue to the method of translation. The views of prominent men concerning the nature of God in Joseph Smith's day are presented in contrast to the Book of Mormon's description of God's character and Jesus Christ as the Savior. The nature of man and his/her relationship with God was a new concept in Joseph Smith's day when men were concerned mainly with the nature of God. A clear view of individual agency to choose and his accountability for those choices makes the role of the Holy Ghost very important. The teachings of the Book of Mormon consider human life as sacred and protect it. The Book of Mormon teaches that all substance belongs to God and those who have should help those who have not. The revelations Joseph Smith received in connection with the translation of the Book of Mormon gave a clear picture of life after death. [J.W.M.]

R.056 "Rely on Scriptures When Teaching Youth." CN 56 (24 August 1986): 6. It is important for teachers to rely on the scriptures. Includes three ways to better understand the Book of Mormon. [M.D.P.]

R.057 "Rely on the Book of Mormon, Says President Benson." Ensign 18 (September 1988): 74. A news report of President Benson's message on the manner in which the Book of Mormon brings men unto Jesus Christ. [L.D.]

R.058 "A Remarkable Prediction." Deseret Weekly 48 (24 March 1894): 419-20. The joining of the sticks of Judah and Joseph (the Bible and the Book of Mormon) will precede the gathering of Israel. [D.M.]

R.059 "A Remarkable Vision." MS 70 (May 1908): 305-11. In part of his vision recorded in the Book of Mormon, Nephi saw Columbus who would discover the New World (1 Nephi 13:12-13). [B.D.]

R.060 Remy, Jules. A Journey to the Great Salt Lake City. 2 vols. London: Jeffs, 1861. A historical work against Mormonism. Volume 1 discusses Joseph Smith's character and the events surrounding the appearance of the Book of Mormon. The author supports the Spaulding theory. [M.R.]

R.061 Rencher, Alvin C., comp. "Book of Mormon Authorship Chronology." Provo, UT: FARMS, 1986. Lists scriptural references and authors of the Book of Mormon in chronological order from 1 Nephi to Moroni, thus identifying authorship. [J.W.M.]

R.062 Renfroe, James E. "Book of Mormon: Is It Scripture?" Restoration Witness 7 (April 1969): 2-3, 14. Sets forth criteria to qualify writings to be called scripture and then asks if the Book of Mormon is scripture. Scripture must center on God, reveal Christ, have a moral and ethical approach to its teachings, and has to agree with previously accepted scripture. Issues a challenge for the reader to find out for oneself whether or not the Book of Mormon is scripture. [J.W.M.]

R.063 Reorganized Church of Jesus Christ of Latter Day Saints. The Book of Mormon. Independence, MO: Herald House, 1977. A pamphlet that summarizes the origin and story of the Book of Mormon. States that the Book of Mormon is evidence that the Lord yet reveals his will to humanity in modern times. [J.W.M.]

R.064 Reorganized Church of Jesus Christ of Latter Day Saints. Book of Mormon. Independence, MO: Herald House, 1978. The Book of Mormon stands with the Bible and the Doctrine and Covenants to testify that God works among all people in all places. This pamphlet tells the story and origin of the Book of Mormon. It points out its uses and issues an invitation to heed its inspired message. [J.W.M.]

R.065 Reorganized Church of Jesus Christ of Latter Day Saints. "Book of Mormon Committee Report." SH 31 (23 August 1884): 545-48. A committee was appointed to compare the first edition of the Book of Mormon with the 
1884 edition used by the RLDS church. Though the changes are many, the doctrine is not affected. [J.W.M.]

R.066 Reorganized Church of Jesus Christ of Latter Day Saints. Book of Mormon Institute Outlines: January 7-14, 1951. Independence, MO: Herald House, 1958. A proposed outline for institute teaching of the Book of Mormon presented by the RLDS church. Included are notes on the doctrinal, historical, geographical, archaeological, linguistic, evangelical, and biblical aspects of the book. [A.C.W.]

R.067 Reorganized Church of Jesus Christ of Latter Day Saints (Publicity Department). "Book of Mormon Story and Essay Contest." SH 74 (2 November 1927): 1275. Announcement of a writing contest. Church members are invited to write poetry, fiction, or scholarly works on Book of Mormon topics. [J.W.M.]

R.068 Reorganized Church of Jesus Christ of Latter Day Saints. The History of the Reorganized Church of Jesus Christ of Latter Day Saints. Independence, MO: Herald Publishing House, 1951. Retells the events of the coming forth of the Book of Mormon as told by Joseph Smith and his associates. [J.W.M.]

R.069 Reorganized Church of Jesus Christ of Latter Day Saints. An Invitation to Read the Book of Mormon. N.p: n.p., n.d. An overview of the Book of Mormon. Suggests three ways of reading the book: read from start to finish, follow the historical sequence, or search specific doctrines. [J.W.M.]

R.070 Reorganized Church of Jesus Christ of Latter Day Saints. The "Manuscript Found" or "Manuscript Story" of the Late Rev. Solomon Spaulding, from a Verbatim Copy of the Original Now in the Care of Pres. James H. Fairchild, of Oberlin College, Ohio. Including Correspondence Touching the Manuscript, Its Preservation and Transmission until It Came into the Hands of the Publisher. Lamoni, lowa: RLDS Church, 1885. Explains the manner in which the Spaulding Manuscript was preserved and placed in the possession of the RLDS church. Includes letters from James $\mathrm{H}$. Fairchild stating that the Spaulding theory for the Book of Mormon need be relinquished and from L. L. Rice explaining how he had obtained the manuscript. Includes a reprint of the manuscript. [J.W.M.]

R.071 Reorganized Church of Jesus Christ of Latter Day Saints. The Message of the Book of Mormon is True About: ... Rozelle, New S Wales: Standard Publishing House, n.d. A series of one-page pamphlets that presents Book of Mormon passages concerning such topics as: "Reality of God," "Deity of Jesus," "Salvation Through Christ," "Agency of Man," "Immortality of Man," "Baptism," "Miracles and the Gifts of the Spirit," and the "Kingdom of God." Each pamphlet contains three or four passages of scripture from the Book of Mormon that exemplify the doctrine expressed in the title. [J.W.M.]

R.072 Reorganized Church of Jesus Christ of Latter Day Saints. The New Testament of Ancient America. Independence, MO: Herald Publishing House, 1955. Contains an adaptation of 3 Nephi 1-14, followed by an overview of the Book of Mormon and its coming forth. The purpose of the book is to be a witness of God's dealings with man and the messiahship of Christ. Old Testament scriptures are fulfilled by the book and archaeology testifies of its truthfulness. It does not supersede the Bible, but sustains it. [J.W.M.]

R.073 Reorganized Church of Jesus Christ of Latter Day Saints. Origin of the Book of Mormon. Plano, IL: Reorganized Church of Jesus Christ of Latter Day Saints, 1876. Rebuttal to an article published in Argus on the "origin of the Mormon Bible" that proposes that the Book of Mormon was a plagiarism of the Spaulding manuscript. This article compares the history of the Spaulding manuscript with Joseph Smith's history and points out the improbability that the manuscript could have been used by either Joseph Smith or Sidney Rigdon to produce the Book of Mormon manuscript. [J.W.M.] 
R.074 Reorganized Church of Jesus Christ of Latter Day Saints. Out of the Dust: Selections from the Book of Mormon. Independence, MO: Herald House, 1957. Selections of scriptures from the Book of Mormon as they relate to varying principles and subjects contained in the gospel of Jesus Christ. Topics covered include belief, steadfastness, humility, the Spirit, hope, and sacrifice. [D.S.T.]

R.075 Reorganized Church of Jesus Christ of Latter Day Saints. Outline Studies of the Book of Mormon Institute. January 7-14, 1951, Stone Church. Independence, MO: Herald House, 1951. Contains specific outlines of various studies presented at a conference during the dates mentioned above. The subjects discussed included the Book of Mormon story, teachings particular to the Book of Mormon, and evidences within the Book of Mormon that support its authenticity. [D.S.T.]

R.076 Reorganized Church of Jesus Christ of Latter Day Saints. Overview of the Book of Mormon. Independence, MO: Zarahemla Research Foundation, 1991. An overview of the Book of Mormon that outlines and deals with the peoples, lands, and books contained in the Book of Mormon. [D.S.T.]

R.077 Reorganized Church of Jesus Christ of Latter Day Saints. Pronouncing Vocabulary of the Book of Mormon. Lamoni, IA: Herald House, 1902. Guide for standardized pronunciation of Book of Mormon names. Includes people and places and a scripture reference for each. [A.C.W.]

R.078 Reorganized Church of Jesus Christ of Latter Day Saints. Question Time: Answers to 457 Often Asked Questions. Independence, MO: Herald House, 1955. This book of questions and answers deals with the subject of the Book of Mormon on pages 119 to 142. Discusses the origin of the book, different editions, changes in the text, the original manuscript, and others. [J.W.M.]

R.079 Reorganized Church of Jesus Christ of Latter Day Saints. Revelation and Scripture. Independence, MO: Herald House, 1979. Revelation is the transmitting of God's love and purposes for individuals or mankind. There are a multitude of ways in which revelation is received-through study and meditation or on an intuitive or emotional level. Thus, the honest may feel disagreement concerning interpretation of

R.080 Reorganized Church of Jesus Christ of Latter Day Saints. The Spiritual Wife System Proven False and the True Order of Church Discipline. Bloomington, Illinois: Wife Fooler Power Press, 1856. Mormons who have been led astray from the truth by Brigham Young and his party should take heed to the Book of Mormon, which condemns polygamy. [J.W.M.]

R.081 Reorganized Church of Jesus Christ of Latter Day Saints. "Why do you need the Book of Mormon? Isn't the Bible enough?" In Reorganized Latter Day Saint Distinctives, 12-13. Independence, MO: Herald Publishing House, n.d. The Bible holds first place in the canon of law and doctrine but is supplemented by the second witness for Christ-the Book of Mormon. It is the testimony of those who wrote it and those who brought it forth. The RLDS church accepts the testimony of Joseph Smith and others concerning the book and its coming forth. [J.W.M.]

R.082 Reorganized Church of Jesus Christ of Latter Day Saints. Why I Believe the Book of Mormon. Lamoni, IA: Herald House, 1909. A missionary tract centered upon the Book of Mormon that comprises a dialogue of questions and answers, an overview of its contents, an explanation that it teaches of Jesus Christ, and biblical scriptures about the book. [J.W.M.]

R.083 Report of the Committee on American Archaeology. Lamoni, IA: Herald Publishing House, 1902. Contains maps and an outline of Book of Mormon history as prepared by the RLDS Committee on American Archaeology. 
Outlines the Nephite history, Jaredite history, describes conditions discovered by early explorers and priests after Columbus, and gives archaeological evidence of extinct animals and civilizations that were mentioned in the Book of Mormon,. [J.W.M.]

R.084 Report of the Committee on American Archaeology. Lamoni, IA: Herald House, 1910. A work on Book of Mormon archaeology and geography. Outlines the history of the Nephites and Jaredites with the intention of creating a map of Book of Mormon events. Includes professional opinions regarding the origin of the inhabitants of ancient America. Several maps are also included. [B.D.]

R.085 "Reporter Hears David Whitmer Testify of Seeing Gold Plates." CN 32 (23 June 1962): 20. David Whitmer saw the gold plates and withstood persecution for his beliefs. Whitmer later testified to a reporter that he saw the plates and heard the angel that brought them. [M.D.P.]

R.086 "Reprint Shows Patent of First Book of Mormon Edition." CN (28 November 1931): 1. Contains a photograph and transcription of the patent for the first edition of the Book of Mormon filed by Joseph Smith Jr., 11 June 1829. [A.T.]

R.087 Revealing Statements by the Three Witnesses to the Book of Mormon. Salt Lake City: Modern Microfilm, n.d. This polemic contains photomechanical reprints of rare documents of selected materials written by Oliver Cowdery, Martin Harris, and David Whitmer, the Three Witnesses of the Book of Mormon. Suggests that there is a conspiracy by the Church to cover up the poor character of Joseph Smith. [J.W.M.]

R.088 "The Revolt of Young Mormonism." The Literary Digest 51 (10 July 1915): 66-67. Young Mormons are disillusioned because F. S. Spaulding has proven that Joseph Smith was not an inspired translator. University of Utah professors have been expelled in order to quell growing progressive thinking among students. There are fears that the Book of Mormon will be proven to be false through modern archaeological research done at the university. [J.W.M.]

R.089 Reynolds, Alice Louise. "The Book of Mormon Tested." Relief Society Magazine 10 (September 1923): 42729. Faith-promoting stories of people who received a testimony of Jesus Christ after reading the Book of Mormon. [J.W.M.]

R.090 Reynolds, Arch S. How Did Joseph Smith Translate?: A Study of the Method of his Translation of the Various Books of Scriptures. Springville, UT: Art City Publishing, 1952. The prophet Joseph Smith translated the Book of Mormon by means of the seer stone, the Urim and Thummim. Excerpts from the journals of Joseph Smith, Oliver Cowdery, David Whitmer, Emma Smith, and Martin Harris declare his methods of translation. The characters appeared sentence by sentence and the translation below it. George Reynolds and B. H. Roberts suggest that Moroni may have assisted him. [J.W.M.]

R.091 Reynolds, Arch S. The Urim and Thummim and Other Media Used by the Prophet Joseph Smith to Translate The Scriptures. Springville, UT: Art City, 1950. Uses the Bible, Book of Mormon, and historical accounts from the early writers of the Church to show that the Urim and Thummim and other "media" have been used since ancient times to receive communication from God. Joseph Smith also employed such media to translate the scriptures. [J.W.M.]

R.092 Reynolds, George. "Aaron, Son of Mosiah." Juvenile Instructor 26 (1 November 1891): 650-53. Aaron chose missionary service over the opportunity to serve as king and suffered hardship and inhumane treatment to preach 
the gospel to the Lamanites. Though little is known about him, the Book of Mormon sets forth the greatness of his character. [J.W.M.]

R.093 Reynolds, George. "Agriculture among the Nephites." Juvenile Instructor 15 (15 March 1880): 71. Deals with aspects of agriculture in the Book of Mormon. [D.M.]

R.094 Reynolds, George. "Akish, the Jaredite." Juvenile Instructor 26 (15 October 1891): 631-33. An article for youth that draws attention to the fact that the downfall of the Jaredites was due to their desire to have a king rule over them. King Akish's deeds of cruelty, treachery, and iniquity created a kingdom so filled with corruption and secret societies that civil war broke out and ended only after the destruction of the nation. [J.W.M.]

R.095 Reynolds, George. "The Alma Family." MS 42 (19 January-3 May 1880): 33-37, 49-52, 65-68, 81-84, 97101, 129-31, 145-47, 160-64, 177-79, 193-95, 225-26, 241-43, 257-58, 278-79. Presents a life sketch of the Alma family, many of whom became prophets. The life of Alma the Younger is compared to the Apostle Paul-both were called upon to repent and became great missionaries for the Lord. The prophecies of Alma are among the most numerous, important, and interesting in the Book of Mormon, and his inspired advice to his sons contains many doctrinal matters. Helaman the son of Helaman, grandson of Alma, carried on the work of righteousness in spite of the Gadianton robbers. His son Nephi was a great prophet who paved the way for the visit of Christ in America. Nephi's brother Lehi and Lehi's son Nephi were also great leaders. [J.W.M.]

R.096 Reynolds, George. "Amulek." Juvenile Instructor 10 (6 February 1875): 35-36. Biographical sketch of Amulek who was a man "of liberal education, of great faith, of unswerving integrity, and untiring zeal for the cause of truth." Also discusses Alma, Zeezrom, and the divine justice displayed in the destruction of Ammonihah. [A.C.W.]

R.097 Reynolds, George. Are We of Israel? Independence, MO: Zions, August 1931. The Book of Mormon clearly shows that the promises made to Abraham, Jacob, and Joseph were fulfilled at least partially through Lehi's family, who were of the house of Manasseh. Brigham Young indicates that Latter-day Saints are of the house of Ephraim, and are being gathered by the Book of Mormon. [J.W.M.]

R.098 Reynolds, George. "The Art of War among the Nephites." Juvenile Instructor 15 (15 April 1880): 77, 94. Describes different aspects of warfare as found in the Book of Mormon, with emphasis on the battle techniques of Moroni. Notes that detailed accounts of warfare do not appear in the Book of Mormon until the period of the judges. [D.M.]

R.099 Reynolds, George. "The Bible and the Book of Mormon-A Parallel." Young Woman's Journal 9 (October 1898): 490-92. Shows parallels and commonalties between the Book of Mormon and the Bible. For example, both books were written by different men over a span of several centuries and both contain hymns or psalms. [D.M.]

R.100 Reynolds, George. "The Book of Mormon and the Three Witnesses." Juvenile Instructor 17 (15 September 1882): 281. Examines the authenticity of the Book of Mormon in light of the testimonies of the Eight Witnesses and the Three Witnesses, noting that although some left the Church, none ever denied that they had seen the gold plates. [A.C.W.]

R.101 Reynolds, George. "The Book of Mormon and the Three Witnesses." MS 44 (9 October 1882): 645-47. Testimonies of Three Witnesses are tangible evidence of the Book of Mormon's veracity. If Joseph Smith were an impostor, he would have showed the plates more widely for credence. Having but a few witnesses is further proof of its truthfulness. [A.C.W.] 
R.102 Reynolds, George. Chronological Chart of Nephite and Lamanite History. Salt Lake City: Deseret Book, 1956. A full color chart with a historical time line dealing with the Nephites and Lamanites. [J.W.M.]

R.103 Reynolds, George. Complete Concordance of the Book of Mormon. Salt Lake City: Deseret Book, 1900. A concordance or alphabetical listing of all the words of the Book of Mormon (except twenty of the most common words, such as a, the, and) accompanied with scriptural references and a brief excerpt of the scriptural passage showing the context of each word of the concordance. [L.D.]

R.104 Reynolds, George. Dictionary of the Book of Mormon; Comprising its Biographical Geographical, and Other Proper Names; Together with Appendices by Janne M. Sjodahl. Salt Lake City: Juvenile Instructor Office, 1883, $[R] 1954$. This dictionary contains all of the places and people of the Book of Mormon. Each entry comprises a thorough treatment of the subject in clear and understandable vocabulary; scriptural references are included. [J.W.M.]

R.105 Reynolds, George. "Domestic Life among the Nephites." Juvenile Instructor 14 (15 December 1879): 285-86. A description of certain aspects of Nephite living. Includes comments on textiles, ornamentation, architecture, gardens, interior decorations, foods, and transportation. [D.M.]

R.106 Reynolds, George. "Evidences of the Book of Mormon: Some External Proofs of its Divinity." Contributor 17 (1895-1896): 164-68, 231-38, 271-78, 361-68, 417-24. Also in MS 59 (10, 17, 24, June, 1, 8 July 1897): 353-58, 369-76, 385-93, 401-9, 417-25. A five-part series that includes a brief overview of the Book of Mormon, an account of Spanish conquerors who destroyed evidence of Hebrew influence reasoning that "Satan had counterfeited in this people the history, manners, customs, traditions, and expectations of the Hebrews," a description of artifacts containing Hebrew characters, and evidence that the religious traditions of the Indians corroborate Book of Mormon statements. [A.T.]

R.107 Reynolds, George. "He Shall Perish." IE 2 (September 1988): 801-6. 2 Nephi 10 prophesies that a king will never be raised up unto the gentiles upon the land. Reynolds tells of the tragic fates of Louis Napoleon and Maximilian who tried to establish an empire in Mexico (1861) after the Book of Mormon had come forth and warns all people against attempting such a thing. [B.D.]

R.108 Reynolds, George. "Historians of the Nephites." Contributor 1 (March 1880): 137-38. There were four families who were charged with the care of the plates that contained the records of the Nephites. Jacob's family, King Benjamin's family, Alma and his family, and Mormon and his son Moroni. The author provides a dated list of the historians. [J.W.M.]

R.109 Reynolds, George. "History of the Book of Mormon." Contributor 5 (October-December 1833, JanuarySeptember 1884): 1-5, 41-47, 81-85, 121-25, 161-68, 201-6, 241-46, 281-86, 321-27, 361-67, 401-8, 441-47. Twelve-part series. Discussions include: the discovery, translation, and contents of the gold plates; Oliver Cowdery's description of Hill Cumorah; the Three Witnesses; loss of the 116 pages of the Book of Mormon and the substitution of the small plates of Nephi; the 1830 edition; the history of the Book of Mormon, including the abridgment work of Mormon; a synopsis of Nephite history, which is divided into 3 epochs; the history of the Jaredites. [L.D.]

R.110 Reynolds, George. "Internal Evidences of the Book of Mormon." Juvenile Instructor 17 (15 August 1882): 251-52. Cites historical consistency, absence of anachronisms, purity of doctrines, harmony with Bible and Indian 
traditions, prophecies of the Book of Mormon that have been fulfilled, and scientific truths that accord with the Book of Mormon. Refutes criticisms and polemical arguments. [A.C.W.]

R.111 Reynolds, George. "Internal Evidences of the Book of Mormon: Showing the Absurdity of the 'Spaulding Story.'" Juvenile Instructor 17 (1 August 1882): 235-38. Also in MS 44 (August 1882): 539-41, 548-51. Refutes the Spaulding manuscript as a basis for the creation of the Book of Mormon, pointing out wide differences between the two, including background, dates, characters, and content. Argues that if Joseph Smith were "too illiterate" to write the Book of Mormon, he was equally as incapable of changing the Spaulding manuscript into the Book of Mormon. [A.C.W.]

R.112 Reynolds, George. "The Lamanites (A Book of Mormon Sketch)." MS 42 (June-July 1880): 385-88, 401-4, 417-20, 433-36, 449-52, 465-67. Sketches out the character of the Lamanites. Also writes concerning Sariah, Lehi's wife. [B.D.]

R.113 Reynolds, George. "The Land of the Nephites." Juvenile Instructor 15-16 (15 November; 1, 15 December 1880; 1, 15 January; 1 February 1881): 261, 274-75, 286, 7-8, 22-23, 26-27. A series of essays on Book of Mormon geography. To the earlier Nephites "the whole of North America was known as the land of Mulek, and South America as the land of Lehi." From the period of Mosiah until Christ South America was "divided into two grand divisions": Zarahemla and the land of Nephi. [D.M.]

R.114 Reynolds, George. "Language of the Nephites." Juvenile Instructor 15 (15 August 1880): 191-92. Compares two views concerning the language of the Nephites: (1) people wrote and spoke Egyptian; or (2) they wrote Hebrew words in Egyptian characters. Sees Hebrew roots in the following Book of Mormon words: Ziff, Rameumpton, Sheum, Gazelem, and Rabbanah. [D.M.]

R.115 Reynolds, George. "The Language of the Record." Contributor 17 (February 1896): 231-38. A listing of numerous scrolls, inscriptions, and tablets purportedly found on the American continent with Hebrew or Egyptian characters upon them, and a comparison between American Indian languages and Hebrew with similarities noted. All these are proposed as evidence of the Hebrew ancestry of American Indians and the truthfulness of the Book of Mormon record. [S.H.]

R.116 Reynolds, George. "The Laws of the Nephites." Juvenile Instructor 15 (1, 15 January, 1, 15 February, 1 March 1880): 5, 22-23, 27-28, 46-47, 59. Discusses the Nephite political system under the monarchy and judges. Also considers legal matters under the judges, such as procedures for being heard as the "voice of the people," various sanctions for crime, and treatment of prisoners of war. [D.M.]

R.117 Reynolds, George. "Lesser Lights of the Book of Mormon." Contributor 1 (April 1880): 149-51. Also in MS 81 (19 June 1919): 388-90. Enos rose to prominent leadership through his humility, faith, and concern for others. This is evidenced by his prayer while hunting in the forest. [J.W.M.]

R.118 Reynolds, George. "Lesser Lights of the Book of Mormon: Antipus and Muloki." MS 81 (31 July 1919): 48184. A description of the life and activities of two lesser-known characters of the Book of Mormon, Antipus and Muloki. Antipus was a Nephite military leader until about 62 B.C. and Muloki was a fellow missionary of the four sons of Mosiah. [B.D.]

R.119 Reynolds, George. "Lesser Lights of the Book of Mormon: Jarom and Zoram." MS 81 (26 June 1919): 41114. Reynolds describes the Nephite people of Jarom's time. Zoram was the commander of the Nephite armies 
around 81 B.C. He led the Nephites to free Nephite prisoners. [B.D.]

R.120 Reynolds, George. "Lesser Lights of the Book of Mormon: Samuel, the Lamanite." MS 81 (24 July 1919): 467-70. A synopsis of Samuel the Lamanite including his prophecies and the condition of unrighteousness among the Nephites. [B.D.]

R.121 Reynolds, George. "Lesser Lights of the Book of Mormon: Teancum." MS 81 (14 August 1919): 522-26. A description of the military leadership and exploits of Teancum. Teancum killed Morianton, Amalickiah, and Ammoron with his own hands. [B.D.]

R.122 Reynolds, George. "Lessons from the Life of Nephi." Juvenile Instructor 26 (15 April-1 October 1891): 23335, 282-84, 297-99, 348-51, 373-76, 406-9, 437-40, 475-77, 503-4, 536-38, 574-77, 586-87. A narrative of Nephi's life and lessons that may be learned from the life of Nephi. At times it is better to suffer wrongs than to demand one's rights, and the purposes of God will not be thwarted. [J.W.M.]

R.123 Reynolds, George. "The Moneys of the Nephites." Juvenile Instructor 15 (1 November 1880): 249-50. Lays out the monetary measurement of the Nephites as codified by Mosiah. The coins are named after people or places. Barley seems to have been the standard of measurement, just as was the case from the races from which the English people sprang. [D.M.]

R.124 Reynolds, George. The Myth of the "Manuscript Found" or the Absurdities of the "Spaulding Story." Salt Lake City: Juvenile Instructor Office, 1883. Sets forth the absurdities that are connected with the Spaulding manuscript. "The upholders of [the myth of the manuscript found] are not only at variance with each other, but that all their assertions are inconsistent with the well-known facts associated with its discovery." [L.D.]

R.125 Reynolds, George. "Nephite Proper Names." Juvenile Instructor 15 (15 September 1880): 207-8. Lists Book of Mormon proper names that may or may not be found in the Bible, including Sariah, Nephi, Melek (or Mulek), Gershon, and Isabel. Looks for Hebrew or Egyptian roots. [D.M.]

R.126 Reynolds, George. "The Nephites under the Judges." Contributor 2 (February-May): 139-42, 171-74, 2058, 235-38. Four-part series. For 120 years following the death of King Mosiah, the Nephites were under the rule of the Judges. Their rule was not always peaceful nor their government stable. There were internal as well as external enemies. Priestcrafts and corruption were introduced by Nehor, Amlici, Korihor, and others. The decline in Nephite morality led to the existence of the Gadianton robbers. Samuel the Lamanite preached repentance but few received his words. [J.W.M.]

R.127 Reynolds, George. "Objections to the Book of Mormon." Contributor 3-4 (December 1881-February 1882, October 1882): 81-83, 105-8, 134-37, 4-6. Discusses arguments against the Book of Mormon-objections are based on falsehoods, dishonesty, and insincerity. [L.D.]

R.128 Reynolds, George. "The Originator of the 'Spaulding Story.'” MS 44 (23 October 1882): 676-79. A history of the Spaulding manuscript that deals with the major characters of the story-Solomon Spaulding, P. Hurlburt, Mrs. Davidson, and E. D. Howe. [B.D.]

R.129 Reynolds, George. "Personal Appearance of the Nephites." Juvenile Instructor 15 (15 May 1880): 110-11. Describes the personal appearance of the Nephites as being "white and delightsome people," perhaps "well proportioned, ruddy of countenance, auburn hair and light eyed." [D.M.] 
R.130 Reynolds, George. "The Repentant Lawyer." MS 42 (January 1880): 1-3. Zeezrom was the leading lawyer in the city of Ammonihah who sought every opportunity to win a case, especially against the servants of God. However, he soon recognized his guilt and wished to repent. [B.D.]

R.131 Reynolds, George. "Science and Literature Among the Nephites." Juvenile Instructor 15 (1 May 1880): 105-6. The Nephite civilization began with highly intelligent and learned leaders who were well acquainted with geography and astronomy. They had access to unpolluted scriptures, including the otherwise unknown writings of Zenos, Zenock, Neum, and Ezias. They may have been familiar with the books of Abraham and Joseph. [D.M.]

R.132 Reynolds, George. "Shiz-The Headless." IE 3 (June 1900): 588-89. Discusses ridicule given to the Book of Mormon concerning the death of Shiz and Coriantumr's race for the rulership of the Jaredite nation. [L.D.]

R.133 Reynolds, George. "The Skeleton in Armor." MS 40 (25 November 1878): 737-40. Reynolds quotes an article in the American Magazine of 1837 that describes the excavation of a skeleton in armor and having arrows with brass arrowheads. Reynolds discusses the possibility that this was a Jaredite, Nephite, or Lamanite and concludes that it was probably a Jaredite. [B.D.]

R.134 Reynolds, George. Story of the Book of Mormon. Salt Lake City: J. H. Parry, 1888. Retells the entire story of the Book of Mormon. Includes illustrations. [A.T.]

R.135 Reynolds, George. "Testimony to the Book of Mormon." MS 49 (14 February 1887): 104-7. Reynolds writes of David Whitmer's continued testimony of the Book of Mormon. The Spaulding theory is definitely false and the Book of Mormon is from God. The only witnesses to the authenticity of the Book of Mormon are the Three Witnesses and the Eight Witnesses. [B.D.]

R.136 Reynolds, George. "Three Prophets in Three Distant Ages Born." Juvenile Instructor 14 (15 October 1879): 238-39. The biblical prophets Joseph and Samuel and Book of Mormon prophet Nephi are noteworthy examples to the youth of the Church. Discusses Nephi's love of Isaiah's writings and compares the Book of Mormon version of Isaiah with the biblical. [A.C.W.]

R.137 Reynolds, George. "Time Occupied in Translating the Book of Mormon." Juvenile Instructor 17 (15 October 1882): 315-17. Examines the sequence of events during the translation period of the Book of Mormon and concludes that the work must have happened as Joseph Smith claimed. The time it took to translate the book was relatively short because of divine aid and the use of Urim and Thummim. [A.C.W.]

R.138 Reynolds, George. "Time Occupied in Translating the Book of Mormon." MS 44 (December 1882): 791, 798 99. An analysis of how long it took to translate the Book of Mormon and how many pages were completed per day. From April 7 to May 15 Joseph Smith translated 503 pages and from May 15th to June 11th he translated 120 pages. [B.D.]

R.139 Reynolds, George. "The Zoramites." Juvenile Instructor 14 (1 December 1879): 272-73. Retells the story of the Zoramites, explaining their heresies, their persecution of poor people, and the resulting war. [A.C.W.]

R.140 Reynolds, George, and Janne M. Sjodahl. Book of Mormon Geography: The Lands of the Nephites and the Jaredites. Salt Lake City: Deseret Book, 1957. It is difficult to identify the geography of the Book of Mormon, as there is little effort made by the writers to describe physical features. The speculation of Reynolds and Sjodahl 
follow in five parts, considering all of the geographical entries of the Book of Mormon. Each city is considered according to the description contained within the Book of Mormon. [J.W.M.]

R.141 Reynolds, George, and Janne M. Sjodahl. Commentary on the Book of Mormon. 7 vols. Salt Lake City: Deseret Book, 1955, [R]1960. This multivolume work contains verse-by-verse commentary on the Book of Mormon. The text of the Book of Mormon is included. Also includes discussions of the history and missions of major personalities of the book, treatment of word meanings and usages including comparisons with biblical terms, comments and testimonies of Church leaders, discussion of doctrine, and each volume outlines the chronology of the scriptures included in its scope. [L.D.]

R.142 Reynolds, Mike H. "Book of Mormon Distribution Grows." Evangel 39 (October 1992): 9. Reports that Book of Mormon distribution has increased in the last year. Warns that the Book of Mormon lacks the archaeological proof that supports the Bible and that it disagrees with doctrines of the Mormon church. [A.C.W.]

R.143 Reynolds, Noel B. "Book of Mormon, Government and Legal History in The." In Encyclopedia of Mormonism, edited by Daniel H. Ludlow, 1:160-62. 5 vols. New York: Macmillan, 1992. The three main Book of Mormon groups -Nephite, Lamanite, and Jaredite-were ruled at times by hereditary kings. The Nephites changed to a reign of judges after a period of about 400 years. Nephites based their laws on the Mosiac code. Continual warfare existed between Nephites and Lamanites except from A.D. 33 to A.D. 250 when both lived harmoniously under an ecclesiastical system without judges or kings. [N.K.Y.]

R.144 Reynolds, Noel B. "The Brass Plates Version of Genesis." In By Study and Also by Faith, edited by John M. Lundquist and Stephen D. Ricks, 2:136-73. Salt Lake City: Deseret Book and FARMS, 1990. A textual analysis methodology is presented for measuring dependence and independence of separate texts. This methodology is used to show that the Book of Mormon passages of Genesis, originating from the brass plates, are much more like the version of Genesis in the Pearl of Great Price, and are independent from the Genesis text in the Book of Mormon. The common phrases, as verified by computer searching, are put into the model, weighted, and scored. [A.A.]

R.145 Reynolds, Noel B. "The Gospel as Taught by Nephite Prophets." In Reexploring the Book of Mormon, edited by John W. Welch, 257-59. Salt Lake City: Deseret Book and FARMS, 1992. Examines a six-point formula that defines the "gospel" and "doctrine" of Jesus Christ. The formula is outlined in 2 Nephi 31:2-32, 3 Nephi 11:23-39, and 3 Nephi 27:13-21. [E.G.]

R.146 Reynolds, Noel B. "The Gospel of Jesus Christ as Taught by the Nephite Prophets." BYU Studies 31 (Summer 1991): 31-50. The concept of the gospel in the Book of Mormon comprises a "six-point formula" consisting of the following: repentance, baptism, the Holy Ghost, faith, endurance to the end, and eternal life. Three core texts provide a definition of the gospel (2 Nephi 31, 3 Nephi 11:31-41, and 3 Nephi 27:13-21) and other passages aid the discussion, utilizing the classical rhetorical device of merismus. [D.M.]

R.147 Reynolds, Noel B. "How to 'Come Unto Christ.' "Ensign (22 September 1992): 7-13. The meaning of the gospel, or the manner in which individuals come unto Christ, is set forth in the Book of Mormon (2 Nephi 31, 3 Nephi 11, and 3 Nephi 27). The gospel of Christ includes belief, repentance, baptism, Holy Ghost, and enduring to the end, with the Atonement of Jesus set at its center. [A.C.W.] 
R.148 Reynolds, Noel B. "Nephi 1." In Encyclopedia of Mormonism, edited by Daniel H. Ludlow, 3:1003-5. 5 vols. New York: Macmillan, 1992. An overview of Nephi's major accomplishments, and a general description of his history, visions, record keeping, and literacy. [A.T.]

R.149 Reynolds, Noel B. "Nephi's Outline." BYU Studies 20 (Winter 1980): 131-49. Also in Book of Mormon Authorship: New Light on Ancient Origins, edited by Noel B. Reynolds, 53-74. Provo, UT: Brigham Young University Religious Studies Center, 1982. References to the brass plates indicate that they contain information not found in the Bible. Examines indirect textual evidence in the Book of Mormon to prove other "distinctive contents of the plates of brass." 1 Nephi consists of two accounts, an abridgment of Lehi's writings and Nephi's own record. Eight tables reveal the parallel structure of these two records. This work is reviewed in O.052. [E.G.]

R.150 Reynolds, Noel B. "Nephi's Political Testament." In Rediscovering the Book of Mormon, edited by John L. Sorenson and Melvin J. Thorne, 220-29. Salt Lake City: Deseret Book and FARMS, 1991. The struggle over the right to power and rule created centuries of strife and war in the Book of Mormon. The book was written to show that those who accepted the teachings of Christ accepted Nephi as the legitimate ruler. The Lamanites contended that the eldest son/legitimate ruler had been usurped. This explains the Lamanite desire to dominate. [J.W.M.]

R.151 Reynolds, Noel B. "Nephite Uses and Interpretations of Zenos." In The Allegory of the Olive Tree: The Olive, the Bible, and Jacob 5, edited by Stephen D. Ricks and John W. Welch, 21-49. Salt Lake City: Deseret Book and FARMS, 1994. An examination of the language and phraseology used by Book of Mormon prophets - Lehi, Nephi, Jacob, Alma, Samuel, Mormon, and Moroni-shows the influence that the earlier prophet Zenos had upon their writings. Though centuries later the influence is faint, Benjamin's teachings reflect the teachings of Zenos. [J.W.M.]

R.152 Reynolds, Noel B. "The Political Dimension in Nephi's Small Plates." BYU Studies 27 (Fall 1987): 15-37. Explains Nephi's political reasons for writing the small plates. Nephi's "small plates systematically defend the Nephite tradition concerning origins and refute the competing account advanced by the Lamanites. Thus, the writings of Nephi can be read in part as a political tract or 'lineage history', written to document the legitimacy of Nephi's rule and religious teachings." [B.D.]

R.153 Reynolds, Noel B. Review of The Book of Mormon: Second Nephi, The Doctrinal Structure, by Monte S. Nyman, and Charles D. Tate Jr. Review of Books on the Book of Mormon 2 (1990): 182-86. Book review.

R.154 Reynolds, Noel B., ed. Book of Mormon Authorship: New Light on Ancient Origins. Provo, UT: Brigham Young University Religious Studies Center, 1982. A collection of articles by various authors previously published in BYU Studies and in the Ensign. > The object of this collection is to rigorously test the claims of antiquity of the Book of Mormon. [J.W.M.]

R.155 Rhoades, J. S. "Mormonism versus the Bible." The Christian Statesman 48 (April 1914): 180-81. A polemical article against Mormonism wherein the writer compares Joseph Smith and the Book of Mormon with Mohammed and the Koran. The coming forth of the plates and the visions of Joseph Smith are unsubstantiated by any witnesses. The author considers Mormonism to be a "brazen-faced deception ... as black as the regions of hopeless night." [M.R.]

R.156 Rice, Moyle Q. "The Language and Style of the Book of Mormon." M.A. thesis, University of Nebraska, 1937. A literary analysis of the Book of Mormon. The author compares its language and style with the Bible attempting to determine what influence the Bible may have had on the Book of Mormon. [M.R.] 
R.157 Rich, Ben E., comp. Scrapbook of Mormon Literature. 2 vols. Chicago: Henry C. Etten, 1912. Two-volume compilation includes tracts and articles of varying authorship. Both volumes contain early missionary tracts, instructions to missionaries as to their conduct in the mission field, doctrinal statements from Joseph Smith and other Church leaders, and statements about Mormonism from people both in and out of the Church. Includes a list of prophecies made by Joseph Smith. Includes an analysis of the Book of Mormon and discusses doctrines taught within the book. [L.M.]

R.158 Rich, Benjamin Leroy. The Book of Mormon: a lecture given by invitation April 29, 1900 before the Ohio Liberal Society, Cincinnati, Ohio. N.p.: n.p., 1900. Defends the Book of Mormon by giving an overview of its story as a sacred history of the early inhabitants of America and a historical account of the coming forth of the book. Tells the history of the Spaulding theory, and discusses Martin Harris's visit to Professor Anthon as a fulfillment of Isaiah 29. [J.W.M]

R.159 Rich, Edward S. The God of Israel: The Same Yesterday, Today and Forever. Salt Lake City: Utah Printing, 1939. Written as an expanded version of the author's booklet Jehovah-Christ: Is He Our Elder Brother?, this book suggests that some truths taught in the Book of Mormon conflict with commonly held opinions of the Saints. One such teaching is that Jesus Christ is the Eternal God of this world, and should be worshipped and prayed to as such. Numerous scriptural quotations are given as evidence that Jehovah is our God, the God of this earth, and is the God on whom we should call for salvation. [L.M.]

R.160 Rich, Edward S. Jehovah-Christ, Is He Our Elder Brother?R.161 Rich, Edward S. Thy God Reigneth. Salt Lake City: Vanity, 19?. A collection of essays on the iron rod, God's forethought in providing scriptures for the latter days, witnesses for each Book of Mormon author, the God of Abraham, Isaac and Jacob, the God of the Book of Mormon, a discussion of 3 Nephi, and continuing in the word of God. [D.M.]

R.162 Rich, Edward S. The Word of God is Truth, a Discussion of the Scriptures. N.p., 1967. The Book of Mormon confirms the biblical account, and Rich exhorts the reader to continuously study the infallible word of God. He cites prophecies concerning the coming forth of the Book of Mormon, and discusses the words of ancient and modern prophets concerning the nature of God and Christ, the Savior's role on earth and in the eternities, and latter-day events on earth. [L.M.]

R.163 Rich, John W., comp. The Book of Mormon on Trial, Based on the 'Trial of the Stick of Joseph' by Jack West. Sacramento: Fritz'n Rich, 1963. Based on Jack West's "Trial of the Stick of Joseph," John Rich and illustrator Fritz Alseth use caricature illustrations to portray a mock trial of the Book of Mormon. With biblical references, archaeological evidences, and the testimonies of the Three and Eight Witnesses, the Book of Mormon is proved authentic. [A.C.W.]

R.164 Rich, Russell R. "The Dogberry Papers and the Book of Mormon." BYU Studies 10 (Spring 1970): 315-20. Speaks of the Dogberry Papers, a circulating paper written by Esquire Cole. The first articles concerning Joseph Smith and the Book of Mormon were very negative. Cole changed his views and started printing chapters of the Book of Mormon in his paper. When Cole discontinued printing the chapters and began to speak evil of Joseph, the popularity of the paper decreased. [G.A.]

R.165 Rich, Russell R. "Where were the Moroni Visits?” BYU Studies 10 (Spring 1970): 255-58. Attempts to determine the location of Moroni's visits to Joseph Smith. [G.A.] 
R.166 Rich, Wendell O. A Chronology of the Book of Mormon. Logan: n.p., 1949. A chart that shows the chronology of events that take place in the Book of Mormon. It portrays the Nephites, Lamanites, and Mulekites on a timeline extending from 600 B.C. to A.D. 450, and shows corresponding world events in Greece, Rome, and Babylon. [A.C.W.]

R.167 Richards, A. Z., Jr. "The Book of Mormon in Russian." MS 99 (4 March 1937): 134-35, 141. Describes the labors of Andre K. Anastasiou in preparing a Russian translation of the Book of Mormon. [R.H.B.]

R.168 Richards, A. Z., Jr. "The Star in the Western Sky." MS 98 (17 December 1936): 810-12. Many prophesied of the star that would appear at the Savior's birth, including Samuel the Lamanite, whose prophecy was quite detailed. [J.W.M.]

R.169 Richards, F. D. "Secret Combinations." MS 30 (30 May 1868): 344-48. The author points out the existence of secret organizations in the United States: the Ku Klux Klan, the Loyal League, the Grand Army of the Republic and Fenianism. The Book of Mormon shows how secret societies brought destruction. Richards quotes all of Ether 8:13-26 and Helaman 6:22-30, and urges the Saints to "keep from all secret combinations and political associations." [B.D.]

R.170 Richards, Franklin D. Bibliography of Utah: Book of Mormon. N.p., July 1884. In answer to questions by historian Herbert Bancroft, Richards gave a brief overview of the Book of Mormon story and how it came forth. This account contains many quotes concerning the Book of Mormon from Joseph Smith, Orson Pratt, and others. [J.W.M.]

R.171 Richards, Franklin D. "The Book of Mormon." N.p., 1884. Recounts the story of the Book of Mormon, beginning with the Jaredites departure at the time of the Tower of Babel. Includes a list of Book of Mormon translations, listing languages, dates, and the person who was in charge of the translation and publication. If the doctrinal, historical, and prophetic parts of the Book of Mormon are compared with other sources, it will be discovered there is much to substantiate its authenticity. [J.W.M.]

R.172 Richards, Franklin D. "Holding Fast To The Iron Rod." In Collected Discourses Delivered By President Wilford Woodruff, His Two Counselors, the 12 Apostles, and Others, (1886-1889), edited by Brian H. Stuy, 1:103-12. Sandy, UT: B. H. S. Publishing 1987. All members of the Church need to hold to the iron rod (1 Nephi 8), which is the word of God. By staying on the straight and narrow path one can obtain eternal life and supernal joy. [J.W.M.]

R.173 Richards, Franklin D. "The Lamanites." MS 16 (21 October 1854): 657-61. Writes that the wild imaginations of men have blinded them to the pure and simple truth. They have imagined all sorts of theories of the Indians' descent yet they do not believe the Book of Mormon, which tells the truth plainly. The LDS policy toward the Indians is to try to educate, elevate, and convert the Indians. He quotes from Mormon 5:19-20 that the gentiles will scatter the Lamanites after which the Lord will remember the covenant he has made with Abraham and all the house of Israel. [B.D.]

R.174 Richards, Franklin D. "Origin of American Aborigines." Contributor 17 (May 1896): 425-28. Also in MS 58 (22 October 1896): 683-87. Also published as "Origin of the American Aborigines." Liahona 14/20 (1916-1917): 305-8; and "Ephraim and Manasseh In America." The Utah Genealogical and Historical Magazine 23 (April 1932): 6671. The prophet Joseph Smith taught in the Nauvoo House concerning the stick of Joseph, Ephraim, and Manasseh. Lehi was of the family of Manasseh and Ishmael and his family were of the house of Ephraim. The one hundred sixteen lost pages of the Book of Mormon contained a clear account of Ishmael's ancestry. That is the 
reason, the prophet said, that no mention of Ishmael's genealogy is in the Book of Mormon. Richards discusses the marriage relationships and union of the families. Lehi's sons married Ishmael's daughters thus combining the two tribes. Richards writes that this fulfills the prophecy in Genesis 48:20 that Ephraim and Manasseh together should become a multitude of nations. [J.W.M.]

R.175 Richards Franklin D. "Revelation and Priesthood." Deseret Weekly 52 (4 January 1896): 65-67. Also in Collected Discourses 4:367-75. People have a hard time accepting the Book of Mormon because of the tradition that teaches that the heavens are sealed. The Book of Mormon and the Bible fulfill the prophecy in Ezekiel 37. "The Book of Mormon is the Bible of the American continent." [D.M.]

R.176 Richards, Franklin D., and James A. Little. "Book of Mormon Chronology." In Richards' and Little's A Compendium of the Doctrines of the Gospel, 289-301. Salt Lake City: Deseret News Press, 1882. A list of Book of Mormon events with their attendant dates in chronological order. [J.W.M.]

R.177 Richards, Franklin D., and James E. Little. "Book of Mormon-Evidences of Its Divine Authenticity." In A Compendium of the Doctrines of the Gospel, 95-101. Salt Lake City: Deseret News Co., 1882. The Book of Mormon fulfills the prophecy of Enoch, King David, Isaiah, Ezekiel, and Joseph who was sold into Egypt (see 2 Nephi 3). Orson Pratt said that there is nothing in all of the ancient ruins that conflict with the Book of Mormon. There is no contradiction in the book itself in history, prophecy, or doctrine, nor is there any conflict with the Bible. Many of the Book of Mormon's prophecies have been fulfilled. [J.W.M.]

R.178 Richards, George F. Untitled talk. CR (April 1912): 37-41. Jesus Christ is the noblest son of God and his redemptive mission was performed in behalf of all men. In similitude of the Savior we esteem Joseph Smith as one of noblest of the sons of God. His mission to bring forth the Book of Mormon and to restore truth to the earth is one of greatest importance to all the world. The Book of Mormon is one of the greatest evidences that Joseph Smith was a prophet of God. [J.W.M.]

R.179 Richards, George F. Untitled talk. CR (April 1927): 88-92. It is most important to teach all men the gospel and to give them the opportunity to have the saving ordinances. Men of the world need a tutor to understand the scriptures. Witnesses of the Book of Mormon testify that an angel laid the plates before them and a voice from heaven declared that the plates had been translated by the gift and power of God. [J.W.M.]

R.180 Richards, Joel. "A Book to Bring the World to Christ." Instructor 103 (October 1968): 412-13, 418. Speaks of the distribution of the Book of Mormon, and gives testimonial accounts of missionaries and converts who have felt the power of the Book of Mormon. Missionaries who use the Book of Mormon in their proselytizing efforts have great success. [G.A.]

R.181 Richards, LeGrand. ".. Always Be a Missionary." IE 61 (December 1958): 960-64. As a part of the restoration of the gospel, the Book of Mormon became the companion volume of the Bible. No one who reads the Bible sincerely can deny that a volume of scripture is needed to record the fulfillment of the promises made to Joseph. [J.W.M.]

R.182 Richards, LeGrand. "America, A Land of Promise." In BYUSY (16 April 1957). Provo, UT: BYU Press. America, North and South, is a land that is choice above all others. The Book of Mormon enumerates the promises and responsibilities given to those who possess them. [J.W.M.] 
R.183 Richards, LeGrand. "The Book of Mormon." IE 70 (June 1967): 38-42. Book of Mormon scriptures clarify perplexing biblical passages such as John 10:16, Ezekiel 38:18-19, and Isaiah 29:1-2. [B.W.J.]

R.184 Richards, LeGrand. "The Book of Mormon, An Aid to Testimony." IE 49 (November 1946): 709, 748, 750. There is "no motivating power in this world" comparable to the testimony of truth concerning Jesus Christ and there is no greater testimony of Jesus Christ than that of the Book of Mormon. [J.W.M.]

R.185 Richards, LeGrand. "The Book of Mormon Fulfills Bible Prophecies." In Richards's A Marvelous Work and a Wonder, 55-69. Salt Lake City: Deseret Book, 1950, [R] 1974. The Bible contains many prophecies that confirm the need for the Book of Mormon. [J.W.M.]

R.186 Richards, LeGrand. "Book of Mormon Fulfills Prophecy." CR (April 1976): 121-24. Isaiah's writings are of great importance for this time; for instance, Isaiah 29 is a powerful witness for the restoration and Book of Mormon-truly a "familiar spirit," and a "marvelous work and a wonder." [R.C.D.]

R.187 Richards, LeGrand. "The Book of Mormon Is Scripture." In LDS Area General Conference Report, Munich \#1. Salt Lake City: Deseret Book, 1973. The Church has the most important message that the modern world has to hear: a man lived on this earth, died, and then has returned with a message from God. Moroni, an ancient American prophet, has returned with the record of his people. This record is a message from God. [J.W.M.]

R.188 Richards, LeGrand. "Book of Mormon Revelation Clarifies Scriptures." CR (April 1967): 18-23. "The Book of Mormon has made possible the proper interpretation and understanding of many of the holy scriptures of the Bible that no theologian could properly understand or explain until the Book of Mormon came forth." Elder Richards gave several examples: "other sheep," Joseph's fruitful bough, Ezekiel's two sticks, Isaiah 29, the mountain of the Lord's house, and the New Jerusalem. [R.C.D.]

R.189 Richards, LeGrand. " 'Church of the Air' Address: A New Witness for Christ." CN 27 (7 December 1957): 10. The Book of Mormon is a witness for Christ of great value. Quotes Ezekiel 37:15-20, John 10:16, and discusses Christ's visit to the Nephites as recorded in 3 Nephi. [A.C.W.]

R.190 Richards, LeGrand. "The Coming Forth of the Book of Mormon." In Richards's A Marvelous Work and a Wonder, 41-54. Salt Lake City: Deseret Book, 1950, 1974. Reviews the story of the coming forth of the Book of Mormon, tells how Professor Anthon fulfilled Isaiah's prophecy (Isaiah 29:11), discusses Moroni's prophecy concerning Joseph Smith, the testimony of the Three Witnesses, the Lord's promise in Moroni 10:4-5, and teaches that the Book of Mormon is a new witness for Christ. [A.C.W.]

R.191 Richards, LeGrand. "Evidences of the Divinity of the Book of Mormon." In Richards's A Marvelous Work and a Wonder, 71-82. Salt Lake City: Deseret Book, 1950, 1969, 1974. Discusses the testimonies of the Three and Eight Witnesses to the Book of Mormon. Using the scriptures as a guide Richards discusses the Urim and Thummim, the origin of the Indians, Nephi's testimony and the promised witness to the truthfulness of the book for seekers of the truth. [L.D.]

R.192 Richards, LeGrand. "God Moves in a Mysterious Way." IE 73 (December 1970): 69-71. Speaks concerning God and Christ, and teaches that Old Testament prophets foretold of the coming forth of the Book of Mormon. [J.W.M.] 
R.193 Richards, LeGrand. "Isaiah and Book of Mormon Prophecies." CR (October 1966): 41-44. The Book of Mormon teaches that the writings of Isaiah are very important for those of the present era. Isaiah saw this day in detail. He saw the Restoration, Joseph Smith, the Book of Mormon, Salt Lake City, and many other things. [R.C.D.]

R.194 Richards, LeGrand. "Joseph's Message to Judah." In Richards's Israel! Do You Know?, 41-72. Salt Lake City: Deseret Book, 1954, 1976. Quotes extensively from 1, 2, and 3 Nephi, Helaman, Jeremiah, Ezekiel, and Isaiah to show that the Book of Mormon is the stick of Joseph and that it prophesies of Christ. [A.C.W.]

R.195 Richards, LeGrand. "The Lamanites, A People of Promise." In BYUSY (24 February 1970). Provo, UT: BYU Press. The promises of the Book of Mormon found in Alma and 2 Nephi are being fulfilled and the Lamanites are bearing witness of its truthfulness. [J.W.M.]

R.196 Richards, LeGrand. "A Marvelous Work." IE 58 (June 1955): 440-46. Describes the importance of the Book of Mormon in the Restoration, missionary work, and daily life. Author gives his witness to the truthfulness and validity of the book. [E.G.]

R.197 Richards, LeGrand. "The Most Important Message." IE 66 (June 1963): 518-21. The Book of Mormon is tangible evidence that the angel Moroni came to visit the earth with the greatest message possible: that Jesus is the Christ. The author states that some prophecies and statements found in the Bible can only be understood by the added information found in the Book of Mormon. [J.W.M.]

R.198 Richards, LeGrand. "A New Witness for Christ." Salt Lake City: n.p., 1957. A tract that introduces the Book of Mormon by presenting biblical scriptures that speak of the Book of Mormon. [D.W.P.]

R.199 Richards, Le Grand. "Ours ... The Greatest Message." IE 62 (June 1959): 438-39. The Book of Mormon is the most tangible evidence that the message and work of Joseph Smith is true; it is a witness of Jesus Christ. The author uses stories and letters of members and non-members to verify his message that people all over the world recognize the value of the Book of Mormon. [J.W.M.]

R.200 Richards, LeGrand. "The Stick of Joseph; Joseph's Message to Judah." In Richards's Israel! Do You Know?, 2572. Salt Lake City: Deseret Book, 1954, 1976. Uses the biblical prophecy recorded in Ezekiel 37 to determine that the Book of Mormon represents the stick of Joseph. The Book of Mormon shows Judah that the law of Moses has been fulfilled and that Jesus Christ is God. [A.C.W.]

R.201 Richards, LeGrand. Untitled talk. CR (April 1937): 62-65. The Book of Mormon is the most tangible evidence of the divine mission of the prophet Joseph Smith and a testimony of it is extremely important. It explains the origin of the early civilizations of America. [B.D.]

R.202 Richards, LeGrand. Untitled talk. CR (September, October 1949): 49-54. A testimony of the Book of Mormon. Mentions that there were horses in ancient America as claimed by the Book of Mormon and that its prophecies are being fulfilled. [B.D.]

R.203 Richards, LeGrand. Untitled talk. CR (April 1963): 115-19. A national commentator said the most important message would be discovered by a man who lived on the earth and who had died and returned with a message from God. Moroni has done just that and the tangible evidence of the visit is the Book of Mormon. It clarifies prophecies in the Bible that have puzzled men for centuries. [J.W.M.] 
R.204 Richards, LeGrand. Untitled talk. In Official Report of the First Area General Conference for Germany, Austria, Holland, Italy, Switzerland, France, Belgium and Spain, August 1973, 34-37. Salt Lake City: Church of Jesus Christ of Latter-day Saints, 1973. Recalls the story of a news broadcaster who declared the message of greatest importance would be that a man that had lived on this earth and died had come back to give a message from God. The Church of Jesus Christ of Latter-day Saints is unique in that it was organized because of just such a message brought by Moroni. It is the companion volume to the Bible. [J.W.M.]

R.205 Richards, Louisa Lulu Greene. Branches That Run over the Wall: A Book of Mormon Poem and Other Writings. Salt Lake City: Magazine Printing, 1904. Several Book of Mormon characters come to life in this collection of poems that describe the Lehite departure from Jerusalem, courtships, marriages between the families of Lehi and Ishmael, and related items. [A.C.W.]

R.206 Richards, Lulu Greene. "A Treasured Volume." MS 96 (28 June 1934): 411-12. The copy of the Book of Mormon owned by Hyrum Smith at the time of his martyrdom is a cherished heirloom. [A.C.W.]

R.207 Richards, Samuel W. "The Aztec City in Central America-The Lost Tribes." MS 14 (20 November 1852): 614-16. Presents a reprint of an article from the Boston U.S. Weekly Journal that tells of an ancient Aztec city whose inhabitants are believed to be part of the lost ten tribes. Their record is found in a book of parchment bound by brazen clasps and containing curious heiroglyphics. Richards predicts that evidence in support of the Book of Mormon will overwhelm the skepticism regarding its origins. [J.W.M.]

R.208 Richards, Samuel W. "Discovery of Ruined Cities in California." MS 15 (17 December 1853): 817-20. Writes concerning an article from the San Francisco Herald that describes ruined cities of California. "The wonderful and magnificent ruins ... continue to puzzle and astonish the learning and wisdom of the great men of the nineteenth century, while every fresh discovery is an increasing evidence in favor of the Book of Mormon." [D.M.]

R.209 Richards, Samuel Whitney. Experiences with Oliver Cowdery. Salt Lake City: author, 1907. A typescript wherein Richards recalls visiting with Oliver Cowdery. Cowdery recalls the manner in which Joseph Smith translated the Book of Mormon from the gold plates. [D.W.P.]

R.210 Richardson, Ebbie L. V. "David Whitmer, a Witness to the Divine Authenticity of the Book of Mormon." M.A. thesis, Brigham Young University, 1952. A thesis that examines the life of David Whitmer, his testimony of the divinity of the Book of Mormon, and his involvement with the Mormons. As one of the witnesses who saw an angel and the gold plates, Whitmer's testimony of the Book of Mormon is valuable. [A.C.W.]

R.211 Ricks, Eldin. "Book of Mormon." Provo, UT: Brigham Young University, 1960. Presents Book of Mormon lessons dealing with Nephi, the Three Witnesses, and formulas for peace and national survival during times of war. [D.W.P.]

R.212 Ricks, Eldin. Book of Mormon Commentary. Volume 1. Salt Lake City: Deseret News, 1951. Sets forth biblical prophecies that relate to the Book of Mormon, tells the historical facts surrounding the coming forth of the Book of Mormon, and provides commentary on 1 Nephi. [A.C.W.]

R.213 Ricks, Eldin. Book of Mormon Study Guide. Salt Lake City: Deseret News Press, 1955. Ricks's instructional aid to Book of Mormon study consists of a series of detailed questions that follow the sequential order of the text of the Book of Mormon. The study guide is in a workbook format with space provided to answer the questions and is designed to accompany the reading of the scriptural text. [A.C.W.] 
R.214 Ricks, Eldin. "Book of Mormon: Title Page from the Book of Mormon." In The Encyclopedia of Mormonism, edited by Daniel H. Ludlow, 1:144. 5 vols. New York: Macmillan, 1992. A brief discussion of the title page of the Book of Mormon. The title page was used as the description of the Book of Mormon for the federal copyright application. [A.T.]

R.215 Ricks, Eldin. The Book of Mormon: Wide Margin Edition. Provo, UT: Ricks, 1987. A loose-leaf size edition of the Book of Mormon text with wide, lined margins designed for personal study notes. [J.W.M.]

R.216 Ricks, Eldin. The Case of the Book of Mormon Witnesses. Salt Lake City: Olympus, 1963. A supplement to Ricks's Book of Mormon Study Guide that consists of testimonies by numerous witnesses to the authenticity and veracity of the Book of Mormon. Includes a background history of Joseph Smith and the gold plates and testimonies of the Three Witnesses, the Eight Witnesses, Lucy Mack Smith, Brigham Young, and others. [A.C.W.]

R.217 Ricks, Eldin. Combination Reference: A Simple and Orderly Arrangement of Selected References to the Standard Works of the Church of Jesus Christ of Latter-day Saints. Salt Lake City: Deseret Book, 1943, 1969. An arrangement of scriptural references to the standard works of the Church organized in dictionary format by subject. Subjects include angels, antiquity of the gospel, apostasy, baptism, Bible, confirmation, and death. [L.D.]

R.218 Ricks, Eldin. "The Formation of the Book of Mormon Plates." IE 63 (1960): 796-97, 852-54. Explains the different writings that comprise the plates given to Joseph Smith. They include: (1) Mormon's abridgment, (2) the small plates, (3) the plates (abridgment) of Mormon, and (4) the sealed plates. [R.C.D.]

R.219 Ricks, Eldin. "Moroni, Visitations of." In Encyclopedia of Mormonism, edited by Daniel H. Ludlow, 954-55. 5 vols. New York: Macmillan, 1992. Discusses the visitations of Moroni to Joseph Smith, the Three Witnesses, Mary Whitmer, W. W. Phelps, Heber C. Kimball, John Taylor, and Oliver Granger. [B.D.]

R.220 Ricks, Eldin. "Nephi." In Know Your Religion: Our Prophets, Old and New, 2:1-16. Provo, UT: Brigham Young University, 1960. Retells the story of Nephi. [D.M.]

R.221 Ricks, Eldin. Plan for a Daily Reading of the Four Standard Works. Salt Lake City: Mountain West, 1973. A booklet formatted to allow readers of the Book of Mormon to plan daily scripture study. [D.M.]

R.222 Ricks, Eldin. "The Plates That Mormon Found and the Manuscript That Joseph Lost." In The Ninth Annual Sydney B. Sperry Symposium: The Book of Mormon, 60-82. Provo, UT: BYU Educational System, 24 January 1981. The 116 pages of lost manuscript were translated from the book of Lehi (large plates of Nephi). The small plates of Nephi that replaced them are of great value to "our day." The large plates contained secular history, genealogy, and sacred writings. The small plates covered the time period of Lehi to Mosiah with sacred writings selected for a purpose that Nephi did not know. While abridging the plates Mormon came upon the small plates. He saw their value and included them in his record, adding his own appendage. [J.W.M.]

R.223 Ricks, Eldin. Review of Who's Who in the Book of Mormon, rev. ed. by Robert J. Matthews. BYU Studies 8 (1968): 353. Book review.

R.224 Ricks, Eldin. "The Small Plates of Nephi and the Words of Mormon." In The Book of Mormon: Jacob through Words of Mormon, To Learn with Joy, edited by Monte S. Nyman and Charles D. Tate Jr., 209-19. Provo, UT: Brigham Young University Religious Studies Center, 1990. Making sense of the "Words of Mormon appendage" requires an understanding of the records that Mormon was abridging. Mormon found the small plates that contained a 
religious record only, added his own appendage and placed them with his abridgment. Thus, in spite of the loss of the 116 pages, the entire record of the Nephites is available. [J.W.M.]

R.225 Ricks, Eldin. Story of the Formation of the Book of Mormon Plates, an Analysis of the Sources and Structure of the Sacred Record. Salt Lake City: Deseret News Press, 1958. Discusses Joseph Smith's reception and translation of the gold plates. Mormon abridged the large plates of Nephi that contained a more secular record of the time from Lehi's exodus to the time of King Benjamin, who then began to write the more spiritual approach. Mormon included the small plates of Nephi with his abridged record. His only addition was a short transition piece that he placed in the record. [J.W.M.]

R.226 Ricks, Eldin. "The Words of Mormon." In Encyclopedia of Mormonism, edited by Daniel H. Ludlow, 1:149. 5 vols. New York: Macmillan, 1992. Describes the date and purpose of the book entitled the Words of Mormon. [A.T.]

R.227 Ricks, Joel E. "America's Ancient Inhabitants." MS 55 (October 1893): 672-75, 695-98, 711-14. A report of the author's explorations in Salt River Valley, Arizona, wherein he hypothesizes that the inhabitants of Salt River Valley came from Hagoth's voyages to the north country (Alma 63). The peoples had buildings and temples made of cement and probably used metal. [B.D.]

R.228 Ricks, Joel E. "The Book of Mormon a Divine Record: Witnesses Never Denied Their Testimony." Liahona 14 (3 April 1917): 631. A note affirming that the witnesses to the Book of Mormon were constantly true to their testimony. [D.M.]

R.229 Ricks, Joel E. "Book of Mormon Geography." Brigham Young College Bulletin: Society Report 3 (15 December 1904): 1-19. Believes that Book of Mormon geography is discernible. Identifies the "narrow neck of land" as the Isthmus of Panama and the "River Sidon" as the river Magdalena. Maps included. [J.W.M.]

R.230 Ricks, Joel E. Helps to the Study of the Book of Mormon. Independence, MO: Zion's, 1916. This instructional aid intended to increase understanding of the Book of Mormon includes a chronology, maps, photos, an account of how Joseph Smith obtained the gold plates, and a dictionary of proper names found in the Book of Mormon. Ricks also presents an explanation of the Urim and Thummim and uses geography, archaeology, ancient traditions, and biblical prophecies to demonstrate the divinity of the Book of Mormon. [A.C.W.]

R.231 Ricks, Joel E. The Geography of the Book of Mormon. Logan: n.p., 1939. The purpose in writing this text is to "emphasize the geographic references in the [Book of Mormon], and to ... identify those locations in the light of modern geography." Concludes that the Book of Mormon events covered both the North and South American continents, basing these ideas on the supposition that Panama is the "narrow neck of land." Several maps are included. [A.C.W.]

R.232 Ricks, Joel E. "The Land of Zarahemla." Juvenile Instructor 41 (1, 15 April, 15 November 1906): 193-96, 22528, 673-77. Identifies an area in Bogata, Columbia as the Land of Zarahemla. Presents photographs and a description of the geography, climate, and vegetation of the area, drawing parallels with passages of the Book of Mormon text. [J.W.M.]

R.233 Ricks, Joel E. "Modern Research and the Book of Mormon." MS 72 (28 July 1910): 465-69. Writes of various external evidences of the Book of Mormon that Joseph Smith, according to Ricks, would not have been 
aware of. Mentions the great ruins that have been discovered in Central and South America, evidence of iron, wool, cement, elephants, and domesticated horses, ox, sheep, and swine. [B.D.]

R.234 Ricks, Joel E. The Nephites in Story. Logan: n.p., 1940. Comprises a storybook version of the Nephite history for youth that sequentially covers all of the general Book of Mormon events, with the omission of the Jaredite record. Includes maps, geographical information, and archaeological data and suppositions, which the author incorporates into the story. [A.C.W.]

R.235 Ricks, Joel E. "A Study of Book of Mormon Geography." Brigham Young College Bulletin 3 (15 December 1904): 1-19. Suggests that the land northward is North America, the land southward is South America. The narrow neck is the Isthmus of Panama. The Hill Cumorah mentioned in the Book of Mormon is the same as the Hill Ramah of the Jaredites and is where Joseph Smith discovered the plates. Ricks continues to suggest precise locations for almost all cities mentioned in the Book of Mormon. [B.D.]

R.236 Ricks, Joel E. "Urim and Thummim." IE 18 (May 1915): 611-15. Gives a definition of the Urim and Thummim and discusses its history using the scriptures as a guide. [L.D.]

R.237 Ricks, Joel E. "Urim and Thummim." MS 86 (21 August 1924): 529. Sets forth a description and history of the Urim and Thummim. [A.T.]

R.238 Ricks, Joel E. Whence Came the Mayas. Salt Lake City: n.p., 1943. Uses archaeological, geographical, scriptural, and historical information to theorize that the Mayan culture was related to the cultures of the Nephites and Jaredites. Desires to prove that advanced civilizations lived on the American continent before the arrival of Columbus. [A.C.W.]

R.239 Ricks, Kellen. "The Lost License." CN 59 (1 April 1989): 16. A man returns a lost license to its owner with a copy of the Book of Mormon. [J.W.M.]

R.240 Ricks, Kellen." 'Share Testimonies This Year,' Sisters Urged." CN 59 (25 March 1989): 8-9. Relief Society President Barbara Winder presents members with copies of the Book of Mormon and challenges them to become "personally involved" with the Book of Mormon as a missionary tool. [J.W.M.]

R.241 Ricks, Kellen. "Someone is Waiting." CN 59 (14 January 1989): 16. A husband and wife put their testimony and picture in copies of the Book of Mormon and distribute them. [J.W.M.]

R.242 Ricks, Shirley S. Review of Book of Mormon Companion: Dictionary \& More, by Carol Rowbery, et al. Review of Books on the Book of Mormon 2 (1990): 24-25. Book review.

R.243 Ricks, Shirley S. Review of Fun for Family Night: Book of Mormon Edition, by Allen K. Burgess and Max H. Molgard. Review of Books on the Book of Mormon 3 (1991): 81-83. Book review.

R.244 Ricks, Stephen D. "Benjamin." In Encyclopedia of Mormonism, edited by Daniel H. Ludlow, 1:99-100. 5 vols. New York: Macmillan, 1992. A description of King Benjamin who was also the prophet of his people and was entrusted with the small plates by Amaleki. [B.D.]

R.245 Ricks, Stephen D. "Book of Mormon Studies." In Encyclopedia of Mormonism, edited by Daniel H. Ludlow, 1:205-9. 5 vols. New York: Macmillan, 1992. Historical overview of analyses, criticisms, and defenses of the Book 
of Mormon. Notes in detail those by Alexander Campbell, Orson Pratt, George Reynolds, Janne M. Sjodahl, B. H. Roberts, Francis Kirkham, Hugh W. Nibley, John L. Sorenson. [N.K.Y.]

R.246 Ricks, Stephen D. "The Coronation of Kings." In Reexploring the Book of Mormon, edited by John W. Welch, 124-26. Salt Lake City: Deseret Book and FARMS, 1992. Examines Mosiah 1-6 in light of ancient Near Eastern kingship rites, including the location of the sanctuary, investiture with insignia, anointing, receipt of a regal name, and other elements. [N.K.Y.]

R.247 Ricks, Stephen D. "Deuteronomy: A Covenant of Love." Ensign 20 (April 1990): 55-59. The entire book of Deuteronomy appears to follow the structure of a covenant ceremony, perhaps written for the passing of the mantle of leadership from Moses to Joshua. The book of Mosiah in the Book of Mormon resembles this process. The elements of covenant making follow a suggested outline: an introduction of the covenant parties, a review of history, individual commandments, blessings and cursings, witness and oaths of acceptance, and the reading of the covenant and the deposit of the text. [J.W.M.]

R.248 Ricks, Stephen D. "Fasting in the Book of Mormon and the Bible." In The Book of Mormon: The Keystone Scripture, edited by Paul R. Cheesman, S. Kent Brown, and Charles D. Tate Jr., 127-36. Provo, UT: Brigham Young University Religious Studies Center, 1988. Also published as "Fasting

R.249 Ricks, Stephen D. ' 'Holy War' in the Book of Mormon and the Ancient Near East." In Reexploring the Book of Mormon, edited by John W. Welch, 202-5. Salt Lake City: Deseret Book and FARMS, 1992. In this paper, Ricks sets forth the ideology of holy war in the Book of Mormon. Wars in the ancient Near East were always waged with approval and direction of the gods or God. Joshua's and Israel's soldiers were to be ritually clean when going into battle. Moroni in his battles used prophetic advice. Helaman's stripling Ammonite warriors were noted for their moral purity. [N.K.Y.]

R.250 Ricks, Stephen D." 'Holy War': The Sacral Ideology of War in the Book of Mormon and in the Ancient Near East." In Warfare in the Book of Mormon, edited by Stephen D. Ricks and William J. Hamblin, 103-17. Salt Lake City: Deseret Book and FARMS, 1990. Ancient Israel had a sacral ideology of war stating God gave them the right to rule and conquer. Violations of ritual purification caused the loss of battles and wars. The Book of Mormon peoples used the Lord's guidance to know when, where, and how to meet their enemies. Apostate cities were to be destroyed and when the Nephites lost their righteous qualities, they were defeated. [N.K.Y.]

R.251 Ricks, Stephen D. "I Have a Question: Many times in prophecy, the present and past tenses are used, even though the prophecy refers to a future event. Can you explain the use of verb tenses in prophecy?" Ensign 18 (August 1988): 27-28. Explains that future events are so vivid in a prophet's mind that they are described as if they had already occurred; Abinadi's defense to King Noah in Mosiah 16 is a particularly good example. [E.G.]

R.252 Ricks, Stephen D. "I Have a Question: The name of one of the Lord's disciples listed in 3 Nephi 19:4Timothy-seems to be Greek in origin. Is there an explanation for the appearance of a Greek name in the Book of Mormon?" Ensign 22 (October 1992): 53-54. Gives several plausible explanations for the appearance of "Timothy" and "Lachoneus" (another word of possible Greek origin) in the Book of Mormon. Discusses the possibility of Mulekite contact with Grecian influences, and evidence of ancient contacts between Israelites and Greeks. [A.C.W.]

R.253 Ricks, Stephen D. "The Ideology of Kingship in Mosiah 1-6." In Reexploring the Book of Mormon, edited by John W. Welch, 114-16. Salt Lake City: Deseret Book and FARMS, 1992. The rites of a new king commonly known 
in Egyptian and Mesopotamian societies were used in Israel and described in the Book of Mormon. The elements of kingship found in the Book of Mormon include accession to the throne, ambivalent view of kingship, the king as a protector for the weak, and covenants with the Lord. The rich and complex ideology is most excellently portrayed in the book of Mosiah. [N.K.Y.]

R.254 Ricks, Stephen D. "Joseph's Smith's Means and Methods of Translating the Book of Mormon." Provo, UT: FARMS, 1984. In an argument against the "automatic method" of translating the Book of Mormon, Ricks points out that Joseph Smith's own statements establish that it was through the "gift and power of God" and by means of the Urim and Thummim that the Book of Mormon was translated. [J.W.M.]

R.255 Ricks, Stephen D. "King, Coronation, and Covenant in Mosiah 1-6." In Rediscovering the Book of Mormon, edited by John L. Sorenson and Melvin J. Thorne, 209-19. Salt Lake City: Deseret Book and FARMS, 1991 King Benjamin's farewell address and Mosiah's succession to his father's throne reflect features of ancient Israelite and near eastern culture. The coronation of the new King took place in the temple and involved a new name and an anointing. A renewal of the covenant was also important. Article contains a table of similarities and scriptural passages that show the comparisons. [J.W.M.]

R.256 Ricks, Stephen D. "Olive Culture in the Second Temple Era and Early Rabbinic Period." In The Allegory of the Olive Tree: The Olive, the Bible, and Jacob 5, edited by Stephen D. Ricks and John W. Welch, 460-76. Salt Lake City, Deseret Book and FARMS, 1994. Using ancient sources in the Apocrypha, Pseudepigrapha, Mishnah, and Talmud, this article explores the role of the olive in the Second Temple period and the early rabbis and shows how they relate to the themes in Jacob 5. The pruning, nourishing, dunging, and engrafting that are so much a part of Jacob 5 are also contained in the literature of the Second Temple era. [J.W.M.]

R.257 Ricks, Stephen, D. Review of Lehi in the Desert, The World of the Jaredites, There Were Jaredites, by Hugh W., Nibley. Review of Books on the Book of Mormon 2 (1990): 143-63. Book review.

R.258 Ricks, Stephen D. Review of Studies in Scripture: Volume 7, 1 Nephi to Alma 29; Volume 8, Alma 30 to Moroni, edited by Kent P. Jackson. Review of Books on the Book of Mormon 1 (1989): 89-91. Book review.

R.259 Ricks, Stephen D. Review of The Use of the Old Testament in the Book of Mormon, by Wesley P. Walters. Review of Books on the Book of Mormon 4 (1992): 235-50. Book review.

R.260 Ricks, Stephen D. "Treaty/Covenant Patterns in King Benjamin's Address.” BYU Studies 24 (Spring 1984): 151-62. Treaty-covenant assemblies were common in the ancient Near East, one of which was the Feast of the Tabernacles. King Benjamin's address (Mosiah 1-6) was perhaps related to the Feast of the Tabernacles. It may well be related to the covenants made at Sinai. It is possible that it also reflects an even more ancient Near Eastern covenant renewal pattern. [J.W.M.]

R.261 Ricks, Stephen D., and Robert F. Smith. "New Year's Celebrations." In Reexploring the Book of Mormon, edited by John W. Welch, 209-11. Salt Lake City: Deseret Book and FARMS, 1992. The New Year's celebrations of the Book of Mormon and the Old Testament assume great importance for coronation of kings, covenant renewal, feast days, and other activities. The Lamanites were confused to find their king Amalickiah dead on New Year's day (Alma 62:36-39). Joseph Smith did not realize that he took the plates from Hill Cumorah on the Jewish New Year's day. [N.K.Y.] 
R.262 Ricks, Stephen D., and William J. Hamblin. "Conference on Warfare in the Book of Mormon." In Reexploring the Book of Mormon, edited by John W. Welch, 199-201. Salt Lake City: Deseret Book and FARMS, 1992. Report of the Conference on Warfare held in 1987. Papers presented deal with weapons mentioned in the Book of Mormon, scholars' views of Mesoamerican warfare, Nephite, Jaredite, and Mayan warfare, warfare rituals in the Book of Mormon, martial law, and Gadianton robbers' counter culture. [N.K.Y.]

R.263 Ricks, Stephen D., and John W. Welch, eds. The Allegory of the Olive Tree: The Olive, the Bible, and Jacob 5. Salt Lake City: Deseret Book and FARMS, 1994. Articles by various authors examine Zenos's allegory in Jacob 5 as a symbol of Christ, Nephi's uses and interpretations of the allegory, textual analyses, ancient historical and religious backgrounds of the symbolism of the olive tree, the olive in early Jewish and Christian writings, and botany and horticulture of olives. [J.W.M.]

R.264 Ricks, Stephen D., and William J. Hamblin, eds. Warfare in the Book of Mormon. Salt Lake City: Deseret Book and FARMS, 1990. Publishes the papers presented at the FARMS Symposium on Warfare in the Book of Mormon. See annotations under individual authors. [J.W.M.]

R.265 Ricks, Welby W. "Discoveries of Purported Ancient Hebrew Writing in Eastern United States." UASN 13 (25 June 1953): 3. Also in Christensen, Ross T. Progress in Archaeology: An Anthology, 210-11. Provo, UT: Brigham Young University, 1963. Few discoveries of the Hebrew script known by Nephite peoples have been made. However, one find in Newark, Ohio, has Hebrew-like inscriptions. [J.W.M.]

R.266 Ricks, Welby W. "The Kinderhook Plates." IE 65 (September 1962): 636-37, 656, 658-59. The Kinderhook plates remind one of the gold plates. They were metal plates clasped together with a ring. Hieroglyphics were imprinted upon them. They were taken to Joseph Smith to translate. He declared them to be genuine antiMormon literature and proclaimed them to be a hoax. [J.W.M.]

R.267 Ricks, Welby W. "A Purported Phoenician Inscription in New Mexico." In Papers of the Fifteenth Annual Symposium on Archaeology of the Scriptures, edited by Ross T. Christensen, 94-100. Provo, UT: Brigham Young University, 1964. A purported Phoenician inscription in New Mexico bearing an abbreviated form of the Ten Commandments in Hebrew is found to be fraudulent after a thorough investigation. Investigations must be made to insure the continued success of Book of Mormon archaeology and the reputation of the LDS church. [J.W.M.]

R.268 Riddle, Chauncey C. Code Language in the Book of Mormon. Provo, UT: FARMS, 1992. Identifies four major kinds of hidden meanings or code language in the Book of Mormon: (1) obscure usages, (2) technical usages, (3) metaphorical/allegorical usages, (4) double entendres. The author explains such terms as: "looking beyond the mark," "innocent blood," the "tree of life," "prosper in the land," "the seed of Abraham," "amen," "house of Israel," and the name of God. [B.D.]

R.269 Riddle, Chauncey C. "Days of Wickedness and Vengeance: Analysis of 3 Nephi 6 and 7." In The Book of Mormon: Helaman through 3 Nephi 8, According to Thy Word, edited by Monte S. Nyman and Charles D. Tate Jr., 191205. Provo, UT: Brigham Young University Religious Studies Center, 1992. Draws parallels between the period just before the cataclysm in 3 Nephi and the present age, including: (1) the main participants in both eras are of the house of Israel, (2) the fury of Satan is increased, and (3) the coming of Christ ends the destruction. [D.M.]

R.270 Riddle, Chauncey C. "Korihor: The Arguments of Apostasy." Ensign 7 (September 1977): 18-21. Korihor's arguments (Alma 30) are examined. He argues naturalistic empiricism (knowing all truth by the senses, which 
disqualifies the spiritual), humanism (success comes only by human means), and relativism (the individual judges his own actions according to his own criteria). [J.W.M.]

R.271 Riddle, Chauncey C. "Pride and Riches." In The Book of Mormon: Jacob through Words of Mormon, To Learn with Joy, edited by Monte S. Nyman and Charles D. Tate Jr., 221-33. Provo, UT: Brigham Young University Religious Studies Center, 1990. Jacob instructs his people concerning pride and riches in Jacob 2:12-21. It is a call to humility and proper attitudes toward wealth, faith in Christ and the attaining of a fullness of faith, which is charity. From charity grows the desire to share. That which must be shared first is the gospel of Jesus Christ, then that which is shared is done in the Lord's own way. [J.W.M.]

R.272 Ridenour, Fritz. So What's the Difference. Glendale, CA: G/L Publications, 1967. A polemical work attempting to describe and criticize the beliefs of numerous religious groups both Christian and non-Christian. Pages 153-67 deal with Mormonism. The Anthon denial is cited as proof against the Book of Mormon and the author notes several absurdities and anachronisms. [M. R.]

R.273 Ridges, David J. Isaiah Made Easier: A Quick-Reference Manual for Bible and Book of Mormon Students. Springville, UT: Copies Plus Printing, 1991. Includes the text of Isaiah from the Bible and the Book of Mormon with parenthetical comments to help the reader understand various Hebraisms or literary devices. This work is reviewed in S.741. [E.G.]

R.274 Rigdon, John Wickliff. "Sidney Rigdon and the Early History of the Mormon Church." In Friendship, New York Sesqui Centennial Times, Sesqui Centennial Edition (July, 1965): 2-3. The only living son of Sidney Rigdon tells of Sidney Rigdon's conversion to the Church. He states that soon after his joining the Church, Sidney was accused of writing the Book of Mormon. Sidney always denied this allegation and the idea that he had known Solomon Spaulding. [J.W.M.]

R.275 Riggs, Timberline W. "What is the Book of Mormon and Who Was Joseph Smith?" In Riggs's A Skeptic Discovers Mormonism, 96-104. Salt Lake City: Deseret Book, 1946. Story of the coming forth of the Book of Mormon, with a testimony of its divine nature. [J.W.M.]

R.276 Riley, Isaac Woodbridge. The Founder of Mormonism: A Psychological Study of Joseph Smith, Jr. New York: Dodd, Mead, 1902. A work that attempts to understand the psychological and environmental factors that influenced Joseph Smith, his early visions, and the Book of Mormon. Chapter 4 and 5 introduce possible sources behind the Book of Mormon such as Joseph Smith, Sr's dream of the tree of life, Ethan Smith's View of the Hebrews, Elias Boudinot, Josiah Priest, the Westminster Confession, popular contemporary religious ideas, and others. Appendix II discusses the possibility that Joseph Smith was an epileptic, which would presumably explain his visions. Appendix III contains a discussion of the Spaulding-Rigdon theory and the author's reasons for rejecting it in favor of a psychological explanation. [M. R.]

R.277 Riley, Isaac Woodbridge. "The Sacred Books of the Mormons." Bookman 20 (September 1904): 80-82. A polemical article against Mormonism wherein the writer views Mormon beliefs as being somewhat antiquated. It is asserted that few Mormons have ever read the Book of Mormon. [M. R.]

R.278 Riley, William L. "A Comparison of Passages from Isaiah and Other Old Testament Prophets in Ethan Smith's 'View of the Hebrews' and the Book of Mormon." M.A. thesis, Brigham Young University, 1971. Compares the Book of Mormon and the View of the Hebrews. The parallels have also been studied by B. H. Roberts and Hugh Nibley, 
who say that any connections that may be made are also found in the Bible. The emphasis of this paper is on passages from Isaiah that are common to all three books. [J.W.M.]

R.279 Ritchie, Dwight C. "The 'Book of Mormon' Hoax: An Exposure of One of the World's Wickedest Religious Frauds." Hamilton, Montana: Vanity, 195?. Two-page paper claiming that Joseph Smith perpetrated a blunder on the basis of the characters shown to Charles Anthon. [D.M.]

R.280 Ritchie, Dwight C. The Mind of Joseph Smith: A Study of the Words of the Founder of Mormonism Revealing 24 Symptoms of Mental Derangement. Hamilton, MT: Ritchie, 1954. A psychological study of Mormonism's founder, with an attempt to demonstrate that the Book of Mormon is a forgery and that Joseph Smith was deranged. [M.R.]

R.281 Ritchie, William A. "Their Mouths Are Stopped with Dust." Archaeology 4 (September 1952): 136-44. Summary of the latest excavations in New York, providing the archaeological history of the state. Lists evidences supporting the movements of Book of Mormon peoples in New York. This work is reviewed in W.062. [E.G.]

R.282 Robbins, James H. "Readers' Research: The Question of Lehi's Lineage." ZR 5 (Summer 1979): 3-4. Suggests that Lehi's ancestors may have defected from the Northern Kingdom (2 Chronicles 11:16) and were assimilated into the tribes of the Southern Kingdom as an explanation to Book of Mormon critics that all Israelites knew their lineage and Lehi found his only by reading the brass plates. [A.T.]

R.283 Robbins, James H. "A Testimony: Scriptures of the Future." ZR 8 (Spring 1980): 7-8. Lists Book of Mormon passages that tell of scriptural writings that would come forth in a future day. Also includes a Three Nephite story. [A.T.]

R.284 Robe, Russell. Persuasion and Perplexity: A Faith-Promoting Analysis of Anti-Mormon Propaganda. Salt Lake City: Emblem Editions, 1990. Explains the motives and psychological structure of anti-Mormon communications. Offers advice to those who are troubled by faith-destroying rhetoric. [D.M.]

R.285 Roberts, B. H. "Accounting for Evident Transcriptions of Bible Passages in the Translation of the Nephite Record." In Roberts's Defense of the Faith and the Saints, 1:269-74. 2 vols. Salt Lake City: Deseret News, 1907, 1912. Joseph F. Smith answers the objection that some passages in the Book of Mormon follow the King James English translation verbatim and others so closely resemble it that it appears they were copied. It seems that it is of minor importance compared to the overwhelming evidence that the book is true. The Nephites did carry Old Testament records with them. Some portions were quoted by the Savior who carried the same message to both continents. When Joseph Smith recognized this fact he may have used the Bible to assist the translation process. [J.W.M.]

R.286 Roberts, B. H. "Analysis of the Book of Mormon." Contributor 10 (February 1889): 126-30. Reprinted in Scrap Book of Mormon Literature, compiled by Ben E. Rich, 1:154-61. 2 vols. Chicago, IL: Etten, 1913. Gives an analysis of the composition of the Book of Mormon, provides an explanation of Mormon's work of abridgment, identifies the contributors to the Book of Mormon text, and presents a comparison of the Book of Mormon Isaiah with the biblical Isaiah. [C.F.C.]

R.287 Roberts, B. H. Analysis of the Book of Mormon: Suggestions to the Reader. Salt Lake City: Deseret News Co., n.d. Examines the structure of the Book of Mormon-the first section of the Book of Mormon represents a verbatim translation of the "smaller plates" of Nephi and the remainder is an abridgment with comments, 
warnings, prophecies, and admonitions mixed with narrative by Mormon and his son Moroni. Compares biblical passages with similar verses quoted in the Book of Mormon. [J.W.M.]

R.288 Roberts, B. H. "Answers to Questions Respecting the Manual Theory of Translating the Book of Mormon." In Roberts's Defense of the Faith and the Saints, 1:275-311. 2 vols. Salt Lake City: Deseret News, 1907, 1912. In an effort to answer the rumor that the seer stones were responsible for the translation of the Book of Mormon, Roberts notes that the mechanical theory (word-for-word translation) has led to some difficulties-it often results in unintelligible jargon. The Book of Mormon is not a literal translation. Article contains additional theories with responses by Brother Roberts. [J.W.M.]

R.289 Roberts, B. H. "The Apostasy: Section IX. The Nephite Christian Church." In Roberts's Outlines of Ecclesiastical History: A Textbook, 215-18. Salt Lake City: Church of Jesus Christ of Latter-day Saints, 1950. Concise summary of the Nephite path from righteousness after Christ's visit to utter destruction and anarchy a few centuries later. Identifies pride, wealth, class distinctions, anti-Christian church persecution, the revival of Nephite/Lamanite distinctions and secret combinations, and an attempt at church reorganization as the factors that led to apostasy on the western hemisphere. [A.C.W.]

R.290 Roberts, B. H. "The Belief Among Christians that the Bible Contains All the Revelations Given to Man by God." MS 50 (1888): 344-47. Bible passages are used to refute the belief that the Bible contains all the revelation God has ever given to man. [B.R.M.]

R.291 Roberts, B. H. "The Belief Among Christians that the Canon of Scripture is Closed." MS 50 (1888): 330-35. Bible passages are used to show that revelation from God has not ceased, that prophecy continues in modern times, and that the Book of Mormon is a new witness for Jesus Christ brought forth through this modern revelation. Bible passages that have been used to cast doubt on the Book of Mormon are explained and the arguments refuted. [B.R.M.]

R.292 Roberts, B. H. "Bible Quotations in the Book of Mormon and the Reasonableness of Nephi's Prophecies." IE 7 (January 1904): 179-96. See also A Book of Mormon Treasury, 173-89. Salt Lake City: Bookcraft, 1959, 2nd edition 1976. Discusses the close similarities between the Sermon on the Mount in Matthew 5-7 and in 3 Nephi 12-14, and suggests that Joseph Smith used the available language of the New Testament to ease the burden of translating. [J.W.W.]

R.293 Roberts, B. H. "Book of Mormon." MS 50 (27 August 1888): 552-54. Affirms the need for a "New Witness" to confirm the divine nature and authenticity of the Bible. The Book of Mormon is the new witness and was translated by the "gift and power of God." [J.W.M.]

R.294 Roberts, B. H. "The Book of Mormon a Witness for the Christ." Liahona 27 (9 July 1929): 48. The Book of Mormon gives the account of the resurrected Christ visiting and teaching the ancient inhabitants of the western world. The purpose of the Book of Mormon is to convince both Jew and gentile that Jesus is the Christ, the Eternal God. [C.F.C.]

R.295 Roberts, B. H. "Book of Mormon Controversy." MS 50 (20 February 1888): 113-17. Roberts responds to Mr. Bolitho, who attempts to prove the Book of Mormon false by showing that the Book of Mormon dates of Christ's birth and death do not accord with the Bible. Roberts explains the possible differences between Nephite and Jewish calendrical systems, citing scripture and chronologists. [A.C.W.] 
R.296 Roberts, B. H. "The Book of Mormon Defended by B. H. Roberts." Deseret Evening News (5 December 1903): 21. Response to an accompanying article, "The Book of Mormon attacked by 'M.' " Roberts refutes common accusations that the Book of Mormon plagiarizes Shakespeare and the New Testament. [A.C.W.]

R.297 Roberts, B. H. Book of Mormon Difficulties. N.p., 1977. Collection of unpublished papers defending the Book of Mormon. Discusses linguistics, the question of the origin of the native Americans, the literature available to Joseph Smith when he translated the Book of Mormon, similarities between the Book of Mormon and Ethan Smith's View of the Hebrews, and the Christ figure in America. Roberts declares his faith in the Book of Mormon believing that in time God will vindicate it and all will know of its truthfulness though now they scoff. [J.W.M]

R.298 Roberts, B. H. "A Book of Mormon Study" (1922). In Studies of the Book of Mormon, edited by Brigham D. Madsen, 149-319. Urbana and Chicago: University of Illinois Press, 1985. A working paper raising questions for further research about possible relationships between the Book of Mormon and Ethan Smith's View of the Hebrews and other sources that explore the possibility that the American Indians were descendants of the lost ten tribes. [J.W.W.]

R.299 Roberts, B. H. "Book of Mormon Translation: Interesting Correspondence on the Subject of the Manual Theory." IE 9 (July 1906): 706-13. A response to an inquiry made concerning the theory of translation of the Book of Mormon as presented in the Senior Manual of 1905-1906. [B.R.M.]

R.300 Roberts, B. H. "The Book of Mormon: What the Record Contains." Liahona 14 (1916-1917): 1-2. A brief description of the Book of Mormon and its people, and a discussion of its purpose as a witness for Jesus Christ. [B.R.M.]

R.301 Roberts, B. H. "A Call to Repentance." IE 25 (December 1922): 159-65. America is a choice land and all who possess it must repent and serve God or be swept off. [B.R.M.]

R.302 Roberts, B. H. "Changing Emphasis Stressing the Deity of Christ and the Purposes of God in the Earth Life of Man." DN Church Section (24 December 1927): 5. The Book of Mormon shows that God spoke to the Jews in the Old Testament, the Christians in the New Testament, and the inhabitants of the American continents. A New Jerusalem or Zion is to be built up in the last days. The Book of Mormon declares the divinity of Christ and 3 Nephi is the fifth Gospel that declares that Christ appeared to the people of the New World after his resurrection. [C.F.C.]

R.303 Roberts, B. H. "Christ in the Book of Mormon: His Appearance on the American Continent." IE 27 (1924): 188-92. Reprinted as Roberts, B. H. "Christ in the Book of Mormon." In A Book of Mormon Treasury, 241-46. Salt Lake City, Bookcraft, 1959, 2nd edition 1976. Discusses the pre-mortal spirit life of Christ; the revelation of Christ to the brother of Jared; the Nephite knowledge of Christ through visions and revelations; and the visit of the risen Christ among the Nephites. [C.F.C.]

R.304 Roberts, B. H. "Christ in the Traditions of American Native Races." IE 20 (May 1917): 571-97. Native American traditions and beliefs are correlated with the birth and death of Jesus Christ and the Book of Mormon account of Christ's coming to the western hemisphere. [B.R.M.]

R.305 Roberts, B. H. "Christian Argument Applied to Mormonism." Liahona 26 (5 February 1929): 389-93. The angel Moroni visited Joseph Smith telling him of the records that contain an abridged history of the ancient 
inhabitants of America and the fullness of the gospel. Joseph Smith received the plates and translated them using the Urim and Thummim. Witnesses testified of the plates. [C.F.C.]

R.306 Roberts, B. H. "Christ's Personal Appearance in the Western Hemisphere: The Supreme Message of the Book of Mormon." IE 20 (April 1917): 477-99. Writes of a monument of Christ erected on the border of Argentina and Chile as a sign of peace between the two nations. Another monument of Christ, the LDS temple, was built in Hawaii. "Those who believe in the Book of Mormon also believe that this group of islands was colonized by certain adventurous people from the mainland of America [Hagoth, Alma 63]." These two monuments have been erected on a land that Christ once visited. [B.D.]

R.307 Roberts, B. H. A Comprehensive History of the Church of Jesus Christ of Latter-day Saints. 6 vols. Salt Lake City: Deseret Book, 1930. A history of the Church, including detailed discussions of the coming forth of the Book of Mormon, Joseph obtaining the plates, Lucy Mack Smith's description of the Urim and Thummim, the translation, Professor Anthon's letter, and the loss of the 110 pages of manuscript. Examines the mode of translation as reported by those who were near the prophet. Reports the testimony of the Three Witnesses and the Eight Witnesses, discusses anti-Mormon criticism and the excommunication of the Three Witnesses. Reveals details of the publication of the Book of Mormon, the efforts to thwart its publication, and other problems concerning the copyright. Provides an analysis of the purpose and structure of the book. Considers the conflict between Book of Mormon teachings and the revelation given to the Prophet on marriage. [J.W.W.]

R.308 Roberts, B. H. "Corianton." In A Scrapbook, edited by Lynn Pulsipher, 73-117. Provo, UT: Pulsipher, 1989. Also in Contributor 10 (1889): 324-30. Fictional account of Corianton, son of Alma the Younger, based on the Book of Mormon. Corianton is led astray by Korihor, repents and becomes a successful missionary, then is seduced by Isabel, who is disguised as a virtuous Nephite. Corianton repents once again after hearing his father's lecture. [A.C.W.]

R.309 Roberts, B. H. Corianton: A Nephite Story. Salt Lake City: n.p., 1902. A fictional narrative based on the Book of Mormon story of Corianton found in the book of Alma. [B.R.M.]

R.310 Roberts, B. H. "David Whitmer." Contributor 9 (March 1888): 169-72. Presents a history of David Whitmer's life, the circumstances of the viewing of the plates, his final testimony, the charges that he had denied his testimony, and his rebuttal. He is declared a faithful witness to his death. [J.W.M.]

R.311 Roberts, B. H. "David Whitmer." MS 50 (20 February 1888): 120-23. Reviews the life of David Whitmer who retained his testimony of the Book of Mormon until his death in 1888. [B.D.]

R.312 Roberts, B. H. Defense of the Faith and the Saints. 2 vols. Salt Lake City: Deseret News, 1907. Investigates the manner of translation of the Book of Mormon. The process seems to indicate great spiritual, mental, and physical effort had to be made on the part of the translator in connection with his use of the Urim and Thummim. A thorough examination is made of the Spaulding theory, the allegations that the Prophet Joseph had met secretly with Sidney Rigdon before the Book of Mormon's publication, and Rigdon's denials. The Book of Mormon originated as a sacred record of ancient inhabitants of America, preserved by the hand of God. [J.W.M.]

R.313 Roberts, B. H. "Destruction of Ancient Nations in America-The Book of Mormon Message to the Gentile Nations Occupying the Land." IE 27 (February 1924): 288-92. The Jaredite/Nephite nations were destroyed because of wickedness. America is a choice land and all who possess it must live righteously or be swept off of the 
land. The gentile nations who occupy America during the present era must worship God or be destroyed as were earlier inhabitants. [B.R.M.]

R.314 Roberts. B. H. "Direct Testimony of the Christ of Himself." DN Church Section (1 November 1930): 1. The appearance of the Savior to a group of people in the land Bountiful after his ascension into heaven (3 Nephi) was personal testimony of Christ himself. The people on the American continent were the "other sheep." [C.F.C.]

R.315 Roberts, B. H. "Doubling the Evidence for Faith." DN Church Section (18 October 1930): 1. The more evidence there is, the stronger faith will become. The Book of Mormon increases the evidence for supreme religious truths. Bringing forth this book may be said to double the divine evidence for these truths. This book is a new volume of scripture, the voice of the inhabitants of the western continent testifying that they were not neglected by God. [C.F.C.]

R.316 Roberts, B. H. "Doubling the Evidence of Faith." Liahona 28 (2 April 1931): 543. The Book of Mormon came forth at a time when there was a great need for faith. It is a record of God's personal dealings with the ancient inhabitants of America and its purpose is to convince the Jew and gentile that Jesus is the Christ, the Eternal God. [C.F.C.]

R.317 Roberts, B. H. "Eastertide in the Western Hemisphere A.D. 34." CN 1 (4 April 1931): 1, 8. Refers to the prophecy of Samuel the Lamanite about Christ's birth and the prophecy's subsequent fulfillment (3 Nephi 8-11). The Easter event in the western world was "established by ocular and auditory evidence." [A.C.W.]

R.318 Roberts, B. H. "Enlargement of Evidence for Faith." DN Church Section (11 October 1930): 1. Discusses John 10:14-16 where the Savior speaks of his other sheep. The Book of Mormon reveals that this other "fold" was the branch of Israel in America. [C.F.C.]

R.319 Roberts, B. H. "The Fifth Gospel." MS 67 (12, 19, 26 January; 2 February 1905): 17-20, 43-46, 52-55, 7578. Defines the contributions of 3 Nephi: the appearance of the risen Christ on the American continent, his ministry was not limited to the eastern hemisphere, he also visited the lost tribes of Israel and raised up prophets in the Americas who foretold his appearance. Roberts notes the distinction made between the Savior's remarks to the twelve and those to the multitude, and points out that 3 Nephi specifies the proper mode of baptism and the sacrament. [R.H.B.]

R.320 Roberts, B. H. "The Gospel is the Power of God unto Salvation and If Obeyed Will Redeem Men from the Bondage of Sin and Bring Them Life Eternal." DN Church Section (15 September 1928): 5. Defines "the Gospel” as the power of God unto salvation. It is salvation from death. All will be resurrected. When the resurrected Christ appeared to the Nephites he left a multitude of witnesses. [C.F.C.]

R.321 Roberts, B. H. "Higher Criticism and the Book of Mormon." IE 14 (June, July 1911): 665-77, 774-86. Also found in "Book of Mormon Essays by B. H. Roberts." Provo, UT: FARMS. Produces a Mormon view of the historicalcritical method of biblical source analysis. "The methods ... of higher criticism we recognize as proper; but we must disagree as to the correctness of many of the conclusions arrived at by that method." The author deals with the literary critics by delivering logic against logic, but also establishes the spiritual nature of the Book of Mormon. [D.W.P.]

R.322 Roberts, B. H. "His Final Decade: Statements about the Book of Mormon (1924-33)." Provo, UT: FARMS, 1990. A composite of Book of Mormon quotes made by Roberts in Church conferences, letters, and other works. 
Subjects include: understanding the implications of the "work of God," serving the Lord is a prerequisite for preserving America, the Book of Mormon is a witness of the truthfulness of the Bible, and many others. [J.W.M.]

R.323 Roberts, B. H. History of the Church of Jesus Christ of Latter-day Saints, Volume One. Salt Lake City: Deseret News, 1902. Contains the story of the coming forth of the Book of Mormon interspersed with journal entries, important footnote accounts, newspaper articles, accounts given to scribes, and commentary. Discusses Moroni's visit, the circumstances under which the records were delivered to the prophet, the attempts to steal them, the work of translation, Martin Harris's visit to Professor Anthon, the loss of the 116 pages of manuscript, the translation process, the restoration of the Aaronic Priesthood, the Witnesses of the Book of Mormon, copyright laws, and the publication of the book. [J.W.M.]

R.324 Roberts, B. H. "The Holy Ghost-Witness of the Father and of the Son." DN Church Section (31 January 1931): 1. Bearing witness of the Father and of the Son-and especially of the Son-seems to be the major function of the Holy Ghost, Supreme Witness for God (1 Nephi 12:18). [C.F.C.]

R.325 Roberts, B. H. "Jacob and Benjamin." In A Scrapbook, edited by Lynn Pulsipher, 68-71. Provo, UT: Pulsipher, 1989. Also in MS 50 (1888): 773-75. Short biographical sketches of Jacob and King Benjamin. Jacob saw the Redeemer in his youth and recorded the prophecy of Zenos. Benjamin was an able warrior and wise and industrious leader. [A.C.W.]

R.326 Roberts, B. H. "Jesus is God Revealed." DN Church Section (22 November 1930): 1. Christ is God manifested. If men would know God, all they have to do is hold up a clear vision of the Christ. Christ appeared to the people in Bountiful after his resurrection. [C.F.C.]

R.327 Roberts, B. H. "Jesus is the Christ-The Eternal God." Liahona 23 (1925): 29-31. Gives the purpose of the Book of Mormon; identifies Jesus Christ as deity and discusses the "Light of Christ." [C.F.C.]

R.328 Roberts, B. H. "Jesus the Creator." DN Church Section (6 December 1930): 1. Refers to Jesus as the "Creator of all things," as well as "the Father of Heaven and of Earth." This same thought is repeated in the Book of Mormon by Mosiah, Alma, Nephi, and Moroni in connection with the idea that Jesus is "the Creator." [C.F.C.]

R.329 Roberts, B. H. "Jesus the Redeemer." DN Church Section (13 December 1930): 1. Jesus came that he might redeem the children of men from the Fall, and because they are redeemed they are free (2 Nephi 2:22-27). Resurrection from the dead is as universal as death-therefore Jesus is referred to as the Redeemer. [C.F.C.]

R.330 Roberts, B. H. "Jesus the Savior." DN Church Section (20 December 1930): 1. Scriptural passages point out the difference in Christ as a "Redeemer" and Christ as a "Savior" (Alma 22:14; Helaman 15:18). Christ's work brings universal redemption from physical death through resurrection, and brings salvation from the effects of individual sin through faith and repentance. [C.F.C.]

R.331 Roberts, B. H. (Reported by Frank W. Otterstrom). "Latter-day Saints Have Important Message to Deliver Concerning Personality of God and Plan of Salvation." DN (27 May 1922): 12. Sets forth the necessity of sharing the restored gospel knowledge with others. Mormonism has a unique understanding of God and man's purpose. He expounds upon 2 Nephi 2:25; discusses the prophecies in the Book of Mormon concerning the gentiles and America. [A.C.W.] 
R.332 Roberts, B. H. "The Lord Hath Spoken." Brooklyn, NY: Eastern States Mission, May, 1923. A new tracting system is extended mission-wide. In tract number four, a description of the Book of Mormon by Joseph Smith is given. The tract also discusses the resurrected Christ in America, the sacrament of the Lord's Supper, the Book of Mormon as a "Fifth Gospel," "other sheep," the Book of Mormon as a witness for the Gospel as well as for the Christ, and baptism. [C.F.C.]

R.333 Roberts, B. H. "The Making of the Record Pertaining to the Natives of the Americas-the Location of the Record Revealed to Joseph Smith and Its Translation." MS 50 (1888): 393-97. A discussion of the origin of the Book of Mormon. It is an abridgment by Mormon from many other writings of ancient prophets and was hidden by Moroni in the Hill Cumorah; its location was revealed to Joseph Smith and he translated and published the book. [B.R.M.]

R.334 Roberts, B. H. "Man (3) Purpose of Man's Life." DN Church Section (7 March 1931): 1. "Men are that they might have joy" (2 Nephi 11:25-27). The resurrected man can die no more, his spirit and body will never be divided again, and thus will progress through the eternities if he wills it so (Alma 11:45). [C.F.C.]

R.335 Roberts, B. H. "Man (4) In What His 'Joy' Consists." DN Church Section (14 March 1931): 1. Joy comes from experiencing and knowing opposites, and then choosing the better part (2 Nephi 2:25). [C.F.C.]

R.336 Roberts, B. H. "Man (5) Free Agency of." DN Church Section (21 March 1931): 1. The doctrine of free agency is strongly set forth (2 Nephi 2:26-27; Alma 29:4). [C.F.C.]

R.337 Roberts, B. H. "The Manner of Translating the Book of Mormon." In Roberts's Defense of the Faith and the Saints, 1:255-69. 2 vols. Salt Lake City: Deseret News, 1907. Statements from Oliver Cowdery, David Whitmer, Martin Harris, and others regarding the Urim and Thummim and the manner in which the Book of Mormon was translated. [J.W.M.]

R.338 Roberts, B. H. "A Master Stroke of Philosophy in the Book of Mormon." DN Church Section (16 June 1928): 5. 2 Nephi 2:11-14 presents a brilliant philosophical discussion on the idea that there must be opposition in all things. The very existence of humanity depends upon these opposites. [C.F.C.]

R.339 Roberts, B. H. "Miriam: A Story of Zarahemla." In A Scrapbook, edited by Lynn Pulsipher, 247-61. Provo, UT: Pulsipher, 1989. Also in Contributor 10 (1889): 94-101. Fictional story, set in the time of Nephi, son of Helaman, in which the characters watch for signs of Christ's birth and receive great joy. [A.C.W.]

R.340 Roberts, B. H. (Reported by Joseph Anderson). "Modern Revelation Challenges Wisdom of Ages to Produce More Comprehensive Conception of the Philosophy of Life." DN (21 April 1923): 7. Adding to the five known philosophies of life, Epicureanism, Stoicism, Platonism, (fourth not mentioned), and Christianity is the sixth philosophy, or the Philosophy of God in the Dispensation of the Fullness of Times. It brings a unity to life. The teachings in the Book of Mormon, Pearl of Great Price, and Doctrine and Covenants clarify the meaning of life. [J.W.M.]

R.341 Roberts, B. H. "Mormon Views of America." In Roberts's Defense of the Faith and the Saints, 1:403-41. 2 vols. Salt Lake City: Deseret News, 1907. The Book of Mormon teaches that the two American continents are a promised land dedicated to the seed of Joseph and the gentile races, to be free from bondage if the inhabitants will but serve God, a sacred land where the New Jerusalem will be established. [J.W.M.] 
R.342 Roberts, B. H. (Reported by Frank W. Otterstrom). "Mormon View of the Atonement of Christ." DN (8 October 1910): 31. Tabernacle discourse explaining the LDS perspective on Jesus' role as the Savior of mankind. Quotes Nephi's words (2 Nephi 25), King Benjamin's speech, and modern revelation. Discusses the role of the twelve Nephite apostles, the role of faith, and the conditions of salvation. [A.C.W.]

R.343 Roberts, B. H. "Moroni: A Sketch of the Nephite Republic." Contributor 11 (1889-90): 15-18, 54-58, 81-85, 131-36, 164-68, 227-31, 262-66, 293-96, 335-88, 445-50. An account of the government and politics of the Nephites prior to and during the time of the Nephite republic as described in the book of Mosiah. Main emphasis is on Captain Moroni and his leadership. [B.R.M.]

R.344 Roberts, B. H. "The Mythology and Traditions of the Natives of the Americas; The Amazement of the Catholic Priests." MS 50 (1888): 360-63. Discusses the experiences of the Catholic priests who accompanied Cortez on his expedition to the Americas and conquest of the Aztecs. They discovered the Native American traditions and myths to be similar to their own traditions and rites of worship. [B.R.M.]

R.345 Roberts, B. H. "The Necessity of a New Witness." MS 50 (1888): 313-15. Describes why the Book of Mormon is needed as a new witness for God. [C.F.C.]

R.346 Roberts, B. H. "Nephi." In A Scrapbook, edited by Lynn Pulsipher, 65-67. Provo, UT: Pulsipher, 1989. Also in MS 50 (1888): 132-34. Short biographical sketch of Nephi 1 , showing his faith in and obedience to God. Nephi labored as an "agriculturist, miner, architect, builder, engraver, warrior, ruler, instructor, prophet, seer, and revelator." [A.C.W.]

R.347 Roberts, B. H. "A Nephite's Commandments to His Three Sons." IE 3 (June-September 1900): 570-78, 65357,760-66, 835-43. Also found in "Book of Mormon Essays by B. H. Roberts." Provo, UT: FARMS. The story of Alma the Younger's conversion. Just before he died, he delivered to his sons Helaman, Shiblon, and Corianton his "commandments," a father's advice and admonitions. Each son is different, and therefore Alma's advice was different for each of his sons. [C.F.C.]

R.348 Roberts, B. H. "A New Witness for God." Contributor 9-10 (July 1888-January 1889): 322-38, 377-402, 413-17, 457-63, 19-22, 48-54, 90-94. Cessation of revelation is contrary to the teachings of Christ. There is a vast amount of archaeological evidence to prove there were ancient civilizations in pre-Columbian America. The Christian theme known in ancient American mythology, symbols, and traditions suggests that God dealt with the western world the same as the eastern. The Book of Mormon reveals the story of these ancient people. Book of Mormon prophecies are being fulfilled; they bear witness of the divine authenticity of the Book of Mormon. [J.W.M.]

R.349 Roberts, B. H. New Witnesses for God. Salt Lake City: Deseret News, 1909, [R]1951. Extensive treatise on Joseph Smith as a witness for God, the coming forth of the Book of Mormon, Book of Mormon lands, peoples, government, evidences of the truth of the Book of Mormon, the Three Witnesses, philosophical considerations, and many other subjects advanced as secondary evidences in support of the truth of the Book of Mormon. [J.W.W.]

R.350 Roberts, B. H. "An Objection to the Book of Mormon Answered." IE 12 (July 1909): 681-89. An answer to the criticism that certain chapters of Isaiah were written after Lehi's departure from Jerusalem and thus could not have been included in the Book of Mormon. [B.R.M.] 
R.351 Roberts, B. H. "One More Ray of Light." DN Church Section (24 December 1927): 6. 2 Nephi 2:24-25 constitutes a great message to the world. The only way to obtain perfect wisdom is from perfect knowledge. [C.F.C.]

R.352 Roberts, B. H. "The Origin and History of the Native of the Americas - The Visitation of the Messiah." MS 50 (1888): 376-80. The Book of Mormon story of Lehi's flight from Jerusalem to the western hemisphere explains the origin of the native American people and their traditions and rites that are similar to Christian traditions and religious rites. [B.R.M.]

R.353 Roberts, B. H. "Origin of the Book of Mormon." American Historical Magazine 3-4 (1908-1909): 441-68, 551-80, 22-44, 168-96. See also Roberts's Defense of the Faith and the Saints, that stated the theory that Spaulding's Manuscript Found was the source from which the Book of Mormon originated. [B.R.M.]

R.354 Roberts, B. H. "Originality of the Book of Mormon." IE 8 (September/October 1905): 801-15, 881-902. Also found in "Book of Mormon Essays by B. H. Roberts." Provo, UT: FARMS. Shows that the Book of Mormon is original in its thoughts and ideas and is not the thoughts or philosophy of Joseph Smith and his associates. Discusses the doctrine of truth, the doctrine of opposite existences, the agency of man, the Atonement, the Fall of Adam, and the purpose of man's existence. [C.F.C.]

R.355 Roberts, B. H. A Parallel between the Book of Mormon and A View of the Hebrews by Ethan Smith. N.p., c. 1922. Reprinted in Studies of the Book of Mormon, edited by Brigham D. Madsen, 321-344. Urbana and Chicago: University of Illinois Press, 1985. A short summary of possible relationships between the Book of Mormon and the View of the Hebrews presented in "A Book of Mormon Study" (1922). [J.W.W.]

R.356 Roberts, B. H. "The Probability of Joseph Smith's Story." IE 7 (1904): 321-31, 417-32. Also found in "Book of Mormon Essays by B. H. Roberts." Provo, UT: FARMS. Events surrounding the translation of the Book of Mormon. The visitation of angels, the use of the Urim and Thummim to translate records, the giving of the gold plates back to the angel Moroni, and the loss of the 116 pages should not be looked upon as improbable. [C.F.C.]

R.357 Roberts, B. H. "The Prophecy Pertaining to There Being Three Witnesses-The Testimony of the Three Witnesses-Testimony of the Eight Witnesses." MS 50 (1888): 408-13. An explanation of why Joseph Smith never displayed the golden plates for public view to prove their authenticity. The Lord works by faith and establishes truth through the testimony of witnesses. Includes the testimonies and stories of the Three Witnesses and Eight Witnesses. [B.R.M.]

R.358 Roberts, B. H. "Purpose of Man's Creation." Liahona 28 (25 November 1930): 274. Alma says that after the resurrection there is no dissolution that takes place, but spirit and body become inseparably united into one spiritual personage, spirit predominating, and that is why the revelations say, "Man is spirit." [C.F.C.]

R.359 Roberts, B. H. "Ramah-Cumorah in the Land of Ripliancum." DN Church Section (3 March 1928): 8. The Hill Cumorah was recently purchased by the Church. Mormon hid all the records he had (Mormon 6:6), except the abridgment that he gave to his son Moroni. Some say that Moroni wandered from the Hill Ramah-Cumorah before depositing the records. [C.F.C.]

R.360 Roberts, B. H. Rasha the Jew: A Message to All Jews. Salt Lake City: Deseret News Press, 1932. First published as The Redeemed Hebrew, 1926. A message to all Jews that Jesus is the Christ, the Eternal God, and that a new witness to these truths has been brought forth. The Book of Mormon brings knowledge of Christ in the 
New World as it discusses the signs of his birth and death. The divinity of Christ is proclaimed in the Book of Mormon. The testimony of the Three Witnesses and the Eight Witnesses is given to prove that Joseph Smith had the ancient American record. [C.F.C.]

R.361 Roberts, B. H. "Recapitulation of the Foregoing Chapters-The Final Test of the Book of Mormon-The Author's Closing Testimony." MS 50 (1888): 456-61. A review of the prophecies concerning the Book of Mormon, the evidence of its authenticity, and the author's testimony to its truthfulness. [B.R.M.]

R.362 Roberts, B. H. (Reported by Frank W. Otterstrom) "The Relative Tax on Human Credulity between Ancient and Modern Dispensations of the Christian Religion." DN Church Section (1 December 1923): 6. A discourse proposing that disbelief in gospel truths and miracles is not unique to the latter days. The Book of Mormon verifies that Christ existed pre-mortally and testifies of the reality of his birth, death, resurrection, and divinity. [A.C.W.]

R.363 Roberts, B. H. "Remarks on the Foregoing Article (Mansfield's 'Jacob's Isle')." IE 7 (February 1904): $267-69$. A discussion of the meaning of the word "isle" as contained in biblical and Book of Mormon geography. Agrees with Mansfield that Jacob's reference to the lands of the Book of Mormon as an "isle of the sea" means a body of land (however large) reached by crossing an ocean. [B.R.M.]

R.364 Roberts, B. H. Roberts' Manuscripts Revealed: A Photographic Reproduction of Mormon History. Salt Lake City: Modern Microfilm, 1980. Reproduction of parts of B. H. Roberts's 1922 typescript work "A Book of Mormon Study." It is heavily edited to focus on Roberts's questions and concerns about the Book of Mormon, not his answers nor his testimony. [J.W.M.]

R.365 Roberts, B. H. The Seventy's Course in Theology: A Survey of the Books of Holy Scripture, Vol. 1. Dallas, TX: S. K. Taylor, 1907. Contains seven lessons on the Book of Mormon. Discusses the visitation of Moroni, and the translation and publication of the book. Includes an analysis of the contents, the purpose, and value of the Book of Mormon. [J.W.M.]

R.366 Roberts, B. H. "Sign of the Christ Birth in Western Hemisphere." DN Church Section (20 December 1930): 2. Reprinted as "First Christmas on Western Hemisphere." DN Church Section (23 December 1939): 1, 8. Retells the story of Samuel the Lamanite's prophecy to the Nephite people of the signs that would occur at Christ's birth in the Western Hemisphere. [D.W.P.]

R.367 Roberts, B. H. "Some Contributions of Mormonism to Modern Religious Thought." Deseret Evening News (8 December 1906): 31. States that the Book of Mormon is invaluable in expounding one's understanding of God's justice, mercy, doctrine and plan of salvation; applying such knowledge builds character. [A.C.W.]

R.368 Roberts, B. H. "Some Objections to the Book of Mormon Answered." IE 5 (March 1902): 339-50. Uses the Bible and historical records to answer alleged contradictions contained in the Book of Mormon regarding Christ being born at Jerusalem, the date of Christ's birth, and the three days of darkness that covered the earth at his crucifixion. [B.R.M.]

R.369 Roberts, B. H. "The Spaulding Theory of the Book of Mormon-The Theory That Sidney Rigdon Wrote the Book of Mormon." MS 50 (1888): 424-28. Argues against the Solomon Spaulding theory for the origin of the Book of Mormon and the idea that Sidney Rigdon wrote the Book of Mormon. [B.R.M.] 
R.370 Roberts, B. H. "The Spirit of the Book of Mormon." MS 67 (8 May 1905): 305-9. Describes the uplifting, enlightening, and inspirational aspects of the Book of Mormon. [R.H.B.]

R.371 Roberts, B. H. Studies of the Book of Mormon. Edited by Brigham D. Madsen with a biographical essay by Sterling M. McMurrin. Urbana, IL: University of Illinois Press, 1985. A collection of letters by B. H. Roberts concerning his work on the Book of Mormon in 1921-22, together with "Book of Mormon Difficulties: A Study" (1922) and "A Book of Mormon Study" (1922), with "A Parallel" (1927). The biographical essay praises Roberts as an honest and vigorous intellectual and emphasizes his concern about Book of Mormon questions for which no satisfactory answer had yet been found. Madsen and McMurrin find that B. H. Roberts seriously questioned the ancient authorship, the origin, the substance, the literary style, and the historical authenticity of the Book of Mormon. This work is reviewed in A.027, S.108, S.261, W.155, H.260, and in S.109. [J.W.W.]

R.372 Roberts, B. H. "Suggestions to the Reader of the Book of Mormon." MS 50 (27 August 1888): 534-58. Suggests that the reader remember that the Book of Mormon is an abridgment of records of a more extensive nature. The first one hundred fifty-seven pages, however, are the writings of Nephi and were inserted just as they came from the hand of Nephi and those kings who followed him. The latter part of the book was the work of Moroni, Mormon's son. The book must be read with real desire and a prayerful heart. The Holy Ghost will attend and confirm the divine origin of the book, but not in an imposing way-the reader must ask. [J.W.M.]

R.373 Roberts, B. H. "The Test of Joseph Smith Being a Prophet and of the Book of Mormon Being a Record from God." MS 50 (1888): 440-47. A discussion of prophecies in the Book of Mormon that have been fulfilled including those concerning the Three Witnesses, the Christian claim that there can be no more Bible, the words of Charles Anthon, and the martyrdom of some of its witnesses. [B.R.M.]

R.374 Roberts, B. H. "Testimony of the New Witness-The Book of Mormon." In A Scrapbook, edited by Lynn Pulsipher, 141. Provo, UT: Pulsipher, 1991. The heart of the Book of Mormon is its testimony of Christ. Prophets prophesied concerning his birth and death and their prophecies were fulfilled. Christ visited the people on the American continent after he was resurrected. [C.F.C.]

R.375 Roberts, B. H. "Translation of the Book of Mormon." IE 9 (April, May 1906): 425-36, 547-53. Roberts defends his theory about the role that the Urim and Thummim and Joseph Smith played in translating the Book of Mormon. He shows that literal translations are difficult or impossible in similar languages, and points out that it would be even harder from the Egyptian-like language of Mormon's plates. [K.M.]

R.376 Roberts, B. H. Untitled talk. CR (October 1901): 33-35. Joseph Smith had great courage in declaring that many would believe in the Book of Mormon. In the face of loneliness and persecution he dared to translate the Nephite record. The numerical count of those who believe its words is a fulfillment of this prophecy. [J.W.M.]

R.377 Roberts, B. H. Untitled talk. CR (4 April 1921): 120. God the Eternal Father and his son Jesus Christ appeared to Joseph Smith in a vision. The Book of Mormon, a new volume of scripture, was revealed. Three Witnesses testified that an angel showed them the original plates. [C.F.C.]

R.378 Roberts, B. H. Untitled talk. CR (6 October 1922): 14-20. Discusses the mission of the United States of America as a promised land, the decrees of God concerning the land of Zion, and predictions of calamities if it fails God as an instrument in the accomplishment of his high purposes. The gentile nation is to be a nursing father and mother to the remnants of Israel. [C.F.C.] 
R.379 Roberts, B. H. Untitled talk. CR (7 April 1923): 63-65. Discusses the purpose of the Book of Mormon as stated on the title page: "to the convincing of the Jew and Gentile that Jesus is the Christ, the Eternal God." God brought forth the Book of Mormon, which is being called the American scripture. At the time it came forth, the Christian world believed in the divinity of Christ and did not need such a statement, but there are many in the Christian world who now need a testimony and witness that Jesus Christ is God. [C.F.C.]

R.380 Roberts, B. H. Untitled talk. CR (7 October 1923): 88-92. Discusses the messages of the Book of Mormon. The Book of Mormon tells of the visit of the Redeemer to the inhabitants of the western world. It predicts the rise of the great Gentile nation-the United States of America. The Book of Mormon is a new witness for God and Christ and the truth of the gospel. [C.F.C.]

R.381 Roberts, B. H. Untitled talk. CR (April 1924): 76-80. Nephi had great visions concerning the life and the mission of Christ. He saw that other books would come forth-the Book of Mormon, the Doctrine and Covenants, and the Pearl of Great Price-to establish the truth of the record of the Twelve Apostles of the Lamb of God. [C.F.C.]

R.382 Roberts, B. H. Untitled talk. CR (October 1925): 144-50. Reprinted in IE (1926): 230-37. Answers the question that a little boy asked, "Why are people?" It cannot be answered in the Old or in the New Testament The Book of Mormon (2 Nephi 2:24-25) teaches the purpose of God in the creation. [C.F.C.]

R.383 Roberts, B. H. Untitled talk. CR (April 1927): 33-38. The Eastern States Mission is making an attempt to take the message of the Book of Mormon to the Jews. The book is to be a witness to the Gentiles and especially to Jews that Jesus Christ is the Son of God. Many shall believe in the Book of Mormon, and they shall carry the words of that book to the remnants of the land, meaning the American Indians. The Jews shall begin to believe in Christ, and they shall begin to gather in upon their promised land, Palestine. [C.F.C.]

R.384 Roberts, B. H. Untitled talk. CR (October 1927): 22-23. Moroni warns that anyone who should possess the land of promise must serve God or be swept off (Ether 2:9-12). [C.F.C.]

R.385 Roberts, B. H. Untitled talk. CR (April 1928): 106-13. Gives examples of truths the world would have lost if the Book of Mormon had not been brought forth (Alma 41:10; 2 Nephi 2:24-25; 1 Nephi 3:7; Ether 12:26-27). The Book of Mormon corrects some errors in the philosophies and religions of men. [C.F.C.]

R.386 Roberts. B. H. Untitled talk. CR (April 1929): 118-21. The Book of Mormon is an important means of acquainting the world with LDS thought. [C.F.C.]

R.387 Roberts, B. H. Untitled talk. CR (April 1930): 41-49. Refers to the Book of Mormon as the record of Joseph in the hands of Ephraim that supplies the world with a new witness for Christ and the fullness of the gospel. [C.F.C.]

R.388 Roberts, B. H. Untitled talk. CR (April 1932): 97. Talks about the role of witnesses. God gave the same commission to the Book of Mormon witnesses in the new dispensation as he did to the ancient witnesses. [C.F.C.]

R.389 Roberts, B. H. Untitled talk. CR (April 1933): 115-20. The United States of America is a choice land. There are two great prophecies in the Book of Mormon: it is a witness of the divinity of Christ, and it gives prophecies concerning the great gentile nation. If the Gentiles sin against the gospel, it shall be taken from among them. But if they will repent, they shall be numbered among his people. [C.F.C.] 
R.390 Roberts, B. H. "What the World Owes the Book of Mormon." MS 90 (4 October 1928): 625-30. A discussion of the value of the Book of Mormon, from its aphorisms to its powerful testimony of Jesus Christ and his resurrection. [B.R.M.]

R.391 Roberts, B. H. "Why Mormonism." Independence, MO: Missions of the Church of Jesus Christ of Latter-day Saints in America, 1932. Series of four pamphlets. Includes an account of revelations to Joseph Smith about the Book of Mormon, Book of Mormon doctrine on the purpose of life, the testimonies of its prophets, and an account of Jesus' visit to America. What is given in the Book of Mormon on the subject of Jesus Christ as deity is not surpassed by any other book of scripture. [E.G.]

R.392 Roberts, Bliss, and Mary Ann Roberts. Picture Scriptures: The Book of Mormon. Salt Lake City: Acorn, 1981. A guide for teaching children the Book of Mormon by using pictures and illustrations. [D.W.P.]

R.393 Roberts, Brian Curtis. "Stylometry and Wordprints: A Book of Mormon Reevaluation." M.A. thesis, Brigham Young University, 1983. Literary authorship analysis using stylometry and wordprints. Several contributors to the Book of Mormon were examined: Mormon, Nephi, Alma the Younger, Moroni, Jesus Christ, Jacob, and Isaiah. The 1830 edition was used. The conclusion is that the "results give every indication that there are multiple authors in the Book of Mormon." [J.W.M.]

R.394 Roberts, David L. The Angel Nephi Appears to David L. Roberts Series: The True Doctrine of Christ Restored, No. 8. Nashport, OH: Vanity, n.d. The founder of the True Church of Jesus Christ Restored claims to have had visitations of Nephi and Elijah. [D.M.]

R.395 Roberts, David L. The Nephite Record. Blacklick, OH: Vanity, 1974. The leader of the True Church of Jesus Christ Restored adapts this pamphlet on the contents and prophetic nature of the Book of Mormon from the series Rays of Living Light by Charles W. Penrose. Discusses the Anthon-Harris episode and prophecies by Isaiah and Ezekiel. [D.M.]

R.396 Roberts, Dorothy S. "The Book of Mormon Was My Answer." Ensign 18 (October 1988): 42-43. A conversion story of a young woman who had a recurring dream similar to that of Lehi's dream of the tree of life. Puzzled by its meaning over a period of years, she found her answer in the Book of Mormon. [J.W.M.]

R.397 Roberts, Richard C. "View of the Hebrews." In Encyclopedia of Mormonism, edited by Daniel H. Ludlow, 4:1509-10. 5 vols. New York: Macmillan, 1992. Describes the content and thesis of Ethan Smith's View of the Hebrews, and the possibility of a relationship with it and the Book of Mormon. I. Woodbridge Riley was the first to suggest a relationship; Mr. Couch asked the Church to respond and B. $H$. Roberts made a study of the issue. B. $H$. Roberts's work was published in 1985 by B. D. Madsen suggesting that B. H. Roberts was not faithful to the Book of Mormon. [B.D.]

R.398 Robertson, E. F. "Is the Book of Mormon True?" SH 76 (19 June 1929): 737-39. Maintains that the truthfulness of the Book of Mormon should be judged upon its moral teachings, not historical and geographical teachings. Robertson shows that the Book of Mormon teaches individuals to follow the will of God, remember him in prayer, obey his Son, honor one's father and mother, love one's family, care for the poor, and to regard one's fellow as an equal. [B.D.]

R.399 Robertson, LaRae Collett. You Can Be a Book of Mormon Expert in Five Minutes a Day. Bountiful, UT: Horizon, 1977. A study guide (instructional aid) that attempts to make the reader an expert on the Book of Mormon. The 
guide includes three parts-memorization of the basic contents of each chapter in the Book of Mormon, memorization of the reader's fifty favorite scriptures, and knowledge of important verses about Jesus Christ. [A.C.W.]

R.400 Robertson, Leroy J. "Oratorio from the Book of Mormon." Ph.D. diss., University of Southern California, 1954. A musical score for a large mixed chorus with solos for bass, baritone, tenor, and soprano parts accompanied by several instruments. This work is reviewed in D.142. [J.W.M.]

R.401 Robertson, Robert S. The Morman [sic] Question. Fort Wayne: Fortnightly Club, January 1901. Transcript of an address made January 7, 1901. Condemns "Mormans," but describes the plates, the Urim and Thummim, and the stone box that held the treasures. [J.W.M.]

R.402 Robertson, W. O. "The Book of Mormon Supported by Archaeology." SH 66 (10 September 1919): 889-90. Examples of how archaeological study may add to the "store of knowledge" and Book of Mormon study. [J.W.M.]

R.403 Robinson, C. H. "Ancient American Races." MS 50 (16 January 1888): 33-36. A report of Professor Chad H. Robinson's lecture on the ancient American races. At a Salt Lake City theatre he displayed five mummified OImec people that were discovered in Arizona. These mummies are of a white race that existed in ancient America. The article describes the discovery of manuscripts and artifacts in Central and South America that support the Book of Mormon. [B.D.]

R.404 Robinson, Christine H. "And the Book of Mormon and the Holy Scriptures Are Given of Me for Your Instruction." Relief Society Magazine 46 (December 1959): 845-46. The Lord has preserved the scriptures for the inspiration and instruction of his children. This divine preservation is particularly evident in the Book of Mormon. The Nephite prophets tell of the importance of the brass plates and the records they kept. We show appreciation by reading their records. [J.W.M.]

R.405 Robinson, Ezra C. Zalmonah, from Book of Mormon History: Prologue and Four Acts. Bountiful, UT: n.p., n.d. A fictionalized play (based on Ether 8-9) characterizing Omer, Akish, Jared, Zalmonah (Jared's daughter), and the struggle for the Jaredite throne. Comprises a prologue and four acts. [A.C.W.]

R.406 Robinson, Harry A. "Book of Mormon Notes: Book of Mormon Priesthood Reviewed." SH 85 (18 June 1938): 781-82, 787. It must not be supposed that the Book of Mormon people had the Melchizedek Priesthood before Christ. The Mosaic law was regulated under the Aaronic priesthood, there is no evidence that the law was practiced under Melchizedek Priesthood authority and that sacrificial offerings were performed by other than Aaronic priesthood holders. Alma speaks of the priesthood after the Order of the Son of God in past tense language. [J.W.M.]

R.407 Robinson, Harry A. B. "Brother Alma, the Younger." Book of Mormon News-Letter. 2 vols. San Antonio, TX: Bob's Printing Service, 1949. Focuses on Lehi's speech to his household-the historical setting, Lehi's covenant and prophecy. Adds some notes on archaeological evidence and the achievements of the Mayans. [J.W.M.]

R.408 Robinson, Harry A. B. Know Your Book of Mormon. San Antonio, TX: The Brothers Alma, 1947. Identified as a "synchronic, chronological study of the Book of Mormon." Contains historical highlights, illustrations, notes, and comments. [D.W.P.] 
R.409 Robinson, Harry Alma. "The Time System of the Book of Mormon." SH 75 (29 February 1928): 249. The time system in the Book of Mormon was based upon astronomical observations. Many of these observations are found within the book itself. The primitive inhabitants of Mesoamerica possessed a knowledge of astrology on which their dating system was based. [J.W.M.]

R.410 Robinson, J. A. "Ancient America Contributes to the Health and Comfort of the World." SH 82 (8 October 1935): 1294. Describes how two herbs-cascara sagrade and quinine-have helped current civilization. He sees this as a contribution made by the descendants of Book of Mormon peoples. [A.T.]

R.411 Robinson, John. "The Nephite Priests of the Melchizedek Order and Their Twelve Ministers." SH 76 (16 January 1929): 59-62. Argues that nobody held the Melchizedek Priesthood after Moses until John the Baptist (JST Exodus 34:1, and D\&C 83:4). Thus, Book of Mormon prophets before Christ's coming did not hold the Melchizedek Priesthood, only the Aaronic Priesthood. The twelve whom Christ set apart to minister on the American Continent were disciples, not apostles, and acted under the authority of the twelve apostles in Jerusalem. [B.D.]

R.412 Robinson, John A. "The Book of Mormon." SH 85 (10 December 1938): 1583-84. It has been more than a century since the Book of Mormon was published. It has been published in sixteen languages. Archaeological evidences support the Book of Mormon. [J.W.M.]

R.413 Robinson, John A. "Book of Mormon Notes." SH 82 (23 April 1935): 524-25. The Mayan Indians achieved advanced scientific achievements in mathematics, astronomy, and with their calendar system. Robinson quotes Book of Mormon passages to show that Book of Mormon peoples possessed the same skills. He defends the 600 B.C. departure date of Lehi against the assertion that 613 b.c. was the Mayan calendar's starting date. [A.T.]

R.414 Robinson, John A. "Book of Mormon Notes: 'The First American Church." SH 84 (7 August 1937): 1009. The Lord's Church was organized from the very time that Lehi landed on the western shores of America and built a temple. [J.W.M.]

R.415 Robinson, John A. "Book of Mormon Notes: The Gadianton Robbers." SH 81 (20 November 1934): 1481, 1484. Likens the Gadianton robbers to modern organized crime. Claims that the "author and founder" of the Gadianton robbers is Satan. [J.W.M.]

R.416 Robinson, Stephen E. "Early Christianity and 1 Nephi 13-14." In The Book of Mormon: First Nephi, The Doctrinal Foundation, edited by Monte S. Nyman and Charles D. Tate Jr., 177-91. Provo, UT: Brigham Young University Religious Studies Center, 1988 The apocalyptic vision of Nephi (1 Nephi 13-14), when combined with the vision of John the Revelator, helps to draw greater historical conclusions about the great and abominable church and the apostasy. [A.T.]

R.417 Robinson, Stephen E. "The 'Expanded' Book of Mormon?" In The Book of Mormon: Second Nephi, The Doctrinal Structure, edited by Monte S. Nyman and Charles D. Tate Jr., 391-413. Provo, UT: Brigham Young University Religious Studies Center, 1989. A rebuttal to a theory proposed by Blake Ostler in "The Book of Mormon as a Modern Expansion of an Ancient Source" as well as other scholarly attacks on the Book of Mormon, including the suggestion that the Book of Mormon relies on Armenian and Anselmic theories. Ostler's claim is based on disallowance of predictive prophecy. Robinson explains how "pre-Christians" could prophecy of Christ, and points out fallacies in Blake's syllogisms. [A.C.W.] 
R.418 Robinson, Stephen E. Review of Early Mormonism and the Magic World View, by D. Michael Quinn. BYU Studies 27 (1987): 88-95. Book review.

R.419 Robinson, Stephen E. Review of The Word of God: Essays on Mormon Scripture, edited by Dan Vogel. Review of Books on the Book of Mormon 3 (1991): 312-18. Book review.

R.420 Robinson, Stephen E. "Warring against the Saints of God." Ensign 18 (January 1988): 34-39. Those who war against Zion, God, and the Saints of God are those who belong to the church of the Devil or the great and abominable church. This article discusses the apostasy of Christ's church after his death and the death of the apostles, and compares the apocalyptic references (including John's Revelation) to the apostasy in 1 Nephi 13-14. Terms and identities relating to the great and abominable church both historically and topologically are defined and discussed. [A.A.]

R.421 Robison, Lindon J. "Economic Insights from the Book of Mormon." Journal of Book of Mormon Studies 1 (Fall 1992): 35-53. Economic systems are distinguished by their emphasis on equity and efficiency. Most countries of the world today have adopted a combination of controls and free-market incentives. The Book of Mormon teaches that only through caring can equity and efficiency be simultaneously achieved. [R.H.B.]

R.422 Robison, Pamela Kaye. Abinadi, Man of God. Independence, MO: Herald House, 1981. An illustrated storybook for children. Features an account of Abinadi, his preaching, and eventual martyrdom. [A.C.W.]

R.423 Robison, Pamela Kaye. Alma. Independence, MO: Herald House, 1985. A fictional account of Alma 1 who fled the presence of King Noah and followed the prophet Abinadi. [D.W.P.]

R.424 Robison, Pamela Kaye. Limhi, Son of Noah. Independence, MO: Herald House, 1989. A retelling of how Limhi, one of the sons of King Noah, determined to do right against all odds. [J.W.M.]

R.425 Robison, Stanford. The Maya Legacy: A Sequel to the Book of Mormon. Las Vegas: Author, 1977. Robinson wishes to tell "the tragic story of the Maya Lamanite who was forsaken by the Lord. It tells of his past, his present, his future, and [the Latter-day Saints'] obligation to this neglected branch of Lehi's family. It is a true story gleaned from historical, archaeological, and sociological facts, and is woven in and around the Book of Mormon narrative." Includes two fold-out maps. [A.C.W.]

R.426 Rodriguez De Fuentes, Carmen. "A Lamp unto My Feet." Ensign 23 (October 1993): 68-69. The author testifies that numerous times in her life the Book of Mormon has guided her in making decisions and given her comfort. [S.H.]

R.427 Rogers, John Thomas. "The Book of Mormon." In Rogers's Communicating Christ To The Cults, 28. Schaumburg, Illinois: Regular Baptist Press, 1983. Argues that the teachings of the Book of Mormon contradict Mormon doctrines. [J.W.M.]

R.428 Rogers, Thomas F. "Thoughts about Joseph Smith: Upon Reading Donna Hill's Joseph Smith: The First Mormon." In By Study and Also by Faith, edited by John M. Lundquist and Stephen D. Ricks, 2:585-618. Salt Lake City: Deseret Book and FARMS, 1990. Members of the Church need to examine the historical accounts of Joseph Smith with an open view, weigh and evaluate the evidence before coming to the conclusion that he was a charlatan. The Book of Mormon contains principles that are not taught anywhere with such clarity. [J.W.M.] 
R.429 Rogers, Thomas L. "The Mormons." Sunday Afternoon 3 (April 1879): 289-99, 415-21. A polemic against the LDS church. Declares the Book of Mormon to be a plagiarized version of the Spaulding manuscript. [J.W.M.]

R.430 Rogerson, Ken. "Channeling T.V. Viewers to the Book of Mormon." Ensign 21 (October 1991): 73-74. The response to the T.V. campaign that offered a free Book of Mormon was so great that additional books had to be ordered. [J.W.M.]

R.431 Rolapp, Henry H. Two Thousand Gospel Quotations, from the Bible, Book of Mormon, Doctrine and Covenants, and Pearl of Great Price. Salt Lake City: Deseret Book, 1918. 2nd edition, Gospel Quotations from the Bible, Book of Mormon, Doctrine and Covenants and Pearl of Great Price. Salt Lake City: Deseret Book, 1923. Includes some 2000 scriptural quotations from the LDS canon arranged according to topic. Topics include the Holy Trinity, man's preexisting relationship with God, Satan and his work, the fall of man, free agency, the Atonement, apostasy from and restoration of the gospel, the Book of Mormon, continuous revelation, priesthood, missionary work, gospel principles and ordinances, the gathering of Zion, and the Second Coming of Christ. [A.C.W.]

R.432 "Role of Sunday School Defined." CN 43 (13 October 1973): 15. President Lee, in telling the role of Sunday School, emphasizes that the Book of Mormon is the keystone of the Church and the most correct book on earth. [M.D.P.]

R.433 Rollins, Kerril Sue. "The Book of Mormon in Hindi, Tamil, and Telugu." Ensign 13 (February 1983): 78-79. A news account announcing the publication of a translation of the entire Book of Mormon in Hindi, and Book of Mormon selections in Tamil and Telugu-"three of the most widely spoken languages in India." Briefly recounts the stories of the translation work in all three languages. [S.P.S.]

R.434 Rollins, Kerril Sue. "The Book of Mormon in Polish." Ensign 12 (June 1982): 74-75. A news account of the translation and publication of the Book of Mormon in Polish. Tells the story of Maria Krolikowska, a polish convert to the Church, and the experiences that prepared her for her calling as the principle translator for the project. [S.P.S.]

R.435 Rolph, Daniel N. "Prophets, Kings, and Swords: The Sword of Laban and Its Possible Pre-Laban Origin." Journal of Book of Mormon Studies 2 (Spring 1993): 73-79. Relates Nephi's and the Three Witnesses' descriptions of the sword of Laban and swords used in the Book of Mormon, and discusses other important swords in Israelite and pre-Israelite tradition. Suggests that the sword of Laban may be one of the swords of Israelite tradition. [A.T.]

R.436 Romney, Joseph B. "Moroni, Angel." In Encyclopedia of Mormonism, edited by Daniel H. Ludlow, 1:953. 5 vols. New York: Macmillan, 1992. A brief description of the angel Moroni who appeared to Joseph Smith September 21, 1823, visited with him on many occasions, and committed the plates to him. [B.D.]

R.437 Romney, Joseph B. "The Savior's Ministry on 3 Nephi-A Pattern for Conversion." In A Symposium on the Book of Mormon, 113-15. Salt Lake City: Church of Jesus Christ of Latter-day Saints, CES, August 1986. 3 Nephi produces a six part pattern for conversion that includes receiving a testimony of Christ, acceptance of the first principles and ordinances of the gospel, and acceptance of the principles of the Sermon on the Mount. [A.T.]

R.438 Romney, Marion G. "America's Fate and Ultimate Destiny." In Brigham Young University 1976 Devotional and Fireside Speeches of the Year, 317-31. Provo, UT: Brigham Young University Press, 1977. Explains how the United States of America is a choice and favored land by the Lord, gives historical insights as to America's divine guidance 
in the past, and explains how the Nephites and Jaredites were not permitted to remain on the land in their wicked state. [A.C.W.]

R.439 Romney, Marion G. "And the Lamanites Shall Blossom as the Rose." IE 66 (June 1963): 498-501. The Lamanites are promised that the covenants made to their fathers will be fulfilled, that a remnant would receive the Book of Mormon, and would associate with other members of the house of Israel in the building of their inheritance in the land of America. [J.W.M.]

R.440 Romney, Marion G. "Atonement-Justice-Mercy." CR (October 1974): 52-56. The Book of Mormon teaches the doctrines of salvation, including the Atonement of Christ, a literal resurrection, the judgment, and justice and mercy. [R.C.D.]

R.441 Romney, Marion G. "The Book of Mormon." Ensign 10 (May 1980): 65-67. Also CR (April 1980): 87-91. Those who read the Book of Mormon and possess its teachings will be judged according to what is written in it. The Church is under condemnation because it has taken lightly the teachings of the book. [J.W.M.]

R.442 Romney, Marion G. "The Book of Mormon." IE 52 (May 1949): 283, 328-30. The Book of Mormon is a witness of the truthfulness of the Bible and is a fortification against modernists who attack the Bible. [J.W.M.]

R.443 Romney, Marion G. "The Church in Mexico." IE 61 (June 1958): 460-64. The Book of Mormon is the promised sign that the work of the Lord has begun among all nations. "We may draw a lesson from the history of the Mexican people and their progenitors," as it is outlined in the Book of Mormon. [J.W.M.]

R.444 Romney, Marion G. "Conference Report, October 7, 1970." In Book of Mormon Talks by General Authorities, 187-89. Provo, UT: FARMS, 1990. Romney testifies of the truth and importance of the Book of Mormon and shows how it purely testifies of Jesus Christ, from the first to the last chapter. [B.D.]

R.445 Romney, Marion G. "Conference Report, April 6, 1975." In Book of Mormon Talks by General Authorities, 2034. Provo, UT: FARMS, 1990. In this discourse Romney emphasizes the importance of the Book of Mormon. The Lord himself said it is true (D\&C 19:26). It is the most correct book on the earth. If youth are familiar with the teachings of the Book of Mormon they will be able to make correct choices when pressured by their peers. [B.D]

R.446 Romney, Marion G. "Conference Report, October 4, 1975." In Book of Mormon Talks by General Authorities, 208-10. Provo, UT: FARMS, 1990. Romney asks, "Can we maintain our basic freedoms, peace, and prosperity for another 200 years?" Yes, he responds, and the Book of Mormon tells how. Ether 2:15 explains that the American continent is a land of promise. [B.D.]

R.447 Romney, Marion G. "Discovering the Book of Mormon." NE (May 1975): 23. Reprinted in Book of Mormon Talks by General Authorities, 205. Provo, UT: FARMS, 1990. Shows that the Book of Mormon teaches faith, courage, and how to receive a forgiveness of sins. [B.D.]

R.448 Romney, Marion G. "Drink Deeply From the Divine Fountain." IE 63 (June 1960): 435-36. Encourages Church members to read the Book of Mormon because the book will fill the reader's mind with "the waters of life," remind him/her of spiritual truths, bring great blessings into the home, cause children and parents to respect once another, and arm the reader against the faulty teachings of the world. [J.W.M.] 
R.449 Romney, Marion G. "Keystone of Our Religion." CN 41 (23 January 1971): 16. Tells that the Book of Mormon is the keystone of the LDS religion, and that Church members need to become familiar with its teachings. [M.D.P.]

R.450 Romney, Marion G. "The Keystone of Our Religion." IE 73 (December 1970): 51-57. Reaffirms that the purpose of the Book of Mormon is to bear witness of Jesus Christ. [J.W.M.]

R.451 Romney, Marion G. "Look to God and Live." IE 65 (December 1962): 944-45. The gospel of Jesus Christ is the answer to all the world's problems. We can "look to God and live" (Alma 37:47). Alma knew the consequences of running counter to that advice. There are three requisites for looking to God: a true knowledge of God, a knowledge of his commandments, and obedience to the commandments. [J.W.M.]

R.452 Romney, Marion G. The Missionary and the Book of Mormon. Salt Lake City: n.p., 1970?. A tract prepared for full-time missionaries that argues that the "Book of Mormon is the most effective piece of missionary literature we have." [D.W.P.]

R.453 Romney, Marion G." 'Mormon' Church Nick-name." CR (April 1979): 71-75. The name "Mormon Church" is a nickname that came from the Book of Mormon prophet called Mormon who abridged most of the materials of the Book of Mormon. [R.C.D.]

R.454 Romney, Marion G. "My Church Shall Be Called In My Name." IE 64 (June 1961): 432-35. Also in CR 131 (April 1961): 116-20. Acceptance of the Book of Mormon requires acceptance of modern revelation and Joseph Smith as a prophet of God. The Church received its name from Jesus Christ, as he said in 3 Nephi 27 and D\&C 115:3-4. [J.W.M.]

R.455 Romney, Marion G. "The Oath and Covenant Which Belongeth to the Priesthood." Ensign 10 (November 1980): 43-45. Priesthood bearers can obtain eternal life only by magnifying their callings. This is achieved by obtaining knowledge-particularly from the Book of Mormon-by complying to the standards of the gospel, and by dedicated service. [J.W.M.]

R.456 Romney, Marion G. "A Pure Heart and Clean Hands." In Look to God and Live, edited by George J. Romney, 261-73. Salt Lake City: Deseret Book, 1971. Expounds on several verses from Alma's discourse on the gospel in Zarahemla (Alma 5). Features a mixture of doctrine and application. [D.M.]

R.457 Romney, Marion G. "Read the Book of Mormon." In Learning For The Eternities, edited by George J. Romney, 81-86. Salt Lake City: Deseret Book, 1977. Romney lists many reasons why individuals should read the Book of Mormon: to substitute the lusts of the world with the things of the Spirit, to anchor one's own children in Christ, to "find the plainest explanation of Christ's divine mission," and to learn the folly of putting trust in the treasures and learning of the world. [J.W.M.]

R.458 Romney, Marion G. "Remember Book of Mormon Teachings." CR (April 1980): 87-91. There are many reasons for Latter-day Saints to read and study the Book of Mormon: the Lord has commanded them to do so, they will be judged by its teachings, it will help them avoid evil and continually meditate upon God, and it will greatly assist youth and families to remain strong and faithful. [R.C.D.]

R.459 Romney, Marion G. "Repentance and Forgiveness." CR (October 1980): 69-73. True repentance, followed by baptism and laying on of hands for the gift of the Holy Ghost, with faith in Christ's Atonement, always brings 
forgiveness. This truth is most clearly taught in the Book of Mormon. [R.C.D.]

R.460 Romney, Marion G. "The Role of the Indian." In BYUSY (15 February 1971). Provo, UT, 1971. Also in Book of Mormon Talks by General Authorities, 190-97. Provo, UT: FARMS, 1990. Discusses the establishment of Zion on the American Continent. The descendants of Joseph, through the lineage of Lehi, will be the builders of Zion with the assistance of the Gentiles. Several Book of Mormon scriptures show the role of the Lamanites in building Zion. [B.D.]

R.461 Romney, Marion G. "The Standard Works of the Church." Relief Society Magazine 56 (June 1969): 406-11. The Book of Mormon is one of the four standard scriptural works of the Church. It was translated by Joseph Smith, is the "keystone of our religion," and the world will be judged by its contents. [J.W.M.]

R.462 Romney, Marion G. Untitled talk. CR (April 1958): 125-29. One message of the Book of Mormon is that the Lamanites were once a favored people of the Lord and they will again be redeemed. Another message is that the inhabitants of all nations must repent or be destroyed. [B.D.]

R.463 Romney, Marion G. Untitled talk. In Official Report of the First Mexico and Central America Area General Conference of the Church of Jesus Christ of Latter-day Saints, Mexico City, Mexico, August 25-27, 1972, 133-37. Salt Lake City: Church of Jesus Christ of Latter-day Saints, 1973. Deals with the teachings of the Book of Mormon, the organization of the Church, and the prophet Moroni, and bears testimony of the Book of Mormon. The Book of Mormon clearly explains that the inhabitants of Mexico share the heritage of the House of Israel. [L.D.]

R.464 Romney, Marion G. "Using the Book of Mormon in Missionary Work." CR (April 1960): 110-13. The Book of Mormon is the most effective missionary tool in the Church. Those who read it daily will increase spirituality, protect their families from all types of evil, and draw closer to God. [R.C.D.]

R.465 Romney, Marion G. "A Warning to America." CR (October 1975): 51-55. The Book of Mormon declares America to be a choice land of freedom, peace, and prosperity, and it will remain a choice land only if its inhabitants are righteous. [R.C.D.]

R.466 Rona, Herbert. Call of the Prophets. Salt Lake City: Visual Arts, 1952. A play based upon Book of Mormon characters and situations. [A.C.W.]

R.467 Root, Azariah S. The Spaulding Manuscript in the Oberlin College Library. Oberlin Library, 12 May 1927. Typewritten statement by an Oberlin College librarian concerning the Spaulding manuscript in Oberlin's possession. [D.M.]

R.468 Roper, Matthew. Review of Covering Up the Black Hole in the Book of Mormon, by Jerald and Sandra Tanner. Review of Books on the Book of Mormon 3 (1991): 170-87. Book review.

R.469 Roper, Matthew. Review of Mormonism: Shadow or Reality? by Jerald and Sandra Tanner. Review of Books on the Book of Mormon 4 (1992): 169-215. Book review.

R.470 Roper, Matthew. Review of "The Priority of Mosiah: A Prelude to Book of Mormon Exegesis," by Brent Lee Metcalfe, from New Approaches to the Book of Mormon, edited by Brent Lee Metcalfe, 395-444. Review of Books on the Book of Mormon 6/1 (1994): 362-78. Book review. 
R.471 Roper, Matthew. Review of The Truth about Mormonism: A Former Adherent Analyzes the LDS Faith, by Weldon Langfield. Review of Books on the Book of Mormon 4 (1992): 78-92. Book review.

R.472 Ropp, Harry L. The Mormon Papers: Are The Mormon Scriptures Reliable? Downers Grove: InterVarsity Press, 1987. Examines the Mormon church's claim to divine authority to determine if the "extrabiblical scriptures the Mormons hold sacred are really the Word of God." Looks at the theories concerning the origin of the Book of Mormon, including the idea that Joseph Smith wrote it himself, the Spaulding/Rigdon theory, and the View of the Hebrews theory. Shows changes in various editions in an attempt to discredit the book. Believes that Book of Mormon geography is a myth. This work is reviewed in W.392 and in Y.008. [A.T.]

R.473 Ropp, Harry L., with revisions from Wesley P. Walters. Are the Mormon Scriptures Reliable? Downers Grove, IL: InterVarsity, 1977. An earlier edition of The Mormon Papers: Are the Mormon Scriptures Reliable? by the same author. [A. T.]

R.474 Ross, John, and Thomas Ross. Scriptural Lessons Taken from the Book of Mormon. Monongahela: Church of Jesus Christ of Latter-day Saints, 1949. A Sunday School instructional aid comprising sixty lessons beginning with the Jaredites and concluding with the book of Moroni. Each lesson includes a retelling of a portion of the Book of Mormon and questions. [A.C.W.]

R.475 Rossiter, Ernest Crabtree. Te Buka A Mormona. Papeete, Tahiti: LDS Church, 1919. A 44-page work that features a series of questions and answers about the Book of Mormon. [D.W.P.]

R.476 Roundy, Phyllis Ann. "Mormon." In Encyclopedia of Mormonism, edited by Daniel H. Ludlow, 2:932-33. 5 vols. New York: Macmillan, 1992. Mormon was the abridger of the gold plates, leader of the Nephite armies, and father of Moroni. The article describes his writings in the Book of Mormon. [B.D.]

R.477 Rowland, Linda. "Chiasmus Settles the Question." ZR 44 (August 1989): 6-7. Testimony that chiasmus in 2 Nephi 2 validates the authenticity of the Book of Mormon. [A.C.W.]

R.478 Royall, Paul F. Nephi in the Promised Land/Wilderness: A Book of Mormon Story Book to Color. 2 Vols. Salt Lake City: Deseret Book, 1973-74. A children's coloring book with a Book of Mormon story line. [D.W.P.]

R.479 Royall, Paul F. "That Our Children May Know." Ensign 1 (October 1971): 6-8. The Book of Mormon is a book of remembrance of the teachings of the fathers designed to teach the children of Lehi about Christ. This book of remembrance is to be supplemented by our own, which should record written testimonies, spiritual experiences, and genealogies of family members. [J.W.M.]

R.480 Roylance, Glen M. "When Men Seek Independence From God." In The Sixth Annual CES Religious Educators Symposium on the Book of Mormon, 82-85. Salt Lake City: Church of Jesus Christ of Latter-day Saints, 1982. Humility is singled out as the quality that keeps an individual most dependent on God. The author uses fictional stories, a poem, and an example of Korihor to show what happens when man trusts in the arm of flesh. [A.T.]

R.481 Royle, J. C. "Faith and Credulity." The Earnest Worker 6 (December 1883): n.p. The Book of Mormon has come forth to test the credulity of the world. Attempts to show that Joseph Smith is not a credible witness. Favors the Spaulding theory. Alleges that during printing parts of the Book of Mormon were lost and could not be duplicated. [J.W.M.] 
R.482 "Ruins Recently Discovered in Yucatan Mexico." TS 4 (November 1842): 15-16. Reports of ruins of temples, castles, and pyramids adorned with reliefs and frescos. Many of the buildings were oriented eastward and possessed walls that were finished with a hard composition like concrete. It was thought that these ruins were archaeological evidences of the Book of Mormon. [J.W.M.]

R.483 "The Rule of Kings Abolished." Relief Society Magazine 5 (November 1918): 647-49. Mosiah sought to teach his people that great iniquity and destruction characterizes the rule of monarchs. [J.W.M.]

R.484 Rumble, Leslie. "The Book of Mormon." Homiletic and Pastoral Review 60 (December 1959): 227-37. A polemical article against the Book of Mormon. The author gives a brief summary of the Book of Mormon narrative and several Christian doctrines included in the book. While admitting that some ancient peoples wrote on metal plates he rejects Joseph Smith's account as an unlikely fiction. He discounts the testimonies of Book of Mormon witnesses on the grounds that they only experienced the things with their spiritual eyes and that it was not a literal experience. [M.R.]

R.485 Rumble, Leslie. "The Book of Mormon." Homiletic and Pastoral Review 60 (January 1960): 338-45. A polemical article against the Book of Mormon. Author considers numerous environmental influences Joseph Smith could have drawn upon: Ethan Smith's View of the Hebrews, plagiarized biblical passages, anti-Catholic influences, anti-Masonry, revival language, Westminster Confession, and others. He appeals to the "automatic unity" theory in order to explain the speed of composition of the Book of Mormon. He alleges that Book of Mormon Isaiah passages quote errors in the King James translation of the Old Testament. He considers anachronistic the assertion that steel, the compass, and horses were known in Book of Mormon times. [M.R.]

R.486 Rumble, Leslie. The Mormons or Latter-day Saints. St. Paul, Minn: Radio Replies Press, 1950. A polemical work against the Book of Mormon. The author discusses the Anthon denials and other alleged anachronisms in the Book of Mormon such as the pre-Columbian presence of certain domesticated animals in America such as the horse, cow, and ox. The Book of Mormon quotes Shakespeare, the Westminster Confession of faith, and plagiarizes the New Testament. [M.R.]

R.487 Rumble, Leslie. A Reply to the Mormon Counter Attack. St. Paul, Minn: Radio Replies Press Society, 1956?. A rebuttal to the works of several apologists from the Reorganized Church of Jesus Christ of Latter Day Saints that attacked Rumble's earlier work, The Mormons or Latter-Day Saints. [M R.]

R.488 Rushton, J. W. The Apostasy and the Restoration. Independence, MO: Herald House, 1957. A pamphlet containing a reprint of articles published in the Saints Herald in October 1903. The Book of Mormon was an important part of the Restoration. [J.W.M.]

R.489 Rushton, J. W. "The Apostasy and the Restoration, Part Two." SH 50 (21 October 1903): 986-89. The Book of Mormon was an important part of the Restoration, as it revealed the origin and the fullness of the gospel delivered to the former inhabitants of America. When Moroni appeared to Joseph Smith to reveal the location of the plates, he quoted many Bible prophecies that the book would fulfill. [J.W.M.]

R.490 Russell, John A. Prehistoric Discoveries in Wayne County Michigan. Detroit, MI: 1911. Tells about an excavation in Wayne County, Michigan that may have a bearing on Book of Mormon archaeology. [D.M.]

R.491 Russell, William D. "Beyond Literalism." In The Word of God: Essay in Mormon Scripture, edited by Dan Vogel, 43-54. Salt Lake City: Signature Books, 1990. Also in Dialogue 19 (Spring 1986): 57-68, and in Restoration Studies 
IV, edited by Marjorie B. Troeh and Eileen M. Terril, 192-201. Independence, MO: Herald House, 1988. An assertion that the Mormons (both LDS and RLDS) are uncritical and naive in their use and interpretation of scripture. For Russel "a prophet's canonical utterances are limited by his humanity and by the culture of which he is a part." The scriptures need not be interpreted literally. For the writer, the Book of Mormon is not an ancient document but rather contains "the thought of the founding prophet just prior to the organization of the Church." Much of the theology of modern Mormonism is incompatible with Book of Mormon teachings. [M.R.]

R.492 Russell, William D. "A Further Inquiry into the Historicity of the Book of Mormon." Sunstone 7 (September 1982): 20-27. In an effort to make "serious inquiry" and "revise our assertions" about the historical account in the Book of Mormon, this RLDS writer asserts that Mormons must be honest and open-minded in their investigations. Two problems in the Book of Mormon examined in this article are: Do the ideas of Lehi and Nephi harmonize with the ideas of Israel at the time of their exodus in 600 b.c.? And there is an improbability that the Savior would have delivered the same sermon to both the Old and New World such as the Sermon on the Mount. [J.W.M.]

R.493 Russell, William D. "The Historicity of the Book of Mormon and the Use of the Sermon on the Mount in III Nephi." In Restoration Studies II, edited by Marice L. Draper and A. Bruce Lindgren, 193-200. Independence, MO: Temple School, 1983. Believes the stories in the Book of Mormon are non-historical and lists several alleged anachronisms in the Book of Mormon, such as deutero-Isaiah, nineteenth-century elements, the tower of Babel, and textual problems with the Book of Mormon's use of the Sermon on the Mount. [M.R. \& D.W.P.]

R.494 Russell, William D. "The Historicity of the Book of Mormon: The Thought of Pre-Exilic Israel and I \& II Nephi Compared." In John Whitmer Historical Association Presidential Address, 129-49. Lamoni, IA: John Whitmer Historical Association, 1977. First demonstrates the manner in which the Book of Mormon is consistent with biblical pre-exilic thought, then shows dissimilarities between the two. Author believes he has found anachronisms in the Book of Mormon and concludes that the book is fiction. [D.W.P.]

R.495 Russell, William D. "History and Mormon Scriptures." Journal of Mormon History 10 (1983): 53-63. The writer notes what he feels are several anachronisms in the Book of Mormon, including Christian theology, preexilic Israel, the remarkable precision with which Book of Mormon prophets predict New Testament events, and uniquely American ideas and concerns. While the Book of Mormon may be inspired, it contains no ancient history. [M.R.]

R.496 Russell, William D. Review of Investigating the Book of Mormon Witnesses, by Richard Lloyd Anderson. Dialogue 16 (Summer 1983): 130-31. Book review.

R.497 Russell, William D. Review of The Voice of One Crying in the Wilderness: Sidney Rigdon, Religious Reformer, 1793-1876, by F. Mark McKiernan. BYU Studies 13 (1973): 584. Book review.

R.498 Rust, Richard Dilworth. "All Things Which Have Been Given of God . . . Are the Typifying of Him: Typology in the Book of Mormon." In Literature of Belief: Sacred Scripture, edited by Neil E. Lambert, 233-43. Provo, UT: Brigham Young University Religious Study Center, 1981. "Holds that the Book of Mormon fulfills its basic mission of testifying of Christ through a 'pervasive typology' as well as by its direct statements, prophecies, and quotations. He defines typology, discusses Book of Mormon teachings regarding it, and then shows its application to Book of Mormon individuals, groups, and objects - with the golden book itself a type of Christ, the ultimate treasure." [A.T.]

R.499 Rust, Richard Dilworth. "The Book of Ether: A Warning For the Last Days." Ensign 18 (December 1988): 1819. Terming the book of Ether a parable based on actual history, this author points out six divisions in the text that 
begin with the phrase, "And now I, Moroni...." The preface to the Book of Ether is in the last two chapters of Mormon. It clearly instructs of faith, the danger of secret combinations, and how a nation that turns from Christ is destroyed. It is a pattern for this day. [J.W.M.]

R.500 Rust, Richard Dilworth, "The Book of Mormon, Designed for Our Day." In Review of Books on the Book of Mormon 2 (1990): 1-23. The literary elements in the Book of Mormon create an experience that motivates and teaches the reader. The epic structure gives the Lamanites a sense of their heritage and shows them how to achieve their greatest potential. Another literary element is Hebrew poetry that relates the covenantal relationship between God and man. Literary elements combined with the spirit are designed to teach the Lamanites of their heritage and the covenants of the Lord, and to convince the Jews and Gentiles that Jesus is the Christ. [J.W.M.]

R.501 Rust, Richard Dilworth. "Book of Mormon Imagery." In Rediscovering The Book of Mormon, edited by John L. Sorenson and Melvin J. Thorne, 132-39. Salt Lake City: Deseret Book and FARMS, 1991. The Book of Mormon is filled with images that appeal to the senses and paint graphic pictures in the mind. There are six main contrasting images: fire (that both purifies and destroys), light and darkness, captivity and deliverance, wilderness or wandering, water or fruitfulness, and dust. [J.W.M.]

R.502 Rust, Richard Dilworth. "Book of Mormon Poetry." NE 13 (March 1983): 46-50. An introductory report on scriptural poetics directed toward the teenage audience. Identified are the principal types of parallelisms, i.e., synonymous, synthetic, antithetical, and staircase parallelisms. [D.W.P.]

R.503 Rust, Richard Dilworth. " 'I Know Your Doing': The Book of Mormon Speaks to Our Times." Ensign 18 (December 1988): 15-18. The Book of Mormon was written anciently specifically for our time with "historical realities" that are "prophetic parallels" significant to us. There are patterns and types that are "custom-made" for Lehi's seed, Jews, and Gentiles, with urgent calls to each group and with the overall message to come to Christ. [J.W.M.]

R.504 Rust, Richard Dilworth. "Poetry in the Book of Mormon." In Rediscovering the Book of Mormon, edited by John L. Sorenson and Melvin J. Thorne, 100-13. Salt Lake City: Deseret Book and FARMS, 1991. Understanding Hebrew poetry enhances the study of the Book of Mormon. There are many examples of parallelistic and chiastic structures that make the teachings and prophecies of the Lord more memorable and meaningful. Some passages of the book are reformatted to reveal their poetic structure. [J.W.M.]

R.505 Rust, Richard Dilworth. "Purpose of the War Chapters in the Book of Mormon." In Warfare in the Book of Mormon, edited by Stephen D. Ricks and William J. Hamblin, 29-32. Salt Lake City: Deseret and FARMS, 1990. The author notes that the largest battle in the first 570 years of Nephite history is covered in two sentences, some wars are covered in one, and others have extensive coverage. Mormon edited history to provide today's world with valuable lessons. One lesson seems to be that a small, faithful, righteous group aided by God can gain victory over large armies. Further it shows the folly of war and how iniquity brings on the destruction of peoples. [N.K.Y.]

R.506 Rust, Richard Dilworth, and Donald W. Parry. "Book of Mormon Literature." In Encyclopedia of Mormonism, edited by Daniel H. Ludlow, 1:181-85. 5 vols. New York: Macmillan, 1992. A wide variety of literary forms and Hebrew poetry are found in the Book of Mormon, including memorable narratives, rhetorically effective sermons, diverse letters, allegory, figurative language, imagery, symbolic types, and wisdom literature. Examples of each are given. The Book of Mormon is a spiritually and literarily powerful book that is direct yet complex, simple yet profound. [N.K.Y.] 
R.507 Ruthven, Malise. The Divine Supermarket: Shopping for God in America. New York: William Morrow and Company, 1989. A book on religious experience in America. Devotes a chapter to the Book of Mormon, stating various theories of its origin. [D.M.]

R.508 Ruthven, Malise. "The Mormons' Progress." Wilson Quarterly (Spring 1991): 23-47. Discusses many aspects of the LDS religion including a section describing Joseph Smith's experiences in bringing forth the Book of Mormon. [D.M.]

R.509 Rytting, Paul. "Mosiah." In Encyclopedia of Mormonism, edited by Daniel H. Ludlow, 2:960-61. 5 vols. New York: Macmillan, 1992. States who Mosiah2 was, how long he reigned, and what reforms he instituted. Before he died, instead of appointing a new king, he established a system of paid judges to govern the people. [B.D.] 
S.

S.001 S. "Origin of the Indians." Juvenile Instructor 16 (1 April 1881): 81-82. Gives seventeen reasons listed by Lord Kingsborough why the Indians are Israelites. [D.M.]

S.002 S., A. F. "Hebrew Culture of American Indians." SH 101 (2 August 1954): 750. Latter-day Saints are not unique in their belief that the Indians have Hebrew origins. Quotes The History of the American Indian by James Adair (1775) to support this claim. [A.C.W.]

S.003 S., H. C. "The Spalding Romance." Journal of History 2 (January 1909): 89-95. A series of communications between A. T. Schroeder and D. H. Bays that appeared in the Christian Evangelist, 9 Aug. 1899-2 Nov. 1899, discussing the possibility that the Spaulding manuscript was the basis of the Book of Mormon. [J.W.M.]

S.004 S., J. M. "Book of Mormon Evidence." MS 79 (24 May 1917): 328-30. Archaeological evidence that horses existed in ancient America supports the Book of Mormon. Evidence of advanced textile art confirms statement of "all manner of fine linen." [A.C.W.]

S.005 S., J. M. "Confirming the Book of Mormon." MS 79 (4 January 1917): 8-10. The Book of Mormon teaches of ancient connections between Asia and America. The article quotes G. Elliot Smith, who theorizes that a cultural migration took place from Egypt to ancient America, c. 900 b.c., citing archaeological evidence. [A.C.W.]

S.006 S., J. M. "Indians Becoming White and Delightsome." MS 79 (February 1917): 72-74. Argues that the Indians of North and South America are making spiritual and "material progress" and becoming "white and delightsome," thus fulfilling a prophecy of the Book of Mormon. [D.W.P.]

S.007 S., J. Z. "The Book of Mormon." MS 42 (19 April 1880): 246-47. Old Indian and Spanish histories that are preserved in Mexican libraries and museums provide evidence of the divine authenticity of the Book of Mormon. [J.W.M.]

S.008 S., L. D. "Interesting Relics of an Ancient People." SH 54 (1 May 1907): 380-81. A reprint of an article written in the Register and Leader by E. H. Robb who finds that America has been inhabited from a very early period of time, which recalls the statements of the Book of Mormon concerning the Nephites and Jaredites. [J.W.M.]

S.009 S., L. P. "The Choice Seer-Who Is He?" The Rod of Iron 1 (June 1924): 22-24. Analyzes 2 Nephi 3 and finds that a choice seer will be a blessing to the descendants of Lehi. The choice seer may be Jesus Christ, whose work was the Book of Mormon. [J.W.M.]

S.010 S., L. P. "The Work of This Dispensation." The Rod of Iron 1 (May 1924): 17-19. The mission of the Book of Mormon and the work of this dispensation is to save souls, to gather Israel, to teach the covenants of God, and to build Zion. [J.W.M.]

S.011 Sabin, Joseph, and W. Eames. "Joseph Smith." In Bibliotheca Americana: A Dictionary of Books Relating to America from Its Discovery to the Present Time, 20:303-29. 27 vols. New York: The Bibliographical Society of America, 1927. The different editions of the Book of Mormon known to the authors of this dictionary are cited, with an annotation describing peculiarities. [B.D.] 
S.012 Sainsbury, C. L., Lyle L. Smith, Forest Morrisett, David L. Veal. "The 'International Timeline' and Mormon Theology." Biblical Archaeology Review 14 (July-August 1988): 10-11, 15. Letters to the editor defend or condemn the advertising of a historical time chart containing biblical and Book of Mormon events. Some maintain that the events of the Book of Mormon do not represent a historical reality, while others believe that the events do represent reality. [J.W.M.]

S.013 Saints Alive. Archaeology Proves the Book of Mormon? Concord, CA: Pacific, 1982. The Book of Mormon's claim that it is a record of God's people in America cannot be sustained by archaeological evidence. Members of the LDS church approach archaeology only in an amateur way. [J.W.M.]

S.014 "Saints Must Study." CN 45 (12 April 1975): 6. Ezra Taft Benson gave a speech saying that every member of the Church should make studying the Book of Mormon a lifetime pursuit. [M.R.]

S.015 Sakuth, F. A. Why Was Joseph Smith A False Prophet? Salt Lake City: Tribune Printing Co., 1903. Author considers it his duty to warn humanity of the dangers of the Church and its false prophet. Joseph Smith was given power to translate the Book of Mormon by God and no other gift was given to him. [J.W.M.]

S.016 Salter, Melvin Sam. The Lord's Promise from Moroni 10:4-5. Sunland, CA: Salter Music, 1957. In this four part song, written in the key of D flat Major, Salter uses the words of Moroni 10:4-5 exhorting the listener to ask God if the Book of Mormon is true. [A.C.W.]

S.017 Salter, Melvin Sam. 'Ye Are They': One of the Sacred Sacramental Songs ... on Doctrinal Subjects of the Church of Jesus Christ of Latter-day Saints. Sunland, CA: Salter Music, 1957. This song, written in the key of F Major for a soprano voice, uses the text of 3 Nephi 15:21-24, which states that the Nephites are the other sheep of whom Jesus spoke in John 10:16. [A.C.W.]

S.018 Salyards, R. S. "The Lord's Prayer in the Book of Mormon." SH 98 (26 February 1951): 202-3. An examination of the Lord's prayer in the Book of Mormon. Believes that Joseph Smith did not copy the Bible in translating the Book of Mormon. [A.C.W.] ook of Mormon. Believes that Joseph Smith did not copy the Bible in translating the Book of Mormon. [A.C.W.]"

S.019 Salyards, R. S. "Original Manuscript of Book of Mormon." SH 52 (22 March 1905): 281-83. Presents a history, description, and photographs of the original manuscript of the Book of Mormon. [J.W.M.]

S.020 Salyards, R. S., Sr. "The Book of Mormon-Its Origin, Nature, and Purpose." SH 84 (17 April 1937): 493-499. Also published as a pamphlet, The Book of Mormon; Its Origin, Nature, and Purpose. A Record of Two Great Civilizations of Ancient America. Independence, MO: Herald House, 1968. Presents notes concerning the origin of the Book of Mormon. The nature of the book is sacred history as well as profane history, it teaches morality and spiritual truths, and it presents a perfect philosophy of life. Its primary purposes are to witness of the divinity of Jesus Christ and to combat the controversies that exist between the Bible and the modern philosophies of men. [J.W.M.]

S.021 "Samuel, the Lamanite Prophet." Young Woman's Journal 31 (December 1920): 695-705. Recreates the drama of Samuel the Lamanite's mission to the Nephites. Continues with discussions about Jesus' appearance to the Lehites. [D.M.]

S.022 Słnchez, JosŽ. "Bibliograf’a Selecta del Libro de Morm-n." In Słnchez’s El Libro de Morm-n Ante La Cr'tica, 461-69. Salt Lake City: Publishers Press, 1992. A select bibliography of books on the Book of Mormon. Its purpose 
is to inform and stimulate Spanish-speaking writers to contribute to the body of fictional and scholarly work on the Book of Mormon. [B.D.]

S.023 Słnchez, JosŽ. "El Libro de Morm-n y Yo." In El Libro de Morm-n Ante la Cr'tica, edited by JosŽ Słnchez, 477-81. Salt Lake City: Publishers Press, 1992. A testimony of the author about the Book of Mormon. [B.D.]

S.024 Słnchez, JosŽ. "Las Traducciones y Ediciones del Libro de Morm-n al Espa-ol." In El Libro de Morm-n Ante la Cr'tica, edited by JosŽ S $¥ n c h e z, 45-65$. Salt Lake City: Publishers Press, 1992. S $¥ n c h e z$ describes the different editions and translations of the Book of Mormon in Spanish from the first edition printed in August, 1875. S $¥ n$ chez describes the many obstacles that hindered the work of translation. [B.D.]

S.025 Słnchez, JosŽ. "MuŽstrenme a un 'Lamanita.'” In El Libro de Mormon Ante la Critica, edited by JosŽ S łnchez, 257-300. Salt Lake City: Publishers Press, 1992. Słnchez asserts that "Lamanites," as the Book of Mormon defines them, do not exist today. He writes that to generally apply the term "Lamanite" to the descendants of Joseph of a whole continent is historically incorrect and must stop. [B.D.]

S.026 Słnchez, JosŽ, ed. El Libro de Morm-n Ante la Cr'tica. Salt Lake City: Publishers Press, 1992. Contains essays on the Book of Mormon including JosŽ Słnchez, "Las Traducciones y Ediciones del Libro de Morm-n al Espa-ol”; JosŽ Słnchez, "MuŽstrenme a un 'Lamanita' "; JosŽ Słnchez, "Bibliograf'a Selecta del Libro de Mormn”; JosŽ Słnchez, "El Libro de Morm-n y Yo"; Mark L. Grover, "Bibliograf’a de la Iglesia Mormona en LatinoamŽrica”; and a small "Encuesta S-bre el art'culo MuŽstrenme a un 'Lamanita, ” compiled by Słnchez. [B.D.]

S.027 Santiago. "Prehistoric Races of Arizona." Contributor 10 (April 1889): 204-6. There is much evidence of an ancient civilization in Arizona. The legends that surround these people closely resemble the story of the Nephites chronicled in the Book of Mormon. [J.W.M.]

S.028 Santiago. "The Title of Liberty." Contributor 11 (1889-1890): 312-13. A poem about Moroni and the Title of Liberty. [A.T.]

S.029 "The Savior in America." Instructor 77 (April 1942): 185-86. An Easter message that includes an extensive quotation from 3 Nephi concerning the appearance of Jesus Christ in America. [R.H.B.]

S.030 "Savior Set Forth Requirements for His True Church When He Spoke to the Ancients." CN 58 (15 October 1988): 10. Jesus Christ declared to the ancient Nephites that his Church must meet two requirements: It must bear his name (3 Nephi 27:8), and it must be built upon his gospel (3 Nephi 27:9-10). [R.H.B.]

S.031 Sawyer, John. "What Was a Mosia?" Provo, UT: FARMS, 1965. The Hebrew word Mosia» (Savior) denotes "a champion of justice in a situation of controversy, battle, or oppression." In Old Testament usage it refers to someone who holds a specific office or position. The Book of Mosiah tells of one Mosia» (Savior) after anotherAlma, Zeniff, and King Mosiah. It is unknown whether Mosiah was always called such or he was given the title after he delivered his people from war by escaping the land of Nephi. [J.W.M.]

S.032 Sbresny, M. A. Mormonism: As It is Today: Some Striking Revelations. London: Stockwell, 1911. A polemical work against Mormonism. The writer notes what he perceives to be several anachronisms in the Book of Mormon, asserting that there is not a "scrap of evidence" in support of the antiquity of Book of Mormon names. The Book of Mormon is merely the "production of an over-imaginative mind." [M.R.] 
S.033 Scharffs, Gilbert W. "Responses and Replies: Answers to Questions About the Church of Jesus Christ of Latter-day Saints." Salt Lake City: Author, 1986. A self-published manuscript that poses several questions and provides answers to questions regarding Book of Mormon archaeology, witnesses, changes in the several editions, and the coming forth of the Book of Mormon. [D.W.P.]

S.034 Scharffs, Gilbert W. The Truth About "The God Makers." Salt Lake City: Publishers Press, 1986. Responds to charges made against Mormonism in the book The God Makers. Some charges that pertain to the Book of Mormon are that Mormon doctrine is not based on the Book of Mormon or the Bible, much of the Book of Mormon is copied from the Bible, Book of Mormon prophets quoted New Testament prophets, the Book of Mormon contains many contradictions, and various others. These are refuted by LDS teachings. [J.W.M.]

S.035 Scharffs, Gilbert W. "Unique Insights on Christ from the Book of Mormon." Ensign 18 (December 1988): 812. The Book of Mormon features many unique insights concerning Jesus Christ and his gospel that are not contained in the Bible. They include specific teachings about Christ's Atonement, the plan of salvation, the Lord's relationship to mankind, free agency, the necessity of grace and works, affirmation of the truthfulness of the Bible, Jesus' eminent position as Jehovah, his priesthood, and his latter-day work. The Book of Mormon witnesses that Jesus is the Christ. [A.A.]

S.036 Scharffs, Horst. "One Hundred Pounds of Potatoes." Ensign 19 (July 1989): 52-53. Discusses a personal testimony of a boy who used his faith in the Book of Mormon to pray for strength. [L.D.]

S.037 Schenck, Joseph. Itzamna, the Dew of Heaven. St. Louis, MO: Vanity, 1968. Itzamna the Dew of Heaven, the blonde, blue-eyed god of the ancient Mayan civilization, has qualities that recall the life and mission of Jesus Christ. [J.W.M.]

S.038 Schenck, Joseph. Temples in the Sky (Archaeological Evidence Relative to the Book of Mormon). St. Louis, MO: Vanity, 1966. Includes numerous photographs and maps, demonstrating that the archaeological ruins of Latin America have an affinity with Egyptian culture, and correlate with the Book of Mormon. [D.M.]

S.039 Schlesinger, Philip J. Isaiah and the Book of Mormon. N.p., 1990. A commentary on Isaiah passages in the Book of Mormon, written by a Jewish convert. This work is reviewed in L.211. [D.M.]

S.040 Schneider, Johann. "The Dream Seemed Meaningless." Ensign 19 (September 1989): 66. A long-forgotten dream comes true when two LDS missionaries teach Johann and Margrit Schneider about the Church and the Book of Mormon. Reading the book brought a realization that the book and the Church were true. [J.W.M.]

S.041 Schobinger, Juan. "La arqueolog'a y el Libro de Morm-n." Anales de Arqueolog'a y Etnolog'a 16 (1961): 25965. Notes briefly some problems he sees with the Book of Mormon and archaeology: the horse did not exist in Mesoamerica contemporaneously with the Nephites; natives with white skin and beards migrated in the PaleoMesolithic period; there are no remains of the Middle-Eastern seeds the Nephites planted (1 Nephi 18:25); many aspects of Nephite culture are not evidenced by archaeology. [B.D.]

S.042 Schofield, K. "Missionary Book Report." Friend 18 (September 1988): 34. Cartoon message for children. A nine-year-old boy presents a book report on the Book of Mormon in his school, impressing his teacher to the point that she desires to read it. [J.W.M.] 
S.043 "The Scholar and the Book of Mormon." Relief Society Magazine 10 (September 1923): 433-34. Scholarly critics of the Book of Mormon, found in large numbers on college campuses, try to discredit the divine origin of the Book of Mormon. [J.W.M.]

S.044 Schoonmaker, Rachael. "BYU Students Relive the Trek." CN 58 (2 January 1988): 11. Students of Brigham Young University walk from Jerusalem to the Red Sea to relive "Lehi's Trek." [M.D.P.]

S.045 Schroeder, Albert Theodore. Authorship of the Book of Mormon, Psychologic Tests of W. F. Prince Critically Reviewed. New York: Albert Theodore Schroeder, n.d. Reprint of article in American Journal of Psychology 30 (1919): 66-72, wherein Schroeder replies to Walter F. Prince, who conducted rigorous psychological tests of the Book of Mormon and the Spaulding manuscript and concluded that it is doubtful that the two works had any connection. Schroeder disagrees with the conclusions of Prince, and reaffirms his position that the Book of Mormon was produced in collaboration with Sidney Rigdon, Parley P. Pratt, Oliver Cowdery, and perhaps Emma Smith, Hyrum Smith, and Joseph Smith. [J.W.M.]

S.046 Schroeder, Albert Theodore. "The Origin of the Book of Mormon." American Historical Magazine 1 (JanuaryNovember 1906): 380-96, 518-33. Desires to demonstrate the Spaulding origin of the Book of Mormon. In spite of the rediscovery of Spaulding's manuscript by President Fairchild, Schroeder proposes that there was a "second" Spaulding manuscript from which Joseph Smith plagiarized in writing the Book of Mormon. [M.R.]

S.047 Schroeder, Albert Theodore. "The Origin of the Book of Mormon." In B. H. Roberts's Defense of the Faith and the Saints, 2:11-91. Salt Lake City: Deseret Book, 1912. Reprint of a series of articles published in American Historical Magazine (September/November, 5 January 1907). When critically viewing the Book of Mormon, three areas of focus must be discussed, (1) Evidence to support its divine origin, (2) internal evidence, and (3) Joseph Smith's ability/inability to produce such a work. The author addresses the latter, suggesting that Sidney Rigdon had access to a second manuscript by Solomon Spaulding. Sidney stole that manuscript and, with Parley P. Pratt and Joseph Smith, rewrote the manuscript and published it as the Book of Mormon. [J.W.M.]

S.048 Schroeder, Albert Theodore. The origin of the Book of Mormon re-examined in its relation to Spaulding's manuscript found. Salt Lake City, n.p., 1901. Provides a brief history of Solomon Spaulding and proposes that a second, re-written, Spaulding manuscript formed the basis for the Book of Mormon. [M.R.]

S.049 "Schroeder Throws More Mud." SH 48 (28 August 1901): 694-95. A response to A. Theodore Schroeder's claim that the Book of Mormon was written by Joseph Smith as a "practical joke." [J.W.M.]

S.050 Schwarz, Ted. Arnold Friberg: The Passion of a Modern Master. Flagstaff, AZ: Northland, 1985. Schwarz's biography of Arnold Friberg includes a history of Friberg's artistic work on the Book of Mormon and reproduces many of his paintings, including the brother of Jared, discovery of the Liahona, Abinadi in Noah's court, and Christ's appearance to the Nephites. [A.C.W.]

S.051 Scott, Columbus. "Book of Mormon Characters and the Book of the Dead." SH 54 (8 May 1907): 398-400. A comparison made between Egyptian hieratic phonetics found in the Book of the Dead and the Book of Mormon characters found in the Anthon transcript shows amazing similarities. [J.W.M.]

S.052 Scott, George L. "Ancient Artifacts Confirm Book of Mormon History." CN 33 (14 September 1963): 8-9. Discusses how certain Latin American artifacts confirm the Book of Mormon. Contains several pictures. [D.M.] 
S.053 Scott, George L. "Ancient Ruins Testify of Gospel Teachings." CN 33 (23 March 1963): 8-9. Tells about baptismal fonts that existed among the QuichŽ Mayas in Guatamala and another font is identified in Peru. [D.M.]

S.054 Scott, George L. "Archaeology Piles Up Evidences Supporting Book of Mormon." CN 31 (30 September 1961): 12, 19. Reports on the increasing number of archaeological finds that do not conflict with the Book of Mormon, and that in some cases support the historical accuracy of the book. The remains of horses and wheels have been discovered. [A.C.W.]

S.055 Scott, George L." 'His Own Voice.' " CN 35 (23 October 1965): 13. An update on the translation and publication of the Book of Mormon into various languages, and the mention of certain scriptures that pose translation problems (e.g., 1 Nephi 16:10, 2 Nephi 1:22, 1 Nephi 5:16, Jacob 7:5). [A.C.W.]

S.056 Scott, George L. "The Printed Word." CN 35 (15 May 1965): 8-9. Update on the publishing history of the Book of Mormon, missionary tracts, and LDS magazines. Includes a chronology of Book of Mormon printings. [A.C.W.]

S.057 Scott, Hazel Imrie. Heroes of the Book of Mormon. Independence, MO: Herald House, 1986. RLDS activity book designed for teaching the Book of Mormon to children. [D.M.]

S.058 Scott, Latayne Colvett. The Mormon Mirage: A Former Mormon Tells Why She Left the Church. Grand Rapids, MI: Zondervan, 1979. An account of why the author left the Mormon church. A chapter on the Book of Mormon explains why it is not a divine work and the manner in which it contains errors made by Joseph Smith. Scott uses archaeological, historical, and linguistic evidence and the Bible to demonstrate the errors of the Book of Mormon. [J.T.]

S.059 Scott, Lloyd R. "I Cannot Read a Sealed Book." CN 63 (16 January 1993): 14. Contradictions shown in two letters written by Professor Charles Anthon about his dealings with Martin Harris including whether or not he gave Harris a written opinion on the authenticity of the characters shown to him. [S.H.]

S.060 Scott, Richard G. "The Power of the Book of Mormon in My Life." Ensign 14 (October 1984): 6-11. Cites several personal experiences to show that the Book of Mormon can be a source of spiritual guidance and strength to those who read it frequently, ponder its principles and teachings, and apply those principles to their lives. The Book of Mormon contains the answers to "specific problems we face in everyday life." [S.P.S.]

S.061 Scott, Richard G. "True Friends That Lift." Ensign 18 (November 1988): 76-77. The Book of Mormon is the most important tool used to correct the effects of false traditions and to resolve problems and challenges, but has no value if the book remains unused. It is "a precious friend provided by a loving Savior." [J.W.M.]

S.062 Scott, Richard G. "We Love You-Please Come Back." CR (5-6 April 1986): 11-13. Also in Ensign 16 (May 1986): 10-12. Studying the Book of Mormon is an important part of the repentance process. Many messages pertaining to repentance are found within its pages. Suffering does not bring repentance; rather, it is faith and the Atonement of Jesus that cure the soul. The Book of Mormon teaches that selfishness is the root of all sin. [J.W.M.]

S.063 Scott, S. W. L. "Some Objections to the Book of Mormon Considered" SH 53 (18 April 1906): 365-74. Many things mentioned in the Book of Mormon have been questioned in times past, but modern scientists are finding evidence that substantiates the Book of Mormon: archaeologists have found that the Wady Rumen flows into the Red Sea and is about three day's journey down the Arabian shore of the Red Sea, answering objections to the 
route of Lehi from Jerusalem; archaeologists have verified that brass was used as a medium upon which records were kept; links have been found between New World and Old World cultures in modes of worship, architecture, and skeletal structure of ancient inhabitants. [J.W.M.]

S.064 Scoville, Monte C. "Counseling With the Lord." Instructor 98 (March 1963): 104-5. Seeking a testimony with real intent and counseling with the Lord allows a testimony of the Book of Mormon to grow. [A.C.W.]

S.065 "Scriptures Come Alive in Primary." CN 59 (30 September 1989): 11. Primary children participated in making a video of stories in the Book of Mormon to help them remember the stories better. [M.R.]

S.066 "Scriptures Given to Queen, Prime Minister." CN 57 (1 August 1987): 7. The Book of Mormon and other scriptures are presented to Queen Elizabeth and the Prime Minister of England. [M.D.P.]

S.067 "The Scriptures Have the Answers." DN Church Section (13 April 1986): 5, 23 President Ezra Taft Benson said that every Latter-day Saint should make the study of the Book of Mormon a lifetime pursuit. The Book of Mormon brings individuals to Christ in two ways: "First it tells in a plain manner of Christ and His Gospel," and second "the Book of Mormon exposes the enemies of Christ." Members are to read it carefully and prayerfully, pondering it as they read, and asking at the conclusion for a testimony of its truth. [M.D.P.]

S.068 "Scriptures on 2,600-Year-Old Silver Scrolls Found in Jerusalem." Ensign 17 (June 1987): 56-57. Silver scrolls found in a burial cave just outside Jerusalem are described. Includes the inscriptions contained thereon. Author concludes that fine metalworking was known at the time Lehi left Jerusalem. [A.T.]

S.069 Searle, Don L. "Book Convinced Him." Ensign 20 (March 1990): 50-52. An Italian scientist/atheist put the Book of Mormon to many scientific tests, only to receive a witness of its truthfulness from the Holy Ghost. [J.W.M.]

S.070 Sears, John. Final State of Mankind, Demonstrated by the Prophecies of the Old and New Testaments, Also the Book of Mormon and the Doctrine and Covenants. Salt Lake City: Joseph Hyrum Parry \& Co., 1886. A booklet containing commentary and scriptural quotes from the Bible, Book of Mormon, and Doctrine and Covenants that pertain to prophecies of the second coming, the new Jerusalem, judgment, and the degrees of glory. [J.A.T.]

S.071 Seastrand, James K., and Rosel Seastrand. "The Holy Bible And The Book of Mormon." In Seastrand's Journey To Eternal Life and Distractions Along The Way: Scriptural Answers To Challenges of LDS Church Beliefs, 137-42. Las Vegas, NV: Newmark Publishing, 1990. An argument for the need for continuous revelation and the Book of Mormon. [J.W.M.]

S.072 "Secular Proofs of the Book of Mormon." MS 61 (April 1899): 229-31. A reprint of an article from the Deseret News that gives the substance of a lecture by George Reynolds. Evidences that prove the ancient inhabitants of this continent were Nephites: Hebrew inscriptions on stone, metal and parchment and a story that a "francisco" discovered a secret "Nephite hiding place," the whereabouts of which he could not reveal under a oath of secrecy. [B.D.]

S.073 "Seed Planted Early, Grows To Testimony." CN 44 (6 July 1974): 5, 10. Personal conversion story. The Book of Mormon was pivotal in Russell Reed's decision to join the Church. [A.C.W.] 
S.074 Seely, David Rolph. "The Allegory of the Olive Tree and the Use of Related Figurative Language in the Ancient Near East and the Old Testament." In The Allegory of the Olive Tree: The Olive, The Bible, and Jacob 5, edited by Stephen D. Ricks and John W. Welch, 290-304. Salt Lake City: Deseret Book and FARMS, 1994. Compares literary language of the Old Testament and the use of figurative language in the ancient Near East to better understand the allegory of Jacob 5. Explains that modern literary terms do not correlate exactly with ancient literary traditions, thus necessitating reader understanding of a text's historical context. [A.C.W.]

S.075 Seely, David Rolph. "Enos and the Words Concerning Eternal Life." In The Book of Mormon: Jacob through Words of Mormon, To Learn with Joy, edited by Monte S. Nyman and Charles D. Tate Jr., 235-50. Provo, UT: Brigham Young University Religious Studies Center, 1990. The "words ... concerning eternal life" (Enos 1:3) provide the catalyst for repentance in the life of Enos. One of the benefits of true conversion is charity, which is a gift of the Spirit. Enos takes the admonition found in his father's teachings and applies them, with true conversion as the end result. Other examples of true conversion are cited. [J.W.M.]

S.076 Seely, David Rolph. "The Image of The Hand of God in The Book Of Mormon and The Old Testament." In Rediscovering The Book of Mormon, edited by John L. Sorenson and Melvin J. Thorne, 140-50. Salt Lake City: Deseret Book and FARMS, 1991. References to the hand, arm, or finger of God appears 345 times in 1,184 pages of the Old Testament and 135 times in the Book of Mormon, an average of once every 3.4 pages in each book of scripture. The references may be understood literally or symbolically. [J.W.M.]

S.077 Seely, David Rolph. "The Ten Commandments in the Book of Mormon." In Doctrines of the Book of Mormon, 1991 Sperry Symposium, edited by Bruce A. Van Orden and Brent L. Top, 166-81. Salt Lake City: Deseret Book, 1992. Book of Mormon theology finds its foundation in the ten commandments and the book shows the consequences of disobedience to them even leading to the destruction of a people; yet Abinadi taught that obedience to them would not bring salvation except for the Atonement of Christ. Although the ten commandments are listed only once in the Book of Mormon, there are twenty-four passages where two or more of the commandments are mentioned together. The ten commandments are applicable to all. The first five commandments demonstrate man's relationship to God, while the second five are concerned with man's relationship with man. [N.K.Y.]

S.078 Seely, David Rolph, and John W. Welch. "Zenos and the Texts of the Old Testament." In The Allegory of the Olive Tree: The Olive, The Bible and Jacob 5, edited by Stephen D. Ricks and John W. Welch, 322-346. Salt Lake City: Deseret Book and FARMS, 1994. Compares the words of Zenos with the words of other early Israelite prophets. Old Testament literature is replete with symbols that represent the house of Israel as an olive tree or a vine. Different prophets use different aspects of the allegory, speaking of destruction and restoration, of scattering and gathering, but always of the involvement of the Lord with the house of Israel. [J.W.M.]

S.079 Seeman, Curt H. "Preparation and Precaution in Scriptural Study; Part II." In 14th Annual Symposium on Archaeology of the Scriptures, edited by Forrest R. Hauck, 12-21. Provo, UT: Extension Publication, Brigham Young University, 13 April 1963. Warns that archaeology cannot verify scriptures; cites the Charles Anthon story to demonstrate the futility of relying upon scholarly authorities for religious beliefs. [A.C.W.]

S.080 Segert, Stanislav. Review of Chiasmus in Antiquity: Structures, Analyses, Exegesis, edited by John W. Welch. Catholic Biblical Quarterly 46 (1984): 336-38. Book review.

S.081 Seibel, George. The Mormon Saints; the Story of Joseph Smith, His Golden Bible and the Church He Founded. Pittsburgh: The Lessing Company, 1919. A polemical work against Mormonism. The author discusses what he 
considers to be various anachronisms and absurdities in the Book of Mormon. [M.R.]

S.082 Seitz, Don C. Uncommon Americans. Indianapolis, Bobbs-Merril, 1925. A historical work that discusses Joseph Smith and Mormonism on pages 1-23. The author considers the Book of Mormon to be "crude in style and inane in contents." He accepts the Spaulding Theory regarding its origin. [M.R.]

S.083 "Seminary Students Certify to Book of Mormon Study." CN 34 (21 March 1964): 10. LDS church President David O. McKay was given three volumes containing the signatures of 12,419 youth who had read the Book of Mormon during the current year. [J.W.M.]

S.084 "Send the Book of Mormon on a Mission." Ensign 7 (October 1977): 21-23. The family-to-family Book of Mormon program has been the means of converting many thousands. The book is a powerful missionary tool that becomes even more effective when personalized by a picture and a testimony. [J.W.M.]

S.085 Sessions, Christine Huber. Review of The Ammonite, by Blaine C. Thomsen. Dialogue 13 (Summer 1980): 135. Book review.

S.086 Sessions, J. Wyley. "The 100th Anniversary of Moroni's Visit Celebrated in Africa." IE 27 (February 1924): 336-37. South African Mission celebrates the anniversary of Moroni's visit by organizing a campaign to sell and distribute copies of the Book of Mormon. [J.W.M.]

S.087 Sexton, George. A Portraiture of Mormonism, or Animad Versions on the Doctrines and Pretensions of the Latterday Saints. London: W. Strange, 1849. Two polemic lectures. Considers Joseph Smith to be an impostor. Tells about the origin of the Book of Mormon and comments on its feasibility or lack thereof. [D.M.]

S.088 Shapiro, R. Gary, comp. An Exhaustive Concordance of the Book of Mormon, Doctrine and Covenants and Pearl of Great Price. Salt Lake City: Hawkes, 1977. An alphabetical listing of nearly every word occurring in the Book of Mormon, Doctrine and Covenants, and Pearl of Great Price with context entries. Words found in the title page and the thirty original chapter headings of the Book of Mormon are also included. [J.T.]

S.089 Sharp, James P. "It Happened in Mexico." IE 43 (January 1940): 22, 32. In response to the accusations of three traveling Methodist preachers, the author attempts to prove through archaeology the existence in preColumbian Central America of horses, cement, and jewelry-things mentioned in the Book of Mormon. [J.T.]

S.090 Sharp, Loretta M. "The Mythic Machiavelli: The Prince and Mandragola. Mythic Patterns in a Portrait of the Artist as a Young Man; Archetypal Patterns in the Book of Mormon." M.A. thesis, Brigham Young University, 1971. Discusses several archetypal patterns that occur in the Book of Mormon. These include the archetypal night journey, the Cain-Abel archetype, the Oedipal statement, the Great Mother archetype, and the resulting masculinity of the book. She provides several examples of each archetype, and relates them to the scriptural context. [A.C.W.]

S.091 Sharp, Marion. I Cry, Mormon. Philadelphia: Dorrance, 1989. Sharp tells the history of the coming forth of the Book of Mormon, the early Church and persecution of the Saints, Joseph Smith's martyrdom, and the pioneer journey, as well as Nephi's story as told in the Book of Mormon, in an epic poem format. [A.C.W.]

S.092 Sharp, W. H. H. "The Angel Moroni." Contributor 1 (March 1880): 142-43. Quotes Revelation 14:6-8 and explains that Moroni was the angel who held the keys of the gospel and came to earth in the latter days to commit 
them to Joseph Smith. Gives a biographical outline of Moroni's mortal life and discusses his latter-day work in bringing the Book of Mormon to light. [A.C.W.]

S.093 Sharp, W. H. H. "A Voice from Heaven." Our Deseret Home 2 (1883): 146. Discusses the wickedness of the American nation as related to the prophecies of Samuel the Lamanite. He includes numerous quotes from the Book of Mormon and information about early explorers of America, and promotes the idea that the earth is a live animal. [A.C.W.]

S.094 Shaw, Faye. "The White Man's Book of Heaven." In Recent Book of Mormon Developments, Articles from the Zarahemla Record, 1:99-100. Independence, MO: Zarahemla Research Foundation, 1992. 2 Nephi 12:79-80 (RLDS versification) prophesies that the gentile book will be carried forth to the Lamanites. This article describes two Nez Perce Indians who traveled to St. Louis, Missouri, from the Northwest to find a book that nobody gave them. [B.D.]

S.095 Shaw, Louise R. " 'Something More.' " CN 59 (11 February 1989): 16. A visit to the public library led Joseph Palozzolo to read the Book of Mormon, which eventually led to his conversion. [J.W.M.]

S.096 Shaw, Mary C. "Pigmy Elephants." IE 39 (January 1936): 19. Newly discovered fossils of elephants were found on an island off the coast of California. This discovery may indicate that the Book of Mormon contains the truth. [J.W.M.]

S.097 Shaw, W. E. "Address to the Book of Mormon." MS 9 (Feb. 1, 1847): 44. A nine-stanza poem dedicated to the Book of Mormon. The ninth stanza summarizes the entire poem: "Now I behold thee, open to my gaze, The Stick of Ephraim sent in these last days, To warn the nations, gather Israel in, Bring Christ to earth, and make an end of sin." [D.W.P.]

S.098 Sheen, Isaac. "Antiquarian Evidences of the Book of Mormon." True L.D.S. Herald 9-10 (May-August 1866): 130-33, 147-50, 163-65, 178-83, 3-5, 20-23, 35-36. Archaeological and historical concepts associated with the Americas and parallels between the Old and New Worlds (i.e., Hebrew and Egyptian languages and customs found among the Indians) are discussed in light of many claims made in the Book of Mormon. [J.T.]

S.099 Sheen, Isaac. "Future Punishment." SH 12 (1 November 1867): 129-31. Compares the doctrine of future punishment as explained in the Book of Mormon with similar ideas set forth in the Book of Covenants. Examines the meanings of "endless" and "eternal," and the concept of judgment. [A.C.W.]

S.100 Sheen, Isaac. "Reply to an Inquiry No. 2." True L.D.S. Herald 10 (15 September 1866): 82-83. Explains how the Book of Mormon contains the fullness of the gospel. [B.D.]

S.101 Sheffield, William. "Voice From the Dust." In Encyclopedia of Mormonism, edited by Daniel H. Ludlow, 4:1538. 5 vols. New York: Macmillan, 1992. Identifies the phrase "voice from the dust" as speaking of the coming-forth of the Book of Mormon using scriptural evidence. [B.D.]

S.102 Sheldon, Henry C. A Fourfold Test of Mormonism. New York: Abingdon Press, 1914. A polemical work against Mormonism and the Book of Mormon. The author notes several examples of what he terms anachronisms and absurdities in the book, such as the use of a compass, animals, pre-Christian knowledge of New Testament events, modern terms and phrases, lack of archaeological evidence, and Jaredite barges. The author considers it ridiculous 
that the Book of Mormon does not agree with the prevalent belief of biblical scholars that certain passages of Isaiah belong to the post-exilic period. [M.R.]

S.103 Sheldon, Louise Palfrey. "Book of Mormon and the Present Status." SH 71 (24 September 1924): 918-20. Writes concerning the gift of seership, the Urim and Thummim, and the Book of Mormon's warning against centralized power. [D.W.P.]

S.104 Sheldon, Louise Palfrey. A Study of the Book of Mormon. Independence, MO: Herald House, 1945. An eightpart instructional aid to study of the Book of Mormon that includes lesson outlines and questions arranged in the same chronological order as the events in the Book of Mormon. [A.C.W.]

S.105 Sheldon, William. Mormonism Examined. Broadhead, WI: William Sheldon, 1876. A polemic against Mormon scriptures. The Book of Mormon contradicts the Bible and is full of gross anachronisms and absurdities. [M.R.]

S.106 Sheldon, William. Mormonism Examined: Was Joseph Smith a Divinely Inspired Prophet? A Refutation of Mormonism. Broadhead, WI: Vanity, n.d. The Book of Mormon conflicts with itself and with the Bible and contains internal proof of its fallacy. One hundred such fallacies are listed, i.e., the Book of Mormon date of the death of Christ disagrees with the Bible, the date of the birth of Christ does not coincide with world history. [J.W.M.]

S.107 Shelton, Ken. Review of Nibley on the Timely and the Timeless, by Hugh W. Nibley. BYU Today (November 1982): 19. Book review.

S.108 Sherlock, Richard. Review of Studies on the Book of Mormon, by B. H. Roberts and Brigham D. Madsen. Sunstone 11 (September 1987): 39. Book review.

S.109 Sherlock, Richard. Review of Studies on the Book of Mormon, by B. H. Roberts and Brigham D. Madsen. Western Historical Quarterly 18 (January 1987): 71-72. Book review.

S.110 Shields, Steven L. "Book of Mormon and Doctrine And Covenants Cross Reference." In Latter-Day Saints Beliefs: A Comparison between the RLDS Church and the LDS Church, 1986, 102-3. Independence, Missouri: Herald Publishing House, 1986. RLDS Book of Mormon passages are cross-referenced with LDS Book of Mormon passages. Discrepancies become apparent as chapter and verse numbers conflict. [J.W.M.]

S.111 Shields, Steven L. Book of Mormon Study Series: Studies in 1 Nephi. Independence, MO: Herald House, 1987. Explores themes found in 1 Nephi: the Nephite sojourn in the wilderness, the tree of life, Nephi's vision, the olive tree, and the Liahona. [J.W.M.]

S.112 Shields, Steven L. Book of Mormon Study Series: Studies in 3 Nephi. Independence, MO: Herald House, 1987. Studies in 3 Nephi: the birth of Christ, Jesus Christ, the son of God, Jesus visits the Nephites, the Sermon on the Mount, other sheep. [J.W.M.]

S.113 Shields, Steven L. "The Process of Translation." Restoration 1 (October 1982): 1, 23. Presents a document written by Lucy Mack Smith to her sister-in-law, Mary Pierce, dated January 23, 1829, which mentions the process of translation. (Editor's note: this document has since been shown to be a forgery.) [J.T.]

S.114 Shields, Steven L. Studies in Alma. 2 vols. Independence, MO: Herald House, 1989-90. A study guide with scriptural paraphrases, questions, and activities designed to aid the reader in understanding the book of Alma. 
[D.W.P.]

S.115 Shields, Steven L. Studies in Helaman. Independence, MO: Herald House, 1990. A study guide with scriptural paraphrases, questions, and activities designed to aid the reader in understanding the book of Helaman. [D.W.P.]

S.116 Shipps, Jan. Mormonism: The Story of a New Religious Tradition. Urbana: University of Illinois Press, 1985. The first two chapters of this book describe the history of the Mormon church until the publication of the Book of Mormon. The author stresses the importance of the Book of Mormon in converting people to Joseph Smith's cause. Only later did the First Vision begin to take prominence. This work is reviewed in A.026. [B.D.]

S.117 Shook, Charles A. American Anthropology Disproving the Book of Mormon. Cleveland: The Utah Gospel Mission, 1930. A polemical tract against the Book of Mormon attempting to demonstrate that many of its claims are false and unsupported by archaeological evidence. Author asserts that there is no evidence for the Hebrew origin of the American Indian, pre-columbian iron and steel, transoceanic migration, and Egyptian language in American white Indians. Other alleged anachronisms are noted. [M.R.]

S.118 Shook, Charles A. Cumorah Revisited or 'The Book of Mormon' and the Claims of the Mormons Re-examined from the Viewpoint of American Archaeology and Ethnology. Cincinnati: Standard, 1910. An attempted refutation of the Book of Mormon's historical claims. Author accepts the Spaulding theory for its origin; he asserts that there is no archaeological evidence that supports the Book of Mormon's claims; he contests the claim that American Indians were once white, that they were of Hebrew descent, or that they had a knowledge of the Egyptian language. Numerous "anachronisms" are noted. [M.R.]

S.119 Shook, Charles A. The True Origin of the Book of Mormon. Cincinnati: Standard, 1914. A polemical work attempting to discredit the Book of Mormon and show that it was derived from an unpublished manuscript written by Solomon Spaulding. The writer attempts to show that some Book of Mormon witnesses such as Oliver Cowdery denied their Book of Mormon testimony. [M.R.]

S.120 Short, John T. The North American of Antiquity: Their Origin, Migrations, and Type of Civilization Considered. 3rd ed. New York: Harper, 1880. An examination of the North Americans of antiquity, from the aspects of archaeology, linguistics, geography, science, calendars, and religion. The Book of Mormon theory regarding the origin of the early North Americans is mentioned "only on the ground of its romantic character, and not on the supposition for a moment that it contains a grain of truth." [A.C.W.]

S.121 Shreeve, Thomas A. "A Sacred History: External Evidences of the Truth of the Book of Mormon." Juvenile Instructor 22-23 (February-December 1887, January-March 1888): 54-55, 76, 90-92, 107-9, 118-19, 142-43, 157-58, 162-63, 190-91, 194-95, 222, 237-38, 242-43, 258-59, 284-85, 300-301, 316-17, 324-25, 340-41, 356-57, 4-5, 34-35, 61, 76-77. Uses historical, linguistic, and archaeological evidence to prove the truthfulness of the Book of Mormon. Basing his facts on research done by noted linguists and archaeologists of the time, the author writes concerning the god Quetzalcoatl, religious customs and ruins of advanced civilizations, comparisons between the Hebrew and Mayan languages, and the Egyptian hieroglyphic writings. Shreeve also tells of similarities in biblical beliefs between early people of both the western and eastern hemispheres and explains why Joseph Smith was incapable of writing the Book of Mormon without divine aid. [A.C.W.]

S.122 Shreeve, Thomas A. "Study of the Book of Mormon." Contributor 9 (1887-1888): 275-80. An address encouraging Book of Mormon study. Tells of the finding of Egyptian characters by Augustus LePlongeon among the Mayans and traditions of Christ's ministration among the American Indians. [A.T.] 
S.123 Shumway, Eric B. "Polynesians." In Encyclopedia of Mormonism, edited by Daniel H. Ludlow, 3:1110-12. 5 vols. New York: Macmillan, 1992. Identifies the Polynesians as descendants of Lehi. Quotes general authorities, including President Joseph F. Smith, who said to the Maoris in New Zealand, "you are some of Hagoth's people." [B.D.]"

S.124 Shute, E. V. "The Horse in Pre-Columbian America." SH 88 (13 December 1941): 1583-85. A collection of written materials concerning horses in pre-Columbian America from the fifty years preceding 1933. [J.W.M.]

S.125 Shute, E. V. "Professor Anthon: A Plagiarist." SH 90 (13 February 1943): 5, 22. Examining the life of Professor Anthon proved him to be an impostor. He knew French well enough to translate a Frenchman's work, and he published it without giving credit where it was due. Perhaps he was "bluffing" concerning his knowledge of Egyptian. [J.W.M.]

S.126 Shute, E. V., A. H. Christianson, Willie C. Adams, Sr. "Shall We Improve the Book of Mormon?" SH 101 (8 November, 20, 27 December 1954): 1076-77, 1232, 1248. Debate concerning editorial changes to the Book of Mormon. Shute desires a complete revision with special attention to punctuation; Christianson refutes Shute's proposed revision saying that changing even a comma changes the book's meaning; Adams points out that language is constantly changing and future editions would be needed to stay current. [A.C.W.]

S.127 Shute, Evan. "The Book of Mormon as Literature." SH 90 (27 February 1943): 263-65, 278. A literary analysis in rebuttal to allegations that the Book of Mormon was poor literature. It is found that it is a very complex document, a historical narrative, and a theological book with a purpose. It is the work of multiple writers, two abridgers, and a translator, all of whom influenced the work with their own style and idioms, yet its clarity never fails. It is "self-consistent" and the "literary style is admirably adapted to the role the book was intended for." [J.W.M.]

S.128 Shute, Evan. "Did Christ Visit America?" SH 89 (14 November 1942): 1450-53. Christ's visit to the American Continent is well supported by histories and native traditions. The author finds that 3 Nephi 4-13 are compatible with many of these histories and traditions. [J.W.M.]

S.129 Shute, R. Wayne, and Wayne E. Brickey. "Prophets and Perplexity: The Book of Helaman as a Case Study." In The Book of Mormon: Helaman through 3 Nephi 8, According to Thy Word, edited by Monte S. Nyman and Charles D. Tate Jr., 177-90. Provo, UT: Brigham Young University Religious Studies Center, 1992. Using the model of J. T. Dillon called "moments of inquiry," the authors show how Nephi2 and Samuel the Lamanite engendered perplexity in their audiences, and may do the same for modern audiences. [D.M.]

S.130 Shute, Wallace B. Terra Nova. Independence, MO: Herald House, 1988. An ambitious epic poem on the Book of Mormon. [D.M.]

S.131 "Significance of Cumorah." MS 97 (12 September 1935): 596-97. Mentions the erection of the Cumorah Monument, identifies Moroni as a resurrected Nephite prophet. Stresses the doctrine of the immortality and resurrection of man. [R.H.B.]

S.132 "Significant English Editions of the Book of Mormon." CN 58 (2 January 1988): 2. A diagram displays the significant languages into which the book has been translated, together with their dates of publication. [R.H.B.] 
S.133 Sill, Sterling W. "Book of Mormon." In BYUSY (24 March 1957). Provo, UT: BYU Press. We may not be able to walk where Jesus walked, but of greater worth is that we can think what Jesus thought. The Book of Mormon reveals the thoughts of Christ. Heroes of the Book of Mormon are worthy of emulation. Sill highlights Mormon, who possessed a celestial mind. [J.W.M.]

S.134 Sill, Sterling W. "The Book of Mormon." In Sill's The Majesty of Books, 38-41. Salt Lake City: Deseret Book, 1974. The Book of Mormon's express purpose is to bring men to Christ. This book also tells of God's commitment to liberty, freedom, and agency. America has a "brilliant future" when Jesus will establish his government with two capitals, one in America, and the other in Jerusalem. [J.W.M.]

S.135 Sill, Sterling W. "A Man Called Jacob." Instructor 102 (November 1967): 424-25. Briefly discusses some of the characteristics of Jacob, son of Lehi. Jacob is portrayed as a man to whom others look for an example of spiritual living. [J.T.]

S.136 Sill, Sterling W. "Mormon and Moroni." Salt Lake City: Salt Lake Institute of Religion, 1973. A devotional that discusses the lives of Mormon and Moroni. Identifies their greatness and faithfulness and history. [D.W.P.]

S.137 Silver, Cherry B. Review of Rediscovering the Book of Mormon, edited by John L. Sorenson, and Melvin J. Thorne. Review of Books on the Book of Mormon 4 (1992): 166-68. Book review.

S.138 Silver, Gerald. Lehi's Wilderness Journey: An Ensign Sponsored Trip of South Arabia. Salt Lake City: Church of Jesus Christ of Latter-day Saints, October 1977. A filmstrip (94 frames, 16 1/2 minutes) based on a journey to the Arabian Peninsula. Arabia "portrays the geography and cultural conditions that could have existed in Lehi's day and gives the viewer a better feeling for and understanding of the journey that Lehi and his family experienced in traveling from Jerusalem to the land Bountiful." [A.C.W.]

S.139 Silver, Ruth. Review of Illustrated Stories from the Book of Mormon, by Raymond H. Jacobs. Dialogue 3 (Summer 1968): 146. Book review.

S.140 Silverberg, Robert. "And the Mound Builders Vanished from the Earth." In A Sense of History, edited by Byron Dobell, 46-59. New York: American Heritage, 1985. Discussion of the disappearance of the prehistoric race that built ceremonial mounds. Author suggests that Joseph Smith was one who founded a religion based on Mound Builder tales. The article gives a brief account of Joseph Smith and the coming forth of the Book of Mormon, which he claims is "just another literary expression of Mound Builder Mythology." [A.T.]

S.141 Simmerman, Gerald M. "Nephi Confounds the Wicked Judges." Friend 15 (November 1985): 48-49. Nephi, son of Helaman, confronts the wicked judges (Helaman 6-9). [J.W.M.]

S.142 Simmons, Dana. Review of Investigating the Book of Mormon Witnesses, by Richard Lloyd Anderson. Recent Book of Mormon Developments, Articles from the Zarahemla Record, 1:98. Independence, MO: Zarahemla Research Foundation, 1984. Book review. [B.D.]

S.143 Simmons, Dana A. "The Whitmer Transcript." ZR 9 (Summer 1980): 1-2, 4, 8. Reports the find of a document "thought to be the original Anthon transcript." (Editor's note: this document has since been shown to be a forgery.) [A.T.] 
S.144 Simmons, Neil. "Chief Captain Moroni Remembered." In Recent Book of Mormon Developments, Articles from the Zarahemla Record, 2:187-88. Independence, MO: Zarahemla Research Foundation, 1992. Diego Dur $¥ n$ describes Mexican Indians' celebration of Huitzilopochtli, a god who, when alive, was never caught, never taken prisoner in war, and always triumphant. Simmons relates Huitzilopochtli with Moroni. [B.D.]

S.145 Simmons, Neil. "Marijuana and the Book of Mormon." In Recent Book of Mormon Developments, Articles from the Zarahemla Record, 1:127. Independence, MO: Zarahemla Research Foundation, 1984. 2 Nephi 11:94 (RLDS versification) says that Satan leads men by the neck with a flaxen cord. No flax existed in Mesoamerica, but the ancient Americans did use cannabis sativa (common name marijuana), a plant that resembles flax. [B.D.]

S.146 Simmons, Neil, and Raymond C. Treat. "Maya Hieroglyphs Point to the Book of Mormon." ZR 19-21 (Winter, Spring, Summer 1983): 1-5, 24. Examines research into Maya glyphs and states that this research has produced two finds important to Book of Mormon believers: the glyphs are partly phonetic, and the glyphs deal mainly with history. Based upon findings from glyphs, the author proposes Yaxchilan to be Zarahemla and Palenque to be Bountiful. [A.T.]

S.147 Simmons, Rae. "The Need To Study." In Recent Book of Mormon Developments, Articles from the Zarahemla Record, 2:161-62. Independence, MO: Zarahemla Research Foundation, 1992. 2 Nephi 14:4 (RLDS versification) tells us to "feast upon the words of Christ." Simmons writes of her motivation to study and results that came from studying. [B.D.]

S.148 Simmons, Rae. "Zenos: One of the Major Prophets." Witness 70 (Fall 1990): 11. Cites the teachings and prophecies of Zenos included in the Book of Mormon to demonstrate his importance as a prophet. [A.C.W.]

S.149 Simmons, Verneil W. "Another Look at the Book of Mormon Ministry of Christ." ZR 29-31 (Summer, Fall 1985, Winter 1986): 1-3, 23. Suggests that Christ appeared to the Nephites on Rosh Hashanah (near September 22). The institution of the sacrament among the Nephites is compared to the last supper. Warns against the changing of ordinances. [A.T.]

S.150 Simmons, Verneil W. "Archaeology and the Book of Mormon." Restoration Witness 7 (June 1969): 4-5, 14. Upon arriving in Mesoamerica the Spanish destroyed the books of the Mayan people because they considered them evil. An unknown Mayan man rewrote his people's history in the 1550s, and it later resurfaced in 1700 and has come to be known as Popol Vuh, the Book of the people. This and other archaeological finds have many things in common with the Book of Mormon. [J.W.M.]

S.151 Simmons, Verneil W. "Lest We Forget the Lamanite." SH 95 (25 September 1948): 924-28, 936. The gentile members of the Church must remember that the Book of Mormon was written for the Lamanites also. Emphasizes the need to find where and who these people are by using Book of Mormon geographical passages. Finds that the Isthmus of Tehuantepec most clearly fits the description. The Hill Cumorah was the location of the final battles. [J.W.M.]

S.152 Simmons, Verneil W. Peoples, Places and Prophecies: A Study of the Book of Mormon. Independence, MO: Zarahemla Research Foundation, 1986. A discussion of three groups-Jaredites, Nephites, and Mulekites-who traveled from the Old World to the New World. Geographical, historical, and archaeological evidences are cited with the intent to prove the veracity of the Book of Mormon. Author cites the Popul Vuh, the Dead Sea Scrolls, the Bible, and other sources. [A.C.W.] 
S.153 Simmons, Verneil W. "Why I Wrote Peoples, Places, and Prophecies." ZR 8 (Spring 1980): 4-6. Describes the experiences that led her to write: she believed in two Hill Cumorahs and believed the "narrow neck" to be the "Isthmus of Tehuantepec in southern Mexico." [A.T.]

S.154 Simmons, Wayne E. ". . . And they Are One God." In Recent Book of Mormon Developments, Articles from the Zarahemla Record, 1:136-37. Independence, MO: Zarahemla Research Foundation, 1984. The confusion among theologians and scholars about whether God and Christ are two separate beings or the same person is solved by Mosiah 8:28-31 (RLDS versification). The Book of Mormon explains that they are separate but one. Simmons explains this oneness as similar to the oneness of husband and wife. [B.D.]

S.155 Simmons, Wayne E. "It Is Written." In Recent Book of Mormon Developments, Articles from the Zarahemla Record, 1:138-39. Independence, MO: Zarahemla Research Foundation, 1984. An article on the importance of scripture and continuing revelation. 2 Nephi 11:40-42 (RLDS versification) says that the nations that possess the Book of Mormon shall be judged according to it. [B.D.]

S.156 Simmons, Wayne E. "A Patriarchal View of Israel, Part 1." In Recent Book of Mormon Developments, Articles from the Zarahemla Record, 1:130-32. Independence, MO: Zarahemla Research Foundation, 1984. Discusses how RLDS members can be considered part of the house of Israel. Lehi was of the tribe of Manasseh and the Reorganized Church of Jesus Christ of Latter Day Saints is "definitely a divine enterprise in which Ephraim and Manasseh are called together, here in the Americas which is Joseph's land." [B.D.]

S.157 Simmons, Wayne E. "A Patriarchal View of Israel, Part 2." In Recent Book of Mormon Developments, Articles from the Zarahemla Record, 1:133-35. Independence, MO: Zarahemla Research Foundation, 1984. Moroni, in Ether 6:7-8 (RLDS versification), explains that Joseph who was sold into Egypt was a type in that his seed should establish the New Jerusalem on the American Continent. Ezekiel 37:16-19 explains that the Bible and the Book of Mormon, the sticks of Judah and Joseph, will be united. Thus, the Book of Mormon explains the gathering of Israel in the last days especially in the allegory of the olive tree. [B.D.]

S.158 Simon, Jerry F. "Minister the Same Words Which Jesus Has Spoken." In A Symposium on the Book of Mormon, 116-19. Salt Lake City: Church of Jesus Christ of Latter-day Saints, August 1986. The Book of Mormon teaches individuals how to be gospel teachers. A teacher prays, searches the scriptures before teaching, and then receives the Holy Ghost who instructs. One should keep personal opinions personal; opinions should not be taught as truth. One should never teach beyond one's own comprehension, stay away from contentious subjects, and remain silent on the subjects the Lord has chosen to be silent about. Teach the words Jesus spoke. [J.W.M.]

S.159 Simpson, Robert L. "Book of Mormon is the Pivotal Point of Gospel." CN 58 (2 January 1988): 3, 12. Having the Book of Mormon with a whole new set of prophets declaring the same truths of the Old and New Testaments is one of the main keys to LDS strength in the religious world today. [R.H.B.]

S.160 Simpson, Robert L. "The Next Fifteen Minutes." NE 19 (July 1989): 4-6. Simpson as a youth gave a Book of Mormon, complete with testimony, to a friend. The friend showed him an encyclopedia that claimed Joseph Smith and the Book of Mormon to be counterfeit. Devastation turned into testimony three days later in a quorum meeting. [J.W.M.]

S.161 Simpson, W. Sparrow. Mormonism: Its History, Doctrines, and Practice. London: A. M. Pigott, 1853. An evangelical/polemical tract against Mormonism. The Book of Mormon plagiarizes much from the New Testament and the book of Isaiah. The 1834 Anthon denial is cited. The testimonies of Book of Mormon witnesses are 
discredited, contradictions between the Book of Mormon and the Bible are listed. Author accepts the Spaulding theory of the Book of Mormon's origin. [M.R.]

S.162 Sims, George. "Fulfillment of Prophecies of the Book of Mormon Concerning the Land of America." MS 25 (October 1863): 691-94. The Book of Mormon states that "whatsoever nation shall possess [America] shall serve God, or they shall be swept off." This promise to America, the "promised land," was fulfilled in the days of the Jaredites who allowed secret combinations to flourish. Those who remain faithful to Jesus Christ will enjoy the ministration of angels, fellowship with prophets, communion with saints, the gift of the Holy Ghost, and possession of the land of promise. [J.W.M.]

S.163 "Since 1982, Subtitle Has Defined Book as 'Another Testament of Jesus Christ.' " CN 58 (2 January 1989): 4. Explains why the subtitle "Another Testament of Jesus Christ" has been added to the Book of Mormon. [M.D.P.]"

S.164 Sinclair, Upton. "The Book of Mormon." In Sinclair's The Profits of Religion: An Essay in Economic Interpretation, 239-42. Pasadena, CA: Vanity, 1918. Tells the role of Joseph Smith relative to the angel Moroni and the plates with sarcasm. Quotes the testimony of the Three Witnesses. [D.M.]

S.165 Sire, James W. Scripture Twisting: 20 Ways the Cults Misread the Bible. Downers Grove, Illinois: Intervarsity Press, 1980. An evangelical/polemical work written for the intent of dealing with the "cults." The author discusses alleged misinterpretations of Bible prophecy by the Mormons, which supposedly support the Book of Mormon. He considers praying about the Book of Mormon unnecessary and suggests that Joseph may have drawn upon both Spaulding and View of the Hebrews in fabricating the Book of Mormon. [M.R.]

S.166 Sirota, Mark F. Paraphrase and Commentary on the Book of Mormon: 3 Nephi. Mesa, AZ: M. F. Sirota, 1983. A photocopied anthology of texts and commentaries on 3 Nephi 1-10, taken from 4 major sources, including volume 7 of Commentary on the Book of Mormon, by George Reynolds and Janne Sjodahl. [D.W.P.]

S.167 "Sister Shares Her Secret-A Copy of Book of Mormon." CN 58 (31 December 1988): 11. A twin gave her sister a Book of Mormon, and later they were both baptized. [M.D.P.]

S.168 The Sixth Annual Church Educational System Religious Educators' Symposium on the Book of Mormon. Salt Lake City: Church of Jesus Christ of Latter-day Saints, 1982. Papers presented at the sixth annual symposium on the Book of Mormon. Articles by Church educators, including Susan Easton Black, Charles Beckert, Robert Christensen, and numerous others. [J.W.M.]

S.169 Sjodahl, J. M. "America: Is It a Book of Mormon Name?" IE 24 (December 1920): 130-43. An attempt to link the name "America" with a cognate form of the name Mulek, a pre-Christian traveler to the western hemisphere. Author rejects the concept that America was named in honor of Amerigo Vespucci, as has been often assumed. [D.M.]

S.170 Sjodahl, J. M. "Ancient Indian Literature." IE 29 (September 1926): 1035-42. Refers to the record-keeping habits of the inhabitants of the Americas as discovered by European observers. An English translation of several records is given, and a kinship shown between traditions among the American pre-European peoples and the milieu from which the Book of Mormon emerged. [D.M.]

S.171 Sjodahl, J. M. "Archaeological Finds in Arizona." IE 28 (July 1925): 813-21. Several crosses with Latin inscriptions, a spear, and sword that were excavated near Tucson, Arizona, are discussed as possible evidence for 
pre-Columbian contact between the Americas and Europe. Author speculates that a reference to a "mountain" in the inscriptions may be connected to the Hill Cumorah mentioned in the Book of Mormon. [J.T.]

S.172 Sjodahl, J. M. "Archaeological Research and the Book of Mormon." IE 25 (October 1922): 1104-7. Takes the position that contemporary archaeology corroborates the claim that Book of Mormon peoples had Middle Eastern roots. [D.M.]

S.173 Sjodahl, J. M. "Archaeology and the Book of Mormon." MS 87 (26 February 1925): 132-34. The conclusions of modern research of the mound builders coincides with the Book of Mormon account of the Jaredite people. Modern archaeologists conclude that the Indians are of one race, that their migrations were from south to north, and that the original inhabitants of America bear an unmistakable relationship to the Semitic branches of eastern culture and Egypt. [J.W.M.]

S.174 Sjodahl, J. M. Authenticity of the Book of Mormon. Liverpool: MS Office, 1915. Also published as Sjodahl, J. M. "Authenticity of the Book of Mormon," MS 77 (29 July, 5, 12, 19, August 1915): 465-70, 481-87, 497-503, 513-19. Wishes to convince the reader that the Book of Mormon is authentic by using historical, linguistic, and archaeological evidence, plus the testimonies of the eleven witnesses and examples of biblical scriptures that have been fulfilled through the Book of Mormon. The Book of Mormon is a "good book" that leads people to improve themselves and their lives. [A.C.W.]

S.175 Sjodahl, J. M. "Bible and Book of Mormon Evidence." CN 4 (19 May 1934): 1, 7. Refutes scholarly claims that the Bible was written during the 7th century b.c. by examining the contents of the brass plates that Lehi took to the New World. Since the brass plates contained the Pentateuch, chronicles, and prophecies until the reign of Zedekiah, the Book of Mormon offers evidence that the Bible was written at an earlier date. [A.C.W.]

S.176 Sjodahl, J. M. "The Book of Abraham." IE 16 (February 1913): 326-33. Refutes claims made by Rev. J. S. Spalding that the Book of Mormon was not an authentic book because the Book of Abraham was translated incorrectly and that surely means that Joseph Smith was not a translator. Sjodahl points out that the Book of Mormon was translated by the gift and power of God, whereas the book of Abraham required seven years of laborious study coupled with inspiration. One cannot be judged on the merits of the other. [J.W.M.]

S.177 Sjodahl, J. M. "The Book of Mormon and Modern Research." IE 25 (December 1921): 152-58. This defense of the Book of Mormon concludes that archaeological and anthropological data about the pre-Columbian Americas do not contradict the Book of Mormon and often coincide with it. [D.M.]

S.178 Sjodahl, J. M. "Book of Mormon Characters." IE 27 (December 1923): 146-48. Discusses the Anthon transcript and declares that the letter written by Anthon concerning the figures on the paper presented by Martin Harris provides an opinion that is without value. Anthon's brief examination and his finding do not correlate with the characters as preserved. [D.M.]

S.179 Sjodahl, J. M. "Book of Mormon Evidence." MS 76 (3 December 1914): 776-77. Illustrates similarities between the ancient Nephite and Toltec civilizations. The history of the Toltec peoples and their destruction by the Aztecs lends evidence to the historicity and truth of the Book of Mormon. [K.M.]

S.180 Sjodahl, J. M. "Book of Mormon Evidence." MS 79 (May 1917): 328-30. Quotes one source that mentions the discovery of horse bones in America, and another source that describes the discovery of a petroglyph in Arizona which represents dinosaurs and four-toed horses. [B.D.] 
S.181 Sjodahl, J. M. "Book of Mormon Evidence." MS 89 (10 March 1927): 150-51, 157-58. Recent scientific research is used to establish facts mentioned in the Book of Mormon. The use of steel in the Book of Mormon is supported by recent findings of hardened tools and steel implements in anceitn American ruins. [J.T.]

S.182 Sjodahl, J. M. "Book of Mormon Facts." Juvenile Instructor 57 (May-June 1922): 243-45, 305-9. A collection of various facts that attempt to portray the Book of Mormon as an ancient record as well as a prophetic book: World War I and the giving of Palestine to the Jews are shown to be foretold, the mentioning of steel and iron are defended, and the possible origin of the name America is discussed as coming from Book of Mormon people. [J.T.]

S.183 Sjodahl, J. M. "The Book of Mormon Plates." IE 26 (April 1923): 541-45. Discusses the length, width, and weight of the plates, according to witnesses or people who talked to witnesses. He also treats the possible number of words that could have been inscribed on a given leaf. [D.M.]

S.184 Sjodahl, J. M. "Confirming the Book of Mormon." MS 79 (January 1917): 8-10. Quotes G. Elliot Smith who argues that the ancient Americans descended from the Egyptians. His evidence for this theory are the similar practices of circumcision, mummification, tattooing, architecture, and mythology. [B.D.]

S.185 Sjodahl, J. M. "Credibility of the Witnesses." IE 26 (September 1923): 969-79. The author defends the reliability of both the Three and the Eight Witnesses to the Book of Mormon. The witnesses consistently adhered to their testimony and each had an unassailable reputation. [D.M.]

S.186 Sjodahl, J. M. "Credibility of the Witnesses." MS 85 (October 1923): 625-27, 644-47, 661-63, 676-78. A biographical summary about each of the Eleven Witnesses. Sjodahl quotes portions of published testimonies of the Three Witnesses. [B.D.]

S.187 Sjodahl, J. M. "The Fulness of the Gospel." DN Church Section (11 April-30 May 1936): 3, 4, 8, 8, 7, 6, 7, 6, 2. Eight part series. The Book of Mormon records that the faithful of the American Continent were visited by the Jesus and were told they were the "other sheep" that he had spoken of in John 10. There are three groups of people the Savior refers to when he talks of "other sheep": the Jews, the descendants of Lehi, and still others who are unidentified. Baptism was known 147 years before Christ, performed by Alma at the Waters of Mormon. The sacrament represents the Old Testament sacrifices and the Atonement. Three great monuments stand as witnesses of Jesus' work on earth: the sacrament, baptism, and the Sabbath, which bring to remembrance his Atonement, death and burial, and resurrection. Because of repentance the Gentiles have great promises. [J.W.M.]

S.188 Sjodahl, J. M. "Have the Lamanites Jaredite Blood in Their Veins?" IE 31 (November 1927): 56-57. Proposes that not all the Jaredites perished in the final Jaredite cataclysm. He speculates that some of them fled and joined the people of Mulek. [D.M.]

S.189 Sjodahl, J. M. "Hvitra-manna-land and Lamoni." IE 26 (December 1922): 190-93. Relates names from sagas and American geography to Book of Mormon names such as "Laman" and "Lamoni," which the author suggests refers to "white." This is seen as a Book of Mormon evidence. [D.M.]

S.190 Sjodahl, J. M. An Introduction to the Study of the Book of Mormon. Salt Lake City: Deseret Book, 1927. An approach to the Book of Mormon through the study of ancient languages, geography, the history of the LDS church, and the cultures of ancient civilizations in the Old and New Worlds. [J.T.] 
S.191 Sjodahl, J. M. "The Jaredite Lands." IE 42 (June 1939): 336-37, 370-71. An analysis of the geographical statements given in the Book of Ether and possible North American correlations. [J.T.]

S.192 Sjodahl, J. M. "Language of White Indians." IE 28 (April 1925): 568-71. An analysis of the language of "white Indians" found by an American explorer in the mountains of Darien, in Panama, reveals a vast number of words related to old world words in both form and meaning. Some Hebrew words are found in this Indian language. [J.W.M.]

S.193 Sjodahl, J. M. "The Last Struggle Between Nephites and Lamanites." DN Church Section (23 March 1935): 3, 8. Bancroft (Native Races, vol. 1, 628) describes the warfare found among the Mexican people when the Spaniards arrived in the New World. The description is similar to descriptions found in the Book of Mormon concerning the final battle between the Nephites and the Lamanites. [J.W.M.] "

S.194 Sjodahl, J. M. "Meaning of the word 'Mormon.' "IE 30 (March 1927): 433-34. Quotes Joseph Smith's statement that "Mormon" means "more good," or, in other words, "better." The first syllable is English, the second is Egyptian. The "good" in the name is related to the gospel as good news. Several native American languages have superlatives that translate "more good." [D.M.]"

S.195 Sjodahl, J. M. "The Name Moroni." IE 28 (October 1925): 1132-34. The appellation "Moroni” shows up in Asia, the Americas, and even in Paul's exclamation "maranatha" (1 Cor. 16:22). [D.M.]

S.196 Sjodahl, J. M. "New Book of Mormon Evidences." MS 96 (17 May 1934): 305-7. Explores geographical/historical/archaeological implications of Lehi's journey out of Jerusalem. Says hostile Arabs prevented a journey through inhabited areas. [A.C.W.]

S.197 Sjodahl, J. M. "Notes on the Book of Mormon." IE 30 (April, May June, July 1927): 526-31, 623-26, 696700, 795-800. Discusses the gold plates, the burial of the plates at the Hill Cumorah, the Urim and Thummim, the characters on the plates, Joseph Smith's preparation for translation, the scribes, and manuscripts. [D.M.]

S.198 Sjodahl, J. M. "The Signs of the Times: The Book of Mormon." Juvenile Instructor 64 (July 1929): 385. External evidence of the Book of Mormon substantiates its validity. Scientists have tried to prove it a forgery, but after one hundred years they have not succeeded and it has stood the test of time and close examination. [J.W.M.]

S.199 Sjodahl, J. M. "A Study of Book of Mormon Texts." IE 26-27 (July, August, September 1923, November, January, May 1924): 825-30, 880-84, 1045-46, 18-22, 237-39, 675-76. Internal evidences of the Book of Mormon's authenticity are argued using analysis of words and names used in the book that reflect ancient Hebrew customs, and parallels between the Book of Mormon and American Indian languages. [J.T.]

S.200 Sjodahl, J. M. "Suggested Key to Book of Mormon Geography." IE 30 (September 1927): 974-87. Surveys theories on Book of Mormon geography, and offers his own speculation. He concludes that Lehi landed in South America just south of the Isthmus and that he died in Peru. Nephi went on to Ecuador and then Colombia. Zarahemla was located on the Atlantic side of Central America. [D.M.]

S.201 Sjodahl, J. M. A Suggested Key to Book of Mormon Geography. Salt Lake City: Deseret Book, 1957. A large map of the North and South American continents marked with names of cities, rivers, and locations that are found in the Book of Mormon text. [J.W.M.] 
S.202 Sjodahl, J. M. "Tut-Ankh-Amen and Sun-Worship." IE 26 (May 1923): 638-43. Speculates that the Lamanite culture may have established the Egyptian practice of sun-worship in America, accounting for the appearance of this practice among certain Indian groups. [J.T.]

S.203 Sjodahl, J. M. "Two Outstanding Features of Book of Mormon History." Relief Society Magazine 14 (October, November 1927): 475-80, 550-53. Discusses the determination of the people of Ammon not to defend themselves against the Lamanite attack. Some Indian traditions reflect this peaceful approach to war. The united order was practiced among the Nephites after the Savior's visit. Indian traditions hold to many of the principles of the united order. [J.W.M.]"

S.204 Skinner, Andrew C. "Alma's 'Pure Testimony.' "In Studies in Scripture: 1 Nephi to Alma 29, edited by Kent P. Jackson, 294-306. Salt Lake City: Deseret Book, 1987. Using the text of Alma 5-8, this article defines "pure testimony" as that which is "deeply associated with the Savior." It is "clear, plain, and absolute" as well as "clean, cleansing, and purifying." Faith in Christ, a correct understanding of God's character, and true knowledge, which is given only by the Holy Ghost, bring about spiritual rebirth. [J.W.M.]

S.205 Skinner, Andrew C. "The Course of Peace and Apostasy." In Studies in Scripture: Alma 30 to Moroni, edited by Kent P. Jackson, 218-30. Salt Lake City: Deseret Book, 1988. Just 49 verses within 4 Nephi teach a stark contrast between celestial unity and the path of apostasy to deepest depravity. Mormon lived in a time of great wickedness and yet through his relationship with the Second Comforter possessed the strength to live a righteous life-a good lesson for the latter days. [J.W.M.]

S.206 Skinner, Andrew C. "Nephi's Ultimate Encounter with Deity: Some Thoughts on Helaman 10." In The Book of Mormon: Helaman through 3 Nephi 8, According to Thy Word, edited by Monte S. Nyman and Charles D. Tate Jr., 11527. Provo, UT: Brigham Young University Religious Studies Center, 1992. An essay on making one's calling and election sure. Shows the perversion of this doctrine as exhibited by the Zoramites. Nephi's steadfast faithfulness allowed him to attain it, and ultimately he saw God. [D.M.]

S.207 Skinner, Andrew C. "Promises Fulfilled." In Studies in Scripture: Alma 30 to Moroni, edited by Kent P. Jackson, 259-70. Salt Lake City: Deseret Book, 1988. Discusses the law of witnesses and the Three Witnesses to the Book of Mormon, the idea of kingship in Jaredite history, and the effect of secret combinations. The exodus of Jared is likened to Noah's ark. "When the Lord makes a prophecy or promise it must surely come to pass." [J.W.M.]

S.208 Skousen, Royal. "The Book of Mormon Critical Text Project." In Joseph Smith: The Prophet, The Man, edited by Susan Easton Black and Charles D. Tate Jr., 65-75. Provo, UT: BYU Religious Study Center, 1993. A project intending to establish the original English text of the Book of Mormon and to understand its history and changes. Computerized versions of the original text and the printer's text were created, then comparisons made 19 subsequent editions. Findings validate the witnesses' testimony that Joseph Smith saw the words in revelation from God during the translation process. [J.W.M.]

S.209 Skousen, Royal. "Book of Mormon Editions." In Encyclopedia of Mormonism, edited by Daniel H. Ludlow, 1:175-76. 5 vols. New York: Macmillan, 1992. Book of Mormon editions are described and format changes noted. Editions include: 1830, 5,000 copies, E. B. Grandin, New York; 1837, 5,000 copies, P. P. Pratt, Kirtland, Ohio; 1840, 2,000 copies, E. B. Robinson \& Don C. Smith, Cincinnatti, Ohio; 1841, 4,050 copies, Kimball, Young, \& Pratt, Liverpool, England; 1879, Orson Pratt changed format, Salt Lake City, Utah; 1920, James Talmage more changes in format; 1981, Quorum of 12 committee made extensive format changes. RLDS have published editions in 1858, 1874, 1892, 1908, 1966, and 1987. [N.K.Y.] 
S.210 Skousen, Royal. "Book of Mormon Manuscripts." In Encyclopedia of Mormonism, edited by Daniel H. Ludlow, 1:185-86. 5 vols. New York: Macmillan, 1992. There are two Book of Mormon manuscripts in existence-the original manuscript written by scribes from a dictated translation and a manuscript copy of the original given to the publisher. The original was placed in the cornerstone of a building and $75 \%$ of it was destroyed by moisture. The printer's manuscript has on average three differences per page from the original in the form of natural scribal errors and it is in the custody of the RLDS church with only two lines missing on page one. [N.K.Y.]

S.211 Skousen, Royal. "Jacob 4-6: Substantive Textual Variants between Manuscripts and Editions." In The Allegory of the Olive Tree: The Olive, The Bible, and Jacob 5, edited by Stephen D. Ricks and John W. Welch, 105-39. Salt Lake City: Deseret Book and FARMS, 1994. Published as a preliminary report in "Jacob 4-6: Substantive Textual Variants." Provo, UT: FARMS, 1992, and "Jacob 4-6: Textual Notes." Provo, UT: FARMS, 1992. Presents a computerized collation of Jacob 4-6 "based on the original manuscript, the printer's manuscript, the first three editions of the Book of Mormon (1830, 1837, and 1840), and the 1981 edition of the Book of Mormon." Shows the substantive variations between the 1981 edition and the other five sources, ignoring spelling variation, capitalization, and punctuation that makes no difference in the meaning. [J.W.M.]

S.212 Skousen, Royal. "New Fragments from the Original Manuscript of the Book of Mormon." In DLLS Proceedings 1992: Proceedings of the Deseret Language and Linguistic Society 1992 Symposium, 1-4. USA: Deseret Language and Linguistics Society, 1992. Brief overview of the Book of Mormon critical text project with update on recent findings concerning new fragments from the original manuscript. [A.C.W.]

S.213 Skousen, Royal. "The Original Book of Mormon Manuscript." In Reexploring the Book of Mormon, edited by John W. Welch, 9-12. Salt Lake City: Deseret Book and FARMS, 1992. Some 140 differences exist between the original transcript of the Book of Mormon and the copied printer's manuscript. Recent comparisons using computer techniques and access to more legible copies have shown about one correction per manuscript page, most corrections representing natural transcription errors. The original manuscript was often written under difficult circumstances with a quill pen. Changes have been reviewed and found to include corrections for atypical spellings, awkward grammar, and Hebraisms. [N.K.Y.]

S.214 Skousen, Royal. "Piecing Together the Original Manuscript." BYU Today 46 (May 1992): 18-24. Skousen reports on his work on a critical text of the Book of Mormon, notably his work with the Wilford Wood original manuscript fragments, which in 1937 Wood purchased from Lewis Bidamon's son, Charles. The project has illuminated Hebrew-like expressions in the original text, some errors of transmission between the original and the printer's manuscripts, and more information concerning the translation process. [B.D.]

S.215 Skousen, Royal. Review of New Approaches to the Book of Mormon, edited by Brent Lee Metcalfe. Review of Books on the Book of Mormon 6/1 (1994): 121-44. Book review.

S.216 Skousen, Royal. Review of The Book of Isaiah: A New Translation with Interpretive Keys from the Book of Mormon, by Avraham Gileadi. BYU Studies 28 (1988): 124. Book review.

S.217 Skousen, Royal. "Towards a Critical Edition of the Book of Mormon." BYU Studies 30 (Winter 1990): 41-69. Defines and shows a need for a critical edition of the Book of Mormon. Discusses translational methods of Joseph Smith. Summarizes Skousen's work on a new critical edition of the Book of Mormon. [J.W.M.]

S.218 Skousen, W. Cleon. The Challenge of Our Times. Salt Lake City: Bookcraft, 1953. The Book of Mormon is given to test the faith of mankind. It is a companion to the Bible and answers vital questions more now than when 
it was first published. The writings of ancient American prophets are found in the book and many of their prophecies pertain to this time when they are just now being fulfilled. The land of America is a land of importance to God and man. Those who are righteous will be blessed. A warning against pride and secret societies permeates the book. The most significant part of the book is Christ's visit, organizing his church and establishing his ordinances. [J.W.M.]

S.219 Skousen, W. Cleon. Hidden Treasures from the Book of Mormon. 4 vols. Provo and Salt Lake City: Dana Press and Publisher's Press, 1971-1972. A four-volume work designed as an instructional aid to Book of Mormon study. The workbook format proceeds verse by verse, with accompanying commentaries, maps, drawings, fill-in-theblank questions, charts, and topics of discussion. [A.C.W.]

S.220 Skousen, W. Cleon. "The Importance of Isaiah's Ministry." In Skousen's The Fourth Thousand Years, 513-42. Salt Lake City: Bookcraft, 1966. Only Nephi was allowed to distribute the same amount of details concerning the last days as Isaiah did. The Book of Mormon establishes the authorship of the book of Isaiah. The important ministry of Isaiah and the unity of the text he wrote is exhibited by his writings preserved in the Book of Mormon. [J.W.M.]

S.221 Skousen, W. Cleon. "Isaiah and Nephi Write About America and Modern Times." In Skousen's The Fourth Thousand Years, 578-603. Salt Lake City: Bookcraft, 1966. Because of Nephi's great depth of understanding of Isaiah's writings, both culturally and spiritually, his commentary is of inestimable value concerning the prophecies that relate to America. Isaiah and Nephi both saw the coming forth of the Book of Mormon, Martin Harris's visit to professor Anthon, and the witnesses who would testify of the Book of Mormon's truthfulness. [J.W.M.]

S.222 Skousen, W. Cleon. "The Last Days of Joseph and His Remarkable Prophecies Concerning the Future." In Skousen's The Third Thousand Years, 143-56. Salt Lake City: Bookcraft, 1964. Genesis 50 concerns the prophecy of Joseph who was sold into Egypt, his posterity and the record they would keep-the Book of Mormon. A comparison between the text of the Inspired Version of Genesis 50 and the Book of Mormon text that correlates with it shows the integrity of Joseph Smith as a translator. The two renditions agree in content, but disagree in detail because of the different authorship of the two accounts. [J.W.M.]

S.223 Skousen, W. Cleon. "The Prophet Lehi, Contemporary of Jeremiah." In Skousen's The Fourth Thousand Years, 698-701. Salt Lake City: Bookcraft, 1966. Though Jeremiah fails to mention his contemporary laborers by name, Lehi apparently was called to be one of the prophets to whom Jeremiah refers only collectively. Lehi's life was threatened and he was warned by the Lord to leave Jerusalem. His family and the family of Ishmael traveled eight years to safety, taking the records of the Jews with them in the form of brass plates. [J.W.M.]

S.224 Sleight, Thos. "The Book of Mormon." MS 48 (23, 30 August 1886): 529-32, 548-51. Uses biblical scriptures to prove the truthfulness of the Book of Mormon, gives summary of 1 Nephi, discusses plates (who wrote them, what language was used, their size and description). Explains how Joseph Smith found the plates in the Hill Cumorah, and gives a history of the founding of the LDS church. [A.C.W.]

S.225 Sletten, Nettie. God and Mankind versus Satan, Tracts on Divine Judgment and Salvation. New York: Exposition Press, 1957. A book that desires to convince the reader to repent and come to Christ. Sletten holds that the Bible and the Book of Mormon are the words of God and China and Russia are manifestations of Satan. Author does not believe that churches bring one to God, but the scriptures are instrumental in this objective. [A.C.W.] 
S.226 Slivka, Scott. "The Best at Something." NE 19 (July 1989): 19. This high school student desired to know more about the Book of Mormon than anyone in his school, a pursuit that brought feelings of self worth and spiritual security. [J.W.M.]

S.227 Smart, Ninian, and Richard D. Hecht. Sacred Texts of the World: A Universal Anthology. New York: Crossroad, 1982. Contains excerpts from sacred texts and scriptures of many of the world's religions. The editors quote 3 Nephi 21 from the Book of Mormon as a representative scriptural text from Mormonism and state that it represents "the charter for Joseph's foundation of the Church of Jesus Christ of Latter-day Saints and the vision which drew the faithful in their drive to create a new society in the American West." [D.M.]

S.228 Smith, Alice Colton. "In the Service of Your Fellow Men." Relief Society Magazine 56 (July 1969): 546-47. Uses the teachings of the Book of Mormon to show the importance of Christian service by members of the Church. [J.W.M.]

S.229 Smith, Brent D. The House of Israel and Native Americans. Provo, UT: FARMS, 1984. The author proposes "first to explore the antecedents and development of the notion of Hebrew descent; next to examine this view visa-vis contending views in the early years of the American Republic-both in the dialogue of the learned men of the day and the popular view espoused from the pulpit and published in written form; and lastly to touch upon the relationship between the issue of Indian Origins and the ascription of Indian ancestry offered in the Book of Mormon." [B.D.]

S.230 Smith, Brian L. "Joseph Smith: Gifted Learner, Master Teacher, Prophetic Seer." In Joseph Smith: The Prophet, The Man, edited by Susan Easton Black and Charles D. Tate Jr., 169-81. Provo, UT: BYU Religious Study Center, 1993. Joseph Smith was a gifted learner who was taught by the ancient prophets of God. When he went to the Hill Cumorah the heavens were opened and, as Nephi, he was given a panoramic vision. As he translated the Book of Mormon, he asked questions and brought down the very powers of heaven to give him the answers. In the beginning he used the Urim and Thummim, but he became so acquainted with the spirit of revelation and prophecy that in time he no longer needed the instruments. [J.W.M.]

S.231 Smith, C. Paul. I Will Send My Messenger: An Introduction to Mormonism. Dawsonville, GA: Communication Production Specialists, 1988. The Book of Mormon is "Another Testament of Jesus Christ." Presents a brief history regarding the publication of the work, and an overview of its contents. [D.W.P.]

S.232 Smith, Calvin N. "The Other 'Learned' Man." CN 53 (21 August 1983): 6, 12. A brief biographical treatise of Prof. Samuel Latham Mitchill who, in addition to Charles Anthon, was approached by Martin Harris to confirm the legitimacy of the Book of Mormon characters. [J.T.]

S.233 Smith, Conley. "Missionary Moments: The 'Best Missionaries.' " CN 56 (7 December 1986): 16. Testimony of a convert who discovered and joined the Church via the Book of Mormon; he found scriptural prophets such as Nephi and Moroni to be "the best missionaries." [A.C.W.]

S.234 Smith, David A. "Book of Mormon and Ancient Traditions." DN Church Section (6 January 1934): 5. Tells of American Indian traditions that support the Book of Mormon since they are similar to traditions of the Nephite and Lamanite people. [M.D.P.]

S.235 Smith, David A. "Book of Mormon and New Discoveries." DN Church Section (9 December 1933): 3. Gives a brief background of the Aztecs' Calendar Stone and of the disappearance of the Mayas between the time a.d. 400 
and 500. These evidences support the Book of Mormon. [M.D.P.]

S.236 Smith, David A. "I, Nephi Make a Record." DN Church Section (23 December 1933): 3. Gives a brief history of the translation process of the Book of Mormon and cites cases of ancient peoples like the Nephites who also kept records. [M.D.P.]

S.237 Smith, David A. "Origin of the American Indian." DN Church Section (6 May 1933): 5, 7. Since Columbus, the world has tried to find out the origin of the American Indian. The author gives several examples of different theories written on this subject. The members of the LDS church have a true history of the American Indian and that history is the Book of Mormon. [M.D.P.]

S.238 Smith, David A. Untitled talk. CR (April 1931): 100-106. Smith cites contemporary sources that describe ancient American culture in a way that supports the Book of Mormon. Some of the sources he cites are Prescott, Conquest of Mexico; Claverijo, History of Mexico; Holmes, Ancient Cities of Mexico; "New Clues to the Mayan Riddle," Popular Science Monthly, January, 1930. [B.D.]

S.239 Smith, David A., and J. Fred Evans. "Book of Mormon and Mayan Names." DN Church Section (13 January 1934): 6, 8. Argues that some names on the Mayan Calendar are similar enough to Book of Mormon names to clearly confirm the authenticity of the Book of Mormon. God permitted the ecclesiastics in A.D. 1561 to destroy the ancient records of the Indians so that when the Book of Mormon was published there would be no information on the Indians from which Joseph Smith could have been accused of borrowing ideas. [B.D.]

S.240 Smith, David Asael. Suggestions for Book of Mormon Lectures; with Quotations from Leading Archaeologists and Historians. Independence, MO: Zion's, 1949. Quotes from archaeologists and historians to demonstrate the veracity of the Book of Mormon. Includes a discussion of cement, iron, and steel; shows a comparison of Indian traditions and myths with similar stories from the Bible, including Indian belief in communion, baptism, the creation and flood, and the Great White God. [A.C.W.]

S.241 Smith, D. C. "Traits of the Mosiac History Found among the Aztec Nations." TS 3 (15 June 1842): 818-20. Relates Aztec traditions of the flood to the book of Ether in the Book of Mormon. Aztec traditions also reflect the tower of Babel and the dove that confused the tongues of mankind, permitting a select few to speak the same language. [J.W.M.]

S.242 Smith, Don Carlos. Untitled. TS 2 (15 March 1841): 353-55. Response to an article from the Upper Mississippian. Corrects the idea that Mormon was a contemporary prophet among the Latter-day Saints. Notes that the plates Joseph Smith translated were not brass. Defends as feasible the proposition that God can speak now as well as in biblical times. The Book of Mormon title page and the testimony of the Eleven Witnesses are included. [D.M.]

S.243 Smith, Don Carlos, and Ebenezer Robinson. "American Antiquities-More Proofs of the Book of Mormon." TS 2 (15 June 1841): 440-42. Reprint from the (New York) Weekly Herald. Tells of the visit of Mr. Catherwood and Mr. Stephens to Honduras, and of their observations of ruins. They were impressed with the artwork, and the achievement of the ancient inhabitants in architecture. Similarities with Christian motifs are noted. [D.M.]

S.244 Smith, Elbert A. The Great Restoration. Independence, MO: Herald House, n.d. Explores the Great Apostasy and the possible ways of recovering of the Church of Jesus Christ-reform or restoration. The gospel restoration began when Moroni visited Joseph Smith, bringing the original Christian teachings-the Book of Mormon. [J.W.M.] 
S.245 Smith, Elbert A. "Joseph Smith, Junior as a Translator." SH 60 (4 June 1913): 541-45. Responds to an article by the same name written by Rev. Bishop F. S. Spaulding, who attempts to discredit the Book of Mormon by attacking the translation of the book of Abraham. The position of the RLDS church is that Spaulding was not able to discredit the Book of Mormon completely, and it is impossible and unfair to judge the Book of Mormon except upon its own merits. [J.W.M.]

S.246 Smith, Elbert A. The Latter-Day Glory, number 9 of The Angel Message Series. Independence, MO: Herald Publishing House, n.d. This pamphlet recounts the first vision and then gives a reprint of the Church History account of Moroni's visit to Joseph Smith. Contains historical data concerning the organization of the Church and Church history. [J.W.M.]

S.247 Smith, Elbert A. "The Spaulding Romance Theory." SH 66 (1 October 1919): 953-56. Bruce Kinney concluded that there must have been a second Spaulding manuscript since the first one was found and was shown to have had no relationship to the Book of Mormon. This "new theory" suggests that Spaulding found the second manuscript in a cave and translated it-a theory which should be dismissed as was the original theory. [J.W.M.]

S.248 Smith, Elbert A. Statement of Belief on Faith and Doctrine. Independence, MO: Herald House, n.d. Pamphlet of statements resembling the Articles of Faith (written by Joseph Smith in the Wentworth Letter). Includes a statement condemning plural marriage; states that the Book of Mormon declares that a man should have but one wife. [J.W.M.]

S.249 Smith, Elbert A. "The Three Books." SH 97 (23 January 1950): 77-79, 87. Discusses the importance of the Bible, Doctrine and Covenants, and the Book of Mormon. Together they constitute the doctrine of the Church. The Book of Mormon is a valuable testament of Christ from cover to cover. [J.W.M.]

S.250 Smith, Eldred G. "Ask, Seek, and Knock." IE 70 (December 1967): 82-83. Oliver Cowdery and Joseph Smith learned that one of the concepts of the Gospel is to ask, seek, and knock. The process of translation was more than just looking into the Urim and Thummim. Revelation does not come without effort. [J.W.M.]

S.251 Smith, Ethan. View of the Hebrews; or the Tribes of Israel in America. Poultney, VT: Smith and Shute, 1825. Many see this work as the impetus for Joseph Smith's writing the Book of Mormon. However, this work is theoretical, where the Book of Mormon is sacred narrative. This work theorizes that the ten tribes of Israel traversed the Bering Straits. Smith calls upon native American tradition and language to sustain his theory that they are descendants of the Hebrews. [J.W.M.]

S.252 Smith, F. A. "Smith-Bays Debate." SH 48 (20 February, 6 March 1901): 151-93. A debate between D. H. Bays and Heman C. Smith. The debaters discuss the Bible, the Book of Mormon, the Three Witnesses. [J.W.M.]

S.253 Smith, Frederick A. "The Resurrection of the Dead." SH 64 (12 December 1917): 1197-1203. The Book of Mormon teachings concerning the resurrection appear in the books of Mosiah and Alma. These teachings are harmonious with biblical teachings. [J.W.M.]

S.254 Smith, Frederick A. "Why Study the Book of Mormon?" The Rod of Iron 1 (July, August, September 1924): 26. The Book of Mormon is of great historical worth to the American Indians and to those who seek to understand a history of religion. It is a record of the Lord's dealings with his people and gives an account of his doctrine. [J.W.M.] 
S.255 Smith, George Albert. "Book of Mormon Origin: Spaulding." JD 12:332-38. The Book of Mormon is the key to unlocking the messages of the Bible. Criticism arose that the Book of Mormon could not be true, for it is not grammatical and if it had been revealed of God it would have been grammatical. However, the Lord speaks to men in their own language. It is untrue that the Book of Mormon was written by Solomon Spaulding. [J.W.M.]

S.256 Smith, George Albert. "The Book of Mormon-The Savior in the New World." In Sharing The Gospel with Others: Excerpts From the Sermons of President Smith, edited by Preston Nibley, 98-103. Salt Lake City: Deseret News Press, 1948. Includes reprints of two articles. The first is a call to read the Book of Mormon and to share its precious truths with all of God's children. The second article is a conference talk in which the author announces that the Book of Mormon is printed in Braille. He recounts facts concerning the publication of the first edition of the book and the pact made by the people in the area of publication never to read the book. [J.W.M.]

S.257 Smith, George Albert. "Nephi Sees Our Day." CR (April 1918): 36-42. The prophet Nephi looked into the future and saw our day and described present world conditions with its prevalent evil and war. He saw in a detailed way Satan's various tactics in getting mankind to sin against God's laws. [R.C.D.]

S.258 Smith, George Albert. Untitled Talk. CR (April 1930): 64-69. A testimony of the Book of Mormon. Many have believed in the words of the book and the Lord's work has commenced among all nations. [B.D.]

S.259 Smith, George Albert. Untitled Talk. CR (April 1936): 13-16. The newly published Book of Mormon in Braille is part of the effort to distribute the book throughout the world. In fulfillment of the prophecy that many would believe the Book of Mormon (2 Nephi 30:3) the book has been published in many languages and there are more to follow. [J.W.M.]

S.260 Smith, George Albert. Untitled Talk. CR (April 1950): 142-46. A story of Smith's encounter with a tribe of Catawba Indians. Smith gave a man a Book of Mormon and said it explained the origin of the Indians. Smith testifies of the divinity of the Book of Mormon and how glorious it is to have the knowledge it contains. [B.D.]

S.261 Smith, George D. Review of Studies of the Book of Mormon, by B. H. Roberts. John Whitmer Historical Association Journal 6 (1986): 84-85. Book review.

S.262 Smith, George D., Jr. "Defending the Keystone: Book of Mormon Difficulties." Sunstone 6 (May-June 1981): 45-50. Discusses studies completed by B. H. Roberts on the Book of Mormon in which Roberts examined alleged textual problems and anachronisms in the Book of Mormon and also compared certain features of the Book of Mormon with Ethan Smith's work View of the Hebrews. [M.R.]

S.263 Smith, George D., Jr. "Is There Any Way to Escape These Difficulties?': The Book of Mormon Studies of B. H. Roberts." Dialogue 17 (Summer 1984): 94-111. Discusses studies on the Book of Mormon conducted by B. H. Roberts that focus upon alleged problems of the Book of Mormon that critics might raise in the future, compares the Book of Mormon and Ethan Smith's book View of the Hebrews, and examines other elements of Joseph Smith's 19th-century environment. [M.R.]

S.264 Smith, George D., Jr. "Isaiah Updated." In The Word of God: Essays on Mormon Scripture, edited by Dan Vogel, 113-30. Salt Lake City: Signature, 1990. Examines modern Christian interpretations of Isaiah. Mormon understanding differs because of theological beliefs and the Book of Mormon context of Isaiah passages. Smith argues that the Book of Mormon takes Isaiah out of context and that Mormon readers have interpreted passages in ways that Isaiah did not intend. [A.C.W.] 
S.265 Smith, George D., Jr. "Joseph Smith and the Book of Mormon." Free Inquiry 4 (Winter 1983): 21-31. Asserts that the Book of Mormon appealed to people of Joseph Smith's day because it reflected popular ideas of the time, and that it is merely a product of 19th-century concepts and events such as anti-Masonry, revivalism, and magical practices. Author also holds that the Book of Mormon uses biblical material anachronistically and borrows from concepts regarding the Hebrew origin of the Indians. [M.R.]

S.266 Smith, H. A. "Archeology Proves Gold Plates Common as Ancient Indian Books." DN (7 May 1932): 7. Archaeological discoveries in Mexico and Central America demonstrate the abundance and frequent use of gold. Spanish conquistadors describe plates and slabs of gold that match Joseph Smith's description of the gold plates. [A.C.W.]

S.267 Smith, Harry E. "A Book of Mormon Testimony." The Rod of Iron 2 (January 1925): 45. Smith, as a sixteenyear-old Methodist boy, came into contact with a man reading a book. He was invited to attend the man's church. While there he was prompted to quote wonderful scriptures that he did not recognize. He was amazed to find that these scriptures were from the Book of Mormon. [J.W.M.]

S.268 Smith, Hazel Dexter. Lessons from the Book of Mormon. 4 parts. Independence, MO: Herald House, 1933-34. Lessons from the Book of Mormon written in story form. Includes questions for study and discussion, problems to solve, and projects. [J.W.M.]

S.269 Smith, Heman C. "Book of Mormon Witnesses." Journal of History 4 (1911): 357-65. This work examines the reasons behind Oliver Cowdery's and David Whitmer's estrangement from the Church. [A.T.]

S.270 Smith, Heman C. (reported by Annie Allen). "Lectures on Church History, No. 3." SH 48 (2 October 1901): 795. Tells the story of the reception of the gold plates from the hands of Moroni. Joseph Smith was not to rely wholly upon divine power to protect the plates; he had to be diligent and watchful. Also reported is the story of Sidney Rigdon's visit to Professor Anthon and the lost 116 pages. [J.W.M.]

S.271 Smith, Heman C. "The Spaulding Romance." Journal of History 2 (1909): 89-95. Contains a series of letters between A. T. Schroeder of Salt Lake City and C. H. Bays of Battle Creek, Michigan, wherein Schroeder defends the Spaulding manuscript theory for the source for the Book of Mormon and D. H. Bays argues against the theory. [A.T.]

S.272 Smith, Heman C. The Truth Defended, or A Reply to Elder D. H. Bay's, "Doctrines and Dogmas of Mormonism." Lamoni, IA: Herald House, 1901. An apologetic work, written by a former Church Historian of the Reorganized church, responding to criticisms raised by Bays in his work, Doctrines and Dogmas of Mormonism. Bays did not accept the divine origin of the Book of Mormon. Smith defends the book, asserting that Joseph Smith was inspired of God in translating it. [M.R.]

S.273 Smith, Heman Hale. "Biography of David Whitmer." Journal of History 3 (1910): 298-305, 446-54. Contains an account of David Whitmer's conversion, excommunication, and ownership of a Book of Mormon manuscript. [A.T.]

S.274 Smith, Heman Hale. "Martin Harris." Journal of History 4 (1911): 214-22. A biography that relates the story of Martin Harris's loss of the 116 manuscript pages of the Book of Mormon and his experience of seeing the gold plates and signing the testimony of the Three Witnesses. Includes a letter by Martin Harris wherein he states that he never denied the truth of the Book of Mormon. [A.T.] 
S.275 Smith, Henry. "Cumorah." IE 32 (April 1929): 468-70. The Hill Cumorah is adorned by trees and a large sign containing Book of Mormon passages. [J.W.M.]

S.276 Smith Henry A. "An Exciting Discovery." CN 36 (7 May 1966): 6. Tells of the discovery of a sunken city off the coast of Peru and suggests that this might be one of the sunken cities described in the Book of Mormon. [M.D.P.]

S.277 Smith, Henry A. "Interesting Clipping." CN 35 (11 September 1965): 6. A clipping from a newspaper tells about an archaeological find that supports the authenticity of the Book of Mormon. It portrays the tree of life and includes three name glyphs that have been translated as Lehi, Sariah, and Nephi. [M.D.P.]

S.278 Smith, Henry A. "Pre-Columbian Horses." CN 35 (27 November 1965): 6. Cites archaeological evidence of native pleistocene horses in America, refuting previous ideas that horses were introduced by the Spaniards and supporting the Book of Mormon mention of the animal. [A.C.W.]

S.279 Smith, Henry A. "Proof from the Gold of Pyrgi." Instructor 101 (November 1966): 444-45. Discusses recent discoveries that provide evidence that ancient people did write on metal plates, including the finding of gold plates found in Pyrgi, Italy, that bear ancient inscriptions. [L.D.]

S.280 Smith, Henry A. " 'That They May Know....' CN 36 (29 January 1966): 3. Announcing the first publication of the Chinese Book of Mormon, with background information on its translation and publication. [M.D.P.]

S.281 Smith, Hyrum M. Untitled talk. CR (October 1903): 67-71. The world is in ignorance of gospel truth because many plain and precious truths have been removed from the Bible (1 Nephi 13). [B.D.]

S.282 Smith, Hyrum O. The Book of Mormon Evaluated. Independence, MO: Herald House, n.d. The moral precepts of the Book of Mormon are faultless and the book presents its own evidence of its divine origin. The purpose of the Book is to teach of Christ and it supports the claims of the Bible. [J.W.M.]

S.283 Smith, Hyrum O. The Book of Mormon Evaluated. Independence, MO: Herald Publishing, 1855?. Contains a collection of previously published items, "Book of Mormon Lectures" by H. A. Stebbins, "Book of Mormon Talks" by Orion (Hyrum O. Smith), "Book of Mormon Vindicated" by I. M. Smith, and "The Book of Mormon Evaluated" by Hyrum O. Smith. [J.W.M.]

S.284 Smith, Hyrum O. "The Book of Mormon Evaluated." SH 75 (8 February-14 March 1928): 149-50, 184-86, 217-20, 246-49, 280-83, 320-22. A series that discusses internal evidences of the Book of Mormon. The most important way to "prove" either the Bible or the Book of Mormon is to read it, study its teachings, and put them into practice. The Book of Mormon is not a fraud because a fraudulent book could not be so filled with the flawless moral teachings of Christ. It supports the Bible and is a second witness for God. [J.W.M.]

S.285 Smith, Hyrum O. Book of Mormon Talks, Birth Offering Series \#4. Lamoni, IA: Reorganized Church of Jesus Christ of Latter Day Saints, 1902. Written in the form of a discussion between a father and his four children. Answers criticisms of the Book of Mormon. The Book of Mormon is complimentary to the Bible. [A.T.]

S.286 Smith, Hyrum O. Why I Believe the Book of Mormon, An Evening Chat Between Two Friends. Lamoni: Herald House, n.d. A dialogue between two friends wherein one discusses the reasons he has joined the RLDS church. His main reason is the authenticity of the Book of Mormon. As proof of this, he discusses the restoration of the Jews 
to Israel and the power of the United States of America, both as prophesied in the Book of Mormon. He also uses historical evidence from South American Indian traditions. [A.C.W.]

S.287 Smith, I. M. "The Book of Mormon Vindicated." SH 42 (16, 23, 30 January, 6, 13, 20, 27 February, 6, 13 March 1895): 43-46, 58-61, 77-79, 93-96, 106-10, 123-27, 139-42, 156-57, 167-70. A defense of the Book of Mormon and brief summary of its contents. The Book of Mormon is a supplement to the Bible, not a replacement. Satan is active in attempting to discredit the Book of Mormon. The Book of Mormon is the fulfillment of biblical prophecies. [A.T.]

S.288 Smith, Isaac M. The Book of Mormon Vindicated. Independence, MO: Ensign House, 1898, 3rd ed. 1917. Reprinted as Mormonism II: Pro-Mormon Writings of the Twentieth Century, edited by Gary L. Ward, 1-119. New York: Garland, 1990. "A simple statement of facts as to what the Book of Mormon really is, and a plain presentation of the scriptural evidences in favor of its divine origin." Defines the mission of the Book of Mormon, tells of its coming forth and significance to the tribes of Israel, and of the prophecies it contains and fulfills. [A.C.W.]

S.289 Smith, Isaac M. "Is There a Contradiction?" SH 48 (24 April-8 May 1901): 328-32, 345-49, 363-66. A full investigation of the Bible and the Book of Mormon shows no contradiction between the two works. [J.W.M.]

S.290 Smith, Israel A. "Book of Mormon 'Characters.' SH 89 (3 October 1942): 1257-63. A discussion of the Rosetta Stone and Egyptian hieroglyphics and how these finds relate to the Book of Mormon and the story of the Anthon transcript. Includes a facsimile of the Anthon transcript and photographs of Egyptian works and transcript characters. [J.W.M.]

S.291 Smith, Israel A. "Book of Mormon Editorship: Grammatical Structure, Language, and Absence of Anachronisms." SH 98 (7 May 1951): 437-40. Focuses on the Book of Mormon's grammatical structure, language, and absence of anachronisms. Suggests the Book of Mormon as an antidote to latter-day secularism, then proceeds to give evidence of its Hebrew origin. [A.C.W.]

S.292 Smith, Israel A. The Language of the Book of Mormon. Independence, MO: Herald House, 1942, 1958. Reprinted from "A 'Sealed' Book." SH (28 February, 3, 17 March 1942): 262-63. Tells of Martin Harris's visit to Professor Charles Anthon and explains that the "Anthon Transcript" is in the possession of the RLDS church. Author points out similarities between this document and photographs from recognized Egyptian works and discusses the language and writing of the Book of Mormon. [A.C.W.]

S.293 Smith, Israel A. "The Origin, Purpose, and Preservation of the Book of Mormon." SH 98 (12 March 1951): 245-47, 254-55. Discusses the testimonies of the Three and Eight Witnesses, Moroni's angelic ministrations to Joseph Smith, and the purpose of the Book of Mormon as stated by Joseph Smith, the Book of Mormon itself, and other scripture. Concludes with an explanation of how the Book of Mormon has been preserved and invites the audience to examine the original manuscript kept by the RLDS church. [A.C.W.]

S.294 Smith, Israel A., et al. Outline Studies of the Book of Mormon Institute. Independence, MO: Herald House, 1951. Contains outlines of sermons by RLDS church dignitaries, including I. A. Smith, D. O. Chesworth, W. Wallace Smith, Maurice L. Draper, H. E. Velt, and R. A. Cheville. Topics include Book of Mormon history and doctrine. [D.M.]

S.295 Smith, J. H. "The Last Living Witness to the Book of Mormon." MS 45 (20 August 1883): 536-38. Because the prophet Joseph Smith took no credit for the discovery of the ancient plates and the translation thereof, men have criticized this book more than any other. Had he claimed to have found and translated them by his own 
genius, people would believe the Book of Mormon and proclaim Joseph a clever and learned man. The Book of Mormon is filled with internal evidences of its divinity, and there are also the testimonies of the witnesses. [J.W.M.]

S.296 Smith, J. H. "A Marvelous Work and a Wonder." MS 45 (8 October 1883): 648-52. Isaiah 29 prophesies future events concerning the Book of Mormon. The history of the Church proves that the Mormon church is a marvelous work and a wonder. Most of the persecution against the Church stems from the Book of Mormon. [B.D.]

S.297 Smith, J. H. "The Unpardonable Sin and the Three Witnesses." MS 50 (March 1888): 177-79. Evaluates the Three Witnesses' lives in respect to Paul's words on the unpardonable sin (Hebrews 6:4-6). Smith declares that the Three Witnesses did not commit the unpardonable sin as described by Paul. He maintains that "it surely was the purpose of God that they should go the road they had traveled." [B.D.]

S.298 Smith, J. R. "The Book of Mormon in the Light of Recent Jewish Archaeological Research." IE 34 (July 1931): 522-23, 559-60. A Jewish archaeologist, Isadore Lhevinne, affirms that Jews discovered America. Evidence shows that Jews reached Mexican shores on more than one occasion hundreds of years before Columbus. [J.W.M.]

S.299 Smith, J. Steven. Does the Bible Prophesy of the Book of Mormon? Safety Harbor, FL: EMFJ Ministries, 1980? A polemical tract that claims that Ezekiel 37:15-19 has nothing to do with the Book of Mormon. [D.W.P.]

S.300 Smith, James E. Review of "Multiply Exceedingly: Book of Mormon Population Sizes," by John C. Kunich, from New Approaches to the Book of Mormon, edited by Brent Lee Metcalfe, 231-67. Review of Books on the Book of Mormon 6/1 (1994): 255-96. Book review.

S.301 Smith, Jesse N. Untitled talk. CR (April 1905): 50-52. As a child, the author had in his possession an old first edition of the Book of Mormon because his family was very poor. He was embarrassed and felt inferior to the other children. The Prophet Joseph Smith gave him a new Book of Mormon and encouraged him to read it at school as well as at home. When young married couples begin their lives together, the author invites them to possess their own copies of the book. [J.W.M.]

S.302 Smith, John L. "The Book of Mormon." The Evangel 39 (April 1992): 5. Discusses Ezra Taft Benson's claim that the Book of Mormon is the most correct book on earth to show that Mormonism is not a Christian denomination. [A.C.W.]

S.303 Smith, John L. Has Mormonism Changed? Clearfield, UT: Utah Evangel Press, 1961. In the beginning Joseph Smith patterned Mormonism after six groups: Roman Catholicism, Campbell's teachings, the Pharisees, Masonry, Islam, and Rosicrucianism. Smith's claims to have translated the Book of Mormon by the power of God have no foundation. LDS doctrines and practices have changed. [J.W.M.]

S.304 Smith, John L. Hope or Despair? Mormonism-True or False. Clearfield, UT: Utah Evangel Press, 1957. Written to show Mormon missionaries, by the use of their own written material, the fallacy of their claims. The Book of Mormon itself is evidence of its fallacy. Shows the title page of the 1830 edition that proclaims Joseph Smith as its author. The Book of Mormon condemns polygamy and the book admits its own imperfection. [J.W.M.]

S.305 Smith, John L. "Moroni's Visits." The Evangel 39 (March 1992): 5. Questions the validity of visits by Moroni to Joseph Smith, the existence of the plates, and the veracity of the First Vision. Casts doubts on the characters of the Three Witnesses. [A.C.W.] 
S.306 Smith, John L. Who Wrote the Book of Mormon? Marlow, OK: Utah Missions, n.d. A brief polemical pamphlet attempting to discredit the Book of Mormon. The critic enumerates various anachronisms in the Book of Mormon such as poor grammar, repetitive expressions such as "and it came to pass," the method of translating, and plagiarisms from the Bible. [M.R.]

S.307 Smith, John L. Witnessing Effectively to Mormons. Marlow, OK: Utah Missions, 1975. An evangelical work for those attempting to win over Mormons. This is accomplished by pointing out "Protestant" doctrines within the Book of Mormon and doctrinal contradictions with the Bible, and through other means. [M.R.]

S.308 Smith, Joseph. "Correspondence." TS 4 (15 May 1843): 194. A letter to the editor written by Joseph Smith in rebuttal to the allegation that the word "Mormon" was translated from a Greek word. Joseph interprets the word "Mormon" to mean "more good." He attests that the language from which the plates were translated was Reformed Egyptian. He reaffirms the divine intervention of God in the translation process. [J.W.M.]

S.309 Smith, Joseph. Joseph Smith Tells His Own Story. Independence, MO: Price Publishing, 1985. A reprint of articles from the Times and Seasons vols. 3 and 4 in which Smith published his own story of family history, the First Vision, the coming forth of the Book of Mormon, and the organization of the Church. [J.W.M.]

S.310 Smith, Joseph. "Joseph Smith's 1832 Account of His Early Life." In Joseph Smith's 1832-34 Diary: Never Before Published, transcription by H. Michael Marquardt, 1-13. Salt Lake City: Modern Microfilm, 1979. Displays a photocopy of the original 1832 manuscript written by Joseph Smith and a transcript of Joseph Smith's 1832 history of the coming forth of the Book of Mormon. [J.W.M.]

S.311 Smith, Joseph. The Prophet Joseph Smith Tells His Own Story; A Brief History of the Early Visions of the Prophet. Independence, MO: Zion's, n.d. An account of Joseph Smith's history, written in 1838. A further history is added by an unknown author and includes a description of the organization of the Church, the Kirtland Temple dedication, the Saints' persecution in Missouri, the trek to Illinois, the martyrdom of Joseph and Hyrum, and the move westward. [J.W.M.]

S.312 Smith, Joseph. "Traits of the Mosaic History." TS 3 (15 June 1842): 818-20. Refers to the Aztec version of the flood and links it to the book of Ether. [D.M.]

S.313 Smith, Joseph. Visions of Joseph Smith the Seer. Plano, IL: RLDS Church, 1879. Provides the historical details of Joseph Smith's First Vision and of the coming forth of the Book of Mormon. It states the testimonies of the Eleven Witnesses, and then proceeds to give archaeological evidence of the divine authenticity of the Book of Mormon. This evidence is comprised of Hebrew inscriptions found by the mounds built near Newark, Ohio. [A.C.W.]

S.314 Smith, Joseph. Visions of Joseph Smith the Seer; Discoveries of Ancient American Record and Relics, with the Statements of Dr. Lederer (Converted Jew) and Others. Lamoni, IA: Reorganized Church of Jesus Christ of Latter Day Saints, 1879. Rehearses the Joseph Smith story. It contains a description of the Hill Cumorah and the visit of the angel Moroni. It gives an account of the Book of Mormon. Recounts the discovery of artifacts that had Hebrew inscriptions upon them. The testimonies of the Three Witnesses were substantiated by later affirmation. [J.W.M.]

S.315 Smith, Joseph, and Fred Madison Smith, eds. "Another Book of Mormon Vindication." SH 47 (24 October 1900): 686-87. Reprint of an article from Inter-Ocean (23 September 1900), which tells of a discovery of nearly 2,000 human skeletons in Galveston, Texas. Scientists were of the opinion that the city was destroyed by a giant 
tidal wave. The Saints' Herald article proposes that this occurred during the destruction at the time of Shiz and Coriantumr. [A.T.]

S.316 Smith, Joseph, and Fred Madison Smith, eds. "Another Testimony for the Book of Mormon." SH 47 (11 July 1900): 445. Report and commentary on an article from the Denver Republican (9 June 1900), which told of a trip that E. S. Compston of Harvard University made to Central America. Compston reported that he saw many similarities to the Book of Mormon but believed that Joseph Smith learned about these ruins from a traveler; yet many of the places Compston visited had never been viewed before. [A.T.]

S.317 Smith, Joseph, and W. W. Blair, eds. "Second Book of Mormon." SH 35 (10 March 1888): 147-48. Reprint of an article from Inter-Ocean (30 January 1888) concerning two copper plates that Joseph Smith allegedly claimed to be genuine and relating to the Mormon faith. Smith put on his "magical spectacles" and translated the plates into the Second Book of Mormon. Included is a rebuttal to this article from the Times and Seasons (1 May 1843) that states the plates, known as the Kinderhook Plates, were shown to Smith, but then taken away before he could make a translation. [A.T.]

S.318 Smith, Joseph III. "Last Testimony of Sister Emma." SH 26 (1 October 1879): 289-90. This interview conducted by Emma Smith's son in part concerns the Book of Mormon, its translation and publication. The question and answer format of the article declares that the prophet Joseph had not met Sidney Rigdon until after the publication of the book. Emma assisted in the translation, handled the cloth-wrapped plates, and verifies the book's divine authenticity. [J.W.M.]

S.319 Smith, Joseph F. "The Manuscript Found." IE 3 (February, March, April 1900): 241-49, 377-83, 451-57. This three-part essay describes in detail the author's experience in obtaining Solomon Spaulding's romance while in Honolulu. [D.M.]

S.320 Smith, Joseph F. "Original Manuscript of the Book of Mormon." DN (23 December 1899): 21. In rebuttal to "shameless falsehoods" that accuse the Church of Jesus Christ of Latter-day Saints of trying to buy the original manuscript of the Book of Mormon for purposes of trying to alter the text in favor of polygamy, this article states that these allegations are not true. Includes facts concerning the publication of the Book of Mormon and the location of the original manuscript. [J.W.M.]

S.321 Smith, Joseph F. "The Original Manuscript of the Book of Mormon." IE 3 (November 1899): 61-65. Challenges allegations printed in U.S. newspapers that David Whitmer had possession of the original manuscript of the Book of Mormon, and that elders from the Church visiting him in Richmond, Missouri, offered him $\$ 100,000$ for it. [D.M.]

S.322 Smith, Joseph F. "Testimonies of the Witnesses to the Book of Mormon." IE 30 (September 1927): 948-54. Writes concerning the law of witnesses, the Three Witnesses, and other witnesses of the Book of Mormon. [J.W.M.]

S.323 Smith, Joseph F. "Where Is the Original Manuscipt of the Book of Mormon?" IE 2 (November 1899). Also in A Book of Mormon Treasury, 11-15. Salt Lake City: Bookcraft, 1959, 1976. Refutes a claim made in an article printed in the St. Louis Republic concerning the whereabouts of the original manuscript of the Book of Mormon by arguing that the manuscript was placed in the southwest corner of the Nauvoo house. [A.T.] 
S.324 Smith, Joseph F., Jr. "The Original Manuscript of the Book of Mormon." IE 10 (June 1907): 572-76. The original manuscript of the Book of Mormon remained in the hands of Joseph Smith who put the pages in the cornerstone of the Nauvoo house. These were nearly destroyed by water and time. The only remnants are now in the possession of the Church. [J.W.M.]

S.325 Smith, Joseph Fielding. "Alma on the Resurrection." In Answers to Gospel Questions, 1:35-37. 5 vols. Salt Lake City: Deseret Book, 1957. A discussion and interpretation of Alma 40:19, or Alma's doctrine concerning the order of the resurrection among those who died before or after the time of Christ. [L.D.]

S.326 Smith, Joseph Fielding. "Archaeological Investigation and the Book of Mormon." In Answers to Gospel Questions, 2:195-98. 5 vols. Salt Lake City: Deseret Book, 1958. Determines that there is no evidence that nonLDS archaeologists have used the Book of Mormon as a guide for their archaeological work in the Americas. [L.D.]

S.327 Smith, Joseph Fielding. "Are there any Vital Changes in the Book of Mormon?" In Answers to Gospel Questions, 2:199-201. 5 vols. Salt Lake City: Deseret Book, 1958. Discusses typographical errors made in the early copies of the Book of Mormon, the preservation of parts of the original manuscript, and how having the proper spirit prevents criticism. [L.D.]

S.328 Smith, Joseph Fielding. "The Baptism of Alma." In Answers to Gospel Questions, 3:203-4. 5 vols. Salt Lake City: Deseret Book, 1960. Discusses the baptism and priesthood ordination of Alma and postulates that Alma held the priesthood before he fled the court of King Noah. [L.D.]

S.329 Smith, Joseph Fielding. "The Book of Mormon-A Divine Record." IE 64 (December 1961): 924-27. A plea to study the Book of Mormon again and again is made with the promise that the Lord has "greater things" to manifest if members of the Church will esteem the Book of Mormon. [J.W.M.]

S.330 Smith, Joseph Fielding. "The Book of Mormon," "A Divine Record," "The Three Witnesses," and "The Prophesied Future of the Indian People." In Smith's Seek Ye Earnestly... , 377-403. Salt Lake City: Deseret Book, 1970. These chapters provide a defense of the Book of Mormon. Smith discusses the adverse conditions under which the book was published, and he issues the warning that every member must read the Book of Mormon to know for himself/herself for no "member of the church can stand approved in the presence of God who has not seriously and carefully read the Book of Mormon." The witnesses of the Book of Mormon never denied their testimony of that book. The promises made to the Nephite prophets concerning their descendants are great. [J.W.M.]

S.331 Smith, Joseph Fielding. "Book of Mormon Critics Refuted." IE 65 (December 1962): 906-7. Also in CR 132 (October 1962): 21-22. A plea to the members of the Church to study the Book of Mormon. Critics of the Book of Mormon visit the homes of members pointing out the changes in the Book of Mormon and discrepancies with the Bible. [J.W.M.]

S.332 Smith, Joseph Fielding. "Book of Mormon Establishes Location of Historic Region." CN 24 (27 February 1954): 2-3. Takes issue with the view that the Hill Cumorah is located in Mexico or Central America and argues that the hill was located in upstate New York near Palmyra. [D.M.]

S.333 Smith, Joseph Fielding. "Coming Forth of the Book of Mormon and Witnesses of Book of Mormon." In Doctrines of Salvation, Vol 2: Sermons and Writings of Joseph Fielding Smith, edited by Bruce R. McConkie, 209-43. Salt Lake City: Bookcraft, 1956. Rehearses the events of the translation and the subsequent publication of the 
Book of Mormon. He discusses the Urim and Thummim, and tells of the important mission of Samuel H. Smith when he placed a Book of Mormon in the home of John P. Greene. Witnesses of the book are discussed along with the location of Cumorah in western New York. [J.W.M.]

S.334 Smith, Joseph Fielding. "Did the Nephites Have a Church Organization Before the Days of Alma?" IE 62 (August 1959): 584-85. Also in Answers to Gospel Questions, 3:38-41. 5 vols. Salt Lake City: Deseret Book, 1960. Asserts that the Nephites did indeed have a church organization before the days of Alma, and that Lehi, King Benjamin, and King Mosiah each had a church organization. Whenever and wherever there were gospel ordinances administered by a minister there was a church organization. [R.C.D.]

S.335 Smith, Joseph Fielding. Essentials in Church History. Salt Lake City: Deseret Book, 1979. Contains a historical account of the coming forth of the Book of Mormon-the visit of the angel Moroni, the translation, the lost manuscript, the witnesses and their testimonies. [J.W.M.]

S.336 Smith, Joseph Fielding. "For Ye Are Bought With a Price." In BYUSY (14 May 1957). Provo, UT: Brigham Young University. Recounts the plan of salvation from the Fall of Adam to the atoning sacrifice of Jesus Christ using quotations from 1 and 2 Nephi. [J.W.M.]

S.337 Smith, Joseph Fielding. "Handling Anti-Book of Mormon Charges." CR (October 1961): 18-20. A strong encouragement to the members of the Church to read and study the Book of Mormon. The only reason the antiMormon critics are able to discourage or disturb members is either because they lack "the faith" or they do not have "the background in knowledge to resist these false teachers." [R.C.D.]

S.338 Smith, Joseph Fielding. "The Hill Cumorah." DN Church Section (20 July 1935): 1, 8. Written for the dedication of the monument of Moroni that stands on the Hill Cumorah. Retells the story of Mormon's and Moroni's abridging the Book of Mormon, Moroni's appearances to Joseph Smith, and Joseph Smith's receiving the plates from Moroni at the Hill Cumorah. [M.D.P.]

S.339 Smith, Joseph Fielding. "How Can First Nephi 3:7 and Doctrine and Covenants 84:4 be Reconciled?" IE 65 (September 1962): 630-31. Also in Answers to Gospel Questions, 4:111-15. 5 vols. Salt Lake City: Deseret Book, 1963. Discusses Matthew 12:39 to show that there are no contradictions between 1 Nephi 3:7 and D\&C 84:4. He concludes that the injunction of the Lord to build a temple was hampered by such opposition that the plan of the Lord was merely postponed-"the purposes of the Lord will prevail." [J.W.M.]

S.340 Smith, Joseph Fielding. "How Was Lehi a Descendant of the Jews?" IE 58 (October 1955): 702. Also in Answers to Gospel Questions, 1:142-43. 5 vols. Salt Lake City: Deseret Book, 1957. Lehi and the Nephites are referred to as "Jews" in several Book of Mormon and Doctrine and Covenants passages (2 Nephi 30:4; D\&C 19:27; D\&C 57:4), even though they were literal descendants of Ephraim and Manasseh (Alma 10:3). They were Jews not so much by actual descent as by citizenship, having lived in Jerusalem in the kingdom of Judah, or through intermarriage. [R.C.D.]

S.341 Smith, Joseph Fielding. "Is There a Contradiction Between Alma 7:10 and Matthew 2:5-6?" IE 58 (April 1955): 222. Also in Answers to Gospel Questions, 1:172-75. 5 vols. Salt Lake City: Deseret Book, 1957. There is no contradiction. Joseph Smith and all of his associates knew perfectly well that Bethlehem was where Jesus was born. The expression used in Alma 7:10 was not that Jesus was born in Jerusalem, but at Jerusalem. This is a Hebrew expression and simply refers to a geographical area-Jerusalem and environs, including Bethlehem. [R.C.D.] 
S.342 Smith, Joseph Fielding. "Is There a Contradiction Between Jacob 2:24-27 and Doctrine and Covenants 132:39?" In Answers to Gospel Questions, 4:212-15. 5 vols. Salt Lake City: Deseret Book, 1963. Concludes there is no contradiction based on Jacob 2:30 and 2 Samuel 12:7-8. [L.D.]

S.343 Smith, Joseph Fielding. "Joseph Smith's 'Translation' of the Scriptures." IE (1914): 589-96. Quotes the Eighth Article of Faith declaring that Latter-day Saints believe both the Bible and the Book of Mormon to be the words of God. Nephi taught that the Hebrew scriptures had "plain and precious parts" removed. For this reason Joseph Smith was called on to revise the Bible and produce an "inspired translation." [J.W.M.]

S.344 Smith, Joseph Fielding. "Judgments of the Lord to Pour Forth." IE 69 (December 1966): 1099-100. There is great need throughout the world for repentance and purification through the atoning sacrifice of Jesus Christ. For the good of mankind Satan was cast down to the earth that there might be an opposition in all things and punishments affixed. Those who profit from the experiences of others and are willing to look to God and live will be spared from the calamities that will plague the earth in these last days. [J.W.M.]

S.345 Smith, Joseph Fielding. "Keep the Commandments." IE 53 (December 1950): 965-66. Church members (and those in the world if they only knew) should be grateful that the Lord has given further or/and clearer light of revelation in the Book of Mormon and other modern scriptures. [R.C.D.]

S.346 Smith, Joseph Fielding. "Nephi Sees Our Day." In Proceedings of the Manchester Area Conference, 5-7. Salt Lake City: Church of Jesus Christ of Latter-day Saints, 1972. The prophet Nephi saw the latter days in vision, with all of their evil and all of their good. [J.W.M.]

S.347 Smith, Joseph Fielding. "Nephite Baptisms and the Gift of the Holy Ghost." IE 65 (June 1962): 390-91. The gift of the Holy Ghost may not be received without the laying on of hands. Book of Mormon prophets had the authority to bestow that gift. The Lord did not overlook any necessary ordinances for the Nephites when he visited with them following his resurrection. [J.W.M.]

S.348 Smith, Joseph Fielding. "Nephites and Lamanites." In Smith's Progress of Man, 130-43. Salt Lake City: Deseret New Press, 1940. Jacob 5 in the Book of Mormon provides the history of the house of Israel. Today this is a record of warning to all to avoid the pitfalls and rebellions that destroyed those who formerly inhabited this continent. [J.W.M.]

S.349 Smith, Joseph Fielding. "No One Can Stand Approved Who Has Not Read the Book of Mormon." CN 31 (7 October 1961): 8. Refutes claim of one thousand changes in Book of Mormon since its first publication. Exhortation to read the Book of Mormon and gain a testimony of its truthfulness. Members of the LDS church are on probation and, if proven worthy, will receive the fullness of the sealed portion of the plates. [A.C.W.]

S.350 Smith, Joseph Fielding. "Origin of the First Vision." IE 23 (April 1920): 496-505. The First Vision answered many questions prevalent in the 19th century. The account of that vision agrees with the doctrine of the Church and the Book of Mormon. Those who read the Book of Mormon will know of its truthfulness and authenticity. [J.W.M.]

S.351 Smith, Joseph Fielding. "The Original Manuscript of the Book of Mormon." In Book of Mormon Treasury, 1618. Salt Lake City: Bookcraft, 1959, 1976. The original copy of the Book of Mormon manuscript was nearly destroyed while it rested in the cornerstone of the Nauvoo House. Its fragments are now in different locations. The Reorganized church has the printer's copy of the Book of Mormon. [A.T.] 
S.352 Smith, Joseph Fielding. "Predictions in the Bible Concerning the Book of Mormon." IE 26 (September 1923): 958-62. Also in A Book of Mormon Treasury, 190-95. Salt Lake City: Bookcraft, 1959, 1976. Discusses Bible predictions that have been associated with the Book of Mormon-the prophetic blessings that Jacob gave Joseph and his two sons, the oracles in Micah and Isaiah, parts of Isaiah 29, Ezekiel 37, and John 10. [D.M.]

S.353 Smith, Joseph Fielding. "The Present Status of the Lamanites." In Answers to Gospel Questions, 3:122-23. 5 vols. Salt Lake City: Deseret Book, 1960. Discusses the curse of dark skin being placed upon the Lamanites and how their evil ways brought back the curse of dark skin after it had been removed. [L.D.]

S.354 Smith, Joseph Fielding. "President Smith Calls For More Study, Research." CN 32 (13 October 1962): 7, 9. Exhorts members of the LDS faith to read the Book of Mormon. Discusses prophecy concerning Christ's birth in the land of Jerusalem and the covenant of Mosiah 5:7. Concludes with testimony, and points out the effectiveness of testimony and knowledge against those critical of the Book of Mormon. [A.C.W.]

S.355 Smith, Joseph Fielding. "The Priesthood of the Nephites." IE 59 (March 1956): 142-43. Also in Answers to Gospel Questions, 1:123-26. 5 vols. Salt Lake City: Deseret Book, 1957. Discusses whether or not the Nephites had the Aaronic priesthood, concluding that the Nephites operated under the Melchizedek priesthood from the time of Lehi to the coming of Christ. [L.D.]

S.356 Smith, Joseph Fielding. "Principles of the Gospel: The Divine Law of Witnesses." DN Church Section (8 April 1939): 1, 4, 6, 8. The divine law of witnesses is fixed and definite. More than one witness is required, and had good records been kept through the ages one would probably find this to be so from the beginning. Three witnesses were called to testify of the Book of Mormon; they never denied this testimony, though two were excommunicated. [J.W.M.]

S.357 Smith, Joseph Fielding. "Progression and Retrogression." IE 22 (April 1919): 465-73. In rebuttal to the theory of evolution, this article points out that the first man on earth was intelligent, kept records, and knew the gospel. Then the children of men rebelled and fell into a degenerate state. Ancient America and the Book of Mormon are good examples of progression and retrogression. [J.W.M.]

S.358 Smith, Joseph Fielding. "Publication of the Book of Mormon." Relief Society Magazine 14 (September 1927): 423-29. Quotes Samuel H. Smith's story of the coming forth of the Book of Mormon; praises the title page and the promise therein. Gives historical facts concerning the publication and sales of the book. [J.W.M.]

S.359 Smith, Joseph Fielding. "Rebaptism of Nephi III." In Answers to Gospel Questions, 3:205-6. 5 vols. Salt Lake City: Deseret Book, 1960. Discusses 3 Nephi 11:21, Helaman 16:3-4, and 3 Nephi 11:28, and how the people were rebaptized when Christ came because the law of Moses was done away with and they were living a new law based on 3 Nephi 9:15-22, 11:10-40, 12:18-19, and 15:4-10. [L.D.]

S.360 Smith, Joseph Fielding. The Restoration of All Things: A Series of Radio Talks. Salt Lake City: Deseret News, 1944. Since the day of publication of the Book of Mormon, the flood of opposition towards it has increased. The Book of Mormon answers the critics successfully, fulfills biblical prophecy, and is a testimony against the world. Since not all believe, special witnesses had to be chosen. The Three Witnesses of the Book of Mormon remained true to their testimonies. [J.W.M.]

S.361 Smith, Joseph Fielding. "Seasons of Prayer." CR (October 1919): 141-46. An admonition to pray, as the Book of Mormon instructs, at all times and places. If members of the LDS church are not praying it is because, as the 
Book of Mormon teaches, they do not have the Spirit, for if they had it, then they would be praying. [R.C.D.]

S.362 Smith, Joseph Fielding. "The Stick of Joseph in the hand of Ephraim." In Answers to Gospel Questions, 3:19798. 5 vols. Salt Lake City: Deseret Book, 1960. If Lehi is of the house of Manasseh, how can the Book of Mormon claim to be the stick of Ephraim referred to in Ezekiel 37? Smith argues that Ishmael, co-founder of the Lehi colony, was of the house of Ephraim. He also analyzes the Ezekiel passage finding that the stick was of Joseph thus including both Ephraim and Manasseh. [J.W.M.]

S.363 Smith, Joseph Fielding. "Testimonies of the Witnesses to the Book of Mormon." IE 30 (September 1927): 948-54. Also in Book of Mormon Treasury, 30-38. Salt Lake City: Bookcraft, 1959. Sets forth the Lord's law of witnesses as recorded in the scriptures. The provision for witnesses to testify regarding the reality of the gold plates perfectly fits the scriptural pattern and the Book of Mormon itself predicted that there would be such witnesses. The Book of Mormon witnesses remained true to their testimonies all of their lives. [D.M.]

S.364 Smith, Joseph Fielding. "They Bear Witness." IE 59 (December 1956): 921-22. The Lord has always had witnesses to bear testimony of his truths-the coming forth of the Book of Mormon follows suit. All who read the Book of Mormon may read the testimony of the Three Witnesses. [J.W.M.]

S.365 Smith, Joseph Fielding. "Three Days of Darkness." IE 62 (October 1959): 728. Also in Answers to Gospel Questions, 3:44-45. 5 vols. Salt Lake City: Deseret Book, 1960. Luke 23:44 states that at Christ's crucifixion there was a period of darkness over all the earth until the ninth hour. The Book of Mormon, however, states that it was a three-day darkness on the American Continent. Both accounts are correct. The God of miracles who caused a three-hour darkness on one continent also caused a three-day darkness on the other. The greater period of darkness came because of the extreme wickedness of those in America. [R.C.D.]

S.366 Smith, Joseph Fielding. "The Three Witnesses." IE 69 (July 1966): 612, 652. The Three Witnesses remained faithful to their testimonies of having seen the plates. While all three fell away from the Church, Oliver Cowdery and Martin Harris returned and died faithful members. David Whitmer never returned, but reaffirmed his testimony to his dying day. [J.W.M.]

S.367 Smith, Joseph Fielding. "Translation and Publication of the Book of Mormon." IE 30 (September 1927): 94648. Surveys the events leading to the publication of the Book of Mormon and discusses the length of translation time, the roles of Martin Harris, Oliver Cowdery, and the Three Witnesses, the obtaining of the copyright, and the preparation for publication. [D.M.]

S.368 Smith, Joseph Fielding. "Translation of the Book of Mormon." MS 89 (22 September 1927): 593-95. The translation of the Book of Mormon commenced about April 7, 1829, and the copyright is dated June 11, 1829. In this short period of just under two months the translation was completed. [J.W.M.]

S.369 Smith, Joseph Fielding. "Urim and Thummim." IE 57 (1954): 382-83. A brief historical sketch of what is known about the Urim and Thummim, from the brother of Jared, Abraham, Moses, Mosiah, and Joseph Smith. [R.C.D.]

S.370 Smith, Joseph Fielding. "Were the Nephite Twelve, Apostles?" In A Book of Mormon Treasury, 152-53. Salt Lake City: Bookcraft, 1959, 1976. Also in Answers to Gospel Questions, 1:121-22. Salt Lake City: Deseret Book, 1957. States that the Nephite twelve disciples were apostles, possessing powers and authority similar to that held by Peter and the twelve apostles in Jerusalem. [A.T.] 
S.371 Smith, Joseph Fielding. "When Did Jesus Appear to the Nephites?" IE 64 (May 1961): 296-97. The appearance of Christ in America occurred shortly after his ascension from the Mount of Olives into heaven. [J.W.M.]

S.372 Smith, Joseph Fielding. "Where Are the Plates?" IE 30 (September 1927): 948-54. Possession of the actual golden plates is not requisite according to God's law of witnesses, which is fulfilled by the witness of the Spirit and the Three and Eight Witnesses. [S.H.]

S.373 Smith, Joseph Fielding. "Where Did Alma Get His Authority?" IE 66 (July 1963): 582-83. Also in Answers to Gospel Questions, 4:161-64. Salt Lake City: Deseret Book, 1963. Explains that since there were no members of the tribe of Levi among the Nephites, the Nephites officiated by virtue of the Melchizedek Priesthood rather than the Aaronic. Concludes that Alma received the priesthood before Noah became king and remained righteous enough to retain this authority, although he immersed himself while baptizing Helam as part of the repentance process. [A.C.W.]

S.374 Smith, Joseph Fielding. "Where Is the Hill Cumorah?" DN Church Section (10 September 1938): 1, 6. The Hill Cumorah was the same as the Jaredite hill Ramah. It seems that the Hill Cumorah of New York is the exact hill spoken of in the Book of Mormon. [J.W.M.]

S.375 Smith, Joseph Fielding. "Who Were the Prophets Zenos and Zenock?" In Answers to Gospel Questions, 4:138-42. Salt Lake City: Deseret Book, 1963. There are no records of the Hebrew prophets Zenos and Zenock other than the fragments attributed to them in the Book of Mormon, notably Zenos's allegory of the olive tree in Jacob 5. [A.C.W.]

S.376 Smith, Joseph Fielding. "The Witness of the Book of Mormon." DN (19 August 1944): 14, 16. Many say they would believe the Book of Mormon if the plates were on display. Smith explains that the Lord works by faith (2 Nephi 27:22-23). There are, however, the testimonies of the Three Witnesses and the Eight Witnesses who testify that the plates existed. [B.D.]

S.377 Smith, Joseph Fielding. "Your Question Answered by Joseph Fielding Smith Regarding Mosiah 15." IE 65 (March 1962): 150, 214-15. There have been many intelligent, honest men who never heard the gospel and will not be held accountable for their sins, for their acts were done in faith and obedience to what they had been taught. [J.W.M.]

S.378 Smith, Joseph Fielding. "Your Question Answered by Joseph Fielding Smith-The Debt We Owe." IE 64 (November 1961): 800-801. Jacob (2 Nephi 9) taught concerning the Atonement and mission of Jesus Christ, and Aryan's debt to him. Out of love members of the Church should show deep gratitude by obedience and in humble prayer. [J.W.M.]

S.379 Smith, Julina. "A Discussion of the Inter-relation of the Latter-day Saints and the American Indians." M.A. thesis, Brigham Young University, 1932. Deals with the historical relations between the Mormons and the Indians, and gives a brief overview of the Book of Mormon, explaining how that and biblical prophecies have influenced relations between the Latter-day Saints and the American Indians. [A.C.W.]

S.380 Smith, Lucy. "The Printing of the Book of Mormon." Restoration Voice 69 (January/February 1990): 5-8. Reprinted from Joseph Smith the Prophet and His Progenitors. Historical narrative concerning Joseph Smith's 
meetings with E. B. Grandin, Oliver Cowdery's manuscript transcriptions, securing the copyright, and other details associated with the printing of the Book of Mormon. [A.C.W.]

S.381 Smith, Lucy Mack. Biographical Sketches of Joseph Smith the Prophet and His Progenitors for Many Generations. Liverpool, England: S. W. Richards, 1st edition, 1853. 2nd edition, Plano, IL: RLDS Church, 1880. Deals with events in the lives of the author's family members. She discusses her son Joseph and the coming forth of the Book of Mormon, and gives in detail historical facts about the origin and early days of the Church of Jesus Christ of Latterday Saints, including the events surrounding the translation of the Book of Mormon and the 116 pages of lost manuscript. [A.C.W.]

S.382 Smith, Lucy Mack. "History of the Prophet Joseph by his Mother, Lucy Smith: Chapters XXIV-XXVIII." IE 5 (April 1902): 401-21. The Improvement Era reprinted all of Lucy Smith's history. These chapters record that Joseph brought home the breast plate, the translation began, Mrs. Harris was opposed the work, Martin Harris lost the 116-page manuscript, the Urim and Thummim was taken from Joseph Smith, and Oliver Cowdery wrote for Joseph as a scribe. [B.D.]

S.383 Smith, Lucy Mack. Letter to Sister-In-Law Mrs. Mary Pierce. N.p., n.d. Hoffman forgery. A transcript of the letter was printed in CN 52 (28 August 1982): 3. [J.W.M.]

S.384 Smith, Lucy Mack, and James Patrick McEwan. "The Book of Mormon-A Latter-day Missionary of the Restored Gospel." Instructor 94 (July 1959): 254-55. Lucy Mack Smith relates the conversion of Mrs. and Rev. John P. Greene, Phineas Young, Brigham Young, Mrs. Murray, and the wife of Heber C. Kimball through a single copy of the Book of Mormon left with Rev. Greene. [R.H.B.]

S.385 Smith, Lyle. "Chiasmus." Witness 65 (May 1989): 4-6. Chiasmus is a Hebrew literary style that renders words, phrases, or ideas in an intentional order then immediately repeats them. It is prevalent in the Book of Mormon. Includes examples. [J.W.M.]

S.386 Smith, Lyle. "Diving For Underwater Ruins." Witness 80 (Spring 1993): 8. Reports an expedition to Lake Peten Itza where manmade mounds lay at the bottom of the lake, in keeping with the Book of Mormon, which reports that cities sank at the crucifixion of Christ. [J.W.M.]

S.387 Smith, Lyle. "Maya Language and the Book of Mormon." Witness 70 (Fall 1990): 12-14. Finds parallels between Maya hieroglyphs and themes in the Book of Mormon to demonstrate the validity of Mesoamerica as the setting for Book of Mormon events. [A.C.W.]

S.388 Smith, Lyle. "Mirror Images in Mesoamerica." Witness 66 (Fall 1989): 4-7, 10. Chiasmus is used so profusely in the Book of Mormon that this author examines the mirror image of chiasmus in other forms such as art and architecture. The article contains figures and photographs as examples. [J.W.M.]

S.389 Smith, Lyle. "Royal Fifth." Witness 69 (Summer 1990): 14-15. Michael Coe has noted that the books of Mayan writing were reportedly very similar in appearance to Egyptian, thus vindicating the Book of Mormon. [A.C.W.]

S.390 Smith, Lyle. "Teotihuacłn: A City of Our God?” Witness 78 (Fall 1992): 10-14. Examines archaeological and religious history of the city of Teotihuac $¥ n$ between 100 b.c. and a.d. 400 to discover correlations with Book of Mormon cultural history. [A.C.W.] 
S.391 Smith, Lyle, and Sherrie Kline Smith. "Palenque Tablet of 96 Glyphs." Witness 76 (Spring 1992): 10-14. "The Tablet of 96 Glyphs from Palenque provides a strong witness that the Maya knew about and utilized the same literary practices as Hebrew writers." The writers point out literary practices that appear in the Book of Mormon: the phrase "it came to pass," chiasmus, and paired opposites. [B.D.]

S.392 Smith, Oliver R. "Low Out of the Dust." IE 40 (October 1937): 611, 631. The Hill Cumorah pageant, "Americas Witness for Christ," was prepared from the Book of Mormon by H. Wayne Driggs. It depicts scenes from the Book of Mormon, which proclaims a solemn message of Christ. [J.W.M.]

S.393 Smith, Paul Thomas. The Story of the Joseph Smith Transcript of Characters from the Book of Mormon. Salt Lake City: Author, 1980. Retells the story of Martin Harris's visit to Anthon with the Book of Mormon characters. Also contains some primary sources and letters dealing with the characters. [D.W.P.]

S.394 Smith, Penny F. "The Book of Mormon." In The People's Almanac \#2, edited by David Wallenchinsky and Irving Wallace, 1170-71. New York: William Morrow, 1978. General description of the contents of the Book of Mormon as well as a Mormon and non-Mormon view of its origins. The publishing history of the Book of Mormon is also noted. [J.T.]

S.395 Smith, R. H. "Indian Traditions." Juvenile Instructor 14 (15 February 1879): 46-47. Says Indian traditions support authenticity of Book of Mormon. Encourages youth to carry gospel to these "poor, ignorant Lamanitessince they are ready to receive a record of their forefathers." [A.C.W.]

S.396 Smith, Richard Pearson. "The Nephite Monetary System." IE 57 (May 1954): 316-17. A scholarly analysis of the monetary system of the Nephites used around 82 b.c. and described in Alma 11. The Nephite system was a slight modification of a binary system, where each unit would have twice the value of the next smaller one. Shows parallels with similar systems in Egypt and Macedonia. [R.C.D.]

S.397 Smith, Robert F. "Book of Mormon Event Structure: Ancient Near East, with Excursus, The Arabian Nexus." Provo, UT: FARMS, 1984. Explores the events that occurred in the ancient Near East preceding the time and just following Lehi's departure for the promised land. It includes a suggested dating system for Book of Mormon peoples based upon the Mesoamerican calendar. Includes a discussion of the Southern Arabian Peninsula and Lehi's excursion in the wilderness. [J.W.M.]

S.398 Smith, Robert F. "The 'Golden Plates.' " In Reexploring the Book of Mormon, edited by John W. Welch, 275-78. Salt Lake City: Deseret Book and FARMS, 1992. It was a common ancient American practice to make plates of tumbaga alloy and treat them with acid to remove surface copper. This left a soft gold surface easy to engrave yet supported by a strong thin sheet. A total of 120-200 plates written on both sides with one third sealed would leave from 80-266 surfaces for the record we have. [N.K.Y.]

S.399 Smith, Robert F." 'It Came to Pass' in the Bible and the Book of Mormon." Provo, UT: FARMS, 1984. The use of the Book of Mormon passage "it came to pass" is comparable to the use of the phrase wayehi in the Old Testament. The article includes tables showing the comparisons made. [J.W.M.]

S.400 Smith, Robert F. "The Land of Jerusalem: The Place of Jesus' Birth." In Reexploring the Book of Mormon, edited by John W. Welch, 170-72. Salt Lake City: Deseret Book and FARMS, 1992. Scholars allege the Book of Mormon was in error when it claimed that Jesus was born in the land of Jerusalem. The land of Jerusalem 
designation, used only once in the Bible, also included the area of Bethlehem and is confirmed by several recent studies. [N.K.Y.]

S.401 Smith, Robert F. "Lodestone and the Liahona." In Reexploring the Book of Mormon, edited by John W. Welch, 44-46. Salt Lake City: Deseret Book and FARMS, 1992. Laman could not explain why the Liahona worked by faith and why the writing on it was changed from time to time. The use of magnetite as a compass was well known in this time period. Use of magnetic ores for compasses was known among the Olmecs of Vera Cruz, Mexico. [N.K.Y.]

S.402 Smith, Robert F. "New Information About Mulek, Son of the King." In Reexploring the Book of Mormon, edited by John W. Welch, 142-44. Salt Lake City: Deseret Book and FARMS, 1992. Mulek connects the Book of Mormon with the Old Testament as it has been confirmed that he was a son of King Zedekiah. The Old Testament names him Malachiah, the son of Hammelech, or more accurately MalkiYahu, son of the king. [N.K.Y.]

S.403 Smith, Robert F. "Shakespeare and the Book of Mormon." Provo, UT: FARMS, 1981. Lehi's expression, "the cold and silent grave, from whence no traveler can return" (2 Nephi 1:14) has been the object of scorn and ridicule by Book of Mormon critics for more than a century. According to these critics Joseph Smith plagiarized a quotation of Shakespeare's Hamlet. Smith addresses the problem of Lehi's/Shakespeare's expressions by noting and discussing similar phraseology in both modern and ancient texts. Lehi's expression speaks metaphorically of death, the grave, the netherworld, and afterlife, not unlike many other ancient sources. [D.W.P.]

S.404 Smith, Robert F. "Some Neologisms from the Book of Mormon." In Conference on the Language of the Mormons, 64-68. Provo, UT: Language Research Center, Brigham Young University, 31 May 1973. Discusses some of the more popular neologisms found in the Mormon canon. Emphasis is placed upon word origins and pronunciation. [D.S.T.]

S.405 Smith, Robert F. "Textual Criticism of the Book of Mormon." In Reexploring the Book of Mormon, edited by John W. Welch, 77-79. Salt Lake City: Deseret Book and FARMS, 1992. Discusses instances of changes made in earlier and later Book of Mormon editions, and differences between the Book of Mormon and the King James Bible-i.e., Joseph Smith uses Ramah whereas the King James Bible uses Ramath, 2 Nephi 27:3 reads Zion instead of Ariel, or City as in Isaiah 29:7, and the 1981 Book of Mormon has replaced fathers with father in Jacob 2:27 as per the original printer's manuscript. [N.K.Y.]

S.406 Smith, Robert F., Gordon C. Thomasson, and John W. Welch. "What Did Charles Anthon Really Say?" In Reexploring the Book of Mormon, edited by John W. Welch, 73-76. Salt Lake City: Deseret Book and FARMS, 1992. Relates events of Martin Harris's meeting with Charles Anthon and subsequent statements by Anthon negating the experience. Shows by phraseology and contradictions that Anthon lied afterwards to protect his reputation. [A.C.W.]

S.407 Smith, R. H. "Albino Zunis." Juvenile Instructor 13 (1 April 1878): 81-82. Infers that albino Indians are a genetic reminder of an earlier lighter-skinned ancestry. [D.M.]

S.408 Smith, R. H. "Indian Traditions." Juvenile Instructor 14 (15 February 1879): 46-47. Recounts missionary labors among the Pueblo and Zuni Indians, who recognized the message in the Book of Mormon as belonging to their ancestors. [D.M.]

S.409 Smith, Robert William. Miniature Model of the Gold Plates. Salt Lake City: Pyramid, 1938. Presents a paper and wood model of the gold plates. [D.W.P.] 
S.410 Smith, Robert William. Other Sheep; a Saga of Ancient America. Salt Lake City: Pyramid, 1939. Using characters from the Book of Mormon, the author produces a fictitious story of the time surrounding Jesus' visit to the people of ancient America. [D.S.T.]

S.411 Smith, Robert William, comp. The Mystery of the Ages Containing Information Regarding the Great Pyramid of Gizeh in Egypt and the Pyramids and Peoples of Ancient America. Salt Lake City: Pyramid, 1931. This booklet calls attention to the wonder of the Great Pyramid of Egypt and points out that ancient Americans show archaeological similarities to the ancient Egyptians. Smith discusses astronomy and geometry as related to the construction of these ancient structures and explores how Mayan ruins and the legend of Quetzalcoatl relate to the Book of Mormon. [A.C.W.]

S.412 Smith, Sherrie D. "Chinese Civilization and the Book of Mormon." ZR 13-14 (Summer, Fall 1981): 1-4. Contains " 'evidences' that the Jaredites went across Asia through China"-shows parallels between the Chinese dragon and Quetzalcoatl, and between a lighted stone in Chinese tradition and the stones used in the Jaredite barges. The real name of the brother of Jared was never given, a practice that is still a tradition in China. [A.T.]

S.413 Smith, Sherrie D. "Jade: Stones of Light." ZR 24-26 (Fall 1984): 4-5. Examines the criteria for the substance of the 16 Jaredite stones. The author argues that jade fits each criteria of the substance that was used. [A.T.]

S.414 Smith, Sherrie D. "Sacred Stones." ZR 24-26 (Spring, Summer, Fall 1984): 1-3. Contains a brief description of a trip that the author took to Central America to visit possible Book of Mormon locations. The author concluded that the Pi disks (circular jade disks found in a tomb at Monte Alban) and doughnut shaped objects represented the 16 Jaredite stones used for lighting the barges. [A.T.]

S.415 Smith, Sherrie Kline. "Copłn Carvings Depict Nephite/Lamanite Warfare Methods." Witness 69 (Summer 1990): 12-13. After viewing carvings that depicted women as victims of war in Cop $¥ n$, Honduras, the author better understood passages in Mormon and Moroni concerning the final destruction of the Nephites. [A.C.W.]

S.416 Smith, Sherrie Kline. "The La Mojarra Stela: Can It Be the Coriantumr Stone?” Witness 80 (Spring 1993): 48. Archaeologists consider the La Mojarra Stela, discovered in 1986, to be the most important key to understanding the spread of Mesoamerican writing and calendrical practices. Some Book of Mormon believers wonder if this is the stone of Coriantumr (Omni 1:35-40). Included are photographs of the stone. [J.W.M.]

S.417 Smith, T. C. The Book of Mormon and Mormonism. Denver: author, 1912. A polemical work against Mormonism. After giving a brief account of the Book of Mormon narrative, the author notes alleged anachronisms and absurdities in the book. Supports the Spaulding theory in order to account for its origin. [M.R.]

S.418 Smith, T. C. The Credentials of the Book of Mormon and Mormonism. Denver: Rev. T. C. Smith, 1912. A polemical tract against the Book of Mormon. The author asserts that the idea that written records were ever kept on metal plates is improbable and absurd. He follows Riley's explanation that Joseph may have been an epileptic. Most of the work is devoted to a criticism of the translation process. He further asserts that "the testimony of the spirit is never proof of material facts. To accept it as such is to abdicate reason, and enthrone credulity and superstition." [M.R.]

S.419 Smith, T. C. The External Evidences of the Book of Mormon. Denver: author, 1912. A polemical work against the Book of Mormon. The author notes problems with the accounts and testimonies of Book of Mormon witnesses, whose characters he asserts were unreliable and reprobate. He discusses the 1834 Anthon denial and 
problems with the translation of the Book of Mormon. He also describes what he feels are numerous anachronisms and absurdities in the Book of Mormon. He favors the Spaulding explanation of Book of Mormon origins. [M.R.]

S.420 Smith, T. J. "Objections to the Book of Mormon Answered By Its Own Evidence-Part 2." SH 63-64 (13, 20, 27 December 1916, 3 January 1917): 1216-17, 1242-44, 1264-66, 9-11. Series of articles that offer "plain, simple and reasonable explanations" of difficult passages in the Book of Mormon. Most arguments deal with the events that occurred near the Hill Cumorah in New York state and the other events that transpired in Central America and attempt to explain these events in relation to the great distance between the two locations. Many evidences in the Book of Mormon sustain the fact that the United States was thickly inhabited by the Nephite people who had traveled northward both by land and in ships by sea. [A.T.]

S.421 Smith, Timothy L. "The Book of Mormon in a Biblical Culture." In Encyclopedia of Mormonism, edited by Daniel H. Ludlow, 1:168-69. 5 vols. New York: Macmillan, 1992. The Book of Mormon doctrines match those of early Christian Apostolic times and give clear direction on biblical ordinances such as baptism of adults and children, the sacrament, doctrines of the Holy Ghost, the nature of God, the function of priesthood, and continued life after death. The book defines very well how biblical prophecies will be fulfilled in latter days. [N.K.Y.]

S.422 Smith, Timothy L. "The Book of Mormon in a Biblical Culture." In Journal of Mormon History 7 (1980): 3-21. The Book of Mormon is not only consistent with biblical teachings but supplements its doctrine. With the coming of the Book of Mormon, clear direction was given on issues that had been declared essential for salvation, such as baptism by immersion, the gift of the Holy Ghost, universal redemption, the necessity of righteousness, obedience, and good works. He gives many other examples of concepts that are parallel in both the Book of Mormon and Bible. [C.W.B.]

S.423 Smith, Virgil B. "The Book of Mormon." In Smith's How To Spark Gospel Learning, 33-38. Salt Lake City: Inland West Distributors, 1961. A teaching guide for parents. This chapter posses pertinent questions concerning the Book of Mormon, how people know it is true, why are the plates made of gold, and others. Scriptural quotations suggest answers. [J.W.M.]

S.424 Smith, Walter W., and J. A. Gunsolley Book of Mormon and Zion's Religio-Literary Society. Lamoni: Herald House, 1911. A manual of lessons for the "Religio-Sunday School," divided into six courses of study, each containing a lesson plan, with diagrams, lectures, and Book of Mormon and biblical references and questions. Its subjects cover the Book of Mormon and its books, geography, and institutions, and Mormon history and the Zion's Religio-Literary Society. [C.W.B.]

S.425 Smith, Walter Wayne "The Book of Mormon, Its Translation and Publication." Journal of History 14 (January 1921): 1-37. History of the manuscript of the Book of Mormon written by the Church Historian of the Reorganized church. It includes historical accounts by Oliver Cowdery, the testimony of the Three Witnesses, the Eight Witnesses, the copyright, and the preface to the first and subsequent editions. Photographs of the original manuscript are also reproduced. [J.W.M.]

S.426 Smith, Walter Wayne. Outline Studies of the Book of Mormon. Independence, Missouri: Herald House, 1930. A study guide/lesson plan for the Reorganized church with five parts and twenty-one lessons. Lessons deal with the book's authenticity, authors, chronology, groups of people, doctrines, and social relations among the different people. [J.W.M.] 
S.427 Smith, Wilber R. "Book of Mormon Authenticity." SH 89 (21 March 1942): 365. The epistles of Clement to the Corinthians are further proof that the Book of Mormon came from God. These two epistles were discarded from the Canon "because the legend of the 'Phoenix Bird' was used as an illustration," and "because they taught the heresy that there were lands beyond the ocean." [J.W.M.]

S.428 Smith, William. "Evidences of the Book of Mormon." M\&A 3 (January 1837): 433-35. Defends the Book of Mormon, drawing on proof texts found in Genesis 48-49, Psalm 85:11, and Ezekiel 37. Links truth and law with the descendants of Joseph, as found in the Book of Mormon. [D.M.]

S.429 Smith, William. William Smith on Mormonism: A True Account of the Origin of the Book of Mormon. Lamoni, IA: n.p., 1883. Personal account of the organizations of the LDS \& RLDS churches as well as the coming forth and translation of the Book of Mormon. He relates first-hand experiences from the family of Joseph Smith and gives his personal testimony of the veracity of the book. [C.W.B.]

S.430 Snell, James. The New Covenant. N.p.: n.p. At about the time Lehi left Jerusalem, Jeremiah propheised that a new covenant would be given to Israel. Discusses the "new covenant" between Lehi and the Lord and the restoration of that covenant in the latter days. [A.C.W.]

S.431 Snell, Jim, ed. An Open Book: The Book of Mormon. 37 issues. Kansas City: Snell's Print Shop, 1970-1982. Snell encourages Latter-day Saints to live righteously and gives a great deal of advice in areas such as repentance, avoidance of pride, obedience to the commandments, and dependence on God for faith. [C.W.B.]

S.432 Snow, Edward. Review of Living the Book of Mormon: A Guide to Understanding and Applying Its Principles in Today's World, by Allan K. Burgess. Review of Books on the Book of Mormon 4 (1992): 20. Book review.

S.433 Snow, Eliza R. "History of Jesus." Juvenile Instructor 3 (15 March, 1 April, 15 April, 1 May, 15 May, 1 June 1868): 43, 51, 58, 67, 79-80, 82-83. Chronicles Jesus' visit to the Lehites after the cataclysm. [D.M.]

S.434 Snow, Erastus, and Benjamin Winchester. "An Address to the Citizens of Salem (Mass.) and Vicinity." TS 3 (15 November 1841): 581-82. Part of an open letter proclaiming the message of the Restoration. Shows the Book of Mormon to be a fulfillment of prophecy. Addresses the objection concerning the anathema of adding to the book of Revelation. Quotes Parley P. Pratt regarding the Book of Mormon as a record of ancient America. [D.M.]

S.435 Snow, Harold L. "Ancient Pictographs of Southern Utah." IE 30 (December 1926): 163-65. Corresponding words in ancient near Eastern languages and those of American Indians is seen as evidence of the truthfulness of the Book of Mormon because Latter-day Saints believe the book is a sacred history of ancient inhabitants of America who came from Jerusalem. [J.W.M.]

S.436 Snow, Leroi C. "Solomon Spaulding Manuscript." Deseret Evening News 161 (26 May 1900): 1. Author compares the Spaulding manuscript with the Book of Mormon and concludes that no "sane person" would believe there was a connection between the two works. [D.W.P.]

S.437 Snow, Leroi C. "When Queen Victoria Received a Book of Mormon." IE 40 (July 1937): 417. In 1842 Lorenzo Snow made the presentation of a richly bound Book of Mormon to Queen Victoria, Queen of England. [J.W.M.] 
S.438 Snow, Stephen R. Untitled. Mormon History Association Newsletter 44 (June 1980): 15. In answer to a question concerning Doctrine and Covenants 10, the author answers that the small plates of Nephi were not translated before June 1829, after the 116 pages were lost. [J.W.M.]

S.439 Snyder, John Jacob. Glad Tidings. Kansas City: Truth Publishers, 1920. The Book of Mormon fulfills the words of the prophet Isaiah. It is an important book for the salvation of man, but the RLDS church condemns the Doctrine and Covenants and declares the "Mormon church" a stumbling block to the acceptance of the Book of Mormon. The witnesses to the book never denied their testimony. [J.W.M.]

S.440 Snyder, John Jacob. Truth: Number 2 (The Truth of the Book of Mormon). Salt Lake City: John Jacob Snyder, 1896. Snyder believes in and preaches Book of Mormon doctrines but rejects the teachings and authority of the LDS church. Believes Mormons have gone astray since the days of Joseph Smith. [D.W.P.]

S.441 "Sold 51,276 Books of Mormon." CN 33 (28 December 1963): 5. Reports on Book of Mormon sales and distributions. [E.G.]

S.442 "The Sole Surviving Witness of the Authenticity of the Book of Mormon." In History of Ray County, MO., 45661. St. Louis, MO: Missouri Historical Co., 1881. An objective discussion of David Whitmer, the last of the Three Witnesses of the Book of Mormon. Produces Whitmer's last statement in 1881, affirming his testimony of the Book of Mormon. [D.W.P.]

S.443 "Solomon Spaulding's Manuscript." The Oberlin Review 13 (24 October 1885): 27-28. Recounts the theory that the Book of Mormon was created from Spaulding's Manuscript Found. With the finding of that document by L. L. Rice the theory is weakened. [D.M.]

S.444 "Some of Mormon's Teachings." Evening and Morning Star 1 (January 1833): 60. Quotes extensively from Mormon's writings to teach the Saints of truth, goodness, and glory. The Saints are to be mindful of the words of the prophets, to keep them growing in grace. [E.G.]

S.445 "Some Teens Squirm Their Way Through." IE 68 (November 1965): 1042-51. The Book of Mormon teaches "choice lessons of life." References are cited to illuminate reasons for reading the scriptures, understanding the agency of mankind, listening to the Psalm of Nephi, seeking good counsel, and having faith. Commentary is included. [J.W.M.]

S.446 Sommerfeldt, Vern D. "A New Perspective for Stimulating Personal Study of the Book of Mormon." Ph.D. diss., Brigham Young University, 1988. Many Church members undervalue the Book of Mormon as a basis for personal and family gospel study. Members treat the book carelessly and receive condemnation or treat it respectfully and reap blessings. The purpose of the Book of Mormon is to persuade men to come to Christ. It is the key that validates and clarifies the meaning of other sacred writings. [J.W.M.]

S.447 Sondrup, Steven P. "The Psalm of Nephi: A Lyric Reading." BYU Studies 21 (Summer 1981): 57-72. Looks not at the acoustic features of the Psalm of Nephi (alliteration, rhythm, assonance, and the like), but at its lyric qualities. States that the psalm is "an intricately patterned system of ideational parallels" that is the "essence of lyricism." The total significance of reading 2 Nephi 4 as lyric poetry becomes evident when other lyric poems from the scriptures are read in juxtaposition. "Thematically similar Old Testament psalms" mentioned by the author include Psalms 51 and 84. [D.W.P.] 
S.448 Sonne, Alma. "Book of Mormon a Great Converter." IE (June 1953): 424. A brief summary of the missionary journey of Samuel Smith and his usage of the Book of Mormon, which resulted in the conversion of Rev. John P. Greene and others. [R.H.B.]

S.449 Sonne, Alma. "The Book of Mormon: A Great Missionary." In BYUSY (4 March 1958). Provo, UT: BYU Press, 1958. A man studying to be a Catholic priest reads the Book of Mormon and becomes convinced of its truth. He finds answers in the Book of Mormon that he could not find during in his biblical studies. [A.C.W.]

S.450 Sonne, Alma. "Book of Mormon-Builder of Faith." CN 32 (29 December 1962): 24. Excerpts from a conference address explains that the Book of Mormon's "high and noble purpose" is to testify of Christ to both Jew and Gentile. Reminds readers that the Book of Mormon serves to "build faith and convert souls." [A.C.W.]

S.451 Sonne, Alma. "Read the Book of Mormon." IE 64 (December 1961): 964-67. Writes concerning the value of reading the Book of Mormon. Adds his testimony to those of the Three Witnesses, Joseph Smith, and the book itself. [J.W.M.]

S.452 Sonne, Alma. "Truth Will Prevail." IE 60 (June 1957): 408-9. In spite of an "avalanche of abuse and ridicule," the Book of Mormon stands true and powerful. The Book of Mormon reveals many truths, the purposes of God, and the results of wrong doing; it also emphasizes the sanctity of the commandments, proclaims the deity of Christ, and confirms the teachings of the Holy Ghost. [J.W.M.]

S.453 Sonne, Alma. "Urim and Thummim." MS 111 (April 1949): 101, 127. Prophets of old used the Urim and Thummim. The claims made by Joseph Smith were not illogical. King Saul used the devices as well as Moses and others. Joseph Smith's account of using them is not out of harmony with these accounts. They are defined as "lights" and "perfections." [J.W.M.]

S.454 Sons of the Utah Pioneers. People of the Book of Mormon: Musical Drama. Salt Lake City: n.p., 1960. Advertisement for a musical drama with actors Bryce Chamberlain and Francis Urry starring as Nephi and Lehi, respectively. [J.W.M.]

S.455 Sorensen, Parry D. "Light Out of Darkness." MS 98 (18 February 1937): 103. The Book of Mormon is published in Braille, fulfilling the prophecy in Isaiah that "the blind shall see out of obscurity and out of darkness." [J.W.M.]

S.456 Sorenson, A. D. "Lehi on God's Law and an Opposition in All Things." In The Book of Mormon: Second Nephi, The Doctrinal Structure, edited by Monte S. Nyman and Charles D. Tate Jr., 107-32. Provo, UT: Brigham Young University Religious Studies Center, 1989. Analyzes Lehi's teachings in 2 Nephi 2:11, exploring opposition and "ethical opposites." The implications are far-reaching: God's laws make existence possible. [A.C.W.]

S.457 Sorenson, Donna D. "America-A Choice Land." Relief Society Magazine 27 (May 1940): 343-44. The Book of Mormon prophesied of Christopher Columbus and declares America to be "a choice land," "a land of liberty." The fulfillment of this promise rests upon obedience to Jesus Christ by those who occupy the land. [J.W.M.]

S.458 Sorenson, Elaine Shaw. "Seeds of Faith: A Follower's View of Alma 32." In The Book of Mormon: Alma, The Testimony of the Word, edited by Monte S. Nyman and Charles D. Tate Jr., 129-40. Provo, UT: Brigham Young University Religious Studies Center, 1992. Alma defines faith as hope for things not seen which are true. He compares faith to planting and growth of a seed that if nourished would bring forth the fruit of eternal life. The 
author says the fruit is most precious and sweet and those who eat it will be filled and never hunger or thirst. [N.K.Y.]

S.459 Sorenson, John L. "Ancient America and the Book of Mormon Revisited." Dialogue 4 (Summer 1969): 80-94. Notes shared patterns between ancient Mesoamerica and the Near East in the following areas: architecture, astronomy, calendrical systems, writing, burial practices, use of incense, figurines, sacrifice, ritual washing, sanek symbolism, tees, and kingship complex. These connections indicate that the Book of Mormon is an ancient text. [A.C.W.]

S.460 Sorenson, John L. An Ancient American Setting for the Book of Mormon. Salt Lake City: Deseret Book and FARMS, 1985. A treatment of geography that settles on a "plausible" scene in Mesoamerica (the Grijalva River as the Sidon), treats the nature of "history" in the scripture, and discusses how scholars learn about the ancient world. Specific data from external studies are then used to shed light on the Nephite record book by book. This work is reviewed in W.058, and in A.079. [J.L.S.]

S.461 Sorenson, John L. "Ancient Europeans in America?" In Reexploring the Book of Mormon, edited by John W. Welch, 108-10. Salt Lake City: Deseret Book and FARMS, 1992. Inscriptions thought to have been made by ancient Celts have been found in caves and rock shelters near Springfield, Colorado. Ogam writing known in Ireland was found in caves in Colorado. [N.K.Y.]

S.462 Sorenson, John L. Animals in the Book of Mormon: An Annotated Bibliography. Provo, UT: FARMS, 1992. Annotated bibliography facilitating inquiry concerning Book of Mormon uses of animals, the presence and significance of animals in ancient Mesoamerica, and the usage of animal terms in Semitic languages. Includes comprehensive listing of all significant Book of Mormon statements about animals. [A.C.W.]

S.463 Sorenson, John L. "Anthropological Approaches to the Book of Mormon." In Book of Mormon Institute, 25-36. Provo, UT: Brigham Young University Extension Publications, 5 December 1959. Calls for contextual study of the scripture in all its human dimensions-biological, linguistic, cultural, social-which can provide broad confirmation, rather than seeking anecdotal "proofs," as has been typical. [J.L.S.]

S.464 Sorenson, John L. "Asia-North America Linguistic Tie-Up, a Review." UASN 14 (August 1953). Recent linguistic and archaeological comparisons support the idea of specific movements across Bering Strait. But linguistic studies, not attempted yet, may also show a connection to the Near East. [J.L.S.]

S.465 Sorenson, John L. "Bible Prophecies of the Mulekites." In A Book of Mormon Treasury, 229-37. Salt Lake City: Bookcraft, 1959. Speculating that Mulek was a pre-adolescent, possibly an infant, the author suggests that many elements in the Book of Mormon might lead one to think that Mulek was brought to the New World by Phoenicians. It is further suggested that Ezekiel 7:22 clearly tells of a child of Zedekiah who was a "tender twig" to be "cropped" and "planted" in another land. [J.W.M.]

S.466 Sorenson, John L. "Book of Mormon." In Encyclopedia U.S.A. Vol. 7, n.p. Gulf Breeze, FL: Academic International, 1986. A descriptive characterization of the origin, history and other contents, and influence of the Book of Mormon. [J.L.S.]

S.467 Sorenson, John L. "The Book of Mormon as a Mesoamerican Codex." SEHA 139 (December 1976): 1-9. Reprinted, Provo, UT: FARMS, 1981. Referring to Anthon's statements that what he saw had a codex format, this 
piece discusses points that are compatible with an interpretation of the Book of Mormon as a Mesoamerican codex. [J.L.S.]

S.468 Sorenson, John L. "Book of Mormon Geography in the Light of Ceramic Distributions." UASN 8 (November 1952). The sequence of pottery distribution around Guatemala City is suggested as alignable with Nephite culture history in that area. [J.L.S.]

S.469 Sorenson, John L. "Book of Mormon Peoples." In Encyclopedia of Mormonism, edited by Daniel H. Ludlow, 1:191-95. 5 vols. New York: Macmillan, 1992. The Book of Mormon describes fifteen distinct groups of people: Nephites, Lamanites, Mulekites, Jaredites, Jacobites, Josephites, Zoramites, Ishmaelites, people of Zeniff, people of Alma, Amulonites, Amlicites, Amalekites, Anti-Nephi-Lehies, Ammonites, and minor groups such as people of Nehor and the Gadianton robbers. Includes a description of each group. [N.K.Y.]

S.470 Sorenson, John L. “The 'Brass Plates' and Biblical Scholarship.” Dialogue 10 (Autumn 1977): 31-39. Reprinted, Provo, UT: FARMS, 1977. A detailed statement of what is known of the content, form, and history of the brass plates. The ways in which its contents differ from the Masoretic version are consistently parallel to those distinguishing the Elohist (E) version of "the Old Testament." [J.L.S.]

S.471 Sorenson, John L. "The Challenge of the Maya Mystery." IE 54 (October 1951): 712-13, 738, 740. Giving a history of the Gates Collection of Mayan literature located at Brigham Young University, this author hopes that the origin of the Mayan culture may be found through study and a greater understanding. [J.W.M.]

S.472 Sorenson, John L. "The Chronological Discrepancy between Alma 53:22 and Alma 56:9." Provo, UT: FARMS, 1990. Alma 53:22 and Alma 56:9 give dates for the same event two years apart. Examines how this chronological discrepancy may be explained. [J.L.S.]

S.473 Sorenson, John L. "A Collection of References to Trans-Oceanic Contacts with the Americas Before the Recognized Discoveries." New-England Antiquities Research Association 67 (1971-72): 78-80, 38-40. A bibliography of transoceanic travels to America prior to Columbus. The work has been superseded with later works. [D.W.P.]

S.474 Sorenson, John L. "Comparison of Fundamental Traits of the Book of Mormon and Ancient American Civilizations." UASN 4 (20 January 1952). Also in Progress in Archaeology: An Anthology, edited by R. T. Christensen, 108. Provo, UT: University Archaeological Society, Special Publications, No. 4. A list of 23 traits considered by Steward as characteristic of early "formative" culture common to both Mesoamerica and the Andean region is compared with Book of Mormon culture. None of Steward's elements are contrary to the Book of Mormon. [J.L.S.]

S.475 Sorenson, John L. "The Composition of Lehi's Family." In By Study and Also by Faith, edited by John M. Lundquist and Stephen D. Ricks, 2:174-96. Salt Lake City: Deseret Book and FARMS, 1990. By investigating references in the Book of Mormon to those who came to the new land with Lehi, an educated speculation is made with respect to the ages, occupations, and number of people. A list is presented according to the assumptions made, showing the make up of the intermarrying Lehi and Ishmael families. [A.A.]

S.476 Sorenson, John L. "A Cultural Summary of Israelite Palestine at the End of the Middle Iron Age (7th Century b.c.)." Book of Mormon Working Paper, No. 1, September 1963. Photocopy. Lists features that hold potential value for an anthropological and archaeological comparison of Palestine with the New World. [J.L.S.] 
S.477 Sorenson, John L. "A Day and A Half's Journey for a Nephite." In Reexploring the Book of Mormon, edited by John W. Welch, 187-88. Salt Lake City: Deseret Book and FARMS, 1992. The location of the narrow neck of land has been a puzzle. The Isthmus of Tehuantepec measures 120 miles and is now thought by many to be the 'narrow neck of land' and is within the range of a Nephite journey of a day and a half. [N.K.Y.]

S.478 Sorenson, John L. "Digging into the Book of Mormon: Our Changing Understanding of Ancient America and Its Scripture." Ensign 14 (September-October 1984): 26-37, 12-23. Reprinted, Provo, UT: FARMS, 1984. Locates Book of Mormon lands in Mesoamerica and discusses problems of method in comparing the scripture to "scientific findings," then summarizes some recent findings about Mesoamerican civilization (e.g., warfare, writing, roads, metals, population) particularly relevant to the Book of Mormon. [J.L.S.]

S.479 Sorenson, John L. "Directions in Book of Mormon Geography." Book of Mormon Working Paper, No. 3, September 1963. Photocopy. Ethnographic and documentary examples show the difficulties in matching a culture's direction terminology to the modern world map. [J.L.S.]

S.480 Sorenson, John L. "Early Archaeological Sequences in Highland Guatemala, A Review." UASN 17 (January 1954). New details on archaeology of the area around Guatemala City in Book of Mormon times are given. Some features can be compared with the ancient Near East. [J.L.S.]

S.481 Sorenson, John L. "The Elephant in Ancient America." UASN 4 (January 1952). Radiocarbon dating indicates early culture in Arizona was contemporaneous with mastodons in the vicinity of 4000 b.c. This may be the first serious evidence supporting the survival of this animal as late as the Jaredites. The book of Ether has "elephants" less than two millennia later. [J.L.S.]

S.482 Sorenson, John L. "An Evaluation of the Smithsonian Institute, 'Statement Regarding the Book of Mormon.'" Provo, UT: FARMS, 1982. The form letter passed out by the Smithsonian in response to inquiries about the Book of Mormon contains considerable irrelevant or erroneous information that is critically analyzed here. [J.L.S.]

S.483 Sorenson, John L. "Evidences of Culture Contacts between Polynesia and the Americas." M.A. thesis, Brigham Young University, 1952. Language and cultural traits of Polynesia and the Americas are compared under scores of headings. The abundant parallels indicate voyages as explanations but lack of geographical and chronological clustering leaves the picture unclear, and provides no good evidence for the LDS Hagoth-Polynesian supposition. [J.L.S.]

S.484 Sorenson, John L. "Fortifications in the Book of Mormon Account Compared with Mesoamerican Fortifications." In Warfare in the Book of Mormon, edited by Stephen D. Ricks and William J. Hamblin, 425-44. Salt Lake City: Deseret Book and FARMS, 1990. Archaeological discoveries have found 262 Mesoamerican sites with extensive defensive fortifications. Sorenson provides tables of sites, and types of fortification, and compares them with Book of Mormon descriptions. [N.K.Y.]

S.485 Sorenson, John L. "Further on Authentication and Elucidation of the Book of Mormon." UASN 6 (May 1952). Also in Progress in Archaeology: An Anthology, edited by R. T. Christensen, 147-48. Provo, UT: University Archaeological Society, Special Publications, No. 4. Comparison of Book of Mormon cultures with known New or Old World cultures can be directed toward authentication or elucidation. Little has been done toward shedding light on the scriptures. Almost all necessary work has only begun. [J.L.S.] 
S.486 Sorenson, John L. "The Gates of God." NE 5 (March 1975): 18-25. The architecture of towers in the Book of Mormon may have been influenced by Old World structures such as the Tower of Babel. The idea that elevation was sacred is seen in the towers of Nephi, King Benjamin, and the Zoramites, but the towers may also have had political significance. Includes photos of Mesoamerican structures that could be interpreted as towers. [A.C.W.]

S.487 Sorenson, John L. The Geography of Book of Mormon Events: A Source Book. Provo, UT: FARMS, 1992. A comprehensive analysis of Book of Mormon geography. Sorenson gives a history and summary of all Latter-day Saints who have written on geography. He indicates what the text says, verse by verse, on geography and presents a trial map based on the text. Also presents problems of establishing distances and deciphering directional statements in the Book of Mormon. This work is reviewed in J.057. [B.D.]

S.488 Sorenson, John L. "I Have A Question? I have heard that the sizes of the Nephite and Lamanite populations indicated in the Book of Mormon do not make sense. What do we know about their numbers?" Ensign 22 (September 1992): 27-28. Discusses population growth among Lehi's colony, both natural and through assimilation of resident groups. Mentions Sherem as proof of "outsiders," but concludes that information in the Book of Mormon record is too limited for a clear picture to be constructed. [A.C.W.]

S.489 Sorenson, John L. "Incense-Burning and 'Seer' Stones in Ancient Mesoamerica: New Evidence of Migrations of Biblical Peoples to the New World." UASN 21 (July 1954). Also in Progress in Archaeology: An Anthology, edited by R. T. Christensen, 118-19. Provo, UT: University Archaeological Society, Special Publications, No. 4. Summary of an unpublished, lengthy paper that emphasizes certain parallels in ideas and practices between the ancient Near East and Mesoamerica. [J.L.S.]

S.490 Sorenson, John L. "Indications of Early Metal in Mesoamerica." UASN 5 (1954): 1-5. The first seriously documented challenge to the orthodox view that metals in Mesoamerica were only late. Cites a score of possible exceptions. [J.L.S.]

S.491 Sorenson, John L. "Instant Expertise on Book of Mormon Archaeology, A Review Article." BYU Studies 16 (Spring 1976): 429-32. Books by Farnsworth, West, Priddis, and Cheesman display defective scholarship despite the zeal of the writers. Gullible LDS book-buyers are blamed for encouraging such poor products. [J.L.S.]

S.492 Sorenson, John L. "The Land of Promise." NE 5 (January 1975): 20-29. A collection of photographs by James Christensen and Book of Mormon scriptures suggest possible Book of Mormon sites to help readers visualize the scriptures more fully. [J.W.M.]

S.493 Sorenson, John L. "Latest Discoveries." In Reexploring the Book of Mormon, edited by John W. Welch, 111-13. Salt Lake City: Deseret Book and FARMS, 1992. Large stone carvings found in many places continue to baffle archaeologists and linguists. Press releases of "latest discoveries" have not been seasoned by time or studies and are often not accurately reported by the press. It may take years of study to assess the stones' import and meaning. [N.K.Y.]

S.494 Sorenson, John L. "The Maya Mystery." IE 54 (October 1951): 712, 738, 740. Gives the history and backgrounds of the important William Gates Collection of Mayan documents, including copies of three very ancient (pre-Spanish) Mayan Codices. The acquisition of this important Mayan library was conducted by Dr. Wells Jakeman for BYU in 1946. It remains for future competent scholars to interpret the mysteries of the Mayan language and culture. [R.C.D.] 
S.495 Sorenson, John L. "Mesoamericans in Pre-Columbian North America." In Reexploring the Book of Mormon, edited by John W. Welch, 218-20. Salt Lake City: Deseret Book and FARMS, 1992. Book of Mormon records conflict with the view that American civilization moved from the Bering Sea southward. Archaeological, linguistic, and historical evidence now confirms the Book of Mormon description of movement from south to north. [N.K.Y.]

S.496 Sorenson, John L. "Mesoamericans in Pre-Spanish South America." In Reexploring the Book of Mormon, edited by John W. Welch, 215-17. Salt Lake City: Deseret Book and FARMS, 1992. Current research has shown that for 4,000 years people, materials, and ideas have moved fluidly between both American continents even though Book of Mormon histories cover just Mesoamerica. Linguistic studies, material trading, biological studies, and other information confirm cultural interplay as Alma 63:4 and Helaman 3:8 indicate. [N.K.Y.]

S.497 Sorenson, John L. Metals and Metallurgy Relating to the Book of Mormon Text. Provo, UT: FARMS, 1992. Contains an annotated bibliography of sources on the Old World metallurgical background of peoples who may have emigrated to America from southwest Asia and some related methodological issues, and an annotated bibliography on aspects of the history of pre-Columbian metalworking in the New World, with emphasis on Mesoamerica. Includes an index and commentary regarding probable and possible pre-A.D. 900 Mesoamerican metal specimens, and a summary of statements in the Book of Mormon text about metals, ores, and metal processing, with notes on Hebrew usage of metal-related terms. [B.D.]

S.498 Sorenson, John L. "The Mulekites." BYU Studies 30 (Summer 1990): 6-22. Reprinted, Provo, UT: FARMS, 1990. An attempt to synthesize all that is known from the Book of Mormon and collateral biblical records about the Mulekites. [J.L.S.]

S.499 Sorenson, John L. "Nephi Speaks to Our Day with Plain and Precious Prophecy." Instructor 97 (September 1962): 309, 319. Nephi concentrated on the hopeful future-our day, when his family's descendants are beginning to flourish-rather than ugly details of intervening history. [J.L.S.]

S.500 Sorenson, John L. "Nephi's Garden and Chief Market." In Reexploring the Book of Mormon, edited by John W. Welch, 236-38. Salt Lake City: Deseret Book and FARMS, 1992. Nephi 2's garden near a highway leading to the chief Zarahemla market seemed incompatible with ancient urban settlements. For decades the existence of large urban cities in Mesoamerica was disputed but has since been proved, as well as the existence of chief markets in pre-Columbian Mexico. [N.K.Y.]

S.501 Sorenson, John L. "The Nephite Calendar in Mosiah, Alma, and Helaman." In Reexploring the Book of Mormon, edited by John W. Welch, 173-75. Salt Lake City: Deseret Book and FARMS, 1992. The Book of Mormon refers to dates in the Nephite time reckoning system, but there is no method of correlating the dates to our own calendar. Research has shown that major battles coincided with the end of the Nephite year. [N.K.Y.]

S.502 Sorenson, John L. "Nephite Social Structure." Book of Mormon Working Paper, No. 7, February, 1964. Duplicated by author. An analysis of the Book of Mormon text from a social anthropological viewpoint, which discusses how Nephite society was organized and functioned. [J.L.S.]

S.503 Sorenson, John L. "New Evidence of Migration of Biblical People to the New World." UASN 21 (2 July 1954). Current research shows many parallels in the use of incense in Old and New World religious rituals, and a connection is seen in the use of "seer stones." [J.W.M.] 
S.504 Sorenson, John L. "Observations on Nephite Chronology." Book of Mormon Working Paper, No. 8, 1970. Duplicated by author. Considers the 360-day "tun" year and other suggestions in attempting to settle beginning and ending points for Nephite chronology. [J.L.S.]

S.505 Sorenson, John L. "Once More: The Horse." In Reexploring the Book of Mormon, edited by John W. Welch, 98100. Salt Lake City: Deseret Book and FARMS, 1992. Book of Mormon references to horses have little supporting evidence prior to A.D. 1500. True horses are documented into the late glacial age in America and might well have existed as late as 2000 B.C. Argentine scientists maintain their horses were native and not of Spanish origin. Horse remains have been found in Mayapan and other Yucatan sites where the dating is yet to be done. [N.K.Y.]

S.506 Sorenson, John L. "Plain and Precious Prophecy." Instructor 97 (September 1962): 309-19. Nephi's prophecies focused on people and principles, as he viewed the "sweep of history and God's plan." Almost half of Nephi's discourse about his vision was related to the influence of a book of scripture. [A.C.W.]

S.507 Sorenson, John L. "Possible 'Silk' and 'Linen' in the Book of Mormon." In Reexploring the Book of Mormon, edited by John W. Welch, 162-64. Salt Lake City: Deseret Book and FARMS, 1992. The Book of Mormon reference to silk and linen in Alma 1:29 is questioned by scholars. Cloth fiber made from cocoons of insect larva is known in the wilds of Mexico. Kapok from the silk cotton tree in Yucatan, and rabbit fur garments made by Aztecs exist, and items inventoried by the Spaniards included linen. Linen-like fibers made from yucca and other plants and bark cloth from the fig tree sustain Book of Mormon claims. [N.K.Y.]

S.508 Sorenson, John L. "Preclassic Metal?" American Antiquity 20 (July 1954): 64. Points out apparent exceptions in the professional literature to the assumption that metal use in Mesoamerica was only late. [J.L.S.]"

S.509 Sorenson, John L. "Prophecy Among the Maya." In Reexploring the Book of Mormon, edited by John W. Welch, 263-65. Salt Lake City: Deseret Book and FARMS, 1992. Maya bobatil foretold specific events and these were written in books. The coming of the Spaniards was predicted to the day and year. They saw history repeated in cycles and governed their lives by prophetic outlook. Such practices continued Book of Mormon prophetic tradition. [N.K.Y.]

S.510 Sorenson, John L. "A Reconsideration of Early Metal in Mesoamerica." Katunob 9 (March 1976): 1-8. Reprinted in Metallurgy in Ancient Mexico, by W. Bray, J. L. Sorenson, and J. R. Moriarty, III. University of Northern Colorado, Museum of Anthropology, Miscellaneous Series, No. 45, 1982. Reprinted, Provo, UT: FARMS, 1982. Metals technology was present in Mesoamerica during Book of Mormon times, contrary to received opinion. [J.L.S.]

S.511 Sorenson, John L. Review of Answers to Book of Mormon Questions, by Sidney B. Sperry. Dialogue 3 (Spring 1968): 118-20. Book review.

S.512 Sorenson, John L. Review of Book of Mormon Evidences in Ancient America, by Dewey Farnsworth. UASN 18 (25 February 1954): 2-5; and in the UAS anthology Progress in Archaeology (1963): 103-6. Book review.

S.513 Sorenson, John L. Review of "Does the Shoe Fit? A Critique of the Limited Tehuantepec Geography," by Deanne G. Matheny, from New Approaches to the Book of Mormon, edited by Brent Lee Metcalfe, 269-328. Review of Books on the Book of Mormon 6/1 (1994): 297-361. Book review. 
S.514 Sorenson, John L. Review of Mapping the Action Found in the Book of Mormon, by Harold K. Nielsen. Review of Books on the Book of Mormon 1 (1989): 119-20. Book review.

S.515 Sorenson, John L. Review of The Americans Before Columbus, by Dewey and Edith Farnsworth. BYU Studies 16 (Spring 1976): 429-32. Book review.

S.516 Sorenson, John L. Review of The Book and the Map. New Insights into Book of Mormon Geography, by Venice Priddis. BYU Studies 16 (Spring 1976): 429-32. Book review.

S.517 Sorenson, John L. Review of These Early Americans: External Evidences of the Book of Mormon, by Paul Cheesman. BYU Studies 16 (Spring 1976): 429-32. Book review.

S.518 Sorenson, John L. Review of Trial of the Stick of Joseph, by Jack West. BYU Studies 16 (Spring 1976): 429-32. Book review.

S.519 Sorenson, John L. "Seasonality of Warfare in the Book of Mormon and in Mesoamerica." In Warfare in the Book of Mormon, edited by Stephen D. Ricks and William J. Hamblin, 445-78. Salt Lake City: Deseret Book and FARMS, 1990. Reviews possible calendars used by the Nephites and notes in extensive tables the time of year when battles and preparations for battles were made. The records show that most occurred during the end of dry season in Mesoamerica. [N.K.Y.]

S.520 Sorenson, John L. "Seasons of War, Seasons of Peace in the Book of Mormon." In Rediscovering the Book of Mormon, edited by John L. Sorenson and Melvin J. Thorne, 249-55. Salt Lake City: Deseret Book and FARMS, 1991. A popular version of "Seasonality of Warfare in the Book of Mormon and in Mesoamerica," in Warfare in the Book of Mormon, edited by Stephen D. Ricks and William J. Hamblin, 445-78. [J.L.S.]

S.521 Sorenson, John L. "The Significance of an Apparent Relationship Between the Ancient Near East and Mesoamerica." In Man Across the Sea, edited by Carol L. Riley, 219-41. Austin: University of Texas Press, 1971. Reprinted, Provo, UT: FARMS, 1981. Lists the major published body of evidence on possible transoceanic contacts between the Old and New Worlds. [J.L.S.]

S.522 Sorenson, John L. "Silk and Linen in the Book of Mormon." Ensign 22 (April 1992): 62. Excerpt from Sorenson's An Ancient American Setting for the Book of Mormon giving archaeological support for the mention of silk and linen in the Book of Mormon. Native American plants and fibers were used to make cloth similar to silk from the Far East and European linen. [A.C.W.]

S.523 Sorenson, John L. "Social Structure and Cult among the Nephites." Paper presented to the Annual Symposium of the Society for Early Historic Archaeology, October 1974, Provo, UT. An expanded version of "Nephite Social Structure." [J.L.S.]

S.524 Sorenson, John L. "Some Mesoamerican Traditions of Immigration by Sea." Provo, UT: FARMS, 1955. Quotes pre-Columbian and early Spanish records of traditions from various sources indicating that the ancestors of the Indians made oceanic voyages to the Americas. [D.M.]

S.525 Sorenson, John L. "Some Voices from the Dust: A Review of Papers of the Fifteenth Annual Symposium on the Archaeology of the Scriptures." Dialogue 1 (Spring 1966): 144-49. Puts the Society for Historical Archaeology 
in context in the history of LDS thought about archaeology then evaluates papers by Jakeman, Tucker, Norman, Putnam, and others as sometimes displaying lack of currency and narrow range of methodology. [J.L.S.]

S.526 Sorenson, John L. "Study Maps of the Book of Mormon." Provo, UT: FARMS, 1985. Packet of maps excerpted from An Ancient American Setting for the Book of Mormon. [J.L.S.]

S.527 Sorenson, John L. "Teotihuacłn Sequence Revised, A Review." UASN 14 (August 1953). A recap of recent elaboration of the ceramic sequences in central Mexico and highland Guatemala (including an indication of volcanism around the time of Christ). Implies that the highland areas were more advanced than the lowlands in Book of Mormon times, as the scripture suggests. [J.L.S.]

S.528 Sorenson, John L. "The Twig of the Cedar." IE 60 (May 1957): 330-31. Also "Bible Prophecies of the Mulekites." In A Book of Mormon Treasury, 229-37. Salt Lake City: Bookcraft, 1959. Reprinted, Provo, UT: FARMS, 1981. Relates Ezekiel 17:22-24 to Mulek's transplantation to America. A Mexican tradition of the arrival of an immigrant group by sea may also be related to Mulek. [J.L.S.]

S.529 Sorenson, John L. "Traditions of Immigration by Sea in the Peopling of Meso-America." El México Antiguo 8 (1955): 425-39. Also in "Traditions of Immigration by Sea in the Peopling of Meso-America." Provo, UT: FARMS, 1955. Documents a variety of traditions that show that the idea that ancestors had arrived by sea was widespread. [J.L.S.]

S.530 Sorenson, John L. "Transoceanic Crossings." In The Book of Mormon: First Nephi, The Doctrinal Foundation, edited by Monte S. Nyman and Charles D. Tate Jr., 251-70. Provo, UT: Brigham Young University Religious Studies Center, 1988. The text of 1 Nephi 17-18 is analyzed in detail to infer all possible details about constructing and sailing the ship, and about the route and schedule followed. [J.L.S.]

S.531 Sorenson, John L. "True Arch." UASN 17 (January 1954). An example of an unquestionable true arch is pointed out in the Maya area. Lack of this feature can no longer be used to argue against Old-New World contacts; rather, we must ask why, since they knew the idea, the Maya did not utilize it more. [J.L.S.]

S.532 Sorenson, John L. "Wheeled Figurines in the Ancient World." Provo, UT: FARMS, 1981. A substantial though unpolished survey of the literature under four headings: Mesoamerican wheeled figurines, function, wheels and movement in Mesoamerican belief, and wheeled figurines in the Old World. A brief appendix relates the material to the few statements in the Book of Mormon about "chariots." [J.L.S.]

S.533 Sorenson, John L. "When Lehi's Party Arrived in the Land, Did They Find Others There?" Journal of Book of Mormon Studies 1 (Fall 1992): 1-34. Numerous Book of Mormon references infer the presence of other population groups present in America when Lehi's group landed. The presence of multiple languages among population groups in Mesoamerica strongly implies that ancestral people were in America for thousands of years. When Amulek met Alma in the city of Ammonihah he promptly identified himself as a Nephite, an indication that he lived among a non-Nephite population. The crew(s) of the ship(s) that brought Mulek's party were probably Phoenician, as all Mediterranean ports were then in Babylonian hands. [R.H.B.]

S.534 Sorenson, John L. "Where in the World? Some Views on Geography, Part 1." Book of Mormon Working Paper, No. 2, September 1963. Basics later given in chapter 1 of An Ancient American Setting for the Book of Mormon. [J.L.S.] 
S.535 Sorenson, John L. "Winds and Currents: A Look at Nephi's Ocean Crossing." In Reexploring the Book of Mormon, edited by John W. Welch, 53-56. Salt Lake City: Deseret Book and FARMS, 1992. Discusses Nephi's route and ocean crossing. Departure from Arabia is best from April 1-15 to avoid dangerous swells near India. The great storm Nephi describes could have been in the Bay of Bengal, where such are common. Eastern travel across the Pacific has been confirmed by studies of the El Ni-o phenomenon. Such a Pacific Ocean crossing is estimated to have taken less than a year. Liahona guidance would have optimized the time. [N.K.Y.]

S.536 Sorenson, John L. "The World of the Book of Mormon." Provo, UT: Brigham Young University, Extension Division, Leadership Week Publications, 1955. Transcripts of five lectures pertaining to the world of the Book of Mormon: the physical world, the cultural world (in two parts), the world of ideas, and the transmission of ideas. The aim is to provide context in order to aid understanding of the scripture. Includes question-and-answer sessions. (Many ideas in Sorenson's 1985 book were first introduced in these lectures.) [J.L.S.]

S.537 Sorenson, John L. "Writing Systems Among the Book of Mormon Peoples." NE 7 (November 1977): 48-50. A popular-level discussion of how Mesoamerican writing systems worked and points of similarity to what the Book of Mormon says about Nephite writing. [J.L.S.]

S.538 Sorenson, John L. "The Years of the Jaredites." Provo, UT: FARMS, 1969. In an earlier version "A Possible Absolute Chronology for the Jaredites." Book of Mormon Working Paper, No. 5, December 1963. Duplicated by the author. The book of Ether is analyzed historically and logically to infer a scheme of absolute dates extending from about 3000 to 500 b.c. Also divides Jaredite history into seven developmental stages. [J.L.S.]

S.539 Sorenson, John L., Angela Crowell, and Allen J. Christensen. "Parallelism, Merismus, and Difrasismo." In Reexploring the Book of Mormon, edited by John W. Welch, 80-82. Salt Lake City: Deseret Book and FARMS, 1992. A discussion of poetic devices common to the Book of Mormon and Old Testament and Mesoamerican texts, including chaismus, parallelistic couplets, merismus, and difrasismo. [N.K.Y.]

S.540 Sorenson, John L., and Gareth W. Lowe. "Explorations in Southern Mexico; Report of Field Work, NWAF Expedition of 1953." UASN 13 (June 1953). Explains the origin of the NWAF, accomplishments of its first season's work in Tabasco and Chiapas (in which the authors participated), and the supposed conceptual tie to the Book of Mormon. [J.L.S.]

S.541 Sorenson, John L., Gordon C. Thomasson, and Robert F. Smith. "Old World Languages in the New World." In Reexploring the Book of Mormon, edited by John W. Welch, 29-31. Salt Lake City: Deseret Book and FARMS, 1992. Reports cognates in American Indian and Ob-Ugarian languages. Linguistic developments support the theory that Old and New World languages are related, thus strengthening the case for the Book of Mormon. [E.G]

S.542 Sorenson, John L., and John W. Welch. "Seven Tribes: An Aspect of Lehi's Legacy." In Reexploring the Book of Mormon, edited by John W. Welch, 93-95. Salt Lake City: Deseret Book and FARMS, 1992. Examines the division of Lehi's descendants into seven tribes: Nephites, Jacobites, Josephites, Zoramites, Lamanites, Lemuelites, and Ishmaelites. Observes that this tribal structure was established at Lehi's final blessing and endured until the collapse of Nephite society almost one thousand years later. It served important religious, military, political, and legal functions. [A.C.W.]

S.543 Sorenson, John L., and Martin H. Raish. Pre-Columbian Contact with America across the Oceans: An Annotated Bibliography. 2 vols. Provo, UT: Research Press, 1990. More than 5,600 literature items in many languages are listed covering pro- and anti- positions, theory, and methodology. Detailed bibliographical data and annotations, 
some very detailed, are provided for most items, reporting how they relate to the topic. This work is reviewed in H.036. [J.L.S.]

S.544 Sorenson, John L., and Martin H. Raish. Transoceanic Culture Contacts between the Old and New Worlds in PreColumbian Times: A Comprehensive Annotated Bibliography. Provo, UT: FARMS, 1988. Superseded by Sorenson and Raish 1990. [J.L.S.]

S.545 Sorenson, John L., and Paul Y. Hoskisson. "Lost Arts." In Reexploring the Book of Mormon, edited by John W. Welch, 101-4. Salt Lake City: Deseret Book and FARMS, 1992. Arts and technology once known, lost, and rediscovered in Central and South American civilizations include concrete arches found Guatemala and Peru, potter's wheels and a lathe discovered in burial sites at Pashash in Peru, and ceramics found among early Polynesian cultures. [N.K.Y.]

S.546 Sorenson, John L., and Robert F. Smith. "Barley in Ancient America." In Reexploring the Book of Mormon, edited by John W. Welch, 130-32. Salt Lake City: Deseret Book and FARMS, 1992. In recent times pre-Columbian barley has been discovered at Phoenix, Arizona, and in caves of Oklahoma, recalling the mention of barley in the Book of Mormon. Further studies need to be made to establish how and when such barley discovered was grown. [N.K.Y.]

S.547 Sorenson, John L., and Robert F. Smith. "Two Figurines From the Belleza \& Sanchez Collection." In Reexploring the Book of Mormon, edited by John W. Welch, 18-19. Salt Lake City: Deseret Book and FARMS, 1992. The figurines found on the Pacific Coast beach of Acajutla, Sonsonate, El Salvador, clearly belong to a class of ancient Egyptian funerary statuettes known as ushabti. Both figurines, incised with hieroglyphic Egyptian texts, were popular for much of Egyptian history. [N.K.Y.]

S.548 Sorenson, John L., and Melvin J. Thorne, eds. Rediscovering the Book of Mormon. Salt Lake City: Deseret Book, 1991. New discoveries about the Book of Mormon made by LDS scholars. The essays show meaningful and complex patterns in the Book of Mormon-patterns of style, ideas, history, and actions. They also provide considerable evidence for the authenticity of the Book of Mormon. This work is reviewed in C.331 and in S.137. [J.L.S.]

S.549 Sorensen, Parry D. "A Witness of Divine Truth." MS 99 (July 1937): 426-28. Martin Harris acted as Joseph's scribe during the translation of the Book of Mormon. He became convinced of the authenticity of the translation upon showing a translation and copies of the original characters to two well-known experts. He was one of the Three Witnesses and never denied his testimony of the Book of Mormon. [K.M.]

S.550 Sorensen, S. K. "Alexander Campbell on the Book of Mormon." SH 52 (13 September 1905): 879. An apologetic piece that responds to a pamphlet written by Alexander Campbell, who charged that Joseph Smith was the author of the Book of Mormon. [J.W.M.]

S.551 "A Souvenir from Hotel: A Copy of the Book of Mormon." CN 55 (24 March 1985): 4. Hotel guests are encouraged to take home copies of the Book of Mormon donated by Church members. [J.W.M.]

S.552 Sowell, Madison U. "Defending the Keystone: The Comparative Method Reexamined." Sunstone 6 (MayJune 1981): 44, 50-54. Discusses the theory that Joseph Smith gleaned ideas for the Book of Mormon from Ethan Smith's View of the Hebrews. The writer reviews responses to this theory made by B. H. Roberts and Hugh Nibley, and concludes that the two books do contain some common features. [M.R.] 
S.553 Sowers, Kenneth. "The Mystery and History of the Urim and Thummim." In Restoration Studies II, edited by M. Draper and A. Lindgren, 75-79. Independence, MO: Temple School, 1983. Examines the historical accounts concerning the Urim and Thummim. It appears that the interpreters of the Book of Mormon are separate items from the Urim and Thummim described in the Bible. [J.W.M.]

S.554 Spain, Carolyn Y., and Eldred F. Spain. Studies in Mosiah. Independence, MO: Herald House, 1989. A study aid designed to assist individuals in their study of the book of Mosiah. Contains commentary and discussion questions. [D.W.P.]

S.555 Spalding, Franklin Spencer. Joseph Smith, Jr., as a Translator: An Inquiry Conducted by Rt. Rev. F. S. Spalding; with the Kind Assistance of Capable Scholars. Salt Lake City: Arrow, 1912. Presents the opinions of scholars that the translation of the Pearl of Great Price was a total failure, and Smith's inaccurate translation of the Book of Abraham dismisses any accuracy of the Book of Mormon. [J.W.M.]

S.556 Spalding, Samuel J. Spalding Memorial: A Genealogical History of Edward Spalding, of Massachusetts Bay, and His Descendants. Boston, MA: Alfred Mudge \& Son, 1872. Includes a brief notice regarding Spalding/Rigdon and the origin of the Book of Mormon. [D.M.]

S.557 "Spanish, Korean Visitors Receive Book of Mormon in Own Language." CN 56 (19 October 1986): 10. Tells of Hispanic and Korean visitors to the open house of the Denver Temple who received personalized Books of Mormon in their own languages. [M.D.P.]

S.558 "Spanish-Speaking Members Appreciate Scripture Helps." CN 63 (11 December 1993): 5. The new Spanish edition of the Book of Mormon with its improved footnotes helps Spanish-speaking members study more effectively. [S.H.]

S.559 Spatz, Frances. "The Stick of Joseph." In The Good News: An outline story of the rise, fall, attempts at reformation, and final restoration of the Church of Jesus Christ, edited by Garland E. Tickemyer, F1-F10. N.p.: n.p., n.d. Provides lesson materials concerning the Book of Mormon for use in missionary work. Includes scriptural passages from the Old Testament and Book of Mormon, legends of the Indians and Aztecs, the coming forth of the Book of Mormon, and the testimony of the witnesses. [J.W.M.]

S.560 Spaulding, Solomon. The "Manuscript Found" or "Manuscript Story" of the Late Rev. Solomon Spaulding. Lamoni, IA: Reorganized Church of Jesus Christ of Latter Day Saints, 1855; Salt Lake City: Deseret News, 1886. A fictional novel claimed by many to have been the basis used by Joseph Smith to create the Book of Mormon. It is a story of a group of Romans driven to the Americas by a tremendous storm in the third century a.d. The manuscript contains descriptions of the "natives" and the castaways' dealings with them. [A.T.]

S.561 Spaulding, Solomon. The "Manuscript Found"-The Solomon Spaulding Manuscript. Oberlin College Library, 1908. A fictional account of a Roman citizen who made his way to the American continent and there set up a colony among the natives. Includes an introductory letter by L. L. Rice, who found the manuscript, in which he concludes that this story was not the basis for the Book of Mormon. [A.C.W.]

S.562 "The Spaulding Theory Again." SH 50 (26 August 1903): 786-87. Though the Spaulding theory has been proved false articles still appear in magazines and newspapers claiming the theory is true. [J.W.M.] 
S.563 "Spaulding's 'Manuscript Found." Presbyterian Banner (16 September 1885): 17-18. Fifteen witnesses claimed that Book of Mormon names are from Spaulding's manuscript. Spaulding's widow testified that her husband had a variety of other manuscripts-the Book of Mormon must have been taken from one of these. [J.W.M.]

S.564 Spence, Robert S. "Signs of Christ's Coming." Contributor 4 (June 1883): 356-57. Using the text of Ezekiel concerning the "stick of Joseph," the author examines Old Testament scriptures and Indian legends to establish that the coming forth of the "stick of Joseph," the Book of Mormon, was a sign of Christ's second coming. [J.W.M.]

S.565 Spencer, Edward B. T. "Notes on the Book of Mormon." Methodist Review 65 (January 1905): 31-43. A polemical review of the Book of Mormon. The writer comments on poor grammar, reformed Egyptian, King James English, New Testament plagiarisms, Ziff, cureloms, and cumoms. [M.R.]

S.566 Spencer, Geoffrey F. The Burning Bush: Revelation and Scripture in the Life of the Church. Independence, MO: RLDS Department of Education Herald Publishing House, 1975. A study guide that explores the importance of scriptures and revelation in the lives of RLDS church members. Provides references for background reading material on the Book of Mormon, commentary on historical facts, and work assignments to enlarge understanding of Book of Mormon messages. [J.W.M.]

S.567 Spencer, Geoffrey F. "A Reinterpretation of Inspiration, Revelation, and Scripture." In The Word of God: Essays in Mormon Scripture, edited by Dan Vogel, 19-27. Salt Lake City: Signature, 1990. First appeared as "A Reinterpretation of Inspiration, Revelation, and LDS Scripture." University Bulletin 20 (Winter 1968): 41-51, 103. Decries a "literalist" interpretation of Mormon scripture. Revelation is non-propositional and there are no "revealed truths." Rather than foretelling future events, prophets were inspired to understand God's will in their own day. Instead of developing a set of doctrines based upon scripture, we should strive for a personal relationship with God. Revelation is not an infallible source of doctrine. Explores the nature of the changes in the Book of Mormon before and after the first printing, compares the Book of Mormon, Bible, and Inspired Version. [M.R.]

S.568 Spencer, James R. Beyond Mormonism: An Elder's Story. Grand Rapids, Michigan: Chosen Books, 1984. A former Mormon gives a personal account of how he came to lose faith in Mormonism and the Book of Mormon and eventually reject Mormonism altogether. [M.R.]

S.569 Spencer, James R. Have You Witnessed to a Mormon Lately? Old Tappan, NJ: Chosen Books, Fleming, Revell Co., 1986. Contains a warning to those who read and pray about the Book of Mormon. "God is not into burning bosom formulas." Spiritual experiences do not come in this way; it may be counterfeit and is very dangerous. The Book of Mormon is filled with plagiarized scriptures from the Bible intermingled with fraudulent material. The Book of Mormon is full of inconsistencies. The Spaulding theory is favored. [J.W.M.]

S.570 Spencer, Marjorie M. "My Book of Mormon Sisters." Ensign 7 (September 1977): 66-71. This author made extensive notes about women in the scriptures. She expounds upon their characteristics and examples for others to follow (or not follow). She explores the adjectives used to describe them, the tribulations they endured, and the doctrine that is presented to both male and female. [J.W.M.]

S.571 Spencer, Orson. "Letter of Orson Spencer." TS 4 (2 January 1843): 49-59. Thoughtful description of the dynamics of the author's conversion. After hearing negative things about the Book of Mormon, Spencer studied the book and was converted to Jesus Christ. [D.M.] 
S.572 Spencer, Orson. "Seventh Letter of Orson Spencer to the Rev. W. Crowel A. M." MS 9 (1 September 1847): 258-62. Discusses the Book of Mormon within the context of the establishment of the Latter-day kingdom of God, citing Isaiah 29 as a prooftext. Responds to perceived weaknesses in language by writing that "an uninspired man might as well attempt to originally compose the Old and New Testament" as the Book of Mormon. [D.M.]

S.573 Spencer, Pearl. "The Peace Pipe and the Book of Mormon." IE 35 (July 1932): 545. The Indian legend concerning the peace pipe is one of great significance to the Book of Mormon. The pipe was a symbol of Jesus, the Prince of Peace. The account of Jesus' visit to the Americas might help to explain this legend more fully. [J.W.M.]

S.574 Sperry, Sidney B. "The American Gospel." DN Church Section (18 January 1947): 10, 12. Explains that the American gospel is the gospel taught by Jesus Christ when he administered to the Nephites on the American continent. Many of the principles Jesus taught were the same as he had taught in the Holy Land among the Jews. [M.D.P.]

S.575 Sperry, Sidney B. Ancient Records Testify in Papyrus and Stone. Salt Lake City: General Boards of MIA, 1938. A lesson manual for archaeology or religion students that deals with cuneiform records, the writings and translations of several Egyptian and Hebrew works, an analysis of the significance of the Book of Abraham, and the relation of the significance of these various findings to the Book of Mormon. [C.W.B.]

S.576 Sperry, Sidney B. Answers to Book of Mormon Questions. Salt Lake City: Bookcraft, 1967. Resolves diverse questions about the Book of Mormon text as it relates to the Pentateuch, the writings of Isaiah, Shakespearean quotations, New Testament citations, domesticated animals, and others. This work is reviewed in S.511. [D.L.L.]

S.577 Sperry, Sidney B. "The Book of Mormon and Textual Criticism," In Book of Mormon Institute, 1-8. Provo, UT: Brigham Young University Extension Publications, 5 December 1959. Argues against multiple authorship of the book of Isaiah and the first five books of Moses (the Pentateuch), with evidence from the Book of Mormon. Proposes that some textual variants in Isaiah as quoted in the Book of Mormon have an ancient source; argues that the Book of Mormon text can help determine the text of the Bible; and proposes that "Son of Righteousness" in the Book of Mormon should actually be "Sun of Righteousness." [R. S.]

S.578 Sperry, Sidney B. "The Book of Mormon as Translation English." IE 38 (March 1935, October 1954): 14041, 187-88, 703. Response to the argument that the Book of Mormon is an "imitation of biblical dictation." Sperry demonstrates that the Book of Mormon is an inspired translation, not simply an anthology of quotations, thoughts, or sayings of Joseph Smith, by examining various Isaianic passages in the Book of Mormon and comparing them with the Isaiah of the Septuagint, the Authorized Version, and the Hebrew text. [D.W.P.]

S.579 Sperry, Sidney B. Book of Mormon Chronology. Salt Lake City: Deseret Book, 1970. Written to correct minor errors in the chronology of the 1920 edition of the Book of Mormon. Book-by-book discussion of the given chronology, suppositions, and variant interpretations. [A.C.W.]

S.580 Sperry, Sidney B. Book of Mormon Compendium. Salt Lake City: Bookcraft, 1968. Thorough commentary on many aspects of the Book of Mormon. At least one chapter is devoted to each book of the Book of Mormon, plus chapters on the origin and translation, language and script, title page, witnesses, the Isaiah problem, the concept of God, teachings concerning death and the hereafter, and personal religion and brotherhood in the Book of Mormon. [A.C.W.] 
S.581 Sperry, Sidney B. "Book of Mormon Contributions to the Archaeology of the Old Testament." In Sperry's Ancient Records Testify in Papyrus and Stone, 229-40. Salt Lake City: General Boards of M.I.A. of the Church of Jesus Christ of Latter-day Saints, 1938. Deals directly with how the Book of Mormon contributes to the authenticity of the Bible. Sperry uses Book of Mormon references to argue that Moses wrote the Pentateuch, and that Isaiah wrote the works that bear his name. The Book of Mormon is a companion to the Bible. [G.A.]

S.582 Sperry, Sidney B. "Book of Mormon Essays by Sidney B. Sperry." Provo, UT: FARMS, n.d. A series of essays published under one title. The articles included are "The Book of Mormon and Textual Criticism," "The Book of Mormon's Message on Brotherhood," "Some Universals in the Book of Mormon," "Did Father Lehi Have Daughters Who Married the Sons of Ishmael?", "The Lamanites Portrayed in the Book of Mormon," "Moroni the Lonely," and "Some Problems of Interest Relating to the Brass Plates." [J.W.M.]

S.583 Sperry, Sidney B. Book of Mormon Lectures. Los Angeles: n.p., 1952. A typescript of six lectures. The author presents a discussion on reformed Egyptian, the books of $2 \mathrm{Nephi}$, Alma, and $3 \mathrm{Nephi}$, and the question regarding Isaiah in the Book of Mormon. [D.W.P.]

S.584 Sperry, Sidney B. Book of Mormon Studies: Student Manual and Teacher's Supplement. Salt Lake City: Deseret Sunday School Union Board, 1947. A Sunday School manual for the study of the Book of Mormon. Each chapter of the Book of Mormon is outlined and a brief summary is provided. Sperry also gives scriptural references, along with other bibliographic material suitable for outside reading. [G.A.]

S.585 Sperry, Sidney B. Book of Mormon Testifies. Salt Lake City: Bookcraft, 1952. The author analyzes each book in the Book of Mormon by giving its literary structure, purposes for writing, and content. The Book of Mormon is summarized in three main messages: a warning to the inhabitants of the American continent, the testimonies of Christ, and the Lord's promises to Israel. [G.A.]

S.586 Sperry, Sidney B. "The Book of Mormon's Message on Brotherhood." Ensign 3 (March 1973): 57-59. Cites various incidents from the Book of Mormon to show the teaching and practices of the Nephites concerning brotherhood and social justice. It particularly deals with the relations between family members, neighbors, workers, and enemies. [B.T.]

S.587 Sperry, Sidney B. "The Concept of God in the Book of Mormon." DN (25 January 1947): 10, 12. Sperry describes the nature of God as taught by the Book of Mormon. [B.D.]

S.588 Sperry, Sidney B. "Did Father Lehi Have Daughters Who Married the Sons of Ishmael?" IE 55 (September 1952): 642. Also in A Book of Mormon Treasury, 154-56. Salt Lake City: Bookcraft, 1959, 1976. Lehi had at least two "daughters who married the sons of Ishmael." According to Erastus Snow, the sons of Ishmael "married into Lehi's family" and 2 Nephi 5:6 indicates that Nephi had sisters. [A.T.]

S.589 Sperry, Sidney B. "Hebrew Idioms in the Book of Mormon." IE 57 (October 1954): 703, 728-29. Technical study of Hebrew grammar and idioms found profusely throughout the Book of Mormon. Compound Hebrew prepositions, plural compounds, and over three dozen examples of Hebrew idioms are given in the article. These studies support the idea that the Book of Mormon was originally written in Hebrew. [R.C.D.]

S.590 Sperry, Sidney B. "The Isaiah Problem in the Book of Mormon." IE 42 (September 1939): 524-25, 564-69. The Book of Mormon quotes twenty-one whole chapters and parts of other chapters of Isaiah. The authorship of Isaiah has been questioned by prominent scholars, and this "higher criticism" brought about the disintegration of 
belief in the unity of Isaiah. Some have faithfully held to the belief of unity and Sperry gives their reasoning. [J.W.M.]

S.591 Sperry, Sidney B. "The Isaiah Quotation: 2 Nephi 12-24." Provo, UT: FARMS, 198?. Analyzes the Lord's words to Israel through Isaiah the prophet and concludes that these teachings tell of (1) the coming of Christ and the power of his Atonement, (2) the prophecies of the latter days of interest to Nephi's people and the house of Israel, (3) the Lord who will redeem his people in the last days and remain in their midst, and (4) the judgments of God concerning the nations of the earth. [J.W.M.]

S.592 Sperry, Sidney B. Knowledge is Power. Salt Lake City: Bookcraft, 1958. Chapters 12-20 deal with the Book of Mormon. Discusses the last years of Moroni's life, Hebrew idioms in the Book of Mormon, the meaning of the Urim and Thummim, Lehi's daughters, and the parallelistic features found in Isaiah and in the Book of Mormon. [G.A.]

S.593 Sperry, Sidney B. "The Lamanites Portrayed in the Book of Mormon." IE 51 (December 1948): 792-93, 82627. Also in A Book of Mormon Treasury, 114-21. Salt Lake City: Bookcraft, 1959, 1976. Sets forth Book of Mormon characteristics and prophecies regarding the Lamanites. The Lamanites were used as a scourge to the Nephites; often the Lamanites were more righteous than the Nephites; the American Indians are descendants of Book of Mormon peoples; and the Lamanites will yet "receive the gospel" and become a "white and delightsome people." [A.T.]

S.594 Sperry, Sidney B. "Moroni the Lonely, The Story of the Writing of the Title-Page to the Book of Mormon." IE 47 (February 1944): 83, 116, 118. Also in IE 73 (November 1970): 110-11, and in A Book of Mormon Treasury, 12226. Salt Lake City: Bookcraft, 1959, 1976. Moroni was alone for thirty-six years. He finished the Book of Mormon, abridged the book of Ether, and wrote the title page. [J.W.M.]

S.595 Sperry, Sidney B. "Moroni's Mission and the Bible." MS 97 (12, 19 September 1935): 594-95, 604-5. Describes the first visitation of the angel Moroni to Joseph Smith, Joseph's call to the ministry, and scriptures quoted and interpreted by Moroni. Emphasis is placed on prophecies of key events in the latter days. [R.H.B.]

S.596 Sperry, Sidney B. "Nature and Origin of Modern Scripture." DN (23 November 1946): 10, 12. Describes the nature and origin of the Book of Mormon as well as the Doctrine and Covenants. [B.D.]

S.597 Sperry, Sidney B. "Omni and the Words of Mormon." Provo, UT: FARMS, 1984. Analyzes Omni 1:16-30, written by Amaleki, son of Abinadom, which explains the relationship of the descendants of Mosiah to the Mulekites in Zarahemla. "Book of Mormon history from Omni 12 is a history of the Mulekite people who adopted Nephite Leadership and Nephite Culture." Also, the Book of Omni gives an account of King Benjamin's life. [B.D.]

S.598 Sperry, Sidney B. Our Book of Mormon. Salt Lake City: Bookcraft, 1950. Simplifies the complex structure of the Book of Mormon by providing an overall synopsis of the text. He orders the fifteen books of the Book of Mormon into four divisions: (1) the small plates of Nephi, (2) Mormon's explanatory notes, (3) the literary labors of Mormon, and (4) the literary labors of Moroni; he follows with a literary synopsis of each of the fifteen books. Several types of literature are identified, including "the American Gospel" (3 Nephi 1:4-21; 8-28, Jesus' Nephite ministry), pastoral, prophetic, and war epistles, one psalm, one lamentation, memoir, prophetic discourse, oratory, patriarchal blessings, symbolic prophecy, prophetic narrative, prophetic dialogue, allegories, prayers, songs, and genealogies. More than fifty percent of the book is "historical narrative." Deals with the problem of biblical texts 
(Isaiah, the Sermon on the Mount, 1 Corinthians chapters 12 and 13) found in the Book of Mormon. This work is reviewed in N.096. [D.W.P.]

S.599 Sperry, Sidney B. "Personal Religion and Brotherhood in the Book of Mormon." DN (1 February 1947): 10, 12. Explains that the Nephites had a personal relationship with God. This close relationship accounts for their noble ideas and modes of conduct. We can learn from Nephite views on riches, pride, power, inequality, authority, and the vain things of the world. [B.D.]

S.600 Sperry, Sidney B. The Problems of the Book of Mormon. Salt Lake City: Bookcraft, 1964. Divides the "problems" of the Book of Mormon into two categories. The first are technical, doctrinal, and interpretive problems for members of the Church. The second relates to those raised by critics of the book and the Church. He addresses the nature of man, the problem of history, the use of the Urim and Thummim, the "Gentiles" of the Book of Mormon, the brass plates, Jesus as the Father and the Son, the Pentateuch, Isaiah, Sermon on the Mount, and more. The last five chapters answer criticism raised by apostate Arthur Budvarson. [J.W.M.]

S.601 Sperry, Sidney B. "Records of Judah and Ephraim: Explanation of term 'Stick.' " DN Church Section (3 December 1932): 1, 4. A rebuttal to an earlier article (James H. Anderson, 20 February 1932) concerning the meaning of the term stick in Ezekiel 37:15-17. Sperry argues that the stick of Ephraim is the Book of Mormon and the stick of Judah is the Bible. [A.T.]

S.602 Sperry, Sidney B. Science, Tradition and the Book of Mormon. Salt Lake City: Church of Jesus Christ of Latterday Saints, MIA, 1973. A reference manual for the youth. Sperry talks of the migration of the Jaredites and Nephites, suggesting also some possible landing sites. He gives archaeological evidence that relics found in ancient China resemble those found in the ancient Americas. Many Indian legends tell of a sacred book that was taken away that would return to the earth, and Sperry compares this legend with the Book of Mormon. [G.A.]

S.603 Sperry, Sidney B. "Some Contributions of Modern Revelation to the Understanding of the Bible." DN Church Section (24 August 1935): 2, 7. Gives several examples on how “modern revelation," including the Book of Mormon, gives more understanding to the Bible. The Book of Mormon shows that the five books of Moses were indeed written by one author, Moses, instead of several authors as many scholars claim. [M.D.P.]

S.604 Sperry, Sidney B. "Some Problems of Interest Relating to the Brass Plates." IE 54 (September 1951): 638 39, 670-71. Raises numerous unanswered questions about brass plates. How did current writings of Jeremiah get recorded on the plates when they were guarded exclusively by Laban? What merit does Old Testament criticism about the origin of the Pentateuch and Deuteronomy have in light of what is known about the brass plates? How did Laban, a descendant of Joseph, come to be the custodian of the plates in Jerusalem, the capitol of the southern kingdom of Judah? [R.C.D.]

S.605 Sperry, Sidney B. "Some Universals in the Book of Mormon." IE 49 (April 1946): 212-13, 240-42. Also in DN (15 February 1947): 10, 12. Universal teachings in the Book of Mormon include the truth that all men are equal before God (1 Nephi 17:33-35, 2 Nephi 26:33); certain truths are found in all the world (Alma 29:8); spiritual truths may be tested and faith increased (Alma 32); men are that they might have joy (2 Nephi 2:30); when you serve men, you serve God (Mosiah 2:16-18). [B.D.]

S.606 Sperry, Sidney B. "The Teaching Concerning Death, Judgment and the Hereafter in the Book of Mormon." DN (8 February 1947): 10, 12. The Book of Mormon clearly teaches God's plan in respect to the afterlife. Death is necessary for all individuals (2 Nephi 2:22-25). This life is the time to prepare to meet God (Alma 34:32, 34-35). In 
the spirit world there is a division of people who await the resurrection (Alma 40:9-14). There will be a judgment and all will be given a just reward according to their actions and desires (Alma 41:3-5, 2 Nephi 9:14). [B.D.]

S.607 Sperry, Sidney B. "The Text of Isaiah in the Book of Mormon." M.A. thesis, University of Chicago Divinity School, 1926. A detailed study of the parallels in Isaiah texts in the Bible and Book of Mormon. This study includes tables in both English and Hebrew showing the textual differences. The conclusions are that the text of Isaiah considered Deutero-Isaiah dates earlier than 600 b.c. when Lehi brought the plates of Laban to the American continent and that Joseph Smith worked independently from the King James Version. [J.W.M.]

S.608 Sperry, Sidney B. Themes of the Restored Gospel. Salt Lake City: Bookcraft, 1950. The majority of the book is devoted to "the spirit of modern scripture," in which Sperry discusses modern scriptural doctrine, including teachings found in the Book of Mormon. He explores the concept of God, great personalities of the Book of Mormon, personal religion, brotherhood, the hereafter, judgment, and universal aspects of the Book of Mormon. [C.W.B.]

S.609 Sperry, Sidney B. "Three Great Personalities of the Book of Mormon." DN Church Section (4 January 1947): 10, 12. Gives the "outstanding characteristics" of three great men in the Book of Mormon-Nephi, Jacob, and Enos. Nephi was faithful and a great spiritual leader, Jacob believed and defended the sanctity of the home, and Enos received "an unshakable faith" in God. [M.D.P.]

S.610 Sperry, Sidney B. "Three Outstanding Messages of The Book of Mormon to This Generation." MS 113 (September-November 1951): 202-3, 222, 226-27, 239, 245, 256-58, 265. The Book of Mormon is first a warning voice to our day and time. We must serve God or perish, and beware of secret combinations. Second, it is a testimony that Jesus is the Christ. The third outstanding message shows the Lord's concern toward the house of Israel. [J.W.M.]

S.611 Sperry, Sidney B. "Were There Two Cumorahs?" Provo, UT: FARMS, 1964. A careful study of the passages of scripture found in the Book of Mormon concerning the hill in which the sacred records were hidden by Mormon seems to indicate that it was located in Middle America. The theory that the records were first deposited in the hill Cumorah in New York state seems to fall apart when the text of the Book of Mormon is closely examined. The conclusion is that the records must have been transported. [J.W.M.]

S.612 Sperry, Sidney B. "What is the Meaning of Urim and Thummim?" IE 43 (November 1940): 657, 690, $692-93$. Sperry analyzes the Assyrian and Babylonian similarities to the Hebrew Urim and Thummim to find a better translation than the unsatisfactory "lights and perfection." He concludes that a better translation is "revelations and visions" or "revelations and manifestations." He speculates on the manner in which the instrument functioned. [B.D.]

S.613 Sperry, Sidney B., and H. Grant Vest. "The Problem of Isaiah in the Book of Mormon." CN 3 (16 September 1933): 3, 7. Addresses the problems raised by the Isaiah portions contained in the Book of Mormon, including the multiple authorship of Isaiah and resulting conflict in dates, and the similarities and differences between the King James Version wording and Joseph Smith's translation. Cites the various Hebrew texts to support claims that the Book of Mormon translation is the most accurate. [A.C.W.]

S.614 Stafford, Harry Errald. The Early Inhabitants of the Americas. New York: Vantage Press, 1959. Uses archaeological evidence, legends, traditions, and myths of the native inhabitants, as well as historical accounts to show that the Book of Mormon coincides with ancient evidence and thus it must surely be the record of the 
ancient inhabitants of the Americas. Ties Book of Mormon migrations with specific locations and civilizations according to Book of Mormon texts. [J.W.M.]

S.615 Stallings, Sandra. "Cham Nap." NE 16 (May 1986): 38-39. A 14-year-old Cambodian boy struggled to read the Book of Mormon to strengthen his testimony and to learn English. [J.W.M.]

S.616 Stapley, Delbert L. "Christ's Visit to the Western Hemisphere Following His Resurrection." Relief Society Magazine 40 (March 1953): 211-15. Christ's visit to the American continent brought hope and assurance of eternal life. There had been ample evidence of his crucifixion and death as foretold by Samuel the Lamanite. Mormon considered this story of great importance to Jews and Gentiles of the latter days. The witnesses of the New World testified and supported the New Testament's account of the Savior's crucifixion and resurrection. [J.W.M.]

S.617 Stapley, Delbert L. "The Glorious Standard." IE 66 (December 1963): 1103-6. Recalls Book of Mormon prophecies that foretold the discovery and establishment of the promised land of America. There are blessings for those who keep God's commandments and cursings for those who do not. The constitution was divinely inspired. [J.W.M.]

S.618 Stapley, Delbert L. "Overcoming Evil Designs: Nephi's Counsel." CR (October 1961): 20-24. Notes Nephi's teaching that Satan will try to deceive in the last days, and reviews schemes used by Satan today. We cannot with safety say "all is well in Zion." [R.C.D.]

S.619 Stapely, Delbert L. Untitled talk. CR (April 1963): 33-38. Jacob gave important counsel that was designed to protect homes and families from immoral behavior. Yielding to the temptation that leads to immoral behavior will lead to broken homes and innocent victims who are affected both psychologically and spiritually. [J.W.M.]

S.620 Stapley, Delbert L. "The Vision of Lehi." IE 69 (June 1966): 504-6. Also in CR (April 1966): 23-27. Lessons can be learned from the record of Lehi's vision of the tree of life. Prayer and humility are important to learning the truth by the power of the Holy Ghost. Temptation may come in attractive attire that blurs perception and weakens sensibility. [J.W.M.]

S.621 Stapley, Orley S. Untitled talk. CR (October 1916); 111-13. A woman who was very ill accepted the Book of Mormon as true, desired baptism, and believed she would be made whole. She had to be carried into the waters of baptism, but was able to walk out. Evidence of ancient fortifications and cities lie all around and are memorials to the people who lived anciently in the Americas. [J.W.M.]

S.622 Stark, Amy Carroll. "The Valley of Peace." IE 36 (January 1933): 136-38, 186-88. A fictional story of Lehi's family and the Exodus as seen from the eyes of Lemuel's wife. [J.W.M.]

S.623 Starks, Arthur E. Combined Concordances for the Scriptures. Independence, MO: Herald House, 1962, 1975. This volume comprises A Concordance Supplement for the Inspired Version of the Holy Scriptures, A Complete Concordance to the Book of Mormon, and A Complete Concordance to the Doctrine and Covenants. These concordances are based on the RLDS scriptures and use their chapter-verse divisions. Formatted alphabetically by words and key phrases. [A.C.W.]

S.624 Starks, Arthur E. Complete Concordance to the Book of Mormon. Independence, MO: Herald House, 1950. A concordance to the Book of Mormon published by the Reorganized Church of Jesus Christ of Latter Day Saints. 
Format is dictionary style, by words and key phrases with cross references. [L.D.]

S.625 Stathis, Stephen W., and Charles H. Whittier. "The Enigma of Solomon Spaulding." Dialogue 10 (1977): 7073. Brief biography of Solomon Spaulding, deploring the fact that he is only remembered today for his connection to the Book of Mormon manuscript when his life consisted of so many other noteworthy accomplishments. [A.C.W.]

S.626 Stayner, Charles W. Alleged "Objectionable Features" In The Religion of The Latter-day Saints. Liverpool: Albert Carrington, n.d. One of the most "objectionable features" of the Church of Jesus Christ of Latter-day Saints is the Book of Mormon. The book is not a substitute for the scriptures. [J.W.M.]

S.627 Stayton, Linda L. "I Felt Drawn To That Book." Ensign 7 (September 1977): 73-74. A long search for a religion that could be accepted led this guilt-ridden lady to investigate many churches. A visit to Nauvoo and a gift of the Book of Mormon was the answer to prayers. [J.W.M.]

S.628 Stearn, Jess “Her Last Life." In Stearn's The Search for a Soul: Taylor Caldwells' Psychic Lives, 1972, 1973, 17994. New York: Doubleday and Company, 1972, 1973. Recollections of past lives and experiences of a hypnotic patient were related to Joseph Smith and Aztec and Incan experiences. The woman in the trance had related the same facts as the story of the Book of Mormon and its coming forth. [J.W.M.]

S.629 Stebbins, H. A. "Indian Progress Towards Book of Mormon Fulfillment." SH 50 (22 July 1903): 671-72. The recent progress of the American Indian fulfills Book of Mormon prophecy. Interest in the Indian by the U.S. government is making this fulfillment possible. [J.W.M.]

S.630 Stebbins, Henry A. The Book of Mormon Lectures: Claims of the Book of Mormon Examined in the Light of History, Archaeology, Antiquity, and Science. Independence, MO: Ensign House, 1894, [R]1901. A series of nine lectures that begins with Stebbins's testimony of the Book of Mormon followed by an overview of its history. Lectures deal with archaeology, geography, linguistics, the Biblical scriptures, and other items. [A.C.W.]

S.631 Stebbins, Henry A. Modern Knowledge of the Antiquities of America. Independence, MO: Ensign Publishing, March 1897. American antiquities support the claims of the Book of Mormon. Prior to the publication of the book extensive facts about the ancient Americans' language, ancestry, and works were unknown to the world. Gives information about publication dates for works about American antiquities and when their use began in America. [J.W.M.]

S.632 Stebbins, Henry A. "Prehistoric America and the Book of Mormon." Journal of History 6 (1913): 2-19. Archaeologists have uncovered great civilizations in America. The scattering from the tower of Babel led people "everywhere" on the earth and the Book of Mormon bears witness of that fact. The book supports the Bible both in history and doctrine. It teaches of Christ and the historians have recorded that American natives had knowledge of Christianity before the Spanish came. [J.W.M.]

S.633 Stebbins, Henry A., and Marietta Walker. "The Book of Mormon." In A Compendium of the Faith and Doctrine of The Reorganized Church of Jesus Christ For The Use of the Ministry And of Church Schools, 78-83. Lamoni, IA: The Board of Publication, 1888. Quotes biblical passages from the books of Ezekiel, Genesis, Deuteronomy, Psalms, Isaiah, Hosea, Zechariah, and Daniel to prove that the Book of Mormon is the "Stick of Joseph." These are followed by passages from 1 and 2 Nephi and the Doctrine and Covenants. [J.W.M.] 
S.634 Stecker, Alexander T. Review of Since Cumorah, by Hugh W. Nibley. BYU Studies 8 (Summer 1968): 465-68. Book review.

S.635 Steed, A. Merlin. "The Dawning Day For The Lamanites." MS 95 (1 June 1933): 353-59, 363. Describes a time when Indian students visited the Alberta, Canada Temple. They saw wall paintings that depicted Lehi offering a sacrifice after landing on American soil, and a picture of Christ administering the sacrament to a Lamanite at his coming after his resurrection. [B.D.]

S.636 Stendahl, Krister. "The Sermon on the Mount and Third Nephi." In Reflections on Mormonism: JudaeoChristian Parallel, 139-54. Provo, UT: Brigham Young University Religious Studies Center, 1978. 3 Nephi 11-26 is the New Testament part of the Book of Mormon, the teachings and ministry of the Savior. It is apocryphal in nature. The Book of Mormon text is significantly different from the New Testament, baptism being the central feature. 3 Nephi introduces a Johannine Jesus rather than a Matthean portrayal, and proclaims Jesus as the Mosiah, the Redeemer. [J.W.M.]

S.637 Stenhouse, Thomas B. H. The Rocky Mountain Saints. New York: Appleton, 1873. A historical work on Mormonism written by a former Mormon. Chapters 2, 3, and 48 deal specifically with the Book of Mormon. The discussion of the Book of Mormon is highly polemical. Among the anachronisms set forth by the author are the account of the Jaredite barges, the description of desert life, the presence of various domesticated animals before Columbus, Christians before the time of Christ, and alleged plagiarisms from the New Testament. [M.R.]

S.638 "Stephens' Work on Central America." TS 4 (1 October 1843): 346-47. This article deals directly with Mr. Stephens and his book, Incidents of Travel in America, wherein Stephens records his discoveries of ancient cities in Central America, Chiapas, and Yucatan. Stephens states that "hieroglyphical representations, sculpture and rich specimens of architecture" lead him to believe that a highly advanced society once inhabited these areas. This work is reviewed in P.386. [G.A.]

S.639 Stevens, Thelona D. "Book of Mormon Names in Indian Languages." SH 115 (1 July 1968): 456. List based on research by Pearl Kinnaman demonstrating that names such as Laman, Nephi, Angola, Antipas, Anti, Kish, Moroni, Timothy, and Helaman appear in Indian languages. [A.C.W.]

S.640 Stevens, Thelona D. Book of Mormon Studies. Independence, MO: Herald House, 1948, [R]1972. A lesson manual that works as a guide for reading the Book of Mormon supported by the Inspired Version of the Bible and the Doctrine and Covenants. Stevens gives an introduction to the Book of Mormon and then explores its contents. She discusses in detail the Jaredites, the Mulekites, the division of the Nephites and Lamanites, and Christ and his restored gospel. [C.W.B.]

S.641 Stevens, Thelona D. "Composition of the Plates of the Book of Mormon." SH 94 (27 December 1947): 1177-78. Biblical and archaeological evidence indicate that a wide variety of materials were used for record keeping, including papyrus, parchment, clay tablets, brass, and other metals. The Book of Mormon mentions plates of brass, of ore (gold, silver, and copper), and of pure gold. [A.C.W.]

S.642 Stevens, Thelona D. The Everlasting Covenant. Independence, MO: Foundation for Research on Ancient America, 1984. Discusses how the Book of Mormon was translated, and the phraseology in the book that identifies the everlasting covenant of salvation. The Book of Mormon uses different language than the Doctrine and Covenants and Bible with regard to the everlasting covenant. [D.W.P.] 
S.643 Stevens, Thelona D. "How Book of Mormon Studies Came Into Being." In Recent Book of Mormon Developments, Articles from the Zarahemla Record, 1:114-16. Independence, MO: Zarahemla Research Foundation, 1984. An explanation of how the author developed the Book of Mormon studies lessons for the RLDS Department of Religious Education. [B.D.]

S.644 Stevens, Thelona D. An Introduction to the Book of Mormon. Independence, MO: Foundation for Research on Ancient America, 1984. A booklet briefly setting forth a number of topics dealing with the Book of Mormon, including the language, translation, title page, manuscripts, archaeology, geography, witnesses, composition of the plates, and other items. [D.W.P.]

S.645 Stevens, Thelona D. "The Language of the Book of Mormon." SH 94 (6 December 1947): 1103-5. Discusses Nephi's knowledge of Egyptian and Hebrew and how the Book of Mormon plates were only written upon by a distinct class of educated people. The Jaredites "presumably [spoke] the language of Adam," but Moroni translated their record into reformed Egyptian using the Urim and Thummim. Argues that the brass plates were also written in Egyptian since it took less space than Hebrew, and Moses knew both languages. [A.C.W.]

S.646 Stevens, Thelona D. "Mexico: The Valley Shall Bloom Again." SH 89 (22 August 1942): 1082-83, 1087. The peoples of the Book of Mormon were destroyed and their lands were not cared for. The Book of Mormon records this "sad fate" because of their iniquity, but in these latter days the land will again become fruitful if the people will serve the God of the land, Jesus Christ. [J.W.M.]

S.647 Stevens, Thelona D. Nephi, Son of Lehi. Independence, MO: Foundation for Research on Ancient America, 1986. Booklet has short essays about Nephi, addressing his role as a shipbuilder, his leadership qualities, his priesthood, and his interest in educating his people. [D.M.]

S.648 Stevens, Thelona D. "The Purposes of the Book of Mormon in the Divine Plan." SH 88 (19 April 1941): 499500. The primary purpose of the Book of Mormon is to provide the world with a second witness for Christ. Another purpose is to present the plan of salvation for all people. [J.W.M.]

S.649 Stevens, Thelona D. A Summary of the Book of Mormon: Book by Book. Independence, MO: Foundation for Research on Ancient America, 1984. A booklet that provides a concise historical summary of each of the fifteen books of the Book of Mormon. [D.W.P.]

S.650 Stevenson, Bertha S. "The Third Witness." IE 37 (August 1934): 458-59. Chronicles the final years of Martin Harris's life and his journey to Utah. Harris spoke to congregations bearing his witness of the Book of Mormon. He died in July 1870 and was buried with a Book of Mormon in one hand and a Doctrine and Covenants in the other. [J.W.M.]

S.651 Stevenson, E. "A Visit to David Whitmer." Juvenile Instructor 22 (February 1887): 55. David Whitmer, the final surviving witness for the Book of Mormon, bore an undimmed testimony of the Book of Mormon and told of the visit of one of the three Nephites. [J.W.M.]

S.652 Stevenson, Edward. "Historical Scenes Around Cumorah Hill." Utah Monthly Magazine 8 (April-May 1892): 242-46, 289-91. Describes the location and appearance of the Hill Cumorah, and then tells of the Jaredite and Nephite destructions that had occurred there. Stevenson then discusses America as a land of liberty and Moroni's final act of burying the plates in the Hill Cumorah. [A.C.W.] 
S.653 Stevenson, Edward. Reminiscences of Joseph, the Prophet, and the Coming Forth of the Book of Mormon. Salt Lake City: Edward Stevenson, 1893. The author presents his own and others' eyewitness accounts of events in the life of Joseph Smith. This book gives the history of Joseph's childhood through his martyrdom. Includes a description of Cumorah, speaks of its history, and gives descriptions of the things Joseph received with the golden plates. [L.M.]

S.654 Stevenson, Edward. "The Three Witnesses To The Book of Mormon." MS (May 1886): 341-43. As a witness who sat in the presence of the prophet Joseph and the Three Witnesses, this author presents his accounts of some of the occasions when testimonies were born. The author states that he was "deeply inspired" as he heard them many times testify of being in the presence of a heavenly messenger who talked with them and showed them the plates. They were shown the Urim and Thummim and told these seer stones were used by ancient prophets. [J.W.M.]

S.655 Stevenson, H. Lecture on Mormonism. Newcastle: J. Blackwell and Company, 1839. A polemical tract based on a lecture given to a Methodist congregation in Alston in 1838. The Book of Mormon is "a foolish and wicked forgery" that has no historical basis whatsoever. It is a book full of anachronistic statements, absurdities, and contradictions with the Bible. [M.R.]

S.656 Stevenson, W. Fleming. "A City of Saints." Frank Leslie's Sunday Magazine 7 (April 1880): 406-16. Description of a visit to Salt Lake, with a report of conversations with LDS members. Tells about the Book of Mormon, and includes references to the Spaulding fabrication. [D.M.]

S.657 Stewart, David Grant. The Jaredites Were Black. United States: National Translator Certification Service, 1984. Written as a discussion between three friends. It is proposed that the Jaredites were descendants of Naphtahim, son of Mizraim, grandson of Noah who left Egypt shortly after the confusion of tongues. They were black and had no priesthood, but were highly blessed of the Lord. It is thought that they were OImecs who occupied Mexico. [J.W.M.]

S.658 Stewart, F. L. Exploding The Myth About Joseph Smith, The Mormon Prophet. New York: House of Stewart Publications, 1967. Written in rebuttal to No Man Knows My History, by Fawn Brodie. Finds numerous discrepancies, erroneous claims and associations. Brodie's claim that Joseph Smith's family was irreligious is an error. The Kentucky revivals had no connections with the New York religious controversies. Investigates the "Dogberry articles" that ran in the Palmyra Reflector and finds that evidence was overlooked by Brodie. Joseph Smith could not have written the Book of Mormon with his limited access to education and written materials. [J.W.M.]

S.659 Stewart, J.Z. "Interesting Facts: The Divine Authenticity of the Book of Mormon Clearly Proved by Ancient Indian Records." Juvenile Instructor 15 (1 March 1880): 50. The conquering Spaniards burned the histories of the Mexican natives, but a few survived and are in the Aztec museum in Mexico. The histories there as well as in Central and South America offer astonishing proof that the Book of Mormon is true. [D.M.]

S.660 Stewart, Margery S. "The Bright Warrior." IE 56 (May 1953): 326-27, 358-60, 362-63. A fictional story of Samuel the Lamanite as might have been seen through the eyes of a Nephite boy named Nathan. [J.W.M.]

S.661 Stewart, Ora Pate. "Article of Faith Eight: We believe the Bible ..." In Stewart's We Believe: A Simplified Treatment of the Articles of Faith, 85-90. Salt Lake City: Bookcraft, 1954. Stewart points out that the "Bible is not the complete history of God's dealings with man; neither is the Book of Mormon." However, it is the word of God. The 
Bible has mistakes of omission that took place during the time of copying and multiple translations. This is not so for the Book of Mormon, which was translated under divine supervision only once. The "Stick of Judah" and the "Stick of Joseph" are "one in the testimony they bear." [J.W.M.]

S.662 Stewart, Ora Pate. Branches Over the Wall. Salt Lake City: Bookcraft, 1950. Retelling of the Book of Mormon in simplified language. [A.C.W.]

S.663 Stewart, Ora Pate. Dear Land of Home. Salt Lake City: Deseret Book, 1960. Retells story of the people of Zeniff in the form of a fictionalized account that incorporates quotes from Book of Mormon text. Zeniff's story is a warning, and it "presents a miniature of the whole Book of Mormon message." [A.C.W.]

S.664 Stewart, Ora Pate. Treasures Unearthed. Salt Lake City: Bookcraft, 1953. Stewart discusses various Book of Mormon topics such as the Lamanite curse, the issue of white Indians, Nephi's sisters, calendars, shipbuilding, organized crime, arts, industry, and prophecies concerning our day. The topics are in random order, and are written in the form of short articles. [A.C.W.]

S.665 "The Stick of Ephraim." IE 8 (August 1905): 781-82. Lehi was a descendant of Manasseh and Ishmael was a descendant of Ephraim. Hence, the Book of Mormon is the stick of Joseph, which comprises descendants of Manasseh and Ephraim. [D.M.]

S.666 "The Stick of Ephraim." MS 68 (22 March 1906): 189-91. Addresses the question, "Why is the Book of Mormon called the stick of Ephraim when Lehi descended from Manasseh?" It recounts Ezekiel's prophecy that the sticks of Judah and Joseph would come together. The blessings given to Joseph and Ephraim by the Patriarch Jacob show that as the birthright tribe, Ephraim is nearly always referred to in the Bible instead of Manasseh. Zoram and Ishmael were descendants of Ephraim, and in the latter days the Book of Mormon is being used primarily by descendants of Ephraim. For all of these reasons the Book of Mormon is referred to as the stick of Ephraim. [K.M.]

S.667 "Stick of Joseph." In Encyclopedia of Mormonism, edited by Daniel H. Ludlow, 3:1418. 5 vols. New York: Macmillan, 1992. Latter-day Saints consider the Book of Mormon to be the "Stick of Joseph." It has also been called the "Stick of Ephraim" (Ezekiel 37). [J.W.M.]

S.668 The Stick of Joseph. Los Angeles: Southern California District Seminaries, n.d. A seminary teacher's manual on the Book of Mormon. [D.M.]

S.669 Stick of Joseph-What Is It? Independence, MO: Restored Church of Jesus Christ, 1984. A tract designed to interest people in the Book of Mormon. Contains brief comments, pictures, and illustrations dealing with biblical and Book of Mormon scriptures. [D.W.P.]

S.670 Stiles, Kendall. "Democratic Government in Ancient America." Ensign 22 (April 1992): 62. Discusses Mosiah2's democratic system of government as described in Mosiah, Alma, Helaman, and 3 Nephi. The political structure was based on a system of judges, the people were the ultimate authority, and honesty and accountability were emphasized. [A.C.W.]

S.671 Stocks, Hugh G. The Book of Mormon, 1830-1879: A Publishing History. Los Angeles: MLS Paper, University of California, 1979. Master's thesis: this article is an analytical bibliography that traces the development of the Book of Mormon from its original printing-a 500-page manuscript with no punctuation or paragraphing-to the 
modern, mass-produced (English only) volumes of today. The historical circumstances that surrounded each printing and the technical facts that pertain are presented. [J.W.M.]

S.672 Stocks, Hugh G. "The Book of Mormon Comes to Independence, MO: Missionary Printing and the Independence Editions of the Book of Mormon." Paper delivered at Mormon History Association Annual Meeting, 4 May 1985. A synopsis of the author's 1979 Master's Thesis, with an emphasis on the printing of the Book of Mormon in Jackson County, Missouri. [J.W.M.]

S.673 Stocks, Hugh G. The Book of Mormon in English, 1870-1920: A Publishing History and Analytical Bibliography. Los Angeles: University of California Press, 1986. Examines the production and distribution of the Book of Mormon from 1870-1920. This article contains a description of each printing that took place during this period and the factors that determined the format, location of publication, and cost. A comparison is made between publication of the Book of Mormon and publications of the Seventh-day Adventists and Christian Scientists. [J.W.M.]

S.674 Stocks, Hugh G. "Book of Mormon Translations." In Encyclopedia of Mormonism, edited by Daniel H. Ludlow, 1:213-14. 5 vols. New York: Macmillan, 1992. Book of Mormon translations began with the Danish translation in 1851, 36 complete book translations into other languages by 1990, and selections from the book into 44 additional languages. These selections will be replaced by complete book translations in the near future. [N.K.Y.]

S.675 Stoffel, Jerome. Joseph Smith and the Mormon Dilemma. N.p., 1970-71. A self-published history of Joseph Smith and the restoration of the Church, the coming forth of scriptural records, and the exodus of the Saints to Utah. Two chapters feature the coming forth of the Book of Mormon and the internal character of the work. Author does not accept the Book of Mormon as scripture. [D.W.P.]

S.676 Stoker, Kevin. "The 'Best Missionaries.' " CN 56 (7 December 1986): 16. An article in a magazine led Conley Smith to look for a copy of the Book of Mormon. He attributes his conversion to the "best missionaries"-Nephi through Moroni. [J.W.M.]

S.677 Stoker, Kevin. "Big Welcome for Prophet Deep in Heart of Texas." CN 58 (30 April 1988): 3, 5. President Benson calls on the members to read and teach the Book of Mormon. Elder Peterson urges the members to follow the examples of the prophets in the Book of Mormon. [M.D.P.]

S.678 Stoker, Kevin. "Book of Mormon Being Shipped in Record Numbers." CN 56 (13 July 1986): 3. Update on quantities of Books of Mormon being distributed worldwide. The increased numbers are due mainly to President Benson's emphasis upon the Book of Mormon and the heeding of this counsel. [A.C.W.]

S.679 Stoker, Kevin. "Book of Mormon: 'Wave of Enthusiasm.' " CN 58 (6 February 1988): 5. Reports that Daniel H. Ludlow raised a Book of Mormon in one hand and the Bible in the other and declared that a person cannot accept the Book of Mormon without accepting the Bible. [J.W.M.]

S.680 Stoker, Kevin. "Prophet Told, 'We Prayed You Here.' " CN 58 (5 November 1988): 3, 13. President Benson said that the Book of Mormon was written for people today, and that members should study and teach it. "We have not been using the Book of Mormon as we should," and "our homes are not as strong unless we are using it to bring our children to Christ." [M.D.P.] 
S.681 Stoker, Kevin. "Prophet Urges Following in Savior's Steps." CN 57 (14 February 1987): 3. President Benson told seminary and institute students that "wisdom is the proper application of true knowledge" and that all knowledge and truth are not of equal importance. Seeking knowledge and truth in the scriptures is of greatest worth. Understanding the value of worship in one's life is best achieved by reading the Book of Mormon and following Moroni's counsel. [J.W.M.]

S.682 Stoker, Kevin. "Prophet Visits Area of Father's Mission." CN 57 (17 October 1987): 3-4. President Benson spoke at the Des Moines, lowa Regional Conference, the same area where his father served a mission nearly 75 years earlier. He spoke about using the Book of Mormon correctly in our lives. [M.R.]

S.683 Stoker, Kevin. "Prophet's Counsel Aimed At the 'Rising Generation.' " CN 57 (21 February 1987): 3-4. At a regional conference, President Benson spoke to youth, stressing how vital the Book of Mormon is as a missionary tool in bringing people to Christ. [A.C.W.]

S.684 Stoker, Kevin. "Sent 'Sacred Book.' " CN 57 (16 September 1987): 16. Revisiting the scenes of previous military service brought Normand Laub to the Philippines, where he found many people to whom he sent copies of the Book of Mormon. Because of his influence a new area was opened up for missionary work. [J.W.M.]

S.685 Stoker, Kevin, Kellene Ricks, and John Hart. "Aggression-Beginning of End." CN 58 (12 November 1988): 14. Tells how the Nephites started declining when they became the aggressors by attacking the Lamanites. [M.D.P.]

S.686 "The Stone Box Story." CN 41 (6 February 1971): 16. Tells of different plates and records that were placed in stone boxes in order to preserve them. [M.D.P.]

S.687 Storrer, A. A. "A Dream Come True." Ensign 14 (August 1984): 55. Through prayer and the Book of Mormon a period of indecision about whether this author should join the Church came to an end. [J.W.M.]

S.688 "Stories From the Book of Mormon." (Series) Relief Society Magazine 30-31 (June/July 1943-February 1944): 453-57, 518-21, 647-50, 711-13, 775-77, 61-64, 125-27. This series of Relief Society lessons is designed to stimulate interest in the Book of Mormon, teach the gospel as found in the Book of Mormon, and familiarize the members with its characters and events. [J.W.M.]

S.689 Stories from the Book of Mormon. Salt Lake City: Department of Seminaries and Institutes of Religion, 1967. Booklet illustrates the sacred history of the brother of Jared and his associates. [D.M.]

S.690 Stories from the Book of Mormon: How We Got the Book of Mormon. Salt Lake City: Department of Seminaries and Institutes of Religion, 1967. A pictorial book for children that tells the story of the coming forth of the Book of Mormon. [D.W.P.]

S.691 Stories from the Book of Mormon: Lehi Obeys the Lord. Salt Lake City: Department of Seminaries and Institutes of Religion, 1967. Black and white picture book detailing Lehi's and his family's initial departure into the wilderness. [D.M.]

S.692 Stories from the Book of Mormon: The Book of Mormon. Salt Lake City: Department of Seminaries and Institutes, 1967. A pictorial overview of the Book of Mormon. Illustrations have explanatory subscripts. [D.M.] 
S.693 Stories from the Book of Mormon: The Building of a Ship. Salt Lake City: Department of Seminaries and Institutes of Religion, 1967. Retells, through illustration, the story of how Nephi built a ship by divine mandate. [D.M.]

S.694 Stories from the Book of Mormon: The Precious Record. Salt Lake City: Department of Seminaries and Institutes of Religion, 1967. A black-and-white book of drawings with captions that deal with the acquisition of the plates of brass. [D.M.]

S.695 Stories from the Book of Mormon: The Prophet Abinadi. Salt Lake City: Department of Seminaries and Institutes of Religion, 1967. A picture book containing the story of Abinadi's encounter with King Noah. [D.M.]

S.696 "The Story Behind Stela 5." SEHA 110 (2 December 1968): 1-7. Contains a chronological summary of significant events relative to the discovery and interpretive studies of Stela 5. Three photographs are supplied. [D.M.]

S.697 "Story of Faith: The Brother of Jared." Friend 18 (January 1988): 16-17. Brief illustrated story for children about the brother of Jared. [D.M.]

S.698 "The Story of the Origin of the World's Strangest Book." MS 98 (17 September 1936): 602-4. Recounts the stories of Joseph Smith's vision, of his receiving the plates, of the translation process of the Book of Mormon, and of the witnesses that testified of seeing the Book of Mormon. [M.D.P.]

S.699 Story, Ruth P. "The Book of Mormon and a Feather." Restoration Witness 164 (August 1976): 11-14. The parents of a new convert accepted his conversion and received a Book of Mormon. Reading the book brought warm and wonderful experiences that bear witness of the book's spiritual nature. [J.W.M.]

S.700 Stott, Douglas W. An Analysis of Possible Prophetic Techniques Employed by Mormon in Abridging the Nephite Record for Latter-day Readers. N.p., 1982. Delineates the parts of the Book of Mormon worked on by Mormon. Discusses the lost 116 pages. Refers to the "types" or "situation symbols" from the Old World carried through the Book of Mormon. Points out relevant passages for today's world. [D.M.]

S.701 Stott, G. St. John. "Joseph Smith's 1823 Vision: Uncovering the Angel Message." Religion 18 (October 1988): 347-62. Scott examines the different versions of the account of Joseph Smith's 1823 vision, and he notes how the story was amplified over time. With these comparisons, Scott notes anachronisms that betray the falseness of the origins of the Book of Mormon. [B.D.]

S.702 Stott, G. St. John. "Ordination and Ministry in the Book of Mormon." In Restoration Studies III, edited by Maurice L. Draper, 244-53. Independence, MO: Herald House, 1986. In the Book of Mormon two models exist concerning the call to church service: the first is exemplified in the case of Alma, who issued direct calls and bestowed authority to the ministry by proper ordination within the organized, faithful church. The second is found in the ministry of Abinadi, which was in opposition to the established, but apostate, church and state. The call then is an "unmediated call" directly from God. These "unmediated calls" come through conversion and the turning of one's life to Christ in rebirth. [J.W.M.]

S.703 Stott, G. St. John. "The Seer Stone Controversy: Writing the Book of Mormon." Mosaic: A Journal for the Interdisciplinary Study of Literature 19 (Summer 1986): 35-53. Not accepting Joseph Smith's account regarding the 
coming forth of the Book of Mormon from the gold plates, the author attempts to find other explanations for the book's existence. [D.W.P.]

S.704 Stout, Walter M. The Book of Mormon Practical Geography. Upland, CA: n.p., 1970. Contains maps of Book of Mormon geography that favor the Mesoamerican theory. Book of Mormon scriptural passages provide the criteria for this theory. [J.W.M.]

S.705 Stout, Walter M. Harmony in Book of Mormon Geography. Las Vegas: Chief Litho, 1950. A work that attempts to harmonize the geographical accounts contained in the Book of Mormon with the countries of Nicaragua and Costa Rica located in Central America. [D.S.T.]

S.706 Stout, Walter M. Landing Places of Book of Mormon Colonies. N.p., 196?. Provides hypothetical maps and tries to establish Book of Mormon geographical connections. [D.M.]

S.707 Stowell, Earl. "The Book of Mormon." In Stowell's The Magic of Mormonism, 203-11. Salt Lake City: Bookcraft, 1965. The Book of Mormon is the second witness of Christ offered by the "other sheep" (John 10:16). The miraculous events surrounding its coming forth, its purpose, statistics about the book, and its story are all included. [J.W.M.]

S.708 Stratford, Richard C. Truth. Chicago, IL: Northern States Mission, 1960?. Tract written by a mission president on various points of the Restoration, including information on the Book of Mormon, which "came forth into the world in a most miraculous manner." [D.M.]

S.709 Stroem, Ake V. "Red Indian Elements in Early Mormonism." Temenos 5 (1969): 120-68. Finds the Bible to be the main source for the Book of Mormon. Argues that the Mormon religion is visionary, similar to Islam in that it is based upon the visions of one prophet. "Mormonism differs from Christianity but is in accord with Red Indian religion." Theories of plagiarism concerning Ethan Smith's View of the Hebrews and Spaulding's manuscript are investigated, but found false. [J.W.M.]

S.710 Stubbart, J. M. "The Church in America Before Christ; Its Authority and Priesthood." SH 76 (6 November 1929): 1349-51. Writes that the Nephite church before Christ had all the ordinances and authority necessary for salvation. He continues that the Book of Mormon leaders of the church before Christ held the Melchizedek Priesthood and could not have possessed the Aaronic Priesthood for they were not direct descendants of Aaron. [B.D.]

S.711 Stubbs, Brian D. "Book of Mormon Language." In Encyclopedia of Mormonism, edited by Daniel H. Ludlow, 1:179-81. 5 vols. New York: Macmillan, 1992. The features of Book of Mormon language are typical of a translated work from ancient Near Eastern texts. Nephite historians claimed that they wrote in reformed Egyptian with a Jewish/Hebrew background after being isolated for their thousand-year history. The book's extensive use of Hebrew language patterns, name roots, names with Egyptian and Hebrew backgrounds, and Hebrew poetic types make it clear that Joseph Smith did not imitate the King James Bible to write the Book of Mormon. [N.K.Y.]

S.712 Stubbs, Brian D. "Elements of Hebrew in Uto-Aztecan: A Summary of the Data." Provo, UT: FARMS, 1988. Compares the Uto-Aztecan language with Hebrew. The similarities in the lexical, morphological, and root-specific semantics may point to a connection between the Aztec peoples and the Hebrews of the Old World. [J.W.M.] 
S.713 Stubbs, Brian D. "Hebrew and Uto-Aztecan: Possible Linguistic Connections." In Reexploring the Book of Mormon, edited by John W. Welch, 279-81. Salt Lake City: Deseret Book and FARMS, 1992. Compares Hebrew with the Uto-Aztecan tongues (which include N. Paiute, Shoshoni, Hopi, Papago, Tarahumara, Yaqui, and Nahuatl) with sound correspondence, vocabulary, semantic patterns, fossilized verb forms, and other morphological aspects of the languages. He presents 203 equivalences between Semitic and Uto-Aztecan reflecting many Hebrew roots but shows that developed languages indicate absorption of several languages into a new mixed language over time. [N.K.Y.]

S.714 Stucki, J. U. Some Religious Literature and Prophetic History of America. New York: Vantage Press, 1981. Reprints the title page, lists (in order) the books of the Book of Mormon, and gives the account of Moroni's visit that is also found in the Pearl of Great Price. Contains many excerpts from the book itself, with writings from Nephi, Isaiah, Jacob, King Benjamin, King Mosiah, Alma, Helaman, Captain Moroni, Pahoran, Mormon, and Moroni. [J.W.M.]

S.715 Student Involvement Materials for R 121 ITV Book of Mormon. Provo, UT: BYU Printing Service, 1970. A workbook for university students to be used in conjunction with instructional television (ITV). The workbook coincides with television lectures in which individuals present materials dealing with the first half of the Book of Mormon. [D.W.P.]

S.716 "Students Enjoy Book of Mormon Read-a-Thon." CN 44 (30 November 1974): 13. Seminary students in Eisenhower Junior High participated in an all night Book of Mormon read-a-thon. [M.R.]

S.717 "Study Aids Enhance Spanish Scriptures." CN 63 (11 December 1993): 5. A description of the study aids in the new Spanish edition of the Book of Mormon. Its translation process included an effort to preserve Hebraic elements found in the English edition. [S.H.]

S.718 Study Book of Mormon: First Nephi. Independence, MO: Zarahemla Research Foundation, 1988. Text of 1 Nephi is arranged according to parallelistic and poetic style. Includes notes and comparisons of different editions of the Book of Mormon. [D.W.P.]

S.719 "Study is Focus of Y. Jerusalem Center." CN 55 (28 July 1985): 4. The Book of Mormon was not translated into Hebrew for the purpose of missionary work in Israel, according to Richard P. Lindsay, public relations director of the LDS church. [J.W.M]

S.720 "'Study the Book of Mormon,' President Benson Urges Texans." Ensign 18 (July 1988): 80. A news report in which President Benson invites local Latter-day Saints to become scholars of the Book of Mormon. [L.D.]

S.721 Sturgess, Gary. "The Book of Mormon As Literature." Provo, UT: FARMS, 1982. Judging the Book of Mormon by the standards of ancient literature helps to understand its value. It is not a history. It testified that Jesus Christ is the Eternal God and that the people of Lehi are the chosen of Israel. Chiasmus is found in the Book of Mormon. There is also much typology found in it, reminiscent of Near Eastern literature. [J.W.M.]

S.722 Sukys, Renata W. "Abinadi's Teaching Style." Ensign 22 (April 1992): 28-29. Focuses on the teaching style and doctrines taught by Abinadi to the priests of Noah. [A.C.W.]

S.723 Sumsion, J. Bert. "The Book of Mormon: The Light of the Western Hemisphere." Liahona 14 (1916-1917): 517-19. Touches on the attempts of "learned men" to account for the origins of the American natives, but suggests 
that the answer to their origin is found in the Book of Mormon. [D.S.T.]

S.724 Sundberg, Charles J. The Mysterious Book of Mormon. In Which the Author Asks the Question, 'Does It Appear Truthful?' Sandy, UT: C. J. Sundberg, 1917. Published in Swedish as Kyrklig forvirring gentemot Gudomligheten i naturen... Tillikamed en kortfattad granskning af den foreigifnaurkunden 'Mormons Bok.' Pleasant Grove: Forfattarens Forlag, 1914. A polemical work against the Book of Mormon. The writer deplores the secrecy with which the Book of Mormon came about; the idea that Lehi, a devout Jew, would record the scriptures in the language of corrupt Egyptians; the tiny colony of Lehi building a temple like Solomon's; the Lamanite curse of dark skin; the Anthon denial; and other items pertaining to the Book of Mormon. [M.R.]

S.725 Sunderland, LaRoy. Mormonism Exposed And Refuted. New York: Piercy and Reed Printers, 1838. A careful reading of the Book of Mormon exposes its "meanness" of diction, error in language, contradictions, and gross blasphemies. Any intelligent thinking person could not be deceived by such hypocrisy. The Book of Mormon is directly opposed to the Bible. The Book of Mormon is a book of plagiarism, filled with fraud. Favors the Spaulding theory. [J.W.M.]

S.726 A Sure Foundation: Answers to Difficult Gospel Questions. Salt Lake City: Deseret Book, 1988. Consists of commonly asked questions on various issues and answers by Latter-day Saint writers, some of which deal with the Book of Mormon. See entries under individual authors. [D.M.]

S.727 Sutherland, George C. "Who were the Builders of the Lost City of Nevada?" IE 28 (April 1925): 529-34. An examination of archaeological discoveries unearthed in the Moapa Valley of southern Nevada. The author compares the demise of the culture that built the Lost City to Book of Mormon descriptions of similar cultural deteriorations. [D.S.T.]

S.728 Swartzell, William. Mormonism Exposed, Being a Journal of a Residence in Missouri from the 28th of May to the 20th of August, 1838. Pittsburgh: the author, 1840. Contains sensational lore concerning Joseph Smith and the plates and a section on "the Golden Bible" in the appendix. [D.M.]

S.729 Sweet, James Bradley. A Lecture on the Book of Mormon and the Latter-day Saints. London: Society for Promoting Christian Knowledge, 1857. According to Sweet, the Book of Mormon "is a heap of trash, decked out with texts of Holy Scripture, which scripture it also frequently contradicts." It also contains various anachronisms. [M.R.]

S.730 Sweet, William Warren. "Book of Mormon." In The American Churches, 70-71. New York: AbingdonCokesbury, 1947. The author sees the Book of Mormon as a frontier phenomenon that is couched in biblical style and language, discusses topics of only trivial interest, contains grammatical errors, mentions no cities, does not mention music, all of which indicates to the author that the book is of modern origin. [M.R.]

S.731 Sweet, William Warren. The Story of Religion in America. New York: Harper, 1930. Pages 397-401 contain a brief discussion of Mormonism and the Book of Mormon. Author notes that more recent critics of the Book of Mormon favor the environmentalist explanation over that of the Spaulding theory. [M.R.]

S.732 Swenson, C. A. Seek Ye the Old Path and Walk Therein. Independence, MO: True Church of Christ, n.d. The Book of Mormon is a pure book given in answer to prophecy. However, it is not being used properly and thus condemnation has come upon those who have failed in its proper use. The "revelations" in the Doctrine and 
Covenants do not agree with the Book of Mormon. Many beliefs of the Church of Jesus Christ of Latter-day Saints are contrary to the Book of Mormon. [J.W.M.]

S.733 Swinburne, James K. Beneath The Cloak of England's Respectability. London: Skeffington and Son, 1912. Polemic that denotes aspects of Mormon doctrine and practices a monstrous evil. The Book of Mormon is based on Manuscript Found, the Bible, and the birth story from the tales of the Monk Cyril and the Abbot Joachim. Martin Harris's wife was able to destroy this so-called "revelation of God." The book contains mistakes such as the words of Shakespeare, swords made of steel, and horses. [J.W.M.]

S.734 Swiss, Ralph E. "The Tame and Wild Olive Trees: An Allegory of Our Savior's Love." Ensign 18 (August 1988): 50-52. The chapters preceding the allegory of the olive tree in Jacob 5 provide important insights into why the allegory was included in the Book of Mormon. Zenos's allegory tells of the love of the Master (Jesus) of the vineyard, which love is portrayed as the Master cares for, grieves over, and rejoices in the condition of his vineyard. [J.W.M.]

S.735 Switzler, William F. "The Book of Mormon 1879." Ray County Mirror 6 (29 September 1979): 3-4, 6. Views Joseph Smith as a religious fanatic who used the unpublished work of Solomon Spaulding to create the Book of Mormon. [M.R.]

S.736 Sykes, Egerton. "The Origins of the Book of Mormon." New World Antiquity 24 (March-April 1977): 32-33. In response to a paper read by John Sorenson at the SEHA 23rd Symposium in 1973 the author notes that the LDS tradition in the Book of Mormon is the only perspective that has "reasonable historical background" that explains Mesoamerica and agrees with his own diffusion theory. [J.W.M.]

S.737 Symes, Joseph. "The Best Attested of All Bibles." Deseret Weekly 53 (25 July 1896): 180-81. Also in MS 58 (August 1896): 529-32. While not accepting the supernatural, Symes argues that the Book of Mormon is the best attested, or has the greatest evidences attached to it, of all Bibles (sacred books) in the world. Refers to Joseph Smith's account of the first vision and of the gold plates, as well as the testimonies of the Three and Eight Witnesses. [D.M.]

S.738 Szink, Terrence L. "A Just and a True Record." In Studies in Scripture: Alma 30 to Moroni, edited by Kent P. Jackson, 125-38. Salt Lake City: Deseret Book, 1988. 3 Nephi 1-5 is an example of the cycle of apostasy to righteousness and back to apostasy. It was a time of great peril as society ripened in iniquity and secret oaths held it together. Lachoneus taught that the only safety from this great threat was to obtain strength through personal righteousness. The Nephites were besieged by the Gadianton robbers. [J.W.M.]

S.739 Szink, Terrence L. "Nephi and the Exodus." In Rediscovering the Book of Mormon, edited by John L. Sorenson and Melvin J. Thorne, 38-51. Salt Lake City: Deseret Book and FARMS, 1991. When Nephi authored the account of his family's exodus from the land of Jerusalem, he wrote it in such a way as to pattern it after the exodus from Egypt by the children of Israel. [J.W.M.]

S.740 Szink, Terrence L. "An Oath of Allegiance in the Book of Mormon." In Warfare in the Book of Mormon, edited by Stephen D. Ricks and William J. Hamblin, 35-45. Salt Lake City: Deseret Book and FARMS, 1990. Oaths are important in Book of Mormon history. Moroni's use of the title of liberty is an excellent example. Such a ritual is described in the history of oaths taken by the Hittite soldiers and those in the Kingdom of Mari. In the Old Testament animals were cut in pieces to communicate "come to arms or you will be killed," and in fact, some were 
killed who did not come. The same threats were used in the Book of Mormon where the choice was support the war or die. [N.K.Y.]

S.741 Szink, Terrence L. Review of Isaiah Made Easier, by David J. Ridges. Review of Books on the Book of Mormon 4 (1992): 164-65. Book review.

S.742 Szink, Terrence L. Review of The Messiah in Ancient America, by Bruce W. Warren and Thomas Stuart Ferguson. Review of Books on the Book of Mormon 1 (1989): 132-34. Book review.

S.743 Szink, Terrence L. "To a Land of Promise." In Studies in Scripture: 1 Nephi to Alma 29, edited by Kent P. Jackson, 60-72. Salt Lake City: Deseret Book, 1987. Nephi recorded 1 Nephi 16-18 thirty years after the time it happened. Since Nephi was unable to write all of the experiences, what he did record must have been of great worth. He told of the Liahona, the broken bow incident and the death of Ishmael. A comparison of similarities and significant differences is made between the text of the Bible concerning the Exodus of the children of Israel and the Book of Mormon exodus of the colony of Lehi. [J.W.M.] 
T.

T.001 Takayama, Machiko. Poetic Language in 19th Century Mormonism: A Study of Semiotic Phenomenology in Communication and Culture. Ph.D. diss., Southern Illinois University, 1990. Making an analysis of the Book of Abraham and the Book of Mormon, this dissertation concludes that Joseph Smith was a poet, who produced his scriptures not through plagiarism nor the gift of God, but through a "poetic phenomenon" as defined by Julia Kristeva and Jacques Derrida. [J.W.M.]

T.002 Talbot, Leo P. "Bless Those Elders." Ensign 23 (March 1993): 65. The author's story of conversion to the LDS church as a result of reading the Book of Mormon given to him by missionaries. [S.H.]

T.003 Talbot, Leo B. "A Mailbox, Indecision, and Prayer." NE 11 (October 1981): 28-29. A Book of Mormon left in the author's mailbox lay unread for several years. Prayer seemed to be the way to find the truthfulness of the book and dispel fearful and doubtful feelings. Assurance and conversion followed a simple prayer. [J.W.M.]

T.004 Talbot, Louis T. Mormonism and the Bible. Findlay, OH: Dunham, 1957. A polemical tract against Mormonism that declares the Book of Mormon is "in utter disagreement with the Bible," and "Satanicallyinspired." Discusses the Spaulding theory, the Eight Witnesses, and Charles Anthon. [S.H.]

T.005 Talbot, Louis T. What's Wrong with Mormonism? Findlay, OH: Dunham, 1957. A polemical tract against Mormonism. The writer considers the Book of Mormon to be "the greatest religious hoax ever perpetrated in America." Among other things he discusses the Anthon incident, the testimonies of the Book of Mormon witnesses, the alleged lack of archaeological evidence, the Spaulding theory, and other items. [M.R.]

T.006 Talmage, James E. "The American Nation in Prophecy." DN Church Section (26 July 1930): 6. Says that the Book of Mormon prophesied of the American nation, the United States-the struggle for independence, the establishment of democracy, and that no king would rule over the land. [M.D.P.]

T.007 Talmage, James E. "The American Nation in Prophecy." In Sunday Night Talks, 298-305. Salt Lake City: Church of Jesus Christ of Latter-day Saints, 1931. A radio address commenting on how the Book of Mormon foresaw the founding events of the United States. Presentiments of the U.S. government were indicated in the book of Mosiah. [D.M.]

T.008 Talmage, James E. "The Ancient Apostles and the Nephite Twelve." DN Church Section (27 August 1932): 1, 2. Compares the Twelve Apostles who were with Christ during his ministry with the Nephite twelve that Christ ordained in the Americas, and discusses their relationship, positions, and responsibilities. [M.D.P.]

T.009 Talmage, James E. "The Bible and Other Scriptures." MS 87 (15 January 1925): 37-39. The LDS church accepts both the Bible and the Book of Mormon to be the word of God. The Book of Mormon, however, has received a more correct translation than has the Bible. [D.W.P.]

T.010 Talmage, James E. The Book of Mormon: An Account of Its Origin, with Evidences of Its Genuineness and Authenticity. Salt Lake City: n.p., 1899. The material in this pamphlet was later published as Lectures XIV and XV in The Articles of Faith: A Series of Lectures on the Principal Doctrines of the LDS Church, 261-80. Salt Lake City: Deseret News Press, 1899. Later this was incorporated into A Study of The Articles of Faith, 255-95. Salt Lake City: Church 
of Jesus Christ of Latter-day Saints, 1924. The Book of Mormon came forth by the hand of Moroni to Joseph Smith. The Lord's purpose in preserving the small plates of Nephi was divinely inspired to replace the 116 lost pages of manuscript. Bears testimony of its genuineness including the testimonies of the witnesses. The Book of Mormon is in agreement with the Bible. Archaeologists and ethnologists corroborate the teachings in the book. The ultimate test, however, is the witness of the Spirit to each reader according to the reader's desire and willingness to accept the truth. [J.W.M.]

T.011 Talmage, James E. "The Book of Mormon: Scriptures of the American Continent: Origin of the American Indians." MS 79 (22 February 1917): 113-15. Brief summary of Book of Mormon story, and Joseph Smith's translation. Modern revelation is not improbable. The Book of Mormon is "parallel volume" to the Bible, not a substitute; the two are not contradictory. [A.C.W.]

T.012 Talmage, James E. "The Destiny of the American Nation Declared by Prophecy." MS 79 (25 January 1917): 49-53. A paper that argues that "the commanding position of the United States among the world powers, and the prominent place of the American nation is to maintain as the exponent and champion of human rights were foreseen and predicted centuries before the beginning of the Christian era" by prophets of the Book of Mormon. [D.W.P.]

T.013 Talmage, James E. "How the 'Mormons' Got Their Name." MS 78 (5 October 1916): 625-626. The term "Mormon," a nickname given to members of the Church of Jesus Christ of Latter-day Saints, was derived from the scripture called the Book of Mormon. Members of the Church, however, are quick to point out that the proper name of their Church is the Church of Jesus Christ of Latter-day Saints. [D.W.P.]

T.014 Talmage, James E. "How We Got the Book of Mormon." Instructor 72 (December 1937): 525-26. Under the direction of Moroni, Joseph Smith obtained the plates and translated them according to the gift and power of God. He was an unschooled boy and an instrument in the hands of the Lord who confounded the mighty with his work. [J.W.M.]

T.015 Talmage, James E. "Inspiration the Cause of Popular Opposition." IE 26 (September 1923): 1032. Some reject the Book of Mormon on account of its supernatural origin. Joseph Smith claimed that an angel revealed to him where to find the plates and that God inspired him in translating them. However, the Book of Mormon is harmonious with the Bible, and the story of its origin should not surprise anyone. [B.D.]

T.016 Talmage, James E. "Is the Bible Sufficient?" MS 98 (16 September 1937): 597. Calls attention to the many difficulties that occurred during the translation and publication of the Bible. Although many people reject the Book of Mormon, it is yet the word of God and was translated correctly by a prophet of God. [J.W.M.]

T.017 Talmage, James E. "Isaiah and the Book of Mormon." CR (April 1929): 44-49. Bears witness of the truth of the Book of Mormon, emphasizes that it is the best literature for missionary work, and recommends that we pursue all possible investigation, comparison, research, and scholarship (even for Book of Mormon geography) in Book of Mormon studies. Warns scholars to let the Book of Mormon speak for itself. The Book of Mormon clearly confirms a unity of authorship in Isaiah. [R.C.D.]

T.018 Talmage, James E. "Jesus Is the Christ." IE 66 (December 1963): 1051, 1112. Reprint from MS 80 (1918): 705. Unites the Bible and the Book of Mormon in bearing witness that Jesus is the Christ. An examination of the two texts reveals sixteen important facts concerning Christ's mission, including his premortal and antemortal 
Godhood, his foreordination as the Redeemer, and the predictions of his birth to Mary. The testimony of two witnesses-the Bible and the Book of Mormon-establishes the truth. [J.W.M.]

T.019 Talmage, James E. Journal Abstracts and Letters 1876-1933. N.p.: n.p., n.d. A collection of papers from letters and journals kept by Talmage. Two letters report Talmage's work on revision of the Book of Mormon, suggesting to the First Presidency a list of minor revisions. [J.W.M.]

T.020 Talmage, James E. "Lehi." MS 88 (3 June 1926): 347. Shows the connection between the name "Lehi" and the Lehigh Valley, Lehigh River, and Lehigh Mountain of Pennsylvania. [D.W.P.]

T.021 Talmage, James E. "A Messenger from the Presence of God." MS 80 (19 September 1918): 593-95. A testimony of the Book of Mormon and explanation of how it came into existence through the appearance of an angel. [B.D.]

T.022 Talmage, James E. "The Michigan Relics: A Story of Forgery and Deception." Deseret Museum Bulletin 2 (September 1911): 1-30. Talmage exposes the fraudulent nature of relics found in Michigan claimed to be of ancient origin. He warns collectors of artifacts and Church members eager for external evidences of the Book of Mormon not to be deceived. Talmage explains his investigation, details eight reasons for his conclusions, and cites other recognized scholars who have labeled the "Michigan relics" as spurious. [L.M.]

T.023 Talmage, James E. "The 'Michigan Relics.' "IE 14 (October 1911): 1049-76. Reprint of article for Deseret Museum Bulletin, September 1911, with the addition of a letter from Miriam Brooks substantiating Talmage's observations. [J.W.M.]

T.024 Talmage, James E. "Ministry of the Resurrected Christ on the Western Continent." In Talmage's Jesus the Christ: A Study of the Messiah and His Mission According to Holy Scriptures Both Ancient and Modern, 721-44. Salt Lake City: Deseret Book, 1982. A rehearsal of the Book of Mormon record of Samuel the Lamanite's prophecy, the signs of Christ's birth, Christ's ministry in America, the destruction at his death, and subsequent visits and ministration. [J.W.M.]

T.025 Talmage, James E. "A New Witness for Christ." Liahona 21 (June 1924): 494-95. Although the Book of Mormon is an invaluable history, its priceless character lies in its role as a second testimony of Jesus Christ. [L.M.]

T.026 Talmage, James E. "A New Witness of the Christ." MS 80 (October 1918): 689-91. The Book of Mormon would be nothing more than an "important contribution to the common find of human knowledge" if all it were no more than a history of the ancient Americans, but it is a new witness for Jesus Christ's mission and ministry. [B.D.]

T.027 Talmage, James E. "A Night of Light." MS 86 (18 December 1924): 801-4. For centuries members of the Nephite and Lamanite communities looked forward to the time when Jesus would be born into the world. Such an occasion would be "a night of light" unto the world. [D.W.P.]

T.028 Talmage, James E. "Olden Scriptures and New." DN Church Section (19 July 1930): 5. Both the Bible and the Book of Mormon testify of Christ. Author tells of the importance and significance of the two. [M.D.P.]

T.029 Talmage, James E. "Olden Scriptures and New." In Sunday Night Talks, 288-97. Salt Lake City: Church of Jesus Christ of Latter-day Saints, 1931. Two books of scripture, from both sides of the world, bear witness of Christ. The Book of Mormon is an "independent witness of the Christ." [D.M.] 
T.030 Talmage, James E. "One Hundred Years Ago Today." MS 89 (22 September 1927): 600-603. Recalls the coming forth of the Book of Mormon through Moroni, the Nephite prophet who appeared as an angel to Joseph Smith. Emphasizes that the Book of Mormon "stands as an independent witness of Jesus the Christ as the Son of the Eternal Father, and as the Redeemer." [D.W.P.]

T.031 Talmage, James E. "Priesthood-In Ancient America." DN Church Section (12 August 1933): 4, 7. The Nephites continued Lehi's priesthood, especially the Aaronic priesthood connected with the law of Moses. The Book of Mormon is a witness of God that gives the account of God's dealing with man through his holy priesthood. In time, both the Aaronic and Melchizedek Priesthoods were lost on both hemispheres. [J.W.M.]

T.032 Talmage, James E. "Scriptures of the American Continent." DN Church Section (25 February 1933): 6. Presents the Book of Mormon as a scripture that originated on the American continent and gives a summary of its contents. [D.W.P.]

T.033 Talmage, James E. "Scriptures of the American Continent." Liahona 14 (1917): 611-12. Summarizes the Book of Mormon and the story of its coming forth, and explains that much of the opposition to the book was due to Joseph's claim that he had been visited by an angel and received divine help in its translation. This claim was an affront to the dogma that miracles had ceased. [L.M.]

T.034 Talmage, James E. "Scriptures of the American Continent." MS 82 (29 July 1920): 491-93. The Book of Mormon is a record written on gold plates of the ancient people of the New World, taken from the Hill Cumorah and translated from Reformed Egyptian and published in 1830. It includes the history of Lehi's people from 600 B.C. to A.D. 420. Joseph Smith claimed it was done through the power of God and revelation, and that brought much persecution. The idea of supernatural intervention opposed all the theological theories of his day. The Book of Mormon in no way replaces the Bible nor contradicts it. [J.W.M.]

T.035 Talmage, James E. "Sheep of Another Fold." MS 80 (10 October 1918): 641-43. Talmage describes the eloquence and beauty of the parable of the shepherd in John 10. No one understood John 10:16 until the Book of Mormon taught that the other sheep were the scattered remnants of the house of Israel, some of whom were the Nephites and Lamanites. [B.D.]

T.036 Talmage, James E. "The Stick of Joseph." MS 88 (June 1926): 376-78. The Book of Mormon is the stick of Joseph identified in Ezekiel 37:15-20. Lehi is a descendant of Joseph through Manasseh and Ishmael is the descendant of Ephraim, thus completing the house of Joseph. [J.W.M.]

T.037 Talmage, James E. The Story and the Philosophy of 'Mormonism.' Salt Lake City: Deseret News Press, 1920. Gives a narrative of the coming forth of the Book of Mormon, Moroni's visit and instructions to Joseph Smith. The Book of Mormon does not take the place of the Bible. The Bible foretold of the coming forth of the Book of Mormon. The Spaulding theory regarding the origin of the Book of Mormon has been disproved. [J.W.M.]

T.038 Talmage, James E. "The Story of 'Mormonism.' " In Talmage's The Story of Mormonism, 5-26. Salt Lake City: Deseret Book, 1930. Gives the story of Joseph Smith, the first vision, and the coming forth of the Book of Mormon. The Book of Mormon is a companion to the Bible, not a replacement. Latter-day saints believe that the Bible foretold of the Book of Mormon. The Spaulding theory has been disproved. [J.W.M.]

T.039 Talmage, James E. "A Testimony from the Dust." MS 87 (5 February 1925): 92-93. The coming forth of the Book of Mormon fulfills the prophecy of Isaiah that a testimony or speech would come forth "out of the dust" 
(Isaiah 29:4). [D.W.P.]

T.040 Talmage, James E. "Unique Character of Contents of the Book of Mormon." IE 26 (September 1923): 1015-18. While the historical and ethnological information in the Book of Mormon is invaluable, the theological themes are far more important. The theological aspects in the Book of Mormon harmonize with those of the Bible. [D.M.]

T.041 Talmage, James E. Untitled talk. CR (October 1917): 138-44. Doctrines of the Bible are clarified by the Book of Mormon such as heaven and hell, baptism of infants, and the plan of salvation. [J.W.M.]

T.042 Talmage, James E. The Vitality of Mormonism: Brief Essays on Distinctive Doctrines of the Church of Jesus Christ of Latter-day Saints. Salt Lake City: Deseret Book, 1948. Chapters 33-41, dedicated to the Book of Mormon, set forth the importance of the Book of Mormon in relation to the Bible, the account of Moroni's visit to deliver the plates, the story of the Book of Mormon, the witnesses of the book, Ezekiel's prophecy of the sticks of Joseph and Judah, the Book of Mormon as a witness for Christ, Jesus' organization of the church in the Americas with all of the ordinances essential for salvation, Christ's visit to his "other sheep" in America, and related items. [J.W.M.]

T.043 Talmage, James E. "A Voice from the Dust." DN Church Section (12 July 1930): 5. A brief history of the restoration of the Church and of the translation, the contents, and the importance of the Book of Mormon. [M.D.P.]"

T.044 Talmage, James E. "A Voice from the Dust." In Sunday Night Talks, 278-87. Salt Lake City: Church of Jesus Christ of Latter-day Saints, 1931. Cites Isaiah 29 and Ezekiel 37 as prophecies about the Book of Mormon. Gives an overview of the Book of Mormon and discusses its translation. [D.M.]

T.045 Talmage, James E. Voices of the Dead, a Testimony from the Dust. N.p., n.d. Internal evidence testifies that the Book of Mormon fulfills both Old Testament prophecies as well as prophecies that are found within the pages of the Book of Mormon itself. [J.W.M.]

T.046 Talmage, James E. "What is Mormonism?" MS 87 (22 January 1925): 58-64. Presents an overview of the contents of the Book of Mormon, emphasizing the fact that Jesus Christ is the central character of the book, and that the LDS church is clearly distinguished from other Christian sects by the manner in which it believes in modern revelation. The Book of Mormon is an example of such revelation. [D.W.P.]

T.047 Talmage, James E. "When Christ Stood on American Soil." DN Church Section (11 March 1933): 6. According to prophecy, Jesus Christ visited many persons on the American continent shortly after his resurrection. He established his Church and taught the people his gospel. [D.W.P.]

T.048 Talmage, James E. "Whence Came the American Indians?" MS 87 (29 January 1925): 74-76. Briefly presents the history of Lehi and his family, including the separation between the Nephites and Lamanites. Descendants of the Lamanites became the American Indians. [D.W.P.]

T.049 Tanner, Alva A. Book of Mormon Plagiarism. Oakley, ID: n.p., 1924. Tanner lists twenty passages from the Book of Mormon that were plagiarized from the Bible. Book of Mormon names do not match names of any native American cities or peoples. Book of Mormon prophets could not have known of Christ before his birth and Joseph Smith was not born from Lehi's genealogy as the Book of Mormon says he was. [B.D.] 
T.050 Tanner, Alva A. The Book of Mormon Tested: Hieroglyphs on Marble In Central America Testify Against It. Oakley, ID: by the author, April 1916. Argues against the claims made by the Book of Mormon and its authenticity. The Book of Mormon characters on the transcript taken to Professor Anthon hold no resemblance to those found in ancient American hieroglyphs preserved in marble. [J.W.M.]

T.051 Tanner, Alva A. Facts about the Book of Mormon. Oakley, ID: by the author, 1918. This pamphlet, produced to replace A Key to the Book of Mormon, concludes there could be no divinity to the Book of Mormon since "the Jews never kept any records upon plates of brass." The author calls upon science, the Bible, and hieroglyphs to prove the Book of Mormon false. Presents evidence that the characters of the transcript presented to Anthon are not genuine. [J.W.M.]

T.052 Tanner, Alva A. A Key to the Book of Mormon. Oakley, ID: by the author, 1916. Offers a challenge to all the world to examine the Book of Mormon closely to see if it will stand up under "every test" and analysis. Names used for cities and men never existed on this continent. Book of Mormon characters presented to Anthon are compared with Mayan hieroglyphs and there is no resemblance. Parts of the Book of Mormon have been borrowed from Shakespeare and the Bible. [J.W.M.]

T.053 Tanner, Amasa. Humbug Gospel. N.p., n.d. A polemical pamphlet that offers evidence that Joseph Smith did not translate the Book of Mormon from an ancient text by arguing that Mayan hieroglyphics are not similar to the characters of the Anthon transcript. [J.W.M.]

T.054 Tanner, David S. Heaven and Earth: Past, Present and Future. A Correlation of LDS Scripture and Other Writings. Volume II. San Jose, CA: Davis S. Tanner, 1976. Covers the period of time from Solomon to Christ. Shows a comparative chronologically of the Bible, the Book of Mormon, the Doctrine and Covenants and the Pearl of Great Price, as well as early Church writings and writings of Joseph Fielding Smith. [J.W.M.]

T.055 Tanner, Jerald. "A Cover-Up Revealed: Joseph Smith's Attempt to Save the Book of Mormon." Salt Lake City Messenger 74 (February 1990): 1-13. Article advertising the author's book Covering Up The Black Hole in the Book of Mormon. Suggests that there is too much emphasis on Christ in the "Old Testament portion" of the Book of Mormon, gives examples of how Joseph Smith plagiarized from the Bible, and claims that a lack of Jewish festivals in the Book of Mormon proves its Protestant origin. [A.C.W.]

T.056 Tanner, Jerald. An Examination of “Who Really Wrote the Book of Mormon?” N.p., August 1978. Tanner refutes the theory in Who Really Wrote the Book of Mormon? by Cowdery, et al., and other works, that the Book of Mormon is related to the Spaulding manuscript. [B.D.]

T.057 Tanner, Jerald. The Facts about the Book of Mormon. Salt Lake City: Vanity, 1962. Polemic challenging classic LDS Bible prooftexts prophesying of the Book of Mormon, attempting to diminish the impact of the testimonies of the Three Witnesses, discussing modes of translation, and citing attitudes of the Smithsonian Institute. [D.M.]

T.058 Tanner, Jerald. Tracking the White Salamander: The Story of Mark Hofmann, Murder and Forged Mormon Documents. Salt Lake City: Utah Lighthouse Ministry, 1986. The author finds that the Martin Harris 1873 "White Salamander Letter," "Joseph Smith III Blessing," "Lucy Mack Smith's 1829 Letter," and "Joseph Smith's 1825 letter" were forgeries. Reports the investigation of Mark Hofmann in chronological order. Contains interviews and newspaper reports concerning the investigation. [J.W.M.] 
T.059 Tanner, Jerald, and Sandra Tanner. 3,913 Changes in the Book of Mormon. Salt Lake City: Modern Microfilm, 1969. Indicates the textual changes made in the Book of Mormon since the 1830 edition. [M.R.]

T.060 Tanner, Jerald, and Sandra Tanner. Archaeology and the Book of Mormon. Salt Lake City: Modern Microfilm, 1969. Polemical treatise challenging claims that some LDS members make regarding American archaeological finds and their implications for the Book of Mormon. Includes material on the Bat Creek Cave, the Kinderhook plates, and Stela 5. [D.M.]

T.061 Tanner, Jerald, and Sandra Tanner. "B. H. Roberts Manuscript Revealed." Salt Lake City: Modern Microfilm, 1980. A reprint of much of B. H. Roberts's informal and unpublished studies, A Book of Mormon Study, and Book of Mormon Difficulties. [M.R.]

T.062 Tanner, Jerald, and Sandra Tanner. Book of Mormon 'Caractors' Found. Salt Lake City: Modern Microfilm, 1980. A polemical booklet attempting to show how the 1980 discovery of the Anthon Transcript casts doubt upon the truthfulness of the Book of Mormon. (Editor's note: this transcript has since been shown to be a forgery.) [M.R.]

T.063 Tanner, Jerald, and Sandra Tanner. The Case Against Mormonism. 3 vols. Salt Lake City: Utah Lighthouse Ministry, 1967, 1968, 1971. These volumes repeat much of the material found in the Tanners' Mormonism: Shadow or Reality. Volume 2 deals entirely with the Book of Mormon. Over 400 parallels between verses in the New Testament and the Book of Mormon are given. Contains a discussion of theories regarding the Hebrew origin of the American Indians that were common in the days of Joseph Smith. The authors believe that the Book of Mormon is a product of Joseph Smith's environment. [M.R.]

T.064 Tanner, Jerald, and Sandra Tanner. The Changing World of Mormonism. Chicago, IL: Moody Bible Institute, 1980. Presents research that the authors claim shows Mormonism to be false. The Book of Mormon is anachronistic; it draws upon Ethan Smith's View of the Hebrews. The testimony of the witnesses cannot be trusted, archaeology does not support the Book of Mormon, and the Anthon transcript harms the case for the book. [B.D.]

T.065 Tanner, Jerald, and Sandra Tanner. Covering Up the Black Hole in the Book of Mormon. Salt Lake City: Utah Lighthouse Ministry, 1990. The authors provide "devastating" evidence that the Book of Mormon is a product of the 19th century. Upon losing the 116 pages of the Book of Mormon, Joseph Smith generalized information because he could not remember all the details of his original 116 pages. In order to further fill in this gap Smith plagiarized from the Bible in order to save his work. The presence of chiasmus in the Book of Mormon is unimpressive because similar structures can be found in Joseph Smith's writings. This work is reviewed in N.145, T.335, and in R.468. [M.R.]

T.066 Tanner, Jerald, and Sandra Tanner. A Critical Look: A Study of the Overstreet "Confession" and the Cowdery "Defense." Salt Lake City: Modern Microfilm, 1967. An analysis of two purported denials by Oliver Cowdery of his testimony regarding Mormonism and the Book of Mormon. The writer concludes that the two documents are probably spurious forgeries. [M.R.]

T.067 Tanner, Jerald, and Sandra Tanner. Did Spaulding Write the Book of Mormon? Salt Lake City: Utah Lighthouse Ministry, 1977. A critical appraisal of the research presented by Davis, Cowdery, and Scales (Who Really Wrote the Book of Mormon, 1977) regarding the possible involvement of Solomon Spaulding in the production of the Book of Mormon. The authors conclude that Spaulding had no part in producing the book. Contains a photomechanical reprint of Solomon Spaulding's Manuscript Story, a reprint of Chapter 5 of Mormonism: Shadow or Reality, 1972 
edition, and the B. H. Roberts list of 18 parallels between Ethan Smith's View of the Hebrews and the Book of Mormon. [M.R.]

T.068 Tanner, Jerald, and Sandra Tanner. Examination of B. H. Roberts' Secret Manuscript. Salt Lake City: Utah Lighthouse Ministry, 1979. Examines B. H. Roberts's unpublished manuscript, "A Book of Mormon Study," and concludes that Mr. Roberts believed that the Book of Mormon was of human origins, and had been influenced by Priest's Wonders of Nature and Providence and Ethan Smith's View of the Hebrews. Shows photographs of the unpublished manuscript. [J.W.M.]

T.069 Tanner, Jerald, and Sandra Tanner. "Ferguson's Rejection of the Book of Mormon Verified." Salt Lake City Messenger 76 (November 1990): 6-10. Advertisement for the authors' work Ferguson's Manuscript Unveiled, which deals with Thomas Ferguson's loss of faith in the Book of Mormon as an ancient book. [A.C.W.]

T.070 Tanner, Jerald, and Sandra Tanner. Lucy Smith's 1829 Letter. Salt Lake City: Modern Microfilm, 8 September 1982. In an attempt to discredit the idea that Joseph Smith could not have written the Book of Mormon himself, this article features a reproduction of a letter supposedly written by Lucy Smith, the mother of Joseph Smith. The letter has since been proven to be a Hofmann forgery. [J.W.M.]

T.071 Tanner, Jerald, and Sandra Tanner. Major Problems of Mormonism. Salt Lake City: Utah Lighthouse Ministry, 1989. A condensed version of Mormonism: Shadow or Reality? [M.R.]

T.072 Tanner, Jerald, and Sandra Tanner. Mormon Scriptures and the Bible. Salt Lake City: Utah Lighthouse Ministry, 1970. The Book of Mormon was influenced by Thomas Paine's The Age of Reason. The LDS church and its Book of Mormon undermine the Bible, and in doing so will destroy the very foundation upon which the Book of Mormon rests. Evidence is presented that shows that modern archaeological finds such as the Dead Sea Scrolls prove the Book of Mormon false in its attack on the Bible. [J.W.M.]

T.073 Tanner, Jerald, and Sandra Tanner. Mormonism, Magic, and Masonry. Salt Lake City: Utah Lighthouse Ministry, 1983. The "familiar spirit" of which the Book of Mormon speaks is used in the Bible to refer to evil spirits. The authors discuss the Masonic Enoch legend of a gold plate and draw comparisons with Mormon accounts. [M.R.]

T.074 Tanner, Jerald, and Sandra Tanner. Mormonism: Shadow or Reality? 4th ed. Salt Lake City: Utah Lighthouse Ministry, 1987. An exposé of Mormonism. Asserts that the witnesses of the Book of Mormon were fickle and unreliable. Discusses various environmental factors that influenced Joseph Smith in the production of the Book of Mormon such as religious revivals, Protestant teachings of the time, anti-masonry, the Bible, theories regarding the Hebrew origin of the American Indian and Shakespeare's writings. Various anachronisms are also discussed. Contains a criticism of stylometry and the Book of Mormon. Discusses Nephite coins, the Anthon incident, the Bat Creek inscription, Kinderhook plates, the Newark Stones, Izapa Stela 5, Book of Mormon geography, and others. This work is reviewed in R.469. [M.R.]

T.075 Tanner, Jerald, and Sandra Tanner. Serious Charges against the Tanners. Salt Lake City: Utah Lighthouse Ministry, 1991. In a rebuttal to charges that they are "demonized agents of the Mormon Church," the authors give a critical review of Loftes Tryk's book The Best Kept Secrets of the Book of Mormon and discredit allegations made by Tryk that the Book of Mormon purposefully advocates the worship of Satan. [M.R.] 
T.076 Tanner, Jerald, and Sandra Tanner, eds. Roberts' Manuscripts Revealed. Salt Lake City: Modern Microfilm, 1980. A duplication of B. H. Roberts's personal "A Book of Mormon Study" (two copies) and "A Parallel," which compared the Book of Mormon with Ethan Smith's View of the Hebrews, using double columns. [D.M.]

T.077 Tanner, John S. "Jacob and His Descendants As Authors." In Rediscovering The Book of Mormon, edited by John L. Sorenson and Melvin J. Thorne, 52-66. Salt Lake City: Deseret Book and FARMS, 1991. The writings of Jacob and his descendants display a "stylistic diversity." The style change from the small plates of Nephi to Mormon's abridgment of the large plates of Nephi is rough, providing evidence of the splice of one record into another. [J.W.M.]

T.078 Tanner, John S. "Jacob, Son of Lehi." In Encyclopedia of Mormonism, edited by Daniel H. Ludlow. 2:713-14. 5 vols. New York: Macmillan, 1992. Jacob, son of Lehi, was born in the wilderness and suffered tribulation much of his life. He was the successor to Nephi as the spiritual leader of the Nephites. His writings teach of the coming of Christ and the scattering and subsequent gathering of Israel. [B.D.]

T.079 Tanner, John S. "Literary Reflections on Jacob and His Descendants." In The Book of Mormon: Jacob through Words of Mormon, To Learn with Joy, edited by Monte S. Nyman and Charles D. Tate Jr., 251-70. Provo, UT: Brigham Young University Religious Studies Center, 1990. The portion of the small plates of Nephi recorded by Jacob and his descendants are first person documents that best reveal the man through the style of writing that he uses. Jacob was a sensitive man who endured great hardship in his youth. He was visited by Christ. His words are pleading and mournful, reflecting his quiet nature. [J.W.M.]

T.080 Tanner, Martin. Review of "Anti-Universalist Rhetoric in the Book of Mormon," by Dan Vogel, from New Approaches to the Book of Mormon, edited by Brent Lee Metcalfe, 21-52. Review of Books on the Book of Mormon 6/1 (1994): 420-33. Book review.

T.081 Tanner, Morgan W. "Book of Ether." In Encyclopedia of Mormonism, edited by Daniel H. Ludlow, 1:156-57. 5 vols. New York: Macmillan, 1992. The book of Ether is an edited version of the twenty-four gold plates found by Limhi and translated by Mosiah. Its themes include secret combinations, the importance of following prophets, and wickedness brings destruction. It teaches of Christ's premortal spirit body, that Three Witnesses would testify of the Book of Mormon, and that a New Jerusalem will be built in the western hemisphere. [B.D]

T.082 Tanner, Morgan W. "Jaredites." In Encyclopedia of Mormonism, edited by Daniel H. Ludlow, 2:717-20. 5 vols. New York: Macmillan, 1992. The Jaredites, named after their leader Jared, left the Old World at the time of the Tower of Babel, about the third millennium B.C. Their record appears in the book of Ether in the Book of Mormon, and is comparable to Near Eastern epics. They were annihilated sometime between 600 and 300 B.C. [J.W.M.]

T.083 Tanner, N. Eldon. "Book of Mormon and America's History and Destiny." CR (April 1976): 73-78. All the major events that shaped the destiny of the Americas have been recorded or prophesied in the Book of Mormon. Includes the historical events related to the Jaredites, Lehi, Columbus, the Pilgrims, the United States, the U.S. Constitution, the Restoration, and America's future. [R.C.D.]

T.084 Tanner, N. Eldon. "Christ in America." Ensign 5 (May 1975): 34-36; see also CR 145 (April 1975): 51-55. Retells the story of Christ's visit to America after his resurrection, with mention of Old Testament prophecies of the Book of Mormon. [B.T.] 
T.085 Tanner, N. Eldon. "I Will Go And Do The Things..." IE 66 (December 1963): 1060-61. In response to his calling as a member of the First Presidency, Tanner quotes Nephi who said "I will go and do the things which the Lord hath commanded" (1 Nephi 3:7). [J.W.M]

T.086 Tanner, N. Eldon. "The Inevitable Choice." Ensign 7 (September 1977): 2-5. The Book of Mormon is a study of the nature of man. The extremes of both good and bad behavior are exhibited as well as those who fit into the gray area. The inevitable choice must be made-righteousness and great blessings or wickedness and destruction. [J.W.M.]

T.087 Tanner, N. Eldon. "Savior's Teachings Needed Today." CR (April 1975): 51-55. An address having four main points: (1) the great countries of South America are part of the Book of Mormon lands; (2) the Bible predicts the coming forth of the Book of Mormon in several places, including Ezekiel 37:16-17; John 10:16; Revelation 14:6-7; (3) 3 Nephi, known as the "fifth gospel," provides greater detailed information about Christ's ministry than do the four gospels in the New Testament; (4) Christ ministered to the Nephites in the New World. [R.C.D.]

T.088 Tanner, N. Eldon. "The Two Great Commandments." IE 68 (June 1965): 527-28. Also in CR (April 1965): 93-96. Tells of his challenge to the Saints to read the Book of Mormon, and gives examples of people whose lives benefited from it. Keeping the two great commandments, first to love God with all your whole soul and the second to love your neighbor, begins within the walls of your own home. [J.W.M.]

T.089 Tanner, Sandra. Do You Realize? North Hollywood, CA: n.p., n.d. Passages from the Book of Mormon are juxtaposed with those found in various sources including the Journal of Discourses and the Doctrine and Covenants with the intent of showing that the doctrines of the Book of Mormon contradict other Church teachings on the same subject. [B.D.]

T.090 Tanner, Sandra. Does the Book of Mormon Agree with the Bible? Salt Lake City: n.p., 196?. Presents parallel columns showing similarities between New Testament scriptures and counterpart scriptures in the Book of Mormon. The two scriptures agree because the Book of Mormon plagiarized the Bible. [D.M.]

T.091 Tary, O. J. "The Book of Mormon." SH 83 (28 November 1936): 1485-86. A testimonial about the truthfulness of the Book of Mormon. The author makes statements defending the Book of Mormon against charges that it is a replacement for the Bible and that it was plagiarized from the Spaulding manuscript. [A.T.]

T.092 Tate, Charles D. "Book of Mormon References to Deity." Ensign 22 (April 1992): 63. "In keeping with its declared purpose as a witness of Jesus Christ, the Book of Mormon contains 476 references to Him by name in its 531 pages," almost one reference per page. Only 30 pages contain no specific name reference to deity, excluding pronouns. [A.C.W.]

T.093 Tate, George S. "The Typology of the Exodus Pattern in the Book of Mormon." In Literature of Belief: Sacred Scriptures, edited by N. Lambert, 245-62. Provo, UT: Brigham Young University Religious Study Center, 1981. A condensed version of the same article is found in "Nephi and the Exodus." Ensign 17 (April 1987): 64-65. By establishing through literary analysis that the biblical Exodus theme finds typological fulfillment in historical events and occurrences of the Book of Mormon, Tate demonstrates that "typological unity" exists in the Book of Mormon. This theme plays a prominent role, and finds actual and figural usage in the Book of Mormon. It is a recurring theme built upon by many inspired writers - Nephi, Jacob, and Alma the Younger. [D.W.P.] 
T.094 Taves, Ernest H. Trouble Enough: Joseph Smith and the Book of Mormon. Buffalo: Prometheus, 1984. A polemical work against Joseph Smith and the Book of Mormon. Among other things, the author attempts to use stylometry to establish the single authorship of the Book of Mormon by Joseph Smith. This work is reviewed in G.100, L.086, W.156, and in H.272. [M.R.]

T.095 Taylder, T. W. P. The Mormon's Own Book; or, Mormonism Tried by Its Own Standards, Reason, and Scripture. London: Partridge, 1857. A polemical work against Mormon scripture. Author accepts the Spaulding theory and asserts that the Book of Mormon plagiarizes the Bible, contains ungrammatical expressions and absurd anachronisms, contradicts the Bible, and contains many evidences of being a "vile imposture." [M.R.]

T.096 Taylor, Alma O. "The Book of Mormon's Emphasis on America." CN 4 (3 March 1934): 3, 5. Text of an address dealing with the Book of Mormon's history and prophecies about America. Nephi's vision of the land of promise and Moroni's warning to the Gentiles are lessons for us today. [A.C.W.]

T.097 Taylor, Alma O. “Independent Faith.” Young Woman's Journal 23 (January 1912): 9-11. Relates his conversion relative to the Book of Mormon and explains how he applied the instructions to Oliver Cowdery to himself (D\&C 8-9) when he was commissioned to translate the Book of Mormon into Japanese. [D.M.]

T.098 Taylor, Arthur B. "The Angel's Message; the Everlasting Gospel." SH 85 (10 September 1938): 1167-69. Contains a rehearsal of the great apostasy and events related to the Restoration, including the coming forth of the Book of Mormon from the hands of the angel Moroni. The book contains the message of the everlasting gospel. [J.W.M.]

T.099 Taylor, Bessie. "Putting into Practical Use the Message of the Book of Mormon." SH 92 (10 February 1945): 126. The Book of Mormon, Doctrine and Covenants, and Bible are companion scriptures that fill many of the needs of humanity. The Doctrine and Covenants gives instructions on a social level and the Book of Mormon prepares the individual to meet the challenges of the present day, bears witness of Christ, and warns of pride and arrogance. [J.W.M.]

T.100 Taylor, Debbie. Lehi Obeys God's Command. Independence, MO: Foundation for Research on Ancient America, 1987. An illustrated storybook about Lehi, paraphrased and told in first person from the perspective of Nephi. [D.M.]"

T.101 Taylor, Hal L. "A Man May Know For Himself." In Ninth Annual Sydney B. Sperry Symposium: The Book of Mormon, 96-102. Provo, UT: Brigham Young University, 1981. The promise given in Moroni 10:4-5 is of great importance to members of the Church. Each individual must know the truth and receive a testimony for himself/herself. Author presents details on how this may be accomplished. [J.W.M.]

T.102 Taylor, J. "Ancient Ruins." TS 5 (December 1844): 744-48. The immense ruins in Central America should dispel any doubts that the Book of Mormon records the history of ancient civilizations of America. [J.W.M.]

T.103 Taylor, J. "Stephens' Works on Central America." TS 4 (1 October 1843): 346-47. It is helpful to compare Stephens's writings on Central America with the Book of Mormon, for his works help to verify the Book of Mormon. [J.W.M.]

T.104 Taylor, John. Answer to Some False Statements and Misrepresentations Made by the Rev. Robert Heys, Wesleyan Minister, in an Address to History Society in Douglas and its Vicinity, on the Subject of Mormonism. Nauvoo: Penrice and 
Wallace, 1840. Argues against false statements made regarding the coming forth of the Book of Mormon and the idea that Sidney Rigdon had altered the Spaulding manuscript to produce the Book of Mormon. [J.W.M.]

T.105 Taylor, John. "The Book of Mormon and the Atonement." In Taylor's Mediation and Atonement, 40-54. Salt Lake City: Deseret News Co., 1882. Extracts from the books of Ether, 1 and 2 Nephi, Mosiah, Alma, Helaman, and Mormon that speak of Christ's Atonement. No commentary on these scriptures, simply direct quotes from the Book of Mormon. [A.C.W.]

T.106 Taylor, John. Calumny Refuted and the Truth Defended, Being a Reply to the Second Address of the Rev. Robert Heys, Wesleyan Minister the Wesleyan Methodist Societies in Douglas and its Vicinity. Nauvoo: Penrice and Wallace, 184?. Through the employment of biblical scriptures, Taylor answers Rev. Heys's complaints about "Mormonism." Heys argues against Mormon doctrines: the Book of Mormon does not possess equal authority with the Bible; little children are incapable of sin; all without the law are alive in Christ; immersion is the proper mode of baptism; it is a mockery before God to baptize little children. [J.W.M.]

T.107 Taylor, John. An Examination into and an Elucidation of the Great Principle of the Mediation and Atonement of our Lord and Savior Jesus Christ. Salt Lake City: Deseret News, 1892. Chapter 14 points out many references to Christ's Atonement in the Book of Mormon. The law of Moses was a shadow and type of the Atonement, which was fulfilled by Jesus who gave his own life. [J.W.M.]

T.108 Taylor, John. "God Is Cognizant of All Things." JD 26 (14 December 1884): 30-39. A commission of professors and scientists are meeting to examine the manuscript of the Book of Mormon to determine its validity. Whatever they decide does not affect the Book of Mormon, for it is true. The Book of Mormon and other scriptures outline the purpose of the creation of man. [J.W.M.]

T.109 Taylor, John H. Untitled talk. CR (April 1941): 39-40. Taylor points out some lessons learned from Lehi's dream. The tree of life is the love of God. [B.D.]

T.110 Taylor, M. Henry. "Paul Henning, Early Latter-day Saint Archaeologist." In Papers of the Fifteenth Annual Symposium on Archaeology of the Scriptures, edited by Ross T. Christensen, 90-93. Provo, UT: Brigham Young University, 1964. Paul August E. Henning devoted his life to Book of Mormon archaeology in Mexico uncovering the external evidences that would prove the authenticity of the book. [J.W.M.]

T.111 Taylor, Robert. "The Most Unusual Book in the World." Restoration Witness 164 (September 1976): 26-30. The final editors of the Book of Mormon, Mormon and Moroni, selected the message of the Book of Mormon under the inspiration of God. It was their intent to present a clear message by relating the events of their era to those who would live in the present era. The book is also a testimony of Christ. [J.W.M.]

T.112 Taylor, Russell C. Preview of Book of Mormon Highlights. N.p., September 1940. This outline, prepared for missionaries, contains twelve reading assignments, each of which provides study helps intended to assist the missionaries in stimulating the interest of investigators. [J.W.M.]

T.113 Teacher Test Handbook for the Book of Mormon Student Manual. Provo, UT: BYU Religious Instruction and the Instructional Development Program, 1972. Recommendations for lessons and sample questions with answers for teachers of Book of Mormon classes. [J.W.M.] 
T.114 "Teachings of the Book of Mormon." Young Woman's Journal 24-25 (July 1913-June 1914): 443-47, 44750, 507-11, 511-14, 564-67, 567-71, 635-39, 639-44, 697-701, 701-6, 764-68, 768-72, 57-61, 61-66, 123-26, 126-30, 188-91, 192-95. Series of lessons that teach Book of Mormon doctrine. Subjects include: Father in Heaven, divine nature of man, the Fall, the Atonement, priesthood among the Nephites, faith, sin, resurrection, salvation of the dead, the Second Coming, judgment, continual revelation, testimony, the doctrine of reward, the spiritual and the natural world. [K.M.]

T.115 "Teachings of the Book of Mormon on Priesthood." Rod of Iron 1 (October 1924): 37-39. The Book of Mormon teaches that men were ordained to the priesthood before they came to earth. God gives the priesthood to men, and then they are born to the priesthood in the patriarchal lineage. The priesthood is an eternal institution and the calling of men to it can only come through God. [J.W.M.]

T.116 Teasdale, Andrew. "1991 Book of Mormon Bibliography." In Review of Books on the Book of Mormon 4 (1992): 263-72. Bibliography.

T.117 Teasdale, Andrew. "Book of Mormon Bibliography." In Review of Books on the Book of Mormon 3 (1991): 323-36. Bibliography.

T.118 Techter, David. "Who Wrote the Book of Mormon." Fate Magazine 30 (March 1977): 38-46, 73-77. Briefly tells of the origin and story of the Book of Mormon. Outside of the circle of Mormonism, scholars cannot share the enthusiasm. Martin Harris's approach to Professor Anthon reveals a "country bumpkin" whose claims are spurious. D. P. Hurlburt alleged that the manuscript was based on Spaulding's writings. The author claims the Mormons get around any sensible claims by way of their "extravagant tale" and their witnesses. Lists James E. Talmage's five "proofs" of authenticity, and then claims that three of these are proof that the Book of Mormon is an intentional fraud. [J.W.M.]

T.119 Terry, Keith C. Out of Darkness. U.S.A.: J. B. Media International, 1991. A long story book incorporating information that has recently been disclosed from Book of Mormon studies. [D.M.]

T.120 Terry, Keith, and Ann Terry. "Emma... Her Beginnings." In Terry's Emma: The Dramatic Biography of Emma Smith, 3-13. Santa Barbara, CA: Butterfly publishing, 1979. Emma Smith was the courageous woman, wife of the prophet. She helped her husband go to the Hill Cumorah and waited until he returned with the heavy load of plates. Emma assisted in the translation and defended her husband to the skeptics. She carried the original manuscripts of the Book of Mormon under her skirts through the freezing wilderness of Missouri into Illinois. [J.W.M.]

T.121 "Testimonies of Four Witnesses of the Book of Mormon." IE 71 (September 1968): 14. Transcriptions of the testimonies of Emma Smith, Martin Harris, Oliver Cowdery, and David Whitmer testifying of the truthfulness of the Book of Mormon. [L.D.]

T.122 "Testimonies of the Book of Mormon." Ensign 13 (December 1983): 6-9. A collection of testimonies on the Book of Mormon by LDS church presidents from Joseph Smith to Spencer W. Kimball. [D.M.]

T.123 "Testimonies Shared Before Couple Arrives." CN 59 (4 November 1989): 4. A couple who had been sending copies of the Book of Mormon to Suaziland were called there to serve a mission. Half of the members had received copies from them. [M.R.] 
T.124 "Testimony of Savior Runs Through Book 'Like Golden Thread." DN Church Section (29 June 1986): 7. Boyd K. Packer said that the message of the Book of Mormon is to testify of Jesus Christ and this "message reappears throughout the pages of the book like a golden thread." Reading and studying the Isaiah chapters will lend insight into the Bible as never before. [M.D.P.]

T.125 The Testimony of Three Witnesses. Issaquah, WA: Saints Alive in Jesus, 1982?. A polemical tract attempting to discredit the testimony of Joseph Smith and each of the Three Witnesses. [D.M]

T.126 "The Testimony of Three Witnesses and The Testimony of Eight Witnesses." Evening and Morning Star 1 (January 1833): n.p. Gives the Testimonies of the Three and Eight Witnesses and a hymn rejoicing in their testimony of the Book of Mormon. [M.D.P.]

T.127 "Thai Translation Printed." Ensign 7 (January 1977): 95-96. A group of nine translators worked for a period of seven years to provide the Thai Book of Mormon. The first edition includes 3,000 copies. [J.W.M.]

T.128 "That They May Know." NE 7 (October 1977): 35-37. A new proselytizing method is to put your testimony in the front cover of the Book of Mormon along with your picture. Examples are given. [M.D.P.]

T.129 Thatcher, Moses. "Ancient American Civilizations and Their lessons." In Collected Discourses Delivered by President Wilford Woodruff, His Two Counselors, The 12 Apostles, and Others, Vol. 1. (1886-1889), edited by Brian H. Stuy, 171-77. Sandy, UT: B. H. S. Publishing, 1987. The ruins of the people of Nephi that are found in Central America and Mexico show that they were not barbarians, but intelligent, civilized people. The record of their civilization has come forth in the Book of Mormon. There is much evidence left to verify the Book of Mormon, even though the Spaniards destroyed the people's records. [J.W.M.]

T.130 Thatcher, Moses. "Divine Origin of the Book of Mormon." MS 43 (6, 13, 27 June 1881): 353-56, 369-72, 385-87, 401-2. Presents historical evidences to prove the divine authenticity of the Book of Mormon. He quotes from the Popol Vuh to show that the Quiche's creation account is similar to that of the Bible; he also refers to Ixtlelxochitl to argue that the accounts of the flood are similar. [B.D.]

T.131 Thatcher, Moses. "An Interesting Lecture: Delivered by Apostle Moses Thatcher in Ogden, Utah." MS 50 (17-24 December 1888): 801-4, 817-20. A two-part series reprinted from the Deseret News-a transcript of a lecture given by Moses Thatcher. The people who constructed the pyramids of the sun and the moon were white. There was a high quality of cement found and the interior of the rooms were beautifully painted. These people taught traditions of a white man who taught them to cultivate their ground, and would some day return to be their king. [J.W.M.]

T.132 "Theology and Testimony: Guide Lessons" Relief Society Magazine 6 (September-December 1919): 489-92, 548-50, 610-14, 671-73. The pivotal point in history was the coming of Christ. No greater prophecies exist that looked forward to Christ than the Book of Mormon; they are unexcelled for their detail and clarity. 1 Nephi 15 declares the restoration of the Jews. Lamanites have been victims of their conqueror's injustice, but their hour of bondage is passing (1 Nephi 15, 2 Nephi 30). Miracles performed among the Nephites can be arranged into three categories: healing the sick and raising the dead, deliverance of God's servants, and the punishment of the wicked. [J.W.M.]

T.133 "Theology: Church History-The Book of Mormon Revealed." Relief Society Magazine 31 (August 1944): 467-71. As part of a Church history series, this lesson quotes much of Joseph Smith-History concerning the 
coming forth of the Book of Mormon. [J.W.M.]

T.134 "Theories on the Origin of Man." Juvenile Instructor 3 (15 August 1868): 124-25. "The Indians on this continent are of the House of Israel." They were cursed as a result of their abominations. [D.M.]

T.135 "They Worked in Cement." CN 52 (19 June 1982): 16. Recounts how the peoples of the Book of Mormon worked with wood and stone. The ancient ruins in South America are remnants of the peoples in the Book of Mormon. The conclusion is drawn that the inhabitants of ancient America were just as advanced as the peoples of Palestine. [G.A.]

T.136 "This Is the Decade of the Seventies." CN 40 (28 February 1970): 3. Nearly 45,000 copies of the Book of Mormon have been placed in motels, hotels, and businesses. Some conversions have been reported but the total number of converts cannot be known. [J.W.M.]

T.137 Thomas, Albert H. "External Evidences of the Book of Mormon." MS 67 (27 April 1905): 269-72. Quotes contemporary historians and ancient authors whose writings confirm or support historical elements of the Book of Mormon. Among these are Lord Kingsborough who was impressed by the knowledge of Genesis possessed by the American Indians; Rosales who relates a Chilean tradition of a visitation by a wonderful personage who taught them of the creator; Prescott who tells of astonished Catholics who found the sign of the cross and a ceremony of partaking of the body and blood of deity. [R.H.B.]

T.138 Thomas, Brett P. "They Did Remember His Works." In The Book of Mormon: Helaman through 3 Nephi 8, According To Thy Word, edited by Monte S. Nyman and Charles D. Tate Jr., 93-113. Provo, UT: Brigham Young University Religious Studies Center, 1992. Shows a connection between the instructions given by Helaman to his sons Nephi and Lehi and the spiritual outpouring that occurred when the two sons were imprisoned by a group of Lamanites. [D.M.]

T.139 Thomas, Darwin L. "Being Parents, Being Children." Ensign 7 (September 1977): 12-17. At a time when families are in crisis the Book of Mormon gives great comfort. Parents' responsibility is to teach their children. Children have the responsibility to believe their parents and then to desire to know for themselves. [J.W.M.]

T.140 Thomas, Darwin L., and Kim Thomas. "Youth and the Book of Mormon." NE 7 (September 1977): 8-12, 14. The Book of Mormon has a message for our day. The responsibility of parents to teach is equaled by the responsibility of youth to learn from their parents, to know for themselves through the witness of the Holy Ghost, and to prepare for the future by studying the Book of Mormon. [J.W.M.]

T.141 Thomas, David G. Book of Mormon Records. N.p., n.d. An outline of the different records either contained in or referred to in the Book of Mormon with an accompanying diagram. [J.W.M.]

T.142 Thomas, Gordon K. "The Book of Mormon in the English Literary Context of 1837." BYU Studies 27 (Winter 1987): 37-45. Poets in England in the early nineteenth century believed they would play an important role in a "restoration" of what they believed was imminent. A vast amount of ancient writings were discovered at this time. Some were revealed as counterfeits, so though the world was ready for ancient writings suspicion clouded every claim. The mixed atmosphere of excitement and distrust met early Mormon missionaries in England. [J.W.M.] 
T.143 Thomas, H. Richard. "Song of Nephi." Instructor 102 (October 1967): 409-11. 2 Nephi 4:16-35 shares much of the character and attitude of Nephi. The Song of Nephi begins with a feeling of despair and ends with an inspiring prayer of commitment to a better way of life. It is a pattern to follow on the road to repentance. [J.W.M.]

T.144 Thomas, Janet. "How Rare a Possession." NE 17 (November 1987): 28-33. Reports on the making of the film How Rare a Possession. The film recreates the life of Vincenzo D. Francesca and many Book of Mormon scenes. [J.W.M.]

T.145 Thomas, Janet. "New Summer Friends." NE 23 (June 1993): 32-35. High school "Students Trying Out Moroni's Promise" (S.T.O.M.P.) read the Book of Mormon during the summer to gain a testimony. [S.H.]

T.146 Thomas, M. Catherine. "A Great Deliverance." In Studies in Scripture: 1 Nephi to Alma 29, edited by Kent P. Jackson, 103-14. Salt Lake City: Deseret Book, 1987. 2 Nephi 3-5 contains three main ideas: Joseph in Egypt, Nephi's psalm, and the mark of the dark skin. These chapters are replete with the Savior's commitment and love for his children. Nephi's account records important promises to the descendants who carry the mark upon them. [J.W.M.]

T.147 Thomas, M. Catherine. "Jacob's Allegory: The Mystery of Christ." Provo, UT: FARMS, 1992. Points out two key questions that Jacob asks in the text that alert the reader that the allegory is going to deal with grace and atonement and their relationship to Israel. Jacob asks, "Why not speak of the atonement of Christ, and attain to a perfect knowledge of him?" (Jacob 4:12), and then he asks, "How is it possible that these [Jews], after having rejected the sure foundation can ever build upon it, that it may become the head of their corner?" (Jacob 4:17-18). Jacob reveals the mystery of Christ's true nature and divine activity in the lives of men. [B.D.]

T.148 Thomas, M. Catherine. "Jacob's Allegory: The Mystery of Christ." In The Allegory Of The Olive Tree: The Olive, the Bible, and Jacob 5, edited by Stephen D. Ricks and John W. Welch, 11-20. Salt Lake City: Deseret Book and FARMS, 1994. The symbolism of the olive tree in Jacob 5 is layered. The tree seems to reflect Christ on one level, the branches represent Israel on another, and the individual on still another. The greatest value of the allegory lies in Jacob's explanation of the constant awareness of the Lord and the Spirit's unceasing work in behalf of the individual. [J.W.M.]

T.149 Thomas, M. Catherine. "A More Excellent Way." In Studies in Scripture: Alma 30 to Moroni, edited by Kent P. Jackson, 271-81. Salt Lake City: Deseret Book, 1988. Ether 9-15 outlines only two ways of living, "each antithetical to the other." Either one must choose God and his will or Satan and his evil doings. The choices individuals make set the course of their lives. Deliverance comes from a reversal of choices. Faith is an important element in the reversal process and implies the need for healthy desire. [J.W.M.]

T.150 Thomas, M. Catherine. "Theophany." In Studies in Scripture: Alma 30 to Moroni, edited by Kent P. Jackson, 172-83. Salt Lake City: Deseret Book, 1988. Theophany, or the appearance of God to man, teaches more in a few minutes than centuries of man's reasoning can produce. 3 Nephi 17-19 displays the Savior's great empathy for the people and his love of children. So profound was the appearance of the Savior among the Nephites that much could not be written. [J.W.M.]

T.151 Thomas, M. Catherine. "Types and Shadows of Deliverance in the Book of Mormon." In Doctrines of the Book of Mormon, 1991 Sperry Symposium, edited by Bruce A. Van Orden and Brent L. Top, 182-93. Salt Lake City: Deseret Book, 1992. There are many examples in the Book of Mormon of deliverance of individuals from sin, 
groups from bondage, and armies from harm. Accounts of journeys help one to understand deliverance. Ultimately the greatest deliverance is from sin. [N.K.Y.]

T.152 Thomas, Mark. "Listening to the Voice from the Dust: Moroni 8 As Rhetoric." Sunstone 4 (January/February 1979): 22-24. Rhetoric is a tool to understanding; it is an approach to literature that attempts to discover how the writer presents his vision to the reader. There are three types of letters in the Book of Mormon-war epistles, narratives, and doctrinal. This article focuses on a letter Mormon wrote to his son Moroni on infant baptism. [J.W.M.]

T.153 Thomas, Mark. "The Meaning of the Revival Language in the Book of Mormon." Sunstone 8 (May/June 1983): 19-25. Shows certain similarities between activities and language in the Book of Mormon and those found in religious revivals of the early nineteenth century. Includes some interesting comparisons, such as being saved from our sins, not in them. [M.R.]

T.154 Thomas, Mark. "Scholarship and the Future of the Book of Mormon." Sunstone 5 (May/June 1980): 24-29. The Book of Mormon has features common to any literary work. It has historical background, literary forms, symbols, and grammar. Mormon scholars should use textual criticism, historical criticism, and literary criticism to interpret the Book of Mormon as scholars of other literary works have used. This method is invaluable to expose the message. [J.W.M.]

T.155 Thomas, Mark D. Review of Warfare in the Book of Mormon, edited by Stephen Ricks and William J. Hamblin. Sunstone 15 (September 1991): 62. Book review.

T.156 Thomas, Mark D. "A Rhetorical Approach to the Book of Mormon: Rediscovering Nephite Sacrament Language." In New Approaches to the Book of Mormon, edited by Brent Lee Metcalfe, 53-80. Salt Lake City: Signature, 1993. Focusing on the audience rather than on the antiquity of the Book of Mormon, this author determines that the Book of Mormon was written for the nineteenth century with nineteenth-century language. The usage of modern language in connection with the Lord's Supper anticipates a future audience rather than a Nephite audience that was being introduced to the sacrament for the first time. The Book of Mormon answered the nineteenth-century controversy concerning the language and liturgical forms to be used in the sacrament. This work is reviewed in A.106. [J.W.M.]

T.157 Thomas, Mark D. "Scholarship and the Book of Mormon." In The Word of God: Essays on Mormon Scripture, edited by Dan Vogel, 63-79. Salt Lake City: Signature, 1990. Attempts to outline the value of various approaches to Book of Mormon study. Suggests interpreting the book as a nineteenth-century document and that certain phrases and ideas found in the Book of Mormon only make sense in a modern context. [M.R.]

T.158 Thomas, Mark D. "Swords Into Pruning Hooks." Sunstone 15 (October 1991): 55. Discusses the historicity of the Book of Mormon and the mistranslation of "steel bow" for the biblical "brass bow"; since the premise of the Book of Mormon was that it came forth to correct errors in the Bible, then it should do just that. Finds that the Book of Mormon is a nineteenth-century document with a powerful, spiritual message. [J.W.M.]

T.159 Thomas, Robert K. "A Literary Analysis of the Book of Mormon." M.A. thesis, Reed College, 1947. A literary analysis of the Book of Mormon. After briefly examining theories regarding its origin, the author examines several historical and philosophical claims and contributions of the book. Also contains a short discussion of the allegation that the Book of Mormon quotes Shakespeare. Thomas concludes that the Book of Mormon represents a significant literary achievement. [M.R.] 
T.160 Thomas, Robert K. "A Literary Critic Looks at the Book of Mormon." In A Believing People, 213-19. Provo, UT: Brigham Young University Press, 1974. Through a critical evaluation and literary analysis, the author examines the extent to which Joseph Smith as a translator is responsible for the language and style of the Book of Mormon. New England influences such as "the more part" and "hefted" are only superficial. Joseph Smith was more than inspired of God, he surely partook of the gift and power of God. [J.W.M.]

T.161 Thomas, Robert K. "A Literary Critic Looks at the Book of Mormon." In To the Glory of God, edited by Charles D. Tate and Truman G. Madsen, 149-61. Salt Lake City: Deseret Book, 1972. Introduces the idea that the Book of Mormon itself "claims to be Hebraic history." That is, it is a book of "God's dealings with his chosen people -no more, no less." Thomas writes concerning a few Book of Mormon characters-Nephi, Abinadi, Enos, Jarom, Omni, Amaron, Chemish, Abinadom, Amaleki-personalities who fit the "Hebraic pattern" of history, a pattern that is constant throughout the Book of Mormon. [D.W.P.]

T.162 Thomasson, Gordon C. "Choosing Our Language after We Choose a 'Language of the Church': or, Who Do We Want to Talk to and Will They Hear Us?" In Conference on the Language of the Mormons, 35-42. Provo, UT: BYU Language Research Center, 1974. Choosing a language for a given area involves decisions of a social and political nature beyond the linguistic issues. Using a particular language may mark a person in a political sense. It may suggest values not consistent with the gospel. It is an extremely hard task. Finding the right language in which to translate the Book of Mormon is critical. [J.W.M.]

T.163 Thomasson, Gordon C. "'Daddy, What's a Frontier?': Second Thoughts on the Environment that Supposedly Produced the Book of Mormon." N.p., 25 April 1970. Address delivered at a Brigham Young University Book of Mormon Symposium. Questions the assumptions of those who claim that the Book of Mormon is merely a reflection of Joseph Smith's environment. Critiques theses that have associated early Mormon history with aspects of the American frontier. [D.M.]

T.164 Thomasson, Gordon C. "I Have a Question: What exactly does the word 'Lamanite' mean?" Ensign 7 (September 1977): 39-40. Lamanites were not only the descendants of Laman, but also those who desired to destroy the people of Nephi. The line of division between Nephites and Lamanites seems to be rather fluid. In modern times the term may be applied to the descendants of Book of Mormon peoples. [J.W.M.]

T.165 Thomasson, Gordon C. "Lamanites." In Encyclopedia of Mormonism, edited by Daniel H. Ludlow, 2:804-5. 5 vols. New York: Macmillan, 1992. Describes the Lamanites as descendants of Laman and Lemuel, sons of Lehi. However, generally the Lamanites were those who were not Nephites. [B.D.]

T.166 Thomasson, Gordon C. "Mormon Symbols: Structures of Mormon Consciousness and the Basis of Mormon Communication Activities, Mormon Language, and Mormon Arts." In Conference on the Language of the Mormons, edited by Harold Madsen and John L. Sorenson, 75. Provo, UT: Brigham Young University Language Research Center, 1973. Mormon logic and thinking are based symbols, rituals, and temple iconography that had their roots in the Book of Mormon. The worldview that has grown out of this book has attached new symbols to English words that carry specific and unique implications. [J.W.M.]

T.167 Thomasson, Gordon C. "Mosiah: The Complex Symbolism and the Symbolic Complex of Kingship in the Book of Mormon." Provo, UT: FARMS, 1982. Also in Journal of Book of Mormon Studies 2 (Spring 1993): 21-38. With the purpose of bringing people to Christ, Mormon included more material from the reign of Mosiah in his abridgment than any other king except for Nephi, son of Lehi. The responsibility of Mosiah's kingship to his 
subjects is likened to God's responsibility for his children. Noah is likened to Satan and his usurping of power and the potential destruction of those who allow such rule. Photographs of symbols of kingship are included. [J.W.M.]

T.168 Thomasson, Gordon C. "Righteousness As a Counterculture." NE 2 (April 1973): 46-49. Most preColumbian cultures that archaeologists have discovered have been civilizations based on warfare, aggressive and competitive in nature. They are cultures familiar to Book of Mormon readers as having roots in societies that rejected the gospel. They result in blood sacrifice instead of the individual's need for the personal sacrifice of a broken heart and contrite spirit. [J.W.M.]

T.169 Thomasson, Gordon C. "The Survivor and the Will to Bear Witness." In Reexploring the Book of Mormon, edited by John W. Welch, 266-68. Salt Lake City: Deseret Book and FARMS, 1992. Mormon, Moroni, Alma and many others were witnesses of the destruction of large numbers of people. Their reactions can be compared to those of survivors of Hitler's and Stalin's death camps. As survivors they documented the atrocities. Their records bear distinctive and unexpected similarities to other descriptions of similar experiences. [N.K.Y.]

T.170 Thomasson, Gordon C., ed. War, Conscription, Conscience, and Mormonism. Santa Barbara: Mormon Heritage, 1971. A collection of essays by recognized authorities and scholars of the Church that reflect individual opinions on the subjects of war, conscription, conscience, and Mormonism. Cites relevant Book of Mormon precedents, such as Anti-Nephi-Lehies. [D.S.T.]

T.171 Thompson, Anita. "Please Read It to Me." NE 20 (July 1990): 8-10. Personal story. Author tells of the Book of Mormon's influence in her son's life. [E.G.]

T.172 Thompson, Charles B. "Evidences in Proof of the Book of Mormon." TS 3 (1 January 1842): 640-44. Excerpts from a book by the same title. Compares descriptions of ancient American fortifications with comparable fortifications in the book of Alma. Discusses the Gadianton robbers and the visit of Martin Harris to Dr. Mitchel. [D.M.]

T.173 Thompson, Charles B. Evidences in Proof of the Book of Mormon Being a Divinely Inspired Record. Batavia, NY: D. D. Waite, 1841. Three parts. Sets forth evidences to prove the Book of Mormon's truthfulness to benefit those embarking on missionary work, for the encouragement of those who had just joined the Church, and to correct false doctrine concerning the Book of Mormon's "real intent and character." Discusses scriptural accounts of the scattering and gathering of Israel, the sign of the record of Joseph, and America as a land of promise. Refutes allegations made against the Book of Mormon and issues a warning to the inhabitants of America. [J.W.M.]

T.174 Thompson, G. Forrest. Greetings between Judah and Joseph. Idaho Falls, ID: Vanity, 1990. A 49-chapter commentary on Zenos's parable of the olive tree in Jacob 5. [D.M.]

T.175 Thompson, John E. The Masons, the Mormons and the Morgan Incident. Ames, IA: Iowas Research Lodge, 1984. An historical treatment of the possible effects of Freemasonry on Mormonism. The writer recounts the anti-Masonic hysteria during the late 1820's following the death of William Morgan. He notes that since many people of the time referred to Freemasonry as a "combination" or "secret society," the Book of Mormon's Gadianton Robbers may reflect environmental influence. [M.R.]

T.176 Thompson, Stephen E. Review of Southwestern American Indian Rock Art and the Book of Mormon, by James R. Harris, Sr. Review of Books on the Book of Mormon 4 (1992): 65-76. Book review. 
T.177 Thomsen, Blaine C. The Ammonite. Independence, MO: Herald House, 1979. A fictional story of Jothan, an iron worker of King Lamoni's court who fashioned an important sword, and of Ammon who became a shepherd for Lamoni. This work is reviewed in S.085. [J.W.M.]

T.178 "Thor Heyerdahl's Voyages Support Book of Mormon, He Tells Professor." CN 59 (29 April 1989): 11. Thor Heyerdahl, seaman and explorer, provides the following statement regarding his famous sea voyage to Paul R. Cheesman: "I don't understand why your people work so hard at trying to convince people that the Book of Mormon is a correct record. I have already proven to the world that such a voyage as described in this book is perfectly possible." [D.M.]

T.179 Thorgeivson, J. "The Nine Bibles of the World." MS 83 (27 January 1921): 60-61. Lists nine books that serve as foundations for different religions, or the nine bibles of the world, in which is included the Book of Mormon. [M.D.P.]

T.180 Thorne, Melvin J. "Ezias." In Encyclopedia of Mormonism, edited by Daniel H. Ludlow, 2:481. 5 vols. New York: Macmillan, 1992. Ezias was a prophet of Old Testament times mentioned by Nephi in Helaman 8:13-20. [B.D.]

T.181 Thorne, Melvin J. "Helaman1." In Encyclopedia of Mormonism, edited by Daniel H. Ludlow, 2:584. 5 vols. New York: Macmillan, 1992. Helaman, the son of King Benjamin, became a king of the Nephites. [J.W.M.]

T.182 Thorne, Melvin J. "Moroni1." In Encyclopedia of Mormonism, edited by Daniel H. Ludlow, 2:955-56. 5 vols. New York: Macmillan, 1992. The first Moroni mentioned in the Book of Mormon lived prior to Christ's birth and was but twenty-five years old when he commanded the Nephite armies. He raised the title of liberty to rally his people to the defense of their freedom. [J.W.M.]

T.183 Thorne, Melvin J. "Mosiah1." In Encyclopedia of Mormonism, edited by Daniel H. Ludlow, 2:959. 5 vols. New York: Macmillan, 1992. King Mosiah, father of Benjamin, led his people away to protect them from the Lamanites about 200 B.C. and discovered and settled with the people of Zarahemla. He interpreted the writings of the Jaredites. [J.W.M.]

T.184 Thorne, Melvin J. "Nephi2." In Encyclopedia of Mormonism, edited by Daniel H. Ludlow, 3:1005. 5 vols. New York: Macmillan, 1992. Nephi2 was the Nephite chief judge in 39 B.C., served a mission to the Lamanites, and ruled during the great famine recorded in the book of Helaman. [A.T.]

T.185 Thorne, Melvin J. "Nephi3." In Encyclopedia of Mormonism, edited by Daniel H. Ludlow, 3:1006. 5 vols. New York: Macmillan, 1992. Nephi3, the son of Nephi2, was a man of great faith who heard the voice of Jesus Christ declaring that he would be born on the morrow; he was the leading disciple of the American Church following the resurrection of Christ. [A.T.]

T.186 Thorne, Melvin J. "Nephi4." In Encyclopedia of Mormonism, edited by Daniel H. Ludlow, 3:1006. 5 vols. New York: Macmillan, 1992. Nephi4 was the record keeper during the time when the descendants of Lehi lived the law of consecration. His death took place after A.D. 110. [J.W.M.]

T.187 Thornock, A. LaVar, Mervin L. Gifford, Vernon W. Mattson Jr., John Child, and Duane H. Marchant. "The Book of Mormon." In Is There An Answer? edited by A. LaVar Thornock, 41-47. Pocatello, ID: Carter's Printing, 1968. Prepared to answer many common objections to LDS theology. Objections include: the Bible does not 
speak of the Book of Mormon; since the Bible is complete there should be no need for additional scripture; Mormons use a different Bible; much is copied from the Bible; Joseph Smith wrote the book; Lehi is not mentioned in the Bible; and the gold plates are not available to view. [J.W.M.]

T.188 Thornock, W. Rudger. "Indian Artifacts from Klamath Falls." IE 44 (April 1941): 216, 231. The existence of Indian artifacts help to form the conclusion that two separate cultures existed in ancient Northwestern America. [J.W.M.]

T.189 Thornton, H. Newton. "A Record of the Mighty Deed on this Continent to be Preserved." IE 24 (October 1921): 1084-85. "External evidence of the historical credibility and truth of the Book of Mormon" is found in the reconstruction of ruins in Mexico and Central America. Two pyramids found in Mexico and the ruins of a great city that existed three to four thousand years ago bear witness of a great civilization. [J.W.M.]

T.190 Thorup, Joseph F. "Book of Mormon in Greek." IE 12 (March 1909): 329-32. An announcement regarding the translation of the Book of Mormon in Greek. Includes an extract in Greek of 3 Nephi 11 and extols the beauty and value of the Greek language. [D.M.]

T.191 "Those Gold Plates." CN 44 (17 August 1974): 16. A gold plate inscribed with Phoenician alphabet characters was found near Pygri, Italy. Gold plates were used in the ancient world. [M.R.]

T.192 "Those 'Ignorant' Aborigines." CN 24 (30 January 1954): 16. Shows that the ancestors of the Peruvians were exceptionally intelligent and civilized as demonstrated by sophisticated surgical techniques. Such things support the Book of Mormon. [D.M.]

T.193 "Three India Translations Complete." CN 52 (14 August 1982): 3. The Book of Mormon is translated into three Indian languages-Hindi, Telugu, and Tamil-making it available to over three hundred million people of India. [G.A.]

T.194 "Three Nephite Disciples Have a Special Mission to Perform." CN 58 (15 October 1988): 10. The Three Nephite disciples possess translated bodies and have a mission to perform, perhaps similar to the missions performed by Moses and Elijah. [R.H.B.]

T.195 "The Three Witnesses." Historical Record 7 (1888): 609-24. Contains the testimony of the Eight Witnesses and a biographical sketch of each. [J.W.M.]

T.196 Thurman, Dillard. "Book of Mormon vs. Word of God." Gospel Minutes 31 (1 October 1982): 1-3. This polemic literature reviews several Book of Mormon passages, pointing out weaknesses in sentence construction and questions the doctrine according to biblical passages. [J.W.M.]

T.197 Tice, Richard. "How Rare a Possession." Ensign 18 (January 1988): 14-17. Discusses the making of a film, "How Rare a Possession." The film's purpose is to create a deeper appreciation and awareness of the Book of Mormon, to strengthen testimonies of the scripture, and to encourage people in and out of the Church to read and study the book. [A.A.]

T.198 Tiffany, Joel. "Among the Mormons (An Interview with Martin Harris)." Tiffany's Monthly 5 (May-July 1859): 46-51, 119-21, 163. Tells about Joseph Smith's use of a seer stone to translate the Book of Mormon. Calls 
the character of Joseph Smith into question but bears witness that the Book of Mormon is the work of God. [J.W.M.]

T.199 Tiffin, Dalton A. Some Important Reminders: The Divine Origin of the Book of Mormon. Weston, Ontario: Dalton A. Tiffin, n.d. Pamphlet attempting to prove the validity of the Book of Mormon. Includes the testimony of the Three and Eight Witnesses, an account of the finding of the Spaulding manuscript, a reprint of a letter from the president of Oberlin College where the Spaulding manuscript is kept. [J.W.M.]

T.200 Tiffin, Dalton A. While God's Revealed Plans for Revolutionizing the American Continent Are Unfolding ... The Original New Testament Church of Christ of the Bible and Book of Mormon is Defended. Weston, Ontario: n.p., 1948. Contends that the church of Christ existed in the New Testament and Book of Mormon but that Mormonism is not in harmony with this ideal. Quotes Joseph Smith's history relevant to receiving and translating the Book of Mormon; reinterprets Book of Mormon prophecies to show that Lamanites will join the resurrected members of Christ's church in a revolution against American Gentiles as Moroni returns and rules as God's spokesman. [E.G.]

T.201 "A Time for Renewal." CN 56 (14 September 1986): 16. Three years after the First Vision, Joseph Smith beheld an angel in his room three times in one night. The next day he went to the nearby Hill Cumorah. There he found the gold plates that were translated into the Book of Mormon. [M.R.]

T.202 "Time for the Feast." NE 16 (May 1986): 28-29. An instructional aid for young people. A program is presented whereby a person may read the entire standard works in four-and-one-half years by reading one chapter a day. [B.D.]

T.203 Tingle, Donald S. "Latter-day Saints (Mormons)." In A Guide to Cults and New Religions, edited by Ronald M. Enroth, 117-34. Downers Grove, IL: InterVarsity, 1983. In an attempt to give the "true facts" of Mormonism, this polemical article questions the apostasy that Mormons claim made the restoration necessary, discusses ambiguous doctrine, claims that Joseph Smith wrote the Book of Mormon by borrowing from the Bible, Solomon Spaulding, and Ethan Smith, points out changes in the Book of Mormon. [J.W.M.]

T.204 Tingle, Donald S. Mormonism: Examining the Fastest Growing Religion in the World. Downers Grove, IL: InterVarsity Press, 1981. The author recounts the events that brought forth the Book of Mormon, and the effects that the book had on the people and history. The Book of Mormon cannot be "the most correct" book as at least 3,913 changes have been made since the 1830 edition, and the current edition disagrees with the earlier edition. The Book of Mormon originated from the Manuscript Found, the View of the Hebrews, "The Wonders of Nature and Providence Displayed," or Joseph Smith received his visions "under the influence of demonic powers." The concept of God in Mormon theology is contradicted by the Book of Mormon. [J.W.M.]

T.205 Tobin, Tammy L. "Truly the Word of God." Ensign 13 (December 1983): 20-21. Author recounts her conversion to the gospel through the Book of Mormon. As a Catholic nun, she encountered two missionaries who gave her a copy of the Book of Mormon and challenged her to read the account of the Jesus Christ's visit to the Americas. As she did she knew the story was true and was baptized the following Sunday. [S.P.S.]

T.206 Todd, Jay M. "An Encore of the Spirit." Ensign 21 (October 1991): 32-42. Choir members touring eastern European countries tell of spiritual experiences they had when they were able to give Books of Mormon to spiritually hungry people. [J.W.M.] 
T.207 Toinet, Paul. Religions Sans Frontiers? N.p., 19 May 1970. In French with an English translation by Roger L. Dock. With the idea of being objective, this article focuses on the Book of Mormon teachings concerning polygamy and Joseph Smith's translation of the Book of Mormon. A comparison is made between biblical passages and Book of Mormon passages, pointing out the differences. Book of Mormon claims declaring America as the promised land are arrogant and chauvinistic. [J.W.M.]

T.208 Tolle, James M. Is the Book of Mormon from God? San Fernando, CA: Marion Publishing Co., 1957. Investigates the historical character of the Book of Mormon and finds that it is filled with preposterous stories, absurdities, and contradictions. Supposes that it is a modern composition, using modern words unknown to the ancients. Much of it is copied from the Bible, but it contradicts, conflicts with, and undermines the Bible. [J.W.M.]

T.209 Top, Brent L. "Faith Unto Repentance." In Doctrines of the Book of Mormon, 1991 Sperry Symposium, edited by Bruce A. Van Orden and Brent L. Top, 194-211. Salt Lake City: Deseret Book, 1992. Prophets have always been told to teach repentance and faith on the Lord. Faith is clearly identified in the Book of Mormon as the foundation of repentance. Enos and Ether were told their sins were forgiven through their faith in Christ. The book cites the importance of broken hearts and contrite spirits that lead to confession of guilt and submission to God's will. Confession is cited as being effective if sins are forsaken. Alma discusses the "mighty change of heart." [J.W.M.]

T.210 Tope, Wally. The Book of Mormon Priesthood. N.p: Wally Tope, n.d. Leaflet refuting Orson Pratt's statement that the Book of Mormon stands the test of time with no contradictions, absurdities, or unreasonableness. This author points out areas where he feels the Book of Mormon contradicts science, the Bible, archaeology, and reason. Joseph Smith contradicts his own words. [J.W.M.]

T.211 Tope, Wally. Why Should I Pray about the Book of Mormon When ...? La Canada Flintridge, CA: Wally Tope, 1982. A polemic leaflet to show that the burning feeling one experiences when reading the Book of Mormon is not evidence of the book's truthfulness, since it fails the test of comparison with the Bible. Joseph Smith contradicted his own words and the Book of Mormon has been changed time and again. [J.W.M.]

T.212 A Topical Guide to the Scriptures of the Church of Jesus Christ of Latter-day Saints. Salt Lake City: Deseret Book, 1977. Six hundred forty topics are alphabetically listed, including Book of Mormon references. References include a line of the scripture for easier identification. [J.W.M.]

T.213 Toscano, Paul James. "Priesthood Concepts in the Book of Mormon: Insights on Church Leadership and Organization." Sunstone 13 (December 1989): 8-17. In the approximately sixty passages alluding to the priesthood in the Book of Mormon, the offices of the priesthood were given to individuals who "labored diligently" to teach the people of Christ. The role between secular and non-secular was not separated in the Book of Mosiah. Priesthood leaders were ordained by one central figure, the high priest. The roles of church and state separated when Alma the Younger applied himself wholly to the duties of the priesthood. Following Christ's appearance, twelve disciples were chosen and the role of high priest disappeared. The author ends with a call to return to the equality of members taught in the Book of Mormon. [J.W.M.]

T.214 Totten, Norman. "Categories of Evidence for Old World Contacts with Ancient America." In The Book of Mormon: The Keystone Scripture, edited by Paul R. Cheesman, S. Kent Brown, and Charles D. Tate Jr., 187-205. Salt Lake City: Bookcraft, 1988. Early explorers found the peoples of the Americas to be widely varied in culture and physical appearance. It is argued that the diffusion theory allows for greater understanding than the isolation 
theory. There are considerable amounts of evidence indicating there were many cultures present in America prior to Columbus in 1492. [J.W.M.]

T.215 Towle, Nancy. Vicissitudes Illustrated in the Experience of Nancy Towle in Europe and America. Charleston: For the authoress by James L. Burges, 1832. The personal account of a woman preacher's experiences while preaching in America. Pages 137-46 discuss her encounter with the Book of Mormon and the Mormons in Kirtland. Appalled by the pretensions of such a book, she dismisses it as a deceitful fraud. [M.R.]

T.216 Towne, C. S. The Angelic Ministry of Mormonism Weighed in the Balance. McMinnville, TN: Standard House, 1902. A polemical tract against Mormonism. The writer notes problems with the claims of Joseph Smith and the Book of Mormon witnesses regarding the revelatory events surrounding the coming forth of the Book of Mormon. [M.R.]

T.217 Townsend, Joseph Long King. "The Miraculous Book of Mormon." IE 30 (September 1927): 1027-28. A lengthy poem about the coming forth of the Book of Mormon from the Hill Cumorah. [J.W.M.]

T.218 Townshend, George. The Conversion of Mormonism. Hartford, CT: Simonds, 1911. A polemical work against Mormonism. The author notes various traces of environmental influences in the Book of Mormon such as modern theological ideas and anti-Catholic and anti-Masonic material. [M.R.]

T.219 Townshend, George. Why I Am Not a Mormon. Denver, CO: Alexander \& Meyer, 1907. A polemical tract against Mormonism. Among the reasons cited for his rejection of the Book of Mormon are the Anthon denial, the concept of "reformed Egyptian," the Book of Mormon claim of pre-Columbian domesticated animals in the Americas, such as the horse, the cow, the term Sheum, and the book's condemnation of polygamy. [M.R.]

T.220 "Traits of the Mosaic History Found among the Aztec Nations." TS 3 (15 June 1842): 818-19. This article describes a painting of Aztec origin, published by Baron Humbolt in his volume, Researches in Mexico. It is a legend or myth of a great deluge, of how a man, his wife, children, and animals were saved by entering an immense canoe, and then of a subsequent confusion of languages-which the article assumes is Noah and his family. This is important support for the Book of Mormon. [J.W.M.]

T.221 "Transatlantic Antiquities." MS 6 (1 August 1845): 56-57. Briefly tells of the research of Josiah Priest, Stephens, and Catherwood and their discoveries of the remains of mighty cities on the American continent that testify of the Book of Mormon. [M.D.P.]

T.222 "Translation of the Book of Mormon." IE 6 (December 1902): 153. A short paragraph answering the question: "Into what languages has the Book of Mormon been translated and printed?" [L.D.]

T.223 "The Translation of the Book of the Mormon." Young Woman's Journal 4 (November 1892): 79-81. Provides suggestions for a lesson about the translation of the Book of Mormon. Emphasizes the role of Martin Harris. [E.G.]

T.224 Traum, Samuel W. Mormonism against Itself. Cincinnati: Standard, 1910. Chapters 1-10 of this polemical work against Mormonism deal with the Book of Mormon. The author considers the book a fraud on the basis that it contains gross anachronisms and absurdities such as the mention of steel and domesticated animals in America before Columbus. He attempts to discredit the testimonies of the Book of Mormon witnesses, raises the issue of the means of translation, finds corrections in the volume anachronistic, and discredits Mormon interpretations of 
Hebrew prophecies that are used to support the Book of Mormon. He also highlights what he sees as absurdities in Nephi's description of their desert journey, suggests that the claim of Israelite influence upon American peoples is unfounded and unsupported by any substantial evidence, discusses alleged philological and linguistic problems with the book, and asserts that there is no archaeological or historical evidence to support Book of Mormon claims. [M.R.]

T.225 "Traveling in the Wilderness." Friend 19 (August 1989): 8-10. Cartoon depiction for children of Lehi's family traveling in the wilderness. [J.W.M.]

T.226 "Treasure the Scriptures, Counsels Pres. Tanner." CN 43 (1 September 1973): 11. N. Eldon Tanner tells the members to study the scriptures, including the Book of Mormon. [M.D.P.]

T.227 Treat, Mary Lee. "Another 'Wise Purpose' for the Small Plates." ZR 11 (Winter 1981): 1-2. Discusses a possible "wise purpose" for the small plates. Since Nephi and Lehi experienced Jerusalem and the Old World their writings have a more distinct Jewish flavor to them. This is essential for a witness to Jews that Jesus is the Messiah and that the Book of Mormon is true. [A.T.]

T.228 Treat, Mary Lee. "A Call to Repentance." In Recent Book of Mormon Development, Articles from the Zarahemla Record, 2:214. Independence, MO: Zarahemla Research Foundation, 1992. As Treat was examining pottery in Guatemala, she thought how shameful it was that only pottery was left from a once-great nation. She realized that she must repent and the whole nation must repent or it will die as the Nephites died. [B.D.]

T.229 Treat, Mary Lee. "The Consistency of Satan's Tactics." ZR 62 (July/August 1992): 2-4. Summarizes the tactics and pitfalls of the three great anti-Christs, Sherem, Nehor, and Korihor. The blandishments resorted to by these three are recognizable today, both in and out of the church. [D.M.]

T.230 Treat, Mary Lee. "The Faith of Christ." ZR 64 (November/December 1992): 1, 4. Points out that the Book of Mormon prophets before Christ believed in and testified of Christ. Suggests that those who live at the current time follow their example. [D.M.]

T.231 Treat, Mary Lee. "The Lamb Chapter." ZR 41 (February 1989): 3. Nephi uses the word lamb 59 times. The term is found just a few other times in the Book of Mormon. John the Revelator uses lamb much more than other New Testament writers. Perhaps the frequent use of lamb by John and Nephi was due to their being shown the same vision. [A.T.]

T.232 Treat, Mary Lee. "The Learning of the Jews. The Purpose Principle in Action: Why Heads." ZR 42 (April 1989): 3. Also in Recent Book of Mormon Development, Articles from the Zarahemla Record, 2:42-43. Independence, MO: Zarahemla Research Foundation, 1992. According to the "purpose principle," everything in the Book of Mormon is there for a purpose. In Jacob 1:4 Jacob writes that he should engraven the heads of preaching, revelation, or prophesying on the plates. As used here, "heads" is a Hebraism meaning the most important or best of such teachings. [B.D.]

T.233 Treat, Mary Lee. "Maya Hieroglyphs for Cardinal Directions Found-Or North is North." ZR 32-33 (1986): 14. People deciphering Book of Mormon geography have argued about whether the Nephite "north" is true north. This article reports hieroglyphs found in Rio Azul that were oriented correctly to the cardinal directions. [A.T.] 
T.234 Treat, Mary Lee. "No Erasers." ZR 13-14 (Fall 1981): 5. Lists verses where mistakes were made by the engraver of gold plates and the way in which the engraver corrected them. These include 1 Nephi 2:41, 1 Nephi 3:245, and Alma 14:112 (RLDS versification). [A.T.]

T.235 Treat, Mary Lee. "O House of Israel." ZR 47 (February 1990): 3-4. This article presents the results of a word-by-word comparison of Isaiah passages used in the Book of Mormon. Entire verses and phrases are lost from the book of Isaiah in the Bible, and the biblical Isaiah had lost the concept of the restoration of the entire House of Israel. [A.T.]

T.236 Treat, Mary Lee. "Salvation: Not Just for the Life to Come." ZR 61 (May/June 1992): 3. Writes that salvation through Christ does not concern only the after-life reward but salvation from worldly evils during mortality. [B.D.]

T.237 Treat, Mya L. Review of Understanding the Difficult Words of Jesus, by David Biven and Ray Blizzard Jr. Recent Book of Mormon Development, Articles from the Zarahemla Record, 2:47-48. Independence, MO: Zarahemla Research Foundation, 1992. Book review.

T.238 Treat, Raymond C. "1980 and the Book of Mormon." ZR 12 (Spring 1981): 3. 1980 was a Jubilee year according to Jewish tradition. It was also a special year for the Book of Mormon. Three important events were "(1) the discovery of the original Anthon Transcript, (2) the presentation of a portion of the Book of Mormon in Hebrew to some Jews in Israel, and (3) the publication of Ralph Lesh's map of Book of Mormon geography." [A.T.]

T.239 Treat, Raymond, C. "Another Ancient Pattern: Chiastic Structure in the Book of Mormon." ZR 17, 18 (Summer/Fall 1982): 8-12. A brief review of an ancient literary form known as chiasmus. The material presented offers insight into the structure and history of chiasmus and its occurrence in the Book of Mormon as additional evidence to the book's historical authenticity. [D.S.T.]

T.240 Treat, Raymond C. "Another Example of Convergence: Transoceanic Contact." In Recent Book of Mormon Development, Articles from the Zarahemla Record, 1:19-21. Independence, MO: Zarahemla Research Foundation, 1992. Writes that "the present position of New World archaeology on the subject of transoceanic contact has converged and is in harmony with the Book of Mormon claim of limited contact." He quotes several sources to support his claim. [B.D.]

T.241 Treat, Raymond C. "Another Hebrew Breakthrough: The Importance of Midrash." ZR 57 (October 1991): 1. Reports that Angela Crowell's identification of midrash in the Book of Mormon brings new understanding of the book's Hebraic structure. [A.C.W.]

T.242 Treat, Raymond C. "Approaches to Studying the Book of Mormon." ZR 19, 20, 21 (Winter/Spring/Summer 1983): 10-13. The Book of Mormon is important and relevant today. The article outlines several different methods of Book of Mormon study and the merits of each: "the straight through method," "reading the research of others," "the topical method," examining definitions and synonyms, and pondering. [A.T.]

T.243 Treat, Raymond C. "Are You Listless? A New Revelation about the Book of Mormon." ZR 60 (March/April 1992): 2-4. Refers to a study by J. M. Cascione showing that the Bible contains lists of items in combinations of twos, threes, fours, fives, sixes, sevens, tens, and twelves, each of which is associated with a particular category, as in Hebrew poetry. Gives examples from the Bible and Book of Mormon. [D.M.] 
T.244 Treat, Raymond C. "Are You Really a Book of Mormon Believer?" In Recent Book of Mormon Development, Articles from the Zarahemla Record, 2:221. Independence, MO: Zarahemla Research Foundation, 1992. According to God, in order to be a true believer in the Book of Mormon one must evidence five elements. The true believer must feast on the words of Christ, ponder, know about types, know the story line, and do the things in verse 103 of Alma 14 (RLDS versification). [B.D.]

T.245 Treat, Raymond C. "Becan: A Dramatic Validation of a Book of Mormon Warfare Pattern." ZR 8 (Spring 1980): 1-3. Contains a map, restoration drawing, cross section and artist's reconstruction of the walls of Becan. This city, located in Guatemala, is perhaps one of the cities fortified by general Moroni as it has trenches dug outside the walls that correspond to the information found in the book of Alma. [A.T.]

T.246 Treat, Raymond C. "Benefits of In-Depth Study." ZR 22-23 (Fall 1983 and Winter 1984): 8-10, 13. This is a continuation of "Approaches to Studying the Book of Mormon" (ZR 19-21). Studying chiasmus, charting scriptures, defining words and phrases, identifying types, pondering and topical study, are all suggested as methods for understanding the Book of Mormon. The author gives examples of each. [A.T.]

T.247 Treat, Raymond C. "The Book of Mormon and Mesoamerican Outlines Compared: Beginning, Highpoints, and Endings." ZR 2 (September 1978): 1-2, 6. Compares the Jaredites to the Olmec people and states that the archaeological evidence shows that the OImec civilization began, had its high point, and ended at times that match the Jaredite civilization. Also compares the Mulekites, Nephites, and Lamanites with the Classic Maya. [A.T.]

T.248 Treat, Raymond C. "The Book of Mormon is Our Key to the Future." ZR 27-28 (Winter, Spring 1985): 813. Encourages readers to study and ponder the Book of Mormon to learn how the Book of Mormon is the "key to the future." The author has found five topics in which it helps us understand the future: "the gospel," "additional scripture," "zion," "the restoration of the house of Israel," and "more of Jesus Christ." [A.T.]

T.249 Treat, Raymond C. "A Book of Mormon Tour Guide: Chichen Itza." ZR 9 (Summer 1980): 5-8. Contains maps and photographs of Chichen Itza, a summary of the archaeological work, and "site description and culture history," as well as Book of Mormon correlations suggesting that this possibly was a Lamanite city. [A.T.]

T.250 Treat, Raymond C. "A Book of Mormon Tour Guide: Monte Alban." ZR 6 (Fall 1979): 2-7. Contains pictures, maps, site description, and Book of Mormon connections to of the ruins at Monte Alban. Author concludes that Monte Alban was possibly a Jaredite city as well as a possible Lamanite, Mulekite, or Nephite city. [A.T.]

T.251 Treat, Raymond C. "Book of Mormon Tour Guide: Palenque." ZR 19-21 (Winter, Spring, Summer 1983): 16-18, 24. Contains photographs, maps, drawings, site description, and archaeological notes of the temples at Palenque and proposes that Palenque is the city Bountiful. [A.T.]

T.252 Treat, Raymond C. "Book of Mormon Tour Guide-Part 4: Yaxchilan." ZR 19-21 (Winter, Spring, and Summer 1983): 6-9, 20. Contains maps, a topographical drawing, site description, and photographs of Yaxhilan and suggests that Yaxxchilan was Zarahemla. [A.T.]

T.253 Treat, Raymond C. "Book of Mormon Tour Guide: Teotihuacán-City of the Gods." ZR 4 (Spring 1979): 58. Gives a history of archaeological work and Book of Mormon correlations. Suggests that Teotihuacán is a city of the "land northward" spoken of in Alma and Helaman. [A.T.] 
T.254 Treat, Raymond C. "Book of Mormon Warfare: More Than Meets the Eye." ZR 65 (January/February 1993): 1-4. Book of Mormon warfare is a type for spiritual warfare. The 3 Nephi story of Lachoneus as an illustration of this principle. [A.T.]

T.255 Treat, Raymond C. "The Chinese Language and the Book of Mormon." ZR 12 (Spring 1981): 1-3. Examines work done by $\mathrm{C}$. H. Kang who has shown biblical influence in the make-up of Chinese characters. The author suggests that there is evidence of the "Jaredite Pattern" in the characters. [A.T.]

T.256 Treat, Raymond C. "Classic Maya Population: An Example of Convergence." ZR 1 (February 1978): 5. Considers archaeological evidence that shows Classic Maya population levels to be concurrent with those found in the Book of Mormon. [A.T.]

T.257 Treat, Raymond C. "Classic Maya Subsistence: Another Example of Convergence." ZR 1 (December 1978): 5, 8. Examines Classic Maya food to show a convergence between Mesoamerican archaeology and the Book of Mormon. Archaeologists are learning that population levels were too high to be supported by slash-and-burn agriculture. [A.T.]

T.258 Treat, Raymond C. "The Convergence Pace Quickens: Barley Found in the New World." ZR 22-23 (Fall 1983 and Winter 1984): 1-3, 14-15. Also in Recent Book of Mormon Development, Articles from the Zarahemla Record, 1:15-17. Independence, MO: Zarahemla Research Foundation, 1992. According to a scientific report, barley has been excavated from an ancient Indian site in Arizona. Such a discovery appears to be significant evidence of the authenticity of the Book of Mormon. [B.D.]

T.259 Treat, Raymond C. "Editorial Comment: Chiasmus in the News." ZR 47 (February 1990): 1. Comments on recent negative publicity given the Book of Mormon when Jefferey Lundgren convinced his followers that chiasmus was the only way God speaks in scripture. [A.C.W.]

T.260 Treat, Raymond C. "El Mirador: Massive Guatemala Site Shows Great Promise." In Recent Book of Mormon Development, Articles from the Zarahemla Record, 1:27-29. Independence, MO: Zarahemla Research Foundation, 1992. Describes some of the discoveries of the preliminary work done in El Mirador and concludes that it "promises to be one of the more interesting sites to believers in the Book of Mormon." [B.D.]

T.261 Treat, Raymond C. "The Four Levels." In Recent Book of Mormon Development, Articles from the Zarahemla Record, 1:148-53. Independence, MO: Zarahemla Research Foundation, 1992. The four levels in which God classifies individuals are the celestial, terrestrial, telestial, and no glory. In order to understand the life styles of each level, Treat uses the four responses to the word of God as found in Lehi's vision of the rod of iron, the parable of the sower, and Alma's parable of the seed. [B.D.]

T.262 Treat, Raymond C. "The Growing Together of the Bible and the Book of Mormon." In Recent Book of Mormon Development, Articles from the Zarahemla Record, 2:215. Independence, MO: Zarahemla Research Foundation, 1992. The ancient Hebrew nature of both texts is revealed as the Bible and the Book of Mormon "grow together" as prophesied in 2 Nephi 2:20-23 (RLDS versification). [B.D.]

T.263 Treat, Raymond C. "The Hidden Principle: Come unto Christ." ZR 65 (January/February 1993): 2-3. The phrase "come unto Christ" (or similar phraseology) is found 43 times in the Book of Mormon. This phrase "describes a covenant relationship," a spiritual covenant made before baptism (see Mosiah 18:10; 21:32-33). "To become as a little child" (3 Nephi 9:22) is synonymous with coming unto Christ. [A.T.] 
T.264 Treat, Raymond C. "The Importance of Covenant in the Restoration of the House of Israel." ZR 50 (August 1990): 3-4. The Book of Mormon begins and ends with the concept of covenant. It is found in the opening and closing verses. This article encourages Book of Mormon readers to study the covenants found in the Book of Mormon in order to gain understanding and to be "used by God to assist" in his work. [A.T.]

T.265 Treat, Raymond C. "The Lucy Mack Smith and Martin Harris Letters: The Continuation of a Pattern." ZR 17-18 (Summer and Fall 1982): 14-15. Contains a recently found letter by Martin Harris wherein he gives his testimony regarding the contents of the Book of Mormon. (Editor's note: this letter has since been proven to be a forgery.) [A.T.]

T.266 Treat, Raymond C. "Massive Guatemala Site Shows Great Promise." ZR 7 (Winter 1979-1980): 1-2, 7-8. Documents the history of archaeological work at El Mirador in Guatemala and suggests that this was a city abandoned by the Nephites about A.D. 300 (concurrent with the archaeological record). [A.T.]

T.267 Treat, Raymond C. "Mesoamerican Archaeology and the Book of Mormon." ZR 5 (Summer 1979): 1-2, 6-8. Through illustrated outlines, the article compares the major points of the Mesoamerican and Book of Mormon cultural histories. The evidence and correlations presented support the authenticity of Book of Mormon cultural history. [D.S.T.]

T.268 Treat, Raymond C. "Mesoamerican Linguistics." ZR 34 (1986): 4-6. Discusses the development of the Mayan language based upon the research of Cambell and Kaufman and proposes that the Mayan language is descended from that of the Nephites. Briefly discusses the relationship of the Olmec-Jaredite languages. [A.T.]

T.269 Treat, Raymond C. "Micmac-A Translation Key?" ZR 11 (Winter 1981): 5, 8. Reports the finding by Mark Hofmann of the original Anthon Transcript. (Editor's note: this transcript has since been shown to be a forgery.) [A.T.]

T.270 Treat, Raymond C. "More to Come: Six Steps to Spiritual Power." ZR 13-14 (Summer and Fall 1981): 8-9, 12-14, 16. Suggests a six step approach using the Book of Mormon to develop spiritual power-study, fast, pray, humility, faith in Christ, joy and consultation, yielding to God, sanctification, purification, spiritual power. Follow these steps to prepare to receive the remaining portions of the Book of Mormon and to bring forth Zion. [A.T.]

T.271 Treat, Raymond C. "Mormon's Hidden Message." ZR 10 (Fall 1980): 1-2, 4. Perhaps Mormon included so much information about geography in the Book of Mormon for the following reasons: to aid the gentiles in locating the remnant, to locate the Hill Cumorah, to provide a historical base similar to the Bible, and to enrich the understanding of the reader. [A.T.]

T.272 Treat, Raymond C. "Needed: A Revelation about Types." ZR 59 (January/February 1992): 2-4. Types in the scriptures are important for us to understand in order to get all we can from the scriptures. The Lehite's journey in the wilderness is a type of our spiritual journey, Nephite warfare descriptions are types, and the 158 years between Mosiah2 and the coming of Christ is a type of the period of restoration and the second coming. [B.D.]

T.273 Treat, Raymond C. "Never Murmur." In Recent Book of Mormon Development, Articles from the Zarahemla Record, 2:220. Independence, MO: Zarahemla Research Foundation, 1992. "The opening story of the Book of Mormon-the journey of Lehi and his group from Jerusalem to the Land of Promise-is a classic story of the contrast between murmuring and not murmuring." Murmuring or complaining is the result of unbelief. This is constantly shown in the examples of Laman and Lemuel. [B.D.] 
T.274 Treat, Raymond C. "A New Insight: Why Joseph?" ZR 58 (December 1991): 1, 4. The writers of the Book of Mormon emphasized that Lehi was a descendant of Joseph because they knew that the tribe of Joseph would be the means of saving the rest of the house of Israel in the last days. Those of the lineage of Ephraim and Manasseh will work together as the tribe of Joseph in the last days. [J.W.M.]

T.275 Treat, Raymond C. "The Primary Purpose of the Book of Mormon." ZR 61 (May/June 1992): 1-2, 4. Proposes that the primary purpose of the Book of Mormon is to inform the Lamanites concerning the covenants made to their fathers. The secondary purpose is to convince the Jews and Gentiles of Jesus' Christological mission. Suggests that we be more diligent in bringing the Book of Mormon to the attention of the Lamanites. [D.M.]

T.276 Treat, Raymond C. Recent Developments in Belize. Independence, MO: Foundation for Research on Ancient America, 1984. According to some Book of Mormon scholars, Belize is the most likely location of the Jaredite civilization. Archaeologists have found evidence to validate Book of Mormon historical references there. [J.W.M]

T.277 Treat, Raymond C. "The Significance of the Dead Sea Scrolls." ZR 66 (March/April 1993): 4. The author sees the publication of the Dead Sea Scrolls to be a catalyst for bringing the Bible and Book of Mormon together (2 Nephi 3:12). [A.T.]

T.278 Treat, Raymond C. "The Significance of Understanding the Difficult Words of Jesus." In Recent Book of Mormon Development, Articles from the Zarahemla Record, 2:49. Independence, MO: Zarahemla Research Foundation, 1992. The book, Understanding the Difficult Words of Jesus, by Biven and Blizzard argues that the thought patterns and idioms in the New Testament are Hebrew. Treat writes that "non-restoration Christian's... interest in the Hebrew nature of both the Old and New Testament is ... a necessary prelude to their recognition of the Hebrew nature-and consequently, the divinity - of the Book of Mormon." [B.D.]

T.279 Treat, Raymond C. "A Simplified Look at Mesoamerica." ZR 13-14 (Summer and Fall 1981): 7, 10-11, 15. Examines the archaeological finds from the Pre-Classic period (2000 B.C.-A.D. 100), and Classic (A.D. 100-900) in Mesoamerica. The author relates these finds to the Jaredite, Mulekite, Lamanite, and Nephite civilizations. Parallels are drawn between the Olmecs and the Jaredites as well as the Nephites/Lamanites and the Maya. [A.T.]

T.280 Treat, Raymond C. "Toward a Better Understanding of Science." In Recent Book of Mormon Development, Articles from the Zarahemla Record, 1:3. Independence, MO: Zarahemla Research Foundation, 1984. Scientists do not gradually accumulate knowledge in a continuous upward movement, but progress by jumping from one paradigm to another. Studying American archaeology can be rewarding as long as we realize which paradigm the archaeologists are using. If we realize this our testimonies of the Book of Mormon will not be affected by seemingly contradictory archaeological evidence. [B.D.]

T.281 Treat, Raymond C. "Transoceanic Contact: Another Example of Convergence." ZR 2 (Spring 1979): 1-2, 12. Mesoamerican archaeology is gradually converging with the pattern presented by the Book of Mormon. Article discusses recent evidence of ancient transoceanic contacts between the New and Old Worlds. [A.T.]

T.282 Treat, Raymond C. "Understanding Our Covenant." In Recent Book of Mormon Development, Articles from the Zarahemla Record, 2:34-39. Independence, MO: Zarahemla Research Foundation, 1992. Explains the steps in a Hebrew covenant as written by Richard Booker in The Miracle of the Scarlet Thread. If we understand the covenant that we have made with God we will not harm anyone, doubt will be dispelled, and we will receive power. The purpose of the Book of Mormon is to establish the covenant. [B.D.] 
T.283 Treat, Raymond C. "Volcanoes, Archaeology and the Book of Mormon." ZR 16 (Spring 1982): 1-2, 8. "This article discusses two ancient volcanic eruptions in El Salvador and their significance to the Book of Mormon." The eruptions were ca. A.D. 600 and ca. A.C.W. 260. The author predicts that further digs in these areas will uncover tremendous finds relating to the Book of Mormon. [A.T.]

T.284 Treat, Raymond C. "What is in the Book of Mormon is There for a Purpose." ZR 24/25/26

(Spring/Summer/Fall 1984): 12-15, 21-22. The Book of Mormon was written for today. The article contains three charts-one showing how the Book of Mormon contents were divinely controlled, one illustrating that we have less than one percent of what was written, and a chart of the eight tribes of Nephites. [A.T.]

T.285 Treat, Raymond C. "Wheat and Barley: Problem or Opportunity." ZR 1 (September 1978): 7-8. Because of scarcity of evidence, lack of interest, and faulty research design evidence of wheat and barley in the New World prior to the 1500s has not been located. With new technology, phytoliths (fossilized plant cells) will show the presence of these grains during Book of Mormon time periods. [A.T.]

T.286 Treat, Raymond C. "Wordprints: Further Evidence for Book of Mormon Authorship." ZR 22-23 (Fall 1983 and Winter 1984): 4-5, 15. Contains a brief review of Book of Mormon Authorship published by the Brigham Young University Religious Studies Center. The article contains a description of Manovia, Cluster Analysis, and Discriminant Analysis. These studies support the Book of Mormon claim that it was written by a number of ancient authors. [A.T.]

T.287 Treat, Ray, and Mary Lee Treat. "158 Years: A Type for Our Day." ZR 46 (December 1989): 1-4. Examines the possibility that the 158 years covered from the "Reign of King Mosiah II in 124 B.C. to the coming of Christ in A.D. 34" is a type of the Second Coming of Christ. [A.T.]

T.288 "Triple Combination Is Now off the Press." CN 51 (26 September 1981): 3. The newly published triple combination contains about 200 changes, most of which are minute and reflect the original wording of the 1840 edition of the Book of Mormon, and a new footnoting system. [J.W.M.]

T.289 Tryk, Loftes. The Best Kept Secrets in the Book of Mormon. Redondo Beach, CA: Jacob's Well Foundation, 1988. An attempt to show through several arbitrary tests the identification of "power words," "hidden meanings," and "subliminal" messages the erroneous nature of the Book of Mormon. Unable to account for complexities such as chiasmus in the Book of Mormon, the author proposes a Satanic inspiration theory for its origin. Several unique interpretations of the meaning of certain Book of Mormon proper names are proposed. This work is reviewed in P.210. [M.R.]

T.290 Tucker, Pomeroy. The Origin, Rise, and Progress of Mormonism. New York: D. Appleton, 1867. A polemical work that outlines the history of Joseph Smith, the publication of the Book of Mormon, and the history of the Church from an outsiders point of view. An attached appendix gives extracts from the Book of Mormon. [J.W.M.]

T.291 Tuckett, Madge Harris, and Belle Harris Wilson. The Martin Harris Story. Provo, UT: Press Publishing, 1983. A biographical treatise of Martin Harris that includes a discussion of his willingness to sacrifice much of his own property and personal life, in spite of his own doubts and apprehensions, to assist with the publication of the Book of Mormon. [J.T.]

T.292 Tullidge, Edward W. "The Coming Forth of the Book of Mormon." In Tullidge's Life of Joseph the Prophet, 693. Plano, IL: RLDS Church, 1880. Provides a detailed narrative of the coming forth of the Book of Mormon from 
Moroni's first visit to the publication of the book and organization of the Church. Uses Joseph Smith's own descriptions of events interspersed with accounts from Oliver Cowdery, Lucy Mack Smith, and the three witnesses. [J.W.M.]

T.293 Turnbull, John S. A Dictionary of the Book of Mormon. Salt Lake City: n.p., 1946? Defines proper names in the Book of Mormon. [D.M.]

T.294 Turley, Reid Pinegar, and Linda D. Turley. "The Book of Mormon." In Turley's And Ye Shall Teach, 25-38. N.p.: n.p., 1978. A collection of imaginative object lessons, as well as scriptural passages and quotes from leaders of the Church to aid teachers and speakers. [J.W.M.]

T.295 Turley, Richard E., Jr. "Seer Stones." In Encyclopedia of Mormonism, edited by Daniel H. Ludlow, 3:1293. 5 vols. New York: Macmillan, 1992. Joseph Smith records that the angel Moroni gave him the Urim and Thummim to translate the Book of Mormon. He used these and other seer stones in a variety of ways, but primarily to receive revelation. [J.W.M.]

T.296 Turner, Denise. “Anna's Book of Mormon Christmas." Ensign 20 (December 1990): 20-21. Anna, a new convert to the Church, received a Book of Mormon for Christmas. Her joy in the gospel was an inspiration to all who knew her. [J.W.M.]

T.297 Turner, Floy L, comp. Prophecies and Sermons from the Book of Mormon. Provo, UT: J. Grant Stevenson, 1965. Book of Mormon texts that focus primarily on visions, prophetic utterances, and sermons. [J.A.T.]

T.298 Turner, Floy L., comp. Readings from the Book of Mormon. Provo, UT: J. Grant Stevenson, 1965. An abridgment of the Book of Mormon for the purpose of introduction or review. [J.A.T.]

T.299 Turner, J. B. Mormonism in All Ages, or the Rise, Progress, and Causes of Mormonism with the Biography of Its Author and Founder Joseph Smith, Jr. New York: Platt and Peters, 1842. Pages 149-222 of this work deal critically with the Book of Mormon. Author is consigned to condemn both book and author to the flames. Joseph Smith's character is discredited and the testimony of Book of Mormon witnesses is dismissed. Turner shows how the book contradicts the Bible and contains absurdities and anachronisms. It plagiarizes the New Testament and is unworthy of the belief of any reasonable human being. [M.R.]

T.300 Turner, Jule Ann Bishop. "Costumes of Ancient Meso-America: An Art and Research Project." Closure Project (B.I.S.), Brigham Young University, Dept. of Independent Studies, 1990. Investigates the use of silk and cotton in Mesoamerica, considering a Book of Mormon time frame and geographical context. Discusses weaving and dyeing processes and symbols incorporated in costumes and clothing. [E.G.]

T.301 Turner, Orasmus. History of the Pioneer Settlement of Phelps \& Gorham's Purchase and Morris Reserve. Rochester, NY: William Alling, 1852. A history of Western New York. Discusses Mormonism and the origins of the Book of Mormon. The writer favors the Spaulding origin and dismisses the Book of Mormon as a "money making" scheme. [M.R.]

T.302 Turner, Orasmus. "Origin of the Mormon Imposture." Littell's Living Age 30 (July-September 1851): 42931. Exerpts from Turner's History of the Pioneer Settlement of Phelps \& Gorham's Purchase and Morris Reserve. Biographical account of Smith family with negative statements about Joseph's character and the gold bible he dug 
up from Mormon Hill. Discusses Martin Harris's role in the "translation" process, wishing that such a fraud could have been omitted to preserve the decency of the United States. [E.G.]

T.303 Turner, Rodney. "A Faith unto Salvation." In Studies in Scripture: Alma 30 to Moroni, edited by Kent P. Jackson, 16-27. Salt Lake City: Deseret Book, 1988. The false teachings of Korihor and the Zoramites contained in Alma 31-33 are indicative of latter-day false doctrines. To combat these heresies Alma presented the "virtue of the word of God." Faith in the Lord Jesus Christ and hope in him provides the antidote to the false teachings of the world. Prayer is an essential part of faith. [J.W.M.]

T.304 Turner, Rodney. "The Great Conversion." In Studies In Scripture: Vol. 7, 1 Nephi to Alma 29, edited by Kent P. Jackson, 205-29. Salt Lake City: Deseret Book, 1987. The mission of the Holy Ghost is most clearly defined in Mosiah 1-6. King Benjamin must have made an intense study of Nephi and the brass plates, applied their teachings in his life and taught others the same. Quickened by the Holy Spirit, King Benjamin was well aware of the Savior's teachings and the role of the Holy Ghost. [J.W.M.]

T.305 Turner, Rodney. Great Families of the Book of Mormon. Provo, UT: Brigham Young University, 1957. A series of five lectures dealing with five Book of Mormon families. The Lehite family featured two opposite characters-Nephi and Laman. The family of Mosiah included Mosiah, 1 , Benjamin, Mosiah2, and his four sons. The house of Alma represents "the greatest of the ruling houses in the Book of Mormon." This family included Alma 1 and Alma 2 , Helaman 1 , Helaman, Nephi, Lehi, and others. The family of Mormon (Mormon and Moroni) witnessed the decline and fall of the Nephite nation. The family of Christ is represented by those who become his spiritual sons and daughters. [D.W.P.]

T.306 Turner, Rodney. "The Infinite Atonement of God." In Studies In Scripture: Vol. 8, Alma 30 to Moroni, edited by Kent P. Jackson, 28-40. Salt Lake City: Deseret Book, 1988. Amulek's teachings to the Zoramites constitute chapters 34-55 of Alma. Contrary to the doctrine of Augustine, Amulek teaches that man is "carnal, sensual, and devilish by nature," but he is not doomed to stay that way. Through the Atonement of Christ men may rise above that nature to be given a kingdom in the Lord's eternal worlds. This life is a probationary state and whatever spirit that a man possesses in this life will rise with him in the resurrection. [J.W.M.]

T.307 Turner, Rodney. "The Lamanite Mark." In The Book of Mormon: Second Nephi, The Doctrinal Structure, edited by Monte S. Nyman and Charles D. Tate Jr., 133-57. Salt Lake City: Bookcraft, 1989. God is not racist, but it is not by chance that the color of one's skin differs from another's. God judges by looking upon the heart. The Lord blesses and curses according to an individual's righteousness or wickedness. "Marks" are symbolic of the withdrawal of the Spirit and are related to natural consequences of adopting negative characteristics. Dark skins were for the identifying process and can and will be lifted for the righteous. [J.W.M.]

T.308 Turner, Rodney. "Morality and Marriage in the Book of Mormon." In The Book of Mormon: Jacob through Words of Mormon, To Learn with Joy, edited by Monte S. Nyman and Charles D. Tate Jr., 271-85. Salt Lake City: Bookcraft, 1990. Stresses the plague that sexual sin has become. In the Book of Mormon immorality is listed as a sin. Nephites at certain times were considered more unrighteous than the Lamanites because of their immoral practices. The three great sins that plagued Book of Mormon peoples were denying the Holy Ghost, murder, and sexual immorality. [J.W.M.]

T.309 Turner, Rodney. "The Personal Message of the Book of Mormon." In Know Your Religion: Our Standard Works, 13-26. Provo, UT: Brigham Young University, 1958. Messages of the Book of Mormon include: free agency 
-the opportunity to make choices, faith-the key to perfect knowledge and eternal life; doing the right things for the right reason constitutes religion; our personal fellowship with Jesus Christ depends on our doing righteous things because we want to. [J.W.M.]

T.310 Turner, Rodney. "The Prophet Nephi." In The Book of Mormon First Nephi: The Doctrinal Foundation, edited by Monte S. Nyman and Charles D. Tate Jr., 79-97. Provo, UT: Brigham Young University Religious Studies Center, 1988. Briefly describes the lineage of Lehi, then examines the portion of the Book of Mormon dealing with Nephi, specifically focusing on Nephi's relationship with his brothers, the confrontation with Laban, Nephi's vision, the kingdom set up by Nephi in the Americas, and the Psalm of Nephi. [A.T.]

T.311 Turner, Rodney. "The Three Nephite Churches of Christ." In The Book of Mormon: The Keystone Scripture, edited by Paul R. Cheesman, S. Kent Brown, and Charles D. Tate Jr., 100-126. Provo, UT: Brigham Young University Religious Studies Center, 1988. The three churches of "organized bod[ies] of believers in Christ or God" established in the Book of Mormon by Nephi, Alma, and Jesus Christ are discussed. The rise and decline of each are outlined with modern-day applications. [J.A.T.]

T.312 Turner, Rodney. "Two Prophets: Abinadi and Alma." In Studies in Scripture: 1 Nephi to Alma 29, edited by Kent P. Jackson, 240-59. Salt Lake City: Deseret Book, 1987. Discusses Mosiah 14-18. Likening Abinadi to John the Baptist, the author points out that both were prophets of the law of Moses. They preached repentance, warned of the judgments of God, and testified of Christ. Both were victims of priestcrafts and both died violent deaths. They were preparatory prophets who paved the way of transition from old covenants under the law of Moses to the new covenants in Christ. Alma assumed the critical role of carrying on the message of salvation that Abinadi had presented and created a Zion society. [J.W.M.]

T.313 Tuttle, A. Theodore. "Field White to Harvest-South America." IE 68 (June 1965): 501-2. The South American people are descendants of Israelites who built great civilizations and walked and talked with the risen Lord. The Book of Mormon is a record of their departure from their homeland, their wars, and their destruction. Their legends still contain fragments of their Book of Mormon heritage. [J.W.M.]

T.314 Tuttle, A. Theodore. South America, Land of Promise. Provo, UT: Brigham Young University Press, 1964. "A land choice above all other lands" as declared in the Book of Mormon includes South America as well as North America. South America is a land of great potential. The call to students of BYU is to missionary work among the loving but underprivileged people of South America. [J.W.M.]

T.315 Tuttle, Carol Wagner. "I'm Afraid to Talk to My Neighbor about the Church Because ..." Ensign 18 (March 1988): 30-32. Analyzing our feelings is one way to understand our fear concerning giving away a Book of Mormon to nonmember friends, sharing a testimony, or inviting someone to meet the missionaries. [J.W.M.]

T.316 Tvedtnes, John A. "Book of Mormon Tribal Affiliation and Military Caste." In Warfare in the Book of Mormon, edited by Stephen D. Ricks and William J. Hamblin, 296-326. Salt Lake City: Deseret Book and FARMS, 1990. Examines evidence that tribal affiliation remained important in Nephite/Lamanite society throughout the entire Book of Mormon period and that military leaders tended to come from certain lineage groups. The author suggests that this is why such Nephite military leaders as Mormon, Moronihah and the two Moronis began their careers at such a young age. [J.A.T.]

T.317 Tvedtnes, John A. "Borrowings from the Parable of Zenos." In The Allegory of the Olive Tree: The Olive, The Bible, and Jacob 5, edited by Stephen D. Ricks and John W. Welch, 373-462. Salt Lake City, Deseret Book and 
FARMS, 1994. Many of the biblical and pseudepigraphic writers had access to the parable of Zenos and they each borrowed elements from it. The task of combining these many elements in order to write Jacob 5 would have been far beyond the capabilities of Joseph Smith. [J.W.M.]

T.318 Tvedtnes, John A. "Burial as a Return to the Womb in Ancient Near Eastern Belief." SEHA 152 (March 1983): 5-7. A textual and etymological study of evidence that the tomb was, in the ancient Near East, considered to be like the mother's womb. One of the words examined is the Hebrew maqôm, normally rendered "place" in English. Author cites examples of the use of the word in the Bible and Phoenician texts that mean "tomb." Examples from the Book of Mormon of the English word "place" are similarly used. [J.A.T.]

T.319 Tvedtnes, John A. "Colophons in the Book of Mormon." In Rediscovering the Book of Mormon, edited by John L. Sorenson and Melvin J. Thorne, 32-37. Salt Lake City: Deseret Book and FARMS, 1991. Defines colophons as signposts that most often appear following a text to recap, explain, or mark the end. Nephi and editors that followed him included many prefaces to the materials they abridged as well as summaries to conclude. These important highlights show the amount of editorial judgment required by the editors. [J.W.M.]

T.320 Tvedtnes, John A. "Colophons in the Book of Mormon." In Reexploring the Book of Mormon, edited by John W. Welch, 13-17. Salt Lake City: Deseret Book and FARMS, 1992. Many Book of Mormon chapters begin with a colophon, a statement by the author certifying that he is the author of the work. This was common among Egyptian documents and biblical writings. It served as a copyright. Nephi, Mormon, Alma, Enos, writings of Samuel the Lamanite, and others include one or more colophons in their writings. [N.K.Y.]

T.321 Tvedtnes, John A. "Composition and History of the Book of Mormon." NE 4 (September 1974): 41-43. A brief explanation of the origin and transmission of the various records compiled by Mormon into the book that bears his name. Accompanied by a flow chart. [J.A.T.]

T.322 Tvedtnes, John A. "Hebraisms in the Book of Mormon: A Preliminary Survey." BYU Studies 11 (Autumn 1970): 50-60. A condensed version also found in "I Have a Question: Since the Book of Mormon is largely the record of a Hebrew people, is the writing characteristic of the Hebrew language?" Ensign 16 (October 1986), 6466. Modified for publication in A Sure Foundation: Answers to Difficult Gospel Questions 21-26. Salt Lake City: Deseret Book. A survey of Hebraisms-Hebrew words, idioms, and expressions-contained in the Book of Mormon. The Hebraisms anciently endured the language alterations of the Nephites (see Mormon 9:33) and in the nineteenth century survived the translation of the gold plates from "reformed Egyptian" (Mormon 9:32) to English. Several Hebrew types found in the Book of Mormon are identified, including Hebrew plurals, idiomatic words and expressions, the repetition of the conjunction and, pronominal suffixes, the construct state, adverbs, the cognate accusative, and the employment of the Hebrew prepositional phrase bo. [D.W.P.]

T.323 Tvedtnes, John A. "The Hebrew Background of the Book of Mormon." In Rediscovering the Book of Mormon, edited by John L. Sorenson and Melvin J. Thorne, 77-91. Salt Lake City: Deseret Book and FARMS, 1991. Using earlier articles on this subject as a basis, the author has greatly expanded the range of Hebraisms and the number of examples used. [J.A.T.]

T.324 Tvedtness, John A. "The Hebrew Background of the Book of Mormon." Witness 77 (Summer 1992): 7-10. Portions of Tvedtnes's article from Rediscovering the Book of Mormon are reprinted here. The 1966 revision of the Book of Mormon corrected expressions that were considered awkward in English. This destroyed much of the evidence of the book's ancient characteristics and Hebrew language patterns. The Hebraic expressions found in the 1930 edition assist in proving the authenticity of the book. [B.D.] 
T.325 Tvedtnes, John A. "I Have A Question: What were the ages of Helaman's 'stripling warriors'?” Ensign 22 (September 1992): 28. Using the law of Moses' stipulation that Israelite soldiers be at least twenty years old, Tvedtnes examines the circumstances and time frame surrounding the people of Ammon, their oath, and their sons' appearance as valiant soldiers. Concludes that it is highly probable that the stripling warriors were between 21 and 26. [A.C.W.]

T.326 Tvedtness, John A. "Identification." NE 5 (May 1975): 50. A quiz to identify characters from the Book of Mormon and the Bible. [J.W.M.]

T.327 Tvedtnes, John A. "Isaiah Variants in the Book of Mormon." In Isaiah and the Prophets, edited by Monte Nyman, 165-77. Salt Lake City: Bookcraft, 1984. Originally presented at the "Isaiah and the Prophets" symposium held at Brigham Young University on March 19-20, 1982, this paper is a much abbreviated version of the longer study of the same name. Author selects various types of variants from the original study, with emphasis on those supporting the Book of Mormon version of Isaiah. [J.A.T.]

T.328 Tvedtnes, John A. "The Isaiah Variants in the Book of Mormon." Provo, UT: FARMS, 1983. An extensive examination of all of the Book of Mormon Isaiah quotes that vary from those given in the King James Bible. The author cites ancient Hebrew manuscripts and early Bible versions that also show variants, and classifies variants according to the degree of support they give to the Book of Mormon version. [J.A.T.]

T.329 Tvedtnes, John A. "King Benjamin and the Feast of Tabernacles." In By Study and Also by Faith, edited by John M. Lundquist and Stephen D. Ricks, 2:197-237. Salt Lake City: Deseret Book and FARMS, 1990. A considerably expanded version of the author's 1978 article, "The Nephite Feast of Tabernacles." The revision presents additional evidence to support the idea that the Nephite gathering in Zarahemla under King Benjamin was in celebration of the Israelite Feast of Tabernacles. [J.A.T.]

T.330 Tvedtnes, John A. "The Language of my Father." NE 1 (May 1971): 19. A combination Hebrew/Egyptian text was found at Arad, which may contain language similar to the "reformed Egyptian" in which the original Book of Mormon was written. [J.A.T.]

T.331 Tvedtnes, John A. "Linguistic Implications of the Tel-Arad Ostraca." SEHA 127 (October 1971). Originally presented as a paper at the 20th annual Symposium on the Archaeology of the Scriptures \& Allied Fields, the article examines some of the sixth century Hebrew ostraca uncovered at Arad, with emphasis on a combination Hebrew/Egyptian text that may be similar to the "reformed Egyptian" in which the original Book of Mormon was written. [J.A.T.]

T.332 Tvedtnes, John A. "Mormon's Editorial Promises." In Rediscovering the Book of Mormon, edited by John L. Sorenson and Melvin J. Thorne, 29-31. Salt Lake City: Deseret Book and FARMS, 1991. The consistency in Mormon's work as an editor is illustrated by the promises he made to return to specific topics and the fulfillment of those promises. In some cases, it was Mormon's son who accomplished what his father had set out to do. The author concludes that Mormon planned and executed his work. [J.A.T.]

T.333 Tvedtnes, John A. "The Nephite Feast of Tabernacles." Provo, UT: FARMS, 1978. Also in Tinkling Cymbals: Essays in Honor of Hugh Nibley, edited by John W. Welch, 145-77. Provo, UT: John W. Welch, 1978. An examination of textual evidence that the Nephite assembly conducted by King Benjamin in the city of Zarahemla (Mosiah 2-6) was a celebration of the Israelite Feast of Tabernacles. The author elicits evidence from the Bible and the Mishnah. [J.A.T.] 
T.334 Tvedtnes, John A. "A Phonemic Analysis of Nephite and Jaredite Proper Names." SEHA 141 (December 1977): 1-8. Originally presented as a paper at the 22nd annual Symposium on the Archaeology of the Scriptures \& Allied Fields, the article analyzes the sound system of the Nephite and Jaredite languages, using transliterations of names from these languages found in the English Book of Mormon. The author concludes that the Nephite names reflect the phonology of the Hebrew language, while the Jaredite names have a different origin. [J.A.T.]

T.335 Tvedtnes, John A. Review of Covering Up the Black Hole in the Book of Mormon, by Jerald and Sandra Tanner. Review of Books on the Book of Mormon 3 (1991): 188-230. Book review.

T.336 Tvedtnes, John A. Review of In Search of Cumorah: New Evidences of the Book of Mormon from Ancient Mexico, by David A. Palmer. SEHA 149 (June 1982): 9-10. Book review.

T.337 Tvedtnes, John A. Review of Little Known Evidences of the Book of Mormon, by Brenton G. Yorgason. Review of Books on the Book of Mormon 2 (1990): 260-66. Book review.

T.338 Tvedtnes, John A. Review of New Approaches to the Book of Mormon, edited by Brent Lee Metcalfe. Review of Books on the Book of Mormon 6/1 (1994): 8-50. Book review.

T.339 Tvedtnes, John A. Review of Since Cumorah, by Hugh W. Nibley. Review of Books on the Book of Mormon 2 (1990): 175-81. Book review.

T.340 Tvedtnes, John A. Review of The Use of the Old Testament in the Book of Mormon, by Wesley P. Walters. Review of Books on the Book of Mormon 4 (1992): 220-34. Book review.

T.341 Tvedtnes, John A. "The Sons of Mosiah: Emissaries of Peace." In Warfare in the Book of Mormon, edited by Stephen D. Ricks and William J. Hamblin, 118-24. Salt Lake City: Deseret Book and FARMS, 1990. Presents evidence from the Book of Mormon that the primary impetus for the Lamanite mission of the sons of Mosiah was to establish peaceful relations between the Nephites and the Lamanites. [J.A.T.]

T.342 Tvedtnes, John A. "The Theology of 'Battlestar Galactica.' "In Latter-day Science Fiction, edited by Benjamin Urrutia, 2:130-36. Ludlow, MA: Parables, 1985. The author alludes to elements shared by the Book of Mormon and stories in the television series "Battlestar Galactica," along with other peculiarly "Mormon" aspects of the series. [J.A.T.]

T.343 Tvedtnes, John A. "The Timing of Christ's Appearance to the Nephites." In When Did Jesus Appear to the Nephites in Bountiful. Provo, UT: FARMS, 1989. Originally presented as a paper at the annual Symposium on the Archaeology of the Scriptures \& Allied Fields, October 1988, the article challenges proposals by Kent Brown and Jerome Horowitz that Christ's appearance to the Nephites in the city Bountiful took place several months after his resurrection. [J.A.T.]

T.344 Tvedtnes, John A. "Vineyard or Olive Orchard?" In The Allegory of the Olive Tree: The Olive, The Bible, and Jacob 5, edited by Stephen D. Ricks and John W. Welch, 477-83. Salt Lake City, Deseret Book and FARMS, 1994. Also published as a preliminary report as "Vineyard or Olive Orchard?" Provo, UT: FARMS, 1992. Discusses the term vineyard and the term orchard as used in Jacob 5 and in the King James Bible. Semitic languages may imply a more general meaning to the word translated as vineyard. The broader sense of the word means "generous, good, fertile land," and may include both orchard and vineyard in Egyptian. In Coptic it may mean garden. The use of the word in Jacob 5 follows ancient tradition. [J.W.M.] 
T.345 Tvedtnes, John A. "Was Lehi a Caravaneer?" Provo, UT: FARMS, 1984. Challenges Nibley's suggestion (in Lehi in the Desert) that Lehi was involved in the caravan trade. He provides evidence that this was not the case and elicits evidence that Lehi's family may have been involved in metallurgy. [J.A.T.]

T.346 Tvedtnes, John A. "Was Mormon a Member of a Military Class?" SEHA 163 (April 1988): 3-5. Suggests that Mormon became a military leader because he belonged to a military caste whose responsibility it was to lead the Nephite armies. [J.A.T.]

T.347 Twain, Mark (Samuel Clemens). Roughing It. Hartford, CT.: American Publishing Company, 1872. Pages 108-41 contain a satirical commentary by the author on the Mormons. Author discusses the content and style of the Book of Mormon and finds it "insipid," "slow," and "tiresome." Joseph Smith appears to have plagiarized from the New Testament. [M.R.]

T.348 "Twenty-five Books That Have Changed America." CN 40 (8 August 1970): 15. The Book of Mormon is listed in Robert Down's Books That Changed America. Down draws parallels between the beginnings of early Christianity, early development of the Church and the coming forth of the Book of Mormon. [J.W.M.]

T.349 "Twenty-Second Day of September." MS 98 (16 September 1937): 600-601. Discusses the translation Joseph Smith made of the golden plates, the conclusion scholars have made, the Three Witnesses, and the Eight Witnesses. [L.D.]

T.350 "Two Manuscript Pages Acquired." CN 53 (21 August 1983): 14. Tells history of the original Book of Mormon manuscript and explains that Brent Ashworth obtained two pages of the manuscript. (Editor's note: these have since been shown to be forgeries.) [A.T.]

T.351 "Two Sets of Plates Make Up the Book of Mormon." CN 58 (25 June 1988): 10. Joseph Smith translated two sets of plates: the small plates of Nephi and the plates of Mormon. Includes a chart. [M.D.P.]

T.352 Tyler, Daniel. "The Book of Mormon." Juvenile Instructor 12 (1 July 1877, 15 July 1877, 1 August 1877, 15 August 1877, 15 September 1877): 147-48, 159-60, 170-71, 182-83, 212-13. Series on Book of Mormon evidences taken from Isaiah 29, Ezekiel 37, and Genesis 48 and 49. Accepts as valid the testimonies of the Book of Mormon witnesses. [D.M.]

T.353 Tyler, V. Lynn. "Marvelous Works and Wonders." Ensign 4 (July 1974): 54. Tells of the first missionary movement that occurred in Scandinavia. It was there that the first non-English Book of Mormon was printed (Danish). [M.D.P.]

T.354 Tyree, Alan. "Christian Witness of the Book of Mormon." SH 139 (June 1992): 231-34, 244. Focuses on how to be a credible witness, explains the three types of faithful Latter-day Saints, discusses faith, reason, and the Book of Mormon, explores Book of Mormon origins, and questions where the Book of Mormon fits into the subject of evangelism. Concludes that there is no reason to apologize for the Book of Mormon, and it should be accepted as scripture and a witness for Christ. [A.C.W.] 
U.001 Udall, Larry, and Gloria. "Book of Mormon Title Page Reset in Type." CN 60 (29 December 1990): 3. The original title page of the Book of Mormon was reset in type by Paul Miller. The new printing will go to the Museum of Church History. [M.R.]

U.002 Ultican, Helen. "Joy Comes in Witnessing about the Book of Mormon." In Recent Book of Mormon Development, Articles from the Zarahemla Record, 2:165. Independence, MO: Zarahemla Research Foundation, 1992. A testimony of the joy of sharing and witnessing of the Book of Mormon. [B.D.]

U.003 Ultican, Helen. "Lifted up in Pride." ZR 29-31 (Summer/Fall 1985/Winter 1986): 11, 21-22. A topical study of teaching about pride in the Book of Mormon. The author has found 61 references and reprints several of these passages with a commentary on each. The author cautions readers to avoid the snare of pride. [A.T.]

U.004 Underwood, Grant. "Book of Mormon Usage in Early LDS Theology." Dialogue 17 (Autumn 1984): 35-74. Doctrinal history or historical theology must be founded in scripture. This study explores the pre-Utah period of the use of Book of Mormon scriptures and identifies scriptures that were used most frequently and how they were understood. A comprehensive study is made with tables, graphs, and index references. [J.W.M.]

U.005 Underwood, Grant. "The Earliest Reference Guides to the Book of Mormon." Journal of Mormon History 12 (1985): 69-89. The study of the interpretations of the Book of Mormon text in the early days of the Church is helped by three documents called "reference guides." One is thought to have been printed in Kirtland in 1835 , another in 1841 as part of the first European edition of the Book of Mormon, and the third a year later in Philadelphia, about which little is known. [J.W.M.]

U.006 Underwood, Grant. "Insights from the Early Years: 2 Nephi 28-30." In The Book of Mormon: Second Nephi, The Doctrinal Structure, edited by Monte S. Nyman and Charles D. Tate Jr., 323-39. Salt Lake City: Bookcraft, 1989. Life's experience was a great testimony to early Saints of the validity of the Book of Mormon because 2 Nephi 2830 described the religious beliefs that prevailed in their day. Some early Mormon writers drew parallels between the scriptures in these chapters and popular religions of the day. The Lord may have been very specific in his description of Christianity in Joseph Smith's day. [J.W.M.]

U.007 Underwood, Grant. "Jacob 5 in the Nineteenth Century." In The Allegory of the Olive Tree: The Olive, the Bible, and Jacob 5, edited by Stephen D. Ricks and John W. Welch, 50-69. Salt Lake City: Deseret Book and FARMS, 1994. Early leaders of the Church understood the allegory of the olive tree and saw their roles as servants of the Lord to assist in the final pruning and grafting in of the Master's vineyard. They saw themselves as a true branch of the olive tree planted in the poorest spot of ground, and used passages of Jacob 5 in their sermons to encourage members to do good works and promote the building of Zion. [J.W.M.]

U.008 Underwood, Grant R. "The Millenarian World of Early Mormonism." Ph.D. diss., University of California, Los Angeles, 1988. Includes a chapter entitled, "The Book of Mormon and the Millenarian mind." Deals with the relationship between the Book of Mormon and early LDS concepts of the New Jerusalem, the role of the Lamanites as descendants of Joseph, and the gathering of Israel. Includes tables on early Book of Mormon citations in Church publications. [D.M.] 
U.009 "Unique Method of Recording Book of Mormon Readers." SH 74 (2 November 1927): 1275. Reports on the results of a new reading program and method of reporting pages read. [J.W.M.]

U.010 "An Unusual Mission." CN 43 (8 December 1973): 16. A story of a man who sought out the Three Witnesses and heard their testimony of the Book of Mormon. [M.D.P.]

U.011 "Update: Book of Mormon Translations." Ensign 20 (February 1990): 80. In the first 20 years the Book of Mormon was only printed in English, the next 127 years brought 30 translations, and in the last 10 years the book was translated into 63 additional languages. [J.W.M.]

U.012 "Update: Translation of the Book of Mormon." Ensign 21 (April 1991): 75. For twenty years after publication the Book of Mormon was printed only in English, but during the next 127 years, 31 translations were completed, and in the past 11 years, 64 new translations have been made. [J.W.M.]

U.013 Urrutia, Benjamin. "The Name Connection." NE 13 (June 1983): 38-41. A brief report on the possible origins and meaning of select Book of Mormon proper names-i.e., Mormon, Cumorah, Shiblon, and Mosiah. [J.A.T.]

U.014 Urrutia, Benjamin. Review of Early America and the Book of Mormon: A Photographic Essay of Ancient America, by Paul R. Cheesman. Dialogue 8 (Summer 1973): 92. Book review.

U.015 Urrutia, Benjamin. "Shiblon, Coriantumr, and the Jade Jaguars." SEHA 150 (August 1982): 1-3. The names "Shiblon" and "Corianton" relate to the lion cub. In ancient America the jaguar, which is in the same family as the lion, was prominent, as found in several artifacts. These relationships may go back to the Jaredites. [D.M.]

U.016 "'Use the Book of Mormon,' President Benson Tells Michigan Area Conference." Ensign 16 (December 1986): 68. President Benson said that "God told Mormon what to include in the abridgment for our day." The Book of Mormon is for us. We must use the book to answer objections. [J.W.M.]

U.017 "Use Book of Mormon to Counter Error, President Benson Teaches." Ensign 19 (January 1989): 75-76. Ezra Taft Benson told members to "use the Book of Mormon in handling objections to the Church." He gave a fourstep method on how to do so and said that the Book of Mormon "exposes the enemies of Christ, confounds false doctrine, lays down contentions, and fortifies the humble followers of Christ." [M.D.P.]

U.018 Utah Tract and Bible Society. Mormonism and the Bible, do they agree? More than half a hundred comparisons in deadly conflict. Salt Lake City: n.p., n.d. Compares fifty-three points of doctrine of the LDS church and the Book of Mormon that conflict with biblical passages. Includes eternal marriage, reception of the Spirit depends on the laying on of hands, and other faulty doctrines. [J.W.M] 
V.001 Valk, M. H. A. Van Der. De Profeet der Mormonen, Joseph Smith Jr. Kampen: J. H. Kok, 1921. Biographical account of the Smith family. Discusses Joseph's role as translator of the golden plates and his claims to expertise in the languages of antiquity. [A.C.W.]

V.002 Valletta, Thomas R. "The Captain and the Covenant." In The Book of Mormon: Alma, The Testimony of the Word, edited by Monte S. Nyman and Charles D. Tate Jr., 223-48. Provo, UT: Brigham Young University Religious Studies Center, 1992. A tribute to Moroni, a great man and general who used the covenant-making process to bring about peace between the Nephites and their enemies. Moroni defended his people's liberty and Mormon added this to his record for us to use in our times. [N.K.Y.]

V.003 "Valued Book of Mormon Copy and Quilt Are Special Gifts." CN 45 (15 November 1975): 4. Story of a first edition Book of Mormon given to President Spencer W. Kimball. [M.D.P.]

V.004 Van Allsburg, Phillip W., Jr. The Book of Mormon Dictionary: A Reference Guide for Young People. Monongahela, PA: n.p., 1983. Simplified for young people, this dictionary booklet provides definitions and illustrations of Book of Mormon words. [J.W.M.]

V.005 Van Den Berghe, Elizabeth S. "Edwin Dharmaraju Taking the Gospel Home to India." Ensign 20 (April 1990): 60-62. Converted through reading the Book of Mormon, Edwin Dharmarju arranged for the book to be translated into Telegu, one of the three most widely spoken languages in India. [J.W.M.]

V.006 Van Den Berghe, Elizabeth S. "His Faith Began with Physics." Ensign 23 (August 1993): 70-73. Narrates the conversion of Tom Ngo to the LDS church. A physics student, Tom gained a testimony of the Book of Mormon by studying its philosophical chapters first and by praying about its truthfulness. [S.H.]

V.007 Van Orden, Bruce A. "An Examination of the Strategies of Instruction Employed by Prophets and Teachers in the Book of Mormon and Their Potential Application to Current LDS Instructional Settings." M.A. thesis, Brigham Young University, 1975. A report on general philosophical principles of teaching and learning found in the Book of Mormon. Analysis of prominent figures such as Lehi, Nephi, Mormon, Alma, and Jesus Christ reveals their teaching preparation, purposes, and style, providing examples and principles of applications for current teachers in the LDS education system. [J.T.]

V.008 Van Orden, Bruce A. "The Indispensable Role and Activities of Unnamed Teachers in the Book of Mormon." In A Symposium on the Book of Mormon, 102-5. Salt Lake City: Church of Jesus Christ of Latter-day Saints, 1979. Little is said about those appointed to be priests and teachers under Jacob, Mosiah, King Benjamin, Alma, Alma the younger, and other leaders. The teachers are not named, but their work was vital to the success of the Church in those times. The same is true in the Church today. [N.K.Y.]

V.009 Van Orden, Bruce A. "George Reynolds: Loyal Friend of the Book of Mormon." Ensign 16 (August 1986): 48-51. This article traces the life of George Reynolds, emphasizing his love of the Book of Mormon and his work in studying and writing about it-especially for the purpose of training the youth of the Church in the Book of Mormon's history and doctrine. [S.P.S.] 
V.010 Van Orden, Bruce A. "The Law of Witnesses in 2 Nephi." In The Book of Mormon: Second Nephi, The Doctrinal Structure, edited by Monte S. Nyman and Charles D. Tate Jr., 307-21. Salt Lake City: Bookcraft, 1989. When revealing any new information to men, the Lord has always followed the law of witnesses. When a new dispensation is inaugurated there is more than one witness. Second Nephi is consistent with this law. In 2 Nephi 11, Nephi explicitly applies this law and connects the testimonies of Jacob, Nephi, and Isaiah with his own. His purpose is to prove to mankind of the mission and reality of Christ and that all men must come to him or perish. [J.W.M.]

V.011 Van Orden, Bruce A. "Sanctification by the Holy Ghost." In Doctrines of the Book of Mormon, 1991 Sperry Symposium, edited by Bruce A. Van Orden and Brent L. Top, 212-22. Salt Lake City: Deseret Book, 1992. The Book of Mormon speaks of sanctification by the Holy Ghost and by the blood of Christ. Alma teaches no one can be saved except his garments are cleansed from sin by the blood of Christ. The author lists 14 steps of sanctification given by Nephi and 27 teachings in Alma 5 that lead to sanctification. Alma concludes when we can not look on sin save it is with abhorrence, the process of sanctification is working. We must practice faith, repentance, develop humility, and yield our hearts unto God. [N. K. Y.]

V.012 Van Orden, Bruce A. " 'We Prophesy of Christ.' Ensign 20 (February 1990): 22-25. 2 Nephi is a record of four witnesses of Christ: Lehi, Jacob, Isaiah and Nephi. Each bear testimony of the restoration of Israel and of the importance of the Atonement in the lives of individuals. [J.W.M.]

V.013 Van Orden, Dell, and Gerry Avant. "The Century Before the Birth of Jesus." CN 58 (23 July 1988): 10. Beginning with 100 b.c., Book of Mormon history is compared with concurrent world history. [J.W.M.]

V.014 Van Orden, Dell, and Malan Heslop. "Book of Mormon-Place in Time." CN 53 (27 November 1983, 4 December 1983): 8-9, 8-9. Chart synchronizing Book of Mormon events with biblical and secular history, beginning with the Jaredites and continuing until the Nephite destruction. [A.C.W.]

V.015 Van Tramp, John C. Prairie and Rocky Mountain Adventures or Life in the West. St. Louis: Miller, 1859. A historical work that also gives a brief discussion of Joseph Smith and Mormonism. He appeals to the Spaulding theory to account for the book's origin. [M.R.]

V.016 Van Wagenen, Genevieve. "Get Out of That Rocking Chair." IE 67 (September 1964): 741. Author visited the grave of Oliver Cowdery, whose testimony of the Book of Mormon is found on the headstone. She desired to tell the Church membership to read the Book of Mormon, it contains hidden treasures. [J.W.M.]

V.017 Vance, Joseph A. "Book of Mormon Readings." MS 72 (7 April 1910): 212-15. Advances two explanations of how Joseph Smith was provided with duplicate texts covering the material in the lost 116 pages of translation. [R.H.B.]

V.018 Vandenberg, John H. "The Book of Mormon Restores Truth." CR (April 1974): 14-17. Members of the Church of Jesus Christ of Latter-day Saints are sometimes called "Mormons" because of the great prophet Mormon whose magnificent work was to write and compose most of the Book of Mormon. The book restores or expands upon many precious true doctrines, such as the nature of the godhead, corporeal individuality, revelation, and man's purpose and destiny. [R.C.D.]

V.019 Vandenberg, John H. "Touchstone of Truth." Ensign 4 (May 1974): 11-13. Also in CR 144 (April 1974): 1417. As a result of the apostasy numerous truths have been lost from the Bible. Many of the truths have been 
restored in the Book of Mormon. [B.T.]

V.020 Vanderwood, J. E. "How Science Confirms the Truthfulness of the Book of Mormon." SH 57 (3 August 1910): 757. Points to the archaeological ruins in Central and South America as scientific confirmation of the truthfulness of the Book of Mormon. [A.T.]

V.021 Vanderwood, J. E. A Story of the Ancestor of the American Indian: An Epic. Independence, MO: J. E. Vanderwood, 1936. Written in poetic form, this pamphlet was created for the express purpose of telling briefly the story and the preservation of the records that were to come forth in the last days as the Book of Mormon. [J.W.M.]

V.022 Varetto, Juan C. "El Libro de Mormon." El Expositor Bautista 36 (April 1943): 119-20. Sets forth an overview of the Book of Mormon while arguing that the Book of Mormon account is not based upon historical reality. [D.W.P.]

V.023 "Variety of Ways Being Used to Present Book of Mormon." CN 60 (28 July 1990): 3. Copies of the Book of Mormon are being made available free of charge to non-members through advertising in newspapers and television, distribution by missionaries. [M.R.]

V.024 Vellinga, M. C. Latest Light on Joseph Smith's Golden Plates. Los Angeles: International Truth Distributors, 1928. A critical tractate that focuses primarily upon the testimonies of the Three and Eight Witnesses who saw the golden plates from which the Book of Mormon was translated. The witnesses are accused of being spiritualists and having dreams and visions manufactured by the devil. Hallucinations and simply being fooled by Joseph Smith are other reasons given. [J.T.]

V.025 Vellinga, M. C. Mormon Mysteries Revealed. Los Angeles, CA: West Coast Publishing, 1927. Writes on a variety of Book of Mormon related subjects to show how the Mormon use of the Bible is incorrect. Discusses the restoration of the gospel by Joseph Smith, the coming forth of the Book of Mormon, the cessation of revelation, the antiquity of the Book of Mormon, "other sheep," and other items. Attempts to dispel the myths by using correct interpretations of the Bible. Finds that Joseph Smith is the author of the Book of Mormon. [J.W.M.]

V.026 Velt, Harold Iven. America's Lost Civilizations. Independence, MO: Herald House, 1948-1949. The high culture and notable achievements found in the archaeology of early American civilizations are outlined and shown to be consistent with the description of civilization found in the Book of Mormon. Christian influence in America before Columbus and Hebrew/Egyptian origins of American aborigines are also discussed in relation to the Book of Mormon. [J.T.]

V.027 Velt, Harold Iven. "The Origin of the Hawaiians." SH 87 (6 April 1940): 431-32. The similarities between the Hawaiian culture and the Mayas of Central America appear in the worship of a white god, Hebrew culture, and language. [J.W.M.]

V.028 Velt, Harold Iven. The Riddle of American Origins. Independence, MO: Herald House, 1941. Uses the Book of Mormon to answer some archaeological riddles, primarily the sudden appearance of great civilizations and subsequent degeneration in ancient America when an evolutionary process would normally be expected. [J.T.]

V.029 Velt, Harold Iven. The Sacred Book of Ancient America. Independence, MO: Herald House, 1952. Biblical prophecies fulfilled by the Book of Mormon and the lives and testimonies of the witnesses of the golden plates are 
reported and shown to support the authenticity of the Book of Mormon. The physical attributes, theological contents, and prophecies of the golden plates (Book of Mormon) are also discussed. [J.T.]

V.030 Velt, Harold Iven. "The Witnesses to the Book of Mormon." SH 92 (14 July 1945): 646-48. Declaring that it is ever God's way to try the faith of "the chosen few" rather than to demonstrate his power to the whole of mankind who may scoff and scorn, this article examines the testimonies of the witnesses to the Book of Mormon and the subsequent events that prove the validity of these testimonies. The angel verified the correctness of the translation and the witnesses never denied this important testimony. [J.W.M.]

V.031 Venderwood, J. E. "How Science Confirms the Truthfulness of the Book of Mormon." SH 57 (3 August 1910): 757. Points to the archaeological ruins in Central and South Americas as scientific confirmation of the truthfulness of the Book of Mormon. [A.T.]

V.032 Vernon, Gregory G. "The Lord Finds a Scripture." In Stories of Insight and Inspiration, edited by Margie Calhoun Jensen, 32-34. Salt Lake City: Bookcraft, 1976. Missionaries working in Alaska were prompted to let the Book of Mormon fall open to any scripture and the book opened to the story of Hagoth. The lady they were teaching was touched by the similarities to her own tribal traditions and indicated that the name Hagoth was familiar to her. [J.W.M.]

V.033 Vessels, Rodney J. The Book of Mormon Speaks. Minneapolis, MN: University of Minnesota Press, 1973. Analyzes the "rhetorical vision" in the Book of Mormon by looking at examples of discourse in the record, such as King Benjamin's address and the missionary discussions given by the sons of Mosiah. Demonstrates how salvation is proclaimed through the spoken word. [A.C.W.]

V.034 Vessels, Rodney J. "I Want to Be a Book of Mormon Missionary." NE 6 (April 1976): 6-8. Vessels tells of his experiences reading the Book of Mormon and lists five ways to become a Book of Mormon missionary. [M.D.P.]

V.035 Vest, H. Grant. "The Problem of Isaiah in the Book of Mormon." M.S. thesis, Brigham Young University, 1938. A textual analysis of the Isaiah scriptures found in the Book of Mormon compared with the King James Version. The similarities, often word for word, between the two texts are explained, but greater emphasis is given to the many differences found in the comparison. Where differences are noted, the Book of Mormon agrees with other versions of Isaiah texts-i.e. the Syriac, Septuagint, and Latin versions. Other differences are found to be Joseph Smith's own word choice while translating. [J.T.]

V.036 Vestal, Kirk H., and Arthur Wallace. The Firm Foundation of Mormonism. Los Angeles: LL Co., 1981. An apologetic work attempting to demonstrate evidence supporting Mormon beliefs. The authors provide a review of some of the evidence tending to support the Book of Mormon's complexity and authenticity. Among the topics discussed pertaining to the Book of Mormon are the Eleven Witnesses, archaeology, linguistic complexities, proper names, the allegory in Jacob 5, the Nephite monetary system, modern philosophies predicted by Book of Mormon writers, and others. [M.R.]

V.037 Vincent, Joseph E. Book of Mormon Lands. Mentone, CA: GEMAC, 1960?. A map published as a study aid for the Book of Mormon. It is not meant to definitively locate specific locations; however, the artist used Mesoamerica as the basis for assumptions. [J.T.]

V.038 Vincent, Joseph E. "Some Views on Book of Mormon Geography." In 14th Symposium on Archaeology of the Scriptures, 61-69. Provo, UT: Brigham Young University Press, 1963. Problems and methodology in defining Book 
of Mormon boundaries and geographic locations of cities, rivers, etc. are outlined. A map is included giving the author's version of Book of Mormon geography. [J.T.]

V.039 Vogel, Dan. "Anti-Universalist Rhetoric in the Book of Mormon." In New Approaches to the Book of Mormon, edited by Brent Lee Metcalfe, 21-52. Salt Lake City: Signature, 1993. Declares that the Book of Mormon audience was not ancient but modern. Its purpose was to counter the doctrine of universal salvation that was a predominant belief in Joseph Smith's day. This essay examines the rhetoric in the Book of Mormon that opposes the doctrine of universal salvation, the debate that took place in early American clutter, the Book of Mormon's role in this debate, and ways that the message of the book might have been perceived by those who first read it. The Book of Mormon contains a "general orthodox theological position." This work is reviewed in T.080. [J.W.M.]

V.040 Vogel, Dan. "The Earliest Mormon Concept of God." In Line Upon Line: Essays on Mormon Doctrine, edited by Gary James Bergera, 17-33. Salt Lake City: Signature, 1989. The social and theological context into which the Book of Mormon came in 1830 explains the earliest views of God by early Book of Mormon readers. It was viewed by those who closely examined the book as far from orthodox. An examination of those views and Book of Mormon passages concludes that the Book of Mormon came forth to correct false doctrine. Through continuing revelation and further understanding, Mormon theology developed toward an "increasingly heterodox direction." [J.W.M.]

V.041 Vogel, Dan. Indian Origins and the Book of Mormon. Salt Lake City: Signature Books, 1986. Author favors a nineteenth-century environmentalist explanation of the Book of Mormon's origin. He summarizes various ideas regarding the Hebrew origin of the American Indian during the centuries before and up to the time of Joseph Smith and attempts to show that these views have since been completely discredited. The Book of Mormon expresses these outdated and incorrect views of native Americans and can therefore be seen as a mere product of its day. [M.R.]

V.042 Vogel, Dan. "Is the Book of Mormon a Translation? A Response to Edward H. Ashment." The Journal of Pastoral Practice 5/3 (1982): 75-91. Responds to an earlier article by Edward Ashment ("The Book of Mormon-A Literal Translation?" Sunstone 5 (March-April 1980): 10-14). The writer cites early statements by Mormons and others regarding the literal word-for-word process of translating the Book of Mormon through the seer stone. The author rejects Ashment's assertion that the translation was conceptual in nature. [M.R.]

V.043 Vogel, Dan. "Mormonism's 'Anti-Masonick Bible."” John Whitmer Historical Association Journal 9 (1989): 1730. Examines the socio-political climate into which the Book of Mormon was introduced in Jacksonian America in 1830. As the term "secret combinations" was used almost exclusively when referring to Freemasonry, the Book of Mormon became known as the "Anti-Masonick Bible." Examines the Book of Mormon text to see how these antimasonic themes are woven throughout. [J.W.M.]

V.044 Vogel, Dan, ed. The Word of God: Essays on Mormon Scripture. Salt Lake City: Signature Books, 1990. A collection of essays, many of which were published previously in Dialogue, Sunstone, John Whitmer Historical Association Journal, Courage, and University Bulletin under other titles. Each essay that is Book of Mormon oriented appears in this bibliography listed under its respective author. This work is reviewed in M.307 and in R.419. [J.W.M.]

V.045 Voros, J. Frederic, Jr. Review of First and Second Nephi and Jacob through Mosiah, vols. 1 and 2 of Doctrinal Commentary on the Book of Mormon, by Joseph Fielding McConkie and Robert L. Millet. BYU Studies 29 (1989): 121. Book review. 
V.046 Voros, J. Frederic, Jr. "Was the Book of Mormon Buried with King Follett?: The Essential Unity of Joseph's Message." Sunstone 11 (March 1987): 15-18. The question "Did the new doctrine that was introduced in the King Follet Sermon 'bury' or eliminate the need for the Book of Mormon?" is explored. Within the LDS church there is a controversy concerning soteriology, the study of how the Atonement of Christ works. The redemptive philosophy emphasizes the Fall, rebirth, and redemption by grace, playing down human effort. The progressive philosophy emphasizes man's effort to learn and looks narrowly upon reliance on God. The conclusion reached is that the King Follet Sermon illuminated the Book of Mormon and wed the redemptive and progressive views. [J.W.M.] 
W.

W.001 W. Review of Indian Legends, by James W. Lesuer. MS 91 (28 March 1929): 202-3. Book review.

W.002 W., H. L. "The Question Box." Christian Century (30 June 1937): 841. Deuteronomy 5:22 records that the Lord wrote the Ten Commandments on stone tablets and Joseph Smith claims that the Lord gave him a record engraved on plates of gold. The question is what became of these plates? There are many ancient accounts of deities who delivered the law to an intermediary. This book holds a place of honor in the Mormon Church because of its supposed divine origin. [J.W.M.]

W.003 W., J. F. "On Proving the Book of Mormon." MS 81 (16 October 1919): 664-66. The manner in which individuals prove the Book of Mormon to be true is by applying Moroni's promise (Moroni 10:3-5)-by praying to God in the name of Jesus, having faith and a sincere heart. [D.W.P.]

W.004 W., R. C. "Egyptology and the Book of Mormon." IE 26 (February 1923, March 1923, April 1923): 311-27, 437-47, 546-54. Attempts to demonstrate the philological plausibility of the Book of Mormon. The author describes the reliability of Mormon 9:32-33, which says that to save space on the plates the authors wrote in a reformed or shorthand Egyptian, but that if they could have written in Hebrew the record would have been more precise. [D.M.]

W.005 Waddoups, William. "Martin Harris and the Book of Mormon." IE 26 (September 1923): 980-81. A presentation of two recorded testimonies of Martin Harris concerning his vision as one of the Three Witnesses. [D.M.]

W.006 Waddoups, Wm. M. "Traditions and Legends of the Polynesians." IE 23 (October 1920): 1072-76. Describes Hawaiian myths that resemble biblical myths. The writer asserts that they have myths of the Old Testament and not the New Testament because "Hagoth and his company, from whom we believe the Polynesian islanders originate, sailed from the Northern part of South America." Polynesians have a legend of a visit from one of the gods who promised he would return. The islanders mistook Captain Cook for the god Lono. [B.D.]

W.007 Wadsworth, Richard. "I Have a Question: Does the Book of Mormon prophesy of the prophet Joseph Smith?" Ensign 19 (April 1989): 52-53. Rarely is a prophet named by name in prophesy; however his mission is often foretold. The Book of Mormon has ten references to Joseph Smith's mission. [J.W.M.]

W.008 Wakefield, Chris. The Book of Mormon Chart of Men in Office. Idaho Falls, ID: C. L. Wakefield, 1984. A chronological chart of every man mentioned in the Book of Mormon and the offices held by each-i.e., prophet, king, military personality. [J.T.]

W.009 Wakeman, W. E. "The Lamanites, the Gentiles and Zion." SH 101 (15 March 1954): 249, 259. The Lamanites are the descendants of both Judah and Manasseh and possibly "the seed of Zedekiah." Gentile may apply to all non-Jewish nations of the world or to the separated house of Israel. [J.W.M.]

W.010 Waldman, Nahum, Alan Goff, and John W. Welch. "The Breaking of the Bow." Provo, UT: FARMS, 1983. The breaking of the bow symbolism of Near Eastern culture is present in the Book of Mormon. The symbolism has four parts: It represents military power, symbolizes the establishment of political mastery, exalts the power of God 
in the Old Testament, and symbolizes sexual vigor. Nephi's brothers accuse him of usurping power; while the bow was broken there was no peace. [J.W.M.]

W.011 Walker, Elder, and Sister Lionell. "Missionary Moments: Sent 'Sacred Book.'” CN 57 (19 September 1987): 16. Copies of the Book of Mormon presented to families in the Philippines encourage many to convert to Mormonism. [A.C.W.]

W.012 Walker, Gary Lee. "The Downfall of the Nephite Nation: Lessons for Our Time." In Studies in Scripture: Alma 30 to Moroni, edited by Kent P. Jackson, 139-48. Salt Lake City: Deseret Book, 1988. So murderous had the Gadianton robbers become in 3 Nephi 6-10, that the Lamanites and Nephites banded together and through their repentance they were delivered. Three short years found them prosperous and proud. Secret combinations arose to destroy the people of God and chaos reigned; tribal organization prevailed. Studying these chapters and applying the lessons found therein to our day is essential. [J.W.M.]

W.013 Walker, Ronald W. "Books Arrive." CN 49 (27 October 1979): 16. Missionary work began in Turkey in 1884, but progress was slow because of a lack of printed materials. In 1906 the Book of Mormon was available in Turkish, and 250 copies arrived but were impounded for two years by the government. They were released upon intervention by the U.S. Secretary of State. [M.R.]

W.014 Walker, Ronald W. Review of Joseph Smith and the Beginning of Mormonism, by Richard L. Bushman. Sunstone 10 (April 1985): 58. Book review.

W.015 Walker, Ronald W. "Task of Translation." CN 50 (1 March 1980): 16. The story of the translation of the Book of Mormon into Japanese. [M.D.P.]

W.016 Walker, Steven C. "More Than Meets the Eye: Concentration of the Book of Mormon." BYU Studies 20 (1980): 199-205. The Book of Mormon is a literary concentrated book, with few excess words, rare verbal superfluity, and little prolix. Its density compares to that of the King James Version of the Bible. Speaking of Book of Mormon history Walker states, "The Book of Mormon manages to cram over three thousand years' worth of complex migrations and wars and political upheavals and cultural evolutions and intimately detailed religious chronicles of several peoples into its 522 pages." Not only is the history concentrated, with selections and wording carefully chosen by inspired writers and editors, but the Book of Mormon contains many figures of speech that demonstrate stylistic brevity-such as aphorisms, parallelisms, humor, questions, and chiasmus. [D.W.P.]

W.017 Walker, Steven C., and Richard S. Van Wagoner. "Joseph Smith: 'The Gift of Seeing.' In A Book of Mormons, 287-94. Salt Lake City: Signature, 1982. Joseph Smith was the recipient of the plates at the hands of Moroni, and the subsequent translation was through the gift and power of God. [J.W.M.]

W.018 Wall, Gary L. "Book of Mormon Authenticity Battle Still Rages." Moody Monthly (November 1977): $10-11$. Three researchers claim that the Book of Mormon was written by Solomon Spaulding rather than Joseph Smith. [D.W.P.]

W.019 Wallace, Anthony. Among the Seneca Indians of New York. Fresno, CA: Book of Mormon Foundation, 1960. Events and predictions of the Book of Mormon are closely related to events that transpired among the Seneca Indians in the years 1798 and 1815. [J.W.M.] 
W.020 Wallace, Arthur. "The Allegory of the Tame and the Wild Olive Trees Horticulturally Considered." In Scriptures for the Modern World, edited by Paul R. Cheesman and C. Wilfred Griggs, 113-20. Provo, UT: Brigham Young University Religious Studies Center, 1984. The horticultural preciseness in the allegory of the olive tree recorded in Jacob 5-6 helps to show that Joseph Smith did not write the Book of Mormon, but translated it. Whoever wrote the allegory had a profound knowledge of the science of olive tree cultivation. [B.D.]

W.021 Wallace, Arthur. Can Mormonism be Proved Experimentally? Ann Arbor, MI: Edward Brothers, 1973. A partial revision of Evidence in Science and Religion (Los Angeles, CA: Arthur Wallace, 1966) by the same author. His description of "science vs. religion" contains most of the revisions. [J.T.]

W.022 Wallace, Arthur. Evidence in Science and Religion. Los Angeles: Wallace, 1966. Argues that science and religion cannot "prove" or "disprove" the existence of God; however, reason and faith each have their role to play in the pursuit of truth. Modern scientific methods along with modern revelation (i.e. Joseph Smith and the Book of Mormon) are outlined as a means for drawing conclusions concerning the reality of God. [J.T.]

W.023 Wallace, Arthur, compl. America's Witness for Jesus Christ: The Book of Mormon. Salt Lake City: Utah Publishers Press, 1978. An abridged version of the Book of Mormon with an emphasis on Christ-related material. Also includes an index of name-titles used in the Book of Mormon to describe Christ. [J.T.]

W.024 Wallace, Henry A. "Wallace Extols Power of Great Books As National Fair Is Opened by Publishers." New York Times (5 November 1937): 3. Many books, including the Bible, are cited for their powerful influence, and the Book of Mormon is extolled as "the most powerful" American religious book to come forth in the nineteenth century. Though it has affected only one percent of the people, that percentage was affected in such a profound way as to affect the whole of the United States. [J.W.M.]

W.025 Wallis, James H. "A Fascinating Story." MS 95 (6 April 1933): 225-29. Book of Mormon gives world new light on ancient history. Archaeology confirms its truth. Quetzalcoatl stems from Christ's visit. Hagoth's expeditions possibly settled South Pacific islands. Politics and war are highly developed in Book of Mormon, which is a divine record. [A.C.W.]

W.026 Walter, Charles. "The Book of Mormon." Scribner's Monthly 20 (1880): 613-18. An ex-Mormon, having met the daughter of Solomon Spaulding, tells Spaulding's "real" story. He includes Thurlow Weed's and Matilda Spaulding McKinstry's statements concerning the Manuscript Found. He finds that the Book of Mormon is a plagiarism of Spaulding's manuscript. [J.W.M.]

W.027 Walters, Wesley P. An Examination of B. H. Roberts' Secret Manuscript. Salt Lake City: Modern Microfilm Co., 1979. Seeks to prove that Roberts believed the Book of Mormon was of human origin and influenced by View of the Hebrews. [A.C.W.]

W.028 Walters, Wesley P. The Human Origins of the Book of Mormon. Clear Water, FL: Ex-Mormons for Jesus, 1980. Asserting that B. H. Roberts introduced the idea that Joseph Smith wrote the Book of Mormon himself, this article points out that the Book of Mormon is in conflict with scientific findings. Linguistically there is no link between Old and New World languages; all American races could not be from one family. Looking at the Book of Mormon carefully gives internal evidence that the origin of the book lies in the undeveloped mind of Joseph Smith. [J.W.M.] 
W.029 Walters, Wesley P. "Mormonism." Christianity Today 5 (19 December 1960): 8-10. A piece critical of Mormonism that contends that the Book of Mormon plagiarizes the New Testament, has undergone numerous changes, and contains strands of Protestant doctrines common to Joseph Smith's day. [M.R.]

W.030 Walters, Wesley P. "The Origins of the Book of Mormon." The Journal of Pastoral Practice 3/3 (1979): 12352. The author discusses two unpublished manuscripts written by B. H. Roberts dealing with the Book of Mormon, one entitled "Book of Mormon Difficulties" and the other "A Book of Mormon Study." The first manuscript discusses alleged anachronisms found in the Book of Mormon, and the second describes modern environmental factors that may have assisted Joseph Smith in producing the Book of Mormon. Walters considers that Roberts's arguments are just as valid now and asserts that Roberts may have lost faith in the Book of Mormon. [M.R.]

W.031 Walters, Wesley P. "The Spaulding Manuscript (or Affair)." The Journal of Pastoral Practice 2 (1978): 13344. Reports that three newspapers had recently published the news that a portion of the Book of Mormon has been "positively identified as having been written by the hand of Solomon Spaulding." [J.W.M.]

W.032 Walters, Wesley P. "The Use of the Old Testament in the Book of Mormon." M.A. thesis, Covenant Theological Seminary, 1981. The Book of Mormon incorrectly mingles Old and New Testament teachings and ideas. Walters attempts to show how the Old Testament provided models for the proper names and events of the Book of Mormon. He shows anachronistic uses of Old Testament passages in the Book of Mormon, including Isaiah variants. Joseph Smith incorrectly applied modern eschatological themes, such as those borrowed from Ethan Smith's View of the Hebrews, to Book of Mormon peoples living before the time of Christ. This work is reviewed in R.259, and in T.340. [M.R.]

W.033 Walters, Wesley P. "Whatever Happened to the Book of Mormon?" Eternity 31 (May 1980): 32-34. An evangelical approach to the Book of Mormon criticizing the work for various alleged anachronisms found in it. [M.R.]

W.034 Walton, Geri. "Converts Thank Prophet, Wife." CN 57 (12 September 1987): 12. Reports on the influence that President Benson's written testimony within a Book of Mormon had upon a family in Calgary, Alberta, Canada. [A.C.W.]

W.035 Walton, Veva (Fike). "A Review of the Book of Mormon." An Album of Reviews 9 (1966): 1-6. A straightforward description of the Book of Mormon. Concludes that the Book of Mormon will provide interesting reading for those who are interested in the gospel as taught in the Bible. [D.M.]

W.036 Wandell, Charles W. "Letter." TS 2 (15 September 1841): 544-45. Missionary letter sent to the Times and Seasons. Includes an excerpt of a statement by Charles Anthon, who describes the characters given to him by Martin Harris, with the intention of discrediting the LDS story about him. The author then cites works by Humboldt, Raffinesque, and Stephens to argue that Anthon's description unwittingly coincides with inscriptions found in Latin America. [D.M.]

W.037 Wanted! One Hundred Thousand Men and Women to Read the American Volume of Scripture. Chicago, IL: The Northern States Mission, n.d. This pamphlet makes a plea to read the Book of Mormon, with a brief overview of the book and the testimonies of the witnesses. [J.W.M.] 
W.038 "War and the Art of War among Book of Mormon Peoples." Relief Society Magazine 5 (October 1918): 59296. Methods of warfare in the Book of Mormon were elementary in the beginning but became more sophisticated with time and under Moroni grew to an art. Still the weapons were crude and the armaments were fairly ineffective and many people were killed, ravaged, and raped. [J.W.M.]

W.039 Ward, C. Fenwick. Mormonism Exposed [The Second of a Series of Lectures]: The Origin of Mormonism-Fiction or Fraud. Manchester: Taylor, Garnett, Evans, 1898. A polemical tract against the Book of Mormon in which the writer notes various absurdities in the book and the story of its origin. He discusses issues of translation, the character of the Book of Mormon witnesses, lack of scientific evidence, ethnological difficulties, Jaredite barges, and alleged Bible plagiarism. He appeals to the Spaulding theory to explain its origin. [M.R.]

W.040 "Ward Heeds Council to Read Book of Mormon." CN 60 (20 October 1990): 13. The Applewood Ward completed a program to read the Book of Mormon in ninety days, helping those who were reading it for the first time. [M.R.]

W.041 Ward, John H. "Ancient American Civilization." Juvenile Instructor 18 (1 January 1883): 4-7. Relates the Book of Mormon to archaeological finds throughout the Americas. Discusses marriage customs, baptism, and legends. Adds information about the Mexican calendar, textiles, and landscaping. [D.M.]

W.042 Ward, John H. The Hand of Providence: As Shown in the History of Nations and Individuals, From the Great Apostasy to the Restoration of the Gospel. Salt Lake City: Juvenile Instructor's Office, 1883. Relics have been discovered in almost every part of the western continent that testify of ancient civilizations. Ancient civilizations of America were highly developed. The Book of Mormon is their record. There are many evidences that indicate this is true: breast plates, elephant remains, architecture, bronze, fine cloth, and many others. [J.W.M.]

W.043 Ward, Thomas. "American Antiquities." MS 7 (1 March 1846, 15 March 1846): 67-71, 85-87. Millennial Star editor quotes writings by Josiah Priest and others concerning mounds found in the U.S., and then quotes excerpts from the book of Alma dealing with Moroni and his fortifications. [D.M.]

W.044 Ward, Thomas. "The Book of Mormon." MS 6 (15 August 1845): 65-70. Sacred works other than those contained in the Bible exist, as biblical authors have recorded-the Book of Jasher, Book of the Acts of Solomon, Book of Nathan, Book of Gad, and others. Using Old Testament references, the author claims that the seed of Abraham occupied the American Continent as well as the Old World. The stick of Joseph and the stick of Judah are combined in the Book of Mormon and the Bible. [J.W.M.]

W.045 Wardell, Julie. "Congratulations!" Friend 18 (December 1988): 21. For children, an award for reading the Book of Mormon. [J.W.M.]

W.046 Wardle, James D. "Book of Mormon Cross Reference: Index By Chapters." SH 97 (3 July 1950): 644-45. Contains tables of comparison between the RLDS and the LDS editions of the Book of Mormon. [J.W.M.]

W.047 Wardle, James D. Selected Changes in the Book of Mormon. Salt Lake City: Modern Microfilm Co., 1963. A list of select changes between the first edition of the Book of Mormon, published in 1830, and subsequent editions. Typographical errors as well as "intentional" and "deliberate" changes are noted. [J.T.]

W.048 Wardle, James D. "Shall We Improve the Book of Mormon?" SH 102 (21 March 1955): 273-74. The first edition of the Book of Mormon contained hundreds of typographical and grammatical errors. Minor changes have 
been made "which have improved the subject matter," but there are no material differences. Examples of changes that need to be made appear in the article, to the conclusion that there is a need to correct but not change the text. [J.W.M.]

W.049" 'Warm Heart' Is Answer to Child's Prayer about Book." CN 58 (31 December 1988): 8-9. A child's testimony of the Book of Mormon. [A.C.W.]

W.050 Warner, C. Terry. "Jacob." Ensign 6 (October 1976): 24-30. Jacob was a powerful teacher who had seen Christ face to face and enjoyed the ministrations of angels. Jacob was born in the wilderness, listened to Laman and Lemuel contend with his father and brother, and was not deceived. He faced Sherem, the anti-Christ, and also recorded the allegory of Zenos. [J.W.M.]

W.051 Warner, C. Terry. "An Open Letter to Students: On Having Faith and Thinking for Yourself." NE 1 (November 1971): 14-19. Uses the story of Alma and Korihor to teach about faith and reasoning. [M.D.P.]

W.052 Warner, Elisha. Old Testament Patriarchs. Salt Lake City: Max Warner, 1966. Contains many teachings of the Book of Mormon concerning the Old Testament patriarchs and a talk on the Book of Mormon. The author gives his view of what the Book of Mormon is and why Mormon wrote the book. [J.W.M.]

W.053 Warner, Ross W. The Fulfillment of Book of Mormon Prophecies. Salt Lake City: Hawkes, 1975. Believes that the Holy Ghost is the primary witness of the Book of Mormon but suggests that the reader's testimony of the book will also be enhanced by understanding the fulfillment of Book of Mormon prophecies. Prophecies discussed pertain to the coming forth of the Book of Mormon, Joseph the seer, America, the land of promise, the Gentiles, the Lamanites, the Jews, and the idea that there would be two churches only. [R.J.L.]

W.054 Warner, Ross W. "Prophecies in the Book of Mormon Relating to Our Times." In A Symposium on the Book of Mormon, 106-8. Salt Lake City: Church of Jesus Christ of Latter-day Saints, 1979. Provides a list of 54 prophecies given in the Book of Mormon and supplies a reference to where they have been discussed in Church literature. [N.K.Y.]

W.055 Warner, Ross W. "A Study of Problems Relative to the Fulfillment of Selected Prophecies in the Book of Mormon, with Particular Reference to the Prophetic View from 1830 Onward." M.S. thesis, Brigham Young University, 1961. "The purpose of this study is to classify under appropriate headings the prophecies of the Book of Mormon relating to the period 1830 to 1961, to see what evidence exists regarding the fulfillment of such prophecies and to summarize the findings. These prophecies have been classified under the following chapter headings: the Book of Mormon, Joseph the seer, America-land of promise, the Gentiles, the Lamanites, the Jews, and two churches only." [A.T.]

W.056 Warnick, Lee. "Book of Mormon in 80th Language." CN 58 (9 January 1988): 3, 7. The Book of Mormon is translated into seven new languages, making a total of 80 languages. [J.W.M.]

W.057 Warren, Bruce W. "A Cautious Interpretation of Mesoamerican Myth: Reflections Upon Olmec-Jaredite Roots." SEHA 154 (July 1983): 1-8. Suggests that some of the legends of the Popol Vuh have affinities with the book of Ether. Notes the meaning of "Shiblon" (lion cub) and a possible connection with Ixbalan (little jaguar). [D.M.] 
W.058 Warren, Bruce W. Review of An Ancient American Setting for the Book of Mormon, by John L. Sorenson. BYU Studies 30 (1990): 127. Book review.

W.059 Warren, Bruce W. Review of Christianity in America before Columbus? by Donald W. Hemingway. Review of Books on the Book of Mormon 2 (1990): 98-99. Book review.

W.060 Warren, Bruce W. Review of Deciphering the Geography of the Book of Mormon: Settlements and Routes in Ancient America, by F. Richard Hauck. BYU Studies 30/3 (1990): 127. Book review.

W.061 Warren, Bruce W. Review of The World of the Jaredites, by Hugh Nibley. UASN 27 (1 June 1955): 27.0. Book review.

W.062 Warren, Bruce W. Review of Their Mouths Are Stopped with Dust, by William A. Ritchie. UASN 15 (8 October 1953): 15. Book review.

W.063 Warren, Bruce W. "Secret Combinations, Warfare, and Captive Sacrifice in Mesoamerica and the Book of Mormon." In Warfare in the Book of Mormon, edited by Stephen D. Ricks and William J. Hamblin, 225-36. Salt Lake City: Deseret Book and FARMS, 1990. Writes concerning secret combinations and human sacrifice among Jaredite, Nephite, and later Mesoamerican societies, and sets forth their cruelty and depravity. [N.K.Y.]

W.064 Warren, Bruce W., and Thomas Stuart Ferguson. The Messiah In Ancient America. Provo, UT: Book of Mormon Research Foundation, 1987. New archaeological discoveries in Mesoamerica confirm the validity of the Book of Mormon. The authors discuss historical accounts, traditions, and myths and display photographs of ancient pictographs concerning Quetzalcoatl as the Christ figure in America who taught Christian values and ordinances. The Book of Mormon is another testament of Jesus Christ. This work is reviewed in S.742. [J.W.M.]

W.065 Washburn, Jesse A. Chronology Chart: Bible and Book of Mormon Events. Provo, UT: n.p., 1928. Contains four maps and a long fold-out chronological chart showing sacred and secular events from both the Bible and the Book of Mormon. [D.M.]

W.066 Washburn, Jesse A. "A Study of the Geography of the Book of Mormon as Found within the Record Itself." M.S. thesis, Brigham Young University, 1940. Examines the travel and geographical locations of the Jaredites, Mulekites, Nephites, and Lamanites. The issue of birth and death rates in relation to population size is also discussed. [R.J.L.]

W.067 Washburn, Jesse A., and Jesse N. Washburn. An Approach to the Study of Book of Mormon Geography. Provo, UT: NE, 1939. The author believes the geographical background of Book of Mormon events influences other aspects of the record, such as doctrinal interpretations. Scriptural references of the travel and place locations of the Jaredites, Mulekites, Nephites, and Lamanites are enhanced by discussion of population sizes, simple maps, and other illustrations. [R.J.L.]

W.068 Washburn, Jesse A., and Jesse N. Washburn. From Babel to Cumorah. Provo, UT: New Era Publishing, 1937, [R]1958. This book conveys in narrative form the journeys of the Book of Mormon people, beginning with the Jaredites and concluding with Moroni. Provides a chronological sequence of events contained in the sacred record. [J.W.M.] 
W.069 Washburn, Jesse N. An Army with Banners: A Story from the Book of Mormon. New York: Carlton Press, 1972. A fictional account based on a series of incidents recorded in the Book of Mormon, Alma 46-62. Captain Moroni's military campaigns are a significant part of the story line. [R.J.L.]

W.070 Washburn, Jesse N. Book of Mormon Geography for Sunday School Teachers and Others. N.p., 1977. An intensive study of Book of Mormon geography for Sunday School teachers. The author includes six maps and a list of all the Book of Mormon passages dealing with geography. His conclusions are general-placing Book of Mormon locations in Central America or southern Mexico. [A.T.]

W.071 Washburn, Jesse N. Book of Mormon Guidebook and Certain Problems in the Book of Mormon. Orem: Washburn, 1968. A student manual that discusses the geographical setting, organizational structure, and narrative storyline of the Book of Mormon. To a lesser extent, doctrinal teachings are also examined. These areas of study are divided into three parts involving the Jaredites, Mulekites, and Nephites. [R.J.L.]

W.072 Washburn, Jesse N. Book of Mormon Lands and Times. Bountiful: Horizon, 1974. Exploring the commentary, narrative, and setting of the Book of Mormon, Washburn applies scholarly and geographical theory to point out the consistency of detail. Such consistency helps establish its divine origin. [J.W.M.]

W.073 Washburn, Jesse N. The Contents, Structure and Authorship of the Book of Mormon. Salt Lake City: Bookcraft, 1954. Analyzes the complex nature of the Book of Mormon, chapter by chapter, and looks at poetry, message, historical narrative, parables, and language. The Book of Mormon will stand any test for authenticity. [J.W.M.]

W.074 Washburn, Jesse N. The Miracle of the Book of Mormon. Orem, UT: Book Production Services, 1984. Divides the Book of Mormon into elements of doctrine, narrative, geography, structure, and miscellany. Correlates Book of Mormon scriptures with biblical chronological events, divides the geography into four lands (maps are included), the way in which the book is presented, and miscellaneous items of poetry and chiasmus. [J.W.M.]

W.075 Washburn, Jesse N. "Mulek of Zarahemla." IE 51 (January-October 1948): 22-24, 48, 53, 90-92, 154-56, 218-20, 296-97, 336-37, 378-80, 442-43, 506-7, 535-36, 566-67, 603-5, 634-36. A novel based on the fictional character Mulek, an inhabitant of the city of Zarahemla during the war between Amalickiah and Moroni. [S.H.]

W.076 Washburn, Jesse N. The Son of Mormon. Ogden, UT: n.p., n.d. Central to the Book of Mormon are the prophets Mormon and Moroni. Moroni abridged the Book of Ether and authored Mormon 8-9 and the book of Moroni. Washburn presents a fictitious narrative of Moroni's story told in first person as though Moroni had recorded it. [J.W.M.]

W.077 Watkins, Arthur V. "The Nephite Shepherd, Part One: I, The Awakening of Zemnarihah and II, Prophecy of Samuel the Lamanite." IE 13 (November 1910): 64-68, 120-24, 239-45, 297-301. "The Nephite Shepherd, Part Two: I, Tomorrow-and then-a Kingdom! and II, Watching and Waiting." IE 14 (November 1911): 64-68. This series is a fictional story of Zemnariah, Kishkumen, and their Gadianton society, the prophecy of Samuel the Lamanite, the secret plans to put to death the believers of Samuel the Lamanite's prophecies, the miraculous light that saved them, and the renewed faith in the Savior as the signs of his birth appeared in the heavens. [J.W.M.]

W.078 Watson, Wingfield. The Book of Mormon. An Essay on Its Claims and Prophecies. Boyne, MI: n.p., 1884. In defense of the Book of Mormon, this author briefly explains the contents of the book, then gives twelve truths about it, some of which are: no man can prove that it is not true; there is no ground to reject it as revelation from 
God; it is supported by witnesses; is not opposed in any way to science; it does not oppose the teachings of the Bible; its teachings improve lives. [J.W.M.]

W.079 Watson, Wingfield. Latter-day Signs, The Book of Mormon. Lyons: n.p., 1897. The Book of Mormon fulfills the promise that the gospel would be preached in all the world (Matthew 24:14). In spite of the "army of sectarian preachers" who combine against it, the Book of Mormon will spread throughout the earth. Signs and wonders will follow those who believe. The gospel is the same in the Book of Mormon as in the New Testament, but the Book of Mormon clarifies passages that are difficult to understand. It is also warning voice. [J.W.M.]

W.080 Watt, Ronald G. " 'Had You Stood in the Presence of Peter,' A Letter From Oliver Cowdery to Phineas Young, 1846." Ensign 7 (February 1977): 78-79. As one of the three witnesses to the Book of Mormon, Oliver Cowdery had been an important asset to the Restoration. He assisted in the translation of the Book of Mormon and stood in the presence of angels, including Peter. This letter includes his petition to be allowed to return to the Church. [J.W.M.]

W.081 Watt, Ronald G. "Long Search Ends." CN 42 (8 October 1977): 20. A conversion story of a man who was interested in the gospel when he heard Oliver Cowdery testify that he did see the gold plates and the angel. [M.D.P.]

W.082 Wauchope, Robert. Lost Tribes and Sunken Continents: Myth and Method in the Study of American Indians. Chicago: University of Chicago Press, 1962. Chapter 4 is titled "Lost Tribes and the Mormons." Edward King and others of his time held to the theory that the Mesoamerican people were descendants of the "Lost Tribes of Israel." The Church of Jesus Christ of Latter-day Saints denies the Book of Mormon is about the Lost Ten Tribes but asserts that Hebrews of Jerusalem came to America. Parallels between the Book of Mormon and accounts of Ixtilxochitl and Popol Vuh seem to support the Book of Mormon. [J.W.M.]

W.083 Wayne, John Lakmord. "Solomon Spaulding's Manuscript." Hobbies-The Magazine for Collectors 51 (July 1946): 78, 79, 82. This article passes on much misinformation about the Spaulding story, seemingly unaware of what has been written since the mid-1880s. "No copy of this curious romance of a pre-historic American race is now known to exist. The discovery of the manuscript would mean a fortune to the person discovering it." [D.M.]

W.084" 'We Add Our Witness': Living Prophets Share Their Feelings about the Book of Mormon." Ensign 19 (March 1989): 5-9. Testimonies about the Book of Mormon from living prophets and apostles, including Ezra Taft Benson, Gordon B. Hinckley, and Thomas S. Monson. [L.D.]

W.085 Weaver, Gregg. "Finding the Word of God." In Stories of Insight and Inspiration, edited by Margie Calhoun Jensen, 41-43. Salt Lake City: Bookcraft, 1976. In his search for a religious philosophy this man had neglected Christianity. He was impressed to read about Jesus Christ. In spite of intentions to read the Bible to learn about the Son of God, he found himself reading the Book of Mormon and received a testimony of the Savior. [J.W.M.]

W.086 Webb, Robert C. (James Edward Homans). The Case Against Mormonism. New York: L. L. Walton, 1915. A response to criticisms raised by various critics of Mormonism, written by a non-Mormon under the pseudonym of Robert C. Webb. Provides a discussion of prominent criticisms of the Book of Mormon including the Anthon denials, reformed Egyptian, Solomon Spaulding, Shakespeare, and modern phrases. [M.R.]

W.087 Webb, Robert C. (James Edward Homans). "Egyptology and the Book of Mormon." IE 26 (February-April 1923): 311-27, 437-47, 546-54. Essay that proposes that the characters on the gold plates were derived from 
Hieratic or Demotic Egyptian (Mormon 9:32-33). Analysis of other major written languages available ca. 600 B. C. -i.e. Phoenician-Hebrew, Egyptian hieroglyphs, cuneiform-reveals that they do not meet the writing requirements outlined in the Book of Mormon itself. The nature of the gold plates as an alloy is also discussed. [J.T.]

W.088 Webb, Robert C. (James Edward Homans). Joseph Smith as Translator, A Candid Examination of His Claims to Have Translated the Book of Mormon. Salt Lake City: Deseret News Press, 1936. A non-Mormon writing under the pseudonym of Robert C. Webb discusses issues relate

W.089 Webb, Robert C. (James Edward Homans). The Real Mormonism: A Candid Analysis of an Interesting But Much Misunderstood Subject in History, Life and Thought. New York: Sturgis and Walton, 1916. A response to various anti-Mormon criticisms, written by a non-Mormon under the pseudonym of Robert C. Webb. Discusses the coming forth of the Book of Mormon and the numerous theories of Book of Mormon origins raised by unbelievers. [M.R.]

W.090 Webb, Robert C. (James Edward Homans). "Truth Seeking: Its Symptoms and After Effects." IE 16 (13 September 1913): 1075-91. Also in DN (5 July 1913): 8-9. A response to Reverend F. S. Spalding's pamphlet Joseph Smith, Jr., as a Translator. Spalding attacks the Book of Mormon by testing the translation of the book of Abraham, saying that the validity of the Book of Mormon rests upon the correct translation of the book of Abraham. Webb warns that the opinions of the scholars contacted are merely opinions and premature as well. [J.W.M.]

W.091 Weddle, Donna. Book of Mormon Studies for Youth: Fullness of the Gospel. Independence, MO: Mothers in Israel, 1984. Four lesson manuals for youth. Prepared largely for secondary school students. Contains objectives, commentary, and questions. [D.M.]

W.092 Weed, Grant B. Speeches Given As a Part of a Series on Sunday Evening on Temple Square. N.p., 22 June 1958. The Book of Mormon is a history of God's dealings with his people as is the Bible. It teaches gospel principles with clarity. [J.W.M.]

W.093 Weed, Harriet A., ed. Autobiography of Thurlow Weed. Boston: Houghton, Mifflin, and Company, 1884. Pages 358-59 contain Thurlow Weed's recollection of his rejection of the opportunity to print the Book of Mormon in 1830. He considers Joseph Smith to have been an impostor. [M.R.]

W.094 Weeks, Marvin E. Consolidated Concordance: Book of Mormon, Doctrine and Covenants, Inspired Version of the Bible. Independence, MO: School of Saints, 1984. Contains hundreds of topics with scriptural cross-references from the Book of Mormon, Doctrine and Covenants, and the Inspired Version of the Bible. [J.W.M.]

W.095 Weight, G. Dale. "A Great Guide in Solving Problems." Instructor 105 (October 1970): 362-63. Demonstrates Book of Mormon's influence on youth. Stories of Alma the Younger, Enos, Ammon, Joseph Smith, and Jesus Christ are especially applicable; the Book of Mormon gives youth a "cause" with which to identify. [A.C.W.]

W.096 Weiland, Kurt. Review of Warfare in the Book of Mormon, edited by Stephen D. Ricks and William J. Hamblin. Review of Books on the Book of Mormon 3 (1991): 141-146. Book review. 
W.097 Weiner, George. "America's Jewish Braves." Mankind 4 (n.d.): 56-64. In 1644 Antonio de Montezinos, a Jewish adventurer, declared he had found the lost Ten Tribes in America. The Spanish, who in the Inquisition tried to eliminate Jewish influence, continued to do so in America. They destroyed artifacts and architecture that made the link. The belief that the Lost Ten Tribes were in America has had a profound influence on the history of the world. Among the books written supporting this theory, the Book of Mormon is a significant work. [J.W.M.]

W.098 Weiser, R. "Mormonism." Evangelical Review 10/37 (1859): 80-100. Supercilious essay on the Mormon system, including the Book of Mormon: "When the Golden Bible was first announced ... it was considered too ridiculous for serious refutation." The author discusses Spaulding, Book of Mormon witnesses, Anthon, and the plates. [D.M.]

W.099 Weisman, Howard. "The Lord Is with Us." Ensign 20 (April 1990): 30-32. The Holy Ghost bore witness to this Jewish convert of the truthfulness of the Book of Mormon. He was able to understand his Jewish religion and the purpose of the temple better, and to unite his family in death as they had been in life. [J.W.M.]

W.100 Welburn, Judith. "Like Ripples on a Lake, Book Has Endless Influence on Lives." CN 59 (19 August 1989): 11-12. An illness gave this author time to read the Book of Mormon and she was converted by its message. The book, left by unknown missionaries, resulted in 21 baptisms. [J.W.M.]

W.101 Welch, John W. "Alma 36: A Masterpiece." In Rediscovering the Book of Mormon, edited by John L. Sorenson and Melvin J. Thorne, 114-131. Salt Lake City: Deseret Book and FARMS, 1991. A popular condensation of Welch's "Chiasmus in Alma 36." Provo, UT: FARMS, 1989. Alma 36 is an excellent example of chaismus in the Book of Mormon. [J.W.W.]

W.102 Welch, John W. "Ammon and the Cutting Off the Arms of Enemies." In Reexploring the Book of Mormon, edited by John W. Welch, 180-82. Salt Lake City: Deseret Book and FARMS, 1992. In the ancient Near East, it was a common practice for conquering soldiers to remove victim's body parts as a sign of victory, or perhaps also to obtain an accurate accounting of the dead. Cutting off arms became a customary punishment for thieves in the Moslem world. It may have been symbolic. The story of Ammon fits these ancient Near Eastern traditions. [J.W.M.]

W.103 Welch, John W. "Ancient Near Eastern Law and the Book of Mormon." Provo, UT: FARMS, 1981. Displays five ways the study of biblical law can enhance Book of Mormon understanding and five cases where the Book of Mormon can shed light on biblical legal studies. [J.W.W.]

W.104 Welch, John W. "B. H. Roberts: Seeker after Truth." Ensign 16 (March 1986): 56-62. Reprinted in A Sure Foundation: Answers to Difficult Gospel Questions, 60-74. Salt Lake City: Deseret Book, 1988. Historical explanation of why B. H. Roberts wrote a Book of Mormon study forcefully pointing out problems that defenders of the faith should address, especially regarding the View of the Hebrews and American antiquities; gives evidence that Roberts did not lose faith in the Book of Mormon. [J.W.W.]

W.105 Welch, John W. "Benjamin's Speech: A Classic Ancient Farewell Address." In Reexploring the Book of Mormon, edited by John W. Welch, 120-23. Salt Lake City: Deseret Book and FARMS, 1992. Certain themes appear consistently in farewell addresses of many ancient religious and political leaders, as if the speakers were following a pattern. Recent research finds Benjamin's speech to be the most complete example of this speech topology yet found anywhere in world literature. [R.H.B.] 
W.106 Welch, John W. "Book of Mormon Religious Teachings and Practices." In Encyclopedia of Mormonism, edited by Daniel H. Ludlow, 1:201-5. 5 vols. New York: Macmillan, 1992. Describes basic doctrines as taught by Jesus: repentance, baptism, priesthood authority, sacrament prayers, church worship, covenants, the church name, manner of worship, rich versus poor, and excommunication. Verification of belief in Christ before his advent is offered in covenants, worship, miracles, prayer, fasting, and other teachings from the Book of Mormon. [N.K.Y.]

W.107 Welch, John W. "A Book You Can Respect." Ensign 7 (September 1977): 45-48. Personal experiences with scholars, involving chiasmus, ancient history, philosophy, and textual studies, showing how scholarship can help enhance respect for the Book of Mormon, while leaving proof of the book's truthfulness in the sphere of testimony. [J.W.W.]

W.108 Welch, John W. "The Calling of a Prophet." In The Book of Mormon: First Nephi, The Doctrinal Foundation, edited by Monte S. Nyman and Charles D. Tate Jr., 35-54. Provo, UT: Brigham Young University Religious Studies Center, 1988. Analyzes the call of Lehi in light of ancient Israelite prophetic literature, showing that the elements of Lehi's throne vision and prophetic commission in 1 Nephi 1 compares closely with the cultural and religious experiences and expectations in Israel and neighboring civilizations in Lehi's day. [J.W.W.]

W.109 Welch, John W. "The Case of an Unobserved Murder." In Reexploring the Book of Mormon, edited by John W. Welch, 242-44. Salt Lake City: Deseret Book and FARMS, 1992. The trial of Seantum for his murder of the chief judge is analyzed. Cases of unwitnessed murders presented special problems under the law of Moses. Seantum's self-incriminating confession satisfies all three special requirements needed to override the normal two-witness rule. [R.H.B.]

W.110 Welch, John W. "Chiasmus Bibliography." Provo, UT: FARMS, 1987. A listing of about 400 books, articles, and papers dealing with chiasmus in the Bible, Book of Mormon, and elsewhere in world literature. [J.W.W.]

W.111 Welch, John W. "Chiasmus in Alma 36." Provo, UT: FARMS, 1989. A detailed analysis of the chiastic structure of Alma 36, comparing several proposed arrangements of this chapter, giving statistical and linguistic evaluations of its chiasticity, and correlating it with Mosiah 27 and Alma 38. [J.W.W.]

W.112 Welch, John W., ed. Chiasmus in Antiquity. Hildesheim: Gerstenberg Verlag, 1981. A team of scholars analyze chiasmus in Akkadian, Ugaritic, Hebrew, Aramaic, Greek, Latin, and the Book of Mormon. Includes extensive bibliography and register of chiastic passages in many literatures. This work is reviewed in D.080, S.080, and K.130. [J.W.W.]

W.113 Welch, John W. "Chiasmus in Biblical Law: An Approach to the Structure of Legal Texts in the Hebrew Bible." In Jewish Law Association Studies IV, edited by Bernard Jackson, 5-22. Atlanta, GA: Scholars, 1990. Demonstrates the existence and explores the function of chiasmus and parallelism in Biblical legal texts. In connection with Leviticus 24:13-23, discusses the chiastic structure of Alma 41:13-15. Also provides literary analysis of Exodus 21:2-23:19. [A.C.W.]

W.114 Welch, John W. "Chiasmus in Helaman 6:7-13." In Reexploring the Book of Mormon, edited by John W. Welch, 230-32. Salt Lake City: Deseret Book and FARMS, 1992. Another example of chiasmus has been discerned in Helaman 6:7-13. Chiasmus encompasses the entire report for the year, suggesting that the account was written as a single literary unit that Mormon copied verbatim from the large plates of Nephi. The literary structure of the chiasmus is analyzed. [R.H.B.] 
W.115 Welch, John W. "Chiasmus in Helaman 6:7-13." Provo, UT: FARMS, 1987. Analysis of the chiastic structure of the complete text of Helaman 6:7-13, a Nephite annal recording an unusual period of unity and peace between Nephites and Lamanites. [J.W.W.]

W.116 Welch, John W. "Chiasmus in the Book of Mormon." BYU Studies 10 (Autumn 1969): 69-84. Also in Book of Mormon Authorship: New Light on Ancient Origins, edited by Noel B. Reynolds, 33-52. Provo, UT: Brigham Young University Religious Studies Center, 1982. The first article published about chiasmus in the Book of Mormon. Gives examples of extended inverted parallelisms from the Old Testament and Book of Mormon. [J.W.W.]

W.117 Welch, John W. "Chiasmus in the Book of Mormon." NE 2 (February 1972): 6. Popular presentation of the discovery and significance of chiasmus in the Book of Mormon, building on conclusions generally accepted by biblical scholars. [J.W.W.]

W.118 Welch, John W. "Criteria for Identifying the Presence of Chiasmus." Provo, UT: FARMS, 1989. Sets forth a series of criteria to be employed in calculating the degree to which a text manifests chiasmus, and discusses the extent to which modern readers can determine if the presence of chiasmus in a text was intentionally created by the ancient author. [J.W.W.]

W.119 Welch, John W. "Decorative Iron in Early Israel." In Reexploring the Book of Mormon, edited by John W. Welch, 133-34. Salt Lake City: Deseret Book and FARMS, 1992. Mosiah 11:8 mentions "all manners of precious things, of gold, and of silver, and of iron." Although a person today would not normally consider using iron as a precious decoration, evidence is presented to show that this was done in antiquity. [R.H.B.]

W.120 Welch, John W. "The Destruction of Ammonihah and Law of Apostate Cities." In Reexploring the Book of Mormon, edited by John W. Welch, 176-79. Salt Lake City: Deseret Book and FARMS, 1992. The law of Moses contains instructions to utterly destroy apostate cities and to gather and burn all their spoil (Deut. 13:12-16). Recent research has uncovered several striking affinities between the account of the destruction of the wicked city of Ammonihah and this ancient Israelite law (Alma 16:9). [R.H.B.]

W.121 Welch, John W. "The Execution of Zemnarihah." In Reexploring the Book of Mormon, edited by John W. Welch. 250-52. Salt Lake City: Deseret Book and FARMS, 1992. Zemnarihah, the captured leader of the Gadianton robbers, was hanged upon the top of a tree, the tree was then felled and the people sang out "all as one" in praise of God (3 Nephi 4:30-33). Several evidences are presented that suggest that some kind of ancient ritual was being observed. [R.H.B.]

W.122 Welch, John W. "Exemption From Military Duty." In Reexploring the Book of Mormon, edited by John W. Welch, 189-92. Salt Lake City: Deseret Book and FARMS, 1992. The people of Ammon, having taken an oath never again to take up arms, were the only Book of Mormon group given an exemption from military service. This privilege was consistent with ancient Israelite law. [R.H.B.]

W.123 Welch, John W. "The Father's Command to Keep Records in the Small Plates of Nephi." Provo, UT: FARMS, 1984. Nephi's instructions to Jacob consistently determined the character and contents of the books of Jacob, Enos, Jarom, and Omni. Nephi instructed that only prophecy, preaching, and little history be included. [J.W.W.]

W.124 Welch, John W. "Finding Answers to B. H. Roberts's Questions." Provo, UT: FARMS, 1985. Recent data and scholarly work provide plausible answers to questions asked by Mr. Couch in 1921 and about which Roberts prepared a working paper, regarding Native American origins, languages, horses, and archaeology. [J.W.W.] 
W.125 Welch, John W. "Getting Things Strai[gh]t." In Reexploring the Book of Mormon, edited by John W. Welch, 260-62. Salt Lake City: Deseret Book and FARMS, 1992. In contemporary English straight usually means "not crooked," while the word strait means "narrow." In the 1829 manuscripts of the Book of Mormon the spelling straight was never used; Oliver Cowdery always spelled these homonyms as strait. The 1828 American Dictionary of the English Language shows both spellings as interchangeable. The words straight and strait are both used in the King James Version of the Old Testament. Understanding their range of meaning in Hebrew may shed light on ideas intended by Isaiah, Lehi, and Nephi. [R.H.B.]

W.126 Welch, John W. "Hugh Nibley and the Book of Mormon." Ensign 15 (April 1985): 50-56. An account of Hugh Nibley's favorite discoveries and monumental contribution to Book of Mormon scholarship. [J.W.W.]

W.127 Welch, John W. "I Have a Question: How long did it take Joseph Smith to translate the Book of Mormon?" Ensign 18 (January 1988): 46-47. Historical records show that it took only sixty-five or less working days to translate the Book of Mormon. Welch discusses the order of probable translation-Mosiah to Moroni in AprilMay, and the small plates of Nephi in June. [J.W.W.]

W.128 Welch, John W. "If a man ... The Casuistic Law Form in the Book of Mormon." Provo, UT: FARMS, 1987. Explores the evidence that Nephite law continued to use the casuistic law form prevalent in biblical law. [J.W.W.]

W.129 Welch, John W. "Jacob's Ten Commandments." In Reexploring the Book of Mormon, edited by John W. Welch, 69-72. Salt Lake City: Deseret Book and FARMS, 1992. An analysis is provided of the ten essential principles and rules of Nephite religion in 2 Nephi 27-38. [R.H.B.]

W.130 Welch, John W. "Jesus Christ in the Book of Mormon." In Encyclopedia of Mormonism, edited by Daniel H. Ludlow, 2:748-50. 5 vols. New York: Macmillan, 1992. Summary of the main teachings of the prophets in the Book of Mormon about Jesus Christ, his Atonement, his resurrection, his role in the Plan of Salvation, the judgment, and individual prophecies about his mortal mission and Godhood. [B.D.]

W.131 Welch, John W. "Joseph Smith: 'Author and Proprietor." " In Reexploring the Book of Mormon, edited by John W. Welch, 154-57. Salt Lake City: Deseret Book and FARMS, 1992. Discusses copyright laws and explains that the terms "author" and "proprietor" were legally correct descriptions of Joseph Smith's relationship with the Book of Mormon and not inconsistent with his role as translator. [A.C.W.]

W.132 Welch, John W. "Judicial Process in the Trial of Abinadi." Provo, UT: FARMS, 1981. The trial of Abinadi, as recorded by Alma, who was a priest in the court of Noah, is shown to have followed ancient Israelite legal practices and is interpreted accordingly. [J.W.W.]

W.133 Welch, John W. "King Benjamin's Speech in the Context of Ancient Israelite Festivals." Provo, UT: FARMS, 1985. A report on Mosiah 1-6 in light of ancient Israelite and Jewish rituals and practices associated with the celebration of New Year, Day of Atonement, and Feast of Tabernacles, particularly on Sabbatical Years. [J.W.W.]

W.134 Welch, John W. "The Last Words of Cenez and the Book of Mormon." In The Allegory of the Olive Tree: The Olive, The Bible, and Jacob 5, edited by Stephen D. Ricks and John W. Welch, 305-21. Salt Lake City: Deseret Book and FARMS, 1994. In the late nineteenth century a work called Biblical Antiquities or Liber Antiquitatum Biblicarum surfaced. It includes the history of a great prophet-warrior-leader named Kenaz. Spelling variants are Cenez, Zenec, and Zenez. He is mentioned by Josephus as Keniazos. These writings concerning him closely resemble 
Jacob 4-6. It is unlikely that Cenez is either Zenos or Zenoch found in the Book of Mormon. These writings were published in Latin in 1893 and were not translated into English until 1917. [J.W.M.]

W.135 Welch, John W. "Law and War in the Book of Mormon." In Warfare in the Book of Mormon, edited by Stephen D. Ricks and William J. Hamblin, 46-102. Salt Lake City: Deseret Book and FARMS, 1990. Customary Jewish law and ancient Israelite attitudes toward war seem to have persisted among Book of Mormon peoples. This article explores the effect of martial law on government, politics, political offices, and freedom of travel, as well as the legal obligation to fight, exemptions from military duty, treatment of captives, and other legal duties of soldiers and citizens. [J.W.W.]

W.136 Welch, John W. "The Law of Mosiah." In Reexploring the Book of Mormon, edited by John W. Welch, 158-61. Salt Lake City: Deseret Book and FARMS, 1992. Subtle and sometimes technical information concerning the changes in Nephite law and society that accompanied the introduction of the law of Mosiah in 92 B.C. are faithfully preserved in the Book of Mormon. [R.H.B.]

W.137 Welch, John W. "Legal Perspectives on the Slaying of Laban." Journal of Book of Mormon Studies 1 (Fall 1992): 119-41. This article marshals ancient legal evidence to show that Nephi's slaying of Laban should be understood as a protected manslaughter rather than a criminal homicide. Exodus 21:13 protected more than accidental slayings or unconscious acts, particularly where God was seen as having delivered the victim into the slayer's hand. Nephi did not commit the equivalent of a first-degree murder under the laws of his day. [R.H.B.]

W.138 Welch, John W. "Lehi's Counsel Vision and Mysteries of God." In Reexploring the Book of Mormon, edited by John W. Welch, 24-25. Salt Lake City: Deseret Book and FARMS, 1992. The vision of the council of God's heavenly hosts, as seen by Lehi and other prophets, made them privy to the secret decrees of the council. These secret decrees are believed to be what constituted the "mysteries" of God. [R.H.B.]

W.139 Welch, John W. "Lehi's Last Will and Testament: A Legal Approach." In The Book of Mormon: Second Nephi, The Doctrinal Structure, edited by Monte S. Nyman and Charles D. Tate Jr., 61-82. Provo, UT: Brigham Young University Religious Studies Center, 1989. Near Eastern family law explains Lehi's position over his sons, their marriages, their family organization, and the rights of the firstborn sons. [J.W.W.]

W.140 Welch, John W. "Longevity of Book of Mormon People and The 'Age of Man.'” The Journal of Collegium Aesculapium 3 (1985): 34-45. Plausible birth- and death-dates are developed for the lineages of Lehi, Mosiah 1 , Alma the Elder, and Jared, with resulting insights into the lives of Book of Mormon prophets. The article includes a chart of comparative life spans of Book of Mormon characters. [J.W.W.]

W.141 Welch, John W. "The Lord's Prayers." Ensign 6 (January 1976): 14-17. New Testament prayers of Jesus are discussed in the context of Jewish prayer practices and are related to the prayers of Jesus preserved in 3 Nephi. Jesus gave thanks to God especially for revelation, asked for forgiveness, and asked that God's will be done and temptation resisted. [J.W.W.]

W.142 Welch, John W. "A Masterpiece: Alma 36." In Rediscovering the Book of Mormon, edited by John L. Sorenson and Melvin J. Thorne, 114-31. Salt Lake City: Deseret Book and FARMS, 1991. Chiasmus is a phenomena that occurs in ancient poetry. Alma 36 follows the same pattern. The chapter is reformatted and six levels of complexity are pointed out. [J.W.M.] 
W.143 Welch, John W. "The Melchizedek Material in Alma 13:13-19." In By Study and Also by Faith, edited by John M. Lundquist and Stephen D. Ricks, 2:238-72. Salt Lake City: Deseret Book and FARMS, 1990. Compares references to Melchizedek, including Alma 13:13-19, other Book of Mormon references, biblical references, traditions of Jewish writers and early Christians, references in the Old and New Testaments, and insights by Joseph Smith in his Inspired Version of the Bible. Alma clarifies much of the mystery surrounding Melchizedek. [A.A.]

W.144 Welch, John W. "The Narrative of Zosimus and the Book of Mormon." BYU Studies 22 (Summer 1982): 311-32. Examines parallels between 1 Nephi and a little-known but early pseudepigraphon about a man who has a vision similar to Lehi's and meets a group in this vision that escaped the Babylonian destruction of Jerusalem and were taken across the ocean by God. [J.W.W.]

W.145 Welch, John W. "The Nephite Sacrament Prayers: From King Benjamin's Speech to Moroni 4-5." Provo, UT: FARMS, 1986. Also in abbreviated form in "Our Nephite Sacrament Prayers." In Reexploring the Book of Mormon, edited by John W. Welch, 286-89. Salt Lake City: Deseret Book and FARMS, 1992. Shows how the LDS sacrament prayers come from Moroni 4-5, not originally from D\&C 20, and that the Nephite prayers are a liturgical reenactment of the precise words of Jesus in 3 Nephi 18. The sacramental prayer language extends back at least to the words of King Benjamin in Mosiah 5. [J.W.W.]

W.146 Welch, John W. "New Testament Word Studies." Provo, UT: FARMS, 1991. An analysis of word meanings in the New Testament shows a consistency between the original usage of words in the New Testament and their usage in the Book of Mormon. [J.W.M.]

W.147 Welch, John W. "No, Sir, That's Not History!" In Reexploring the Book of Mormon, edited by John W. Welch, 88-92. Salt Lake City: Deseret Book and FARMS, 1992. Presents an analysis of B. H. Roberts's writing of Studies of the Book of Mormon and Ethan Smith's View of the Hebrews. Roberts began the study in January 1922 and completed it May 29, 1922 before leaving to preside over the Eastern States mission. Roberts's subsequent labors and testimonies concerning the Book of Mormon show his belief in this scripture. [R.H.B.]

W.148 Welch, John W. "Number 24." In Reexploring the Book of Mormon, edited by John W. Welch, 272-74. Salt Lake City: Deseret Book and FARMS, 1992. Certain numbers were meaningful in antiquity. Seven was the number of spiritual perfection, twelve was a governmental number. The number twenty-four was associated with heavenly government, especially priestly judgment and temple service. Eight occurrences of the number twentyfour in the Book of Mormon are analyzed. [R.H.B.]

W.149 Welch, John W. "The Plain and Precious Parts." In Reexploring the Book of Mormon, edited by John W. Welch, 37-40. Salt Lake City: Deseret Book and FARMS, 1992. The loss of many plain and precious parts of the gospel is seen as consisting of three stages: (1) the meaning or understanding of the Savior's teachings is altered; (2) covenants are lost through neglect of their performance; and (3) eventually things are physically lost from the Bible, a consequence of the first two actions. [R.H.B.]

W.150 Welch, John W. "Preliminary Comments on the Sources behind the Book of Ether." Provo, UT: FARMS, 1986. Discusses records and sources used by Ether and Moroni to produce the book of Ether, including an archaic king list, the record of the brother of Jared, and the prophecies of Ether-recognizable as separate text fragments appended together by Moroni's abridging. [J.W.W.] 
W.151 Welch, John W. "Recent Developments in Book of Mormon Research." Provo, UT: FARMS, 1986. Gives teachers practical suggestions about the use of current Book of Mormon research in the classroom. [J.W.W.]

W.152 Welch, John W. Review of A Witness and a Warning: A Modern-Day Prophet Testifies of the Book of Mormon, by Ezra Taft Benson. Review of Books on the Book of Mormon 1 (1989): 1-2. Book review.

W.153 Welch, John W. Review of Joseph Smith and the Origins of the Book of Mormon, by David Persuitte. Pacific Historical Review 55 (November 1986): 619-23. Book review.

W.154 Welch, John W. Review of New Approaches to the Book of Mormon, edited by Brent Lee Metcalfe. Review of Books on the Book of Mormon 6/1 (1994): 145-88. Book review.

W.155 Welch, John W. Review of Studies of the Book of Mormon, by B. H. Roberts, edited by Brigham D. Madsen. Pacific Historical Review 55 (November 1986): 619-23, and also CN 55 (15 December 1985): 11. Book review.

W.156 Welch, John W. Review of Trouble Enough: Joseph Smith and the Book of Mormon, by Ernest H. Taves. Pacific Historical Review 55 (November 1986): 619-23. Book review.

W.157 Welch, John W. "Series of Laws in the Book of Mormon." Provo, UT: FARMS, 1987. Discussion of texts in the Book of Mormon that list laws and compares them with law lists and codes from the Old Testament and the ancient Near East. Shows internal logical development in Nephite legal history. [J.W.W.]

W.158 Welch, John W. "The Sermon at the Temple." In Reexploring the Book of Mormon, edited by John W. Welch, 253-56. Salt Lake City: Deseret Book and FARMS, 1992. Jesus' Sermon on the Mount (Matthew 5-7) presents serious challenges to scholars. The Savior's Sermon at the Temple (3 Nephi 11-18) provides a context for understanding the Sermon on the Mount. [R.H.B.]

W.159 Welch, John W. The Sermon at the Temple and the Sermon on the Mount: A Latter-day Saint Approach. Salt Lake City: Deseret Book and FARMS, 1990. A thorough LDS interpretation of the Sermon on the Mount in Matthew 5-7 and analysis of the words of Jesus at the temple in Bountiful in 3 Nephi 11-18. The Book of Mormon provides keys to unlock the mystery of the Sermon on the Mount. 3 Nephi is a covenantal temple text, giving instructions and commandments relevant to covenant making. A table compares the texts of Matthew 5-7, 3 Nephi 12-14, and the Joseph Smith Translation of Matthew 5-7. [J.W.W.]

W.160 Welch, John W. "Some Old World Perspectives on the Book of Mormon; A Book You Can Respect." Ensign (September 1976): 27-30, 45-48. Welch gives a summary of the history of Judah during Lehi's lifetime in order to understand the setting of the quest for a promised land, and shows the many ways the Book of Mormon can be respected as a literary masterpiece. [B.D.]

W.161 Welch, John W. "Statutes, Judgments, Ordinances, and Commandments." In Reexploring the Book of Mormon, edited by John W. Welch, 62-65. Salt Lake City: Deseret Book and FARMS, 1992. 2 Nephi 5:10 mentions that the people observed the "judgments, and the statutes, and the commandments ... according to the law of Moses." An analysis of the associated Hebrew terms is provided. [R.H.B.]

W.162 Welch, John W. "Study, Faith, and the Book of Mormon." In Brigham Young University 1987-88 Devotional and Fireside Speeches, 139-49 Provo, UT: Brigham Young University, 1988. Reprinted as "Study and Faith in the Book of Mormon." BYU Today 42 (September 1988): 18-24 Discusses scholarly studies that can increase 
appreciation for the Book of Mormon. The Book of Mormon will remain a sealed book to all those who do not approach it with both spiritual faith and academic rigor. [J.W.W.]

W.163 Welch, John W. "A Study Relating Chiasmus in the Book of Mormon to Chiasmus in the Old Testament." M.A. thesis, Brigham Young University, 1970. Defines simple, compound, and complex chiasmus, surveys the use of chiasmus in Ugaritic epics, the Old Testament, Homer, and later Greek and Latin authors, and compares the appearance of chiasmus in those literatures with chiasmus in the Book of Mormon. The degree of use of chiasmus in the Book of Mormon is similar to that in the Old Testament. [J.W.W.]

W.164 Welch, John W. "Synagogues in the Book of Mormon." In Reexploring the Book of Mormon, edited by John W. Welch, 193-95. Salt Lake City: Deseret Book and FARMS, 1992. The Book of Mormon describes a considerable diversity in synagogues. Some were built after the manner of the Jews, some after the manner of the Nehors, and one in Antionum after a manner that amazed Alma and his companions. Similarly, ancient Israelite communal worship appears to have begun as a flexible practice and was known in several developmental stages. [R.H.B.]

W.165 Welch, John W. "Ten Testimonies of Jesus Christ from the Book of Mormon." In Doctrines of the Book of Mormon, 1991 Sperry Symposium, edited by Bruce A. Van Orden and Brent L. Top, 223-42. Salt Lake City: Deseret Book, 1992. Analyzes the names, descriptions, and testimonies of Jesus Christ used by Lehi, Nephi, Jacob, Benjamin, Abinadi, Alma, Amulek, Samuel the Lamanite, Mormon, and Moroni, to show that each prophet used a different and often unique set of theological terms and concepts, christologically significant and also strongly connected to the personal experiences and perceptions of each prophet. [J.W.W.]

W.166 Welch, John W. "Theft and Robbery in the Book of Mormon and Ancient Near Eastern Law." Provo, UT: FARMS, 1985. Ancient law distinguished between the crimes of theft and robbery, a distinction also consistently evident in the Book of Mormon. [J.W.W.]

W.167 Welch, John W. "They Came from Jerusalem: Some Old World Perspectives on the Book of Mormon." Ensign 6 (September 1976): 26-31. Reprinted in The Book of Mormon, It Begins with a Family, 14-22. Salt Lake City: Deseret Book, 1983. Overview of Jerusalem during Lehi's lifetime and the probable impact of the reforms of Josiah on Book of Mormon thought. Deals with conditions in Jerusalem and surrounding nations about 600 B.C., the urgency of record-keeping in that era, the state of turmoil and flux, and the role of prophets like Jeremiah. [J.W.W.]

W.168 Welch, John W. "Thieves and Robbers." In Reexploring the Book of Mormon, edited by John W. Welch, 24849. Salt Lake City: Deseret Book and FARMS, 1992. Under ancient Near Eastern law there were significant differences between a thief and a robber. The former was usually a local person who was tried and punished under civil law by fellow townspeople. The latter was treated as an outsider, was dealt with under military law, and could be executed. These ancient legal and linguistic distinctions are observable in the Book of Mormon. [R.H.B.]

W.169 Welch, John W. "Three Accounts of Alma's Conversion." In Reexploring the Book of Mormon, edited by John W. Welch, 150-53. Salt Lake City: Deseret Book and FARMS, 1992. The Book of Mormon provides three accounts of Alma's conversion. Numerous phrases used in parallel throughout all three accounts show that a single person was the author of all three. [R.H.B.]

W.170 Welch, John W. "The Translation of the Book of Mormon: Basic Historical Information." Provo, UT: FARMS, 1986. Extensive chronological listing, day by day, of all events known to have transpired in connection 
with the translation of the Book of Mormon or in the life of Joseph Smith from September, 1827, to March, 1830. Extensive footnotes document from primary sources all known factors pertinent to the time of translation. The article includes an appendix on the order in which the books of the Book of Mormon were translated and an extensive bibliography. [J.W.W.]

W.171 Welch, John W. "An Unparallel." Provo, UT: FARMS, 1985. By pointing out numerous differences and contradictions between the Book of Mormon and View of the Hebrews, this paper counters the claim that Joseph Smith relied on View of the Hebrews, relevant to an extensive paper prepared by B. H. Roberts in 1922. [J.W.W.]

W.172 Welch, John W. "View of the Hebrews: 'An Unparallel.'" In Reexploring the Book of Mormon, edited by John W. Welch, 83-87. Salt Lake City: Deseret Book and FARMS, 1992. Presents an analysis of the parallels and of the lack of them between the Book of Mormon and Ethan Smith's 1823 View of the Hebrews. The differences far outweigh the similarities between these two texts. [R.H.B.]

W.173 Welch, John W. "Was Helaman 7-8 an Allegorical Funeral Sermon?" In Reexploring the Book of Mormon, edited by John W. Welch, 239-41. Salt Lake City: Deseret Book and FARMS, 1992. It was not uncommon for early Israelite prophets to use striking conduct to emphasize the import of their warnings (Jeremiah 13:1-11; Jeremiah 19:1-13; 1 Kings 11:29-39; 2 Kings 11:29-39; 2 Kings 13:15-19; Isaiah 20:2-6). It is suggested that Nephi's sermon from a tower in his yard employed similar imagery to draw a crowd and to emphasize his warning message. [R.H.B.]

W.174 Welch, John W. "What Is B. H. Roberts' 'Study of the Book of Mormon' and How Have Critics Used It to Discredit the Book of Mormon?" In A Sure Foundation: Answers to Difficult Gospel Questions, 60-74. Salt Lake City: Deseret Book, 1988. Papers written in 1922 by B. H. Roberts bluntly state problems and arguments that could be used against the Book of Mormon, but he was firm in his faith in the Church and the Book of Mormon. His contention was that the power of the Holy Ghost was the source for finding the truth of the Book of Mormon and external evidence was not reliable. [J.W.M.]

W.175 Welch, John W. "What Was a 'Mosiah?' " In Reexploring the Book of Mormon, edited by John W. Welch, 1057. Salt Lake City: Deseret Book and FARMS, 1992. Although the exact derivation of the Book of Mormon name Mosiah is unknown, it appears that the term is identical to the Hebrew moshiah, whose key meaning is "savior." Interestingly, this term applies perfectly to the Mosiahs in the Book of Mormon. [R.H.B.]

W.176 Welch, John W., S. Kent Brown, and John A. Tvedtnes. "When Did Jesus Appear to the Nephites in Bountiful?" Provo, UT: FARMS, 1989. Three theories about the timing of Jesus' appearance in Bountiful are set forth: shortly after the crucifixion, about 50 days after the crucifixion, and about 11 months after the crucifixion. Given the ambiguous reference in 3 Nephi 10, no definite conclusion can be reached. [J.W.W.]

W.177 Welch, John W. "Why Study Warfare in the Book of Mormon?" In Warfare in the Book of Mormon, edited by Stephen D. Ricks and William J. Hamblin, 3-24. Salt Lake City: Deseret and FARMS, 1990. Essay explaining the importance of war in the religious world view of the Nephites, listing and naming the main Nephite conflicts, and discussing methodological problems that must be observed in studying the war chapters in the Book of Mormon. Concludes that no study of the Book of Mormon, either as an ancient document or as it speaks to the modern world, can be well-grounded without an understanding of the book's perception and ideology of war. [J.W.W.]

W.178 Welch, John W. "Words and Phrases in Jacob 5." In The Allegory of the Olive Tree: The Olive, The Bible, and Jacob 5, edited by Stephen D. Ricks and John W. Welch, 174-85. Salt Lake City: Deseret Book and FARMS, 1994. 
Report of a computer count of the words in Jacob 5. There is a great deal of repetition of words in the allegory, and the vocabulary more closely resembles the Hebrew vocabulary of the Old Testament than the New. Some exact phrases may be reminiscent of the theophany of Mt. Sinai; others relate to early anti-pagan language. [J.W.M.]

W.179 Welch, John W. "Zenez, Zenec, Cenez, Kenaz-Zenoch, Zenos." Provo, UT: FARMS, 1992. Concludes that the Cenez (Pseudo-Philo in Charlesworth's Old Testament Pseudepigrapha 2:297-377) cannot be the Zenos nor the Zenoch of the Book of Mormon. However, the text, or a predecessor text, of Cenez may have been known to the Nephites. [B.D.]

W.180 Welch, John W., ed. Reexploring the Book of Mormon. Salt Lake City: Deseret Book and FARMS, 1992. A series of updates on current book of Mormon research, edited to make them useful to scholars and general readers. Introductions place each update in context, giving the questions and problems that stimulated the original research and the direction of subsequent research. [J.W.W.]

W.181 Welch, John W., David Fox, Roger Keeler, Paul Hoskisson, Deloy Pack, Robert Smith, and Bruce Warren. "Words and Phrases." In Reexploring the Book of Mormon, edited by John W. Welch. 282-85. Salt Lake City: Deseret Book and FARMS, 1992. The occurrences and significance of several words and phrases are examined. These include: Lord God Omnipotent, Holy One of Israel, island and isles of the sea, great and abominable church, heart, from whence no traveler can return, second death, and it came to pass. [R.H.B.]

W.182 Welch, John W., and David J. Whittaker. "Mormonism's Open Canon: Some Historical Perspectives on Its Religious Limits and Potentials." Provo, UT: FARMS, 1987. Explores historically the balance in Mormonism between its acceptance of an open canon and its strict adherence to scripture as the word of God. Traces the LDS experience with the continuous revelation of God's will "line upon line." [J.W.W.]

W.183 Welch, John W., David R. Benard, and Daniel C. Peterson. "Secret Combinations." In Reexploring the Book of Mormon, edited by John W. Welch, 227-29. Salt Lake City: Deseret Book and FARMS, 1992. Points out flaws in the argument that Joseph Smith borrowed the term secret combinations from a term used to refer to a "supposed conspiracy among the Freemasons" in New York in the 1820s. This is unlikely since the phrase was not used until much later. [J.W.M.]

W.184 Welch, John W., Donald W. Parry, and Stephen D. Ricks. " 'This Day.' " In Reexploring the Book of Mormon, edited by John W. Welch, 117-19. Salt Lake City: Deseret Book and FARMS, 1992. The words "this day" appear eighteen times in the Book of Mormon. The legal and religious implication of the term indicates high holy days, which in and of themselves produced a binding legal effect on holy religious status. [R.H.B.]

W.185 Welch, John W., Gary Gillum, and DeeAnn Hofer. Comprehensive Bibliography of the Book of Mormon Arranged Alphabetically by Author. Provo, UT: FARMS, 1987. Book of Mormon bibliography arranged alphabetically by author. [J.W.M.]

W.186 Welch, John W., Gary Gillum, and DeeAnn Hofer. Comprehensive Bibliography of the Book of Mormon Arranged Chronologically. Provo, UT: FARMS, 1987. This one hundred page bibliography of books and articles written about the Book of Mormon is listed according to their date of publication. [J.W.M.]

W.187 Welch, John W., Gary Gillum and DeeAnn Hofer. Comprehensive Bibliography of the Book of Mormon Arranged by Subject. Provo, UT: FARMS, 1987. Bibliography of books and articles about the Book of Mormon 
arranged according to subjects. [J.W.M.]

W.188 Welch, John W., and Gordon C. Thomasson. "The Sons of the Passover." In Reexploring the Book of Mormon, edited by John W. Welch, 196-98. Salt Lake City: Deseret Book and FARMS, 1992. The similarities of Alma's instructions to his sons with the Jewish holiday of Passover are striking. The pattern in Alma's instructions follow Passover traditions found at the time of Christ (perhaps earlier). [J.W.M.]

W.189 Welch, John W., Gordon C. Thomasson, and Robert F. Smith "Abinadi and Pentecost." In Reexploring the Book of Mormon, edited by John W. Welch, 135-38. Salt Lake City: Deseret Book and FARMS, 1992. Moses received the Ten Commandments at about the same time as the celebration of Pentecost. With this association the story of Abinadi in Mosiah 11-17 comes vividly to life. [R.H.B.]

W.190 Welch, John W., and Matthew G. Wells. "Concrete Evidence for the Book of Mormon." In Reexploring the Book of Mormon, edited by John W. Welch, 212-14. Salt Lake City: Deseret Book and FARMS, 1992. Originally published in May 1991. The superior quality of cement found in many archaeological sites is consistent with the Book of Mormon account in Helaman 3:7-11 that dates the technology at approximately 46 B.C. These finds are also helpful in locating Book of Mormon lands. [J.W.M.]

W.191 Welch, John W., Robert F. Smith, and Gordon C. Thomasson. "Dancing Maidens and the Fifteenth of Av." In Reexploring the Book of Mormon, edited by John W. Welch, 139-41. Salt Lake City: Deseret Book and FARMS, 1992. In ancient Israel maidens would gather to dance on the 15th day of the month of Av. Lehi and his people would have known of this tradition and perhaps the Lamanite daughters had gathered in celebration of a vestige of this event. [R.H.B.]

W.192 Welch, John W., Spencer Palmer, and William Knecht. "An Unparallel: Ethan Smith and the Book of Mormon," with "View of the Hebrews: Substitute for Inspiration." Provo, UT: FARMS, 1985. Two papers, "An Unparallel," by Welch, and "View of the Hebrews," by Palmer and Knecht, reprinted from BYU Studies. See entries and annotations above. [D.W.P.]

W.193 Welch, John W., and Tim Rathbone. "Book of Mormon Translation by Joseph Smith." In Encyclopedia of Mormonism, edited by Daniel H. Ludlow, 1:210-12. 5 vols. New York: Macmillan, 1992. Few details of the translation process are known except that Joseph Smith used the "Nephite interpreters." Joseph Smith knew no foreign languages but dictated the Book of Mormon page by page to scribes without reviewing what was previously written. [N.K.Y.]

W.194 Welch, John W., and Tim Rathbone. "How Long Did It Take Joseph Smith to Translate the Book of Mormon? In Reexploring the Book of Mormon, edited by John W. Welch, 1-8. Salt Lake City: Deseret Book and FARMS, 1992. Cf. Ensign 18 (January 1988): 46-47. Sets forth the time it took Joseph Smith to translate the Book of Mormon, pointing out that it was a phenomenal achievement. [N.K.Y.]

W.195 Welch, John W. and Tim Rathbone. "Textual Consistency." In Reexploring the Book of Mormon, edited by John W. Welch. 21-23. Salt Lake City: Deseret Book, and FARMS, 1992. The miraculous nature of the task of dictating the Book of Mormon is revealed in several ways-the first copy was the final copy; it was remarkably free of strikeovers; only minor changes have been made in spelling, punctuation, capitalization, and grammar. The greatest miracle is the consistency within the text. Cites examples of material used with consistency-Alma's conversion accounts, King Benjamin's address, the prophecy of Zenos, King Benjamin's legal teachings. [J.W.M.] 
W.196 Welch, John W., and Tim Rathbone. "The Translation of the Book of Mormon: Preliminary Report on the Basic Historical Information." Provo, UT: FARMS, 1986. Summarizes basic historical information pertaining to the translation of the Book of Mormon by Joseph Smith. Section I gives an annotated chronology of events from 1827 through 1830. Section II examines two theories about the order in which the texts of the Book of Mormon were translated. Section III shows that the 590 pages printed in the 1830 edition of the Book of Mormon were translated, dictated, and written all within an extremely short and intensely busy period of time. [B.D.]

W.197 Weldon, Clair. The Book of Mormon. Independence, MO: RLDS Church, 1976. Deals with Book of Mormon origins and context, including Nephite culture, Jaredite history, and the ministry of Jesus Christ. [J.W.M.]

W.198 Weldon, Clair E. "The Divine Authenticity of the Book of Mormon." Courage: Journal of History, Thought \& Action 1 (December 1970): 102-6. Written to tell readers that the Book of Mormon is an authentic and divine work. Readers can determine its authenticity trough personal study and prayer. [J.W.M.]

W.199 Weldon, Clair E. "Let Us Not Be Confused." SH 98 (5 February 1951): 128-30, 139. Explains the importance of Book of Mormon, and gives archaeological evidence to authenticate it. Discusses the serpent symbol as representing Satan, and believes that it is a perversion of Christ as the brazen serpent. [A.C.W.]

W.200 Weldon, Roy E. The Bible Points to the Book of Mormon and the New World. Independence, MO: Herald House, 1969. Pamphlet filled with pictures, archaeological evidence, legends, and traditions designed to persuade one to believe that the Book of Mormon fulfills biblical prophecies. The Book of Mormon is related to the "Popul Vuh"-the Mayan book of God. [J.W.M.]

W.201 Weldon, Roy E. "Biblical Evidences Pointing toward the Book of Mormon." SH 94 (5 July 1947): 624. A list of 113 scriptures from the King James and Inspired Version of the Bible that are evidences for the Book of Mormon. Includes scriptures that mention archaeology related to the Book of Mormon. [A.C.W.]

W.202 Weldon, Roy E. "The Book of Mormon and the Restoration Movement." SH 93 (15 June 1946): 606-7. The Book of Mormon is "that point in our religion where faith sets foot on solid ground. Where concrete meets abstract and heaven touches earth." Archaeological evidence is convincing but the surface is still unscratched. Joseph Smith and the Book of Mormon possess the secret of ancient and future America. [A.C.W.]

W.203 Weldon, Roy E. "Book of Mormon Deeps." SH 112, 113, 114, 115, 117, 119 (15 September 1965, 1 January, 1 July 1966, 1 January 1967, 1 December 1968, July 1970, February 1972, September 1972): 632, 635, 23-24, 450-52, 202, 804-6, 814, 21-22, 30-32, 26-28. Series of articles exploring various aspects of the Book of Mormon. Probation periods and free agency are related to divine interference. Weldon discusses what the Book of Mormon teaches about the devil and anti-Christs, judgment, the Restoration of Israel (relates the six-day war to Book of Mormon prophecies), the Flood of Noah. He explores the doctrines clarified by the restoration, such as baptism, ordination, the trinity, the fall, the Atonement, and resurrection. He discusses Masonry and Ethan Smith's A View of the Hebrews - refuting Alexander Campbell's polemics against the Book of Mormon, showing that Joseph Smith did not use A View of the Hebrews to write the Book of Mormon. [A.C.W.]

W.204 Weldon, Roy E. Book of Mormon Evidences Joseph Smith a Prophet. Independence, MO: Herald House, 1970. This pamphlet contains photographs of artifacts and archaeological evidence that the Book of Mormon described long before their discovery. Joseph Smith passes the biblical test of what makes a true prophet of God. [J.W.M.] 
W.205 Weldon, Roy E. "The Book of Mormon Points the Way to Zion." SH 100 (20, 27 July, 3, 10 August 1953): 682-85, 704-6, 717, 728-30, 739, 754-56, 762. A series of articles written to instruct Church members on how to attain Zion. Discusses the temple of the cross in Palenque, Mexico; that Zion can only be gained with spirituality and endowments of divine power; the necessity of scripture study; the importance of prayer; and the importance of fasting. [A.T.]

W.206 Weldon, Roy E. The Book of Mormon Story in Pictures. Independence, MO: Herald House, 1968. Architecture that resembles Egyptian types and carved reliefs that are unmistakably Hebrew help to explain the "bearded white god" idea found in ancient America. The Book of Mormon records the visit of Christ in America and archaeology verifies the truthfulness of the record. This pamphlet includes photographs, histories, myths, and traditions of ancient America. [J.W.M.]

W.207 Weldon, Roy E. "Emergence of the Nephite Record." Witness 65 (May 1989): 14-15. Mayan traditions state that two migrations of ancestors came to America, one from the east, the other from the west. The Book of Mormon witnesses of a New Jerusalem in America. The Book of Mormon will be used with the Bible to witness for Christ to silence unbelievers. [J.W.M.]

W.208 Weldon, Roy E. "I Know the Nephite Record Is True." SH 127 (July 1980): 331, 337. The author testifies of the truthfulness of the Book of Mormon. His testimony has come from the spirit and through scholarly study. Presents evidence that the Nephites obeyed the Law of Moses and there were elephants as far south as South America. [B.D.]

W.209 Weldon, Roy E. "Moroni-Forgotten Man of a Forgotten People." SH 86 (23 September 1939): 1202-5. Lamanites will be restored to the gospel covenant, fulfilling Book of Mormon prophecy, and Moroni will no longer be the forgotten man of a forgotten people. [A.C.W.]

W.210 Weldon, Roy E. "Moroni to Columbus." SH 97 (27 November 1950): 1141-44. Book of Mormon archaeologists are doing research to find if the "feathered serpent" god of the ancient American is a symbol of Jesus Christ. The Book of Mormon prophesies of an apostasy, which the author concludes was between Moroni and Columbus. [J.W.M.]

W.211 Weldon, Roy E. The Nephite Prophets Speak to Our Day. Independence, MO: Herald House, 1975. Book of Mormon prophets wrote to those who live in the New World and their prophecies are being fulfilled. Prophets, from Nephi to Moroni, saw the gulf of separation that divides the wicked and the righteous in our day. The last days are here with false prophets, anti-Christs, hysteria, irresponsibility, and rationalization. The Book of Mormon confounds false doctrine. [J.W.M.]

W.212 Weldon, Roy E. Nephite Proverbs: Maxims and Truisms. North Kansas City, MO: Color Press, 1989. A listing of scriptures under topic headings. Each scripture is followed by quotations from modern authors that testify of the truthfulness of the scripture. [J.W.M.]

W.213 Weldon, Roy E. "A New Day Dawns for the Book of Mormon." SH 104 (8 April 1957): 317-19, 330. Weldon asks for Book of Mormon research assistants to assist with archaeological research and investigations about Hebraisms and other Book of Mormon topics. The monumental effort of gathering Book of Mormon evidence is one that requires many contributors. [A.C.W.] 
W.214 Weldon, Roy E. "New Evidence on the Urim and Thummim." SH 101 (6 September 1954): 861-63. Likens Mayan "sac-tuns" or holy stones used for prophecy to the Urim and Thummim, and sees the sac-tuns as evidence for the manner in which Joseph Smith translated the Book of Mormon. These are evidence that true seer stones spoken of in the Book of Mormon existed. Joseph Smith translated the plates using a word-for-word translation using these precious instruments of the Lord. [J.W.M.]

W.215 Weldon, Roy E. "A New Star Did Appear." Witness 71 (Winter 1990): 5-7. Discusses the sophistication of Mayan astronomy to show that the ancient inhabitants of the Americas would have noticed the appearance of a new star at Christ's birth. [A.C.W.]

W.216 Weldon, Roy E. Other Sheep: An Examination of the Rich and Convincing Evidences in the Bible. Independence, MO: Price, 1986. The Book of Mormon is defended through analysis of early Spanish Colonial writings regarding the histories of the Aztecs, Toltecs, and Maya, and the author draws parallels between the archaeology of South America and the Book of Mormon. [J.T.]

W.217 Weldon, Roy E. Restoration Witnesses. Independence, MO: Herald House, 1966. A reproduction of fifteen articles found in The Saint's Herald beginning in July 1957. The Book of Mormon's ability to predict future happenings as well as provide information that was later proven by science lend credibility to its authenticity. The Book of Mormon's teachings on evolution and other "philosophies of men" are discussed, as well as anachronisms, and authorship. Weldon compares the philosophies of men with the philosophy of the Book of Mormon. [J.T.]

W.218 Weldon, Roy E. "Society for Archaeological Research: Trip to Mexico and Central America." SH 89 (18 April 1942): 501-3. Reporting of an expedition to Mexico and Central America. Quetzalcoatl appears to be Jesus Christ as identified in the Book of Mormon. The "wise men" talked about in the Bible are also found in ancient American traditions. [J.W.M.]

W.219 Weldon, Roy E. "A Visit to Book of Mormon Lands in Central and South America." SH 96 (15 August 1949): 775-77, 790. Includes Weldon's "archaeological observations" in Central and South America and how he relates them to the Book of Mormon. The Gentiles are expected to carry the Book of Mormon to the Lamanites. [A.C.W.]

W.220 Weldon, Roy E. "When God Moves, Satan Moves." Witness 66 (Fall 1989): 14-15. The Book of Mormons tells of the struggle between God's servants and Satan's servants. Every time the Lord gives revelation and prophecy, Satan tries to intervene. [J.W.M.]

W.221 Weldon, Roy E., and F. Edward Butterworth. Book of Mormon Claims and Evidences: A Cyclopedic Text of Information Pro \& Con Relative to the Book of Mormon. 4 vols. Independence, MO: Buckeye, 1979-1981. Volume one investigates external evidences of the Book of Mormon: agriculture, archaeology, architecture, astronomy, and Indian traditions. Volume two deals with Christ's visit to America and the evidence found to substantiate the Christian influence in America. Volume three explores the Mayan Calendar, Indian legends, evolution vs. divine creation, word origin, and hierogryphs. Volume four continues with metallurgy, migrations, mythology, and symbolism. [J.W.M.]

W.222 Weldon, Roy E., and F. Edward Butterworth. Book of Mormon Deeps; a Comprehensive Text of Known Information Relative to the Internal Evidences of the Book of Mormon. 4 vols. Weldon and Butterworth, 1977-1979. Designed for group study, this philosophical approach shows that Book of Mormon statements of concepts and beliefs are consistent with a high degree of civilization with modern philosophies and life styles. Its moral values apply to our day. Faith is noted as properly coming under the heading of philosophy. The parallels in ancient 
America and modern America are striking concerning rebellion, politics, and the sexual revolution. The prophetic role of the Book of Mormon transcends the role of science. The Book of Mormon adds those plain and precious things that have been taken from the Bible and bears witness of its truthfulness. Includes testimonies that go beyond intellectual reasoning. It is a book of fine literature. [J.W.M.]

W.223 Weldon, Roy, and F. E. Butterworth. Criticisms of the Book of Mormon Answered. Independence, MO: Herald House, 1973. A response to "honest objections and sincere criticisms" against the Book of Mormon, including its origins (i.e., the Spaulding manuscript), the problem of biblical passages quoted verbatim, seeming literary errors, anachronisms, and changes in the Book of Mormon. [J.T.]

W.224 Weldon, Walter. The Purpose of the Book of Mormon. Winner, SD: Walter Weldon, 1976. The roles and identities of Gentiles, Lamanites, and the promised land as outlined in the Book of Mormon are discussed. [J.T.]

W.225 Welker, Roy A. "Sacred Scriptures: Their Place in the Restoration." In Welker's The Divine Church Restored, 155-74. Salt Lake City: Deseret News, 1955. Course of study for priesthood quorums. The Book of Mormon was brought forth "by the gift and power of God and by the use of the Urim and Thummim." The Book of Mormon contributes to the restoration-it is a new testament to Christ, contains a divine message, establishes the truth of the Bible, explains many parts of the Bible, contains a record of a fallen people, and has a lofty spirit that inspires faith in God. [B.D.]

W.226 Welland, Kurt. Review of Warfare in the Book of Mormon, edited by Stephen D. Ricks, and William J. Hamblin. In Review of Books on the Book of Mormon 3 (1991): 141-46. Book review.

W.227 Wells, Elayne. "Brass Plates Form Book of Mormon Base." CN 60 (6 January 1990): 10. The idea of writing down experiences on the gold plates may have been borrowed from the brass plates, which preserved the Nephites' religion, language, and civilization. Without them the Nephites would have "suffered in ignorance." [M.R.]

W.228 Wells, Elayne. "The Void Filled." CN 59 (16 December 1989): 16. More than ten years elapsed after the author read a Book of Mormon borrowed from a library before the missionaries knocked on the door to teach the discussions, which led to this author's conversion. [J.W.M.]

W.229 Wells, J. F. "On Proving the Book of Mormon." MS 81 (October 1919): 664-66. Moroni is very clear on how to prove the truthfulness of the Book of Mormon. All who seek to properly know the truth will have it revealed to them by the Lord. Thousands have done it. The Bible and the Book of Mormon testify of each other. [B.D.]

W.230 Wells, J. F. "The Three Witnesses." Utah Genealogical and Historical Magazine 18-20 (October 1927October 1929): 158-63, 34-38, 69-73, 172-78, 187-90. Includes testimonies and histories of Oliver Cowdery, David Whitmer, and Martin Harris. [J.W.M.]

W.231 Wells, Janette V. "Sharing the Book of Mormon." Friend 22 (April 1992): 2-4. A story of a young girl who shared the message of the Book of Mormon with her friends through her charitable actions. [M.D.P.]

W.232 Wells, Junius F. "The Engraving of the Three Witnesses." IE 30 (September 1927): 1022-25. Discusses the process of making a duplication of the engravings of the Three Witnesses of the Book of Mormon. [L.D.] 
W.233 Wells, Junius F. "Oliver Cowdery." IE 14 (March 1911): 377-94. Documents the connection of Oliver Cowdery with the Prophet Joseph Smith and the translation of the Book of Mormon. [J.W.M.]

W.234 Wells, Junius F. "Oliver Cowdery." MS 73 (6-20 April 1911): 209-15, 225-29, 241-43. Presents a sketch of the life of Oliver Cowdery, in an attempt to dispel inaccuracies previously published. Though he faltered and fell, he should be honored, for he never joined the Church's enemies nor did he deny his testimony of the Book of Mormon as the work of the Lord. Cowdery was the scribe for most of the Book of Mormon and was one of the Three Witnesses. [J.W.M.]

W.235 Wells, R. S. "The Book of Mormon Confirmed." MS 60 (January, February 1898): 24-28, 33-39, 56-63, $72-$ 77, 81-87. Series of five articles with evidence of the authenticity of the Book of Mormon-there were two races of ancient Americans, the Jaredites in North America and the Nephites in South America (Omni 1:23 and Alma 22:30-34); American Indians are of Hebrew origin; there is evidence of ancient metal engraving on tablets in book form; the Peruvians believe they originated from a people led by four brothers; there is evidence of advanced civilizations, ancient coins, and ancient implements on the American continent; there is evidence of great destruction at the crucifixion of Christ and that the Messiah was known to ancient Americans. [B.D.]

W.236 Wells, Robert E. "The Liahona Triad." In Doctrines of the Book of Mormon, 1991 Sperry Symposium, edited by Bruce A. Van Orden and Brent L. Top, 1-15. Salt Lake City: Deseret Book, 1992. The triad of faith, diligence, and heed were required to make the Liahona function for Lehi and his family. Nephi demonstrated faith in getting the brass plates and in building a boat. Mormon and others exemplify diligence and perseverance. The word heed was used much by Nephi in his writing. These things can lead individuals to Christ. There are many different kinds of modern Liahonas: conscience, patriarchal blessings, even the Book of Mormon. [N.K.Y.]

W.237 Wells, Robert E. The Mount and the Master. Salt Lake City: Deseret Book, 1991. Analyzing the Sermon on the Mount, this author compares the account in 3 Nephi with three translations of the Bible. He defines of key words, gives scriptural and personal examples of the concept, explores the state of happiness that is promised in each of the beatitudes, and discusses the required acts and thoughts of achieving such a state. [J.W.M.]

W.238 Wells, Robert E. Untitled talk. In Proceedings of the Santiago, Chile Area Conference, 8-9. Salt Lake City: Church of Jesus Christ of Latter-day Saints, March 1977. The Book of Mormon testifies of Jesus Christ, his doctrine, the power of his name, the reality of his life, and the scope of his priesthood. It contains more information about Christ than does the Bible. He is the creator and is a distinct individual from the Father. He is Jehovah of the Old Testament. [J.W.M.]

W.239 Wells, Rulon S. Untitled talk. CR (October 1934): 108-11. Focuses on the mission of angel Moroni (Revelation 14:6-7) to bring the gospel message to the world through the Book of Mormon. Each nation must have the privilege of hearing the gospel in their own language in order to fulfill the scripture in the book of Revelation. Members of the Church must learn the languages of the world and declare that Jesus Christ has restored his truths again upon the earth. [J.W.M.]

W.240 Wendel, Eileen Chabot. The Book of Mormon Illustrated. Ogden, UT: Brigham Young Publishers, 1982. Selected passages from the Book of Mormon are arranged along with illustrations to provide a "comic book" style of narrative. [J.T.]

W.241 Wendel, Eileen Chabot. Nephi the Valiant. Book 2 of Stories from the Golden Records. Salt Lake City: Deseret Book, 1960. A cartoon-style book for children that tells the story of the Book of Mormon from 1 Nephi to 
the book of Enos. [J.W.M.]

W.242 Wendel, Eileen Chabot. Stories from the Golden Records. Salt Lake City: Deseret Book, 1960. A series of books in cartoon format for children that relate stories from the Book of Mormon. [J.W.M.]

W.243 "Were All the Unsealed Records of the Book of Mormon Translated?" IE 5 (March 1902): 393-95. Claims that Joseph Smith translated all of the unsealed portions of the Book of Mormon. [L.D.]

W.244 West, Camille G. "Antonio's Book." Ensign 21 (March 1991): 28-30. Antonio de Jesus Salazar received his father's Book of Mormon, which had been given to him by a member of the Mormon Battalion in the 1840s in northern New Mexico. Reading the Book of Mormon changed Antonio's life. [J.W.M.]

W.245 West, Franklin L. Fruits of Religion. Salt Lake City: Deseret Book, 1946. The Bible is the main book of scripture for the Church of Jesus Christ of Latter-day Saints; the Book of Mormon is the companion volume of scripture that guides practice, doctrine, and conduct of the Church and clarifies doctrines such as the Lord's interest in all people of the earth, the nature of the soul of man, baptism of little children, democracy, mode of baptism, and the Fall of Adam. [J.W.M.]

W.246 West, Franklin L. "A New Witness for God." DN Church Section (20 April 1946): 10, 12. The Latter-day Saints consider the Book of Mormon to be another witness of Christ. The Book of Mormon contains the same principles of the gospel as the New Testament. [M.D.P.]

W.247 West, Jack H. The Book of Mormon on Trial. Compiled by V. Rich, illustrated by Fritz O. Alseth. Sacramento: Fritz 'n Rich Publishing, 1963. Incorporates West's "The Trial of the Stick of Joseph" into a cartoon mock trail of the Book of Mormon. Charges against the Book of Mormon are countered and evidence given for the truthfulness of the Book of Mormon. [A.C.W.]

W.248 West, Jack H. Trial of the Stick of Joseph: A Lecture Series. Salt Lake City: Sounds of Zion, 1981. Also, in Spanish, Juicio del Palo de Jose: Testigos Personales. Peru: n.p., 1967. A three-part lecture that recounts the events surrounding a mock trial of the Book of Mormon. Analyzes the testimonies of witnesses who claimed to have seen the gold plates, and discusses internal and external evidences of the Book of Mormon. This work is reviewed in S.518. [J.T.]

W.249 West, Roy A. An Introduction to the Book of

W.250 West, Sandee Gladden. "The Ad." Ensign 20 (August 1990): 48-49. A high school student answered an ad in the Reader's Digest and received a Book of Mormon. After reading passages in the book of Mosiah explaining death and resurrection, this young woman learned of her own father's death. The Spirit bore witness of the truthfulness of the teachings. [J.W.M.]

W.251 Westenskow, Melvin. Treasures to Share. Salt Lake City: Deseret Book, 1948. The explanation of the relationship between the Book of Mormon and the Bible is found within the pages of the Book of Mormon itself. Latter-day Saints do not replace the Bible with the Book of Mormon, they are companions, one complimenting the other. The Bible does prophesy of the Book of Mormon in many places, just as it foretells of Christ without revealing his name. The use of metal and cement in the Book of Mormon was once ridiculed, but is now verified by archaeology. The Book of Mormon adds credence to the Bible. It is a second witness to the divinity of Christ. [J.W.M.] 
W.252 Whalen, William J. The Latter-day Saints in the Modern Day World. New York: John Day Company, 1964. Writes concerning the book's origins, contents, witnesses, and anachronisms. Believes that the book is a "remarkable document" and yet states that Joseph Smith could have created it. [D.M.]

W.253 "What about Archaeology and the Book of Mormon?" Utah Christian Tract Society 11 (January-February 1978): 2. Refers to the Smithsonian position of the time on the Book of Mormon and asserts that the Book of Mormon cannot be proven through archaeology. [D.M.]

W.254 "What Happens in the Book of Mormon." Friend 14 (January 1984): 28-29. Eleven pictures for children depicting events of the Book of Mormon. [A.T.]

W.255 "What Is the Book of Mormon?" Utah Christian Tract Society 12 (September/October 1979): 2. Contains several criticisms of the Book of Mormon. [D.M.]

W.256 What Shall We Believe? Phoenix, AZ: Visual Arts Co., n.d. Shows the organization of the Church, the coming forth of the Book of Mormon as the stick of Joseph, the plan of salvation, and the first principles of the gospel. Contains charts of the chronology of the Book of Mormon. [J.W.M.]

W.257 Wheeler, Carl F. "The Book of Mormon versus Polygamy." SH 107 (11 July 1960): 673. Points out that Jacob 2:39 does not condone polygamy. [A.C.W.]

W.258 "When a Book of Mormon Witness Passed On." MS 98 (27 February 1936): 138-39. Brief life story of Oliver Cowdery. He was a special witness for the Book of Mormon and never denied the Book of Mormon even though he was once excommunicated but later rebaptized. [M.D.P.]

W.259 Whence Came the Red Man? Independence, MO: Herald House, 1940. A 13-page pamphlet that describes the provenance of the Indians. It describes how Lehi left Jerusalem to come to America. The RLDS church is the church that brings the Book of Mormon to the Indians. [B.D.]

W.260 "Where Are the Hills of Ramah and Cumorah?" Instructor 75 (January 1940): 8. In an article published by the Messenger and Advocate in Kirtland, Ohio, July, 1835, a quote attributed to Joseph Smith appeared. It described the Hill Ramah as being about one mile west of the Hill Cumorah (in New York). Between these two hills was the final battleground of both the Nephite and Jaredite nations. [J.W.M.]

W.261 "Where the Book of Mormon Went to Press." Ensign 19 (February 1989): 43-47. Presents color photographs and explanations of people, places, and artifacts associated with the first printing of the Book of Mormon. [J.W.M.]

W.262 White, James. Letters to a Mormon Elder. Southbridge, MA: Crowne, 1990. Chapter 8 of this polemicalevangelical work against Mormonism is concerned with proving the absurdity and falsity of the Book of Mormon. White notes historical inaccuracies, asserts that the book contains false doctrines about grace and the nature of the Trinity, points out alleged textual problems, and rejects the use of Old Testament prophecies by Mormons to support claims for the Book of Mormon. [M.R.]

W.263 White, Joseph Welles. "The Influence of Sidney Rigdon upon the Theology of Mormonism." M.A. thesis, University of Southern California, 1947. An historical thesis on Mormonism and the development of its doctrine. The author attempts to examine possible influences of Sidney Rigdon upon Mormon doctrines and scripture, 
saying that the Book of Mormon is a product of its times, with possible connections to the Spaulding manuscript. [M.R.]

W.264 White, Lizzie O. Borgeson, and Dianne Olivia White. Teckinanny: A Story of Early Inhabitants of the Western Hemisphere and Christ's Visit to the Descendants of Lehi. Salt Lake City: Lizzie O. Borgeson White, 1947. A fictional story that tells of two children, one a pioneer girl and the other a native American, who listen to stories about the Book of Mormon inhabitants of America told by the pioneer mother. [J.W.M.]

W.265 Whitehead, Earnest L. A Concise Reference to the Book of Mormon. Utah: Bookcraft, 1920. This pamphlet contains scriptural references to many LDS doctrinal subjects found in the Book of Mormon: authority, America as the promised land, baptism and salvation, baptism of infants, Christ as a personal being, faith and works, an unchangeable gospel, and others. [J.W.M.]

W.266 Whitehead, Earnest L. The House of Israel; a Treatise on the Destiny, History and Identification of Israel in All the Five Branches. Salt Lake City: E. L. Whitehead, 1947. A treatise that discusses the history and prophetic future of the tribes of Israel (including the Book of Mormon people) with particular emphasis on their divine mission and role among the nations of the earth. [J.T.]

W.267 Whiting, Gary R. The Book of Mormon Is Christian: A Study of the Major Christian Doctrines Comparing the Bible and Book of Mormon. Wichita, KS: Zion's Outpost, 1988. The 1908 edition of the Book of Mormon is used for all referencing in this lesson plan that compares the Book of Mormon with the Bible. Patterns in the Book of Mormon are the same as biblical patterns. Biblical evidences for the Book of Mormon are brought to the attention of the student as well as the purpose of the book and Christ's teachings that are contained within its pages. [J.W.M.]

W.268 Whiting, Gary R. "The Testimony of Amaleki." In The Book of Mormon: Jacob through Words of Mormon, To Learn with Joy, edited by Monte S. Nyman and Charles D. Tate Jr., 295-306. Provo, UT: Brigham Young University Religious Studies Center, 1990. Although Amaleki wrote only seventeen verses, he contributed substantially to the Book of Mormon. His writing contains historical information, bears witness of Christ, describes the migration of a Nephite group to Zarahemla, tells of Mulek, gives the Jaredite link, and mentions the people of Zeniff. [J.W.M.]

W.269 Whitman, Charles Walker. "A History of the Hill Cumorah Pageant (1937-1964) and an examination of the dramatic development of the text of America's Witness for Christ." Ph.D. diss., University of Minnesota, 1967. Presents the pageant method, definition, and the myth, writing, directorship, and revisions that subsequently followed. A profound change came about in the community as a result of the pageant. [J.W.M.]

W.270 Whitman, Jason. "Notices of Books: The Book of Mormon." The Unitarian 1 (January 1834): 40-50. A polemical article attempting to discredit the Book of Mormon. The writer notes similarities between Book of Mormon and New Testament language and doctrines. Various anachronisms are mentioned such as the usage of the phrase "it came to pass," poor grammar, modern ideas, a Christian Church before Christ, Gadianton robbers are viewed as nineteenth-century Masons, and lack of Israelite festivals and geographical evidences. [M.R.]

W.271 Whitmer, David. An Address to All Believers in Christ. By a Witness to the Divine Authenticity of the Book of Mormon. Richmond, MO: n.p., 1887. This pamphlet was circulated to refute the claim that the Three Witnesses had denied their testimonies. In spite of his negative feelings toward the Church, David Whitmer strongly testifies of the divine origin of the Book of Mormon. He refutes the Solomon Spaulding manuscript theory and applauds the character of the witnesses. The Book of Mormon denounces the iniquity of polygamy. [J.W.M.] 
W.272 Whitmer, David (written by a Chicago Times reporter). "David Whitmer Interview." Chicago Times (7 August 1875): 1. Denouncing the Latter-day Saints of Utah, Whitmer reaffirms his testimony concerning the Book of Mormon, which is a supplement to the Bible. He further denounces polygamy as a disgrace to the Church. [J.W.M.]

W.273 Whitmer, David. "An Interview with David Whitmer." DN (16 August 1878). In a question/answer interview Whitmer described the plates, the Urim and Thummim, and affirmed his testimony of the Book of Mormon. [J.W.M.]

W.274 Whitmer, David. The Last Witness Dead. Monongahela, PA: Ladies' Uplift Circle of the Church of Jesus Christ, 1936. Reprints obituaries on David Whitmer from Missouri newspapers. Stresses his tenacious testimony as one of the Three Witnesses. States some details of his vision, including the handling of the Urim and Thummim and sword of Laban. [D.M.]

W.275 Whitmer, David. The Solution of The Mormon Problem: What Is It? N.p. : n.p., 1926. Reprint of pamphlet written by David Whitmer entitled "An Address to All Believers in the Book of Mormon," with a preface by John J. Snyder. [J.W.M.]

W.276 Whitmer, David, Sr. "David Whitmer, Sr.: Tested and Sustained." SH 28 (1 June 1881): 168. Refutes a statement by John Murphy that the author denied his testimony as one of the Three Witnesses of the Book of Mormon. [R.M.]

W.277 Whitmer, John. "Address." MA 2 (March 1836): 285-88. Reiterates his testimony as one of the Eight Witnesses of the Book of Mormon. Testimony is borne with conviction. [D.M.]

W.278 Whitney, Orson F. "The Book of Mormon, Historical and Prophetic Phases." IE 30 (September 1927): 94148. Reports of his visit to Palmyra, Manchester, and the Hill Cumorah, outlines many of the features of the Book of Mormon: the history and prophecy in the book, reference to Zion, America as a land of liberty, the relationship of Joseph and Judah, and Jesus Christ in America. [D.M.]

W.279 Whitney, Orson F. History of Utah. 4 vols. Salt Lake City: Cannon \& Sons, 1892. Volume 1 includes a detailed description of the gold plates, an account of the Book of Mormon narrative, and the rise of the Spaulding theory. [J.W.M.]

W.280 Whitney, Orson F. "The Land of Zion." In Whitney's Saturday Night Thoughts, 31-35. Salt Lake City: Deseret News, 1921. Contains an overview of the Book of Mormon, and a discussion of Book of Mormon prophecies related to the responsibilities and position of America. Both Nephite and Jaredite prophets understood that America is the land of Zion. Its destiny is linked closely with Jerusalem. [J.W.M.]

W.281 Whitsitt, William H. Intermediate Examination. Louisville, KY: Southern Baptist Theological Seminary, 1886. A tract that asks questions about Mormonism, but does not answer them. Assumes the Book of Mormon is Sidney Rigdon's redaction of Spaulding's manuscript. [D.M.]

W.282 Whitsitt, William H. Sidney Rigdon, the Real Founder of Mormonism, assembled by Byron Marchant. Salt Lake City: Metamorphosis, 1988. This manuscript was written and remained unpublished until assembled by Byron Marchant. It is a collection of three articles-1885, "The Honolulu Manuscript and the Book of Mormon," 
1891, "Mormonism," and a "Cover Letter" dated August 28, 1908. It purports that Sidney Rigdon wrote the Book of Mormon. [J.W.M.]

W.283 Whittaker, A. C. The Challenge "The Book of Mormon" Makes to the World. Salt Lake City: 196?. Challenging others to duplicate the Book of Mormon, the author has published this list of conditions under which the book was translated. [J.W.M.]

W.284 Whittaker, David J. "Orson Pratt: Early Advocate of the Book of Mormon." Ensign 14 (April 1984): 54-57. Traces Orson Pratt's work as a "student, advocate, and editor" of the Book of Mormon. Recounts how he drew heavily on the work of his brother, Parley P. Pratt, and on his own scientific background to defend the Book of Mormon. Tells of his work in making extensive format changes to the 1879 edition of the Book of Mormon to make it more accessible to students. [S.P.S.]

W.285 Whittier, C. H., and S. W. Stathis. "The Enigma of Solomon Spaulding." Dialogue 10 (Autumn 1977): 70-73. Solomon Spaulding, born in Connecticut in 1761, wrote the romantic novel that is alleged to have provided the "historical" source of the Book of Mormon. It was a fictional novel about a ship of Roman soldiers "in the time of Constantine driven by storm to the New World" who became a part of the Indians. He was known to believe in the Hebrew origin of the Indians. [J.W.M.]

W.286 Whittle, Benson. Review of Early Mormonism and the Magic World View, by Michael Quinn. BYU Studies 27 (1987): 105. Book review.

W.287 "Who Am I? A Book of Mormon Quiz." Friend 4 (March 1974): 38-39. A quiz for children on different characters in the Book of Mormon. [M.D.P.]

W.288 "Who Is Book's Author?" CN 58 (2 January 1988): 16. Church News editorial arguing that Jesus Christ was the ultimate author of the Book of Mormon. [D.M.]

W.289 "Who Wrote the Book of Mormon." Utah Christian Tract Society 10 (July-August 1976): 2. Disputes the view that the Book of Mormon is of divine origin, seeing it rather as a modern composition written by Solomon Spaulding, Sidney Rigdon, and Joseph Smith. [D.M.]

W.290 "Why Ancient Records?" CN 46 (30 October 1976): 16. For many reasons the Lord commanded ancient peoples to keep records - to preserve language, to keep histories, and to teach the gospel. Another reason was to keep future generations from making the same mistakes. [M.R.]

W.291 Why I Believe the Book of Mormon. Lamoni, IA: Board of Publication of the RLDS Church, 1909. An apologetic tract using common prooftexts as well as unusual ones, such as Ezekiel 17 and Hosea 8:11-12. [D.M.]

W.292 "Why Not Investigate?" MS 50 (March 1888): 161-62. The author suggests that some scientific body endeavor to prove or disprove whether archaeological discoveries validate the Book of Mormon. [B.D.]

W.293 Widtsoe, John A. "Alma Speaks to the Twentieth Century." IE 31 (November 1927): 20-31. Reprinted in A Book of Mormon Treasury. Salt Lake City: Bookcraft, 1976, 83-98. Alma the Younger taught principles that are relevant in our day. The combined teachings of Alma connect the premortal life, present day, and future life. Alma's teachings deal with such concepts as the Fall and redemption, the nature of the priesthood, the final judgment, humility, faith, and prayer. [D.M.] 
W.294 Widtsoe, John A. The Book of Mormon. Independence, MO: Zion Printing, 1934. This tract explains briefly the contents, origin, authenticity, witnesses, consistency, archaeological discovery in modern times, and the Bible prophecies concerning the Book of Mormon. [J.W.M.]

W.295 Widtsoe, John A. The Book of Mormon. London: LDS British Mission Office, 1932. Also in DN Church Section (7 January 1933): 6, 7. This small leaflet was written to nonmembers to explain what the Book of Mormon is, its origin, and the authenticity of the book. The author observes that the book is consistent in its textual content. Modern archaeology has corroborated the truthfulness of the book. It supports and fulfills the teachings of the Bible and it is an inspired book. He offers a challenge to test its validity. [J.W.M.]

W.296 Widtsoe, John A. "The Book of Mormon." Number Fifteen in the Centennial Series. In Widtsoe's The Handbook of the Restoration, 237-42. Independence, MO: Zion's Printing, 1944. The Book of Mormon is a historical record of the ancient inhabitants of America, Christ's "other sheep." It reinforces the Bible and sets high moral standards for living. There are many evidences of its authenticity: witnesses, the book's consistency, modern scientific discoveries, Bible prophecies, its inspired contents, and the witness of the Holy Ghost. [J.W.M.]

W.297 Widtsoe, John A. "The Book of Mormon Is Translated." DN (2 March 1949): 23. Widtsoe explains the major events that occurred between the time Joseph Smith received the plates in 1827 and 1830 when the Book of Mormon was published. [B.D.]

W.298 Widtsoe, John A. "Can We Believe the Witnesses to the Book of Mormon?" IE 49 (June 1946): 385, 41415. Also in A Book of Mormon Treasury, 39-43. Salt Lake City: Bookcraft, 1959, 1976. And in Gospel Interpretations. 3 vols. Salt Lake City: Bookcraft, 1947, 2:133-138. Provides several reasons to believe the testimony of the witnesses of the Book of Mormon. [J.W.M.]

W.299 Widtsoe, John A. "Did Joseph Smith Write the Book of Mormon?" DN (16 March 1949): 23. Addresses claims that the Book of Mormon was not divinely written. [B.D.]

W.300 Widtsoe, John A. "Did the Nephites Have the Higher Priesthood before the Coming of Christ?" IE 45 (June 1942): 385, 413, 415. Also in Evidences and Reconciliation, edited by G. Homer Durham, 240-42. Salt Lake City: Bookcraft, 1987. Argues that the Nephites possessed the higher priesthood during the era before the resurrected Jesus visited the Nephites (citing 1 Nephi 5:14-16, Alma 10:3, Mosiah 25:21, and others). [L.D.]

W.301 Widtsoe, John A. "Does the Book of Mormon Forbid Polygamy?" MS 95 (4 May 1933): 296-97. In Jacob's sermon on immorality (Jacob 2) polygamy is not forbidden. What is forbidden is the taking of wives and concubines without the sanction of God. [J.W.M.]

W.302 Widtsoe, John A. "Does the Kon-Tiki Voyage Confirm the Book of Mormon?" IE 54 (May 1951): 318-19. Also published in Evidences and Reconciliations, edited by G. Homer Durham, 3:99-102. 3 vols. Salt Lake City: Bookcraft, 1951. Thor Heyerdahl, a Norwegian explorer, successfully accomplished a 4000-mile sea voyage from the coast of Peru to the Tuamotu Islands across the Pacific. The balsa raft named Kon-Tiki sailed only by wind and ocean currents. The Kon-Tiki voyage clearly demonstrates that such voyages could certainly have been made, similar to the claims made in the Book of Mormon. [R.C.D.]

W.303 Widtsoe, John A. "Evidences for the Book of Mormon." DN (3 April 1949): 23. Widtsoe presents external evidences as proof that the Book of Mormon is authentic: metal plates have been found, reformed Egyptian has 
been proven beyond a doubt, research has indicated that there were multiple authors of the book, religious beliefs of the ancient Americans conform to the Book of Mormon text. [J.W.M.]

W.304 Widtsoe, John A. "Evidences for the Book of Mormon." MS 90 (January 1928): 57-58. Writes that growing evidence has confirmed the Book of Mormon. Widtsoe praises J. M. Sjodahl's An Introduction to the Study of the Book of Mormon, and quotes Sjodahl's testimony of the Book of Mormon. [B.D.]

W.305 Widtsoe, John A. "The Golden Plates Are Seen." DN (9 February 1949): 23. Tells of Joseph Smith's visions of Moroni and how he received the plates. [B.D.]

W.306 Widtsoe, John A. "His Other Sheep." MS 92 (27 March 1930): 200-1. Perhaps the greatest message of the Book of Mormon is that God speaks to all his children, "on one continent or another, in one land or another," all will be taught the gospel of Jesus Christ. [D.W.P.]

W.307 Widtsoe, John A. "Is Book of Mormon Geography Known?" IE 53 (July 1950): 547, 596-97. Also published in Evidences and Reconciliations, edited by G. Homer Durham, 3:93-98. 3 vols. Salt Lake City: Bookcraft, 1951. Also in A Book of Mormon Treasury, 127-30. Salt Lake City: Bookcraft, 1959, 1976. Although there is little definite evidence or data with which to clearly identify Book of Mormon geographical sites, continued earnest, honest, and scholarly studies should not be discouraged. "All such studies are legitimate," but dogmatic conclusions made without actual verifiable data "must at the best be held as intelligent conjectures." [R.C.D.]

W.308 Widtsoe, John A. "Notes on Moroni's Message." Young Woman's Journal 34 (September 1923): $461-65$. Lists fourteen specific points related to Moroni's visit, including the value of repentance, prayer as a catalyst, the promise of universal salvation, and warnings concerning covetousness. [D.M.]

W.309 Widtsoe, John A. "The Power of Moroni's Message." MS 96 (November 1934): 721-27. Concentrates on the work of salvation for the dead as introduced when Moroni quoted Malachi to Joseph Smith. [B.D.]

W.310 Widtsoe, John A. "Scholarship and the Book of Mormon." MS 90 (8 November 1928): 712-13. Although scientific research may substantiate items discussed in the Book of Mormon, there is no need for a scientific explanation for the book. [A.T.]

W.311 Widtsoe, John A. "Truth Restored: A Modern Miracle!" Number Fourteen in the Centennial Series. In Widtsoe's The Handbook of the Restoration, 232-37. Independence, MO: Zion's Printing, 1944. Apostasy came because of the choices that men made, and truth was lost. The Father and the Son appeared to Joseph Smith telling him that an important work would be required of him and that truth would be restored. Joseph translated and published the Book of Mormon thereby re-establishing priesthood authority and the Lord's church. [J.W.M.]

W.312 Widtsoe, John A. "Was Iron Known in Ancient America?" IE 53 (March 1950): 175, 231. Also published in Evidences and Reconciliations, edited by G. Homer Durham, 3:89-92. 3 vols. Salt Lake City: Bookcraft, 1951. The view of scholars in the field of American archaeology holds that the pre-Columbian inhabitants of America did not know of or use iron. However, this article, citing the Science Newsletter of November 12, 1949, recommends that this view may have to be reevaluated on the basis of new findings of iron in ancient America. [R.C.D.]

W.313 Widtsoe, John A. "Was Steel Known When Lehi Left Jerusalem?" IE 50 (May 1947): 304. Argues that steel existed around the time Lehi left Jerusalem, about 600 B.C. [L.D.] 
W.314 Widtsoe, John A. "What Was the Vocabulary of Joseph Smith?" IE 54 (June 1951): 399, 476. Any translation will reflect the vocabulary of the translator. Such was the case with Joseph Smith and the Book of Mormon. An average "fairly well-educated" person possesses an 8,000 word vocabulary. Joseph Smith as a youth would have had a substantially smaller vocabulary. Interestingly, the Book of Mormon has a total vocabulary (including person and place names) of 3,307 words. [R.C.D.]

W.315 Widtsoe, John A. "When Did Joseph Smith Have the First Vision?" In Evidences and Reconciliation, edited by G. Homer Durham. 334-39. Salt Lake City: Bookcraft, 1987. Discusses Joseph Smith's account of the First Vision, when it took place, and the coming forth of the Book of Mormon. [L.D.]

W.316 Widtsoe, John A. "Who Saw the Book of Mormon Plates." DN (9 March 1949): 23. The only material background upon which we may base our faith in the Book of Mormon are the testimonies of the Three Witnesses and the Eight Witnesses. [B.D.]

W.317 Widtsoe, John A. "Why Did Joseph Smith, the Prophet, Need the Help of the Urim and Thummim?" IE 43 (January 1940): 33, 37. The Urim and Thummim were used in connection with priestly functions of the Old Testament and later were important in the translation process of the Book of Mormon. Historically they served to facilitate communication with the Lord. [J.W.M.]

W.318 Widtsoe, John A. "Why Did Joseph Smith the Prophet Need the Help of the Urim and Thummim." In Evidences and Reconciliation, edited by G. Homer Durham, 89-91. Salt Lake City: Bookcraft, 1987. Discusses the purpose of the Urim and Thummim anciently and Joseph Smith's usage of them to translate the Book of Mormon. [L.D.]

W.319 Widtsoe, John A., and Franklin S. Harris. Seven Claims of the Book of Mormon: A Collection of Evidences. Independence, MO: Press of Zion's Printing and Publishing, n.d. A missionary manual that presents seven Book of Mormon claims and gives supporting evidence. The claims include: the Book of Mormon is of divine origin, it consists of writings by successive historians, it was written in reformed Egyptian on metal plates, the native Americans are partly of Hebrew descent, and there were great civilizations in ancient America that Christ visited. [C.C.]

W.320 Widtsoe, Osborne. "The Test of Section Sixty-seven." IE 10 (January 1907): 161-65. Examines the idea that Joseph Smith could not have been an impostor who wrote the Book of Mormon. His limited education and young age at the time make the idea absurd, as does the fact that the educated William E. M'Lellin tried unsuccessfully to create a revelation from the Lord (D\&C 67) similar to the many revelations received by Joseph Smith. [J.W.M.]

W.321 Widtsoe, Osborne J. P. "Other Sheep." In Widtsoe's What Jesus Taught, 291-98. Salt Lake City: Deseret Sunday School Union, 1918. Jesus appeared among the Nephites and declared that they were his "other sheep" who were identified in the book of John. [J.W.M.]

W.322 Widtsoe, Osborne J. P. The Restoration of the Gospel. Salt Lake City: Deseret Book, 1912. Chapter 20 deals with the eleven witnesses who viewed the gold plates of the Book of Mormon. The Three Witnesses reconfirmed their testimonies in their last days of mortality and though three of the Eight Witnesses left the Church, none of the eight denied their testimonies. [J.W.M.] 
W.323 Widtsoe, Osborn J. P. "The Unfair Fairness of Rev. Spaulding." IE (April 1913): 593-603. Reprint from DN (15 February 1913). Explains why Reverent Spaulding's testing of the Book of Mormon by examining the authenticity of the book of Abraham as an ancient Egyptian text is unfair. Latter-day Saints do not value the Bible less than the Book of Mormon. The belief of the Church is that both were divinely inspired of God and are placed on the same plane, though it is recognized that the Bible may have copyists' errors. [J.W.M.]

W.324 Wight, Cyril E. The Book of Mormon, Is It Necessary? Independence, MO: Herald House, 1943. Contains lessons that address the question, "Is the Book of Mormon necessary?" Discusses the Jaredite and Mulekite histories, Lehi's exodus from Jerusalem and journey to the promised land, Nephi's leadership, Zeniff's people and Alma's establishment of the Church in the Waters of Mormon, Alma the Younger's missionary service, missionary work of the sons of Mosiah, the sons of Alma the Younger, Captain Moroni, Helaman, signs of Christ's coming, Mormon's abridgment, Moroni's preservation of the records, and the purpose of the Book of Mormon as a basis for the Restoration and proof that God speaks today. [J.W.M.]

W.325 Wight, La Preal. "I Am Brought Forth to Meet You." IE 53 (October 1950): 781, 810. The Book of Mormon prophet and writer Moroni prophesied that he would come forth "triumphant through the air" at a future date (Moroni 10:34). Wight sees a quite literal fulfillment in this prophecy in the statues of Moroni on the top of the Salt Lake Temple and the Hill Cumorah. Moroni now stands triumphant in the air. [R.C.D.]

W.326 Wilcox, Orrin R. Book of Mormon, Abridged in Rhyme, Part 1, the Exodus 600 B.C. to 545 B.C. Mansfield, MO: n.p., 1972. A poetic rendition of the exodus of Lehi from Jerusalem. [J.W.M.]

W.327 Wilcox, S. Michael. "Book of Moroni." In Encyclopedia of Mormonism, edited by Daniel H. Ludlow, 1:157-58. 5 vols. New York: Macmillan, 1992. Explains the contents and organization of the book of Moroni. Discusses the loosely related but important items that Moroni brought together including ordinances, Mormon's sermons and letters, Moroni's exhortation and farewell including his final testimony of Jesus Christ. [B.D.]

W.328 Wilcox, S. Michael. Choosing the Fullness: Wickedness or Righteousness. Salt Lake City: Bookcraft, 1988. A meditation on the "two ways" theme, which contrasts fruits leading to happiness or misery. Includes a chapter on "the Nephites' rejection of the good." Discusses scriptural warnings and extols the Zion society described in 4 Nephi. [D.M.]

W.329 Wilcox, S. Michael. "I Have a Question: I am confused by the gospel principle of justification by faith. Can you explain it to me?" Ensign 21 (June 1991): 51-53. The Book of Mormon defines this principle particularly well by the words it substitutes in place of justification, such as blameless and guiltless. Justification then is the process through which guilt is removed through faith. [J.W.M.]

W.330 Wilcox, S. Michael. "Nephi's Message to the 'Gentiles." In The Book of Mormon: Second Nephi, The Doctrinal Structure, edited by Monte S. Nyman and Charles D. Tate Jr., 269-86. Provo, UT: Brigham Young University Religious Studies Center, 1989. 2 Nephi 25-33 represents Nephi's final discourse having the purpose of bringing gentile, Jew, and "the remnant of his seed" to Christ. The expression "gentile nation" may be used interchangeably with "Christian nations." Nephi outlines the Messiahship of Christ: He is the eternal God who manifests himself to every nation through signs, miracles, wonders, and through the Holy Ghost. Pride, learning, and the precepts of men stand in opposition to God's work. [J.W.M.]

W.331 Wilcox, S. Michael. "Samuel the Lamanite." In Encyclopedia of Mormonism, edited by Daniel H. Ludlow, 3:1259. 5 vols. New York: Macmillan, 1992. Approximately 5 B.C. Samuel, a Lamanite, preached repentance in 
Zarahemla. He prophesied of Christ's birth and crucifixion. No other evidence of his life and ministry is recorded. [J.W.M.]

W.332 Wilcox, S. Michael. "Spiritual Rebirth." In The Book of Mormon: Mosiah, Salvation Only through Christ, edited by Monte S. Nyman and Charles D. Tate Jr., 247-60. Provo, UT: Brigham Young University Religious Studies Center, 1991. Distinguishing between natural man and the physical body is important in understanding how overcoming the natural man becomes a rebirth through the Atonement of Jesus Christ. The natural man yields to carnal and untamed desires. The physical body, however, is essential to a fullness of joy. Transforming our natural tendencies to Christ-like qualities brings about a death of the old self and brings a "mighty change" or new birth that occurs through the Atonement of Christ, loving him, faith in him, and hope in his mercy. [J.W.M.]

W.333 Wilde, Orrin G. Landmarks of Ancient America. N.p., 1947. A 26-page non-dogmatic pamphlet on Book of Mormon geography. Guesses where locations are in relation to the American continent. [D.M.]

W.334 Wilkins, Olive McFate. From Cumorah's Lonely Hill: An Epic Poem of the Book of Mormon. Salt Lake City: Deseret News Press, 1950. Tells the story of the Book of Mormon in an epic poem. [J.W.M.]

W.335 Wilkinson, Barbara Smith. "Understanding the Nephite Monetary System." In Recent Book of Mormon Developments, Articles from the Zarahemla Record, 2:222-23. 2 vols. Independence, MO: Zarahemla Research Foundation, 1992. An evaluation of the Nephite monetary system as explained in Alma 8 that establishes current American dollar values for Nephite money. [B.D.]

W.336 Wilkinson, LaVern. "Waters of Sebus." IE 30 (February 1927): 346-47. Ammon received the miraculous power of God as the result of obedience to God. Individuals qualify for the Lord's work by diligent study. Power is invested in them by prayer and fasting, and there must be a desire to serve. [J.W.M.]

W.337 Willers, Diedrich. "The First Months of Mormonism: A Contemporary View." Translated and edited by D. Michael Quinn. New York History 54 (July 1973): 317-33. Willers, a German Reformed minister, wrote a letter in June 1830 that provides valuable insights into how the early LDS church and its leaders were perceived. He was interested in and opposed to the new sect. Willers knew the Whitmers, whom he labels as "unstable, spineless men," and Hiram Page, who is "likewise full of superstition." Discusses the role of the Urim and Thummim in translating the Book of Mormon. [A.C.W.]

W.338 Willes, Joseph S. "Could Joseph Smith Have Written the Book of Mormon?" IE

W.339 Willet, H. L. "The Question Box: What Became of the Plates Found by Joseph Smith?" Christianity Today 54 (30 June 1937): 841. Discounts the idea that Joseph Smith possessed gold plates from which came the Book of Mormon. [J.W.M.]

W.340 "William Smith's Story Concerning the Plates of the Book of Mormon." Instructor 75 (January 1940): 6. An interview that took place two weeks before the death of William Smith, wherein Smith avows that he did indeed lift the gold plates from which the Book of Mormon was translated. [J.W.M.]

W.341 Williams, Camille. Review of Finding Christ through the Book of Mormon, by Susan Easton Black. Review of Books on the Book of Mormon 1 (1989): 3-4. Book review. 
W.342 Williams, Camille S., and Donna Lee Bowen. "Ordinary People in the Book of Mormon." Ensign 22 (January 1992): 36-39. Provides examples of "ordinary faithful people" in the Book of Mormon. For instance, Abish demonstrated a strong belief in the Lord, Saria showed a willingness to be obedient, and the story of the daughter of Jared teaches that position and beauty have little connection to faith or to one's ability to serve the Lord. [A.C.W.]

W.343 Williams, Clyde J. "Book of Jacob." In Encyclopedia of Mormonism, edited by Daniel H. Ludlow, 1:147-48. 5 vols. New York: Macmillan, 1992. A description of the book of Jacob, its organization and content. It seems to have three parts: a discourse by Jacob at the temple calling his people to repentance; prophecies of the Atonement of Christ, his rejection by the Jews, and the scattering and gathering of Israel; and the confrontation with the anti-christ, Sherem. [B.D.]

W.344 Williams, Clyde J. "The Book of Mormon and Overcoming Satan." In Doctrines of the Book of Mormon, 1991 Sperry Symposium, edited by Bruce A. Van Orden and Brent L. Top, 243-56. Salt Lake City: Deseret Book, 1992. The Book of Mormon conveys the Lord's messages concerning Satan's role, characteristics, and purpose, and places emphasis on how to identify and overcome Satan's tactics. Twelve tactics are noted and seven principles of overcoming these tactics are listed. [J.W.M.]

W.345 Williams, Clyde J. "Deliverance from Bondage." In The Book of Mormon: Mosiah, Salvation Only through Christ, edited by Monte S. Nyman and Charles D. Tate Jr., 261-74. Provo, UT: Brigham Young University Religious Studies Center, 1991. Relating Mosiah 7-24 to our day, this article identifies the steps that lead to bondage, what must be done to be delivered from it, and to what degree the Lord will help. There are many ways in which modern man brings bondage upon himself, but deliverance always comes by turning to Jesus Christ. [J.W.M.]

W.346 Williams, Clyde J. "An Examination of Influential Factors Affecting Students in Applying Book of Mormon Principles toward the Resolution of Personal Problems." Ph.D. diss, Brigham Young University, 1989. Members of the Church are under the condemnation of the Lord because they have failed to apply the teachings of the Book of Mormon in their lives. The practice of putting oneself into the place of individuals in the Book of Mormon is invaluable; it leads to understanding deity. The Book of Mormon carries a solution to every problem in its pages. [J.W.M.]

W.347 Williams, Clyde J. "The Godhead and Godhood As Taught in the Book of Mormon." In A Symposium on the Book of Mormon, 120-24. Salt Lake City: Church of Jesus Christ of Latter-day Saints, CES, August 1986. Outlines the modern Christian concept of God using the Nicean and Athanasian creeds and states that this concept is based on a misunderstanding of the scriptures. The Book of Mormon defines the following doctrines: (1) there are three distinct beings in the Godhead, (2) the Father and Son possess physical bodies, (3) there is a doctrine of the Fatherhood of Christ, and (4) man can become like God. [A.T.]

W.348 Williams, Clyde J. "Instruments in the Hands of God: The Message of Alma." In The Book of Mormon: Alma, The Testimony of the Word, edited by Monte S. Nyman and Charles D. Tate Jr., 89-106. Provo, UT: Brigham Young University Religious Studies Center, 1992. The sons of Mosiah were instruments in the hand of the Lord to accomplish their missionary labors. To be missionaries, they needed to possess scriptural knowledge, fast and pray, possess patience, serve as examples to the people, and remain faithful in the gospel. In turn, the Lord directed them and their joy in the harvest was great. Their missionary experiences provide us with a model for missionary work today. [N.K.Y.] 
W.349 Williams, D. T. "Mother's Testimony of the Book of Mormon." SH 113 (1 July 1966): 441. Story of how Williams's mother gained a testimony of the Book of Mormon and joined the RLDS church. [A.C.W.]

W.350 Williams, David M. Let Us Go Back to Christ: Looking unto Jesus, the Author and Finisher of Our Faith. Salt Lake City, 1900. Members of the Church must return to the Book of Mormon, for they have begun to stray from the basic principles and doctrines. [J.W.M.]

W.351 Williams, Frederick G., III. "Did Lehi Land in Chile." Provo, UT: FARMS, 1988. See also Reexploring the Book of Mormon, edited by John W. Welch, 57-61. Salt Lake City: Deseret Book and FARMS, 1992. A quote attributed to Frederick G. Williams, I, concerning the landing of Lehi and his group in Chile may not reflect the truth. Three handwritten copies of this statement exist, none of which provides evidence as to their source. [J.W.M.]

W.352 Williams, James. "The Law of the Book of Mormon." American Law Review 34 (1900): 219-23. Claims that the Book of Mormon is a product of plagiarism from the earlier historical romance of Spaulding. The laws given by Mosiah bear a close resemblance to laws existent in the United States. The most interesting law was against the practice of polygamy, which many Mormons practiced in 1900. [J.W.M.]

W.353 Williams, L. E. "The New Witness." MS 73 (23 November 1911): 737-39. Since the Christian world is filled with unbelief, there was a need for a second witness. The Book of Mormon fulfills the prophecies of Ezekiel and Isaiah. Using the "old" (the Bible) and the "new" (the Book of Mormon) to support one another, the searcher for the truth may weigh the evidence favorably. [J.W.M.]

W.354 Williams, Samuel Cole, ed. Adair's History of the American Indians. Johnson City, TN: Watauga Press, 1930. A reprint of Adair's work with an index, extended notes by the editor of Adair's original notes, and an introduction giving an account of Adair and the book. [B.D.]

W.355 Williams, Stephen. "Archaeology and Religion: Where Angels Fear to Tread." In Williams's Fantastic Archaeology: The Wild Side of North American Prehistory, 1991, 156-88. Philadelphia: University of Pennsylvania Press, 1991. Recounts the coming forth of the Book of Mormon, rehearses the Book of Mormon story, and discusses how members of the Church have used Mesoamerican archaeology to prove the book is true. The Kinderhook plates, the Newark Holy Stones, the Mark Hofmann forgeries and other fraudulent archaeological finds are closely tied to Mormonism. Nothing is too preposterous to believe for those who want to do so. This work is reviewed in W.394. [J.W.M.]

W.356 Willis, Bertram T. "Keynote of a Prophet's Life." MS 98 (8 July 1937): 437-38. Alma2 and the sons of Mosiah were miraculously converted to Jesus and his gospel. Alma's missionary experiences may be compared to the ministry of Jesus Christ who also accepted a lower station in life to serve his fellowmen and was subject to mockery and humiliation. [J.W.M.]

W.357 Wilson, David J. "Book of Mormon Witnesses and Their Testimony Meet Legal Standards." Relief Society Magazine 38 (August 1951): 512-15. The Old Testament law of witnesses was approved by Paul the Apostle, Hammurabi, and Utah code: by the mouth of two or three witnesses shall the matter be established. The Three Witnesses and Eight Witnesses of the Book of Mormon fulfill this criteria. The most important witness for which there is no substitute is the Holy Ghost who witnesses to the very soul of man. [J.W.M.]

W.358 Wilson, Douglas. "Prospects for the Study of the Book of Mormon as a Work of American Literature." Dialogue 3 (Spring 1968): 29-41. A non-Mormon, the author suggests that since the Book of Mormon has affected 
millions of Americans and their history, it ought to be seriously counted in the canon of American literature. Reasons why the Book of Mormon has not been studied as such, and logical approaches to its study are explored. [B.D.]

W.359 Wilson, Garth A. "The Mulekites." Ensign 17 (March 1987): 60-64. Traces the history of the Mulekite people, from the events leading up to the destruction of Jerusalem and the flight of one of King Zedekiah's sons with a group of his people, to their discovery by King Mosiah and union with the Nephites. Recounts their involvement in the record of the Book of Mormon and reminds us that they made up the major portion of the Nephite people. [S.P.S.]

W.360 Wilson, L. A. "Bearing on the Book of Mormon." IE 30 (February 1927): 314. Discusses the Chinese account of their first settlement in China. Relates their experiences with the migration of the Jaredites from the Tower of Babel to the great sea. [L.D.]

W.361 Wilson, Luke P. "The Scientific Search for Nephite Remains." Heart and Mind (Fall 1992): 2-3, 5. The supernatural claims of the Book of Mormon cannot be tested, nor can the remains of the culture claimed by the book to have existed be found. Many of the agricultural and metallurgical claims of the book cannot be supported by archaeology. [J.W.M.]

W.362 Wilson, Thomas P. "Odds and Ends: The Book of Mormon Bulletin." Minnequa Historical Society 29 (Fall 1940): 25-26. Gives brief assessment of the Book of Mormon. Says that anthropologists agree on some points with the Book of Mormon. [D.M.]

W.363 Wilson, Timothy B. Mormon's Story: An Adaptation Based on the Book of Mormon. U.S.A.: n.p., 1993. Book of Mormon text reformatted with the actual text in the right-hand column, and a summarized explanation for younger readers in the left-hand column. [A.C.W.]

W.364 Wilson, William A. "Three Nephites." In Encyclopedia of Mormonism, edited by Daniel H. Ludlow, 4:147778. 5 vols. New York: Macmillan, 1992. The Three Nephites (3 Nephi 28:4-9) wished to stay upon the earth until the Lord's Second Coming. Discusses legends and folklore concerning them. [B.D.]

W.365 Wilson, William A. Review of Early Mormonism and the Magic World View, by Michael Quinn. BYU Studies 27 (1987): 96. Book review.

W.366 "Win Riches from Rags for Missionary Work." CN 53 (2 October 1983): 5. Brief account of an individual named Morely Jones, who uses all the money he earns to purchase copies of the Book of Mormon for use by missionaries. [A.T.]

W.367 Winchester, Benjamin. "The Claims of the Book of Mormon Established-It Also Defended." The Gospel Reflector 1 (15 March 1841): 105-23. The American continent was once inhabited by an enlightened people as ancient relics and archaeologists have testified. The author quotes Priest, Davis, Boudinot, and others who believe the aborigines of America belong to the house of Israel. The Book of Mormon gives an account of the destruction of the once enlightened people of the American continent. Its purpose is to clarify false doctrine, to bring people to the Holy One of Israel, to gather the lost ones of Israel, and restore the truth to the earth. [J.W.M.]

W.368 Winchester, Benjamin. "History of the Ancients of America and Also of the Book of Mormon." The Gospel Reflector 1 (15 March 1841): 124-37. Recounts the Book of Mormon story and tells of the coming forth of the 
plates with the Urim and Thummim. It is not new to find sacred instruments deposited in the earth-in the apocrypha Jeremiah hid the ark of the covenant in Mt. Nebo. The plates were hidden from view just as Moses was not allowed to show the tablets of stone to everyone. [J.W.M.]

W.369 Winchester, Benjamin. History of the Priesthood: In Defense of the Doctrine and Position of Latter-day Saints. Philadelphia, PA: n.p., 1843. Analyzes the history of the priesthood from the "beginning of the world to the present time." Chapter seven provides evidence for the authenticity of the Book of Mormon by presenting a brief summary of its content, its purpose, the biblical prophecies that pertain to it, and the positive results that come from reading it. [J.W.M.]

W.370 Winchester, Benjamin. "Introduction to the Subject of the Book of Mormon." The Gospel Reflector 1 (1 March 1841): 98-105. An examination of the prominent objections to revelation and the Book of Mormon. The Book of Mormon is the work of God and has overcome opposition, and those who are earnest seekers of truth have embraced it as an instrument in the hand of God. [J.W.M.]

W.371 Winchester, Benjamin. The Origin of the Spaulding Story: Concerning the Manuscript Found; with a Short Biography of Or. P. Hurlburt. Philadelphia: Brown, Bicking, and Gailpert, 1840. Presents the story of Solomon Spaulding and his manuscript. Discusses the role of Hurlburt in the story. [D.W.P.]

W.372 Winn, Kenneth Hugh. "The Origins of Mormonism and the Book of Mormon as a Republican Document." In Winn's Exiles in a Land of Liberty: Mormonism's Conflict with American Culture 1830-1846, 6-39. Chapel Hill and London: University of North Carolina Press, 1989. Attributes Joseph Smith's anger toward the community as the factor that brought him to reformulate republican values by rewriting them in his work, the Book of Mormon. Joseph Smith's visions reflect a religious young man's aspirations for money and status. [J.W.M.]

W.373 Wipper, Frank F. The Book of Mormon as the Basis for Some Vital Conclusions. Fresno, CA: Book of Mormon Foundation, 196?. Argues that the value of the Book of Mormon lies in its restoration of lost biblical truth and sets forth the idea that the early LDS church went astray by publishing the Book of Commandments and later the Doctrine and Covenants, rather than relying totally on the Bible and the Book of Mormon. [D.M.]

W.374 Wipper, Frank F. Commentary on Some Nephite Record Subjects. N.p.: n.p., 1940?. Presents an outline of several Book of Mormon subjects: (1) priests in the Book of Mormon-finds that Book of Mormon priests were after the order of Melchizedek; (2) the choice seer-the choice seer was to come from the tribe of Joseph who was sold into Egypt. This seer will be named Lehi and he will be weak in speaking and will need a spokesman. This criteria does not fit Joseph Smith; (3) Zion-suggests that Zion is a spiritual condition not a literal gathering; (4) the parable of Zenos-outlines its contents, stressing the need for obedience and an ultimate cleansing. [J.W.M.]

W.375 Wipper, Frank F. Doctrine and Covenants Critically Analyzed as a Sacred Book. Fresno, California: Frank F. Wipper, n.d. Believes that the Doctrine and Covenants wrongly became the substitute for the Book of Mormon. Joseph Smith became a fallen prophet who changed the doctrine taught in the Book of Mormon, which contains the true doctrine. [J.W.M.]

W.376 Wipper, Frank F. Emphasis on the Book of Mormon. Fresno, CA: Frank F. Wipper, 1960?. One year following the publication of the Book of Mormon, a shift of emphasis had taken place among the Latter-day Saints. The Lord warned them in June of 1829 (D\&C 15) to place emphasis upon the writings that he had given to them prior to June of 1829-the Book of Mormon. There is no church upon the earth, only the Book of Mormon guides souls to the truth. [J.W.M.] 
W.377 Wipper, Frank F. The Gift of Translating. Fresno, CA: Frank F. Wipper, 196?. Joseph Smith was called to translate only the Book of Mormon and was given no other gift (D\&C 4:2). By May 1829 Joseph Smith gave up the seer-stones and negative changes came over him. [J.W.M.]

W.378 Wipper, Frank F. Is the Book of Mormon from God? Fresno, CA: Frank F. Wipper, 196?. A rebuttal to James M. Tolle, Is the Book of Mormon from God? Writes about Lehi's genealogy, lights in the barges of Jared, the Liahona, plagiarism of the Bible, and other items. The Book of Mormon is a true document, but after the translation was complete and he gave up the stone Joseph Smith changed in a negative manner. [J.W.M.]

W.379 Wipper, Frank F. Jerald Tanner's Brochure on Mormonism Re-examined: Just A Friendly Discussion. Fresno, CA: Vanity, 196?. Author bears fervent testimony of the Book of Mormon and pleads with Tanner to reconsider his evaluation of the book. Wipper condemns Utah Mormonism and the RLDS church as well. [J.W.M.]

W.380 Wipper, Frank F. Nephite Record Texts. N.p., n.d. A ready reference that lists the custodians of the Nephite records and when they lived. [D.M.]

W.381 Wipper, Frank F. Reaching Up to Grasp the Fullness? Joseph Smith Saints vs. the Book of Mormon. Kansas City: KS: Book of Mormon Foundation, 196?. Applauds David Whitmer, who loved and defended the Book of Mormon, but eschewed other forms of "Latter-day Saintism." [D.M.]

W.382 Wipper, Frank F. Thy Kingdom Come. Fresno, CA: Vanity, 196?. Deals with the kingdom of God throughout the dispensations, including the Book of Mormon period. [D.M.]

W.383 Wipper, Frank F. Translation Correct! Kansas City, KS: Book of Mormon Foundation, 1960. Believes that the Book of Mormon was a word-for-word translation. [J.W.M.]

W.384 Wipper, Frank F. Translation of the Book of Mormon. N.p., 1960?. Several short essays condemning alterations that have been made in the wording and punctuation of the Book of Mormon. The author calls for the release of the original manuscript so that the original version of the translation can be read instead of what is printed now. [B.D.]

W.385 Wipper, Frank F. "The Translation of Them Which You Have Seen Is ... Correct!" Kansas City, KS: Book of Mormon Foundation, 196?. Discusses the translation and manuscripts of the Book of Mormon, arguing that the book was translated accurately. [D.M.]

W.386 Wipper, Frank F. An Unlearned Man: Who "The Lord Should Suffer to Bring These Forth." Fresno, California: Frank F. Wipper, 196?. Wipper's intent is to glorify God and the unlearned man who brought forth the Book of Mormon. [J.W.M.]

W.387 Wipper, Frank F. Witnesses. Fresno, CA: Frank F. Wipper, 1952. A series of mimeographed circulars devoted to promoting the Book of Mormon, but opposing the Latter-day Saint "Mormons" and RLDS churches and their doctrines. [J.W.M.]

W.388 Wipper, Frank F. Wounded in the House of Its Intimates. Kansas City, KS: Vanity, 1960?. Distinguishes between the post-Book of Mormon teachings of the LDS/RLDS churches and the Book of Mormon itself. [D.M.] 
W.389 Wirsing, Whit. "Book of Mormon for South Africans." CN 42 (29 April 1972): 5. The story of how the Book of Mormon was translated into Afrikaans. [M.D.P.]

W.390 Wirth, Diane E. The Challenge to the Critics: Scholarly Evidences of the Book of Mormon. Bountiful: Horizon, 1986. Responds to anti-Mormon comments regarding the authenticity of the Book of Mormon, and sets forth evidence to support Latter-day Saint claims. Addresses the Smithsonian statement, metal plates, stone boxes, wordprints, chiasmus, Hebraisms, reformed Egyptian, Nephite monetary system, the wheel, the tree of life theme on Stela 5 at Izapa, and Christ in America. [B.D.]

W.391 Wirth, Diane E. Discoveries of the Truth. Santa Clara, CA: Vanguard Graphics, 1978. Gives evidence to support her theory that the white and bearded god Quetzalcoatl is Jesus Christ. Issues discussed include Phoenician seafarers, cranial deformations, trepanning, cement, cotton, the wheel, arch, the horse, star of David, and the tree of life. [B.D.]

W.392 Wirth, Diane E. Review of Are the Mormon Scriptures Reliable? by Harry L. Ropp with revisions from Wesley P. Walters. Review of Books on the Book of Mormon 2 (1990): 209-13. Book review.

W.393 Wirth, Diane E. "The Tree of Life Offers Evidence of Pre-Columbian Contact." Pursuit (Fourth Quarter 1981): 168-71. Compares New World examples of the tree of life symbol with examples from Assyria and finds that the basic elements are similar, if not identical. Points out that the Book of Mormon, as the Church of Jesus Christ of Latter-day Saints claims, was written by early inhabitants of America. There is unmistakable evidence of trans-oceanic crossings prior to Columbus. [J.W.M.]

W.394 Wirth, Diane E., and John L. Sorenson. Review of Fantastic Archaeology: The Wild Side of North American Prehistory, by Stephen Williams. Review of Books on the Book of Mormon 4 (1992): 251-53, 254-57. Book review.

W.395 Wirth, Diane E., and Steven L. Olsen. "Four Quarters." In Reexploring the Book of Mormon, edited by John W. Welch, 145-49. Salt Lake City: Deseret Book and FARMS, 1992. Book of Mormon writers use the land division term four quarters in many places. This is a common practice in the Bible (Joshua 15:5, Isaiah 47:15 and 56:11, Mark 1:45, and Acts 9:32), Mayan and Indian writings, and in Ixtilxochitl's documentation. The same usage is common to Ebla and Egyptian records in the Old World. [N.K.Y.]

W.396 Wirthlin, Joseph B. "The Straight and Narrow Way." Ensign 20 (November 1990): 64-66. A serious and constant study of the scriptures, especially the Book of Mormon, will aid our quest through the straight and narrow way. The word of God is the rod to help avoid temptations that will lead out of the straight and narrow path. [J.W.M.]

W.397 "The Witness and the Gold Plates." Friend 14 (August-September 1984): 28-29. A children's story of the Three Witnesses and gold plates. [A.T.]

W.398 Witnesses. Independence, MO: Herald House, 195?. An RLDS tract that presents the testimonies of the Book of Mormon witnesses. [D.M]

W.399 Witnesses of the Book of Mormon. Salt Lake City: Church of Jesus Christ of Latter-day Saints, 1975. A tract addressed to those who do not belong to the LDS church dealing with the biblical law of witnesses, the Three Witnesses and Eight Witnesses of the Book of Mormon. Includes the statements of the witnesses. [D.W.P.] 
W.400 Wittorf, John H., ed. "Joseph Smith and the Prehistoric Mound-Builders of Eastern North America." SEHA 123 (October 1970): 1-9. Shows that Joseph Smith never made a conclusive statement supporting the belief that mounds and the mound builders of Northeastern America represent the remains of Book of Mormon lands or peoples. Discusses the Enon mound, Zelph mound, Adena and Hopwell cultures, and the Kinderhook plates. [B.D.]

W.401 Wixted, T. M. The Mistakes of the Book of Mormon. Brisbane, Queensland, Australia: Public Forum, 1965. Claims that the writer of the Book of Mormon was unaware of the setting of Jerusalem in 600 B.C., that he misunderstood such Hebrew words as "messiah," and points out other mistakes of the book. [D.M.]

W.402 Wolf, Teresa. "A Book for Eveline." Ensign 21 (September 1991): 57-58. A gift of a Book of Mormon, daily study of the book, and visits from the missionaries began to change this lady's life. [J.W.M.]

W.403 Wolfe, Walter M. "The Book of Mormon from a Bible Standpoint." MS 65 (4 June 1903): 353-57. Refutes arguments against the Book of Mormon that use the Bible as evidence, e.g., Revelations 22:18-19. Says Isaiah prophesied of Book of Mormon, as did Ezekiel. [A.C.W.]

W.404 Wolfe, Walter M. “Exploring American Ruins." MS 65 (25 February-19 March 1903): 132-34, 161-64, 176-80. This three-part series presents some legends and traditions of the American Indian in association with ruins, especially of Central America. They seem to prove that the Book of Mormon is historically correct. Throughout the Americas, the Indians believed in a Messiah who came a long time ago and promised to return. The high priest of the Quiche Indians wore a breastplate with seven precious stones. It was a Urim and Thummim used to decide the innocence or guilt of those accused of crimes. It would reveal both past and future events. [J.W.M.]

W.405 Wolfe, Walter M. "Legends Prove Truth of Scripture." MS 65 (April 1903): 241-44. Focuses on the origin of mankind, history, tradition, legends and mythology, and the manner in which the Book of Mormon proves the common source of religious belief. The world will someday understand "the common origin" theory and will believe the Bible and the Book of Mormon. [J.W.M.]

W.406 Wolfe, Walter M. "Modern Research and the Book of Mormon." MS 65 (6 August 1903): 501-3, 507-9. Cites various sources to argue the authenticity of the Book of Mormon. Writes concerning the confusion of tongues at the tower of Babel when God led people over the sea in ships to the islands. With the discoveries of ruins on the American continent the Jewish origin of American natives is being increasingly recognized. [B.D.]

W.407 "Women of the Book of Mormon." Relief Society Magazine 5 (January 1918): 47-50. In the ancient world Hebrew women had more status than in other cultures. Their chastity was imperative under the Mosaic law. Book of Mormon women inherited this culture. Though only three women are named in the book, references to women, mothers, and daughters are numerous. [J.W.M.]

W.408 "Wonders of the Past." CN 52 (19 June 1982): 16. Critics claim that Joseph Smith wrote the Book of Mormon after reading the works of nineteenth-century explorers. However, the explorers wrote about ancient America after the Book of Mormon was published. [M.D.P.]

W.409 Wood, Edward J. "An Interesting Occurrence in Canada." Relief Society Magazine 4 (1917): 135-37. Testimony of Kree Indians in Canada who found "their book" through a vision of their head chief. He visited the spirit world and was told of a book of sacred Indian history, which turned out to be the Book of Mormon. [J.W.M.] 
W.410 Wood, Edward J. Untitled talk. CR (October 1915): 65-68. A Mormon bishop was invited to visit with a gathering of Kree Indians, and was asked by the chief to teach them the gospel. He taught them about the Book of Mormon. Upon completion of his teaching he was told about a vision that the chief had in which he was told of this important book that contained their history. The chief bore witness that this history was the Book of Mormon. [J.W.M.]

W.411 Wood, John Karl. An Approach to the Book of Mormon. Logan, UT: n.p., 1949. Notes that relatively few people read the entire Book of Mormon. Suggests that readers might dispel this problem by learning about Mormon and his interests, which the author explains in summary form. [D.M.]

W.412 Wood, Kathryn. "Hope in Christ." Ensign 22 (December 1992): 17. The power of hope through Christ is shown in the Book of Mormon and can be applied to an individual's personal life. Even though Mormon and Moroni lived in a "hopeless time," they continued to call their people to repentance, and left a record to give hope in our day. [A.C.W.]

W.413 Wood, Wilford C., comp. Joseph Smith Begins His Work. Salt Lake City: Deseret News Press, 1958. An official reproduction of the first edition of the Book of Mormon, printed from the first uncut sheets of the 1830 edition of the Book of Mormon. [L.D.]

W.414 Woodbury, Naomi. "On the Origin of the Jaredites." In 15th Symposium on Archaeology of the Scriptures. 6772. Provo, UT: Brigham Young University, 1964. The religious and cultural elements in the book of Ether should be compared with those of Mesopotamia prior to 2000 B.C. A comparison of the religious teachings of the book of Ether and known Sumerian historical facts is made. Jaredite names are found to be similar to many names belonging to the Sargonid period. [J.W.M.]

W.415 Woodford, Irene Briggs. "The 'Tree of Life' in Ancient America; Its Representations and Significance." M.A. thesis, Brigham Young University, 1950. Offers an interpretation of the Mesoamerican "cross-shaped tree" as being a representation of the tree of life and several important symbolic figures, including the bird, serpent, monster, and the two personages. [B.D.]

W.416 Woodford, Irene Briggs. "The 'Tree of Life' in Ancient America; Its Representations and Significance." UASN Bulletin 4 (March 1953): 1-18. A condensed form of her M.A. thesis, Woodford interprets the Mesoamerican tree of life and its attendant elements. [B.D.]

W.417 Woodford, Robert J., "The Articles and Covenants of the Church of Christ and the Book of Mormon." In Doctrines for Exaltation: The 1989 Sperry Symposium on the Doctrine and Covenants, edited by H. Dean Garrett and Rex C. Reeve Jr., 262-73. Salt Lake City: Deseret Book, 1989. The Book of Mormon contains "all things concerning the foundation of the [Lord's] Church." The influence of the doctrines in the Book of Mormon upon D\&C 20 is shown. [B.D.]

W.418 Woodford, Robert J. "Book of Mormon Personalities Known by Joseph Smith." Ensign 8 (August 1978): 12-15. Cites accounts of visits to Joseph Smith by such Book of Mormon personalities as, Moroni, Alma, Nephi, Mormon, and the Nephite twelve disciples. [B.D.]

W.419 Woodford, Robert J. "The Chains of Hell." Salt Lake City: University of Utah Institute of Religion, 1978. Transcript of a devotional address in which the speaker discusses the devil's chains, the chains of hell, and a number of other Book of Mormon motifs that lead to spiritual well-being. [D.M.] 
W.420 Woodford, Robert J. "I Have A Question: How much do we know about baptism before Christ's time?" Ensign 21 (July 1991): 74-75. The Book of Mormon records contain more than fifty references to baptism prior to the birth of Jesus Christ. Other scriptural passages confirm that baptism was known from the beginning when Adam and Eve were baptized. [J.W.M.]

W.421 Woodhead, William. "Human Sacrifice and Cannibalism." SH 51 (28 December 1904): 1214-17. Trying to place a date when human sacrifice was introduced in ancient America is a matter of controversy. Book of Mormon critics use later dates than the book declares, while many archaeologists use dates that may reflect the book's record. Scholars believe that human sacrifice was a religious ritual. [J.W.M.]

W.422 Woodhead, William. "Machu Picchu and the Megalithic People." SH 64 (23 May-13 June 1917): 485564. Four-part series concerning Peruvian antiquity and its parallels with the Book of Mormon. Machu Picchu in Peru was a cultivated, highly civilized area in Peru two thousand years ago. The Incan civilization that developed there was built by "white, auburn haired, bearded men" and tradition speaks of four brothers who correspond in many ways to the Book of Mormon brothers Laman, Lemuel, Nephi and Sam. Historical, traditional, and archaeological parallels resemble the Book of Mormon. These ancient people were acquainted with the Christianity. [J.W.M.]

W.423 Woodhead, William. "Myths of the New World." SH 47 (18 April-20 June 1900): 259-60, 276-79, $286-$ 88, 308-9, 319-21, 334-36, 352-53, 369-71, 383-85, 398-401. A series of articles documenting New World myths that relate to the Book of Mormon: there were once highly populated cities in Central and South America; North American Indians migrated from South and Central America; the Indians are descendants of four brothers; the Peruvian myth of Manco Capac is based upon Nephi; the Maya empire began at Zarahemla; the Jaredite country was between Costa Rica and Columbia; the cross was a holy symbol in America before Columbus; preColumbian water baptism; the God Quetzalcoat I was born of a virgin, was a high priest, had a white complexion, wore white robes, and had a beard; the "red man" believed that the white man was coming; Indians once had iron tools and glass; the Jaredites were mound builders; bones of animals now extinct have been found in South America (author suggests cureloms and cumoms); pre-Columbian Indians wrote on metal plates. [A.T.]

W.424 Woodruff, Elia S. Untitled talk. CR (October 1928): 54-57. Relates the experience of a Lamanite woman whose house had burned to ashes. As she went back to view the damage the Spirit told her to look for her book, and she found the Book of Mormon, the only book unscorched. This important witness of the value of the book led this woman to become a member of the Church. [J.W.M.]

W.425 Woodruff, Wilford. "The Book of Mormon." MS 6 (15 August 1845): 65-70. Missionary-oriented essay. Justifies the existence of extra-biblical scripture. Explains the roles of the descendants of Joseph in America, using Genesis 48. Shows similarities between Israelite and Indian sacrificial customs. Refers to the "sticks" of Ezekiel 37; also discusses the relevance of Isaiah 29 and Psalm 85. Bears testimony of the part the Book of Mormon plays in the Restoration. [D.M.]

W.426 Woodruff, Wilford. "Discourse (delivered by President Woodruff at General Conference April 14, 1890)." In Collected Discourses Delivered by President Wilford Woodruff, His Two Counselors, the 12 Apostles, and Others, Vol. 1. (1886-1889), edited by Brian H. Stuy, 29. Sandy, UT: B. H. S. Publishing, 1988. The need for revelation is great in the past, present, and future. We have the stick of Judah (Bible), the stick of Joseph (Book of Mormon), and the Doctrine and Covenants. Revelation need not end with these. [J.W.M.] 
W.427 Woodruff, Wilford. "Nephites Found in New Mexico." IE 60 (April 1957): 242-43, 267-69. Also in A Book of Mormon Treasury, 222-28. Salt Lake City: Bookcraft, 1959, 1976. Author declares he found several tribes that he classified as Nephite (because of their beauty, cleanliness, industry, virtues, and purity of national blood) among the American Indians, including the Zunio, Lagumas, and Isletas. [A.T.]

W.428 Woodruff, Wilford. "Transatlantic Antiquities." MS 6 (1 August 1845): 56-57. A testimony that the Book of Mormon's divine truth will one day overwhelm the learned of the world with the Lord's power. [A.C.W.]

W.429 Woods, E. O'Dell. "Nostradamus Prophesied about the Church of Jesus Christ." Mormon Geographic Society Newsletter 1 (Spring 1987): 1, 3. Affirms that Nostradamus predicted the prophetic mission of Joseph Smith, including various aspects of the Book of Mormon. [D.M.]

W.430 Woods, Fred E. "The Record of Alma: A Prophetic Pattern of the Principles Governing Testimony." In The Book of Mormon: Alma, the Testimony of the Word, edited by Monte S. Nyman and Charles D. Tate Jr., 305-19. Provo, UT: Brigham Young University Religious Studies Center, 1992. The book of Alma represents only 1.76 percent of the time period covered in the Book of Mormon but comprises 22.6 percent of the Book of Mormon. Mormon recognized that it was an important work. Alma always bore his witness of the truths he taught. He spent all his days from the time of his conversion trying to lift others to Jesus Christ. We can use his approach to bearing testimony in our work in the Church today. [N.K.Y.]

W.431 Woodstock, Charles B. "The Record and Its Message." In The Message of the Book of Mormon, edited by Charles B. Woodstock, 5-108. Independence, MO: Herald House, 1931-32. A series of thirteen Sunday School lessons for the RLDS church on such topics as the nature and purpose of the Book of Mormon, biblical evidences, discovery of the plates and the translation process, and the history of the Book of Mormon peoples compared with archaeological evidences from Mesoamerica. [B.D.]

W.432 Woodstock, Charles B., and Sylvia McKeage. An Introductory Study of the Book of Mormon. Independence, MO: Herald House, 1941, [R] 1945, [R] 1949. Originally published in Gospel Quarterly 16 (October-December 1941): 2-72. Contains a series of thirteen lessons on topics that deal with the Book of Mormon, prepared for adults of the RLDS church. Topics include a discussion of Lehi, the journey across land and sea, and the teachings of Nephi. [L.D.]

W.433 Woodward, Charles L. The First Half Century of Mormonism: Papers, Engravings, Photographs, and Autographed Letters. 2 vols. New York: n.p., 1880. A collection of newspaper articles, photographs, and related items that present an overview of the Book of Mormon, relate how it came forth, and conclude that Joseph Smith was not the author of the book but Sidney Rigdon used the Spaulding manuscript to lay the foundation of this "magnificent scheme" after hearing about Joseph Smith's claim to have found golden plates. [J.W.M.]

W.434 Woolley, Scott. Review of The Book of Mormon: Jacob through Words of Mormon, to Learn with Joy, edited by Monte S. Nyman and Charles D. Tate Jr. Review of Books on the Book of Mormon 3 (1991): 106-17. Book review.

W.435 Wotherspoon, George. Mormonism: Or the Faith of the Latter-day Saints: Its History and Morals. London: Sunday Lecture Society, 1886. A polemical tract based upon a lecture given against Mormonism and the Book of Mormon. After giving an unsympathetic recounting of the Book of Mormon narrative, the writer asserts that the word "Mormon" means "monster" and that the Book of Mormon was based upon Spaulding's unpublished romance. [M.R.] 
W.436 Wrapper, B. B. "A Book of Mormon Rebel." Witnesses 2 (February 1952): 1-4. Latter-day Saints, like Book of Mormon rebels, are raising insurrection toward their government. Cites many Book of Mormon passages and charges Joseph Smith with usurping power and authority. [J.W.M.]

W.437 Wrapper, B. B. Record of the Nephites. Fresno, CA: Vanity, 196?. Homemade brochure that contains several scriptural texts, and accepts the teachings of the Book of Mormon but despises the doctrines of the LDS church. [D.M.]

W.438 Wright, Cyril E., ed. Study Outline for Senior Religion. The Book of Mormon: Is It Necessary? Independence, MO: Herald Publishing House, 1927. Study guide covers how to know the Book of Mormon is true-through the witness of the Spirit, through the testimony of witnesses, through the testimony of the scriptures, and through archaeological evidences. Also includes a lesson on how to use the book effectively. [J.W.M]

W.439 Wright, David P. " 'In Plain Terms That We May Understand': Joseph Smith's Transformation of Hebrews in Alma 12-13." In New Approaches to the Book of Mormon, edited by Brent Lee Metcalfe, 165-229. Salt Lake City: Signature, 1993. Finding the Book of Mormon to be a modern document authored by Joseph Smith does not diminish its value or assert that Joseph was any less relevant as author rather than as translator. There are many connections between Alma 12-13 and Hebrews. Author believes that Joseph Smith used the book of Hebrews to create Alma 12-13. [J.W.M.]

W.440 Wright, David P. "Historical Criticism: A Necessary Element in the Search for Religious Truth." Sunstone 16 (September 1992): 28-38. Explains two modes of approach toward scriptural historicity-traditionalist and historical critical. Traditionalists look at composition, date, accuracy of events, and chronological order. The historical critical mode does not look at internal or external claims as necessarily true, but looks at the possibility that historical matters are not what are traditionally claimed. The Book of Mormon contains anachronisms in its Isaiah text and other chapters that rely on the New Testament. Suggests that the Book of Mormon is not an ancient text and that Joseph Smith was the author not the translator. [J.W.M.]

W.441 Wright, David P. Review of The God-Inspired Language of the Book of Mormon, by Wade Brown. Review of Books on the Book of Mormon 1 (1989): 10-17. Book review.

W.442 Wright, Dennis A. "Helping Students to Read the Book of Mormon." In A Symposium on the Book of Mormon, 109-10. Salt Lake City: Church of Jesus Christ of Latter-day Saints, 1979. Provides suggestions for the beginning Book of Mormon student. He suggests having students read from 3-5 minutes at a session. A minidrama will help to acquaint students with the characters. Visual aids, small group studies, and creativity help the learner. [N.K.Y.]

W.443 Wright, G. Frederick. "The Recently Discovered 'Solomon Spaulding' Manuscript and the Book of Mormon." Oberlin Review 13 (20 February 1886): 133. Rejects as unfounded the claim of Professor Samuel S. Partello that he had located the Spaulding manuscript, recounting the story of the manuscript's discovery in Honolulu. Holds, nevertheless, that the question of Book of Mormon authorship is irrelevant. [D.M.]

W.444 Wright, H. Curtis. "Ancient Burials of Metal Documents in Stone Boxes." In By Study and Also by Faith, edited by John M. Lundquist and Stephen D. Ricks, 2:273-34. Salt Lake City: Deseret Book and FARMS, 1990. Gives a summary of numerous burials of metallic documents by a multitude of cultures. Many of these records were encased in stone boxes or other containers. Discoveries of metal documents in Alexandria have established 
an archaeological connection between practices of the Ptolemies and Mesopotamian kings. Various methods of preserving ancient records and writings in antiquity are researched and presented. [A.A.]

W.445 Wright, H. Curtis. "Metallic Documents of Antiquity." BYU Studies 10 (Summer 1970): 457-77. Discusses records of antiquity prepared on metal. Cites several metallic documents that exist today, including religious metallic documents and a metallic epigraphy. [L.D.]

W.446 Wright, H. Curtis. "Mulek." In Encyclopedia of Mormonism, edited by Daniel H. Ludlow, 2:969-70. 5 vols. New York: Macmillan, 1992. Describes Mulek and his people. The Book of Mormon asserts that Mulek was a son of Zedekiah who escaped from Jerusalem. Jeremiah 38:6 mentions "Malchiah the son of Hammelech," which may be a reference to Mulek. [B.D.]

W.447 Wright, Ruth B. "Draw Strength from the Book of Mormon." Ensign 20 (November 1990): 78-79. All individuals should gain truth and strength from the Book of Mormon. Correlates Book of Mormon principles to today's world. [L.D.]

W.448 "Written Testimony Invites Spirit." CN 58 (2 January 1988): 5. Personalized copies of the Book of Mormon have been effective missionary tools. [R.H.B.]

W.449 Wunderli, Earl M. The Book of Mormon Speaks on Its Own Origin. Stamford, CT: n.p., March 1979. There is little internal evidence in the Book of Mormon to support Joseph Smith's claim of its origin. The distribution of words and phrases rather leads to the conclusion that there was one writer, Joseph Smith, who wrote about events that he knew about in his own time. [J.W.M.]

W.450 Wunderlich, Jean. "Some Thoughts on the Social Message of the Book of Mormon." IE 41 (April 1938): 222-23, 234-36. Also in A Book of Mormon Treasury, 268-74. Salt Lake City: Bookcraft, 1959, 1976. Uses the discourses of Alma and Amulek to the Zoramites as a partial guide to determine what the Book of Mormon teaches about social action. The work teaches that violence is not a recommended "principle of social action" and "the solution of social difficulties must be sought on the spiritual plane." Also discusses what the Book of Mormon teaches about government. [A.T.]

W.451 Wunderlich, Jean, tr. Ein Leitfaden zum Studium des Buches Mormon. Basel: LDS Swiss-German Mission, 1924. English title Guide to the Study of the Book of Mormon. Deals with the history of the Jaredites, Nephites, Lamanites, and Mulekites and treats the religious practices and religious history of the Book of Mormon peoples. [J.W.M.]

W.452 "Wunderliche heilige: Joseph Smith und die Goldene Bible." Die Gartenlaube (1869): 89-91. Tells of the call of Joseph Smith as a prophet, the coming forth of the Book of Mormon, and a brief summary of the contents of the Book of Mormon. [D.W.P.]

W.453 Wyatt, Geraldine. Dawn of Peace: Narrative Based on Episodes in the Book of Mormon. Independence, MO: Herald House, 1940. A fictitious novel based on various episodes of the Book of Mormon. [B.D.]

W.454 Wycherly, Carolyn. "Church Scriptures Being Translated by Immigrant." CN 41 (November 20, 1971): 11. An announcement that the LDS scriptures are being translated into Romanian by Dr. Emia F. Perry. She began the translation in 1951 before becoming a member of the Church. [J.W.M.] 
W.455 Wyl, W. Mormon Portraits or the truth about the Mormon Leaders. Salt Lake City: Tribune, 1886. An exposé of Joseph Smith and Mormonism. The author advances the Spaulding theory to account for the Book of Mormon's origin. [M.R.] 
Y.001 Yarn, David H. Jr. "The Coming of Moroni, the Mission of Moroni, Bible Prophecies and the Book of Mormon, Witnesses to the Book of Mormon." In Yarn's Faith in a Day of Unbelief, 5-38. Salt Lake City: Deseret Book, 1960. Moroni appeared to Joseph Smith to reveal a record engraved on gold plates. Joseph was instructed by the angel over a period of four years before receiving the plates and translating them. Many witnesses provide their testimonies of the Book of Mormon, three of whom are discussed briefly. [J.W.M.]

Y.002 Yarrington, Roger. "Who was Professor Anthon?" SH 113 (1 July 1966): 442-43. Explains the background of Martin Harris's visit to Charles Anthon, and gives a brief biography of Professor Anthon. Discusses two accounts of the visit and concludes that Harris's simple testimony is the true version. [A.C.W.]

Y.003 Yates, James E. "Book of Mormon Prophecy Concerning the Indians." SH 60 (6 August 1913): 773-75. Comments upon several prophecies concerning the Lamanites, e.g., 1 Nephi 7:15 prophesies of their scattering by the gentiles and 1 Nephi 7:17, 18 prophesies that the Lamanites will be nourished by the Gentiles. [A.T.]

Y.004 Yates, Thomas J. "Succession of Book of Mormon Authors." IE 37 (March 1934): 162. A listing of Book of Mormon authors, the number of years each composed his writings, and their order of succession. Includes scriptural references. [J.W.M.]

Y.005 Yorgason, Blaine, and Brenton G. Yorgason. The Loftier Way: Tales from the Ancient American Frontier. Salt Lake City: Deseret Book, 1985. Contains fictional stories of Nephi, Alma, Moroni, and six other prominent Book of Mormon figures and includes a gospel principle that may be discovered from each story. [A.T.]

Y.006 Yorgason, Blaine, and Brenton G. Yorgason. To Mothers from the Book of Mormon: A Letter to Missionaries and Other Students of the Gospel. Orem, UT: Keepsake Book Cards, 1989. Discusses the positive impact of Sariah, Mary the mother of Jesus, and the mothers of the "sons of Helaman." This work is reviewed in J.117. [D.M.]

Y.007 Yorgason, Brenton G. Little Known Evidences of the Book of Mormon. Salt Lake City: Covenant, 1989. Gives a religious history of Joseph Smith's acquisition and translation of the gold plates by divine assistance, including the use of the Urim and Thummim and the seer stone; discusses word print studies that confirm the authenticity of the Book of Mormon; relates a linguistic analysis explained by a scholar of Arabic; summarizes the contents of the Book of Mormon. This work is reviewed in H.353 and in T.337. [B.D.]

Y.008 Yorgason, Laurence M. Review of Mormon Papers: Are the Mormon Scriptures Reliable?, by Harry L. Ropp. Sunstone 6 (March/April 1981): 9. Book review.

Y.009 "You Fulfill the Scriptures." CN 42 (2 September 1972): 10-11. President Romney told the saints at the Mexico Area Conference that they fulfill the scriptures by using the Book of Mormon and teaching it to their seed. [M.D.P.]

Y.010 Young, Biloine. Exploring the Book of Mormon. 4 parts. Independence, MO: Herald House, 1960. A work designed for youth that discusses the history of the acquisition and translation of the plates, the history of the Jaredites, and Lehi's voyage into the desert. [B.D.] 
Y.011 Young, Brigham. "Faithfulness and Apostasy." JD 2:257-58. Refers to the testimonies of Martin Harris and Oliver Cowdery in relation to the Book of Mormon. Notes that Cowdery bore an aggressive testimony while practicing law in Michigan. [D.M.]

Y.012 Young, Brigham. Untitled talk. CR (October 1901): 66-67. It is the responsibility of the twelve to take the gospel to every nation of the earth, while those of us who stay home must read the scriptures, especially the Book of Mormon. It is a "pure translation from the original." [J.W.M.]

Y.013 Young, Clifford E. Untitled talk. CR (April 1946): 85-89. The motives and intentions of many of history's greatest men were called into question-Abraham Lincoln, Joseph Smith, Oliver Cowdery, and David Whitmer. Cowdery and Whitmer were witnesses of the Book of Mormon who were true to their testimonies. In an interview with James H. Moyle, David Whitmer testified after fifty-two years that the Book of Mormon was a divine book. [J.W.M.]

Y.014 Young, Fred L. "Question Time: Prophecy says that the Book of Mormon is to go to the Jews. Hasn't it been taken to them already?" SH 117 (February 1970): 47. Parley P. Pratt and other missionaries have taken the Book of Mormon to the Holy Land, but all Jews should have an opportunity to hear the gospel. [A.C.W.]

Y.015 Young, Levi Edgar. "Ancient America." Young Woman's Journal 28 (August 1917): 482-87. Concentrating on archaeological finds in Mexico, Yucatan, Central America, and Peru, this article presents the civilizations of ancient America as evidence of the grandeur of pre-Columbian America. [J.W.M.]

Y.016 Young, Levi Edgar. "Christopher Columbus: Was His Work Designed by God?" MS 64 (November 1902): 705-8. A testimony that Columbus was inspired by God, to support 1 Nephi 13:10-12. Includes a brief summary of Columbus's life, highlighting points that show he was inspired, and quotes Columbus's words that God made him the messenger of the new heaven and the new earth, which is spoken of in the book of Revelation, and showed him the spot where to find it. [B.D.]

Y.017 Young, Levi Edgar. "Goldsmiths of Ancient Times." IE 52 (April 1949): 206-8. Spanish libraries contain historical accounts that describe a chamber in which gold plates were found. Ancient American goldsmiths made plates of gold that were thin like paper and on which ancient hieroglyphs were engraved. [J.W.M.]

Y.018 Young, Levi Edgar. "Records of the Lamanites." MS 91 (18 April 1979): 241-43. Summarizes the Book of Mormon story concerning the Hebrew origin of the American Indians. [R.H.B.]

Y.019 Young, Levi Edgar. Untitled talk. CR (April 1924): 50-53. Joseph Smith's reestablishment of the gospel was a high point in history. Tells about Indians from beyond the Rocky Mountains who appeared in St. Louis looking for the book from heaven. [B.D.]

Y.020 Young, Levi Edgar. Untitled talk. CR (October 1928): 102-6. Archaeologist Max Uhle believes the ancient Americans descended from the Asians, via immigration across the Bering Strait. However, other groups may have sailed to America. The Book of Mormon teaches Hebrew doctrine influenced by Christian beliefs and proves that Christianity is a continuation of Judaism. [B.D.]

Y.021 Young, Levi Edgar. Untitled talk. CR (October 1935): 77-79. The Book of Mormon, like the Bible, was written over a period of time by inspired men of God and later translated at great expense to the translators. The 
two books present a divine message that Jesus is the Christ. Only through prayer and revelation as Moroni promises can the knowledge of God come. [J.W.M.]

Y.022 "Young Men Can See Further." IE 64 (October 1961): 758-59, 767. A message to young men comparing the Book of Mormon to binoculars, which allow you to see ahead in order to avoid pitfalls and traps. Uses the story of Nephi and his brothers returning to obtain the brass plates to show that young men should fulfill all of their assignments even if they think they cannot. [M.D.P.]

Y.023 Young Men's Mutual Improvement Association. Manual for 1899-1900, Part I (1805-1839). Salt Lake City: Deseret News, 1899. Prophecies in the Old and New Testaments and Book of Mormon tell of the apostasy. The dispensation of the fullness of times was established through the work of Joseph Smith and the revelation of the Nephite records. [J.W.M.]

Y.024 Young Men's Mutual Improvement Association. Manual for 1903-1904, Vol. 2 part 1. Salt Lake City: Deseret News, 1903. Teaches the importance of the Book of Mormon as a witness for God and the Bible. Explores the Bible in the nineteenth century, the coming forth of the Book of Mormon, the contents of the book, and how it supports the Bible. [J.W.M.]

Y.025 Young Men's Mutual Improvement Association. Manual 1904-1905, Vol. 2 part 2. Salt Lake City: Deseret News, 1904. Deals with external evidences of the Book of Mormon: testimonies of the witnesses, American Indian traditions, and Mesoamerican ruins. [J.W.M.]

Y.026 Young Men's Mutual Improvement Association. Manual for 1905-1906, Vol. 2 part 3. Salt Lake City: Church of Jesus Christ of Latter-day Saints, 1905?. Deals with external and internal evidences of the Book of Mormon. [J.W.M.]

Y.027 Young Men's Mutual Improvement Association. Manual for Junior Classes 1903-1904. N.p.: Church of Jesus Christ of Latter-day Saints, 1903. Among the biographical sketches of ancient prophets are Nephi and Moriancumer, the brother of Jared. [J.W.M.]

Y.028 Young Men's Mutual Improvement Association. Manual for Junior Classes 1904-1905. Salt Lake City: Deseret News, 1904. Biographical sketches of ancient prophets, a continuation of the 1903-1904 manual (see above). Includes King Benjamin, Abinadi, Alma the Younger, Ammon, Mormon, and Moroni. [J.W.M.]

Y.029 Young, R. W., Jr., and Martin W. Roylance. "Concerning American Antiquities." MS 72 (2 June 1910): 33741. This article contains two works, both based on an article by Alice le Plongeon who argues that there is a connection between ancient Americans and ancient Egyptians, the latter originating from ancient America: "New Light Upon the Prophets Divinity" by R. W. Young, which proposes that America is the "old world" where Adam and Eve resided; and "Evidence In Support of The Book of Mormon" by Martin W. Roylance, which adds that the connection between these ancient peoples is explained by the Book of Mormon. He identifies Valparaiso, Chili, as the landing place for the Jaredites. [J.W.M.]

Y.030 Young, S. Dilworth. "The Book of Mormon: Its Own Silent Witness." IE 68 (June 1965): 508-9. Claims that the Book of Mormon and restoration of the gospel fulfill the prophecies in Isaiah 29:13-14 and Daniel 2:35. The Book of Mormon is its own best witness. The Lord only asks the reader to honestly and prayerfully desire to know its truthfulness. [A.T.] 
Y.031 Young, S. Dilworth. "How Could Joseph Know?" Ensign 2 (February 1972): 8-9. A poem about Samuel Smith who used the Book of Mormon to introduce the gospel to the family of Brigham Young. Since that time this work has filled the earth. How could Joseph have known? [J.W.M.]

Y.032 Young, S. Dilworth. "The Seed of Faith." In BYUSY (10 December 1968). Provo, UT: BYU Press. Uses Alma 32 to discuss planting the "seed of faith" concerning the witnesses of the Book of Mormon plates. Includes the testimonies of the Three Witnesses. [J.W.M.]

Y.033 Young, Seymour B. "The Book of Mormon and the Spaulding Manuscript." IE 1 (July 1898): 648-53. Presents a concise historical overview of Solomon Spaulding's Manuscript Found and its purported connection to the Book of Mormon, and concludes that the two writings are so different that they bear no relationship. [D.M.]

Y.034 Young, Seymour B. "The Book of Mormon and the Spaulding Manuscript." MS 60 (21 July 1898): 460-64. Presents a brief historical summary of the events surrounding the origin of the Book of Mormon and the Spaulding manuscript and argues that the Book of Mormon was not taken from the Spaulding manuscript. [A.C.W.]

Y.035 Young, Seymour B. Untitled talk. CR (April 1914): 97-100. Gives a list of the languages in which the Book of Mormon has been translated and published and the year it was done. The most recent translation was Japanese. The success of the first translation of this work into English by Joseph Smith is undeniable. [J.W.M.]

Y.036 Young, Seymour B. Untitled talk. CR (October 1914): 105-7. Samuel the Lamanite's prophecy of the signs of the Jesus' birth touched the lives of those Nephites who accepted the gospel. When a babe was born across the ocean in the Old World many in the New World were inspired by the sign of "a day and a night and a day without darkness." [J.W.M.]

Y.037 Young, T.W. Mormonism: Its Origin, Doctrines and Dangers. Ann Arbor, Michigan: George Wahr, 1900. A polemical work against Mormonism. The author advances a variation of the Spaulding theory and he notes the presence in the Book of Mormon of modern phrases. [M.R.]

Y.038 Young, W. Ernest. A Curriculum of Readings in the Field of Religious Education from Spanish American Sources Designed for Seminary Students. M.A. thesis, Brigham Young University, 1935. States that many archaeological, historical, and traditional evidences of ancient inhabitants of Mexico and Central America are linked with the Book of Mormon. Many items mentioned in the book have been found such as fine linen, elephants, horses, and temples. [J.W.M.]

Y.039 Youngreen, Buddy. "And Yet Another Copy of the Anthon Manuscript." BYU Studies 20 (Summer 1980): 346-47. Discusses the differences found in the Warnky's art studio print of the Anthon Manuscript and the prints Danel W. Bachman used in his article: "Sealed in a Book: Preliminary Observations on the Newly Found 'Anthon Transcript." " [L.D.]

Y.040 Youngreen, Buddy. "The Sacred Record." In Youngreen's Reflections of Emma, Joseph Smith's Wife, 7-9. Orem, UT: Grandin Book, 1982. Cites Emma Smith, wife of Joseph, as a witness to the authenticity of the Book of Mormon. Emma was a scribe for a time, her devotion to the work put her in peril many times, and she risked her life to warn the Prophet of any danger to the plates. [J.W.M.]

Y.041 "Youth of Church Receive Message in Poster Series." CN 32 (27 January 1962): 4. An encouragement for LDS youth to read the Book of Mormon and pray about its contents so that they will know the truth. [A.C.W.] 
Y.042 "Youth 'On Mission' with Book of Mormon." CN 59 (13 May 1989): 12. A handicapped boy in Bountiful, Utah, cannot go on a mission so he donates money to the Book of Mormon fund. [M.R.]

Y.043 "Youths Will 'Lead Out Tomorrow.'" CN 58 (31 December 1988): 7. To promote Book of Mormon reading, young men and young women who read the entire work are given a Book of Mormon patch. [M.D.P.] 
Z.

Z.001 "Zarahemla." TS 3 (1 October 1842): 927-28. Identifies Guatemala as the area where Zarahemla was situated. [D.M.]

Z.002 Zarahemla Research Foundation Staff. "Mayan Glyphs Translated 'It Came to Pass.' " In Recent Book of Mormon Developments, Articles from the Zarahemla Record, 2:32. Independence, MO: Zarahemla Research Foundation, 1992. A short report on recent translations of Mayan glyphs that mean "it came to pass." [B.D.]

Z.003 Zarahemla Research Foundation Staff. "Why Bountiful? Why Desolation?" In Recent Book of Mormon Developments, Articles from the Zarahemla Record, 2:148. Independence, MO: Zarahemla Research Foundation, 1992. See also ZR 52 (December 1990): 1. According to Alma 6:8 (RLDS versification), the Nephites usually named places after the founder. However, bountiful in Hebrew is tob and is a name given to a region in Palestine that was very fertile, and the word for desolation is samem, which means a land wasted by war or natural disaster. Perhaps these names are given because the places were not cities but large areas. [B.D.]

Z.004 "Zeniff." Friend 20 (October 1990): 8-9. Children's illustrated story of Zeniff and his people. [M.R.]

Z.005 Zentgraf, Rochelle. "Acting Out Can Cure Acting Up." Ensign 18 (February 1988): 23. A family teaches their children about Lehi's dream by having them act out the dream in a family play. [L.D.]

Z.006 Ziegler, Wesley. An Analysis of the Book of Mormon. 2nd ed. Pasadena, CA: Publication Press, 1947. A polemical work that asserts that the Book of Mormon was inspired by Satan. [M.R.]

Z.007 Zimmerman, Dean R. Book of Mormon Geography. N.p., 1972?. Counts and lists 119 geographical sites in the Book of Mormon, 103 of which the author believes are identifiable. [D.M.]

Z.008 Zindler, Frank R. "East Is East, Except When North." American Atheist 30 (February 1988): 29-33, 40. An anti-Mormon piece that argues that LDS scholars have changed the location of "the narrow neck of land" from the Isthmus of Panama to the Isthmus of Tehuantepec, creating a problem with the "sea east" and the "sea west." [J.W.M.]

Z.009 Zindler, Frank R. "How Do You Lose a Steel Mill?" American Atheist (January 1988): 27-31. A satirical effort to educate Mormons concerning the mistakes of the Book of Mormon. Topics include the American Indians as descendants of the Jews, steel making, cows, horses, and elephants, and wheel-drawn vehicles. [J.W.M.]

Z.010 Zinser, Raymond D. "Experiment upon My Words." In Recent Book of Mormon Developments, Articles from the Zarahemla Record, 2:157-60. Independence, MO: Zarahemla Research Foundation, 1992. Zinser describes what he experienced while reading the Book of Mormon. He received a profound testimony after reading the Book of Mormon in one month. [B.D.]

Z.011 Zobell, Albert L. "Early Cumorah Pageants." IE 71 (June 1968): 24-27. Discusses the history of the Hill Cumorah pageant, a dramatic production that depicts the people of the Book of Mormon who peopled America many years ago. [L.D.] 
Z.012 Zobell, Albert L. "Some Facts Concerning the Book of Mormon." IE 44 (September 1941): 520. Discusses the first printing and subsequent editions of the Book of Mormon and identifies different formats the Book of Mormon has taken since its first publication. [L.D.]

Z.013 Zobell, Albert L. "Where Are the Original Manuscripts?" IE 63 (November 1960): 802-3, 826, 828. Traces the history of two Book of Mormon manuscripts-the original manuscript and the printer's manuscript. Joseph Smith deposited the original manuscripts in the cornerstone of the Nauvoo House October 2, 1841. It was recovered in 1882. The printer's manuscript is now in the possession of the RLDS church. [R.C.D.]

Z.014 Zobell, Albert L. "Which Translation Did Your Ancestors Read?" IE 64 (May 1961): 318-19. Gives the dates that the Book of Mormon was translated into each language. By May 1961 the Book of Mormon had been translated into 29 different languages. [L.D.]

Z.015 Zobell, Albert L. "Writing Paper for the Book of Mormon Manuscript." IE 72 (February 1969): 54-55. Recounts the contributions of R. Joseph Knight Sr. to Joseph Smith Jr. during the translation of the Book of Mormon. Mr. Knight's aid was instrumental in the process by providing food and the paper that the translation was written on. [B.W.J.]

Z.016 Zobell, Albert L., Sr. "Jaredite Barges." IE 44 (April 1941): 211, 252. Also in A Book of Mormon Treasury, 167-69. Salt Lake City: Bookcraft, 1959, 1976. Passages relating to the Jaredites are used as a basis for examining different aspects of the Jaredite journey including the design of the barges, a possible route of their journey, and their qualifications as ship builders. [A.T.]

Z.017 Zobell, Albert L., Sr. "Romance of the Third Edition of the Book of Mormon." IE 49 (September 1946): 548-49. Also in A Book of Mormon Treasury, 63-66. Salt Lake City: Bookcraft, 1959, 1976. An account of the efforts of Ebenezer Robinson to arrange the printing of the third edition of the Book of Mormon. Also mentions changes made since the second edition. [A.T.]

Z.018 Zobell, Levi A. Alma, Son of Alma: A Story of a Prophet Statesman among the Aboriginese of the Americas. Salt Lake City: Vanity, 1937. A biography of Alma the Younger, employing paraphrases from the Book of Mormon. Includes a section containing the sayings of Alma. [D.M.]

Z.019 Zohner, Marivene. "Home Evening in Lehi's Tent (Almost)." Ensign 19 (July 1989): 66-67. In their family tent in their backyard, a family reenacts the story of Lehi's discovery of the Liahona in the desert. [L.D.]

Z.020 "The Zoramites and the Rameumptum." Friend 23 (September 1993): 8-10. A series of pictures for children illustrating the mission of Alma and Amulek to the Zoramites. [S.H.]

Z.021 Zuck, Roy B. "Letter to a Mormon Elder." Moody Monthly 72 (November 1971): 24-25, 78-81. An open letter addressed to LDS missionaries showing opposition to the Book of Mormon. Refers to the Egyptian characters, Professor Anthon, Jesus' birth at Jerusalem, darkness for three days after the crucifixion, the Smithsonian view on the Book of Mormon, and the Three Witnesses. [D.M.] 


\section{Addendum: 1994-1995 Book of Mormon Bibliography}

Adams, Larry LaMar. Where Does the Two Cumorah Theory Stand? Spanish Fork, UT: the author, 1994.

Adams, William J., Jr. "Lehi's Jerusalem and Writing on Metal Plates." Journal of Book of Mormon Studies 3 (Spring 1994): 204-6.

Adams, William J., Jr. "More on the Silver Plates from Lehi's Jerusalem." Journal of Book of Mormon Studies 4 (Fall 1995): 136-37.

Andersen, Verlan H. The Book of Mormon and the Constitution. Compiled by Hans V. Andersen, Jr. Orem, UT: Sunrise Publishing, 1995.

Anderson, Kenneth W. "The Knowledge Hid Up Because of Unbelief." In The Book of Mormon: Fourth Nephi through Moroni, from Zion to Destruction, edited by Monte S. Nyman and Charles D. Tate, Jr., 31-44. Provo, UT: Religious Studies Center, 1995.

Anderson, Lynn Matthews. The Easy-to-Read Book of Mormon: A Learning Companion. Apple Valley, MN: Estes Book, 1995.

Anderson, Lynn Matthews. "Toward a Feminist Interpretation of Latter-day Scripture." Dialogue 27 (Summer 1994): 185-203.

Asay, Carlos E. "Golden Threads of the Book of Mormon." In Heros from the Book of Mormon, 201-12. Salt Lake City: Bookcraft, 1995.

Aston, Warren P. In the Footsteps of Lehi: New Evidence for Lehi's Journey across Arabia to Bountiful, Salt Lake City: Deseret Book, 1994.

Bagley, Pat. Norman the Nephite's and Larry the Lamanite's Book of Mormon Time Line. Salt Lake City: Deseret Book, 1995.

Barney, Kevin L. "Enallage in the Book of Mormon." Journal of Book of Mormon Studies 3 (Spring 1994): 113-47.

Barney, Kevin L. "Poetic Diction and Parallel Word Pairs in the Book of Mormon." Journal of Book of Mormon Studies 4 (Fall 1995): 15-81.

Baron, Ross David. Review of "Book of Mormon Christology," by Melodie Moench Charles. Review of Books on the Book of Mormon 7/1 (1995): 91-119.

Bateman, Merrill J. "Lehi's Tree and Alma's Seed." In Heros from the Book of Mormon, 16-31. Salt Lake City: Bookcraft, 1995.

Barrus, Ezra McClain. Centered in God. Sacramento, CA: the author, 1994. 
Benson, Ezra Taft. "Joseph Smith: Prophet to Our Generation." Ensign 24 (March 1994): 2-5.

"Bibliography of the Writings of Sidney B. Sperry." Journal of Book of Mormon Studies 4 (Spring 1995): 287-96.

Boehm, Bruce J. "Wanderers in the Promised Land: A Study of the Exodus Motif in the Book of Mormon and Holy Bible." Journal of Book of Mormon Studies 3 (Spring 1994): 187-203.

Brewerton, Ted E. "The Book of Mormon: A Sacred Ancient Record." Ensign 25 (November 1995): 30-31.

Bringhurst, Newell G. "Joseph Smith, the Mormons, and Antebellum Reform-A Closer Look." John Whitmer Historical Association Journal 14 (1994): 73-91.

Brinley, Douglas E. "The Jaredites-A Case Study in Following the Brethren." In The Book of Mormon: Fourth Nephi through Moroni, from Zion to Destruction, edited by Monte S. Nyman and Charles D. Tate, Jr., 45-59. Provo, UT: Religious Studies Center, 1995.

Brooke, John L. The Refiner's Fire: The Making of Mormon Cosmology, 1644-1844. Cambridge: Cambridge University Press, 1994.

Brough, Monte J. "The Prophet Ether: Man of the More Excellent Hope." In Heros from the Book of Mormon, 18994. Salt Lake City: Bookcraft, 1995.

Bunker, Robert L. "The Design of the Liahona and the Purpose of the Second Spindle." Journal of Book of Mormon Studies 3 (Fall 1994): 1-11.

Burgess, Allan K. Timely Truths from the Book of Mormon. Salt Lake City: Bookcraft, 1995.

Bushman, Richard L. Review of Inventing Mormonism: Tradition and the Historical Record, by H. Michael Marquardt and Wesley P. Walters. Review of Books on the Book of Mormon 6/2 (1994): 122-33.

Butler, John M. "The 'Author' and the 'Finisher' of the Book of Mormon." In The Book of Mormon: Fourth Nephi through Moroni, from Zion to Destruction, edited by Monte S. Nyman and Charles D. Tate, Jr., 61-68. Provo, UT: Religious Studies Center, 1995.

Campbell, Les. Review of The Lands of Zarahemla, by E. L. Peay. Review of Books on the Book of Mormon 6/2 (1994): 139-45.

Carmack, John K. "Pahoran: Wartime Statesman, Defender of Freedom." In Heros from the Book of Mormon, 13444. Salt Lake City: Bookcraft, 1995.

Carter, K. Codell, and Christopher B Isaac. Review of Refuting the Critics: Evidences of the Book of Mormon's Authenticity, by Michael T. Griffith. Review of Books on the Book of Mormon 6/2 (1994): 114-17.

Christensen, Joe J. "Captain Moroni, an Authentic Hero." In Heros from the Book of Mormon, 128-33. Salt Lake City: Bookcraft, 1995. 
Christensen, Kevin. "A Response to David Wright on Historical Criticism." Journal of Book of Mormon Studies 3 (Spring 1994): 79-93.

Christensen, Kevin. Review of New Approaches to the Book of Mormon: Explorations in Critical Methodology, edited by Brent Lee Metcalfe. Review of Books on the Book of Mormon 7/2 (1995): 144-218.

Christiansen, Jack R. "Why We Need the Book of Mormon." In Christiansen's Be Strong and of Good Courage, 8999. Salt Lake City: Bookcraft, 1994.

Clark, John. Review of Christ in North America, by Delbert W. Curtis. Review of Books on the Book of Mormon 6/2 (1994): 79-113.

Cobabe, Douglas L. "The Books of Daniel." NE 25 (June 1995): 48-52.

Condie, Spencer J. "Mormon: Historian, General, Man of God." In Heros from the Book of Mormon, 168-79. Salt Lake City: Bookcraft, 1995.

Cook, Gene R. "Moroni's Promise." Ensign 24 (April 1994): 12-16.

Cook, Lyndon W. "David Whitmer: Faithful Dissenter." This People 15 (Fall 1994): 10, 12, 15.

Coutts, Alison V. P. Review of Recent Book of Mormon Developments: Articles from the Zarahemla Record, vol. 2, edited by Raymond C. Treat. Review of Books on the Book of Mormon 7/2 (1995): 253-55.

Cracroft, Richard H. Review of Daniel and Nephi, by Chris Heimerdinger; and Samuel, Moroni's Young Warrior, by Clair Poulson. Review of Books on the Book of Mormon 6/2 (1994): 118-21.

Crowell, Angela M. "The Hebrew Literary Structure of the Book of Mormon." In Restoration Studies, edited by Paul M. Edwards and Darlene Caswell, 5:156-69. Independence, MO: Herald Publishing House, 1993.

Davis, Garold N. Review of The Legacy of the Brass Plates of Laban: A Comparison of Biblical and Book of Mormon Isaiah Texts, by Clay H. Gorton. Review of Books on the Book of Mormon 7/1 (1995): 123-29.

Decker, Ed. Decker's Complete Handbook on Mormonism. Eugene: Harvent House, 1995.

Dellenbach, Robert K. "The Translation Miracle of the Book of Mormon." Ensign 25 (May 1995): 9-11.

Donaldson, Lee L. "The Plates of Ether and the Covenant of the Book of Mormon." In The Book of Mormon: Fourth Nephi through Moroni, from Zion to Destruction, edited by Monte S. Nyman and Charles D. Tate, Jr., 69-79. Provo, UT: Religious Studies Center, 1995.

Draper, Richard D. "Hubris and Ate: A Latter-day Warning from the Book of Mormon." Journal of Book of Mormon Studies 3 (Fall 1994): 12-33.

Eaton, Melanie. "The Reward is Worth the Effort." Ensign 25 (May 1995): 93. 
England, Eugene. Review of Homecoming, vols. 1-5; A Storyteller in Zion: Essays and Speeches; and "An Open Letter to those who are concerned about 'plagiarism' in The Memory of Earth," by Orson Scott Card. Review of Books on the Book of Mormon 6/2 (1994): 59-78.

Eyring, Henry B. "Amulek: The Blessings of Obedience." In Heros from the Book of Mormon, 106-11. Salt Lake City: Bookcraft, 1995.

Faulconer, James E. "The Olive Tree and the Work of God: Jacob 5 and Romans 11." In The Allegory of the Olive Tree: The Olive, the Bible, and Jacob 5, edited by Stephen D. Ricks and John W. Welch, 347-66. Salt Lake City: Deseret Book and FARMS, 1994.

Folsom, Marvin. Review of The Easy-to-Read Book of Mormon: A Learning Companion, by Lynn Matthews Anderson. Review of Books on the Book of Mormon 7/1 (1995): 13-18.

Fowles, John L. "The Jewish Lectionary and Book of Mormon Prophecy." Journal of Book of Mormon Studies 3 (Fall 1994): 118-22.

Garrett H. Dean. "Light in Our Vessels: Faith, Hope, and Charity." In The Book of Mormon: Fourth Nephi through Moroni, from Zion to Destruction, edited by Monte S. Nyman and Charles D. Tate, Jr., 81-93. Provo, UT: Religious Studies Center, 1995.

Gee, John. Review of "The Use of Egyptian Magical Papyri to Authenticate the Book of Abraham: A Critical Review," by Edward H. Ashment. Review of Books on the Book of Mormon 7/1 (1995): 19-84.

Gee, John. Review of Written by the Finger of God: Testimony of Joseph Smith's Translations, by Joe Sampson. Review of Books on the Book of Mormon 7/1 (1995): 219-28.

Gee, John, and Daniel C. Peterson. "Graft and Corruption: On Olives and Olive Culture in the Pre-Modern Mediterranean." In The Allegory of the Olive Tree: The Olive, the Bible, and Jacob 5, edited by Stephen D. Ricks and John W. Welch, 186-247. Salt Lake City: Deseret Book and FARMS, 1994.

Godard, Linda F. Society and the Law: Comparing the Legal Environment in the Book of Mormon with the Litigious Trend of Today's Society. B. A. thesis, Brigham Young University, 1994.

Goff, Alan. Review of "Apologetic and Critical Assumptions about Book of Mormon Historicity," by Brent Lee Metcalfe. Review of Books on the Book of Mormon 7/1 (1995): 170-207.

Gorton, H. Clay. The Legacy of the Brass Plates of Laban: A Comparison of Biblical \& Book of Mormon Isaiah Texts. Bountiful, UT: Horizon, 1994.

Griffith, Michael T. Refuting the Critics: Evidences of the Book of Mormon's Authenticity. Bountiful: Horizon Publishers, 1993.

Groberg, John H. "Enos." In Heros from the Book of Mormon, 47-58. Salt Lake City: Bookcraft, 1995.

Grover, Lisa M. "Rising to the Challenge." NE 25 (June 1995): 44-45. 
"Hagoth." Friend 25 (Jan. 1995): 27.

Hamblin, William J. "The Latest Straw Man." Journal of Book of Mormon Studies 4 (Fall 1995): 82-91.

Hamblin, William J. Review of Explorers of Pre-Columbian America?: The Diffusionist-Inventionist Controversy, by Eugene R. Fingerhut; and Legend and Lore of the Americas before 1492: An Encyclopedia of visitors, Explorers, and Immigrants, by Ronald H. Fritze. Review of Books on the Book of Mormon 7/1 (1995): 120-22.

Hamblin, Willam J. Review of The Sanctity of Dissent, by Paul Toscano. Review of Books on the Book of Mormon 7/1 (1995): 298-316.

Hamblin, William J. Sacred Writings on Bronze Plates in the Ancient Mediterranean. Provo, UT: FARMS, 1994.

Hamblin, William J., Daniel C. Peterson, and George L. Mitton. Review of The Refiner's Fire: The Making of Mormon Cosmology, 1644-1844, by John L. Brooke. Review of Books on the Book of Mormon 6/2 (1994): 3-58.

Hansen, Gerald Jr. "Preparing for the Judgment." In The Book of Mormon: Fourth Nephi through Moroni, from Zion to Destruction, edited by Monte S. Nyman and Charles D. Tate, Jr., 95-104. Provo, UT: Religious Studies Center, 1995.

Hatch, Gary Lynn. "Mormon and Moroni: Father and Son." In The Book of Mormon: Fourth Nephi through Moroni, from Zion to Destruction, edited by Monte S. Nyman and Charles D. Tate, Jr., 105-15. Provo, UT: Religious Studies Center, 1995.

Hauck, F. Richard. "Ancient Fortifications and the Land of Manti." This People 15 (Summer 1994): 46-47, 49-52, 54-55.

Hauck, F. Richard. "Archaeology and the Setting of the Book of Mormon." This People 15 (Spring 1994): 70-83.

Hauck, F. Richard. "In Search of the Land of Nephi." This People 15 (Fall 1994): 52-56, 58-60, 63.

Hauck, F. Richard. "The Trail to Zarahemla." This People 15 (Holiday 1994): 64-65, 67, 69-70.

Hauglid, Brian M. Review of Strangers in Paradox: Exploration in Mormon Theology, by Margaret and Paul Toscano. Review of Books on the Book of Mormon 6/2 (1994): 250-82.

Hawley, Judith A. Nephi and Lehi, Mighty Men of God: Adapted from the Book of Mormon, Helaman 2, 37, 79-120. Independence, MO: OM Resource Center, 1994.

Heimerdinger, Chris. Daniel and Nephi. Salt Lake City: Covenant, 1993.

Heimerdinger, Chris. Tennis Shoes and the Feathered Serpent. American Fork, UT: Covenant, 1995.

Hess, Wilford M., Daniel J. Fairbanks, John W. Welch, and Jonathan K. Driggs. "Botanical Aspects to Olive Culture Relevant to Jacob 5." In The Allegory of the Olive Tree: The Olive, the Bible, and Jacob 5, edited by Stephen D. Ricks and John W. Welch, 484-562. Salt Lake City: Deseret Book and FARMS, 1994. 
Hinckley, Gordon B. "Moroni." In Heros from the Book of Mormon, 195-200. Salt Lake City: Bookcraft, 1995.

Holland, Jeffrey R. "Jacob the Unshakable." In Heros from the Book of Mormon, 32-46. Salt Lake City: Bookcraft, 1995.

Holland, Jeffrey R. "True or False." NE 25 (June 1995): 64-66.

Holmes, David I. "Vocabulary Richness and the Book of Mormon: A Stylometric Analysis of Mormon Scripture." Research in Humanities Computing 3 (1994): 18-31.

Holzapfel, Richard N. "Golden Bible Hill." Mormon Heritage 2 (July-August 1995): 44-46.

Holzapfel, Richard N. "Mormon, the Man and the Message." In The Book of Mormon: Fourth Nephi through Moroni, from Zion to Destruction, edited by Monte S. Nyman and Charles D. Tate, Jr., 117-31. Provo, UT: Religious Studies Center, 1995.

Honey, David B. Review of The Allegory of the Olive Tree: The Olive, the Bible, and Jacob 5, edited by Stephen D. Ricks and John W. Welch. BYU Studies 35 (1995): 238-46.

Honey, David B. "The Secular as Sacred: The Historiography of the Title Page." Journal of Book of Mormon Studies 3 (Spring 1994): 94-103.

Hoskisson, Paul Y. "The Allegory of the Olive Tree in Jacob." In The Allegory of the Olive Tree: The Olive, the Bible, and Jacob 5, edited by Stephen D. Ricks and John W. Welch, 70-104. Salt Lake City: Deseret Book and FARMS, 1994.

Howard, F. Burton. "Ammon: Reflections on Faith and Testimony." In Heros from the Book of Mormon, 120-27. Salt Lake City: Bookcraft, 1995.

Hoskisson, Paul Y. "By What Authority Did Lehi, a Non-Levite Priest, Offer Sacrifices?" Ensign 24 (March 1994): 54.

Huchel, Frederick M. Review of Written by the finger of God, by Joe Samson. Review of Books on the Book of Mormon 6/2 (1994): 150-55.

Hunt, Wallace E., Jr. "The Marketplace." Journal of Book of Mormon Studies 4 (Fall 1995): 138-41.

Hunter, Howard W. "The Pillars of Our Faith." Ensign 24 (September 1994): 54-55.

Jacobson, Lelsle. Review of Questions to Ask Your Mormon Friend: Effective Ways to Challenge a Mormon's Arguments without Being Offensive, by Bill McKeever and Eric Johnson. Review of Books on the Book of Mormon 7/1 (1995): 155-69.

Jensen, Clint. "Why Me?" NE 25 (June 1995): 25.

Johnson, D. Lynn. The Missing Scripture." Journal of Book of Mormon Studies 3 (Fall 1994): 84-93.

Johnson, Mark J. "The Exodus of Lehi Revisited." Journal of Book of Mormon Studies 3 (Fall 1994): 123-26. 
Johnson, Mark J. The Legacy of the Brass Plates of Laban: A Comparison of Biblical and Book of Mormon Isaiah Texts, by Clay H. Gorton. Review of Books on the Book of Mormon 7/2 (1995): 130-38.

Johnson, Matthew Ty. The Development of a Computer-based Book of Mormon Reading Program for the MTC Classroom. Salt Lake City: Deseret Book, 1994.

Johnson, Sherrie. Abinadi. Salt Lake City: Deseret Book, 1994.

Johnson, Sherrie. Alma at the Waters of Mormon. Salt Lake City: Deseret Book, 1994.

Johnson, Sherrie. Ammon and the King. Salt Lake City: Deseret Book, 1994.

Johnson, Sherrie. The Broken Bow. Salt Lake City: Deseret Book, 1994.

Johnson, Sherrie. Captain Moroni's Title of Liberty. Salt Lake City: Deseret Book, 1994.

Johnson, Sherrie. The Gadianton Robbers. Salt Lake City: Deseret Book, 1994.

Johnson, Sherrie. Jesus is Born. Salt Lake City: Deseret Book, 1994.

Johnson, Sherrie. Nephi and Lehi in Prison. Salt Lake City: Deseret Book, 1994.

Judd, Daniel K. "The Spirit of Christ: A Light Amidst the Darkness." In The Book of Mormon: Fourth Nephi through Moroni, from Zion to Destruction, edited by Monte S. Nyman and Charles D. Tate, Jr., 133-46. Provo, UT: Religious Studies Center, 1995.

Judd, Frank F., Jr. "Jaredite Zion Societies: Hope for a Better World." In The Book of Mormon: Fourth Nephi through Moroni, from Zion to Destruction, edited by Monte S. Nyman and Charles D. Tate, Jr., 147-52. Provo, UT: Religious Studies Center, 1995.

Judd, Frank F., Jr., and Terrence L. Szink. Review of Mormons and Jews: Early Mormon Theologies of Israel, by Steven Epperson. Review of Books on the Book of Mormon 7/2 (1995): 106-22.

Killgore, Mark. "Book of Mormon Summer." Ensign 25 (August 1995): 28-29.

King, Arthur Henry. "Language Themes in Jacob 5: 'The Vineyard of the Lord of Hosts is the House of Israel' (Isaiah 5:7)." In The Allegory of the Olive Tree: The Olive, the Bible, and Jacob 5, edited by Stephen D. Ricks and John W. Welch, 140-73. Salt Lake City: Deseret Book and FARMS, 1994.

Klafkowski, Piotr. "Twenty-two Years with the Book of Mormon." In Restoration Studies, edited by Paul M. Edwards and Darlene Caswell, 5:170-85. Independence, MO: Herald Publishing House, 1993.

Kofford, Cree-L. "Abinadi." In Heros from the Book of Mormon, 68-78. Salt Lake City: Bookcraft, 1995.

Lambert, Neal E. " 'And There Was ... a New Writing': The Book of Mormon as a Never-Ending Text." Association for Mormon Letters Annual 2 (1994): 196-200. 
Lane, Jennifer Clark. Review of The Book of Mormon: 3 Nephi 9-30, This Is My Gospel, edited by Monte S. Nyman and Charles D. Tate. Review of Books on the Book of Mormon 6/2 (1994): 134-38.

Lane, Keith H. "The Persuasive Book of Mormon." Latter-Day Digest 3 (January 1994): 35-42.

Larsen, Dean L. "Zeezrom." In Heros from the Book of Mormon, 112-19. Salt Lake City: Bookcraft, 1995.

Larson, Stan. Quest for the Gold Plates: The Odyssey of Thomas Stuart Ferguson in Search of the Book of Mormon. Salt Lake City: Freethinker Press, 1994.

LeBaron, E. Dale. "Ether and Mormon: Parallel Prophets of Warning and Witness." In The Book of Mormon: Fourth Nephi through Moroni, from Zion to Destruction, edited by Monte S. Nyman and Charles D. Tate, Jr., 153-65. Provo, UT: Religious Studies Center, 1995.

Marquardt, H. Michael, and Wesley P. Walters. Inventing Mormonism: Tradition and the Historical Record. Salt Lake City: Smith Research Associates, 1994.

Matthews, Robert J. "The Mission of Jesus Christ-Ether 3 and 4." In The Book of Mormon: Fourth Nephi through Moroni, from Zion to Destruction, edited by Monte S. Nyman and Charles D. Tate, Jr., 19-29. Provo, UT: Religious Studies Center, 1995.

Maxwell, Neal A. "King Benjamin." In Heros from the Book of Mormon, 59-67. Salt Lake City: Bookcraft, 1995.

McConkie, Joseph Fielding. Here We Stand. Salt Lake City: Deseret Book, 1995.

Merrill, Byron R. "There Was No Contention." In The Book of Mormon: Fourth Nephi through Moroni, from Zion to Destruction, edited by Monte S. Nyman and Charles D. Tate, Jr., 167-83. Provo, UT: Religious Studies Center, 1995.

Middleton, Michael W. "Gatherings in the Last Days: Saved in Sheaves, Burned in Bundles." In The Book of Mormon: Fourth Nephi through Moroni, from Zion to Destruction, edited by Monte S. Nyman and Charles D. Tate, Jr., 185-97. Provo, UT: Religious Studies Center, 1995.

Midgley, Louis. Review of Mormon Neo-Orthodoxy: A Crisis Theology, by O. Kendall White, Jr. Review of Books on the Book of Mormon 6/2 (1994): 283-334.

Midgley, Louis. Review of Mormonism: The Story of a New Religious Tradition, by Jan Shipps. Review of Books on the Book of Mormon 7/2 (1995): 219-52.

Midgley, Louis. Review of Religion, Feminism, and Freedom of Conscience: A Mormon/Humanist Dialogue, edited by George D. Smith. Review of Books on the Book of Mormon 7/1 (1995): 229-97.

Millet, Robert L. "Alive in Christ: The Salvation of Little Children." In The Book of Mormon: Fourth Nephi through Moroni, from Zion to Destruction, edited by Monte S. Nyman and Charles D. Tate, Jr., 1-17. Provo, UT: Religious Studies Center, 1995. 
Millet, Robert L. The Power of the Word: Saving Doctrines from the Book of Mormon. Salt Lake City: Deseret Book, 1994.

Miner, Alan C. "A Chronological Setting for the epistles of Mormon to Moroni." Journal of Book of Mormon Studies 3 (Fall 1994): 94-113.

Nelson, Fred W. Review of Light from the Dust: A Photographic Exploration into the Ancient World of the Book of Mormon, by Scot Facer Proctor and Maurine Jensen Proctor. Review of Books on the Book of Mormon 6/2 (1994): 146-49.

Nelson, Russell, M. "Nephi, Son of Lehi." In Heros from the Book of Mormon, 1-15. Salt Lake City: Bookcraft, 1995.

"Nephi and Lehi in Prison." Friend 25 (March 1995): 16-19.

“Nephi Receives Great Power." Friend 25 (August 1995): 16-18.

Nibley, Hugh W. "Promised Lands." Latter-day Digest 3 (February 1994): 4-14, 16.

Norwood, L. Ara. Review of In the Footsteps of Lehi: New Evidence for Lehi's Journey across Arabia to Bountiful, by Warren P. and Michaela Knoth Aston. Review of Books on the Book of Mormon 7/1 (1995): 85-92.

Novak, Gary F. Review of Joseph Smith's Response to Skepticism, by Robert N. Hullinger. Review of Books on the Book of Mormon 7/1 (1995): 139-54.

Nyman, Monte S. "I Have a Question: What is the meaning or known fulfillment of the prophecy, 'kings shall be thy nursing fathers, and their queens thy nursing mothers'?" Ensign 24 (August 1994): 61-62.

Nyman, Monte S. "The Judgment Seat of Christ." In The Book of Mormon: Fourth Nephi through Moroni, from Zion to Destruction, edited by Monte S. Nyman and Charles D. Tate, Jr., 199-213. Provo, UT: Religious Studies Center, 1995.

Nyman, Monte S., and Charles D. Tate, Jr., eds.. The Book of Mormon: Fourth Nephi through Moroni, from Zion to Destruction. Provo, UT: Religious Studies Center, 1995.

O'Driscoll, Jeff. "Zion Zion Zion: Keys to Understanding Ether 13." In The Book of Mormon: Fourth Nephi through Moroni, from Zion to Destruction, edited by Monte S. Nyman and Charles D. Tate, Jr., 215-34. Provo, UT: Religious Studies Center, 1995.

Oaks, Dallin H. "Another Testament of Jesus Christ." Ensign 24 (March 1994): 60-67.

Oaks, Dallin H. "The Historicity of the Book of Mormon." Provo, UT: FARMS, 1994.

Oman, Richard G. "Sacred Connections: LDS Pottery in the Native American Southwest." BYU Studies 35 (1995): 107-28.

Parry, Donald W. "1993 Book of Mormon Bibliography." Review of Books on the Book of Mormon 6/2 (1994): 33548. 
Paulson, Clair. Samuel, Gadianton's Foe. American Fork: Covenant Communications, 1994.

Pearson, Glenn L. Moroni's Promise: The Converting Power of the Book of Mormon. Salt Lake City: Bookcraft, 1995.

Peay, E. L. The Lands of Zarahemla. Salt Lake City: Northwest Publishing, 1993.

Peay, E. L. The Lands of Zarahemla: Nephi's Promised Land in Central America: A Book of Mormon Commentary, vol. 2. Provo, UT: the author, 1994.

Perry, L. Tom. "Alma, the Son of Alma." In Heros from the Book of Mormon, 98-105. Salt Lake City: Bookcraft, 1995.

Peterson, Andrew W. "Samuel the Lamanite." In Heros from the Book of Mormon, 157-67. Salt Lake City: Bookcraft, 1995.

Peterson, Daniel C. "LDS Scholars Refute Attacks on the Book of Mormon." This People 15 (Summer 1994): 28-33.

Peterson, Daniel C. Review of Decker's Complete Handbook on Mormonism, by Ed Decker. Review of Books on the Book of Mormon 7/1 (1995): 38-105.

Peterson, H. Donl. "Moroni, the Last of the Nephite Prophets." In The Book of Mormon: Fourth Nephi through Moroni, from Zion to Destruction, edited by Monte S. Nyman and Charles D. Tate, Jr., 235-49. Provo, UT: Religious Studies Center, 1995.

Pinegar, Rex D. "The Simple Things." Ensign 24 (November 1994): 80-82.

Porter, Larry C. Review of Inventing Mormonism: Tradition and the Historical Record, by Michael H. Marquardt and Wesley P. Walters. Review of Books on the Book of Mormon 7/2 (1995): 123-43.

Poulson, Clair. Samuel, Moroni's Young Warrior. Salt Lake City: Covenant, 1993.

Price, Lynn F. Every Person in the Book of Mormon: A Chronological Reference and Synopsis. Bountiful, UT: Horizon Publishers, 1995.

Prince, James R. "Proving the Prophet's Promise." Ensign 24 (January 1994): 64-65.

Pritchett, Bruce M., Jr. "Lehi's Theology of the Fall in Its Preexilic/Exile Context." Journal of Book of Mormon Studies 3 (Fall 1994): 49-83.

Proctor, Scot Facer, and Maurine Jensen Proctor. Light from the Dust: A Photographic Exploration into the Ancient World of the Book of Mormon. Salt Lake City: Deseret Book, 1993.

"Questions and Answers: I've been studying the Book of Mormon, but the Bible seems boring. Should I read and study the Bible just as much as the Book of Mormon?" NE 25 (June 1995): 16-18.

Rasmus, Carolyn J. "Weak Things Made Strong." In The Book of Mormon: Fourth Nephi through Moroni, from Zion to Destruction, edited by Monte S. Nyman and Charles D. Tate, Jr., 251-62. Provo, UT: Religious Studies Center, 1995. 
Rencher, Alvin C. "Unity through the Power of Charity." In The Book of Mormon: Fourth Nephi through Moroni, from Zion to Destruction, edited by Monte S. Nyman and Charles D. Tate, Jr., 263-75. Provo, UT: Religious Studies, 1995.

Reynolds, Noel B. "Nephite Uses and Interpretations of Zenos." In The Allegory of the Olive Tree: The Olive, the Bible, and Jacob 5, edited by Stephen D. Ricks and John W. Welch, 21-49. Salt Lake City: Deseret Book and FARMS, 1994.

Rhett, James. "The Legacy of Martin Harris: Printing the Book of Mormon." Mormon Heritage 2 (July-August 1995): 14-20.

Ricks, Stephen D., and John W. Welch, eds. The Allegory of the Olive Tree: The Olive, the Bible, and Jacob 5. Salt Lake City: Deseret Book and FARMS, 1994.

Roberts, B. H. The Truth, The Way, The Life. Edited by John W. Welch. Provo, UT: BYU Studies, 1994.

Robinson, Hazel Jean D. "My Lesson from Pahoran." Ensign 24 (February 1994): 40.

Roper, Matthew. "Noah Webster and the Book of Mormon." Journal of Book of Mormon Studies 4 (Fall 1995): 14246.

Roper, Matthew. Review of Answering Mormon Scholars: A Response to Criticism of the Book "Covering Up the Black Hole in the Book of Mormon," vol. 1, by Jerald and Sandra Tanner. Review of Books on the Book of Mormon 6/2 (1994): 156-203.

Rust, Richard Dilworth. "Liminality in the Book of Mormon." Association for Mormon Letters Annual 2 (1994): 20711.

Rust, Richard Dilworth. "Recurrence in Book of Mormon Narratives." Journal of Book of Mormon Studies 3 (Spring 1994): 39-52.

Sampson, Joe. Written by the Finger of God. Salt Lake City: Wellspring Publishing and Distributing, 1993.

"Samuel the Lamanite Tells about Jesus Christ." Friend 25 (October 1995): 16-18.

Samuelson, Cecil O., Jr. "The Brother of Jared." In Heros from the Book of Mormon, 180-88. Salt Lake City: Bookcraft, 1995.

Satterfield, Bruce K. "Moroni 9-10: Remembering How Merciful the Lord Hath Been." In The Book of Mormon: Fourth Nephi through Moroni, from Zion to Destruction, edited by Monte S. Nyman and Charles D. Tate, Jr., 277-88. Provo, UT: Religious Studies Center, 1995.

Saunders, Iain. "I Knew Nephi." NE 25 (June 1995): 12-14.

Scott, Ricard G. "Nephi, Son of Helaman." In Heros from the Book of Mormon, 145-56. Salt Lake City: Bookcraft, 1995. 
Seely, David Rolph. "The Allegory of the Olive Tree and the Use of Related Figurative Language in the Ancient Near East and the Old Testament." In The Allegory of the Olive Tree: The Olive, the Bible, and Jacob 5, edited by Stephen D. Ricks and John W. Welch, 290-304. Salt Lake City: Deseret Book and FARMS, 1994.

Seely, David Rolph, and John W. Welch. "Zenos and the Texts of the Old Testament." In The Allegory of the Olive Tree: The Olive, the Bible, and Jacob 5, edited by Stephen D. Ricks and John W. Welch, 322-46. Salt Lake City: Deseret Book and FARMS, 1994.

Shipps, Jan, and John W. Welch, eds., The William E. McLellin Journals (1831-1836). Urbana, IL and Provo, UT: University of Illinois Press and BYU Studies, 1994.

Skinner, Andrew C. "Zion Gained and Lost: Fourth Nephi as the Quintessential Model." In The Book of Mormon: Fourth Nephi through Moroni, from Zion to Destruction, edited by Monte S. Nyman and Charles D. Tate, Jr., 289-302. Provo, UT: Religious Studies Center, 1995.

Skousen, Royal. "Jacob 4-6: Substantive Textual Variants between Manscripts and Editions." In The Allegory of the Olive Tree: The Olive, the Bible, and Jacob 5, edited by Stephen D. Ricks and John W. Welch, 105-39. Salt Lake City: Deseret Book and FARMS, 1994.

Skousen, Royal. "The Original Language of the Book of Mormon: Upstate New York Dialect, King James English, or Hebrew." Journal of Book of Mormon Studies 3 (Spring 1994): 28-38.

Skousen, Royal. Review of Bible II. Review of Books on the Book of Mormon 6/2 (1994):1-2.

Smith, Larry K. Review of First Nephi: Study Book of Mormon. Review of Books on the Book of Mormon 7/2 (1995): 35.

Smith, Larry K. Review of LDS Collectors Edition CD-ROM. Review of Books on the Book of Mormon 7/2 (1995): 25664.

Smith, Larry K. Review of Overview of the Book of Mormon. Review of Books on the Book of Mormon 7/2 (1995): 1-2.

Snow, Edgar C., Jr. "Narrative Criticism and the Book of Mormon." Journal of Book of Mormon Studies 4 (Fall 1995): 93-106.

Snow, Edgar C., Jr. "One Face of the Hero: In Search of the Mythological Joseph Smith." Dialogue 27 (Fall 1994): 233-47.

Sperry, Sidney B. "Were there Two Comorahs?" Journal of Book of Mormon Studies 4 (Spring 1995): 260-68.

Sperry, Sidney B. "Moroni Expounds Old Testament Scriptures." Journal of Book of Mormon Studies 4 (Spring 1995): 269-86.

Stirling, Mack C. Review of The Book of Mormon: Helaman through 3 Nephi 8, According to Thy Word, by Monte S. Nyman and Charles D. Tate, Jr. Review of Books on the Book of Mormon 7/1 (1995): 208-18. 
Sturgess, Gary L. "The Book of Mosiah: Thoughts about Its Structure, Purposes, Themes, and Authorship." Journal of Book of Mormon Studies 4 (Fall 1995): 107-35.

"'Take One'-Book of Mormon Movie Magic." This People 15 (Fall 1994): 36-39.

Tanner, Jerald and Sandra. Answering Mormon Scholars: A Response to Criticism of the Book "Covering Up the Black Hole in the Book of Mormon," vol. 1. Salt Lake City: Utah Lighthouse Ministry, 1994.

Tanner, Martin S. Review of "Book of Mormon Christology," by Melodie Moench Charles. Review of Books on the Book of Mormon 7/2 (1995): 6-37.

Terry, Keith. Out of Darkness: A Novel. American Fork, UT: Covenant Communications, 1995.

"The Murder of the Chief Judge." Friend 25 (June 1995): 15-19.

Thomas, Janet. "A Great Book." NE 25 (June 1995): 40-41.

Thomas, M. Catherine. "The Brother of Jared at the Veil." In Temples of the Ancient World: Ritual and Symbolism, edited by Donald W. Parry, 388-98. Salt Lake City: Deseret Book and FARMS, 1994.

Thomas, M. Catherine. "Jacob's Allegory: The Mystery of Christ." In The Allegory of the Olive Tree: The Olive, the Bible, and Jacob 5, edited by Stephen D. Ricks and John W. Welch, 11-20. Salt Lake City: Deseret Book and FARMS, 1994.

Thomas, M. Catherine. "Using the Book of Mormon to Face the Tests Ahead." In Watch and Be Ready: Preparing for the Second Coming of the Lord, 16-38. Salt Lake City: Deseret Book, 1994.

Thomasson, Gordon C. "What's in a Name? Book of Mormon Language, Names, and [Metonymic] Naming." Journal of Book of Mormon Studies 3 (Spring 1994): 1-27.

Thompson, John S. "The Jaredite Exodus: A Literary Perspective of a Historical Narrative." Journal of Book of Mormon Studies 3 (Spring 1994): 94-103.

Thorne, Melvin J. "What is FARMS?" This People 16 (Spring 1995): 42-46.

Trimble, Brenda. "The Feathered Serpent." Witness 85 (Summer 1994): 7-9.

Tvedtnes, John A. "Borrowings from the Parable of Zenos." In The Allegory of the Olive Tree: The Olive, the Bible, and Jacob 5, edited by Stephen D. Ricks and John W. Welch, 373-426. Salt Lake City: Deseret Book and FARMS, 1994.

Tvedtnes, John A. "Cities and Lands in the Book of Mormon." Journal of Book of Mormon Studies 4 (Fall 1995): 14750.

Tvedtnes, John A. "Faith and Truth." Journal of Book of Mormon Studies 3 (Fall 1994): 114-17.

Tvedtnes, John A. "Historical Parallels to the Destruction at the Time of the Crucifixion." Journal of Book of Mormon Studies 3 (Spring 1994): 170-86. 
Tvedtnes, John A. "The Influence of Lehi's Admonitions on the Teachings of His Son Jacob." Journal of Book of Mormon Studies 3 (Fall 1994): 34-48.

Tvedtnes, John A. "My First-Born in the Wilderness." Journal of Book of Mormon Studies 3 (Spring 1994): 207-9.

Tvedtnes, John A. Review of Answering Mormon Scholars: A Response to Criticism of the Book "Covering Up the Black Hole in the Book of Mormon," vol. 1, by Jerald and Sandra Tanner. Review of Books on the Book of Mormon 6/2 (1994): 204-49.

Tvedtnes, John A. "Vineyard or Olive Orchard?" In The Allegory of the Olive Tree: The Olive, the Bible, and Jacob 5 , edited by Stephen D. Ricks and John W. Welch, 477-83. Salt Lake City: Deseret Book and FARMS, 1994.

Underwood, Grant. "Jacob 5 in the Nineteenth Century." In The Allegory of the Olive Tree: The Olive, the Bible, and Jacob 5, edited by Stephen D. Ricks and John W. Welch, 50-69. Salt Lake City: Deseret Book and FARMS, 1994.

Valletta, Thomas R. "The Book of Mormon As a Testimony of Jesus Christ." In Serving with Strength throughout the World: Favorite Talks from Especially for Youth, 251-61. Salt Lake City: Deseret Book, 1994.

Valletta, Thomas R. "Jared and His Brother." In The Book of Mormon: Fourth Nephi through Moroni, from Zion to Destruction, edited by Monte S. Nyman and Charles D. Tate, Jr., 303-22. Provo, UT: Religious Studies Center, 1995.

Van Orden, Bruce A. "Preach the Gospel to Every Creature." In The Book of Mormon: Fourth Nephi through Moroni, from Zion to Destruction, edited by Monte S. Nyman and Charles D. Tate, Jr., 323-36. Provo, UT: Religious Studies Center, 1995.

Volluz, Corbin T. "Cry Redemption: The Plan of Redemption as Taught in the Book of Mormon." Journal of Book of Mormon Studies 3 (Spring 1994): 148-69.

Von Harrison, Grant. Use the Book of Mormon to Teach Reading. Provo, UT: n.p., 1994.

Wardle, Lynn D. "Dissent: Perspectives from the Book of Mormon." Journal of Book of Mormon Studies 3 (Spring 1994): 53-73.

Welch, John W. "Criteria for Identifying and Evaluating the Presence of Chiasmus." Journal of Book of Mormon Studies 4 (Fall 1995): 1-14.

Welch, John W. "The Last Words of Cenez and the Book of Mormon." In The Allegory of the Olive Tree: The Olive, the Bible, and Jacob 5, edited by Stephen D. Ricks and John W. Welch, 305-21. Salt Lake City: Deseret Book and FARMS, 1994.

Welch, John W. "Powerful Personal Testimonies of Christ from the Book of Mormon." Witness Part 1: 85-86 (Summer-Fall 1994): 4-7, 10, 6, 11, 14-15.

Welch, John W. "A Study Relating Chiasmus in the Book of Mormon to Chiasmus in the Old Testament, Ugaritic Epics, Homer, and Selceted Greek and Latin Authors." M.A. thesis, Brigham Young University, 1970. 
Welch, John W. "The Temple in the Book of Mormon: The Temples at the Cities of Nephi, Zarahemla, and Bountiful." In Temples of the Ancient World: Ritual and Symbolism, edited by Donald W. Parry, 297-387. Salt Lake City: Deseret Book and FARMS, 1994.

Welch, John W. "Words and Phrases in Jacob 5." In The Allegory of the Olive Tree: The Olive, the Bible, and Jacob 5 , edited by Stephen D. Ricks and John W. Welch, 174-85. Salt Lake City: Deseret Book and FARMS, 1994.

Welch, John W. "Zenos: Hearing Mercy." BYU Studies 33 (1993): 172-73.

Williams, Camille S. Review of The Easy-to-Read Book of Mormon: A Learning Companion, by Lynn Matthews Anderson, and Mormon's Story, by Timothy B. Wilson. Review of Books on the Book of Mormon 7/1 (1995): 3-12.

Wirthlin, Joseph B. "Alma the Elder: A Role Model for Today." In Heros from the Book of Mormon, 79-97. Salt Lake City: Bookcraft, 1995.

Woodworth, Warner P. "The Socio-Economics of Zion." In The Book of Mormon: Fourth Nephi through Moroni, from Zion to Destruction, edited by Monte S. Nyman and Charles D. Tate, Jr., 337-52. Provo, UT: Religious Studies Center, 1995.

Ziebarth, Christian M. "Examining a Nephite/Latter-day Apostolic Parallel." Journal of Book of Mormon Studies 4 (Fall 1995): 151-54. 


\section{Appendix}

\section{Book of Mormon Editions Translated and Published by year}

English, 1830

Danish, 1851

German, 1852

French, 1852

Italian, 1852

Welsh, 1852

Hawaiian, 1855

English (Deseret Alphabet), 1869

Spanish, 1875, selections

Swedish, 1878

Spanish, 1886

Maori, 1889

Dutch, 1890

Samoan, 1903

Tahitian, 1904

Turkish, 1906

Japanese, 1909

Hebrew, 1927

Czech, 1933

Armenian-Western, 1937, selections

English (Braille), 1939

Portuguese, 1940 
Norwegian, 1950

Finnish, 1954

Rarotongan, 1965

Chinese, 1965

Korean, 1967

Afrikaans, 1972

Thai, 1976

Indonesian, 1977

Aymara, 1977, selections

Cakchiquel, 1978, selections

Croatian, 1979

Quechua-Peru, 1979, selections

Greek, 1979, selections

Hungarian, 1979, selections

Kekchi, 1979, selections

Quiche, 1979, selections

Bulgarian, 1980, selections

Navajo, 1980, selections

Quichua-Otavalo, 1980, selections

Arabic, 1980, selections

Czech, 1980, selections

Vietnamese, 1980, selections

Fijian, 1980 
Russian, 1980

Catalan, 1981

Icelandic, 1981

Niuean, 1981, selections

Quechua-Bolivia, 1981, selections

Kuna, 1981, selections

Romanian, 1981, selections

Polish, 1981

Hindi, 1982

Telugu, 1982, selections

Tamil, 1982, selections

Cambodian, 1982, selections

Laotian, 1982, selections

Vietnamese, 1982

Swahili, 1982, selections

Guarani, 1982, selections

Maya, 1983, selections

Sinhala, 1983, selections

Kekchi, 1983

Mam, 1983, selections

Armenian, 1983, selections

Turkish, 1983, selections

Efik, 1983, selections

Chinese, 1983, selections 
Kisii, 1983, selections

Greek (Demotike), 1983, selections

Hmong, 1983, selections

Persian, 1983, selections

Haitian Creole, 1983, selections

Marshallese, 1984, selections

Bengali, 1985, selections

Bislama, 1985, selections

Arabic 1986

Aymara, 1986

Malagasy, 1986, selections

Akan-Fante, 1987, selections

Greek (Demotike), 1987

Zulu, 1987, selections

Pohnpeian, 1987, selections

Papiamento, 1987, selections

Trukese, 1987, selections

Tagalog, 1987, selections

Lingala, 1988, selections

Shona, 1988, selections

Urdu, 1988, selections

Palauan, 1988, selections

Gilbertese, 1988, selections

Chamorro, 1989, selections 
English-Braille, 1989, revision

Ilokano, 1991, selections

Hungarian, 1991

Cebuano, 1992, selections

Hiligaynon, 1994, selections

\section{Translations from English by Language}

Afrikaans, 1972

Akan-Fante, 1987, selections

Arabic 1986

Arabic, 1980, selections

Armenian, 1983, selections

Armenian-Western, 1937, selections

Aymara, 1977, selections

Aymara, 1986

Bengali, 1985, selections

Bislama, 1985, selections

Bulgarian, 1980, selections

Cakchiquel, 1978, selections

Cambodian, 1982, selections

Catalan, 1981

Cebuano, 1992, selections

Chamorro, 1989, selections

Chinese, 1983, selections

Chinese, 1965 
Croatian, 1979

Czech, 1933

Czech, 1980, selections

Danish, 1851

Dutch, 1890

Efik, 1983, selections

English (Braille), 1939

English (Deseret Alphabet), 1869

English, 1830

English-Braille, 1989, revision

Fijian, 1980

Finnish, 1954

French, 1852

German, 1852

Gilbertese, 1988, selections

Greek (Demotike), 1983, selections

Greek (Demotike), 1987

Greek, 1979, selections

Guarani, 1982, selections

Haitian Creole, 1983, selections

Hawaiian, 1855

Hiligaynon, 1994, selections

Hindi, 1982

Hmong, 1983, selections 
Hungarian, 1979, selections

Hungarian, 1991

Icelandic, 1981

Ilokano, 1991, selections

Indonesian, 1977

Italian, 1852

Japanese, 1909

Kekchi, 1979, selections

Kekchi, 1983

Kisii, 1983, selections

Korean, 1967

Kuna, 1981, selections

Laotian, 1982, selections

Lingala, 1988, selections

Malagasy, 1986, selections

Mam, 1983, selections

Maori, 1889

Marshallese, 1984, selections

Maya, 1983, selections

Navajo, 1980, selections

Niuean, 1981, selections

Norwegian, 1950

Palauan, 1988, selections

Papiamento, 1987, selections 
Persian, 1983, selections

Pohnpeian, 1987, selections

Polish, 1981

Portuguese, 1940

Quechua-Bolivia, 1981, selections

Quechua-Peru, 1979, selections

Quiche, 1979, selections

Quichua-Otavalo, 1980, selections

Rarotongan, 1965

Romanian, 1981, selections

Russian, 1980

Samoan, 1903

Shona, 1988, selections

Sinhala, 1983, selections

Spanish, 1875, selections

Spanish, 1886

Swahili, 1982, selections

Swedish, 1878

Tagalog, 1987, selections

Tahitian, 1904

Tamil, 1982, selections

Telugu, 1982, selections

Thai, 1976

Tongan, 1946 
Trukese, 1987, selections

Turkish, 1906

Turkish, 1983, selections

Urdu, 1988, selections

Vietnamese, 1980, selections

Vietnamese, 1982

Welsh, 1852

Zulu, 1987, selections 


\section{Index}

Aaron A.001 R.092

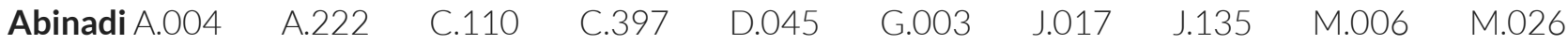

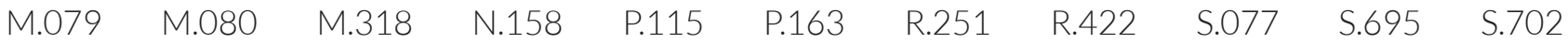

S.722 T.312 W.132 W.189

Abish J.126

$\begin{array}{llllllll}\text { Abraham, book of E.080 } & \text { I.031 } & \text { M.262 } & \text { P.009 } & \text { S.245 } & \text { S.575 } & \text { W.090 } & \text { W.323 }\end{array}$

Abrahamic covenant N.025 R.097

$\begin{array}{llllllll}\text { activity books for children B.024 } & \text { B.025 } & \text { B.219 } & \text { B.295 } & \text { B.474 } & \text { B.525 } & \text { C.226 } & \text { C.236 }\end{array}$

$\begin{array}{lllllllllll}\text { C.306 } & \text { C.440 } & \text { D.090 } & \text { G.137 } & \text { G.138 } & \text { G.139 } & \text { H.025 } & \text { H.183 } & \text { H.373 } & \text { J.166 } & \text { J.167 }\end{array}$

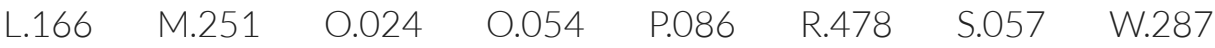

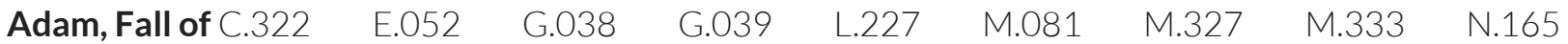

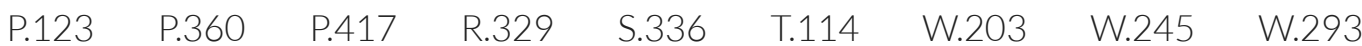

Adam and Eve B.554 $\quad 0.033 \quad$ P.318 Y.029

$\begin{array}{llll}\text { adieu B.409 } & \text { C.413 } & \text { C.418 } & \text { P.243 }\end{array}$

adultery P.082

afterlife C.286 C.361 H.145 S.606

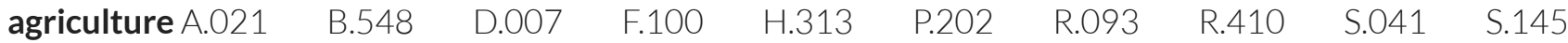

$\begin{array}{llllll}\text { S.546 } & \text { S.646 } & \text { T.131 } & \text { T.258 } & \text { T.285 } & \text { W.020 }\end{array}$

allegory, Jacob's. See Jacob 5; olive

$\begin{array}{lllllllll}\text { Alma, book of B.477 } & \text { C.063 } & \text { H.051 } & \text { H.067 } & \text { H.237 } & \text { J.109 } & \text { K.060 } & \text { M.101 } & \text { P.054 }\end{array}$

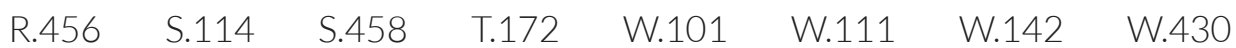

$\begin{array}{llllllllll}\text { Alma }_{1} \text { A.222 } & \text { A.228 } & \text { B.088 } & \text { F.039 } & \text { G.004 } & \text { J.129 } & \text { L.022 } & \text { M.474 } & \text { P.163 } & \text { R.039 }\end{array}$

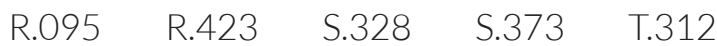

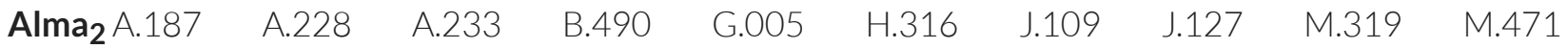

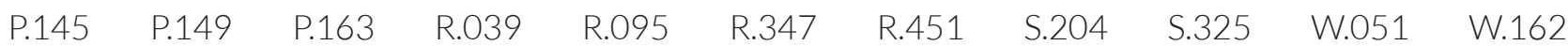

W.293 W.356 Z.018

Amaleki W.268 
$\begin{array}{lllllllll}\text { American Indian B.041 } & \text { B.262 } & \text { B.465 } & \text { B.503 } & \text { B.511 } & \text { C.031 } & \text { C.044 } & \text { C.049 } & \text { C.050 }\end{array}$

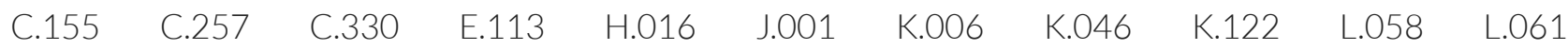
$\begin{array}{llllllllll}\text { L.161 L.244 } & \text { P.001 } & \text { P.080 } & \text { P.249 } & \text { P.380 } & \text { P.381 } & \text { S.379 } & \text { S.408 } & \text { S.629 } & \text { S.709 }\end{array}$ W.354 W.409 W.427 Y.003 Y.019. See also Aztec; Inca; Maya; mound builders

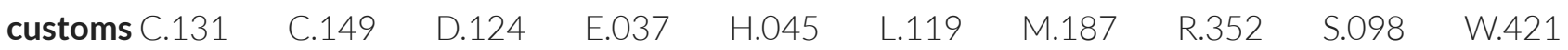

Great Spirit A.042 B.106 B.122 C.131

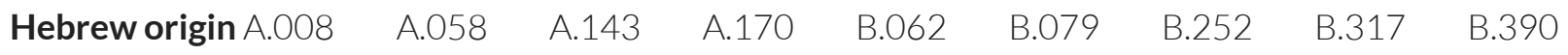

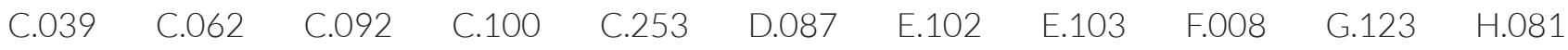

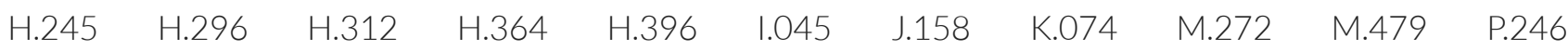

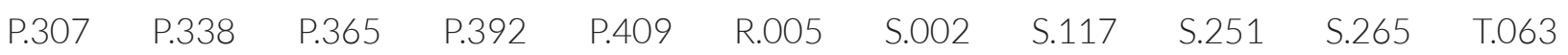

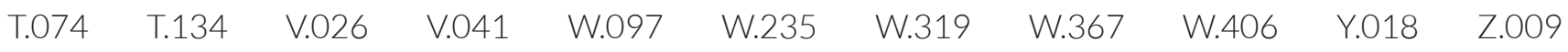

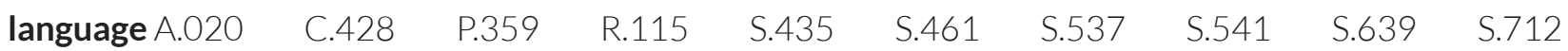
S.713 T.050 T.052 T.053

$\begin{array}{llllllllll}\text { legends B.211 } & \text { B.502 } & \text { B.505 } & \text { C.131 } & \text { C.140 } & \text { C.147 } & \text { C.348 } & \text { D.065 } & \text { D.113 } & \text { E.047 }\end{array}$

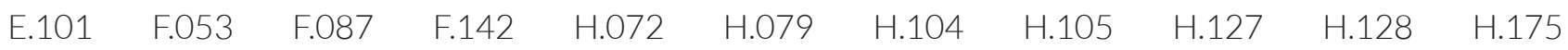

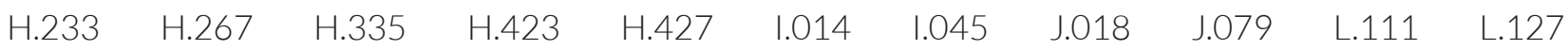

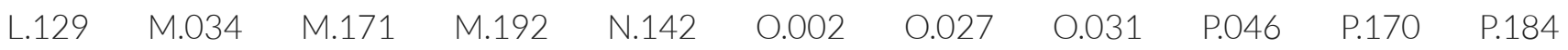
$\begin{array}{lllllllllll}\text { P.194 } & \text { P.267 } & \text { P.312 } & \text { R.304 } & \text { R.344 } & \text { S.037 } & \text { S.128 } & \text { S.144 } & \text { S.234 } & \text { S.240 } & \text { S.241 }\end{array}$ $\begin{array}{lllllllllll}\text { S.286 } & \mathrm{S} .395 & \mathrm{~S} .528 & \mathrm{~S} .529 & \mathrm{~S} .564 & \mathrm{~S} .573 & \mathrm{~S} .602 & \mathrm{~S} .632 & \mathrm{~T} .220 & \mathrm{~T} .313 & \text { W.019 }\end{array}$ $\begin{array}{llllllll}\text { W.041 W.064 W.207 } & \text { W.210 } & \text { W.218 } & \text { W.221 } & \text { W.235 } & \text { W.404 } & \text { W.405 } & \text { W.423 }\end{array}$

$\begin{array}{llllllllll}\text { origin B.436 } & \text { B.437 } & \text { B.446 } & \text { C.101 } & \text { C.102 } & \text { C.103 } & \text { C.124 } & \text { C.138 } & \text { C.149 } & \text { C.223 }\end{array}$ $\begin{array}{lllllllllll}\text { C.308 } & \text { C.453 } & \text { D.032 } & \text { D.113 } & \text { F.001 } & \text { F.076 } & \text { F.107 } & \text { G.002 } & \text { G.206 } & \text { H.023 } & \text { H.069 }\end{array}$ $\begin{array}{lllllllllll}H .122 & H .189 & H .244 & H .268 & H .426 & J .018 & J .065 & J .151 & \text { K.083 } & \text { K.127 } & \text { L.030 }\end{array}$

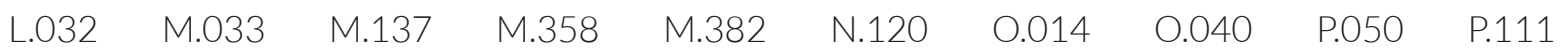

$\begin{array}{lllllllllll}\text { P.121 } & \text { P.316 } & \text { R.173 } & \text { R.174 } & \text { R.191 } & \text { R.227 } & \text { R.297 } & \text { R.298 } & \text { R.352 } & \text { S.001 } & \text { S.120 }\end{array}$

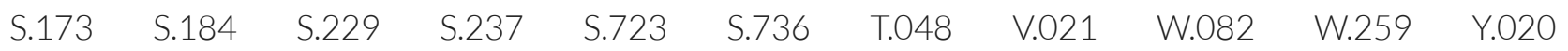

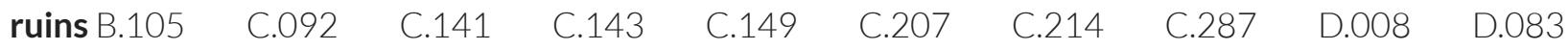

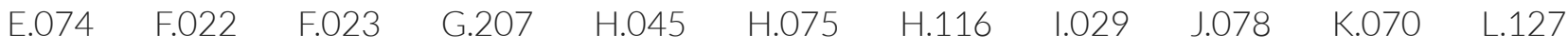

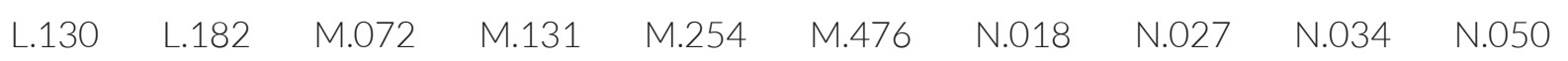

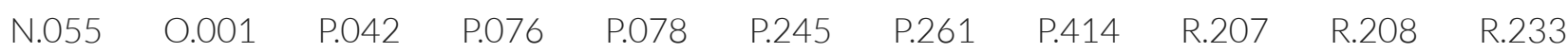

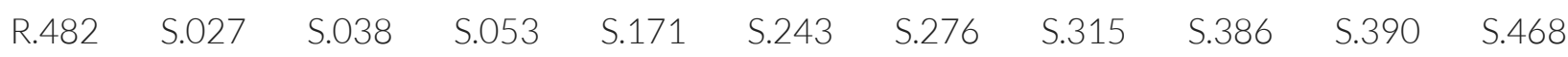

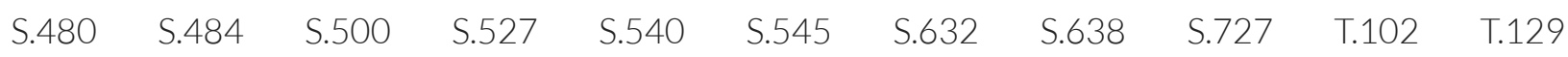

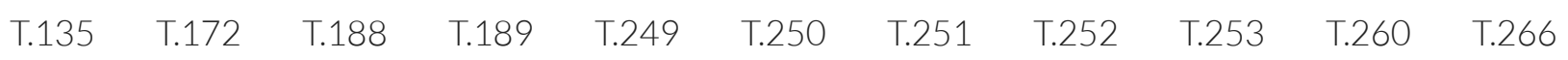

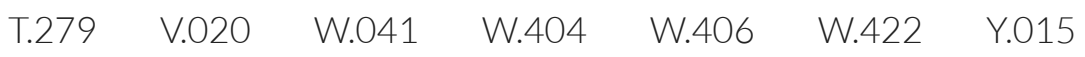

\section{Ammaron M.373}

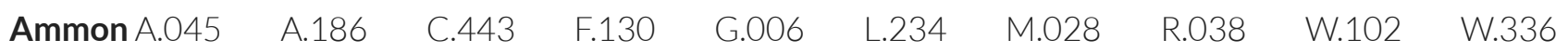




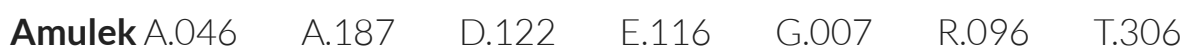

$\begin{array}{lllllllll}\text { anachronisms A.047 } & \text { A.113 } & \text { A.138 } & \text { B.006 } & \text { B.096 } & \text { B.108 } & \text { B.300 } & \text { B.409 } & \text { B.445 }\end{array}$

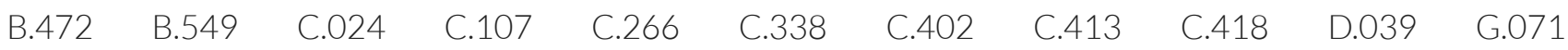

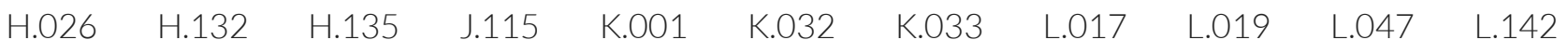

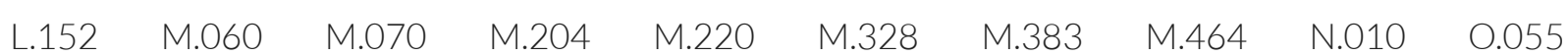

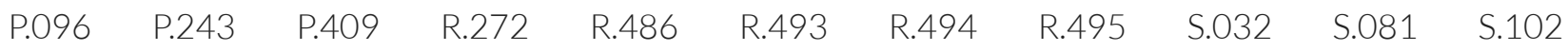

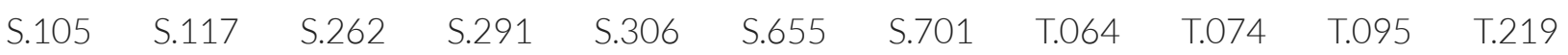

$\begin{array}{llllllllll}\text { T.224 T.299 W.030 W.032 W.033 W.086 W.223 W.270 } & \text { W.401 } & \text { W.440 } & \text { Y.037. }\end{array}$

See also adieu; elephant; horse; iron; King James language; steel

ancient writings in the Americas C.120 $\quad$ C.144 $\quad$ H.076 $\quad$ H.105 $\quad$ H.115 $\quad$ H.126 $\quad$ H.127

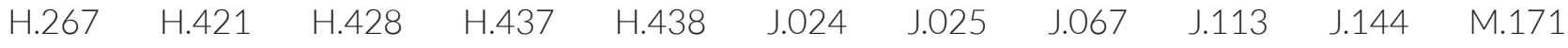

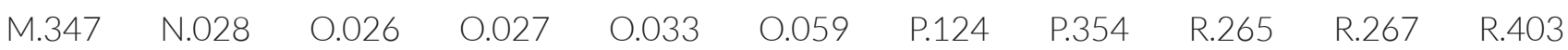

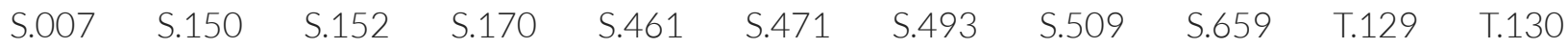

T.220 W.036 W.057 W.082 W.200 W.216 W.415 W.416 Y.017.See also metal

plates; petroglyphs

animals A.038 S.462. See also elephant; horse; mastodon

anteantiosis C.010

$\begin{array}{lllllllll}\text { Anthon transcript A.172 } & \text { B.007 } & \text { B.009 } & \text { C.327 } & \text { C.423 } & \text { C.424 } & \text { C.425 } & \text { F.004 } & \text { G.170 }\end{array}$

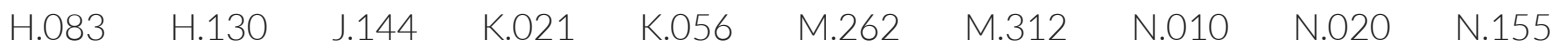

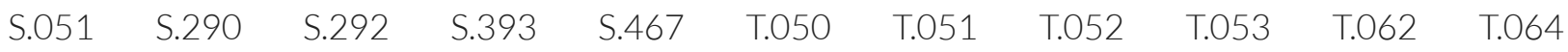

T.269 T.238 W.036 Y.039

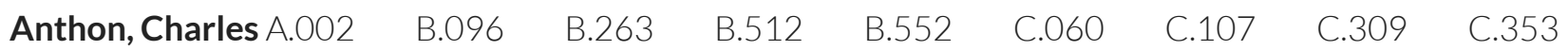

$\begin{array}{lllllllllll}\text { C.423 } & \text { D.028 } & \text { E.001 } & \text { E.107 } & \text { F.004 } & \text { H.393 } & \text { J.165 } & \text { K.057 } & \text { K.058 } & \text { K.059 } & \text { L.044 }\end{array}$

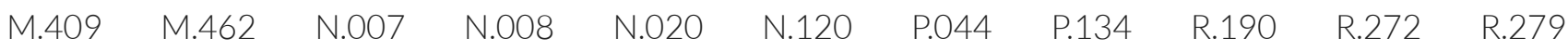

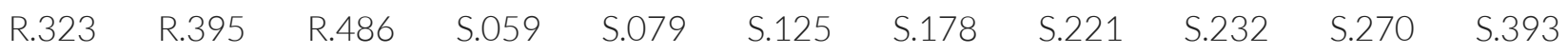

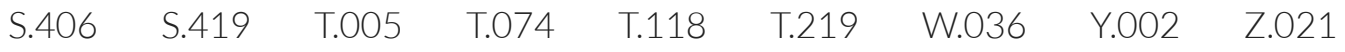

$\begin{array}{lllllllll}\text { anthropology G.165 } & \text { G.166 } & H .245 & H .267 & \text { J.023 } & \text { K.023 } & \text { K.024 } & 0.057 & \text { P.256 }\end{array}$

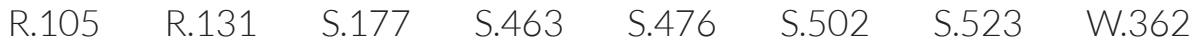

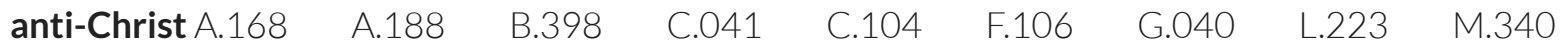

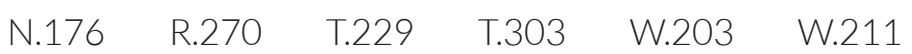

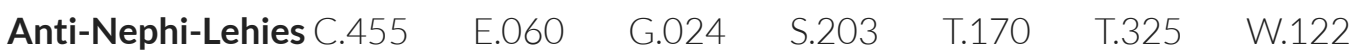

apocryphal writings $A .096$

$\begin{array}{llllllllll}\text { apostasy A.189 } & \text { A.190 } & \text { B.278 } & \text { C.353 } & \text { C.434 } & \text { E.042 } & \text { E.097 } & \text { H.009 } & \text { H.384 } & \text { K.002 }\end{array}$

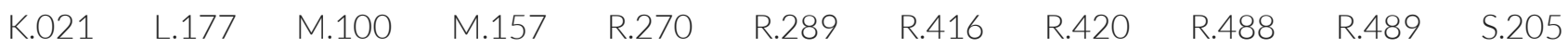

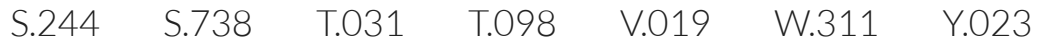




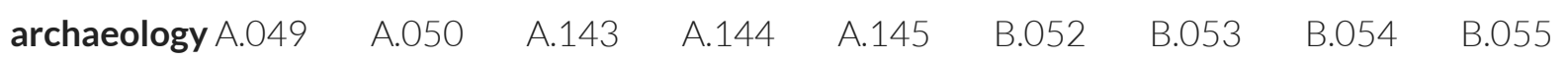
B.103 B.233
B.261
B.317 B.430
B. 438
B. 528
B. 529
B.532
B.551 B.552
C.019 C.100
C.122
C.123
C.124
C.137 C.140
C.143
C.151
C.179
C.191
C.195
C. 200
C.201
C.207
C. 210
C.211 C.213
C.214
C.269
C.313
D.033
D.039 D.070
D.084 D.131
D.145 E.073 E.098
E.109
F.025
F.026 F.051

F.052 F.056 F.150 G.115

G.121

G.129

G.130

G.164 G.165

G.166 G.204

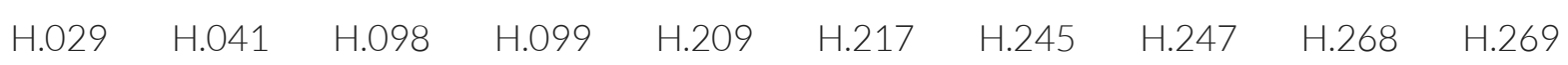

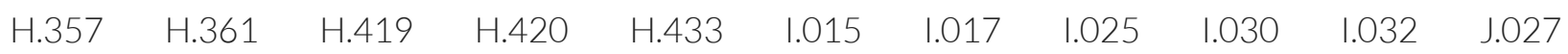

$\begin{array}{llllllllllll}\text { J.030 } & J .031 & J .037 & J .041 & J .044 & J .049 & J .074 & J .078 & K .024 & K .025 & K .067\end{array}$

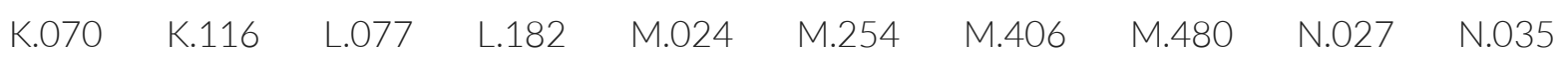

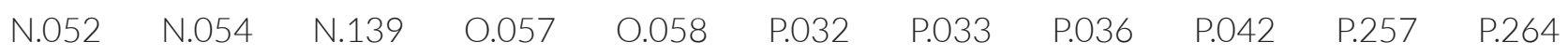

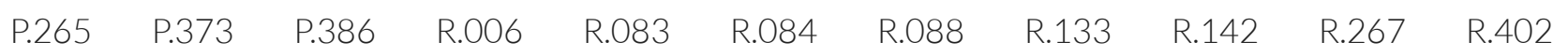

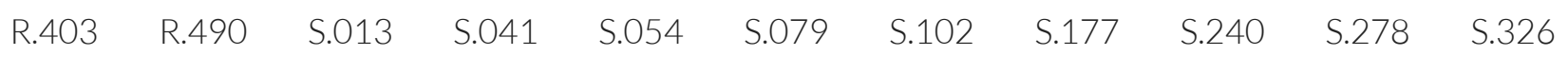

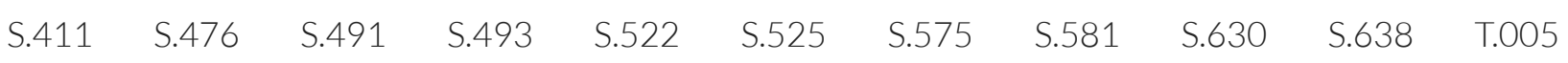

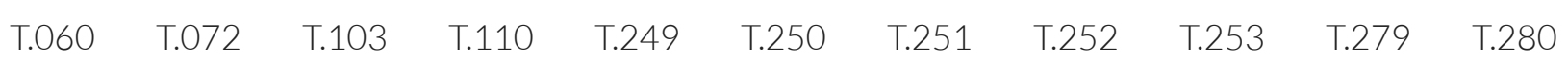

$\begin{array}{llllllllll}T .281 & T .283 & V .020 & V .031 & V .036 & W .064 & W .200 & W .201 & W .204 & W .213\end{array}$

$\begin{array}{lllllll}\text { W.216 W.219 } & \text { W.253 } & \text { W.292 } & \text { W.355 } & \text { W.361 } & \text { W.438 } & \text { Y.015 }\end{array}$

archetypal patterns P.197 S.090

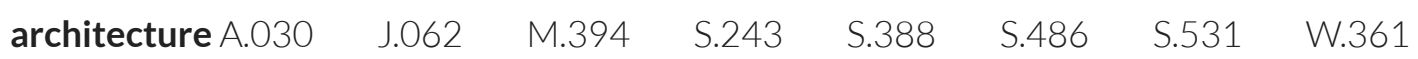

\section{ascension motif $\mathrm{N} .078$}

Assyria C.351 W.393

astrology R.409

Atlantis B.053

$\begin{array}{llllllll}\text { Atonement B.065 } & \text { B.488 } & \text { C.008 } & \text { E.052 } & \text { E.054 } & \text { E.058 } & \text { E.116 } & \text { G.038 }\end{array}$ H.010 $\begin{array}{lllllllll}\text { M.020 M.079 M.082 } & \text { M.088 } & \text { M.105 } & \text { M.121 } & \text { M.153 } & \text { M.33 } & \text { M.336 } & \text { M.338 }\end{array}$

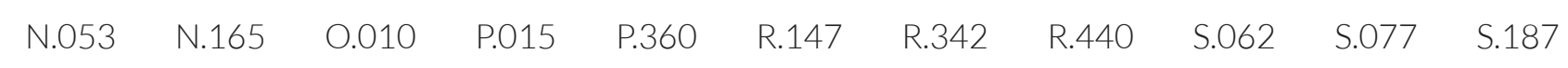
$\begin{array}{lllllllllll}\mathrm{S} .336 & \mathrm{~S} .344 & \mathrm{~S} .378 & \mathrm{~T} .105 & \mathrm{~T} .107 & \mathrm{~T} .147 & \mathrm{~T} .306 & \mathrm{~V} .012 & \mathrm{~V} .046 & \text { W.203 } & \text { W.332 }\end{array}$ W.345

audiocassette tapes C.283 H.183

$\begin{array}{lllllll}\text { authorship of Book of Mormon A.126 } & \text { B.028 } & \text { B.489 } & \text { C.357 } & \text { H.323 } & \text { L.064 } & \text { L.154 }\end{array}$ $\begin{array}{llll}\text { R.061 S.045 W.288 W.289 W.443. See also wordprint } & \text { W. }\end{array}$

divine A.053 B.144 B.290 B.538

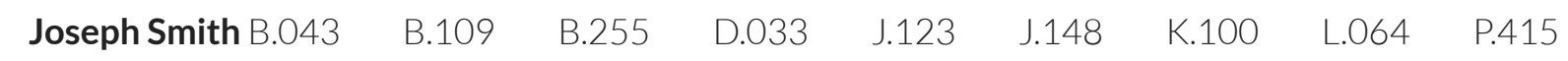
$\begin{array}{lllll}\text { P.416 R.491 } & \text { T.094 } & \text { W.439 } & \text { W.449 }\end{array}$ 
$\begin{array}{llllllllll}\text { multiple A.028 } & \text { A.174 } & \text { A.229 } & \text { B.544 } & \text { B.545 } & \text { H.046 } & \text { H.271 } & \text { H.273 } & \text { H.274 } & \text { H.276 }\end{array}$ $\begin{array}{llllllllll}\text { L.065 } & 0.055 & \text { P.081 } & \text { R.393 } & \text { S.577 } & \text { T.077 } & \text { T.286 } & \text { W.165 } & \text { W.303 } & \text { Y.004 }\end{array}$

Aztec C.356 D.071

Aztec Calendar stone S.235

$\begin{array}{lllllllllll}\text { baptism A.158 } & \text { A.191 } & \text { B.134 } & \text { B.449 } & \text { C.082 } & \text { C.182 } & \text { F.019 } & \text { H.108 } & \text { M.391 } & \text { P.123 } \\ \text { R.146 } & \text { R.319 } & \text { S.053 } & \text { S.187 } & \text { S.328 } & \text { S.359 } & \text { T.106 } & \text { W.245 } & \text { W.420 } & \text { W.423 } & \end{array}$

for the dead E.013 H.108 M.231 M.338 W.309

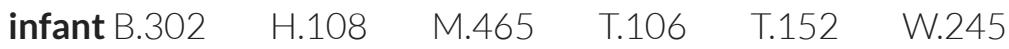

barley R.123 S.546 T.258 T.285

Beit Lei. See Lehi Cave

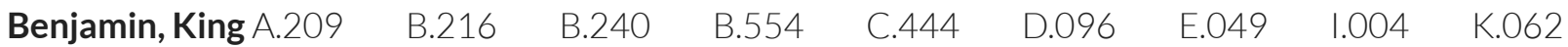

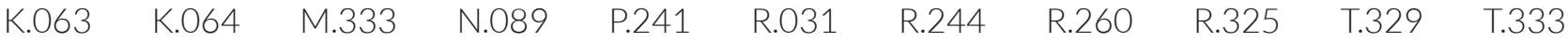
W.105 W.133

Bethlehem M.235 S.341

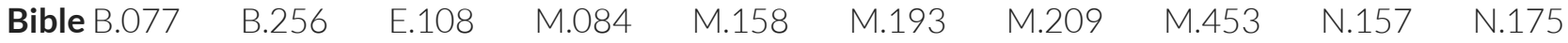

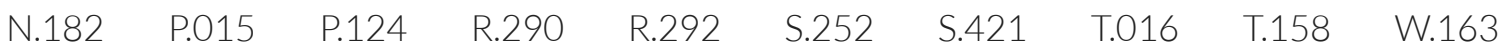

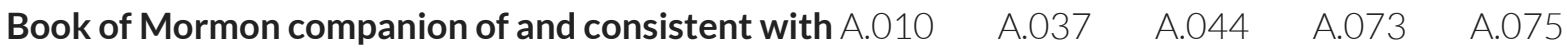
A.114 A.131
A.162
B.064 B.076
B.372
B.476
B. 481
B.482
B. 485
B.531
C.001
C.074
C.075 C.076
C.152 C.231
C. 251
C. 312
C.314 D.013
D.106
D.129
E.013 E.099 F.014
G.159
H.050 H.143
H.225
H.289
J.005

$$
\text { M. }
$$


$\begin{array}{lllllll}\text { loss of plain and precious parts A.015 } & \text { B.299 } & \text { C.056 } & \text { J.159 } & \text { M.183 } & \text { M.328 } & \text { N.130 }\end{array}$

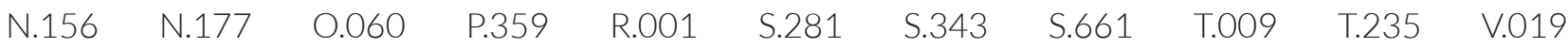
W.149 W.222 W.373

$\begin{array}{lllllll}\text { prophesies of the Book of Mormon B.265 } & \text { B.278 } & \text { B.299 } & \text { B.530 } & \text { C.100 } & \text { C.385 } & \text { C.434 }\end{array}$

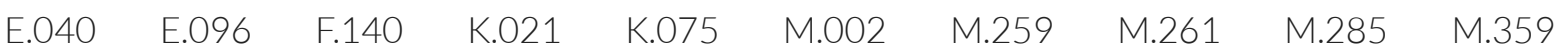

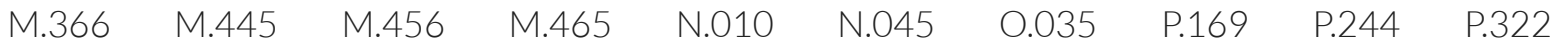

$\begin{array}{lllllllllll}\text { P.348 } & \text { R.177 } & \text { R.185 } & \text { R.192 } & \text { R.198 } & \text { R.212 } & \text { R.489 } & \text { S.224 } & \text { S.287 } & \text { S.352 } & \text { S.360 }\end{array}$

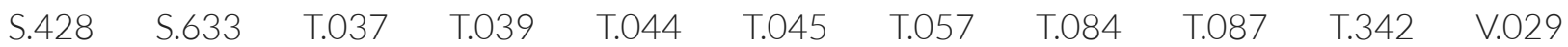

$\begin{array}{llllllll}\text { W.200 W.201 } & \text { W.251 } & \text { W.291 } & \text { W.294 } & \text { W.353 } & \text { W.403 } & \text { W.425 } & \text { Y.030 }\end{array}$

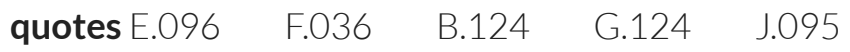

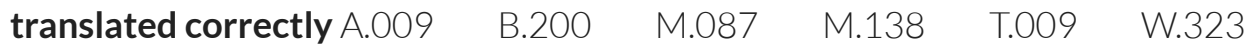

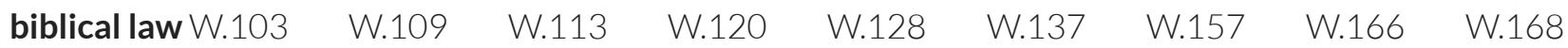

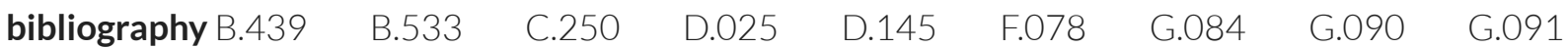

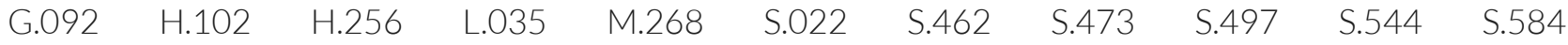

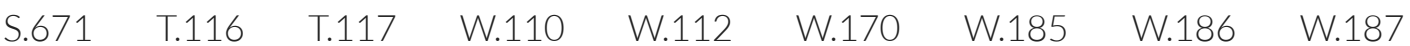

blood vengeance R.019

boasting $A .176$

$\begin{array}{llllllll}\text { Book of Mormon studies A.136 } & \text { A.160 } & \text { B.063 } & \text { B.111 } & \text { B.237 } & \text { B.398 } & \text { B.426 } & \text { B.572 }\end{array}$

$\begin{array}{lllllllllll}\text { C.096 } & \text { C.097 } & \text { C.127 } & \text { C.152 } & \text { C.183 } & \text { C.201 } & \text { G.063 } & \text { G.065 } & \text { G.159 } & \text { G.164 } & \\ \text { G.165 } & \text { G.168 } & \text { H.033 } & \text { H.177 } & \text { H.196 } & \text { H.216 } & \text { J.035 } & \text { K.097 } & \text { K.116 } & \text { K.119 } & \text { L.236 } \\ \text { M.295 } & \text { N.035 } & \text { N.069 } & \text { N.104 } & \text { N.186 } & \text { N.187 } & \text { N.188 } & \text { N.189 } & \text { N.190 } & \text { N.191 } & \\ \text { N.192 } & \text { R.031 } & \text { R.245 } & \text { R.262 } & \text { R.263 } & \text { R.264 } & \text { R.371 } & \text { S.168 } & \text { S.294 } & \text { S.548 } & \text { S.582 } \\ \text { S.630 } & \text { S.643 } & \text { S.726 } & \text { T.170 } & \text { V.044 } & \text { W.151 } & \text { W.162 } & \text { W.180 } & \text { W.192 } & & \end{array}$

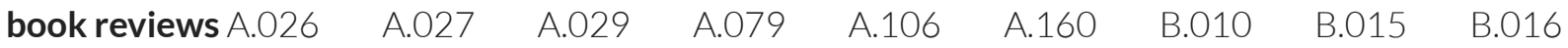

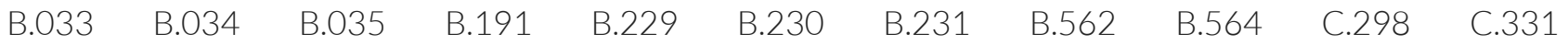

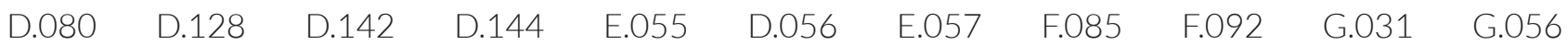

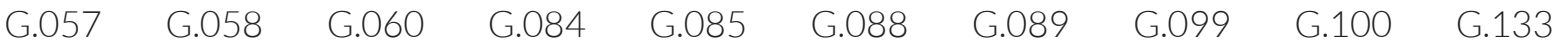

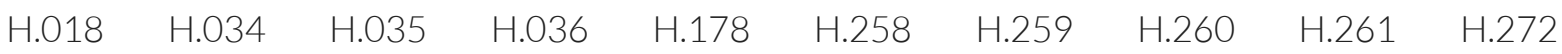

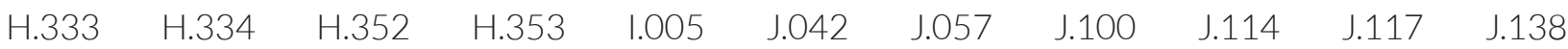

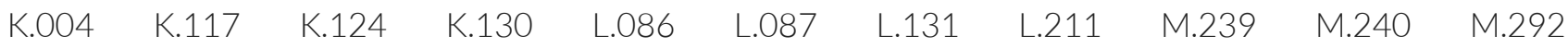

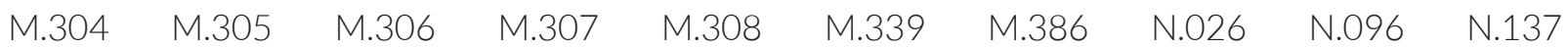

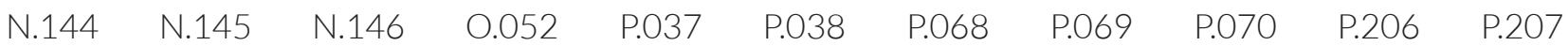

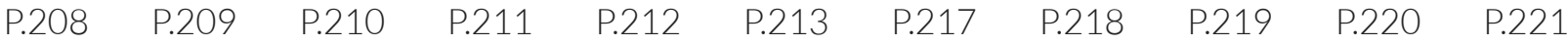

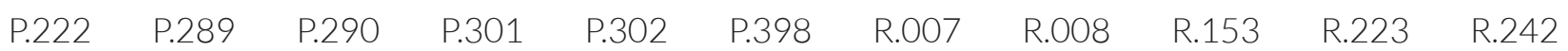

$\begin{array}{lllllllllll}\text { R.243 } & \text { R.257 } & \text { R.258 } & \text { R.259 } & \text { R.418 } & \text { R.419 } & \text { R.468 } & \text { R.469 } & \text { R.470 } & \text { R.471 } & \text { R.496 }\end{array}$

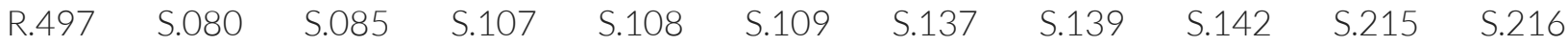

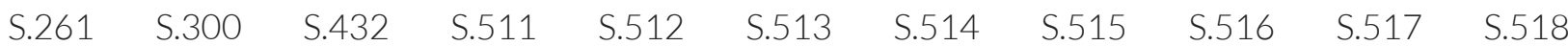

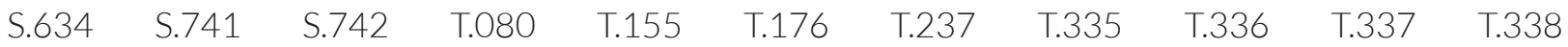


$\begin{array}{llllllll}\text { T.339 T.340 U.014 V.045 W.001 W.014 W.058 W.059 W.060 } & \text { W.061 }\end{array}$

$\begin{array}{llllllll}\text { W.062 W.096 W.152 } & \text { W.153 } & \text { W.154 } & \text { W.155 } & \text { W.156 } & \text { W.226 } & \text { W.286 } & \text { W.341 }\end{array}$

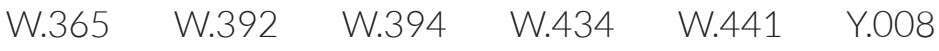

Boudinot, Elias (A Star in the West) J.156 K.083

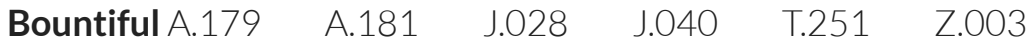

bow G.111 H.031 T.158 W.010

$\begin{array}{lllllllll}\text { brass plates B.187 } & \text { B.204 } & \text { B.414 } & \text { B.453 } & \text { B.454 } & \text { B.466 } & \text { B.535 } & \text { C.168 } & \text { C.426 }\end{array}$

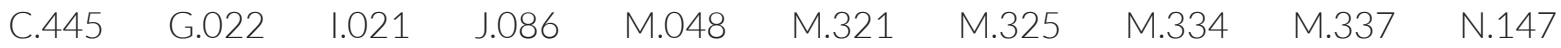

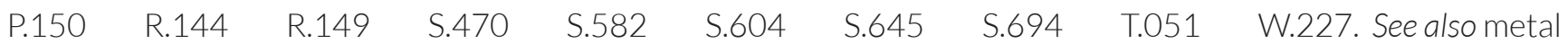

plates

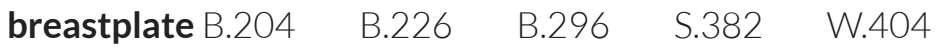

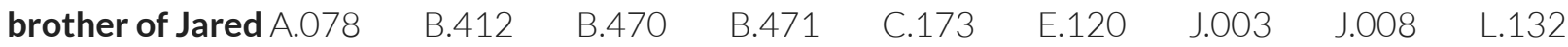

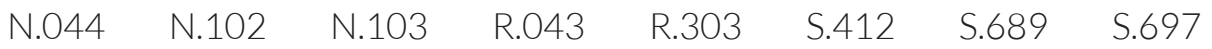

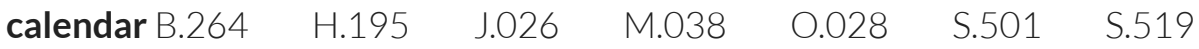

calling and election $\mathrm{S} .206$

Calvinism B.516 C.024

Campbell, Alexander K.095 N.085 S.550 W.203

Campbell, Joseph C.104

canon, open W.182

cantata. See songs

$\begin{array}{lllllll}\text { cardinal directions H.032 } & \text { L.123 } & \text { L.124 } & \text { S.487 } & \text { T.233 } & \text { W.395 } & \text { Z.008 }\end{array}$

Cave of Khirbet Beit Lei. See Lehi Cave

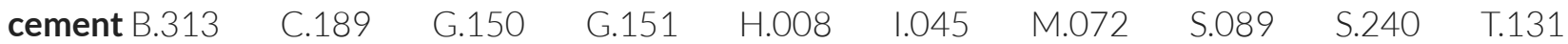
T.135 W.190 W.251 W.391

changes in the Book of Mormon text. See textual variants

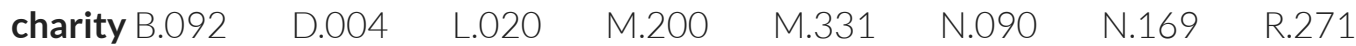

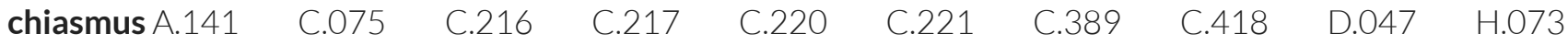

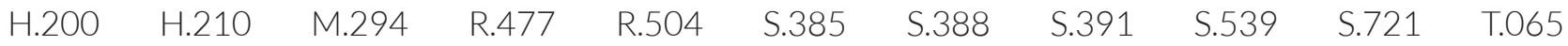




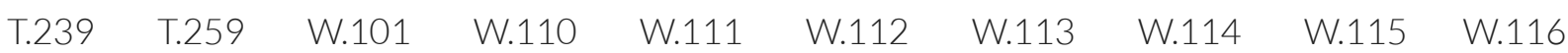
W.117 W.118 W.142 W.163. See also Hebraisms

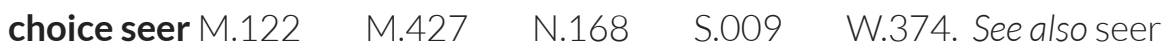

Christ

baptism of A.198 M.162

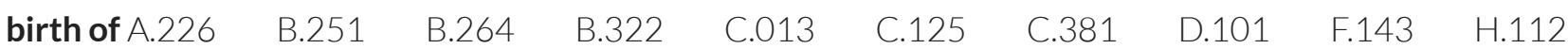

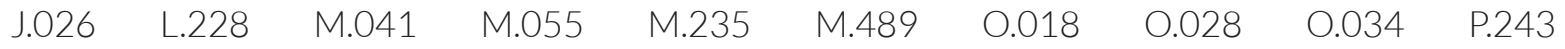

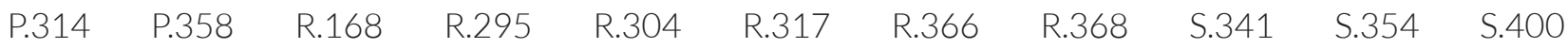

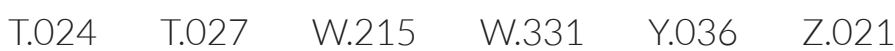

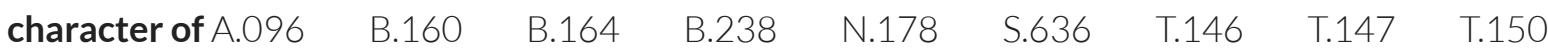

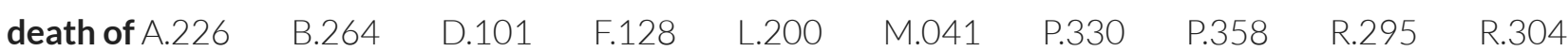

T.024 W.331 Z.021

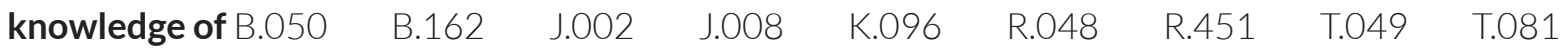
$\begin{array}{lllll}\text { T.230 W.023 W.106 W.130 W.235 W.430 } & \text { W. W. }\end{array}$

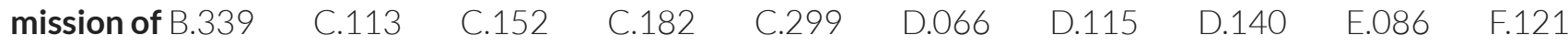

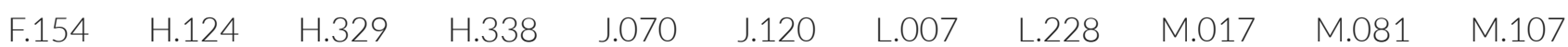

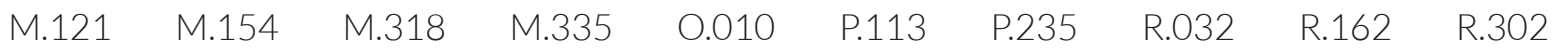
$\begin{array}{lllllllllll}\text { R.303 } & \text { R.328 } & \text { R.330 } & \text { R.342 } & \text { R.362 } & \text { S.009 } & \text { S.344 } & \text { S.378 } & \text { S.636 } & \text { S.734 } & \text { T.030 }\end{array}$ $\begin{array}{llll}\text { T.078 } & \text { T.132 } & \text { W.330 } & \text { W.343 }\end{array}$

$\begin{array}{llllllllll}\text { name of B.237 } & \text { B.238 } & \text { B.242 } & \text { B.300 } & \text { B.411 } & \text { C.113 } & \text { L.164 } & \text { M.081 } & \text { N.023 } & \text { P.224 }\end{array}$ $\begin{array}{llll}\text { T.092 W.023 W.165 W.181 W.238 } & \text { W. }\end{array}$

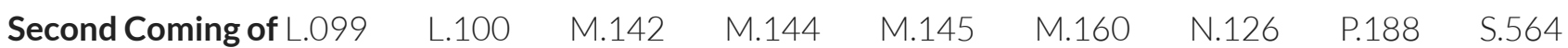

$\begin{array}{lllllllll}\text { teachings of A.169 } & \text { A.191 } & \text { B.089 } & \text { B.091 } & \text { B.093 } & \text { B.163 } & \text { B.468 } & \text { C.008 } & \text { C.056 }\end{array}$

$\begin{array}{lllllllllll}\text { C.254 } & \text { C.293 } & \text { C.310 } & \text { C.417 } & \text { D.003 } & \text { D.066 } & \text { D.115 } & \text { F.019 } & \text { F.121 } & \text { H.020 } & \text { H.046 }\end{array}$

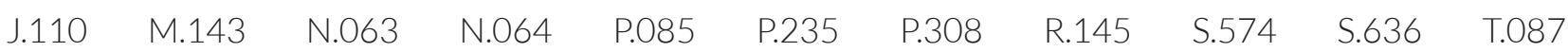
$\begin{array}{lllll}\text { T.278 W.106 } & \text { W.141 } & \text { W.149 } & \text { W.197 } & \text { W.237 }\end{array}$

See also Christ's appearance in America; testify of Jesus Christ

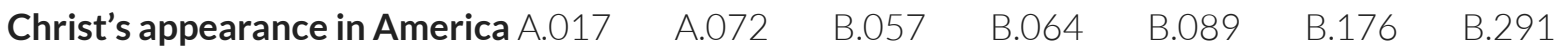

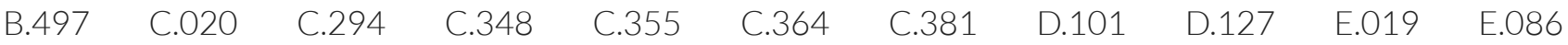

$\begin{array}{lllllllllll}\text { F.019 F.028 } & \text { F.142 } & \text { G.168 } & \text { H.075 } & \text { H.079 } & \text { H.423 } & \text { J.104 } & \text { K.049 } & \text { M.023 } & \text { M.055 }\end{array}$

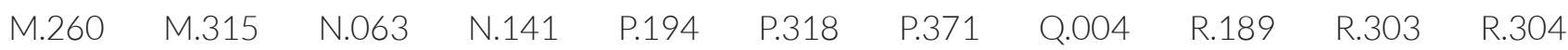

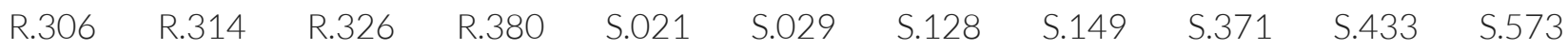

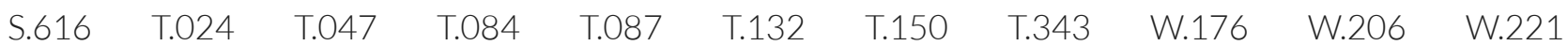
W.390 
$\begin{array}{lllllllll}\text { chronology B.219 } & \text { B.311 } & \text { B.312 } & \text { B.356 } & \text { B.497 } & \text { B.507 } & \text { B.522 } & \text { C.003 } & \text { C.166 }\end{array}$

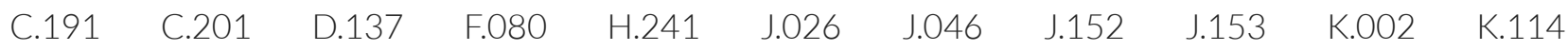

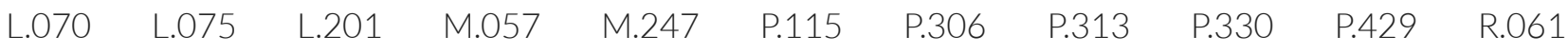

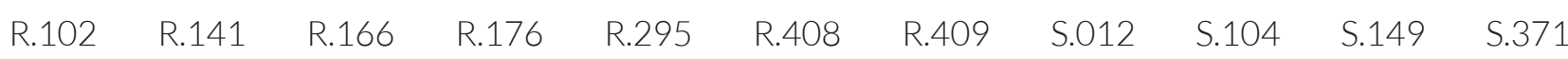

$\begin{array}{lllllllllll}\text { S.397 } & S .472 & S .501 & S .504 & S .538 & S .579 & T .054 & T .247 & \text { T.266 } & \text { T.343 } & \text { V.013 }\end{array}$

$\begin{array}{llllllll}\text { V.014 W.008 W.065 W.068 W.074 W.176 W.256 W.380 } & \text { W.421 }\end{array}$

\section{Civil War B.150}

Clement S.427

climactic forms P.062. See also hebraisms

codex $\mathrm{S} .467 \quad \mathrm{~S} .494$

colophons T.319 T.320

$\begin{array}{lllllllll}\text { Columbus C.225 } & \text { C.355 } & \text { E.113 } & \text { F.079 } & \text { G.037 } & \text { H.089 } & \text { H.2O3 } & \text { H.204 } & \text { H.295 }\end{array}$

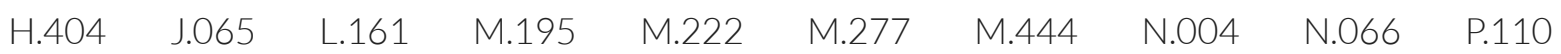

P.194 R.059 $\quad \mathrm{S.457} \quad \mathrm{T} .083 \quad \mathrm{Y} .016$

$\begin{array}{llllll}\text { “come unto Christ” B.154 F.020 } & \text { H.187 } & \text { H.325 } & \text { R.147 } & \text { T.263 }\end{array}$

$\begin{array}{lllllll}\text { coming forth of the Book of Mormon A.031 } & \text { A.055 } & \text { A.094 } & \text { A.117 } & \text { A.119 } & \text { A.163 } & \text { B.011 }\end{array}$
B.104
B.135 B.137
B.196
B.197
B.199
B.202
B.226
B.265
B.287 B.290
B.291 B.424
B.467
B.537 B.568 C.014
C.015 C.052
C.078
C.081 C.087
C.134 C.154
C.295 C.324
C.325
C.368
C.373
C.379
C.382
C.451 D.026
D.028 D.057
D.111
E.008 E.081
E.082
E.089
E.090
E.091 E.093 F.036

$\begin{array}{lllllllllll}\text { F.040 } & \text { F.058 } & \text { F.084 } & \text { F.087 } & \text { F.122 } & \text { F.144 } & \text { F.145 } & \text { G.097 } & \text { G.101 } & \text { G.102 } & \text { G.114 }\end{array}$

$\begin{array}{llllllllll}\text { G.117 } & \text { G.142 } & \text { G.142 } & \text { H.002 } & \text { H.006 } & \text { H.252 } & \text { H.257 } & \text { H.293 } & \text { H.358 } & \text { H.382 }\end{array}$

\begin{tabular}{lllllllllll}
\hline .022 & $J .052$ & $J .081$ & $J .090$ & $J .103$ & $J .130$ & $J .143$ & $K .021$ & $K .082$ & $K .095$ & $K .097$
\end{tabular}

$\begin{array}{lllllllll}\text { L.049 L.150 } & \text { L.177 } & \text { M.008 } & \text { M.245 } & \text { M.297 } & \text { M.299 } & \text { M.315 } & \text { M.345 } & \text { M.357 }\end{array}$

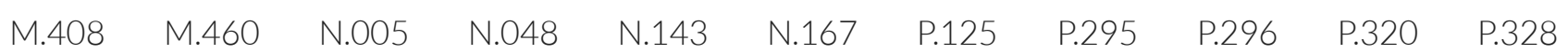

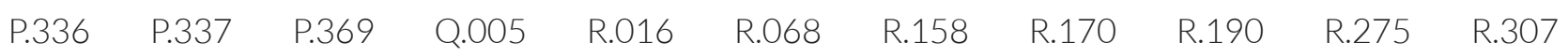

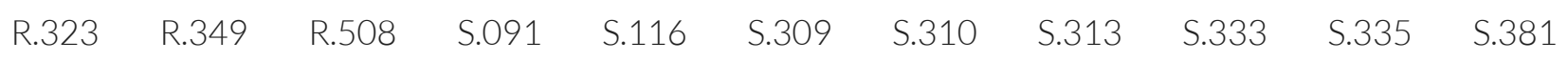

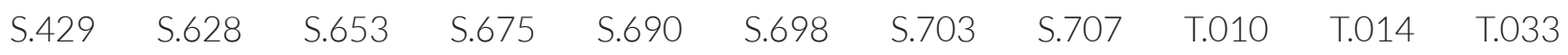

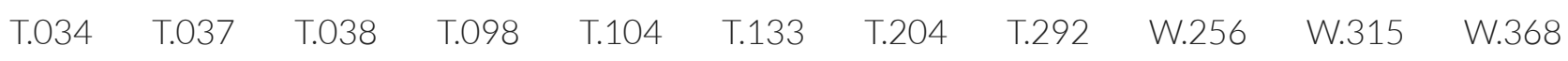

W.452 Y.010

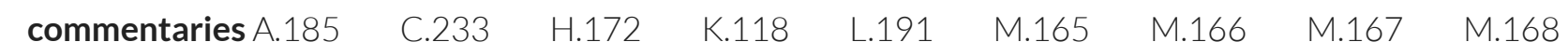
$\begin{array}{lllll}\text { P.225 R.141 } & \text { R.212 } & \text { S.166 } & \text { S.219 } & \text { S.580 }\end{array}$

\section{Communism B.170}

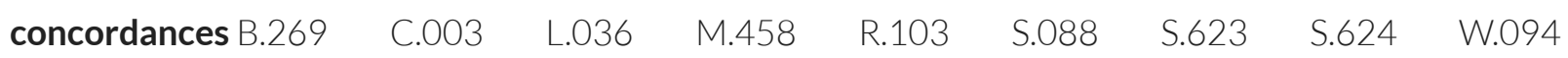


$\begin{array}{lllllllll}\text { conversion stories A.177 } & \text { A.192 } & \text { B.027 } & \text { B.040 } & \text { B.069 } & \text { B.074 } & \text { B.112 } & \text { B.232 } & \text { B.243 }\end{array}$

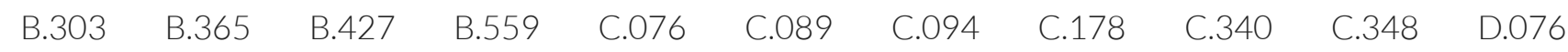

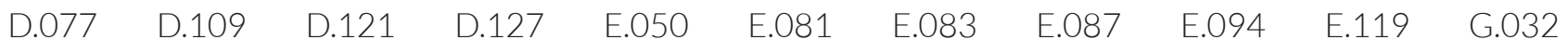

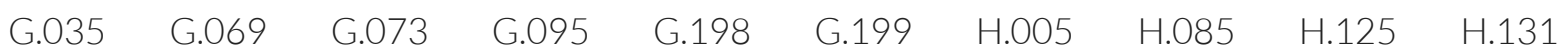

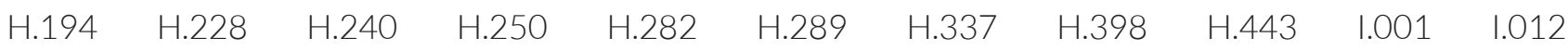

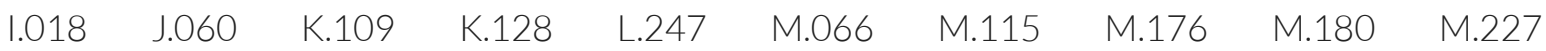

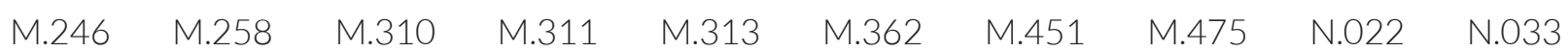

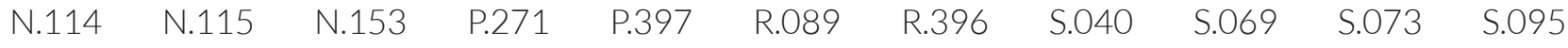

$\begin{array}{lllllllllll}\mathrm{S} .160 & \mathrm{~S} .167 & \mathrm{~S} .233 & \mathrm{~S} .267 & \mathrm{~S} .384 & \mathrm{~S} .571 & \mathrm{~S} .621 & \mathrm{~S} .627 & \mathrm{~S} .684 & \mathrm{~S} .687 & \mathrm{~S} .699\end{array}$

$\begin{array}{lllllllllll}\text { T.002 } & \text { T.003 } & \text { T.097 } & \text { T.205 } & \text { T.296 } & \text { V.005 } & \text { V.006 } & \text { W.081 } & \text { W.085 } & \text { W.099 } & \text { W.100 }\end{array}$ $\begin{array}{lllll}\text { W.228 W.250 W.349 W.402 } & \text { W.424 } & \text { Z.010 }\end{array}$

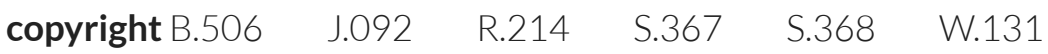

Corianton I.048 M.372 R.308 R.309

Coriantumr $\mathrm{S} .416$

costumes B.475 T.300

cotton D.006 T.300 W.391

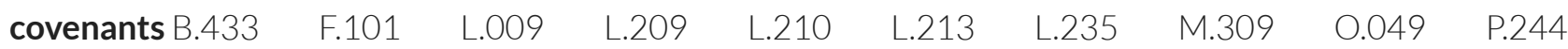

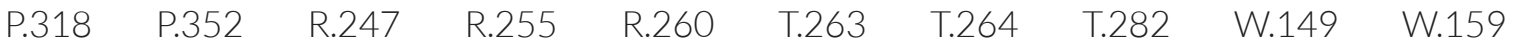

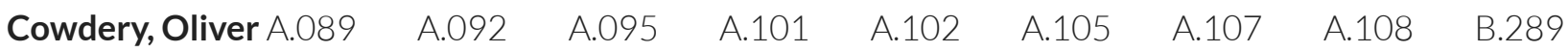

$\begin{array}{lllllllllll}\text { C.368 } & \text { C.369 } & \text { D.078 } & \text { G.144 } & \text { G.202 } & \text { G.203 } & \text { H.013 } & \text { H.359 } & \text { J.122 } & \text { L.112 } & \text { M.454 }\end{array}$

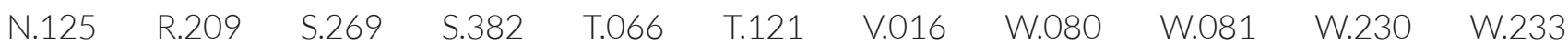

W.234 W.258 Y.011 Y.013

creation G.038 G.105 R.382 T.130

critical text F.002 S.208 S.212 S.217. See also textual variants

critics of the Book of Mormon

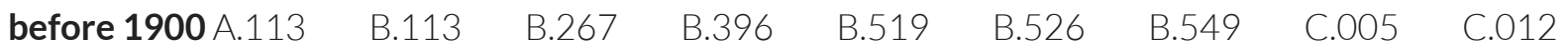

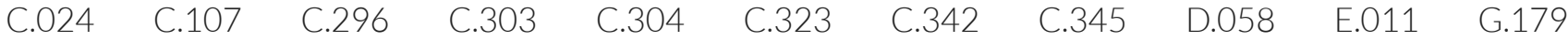

$\begin{array}{llllllllllll}\text { G.206 } & H .019 & H .190 & H .281 & \text { J.115 } & \text { J.137 } & \text { J.139 } & \text { K.026 } & \text { L.017 } & \text { L.153 } & \text { L.183 }\end{array}$

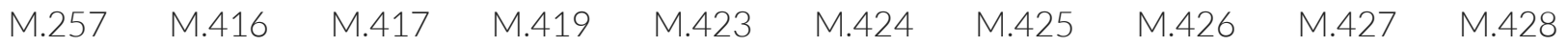

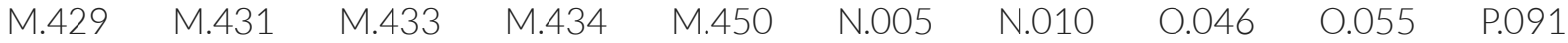

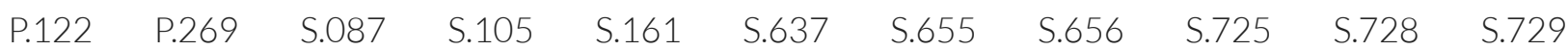

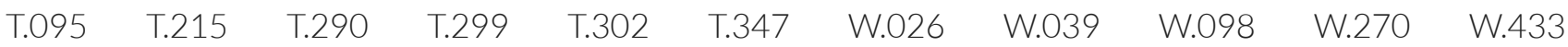

W.435 W.455

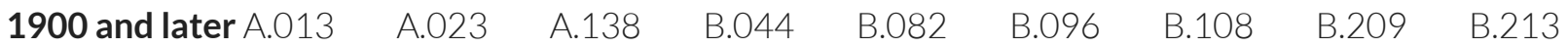

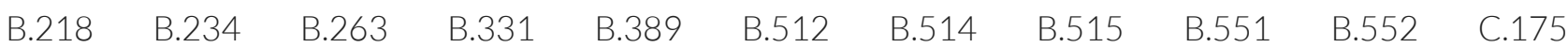


$\begin{array}{llllllllll}\text { C.285 } & \text { C.322 } & \text { C.341 } & \text { C.354 } & \text { C.398 } & \text { C.411 } & \text { C.412 } & \text { D.019 } & \text { D.039 } & \text { D.040 }\end{array}$

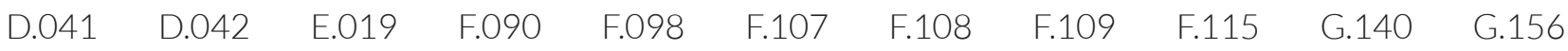

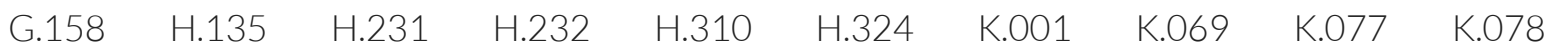

$\begin{array}{lllllllll}\text { K.123 L.018 } & \text { L.048 } & \text { L.141 } & \text { M.069 } & \text { M.184 } & \text { M.228 } & \text { M.231 } & \text { M.355 } & \text { M.439 }\end{array}$

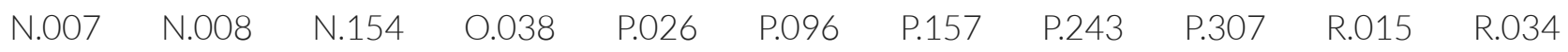

$\begin{array}{lllllllllll}R .087 & R .272 & R .277 & R .401 & R .484 & R .485 & R .486 & R .487 & S .032 & S .058 & S .081\end{array}$

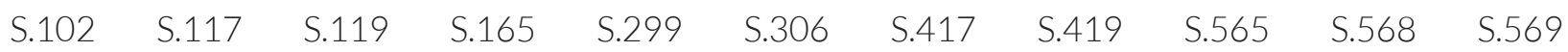

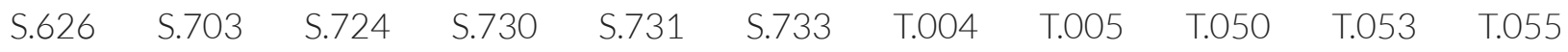

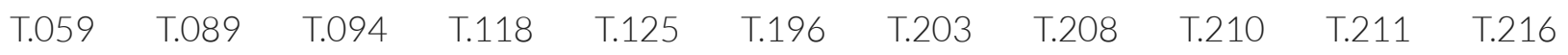

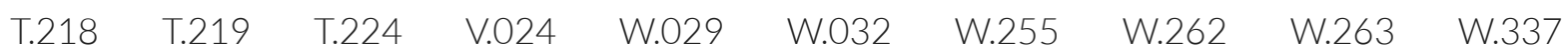

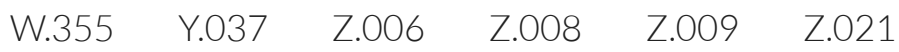

darkness F.128 P.343 S.365

Davidson, Matilda P.377 R.128. See also Spaulding Manuscript

$\begin{array}{lllllllll}\text { Dead Sea Scrolls C.421 } & \text { H.027 } & J .138 & \text { M.093 } & \text { M.112 } & \text { N.051 } & \text { N.098 } & \text { N.099 } & \text { T.072 }\end{array}$ T.277

death $\mathrm{S} .606$

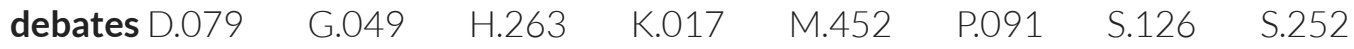

deception avoiding B.149 $\quad$ B.181

Del Rio B.457

$\begin{array}{lllllllll}\text { destruction B.020 } & \text { B.048 } & \text { B.065 } & \text { B.317 } & \text { C.061 } & \text { C.352 } & \text { C.435 } & \text { J.048 } & \text { L.067 }\end{array}$

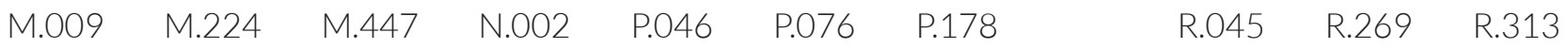

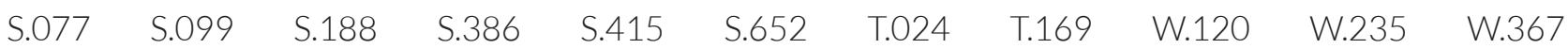

Deuteronomy R.247

discipleship M.125

dispensations $\mathrm{H} .424$

divorce C.106

$\begin{array}{lllllllll}\text { doctrinal change A.025 } & \text { C.228 } & \text { D.041 } & \text { D.067 } & \text { D.068 } & \text { E.111 } & \text { F.059 } & \text { J.163 } & \text { K.110 }\end{array}$

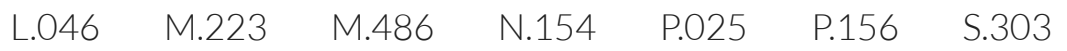

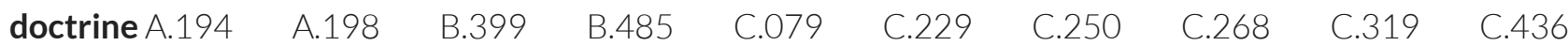

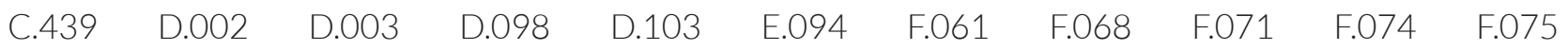

$\begin{array}{llllllllllll}\text { F.146 H.017 } & H .049 & H .309 & H .318 & \text { H.384 } & \text { J.070 } & \text { L.051 } & \text { L.163 } & \text { M.084 } & \text { M.157 }\end{array}$

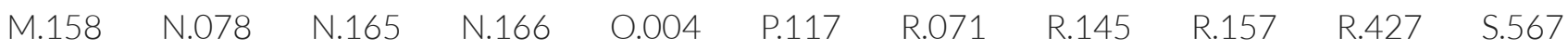

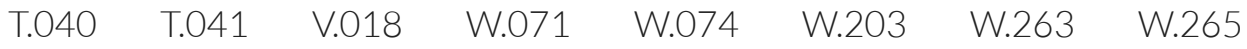


taught in the Book of Mormon differs from the LDS Church D.086 $\quad$ T.204 $\quad$ W.375 W.388

of universal salvation $\vee .039$

$\begin{array}{llllll}\text { use of the Book of Mormon in early LDS doctrine U.004 U.005 U.007 } & \text { U.008 } & \text { V.040 } & \text { V.046 }\end{array}$

$\begin{array}{llllllll}\text { Doctrine and Covenants E.018 } & \text { H.406 } & \text { N.165 } & \text { S.439 } & \text { W.320 } & \text { W.373 } & \text { W.375 } & \text { W.417 }\end{array}$

$\begin{array}{lllllllll}\text { Dogberry, Obediah B.382 } & \text { C.064 } & \text { G.114 } & \text { K.095 } & \text { K.107 } & \text { L.136 } & \text { M.197 } & \text { R.164 } & \text { S.658 }\end{array}$

$\begin{array}{llllllllll}\text { drama D.045 } & \text { D.116 } & \text { E.040 } & \text { G.047 } & \text { G.080 } & \text { G.132 } & \text { H.001 } & \text { K.030 } & \text { L.067 } & \text { L.143 }\end{array}$

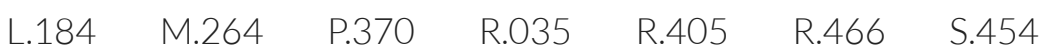

economic systems R.421 S.500

editions of the Book of Mormon B.256 $\begin{array}{llllll}\text { B.286 } & \text { B.297 } & \text { B.315 } & \text { B.359 } & \text { B.419 } & \text { B.509 }\end{array}$

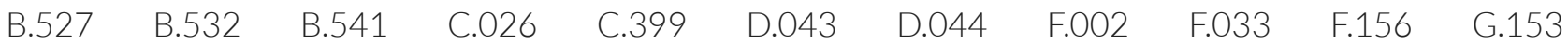

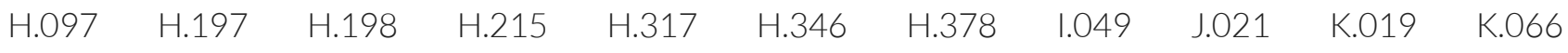

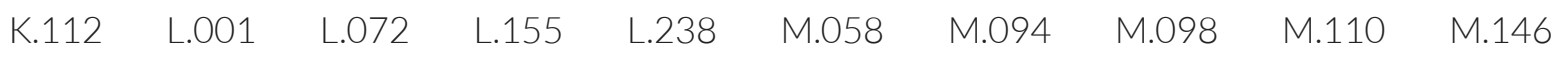

$\begin{array}{llllllllll}\text { M.453 N.031 } & \text { N.042 } & \text { P.020 } & \text { P.021 } & \text { P.022 } & \text { P.361 } & \text { P.368 } & \text { R.040 } & \text { R.109 } & \text { R.215 }\end{array}$

$\begin{array}{lllllllllll}\text { S.011 } & \mathrm{S} .056 & \mathrm{~S} .110 & \mathrm{~S} .209 & \mathrm{~S} .256 & \mathrm{~S} .394 & \mathrm{~S} .455 & \mathrm{~S} .671 & \mathrm{~S} .673 & \mathrm{~T} .059 & \mathrm{~T} .288\end{array}$

$\begin{array}{llll}\text { T.324 W.047 W.284 W.413 Z.012 Z.017. See also translation from English } & \text { W. }\end{array}$

LDS and RLDS cross reference W.046

$\begin{array}{llllllllll}\text { RLDS B.284 } & \text { B.373 } & \text { B.539 } & \text { B.558 } & \text { H.206 } & \text { H.211 } & \text { H.218 } & \text { H.22O } & \text { H.221 } & \text { H.222 }\end{array}$

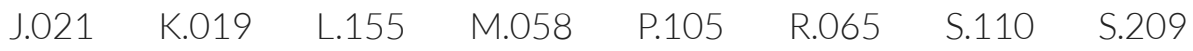

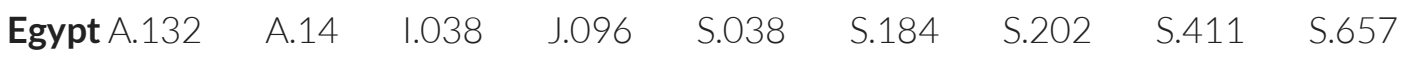

\section{Egyptian}

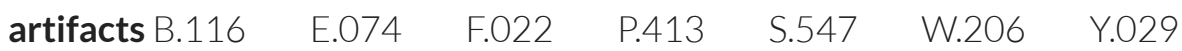

$\begin{array}{llllllllll}\text { language A.172 } & \text { A.174 } & \text { B.053 } & \text { B.055 } & \text { B.075 } & \text { B.211 } & \text { B.450 } & \text { B.453 } & \text { B.463 } & \text { B.466 }\end{array}$

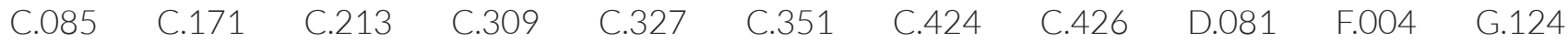

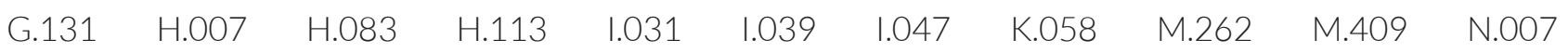

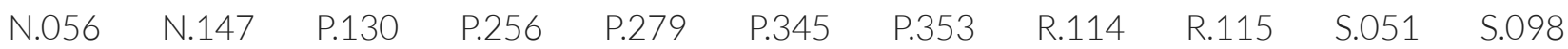

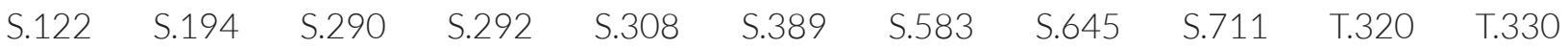

$\begin{array}{lllllll}\text { T.331 W.004 W.086 W.087 W.088 W.303 W.390 Z.021 } & \text { W. }\end{array}$

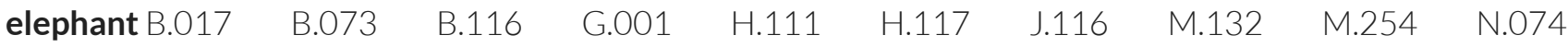

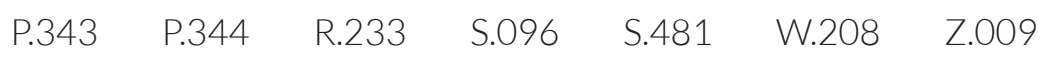

Elijah F.014

encyclopedia B.222 
$\begin{array}{llll}\text { endless punishment B.005 } & \text { B.245 } & \text { P.228 } & \text { S.099 }\end{array}$

Enoch L.122

$\begin{array}{llllllll}\text { Enos A.200 } & \text { E.061 } & \text { E.062 } & \text { E.063 } & \text { J.131 } & \text { M.021 } & \text { R.117 } & \text { S.609 }\end{array}$

Enos, book of A.154 A.199 L.056 L.126 $\quad$ S.075

epanalepsis C.172

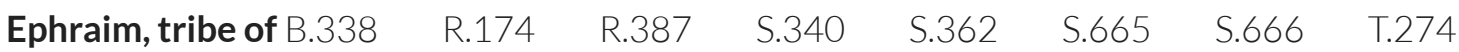

eternal life R.047 R.146

eternal torment B.005

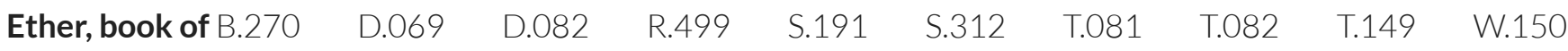

everlasting B.245

everlasting covenant $\mathrm{S} .642$

evolution P.019 P.200 S.357

exaltation C.319

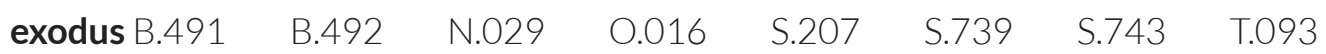

evidences of the Book of Mormon

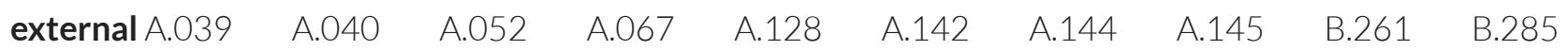

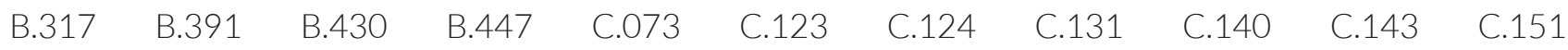

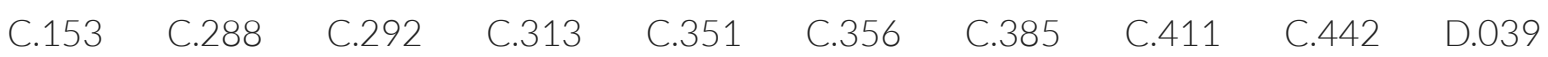

$\begin{array}{llllllllll}\text { D.083 D.145 } & \text { E.027 } & \text { E.074 } & \text { E.075 } & \text { E.098 } & \text { E.112 } & \text { F.119 } & \text { G.121 } & \text { G.152 } & \text { H.041 }\end{array}$

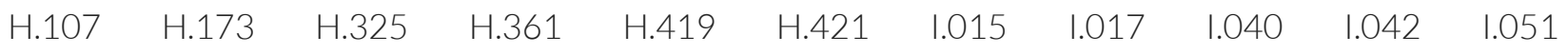

$\begin{array}{llllllllll}K .002 & K .013 & \text { K.067 } & \text { K.073 } & \text { L.092 } & \text { L.109 } & \text { L.182 } & \text { M.261 } & \text { M.298 } & \text { M.403 }\end{array}$

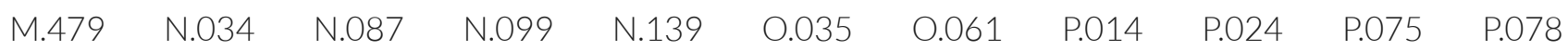

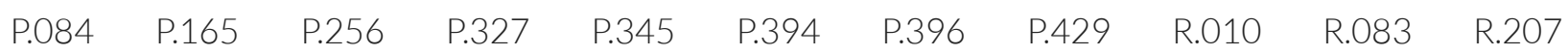

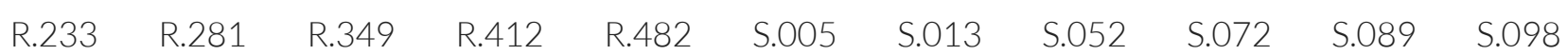

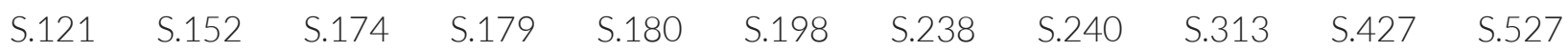

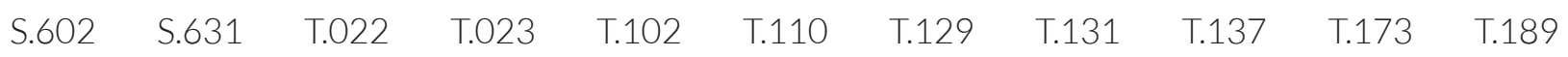

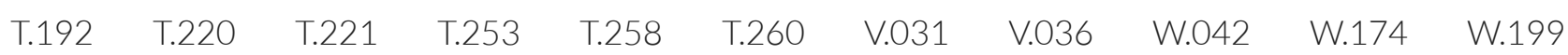

$\begin{array}{llllllll}\text { W.202 W.204 W.217 } & \text { W.221 } & \text { W.235 } & \text { W.248 } & \text { W.292 } & \text { W.295 } & \text { W.303 } & \text { W.304 }\end{array}$

W.310 W.431 W.438 Y.038

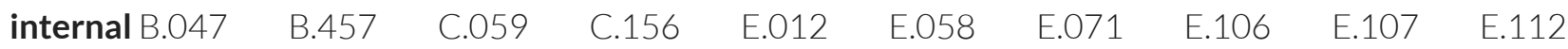
$\begin{array}{llllllllllll}\text { G.147 } & \text { G.164 } & \text { G.175 } & \text { H.107 } & \text { H.422 } & \text { I.051 } & \text { J.076 } & \text { K.037 } & \text { K.067 } & \text { M.004 } & \text { M.293 }\end{array}$ 


$\begin{array}{lllllllllll}\text { M.443 } & \text { M.462 } & \text { N.087 } & \text { N.108 } & \text { O.003 } & \text { O.035 } & 0.061 & \text { P.171 } & \text { P.341 } & \text { R.010 } & \\ \text { R.017 } & \text { R.110 } & \text { R.111 } & \text { R.171 } & \text { R.349 } & \text { R.398 } & \text { R.477 } & \text { S.174 } & \text { S.199 } & \text { S.284 } & \text { S.295 } \\ \text { T.045 } & \text { T.173 } & \text { V.036 } & \text { W.195 } & \text { W.222 } & \text { W.248 } & \text { W.296 } & \text { W.369 } & & & \end{array}$

Ezekiel 17 S.528
Ezekiel 37 A.069
A.074
B.446
C.253 G.200
H.408
K.005
M.172 M.288
N.100 N.182
P.362
R.175
R.200
S.157
S.299
S.362
T.036 T.044

Ezias T.180

Fabius G.178

facsimiles $M .487$

$\begin{array}{llllllllll}\text { faith B.088 } & \text { B.092 } & \text { B.134 } & \text { B.357 } & \text { D.106 } & \text { G.211 } & \text { H.064 } & \text { H.085 } & \text { K.038 } & \text { K.060 }\end{array}$

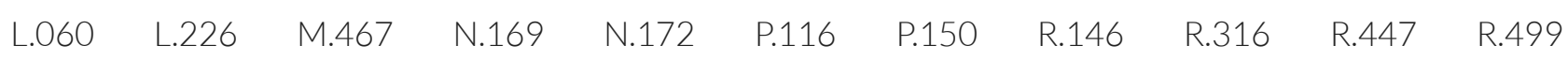

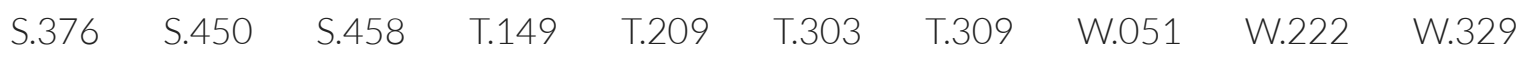

faithful history B.567 M.301. See also historicity of the Book of Mormon

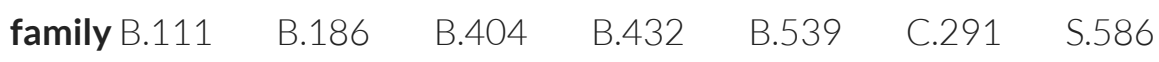

Family Home Evening B.524 B.560 M.051 Z.019

fasting L.233 R.248 W.205

fathers A.193 B.090 C.291 H.055

Feast of Tabernacles T.329 T.333. See also Jewish festivals

$\begin{array}{llllllllll}\text { fiction A.184 } & \text { C.068 } & \text { C.069 } & \text { C.391 } & \text { D.064 } & \text { D.065 } & \text { E.032 } & \text { F.103 } & \text { F.104 } & \text { G.029 }\end{array}$

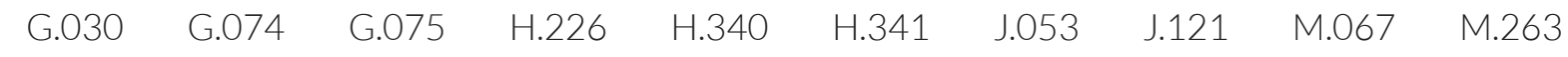

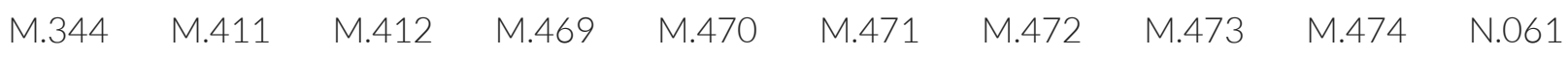

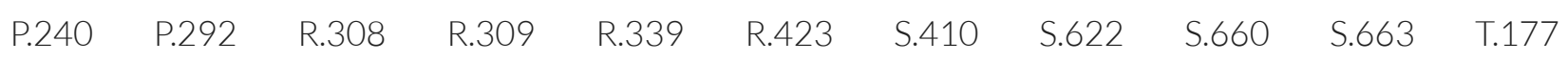

$\begin{array}{llllll}\text { W.069 W.075 W.076 W.077 W.264 W.453 } & \text { Y.005 }\end{array}$

$\begin{array}{llllllll}\text { for children B.023 } & \text { B.026 } & \text { B.444 } & \text { B.577 } & \text { C.029 } & \text { C.030 } & \text { H.227 } & \text { J.120 }\end{array}$

figures of speech. See colophons; epanalepsis; neologisms

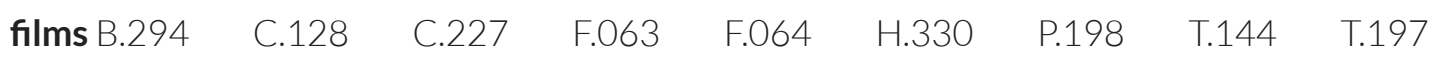

$\begin{array}{lllllll}\text { first edition of the Book of Mormon F.006 } & \text { I.018 } & \text { J.094 } & \text { K.094 } & \text { L.027 } & \text { L.118 } & \text { M.364 }\end{array}$

$\begin{array}{llllll}\text { N.133 } & \text { P.047 } & \text { R.086 } & \text { V.003 } & \text { V.047 } & \text { W.413 }\end{array}$

1 Nephi, book of L.229 $\quad$ P.317 $\quad$ S.111 $\quad$ S.718 $\quad$ S.743 


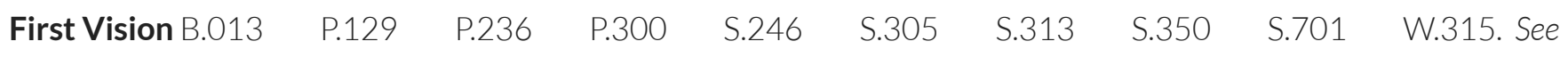
also Smith, Joseph heavenly visitations

flax S.145

foreordination M.324

$\begin{array}{llllllllll}\text { forgeries A.178 } & \text { A.196 } & \text { B.008 } & \text { B.009 } & \text { B.344 } & \text { B.423 } & \text { E.023 } & \text { E.025 } & \text { F.153 } & \text { H.129 }\end{array}$

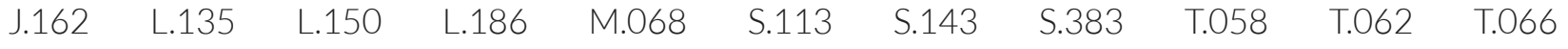

T.070 T.265 T.269 T.340. See also Hofmann, Mark

forgiveness $\mathrm{H} .056 \quad$ I.048 $\quad$ P.241 R.447 R.459

"four quarters" W.395

4 Nephi, book of R.045 W.328

Francesca, Vincenzo D. T.144

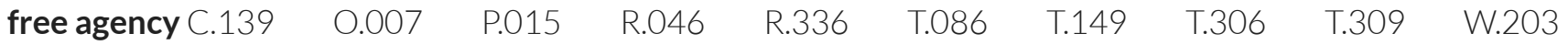

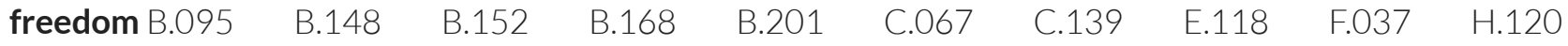

$\begin{array}{llll}H .121 & 0.007 & \text { P.191 } & \text { R.446 }\end{array}$

$\begin{array}{lllllllll}\text { Freemasonry B.115 } & \text { B.221 } & \text { G.125 } & \text { G.126 } & \text { H.135 } & \text { H.311 } & \text { H.397 } & \text { I.046 } & \text { L.119 }\end{array}$

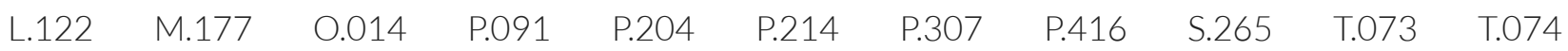

$\begin{array}{llll}\text { T.175 V.043 W.183 W.270 } & \text { W. }\end{array}$

Friberg Arnold B.354 $\quad 1.007 \quad 5.050$

$\begin{array}{llllllll}\text { fulness of the gospel B.121 } & \text { C.318 } & \text { G.076 } & \text { G.157 } & \text { L.105 } & \text { L.167 } & \text { L.194 } & \text { M.157 }\end{array}$

$\begin{array}{llll}\text { M.172 } & \text { M.231 } & \text { P.348 } & \text { S.100 }\end{array}$

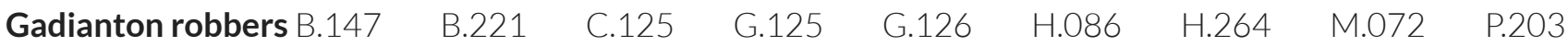
$\begin{array}{lllllll}\text { P.204 P.214 } & \text { R.126 } & \text { R.415 } & \text { S.738 } & \text { T.172 } & \text { T.175 } & \text { W.012 }\end{array}$

gathering of Israel. See Israel gathering

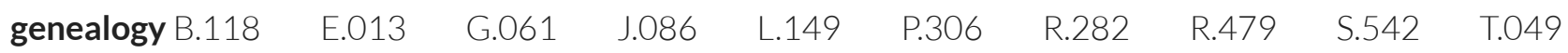

T.274

Genesis, book of R.144 W.425

$\begin{array}{llllllllll}\text { gentiles A.121 } & \text { B.433 } & \text { C.013 } & \text { D.105 } & \text { M.089 } & \text { M.159 } & \text { N.129 } & \text { N.168 } & \text { R.313 } & \text { R.331 }\end{array}$

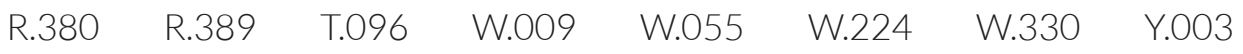

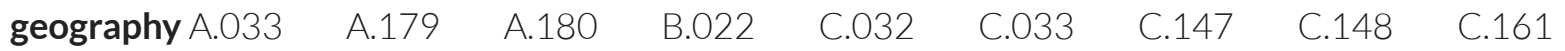

$\begin{array}{lllllllllll}\text { C.176 } & \text { C.190 } & \text { C.191 } & \text { C.194 } & \text { C.201 } & \text { C.203 } & \text { C.207 } & \text { C.297 } & \text { C.448 } & \text { C.449 } & \text { D.024 }\end{array}$ 


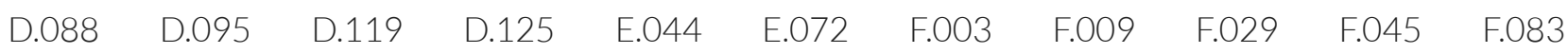

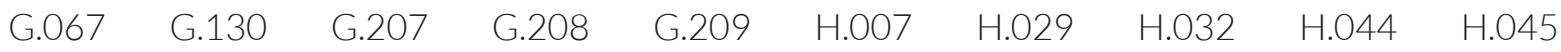

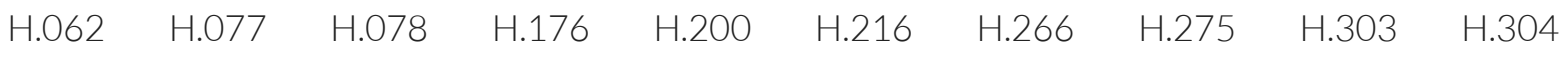

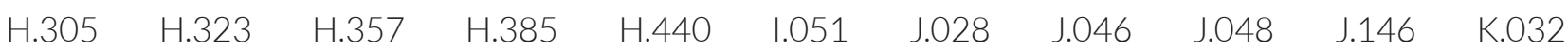

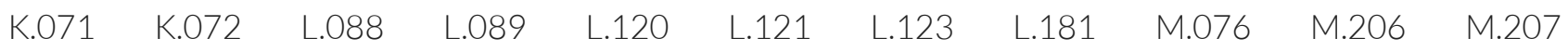

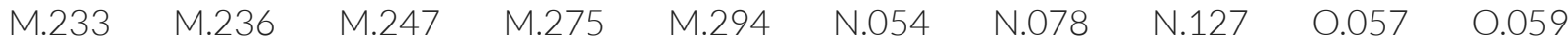

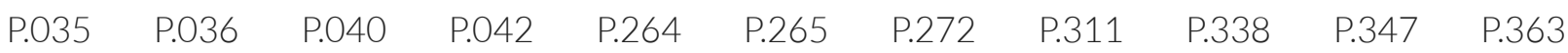

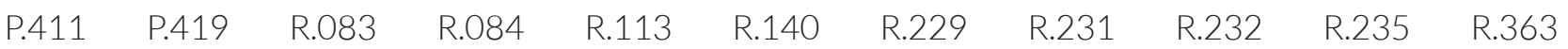

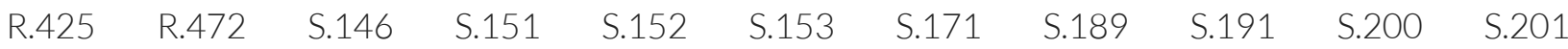

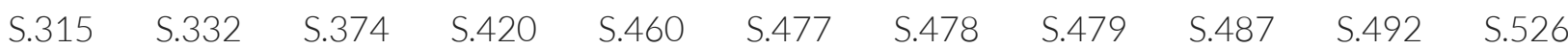

$\begin{array}{lllllllllll}\text { S.534 } & \mathrm{S} .630 & \mathrm{~S} .644 & \mathrm{~S} .704 & \mathrm{~S} .705 & \mathrm{~S} .706 & \mathrm{~T} .074 & \mathrm{~T} .087 & \mathrm{~T} .233 & \mathrm{~T} .238 & \mathrm{~T} .245\end{array}$

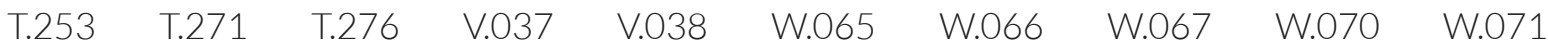

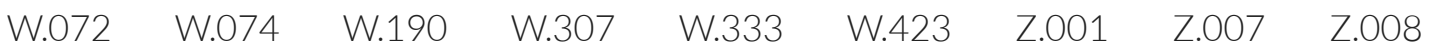

Gideon G.011 J.132

Gidgiddoni J.133

$\begin{array}{llllllllll}\text { Godhead A.025 } & \text { D.103 } & \text { D.123 } & \text { F.074 } & \text { H.015 } & \text { H.338 } & \text { J.011 } & \text { J.163 } & \text { K.110 } & \text { L.249 }\end{array}$

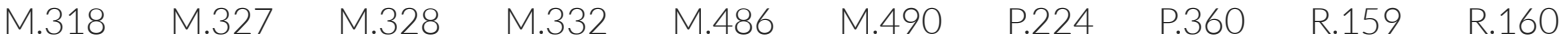

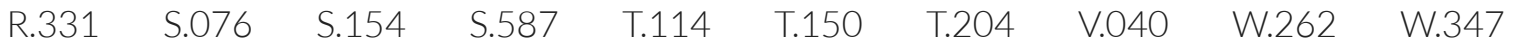

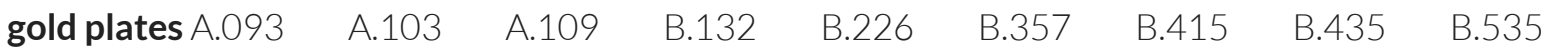

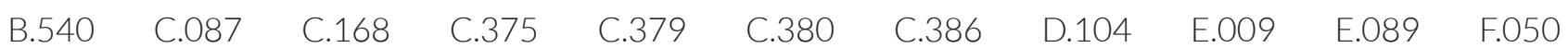

$\begin{array}{llllllllllll}\text { F.110 } & \text { F.147 } & \text { G.115 } & \text { G.116 } & \text { G.117 } & \text { G.118 } & \text { G.146 } & \text { H.090 } & \text { H.103 } & \text { H.109 } & \text { H.251 }\end{array}$

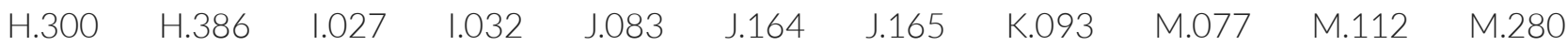

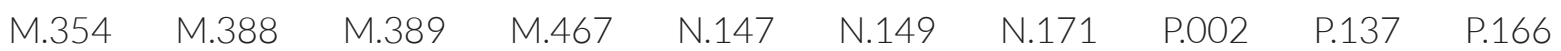

$\begin{array}{lllllllllll}\text { P.180 } & \text { P.189 } & \text { P.236 } & \text { P.262 } & \text { P.431 } & \text { R.085 } & \text { R.109 } & \text { R.357 } & \text { S.183 } & \text { S.197 } & \text { S.224 }\end{array}$

$\begin{array}{lllllllllll}\mathrm{S} .266 & \mathrm{~S} .318 & \mathrm{~S} .363 & \mathrm{~S} .372 & \mathrm{~S} .398 & \mathrm{~S} .409 & \mathrm{~S} .728 & \mathrm{~T} .187 & \mathrm{~T} .191 & \mathrm{~T} .201 & \mathrm{~T} .234\end{array}$

$\begin{array}{lllllllll}\text { V.029 W.002 W.087 W.273 W.279 W.305 W.316 W.339 W.340 } & \text { W.397 }\end{array}$

Y.017. See also metal plates; stone box; tumbaga

$\begin{array}{lllll}\text { hiding place B.282 } & \text { B.542 } & \text { C.380 } & \text { E.089 } & \text { L.089 }\end{array}$

$\begin{array}{lllllllll}\text { government B.202 } & \text { B.250 } & \text { B.565 } & \text { C.016 } & \text { C.097 } & \text { C.098 } & \text { C.161 } & \text { C.219 } & \text { D.029 }\end{array}$

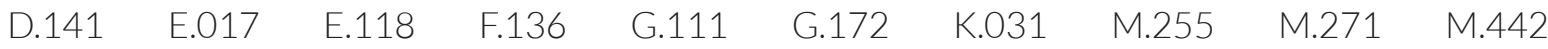

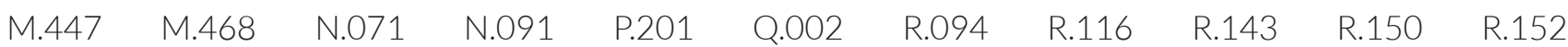

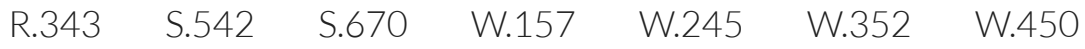

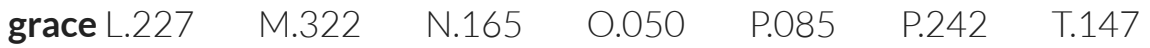

$\begin{array}{llllllllll}\text { grammar B.387 } & \text { C.107 } & \text { F.099 } & \text { H.050 } & \text { H.198 } & \text { H.365 } & \text { L.019 } & \text { L.152 } & \text { P.045 } & \text { P.059 }\end{array}$

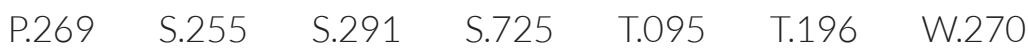

Grandin, E. B. B.508 $\quad 0.037 \quad$ P.300 $\quad$ S.380 
$\begin{array}{llllllll}\text { Great and Abominable Church A.064 } & \text { B.300 } & \text { C.048 } & \text { P.087 } & \text { P.133 } & \text { P.375 } & \text { R.416 } & \text { R.420 }\end{array}$ W.181

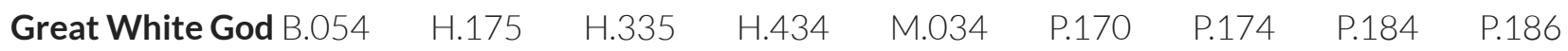

P.194 P.195. See also American Indian legends

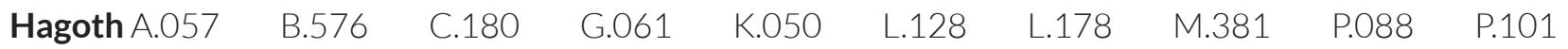
$\begin{array}{lllll}\text { P.265 P.286 } & \text { P.353 } & \text { R.22 } & \text { V.032 } & \text { W.006 }\end{array}$

hand of God S.076

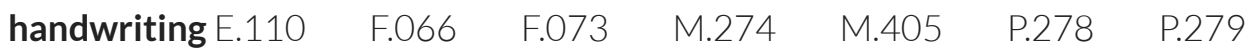

happiness A.230 W.328

Harris, Lucy P.137

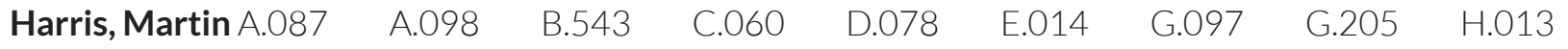

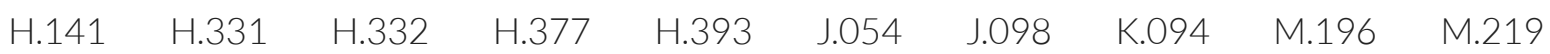

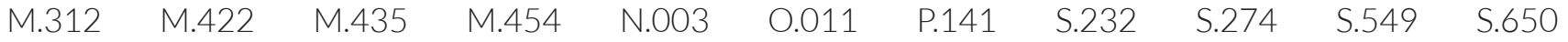

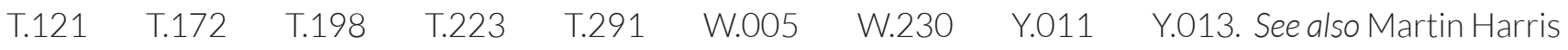
letter

$\begin{array}{lllllllll}\text { Hebraisms B.406 } & \text { B.407 } & \text { B.457 } & \text { B.459 } & \text { B.464 } & \text { B.465 } & \text { B.467 } & \text { C.389 } & \text { C.414 }\end{array}$

$\begin{array}{lllllllllll}\text { C.415 } & \text { C.416 } & \text { F.099 } & \text { H.113 } & \text { K.087 } & \text { L.007 } & \text { L.012 } & \text { L.207 } & \text { M.197 } & \text { M.276 } & \text { N.025 }\end{array}$

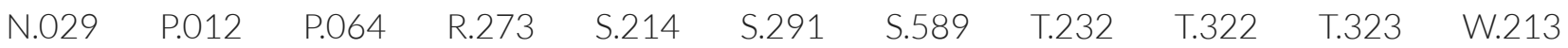

W.390. See also chiasmus; climactic forms; parallelism

$\begin{array}{lllllllll}\text { Hebrew language P.353 } & \text { P.359 } & \text { R.106 } & \text { R.114 } & \text { R.115 } & \text { R.265 } & \text { S.072 } & \text { S.098 } & \text { S.192 }\end{array}$

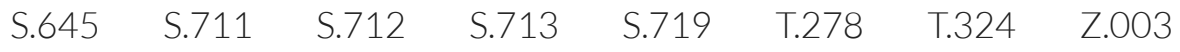

Hebrews, book of W.439

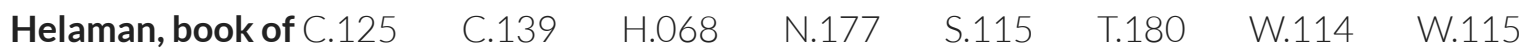

Helaman $_{1}$ T.181

Helaman $_{2}$ C.133

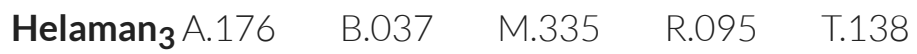

hell D.002

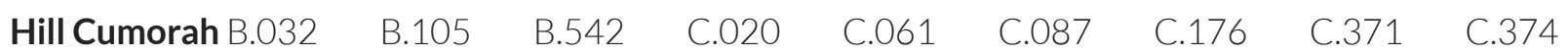

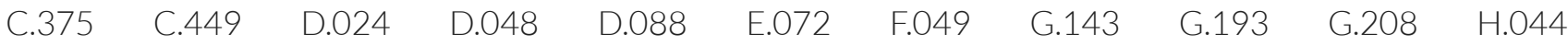

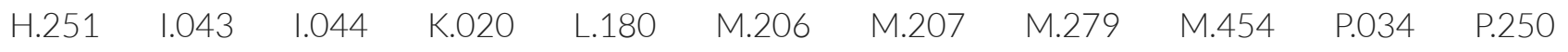




$\begin{array}{lllllllllll}\text { P.265 } & \text { P.300 } & \text { P.335 } & \text { P.343 } & \text { R.235 } & \text { R.359 } & \text { S.131 } & \text { S.275 } & \text { S.332 } & \text { S.333 } & \text { S.338 } \\ \text { S.374 } & \text { S.611 } & \text { S.652 } & \text { S.653 } & \text { T.201 } & \text { W.260 } & & & & & \end{array}$

$\begin{array}{llll}\text { Hill Ramah G.208 M.207 R.235 R.359 W.260 } & \text { R. }\end{array}$

historians of the Book of Mormon B.376 $\quad$ B.405 $\quad$ C.357 $\quad$ D.059 $\quad$ G.033 $\quad$ G.048 $\quad$ G.176

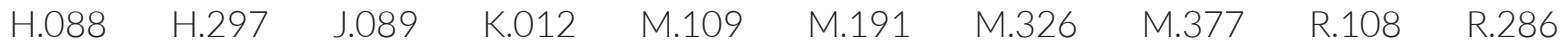

W.008 W.380 Y.004

historicity of the Book of Mormon C.393 $\quad$ G.108 $\quad$ H.255 $\quad$ H.441 $\quad$ J.032 $\quad$ L.071 $\quad$ L.078

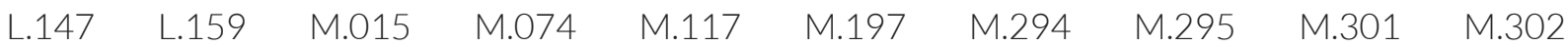

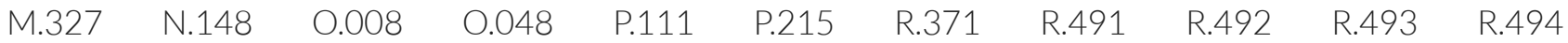

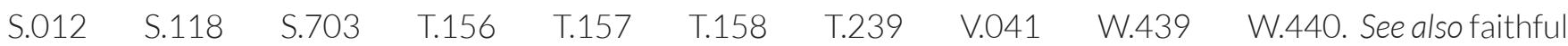

history

Hofmann, Mark A.084 L.150 T.058. See also Anthon Transcript; forgeries; Lucy Mack Smith letter; Martin Harris letter

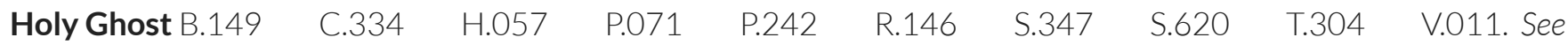
also witness of the Holy Ghost

hope B.092 D.004 N.169 W.412

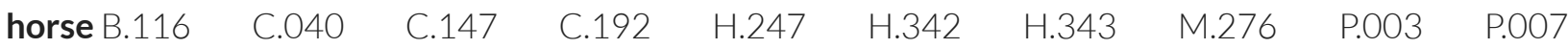

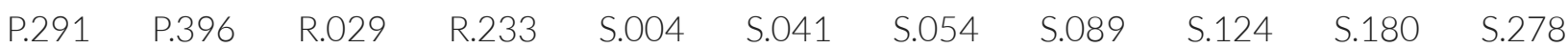

S.505 W.391

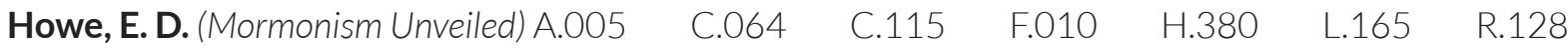

humility M.273 R.480 S.620

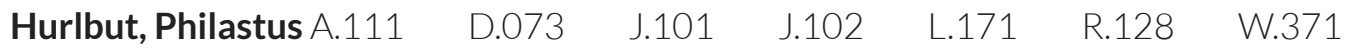

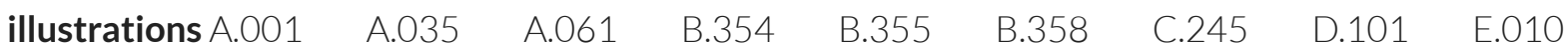

$\begin{array}{lllllllllll}\text { E.069 } & \text { F.017 } & \text { F.018 } & \text { G.053 } & \text { H.229 } & \text { I.007 } & \text { J.118 } & \text { J.119 } & \text { J.145 } & \text { L.115 } & \text { M.460 }\end{array}$

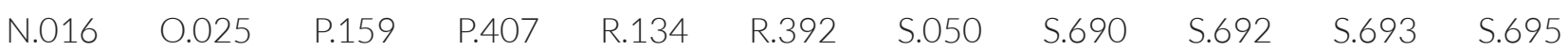

$\begin{array}{llll}\text { T.100 W.240 W.254 Z.004 Z.020 } & \text { Z.0 }\end{array}$

immorality S.619

incense $\mathrm{S.489} \quad \mathrm{S} .503$

indexes to the Book of Mormon. See topical indexes

Indian. See American Indian

infant baptism. See baptism, infant 


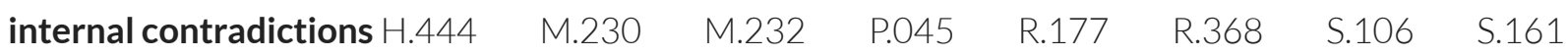

S.304 S.569 W.401

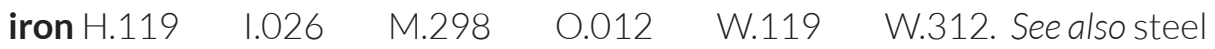

$\begin{array}{llllll}\text { iron rod H.084 L.107 } & \text { P.283 } & \text { R.161 } & \text { R.172 } & \text { T.261 } & \text { W.396 }\end{array}$

$\begin{array}{lllll}\text { Isaiah A.217 J.006 } & \text { N.158 } & \text { R.193 } & \text { R.395 } & \text { S.439 }\end{array}$

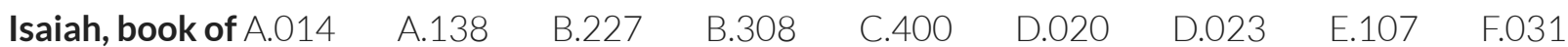

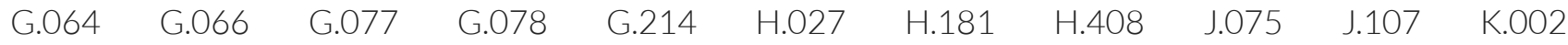

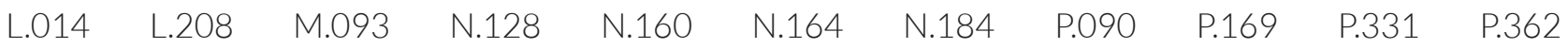

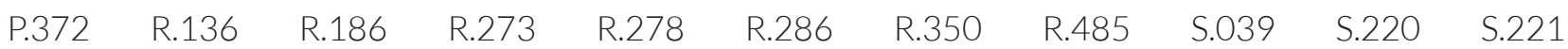

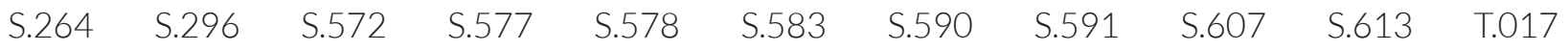

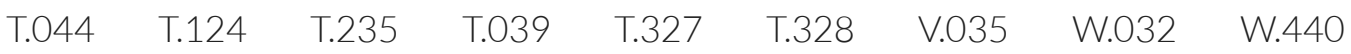

Ishmael B.038 G.109 R.174 S.362

isles M.044 R.363 W.181

Israel

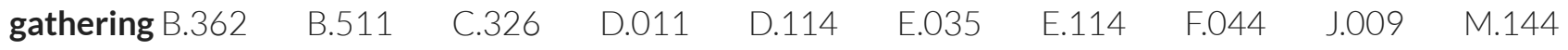

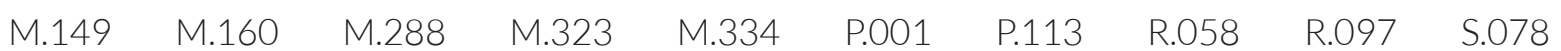

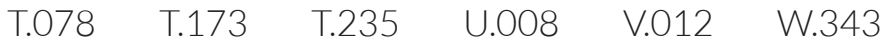

house of M.342 W.266

Ixtililxochitl F.057

Izapa. See Stela 5 Izapa

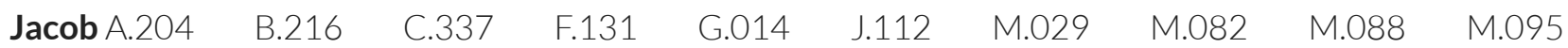

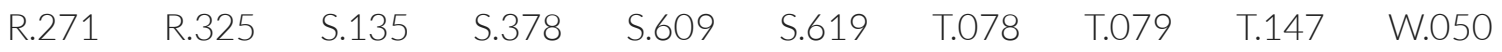

$\begin{array}{llllllllll}\text { Jacob } 5 \text { F.032 } & \text { F.102 } & \text { G.059 } & \text { G.079 } & \text { H.021 } & \text { H.347 } & \text { H.350 } & \text { K.066 } & \text { L.021 } & \text { P.249 }\end{array}$

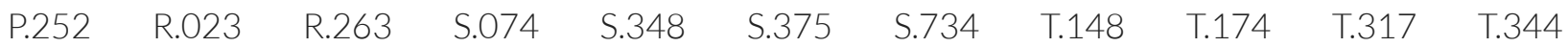

U.007 V.036 W.020 W.178. See also olive

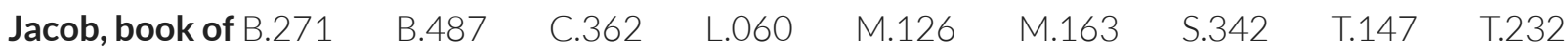

W.134 W.343

Japan $J .064$

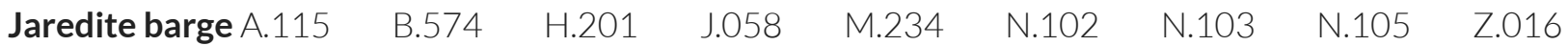


Jaredite stones $\mathrm{S} .413 \quad \mathrm{~S} .414$

\begin{tabular}{|c|c|c|c|c|c|c|c|c|c|c|}
\hline Jaredi & s A.068 & A. 212 & B.258 & B.265 & B. 444 & B. 576 & F.041 & G.180 & H.2O2 & 1.039 \\
\hline J.003 & J.059 & L.162 & L.175 & M.395 & N.105 & N.110 & N.139 & 0.002 & P.177 & P.363 \\
\hline R.029 & S.188 & S.207 & S.412 & S.538 & S.657 & T.082 & T.276 & W.360 & W.414 & \\
\hline
\end{tabular}

language $T .268$

Jarom, book of A.155 R.119

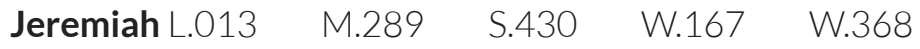

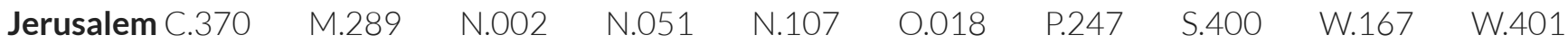

Jesus Christ. See Christ

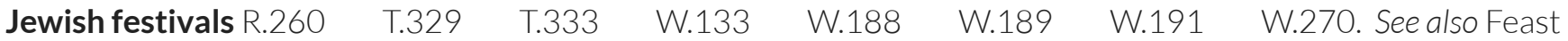

of Tabernacles; Passover

John the Baptist A.108

John the Revelator A.064 M.062 R.416 T.231

John, revelations of M.062

Johnston's army H.253

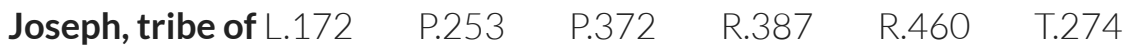

$\begin{array}{llllllll}\text { Joseph of Egypt L.013 } & \text { M.013 } & \text { R.136 } & \text { R.181 } & \text { R.194 } & \text { S.157 } & \text { S.222 } & \text { T.146 }\end{array}$

$\begin{array}{llllllll}\text { Joseph Smith Translation B.266 } & \text { B.308 } & \text { C.310 } & \text { C.419 } & \text { D.143 } & \text { H.413 } & \text { M.084 } & \text { M.321 }\end{array}$

M.337 M.360 $\quad$ S.343 $\quad$ S.567

joy H.207 R.334 R.335 R.351

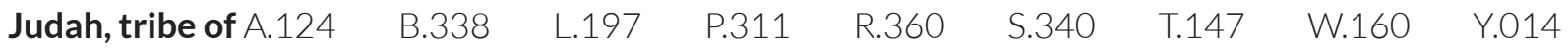

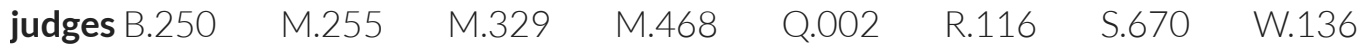

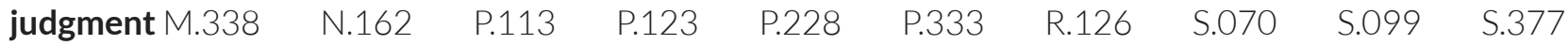

$\begin{array}{llll}\text { S.606 T.114 W.203 W.293 } & \text { W. }\end{array}$

$\begin{array}{lllll}\text { justice and mercy G.038 H.051 } & \text { P.229 } & \text { R.367 } & \text { R.440. See also mercy }\end{array}$

justification L.230 M.322 W.329 
keystone B.142

B.146

B.155

B.159

B.161

B.166

B.182

F.035

M.111

M.138

M.148 M.152

N.173

N.174

R.432

R.449

R.450

R.461

Kinderhook plates A.023

A.051

B.418

C.119

C.120

F.007 K.021

K.054 K.055

\section{King Follet Sermon V.046}
King James language B.085
B.472 C.005 D.072
D.112
H.302
M.024 M.084

$\begin{array}{llll}\text { N.084 P.122 R.285 R.292 } & \end{array}$

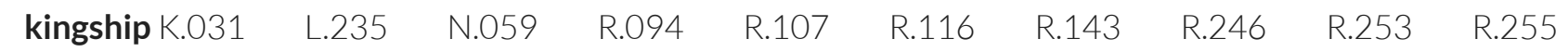

R.483 S.207 T.006 T.167. See also government

\section{Kishkumen B.037}

Knight, Joseph Jr. P.296

Knight, Joseph Sr. H.169 Z.015

Knight, Newell P.296

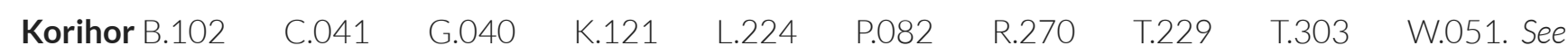
also anti-Christ

\section{La Mojarra Stela S.416}

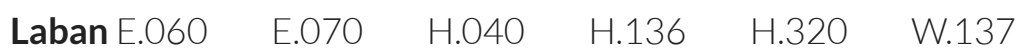

$\begin{array}{llllll}\text { sword B.187 } & \text { B.226 } & \text { H.314 } & \text { R.435 } & \text { I.026 } & \text { W.274 }\end{array}$

Lachish letters N.068 N.077 N.107

Laman P.055 T.273

$\begin{array}{lllllllll}\text { Lamanites A.214 } & \text { B.036 } & \text { B.117 } & \text { C.044 } & \text { C.051 } & \text { C.071 } & \text { C.204 } & \text { C.273 } & \text { C.359 }\end{array}$

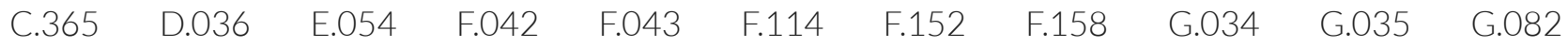

$\begin{array}{lllllllllll}H .315 & H .432 & \text { I.051 } & J .004 & J .037 & J .155 & \text { K.036 } & \text { K.039 } & \text { K.040 } & \text { K.042 } & \text { K.043 }\end{array}$

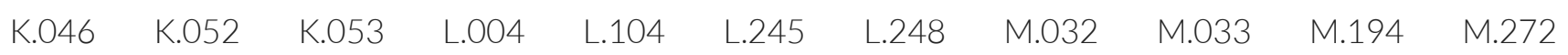

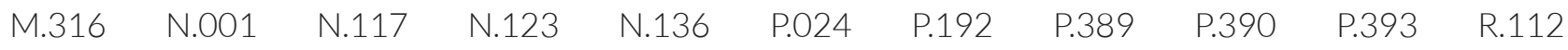

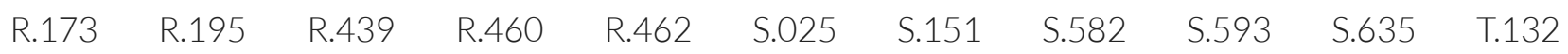

$\begin{array}{llllll}\text { T.164 T.165 } & \text { T.200 } & \text { U.008 } & \text { W.009 } & \text { W.224 } & \text { Y.003 }\end{array}$

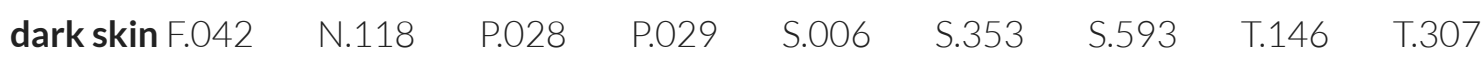

view of Book of Mormon history B.570 K.036 L.236 R.150

“lamb” T.231 
lament B.495 B.496

Lamoni's father A.001 A.045

Lamoni, King A.207 R.024

$\begin{array}{llllllllll}\text { language A.033 } & \text { B.465 } & \text { C.046 } & \text { C.309 } & \text { F.082 } & \text { G.127 } & \text { H.308 } & \text { H.348 } & \text { K.022 } & \text { R.114 }\end{array}$

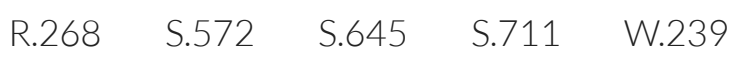

19th century T.153 T.156 T.160

of the Mormons T.166

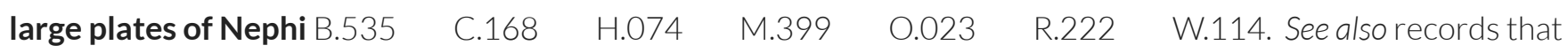

became the Book of Mormon

last days N.097

law of consecration T.186

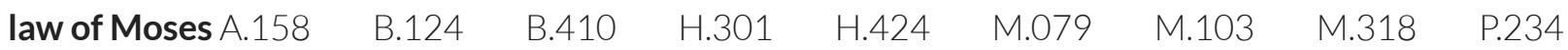

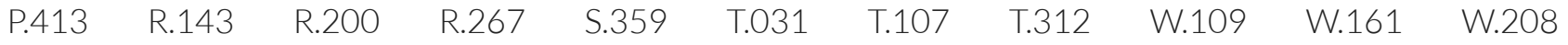

laying on of hands C.082

$\begin{array}{llllllllll}\text { Lehi B.216 } & \text { B.498 } & \text { C.394 } & \text { E.021 } & \text { F.132 } & \text { G.015 } & \text { H.254 } & \text { J.134 } & \text { L.113 } & \text { L.114 }\end{array}$

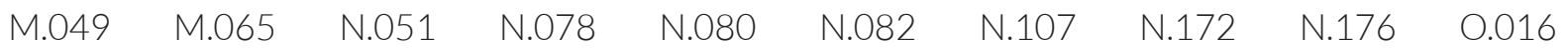

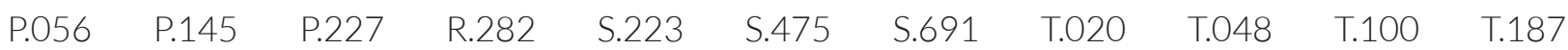

$\begin{array}{llll}\text { T.274 } & \text { T.345 W.108 W.139 }\end{array}$

600 year prophecy $\mathrm{H} .389$

counsel vision W.138

daughters $\mathrm{S} .582 \quad \mathrm{~S} .588 \quad \mathrm{~S} .592$

$\begin{array}{llllllllll}\text { dream of B.235 } & \text { B.249 } & \text { C.185 } & \text { C.293 } & \text { G.139 } & \text { H.084 } & \text { I.011 } & \text { J.011 } & \text { L.082 } & \text { L.115 }\end{array}$

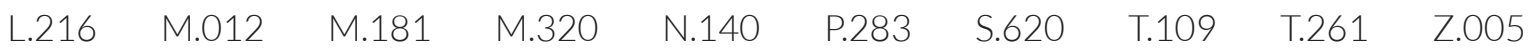

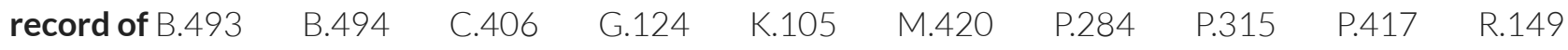

R.222. See also records that became the Book of Mormon

$\begin{array}{llll}\text { Lehi cave B.192 } & \text { G.093 } & 1.030 & \text { I.032 }\end{array}$

Lehi's promises to the Lamanites B.117 K.053

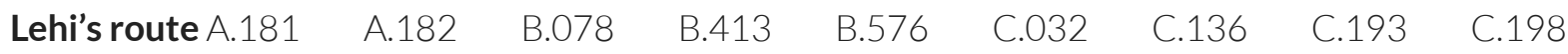

$\begin{array}{lllllllllll}\text { C.289 } & \text { C.429 } & \text { D.088 } & \text { D.099 } & \text { E.006 } & \text { E.059 } & \text { H.001 } & H .007 & H .270 & H .277\end{array}$ 


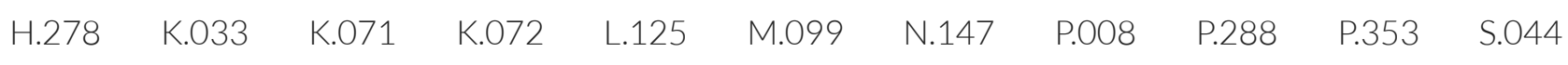

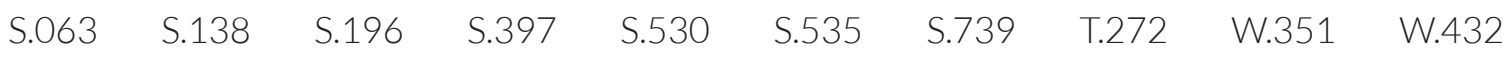

Leitworter A.112

$\begin{array}{lllllllll}\text { lesson manuals B.126 } & \text { B.135 } & \text { B.203 } & \text { B.324 } & \text { B.362 } & \text { B.366 } & \text { B.367 } & \text { B.370 } & \text { B.371 }\end{array}$

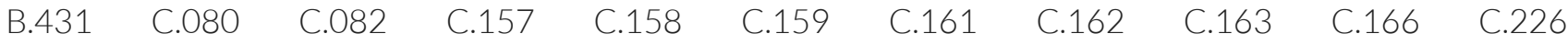

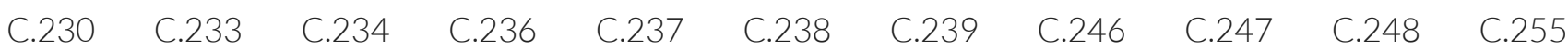

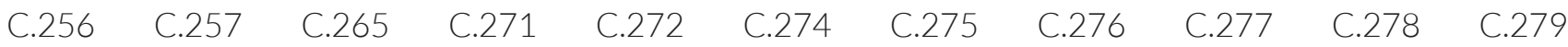

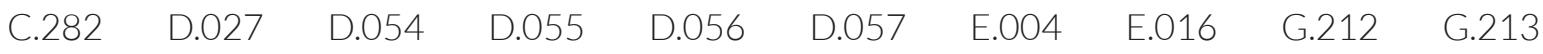

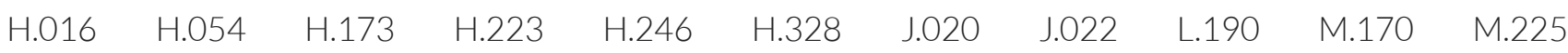

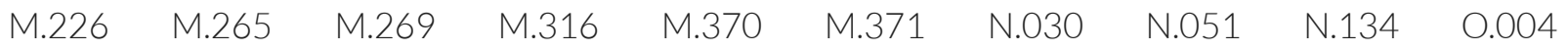

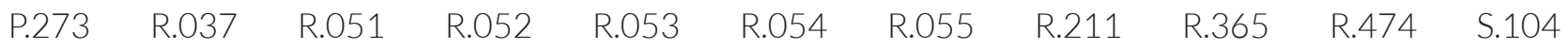

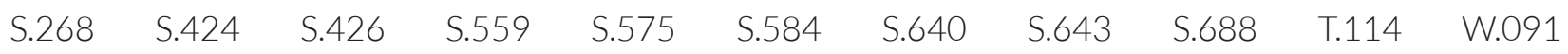

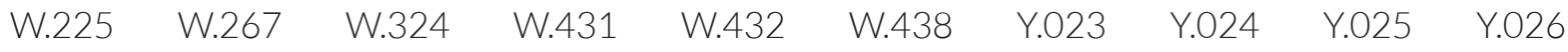

Y.027 Y.028

letters to government officials A.011

$\begin{array}{lllllllllll}\text { Liahona A.136 } & \text { A.169 } & \text { B.529 } & \text { D.120 } & \text { G.135 } & \text { J.109 } & \text { K.038 } & \text { K.045 } & \text { L.145 } & \text { L.206 } \\ \text { N.083 } & \text { P.283 } & \text { S.401 } & \text { S.743 } & \text { W.236 } & \text { Z.019 } & & & & & \end{array}$

Limhi G.054 K.065 R.424

linen S.004 $\quad 5.507 \quad 5.522$

$\begin{array}{llllllllll}\text { linguistics A.020 } & \text { G.127 } & \text { K.066 } & \text { K.118 } & \text { L.009 } & \text { L.015 } & \text { L.240 } & \text { M.164 } & 0.017 & \text { R.297 }\end{array}$

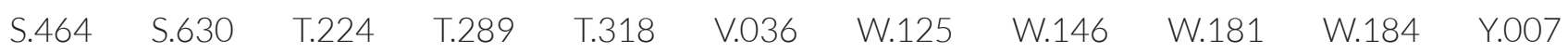

$\begin{array}{llllllllll}\text { literary devices C.172 } & \text { E.058 } & \text { G.079 } & \text { G.105 } & \text { H.196 } & \text { J.160 } & \text { J.161 } & \text { L.043 } & \text { P.062 }\end{array}$ $\begin{array}{llllllll}\text { P.074 P.196 } & \text { R.268 } & \text { R.273 } & \text { R.500 } & \text { S.074 } & \text { S.539 } & \text { T.093 } & \text { T.152. See also anteantiosis; }\end{array}$ chiasmus; climactic forms

$\begin{array}{lllllllll}\text { literary styles A.028 } & \text { B.544 } & \text { B.545 } & \text { C.079 } & \text { D.110 } & \text { E.020 } & \text { F.090 } & \text { H.207 } & \text { H.276 }\end{array}$ $\begin{array}{llll}\text { S.074 } & \text { S.127 } & \text { S.447 } & \text { T.347 }\end{array}$

$\begin{array}{lllllll}\text { literary value of the Book of Mormon B.070 } & \text { B.305 } & \text { B.463 } & \text { C.134 } & \text { C.384 } & \text { E.094 } & \text { G.108 }\end{array}$

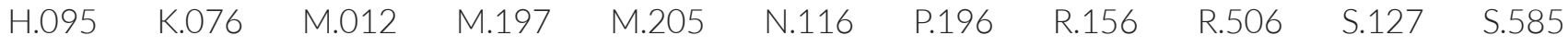

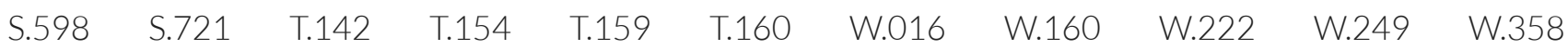
longevity W.140. See also populations

Lord's prayer B.266 C.417 C.419 S.018. See also Sermon on the Mount

$\begin{array}{lllllllll}\text { lost pages, } 116 \text { A.117 } & \text { B.543 } & \text { C.406 } & \text { H.318 } & \text { H.336 } & \text { K.105 } & \text { L.212 } & \text { M.196 } & \text { M.399 }\end{array}$

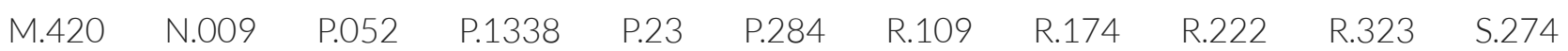
$\begin{array}{lllll}\mathrm{S} .381 & \mathrm{~S} .438 & \mathrm{~S} .700 & \mathrm{~T} .065 & \mathrm{~V} .017\end{array}$ 
lost ten tribes A.008 H.096 L.034

love B.479 B.480

Lucy Mack Smith letter E.025 F.153 L.186 S.383 T.265. See also forgeries

Macpherson, James C.066

magic B.566 Q.005 S.265

Malachi, book of $J .010 \quad$ W.309

$\begin{array}{llllll}\text { Manasseh, tribe of R.174 } & \text { S.156 } & \text { S.340 } & \text { S.665 } & \text { S.666 } & \text { T.274 }\end{array}$

Manti inscriptions A.016

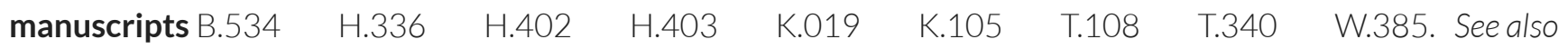

critical text; original manuscript; printer's manuscript

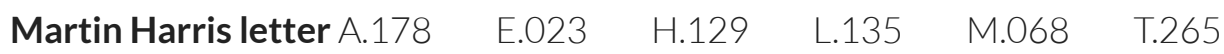

Mary C.381

masonry. See freemasonry

mastodon D.082 M.132. See also animals; elephant

materialism $J .093$

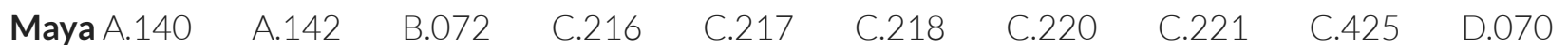

$\begin{array}{lllllllllll}\text { D.081 } & \text { F.023 } & \text { G.123 } & \text { H.039 } & \text { H.076 } & \text { H.426 } & \text { H.429 } & \text { I.025 } & \text { I.039 } & \text { I.047 } & \text { J.039 }\end{array}$

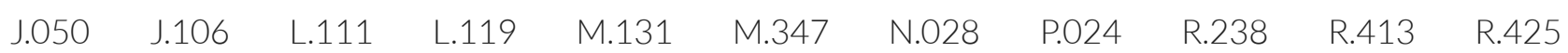

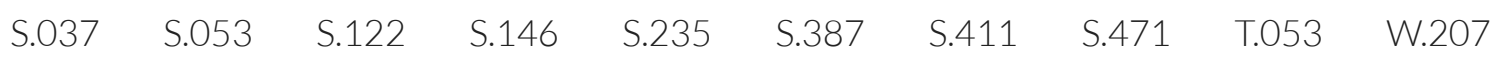

astronomy W.215

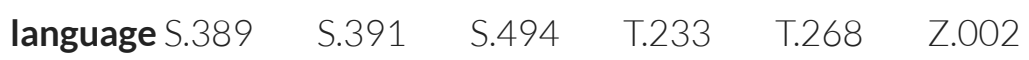

$\begin{array}{llllllll}\text { calendar A.048 } & \text { E.078 } & \text { J.025 } & \text { M.038 } & \text { P.413 } & \text { R.413 } & \text { S.239 } & \text { W.221 }\end{array}$

prophecy $\mathrm{S} .509$

McLellin, William E. A.135 M.241 P.303 W.320

memory A.167

$\begin{array}{lllllll}\text { mercy B.134 } & \text { C.311 } & \text { E.054 } & \text { I.048 } & \text { M.329 } & \text { P.123 } & \text { P.229 }\end{array}$ 
metal plates $\mathrm{A} .006$

B.317 B.324

B.376

C.075 C.120

C.121

C.122

C.249

$\begin{array}{llllllllll}\text { C.258 } & \text { C.259 } & \text { C.430 } & \text { C.431 } & \text { E.001 } & \text { H.099 } & \text { H.114 } & \text { H.115 } & \text { H.118 } & \text { H.123 }\end{array}$

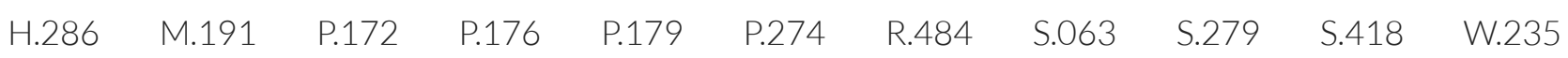

W.303 W.319 W.444 W.445. See also ancient writings in the Americas; brass plates; gold plates;

Kinderhook plates; large plates of Nephi; Padilla gold plates; small plates of Nephi

\begin{tabular}{|c|c|c|c|c|c|c|c|c|c|c|}
\hline metals & .038 & B. 458 & C.123 & C.144 & C.287 & M.276 & N.074 & P.412 & Q.003 & R.031 \\
\hline S.068 & S.181 & 5.490 & S.497 & S.508 & S.510 & T.345 & W.221 & W.251 & W.361 & Y.017. See \\
\hline
\end{tabular}

$\begin{array}{llll}\text { Mexico D.070 P.389 R.443 T.189 W.041 } & \text { P. }\end{array}$

midrash C.420 T.241

$\begin{array}{lllllll}\text { missionary tool, Book of Mormon as A.221 } & \text { B.018 } & \text { B.067 } & \text { B.068 } & \text { B.087 } & \text { B.165 } & \text { B.172 }\end{array}$

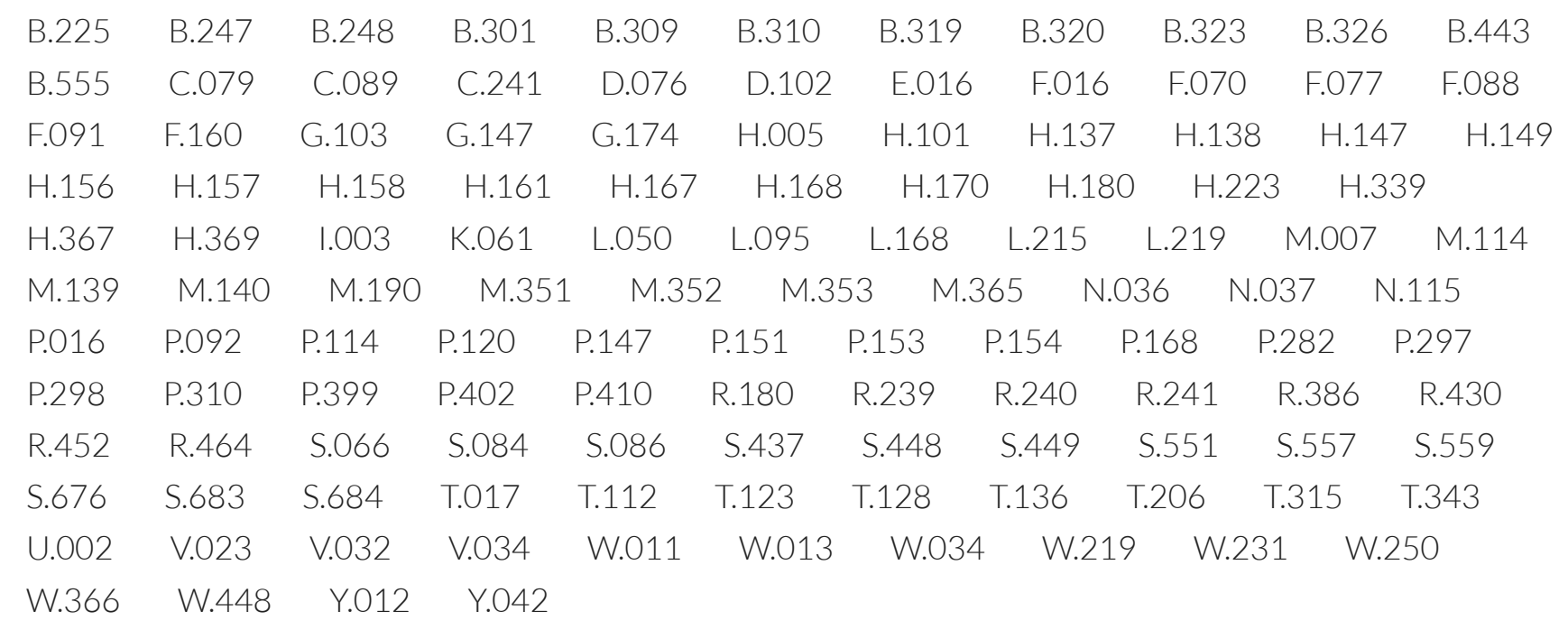

Mitchell, Dr. K.059 S.232 T.172

$\begin{array}{llll}\text { Mohammed M.422 N.070 P.026 P.059 R.155 } & \text { P. }\end{array}$

monetary systems J.096 S.396 V.036 W.335

Monroe Doctrine C.016 M.445 M.447

$\begin{array}{llllllllll}\text { Mormon A.136 } & \text { A.215 } & \text { B.336 } & \text { F.133 } & \text { G.016 } & \text { H.060 } & \text { H.234 } & \text { H.287 } & \text { L.011 } & \text { L.100 }\end{array}$

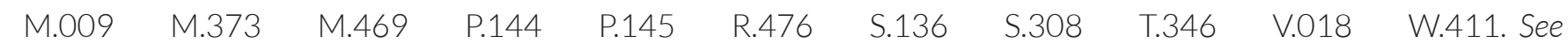
also nickname "Mormon"

\section{Moroni}

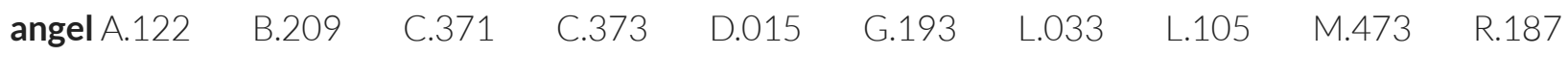

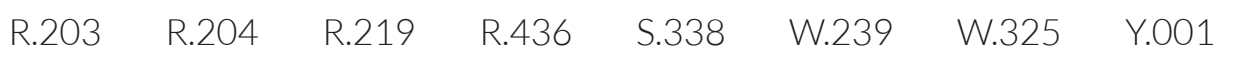




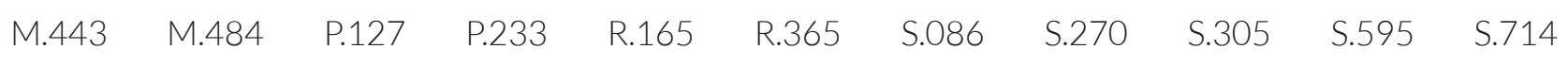

T.030 T.042 T.098 W.305 W.308 Y.001. See also Smith, Joseph, heavenly visitations

$\begin{array}{lllllllll}\text { Moroni's promise B.046 } & \text { B.138 } & \text { B.484 } & \text { B.547 } & \text { E.045 } & \text { E.046 } & \text { E.106 } & \text { E.115 } & \text { F.020 }\end{array}$

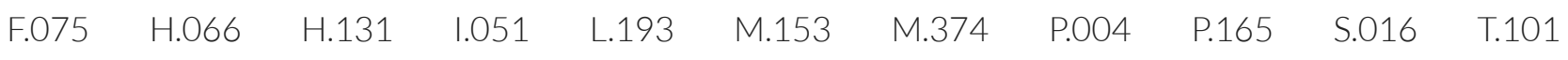

T.211 W.229

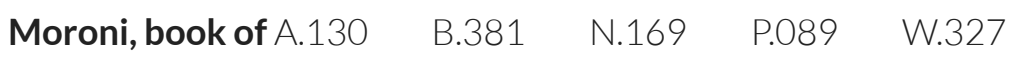

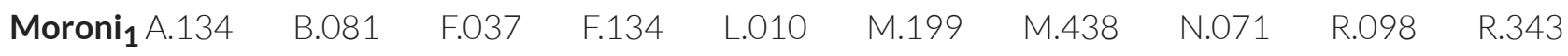

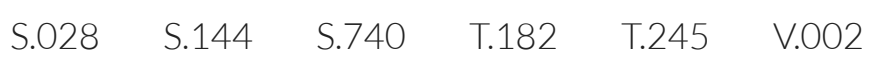

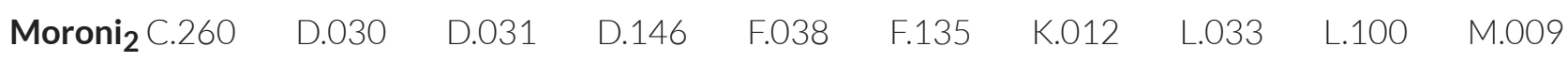

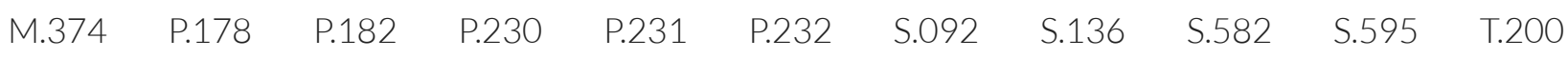

W.209 W.308 W.325 W.418 Y.001

$\begin{array}{lllllllll}\text { Mosiah, book of A.195 } & \text { A.205 } & \text { B.151 } & \text { G.107 } & \text { G.110 } & \text { G.095 } & \text { G.096 } & \text { L.057 } & \text { L.225 }\end{array}$

$\begin{array}{llllllll}\text { M.028 } & \text { P.115 } & \text { P.205 } & \text { P.226 } & \text { S.377 } & \text { S.554 } & \text { T.007 } & \text { T.304 }\end{array}$

$\begin{array}{llll}\text { Mosiah, sons of P.187 } & \text { T.341 } & \text { W.348 } & \text { W.356 }\end{array}$

$\begin{array}{llll}\text { Mosiah }_{1} \text { A.209 A.216 S.031 } & \text { T.167 } & \text { T.183 }\end{array}$

$\begin{array}{llll}\text { Mosiah }_{2} \text { A.209 } & \text { B.250 R.509 } & \text { S.670 }\end{array}$

$\begin{array}{lllllllll}\text { most correct book B.166 } & \text { K.082 } & \text { L.139 } & \text { M.209 } & \text { N.170 } & \text { N.173 } & \text { N.174 } & \text { N.193 } & \text { P.359 }\end{array}$

$\begin{array}{llll}\text { R.432 R.445 } & \text { S.302 } & \text { T.204 }\end{array}$

mothers B.090 B.216 Y.006

$\begin{array}{lllllllll}\text { mound builders A.030 } & \text { B.233 } & \text { C.188 } & \text { C.287 } & \text { C.288 } & \text { D.001 } & \text { D.073 } & \text { D.084 } & \text { F.001 }\end{array}$

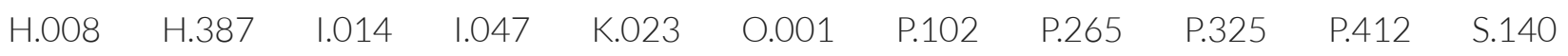
S.173 W.043 W.400 W.423

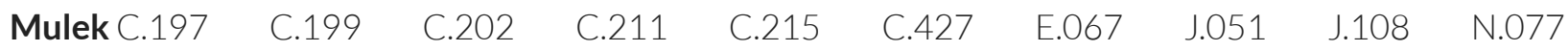

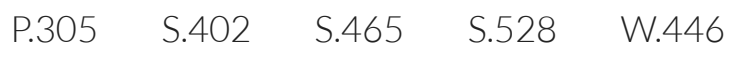

Mulekites S.498 S.597 W.359

murmuring A.175 T.273

mysteries of God B.240

Nag Hammadi N.098

$\begin{array}{lllll}\text { Nahom A.180 A.181 } & \text { A.182 } & \text { C.198 G.109 }\end{array}$ 
$\begin{array}{lllllll}\text { names from the Book of Mormon A.210 } & \text { B.274 } & \text { B.336 } & \text { B.347 } & \text { B.464 } & \text { B.467 } & \text { B.501 }\end{array}$

$\begin{array}{lllllllllll}\text { C.428 } & \text { E.079 } & \text { F.090 } & \text { G.055 } & \text { G.093 } & \text { H.287 } & \text { H.349 } & \text { H.351 } & \text { H.414 } & \text { I.017 } & \text { J.091 } \\ \text { K.113 } & \text { K.114 } & \text { K.129 } & \text { L.011 } & \text { L.207 } & \text { L.240 } & \text { M.343 } & \text { N.056 } & \text { N.058 } & \text { N.074 } & \text { N.083 } \\ \text { N.095 } & \text { P.095 } & \text { P.277 } & \text { P.416 } & \text { R.077 } & \text { R.114 } & \text { R.125 } & \text { R.252 } & \text { S.032 } & \text { S.169 } & \text { S.189 } \\ \text { S.194 } & \text { S.195 } & \text { S.239 } & \text { S.277 } & \text { S.308 } & \text { S.563 } & \text { S.639 } & \text { T.020 } & \text { T.049 } & \text { T.052 } & \text { T.289 } \\ \text { T.293 } & \text { T.334 } & \text { U.013 } & \text { U.015 } & \text { V.036 } & \text { W.088 } & \text { W.175 } & \text { W.414 } & \text { W.435 } & \text { Z.003 } & \end{array}$

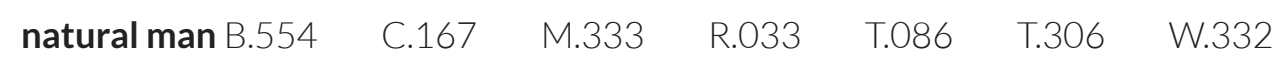

$\begin{array}{llllllll}\text { Near Eastern influences C.075 } & \text { D.110 } & \text { H.355 } & \text { K.005 } & \text { K.087 } & \text { L.004 } & \text { L.207 } & \text { M.242 }\end{array}$

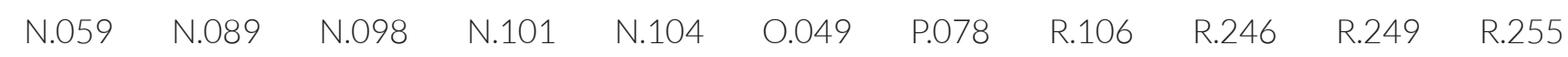

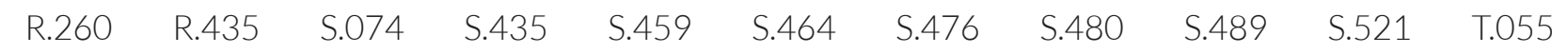

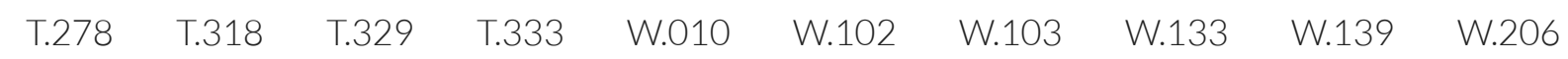

W.395 Y.007. See also Hebraisms; Jewish festivals

\section{Nehor T.229}

Nehum P.090

neologisms $\mathrm{S} .404$

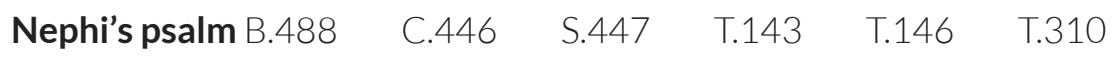

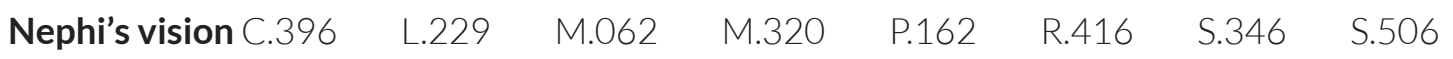

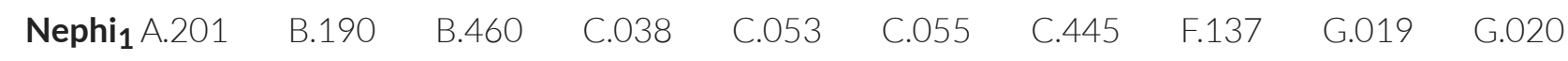

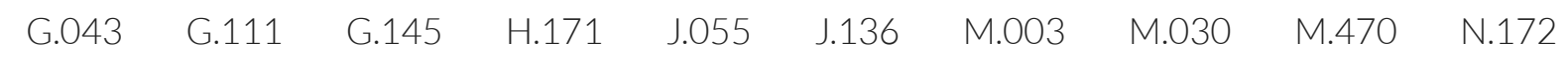

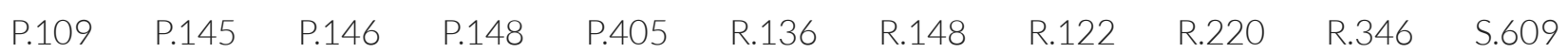

$\begin{array}{llllllll}\text { S.647 } & \text { S.693 } & \text { T.085 } & \text { T.143 } & \text { T.310 } & \text { W.241 } & \text { W.418 } & \text { W.432 }\end{array}$

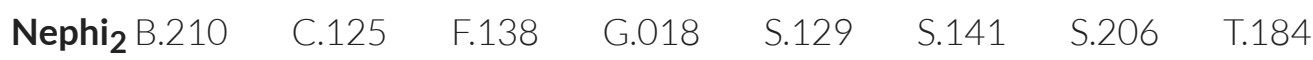

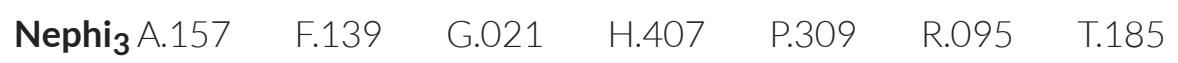

$\mathrm{Nephi}_{4}$ R.095 T.186

$\begin{array}{llllllll}\text { Nephite Twelve D.053 } & \text { H.407 } & \text { P.361 } & \text { R.411 } & \text { S.370 } & \text { T.008 } & \text { T.213 } & \text { W.418 }\end{array}$

Nephites R.129 R.131 W.427

Neum J.007

$\begin{array}{lllllllll}\text { New Jerusalem F.042 } & \text { F.084 } & \text { G.094 } & \text { M.159 } & \text { R.302 } & \text { S.070 } & \text { S.157 } & \text { T.081 } & \text { U.008 }\end{array}$ W.207 
nickname "Mormon" L.011 R.453 T.013 V.018

Noah, King A.004 D.096 J.017 S.695

Nostradamus W.429

numerology L.016 M.179 W.148

oaths C.335 J.125 $\quad$ M.448 P.074 $\quad$ S.740

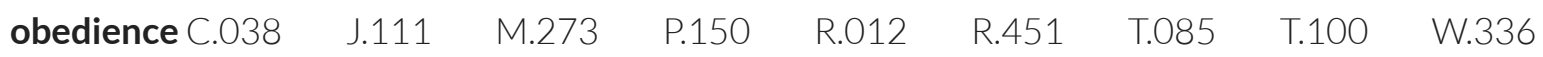

$\begin{array}{llllllllll}\text { olive C.153 } & \text { C.362 } & \text { F.032 } & \text { F.102 } & \text { G.059 } & \text { G.090 } & \text { H.021 } & \text { H.242 } & \text { H.243 } & \text { H.347 }\end{array}$

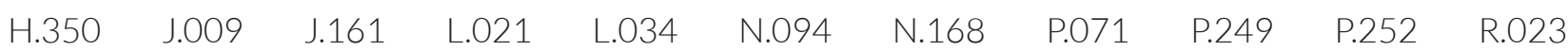

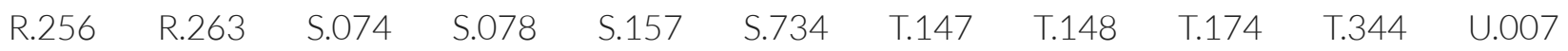

W.020. See also Jacob 5

Omni, book of A.156 D.091 S.416 $\quad \mathrm{S} .597$

opposition M.020 R.335 R.338 S.344 S.456

oral tradition E.020 J.113 L.111

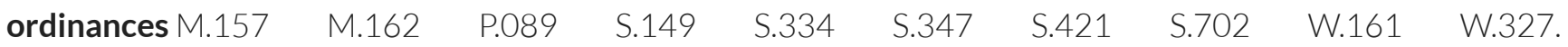

See also Priesthood, ordinances

$\begin{array}{lllllll}\text { origin of the Book of Mormon B.451 } & \text { B.551 } & \text { C.086 } & \text { C.087 } & \text { C.100 } & \text { C.114 } & \text { D.022 }\end{array}$

$\begin{array}{lllllllllll}\text { D.032 } & \text { G.156 } & \text { G.177 } & \text { H.106 } & \text { H.391 } & \text { H.444 } & \text { J.030 } & \text { K.084 } & \text { K.085 } & \text { L.154 } & \text { M.252 }\end{array}$

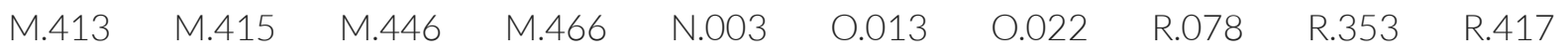

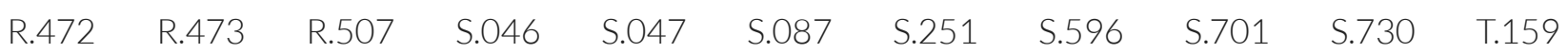

T.301 W.039 W.089 W.197. See also Smith, Ethan (View of the Hebrews); Spaulding theory

$\begin{array}{llllllllll}\text { divine A.044 } & \text { B.239 } & \text { B.259 } & \text { B.260 } & \text { C.034 } & \text { C.372 } & \text { F.067 } & \text { H.425 } & \text { J.076 } & \text { K.017 }\end{array}$

$\begin{array}{llllllllll}\text { K.104 L.006 } & \text { M.178 } & \text { N.021 } & \text { P.018 } & \text { P.323 } & \text { P.329 } & \text { P.331 } & \text { R.135 } & \text { R.333 } & \text { S.272 }\end{array}$

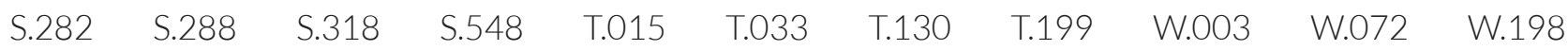

W.319

$\begin{array}{lllllllll}\text { historical document E.088 } & \text { F.003 } & \text { G.189 } & \text { N.060 } & 0.023 & 0.048 & \text { P.111 } & \text { P.279 } & \text { P.311 }\end{array}$

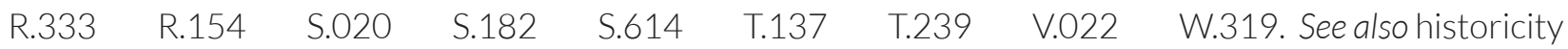

$\begin{array}{llllllll}\text { written by Joseph Smith A.022 } & \text { B.255 } & \text { B.274 } & \text { B.462 } & \text { C.453 } & \text { D.063 } & \text { F.066 } & \text { G.070 }\end{array}$

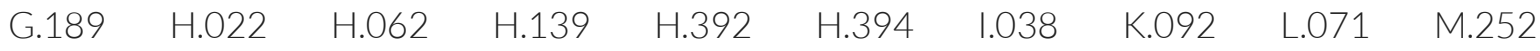

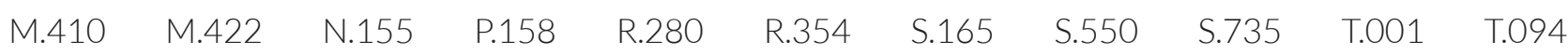

$\begin{array}{llllll}\text { T.203 T.208 } & \text { V.025 } & \text { W.028 } & \text { W.252 } & \text { W.299 } & \text { W.338 }\end{array}$

$\begin{array}{lllllllll}\text { original manuscript B.275 } & \text { B.341 } & \text { B.342 } & \text { B.344 } & \text { B.408 } & \text { B.424 } & \text { C.240 } & \text { E.030 } & \text { F.099 }\end{array}$

$\begin{array}{lllllllllll}\text { G.170 } & H .206 & H .208 & H .219 & H .378 & H .379 & H .403 & J .099 & \text { K.019 } & \text { K.020 } & \text { K.089 }\end{array}$ 
$\begin{array}{llllllllll}\text { L.074 L.076 L.079 } & \text { L.185 } & \text { L.241 } & \text { M.407 } & \text { N.043 } & \text { N.111 } & 0.041 & 0.042 & 0.043\end{array}$

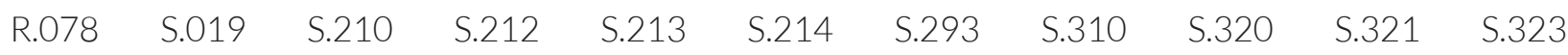

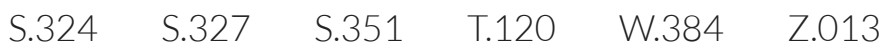

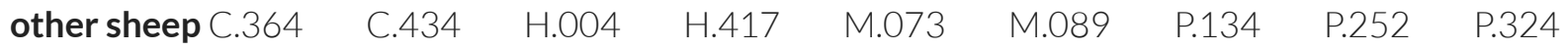

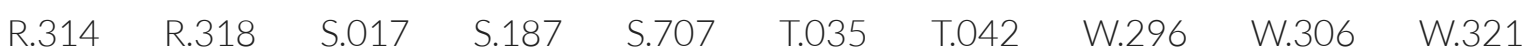

Ottinger, George M. J.145

$\begin{array}{llllllll}\text { overview of Book of Mormon A.007 } & \text { B.288 } & \text { B.447 } & \text { B.484 } & \text { B.504 } & \text { B.510 } & \text { B.536 } & \text { C.006 }\end{array}$

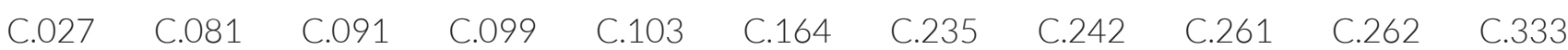

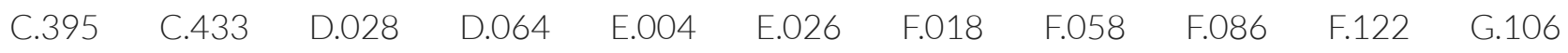

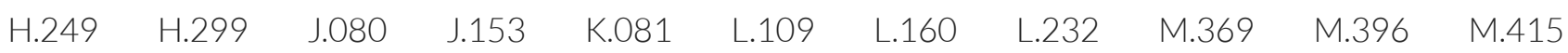

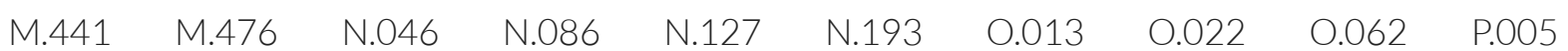

$\begin{array}{lllllllllll}\text { P.264 } & \text { P.347 } & \text { P.369 } & \text { R.027 } & \text { R.028 } & \text { R.041 } & \text { R.076 } & \text { R.106 } & \text { R.134 } & \text { R.158 } & \text { R.171 }\end{array}$

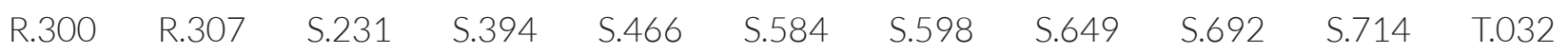

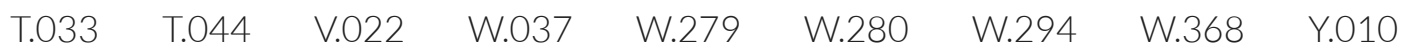

Padilla gold plates M.077

Page, Hiram W.337

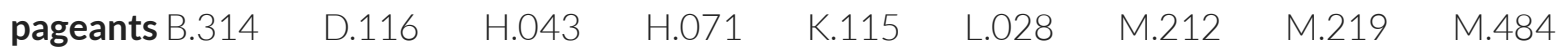

S.392 W.269 Z.011

Pahoran A.197

Paine, Thomas (The Age of Reason) T.072

Palmyra B.013 B.104

$\begin{array}{llllllllll}\text { pamphlet B.297 } & \text { E.096 } & \text { E.104 } & \text { M.391 } & \text { N.038 } & \text { N.039 } & 0.005 & \text { R.063 } & \text { R.064 } & \text { R.071 }\end{array}$ $\begin{array}{lllll}\text { R.391 R.395 W.206 W.259 W.271 } & \text { W. }\end{array}$

parables B.468 T.261

$\begin{array}{llllllllll}\text { parallelisms B.499 } & \text { C.389 } & \text { C.416 } & \text { F.034 } & \text { L.208 } & \text { M.164 } & \text { P.061 } & \text { P.063 } & \text { P.065 } & \text { P.066 }\end{array}$ $\begin{array}{llllll}\text { P.067 R.502 } & \text { R.504 } & \text { S.539 } & \text { S.592 } & \text { S.718 } & \text { W.113. See also Hebraisms }\end{array}$

antithetical P.060 P.073

parenting B.434 H.254 R.036

$\begin{array}{llllllll}\text { parents teach children A.063 } & \text { A.077 } & \text { H.017 } & \text { H.055 } & \text { H.058 } & \text { R.048 } & \text { S.423 } & \text { T.139 }\end{array}$

Passover W.188. See also Jewish festivals 
patent R.086

$\begin{array}{lllll}\text { peace A.205 } & \text { C.454 H.328 } & \text { M.186 } & \text { R.045 } & \text { T.341 }\end{array}$

People of Ammon. See Anti-Nephi-Lehies

Pearl of Great Price A.153 S.555

perplexity $\mathrm{S} .129$

petroglyphs B.017. See also ancient writings in the Americas

Phelps, William W. J.098

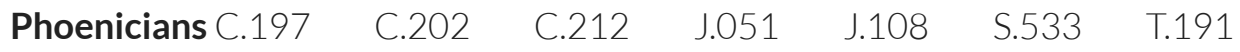

$\begin{array}{llllllllll}\text { plagiarism A.113 } & \text { B.085 } & \text { B.113 } & \text { B.263 } & \text { B.455 } & \text { C.345 } & \text { J.115 } & \text { L.019 } & \text { L.071 } & \text { L.081 }\end{array}$

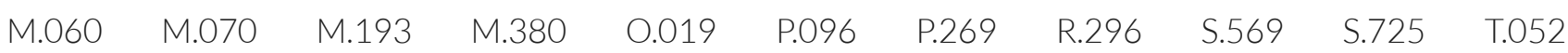

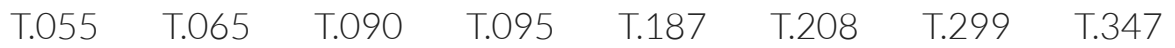

poetry

$\begin{array}{lllllllll}\text { contemporary A.159 } & \text { B.400 } & \text { B.496 } & \text { B.499 } & \text { C.118 } & \text { C.132 } & \text { C.388 } & \text { C.454 } & \text { D.132 }\end{array}$

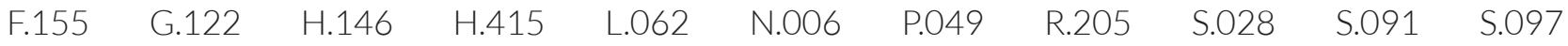

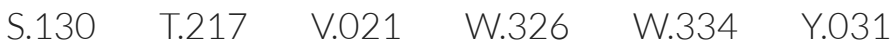

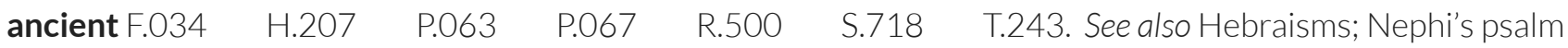

$\begin{array}{llllllllll}\text { polygamy B.267 } & \text { C.346 } & \text { E.002 } & \text { E.003 } & \text { I.016 } & \text { J.115 } & \text { K.018 } & \text { L.069 } & \text { L.140 } & \text { M.042 }\end{array}$

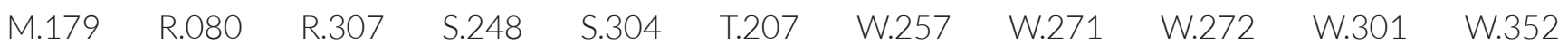

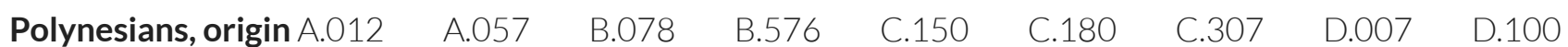

$\begin{array}{lllllllllll}H .313 & H .446 & J .068 & J .069 & J .079 & \text { K.050 } & \text { K.051 } & \text { L.178 } & \text { L.239 } & \text { M.135 } & \text { M.381 }\end{array}$

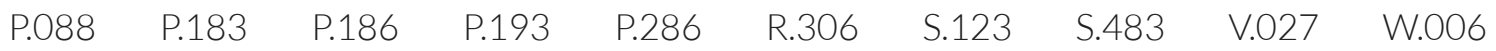

Popul Vuh. See ancient writings in the Americas

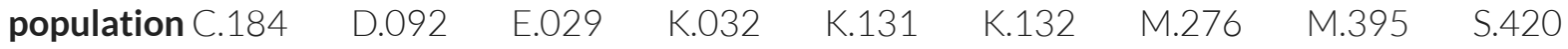

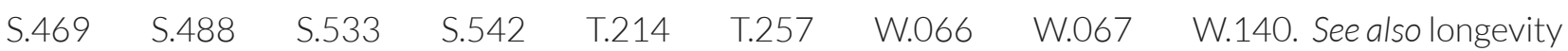

Pratt, Orson A.165 P.296 T.210 W.284

$\begin{array}{llll}\text { Pratt, Parley H.282 H.289 } \quad \text { K.099 W.284 Y.014 } & \text { W. }\end{array}$

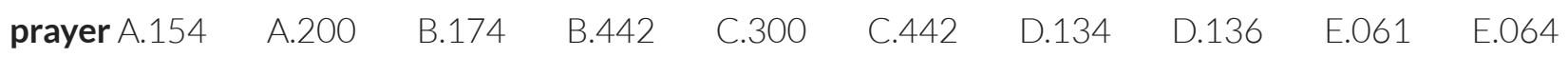

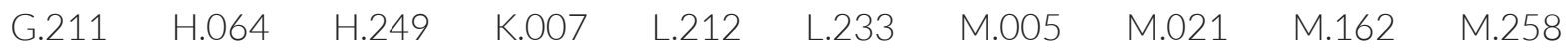

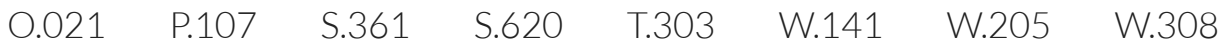


preexistence 0.051

$\begin{array}{llllllllll}\text { pride A.225 } & \text { B.094 } & \text { B.141 } & \text { B.241 } & \text { F.101 } & \text { H.068 } & \text { J.112 } & \text { L.148 } & \text { M.273 } & \text { P.182 }\end{array}$

$\begin{array}{lllll}\text { P.406 } & \text { R.271 } & \text { S.218 } & \text { U.003 } & \text { W.330 }\end{array}$

priestcraft $\mathrm{N} .176$

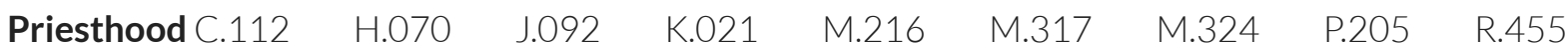

T.213 W.293 W.369

Aaronic S.355

among the Jaredites J.168

$\begin{array}{lllllllll}\text { among the Nephites C.370 } & \text { J.168 } & \text { M.324 } & \text { N.176 } & \text { P.201 } & \text { P.234 } & \text { R.406 } & \text { S.328 } & \text { S.347 }\end{array}$

$\begin{array}{llllll}\text { S.355 } & \text { S.373 } & \text { S.647 } & \text { S.710 } & \text { T.031 } & \text { W.300 }\end{array}$

Christ's teachings concerning S.347

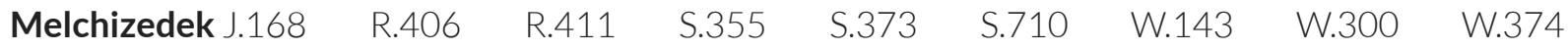

offices B.228 P.201 P.205

ordinances P.089 S.328 S.702

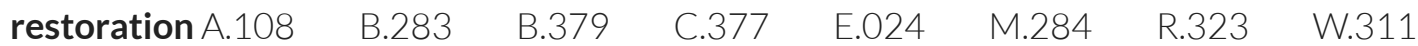

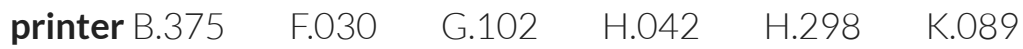

$\begin{array}{llllllll}\text { printer's manuscript B.375 } & \text { D.012 } & \text { H.206 } & \text { H.208 } & \text { H.219 } & \text { L.072 } & \text { L.079 } & \text { L.241 }\end{array}$

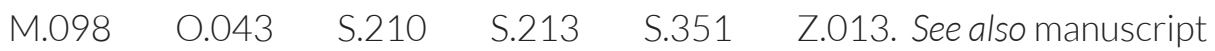

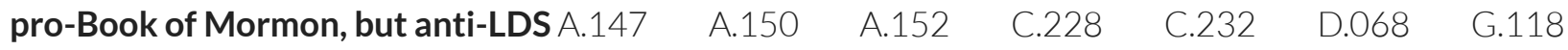

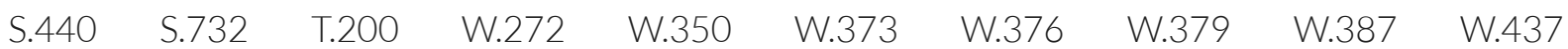

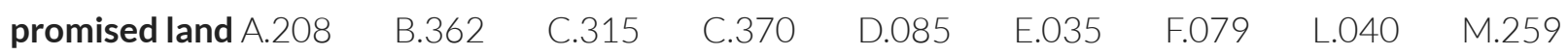

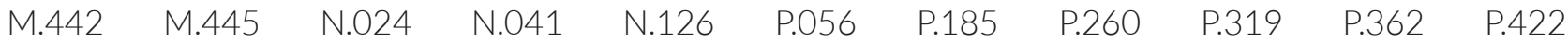

$\begin{array}{lllllllllll}\text { R.182 } & \text { R.301 } & \text { R.313 } & \text { R.341 } & \text { R.378 } & \text { R.384 } & \text { R.446 } & \text { R.465 } & \text { S.162 } & \text { S.457 } & \text { S.617 }\end{array}$

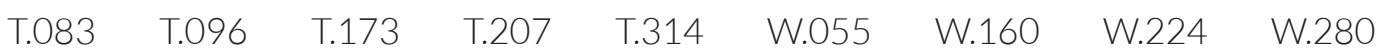

pronunciation guide M.343 P.095 R.077

$\begin{array}{lllllllll}\text { prophecies A.075 } & C .013 & \text { C.015 } & \text { C.031 } & \text { C.034 } & \text { C.037 } & \text { C.050 } & \text { C.071 } & \text { C.349 }\end{array}$

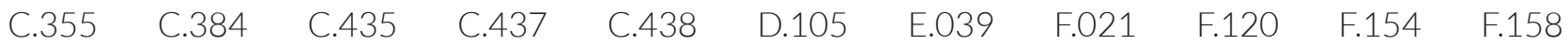

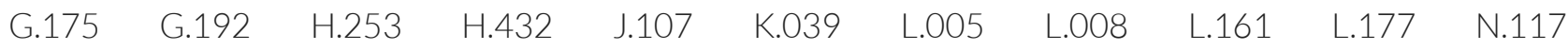

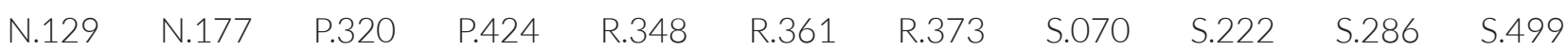

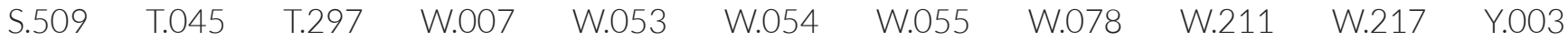




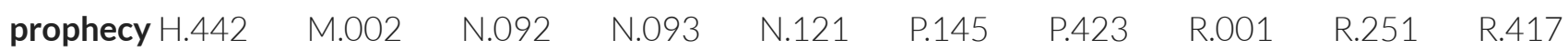
S.700

\section{prophetic curse P.072}

prosperity B.131 B.198 B.241

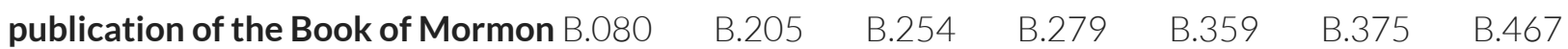

$\begin{array}{llllllllll}\text { B.508 } & \text { B.510 } & \text { C.072 } & \text { C.091 } & \text { G.063 } & \text { G.155 } & \text { H.042 } & \text { H.298 } & \text { H.336 } & \text { H.377 }\end{array}$

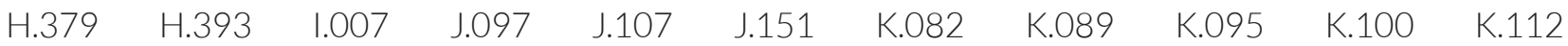

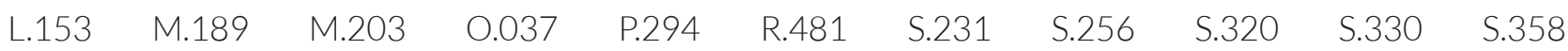

$\begin{array}{llllllllll}\text { S.367 } & \text { S.380 } & \text { S.425 } & \text { S.671 } & \text { S.672 } & \text { T.290 } & \text { T.291 } & \text { W.093 } & \text { W.261 } & \text { W.338 }\end{array}$

Pukei B.382 K.107

$\begin{array}{lllllll}\text { purpose of the Book of Mormon A.049 } & \text { B.056 } & \text { B.058 } & \text { B.059 } & \text { B.060 } & \text { B.061 } & \text { B.142 }\end{array}$

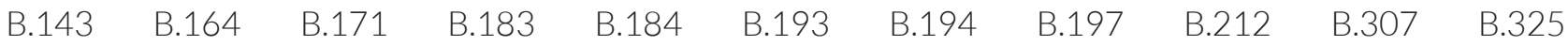

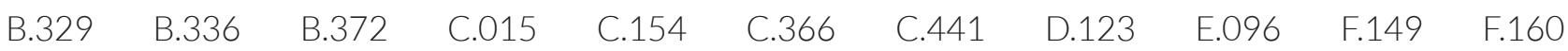

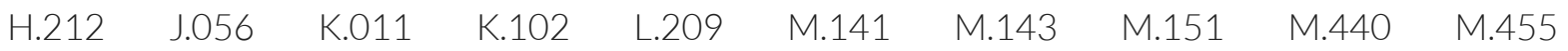

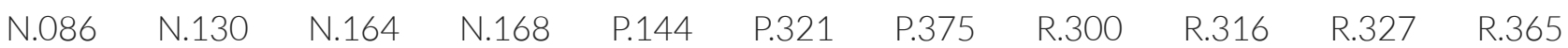

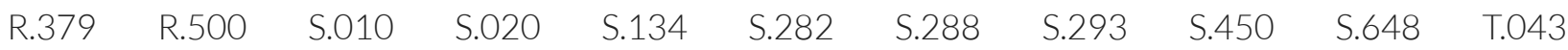

$\begin{array}{lllll}\text { T.092 } & \text { T.275 } & \text { W.330 } & \text { W.367 } & \text { W.431 }\end{array}$

$\begin{array}{lllllllll}\text { Quetzalcoatl A.032 } & \text { B.055 } & \text { C.143 } & \text { C.330 } & \text { G.167 } & \text { H.075 } & \text { H.080 } & \text { H.082 } & \text { H.329 }\end{array}$

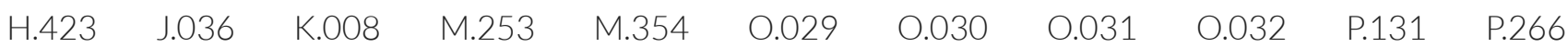

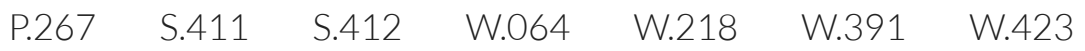

$\begin{array}{llllllllll}\text { racial beliefs D.100 } & \text { E.036 } & \text { E.051 } & \text { G.094 } & \text { H.120 } & \text { J.155 } & \text { M.042 } & \text { P.028 } & \text { P.029 } & \text { R.005 }\end{array}$

Rafinesque, C. S. B.262 J.158 N.085

$\begin{array}{llllllll}\text { read the book, advice to } \mathrm{A} .036 & \mathrm{~A} .056 & \mathrm{~A} .080 & \mathrm{~A} .137 & \mathrm{~A} .183 & \mathrm{~A} .202 & \mathrm{~B} .110 & \mathrm{~B} .051\end{array}$

$\begin{array}{llllllllllll}\text { B.153 } & \text { B.173 } & \text { B.175 } & \text { B.177 } & \text { B.179 } & \text { B.304 } & \text { B.319 } & \text { B.330 } & \text { B.335 } & \text { B.380 } & \text { B.427 } \\ \text { B.428 } & \text { B.550 } & \text { C.105 } & \text { C.339 } & \text { C.383 } & \text { C.404 } & \text { C.439 } & \text { C.450 } & \text { D.069 } & \text { D.089 } & \text { F.015 } \\ \text { F.062 } & \text { F.116 } & \text { F.124 } & \text { G.052 } & \text { G.149 } & \text { G.160 } & \text { H.148 } & \text { H.152 } & \text { H.155 } & \text { H.156 } & \text { H.158 } \\ \text { H.160 } & \text { H.319 } & \text { H.322 } & \text { H.363 } & \text { H.368 } & \text { H.370 } & \text { I.006 } & \text { J.140 } & \text { K.003 } & \text { K.086 } & \text { K.098 } \\ \text { L.024 } & \text { L.025 } & \text { L.026 } & \text { L.029 } & \text { L.093 } & \text { L.156 } & \text { M.011 } & \text { M.051 } & \text { M.151 } & \text { M.155 } & \text { M.250 } \\ \text { M.256 } & \text { M.311 } & \text { M.367 } & \text { N.013 } & \text { O.015 } & \text { P.013 } & \text { P.053 } & \text { P.108 } & \text { P.178 } & \text { P.238 } & \text { P.239 } \\ \text { P.281 } & \text { P.293 } & \text { P.401 } & \text { P.404 } & \text { P.426 } & \text { P.430 } & \text { R.004 } & \text { R.021 } & \text { R.025 } & \text { R.026 } & \text { R.050 } \\ \text { R.069 } & \text { R.221 } & \text { R.372 } & \text { R.441 } & \text { R.448 } & \text { R.455 } & \text { R.457 } & \text { R.458 } & \text { S.014 } & \text { S.060 } & \text { S.067 } \\ \text { S.083 } & \text { S.256 } & \text { S.301 } & \text { S.329 } & \text { S.330 } & \text { S.331 } & \text { S.337 } & \text { S.349 } & \text { S.354 } & \text { S.445 } & \text { S.451 } \\ \text { S.615 } & \text { S.677 } & \text { S.678 } & \text { S.680 } & \text { S.681 } & \text { S.716 } & \text { T.088 } & \text { T.140 } & \text { T.145 } & \text { T.171 } & \text { T.197 } \\ \text { T.202 } & \text { T.226 } & \text { U.009 } & \text { V.016 } & \text { W.037 } & \text { W.040 } & \text { W.045 } & \text { W.244 } & \text { W.411 } & \text { W. } 442 & \\ \text { Y.012 } & \text { Y.041 } & \text { Y.043 } & & & & & & & & \end{array}$


records that became the Book of Mormon C.329 $\quad \begin{array}{lllll}\text { H.074 } & H .093 & \text { H.383 } & \text { I.043 } & \text { J.071 }\end{array}$

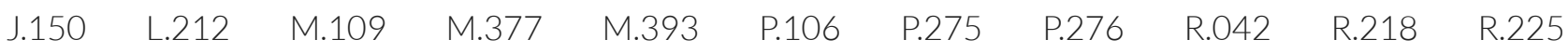

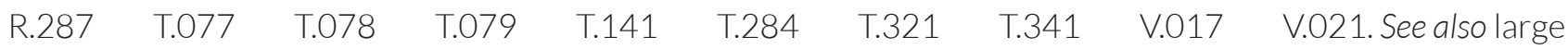
plates of Nephi; Lehi's record; small plates of Nephi

$\begin{array}{lllllllll}\text { reference books B.189 } & \text { B.222 } & \text { B.224 } & \text { B.245 } & \text { B.269 } & \text { B.422 } & \text { B.425 } & \text { B.528 } & \text { B.533 }\end{array}$

$\begin{array}{lllllllllll}\text { C.399 } & \text { C.422 } & \text { C.439 } & \text { E.076 } & \text { F.002 } & \text { F.080 } & \text { G.086 } & \text { G.091 } & \text { H.166 } & \text { H.172 } & \text { H.206 }\end{array}$

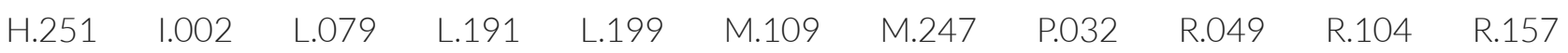

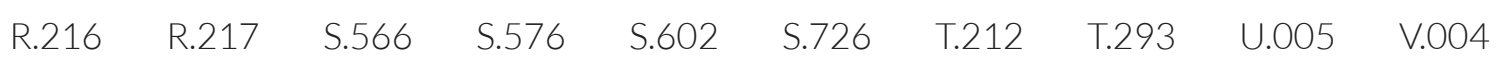

remember C.109 M.303 M.309

$\begin{array}{lllllllll}\text { repentance B.169 } & \text { C.082 } & \text { C.133 } & \text { C.139 } & \text { D.005 } & \text { G.087 } & \text { H.056 } & \text { H.374 } & \text { I.048 }\end{array}$

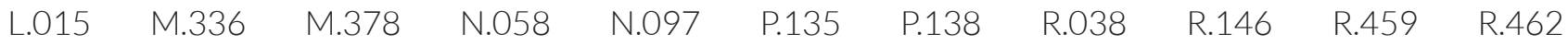

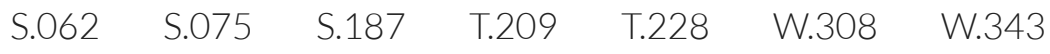

republican values $\mathrm{W} .372$

$\begin{array}{lllllll}\text { responses to Book of Mormon critics A.028 } & \text { A.053 } & \text { B.387 } & \text { B.463 } & \text { C.001 } & \text { C.079 } & \text { C.403 }\end{array}$

$\begin{array}{lllllllllll}\text { C.407 } & \text { F.081 } & \text { F.112 } & \text { F.141 } & \text { G.185 } & \text { G.188 } & \text { H.062 } & \text { H.106 } & \text { H.224 } & \text { H.291 } & \text { I.042 }\end{array}$

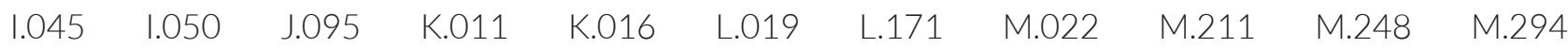

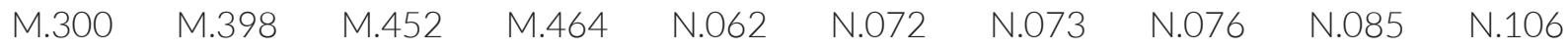

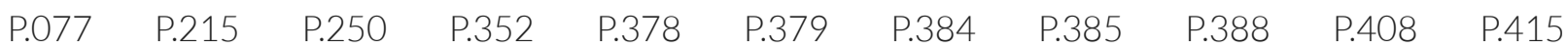

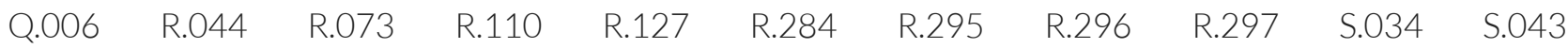

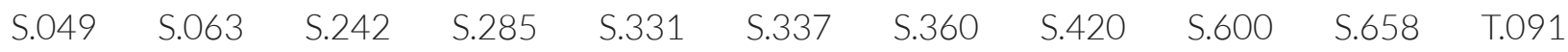
$\begin{array}{llllllllll}\text { T.104 T.106 } & \text { T.163 } & \text { T.173 } & \text { T.187 } & \text { U.016 } & \text { U.017 } & \text { W.079 } & \text { W.086 } & \text { W.089 } & \text { W.090 }\end{array}$ W.223 W.247 W.299 W.378 W.390

$\begin{array}{lllllllll}\text { Restoration B.278 } & \text { B.325 } & \text { C.353 } & \text { E.042 } & \text { E.097 } & \text { F.021 } & \text { F.154 } & \text { H.009 } & \text { H.384 }\end{array}$

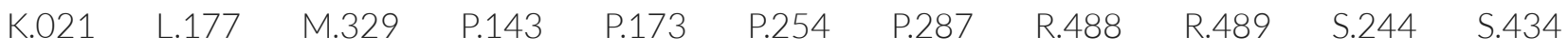
T.043 T.098 W.225 W.311

resurrection A.227 $\begin{array}{llllllll}\text { B.302 } & \text { B.340 } & \text { H.417 } & \text { L.200 } & \text { M.090 } & \text { M.102 } & \text { M.281 } & \text { M.329 }\end{array}$

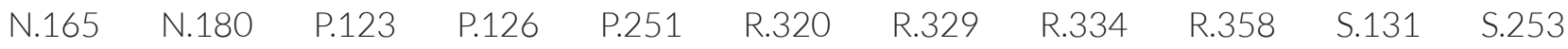
S.325 W.203

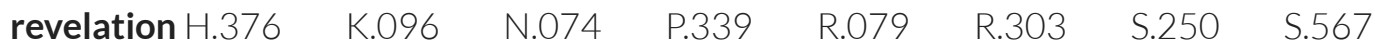

Revelation, book of C.396 M.062 N.131

$\begin{array}{llllllll}\text { revelation, continuing B.065 } & \text { B.159 } & \text { B.188 } & \text { B.449 } & \text { B.482 } & \text { L.069 } & \text { L.171 } & \text { L.187 }\end{array}$

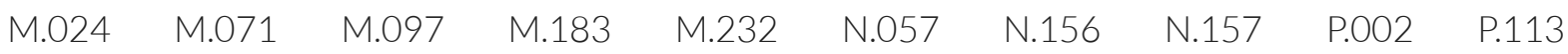

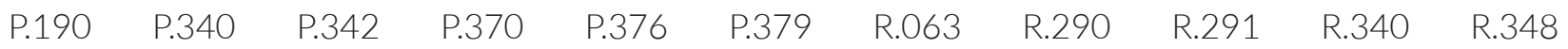

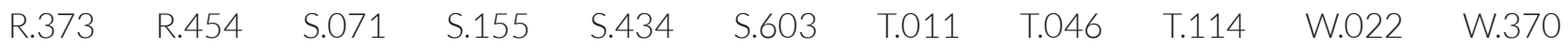
W.425 W.426 
$\begin{array}{llllllll}\text { Rigdon, Sidney B.100 } & \text { B.289 } & \text { C.002 } & \text { C.114 } & \text { M.237 } & \text { N.156 } & \text { R.274 } & \text { W.263 }\end{array}$

righteousness B.433 B.557 T.168

River of Nephi C.203

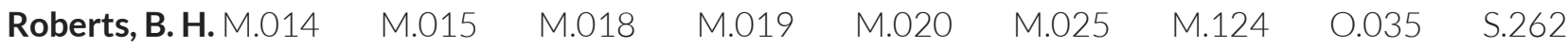

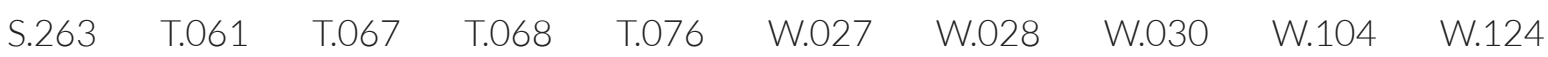
W.147 W.171 W.174

$\begin{array}{lllllllll}\text { Sacrament A.104 } & \text { B.065 } & \text { C.082 } & \text { G.191 } & \text { H.010 } & \text { L.236 } & \text { M.200 } & \text { M.391 } & \text { R.319 }\end{array}$ S.149 S.187 T.156 W.145

Sacred Grove J.072

Salamander letter A.084. See also forgeries; Martin Harris letter

$\begin{array}{lllllllllll}\text { salvation B.318 } & \text { B.516 } & \text { C.319 } & \text { C.436 } & \text { D.004 } & \text { D.106 } & \text { G.157 } & \text { H.125 } & \text { L.227 } & \text { M.153 } \\ \text { M.158 } & \text { M.322 } & \text { N.093 } & \text { N.180 } & \text { P.089 } & \text { P.123 } & \text { Q.001 } & \text { R.320 } & \text { R.330 } & \text { R.367 } & \text { S.336 } \\ \text { S.648 } & \text { S.710 } & \text { T.151 } & \text { T.236 } & \text { T.303 } & \text { V.033 } & \text { W.256 } & \text { W.308 } & \text { W.309 } & & \end{array}$

$\begin{array}{llllllll}\text { Samuel the Lamanite B.210 } & \text { B.251 } & \text { B.495 } & \text { B.496 } & \text { C.125 } & \text { G.025 } & \text { P.425 } & \text { R.120 }\end{array}$

$\begin{array}{lllllllll}\text { R.126 } & \text { R.168 } & \text { R.317 } & \text { R.366 } & \text { S.021 } & \text { S.093 } & \text { S.129 } & \text { T.024 } & \text { W.331 }\end{array}$

Sanctification L.230 M.322 $\quad$ M.330 P.242 V.011

Sariah A.076 D.051 R.112 Y.006

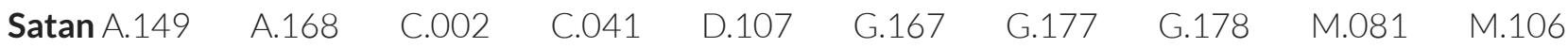

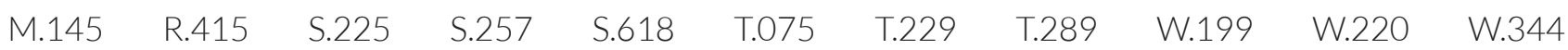
W.419 Z.006

scimitar H.039 H.354. See also warfare

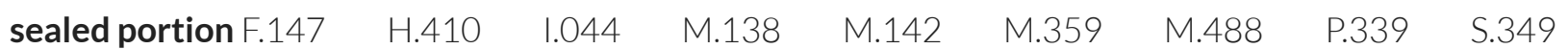

sealing powers B.516 J.010

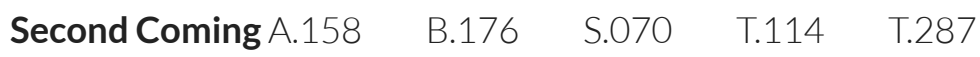

2 Nephi, book of L.227 $\quad$ M.325 N.166 U.006 V.010 V.012

$\begin{array}{llllllll}\text { secret combinations B.115 } & \text { C.043 } & \text { C.045 } & \text { C.058 } & \text { C.438 } & \text { D.129 } & \text { H.265 } & \text { L.094 }\end{array}$

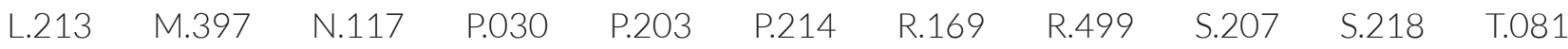

V.043 W.012 W.063 W.183 


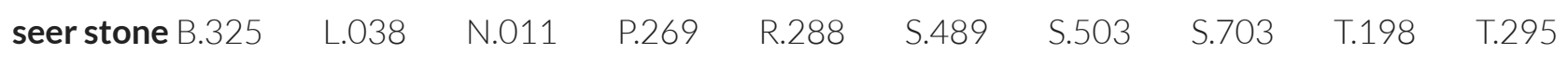

$\begin{array}{lllll}\text { V.042 W.214 W.377 W.378 } & \text { Y.007 }\end{array}$

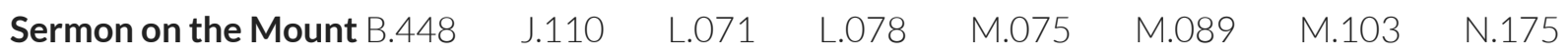

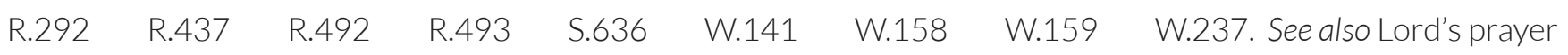

service B.240 S.228

sexual morality T.308

Shakers M.245

$\begin{array}{lllllll}\text { Shakespeare B.082 } & \text { B.267 } & \text { C.057 } & \text { L.152 } & \text { S.403 } & \text { T.052 } & \text { T.159 }\end{array}$

sheep. See other sheep

Sherem T.229 W.343

sign seeking C.002 P.082

silk C.338 S.507 S.522 T.300

simile curses $M .448$

simplified or modernized versions of the Book of Mormon A.082 $\quad$ B.558 $\quad$ F.068 $\quad$ F.071 H.181

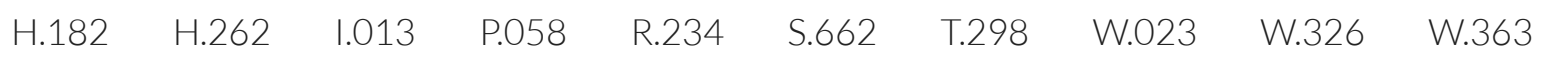

$\begin{array}{llllll}\sin \text { G.045 G.098 L.148 } & \text { M.335 } & \text { M.378 } & \text { T.151 } & \text { T.153 }\end{array}$

slavery C.016

$\begin{array}{llllllll}\text { small plates of Nephi B.535 } & \text { C.168 } & \text { G.036 } & \text { H.074 } & \text { M.348 } & \text { M.399 } & \text { N.181 } & 0.023\end{array}$

$\begin{array}{lllllll}\text { P.051 R.152 } & \text { R.222 } & \text { R.224 } & \text { S.438 } & \text { T.227 } & \text { T.341 } & \text { W.123. See also records that became the }\end{array}$

Book of Mormon

Smith, Alvin A.084

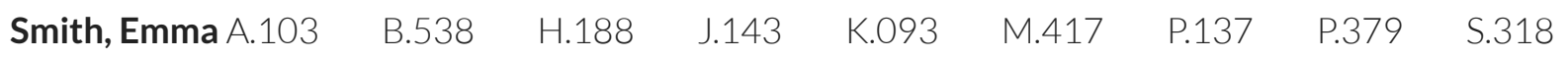

T.120 T.121 Y.040

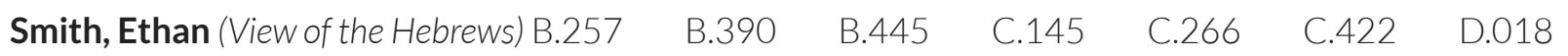

$\begin{array}{lllllllllll}\text { E.038 } & \text { H.312 } & \text { H.360 } & \text { J.156 } & \text { K.083 } & \text { L.090 } & \text { N.067 } & \text { O.014 } & \text { P.043 } & \text { P.157 } & \text { R.276 } \\ \text { R.278 } & \text { R.297 } & \text { R.298 } & \text { R.355 } & \text { R.397 } & \text { S.262 } & \text { S.552 } & \text { S.709 } & \text { S.733 } & \text { T.064 } & \text { T.067 } \\ \text { T.068 } & \text { T.076 } & \text { W.027 } & \text { W.032 } & \text { W.104 } & \text { W.171 } & \text { W.172 } & \text { W.203 } & & & \end{array}$

Smith, Hyrum H.447 R.206 


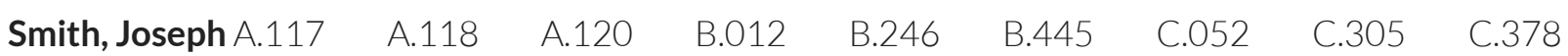

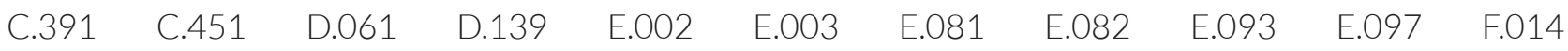

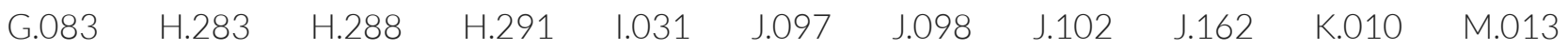

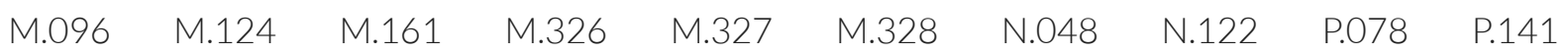

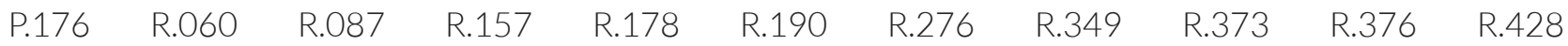

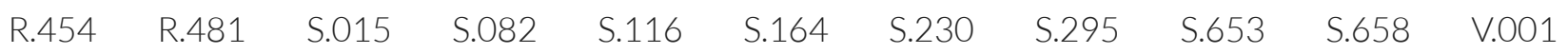
$\begin{array}{lllll}\text { V.015 W.007 W.055 W.372 W.386 W.429 } & \text { W. W. }\end{array}$

fallen prophet T.198 W.375 W.377

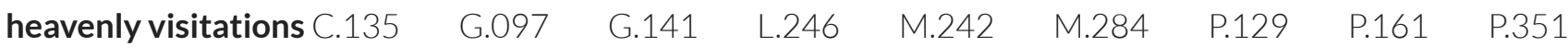
R.219 T.201 W.418

responded to provincial opinions of his time A.081 $\begin{array}{lllll}\text { A.139 } & \text { B.108 } & \text { B.234 } & \text { B.252 } & \text { B.469 }\end{array}$

$\begin{array}{llllllllll}\text { B.565 } & \text { B.571 } & \text { C.022 } & \text { C.171 } & \text { C.211 } & \text { C.409 } & \text { C.452 } & \text { D.050 } & \text { G.070 } & \text { G.189 }\end{array}$

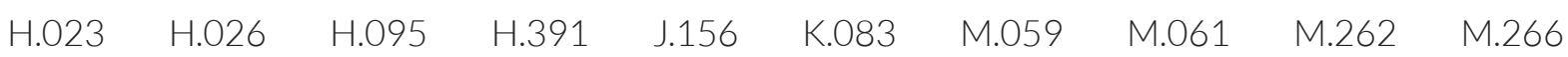

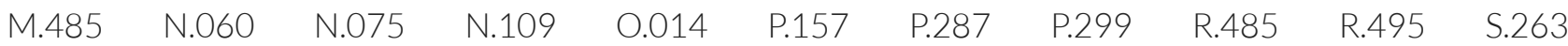

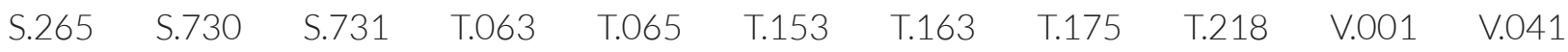

W.029

$\begin{array}{llll}\text { treasure searching A.099 } & \text { H.257 } & \text { H.300 } & \text { M.454 }\end{array}$

Smith, Joseph, Sr. L.049 R.276

Smith, Lucy Mack K.082

Smith, William P.236 P.237 W.340

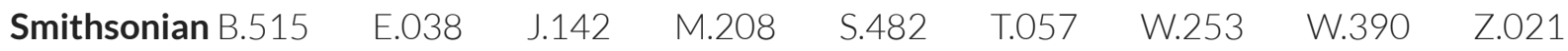

Solomon's temple A.218

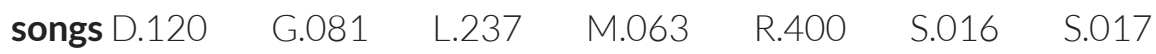

soteriology $\vee .046$

Spafford Manuscript A.126 A.146

$\begin{array}{llllllll}\text { Spaulding Manuscript B.019 } & \text { B.257 } & \text { B.439 } & \text { B.440 } & \text { B.441 } & \text { C.114 } & \text { C.115 } & \text { D.016 }\end{array}$

$\begin{array}{lllllllllll}\text { D.118 } & \text { F.010 } & \text { F.011 } & \text { F.012 } & \text { F.013 } & \text { G.178 } & \text { G.196 } & \text { H.024 } & \text { H.179 } & \text { H.191 } & \text { H.323 }\end{array}$

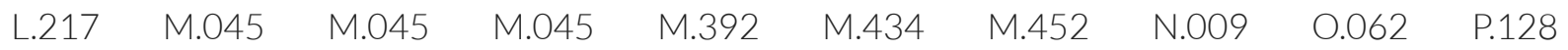

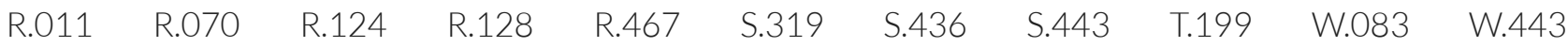

Y.033 Y.034

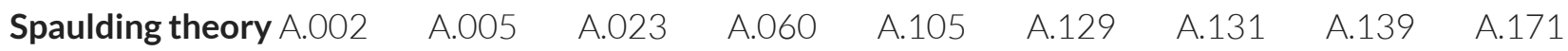
B.003
B.045 B.082
$\begin{array}{lll}\text { B.101 } & \text { B.263 B.272 }\end{array}$
B. 273
B. 274
B.293
B.306
B.324
B.375
B.392
B.393
B.397 B.402
B. 408
B.439
B. 440
B. 441
B.489
B.519 


\section{C.023}

C.091 C.266

C.341 C.381

C.387

C. 401

D.016 D.021

D. 025

D.026

D.072

D.073

D.074

D.075 E.047

E.095

E.110

F.010 F.011

F.05 F.073 F.117 G.071 G.140

G.179

G.196 G.206

H.133

H.134 H.174

H.19

H.192

H.236

H.274

H.281

H.288

H.324

H.375

H.400 H.414

$\begin{array}{lllllllllll}\text { J.101 } & \text { J.102 } & \text { J.137 } & \text { J.147 } & \text { K.017 } & \text { K.026 } & \text { K.033 } & \text { K.034 } & \text { K.079 } & \text { L.003 } & \text { L.006 }\end{array}$

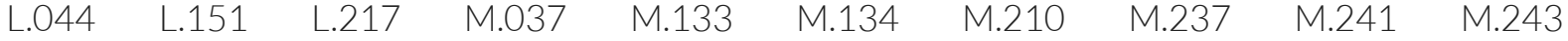

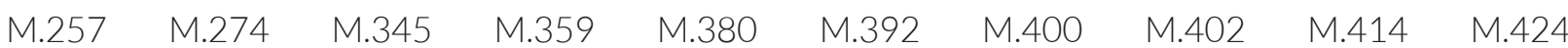

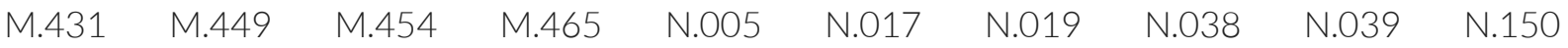

$\begin{array}{lllllllllll}\text { N.151 } & 0.038 & 0.039 & 0.061 & \text { P.004 } & \text { P.031 } & \text { P.044 } & \text { P.059 } & \text { P.091 } & \text { P.097 } & \text { P.098 }\end{array}$

$\begin{array}{lllllllllll}\text { P.122 } & \text { P.128 } & \text { P.132 } & \text { P.157 } & \text { P.199 } & \text { P.278 } & \text { P.304 } & \text { P.377 } & \text { P.363 } & \text { P.385 } & \text { P.418 }\end{array}$

$\begin{array}{lllllllllll}\text { P.432 } & \text { R.011 } & \text { R.060 } & \text { R.073 } & \text { R.112 } & \text { R.124 } & \text { R.274 } & \text { R.276 } & \text { R.312 } & \text { R.353 } & \text { R.369 }\end{array}$

$\begin{array}{lllllllllll}\text { R.429 } & \text { R.481 } & \text { S.003 } & \text { S.045 } & \text { S.046 } & \text { S.047 } & \text { S.082 } & \text { S.247 } & \text { S.255 } & \text { S.271 } & \text { S.417 }\end{array}$

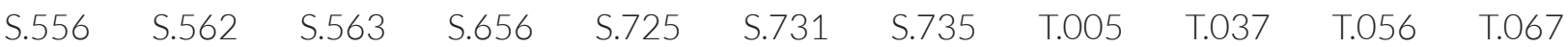

$\begin{array}{llllllllll}\text { T.095 } & \text { T.104 } & \text { T.301 } & \text { V.015 } & \text { W.018 } & \text { W.026 } & \text { W.031 } & \text { W.039 } & \text { W.083 } & \text { W.086 }\end{array}$

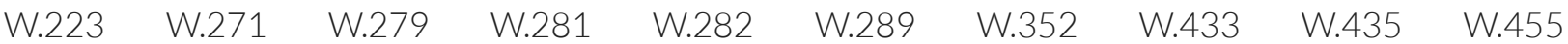

Y.034

$\begin{array}{llllllll}\text { Spaulding Solomon B.253 } & \text { D.016 } & \text { J.074 } & \text { J.158 } & \text { M.405 } & \text { S.625 } & \text { W.285 } & \text { W.371 }\end{array}$

speaking in tongues $\mathrm{C} .083$

spirit world N.180

$\begin{array}{llllllllll}\text { steel B.055 } & \text { B.458 } & \text { C.287 } & \text { D.039 } & \text { I.026 } & \text { I.040 } & \text { I.051 } & \text { L.092 } & \text { N.074 } & 0.012\end{array}$

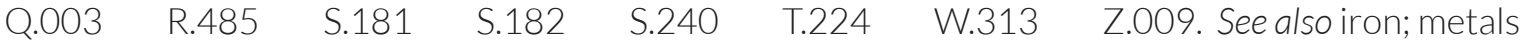

$\begin{array}{lllllllll}\text { Stela 5, Izapa C.205 } & \text { C.206 } & \text { C.209 } & \text { D.097 } & \text { G.046 } & \text { G.186 } & \text { H.362 } & \text { J.029 } & \text { J.033 }\end{array}$ $\begin{array}{lllllllll}\text { J.034 } & \text { J.047 } & \text { N.138 } & \text { P.057 } & \text { R.009 } & \text { S.696 } & \text { T.060 } & \text { T.074 } & \text { W.390. See also tree of life }\end{array}$

$\begin{array}{llllllll}\text { sticks of Judah and Ephraim A.069 } & \text { A.074 } & \text { A.130 } & \text { B.079 } & \text { B.277 } & \text { B.388 } & \text { B.446 } & \text { B.476 }\end{array}$

$\begin{array}{llllllllll}\text { E.041 } & \text { F.072 } & \text { G.094 } & \text { G.200 } & \text { H.292 } & \text { H.395 } & \text { H.411 } & \text { K.005 } & \text { L.214 } & \text { M.286 }\end{array}$

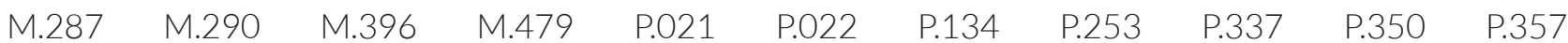

$\begin{array}{lllllllllll}\text { R.030 } & \text { R.058 } & \text { R.194 } & \text { S.362 } & \text { S.564 } & \text { S.601 } & \text { S.633 } & \text { S.661 } & \text { S.665 } & \text { S.666 } & \text { S.667 }\end{array}$

T.036 W.044 W.256 W.425

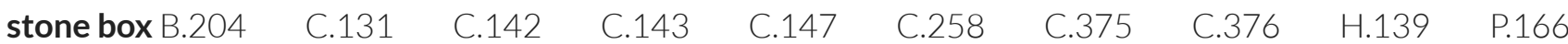
P.179 $\quad$ P.369 $\quad$ S.686 $\quad$ W.444

$\begin{array}{llllll}\text { stories from the Book of Mormon for children A.001 } & \text { A.004 } & \text { A.035 } & \text { A.045 } & \text { A.066 } & \text { A.078 }\end{array}$

$\begin{array}{lllllllllll}\text { B.083 } & \text { B.084 } & \text { B.086 } & \text { B.214 } & \text { B.215 } & \text { B.414 } & \text { B.417 } & \text { B.470 } & \text { B.500 } & \text { B.517 } & \text { B.518 }\end{array}$

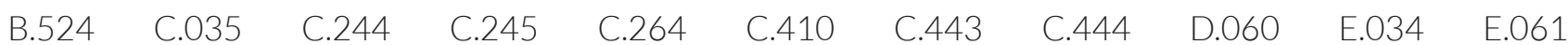

$\begin{array}{lllllllllll}\text { E.062 } & \text { E.063 } & \text { F.028 } & \text { F.038 } & \text { F.039 } & \text { F.040 } & \text { F.041 } & \text { F.118 } & \text { G.003 } & \text { G.004 } & \text { G.005 }\end{array}$

$\begin{array}{llllllllll}\text { G.006 } & \text { G.007 } & \text { G.008 } & \text { G.008 } & \text { G.010 } & \text { G.011 } & \text { G.012 } & \text { G.013 } & \text { G.014 } & \text { G.015 }\end{array}$

$\begin{array}{llllllllll}\text { G.016 } & \text { G.017 } & \text { G.018 } & \text { G.019 } & \text { G.020 } & \text { G.021 } & \text { G.022 } & \text { G.023 } & \text { G.024 } & \text { G.025 }\end{array}$

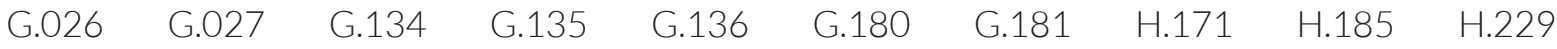

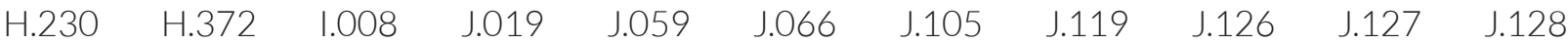

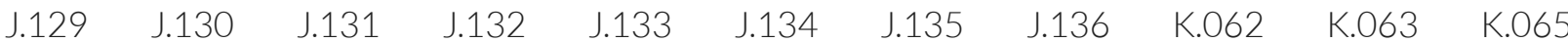


$\begin{array}{lllllllllll}\text { K.121 } & \text { L.068 } & \text { L.098 } & \text { L.113 } & \text { L.114 } & \text { L.115 } & \text { L.116 } & \text { L.145 } & \text { L.160 } & \text { L.175 } & \text { M.048 }\end{array}$ $\begin{array}{llllllllll}\text { M.049 } & \text { M.385 } & \text { M.438 } & \text { M.460 } & \text { M.463 } & \text { N.015 } & \text { N.016 } & \text { N.040 } & \text { N.041 } & \text { P.109 }\end{array}$ $\begin{array}{lllllllllll}\text { P.135 } & \text { P.159 } & \text { P.160 } & \text { P.181 } & \text { P.309 } & \text { P.425 } & \text { R.422 } & \text { S.141 } & \text { S.690 } & \text { S.697 } & \text { T.225 }\end{array}$ W.240 W.241 W.242 W.254

Stowell, Josiah $J .098$

straight/strait W.125

$\begin{array}{lllllllll}\text { study guides A.080 } & \text { A.133 } & \text { A.160 } & \text { B.066 } & \text { B.136 } & \text { B.207 } & \text { B.219 } & \text { B.346 } & \text { B.349 }\end{array}$

$\begin{array}{lllllllllll}\text { B.383 } & \text { B.487 } & \text { B.488 } & \text { B.560 } & \text { B.573 } & \text { B. } 575 & \text { C.117 } & \text { C.243 } & \text { C.250 } & \text { C.262 } & \text { C.265 }\end{array}$

$\begin{array}{llllllllllll}\text { C.439 } & \text { E.007 } & \text { F.072 } & \text { G.033 } & \text { H.054 } & \text { H.059 } & \text { H.063 } & \text { H.182 } & \text { H.185 } & \text { H.371 } & \text { I.023 }\end{array}$

$\begin{array}{llllllllllll}\text { J.013 } & \text { J.014 } & \text { J.141 } & \text { J.149 } & \text { K.035 } & \text { L.191 } & \text { L.192 } & \text { L.195 } & \text { L.196 } & \text { L.198 } & \text { L.201 }\end{array}$

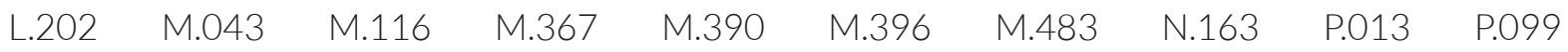

$\begin{array}{lllllllllll}\text { P.117 } & \text { P.119 } & \text { P.155 } & \text { P.258 } & \text { P.270 } & \text { P.423 } & \text { R.028 } & \text { R.050 } & \text { R.213 } & \text { R.399 } & \text { R.475 }\end{array}$

$\begin{array}{lllllllllll}\text { S.114 } & \text { S.115 } & \text { S.190 } & \text { S.219 } & \text { S.554 } & \text { S.566 } & \text { S.715 } & \text { T.242 } & \text { T.246 } & \text { W.071 } & \text { W.222 }\end{array}$

W.249

$\begin{array}{lllllll}\text { subtitle A.125 } & \text { A.127 } & \text { B.345 } & \text { H.166 } & \text { M.320 } & \text { M.432 } & \text { S.163 }\end{array}$

Sumerians B.258 F.005

summary of the Book of Mormon A.073 H.184. See also overview

survivors T.169

Susquehanna County, Pennsylvania B.244

sword of Laban. See Laban, sword of

$\begin{array}{llllllllll}\text { symbols L.119 } & \text { M.012 } & \text { N.094 } & 0.017 & 0.020 & \text { P.039 } & \text { P.072 } & \text { P.283 } & \text { R.263 } & \text { R.501 }\end{array}$ $\begin{array}{lllllll}\text { S.076 } & \text { S.078 } & \text { T.166 } & \text { T.167 } & \text { W.010 } & \text { W.199 } & \text { W.221 }\end{array}$

synagogues $W .164$

$\begin{array}{lllllllll}\text { teaching aids B.195 } & \text { B.223 } & \text { B.224 } & \text { B.321 } & \text { C.187 } & \text { G.062 } & \text { G.120 } & \text { G.181 } & \text { N.179 }\end{array}$

$\begin{array}{lllllllllll}0.045 & 0.063 & \text { P.033 } & \text { R.066 } & \text { R.230 } & \text { R.392 } & \text { S.158 } & \text { S.423 } & \text { S.668 } & \text { T.113 } & \text { T.202 }\end{array}$ $\begin{array}{lllllll}\text { T.294 } & \text { T.326 } & \text { V.007 } & \text { V.008 } & \text { W.070 } & \text { W.151 } & \text { W.442 }\end{array}$

Teancum C.174 R.121

Teichert, Minerva Kohlhepp E.010 J.118

temple worship L.235 $\quad$ M.314 N.050 P.071

$\begin{array}{llllllll}\text { ten commandments B.357 } & \text { C.351 } & \text { C.397 } & 1.047 & \text { P.325 } & \text { P.354 } & \text { R.267 } & \text { S.077 }\end{array}$ 
$\begin{array}{llllllll}\text { testify of Jesus Christ A.136 } & \text { B.059 } & \text { B.146 } & \text { B.154 } & \text { B.236 } & \text { B.237 } & \text { B.238 } & \text { B.242 }\end{array}$

$\begin{array}{lllllllllll}\text { B.301 } & \text { B.302 } & \text { B.307 } & \text { B.340 } & \text { B.345 } & \text { B.364 } & \text { B.388 } & \text { B.429 } & \text { B.449 } & \text { B.477 } & \text { B.483 } \\ \text { B.486 } & \text { C.241 } & \text { C.251 } & \text { C.252 } & \text { C.358 } & \text { C.405 } & \text { D.033 } & \text { D.067 } & \text { D.129 } & \text { D.135 } & \end{array}$

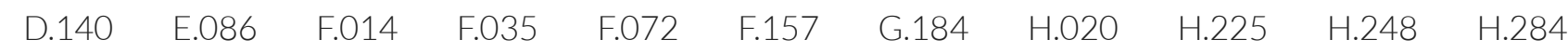

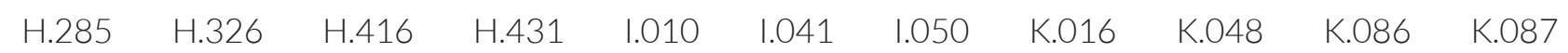

$\begin{array}{lllllllll}\text { K.103 L.059 L.109 } & \text { M.040 } & \text { M.041 } & \text { M.042 } & \text { M.083 } & \text { M.120 } & \text { M.127 } & \text { M.140 }\end{array}$

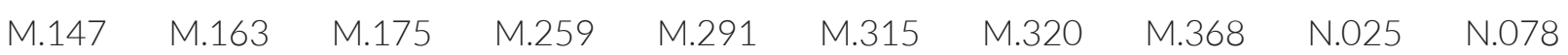

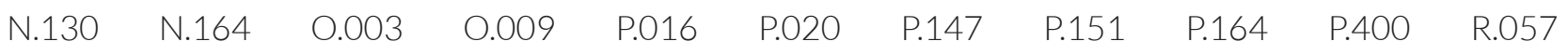

$\begin{array}{lllllllllll}\text { R.072 } & \text { R.081 } & \text { R.082 } & \text { R.184 } & \text { R.189 } & \text { R.197 } & \text { R.199 } & \text { R.294 } & \text { R.300 } & \text { R.314 } & \text { R.326 }\end{array}$

$\begin{array}{lllllllllll}R .327 & R .360 & R .379 & R .387 & R .390 & R .444 & R .450 & R .498 & S .035 & S .067 & \text { S.249 }\end{array}$

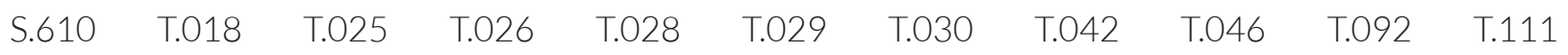

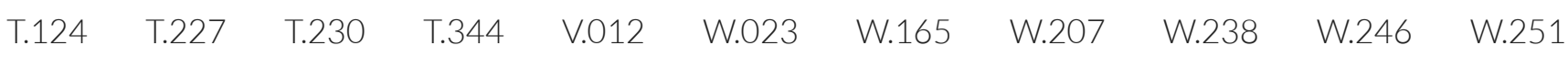

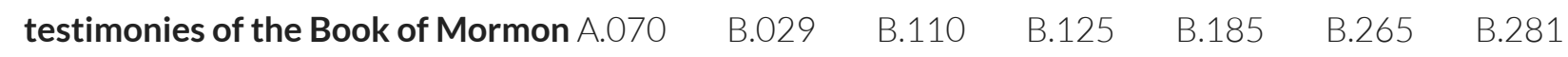

$\begin{array}{lllllllllll}\text { B.285 } & \text { B.294 } & \text { B.364 } & \text { B.426 } & \text { B.481 } & \text { B.520 } & \text { B.553 } & \text { C.009 } & \text { C.017 } & \text { C.054 } & \text { C.072 }\end{array}$

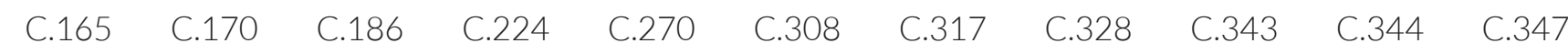

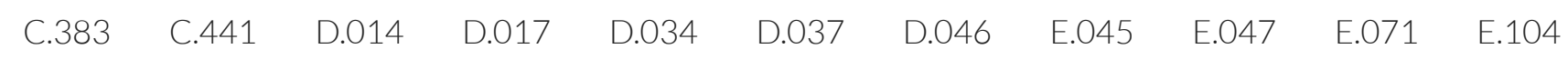

$\begin{array}{llllllllllll}\text { F.048 } & \text { F.097 } & \text { F.127 } & \text { G.051 } & \text { G.118 } & \text { G.150 } & \text { G.155 } & \text { G.157 } & \text { H.066 } & \text { H.094 } & \text { H.294 }\end{array}$

$\begin{array}{lllllllllll}H .447 & I .024 & J .073 & J .124 & J .148 & \text { K.006 } & \text { K.007 } & \text { K.009 } & \text { K.092 } & \text { K.102 } & \text { L.083 }\end{array}$

$\begin{array}{llllllllll}\text { L.133 L.163 } & \text { L.174 } & \text { L.179 } & \text { L.205 } & \text { L.243 } & \text { M.008 } & \text { M.039 } & \text { M.129 } & \text { M.214 } & \text { M.249 }\end{array}$

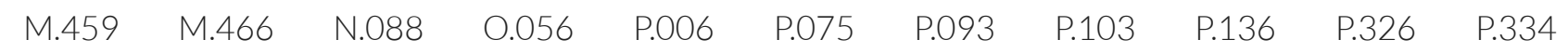

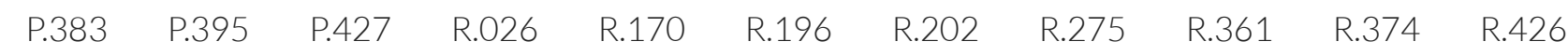

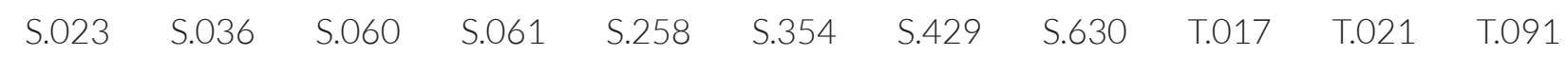

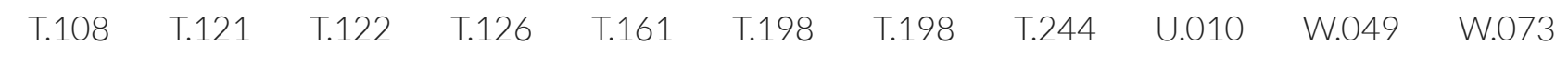
$\begin{array}{lllllll}\text { W.084 W.092 W.107 W.208 W.273 W.304 W.379 W.428 } & \text { W. W. }\end{array}$

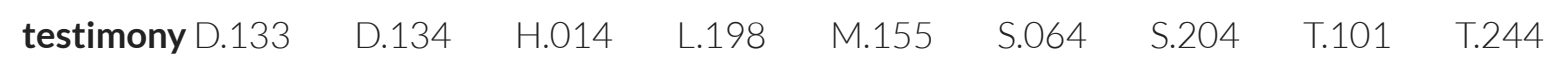

$\begin{array}{lllllllll}\text { textual variants A.059 } & \text { A.148 } & \text { B.021 } & \text { B.085 } & \text { B.297 } & \text { B.315 } & \text { B.419 } & \text { B.513 } & \text { B.539 }\end{array}$

$\begin{array}{lllllllllll}\text { B.551 } & \text { C.011 } & \text { C.012 } & \text { C.026 } & \text { C.266 } & \text { E.031 } & \text { F.033 } & H .026 & H .050 & H .197 & H .211\end{array}$

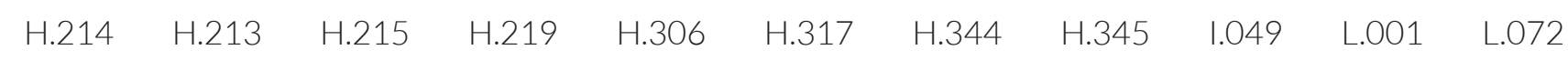
$\begin{array}{llllllllll}\text { L.073 L.074 } & \text { L.079 } & \text { L.080 } & \text { L.155 } & \text { L.203 } & \text { M.094 } & \text { M.110 } & \text { M.185 } & \text { M.224 } & \text { P.018 }\end{array}$

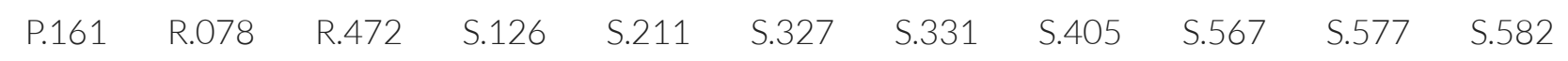
$\begin{array}{lllllll}\text { T.019 T.059 } & \text { T.203 } & \text { T.204 } & \text { W.029 W.047 W.048 W.223 } \quad \text { Z.017. See also critical text }\end{array}$

theophany T.150 W.178

throne 0.053

thieves and robbers W.166 W.168

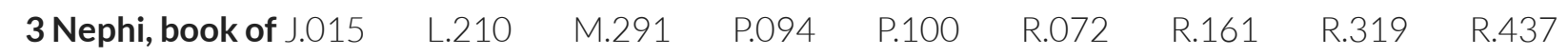
S.112 S.636 S.738

$\begin{array}{lllllllll}\text { Three Nephites A.062 } & \text { B.107 } & \text { B.124 } & \text { C.367 } & \text { G.028 } & \text { H.052 } & \text { H.253 } & \text { H.315 } & \text { H.404 }\end{array}$

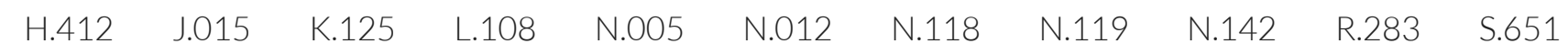
T.194 W.364 
Title of Liberty B.170 F.037 L.010 S.740 T.182

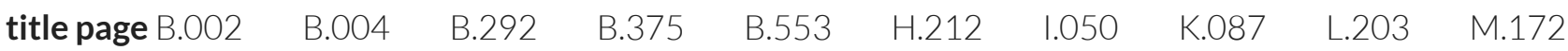

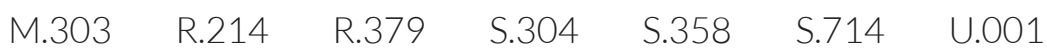

$\begin{array}{lllllllll}\text { topical indexes B.373 } & \text { B.561 } & \text { B.573 } & \text { B.575 } & \text { C.025 } & \text { C.399 } & \text { G.197 } & \text { L.091 } & \text { M.056 }\end{array}$

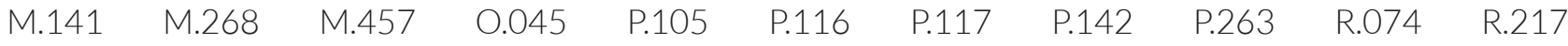

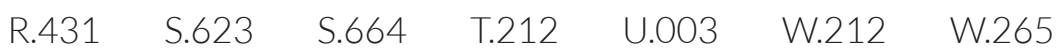

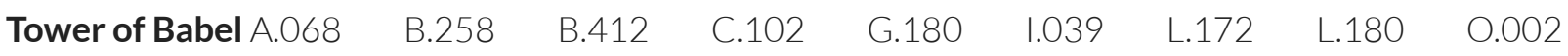
S.241 S.486 T.082 W.406

$\begin{array}{llllllllll}\text { tract C.263 } & \text { C.269 } & \text { C.270 } & \text { C.281 } & \text { E.026 } & \text { F.086 } & \text { H.004 } & \text { H.070 } & \text { I.023 } & \text { L.103 }\end{array}$

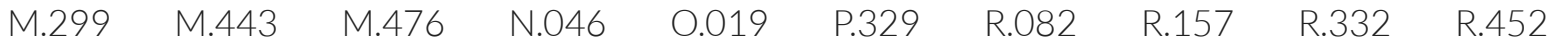
S.669 W.294 W.399

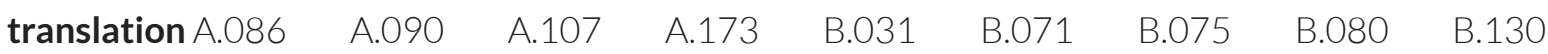

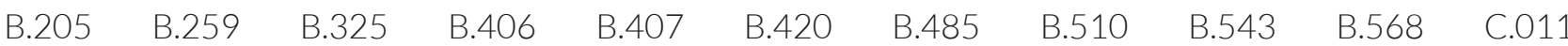

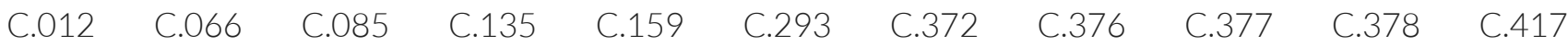

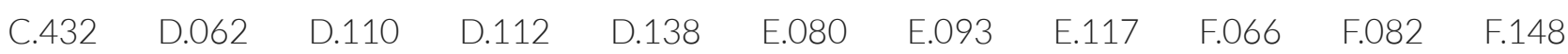

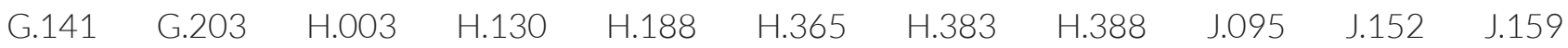

$\begin{array}{lllllllllll}\text { K.082 } & \text { K.090 } & \text { K.093 } & \text { K.095 } & \text { K.100 } & \text { K.105 } & \text { L.037 } & \text { L.038 } & \text { L.039 } & \text { L.090 } & \text { L.152 }\end{array}$

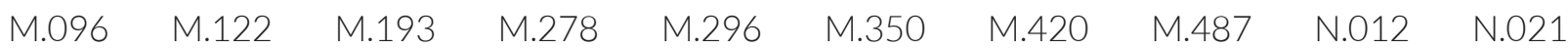

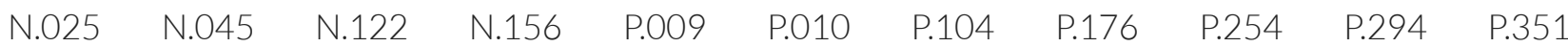

$\begin{array}{lllllllllll}\text { Q.006 } & \text { R.088 } & \text { R.090 } & \text { R.137 } & \text { R.138 } & \text { R.209 } & \text { R.254 } & \text { R.285 } & \text { R.288 } & \text { R.299 } & \text { R.312 }\end{array}$

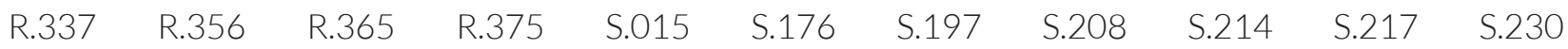

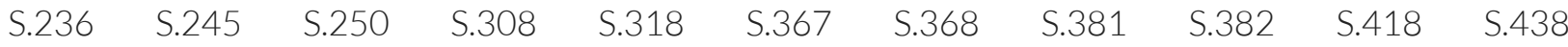

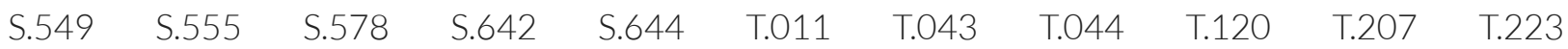

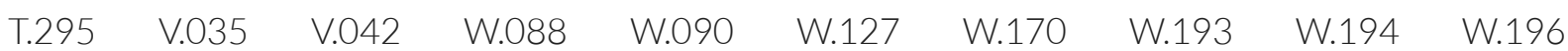

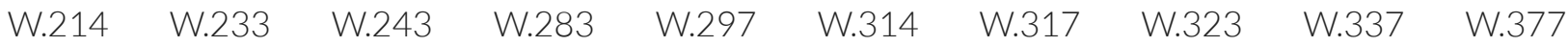
$\begin{array}{llll}\text { W.383 W.384 W.385 } & \text { Y.007 } & \text { Z.015 }\end{array}$

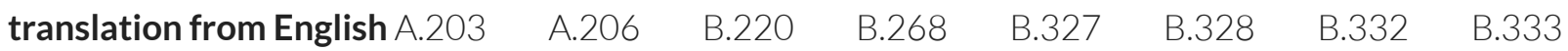

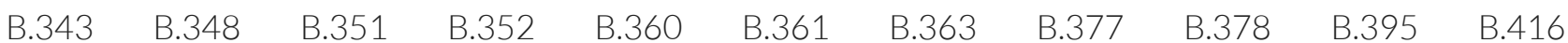

$\begin{array}{lllllllllll}\text { B.473 } & \text { C.021 } & \text { C.083 } & \text { C.084 } & \text { C.093 } & \text { C.336 } & \text { C.392 } & \text { D.038 } & \text { D.126 } & \text { E.068 } & \text { F.069 }\end{array}$

$\begin{array}{llllllllllll}\text { F.093 } & \text { F.094 } & \text { G.119 } & \text { G.162 } & \text { G.194 } & \text { H.150 } & \text { H.151 } & \text { H.153 } & \text { H.154 } & \text { H.164 } & \text { H.239 }\end{array}$

\begin{tabular}{lllllllllll}
\hline .028 & 1.034 & $J .021$ & $J .052$ & $J .063$ & $J .083$ & K.112 & K.120 & L.045 & L.084 & L.102
\end{tabular}

$\begin{array}{lllllllllll}\text { L.158 } & \text { L.217 } & \text { L.218 } & \text { M.136 } & \text { M.363 } & \text { M.387 } & \text { N.049 } & \text { N.152 } & \text { P.020 } & \text { P.421 } & \text { R.167 }\end{array}$

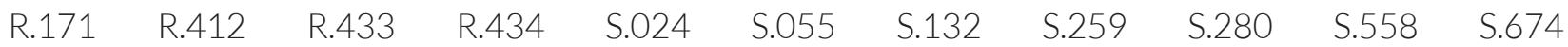

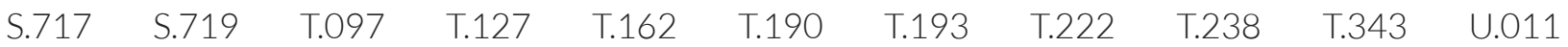
$\begin{array}{llllll}\text { U.012 W.015 W.056 } & \text { W.389 } & \text { W.454 } & \text { Y.035 } & \text { Z.014 }\end{array}$

$\begin{array}{llllllll}\text { transoceanic crossings B.039 } & \text { B.072 } & \text { C.065 } & \text { C.088 } & \text { C.129 } & \text { C.144 } & \text { C.201 } & \text { C.212 }\end{array}$

$\begin{array}{llllllllll}\text { C.214 } & \text { C.215 } & \text { C.223 } & \text { D.006 } & \text { E.066 } & \text { E.105 } & \text { G.128 } & \text { G.129 } & \text { G.163 } & \text { H.104 }\end{array}$

$\begin{array}{lllllllllll}H .111 & H .189 & J .043 & J .051 & J .061 & J .106 & J .146 & \text { L.097 } & \text { L.176 } & \text { M.356 } & \text { N.074 }\end{array}$

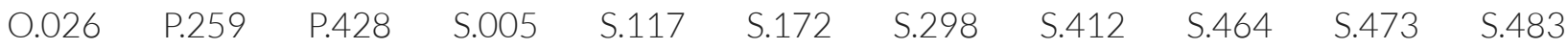




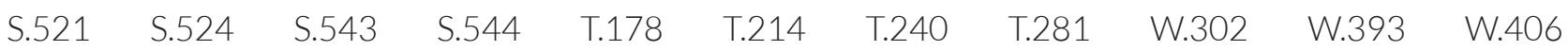
Y.020

$\begin{array}{llllllllllll}\text { tree of life A.116 } & \text { B.235 } & \text { B.249 } & \text { B.413 } & \text { B.421 } & \text { B.445 } & \text { B.546 } & \text { C.131 } & \text { C.196 } & \text { C.205 } \\ \text { C.206 } & \text { C.208 } & \text { C.209 } & \text { C.218 } & \text { C.360 } & \text { D.097 } & \text { G.046 } & \text { G.186 } & \text { G.190 } & \text { H.084 } & \\ \text { H.362 } & \text { I.017 } & \text { J.011 } & \text { J.024 } & \text { J.029 } & \text { J.033 } & \text { J.034 } & \text { J.045 } & \text { J.047 } & \text { J.160 } & \text { J.161 } \\ \text { M.012 } & \text { M.314 } & \text { N.094 } & \text { N.138 } & \text { N.140 } & \text { O.025 } & \text { P.039 } & \text { P.057 } & \text { R.009 } & \text { R.396 } & \text { S.277 } \\ \text { T.109 } & \text { W.391 } & \text { W.393 } & \text { W.415 } & \text { W.416. See also Lehi, dream of tree of life } & & & \end{array}$

tribal structure S.542 T.284 T.316

tumbaga P.431 S.398. See also gold plates; metals

Twain, Mark C.390

$\begin{array}{lllllll}\text { two thousand stripling warriors A.234 } & \text { B.095 } & \text { B.180 } & \text { C.042 } & \text { G.012 } & \text { G.136 } & \text { H.230 }\end{array}$ N.135 T.325

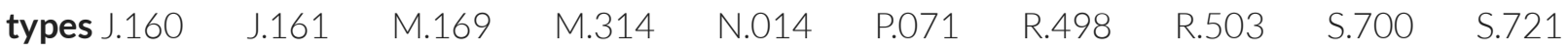

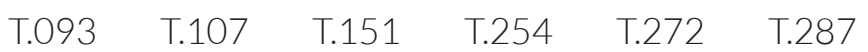

UFOs L.070

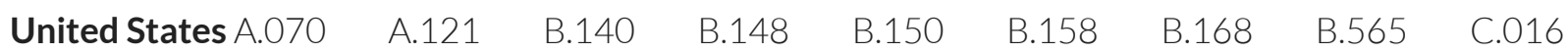

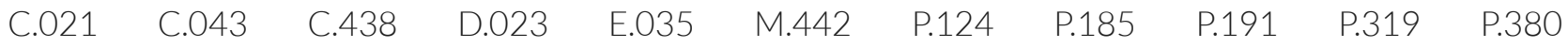
$\begin{array}{lllllll}\text { R.378 } & \text { R.389 } & \text { R.438 } & \text { T.006 } & \text { T.007 } & \text { T.012 } & \text { T.083 }\end{array}$ W.280. See also constitution, United States

$\begin{array}{lllllllll}\text { Urim and Thummim B.031 } & \text { B.226 } & \text { B.456 } & \text { C.011 } & \text { C.012 } & \text { C.135 } & \text { C.386 } & \text { F.125 } & \text { H.116 }\end{array}$

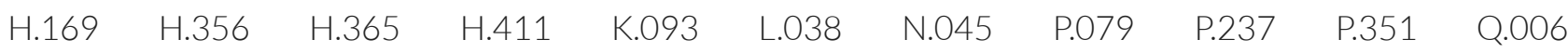

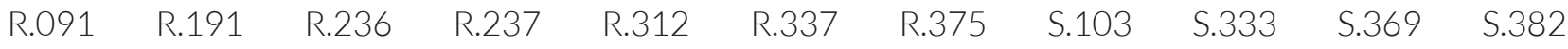

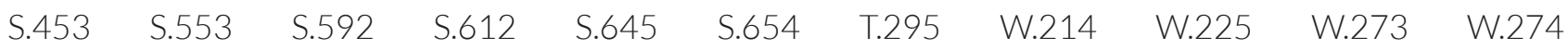
$\begin{array}{lllll}\text { W.317 W.318 W.337 W.368 W.404 } & \text { W.007. }\end{array}$

"vineyard" T.344

Walam Olum B.262. See also ancient writings in the Americas

wandering Jew G.028

$\begin{array}{llllllllll}\text { warB.201 } & \text { C.096 } & \text { E.053 } & \text { F.065 } & \text { G.041 } & \text { G.042 } & \text { G.120 } & \text { H.121 } & \text { H.264 } & \text { H.279 }\end{array}$

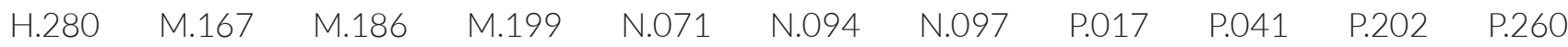

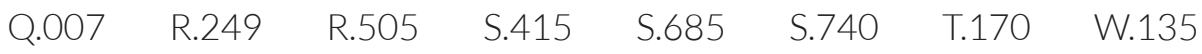

$\begin{array}{lrrrrrrrrrr}\text { warfare } & \text { A.043 } & \text { B.103 } & \text { B.187 } & \text { B.217 } & \text { D.029 } & \text { G.042 } & \text { G.044 } & \text { H.028 } & H .030 & H .033 \\ \text { H.037 } & \text { H.038 } & \text { H.039 } & \text { H.040 } & \text { H.091 } & \text { H.279 } & \text { H.280 } & \text { H.303 } & \text { H.354 } & \text { I.026 } & \text { K.025 } \\ \text { L.234 } & \text { M.169 } & \text { M.267 } & \text { N.051 } & \text { N.101 } & \text { N.108 } & \text { P.412 } & \text { R.098 } & \text { R.133 } & \text { R.262 } & \text { R.264 }\end{array}$




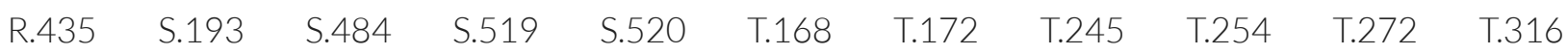
$\begin{array}{lllll}\text { W.038 W.043 W.063 W.102 } & \text { W.122 } & \text { W.177 }\end{array}$

weights and measurements F.005 H.224 J.096 P.202 R.123. See also monetary systems welfare A.024 K.023

Wentworth letter K.099

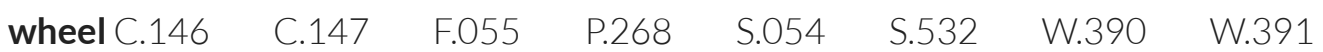

$\begin{array}{llllll}\text { Whitmer family A.110 } & \text { M.053 } & \text { M.201 } & 0.042 & \text { P.139 } & \text { W.337 }\end{array}$

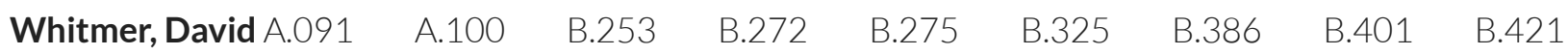

$\begin{array}{llllllllll}\text { C.060 } & \text { C.116 } & \text { C.344 } & \text { D.012 } & \text { D.013 } & \text { D.014 } & \text { G.118 } & \text { H.142 } & \text { H.146 } & \text { H.386 }\end{array}$

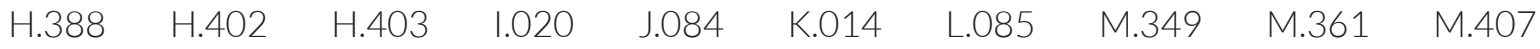

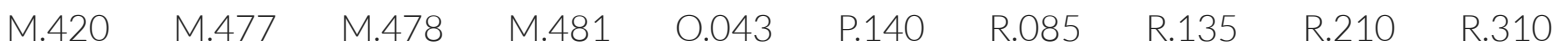

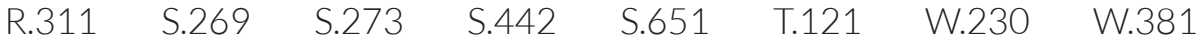

Whitmer, John H.399

wickedness C.352

$\begin{array}{llllllll}\text { witness of the Holy Ghost B.123 } & \text { B.547 } & \text { E.112 } & \text { E.117 } & \text { G.210 } & \text { H.057 } & \text { H.144 } & \text { H.436 }\end{array}$

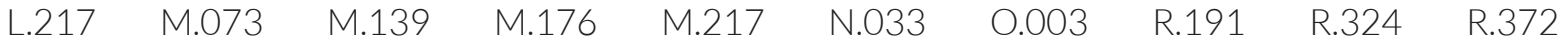
$\begin{array}{lllllll}\text { S.069 S.204 T.010 T.304 W.053 W.174 W.357 W.438. See also Holy Ghost } & \text { W. W }\end{array}$

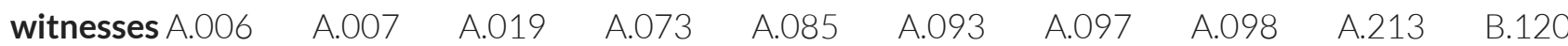

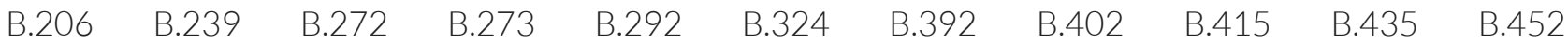

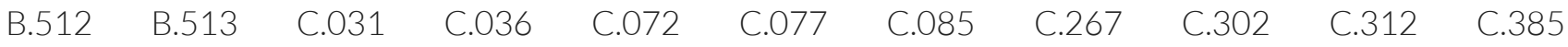

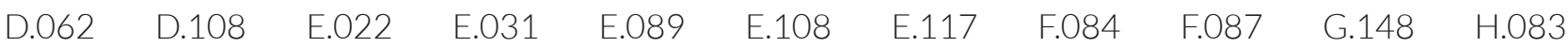

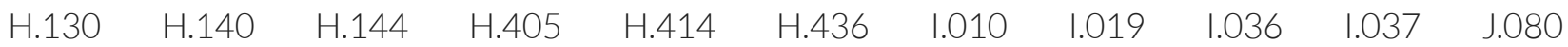
$\begin{array}{lllllllllll}J .085 & J .088 & J .107 & J .142 & J .143 & \text { K.021 } & \text { K.027 } & \text { K.033 } & \text { K.080 } & \text { K.089 } & \text { K.101 }\end{array}$

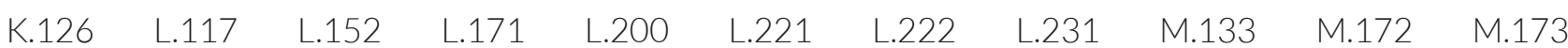

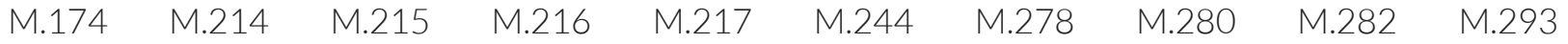

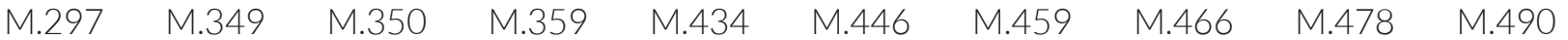

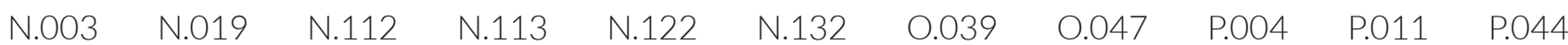

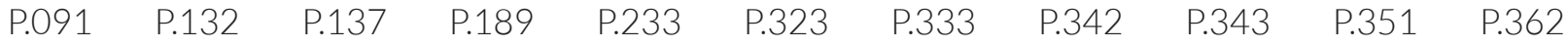

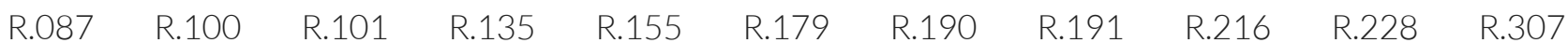

$\begin{array}{lllllllllll}R .345 & \text { R.357 } & \text { R.360 } & \text { R.373 } & \text { R.388 } & \text { R.484 } & \text { S.119 } & \text { S.161 } & \text { S.185 } & \text { S.186 } & \text { S.207 }\end{array}$

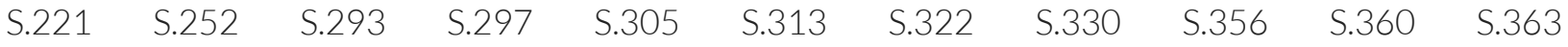

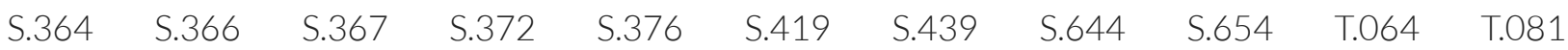

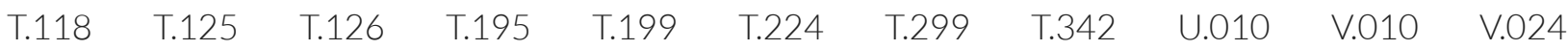
$\begin{array}{llllllllll}\text { V.030 } & \text { V.036 } & \text { W.037 } & \text { W.230 } & \text { W.232 } & \text { W.248 } & \text { W.271 } & \text { W.274 } & \text { W.276 } & \text { W.277 }\end{array}$

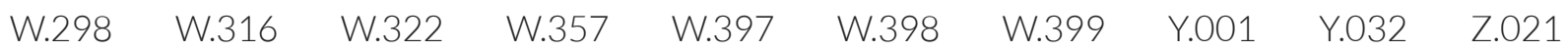




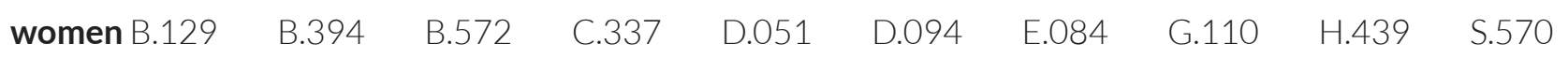

W.407 Y.006

$\begin{array}{lllllllllll}\text { wordprint A.174 } & \text { B.368 } & \text { C.408 } & \text { H.046 } & \text { H.271 } & \text { H.273 } & \text { K.012 } & \text { L.063 } & \text { L.064 } & \text { L.065 }\end{array}$

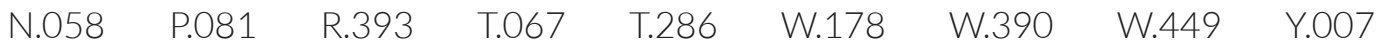

Words of Mormon R.224 R.226

$\begin{array}{lllllllll}\text { "written for our day" A.034 } & \text { B.141 } & \text { B.166 } & \text { B.523 } & \text { C.284 } & \text { D.130 } & \text { J.016 } & \text { K.091 } & \text { L.099 }\end{array}$

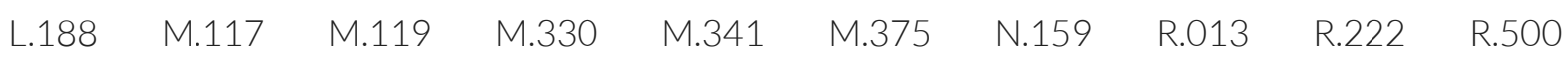

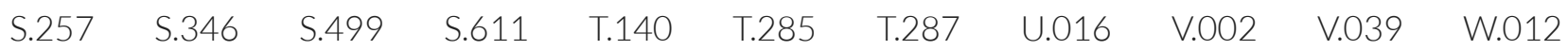

$\begin{array}{llllll}\text { W.054 W.211 } & \text { W.222 } & \text { W.293 } & \text { W.345 } & \text { W.412 } & \text { W.447 }\end{array}$

Young, Brigham A.164 I.018 R.097

Zarahemla C.095 R.232 $\quad$ T.252 $\quad$ W.423 Z.001

Zedekiah E.067 N.002 $\quad \mathrm{S.402} \quad \mathrm{S} .465$

Zeezrom R.130

Zelph B.413 G.104 M.032

$\begin{array}{llll}\text { Zeniff J.017 } & \text { N.161 } & \text { S.663 } & \text { Z.004 }\end{array}$

Zenock J.012 P.090 S.375 W.179

$\begin{array}{llllllllll}\text { Zenos C.362 } & \text { H.242 } & \text { L.204 } & \text { P.090 } & \text { R.151 } & \text { S.078 } & \text { S.148 } & \text { S.375 } & \text { T.174 } & \text { T.317 }\end{array}$

W.134 W.179 W.374

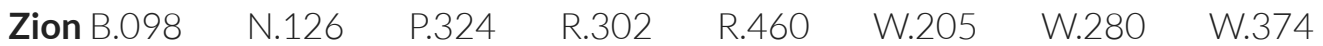

Zion's Camp G.104

Zoram B.038 R.119

$\begin{array}{lllll}\text { Zoramites H.064 R.139 } & \text { S.206 } & \text { W.450 } & \text { Z.020 }\end{array}$

Zosimus W.144 